\title{
NECHUNG THE RITUAL HISTORY AND INSTITUTIONALIZATION OF A TIBETAN BUDDHIST PROTECTOR DEITY
}

\author{
Christopher Paul Bell \\ Winterville, North Carolina \\ BA, Creative Writing and Religion, Florida State University, 2003 \\ MA, Asian Religions, Florida State University, 2006 \\ A Dissertation presented to the Graduate Faculty \\ of the University of Virginia in Candidacy for the Degree of \\ Doctor of Philosophy \\ Department of Religious Studies \\ University of Virginia \\ August 2013
}

Prof. David Germano

Prof. Paul Groner

Prof. Anne Kinney

Prof. Kurtis Schaeffer 
To Cecilia Chung Haynes

who was there from start to finish 


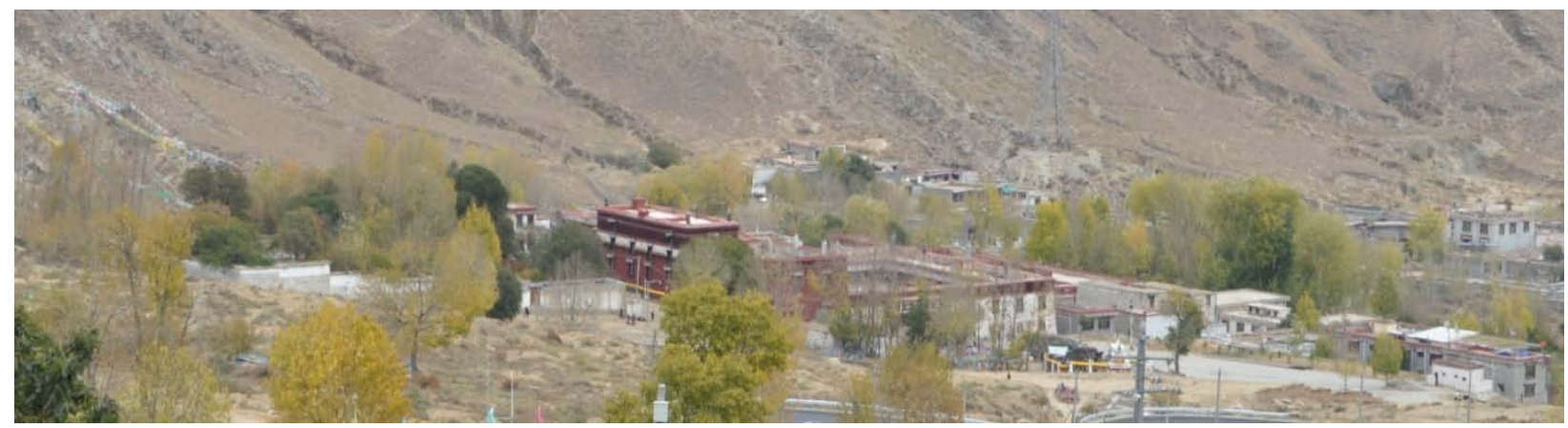

Nechung Monastery viewed from the roof of Deyang College, Drepung Monastery. (Photo: Cecilia Haynes, 2012)
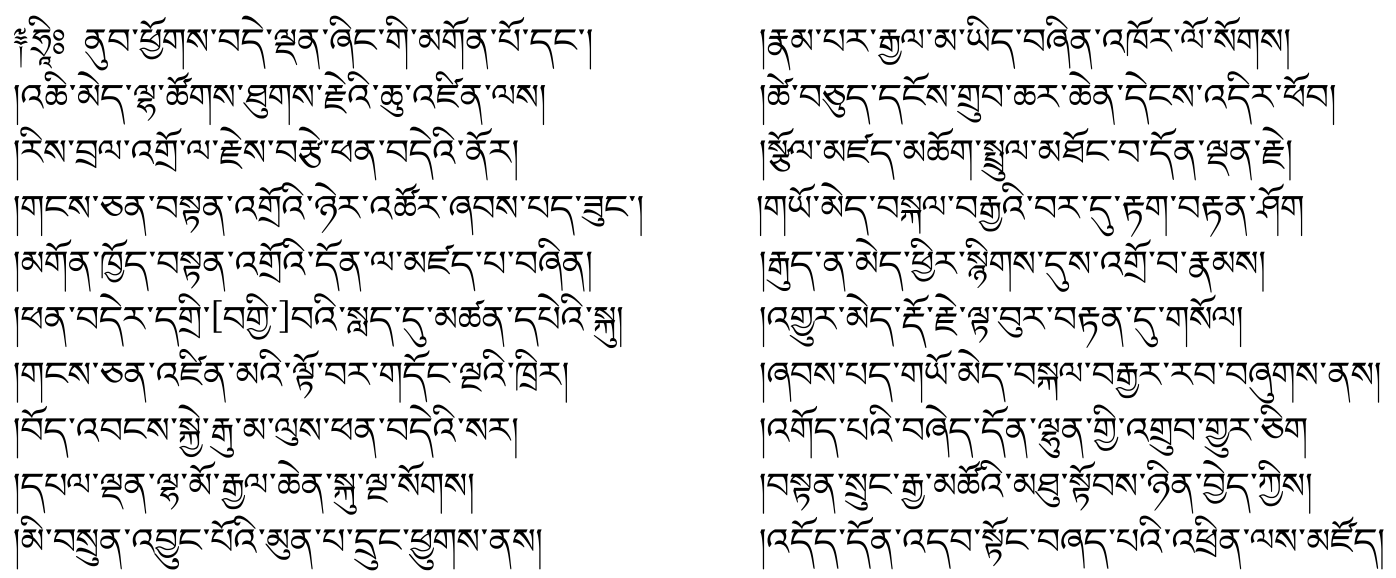

HRĪH! From a compassionate cloud of the host of immortal divinities — such as the Lord of the Western Pure Land Sukhāvatī [Amitābha], Vijayā [Tārā], and Cintāmanicakra [Avalokiteśvara] - a great rain of the attainment of longevity-nectar falls here and now!

[Oh] Lord Meaningful to Behold-Supreme Emanation who impartially bestows on sentient beings the jewels of mercy, beneficence, and happiness - may your two lotus feet eternally and unwaveringly remain as long as a hundred eons for the nourishment of the [Buddhist] teachings and [all] sentient beings of the Snowy Land!

You, Lord, act for the benefit of the [Buddhist] teachings and sentient beings. Accordingly, because you do not perish, I pray that your immutable vajra-like body, possessing the major and minor marks [of the Buddha], will remain steadfast in order to act for the welfare and happiness of the sentient beings of [this] degenerate age!

May your lotus feet fully reside for a hundred eons, without wavering, on the lion throne in the center of this Snowy Land. Then may your desires, established in this land for the benefit and happiness of the Tibetan people and all sentient beings without exception, be spontaneously accomplished!

May the powerful sun of the ocean of those who guard the [Buddha's] teachings - such as Penden Lhamo and the Five Great Sovereign Spirits - expel the darkness of the savage spirits and perform the activities that you desire, which blossom like a thousand-petaled lotus!

Poem requesting the Dalai Lama to remain in the world, recited by the Nechung Oracle (date unknown) ${ }^{1}$

\footnotetext{
${ }^{1}$ This is the entirety of text 3 of the Nechung Liturgy; see Appendix I. This recitation is entitled the "Western Pure Land Poem" (Tib. Nub phyogs bde ldan $\mathrm{ma}$ ), based on its first words.
} 


\section{Table of Contents}

Abstract iv

Acknowledgement $\quad$ V

Note on Tibetan Transcription $\quad$ ix

List of Figures $\quad x$

I. Introduction 1

The Many Gods and Spirits of Tibet $\quad 7$

Review of the Literature 15

Theoretical Position and Methodology 22

Chapter Outline $\quad 26$

II. Chapter 1: Nechung's Mythic Narrative $\quad 29$

The Five Sovereign Spirits $\quad 30$

The Many Lives of Pehar 36

Divine and Demonic Associations $\quad 74$

$\begin{array}{ll}\text { Ontology and Emanation } & 78\end{array}$

$\begin{array}{ll}\text { Chapter Figures } & 85\end{array}$

III. Chapter 2: Nechung's Ritual Pedigree $\quad 106$

Methods for Invoking Dharma Protectors 107

The Many Rites of Nechung $\quad 119$

Liturgical Accretion $\quad 143$

The Central Nechung Rituals and Their Evolution $\quad 145$

$\begin{array}{ll}\text { Dorjé Drakden } & 154\end{array}$

$\begin{array}{lr}\text { Chapter Figures } & 160\end{array}$

IV. Chapter 3: Nechung's Institutional Development 175

$\begin{array}{lr}\text { Physical and Symbolic Architecture } & 176\end{array}$

$\begin{array}{ll}\text { The Many Histories of Nechung Monastery } & 187\end{array}$

$\begin{array}{ll}\text { The Nechung Oracle } & 201\end{array}$

$\begin{array}{ll}\text { Monastery and Chapel Networks } & 225\end{array}$

Chapter Figures $\quad 251$

V. Conclusion $\quad 313$

The Many Lineages of the Fifth Dalai Lama 315

Institution-building and the Power of People $\quad 327$

A Modern Encounter 331

$\begin{array}{lll}\text { VI. } & \text { Appendices } & 334\end{array}$

i. An Outline of the Nechung Liturgy 334

ii. The Central Nechung Rituals $\quad 342$

a.The Ten-Chapter Sādhana of Nyangrel Nyima Özer 344

b.The Offerings and Praises of the Second Dalai Lama 440

c. The Adamantine Melody of the Fifth Dalai Lama 466

iii. The Nechung Register 521

iv. The Hagiography of Jokpa Jangchup Penden 594

Bibliography 


\begin{abstract}
The following monograph is a detailed historical study of the cult of the Tibetan Buddhist protector deity named Pehar (Tib. Pe har) as it grew to prominence at Nechung Monastery (Tib. Gnas chung dgon) in seventeenth-century Lhasa under the auspices of the Fifth Dalai Lama's burgeoning government. This study explores Pehar's mythic and iconographic characteristics, liturgical development, and monastic and institutional deployment at this crucial juncture in Tibetan history. Deity cults are ubiquitous in world religions, but the precise form that they take in Tibetan Buddhism and the dynamics driving the changing popularity of specific deities over the centuries has been inadequately studied. Given his centrality in Tibetan religious history, a sustained examination of Pehar's cult at Nechung Monastery and its influence in later centuries will act as a case study that will significantly enhance our understanding of deity cults within Buddhism and within religious traditions more broadly.

A central dynamic of Tibetan Buddhism is its extensive pantheon of supernatural beings, which collectively function as key players in religious practices across time, space, institutional histories, and sectarian intersections. Perhaps the most fascinating type of such beings is the hybrid figure of the Tibetan Dharma protector (Tib. chos skyong), each of which has complex histories, profoundly local associations, and yet resolutely Buddhist characteristics. Pehar is one of the most significant of such Dharma protectors; he possesses multiple forms and is venerated within all major Tibetan Buddhist sects. According to popular legend, Pehar was subjugated by the great Indian tantric exorcist Padmasambhava in the eighth century and assigned as a protector deity of Samyé Monastery (Tib. Bsam yas dgon pa), Tibet’s first Buddhist monastery. Pehar’s significance increased dramatically during the seventeenth century, when he became intimately linked with the Fifth Dalai Lama and his administration.

The central argument of this study is that the cult of Pehar at Nechung Monastery experienced a meteoric rise in popularity in the seventeenth century primarily through the deliberate efforts of the Fifth Dalai Lama and his regent Sangyé Gyatso in reliance upon multiple mythic, ritual, and institutional devices. Pehar was given greater attention than other deities because of his numerous connections to the Fifth Dalai Lama, which included ancestral, transmissional, institutional, and geopolitical ties. These connections made the deity an ideal choice for inclusion within the larger ritual management of the Fifth Dalai Lama's government.
\end{abstract}




\section{Acknowledgement}

This work could not have been completed without the generous support of numerous advisors, scholars, colleagues, friends, supporters, and family members. First and foremost, I would like to thank my chief advisor David Germano for his tireless aid in both the academic and fiscal aspects of this venture. Professor Kurtis Schaeffer has been equally supportive of this project, and both he and David have given me indispensable advice over the course of my fieldwork and writing. I am also grateful to the other members of my dissertation committee, Professors Paul Groner and Anne Kinney, for their advice and support.

I am especially thankful to Bryan Cuevas, my graduate advisor at Florida State University, who has continued to offer invaluable advice throughout my dissertation research. Kathleen Erndl has also supported me from my time at Florida State to the present, and I am grateful for her guidance. Amy Heller has been a wonderful colleague over the last several years, and her friendship and scholarly insights into Tibetan deity cults have been a constant boon to my work. Urmila Nair has given me valuable perspective on Nechung's ritual corpus and has been tremendously helpful over the course of our correspondence. Nawang Thokmey, the librarian of the Tibetan Collection at the University of Virginia, deserves special mention for diligently supporting my never-ending quest for Tibetan manuscripts. The Tibetan Buddhist Resource Center (www.tbrc.org) has been equally indispensible in generously providing me with several texts important to this work.

The first year of my dissertation research was spent in Hong Kong, where I saved money for my fieldwork. I worked as a Teaching Associate in the School of Humanities and Social Science at the Hong Kong University of Science and Technology. I am again grateful to David Germano for bringing this job prospect to my attention. I would also like to express my sincere gratitude to James Lee, the School's Dean and Chair Professor, as well as Professor Joshua Derman for offering me such an amazing opportunity. I am likewise thankful for the friends and colleagues I made while in Hong Kong, such as Maggie Hui, Daisy Cheung, Yan Guo, Zhou Tao, and Yung Kwan. I will always remember our many wonderful Tibetological conversations.

I am profoundly grateful to Pema Namgyal, Tsering Gyalbo, and Puchung at the Tibetan Academy of Social Sciences (TASS) in Lhasa. Penam sponsored the research visas that allowed Cecilia Haynes and myself to stay for several months in Lhasa so that I could conduct the 
fieldwork necessary for my research. Tsering Gyalbo generously provided essential resources, such as copies of rare texts and important books and articles. Puchung was incredibly generous with his time, traveling with Cecilia and me to numerous sacred centers and even sponsoring a day trip to Samyé Monastery. The kindness and patience of these three individuals is utterly unmatched. I would also like to give a special thanks to Mikmar Tsering, a TASS researcher and good friend who also provided me with numerous materials and memorable conversations. Mikmar patiently transcribed difficult Tibetan manuscripts and visited several monasteries with me, putting me in contact with a number of monks. I am further thankful to Ogyen, Lobsang Nyima, Penba, and Pasang for their friendship and support during my time in Lhasa. I am immensely grateful to the monks of Nechung Monastery, Meru Nyingpa Monastery, Drepung Monastery, Sera Monastery, Gadong Monastery, Tsel Yangön Monastery, Tsel Üling Monastery, Karmasha Chapel, Banakzhöl Chapel, Tengyeling Monastery, Samyé Monastery, and Dorjé Drak Monastery. The monks at each of these sacred centers were incredibly welcoming, graciously allowing Cecilia and me to take innumerable photographs of images and texts. They also patiently talked with me about their sites' deity cults and rituals. This work would have been severely diminished, if not impossible, without their generous support and encouragement.

I am thankful to the Fulbright Program's Institute of International Education (IIE), which helped to financially support my research in Tibet. Janet Upton and Ji Yingnan at the IIEBeijing office were especially helpful in resolving visa issues and problems with institutional affiliation. With their help I was able to secure further research support from the Qinghai University for Nationalities in Xining, Qinghai, to which I am also grateful for assisting in my fieldwork. I am likewise thankful to my friends and colleagues in Xining, Elizabeth Miller, Elizabeth Reynolds, Wesley Chaney, Tim Thurston, and Rinchen Kar, for their encouragement and support. Our numerous gatherings in cafes and restaurants made the bitter Xining winter not just bearable but enjoyable, and I look fondly back at an unforgettable Chinese New Year celebrated with good friends.

I also spent several months in Dharamsala, India, conducting research at the Library of Tibetan Works and Archives (LTWA), as well as speaking with monks at the Nechung and Gadong Monasteries established there. I am grateful to the staff of the LTWA for affording me access to several important texts, as well as for colloquial Tibetan lessons. Sonam Topgyal, an LTWA librarian, deserves special mention for his help in tracking down several texts pertinent to my research. I would further like to thank Roberto Vitali and his wife Cicci for the many stirring 
conversations we had in Dharamsala, and for their support of my work. I am also grateful to John Bellezza for many insightful talks and to Tashi Tsering at the Amnye Machen Institute for his exciting tales about the Nechung Oracle. I am incredibly thankful to the monks at Nechung Monastery, Dharamsala, particularly Yeshé Söpa, for providing me access to important texts and for conversing with me on matters related to Nechung. Yeshé Söpa also generously offered me copies of the late Tupten Püntsok's recently published history of Nechung Monastery. Lastly, I am thankful to my friends and colleagues in Dharamsala, particularly Sara Lewis, Chris Hiebert, Ben Joffe, Michelle Kleisath, and Angela Clyburn, for their insightful discussions and support. Whether through a few rounds of Settlers of Catan, chats over mango smoothies, or dinners in downtown Dharamsala, they helped keep me sane during the exceptionally unpleasant monsoon season.

I would like thank my colloquial Tibetan language instructors at the University of Virginia, Steven Weinberger, Sönam Yangkyi, Tsering Wangchuk, Khenpo Ngawang Dorjee, Eric Woelfel, and Tsetan Chonjore. Their patience and expertise have been instrumental in my acquiring the language skills necessary to conduct interviews in Tibet and India. I am likewise thankful to Chen Shu-chen, my primary Mandarin instructor, whose knowledge and persistence provided me with the practical tools needed to communicate across China. Elizabeth Smith, the Graduate and Fiscal Coordinator of the Religious Studies Department, deserves special mention for patiently helping me with the logistical and bureaucratic pitfalls of graduate school. I am also thankful to my friends and fellow graduate students at the University of Virginia who made my time at UVA truly wonderful, and whose shared insights have impacted the foundations of this work. This includes Geoff Barstow, Gloria Chien, David DiValerio, Chelsea Hall, Benjamin McClintic, Bill McGrath, Manu Lopez, Alison Melnick, Natasha Mikles, Adam Newman, Ben Deitle Nourse, Padma 'Tsho, Rachel Pang, Tsering Perlo, Christie Robinson, Jann Ronis, Brenton Sullivan, Alberto Todeschini, Katarina Turpeinen, Jay Valentine, Jed Verity, and Jongbok Yi. This gratitude also extends to Lindsay and Arnoud Sekreve, who journeyed with me from FSU to UVA, and even to Tibet and Turkey. I could not have survived grad school without you all.

In order to help fund my dissertation writing year, I created a Kickstarter Project entitled, "Nechung: The God of a Tibetan Monastery" (http://www.kickstarter.com/projects/859811179/ nechung-the-god-of-a-tibetan-monastery). The project was a great success and the funds it provided allowed me to complete my dissertation in a timely manner. To express my sincere 
gratitude to the more than fifty backers who donated to my project, I would like to thank them all here. I must first thank my family and extended family members, many of whom generously donated to my Kickstarter project. This includes my parents George and Wanda Bell; my brother James Bell; my aunts Patty Brown, Loretta Earley, Louise Hardison, and Sheila Trevette; my uncles Elwood Hardison and Fred Moyer Sr.; and my cousin Mark Hardison. Next, I would like to thank the professors, colleagues, and friends who believed in and supported my project. This includes Ananth Anthes and Aliya Sonnet, Andrea Arango, Martha Backer, Cameron Bailey, Malcolm Best, Michelle Bryan, Altaire Cambata, Alex Chirico, Kathleen Erndl, Pratima Gopalakrishnan, Richard D. Haynes, Amy Heller, Kelvin Ng and Inness Ho, Barbara Jeffers, Elizabeth Cody Kimmel, Munni Krishna, Karen Lang, Zach Larson, Kristen Muldowney, Sally Ng, Zoe G. Powell, Vivian Rieracker, Valerie Roth, Dinah Russell, Quincy Tse and Vivian Chung, Helen Van de Walker, Jed Verity, Erin Vignali, and Anastasia Warzinski. Lastly, nearly two dozen other individuals were generous enough to support my project, either because they found it interesting or because the content resonated with them. To the following I give my deepest thanks: Kari 'Zael' Alatalo, Marek Belski, Clarence Cherry, Abigail Corfman, Danielle Darwin, Vojta Drevikovsky, Michael Essex, Mickie Flanigan, William Hensley, Aaron Jenkins, Sean Knapp, Kris J. Kraus, Esq., Gregory Krieg, Ben Kudria, Susan Law, Natalie Morris, Wesley and Sarah Pack, Alexander Pattenden, Michael J. Pucci, David F. Reynolds, Victoria Verity, and Brogan Zumwalt. I thank you all for your incredible support.

Finally, I must thank again my parents George and Wanda Bell, for their unconditional support of my unorthodox interests and goals. It will take me a lifetime to express just how grateful I am for their love and encouragement. I want to also express my wholehearted gratitude to Cecilia's parents, Richard Haynes and May Chung. They have provided me with a second home, brought me along on many wonderful adventures across the US, Hong Kong, and the Philippines, and have been amazingly kind and generous toward me.

I save my last and deepest expression of gratitude for my partner Cecilia Haynes, to whom I dedicate this work. She has been by my side throughout the hardest moments of graduate school and dissertation research, taken countless photographs for my work, proofread a barrage of article and chapter drafts, braved many cups of Tibetan butter tea, and kept me balanced throughout all of it. She has truly been there from beginning to end, and I only hope that I can repay her patience and generosity. 


\section{Note on Tibetan Transcription}

Tibetan transliteration and phonetic transcription has been a constant issue in Tibetan Studies. Tibetan words do not translate well into the Latin alphabet due to the presence of many consonants that are part of the orthography of many standard Tibetan syllables but that are not necessarily pronounced in a given dialect. This is complicated by the fact that Tibetan words are pronounced in drastically distinct manners in different Tibetan regions and communities. Nevertheless, since so many Tibetan words are homophonous, these silent consonants in the orthography are essential in distinguishing words for Tibetan scholars and students alike. Therefore, the eminent Tibetologist Turrell Wylie devised a transliteration scheme that has become the standard over the last half-century. ${ }^{1}$

While Wylie's scheme has solved the problem of accurately transliterating Tibetan words, it does not aid Tibetan phonetic pronunciation. "Khri srong lde'u btsan” may be an effective Tibetan transliteration because it includes the silent consonants, but one unfamiliar with Tibetan syllabic construction would not know that this name is pronounced Trisong Deutsen, at least in central Tibetan dialects. To remedy this issue, I have implemented in the present study a variant of the Tibetan and Himalayan Library (THL) Simplified Phonetic Transcription of Standard Tibetan developed by David Germano and Nicolas Tournadre. ${ }^{2}$ This system of phonetic transcription is limited to central Tibetan pronunciations; however, since the following work concerns historical circumstances centered around Lhasa, this is a suitable delimitation. In transliterating Tibetan words, I have also chosen to follow English convention and capitalize the first letter of the word instead of the root letter, as is done in some scholarship. ${ }^{3}$ Tibetan names and words will be written phonetically with the first instance of a word accompanied by its Tibetan transliteration in footnote, or in parenthesis if its in-text citation clarifies a statement. Lastly, the first letter of proper Tibetan names will be capitalized, while generic words will be uncapitalized and italicized. With these systems in place it is hoped that this study will be accessible to non-specialists while providing for specialists the necessary information for further study.

\footnotetext{
${ }^{1}$ See Wylie 1959.

${ }^{2}$ See Germano, Tournadre, and THL 2003.

3 See Cuevas 2003, p.xi, and Martin 1997, pp.20-21, for discussions on capitalizing the first letter of Tibetan words and following other English conventions when transliterating Tibetan.
} 


\section{List of Figures}

Frontispiece: Nechung Monastery viewed from the roof of Deyang College, Drepung Monastery.

ii

(Photo: Cecilia Haynes, 2012)

Figure 1: Gyajin, the central sovereign spirit of the mind; Nechung Monastery Assembly Hall, Lhasa.

(Photo: Cecilia Haynes, 2011)

Figure 2: Mönbuputra, the eastern sovereign spirit of the body; Nechung Monastery Assembly Hall,

Lhasa. (Photo: Cecilia Haynes, 2011)

Figure 3: Shingjachen, the southern sovereign spirit of good qualities; Nechung Monastery Assembly

Hall, Lhasa. (Photo: Cecilia Haynes, 2011)

Figure 4: Kyechik Marpo, the western sovereign spirit of speech; Nechung Monastery Assembly Hall, Lhasa. (Photo: Cecilia Haynes, 2011)

Figure 5: Pehar, the northern sovereign spirit of activities; Nechung Monastery Assembly Hall, Lhasa.

(Photo: Cecilia Haynes, 2011)

Figure 6: The sovereign spirit Jeché Keru; Nechung Monastery Central Chapel, Lhasa.

(Photo: Christopher Bell, 2007)

Figure 7: Mudü Dramkarjé; Meru Sarpa Tsangpa Chapel. (Photo: Christopher Bell, 2011) 91

Figure 8: Dünting Nakpo defeats Mudü Dramkarjé; Meru Sarpa Tsangpa Chapel.

(Photo: Christopher Bell, 2011)

Figure 9: Vajrapāni binds Mudü Dramkarjé; Meru Sarpa Tsangpa Chapel.

(Photo: Christopher Bell, 2011)

Figure 10: Pehar as an Eight-Year-Old Boy; Meru Sarpa Tsangpa Chapel. (Photo: Christopher Bell, 2011)

Figure 11: Pehar Tests Padmasambhava; Meru Sarpa Tsangpa Chapel. (Photo: Christopher Bell, 2011)

Figure 12: Pehar Transforms into a Black Monk; Meru Sarpa Tsangpa Chapel.

(Photo: Christopher Bell, 2011)

Figure 13: Pehar Transformed into a Young Layman; Meru Sarpa Tsangpa Chapel.

(Photo: Christopher Bell, 2011)

Figure 14: Padmasambhava Subjugates Pehar; Meru Sarpa Tsangpa Chapel.

(Photo: Christopher Bell, 2011)

Figure 15: Padmasambhava Confers Empowerments; Meru Sarpa Tsangpa Chapel.

(Photo: Christopher Bell, 2011)

Figure 16: A Central Asian painting of "Vaiśravaṇa in Jang" (Tib. Rnam sras ljangs), $9^{\text {th }}$ century.

(C) Trustees of the British Museum.

Figure 17: A replica of Pehar's sacred leather mask (Tib. bse 'bag smug chung), held at the Pehar

Figures 18a-b: Approximations of Pehar's journey to Tibet in the $8^{\text {th }}$ century and route from Samyé 
Figure 19: Lekden Nakpo and Dünting Nakpo are the Same; Meru Sarpa Tsangpa Chapel.

Figure 20: Hayagrīva, with his horse head(s) bursting forth from Rudra's forehead; Nechung Monastery

Assembly Hall, Lhasa. (Photo: Christopher Bell, 2011)

Figures 21a-b: Samyé Monastery inscribed pillar (Tib. rdo ring), erected at the monastery's founding

(late $8^{\text {th }}$ century), and close-up of inscription mentioning supramundane and mundane deities.

(Photos: Christopher Bell, 2005)

Figure 22: Nechung monks reciting verses for the tenth month ritual to four-armed Avalokiteśvara who Liberates All Beings; Nechung Monastery Assembly Hall, Lhasa. (Photo: Christopher Bell, 2011)

Figures 23a-b: Torma offerings presented to the Five Sovereign Spirits and their retinue during a ritual performance of the Ten-Chapter Sädhana, and glass-encased continuous tormas for Pehar, the Five Sovereign Spirits, and Tsiu Marpo; Meru Nyingpa Monastery Assembly Hall and Tengyeling (Tib. Bstan rgyas gling) Monastery Central Chapel, Lhasa. (Photos: Christopher Bell, 2011)

Figure 24: Glass-encased image of Pehar, to which Chinese jiao have been offered; Nechung Monastery Central Chapel, Lhasa. (Photo: Christopher Bell, 2007)

Figures 25a-b: Ritual dances (Tib. 'cham) performed during 'Universal Incense Offering Day.' Samyé Monastery, Central Temple (Tib. dbu rtse) courtyard, Tibet. (Photos: Christopher Bell, 2007)

Figure 26: Mural of the Nechung Oracle in a trance; Nechung Monastery Assembly Hall, Lhasa.

(Photo: Cecilia Haynes, 2011)

Figure 27: Digitized scans of four folio sides from the original BPLC Tibetan manuscript; Nyi ma 'od zer 1994, pp.235-237.

Figure 28: Central images of Pehar and Tsiu Marpo at the Pehar Kordzöling (Tib. Dpe har dkor mdzod gling); Samyé Monastery, Tibet. (Photo: Lindsay Sekreve, 2007)

Figures 29a-b: Statue of Tsiu Marpo at the Nechung Monastery Central Chapel, Lhasa, and murals of Pehar and Tsiu Marpo at Tengyeling Monastery Side Chapel, Lhasa. (Photos: Christopher Bell, 2007)

Figure 30: A transcription of the full Tibetan text of the Fifth Dalai Lama's Adamantine Melody.

Figure 31: The Assembly of the Quintessential Mind Attainment mandala cosmology adopted by the Fifth Dalai Lama in the Adamantine Melody.

Figure 32: Digitized scans of two folio sides from the original Adamantine Melody manuscript in the Nechung Liturgy; Lobzang Tondan 1983, pp.30-31.

Figure 33: Mural of Dorjé Drakden as the minister of Kyechik Marpo, the western sovereign spirit of speech; Meru Nyingpa Monastery Assembly Hall, Lhasa. (Photo: Cecilia Haynes, 2011)

Figure 34: Mural of Dorjé Drakden with his own consort, minister, and emanation; Meru Nyingpa Monastery Assembly Hall, Lhasa. (Photo: Cecilia Haynes, 2011)

Figure 35: Mural of the Nechung Oracle in a trance surrounded by his retinue; Drepung Monastery, Deyang College Assembly Hall, Lhasa. (Photo: Cecilia Haynes, 2011)

Figure 36: Statue of the Nechung Oracle, the central statue of Nechung Monastery; Nechung Monastery Central Chapel, Lhasa. (Photo: Christopher Bell, 2007)

Figure 37: Nechung Monastery, Lhasa. (Photo: Cecilia Haynes, 2011) 
Figure 38: West Gate of Nechung Monastery, Lhasa. (Photo: Cecilia Haynes, 2011)

Figure 39: Extensive courtyard murals at Nechung Monastery, Lhasa. (Photo: Cecilia Haynes, 2011)

Figure 40: Central building of Nechung Monastery, Lhasa. (Photo: Cecilia Haynes, 2011)

Figure 41: Entrance to the central building of Nechung Monastery, Lhasa. (Photo: Christopher Bell, 2005)

Figure 42: Floor plan of Nechung Monastery, Lhasa. (C) Franco Ricca \& Edizioni dell'Orso, Alessandria/CESMEO, Torino; see Ricca 1999, p.47, Fig.4. Alterations made to image with the author's permission; email correspondence with Franco Ricca, January 28, 2013.

Figure 43: Mantrabhīru (Tib. Dmod pa drag sngags) in union with his consort; Nechung Monastery Assembly Hall, Lhasa. (Photo: Christopher Bell, 2011)

Figure 44: Guru Vidyādhara (Tib. Rig 'dzin slob dpon) in union with his consort; Nechung Monastery Assembly Hall, Lhasa. (Photo: Christopher Bell, 2011)

Figure 45: Vajrakīlāya (Tib. Rdo rje phur ba 'phrin las) in union with his consort; Nechung Monastery Assembly Hall, Lhasa. (Photo: Cecilia Haynes, 2011)

Figure 46: Yamāntaka (Tib. 'Jam dpal sku gshin rje shed) in union with his consort; Nechung Monastery Assembly Hall, Lhasa. (Photo: Christopher Bell, 2011)

Figure 47: Vajrāmṛta (Tib. Rdo rje bdud rtsi yon tan) in union with his consort; Nechung Monastery Assembly Hall, Lhasa. (Photo: Christopher Bell, 2011)

Figure 48: Master Padmākara (Tib. slob dpon Padmā ka ra; lit. "Lotus-born”), a form of Padmasambhava; Nechung Monastery Assembly Hall, Lhasa. (Photo: Christopher Bell, 2011)

Figure 49: Viśuddha (Tib. Yang dag thugs) in union with his consort; Nechung Monastery Assembly Hall, Lhasa. (Photo: Christopher Bell, 2011)

Figure 50: Lotus Speech Hayagrīva (Tib. Pad ma gsung rta mgrin) in union with his consort; Nechung Monastery Assembly Hall, Lhasa. (Photo: Christopher Bell, 2011)

Figure 51: Mātara (Tib. Ma mo rbod gtong) in union with his consort; Nechung Monastery Assembly Hall, Lhasa. (Photo: Christopher Bell, 2011)

Figure 52: Lokastotrapujanātha (Tib. 'Jig rten mchod bstod) in union with his consort; Nechung Monastery Assembly Hall, Lhasa. (Photo: Christopher Bell, 2011)

Figure 53: The Nechung Oracle Tokbep Dzepa (Tib. chos skyong chen po Thog 'bebs mdzad pa); Nechung Monastery Assembly Hall, Lhasa. (Photo: Christopher Bell, 2011)

Figures 54a-c: The Five Buddha Families and White Tara; Nechung Monastery Assembly Hall, Lhasa. (Photos: Christopher Bell, 2011)

Figure 55: The sixth, seventh, and eighth abbots of Ganden Monastery; Nechung Monastery Assembly Hall, Lhasa. (Photo: Christopher Bell, 2011)

Figure 56: Tibetan devotees making offerings in the Birch Tree Chapel; Nechung Monastery Assembly Hall, Lhasa. (Photo: Cecilia Haynes, 2010)

Figure 57: Pehar's soul tree (Tib. bla shing) within the Birch Tree Chapel; Nechung Monastery Assembly Hall, Lhasa. (Photo: Christopher Bell, 2005) 
Figure 58: Great enemy-defeating god (Tib. dgra lha chen po); Nechung Monastery Central Chapel, Lhasa. (Photo: Christopher Bell, 2007)

Figure 59: Toktsen (Tib. Thog btsan), a door guardian; Nechung Monastery Central Chapel, Lhasa. (Photo: Christopher Bell, 2007)

Figure 60: Gyajin; Nechung Monastery Central Chapel, Lhasa. (Photo: Christopher Bell, 2007)

Figure 61: Dorjé Drakden; Nechung Monastery Central Chapel, Lhasa. (Photo: Christopher Bell, 2007)

Figure 62: Goddess Drakgyelma (Tib. lha mo [Rdo rje] grags rgyal ma), the leader of the Twelve Tenma

Figure 64: Hayagrīva in union with his consort; Nechung Monastery Central Chapel, Lhasa. (Photo: Christopher Bell, 2007)

Figure 65: Goddess of the Five Long-Life Sisters (Tib. lha mo Tshe ring mched lnga); Nechung Monastery Central Chapel, Lhasa. (Photo: Christopher Bell, 2007)

Figure 66: Goddess Nyima Zhönnu (Tib. lha mo Nyi ma gzhon nu); Nechung Monastery Central Chapel, Lhasa. (Photo: Christopher Bell, 2007)

Figure 67: Shingjachen; Nechung Monastery Central Chapel, Lhasa. (Photo: Christopher Bell, 2007)

Figure 68: Mönbuputra; Nechung Monastery Central Chapel, Lhasa. (Photo: Christopher Bell, 2007)

Figure 69: Decorated year-long torma casement; Nechung Monastery Desire Realm Chapel, Lhasa.

(Photo: Cecilia Haynes, 2011)

Figure 70: Penden Lhamo thread-cross mansion; Nechung Monastery Desire Realm Chapel, Lhasa. (Photo: Cecilia Haynes, 2011)

Figure 71: Guru Nangsi Zilnön; Nechung Monastery Guru Nangsi Zilnön Chapel, Lhasa.

(Photo: Cecilia Haynes, 2011)

Figure 72: Former site of Pehar's soul lake (Tib. bla mtsho); Nechung Monastery grounds, Lhasa. (Photo: Christopher Bell, 2011)

Figure 73: Modern-day site of Yulokö village (Tib. G.yu lo bkod); near Nechung Monastery, Lhasa.

(Photo: Christopher Bell, 2011)

Figures 74a-c: Pehar's miraculous stone and its vicinity to the deity's soul lake and the Birch Tree Chapel; Nechung Monastery grounds, Lhasa. (Photos: Christopher Bell, 2011)

Figure 75: The estate (Tib. bla brang) of Nechung Rinpoche; Nechung Monastery grounds, Lhasa.

(Photo: Christopher Bell, 2011)

Figure 76: Nechung Monastery, Gangchen Kyishong, Dharamsala. (Photo: Cecilia Haynes, 2012)

Figure 77: Padmasambhava with the red and black protectors (Tib. srung ma dmar nag); Meru Sarpa 
Figure 79: Site of Yangön's Pehar Chapel (Tib. Pe har lcog), now in ruins, surrounded by lay housing;

Tsel Yangön Monastery. (Photo: Christopher Bell, 2011)

Figure 80: Statue of Pehar; Inner Sanctum, Tsel Yangön Monastery. (Photo: Cecilia Haynes, 2011) 295

Figure 81: Deyang College (Tib. Bde yangs grwa tshang), Drepung Monastery.

(Photo: Cecilia Haynes, 2011)

Figure 82: Statue of Jokpa Jangchup Penden (1464-1531); Deyang College Assembly Hall, Drepung

Monastery. (Photo: Cecilia Haynes, 2011)

Figure 83: Murals of the Five Sovereign Spirits surrounding Hayagrīva; Deyang College Assembly Hall, Drepung Monastery. (Photo: Cecilia Haynes, 2011)

Figure 84: Meru Nyingpa Monastery (Tib. Rme ru snying pa). (Photo: Cecilia Haynes, 2011)

Figure 85: Statue of Dorjé Drakden; Meru Nyingpa Monastery Assembly Hall.

(Photo: Cecilia Haynes, 2011)

Figure 86: Gadong Monastery (Tib. Dga’ gdong dgon pa). (Photo: Cecilia Haynes, 2011)

Figure 87: A brief history of Gadong hanging over the monastery's entrance; Gadong Monastery. (Photo: Cecilia Haynes, 2011)

Figure 88: Life-size statue of the Gadong Oracle; Gadong Monastery Central Chapel.

(Photo: Cecilia Haynes, 2011)

Figure 89: Karmasha Chapel (Tib. Karma shag btsan khang). (Photo: Cecilia Haynes, 2011)

Figure 90: Statue of Jatri Mikchikpu; Karmasha Chapel Assembly Hall. (Photo: Cecilia Haynes, 2011)

Figure 91: A 'breath bag' (Tib. dbugs rkyal) used to hold the life breath or souls of beings; Karmasha

Chapel Assembly Hall. (Photo: Cecilia Haynes, 2011)

Figure 92: Banakzhöl Chapel (Tib. Sbra nag zhol rgyal khang). (Photo: Cecilia Haynes, 2011)

Figure 93: Central statue of Shingjachen; Banakzhöl Chapel. (Photo: Cecilia Haynes, 2011)

Figure 94: Statue of Pehar next to the central image of Tsiu Marpo; Tengyeling Monastery Main Chapel.

Figure 95: Mural of the Five Sovereign Spirits surrounding the monastery's local protector; Dorjé Drak Monastery (Tib. Rdo rje brag dgon pa) Assembly Hall. (Photo: Cecilia Haynes, 2011)

Figure 96: Mạ̣dala for Avalokiteśvara who Liberates All Beings, November 23, 2011; Nechung Monastery Assembly Hall. (Photo: Christopher Bell, 2011)

Figures 97a-b: Modern-day maps of Lhasa's old city as well as Drepung and Nechung Monasteries. 


\section{Introduction}

This is the story of two immortals whose friendship has spanned nearly five hundred years across the Tibetan plateau and beyond. The first immortal is the Dalai Lama, the emanation of an enlightened being who voluntarily takes rebirth in the world to benefit sentient beings. The second immortal is a wrathful god named Pehar, ${ }^{1}$ forms of which have taken possession of a human medium, one after another, since the sixteenth century. The purpose of this monograph is to examine in detail the nature of the relationship between these two monolithic figures as it took on particular salience in the seventeenth century during the reign of the Fifth Dalai Lama. ${ }^{2}$ At this time the cult of the protector deity ${ }^{3}$ Pehar and his oracle became state-sanctioned by the new Tibetan government, his ritual cycle was extensively augmented, and his small chapel was dramatically renovated and expanded. This chapel is Nechung Monastery, ${ }^{4}$ which is located on the outskirts of the Tibetan capital of Lhasa. The Fifth Dalai Lama and his burgeoning government endorsed and standardized Nechung Monastery's Tibetan Buddhist deity cult as part of his larger unification project, the effects of which reverberated across Tibet.

The first half of the seventeenth century was a severely contentious time for central Tibet. The previous century had been predominantly characterized by constant political and military conflict between the Geluk ${ }^{5}$ and the Kagyü $\ddot{6}^{6}$ sects of Tibetan Buddhism. The former came to primarily control the central Tibetan region of $\ddot{U}^{7}$ with Lhasa as its capital, and the latter controlled the region west of Ü called Tsang, ${ }^{8}$ with the city of Shigatse ${ }^{9}$ at its center. The lineage of the Dalai Lamas had also gained a measure of power in the sixteenth century due to the relationship that was established between the Third Dalai Lama and Altan Khan, the ruler of the Tümed Mongols. The rivalry between the Gelukpa and Kagyüpa, particularly the Karma Kagyü

\footnotetext{
${ }^{1}$ Tib. Pe har.

${ }^{2}$ Tà la'i bla ma 05 Ngag dbang blo bzang rgya mtsho, 1617-1682; TBRC: P37.

${ }^{3}$ Tib. srung ma.

${ }^{4}$ Tib. Gnas chung dgon.

${ }^{5}$ Tib. Dge lugs. The nominalized form of this adjective is Gelukpa (Tib. Dge lugs pa), with $p a$ or $b a$ being common nominalizers in Tibetan.

${ }^{6}$ Tib. Bka' brgyud.

${ }^{7}$ Tib, Dbus.

${ }^{8}$ Tib. Gtsang.

${ }^{9}$ Tib. Gzhis ka rtse.
} 
sub-sect, ${ }^{10}$ came to a head at the start of the seventeenth century and central Tibet became locked in civil war between Ü and Tsang.

The Fifth Dalai Lama Ngawang Lobzang Gyatso was born in the midst of this turmoil. At an early age this figure was recognized as the fifth incarnation of the Dalai Lama and taken to Drepung Monastery, ${ }^{11}$ one of the three major Geluk monasteries in central Tibet located just outside Lhasa. After spending nearly two decades studying at Drepung, a fateful meeting took place in 1637 between the Fifth Dalai Lama, often called the "Great Fifth," and Güshi Khan, the leader of the Khoshut Mongols. The relationship that developed between the Great Fifth and the Mongol Khan forever changed the face of Tibet. In the years that followed, Güshi Khan subjugated the forces opposing the Gelukpas in central Tibet, as well as in the northeastern Tibetan region of $\mathrm{Amdo}^{12}$ and the eastern region of Kham. ${ }^{13}$ With the Fifth Dalai Lama's enemies subdued, Güshi Khan granted him religious control over much of Tibet in 1642, which eventually developed into full political control. ${ }^{14}$

Regardless of this powerful alliance, the Fifth Dali Lama still struggled to legitimize his burgeoning government and strengthen his centralized control over Tibet amid broader geopolitical unrest. China's Ming Dynasty had crumbled over a protracted period of instability and was replaced by the Manchu Qing Dynasty in 1644. Tentative relations between the Dalai Lama's government and the Qing emperors developed soon after this hegemonic shift. Mongolian troops also had to continue to help protect Tibet's borders, since Bhutan and Nepal would occasionally make incursions along the country's frontiers. Lastly, internal strife remained a constant threat, with previously defeated factions looking for political purchase to regain power, either through sectarian, aristocratic, or regional influence. ${ }^{15}$

In this tense environment, numerous deities were propitiated by various groups to help them secure control. In general, Tibetan deities are tied to specific clans, families, religious sects, or localized communities, and such deities are entreated by these groups to fiercely defend or advance their goals. The histories for many of these deities and the relationship they have with their constituencies are still unknown or poorly understood. Nevertheless, within the larger

\footnotetext{
${ }^{10}$ Tib. Kar ma bka' brgyud.

${ }^{11}$ Tib. 'Bras spungs dgon pa.

${ }^{12}$ Tib. A mdo.

${ }^{13}$ Tib. Khams.

${ }^{14}$ See Yamaguchi 1995.

${ }^{15}$ These historical details are summarized from Ahmad 1970, pp.99-162, Schaeffer 2005a, and Shakabpa 2010, pp.282-379.
} 
pantheon of deities assigned to protect his lineage, monastery, and government, the Great Fifth turned to the Dharma protector ${ }^{16}$ Pehar to safeguard his nascent administration. ${ }^{17}$ Pehar was unique because of the multiple connections that he and the Great Fifth shared. In particular, the Fifth Dalai Lama traced a family connection to Pehar back to the eighth century, he received the transmission of the oldest ritual cycles associated with Pehar, past Dalai Lamas had worshipped him, and the deity has even been associated with Drepung Monastery - the original residence of the Dalai Lamas - since its founding. Pehar also helped the Dalai Lamas secure important ties to powerful Mongol Khans on several occasions, ensuring that the Gelukpa had strong military backing. On top of this, the Fifth Dalai Lama had a personal attachment to Pehar and conversed with him regularly through an oracle. All of these connections made the deity a natural choice for political endorsement, and through the Great Fifth's support Pehar became particularly significant at this time in the consolidation of the Tibetan government.

Nonetheless, Pehar's cult is much older than the seventeenth century. Worship of the deity in Tibet is believed to have originated in the eighth century at Samyé Monastery, ${ }^{18}$ Tibet's first Buddhist monastery southeast of Lhasa, before it was cultivated and further developed at Nechung Monastery from the sixteenth century onward. The cult of Nechung focuses on Pehar and the group of deities that he leads, collectively called the Five Sovereign Spirits, ${ }^{19}$ as well as their many emanations. By converting Nechung's pantheon into a state cult, the Great Fifth established and augmented a ritual hegemony over the capital city of Lhasa and Tibet as a whole, wresting political and symbolic control from past polities, such as the Tselpa Kagyüpa ${ }^{20}$ and advancing the government's own agendas. This was a slow process that continued after the time of the Fifth Dalai Lama and which required state control over, and propagation of, mythic, liturgical, and institutional mechanisms, which are the focus of this study.

Through these mechanisms, Nechung's cult was established at several monasteries and chapels around Lhasa to serve the ultimately pragmatic purpose of protecting and enriching the Dalai Lama's government. The Five Sovereign Spirits were propitiated to protect the Dalai Lama and ensure he lived a long life, and to safeguard the government, the capital city, and Tibet

\footnotetext{
${ }^{16}$ Tib. chos skyong.

${ }^{17}$ The supramundane goddess Penden Lhamo Makzor Gyelmo (Tib. Dpal ldan lha mo Dmag zor rgyal mo) was chosen as the other major deity to guard the Dalai Lama's government; however, this deity will receive only occasional attention in the present work due to the focus on the Nechung cult.

${ }^{18}$ Tib. Bsam yas gtsug lag khang.

${ }^{19}$ Tib. Rgyal po sku lnga.

${ }^{20}$ Tib. Tshal pa Bka' brgyud pa.
} 
at large from external and internal enemies. Such propitiations were enacted through ritual offerings and invocations, as well as statues and images commissioned for the deities. Moreover, since Pehar had specifically been the guardian of Samyé Monastery's treasury, and had other ties to wealth gods, he and his group of divinities were also entreated to augment the government's coffers as well as the treasuries of the monasteries to which they were bound. Such magnifying endeavors are part of a larger set of four ritual activities - which also involve pacifying, subjugating, and destroying maleficent forces - that are often employed within the greater practices of many Tibetan deity cults.

A deity cult is a complex of mythic narratives, divine iconographies, liturgical collections, ritual objects, devotional performances, and sacred sites that are created, coordinated, and consistently engaged by religious practitioners for the purposes of venerating or entreating a specific divinity or group of divinities. In Tibetan Buddhism, such cults can be as simple as a regional god worshipped at a certain site during specific times of the year by a small local populace, or as complicated as a group of deities venerated regularly and simultaneously at numerous religious centers across the country or even the world. Pehar belongs to the latter category-he has an extensive mythos covered in several tantric texts as well as murals; his group, the Five Sovereign Spirits, has detailed and sometimes conflicting iconographies; numerous ritual manuals and entire compendiums have been composed for these deities and are practiced throughout the year; many statues, paintings, and offerings have likewise been created to invoke them; and these ritual manuals and objects, along with the performances that employ them, have been housed at Nechung Monastery, as well as several satellite monasteries and branch chapels in and outside of Tibet. Moreover, Pehar's cult involves several oracles, which not all deities possess, and many of his emanations have their own more limited cults, which have been established at other sites. A proper history of Pehar's deity cult would require an exploration of the above elements, specifically as they came to be enhanced and embodied at Nechung and related places in the seventeenth century.

Examining a deity cult like Pehar's at such a specific and important juncture in its growth and history yields significant insights. It allows us to understand why certain mythological accounts become standardized rather than others, how liturgical manuals evolve and are augmented by ritual specialists over time and to what end, and how sacred centers are converted through the establishment of new deity pantheons and ritual practices. In the latter half of the seventeenth century, the Fifth Dalai Lama deepened his engagement with Pehar in order to 
strengthen his rule. He standardized Pehar's mythology, greatly enriched the ritual practices of the Five Sovereign Spirits, and commissioned the physical renovation and expansion of Nechung Monastery. Other monasteries and chapels also came under the purview of the Nechung cult at this time and in later centuries. Moreover, the Great Fifth's regents supported these endeavors, and his last regent Sangyé Gyatso, ${ }^{21}$ in particular, reinforced this cultic enterprise toward the end of the Great Fifth's life and after his death.

These practices also illustrate how deity cults become bound to institutions and impact Tibetan history and historiography. The Fifth Dalai Lama and his government expanded Pehar's cult at Nechung in the seventeenth century; in turn, the influence of the deity's worship reverberated throughout the following centuries. The Nechung cult would continue to play a significant role in the administrations of future Dalai Lamas, appear in monasteries throughout central Tibet and far afield in Amdo and Kham, and become an important part of the pilgrimage itineraries and regular practices of lay devotees. Furthermore, this cultic expansion was part of a larger narrative of legitimation for the Dalai Lama's government. The Great Fifth relied on a number of other charismatic religious leaders to promote a bold vision of his government as embodying - literally through reincarnation - the once grand Tibetan Empire of the eighth century. Pehar, having played a significant role in this empire as a central Dharma protector of Samyé Monastery, was instrumental in authenticating this grand narrative.

It is also interesting that a hierarch of the conservative Geluk sect like the Fifth Dalai Lama would rely so heavily on an explicitly Nyingma ${ }^{22}$ form of the Five Sovereign Spirits to help ritually maintain his government, given the antagonism that would grow between these sects in later centuries. The Great Fifth drew directly from rituals associated with Pehar that were transmitted by the Northern Treasures tradition ${ }^{23}$ of the Nyingma sect. He also relied on the Second Dalai Lama's materials concerning the deity, though he did not use Sakya ${ }^{24}$ or Kagyü texts. Yet the Fifth Dalai Lama was himself a revealer of Nyingma treasure texts ${ }^{25}$-revelatory works hidden in the past by great tantric masters - and he exemplified a fusion of Geluk monasticism and Nyingma ritualism throughout his adult life. Pehar also had prior connections to the Dalai Lamas and to the Gelukpa at large, given his presence at Drepung Monastery. The

\footnotetext{
${ }^{21}$ Sde srid Sangs rgyas rgya mtsho, 1653-1705; TBRC: P421.

${ }^{22}$ Tib. Rnying ma.

${ }^{23}$ Tib. Byang gter lugs.

${ }^{24}$ Tib. Sa skya.

${ }^{25}$ Tib. gter ma. For a discussion of the Great Fifth's treasure text revelations, see Dudjom Rinpoche 1991, vol.1, pp.821-824.
} 
Nechung Chapel that existed prior to the expanded monastery was even founded by a Drepung abbot. If the Great Fifth were going to choose a Nyingma deity to cement his personal and political pantheon, Pehar was a reasonable choice since he had already made successful inroads into Geluk practice. With their expansion of the Nechung cult, the Fifth Dalai Lama and his regent Sangyé Gyatso incorporated a practice with Nyingmapa roots into their Gelukpa agenda. This deity cult evinces something of the fluidity that existed between the various Tibetan Buddhist sects before boundaries became more solidified from the seventeenth century onward.

Pehar is an important deity to examine for several reasons. As previously stated, the deity was one of the major protectors of Samyé Monastery, which ties him to Tibet's imperial past. Conversely, his connection to the lineage of the Dalai Lamas makes him an important part of Tibet's recent past and present. He is a significant deity in all major Tibetan Buddhist sects, having originated in the Nyingma sect, transferred into the Sakya sect and various Kagyü subsects, and eventually adopted into the Geluk sect. Nechung Monastery reflects this ecumenism since its liturgical canon involves Nyingma, Sakya, and Geluk rites; though, the absence of Kagyü rituals is telling. Alongside his importance to the Dalai Lama, Pehar's centrality within the Tibetan government is still visible today, even in exile. For instance, the Tibetan flag introduced by the Thirteenth Dalai Lama in the early twentieth century prominently references a form of the deity, who is signified by the red rays of light that emanate from the sun at the center of the image. ${ }^{26}$ Moreover, Nechung's monastic institution continues to be a major seat of Pehar's cult — in Tibet, in the Tibetan Government-in-Exile residing within Dharamsala, India, and in Tibetan Buddhist communities around the world.

Pehar's mythic presence in Tibet extends back over a millennium, so a thorough study of this deity is an important step in understanding the broader role and significance of Tibetan deity cults. Nonetheless, given this god's extensive history, a comprehensive investigation would require multiple volumes or at least several articles. Since Pehar's importance reached its apogee under the Fifth Dalai Lama's reign, a detailed study of the rise of this deity's cult at Nechung Monastery would be a solid start in this endeavor. Pehar also represents a useful case study for understanding how dynamic historical change is in Tibet, especially when deity cults intersect with state formation. It is hoped that the present study will begin to unravel some of the

\footnotetext{
${ }^{26}$ The red bands specifically refer to Dorjé Drakden, an important emanation of Pehar that will be discussed in chapter 2. By contrast, the flag's dark blue bands represent Penden Lhamo Makzor Gyelmo; see Central Tibetan Administration 2013. See also Heller 1992a, pp.490-491.
} 
rich mythography, complex ritual history, and robust institutionalization of this important Tibetan Buddhist protector deity.

\section{The Many Gods and Spirits of Tibet}

Despite his significance, Pehar is only a small part of the Tibetan spiritual landscape, which is pervaded by innumerable Buddhist divinities and indigenous gods and spirits. Tibetans have over time developed a loosely systematic series of deity ontologies and typologies to cope with this vast assortment of supernatural agents, drawing from both Indian and local categorization schemes. Since the current work concerns a specific deity that is understood by Tibetans in the context of such an ontological and typological spectrum, it is useful to provide a concise classification of the various types of divinities to which Pehar is mythically and ritually linked. The classification scheme presented in Geoffrey Samuel's Civilized Shamans provides a useful template; it incorporates the two-part system given in Nebesky-Wojkowitz's Oracles and Demons of Tibet - which will be discussed further below-with the taxonomy of deities provided by Giuseppe Tucci in his magnum opus Tibetan Painted Scrolls. ${ }^{27}$

The Tibetan ontological scheme involves four major divisions. First, there are the tutelary deities (Tib. yi dam; Skt. iștadevatā) of Tantric Buddhism. These deities are encountered at the highest levels of Buddhist monastic ritual practice and yogic meditation. Second, there are the supramundane protector deities (Tib. 'jig rten las 'das pa; Skt. lokottara), who are emanations of buddhas and bodhisattvas. Such beings are not usually concerned with worldly affairs. Third, there are the mundane protector deities (Tib. 'jig rten pa; Skt. laukika) who are more often associated with geographical features like mountains, lakes, and trees, and are subject to the law of karma. These deities are focused on worldly matters and constantly interact with humans. Pehar is usually considered a member of this category, though there is some dissension on the issue, which will be explored in chapter 1. Fourth, there is the horde of unconverted local spirits and ghosts, who often bring about illness, bad luck, and calamity. The middle two categories are generally taken up with Dharma protectors, which, as the name

\footnotetext{
${ }^{27}$ However, Samuel's descriptions are themselves drawn from Cornu 1990, pp.226-229; see Samuel 1993, pp.162163.
} 
suggests, are propitiated to protect and maintain the Dharma, the Buddhist teachings; these two groups are the focus of Nebesky-Wojkowitz's book.

According to Samuel, the last two categories of mundane protectors and malevolent local spirits are not wholly distinct - there is a degree of fluidity between them. ${ }^{28}$ The distinction is that mundane deities were once local spirits that were tamed and who now serve the Buddhist teachings, a concept that will be examined later in relation to Pehar. Those spirits still classified as pernicious are placed within the retinues of mundane deities. This fluidity exists in all four divisions and there is some mobility between them, since deities are thought to move up in classification over time as their actions become more purified.

There is also a disorderly taxonomy of various spirit types within the Tibetan universe that intersects with the above scheme. The term demon has become popular in referring to these deities, given their initial penchant for pernicious activity-Nebesky-Wojkowitz's own book title illustrates this usage. This is unfortunate given the stigma and strongly malicious nature associated with the word in Euro-American milieus. The term also suggests the linguistic difficulty inherent in translating these various spirit classes into English. While English has one overarching term for demons, there are many different kinds of supernatural agents that exist in Tibet, possessing vastly different attributes and qualities both beneficent and malevolent. Although most of these beings are generally perceived as angry, violent, and harmful, I choose not to use 'demon' to describe them because of the word's excessive cultural baggage. Instead I use the more neutral term 'spirit.' Other conventions exist that attempt to recognize the individuality of these diverse spirit types by using European supernatural typologies to translate them. For instance, the spirit type called btsan is translated as 'furies' while srin po spirits are called 'orcs,' 'ogres,' and 'gnomes. ${ }^{29}$ While it is admirable to use distinct terms for each spirit, these etic labels also have cultural baggage and convey characterizations that are not true to the original Tibetan concept.

For their part, Tibetans have themselves attempted, with only partial success, to classify these spirit types. One indigenous classification scheme groups these diverse types into 'eight classes of gods and spirits, ${ }^{30}$ although the spirits that make up these eight categories change

\footnotetext{
${ }^{28}$ See Samuel 1993, pp.166-167.

29 These definitions are found in the Rangjung Yeshe electronic dictionary.

${ }^{30}$ Tib. lha srin bde brgyad.
} 
depending on the taxonomy. ${ }^{31}$ Other systems have tried to integrate these spirits more fully into Buddhist cosmology by assigning each spirit type to one or more of the six Buddhist realms of rebirth. For instance, $k l u$ spirits are classified as part of both the god and animal realms, while gnod sbyin are placed in the god realm. ${ }^{32}$ For the purposes of this work, I have developed my own system for translating Tibetan spirit types, which assigns an equivalent English term to each type based on their key characteristics or etymologies. Below I have provided a list of the most important spirit types that will be encountered in this study and, with the exception of four terms, the word 'spirit' is appended to each. The greatest limitation of this system is that it creates a false sense of homogeneity between these entities, suggesting that they have equal significance in Tibetan ritual and cultural contexts when this is not the case. Nevertheless, these neologisms attempt to address the inadequacy of past translations while acknowledging the distinctiveness of these supernatural beings: $:^{33}$

- Sovereign spirits (Tib. rgyal po): The mythic accounts for many of these spirits claim that they were once evil kings or monks who transgressed their vows. They are generally white in color. Pehar and his group of deities are sovereign spirits, and their origins and iconographies reflect these general qualities.

- Imperial spirits (Tib. btsan): These indigenous Tibetan deities are known to be war-like and wrathful. They are red in color and are generally believed to be the spirits of past monks who have rejected their Buddhist vows. Imperial spirits are similar to sovereign spirits except for their body color and helmets. Todd Gibson explored this specific spirit type in his doctoral dissertation, arguing that they are a demonization of the Tibetan imperial line. ${ }^{34}$

- Capricious spirits (Tib. gnod sbyin; Skt. yakșa): These spirits were initially malicious beings that caused diseases and epidemics. In order to signify their later conversion to guardians of the Buddhist teachings, they have become associated with the ancient Indian spirits called yakșas. My translation of this

\footnotetext{
${ }^{31}$ See Nebesky-Wojkowitz 1998, pp.253-317, and Tucci 1999, vol.2, pp.717-730.

${ }^{32}$ These classifications are also given in the Rangjung Yeshe dictionary.

${ }^{33}$ This is an expansion and elaboration of a list first presented in Bell 2006, pp.13-14. The main sources used to compile this list are Samuel 1993, pp.162-163; Tucci 1999, vol.2, pp.717-730; Beyer 1978, pp.293-301; and Kelényi 2003, pp.28-44.

${ }^{34}$ See Gibson 1991.
} 
word is informed by Richard Kohn's understanding, who translates it as 'malefactor/benefactor,' given that they harm or reward seemingly at random. ${ }^{35}$ As an indication of the fluidity of Tibetan spirit types, the Five Sovereign Spirits are also sometimes referred to as capricious spirits.

- Hindering spirits (Tib. bdud; Skt. māra): These spirits are openly malevolent and typically create hindrances, usually to prevent the completion of rituals or success on the path to enlightenment. They are generally black in color and are said to have opposed the Buddhist teachings in their past lives. The associated Sanskrit word refers to the god Māra, the personification of samsāra, who attempted —and ultimately failed - to hinder the enlightenment of the historical Buddha Śākyamuni.

- Barbaric spirits (Tib. srin po; Skt. rākșasa): These fierce and unruly spirits are associated with the Indian demons called rākșasa, the most common demon type encountered in the Indian epics.

- Serpent spirits (Tib. klu; Skt. $n \bar{a} g a$ ): These entities are serpentine deities who generally abide in lakes, rivers, and subterranean realms. They are known to pollute water and hinder the construction of dykes and irrigation works. If angered, they can bring about diseases like leprosy. As their name suggests, they are usually described as having a human head and torso, and a snake tail instead of legs.

- Planetary spirits (tib. $g z a^{\prime}$ ): These spirits personify the planets. Many of these deities have been adopted from Indian astrology, the most popular of which is Rāhula. ${ }^{36}$ Tibetan astrological calculations are an important precursor to most rituals, particularly those pertaining to site consecration, as well as to rites of passage like birthing ceremonies and weddings. Planetary deities must be propitiated and sometimes pacified on these occasions.

- Gods (Tib. lha; Skt. deva): This term is used to refer to celestial beings that inhabit the highest of the six realms of rebirth in Buddhist cosmology; they are generally white in color. However, in Tibetan texts this term's usage is

\footnotetext{
${ }^{35}$ See Kohn 2001, pp.26, 270-271.

${ }^{36}$ See Bailey 2012.
} 
sometimes more generic, referring to supernatural beings overall—ranging from tantric deities to troublesome divinities - much like the word 'god' in English.

- Savage spirits (Tib. $d m u$ ): These spirits are somewhat obscure, though they are considered to be very ancient Tibetan deities. They are extremely savage and noxious in nature, and cause dropsy and drought. There is some mythological connection between this spirit type and a primeval Tibetan clan named $d m u$, which is related to Tibet's early history. ${ }^{37}$

- Transgressor spirits (Tib. dam sri): These are spirits who have violated their vows in past lives and who can inspire individuals to do the same. They are part of a larger class of malevolent spirits called sri.

- Sky spirits (Tib. the'u rang): These are ancient Tibetan spirits of an ambivalent nature that are primarily associated with the sky. They are also harmful and cause death and disease. Erik Haarh explains that these deities were originally the spirits of pre-Buddhist ancestors found in the heavenly spheres. ${ }^{38}$

- Obstructing spirits (Tib. bgegs): These are obstacle-inducing spirits that hinder ritual success, similar to the hindering spirits described above. Other than rituals, these spirits also obstruct spiritual progress more broadly and are often discussed in a pair with human enemies (Tib. dgra).

- Landlord spirits (Tib. sa bdag, gzhi bdag): These spirits are local deities who are tied to a specific area, region, or valley. Often these deities must be propitiated whenever a building is going to be constructed or crops planted on the land that they inhabit. Landlord spirits are the epitome of chthonic Tibetan deities; however, this term is more of a label than a particular type of spirit. Different kinds of spirits can be landlord spirits, and those associated with specific monasteries or temples are also often called 'lords of the sacred place' (Tib. gnas bdag).

- Lords of life (Tib. srog bdag): Like landlord spirits above, this term is more of a title applied to specific deities rather than a general deity type. This label refers to

\footnotetext{
${ }^{37}$ See Tucci 1999, vol.2, pp.713-717. For more on the first Tibetan clans and their mythic descent from a demoness, see Sørensen 1994, pp.125-133.

${ }^{38}$ See Haarh 1969, pp.216-219.
} 
the capacity of some deities to rule over the life of individuals. Members of the Five Sovereign Spirits as well as their retinue are sometimes given this title.

- Enemy-defeating gods (Tib. dgra lha): These spirits are autochthonous Tibetan deities and are often depicted as decorated warriors on horseback. In contrast to the above spirits, I have translated this term as a 'god' because of the distinct lha in the term. Literally, this word would be translated as 'enemy god;' however, this does not make sense since these deities are usually portrayed as allies who defeat one's enemies, hence my gloss. ${ }^{39}$ Todd Gibson makes the compelling argument that these spirits started off as muses. The term was originally spelled sgra lha, meaning 'voice god,' and refers to the spirits that speak into a poet's ear. ${ }^{40}$ Nonetheless, this spirit type has since evolved into a warrior deity and my translation of the term reflects this usage.

- Haughty spirits (Tib. dregs pa): This term does not usually refer to a single spirit but rather to a horde of them. It often generically references the host of Pehar's retinue; however, it just as often applies to other amorphous groupings of worldly and untamed spirits. ${ }^{41}$ The 'eight classes of gods and spirits' mentioned above are also sometimes called the "eight classes of haughty spirits. ${ }^{, 42}$

- Dākinī (Tib. mkha' 'gro ma; lit. "Sky-traversing woman"): These important deities were adopted from Indian tantric cosmology. For this reason, and because the term is already abundantly found in the relevant literature, I will continue with the convention of using the original Sanskrit term rather than an English translation. Dākiniss are a class of ancient female beings, limitless in number, that are found in the entourages of all major Buddhist deities. They fill the intermediate spaces of mandalas, are messengers and inspirers of Buddhist scripture, and often represent pervasive wisdom, which is personified as feminine in Mahāyāna Buddhism. There are different kinds of dākinīs, notably 'flesh-

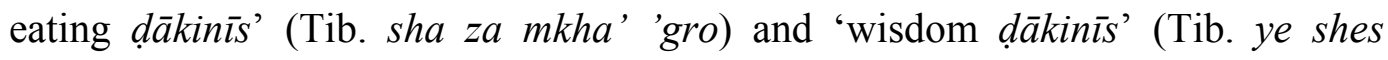
$m k h a$ ' 'gro). The former are demonic worldly beings as fierce as their name

\footnotetext{
${ }^{39}$ See Nebesky-Wojkowitz 1998, pp.318, 337.

${ }^{40}$ See Gibson 1985; see also Nebesky-Wojkowitz 1998, pp.318-340.

${ }^{41}$ See Nebesky-Wojkowitz 1998, pp.253-317.

${ }^{42}$ Tib. dregs pa sde brgyad.
} 
implies, and the latter are enlightened beings representative of transcendence. This dichotomy is akin to that exhibited between mundane and supramundane protector deities. ${ }^{43}$ Dākiniss are involved in all major Tibetan Buddhist ritual processes and are often invoked for protective purposes, especially in order to guard hidden treasure texts until they are revealed. ${ }^{44}$ These deities have a male equivalent (Tib. mkha' 'gro; Skt. $d \bar{a} k a$ ), but they are not nearly as popular in Tibetan Buddhism.

Other spirit types are mentioned in this study, though they will be so rarely encountered that they warrant little discussion here. These include savior spirits (Tib. mgon po), who generally represent forms of the popular Dharma protector Mahākāla or members of his retinue; maternal spirits (Tib. ma mo; Skt. mātrkā), savage goddesses that are also popular in Śaiva Tantrism and Śākta Hinduism; plague spirits (Tib. gnyan), which bring pestilence and cause epidemics; concealed spirits (Tib. sgab 'dre), a type of ghost about which little is known; flesheating spirits (Tib. sha za; Skt. piśáca), which are akin to barbaric spirits in both their characteristics and Indian origin; warrior spirits (Tib. $d p a^{\prime}$ bo; Skt. vira), which represent heroic beings; and mön (Tib. mon), which refers to both a clan that inhabited southern Tibet and to spirits found in Pehar's retinue.

Despite superficial similarities between all these spirits, it is necessary to render their distinctions faithfully in translation in order to reveal significant nuances when they are encountered. As Ronald Davidson has noted, most of these deities were initially indigenous and were later assimilated into Indian Buddhist and tantric classification systems, yet they still retained many of their Tibetan attributes. ${ }^{45}$ Decades earlier, René de Nebesky-Wojkowitz made a similar observation when discussing one of Pehar's emanations named Gyajin (Tib. Brgya byin). This name became the Tibetan translation for the Vedic god Indra, yet references in Tibetan texts to various groupings of brgya byin indicate an autochthonous origin. ${ }^{46}$ Such distinctiveness is often obscured by the constant use of Sanskrit terms as exact analogs. It must

\footnotetext{
${ }^{43}$ For a more detailed discussion of the differences between worldly and enlightened da $\bar{a} k i n \bar{s}$, see Simmer-Brown 2001, pp.53-65.

${ }^{44}$ See Snellgrove 2002, pp.167-168; Beyer 1978, pp.45-47, 399; and Simmer-Brown 2001.

${ }^{45}$ See Davidson 2005, p.217.

${ }^{46}$ See Nebesky-Wojkowitz 1998, pp.99-100.
} 
be remembered that although Buddhist rhetoric treats the above Sanskrit terms as synonymous with their equivalent Tibetan terms, there are significant cultural differences between them.

Geoffrey Samuel relates the above Tibetan pantheon to the Tibetan political system with its lack of centralization and formal bureaucratic structure. ${ }^{47}$ I agree in principle, however, I would add that a better organizational model in Tibetan society that correlates with the above typology of Tibetan spirits is that of the different Tibetan clans. Each spirit type in some sense constitutes a supernatural clan with its own qualities and attributes. They each have their own distinct lands, attire, complexion, and even weaponry. For instance, the lassos of hindering and imperial spirits are the weapons of choice for several deities. Yet there is a degree of fluidity between these spirit groups and there are many instances where they even intermarry. As such, the titles or names of some deities indicate that they are a combination of two spirit 'clans,' and my translations will reflect this when encountered. A spirit that is both a planetary spirit and a hindering spirit, having descended from both clans, will be called a planetary-hindering spirit. The connection between clans and spirits is more overt with the Mön, as noted above; one of Pehar's emanations is even named after this clan. For his part, despite being a sovereign spirit, Pehar's father is a savage spirit and his mother is a serpent spirit. Pehar is also sometimes called a landlord spirit or an enemy-defeating god, though the latter relates to when he takes on the form of this spirit type. In the context of spirits, genealogy and labels are clearly more variable. This clan analogy also does not work with every spirit type listed above. As previously noted, landlord spirits are more of a designation than a type, and $\underline{a} \bar{a} k i n \bar{s} s$ were brought in from South Asian Tantrism. Nevertheless, given how most of these beings and the interactions between them are portrayed, thinking of their differences in terms of clans is useful when encountering them in the literature, which often suggests a cosmology correlative with Tibetan social structures.

The most practical concern with these numerous supernatural agents is that individual gods can become easily conflated. This is because there are multiple deities that have similar names, appearances, and mythologies. During the course of my research, I would often receive conflicting answers when asking monks for the names of certain deity images. That deities are often emanations of other deities adds to the confusion, and can lead to two significant figures being treated interchangeably. This is the case with Pehar and his tertiary emanation Dorjé

\footnotetext{
${ }^{47}$ See Samuel 1993, p.167.
} 
Drakden, whose conflation has important historical and institutional consequences for the deity's cult. This commingling of identities has carried over into scholarly accounts of deities as well. For this reason, I have taken special care to recognize and record individual deities as well as their distinct forms. Regardless of emanational relationship, which can shift over time and vary by sect or author, I define a deity as one possessing a unique name and appearance, and one who is given separate ritual attention. Thus, Pehar is distinct from Dorjé Drakden because they have different names, appearances, and ritual peculiarities. A similar observation can be made with pan-Buddhist deities like Avalokiteśvara ${ }^{48}$ and Hayagrīva. ${ }^{49}$ Though the later is often considered a wrathful emanation of the former, both are still distinct divinities with unique names, forms, and ritual cycles. By contrast, Yangleber ${ }^{50}$ is not an individual deity but simply another name for the protector deity Tsiu Marpo $;^{51}$ they do not have distinct appearances or rituals, and pertinent texts state explicitly that the former is an epithet of the latter. ${ }^{52}$ Likewise, Padmapāni is a common moniker for Avalokiteśvara but does not refer to a distinct deity. However, given the complexity of this Buddhist divinity and the antiquity of his worship, Avalokiteśvara does possess different forms - such as the four-armed ${ }^{53}$ or thousand-armed, thousand-eyed ${ }^{54}$ embodiments - which are not as distinct as emanations but which nonetheless are at the center of their own ritual practices. Pehar also has other forms, in addition to his emanations, and these will be first encountered in chapter 1. Making clear distinctions between different deities and paying attention to appellative, iconographic, and ritualistic distinctions will alleviate confusion and even reveal intriguing changes in deity identities.

\section{Review of the Literature}

The available research on Tibetan deity cults is growing. ${ }^{55}$ Nonetheless, the most comprehensive treatment of Tibetan gods, spirits, and oracles remains Réne de Nebesky-

\footnotetext{
${ }^{48}$ Tib. Spyan ras gzigs.

${ }^{49}$ Tib. Rta mgrin.

${ }^{50}$ Tib. Yang le ber.

${ }^{51}$ Tib. Tsi'u dmar po.

${ }^{52}$ See Bell 2006, pp.147-149.

53 Tib. Phyag bzhi pa; Skt. Caturbhuja.

${ }^{54}$ Tib. Phyag stong spyan stong; Skt. Sahasrabhuja-sahasranetra.

55 See Achard 2002, Bailey 2012, Bell 2006, Bellezza 1997, Blondeau 1998, Dargyay 1985, Dreyfus 1998, Gibson 1985 and 1991, Heller 1988, 1992a, 1992b, 2003, 2005, and 2006, Jovic 2010, Karmay 1998b, 1998c, 1998d, 1998e,
} 
Wojkowitz's Oracles and Demons of Tibet: the Cult and Iconography of the Tibetan Protective Deities, first published in $1956 .^{56}$ Nebesky-Wojkowitz's work has a number of limitations, the primary one being that its approach is predominantly synchronic with rare instances of historical awareness. Most of the book's chapters concentrate on a deity or group of deities and present their iconography and mythic origins, citing or quoting directly from the numerous Tibetan texts listed at the end of the work. This is the richest content in the book, providing as it does impressive details about numerous Tibetan deities previously unknown in modern scholarship. However, the texts cited in these descriptions are usually removed from their historical and institutional contexts, and only some are tied to specific authors and time periods. Because of this, deities are presented in a static fashion; they are given little historic placement and the evolution and shifting composition of their cults is not discussed. While Nebesky-Wojkowitz provides a number of engrossing vignettes that hint at historical engagement with these deities, ${ }^{57}$ they are few and far between. Despite this and other minor deficits, Oracles and Demons of Tibet continues to be the foundational resource for the study of Tibetan deity cults.

The first work to examine a specific spirit type in detail is Todd Gibson's "From btsanpo to btsan: The demonization of the Tibetan sacral kingship." ${ }^{, 58}$ This dissertation explores the early development of imperial spirits and proposes that they evolved from the sacred nature of Tibetan kings. The first monograph to give sustained attention to a specific deity cult is Amy Heller's doctoral thesis "Etude sur le développement de l'iconographie et du culte de Beg-tse, divinité protectrice tibétaine." In this work, Heller examines the historical origins and textual development of the cult of Begtse ${ }^{59}$ particularly as it has developed within the lineage of the Dalai Lamas. Both works have provided structural and contextual inspiration for this study.

Certain aspects of Pehar, as well as his cult at Nechung, have been the focus of a few significant works of scholarship. Nebesky-Wojkowitz's Oracles and Demons of Tibet was the first work to provide consistent details on the deity, since one chapter of the book is dedicated to Pehar and another to the Nechung Oracle. ${ }^{60}$ The chapter on Pehar details the deity's basic

1998f, and 1998g, Kelényi 2003, Kelley 1993, Kohn 2001, Lohia 1994, McCune 2007, Muldowney 2011, Mumford 1989, Stuart 1995, and Willson and Brauen 2000.

${ }^{56}$ See Nebesky-Wojkowitz 1998.

${ }^{57}$ For some specific examples, see Nebesky-Wojkowitz 1998, pp.104-106 (Pe har), 134-136 (Rdo rje shugs ldan), 144 (Nam mkha' sbar 'dzin), 162-165 (Phying dkar ba), 170 (Tsi'u dmar po), 233-234 (Drung yig chen mo), 239241 ('Dam srang rgyal po), and particularly 449-454 (the Gnas chung oracle).

${ }^{58}$ See Gibson 1991.

${ }^{59} \mathrm{Tib}$. Beg tse.

${ }^{60}$ See Nebesky-Wojkowitz 1998, pp.94-133 and 444-454, respectively. 
mythos and the iconography of the Five Sovereign Spirits from divergent sources. The chapter on the Nechung Oracle discusses the general attributes of Nechung and the monastery's oracle, and offers some contemporary historical information. Both chapters are a necessary starting point for exploring the rise of Nechung's cult, though they lack a detailed examination of the deity's ritual and historical development.

Shortly after Nebesky-Wojkowitz's tome was published, Siegbert Hummel wrote a brief obscure article on Pehar. ${ }^{61}$ Published in 1962, this essay is primarily concerned with understanding Pehar's pre-Buddhist central Asian origins by searching for linguistic clues in the deity's various names. Hummel's text relies on Nebesky-Wojkowitz's work, as well as other scholarship of the time, in an attempt to build on prior arguments, but he does little to further the research. The article is valuable only for comprehensiveness; it adds little to research on Pehar's early history and contributes nothing to understanding the deity's seventeenth-century evolution.

Ariane Macdonald was the first to give a historical foundation to Pehar's cult prior to the seventeenth century. Her two articles, "Le culte de Pehar et de Ci'u dmar-po dans la tradition écrite et orale. Histoire du monastère de Gnas-chung et de ses médiums (suite)" and "Les rivalités politiques et religieuses centrées sur Samye au XVIe siècle. La lignée spirituelle du Ve Dalai-Lama dans la littérature, dans l'histoire, et dans l'art," explore the sixteenth-century political and ritual circumstances surrounding the cult of Pehar at Samyé Monastery, his first residence in Tibet. ${ }^{62}$ These discussions also concern the other major protector of Samyé, Tsiu Marpo, whose cult came to prominence in the sixteenth century. Macdonald's one notable error is that she claims Tsiu Marpo and Pehar are the same deity, which is far from true, as will be substantially demonstrated below. ${ }^{63}$ The current study could be perceived as an extensive continuation of the work begun by Macdonald.

Dan Martin also provides two complementary articles that discuss Pehar: "The Star King and the Four Children of Pehar: Popular Religious Movements of 11th-to 12th-century Tibet" and "Lay Religious Movements in 11th- and 12th-Century Tibet: A Survey of Sources." essays primarily concern a controversial eleventh-century religious leader named Sangyé Kargyel, ${ }^{65}$ who was considered a manifestation of Pehar and who is presented in a mischievous

\footnotetext{
${ }^{61}$ See Hummel 1962.

${ }^{62}$ See Macdonald 1978a and 1978b.

${ }^{63}$ See Macdonald 1978a, p.1144.

${ }^{64}$ See Martin 1996a and 1996b.

65 Tib. Sangs rgyas skar rgyal.
} 
and even dangerous light in the accounts Martin discusses. These erudite articles look more broadly at the nature of how successful lineages develop from their origins into institutions - and how unsuccessful ones founder shortly after their origination. However, they also provide glimpses into how Pehar was perceived centuries prior to his inclusion in the lineage of the Dalai Lamas. Martin's work thus offers a useful background for contextualizing the deity's later evolution.

Lin Shen-yu's article "Pehar: A Historical Survey," published in Revue d'Etudes Tibétaines, is an excellent complement to Martin's work. Originally published in Chinese in a Taiwanese journal, ${ }^{66}$ Lin's essay focuses specifically on the development of Pehar's characterization, from his nebulous beginnings to the sixteenth century. She also offers a brief examination of the Fifth Dalai Lama's depiction of the deity, as well as that of eighteenth- and nineteenth-century Tibetan scholars. This essay's main limitation is that it looks exclusively at representations of the deity in historical works and does not include ritual texts. Regardless, Lin's article is a very useful summary of Pehar's changing identities through the centuries.

A 1992 issue of the Tibetan Bulletin, the English-language journal of the Central Tibetan Administration published in Dharamsala, focused on Nechung Monastery. ${ }^{67}$ This attention was due to 1992 being a monkey year in Tibetan calendrics, which is significant for the special holy day called Nechung Monkey Month, to be discussed in chapter 2. This journal issue discusses the Monkey Month, as well as the history of Nechung Monastery and its oracle. The issue also includes an interview with the current Nechung medium, the Venerable Tupten Ngödrup. Much of the information given in this work was provided by the Venerable Tupten Püntsok, the former vajra master of Nechung Monastery in Dharamsala, who would later write a more extensive history of Nechung in Tibetan, discussed below. Although the information this work presents is brief, it is an invaluable summary of key points related to Nechung's history.

Franco Ricca's Il Tempio Oracolare di gNas-chun: Gli Dei del Tibet più Magico e Segreto is the first book to give serious attention to Nechung Monastery. ${ }^{68}$ This work primarily concerns the architectural and iconographic qualities of the monastery, making it an indispensible resource for researching Nechung. The first chapter gives Pehar's basic mythology and describes the Nechung Oracle, while the second chapter offers historical background

\footnotetext{
${ }^{66}$ See Lin 2009 and 2010.

${ }^{67}$ See Tsepak Rinzin 1992.

${ }^{68}$ See Ricca 1999.
} 
pertaining to the Fifth Dalai Lama. The remaining three chapters concern Nechung Monastery's physical structure and the significance of its numerous murals. The book's architectural diagrams and floor plans are especially valuable, as are the accompanying photographs of murals and the extensive lists of deities they represent. The book's one weakness is that it relies solely on secondary materials, basing its historical arguments on pre-existing research rather than using primary Tibetan documents to make new observations. Nevertheless, any study of Nechung Monastery must begin with Ricca's excellent contribution.

Throughout the first decade of this century, anthropologist Urmila Nair has been examining Nechung's rituals in exile at the Nechung Monastery reestablished in Dharamsala. Nair's master's thesis provides a sociological examination of Pehar's ontological status based on ethnographic data. ${ }^{69}$ Moreover, her dissertation explores Nechung's contemporary ritual performance as an example of the politics of spectacle - the contextual representation of concrete acts involving specific discourses and mediating specific epistemologies as invoked by certain actors. $^{70}$ Although Nair's portrayal of Nechung's history in Tibet is compressed and based solely on Nebesky-Wojkowitz's account, ${ }^{71}$ her work offers a vivid portrait of the monastery in Dharamsala and presents an extensive discussion of its ritual practices. Using the Nechung rites as a case study, Nair offers a vigorous theoretical exploration of Tibetan ritual performance through ethnographic observation. Her work is the first true study of the monastery's ritual repertoire, and the current work will act as a complement by examining these rites as historical documents that reveal the evolution of the Nechung cult.

There are also several modern works of Tibetan-language scholarship that serve as useful resources for understanding the cult of Pehar and the deity's place at Nechung in particular. The first work is Ladrang Kalsang's Bod skyong srung ma khag gi lo rgyud, which was translated into English and entitled the Guardian Deities of Tibet. This book concerns the major Tibetan Buddhist protector deities, particularly those propitiated by the Dalai Lama's government. It is a much simpler version of Lelung Jedrung Zhepé Dorjé's eighteenth-century Ocean of OathBound Guardians of the Teachings, which will be discussed in chapter 1. The original Tibetan

\footnotetext{
${ }^{69}$ See Nair 2004.

${ }_{71}^{70}$ See Nair 2010, pp.30-31.

${ }^{71}$ Nair incorrectly states that Nebesky-Wojkowitz's description of the original Nechung Monastery was based on his travels there; see ibid, p.42. Due to the political instability at the time, Nebesky-Wojkowitz was unable to visit Lhasa and conducted the bulk of his research in Kalimpong, West Bengal, India; see Nebesky-Wojkowitz 1998, pp.VII-VIII. Nebesky-Wojkowitz's description of Nechung is based on an oral account he received from the son of a former Nechung Oracle; see ibid, p.445.
} 
edition of Ladrang Kalsang's book cites its sources while the English translation does not. The chapter on Pehar summarizes the key narrative elements of the deity's past lives, and the translation is the first English source to do so. ${ }^{72}$ However, this summary rehashes content quoted in much greater detail within the Fifth Dalai Lama's writings and Lelung Jedrung Zhepé Dorjé's text, both of which will be further discussed below.

In the mid-1980s, in the wake of the Cultural Revolution, a team of Tibetan scholars did an extensive survey of Drepung Monastery for the purposes of preservation. This included transcribing the registers of the monastery's colleges, as well as documenting their histories, abbatial lineages, and sacred contents. ${ }^{73}$ Nechung Monastery was included in this endeavor due to its close historical ties with, and physical proximity to, Drepung. Many of Nechung's historical details, as well as its monastic registers, were recorded by a scholar named Lingön Padma Kelsang. ${ }^{74}$ This information on Nechung, sans the contents of the registers, was first published in a 1988 edition of the Tibetan magazine Bod ljongs nang bstan. ${ }^{75}$ This material was subsequently republished in 2009-including Tibetan transcriptions of the monastery's registers - by the Tibetan Academy of Social Sciences. ${ }^{76}$ This is the first modern work in Tibetan to extensively discuss Nechung Monastery, its contents, and its deity cult.

Meanwhile, since the turn of the millennium there has been a steady accumulation of publications in Dharamsala concerning Nechung Monastery, often put out by the monastery itself. In 2004 two publications were produced, the first of which detailed Pehar's relationship to the Dalai Lamas. ${ }^{77}$ The second publication explored the historical significance of Nechung Monkey Month, as well as the monastery's relationship with the nineteenth-to-twentieth-century treasure-revealer Lerap Lingpa ${ }^{78}$ who will be discussed further in chapter 2 . The first text is at heart just a chain of quotes from the biographies of each of the Dalai Lamas-from the second to the thirteenth incarnation - concerning Pehar or the Nechung Oracle; for this reason it is a valuable reference. The second text is likewise a collection of quotes drawn from the writings of

\footnotetext{
${ }^{72}$ See Bla brang skal bzang 1996, pp.74-87, and Ladrang Kalsang 1996, pp.77-84. The Tibetan edition labels this chapter "King Pehar" (Tib. Pe har rgyal po), while the English edition labels it "Nechung Dorje Dregden (gnas chung rdo rje dregs [sic] ldan)."

${ }^{73}$ See Tibetan Academy of Social Sciences 2009. I would like to thank Tsering Gyalbo for drawing my attention to this work and for generously providing me with a copy.

${ }_{75}^{74}$ Gling dbon Pad ma skal bzang.

${ }^{75}$ See Padma skal bzang 1988. I would like to thank Amy Heller for drawing my attention to this work and for graciously providing me with a copy.

${ }^{76}$ See Tibetan Academy of Social Sciences 2009, pp.439-498; see also Appendix III.

${ }^{77}$ See Department of Religion and Culture 2004.

${ }^{78}$ See Nechung Monastery 2004.
} 
the Fifth Dalai Lama, his regent Sangyé Gyatso, and Lelung Jedrung Zhepé Dorjé, and it is equally useful.

Much of the material from both of these works, as well as the Tibetan Bulletin issue noted above, were later included in the history of Nechung composed and compiled by the Venerable Tupten Püntsok. ${ }^{79}$ Published in 2007, this book is entitled Gnas chung rdo rje sgra dbyangs gling gi chos 'byung kun gsal chu shel dbang po, an English translation of which would be the All-Illuminating Moon: A Dharma History of Nechung Dorjé Drayangling. ${ }^{80}$ This work provides a history of both the Nechung Monastery in Tibet and the one established in Dharamsala, making it a uniquely comprehensive text. Tupten Püntsok's book is also the first to offer a lengthy history of the Nechung Oracle, which ends with a useful list of all known mediums. By citing its sources faithfully, the All-Illuminating Moon is an intriguing blend of traditional Tibetan historiography and modern scholastic practices. Alongside Lingön Padma Kelsang's work, this book presents a standard account of Nechung Monastery that must be consulted before any earnest attempt is made to understand the historical milestones of the monastery's cult.

The final Tibetan source that merits mentioning is Mikmar Tsering's Gnas chung dgon (乃琼寺): Dbang drag rol pa'i dga' tshal gnas chung rdo rje sgra dbyangs gling gi dkar chag mthong ba don ldan, an English translation of which would be Nechung Monastery: $A$ Meaningful-to-Behold Register of Nechung Dorjé Drayangling, the Pleasant Grove where Subjugation and Destruction Manifest. ${ }^{81}$ This is a shorter history than the works produced by Lingön Padma Kelsang and Tupten Püntsok; however, it is distinct for being a bilingual book that presents the details of Nechung's history in Tibetan and Chinese. Published in Lhasa, this work reiterates a lot of the material in Lingön Padma Kelsang's text, though it has additional content culled personally by the author. Mikmar Tsering also makes more observations than Lingön Padma Kelsang, whose main goal was to record the monastery's historical details not analyze them. Though he does not include specific page numbers, Mikmar Tsering cites the sources he uses throughout his book and provides a bibliography.

\footnotetext{
${ }^{79}$ See Thub bstan phun tshogs 2007.

${ }^{80} \mathrm{I}$ am grateful to the Venerable Yeshé Söpa, head monk at Nechung Monastery, Dharamsala, for providing me with copies of this book.

${ }^{81}$ See Mig dmar tshe ring 2010.
} 
All of these Tibetan sources share the same deficiency. While they provide important quotes, useful descriptions, and helpful photographs, as well as a great deal of standard historical information, these books lack a detailed analysis of their contents. Most of these works say the same thing, sometimes word for word, and offer little introspection into historical and textual contradictions or the circumstances behind Nechung's cultic development. All of the scholarship discussed above is limited in some fashion in its approach to Pehar's cult and Nechung Monastery's historical growth. The goal of this study is to fill in the lacunae found in the above works by providing a more thorough analysis of the texts that they discuss-as well as some texts that have not yet been discussed - in order to present a more complete history of Pehar and Nechung Monastery's mythic origins, ritual evolution, and institutional development.

\section{Theoretical Position and Methodology}

Theoretical foundations are currently lacking in Tibetan Studies with regards to research on deity cults. For this reason, my approach draws from several works on Chinese religions that have provided useful templates for understanding the growth of deity cults through diachronic and synchronic models. Richard von Glahn, in his book Sinister Way, offers a rich and compelling history of how the cult of the deity Wutong (Ch. 五通) - a mischievous spirit not unlike Pehar-grew in popularity. ${ }^{82}$ This deity's cult flourished from the Song Dynasty to the Qing Dynasty by means of institutional legitimation working on multiple levels of society, including imperial recognition. Using a different but not necessarily opposing approach, Robert Hymes, in his book Way and Byway, illustrates how Daoist deities act as composite figures possessing multiple aspects in order to appeal simultaneously to various social strata. In particular, he examines the cult of the Three Lords (Ch. 三君) at Hua-kai Mountain, and how the bureaucratic characterization of these deities interacted with local representations. Hymes asks an important question, 'why these deities and not others?' when addressing the rise of their cult, $^{83}$ a line of questioning that has ultimately informed my own approach. Finally, Paul Katz's Demon Hordes and Burning Boats offers the language needed to articulate the processes by which deity cults expand. In examining the cult of Marshal Wen (Ch. 溫元師) in Zhejiang

\footnotetext{
${ }^{82}$ See von Glahn 2004.

${ }^{83}$ See Hymes 2002, pp.121-137.
} 
province, Katz explains that such cults arise out of a 'cogeneration' of multiple narratives and a 'reverberation' of such narratives through multiple social groups. ${ }^{84} \mathrm{I}$ apply the language of this last work in chapter 1 specifically.

I have also found inspiration in the Accretion Theory developed by E. Bruce and A. Taeko Brooks in their book The Original Analects. ${ }^{85}$ In this socio-historical translation of the Analects of Confucius, the authors use linguistic, historical, and archeological evidence to show that the contents of this monolithic work actually developed over a period of 250 years. Their accretion theory has influenced my understanding of Tibetan Buddhist ritual accretion in chapter 2. My analysis of ritual has been further edified by Jonathan Z. Smith's To Take Place. ${ }^{86}$ In this study, Smith argues that the act of ritual is dependent on where it takes place, and that rituals tied to place can be transferred to new locations. This understanding is relevant in chapter 3, when discussing ritual hegemony, and is also pertinent to the reestablishment of Nechung Monastery in India. In my conclusion, I draw on Max Weber's classic notion of routinized charisma, which is applicable to the reincarnating lineage of the Dalai Lamas, the series of human mediums that become periodically possessed by Pehar, and even the institutional mythos that the Dalai Lama's government came to embody. Thus, I have structured the present study using a combination of Chinese models of divinity and broader theoretical frameworks.

My methodological approach is primarily historical, with a secondary ethnographic focus. I have examined and translated strategically selected historical and ritual texts that concern Pehar ranging from the twelfth century to the present. The most significant of these texts make up the appendices, such as core Nechung rituals, the Nechung monastic register, and an important hagiography. Other materials include the Fifth Dalai Lama's autobiography and collected works, the writings of the Great Fifth's regent Sangyé Gyatso, and Lelung Jedrung Zhepé Dorjé's Ocean of Oath-Bound Guardians of the Teachings. These texts help place Pehar within the institutional and political history of the late seventeenth century, especially as it was presented by the Fifth Dalai Lama and Sangyé Gyatso, and offer important insights into the deity's narrative and liturgical identity as it developed.

I have also collected ethnographic data from interviews and discussions with Tibetan monks, scholars, and lay individuals, which provide valuable information on the oral traditions

\footnotetext{
${ }^{84}$ See Katz 1995.

${ }^{85}$ See Brooks and Brooks 1998.

${ }^{86}$ See Smith 1987.
} 
and beliefs surrounding Pehar today. This information will be used to illustrate that the continued worship of deities like Pehar is rooted in historical antecedents - that the past very much informs the present. I conducted my fieldwork on site in Lhasa from December 2010 to January 2011, and again from August 2011 to January 2012. Supplemental material was gathered on site in Dharamsala, Himachal Pradesh, India from June to August 2011 and again from February to March 2012. Although this work focuses on the historical Nechung Monastery near Lhasa, there are occasionally discussions of the Nechung Monastery reestablished in Dharamsala in order to provide information on the contemporary context. For this reason, I will refer to the historical monastery as Lhasa Nechung and the monastery established in India as Dhasa Nechung. ${ }^{87}$

In a recently published article entitled "Start Saying 'White,' Stop Saying 'Western': Transforming the Dominant Vocabulary of Tibet Studies," anthropologist C. Michelle Kleisath argues that white scholars should begin to acknowledge the dominant position that we hold in Tibetan Studies and in most area studies more broadly. Kleisath explains that broaching "the normalization of whiteness in scholarship in English on Tibet" will produce more honest dialogue on white positionality in the field, which will help scholars and their audience locate our research more accurately. ${ }^{88}$ A key characteristic of whiteness, according to race theorists, is that it is often hidden or treated as the default position in scholarship. This erasure, coupled with the invisibility that designations like "Western" provide white racial identity, prevents a critical race consciousness from being reflexively adopted in Tibetan Studies.

I mention this in an effort to disclose my own position as a white scholar, which I recognize has granted me certain advantages in the course of my fieldwork. For instance, monks at various chapels and monasteries connected to Nechung Monastery, which will be discussed in chapter 3, graciously allowed me to photograph manuscripts of their center's liturgical manuals in their entirety. This surprised a Tibetan friend of mine and fellow scholar, who revealed that most monks are not so generous toward him. Moreover, I am aware that while many of the Tibetans I talk with in Tibet constantly live under precarious circumstances, my nationality allows me to come into Tibet and leave fairly comfortably. Concomitant with this is my race, which affords me certain advantages while in country. In recognizing this situation, I am

\footnotetext{
${ }^{87}$ This is the abbreviation I often heard in Dharamsala. It is in accord with the Tibetan penchant for contracting four-syllable words and names by combining the first and third syllable; thus Dharamsala becomes Dhasa.

${ }^{88}$ Kleisath 2013, p.23.
} 
emphasizing that the current work and its arguments, presented as they are in English and intended primarily for Euro-American audiences - with the explicit understanding that it will be made available to Tibetan and Chinese audiences - is constructed in a manner that is inextricably tied to the racial and historical legacy in which I was raised. Just as the veneration of Pehar is historically rooted, so too is the manner in which I present the current research on that veneration.

Connected with this is the issue of my being a non-practitioner of Buddhism, which has elicited different reactions during my attempts to access certain texts. For instance, the foundational ritual manuscript the White Crystal Rosary was considered too secret to show me as someone uninitiated in the practice. ${ }^{89}$ Nevertheless, monks at both Lhasa and Dhasa Nechungs were generous enough to reveal to me, and allow me to photograph, the title page and colophon of the text, which has provided important information on its provenance. Other texts were not so secretive, and disagreement over which texts these were seemed to fall mainly along a geographic line. In my experience, monks in Lhasa were much more amenable to my requests than those in Dharamsala. This understanding was shared by a Swiss Buddhist monk named Lobsang Nyima, who took his vows at a Tibetan Buddhist monastery in India, but who was living and studying in Lhasa while I was there conducting fieldwork. He made a particularly cogent observation about the contextual nature of secrecy and the esoteric aspects of Tibetan Buddhism both in Tibet and in exile.

After the mass exodus of Tibetans in the 1950s, and during the Cultural Revolution a decade later, cultural conservation took on an especially pressing importance. One important reaction to this was E. Gene Smith's textual preservation activities through the Library of Congress's Tibetan Text Publication Project (PL480) in the 1960s and 1970s; the Tibetan Buddhist Resource Center (TBRC) was the ultimate result of this activity. The Tibet Heritage Fund has likewise been an active promoter of Tibetan heritage conservation in recent decades. Given the unstable position religious practices hold in Tibetan cultural areas of China today, such safeguarding activities have continued to be necessary. Nonetheless, cultural conservation has come to be interpreted differently in Tibet and in exiled Tibetan communities, particularly in India. In Tibet, conservation has come to mean being relatively open to outsiders photographing images and scanning texts in order that they may be taken safely outside of Tibet. In exile, such as in Dharamsala or south India, there is less government intervention, so Tibetans have more

\footnotetext{
${ }^{89}$ This work and its significance will be discussed in greater detail in chapter 1.
} 
agency and control over their own practices. Thus, conservation in many instances means preserving the traditional esoteric nature of such practices, placing certain texts and images off limits to outsiders. There is no strong division in this attitude, and there are exceptions in both milieus, but this appears to be the general reaction to modern circumstances in and outside of Tibet when confronted with Tibetan concerns for secrecy. ${ }^{90}$ Regardless, this is an exercise in how the Tibetan Buddhist rhetoric of esotericism must be viewed within specific historical and cultural circumstances, and how the observer's own cultural position plays an important part.

\section{Chapter Outline}

The current work is divided into six sections - the present introduction, three thematic chapters, a conclusion, and the appendices. Chapter 1 concerns the iconography and mythic origins of the protector deity Pehar and the Five Sovereign Spirits overall. In particular, this chapter explores Pehar's mythic narrative as it is given in the Nechung Register, composed by the Great Fifth and Regent Sangyé Gyatso. I rely on seventeenth- and eighteenth-century texts to reconstruct a detailed presentation of how the Fifth Dalai Lama understood Pehar's mythic narrative, as well as how he negotiated with divergent accounts to produce a standard origin story. This standardization had important consequences, since it determined the character of Nechung Monastery and the state cult of the Five Sovereign Spirits from the time of the Great Fifth onward. The chapter will also examine Pehar's relationship to other deities, which will set the stage for symbolic networks between divinities and sacred sites that will be encountered several times throughout this work. Chapter 1 concludes by examining Pehar's ambiguous ontological status. Despite the deity's popularity among the Great Fifth and his cohorts, his large-scale adoption was not a foregone conclusion since some leaders, and even members of the Dalai Lama's administration, felt ambivalent toward Pehar and his wrathful power.

Chapter 2 centers on Nechung Monastery's ritual pedigree. The chapter begins with a general look at the monastery's ritual calendar before concentrating on Nechung's liturgical repertoire. The focus of this examination is further contracted to the two central rituals of the monastery, which have been practiced at Nechung since the seventeenth century. These rituals are also examined in tandem with a collection of brief rites composed by the Second Dalai Lama.

\footnotetext{
${ }^{90}$ Personal correspondence, Lobsang Nyima, Lhasa; January 6, 2012.
} 
Together these three practice manuals illustrate a vivid ritual accretion over several centuries and involving major lineage masters. The chapter ends by taking a closer look at the deity Dorjé Drakden, a tertiary emanation of Pehar with humble beginnings, but whose importance grew to challenge and overtake even Pehar's centrality. Despite being a minor form of Pehar, Dorjé Drakden became more important at Nechung Monastery around the turn of the eighteenth century. The reasons for this shift are still unclear since the relevant literature does not discuss it. Nonetheless, I suggest that it began gradually with Dorjé Drakden possessing the Nechung Oracle more and more over time. With Pehar speaking through the oracle less, Dorjé Drakden grew in influence through his prophecies, advice, and ritual requests. This deity became more actively engaged in Tibetan history from the early eighteenth century onward and eventually superseded Pehar as the central deity of Nechung and its satellites. Now the central statue of Nechung Monastery is, tellingly, a statue of the Nechung Oracle possessed by Dorjé Drakden, and when Tibetans mention the deity of Nechung they are usually referring to the latter rather than to Pehar. ${ }^{91}$

Having discussed Nechung's deities and rituals, chapter 3 examines the monastery itself. The chapter starts with a structural and symbolic exploration of Nechung's architecture and then addresses the monastery's often problematic historical evolution. The centerpiece of the chapter is the Nechung Oracle himself, whose vague beginnings give way to institutionalization and state advancement. While the oracle has had ties to the Dalai Lamas since the sixteenth century, he did not become an important part of the Dalai Lama's government until the seventeenth century. The Nechung Oracle has acted as a clairvoyant advisor to the Dalai Lama and his cabinet since then and continues to do so today. The chapter concludes with an analysis of several monasteries and chapels that have institutional connections to Nechung Monastery, and which form a larger ritual hegemony that reinforces the dominance of the state cult in Lhasa. The exact dates for when each of these sacred centers was converted to the cult of Nechung are currently unknown; however, it appears that some were changed in the seventeenth century in tandem with Nechung while others were absorbed in later centuries.

The conclusion relates the above observations to the Fifth Dalai Lama and his grand enterprise for legitimating his nascent government, in part through the promotion of the Nechung cult. This final section will answer in greater detail the question of why the Great Fifth gave so

\footnotetext{
${ }^{91}$ Some confusion still exists even among Tibetans, though, and images of Dorjé Drakden will occasionally be called or titled Pehar.
} 
much attention to Pehar and chose him to be an important part of his state-building program over and above other available deities. The conclusion's focus will expand out to the Dalai Lama's larger network of individuals who aided him in building institutions through their charismatic power. The mythic, ritual, and institutional networks that these individuals constructed together or elaborated upon had significant religious and cultural reverberations in the centuries that followed. The conclusion ends with a modern anecdote that illustrates how such reverberations have continued to the present day.

Following the conclusion there are four appendices. The first appendix is an outline of the Nechung Liturgy, the ritual corpus for Nechung Monastery collected and organized in 1845. The second appendix consists of three sub-appendices, each providing a Tibetan transcription and English translation of the central rituals important to Nechung. The first sub-appendix is the Ten-Chapter Sädhana, a treasure text 'rediscovered' by the twelfth-century treasure-revealer Nyangrel Nyima Özer; the second consists of six selections from the Offerings and Praises composed in the sixteenth century by the Second Dalai Lama; and the third is the Adamantine Melody composed in the seventeenth century by the Fifth Dalai Lama. These works are the focus of chapter 2. The third appendix is a Tibetan transcription and English translation of the Nechung Register. This work was coauthored in 1682 by the Fifth Dalai Lama and Sangyé Gyatso, and was inscribed on the southern wall of Nechung Monastery's courtyard. As the most important work to detail Nechung's mythic origins and renovation, it will be discussed in chapters 1 and 3. The final appendix is a Tibetan transcription and manuscript facsimile of the Hagiography of Jokpa Jangchup Penden. This figure is significant to Nechung because he founded the first major incarnation of the monastery. For this reason, the contents of this text will likewise be explored in chapters 1 and 3.

As the above outline indicates, this work is an unfolding structure. My approach begins with the deity, continues with the means for invoking the deity, finalizes with the abode of the deity, and concludes with those who began to systematically invoke the deity and why. Primary materials that support the arguments for each chapter are then appended at the end. This layout is not so different from how the character of a Tibetan Buddhist monastery is constructed; it has a founding narrative, ritual framework, and institutional casings, and is established and supported by practitioners and patrons. As with such sacred buildings, and Nechung Monastery in particular, this architecture of words must therefore begin with an infrastructure of myth. 


\section{Chapter 1: Nechung's Mythic Narrative}

The Fifth Dalai Lama's new state was born in violence. This was done in the middle of the seventeenth century through the military conquest of Tibet by Güshi Khan's Mongolian forces, which were patrons of the Gelukpa and of the Fifth Dalai Lama in particular. Pehar, who was revered and endorsed by the Great Fifth, also has a Mongolian background as will be shown below. As a wrathful deity, Pehar embodied and ritually participated in state violence in order to maintain the Dalai Lama's government. Like Güshi Khan's army, Pehar dealt in violence so that the Great Fifth would not have to.

In order to convert the preexisting regional cult at Nechung Monastery into a state cult, the Fifth Dalai Lama standardized Pehar's mythology, augmented his ritual corpus, promoted the Nechung Oracle, and commissioned the monastery's renovation and expansion. This was an ongoing process throughout the latter half of the seventeenth century. For this development to succeed, it was important for the Great Fifth to clarify who Pehar was as a deity. This would shape all ritual engagement with Pehar at Nechung and provide the mythic and historical gravity needed to validate his worship.

In 1682, when Nechung's expansion was completed and a temporary consecration was conducted, a register was inscribed on the southern wall of the monastery's courtyard that described Pehar's tantric significance and mythology, as well as the materials and workers involved in the expansion effort. This Nechung Register (see Appendix III), written by both the Fifth Dalai Lama and Regent Sangyé Gyatso, also lists the numerous texts pertaining to Pehar and the Five Sovereign Spirits that the Great Fifth had at his disposal. ${ }^{1}$ Only a handful of these works are still extant, and some of them are either inaccessible or exist only in fragments. Nevertheless, it is possible from the materials we do have to construct a vivid account of Pehar's mythos as the Fifth Dalai Lama understood it and as he presented it at Nechung Monastery. Moreover, there are alternative and even conflicting accounts of Pehar's origins to which the Great Fifth had equal access, meaning that he had to negotiate with several texts and narrative strands before developing the account he publicized. Through a comparison of these accounts, it is apparent that the Fifth Dalai Lama chose the narrative he did because it presents Pehar equally

\footnotetext{
${ }^{1}$ See Appendix III, p.569.
} 
as a Tibetan deity and as a Buddhist deity. This makes Pehar accessible within a Tibetan milieu while legitimating his worship as a Buddhist divinity.

Both the official Nechung account codified by the Great Fifth and some of the alternative accounts that he did not use are offered in the present chapter. I have directly translated the pertinent texts and fragments in a linear narrative fashion in order to keep as close to the original understanding and significance of these mythologies as possible. These accounts are followed by a discussion of the deities to which Pehar has strong mythic, ritual, and institutional ties. Such connections illustrate the constant interaction that exists between different deities and their cults. However, before we approach Pehar mythically we must first visually introduce the deity and the rest of the Five Sovereign Spirits.

\section{The Five Sovereign Spirits}

Pehar is a complicated god. He has many names, many forms, and many lives, and each of these has complex variations. This is not surprising given that the deity's cult can be traced back nearly a millennium. While it is beyond the scope of this work to give a detailed history of Pehar's cult prior to the seventeenth century, ${ }^{2}$ it is worth establishing basic information about his names and forms before discussing his greater mythic narrative. In particular, it is necessary to understand how Pehar was perceived as a deity and as the leader of a group of deities in the second half of the seventeenth century, especially by the Fifth Dalai Lama, since this conception of the deity is what was established at Nechung at the time of its renovation.

Pehar's name is not overtly Tibetan in etymology as are the names of many other Tibetan deities. $^{3}$ That there are also several Tibetan forms of his name adds to the difficulty of understanding its meaning. Drawing from just the texts cited in this study, we find numerous different Tibetan spellings for Pehar: pe $d k a r,{ }^{4}$ pe $k a r,{ }^{5}$ pe ha $r a,{ }^{6}$ pai ha $r a,{ }^{7}$ dpe har, ${ }^{8}$ and pe

\footnotetext{
${ }^{2}$ For a useful overview of Pehar's history prior to the seventeenth century, see Lin 2010 (see Lin 2009 for the original Chinese article). See also Martin 1996b.

${ }^{3}$ A quick perusal of the table of contents in René de Nebesky-Wojkowitz's Oracles and Demons of Tibet reveals a number of Tibetan deity names that can be translated easily enough; e.g., Dpal ldan tha mo (lit. "Glorious Goddess"), Rdo rje legs pa (lit. "Excellent Vajra"), and Tsi'u dmar po (lit. "Red Heart").

${ }^{4}$ Nyi ma 'od zer 1976-1980, p.309.5.

${ }^{5}$ Tā la'i bla ma 05 1991-1995, vol. 5, p.27.1; see also Appendix III, passim.

${ }^{6}$ Sle lung rje drung 1979, p.36.7; Sle lung rje drung 1976, p.369.3; DL511:228.4.

${ }^{7}$ Sle lung rje drung 1978, p.2.1.

${ }^{8}$ BPLC:216.3.
} 
har. ${ }^{9}$ The fact that many of these variations occur within different editions of the same text suggests that they are primarily due to scribal or regional differences. ${ }^{10}$ For the sake of simplicity and uniformity, I will use the most common phonetic rendering of this deity's name, Pehar, rather than other potential transcriptions (e.g., Pekar, Pehara). Despite these inconsistencies, the meaning of the name has been recognized by scholars since the midtwentieth century to be the Tibetan transliteration of the Sanskrit vihära, meaning 'monastery., 11 Samten Karmay offers the most convincing argument behind this name's origin, ${ }^{12}$ explaining that the earliest use of the word dpe har/dpe dkar was clearly in reference to a monastery or temple (vihāra). It is most likely that since the treasury of Samyé Monastery was called the Pehar Kordzöling ${ }^{13}$ - literally "temple of the monastery treasury" - the deity assigned to protect it came to be called Pehar as a toponymic short-hand. ${ }^{14}$ Significantly, this appears to have been an accepted explanation in seventeenth-century Tibet as well. ${ }^{15}$ This practice of a name referring to a monastery as well as to its primary deity is also evident at Nechung itself, where the term Nechung signifies both the monastery and its central protector deity. These are slightly different contexts, however, since Pehar's name originates from a building within the Samyé Monastery complex while Nechung is the entire monastery.

Other names and epithets have come to refer to Pehar, and it is necessary to briefly discuss them and their contexts since we will encounter them again. ${ }^{16}$ In an edition of the Testament of $\mathrm{Ba}$ attributed to the fourteenth century, ${ }^{17}$ Pehar is referred to as Shingjachen. ${ }^{18}$ This

\footnotetext{
${ }^{9}$ GRSD:56.5; Sle lung rje drung 1978, p.3.1.

${ }^{10}$ See Nebesky-Wojkowitz 1998, p.96 for other variations of this name. Such name variants are not uncommon among Tibetan deities overall, as the other chapters in Nebesky-Wojkowitz's volume make clear.

${ }^{11}$ See Nebesky-Wojkowitz 1998, p.107, for a discussion of previous theories pertaining to the etymological origins of Pehar's name. Ariane Macdonald (1978a, pp.1142-1143) disagrees with this interpretation; however, as Samten Karmay (1998b, p.360n.117) rightly points out, she does not provide a compelling argument for her claim.

${ }^{12}$ See Karmay 1998b, pp.360-361.

${ }^{13}$ Tib. Dpe har dkor mdzod gling.

${ }^{14}$ Karmay (ibid) cites references to the deity Pehar and Samyé's monastic treasury from an edition (Stein 1961) of the Testament of $B a$ (Tib. Sba bzhed), which has since been shown to be likely from the fourteenth century (see Wangdu and Diemberger 2000, pp.XIV, 1). This can be problematic since, as Wangdu and Diemberger (2000, p.2) note, this text has been updated, modified, and edited in the intervening centuries following its ninth-century origins. The Wangdu and Diemberger edition of this text has been tentatively attributed to the eleventh century (ibid, p.XIV), and many of the details cited by Karmay from the Stein edition are not found in this earlier text. Nonetheless, for our present argument, it need only be shown that the term pe har, in whatever variant, indeed meant monastery. In this regard, there is satisfactory evidence; see Wangdu and Diemberger 2000, pp.25, 26n.16, f.1b.6 of the facsimile.

${ }^{15}$ See A myes zhabs 2000, p.423.1-4.

${ }^{16}$ See Nebesky-Wojkowitz 1998, p.96, for more variant names for Pehar not overtly discussed in this study.

${ }^{17}$ See note 14 above.

${ }^{18}$ Tib. Shing bya can; lit. "He who Possesses a Wooden Bird." See Stein 1961, p.36.12. For another fourteenthcentury reference to Shingjachen, see Sørensen 1994, p.378.
} 
name refers to one of the objects confiscated from Pehar's residence at the Bhatahor meditation center and taken to Samyé (see below). While this name appears in the Ten-Chapter Sädhana, a late twelfth-century ritual treasure text rediscovered by Nyangrel Nyima Özer, its mention in historical sources is telling. It is possible that this was Pehar's original name prior to his installation at Samyé Monastery, though no hard evidence yet exists to prove this. Another common epithet for Pehar is the 'Great Emanated Dharma King. ${ }^{19}$ This title was used by the Second Dalai Lama and popularized by the Fifth, ${ }^{20}$ so it is related to the lineage of the Dalai Lamas in particular. Finally, Pehar's most common epithet is the 'sovereign spirit of activities, ${ }^{21}$ a title used to contrast him with the four other deities that he leads. These deities, including Pehar, constitute the Five Sovereign Spirits. ${ }^{22}$

The Five Sovereign Spirits are the central deities of Nechung Monastery and its ritual corpus. Pehar is generally considered the leader of this group, while the other four deities are believed to have emanated from him. However, nothing in the ritual texts that describe these deities states this explicitly, an ambiguity that will be discussed near the end of this chapter. The earliest known textual reference to the Five Sovereign Spirits may be the twelfth-century hagiography of $\mathrm{Ra}$ Lotsawa Dorjé Drak, ${ }^{23}$ the famed translator and propagator of Vajrabhairava's cult; this connection was first identified by Ariane Macdonald. ${ }^{24}$ Ra Lotsawa is also known for having renovated Samyé Monastery, which had fallen into disrepair after the fall of the Yarlung Dynasty. It is unclear when exactly this renovation began, though the hagiography says it was the water-dog year (likely 1082). Macdonald thinks this is an error and dates the renovation to the fire-dog year (1106). She draws on the Blue Annals ${ }^{25}$ and corrects George Roerich in the process, who gave the date 986. Regardless of when exactly the renovation began, Ra Lotsawa's journey to Samyé involved meeting and subjugating the Five

\footnotetext{
${ }^{19}$ Tib. Sprul pa'i chos rgyal chen po. A variant of this epithet is 'Great Emanated Dharma Protector' (Tib. Sprul pa'i chos skyong chen po).

${ }^{20}$ See Appendices IIb and IIc, which are replete with this epithet. See also Tā la'i bla ma 05 1992, texts 10, 11, 13, $14,19,26,40,42,48,69$, and 86 .

${ }^{21}$ Tib. 'Phrin las rgyal po.

${ }^{22}$ Tib. Rgyal po sku lnga. A more literal translation of this phrase would be 'the five forms of the sovereign spirit.' However, for the sake of brevity I have chosen to translate this grouping simply as the Five Sovereign Spirits.

${ }^{23}$ Rwa lo tsā ba Rdo rje grags, 1016-1128/1198; TBRC: P3143. The antiquity of this work is in question. Bryan Cuevas attests that this hagiography is actually a product of the seventeenth century, one that conforms with the Fifth Dalai Lama's stance; email communication, July 18, 2013. Cuevas is currently preparing a translation of Ra Lotsawa's hagiography, which is forthcoming from Penguin Classics. See also Decleer 1992.

${ }^{24}$ See Macdonald 1978a, p.1143.

${ }^{25}$ See Roerich 1996, p.378.
} 
Sovereign Spirits. As Macdonald notes ${ }^{26}$ the only names given in relation to the Five Sovereign Spirits are: Jatri Jenjik, Dorjé Drakden, the Great Capricious Spirit, Jagö Tangnak, and Putra Nakpo. ${ }^{27}$ Fifty to a hundred years after this encounter, the Five Sovereign Spirits were greatly elaborated upon and systematized by Nyangrel Nyima Özer in the Ten-Chapter Sädhana. However, in this ritual text these five names appear in a subordinate fashion; they are the names of the Five Sovereign Spirits' ministers. This curiosity deserves further attention, but will not be examined here.

Regardless of the historical vicissitudes, it is Nyangrel Nyima Özer's hierarchical configuration of these deities, and the iconography he provides for them, that are found at the core of the Nechung rituals. As such, this hierarchy and iconography will be given here in order to provide a more vivid representation of these important figures. Each deity represents one of the four cardinal directions plus the center, and is correlated, respectively, with the five attributes that make up a sentient being. The following descriptions are found in the introduction of the Ten-Chapter Sädhana and are accompanied by photographs of the Five Sovereign Spirits taken at the historical Nechung Monastery outside Lhasa: ${ }^{28}$

Gyajin ${ }^{29}$ is the central sovereign spirit of the $\operatorname{mind}^{30}$ (Figure 1). He is mounted on a long-trunked elephant led by Mönbuputra. ${ }^{31}$ His body is dark blue. He wears black silk garments and a bear-skin fur coat, as well as a thumb-shaped hat ${ }^{32}$ with black silk fringe on his head. He binds enemies with the hindering

\footnotetext{
${ }^{26}$ See Macdonald 1978a, ibid.

${ }^{27}$ See Ye shes seng ge 1974, p.249.3-4. The Tibetan spelling and meaning of these five names will be provided below.

${ }^{28}$ The following descriptions are specifically drawn from the GRSD edition of the Ten-Chapter Sädhana; see Appendix IIa, pp.430-435.

${ }^{29}$ Tib. Brgya byin; Skt. Indra. As discussed in the introduction, despite this name being the Tibetan equivalent for the Hindu god Indra, it likely had an indigenous significance that became glossed over by Indianization. Nonetheless, since this deity rides an Indian elephant for a mount it suggests that this process of identity assimilation was successful at some level.

${ }^{30}$ Tib. dbus phyogs thugs kyi rgyal po.

${ }^{31}$ Tib. Mon bu pu tra; lit. "Son of the Mön." This name suggests some cross-linguistic reiteration; the Tibetan word $b u$ means 'son,' as does the Sanskrit word putra. Another possibility is that while mon bu alone means 'son of the Mön,' this could just be another way of referring to a (male) member of the Mön ethnic group. Either way the meaning is the same. According to Turrell Wylie, the land of the Mön is located at the modern-day intersection of the northeast region of Bhutan, the far northwest region of the Indian state of Arunachal Pradesh, and the southern borderlands of the Tibet Autonomous Region, China; see Wylie 1962, p.119n.51.

${ }^{32}$ Tib. thebs $z h u$; lit. "thumb hat." While this term clearly refers to the type of hat worn by this deity, as well as by several others in this group, its meaning is obscure. I interpret it to refer to the 'thumb-shaped' protrusion at the apex of the hat.
} 
spirit's lasso in his right hand and cuts out their hearts with the razor in his left. He shouts evil mantras, is accompanied by lightening and flames, and dispatches hail and thunderbolts as heralds. His emanation takes the guise of a young layman wearing a large red silk cloak with a crystal rosary around his neck. He raises the tarjani $m u d r \bar{a}^{33}$ with his right hand and wields a copper knife in his left. His consort is Shantinma Marpo. ${ }^{34}$ Adorned with blood and fat, she brandishes an iron hook and a heart-filled skull cup. His minister is the lord of life Jarawa. ${ }^{35}$ He wears a maroon cloak and rides a lion while holding aloft a black silk military standard.

Mönbuputra is the eastern sovereign spirit of the body (Figure 2). He rides a lion and wears a black fur coat on his black body, as well as a thumbshaped hat with black silk fringe on his head. In his right hand is a vajra and in his left is a mendicant's staff. He is accompanied by black bears, and dispatches tigers, leopards, black bears, and grizzly bears as heralds. His emanation is a young arhat wearing saffron-colored religious robes. He carries a mendicant's staff, a razor, and a skull cup, and an anointing vase hangs from his neck. His consort is the female hindering spirit Rolangma Karmo. ${ }^{36}$ Endowed with a white silk dress, she brandishes a holy branch and a heart-filled skull cup. His minister is Jatri Mikchikpu ${ }^{37}$ the butcher. He wears black snakes like a turban and rides a blue horse with a black bottom. ${ }^{38}$ He flings a crystal vajra from his hand.

The capricious spirit Shingjachen Nakpo ${ }^{39}$ is the southern sovereign spirit of good qualities (Figure 3). He is adorned with snakes and tiger-skins, and brandishes a battle axe and the lasso of the hindering spirits. There is a female garuda over his head. He is accompanied by dragons, and he dispatches apes, monkeys, and cats as heralds. His emanation is light blue, wears a bandoleer of red fur, and brandishes a long hooked cane. His consort is the four-armed Sergyi

\footnotetext{
${ }^{33}$ Tib. sdigs mdzub; Skt. tarjanī; this is a threatening mudrā known as the "scorpion gesture."

${ }^{34}$ Tib. Shanting ma dmar po; lit. "Red Tranquility."

${ }^{35}$ Tib. Bya ra ba; lit. "Watchman."

${ }^{36}$ Tib. Ro langs ma dkar mo; lit. "White Female Zombie."

${ }^{37}$ Tib. Bya khri mig gcig pu; lit. "10,000 Birds, One Eye.” Variations of this name give the honorific for eye, spyan, making it Jatri Chenchikpu (Tib. Bya khri spyan gcig pu).

${ }^{38}$ While this text is not explicit about the animal mount, the text that Nebesky-Wojkowitz $(1998$, p.109) cites states that it is a horse. The mural iconography of the deity at Meru Nyingpa Monastery also shows him riding a horse.

${ }^{39}$ Tib. Shing bya can nag po; lit. "Black One with a Wooden Bird."
} 
Putrima Nakmo. ${ }^{40}$ She is endowed with a black silk diadem, wears a bundle of snakes as an earring, and has a bell around her neck. Her right ear is adorned with a lion earring. ${ }^{41}$ In her right hands are a sword and a red lance; in her left are a scimitar and a trident. A banner flaps around her neck, and she wears a necklace of human heads. She possesses an elephant-skin cloak, a petticoat of yellow yakhair felt, and a belt of snakes. Her feet are adorned with iron shackles. She rides a donkey with a red spot on its forehead. His minister Jagö Tangnak ${ }^{42}$ has the appearance of a layman and brandishes a vajra and war hammer.

The enemy-defeating god Kyechik Marpo ${ }^{43}$ is the western sovereign spirit of speech (Figure 4). He rides a white-heeled mule and wears a red silk cloak and a bamboo hat. He brandishes a cane staff and a sandalwood club. $\mathrm{He}$ is accompanied by roaring she-wolves, and he dispatches iron hawks as heralds. His emanation is dark blue, has locks of hair that flow upward and a blazing beard, and is endowed with a tiger-skin garment. He holds aloft a corpse club and a victory banner adorned with a wolf's head. His consort Dzejé Padmakyé $\mathrm{Marmo}^{44}$ is endowed with ornaments. She brandishes a holy branch and a skull cup. His minister Dorjé Drakden ${ }^{45}$ wears monastic robes and rides a camel. He brandishes a mendicant's staff made from a red tree.

The great enemy-defeating god Pehar is the northern sovereign spirit of activities (Figure 5). He rides a white lioness, which is led by Mönbuputra. $\mathrm{He}$ has three faces: the right one is black, the left one is red, and the middle one is white. He wears a bamboo hat. His three right hands brandish an iron hook, an arrow, and a sword. His three left hands brandish a razor, a bow, and a club. His upper body is adorned with white silk garments and his lower body with humanand tiger-skin garments. He dispatches jackdaws as heralds. His emanation wears a human-skin garment and is adorned with a bundle of snakes. He holds

\footnotetext{
${ }^{40}$ Tib. Gser gyi spu gri ma nag mo; lit. "Black Woman with a Golden Razor."

${ }^{41}$ The text cited by Nebesky-Wojkowitz $(1998$, pp.110, 563) is more explicit, stating that this consort's right earring is a lion and her left earring is a snake.

${ }^{42}$ Tib. Bya rgod thang nag; lit. "Black Pine Vulture."

${ }^{43}$ Tib. Skyes gcig dmar po; lit. "Sole-Born Red One." As with Shingjachen above, the deity's body color is in his name so it does not explicitly appear in the description.

${ }^{44}$ Tib. Mdzes byed padma skyes dmar mo; lit. "Beautiful Red Lotus-born Woman."

${ }^{45}$ Tib. Rdo rje grags ldan; lit. "Famous Vajra."
} 
aloft victory banners topped with tiger and wolf heads. His consort is Düza Minkarma ${ }^{46}$ who is dark blue and wears the fur-lined coat of the hindering spirits. She brandishes a holy branch and skull cup. His minister is Putra Nakpo. ${ }^{47} \mathrm{He}$ wears a black silk robe, rides a mule, and brandishes a curved knife.

These central deities are further surrounded by a vast retinue. Each of the cardinal directions is filled with an army led by a brigadier. The right flank brigadier leads a thousand heroes clad in tiger-skin garments. The left flank brigadier leads a hundred thousand black women. The vanguard brigadier leads a thousand arhat monks. And the rearguard brigadier leads a billion ministers and their servants, who are wearing tiger- and leopard-skin garments. There are also harlequins, lion-masked dancers, shadröl, kyidröl, zinpo, and dompo. ${ }^{48}$

The above iconography is visible at both Nechung Monastery and Meru Nyingpa Monastery, ${ }^{49}$ located behind the Jokhang Temple; however, there are minor discrepancies in the mural details. For instance, in the murals of Kyechik Marpo at both Nechung and Meru Nyingpa his consort Dzejé Padmakyé is holding a Tibetan ritual dagger in her right hand instead of a holy branch. Shingjachen's consort Sergyi Putrima is riding an orange horse at Nechung and a black horse at Meru Nyingpa. Shingjachen himself lacks a mount at Nechung, in accordance with the above description, but he rides a black horse at Meru Nyingpa. Such minute differences suggest subtle changes in the iconographic tradition over time, or perhaps just the idiosyncratic tastes of the mural sponsors or painters. Regardless, at Nechung Monastery and related sacred centers the iconography of the Five Sovereign Spirits is fairly consistent with the above descriptions. Despite the ubiquity of these images at such sites, the central mythology of these deities focuses almost exclusively on Pehar, and it is to this mythos that we now turn.

\section{The Many Lives of Pehar}

Pehar is at the center of a rich and convoluted mythology. In his chapter on Pehar, Nebesky-Wojkowitz vividly illustrates a number of the contradictory accounts regarding the

\footnotetext{
${ }^{46}$ Tib. Bdud gza' Smin dkar ma; lit. "Hindering-Planetary Spirit, White-Eyebrowed Woman."

${ }^{47}$ Tib. Pu tra nag po; lit. "Black Son."

${ }^{48}$ For information on these obscure figures, see Appendix IIa, note 1343.

${ }^{49}$ Tib. Rme ru snying pa.
} 
deity's past, from his arrival in Tibet to his eventual transfer to Nechung. ${ }^{50}$ Given this diversity of accounts, there is not one story of Pehar's lifetimes but many, and the incongruities and local differences between them deserve their own attention. Nonetheless, for our purposes, the essential goal is to understand the sources drawn upon by the Fifth Dalai Lama and the narrative he fashioned from these in the promotion of Nechung Monastery.

The most important early source for Pehar's life story appears to be an explanatory $\operatorname{tantra}^{51}$ and treasure text ${ }^{52}$ rediscovered by Nyangrel Nyima Özer entitled the White Crystal Rosary. ${ }^{53}$ There are a number of other tantras important to Pehar's cult, but it appears that they are no longer extant and we are accordingly unsure of their dates. ${ }^{54}$ The White Crystal Rosary is still extant; however, access is restricted due to it being considered an especially esoteric text limited only to those initiated into the deepest practices of the Five Sovereign Spirits. ${ }^{55}$ Even so, monks at both Nechung Monasteries were generous enough to let me photograph the text's titular page and colophon. These monks also informed me that the alternative title for this text is the Tantra of the Sovereign Spirit Jeché. ${ }^{56}$ Judging from the manuscript I was shown, the text is

${ }^{50}$ See Nebesky-Wojkowitz 1998, pp.98-107.
${ }^{51}$ Tib. bshad rgyud.
${ }^{52}$ Tib. gter ma.
${ }^{53}$ Tib. Shel phreng dkar po. As with most treasure texts, this tantra is believed to have been composed by Padmasambhava before being hidden away, to be revealed later at the appropriate time by an incarnation of one of his disciples. The text itself is not available to the uninitiated, but I was told by a Nechung monk that it was rediscovered by Nyangrel Nyima Özer. Other monks at Nechung agreed with this assessment and the Fifth Dalai Lama's Record of Received Teachings (Tib. gsan yig) confirms this as well; see Tā la'i bla ma 05 1991-1995, vol.2, p.615.2-6. However, a portion of this text that was used for a thread-cross ritual manual (see below) explains that it was discovered by the treasure-revealer Rashak Sönam Dorjé (Ra shag Bsod nams rdo rje; TBRC: P7626); see Ra shag Gter ston 1976, p.245.2. According to Guru Tashi (Gu ru Bkra shis, b.18th cent.), this figure was an older contemporary of Nyangrel Nyima Özer (see Gu ru bkra shis 1990, pp.378-379; Cuevas 2001, p.17). As with the more famous Maṇi Kambum (see Kapstein 1992), it is possible that multiple treasure-revealers, like Nyangrel Nyima Özer and Rashak Sönam Dorjé, were involved in the revelation of the White Crystal Rosary.

${ }^{54}$ The titles of these other works are listed in the first half of the Nechung Register composed by the Fifth Dalai Lama (see Appendix III, p.569); they include the Wealth God's Tantra (Tib. Nor lha'i rgyud), the Blue Turquoise Rosary Tantra (Tib. G.yu phreng sngon po'i rgyud), and the Black Iron Rosary Tantra (Tib. Lcags phreng nag po' $i$ rgyud). The latter two works, in tandem with the White Crystal Rosary Tantra, suggest that there was once a much grander tantric cycle tied to Pehar that is no longer available today.

${ }^{55}$ This was explained to me by Geshé Kushog Karma of Nechung Monastery, Dharamsala; email communication, December 19, 2007.

${ }^{56}$ Tib. Rgyal po byes chas kyi rgyud. The title page of the text itself has the following much longer title, which is made up of two quatrains: /Rā dzā man ngag thams cad kyi//bcud phyungs yang snying ches zab po/ /'di ni gcig brgyud tsam nyid las/ /kun la khyab brdal spel byas na/ /chos rgyal byes chas ke ru yi/ /'bod rbad bsad gsum rjes tshang 'khrigs//de'i snying rgyal po'i zhal du rngubs//kun la mi bstan spa gug rgya// This can be translated as: From the very moment this extremely profound distilled essence of all the King's oral instructions is transmitted once, if it is diffused widely and disseminated to anyone, after the Dharma King Jeché Keru is summoned, dispatched, and [does his] slaying, all will be gathered [and] the Sovereign Spirit will devour their hearts. [Therefore, this] cannot be shown to anyone [and must be] sealed in a secret compartment. The colophon gives a much shorter title: Sprul pa'i chos rgyal byes chas ke ru'i 'bod rbad bsad gsum gyi ngag 'don zin bris dang 'brel pa 
39 folios long and concerns a deity named Jeché Keru, ${ }^{57}$ a rare form of Pehar (Figure 6). According to the Fifth Dalai Lama's Record of Received Teachings, he received this treasure text and its attendant practices from lineage-holders of the Northern Treasures tradition. ${ }^{58}$

Since the White Crystal Rosary was available to the Fifth Dalai Lama, and its contents concern Pehar's mythological pedigree, it is an important resource for understanding how the deity's cult was perceived by the Great Fifth himself. While this text as a whole is unavailable, we are fortunate enough to have access to significant portions of it found in other accessible texts. There is a 12-folio thread-cross ritual manual entitled the Thread-Cross Ritual for the Six White [Possessions] of the Sovereign Spirit Pehar, ${ }^{59}$ which was drawn from the White Crystal Rosary; this manuscript is found in a larger collection of texts dedicated to thread-cross rituals. This text, sans a few lines, also makes up most of another thread-cross ritual for Pehar found in the Great Treasury of Precious Termas. ${ }^{60}$ This work is entitled an Arrangement of the Liturgy for the Thread-Cross Ritual for the Six White [Possessions] of the Lord of Life Sovereign Spirit, which was Rediscovered by Rashak [Tertön]. ${ }^{61}$ This latter text is further preceded by two more texts in

spa gug rgyah can. This can be translated as: Recitations for the Summoning, Dispatching, and [Acts of] Slaying of the Emanated Dharma King Jeché Keru, together with Commentary, which is Sealed in a Secret Compartment. The Record of Received Teachings (Tib. thob yig) of Jikmé Lingpa ('Jigs med gling pa, 1730-1798; TBRC: P314) further confirms that the White Crystal Rosary and the Tantra of the Sovereign Spirit Jeché are the same text by listing the text as Rgyal po byes chas shel phreng dkar po; see van Schaik 2000, p.19.

${ }^{57}$ Tib. Byes chas ke ru; lit. "White Sojourner." The colophon of this text explains that the first part of the name is an abbreviation of byes su chas pa, meaning "to travel abroad." This name refers to the deity's ability to travel far in tracking down and defeating enemies. References to this name in the Fifth Dalai Lama's collected works tend to spell the second part of the name as "Katu" or "Ketu;" see Tà la'i bla ma 05 1991-1995, vol.3, p.95.4; and ibid, vol.25, p.492.1. Both words mean "meteor, comet, falling star." Thus, a variant name for this form of Pehar would be the "Sojourning Meteor," which resonates with elements of the mythological account below.

${ }^{58}$ The Fifth Dalai Lama received the first transmission cycle for this text from Zurchen Chöying Rangdröl (Zur chen Chos dbyings rang grol, 1604-1669; TBRC: P650); see Tà la'i bla ma 05 1991-1995, vol.3, pp.95.4-96.4. The second transmission cycle was received from a figure named Tratsangpa Dorjé Mitoktsel (Khra tshang pa Rdo rje mi rtog rtsal); see ibid, pp.96.4-97.1. This refers to Tratsangpa Lochok Dorjé (Khra tshang pa Blo mchog rdo rje, 15951671; TBRC: P2668), who was also an important lineage-holder for the Northern Treasures tradition, as well as a friend of Zurchen Chöying Rangdröl.

${ }_{59}$ Tib. Sher [sic: shel] phreng dkar po'i rgyud las/ Rgyal po pe har gyis dkar po drug mdos; see Ra shag Gter ston 1976. This work was composed using the 'headless' (Tib. dbu med) script and is referenced in note 53 above. The title of the text is explained more fully in its opening preparatory lines, which discuss the six white possessions to be included within the deity's thread-cross mansion. The number six is used with all such possessions. This and related texts were first explored in Macdonald 1978b.

${ }^{60}$ Tib. Rin chen gter mdzod chen mo; TBRC: W20578.

${ }^{61}$ Tib. Srog bdag rgyal po dkar po drug mdos ra shag gter byon gyi ngag 'don khrigs su bsdebs pa; see Ra shag Gter ston and Gra sgom Chos kyi rdo rje 1976-1980. The colophon of this text suggests that yet another individual was involved in the revelation of the White Crystal Rosary, a treasure-revealer named Dragom Chökyi Dorjé. Moreover, it is explained that the text was discovered at the Butsel Serkhang Temple at Samyé Monastery. This is a temple built just outside the monastic complex at the request of Lady Gyelmo Tsün of Pogyong (Pho gyong bza' rgyal mo btsun), one of King Trisong Deutsen's queens. The name of this temple is often translated as Golden Orphan Temple, based on the alternative spelling, Bu tshab gser khang gling; see Harding 2003, p.165. However, 
the Great Treasury that concern this thread-cross ritual. The first of these two works is entitled the Proper Beginning of Residing: the Root Text and the Request for the Deity to Approach for the Thread-Cross Ritual of the Sovereign Spirit, [Specifically] for the Six White [Possessions]. ${ }^{62}$ The colophon of this treasure text explains that it was rediscovered by Nyangrel Nyima Özer at the Bodhi Temple ${ }^{63}$ of Samyé Monastery. The second text appears to be two major texts stitched together by a single editor named Prince Lekdenpa. ${ }^{64}$ This text is entitled the Construction Method, Front Visualization, and Invitation for the Thread-Cross Ritual of the Sovereign Spirit, [Specifically] for the Six White [Possessions]. ${ }^{65}$ The first section of this manuscript is based on material from Pehar's thread-cross ritual proper, and is said to have been rediscovered by Nyangrel Nyima Özer; the second section is drawn from the Precious Garland. ${ }^{66}$ All four of these texts mostly consist of ritual instructions and panegyrics; however, they all have a few lines that mention the life that Pehar led immediately before arriving in Tibet.

Another work that contains fragments of the White Crystal Rosary is an early seventeenth-century history of Samyé Monastery composed by the Sakya hierarch Amézhap Ngawang Künga Sönam. ${ }^{67}$ This text is entitled the Symphony of the Captivating Gods that Grants all Desires and Makes the Wish-fulfilling Dharma Protectors Rejoice: A Good Explanation for the Origins of the Great Monastery of Glorious and Spontaneously Present Samyé and its Guardians of the Teachings. ${ }^{68}$ About six folios of this text either directly quote or summarize content from the White Crystal Rosary that concerns Pehar's former lives.

The last major text to rely heavily on the White Crystal Rosary is a chapter specifically concerning Pehar's origins found in an early eighteenth-century collection of deity hagiographies composed by Lelung Jedrung Zhepé Dorjé. ${ }^{69}$ This important work, entitled the Unprecedented

the spelling given in this text is Bu tshal gser khang gling, bu tshal likely referring to 'om bu tshal, the grove of tamarisk trees surrounding Samyé Monastery. Therefore, I have translated the name of this temple as the Golden Temple of Tamarisk Grove.

${ }^{62}$ Tib. Rgyal mdos dkar po drug mdos kyi gzhung gshegs gsol dang bcas pa bzhugs pa'i dbu phyogs legs so; see Nyi ma 'od zer 1976-1980.

${ }^{63}$ Tib. Byang chub gling.

${ }^{64}$ Rgyal sras Legs ldan pa, 1290-1365; TBRC: P7625.

${ }^{65}$ Tib. Rgyal mdos dkar po drug mdos kyi bcas thabs mdun bskyed/spyan 'dren rnams; see Rgyal sras Legs ldan pa 1976-1980.

${ }^{66}$ Tib. Rin chen phreng ba; Skt. Ratnāvalī. This is an important Buddhist treatise composed by Nāgārjuna (c.150250).

${ }^{67}$ A myes zhabs Ngag dbang kun dga' bsod nams, 1597-1659; TBRC: P791.

${ }^{68}$ Dpal bsam yas lhun gyi grub pa'i gtsug lhag khang chen po bka'srung dang bcas pa'i byon tshul legs par bshad pa chos skyong yid bzhin nor bu dges par byed pa'i yid 'phrog lha'i rol mo dgos 'dod kun 'byung; see A myes zhabs 2000. From now on, this work will be referred to as the Symphony of the Captivating Gods.

${ }^{69}$ Sle lung rje drung bzhad pa'i rdo rje; 1697-1740; TBRC: P675. 
Elegant Explanation Briefly Expounding the Hagiographies and Iconographies of the Ocean of Oath-Bound Guardians of the Teachings, ${ }^{70}$ was composed in 1734, postdating Nechung's expansion by half a century. Nevertheless, it includes important details on Pehar not found in the above sources, and it draws extensively from material used by the Fifth Dalai Lama. Along with the White Crystal Rosary, Lelung's hagiography for Pehar faithfully quotes from the non-extant works noted above, such as the Wealth God's Tantra, the Blue Turquoise Rosary Tantra, and the Black Iron Rosary Tantra. ${ }^{71}$ Given this, despite its eighteenth-century composition it is still a useful resource for understanding Pehar's mythology in the seventeenth century.

Although not a manuscript, there is a series of murals at Meru Sarpa Monastery ${ }^{72}$ in Lhasa that is unique for illustrating much of Pehar's mythos. The Tsangpa Chapel ${ }^{73}$ of Meru Sarpa can be found in the northwest corner of the monastic complex and these murals are just inside this chapel, covering both walls adjacent to the entrance. ${ }^{74}$ These narrative murals show scenes from Pehar's past lives and interactions with famous mythical and semi-historical figures, such as Padmasabhava. Each scene is further accompanied by a brief Tibetan inscription describing the event, though some of the names are misspelled. According to André Alexander, the Tsangpa Chapel in its current form can be traced back to the late seventeenth-century at the earliest. ${ }^{75}$ Although the age of these paintings cannot be ascertained, they corroborate much of the narrative elements found in the above sources. A few of the mural inscriptions state explicitly that they are drawing from the non-extant Black Iron Rosary Tantra. They also include some mythological details not included in Lelung's text, but which are found in the White Crystal Rosary fragments of Amézhap's Samyé history. These murals are an important source for buttressing the disparate narrative elements found in the above resources.

The most important text for constructing Pehar's mythology is the Nechung Register mentioned earlier. The first half of this text was composed by the Fifth Dalai Lama himself and presents an outline of Pehar's lives before Tibet, offering us the bare bones of Pehar's mythology over which the flesh of his story can be laid. Since the Nechung Register was composed in part

\footnotetext{
${ }^{70}$ Tib. Dam can bstan srung rgya mtsho'i rnam par thar pa cha shas tsam brjod pa sngon med legs bshad; see Sle lung rje drung 1976, 1978, 1979, and 2003. From now on, this work will be referred to as the Ocean of Oath-Bound Guardians.

${ }^{71}$ See note 54 above.

${ }^{72}$ Tib. Rme ru gsar pa.

${ }^{73}$ Tib. Tshangs pa loog.

${ }^{74} \mathrm{I}$ am indebted to Mikmar Tsering for informing me about these murals.

${ }^{75}$ See Alexander 2005, p.138; see also the attendant chapter concerning Meru Sarpa's structure, contents, and history overall.
} 
by the Great Fifth, along with the above sources it enables us to reconstruct a clear account of how he perceived Pehar. Other important details can be found in the Fifth Dalai Lama's autobiography and will be cited below when necessary.

The final work used to construct the below account is the Hagiography of Jokpa Jangchup Penden (see Appendix IV), ${ }^{76}$ which details Pehar's arrival at Nechung. Like the second half of the Nechung Register, this text was also composed by Sangyé Gyatso ${ }^{77}$ and discusses both Jokpa Jangchup Penden ${ }^{78}$ and Pehar. In fact, more than a fifth of this hagiography is copied verbatim from the Nechung Register. Jokpa Jangchup Penden was the founder and first abbot of Drepung Monastery's youngest and smallest college, Deyang College. ${ }^{79} \mathrm{He}$ is also traditionally said to be responsible for first building the shrine to Pehar below Drepung and calling it Nechung.

With these various resources in mind I will now introduce a reconstructed mythic hagiography of Pehar as it was most likely understood in the latter half of the seventeenth century.

\section{Pehar's Lives before Tibet}

Many eons ago in the land of the asuras, ${ }^{80}$ there was a devout king named Mahābhūta. $^{81}$ His closest friend was a monk named Lekden Nakpo, who had

\footnotetext{
${ }^{76}$ The full title of this work is A Summary of the Hagiography of Jokpa Jangchup Pendenpa along with the Origins of the Great Dharma Protector (Tib. Lcog pa byang chub dpal ldan pa'i rnam thar rags bsdus chos skyong chen po' $i$ 'byung khungs dang bcas pa); see Sangs rgyas rgya mtsho n.da.

${ }_{78}^{77}$ See Sørensen, Hazod, and Tsering Gyalbo 2007, p.217n.572.

${ }_{79}^{78}$ Log pa Byang chub dpal ldan, 1464-1531.

${ }^{79}$ Tib. Bde yangs grwa tshang. According to the Hagiography of Jokpa Jangchup Penden, Deyang College was founded on the $10^{\text {th }}$ day of the $12^{\text {th }}$ month of the Monkey year (1500), pushing it into the beginning of the next Gregorian calendar year, 1501; see Appedix IV, ff.8b.5-10a.5. Georges Dreyfus (2006a) places Jokpa Jangchup Penden's birth sixty years earlier in 1404, and dates the founding of Deyang College accordingly (1440). I tentatively concur with the dates given in Sørensen, Hazod, and Tsering Gyalbo 2007 (ibid), because they align the events of Pehar's arrival at Nechung with the Second Dalai Lama's lifetime, in accordance with the Nechung Register (see Appendix III, p.579). Nonetheless, Pạnchen Sönam Drakpa (Pạ̣ chen Bsod nams grags pa 2007, p.146) records 15 abbots for Deyang College by the time of his writing, which was 1554 at the latest, the year of his death. If Jokpa Jangchup Penden was still abbot of Deyang in 1529 when Pehar arrives (see below), this leaves at most 25 years for 14 other abbots to take their seat at the college, which seems unlikely.

${ }^{80}$ Tib. a su ra. Only Lelung's history of Pehar in the Ocean of Oath-Bound Guardians gives this place name, so it is possible that this information is a latter accretion to the mythology; see Sle lung rje drung 1976, p.369.4. While there are four editions of Lelung's Ocean of Oath-Bound Guardians available, for the sake of uniformity I will cite the Thimphu edition (Sle lung rje drung 1976). Asura refers to the demi-god realm in traditional Buddhist cosmology.

${ }^{81}$ Tib. Ma ha abu ta. This is a Sanskrit name meaning "Great Being." This name is found in the Nechung Register; see Appendix III, p.563. Lelung's Ocean of Oath-Bound Guardians gives a completely different name, Dharmajvala, meaning "Flame of the Dharma;" see Sle lung rje drung 1976, ibid.
} 
become the King's minister. ${ }^{82}$ Being quite religious, the two friends decided to become fully ordained monks together and were ordained under the abbot Daö Dünting. ${ }^{83}$ King Mahābhūta took the ordination name of Daö Zhönnu, ${ }^{84}$ while Lekden Nakpo took the name Dünting Nakpo. ${ }^{85}$ However, the King delighted in philosophy while the minister delighted in meditation; because of this they drifted apart. ${ }^{86}$ Later, while at the Temple where Nine Evil Spirits Gathered, ${ }^{87}$ Daö Zhönnu saw the beautiful daughter of a Brahmin named Metok Kyér ${ }^{88}$ and was enticed by her. They met and were immediately attracted to each other. After flirting and looking longingly at one another, it was not long before their passions were inflamed. Daö Zhönnu seized Metok Kyé's body and said, "Never before have I seen such a beautifully bejeweled girl like you! Who are you-the daughter of a god, a human, or a capricious spirit? If I cavort with the likes of you and the foundations of my moral discipline and training should decay, then so be it! If an indestructible love-sickness should blaze within me, then let it blaze!" He spread out his saffron robes for bedding, used his sacred leather-bound skull cup as a cushion, set down his monastic staff for a pillow, placed his anointing vase in front of them, and positioned his begging bowl beneath them. With these preparations complete, the two fell to the floor in a sexual frenzy. They were intoxicated by their heightened lust and they enjoyed each other without separating for seven days straight.

The elder abbot of the temple- known as Rapsel ${ }^{89}$ or the heretical teacher Barnang ${ }^{90}$ — saw this elicit activity and chastized Daö Zhönnu, saying, "It is unacceptable for a monk to act like this in a temple of the spiritual community!"

\footnotetext{
${ }^{82}$ Again, Lelung's account differs, explaining that Lekden Nakpo (Tib. Legs ldan nag po; lit. "Black Excellent One") was the son of the King's minister; see ibid, p.369.5. Moreover, Lelung's language with reference to Dharmajvala appears to shift from king (rgyal po) to prince (rgyal po'i bu); see ibid, p.369.6.

${ }^{83}$ Tib. Zla 'od dun ting; lit. "Moonlight Dünting." The meaning of dun ting is uncertain.

${ }^{84}$ Tib. Zla 'od gzhon nu; lit. "Youthful Moonlight."

${ }^{85}$ Tib. Dun ting nag po; lit. "Black Dünting."

${ }^{86}$ The majority of this sentence in the Nechung Register is too obscured by damage to confirm directly. However, drawing from the one visible word, king, and by comparing what precedes and follows it with what is found in Lelung's account, it seems clear that this event is what is meant.

${ }^{87}$ Tib. 'Gong po dgu 'dus kyi lha khang.

${ }^{88}$ Tib. Me tog skyes; lit. "Flower-born."

${ }^{89}$ Tib. Rab gsal; lit. "Brilliant Clarity."

${ }^{90}$ Tib. mu stegs kyi ston pa Bar snang; the word bar snang refers to the heavens or intermediate atmosphere in Tibetan cosmology.
} 
This made Daö Zhönnu feel ashamed and angry. He drew an effigy of the abbot on his religious robes and performed destructive magic against him within his begging bowl. He also continued having sex and keeping intimate company with the Brahmin maiden.

Next his old friend, the monk Dünting Nakpo, reproached him; he said, "You shouldn't act like this!" and then he put a stop [to his lascivious ways]. This angered Daö Zhönnu, who instantly transformed into a lion crouching forward and threatening Dünting Nakpo. The Master of Secrets, Vajrapāni, saw all of this clairvoyantly and protected Dünting Nakpo by [immediately] coating his body with indestructible armor. Daö Zhönnu then transformed into a black bear, growling and menacing his old friend. Vajrapāni responded by restraining him with a lasso. Daö Zhönnu transformed into a dog, a wolf, a tiger, and a boar-each time threatening Dünting Nakpo, and each time Vajrapāni threw a vajra at him in order to protect the monk. Daö Zhönnu transformed into a marmot and dug up the earth [beneath Dünting Nakpo], so Vajrapāni stomped on the marmot's head. ${ }^{91}$ He transformed into a pig and dug up the earth, so Vajrapāni stomped on the pig's head. He transformed into a wolf, so Vajrapāni stomped on the wolf's head. He transformed into an ape, a monkey, a rat, and so forth, and in each case Vajrapāni overpowered him with cakra sorcery so that he could not harm Dünting Nakpo.

In his next life, Daö Zhönnu continued to be angry with the abbot and his Dharma brother, causing his monastic discipline and samaya vow to deteriorate further. Because of his perverse conduct, Daö Zhönnu was born in hell. He came to be called the butcher Ragochen ${ }^{92}$ and experienced immeasurable suffering. Eventually, he transmigrated and was reborn as Chumik Jangchupbar. ${ }^{93} \mathrm{He}$ wandered about without a country of his own, and without food or clothing,

\footnotetext{
${ }^{91}$ Tib. 'phyi bar brdzus nas sa brus pas khyi thod kyi nang du mnan; see Sle lung rje drung 1976, p.371.2. The Paro edition of this text (Sle lung rje drung 1978, p.6.5-6), as well as the Beijing edition (Sle lung rje drung 2003, p.303.17), also share this reading. However, the Leh edition (Sle lung rje drung 1979, p.37.21) has 'phyi thod in place of khyi thod. Generally, the other three editions are more accurate; but in this case my translation is based on the Leh edition, since it exhibits a uniformity seen in the lines that follow. The animal into which Daö Zhönnu transforms is subsequently pressed down upon as an act of exorcism.

92 Tib. Ra mgo can; lit. "Goat-headed One."

${ }^{93}$ Tib. Chu mig byang chub 'bar; lit. "Fountain that Radiates Enlightenment."
} 
before once more crossing paths with the monk Dünting Nakpo. The monk gave Chumik whatever food and clothing he desired, but because Chumik coveted food and wealth he proceeded to attack Dünting Nakpo. When the monk overpowered him, Chumik spoke with an evil aspiration, cursing, "I may be unable to do so in this lifetime, but throughout all my future lives I will come to hurt you!”

After this he was born as Lenmi Jangchupö. ${ }^{94}$ Then he was born as the son of Mujé Tsenpo ${ }^{95}$ and his consort Lumo Dungkyongma, ${ }^{96}$ and named Vajraguhyasamādhi. ${ }^{97}$ At that time, Dünting Nakpo was intensely engaged in meditation at a meditation center, so Vajraguhyasamādhi transformed into a marmot and dug under the building's foundation, causing water to burst forth. This disturbed the monk's meditation, but Vajrapāni exorcized the marmot, stomping on his head. Vajraguhyasamādhi was overpowered yet again and unable to harm Dünting Nakpo. In his next life, he was born as the son of Düpo Köjé Drangkar ${ }^{98}$ and his consort Luza Minkarma. ${ }^{99}$ Just as before, he transformed into a boar next to the meditation center where Dünting Nakpo was meditating and he shook the building's foundation. [However, he was unsuccessful in agitating the monk.] By the evening he became annoyed and manifested phantasmal illusions [in an attempt to distract Dünting Nakpo]. Once more Vajrapāni exorcized him, crushing the boar's head, and he was unable to interrupt his old friend. ${ }^{100}$

\footnotetext{
${ }^{94}$ Tib. Glan mi Byang chub 'od; lit. "Fool, Light of Enlightenment." The spelling of this name is found in the Leh (Sle lung rje drung 1979, p.38.11) and Paro (Sle lung rje drung 1978, p.8.2) editions of this text, and agrees with the spelling found in the Nechung Register; see Appendix III, n.729. By contrast, the Thimphu edition has Glan mi Nub 'od (Sle lung rje drung 1976, p.371.6) and the Beijing edition has Glan mi Nub 'dod (Sle lung rje drung 2003, p.304.6-7), which is likely a misspelling of the Thimphu edition's variant. Lelung further explains that Glan mi Byang chub 'od is found in the non-extant Gathering of Black Clouds Tantra (Tib. Sprin nag 'khrigs pa), while the White Crystal Rosary has Glan mi Dbang phyug 'bar (Sle lung rje drung 1979, p.38.10; Sle lung rje drung 1978, p.8.1)/Glan mi Dbang 'bar (Sle lung rje drung 1976, p.371.6; Sle lung rje drung 2003, p.304.5-6). Given this, the Gathering of Black Clouds Tantra was clearly a source that the Fifth Dalai Lama relied on for constructing Pehar's mythology in the Nechung Register. Moreover, this indicates that these narrative events are likely found in the White Crystal Rosary as well, just not in the fragments we have access to through the key sources discussed above.

${ }^{95}$ Tib. Dmu rje btsan po; lit. "Emperor Lord of the Savage Spirits."

${ }^{96}$ Tib. Klu mo Dung skyong ma; lit. "Female Serpent Spirit, Conch Shell Protectress."

${ }^{97}$ Tib. Badzra gu hya sa ma ti; lit. "Secret Adamantine Meditation."

${ }^{98}$ Tib. Bdud po Skos rje brang dkar; lit. "Hindering Spirit, Appointed Lord with the White Chest."

${ }^{99}$ Tib. Klu gza' Smin dkar ma; lit. "Serpent-Planetary Spirit, White-Eyebrowed Woman."

${ }^{100}$ The details of the events from Daö Zhönnu's tryst with the Brahmin's daughter to this rebirth are unfortunately only found in Lelung's account; see Sle lung rje drung 1976, pp.369.4-372.5. Nevertheless, the Nechung Register provides enough information to strongly suggest that this is the narrative the Fifth Dalai Lama was summarizing.
} 
In his next life, Daö Zhönnu's father was Mujé Tsenpo, ${ }^{101}$ who was chief of all the world's hindering spirits. His mother was Düza Minkarma, ${ }^{102}$ who was the queen of the world's serpent spirits. In the hindering spirit land called Münpé Yungdrung, ${ }^{103}$ they cast a curse together and made love. Five sons were born to them and were called the Five Brother Commanders. ${ }^{104}$ The oldest was named Yabjé Lamé, ${ }^{105}$ then there was Tramtok Nyampajé, ${ }^{106}$ Mudü Dramkarjé, ${ }^{107}$ Tramtok Barwajé, ${ }^{108}$ and Dünak Dongjé. ${ }^{109}$ The middle-born child named Mudü Dramkarjé is the great three-faced man, the sovereign spirit of activities, [Pehar] (Figure 7). ${ }^{110}$ At this time, the monk Dünting Nakpo realized the truth of reality and became an arhat called the great divine monk Lekden Nakpo. Meanwhile, Mudü Dramkarjé enslaved all of the eight classes of gods and spirits of the phenomenal world. He ate small stars for food, bound the sun and moon to his crown, and tormented all sentient beings. [He performed] a variety of malicious

He speaks of the Lord of Secrets, Vajrapāni, subjugating Pehar throughout his past lives. He notes the coupling with the Brahmin's daughter, and the presumably evil aspiration spoken to Dünting Nakpo. Finally, he lists the names of his subsequent births, such as Ragochen, Chumi[k] Jangchupbar, and Lenmi Jangchupö. He ends with the deity's marmot form, which likely refers to Vajraguhyasamādhi. For this reason, though the narrative until now may have been expanded upon in the fifty years between Nechung's founding and Lelung's composition, I trust that it is a close approximation of the story found in the White Crystal Rosary, as well as other such works that where familiar to the Fifth Dalai Lama.

${ }^{101}$ Tib. Rmu rje btsan po; lit. "Emperor Lord of the Savage Spirits." Lelung gives the name Zhe sdang me ltar 'bar ba Bdud rje btsan po, which is literally "Anger Blazing like Fire, Emperor Lord of the Hindering Spirits;" see Sle lung rje drung 1976, p.372.5. Likewise, Amézhap has Bdud rje btsan po; see A myes zhabs 2000, p.411.6.

${ }^{102}$ Tib. Bdud gza' Smin dkar ma, lit. "Hindering-Planetary Spirit, White-Eyebrowed Woman;" see Appendix III, n.732. Lelung gives the name Klu mo Smin dkar ma, literally "Female Serpent Spirit, White-Eyebrowed Woman;" see Sle lung rje drung 1976, p.372.5. Amézhap has Klu gza' Smin dkar ma; see A myes zhabs 2000, p.411.6.

${ }^{103}$ Tib. Mun pa'i g.yung drung; lit. "Dark Swastika."

${ }^{104}$ Tib. Stong dpon mched lnga.

${ }^{105}$ Tib. Yab rje bla med; lit. "Unsurpassed Lord Father."

${ }^{106}$ Tib. Khram thogs nyams pa rje; lit. "Obstructing Charlatan, Lord of Degeneration."

${ }^{107}$ Tib. Smu bdud Khram dkar rje; Lelung has the alternative form Dmu bdud Brang dkar, which literally means "Savage-Hindering Spirit, White Chest;" see Sle lung rje drung 1976, pp.372.6-373.1.

${ }^{108}$ Tib. Khram thogs 'bar ba rje; lit. "Blazing Lord, Obstructing Charlatan."

${ }^{109}$ Tib. Bdud nag stong chen. Lelung has the alternative Bdud nag stong rje; Sle lung rje drung 1976, p.373.1. I strongly suspect that this deity's name is actually Bdud nag stong rje, a literal translation of which is, "Lord of a Thousand Black Hindering Spirits." This would coincide well with the rje found in the names of the other four brothers, as well as their father.

${ }^{110}$ The names and details of this rebirth account are nearly identical between the Nechung Register (Appendix III, p.564) and Lelung's account (Sle lung rje drung 1976, pp.372.5-373.1). However, Amézhap's account, which states that it is drawn from the explanatory tantra of the White Crystal Rosary, is merely a line long. It provides the barest details and does not even give the individual names of the Five Brother Commanders; see A myes zhabs 2000, pp.411.6-412.1. As Figure 7 illustrates, this rebirth of Pehar's can be found among the Meru Sarpa murals. Furthermore, the iconography presented here - which is drawn from Lelung's account—shows Pehar exhibiting three faces in this lifetime. 
acts, such as eating a hundred men every day, a hundred women every evening, and a hundred children every morning. ${ }^{111}$

One day, when the divine monk Lekden Nakpo ${ }^{112}$ was settled in the meditation of Hayagrīva, he had a slight lapse and his concentration became lax. At that moment, Mudü Dramkarjé transformed into a great iron scorpion surrounded by a thousand [smaller] iron scorpions. He bit down hard on Lekden Nakpo's right foot and held it tight. This terrified the monk, who hastened into Vajrapāni’s presence. Brandishing a sandalwood club, Lekden Nakpo traced the shape of an OM and praised Vajrapāni, saying, "Oh! God of gods, Blessed One who is the Protector of the World!" Lekden Nakpo then told Vajrapāni what had transpired and in response Vajrapāni related Mudü Dramkarjé's previous lifetimes, as described above. Furthermore, Vajrapāni said, "Since you are an arhat now, subdue the iron scorpions by meditating on your tutelary deity!" [Emboldened,] Lekden Nakpo swung his sandalwood club overhead and took on the identity of Glorious Hayagrīva. He stood over the scorpion and threatened him. This frightened the sovereign spirit, who showed his true form and then took refuge in Vajrapāni (Figure 8). Vajrapāni placed a vajra over Mudü Dramkarjé’s heart, poured the nectar of immortality over his tongue, gave him the secret name Putri Barwa, ${ }^{113}$ and took his life-essence (Figure 9). In turn, Lekden Nakpo gave him the name enemy-defeating god Khyungshok Barwa. ${ }^{114}$

\footnotetext{
${ }^{111}$ These three sentences are a combination of the material found at this narrative juncture in the Nechung Register (Appendix III, p.564) and Lelung's account (Sle lung rje drung 1976, p.374.1-2), both of which say very similar things but with added details or minor differences.

112 The original text has Mgon po Legs ldan nag po, which is a name variant commonly found in Lelung's citations from the Tantra of the Capricious Spirit Norlha Nakpo; see Sle lung rje drung 1976, p.374.2. For the sake of uniformity I am maintaining the simpler name Lekden Nagpo.

${ }_{113}$ Tib. Spu gri 'bar ba; lit. "Blazing Razor."

${ }^{114}$ Tib. Khyung gshog 'bar ba; lit. "Blazing Garuda Wings." In Lelung's account, this narrative ends with an explanation that it was recounted by Lekden Nakpo and set forth in the 59-chaptered Tantra of the Capricious Spirit Norlha Nakpo (Tib. Gnod sbyin nor lha nag po'i rgyud); see Sle lung rje drung 1976, p.375.1. It is tempting to suggest that the Wealth God's Tantra cited in the Nechung Register (Appendix III, p.569) is the same as this latter text. However, while the Tantra of the Capricious Spirit Norlha Nakpo has 59 chapters, the Nechung Register states that the Wealth God's Tantra has 32 chapters. Ultimately, this point is moot, because even if the Tantra of the Capricious Spirit Norlha Nakpo is a separate text, the Fifth Dalai Lama was familiar with it, as stated in his Record of Received Teachings; see Tà la'i bla ma 05 1991-1995, vol.2, p.615.2-3. As explained above, the details for this encounter are primarily drawn from Lelung's work (Sle lung rje drung 1976, pp.374.1-375.1), but they agree with the kernels of information given in the Nechung Register (Appendix III, pp.563-564). The murals at Meru Sarpa also illustrate this account, though it is highly contracted and shows Mudü Dramkarjé taking refuge in Lekden Nakpo (called by his former name Dünting) before Vajrapāni.
} 
In his next life, Mudü Dramkarjé was born in the sky [realm], where he could not harm or overpower anyone. He descended from the sky in the form of an eight-year-old boy and came to reside in Bhatahor [within Mongolia] (Figure 10). ${ }^{115}$ [One day,] when the great master [Padmasambhava] was dwelling at the Wish-Fulfilling Crystal Cave in Bhatahor, he pretended to be distracted in his meditation. ${ }^{116}$ This great sovereign spirit ${ }^{117}$ transformed into a white lion in order to test the master. He [stood] above the mandala that [Padmasambhava] had constructed, with his mouth wide open, ears upraised, and eyes glaring (Figure 11). ${ }^{118}$ Just as the lion was about to pounce on the great master, Padmasambhava took on the form of Hayagrīva and struck the beast with his khațāñga staff. The white lion fled into the sky.

Not long afterwards, the sovereign spirit transformed into a frightening black monk, took a white meteor about the size of a sheep, and threw it down like lightening onto Padmasambhava's head (Figure 12). The master pretended to faint for a moment ${ }^{119}$ and the implements of his mandala appeared to be disturbed. When Padmasambhava feigned regaining consciousness, there was nobody near him. Once again he took on the form of Hayagrīva and seized the sovereign spirit with the Iron Hook mudrā. ${ }^{120}$ The deity transformed into a young layman holding a 108-bead white crystal rosary in his hands and stood before the master (Figure

\footnotetext{
${ }^{115}$ This brief narrative segment is interesting since it is not included in Lelung's account. It appears to act as an interlude connecting Pehar's epic past to the beginning of his historical presence. Aside from the Nechung Register, the details for this incarnation are found in the Symphony of the Captivating Gods; see A myes zhabs 2000, p.412.12. This form is also depicted among the Meru Sarpa murals. Nebesky-Wojokowitz's discussion of Pehar's origins begin at this point; see Nebesky-Wojokowitz 1998, pp.97-99. He does not discuss any of the events that preceded Pehar's presence at Bhatahor, nor does he mention the following clash between Pehar and Padmasambhava. As for Bhatahor, its location is unknown, though it is generally thought to be in the traditionally Mongolian land situated around modern-day northeastern Qinghai province.

${ }^{116}$ Tib. ting nge 'dzin g.yel ba'i tshul mdzad par/; see Sle lung rje drung 1976, p.377.5. The use of tshul mdzadthe honorific form of tshul byed, 'to pretend'-indicates that Padmasambhava, being omniscient, knew what was going to transpire and played along. This is reinforced in Amézhap's account, which provides the following line in the midst of this scene: gu ru padma nyid mngon par mkhyen pa mnga' bas gnod sbyin gyi bu mthu bo che zhig yin par thugs kyis mkhyen... This can be translated: "Because Guru Padmasambhava possessed complete omniscience, he knew by heart that this was the powerful son of the capricious spirits;" see A myes zhabs 2000, p.412.3-4.

${ }^{117}$ This deity is called a capricious spirit in Amézhap's account; see ibid, p.412.2.

118 Figure 11 places the Wish-Fulfilling Crystal Cave in Yarlung, which agrees with the Chronicle of Padmsambhava (Tib. Padma bka' thang); see note 123 below. However, the White Crystal Rosary places this sacred cave in Bhatahor. This contradiction is noted by Lelung himself; see Sle lung rje drung 1976, p.384.1.

${ }^{119}$ Amézhap goes further by suggesting that Padmasambhava entered into a temporary state of meditative equipoise rather than pretending to faint; see A myes zhabs 2000, p.412.5.

${ }^{120}$ Tib. lcags kyu'i phyag rgya.
} 
13). He then displayed magical emanations with an inconceivable number of weapons, and innumerable ministers. His right flank brigade was a hundred tigerskin-clad warriors. His left flank brigade was a hundred śrāvaka-arhats. His rearguard consisted of a hundred black monks and his vanguard consisted of a hundred black women. His outer ministers were a hundred Mön mercenaries. ${ }^{121}$ His internal ministers were a hundred Mön sons. ${ }^{122}$ His harlequins are a hundred lion-masked dancers and he has a hundred emanations and secondary emanations, as well as apes and monkeys. ${ }^{123}$

Padmasambhava asked, "Who are you?" The layman replied, "I am the son of the hindering spirits and the nephew of the serpent spirits. Can I integrate my samaya vow with yours?" The master said, "If we integrate our vows, can you protect the Buddha's teachings without waning?" The spirit responded, "I can." 124 The master then subjugated him with the Garuda's Wing mudrāa. ${ }^{125} \mathrm{He}$ took his life essence, placed a vajra in his hand, gave him holy water to drink (Figure 14), ${ }^{126}$ conferred empowerments on him with the mudrā of the Five [Buddha] Families, ${ }^{127}$ and gave him five victory banners (Figure 15). ${ }^{128}$ The

${ }^{121}$ Tib. mon bu bha ta. See note 31 for mon bu. The Sanskrit word bhața means 'mercenary, hired soldier.'

${ }^{122}$ Tib. mon bu pu tra; see note 31 above. While this is also the name of one of the Five Sovereign Spirits, it appears to refer to a group of beings in this context.

${ }^{123}$ This encounter between Padmasambhava and Pehar is given in much greater detail within the Chronicle of Padmsambhava, the great hagiography of the master rediscovered by Ogyan Lingpa (O rgyan gling pa, b.1323; TBRC: P4943); see O rgyan gling pa 1996, pp.648.1-655.14. Lelung quotes this entire narrative segment verbatim; see Sle lung rje drung 1976, pp.378.4-384.1. Lelung's summary of this interaction, which is drawn from the White Crystal Rosary, does not include this description of the young layman's retinue; however, the Fifth Dalai Lama mentions such a retinue in the Nechung Register (Appendix III, p.564). This retinue is also described in detail in the Chronicle of Padmsambhava, which the Fifth Dalai Lama was clearly familiar with judging by its mention in his Record of Received Teachings; see Tā la'i bla ma 05 1991-1995, vol.3, p.485.6. For this reason, the Fifth Dalai Lama likely drew these details from the Chronicle of Padmsambhava rather than the White Crystal Rosary. The Chronicle of Padmsambhava also gives Shingjachen as a variant name for Pehar; see O rgyan gling pa 1996, p.648.5. For an outdated, yet nevertheless useful, English translation of this important work, see Douglas and Bays 1978. It is also worth noting that a much more contracted and variant account of this event is given earlier in Lelung's text, which he states is drawn from the Blue Turquoise Rosary Tantra. In this short account, Padmasambhava encounters Pehar at Asura Cave, and when he tames the spirit the master gives him the name Gyelpo Yutrengchen (Tib. Rgyal po g.yu 'phreng can; lit. "Sovereign Spirit with the Turquoise Rosary"); see Sle lung rje drung 1976, pp.375.1-3.

${ }_{124}$ This conversation has a greater affinity with Amézhap's account than with Lelung's, since its meaning is clearer and fuller in the former.

${ }^{125}$ Tib. khyung gshog gi phyag rgya.

${ }^{126}$ Tib. mna' chu blud; see Sle lung rje drung 1976, p.378.3. A myes zhabs 2000, p.413.4 has: lce la a mri ta bzhag. This can be translated: "He placed the nectar of immortality on [the spirit's] tongue."

${ }^{127}$ Tib. rigs lnga'i phyag rgya.

${ }^{128}$ This conferring of empowerments is given in extensive detail within Amézhap's account. This includes the process by which the five victory banners are bestowed on the sovereign spirit, the banners being a tiger, a monkey, 
layman then sang a sad song to the master about the capricious spirits and gave him precious garlands. The master in turn gave him the secret name Dorjé Khyungchen Lutrukdül. ${ }^{129}$

\section{Pehar Comes to Tibet $^{130}$}

\section{[In the eighth century,] King Trisong Deutsen invited Abbot Śāntarakṣita} and Master Padmasambhava to this Snowy Land, and they built the Changeless and Spontaneously Present Monastery of Glorious Samyé based on the model of Otantapūri Monastery. A guardian for Samyé's [treasury] ${ }^{131}$ was needed, so the great master Padmasambhava commanded the king of the serpent spirits, Zurpü

a vulture, a wolf, and a great victory banner proper. These five figures can be seen in the bottom register of Figure 15; see A myes zhabs 2000, pp.413.2-415.6.

${ }_{129}$ Tib. Rdo rje khyung chen Klu 'brug 'dul; lit. "Great Adamantine Garuda, Tamer of Serpent Spirits and Dragons." As with the previous narrative segments, this one is informed by the few details provided in the Nechung Register (Appendix III, pp.564-565) and filled in with details found in Sle lung rje drung 1976 (pp.377.4-378.4) and A myes zhabs 2000 (pp.412.2-415.6). Both sources state that this segment is based on the White Crystal Rosary, although Amézhap specifies that he is summarizing from this textual cycle's explanatory tantra. Nonetheless, since there are still differences between these accounts, I have attempted to produce a narrative closest to the original source by only including details found in both sources. Exceptions have been otherwise noted in footnotes above.

${ }^{130}$ This account of Pehar's "invitation" to Tibet from a foreign land signals the deity's arrival on the stage of Tibetan history. While previous elements of Pehar's mythic origins were drawn from fragments of texts that the Fifth Dalai Lama was familiar with, this narrative is drawn from the Fifth Dalai Lama himself. This story was first composed by the Great Fifth in his history of Tibet, the Song of the Spring Queen that is a Celebration of the New Golden Age: A History that Expounds on the Main Heavenly Kings and Ministers that Ruled over the Land of Snows (Tib. Gangs can yul gyi sa la spyod pa'i mtho ris kyi rgyal blon gtso bor brjod pa'i deb ther rdzogs ldan gzhon nu'i dga'ston dpyid kyi rgyal mo'i glu dbyangs). This work was completed in 1643, just after the Fifth Dalai Lama was appointed religious ruler of Tibet the previous year. For the original Tibetan work, see Tā la'i bla ma 05 1991-1995, vol.19, pp.3-228. A full English translation of this work has been produced by Zahiruddin Ahmad; see Nag-dBan Blo-bZan rGya-mTSHo 1995. This story of Pehar's arrival in Tibet is discussed in the section on the genealogy of the Chongyé (Tib. 'Phyong rgyas) family, the lineage into which the Fifth Dalai Lama was born. The pertinent references are Tà la'i bla ma 05 1991-1995, vol.19, pp.187.4-188.3; and Ṅag-dBañ Blo-bZań rGya-mTSHo 1995, pp.165-166. Giuseppe Tucci was the first to translate sizeable portions of this history; for the section on the Chongyé line, including the segment on Pehar, see Tucci 1999, pp.643-644. Nebesky-Wojkowitz paraphrases Tucci's translations in his own work, though he appears to excise any mention of the figure Dharmapāla, who will be further discussed in the conclusion; see Nebesky-Wojkowitz 1998, pp.100-102.

Nevertheless, the account that I present here is translated from the Fifth Dalai Lama's three-volume autobiography, which he began composing in 1666 and completed in 1681, shortly before his passing; see Schaeffer 2004b, pp.1-3. Since this narrative is just fourteen folios into the first volume of the autobiography, and is based on the earlier version found in the Song of the Spring Queen, it was likely composed around 1666; see Tā la'i bla ma 05 1991-1995, vol.5, pp.27.3-30.2. It is clearly drawn from the account presented in the Great Fifth's 1643 history, being similarly nested within the larger discussion of the Chongyé genealogy. I chose to use this account over the earlier because of their interesting differences, which will be further discussed in the conclusion. My translation draws heavily from Tucci's (1999, pp.734-735), but with significant differences. Lastly, while Pehar's name is spelled Pekar (Tib. Pe kar) in the Fifth Dalai Lama's autobiography, I am transliterating it here as Pehar for the sake of uniformity.

${ }^{131}$ The Fifth Dalai Lama specifies in the Nechung Register (Appendix III, p.565) that the guardianship pertained to the monastery's treasury. 
Ngapa ${ }^{132}$ [to act as the guardian]. The serpent spirit said, "We [serpents] sleep through the three [months of] winter and remain unconscious during that time. [However,] there is a sovereign spirit named $\mathrm{Hu},{ }^{133}$ who descended from the lineage of the savage spirits and is the nephew of the serpent spirits. ${ }^{134} \mathrm{He}$ can pursue anything as small as a needle and he traverses in a day what a vulture traverses in eighteen days. This is [the guardian you should] appoint."

Not long afterward, when Prince Muruk Tsenpo ${ }^{135}$ killed the son of Zhang Gyatsa Lhanang, ${ }^{136}$ Minister Gögan ${ }^{137}$ tried the case. ${ }^{138}$ Because of this, the Prince was sent [into exile] to guard the northern borders. ${ }^{139}$ At that time, the great master [Padmasambhava] summoned Vaiśravana and his eight horsemen. He showed them directly to the king and his ministers, and gave [the deities] orders. An outlier named Göntsön ${ }^{140}$ painted [the god] on a flag according to this vision, and [Padmasambhava ordered] Vaiśravaṇa and his retinue to actually dissolve into the flag. The prince then went with an army to Yarmotang ${ }^{141}$ in Kham, and [General] Zhang Lhazang Lupel ${ }^{142}$ counted the army at Gyazam. ${ }^{143}$ Having counted [accordingly], there were ninety thousand ${ }^{144}$ hawk-headed

\footnotetext{
132 Tib. Zur phud lnga pa; Skt. Pañcaśikhā; lit. "One with Five Topknots."

${ }^{133}$ This refers to Pehar. According to Tucci (1999, p.736), this name is simply the Chinese character 護, meaning 'to protect,' and is equivalent to the Sanskrit pāla.

${ }^{134}$ Admittedly, Tucci's (1999, p.735) rendition of this line maintains an aesthetic rhythm and rhyme.

${ }^{135}$ Tib. Mu rug btsan po.

${ }^{136}$ Tib. Zhang Rgya tsha lha snang.

${ }^{137}$ Tib. 'Gos rgan.

${ }^{138}$ Tib. zhal gce [sic: lce] 'dar gsum dang dga' gsum bcad par...; Tā la'i bla ma 05 1991-1995, vol.5, p.27.6. Tucci elaborates on this confusing fragment by statement that the minister "put the same questions twice viz. if a prince guilty of murder of a subject was punishable and by whom; each time the question was formulated in three different ways so that the king, the ministers, and the subjects in turn trembled (adar) and rejoiced (dga'). Mu ru [sic: rug] btsan po has killed the son of the minister because the latter had forbidden him from entering the room where the king was having council with his father;" Tucci 1999, p.742n.62. For more details on this controversial murder, see Sørensen 1994, p.407.

${ }^{139}$ There is some disagreement about where Prince Muruk Tsenpo was sent. Some sources say to the land of the Mön (southeast), while others say he was sent to the region of Shangs in Tsang (west); see Sørensen 1994, p.407n.1404. It is clear that the Prince being sent north here serves the purposes of the present narrative.

${ }^{140}$ Tib. Mgon brtson.

${ }^{141}$ Tib. G.yar mo thang. This toponym refers to an extensive area surrounding modern-day Qinghai Lake, also known as Kökönor in Mongolian and Tsongön (Tib. Mtsho sngon) in Tibetan. For a more extensive discussion of this area and its historical parameters, see Kapstein 2009, pp.36-39.

142 Tib.Zhang Lha bzang klu dpal.

${ }^{143}$ Tib. Rgya zam.

${ }^{144}$ Tib. khri tsho dgu. Tucci (1999, p.735) has a hundred thousand, which is incorrect.
} 
soldiers, a hundred thousand kumbhạṇda-footed ${ }^{145}$ soldiers with cloven-hoofed feet [like] horses and donkeys, a hundred and twenty thousand soldiers with human bodies and rat tails, and a hundred and thirty thousand soldiers with human bodies and donkey ears. With such a numberless army, the Prince conquered the lands of China, Mongolia, and Drugu. ${ }^{146}$

[When the Prince's army arrived in Bhatahor,] the sovereign spirit Pehar was terrified, so he transformed into a vulture and fled. However, a capricious spirit shot him with an arrow and hit his wing. He fell to the earth, whereupon Vaiśravaṇa and his retinue caught him and led him to Samyé. Throughout all of this, the prince saw the innumerable frightening attendants that Vaiśravana emanated. Taking them as a model he drew a picture of this, which became known as "Vaiśravaṇa in Jang" (Figure 16)... ${ }^{147}$ [Unfortunately, when Pehar arrived in Tibet] he magically unleashed [calamities] like madness and epidemics, so the great master exorcised him, causing him to flee [back] to his homeland... ${ }^{148}$ Śāntarakșita, Padmasambhava, and King Trisong Deutsen discussed the matter and [agreed to] send an emissary in order to invite Dharmapāla ${ }^{149}$ - who was of the Zahor royal line-from the meditation center in Mongolia. Pehar was

\footnotetext{
${ }^{145}$ Tib. grul bum rkang rtse. The grul bum (Skt. kumbhända) refers to a bizarre group of Indian spirits with pitchershaped testicles; see Sutherland 1991, p.66.

${ }^{146}$ Tib. Gru gu. According to the Bod rgya tshig mdzod chen mo, this refers to an ancient kingdom that once existed in the vicinity of modern-day Xinjiang Province and Qinghai Lake, Qinghai Province, China; see Zhang Yisun 1985, p. 400

${ }^{147}$ Tib. Ljangs. According to Wylie (1962, p.119n.50), who uses the alternative spelling 'Jang, this area is in the Tibetan cultural region of Kham, along the modern-day border between the far eastern area of the Tibet Autonomous Region and northwest Yunnan province, China. However, this narrative suggests that this region once extended farther north.

The ellipsis signifies the next three lines, which are not immediately relevant since they concern the fate of the flag possessed by Vaiśravana as it was transferred to various sacred sites in Tibet. The Fifth Dalai Lama also takes this as an opportunity to refute the claims of Lama Sokdokpa (Sog bzlog pa Blo gros rgyal mtshan, 1552-1624; TBRC: P645), with whom he had many grievances; see Tà la'i bla ma 05 1991-1995, vol.5, pp.28.4-29.1. See also Blo gros rgyal mtshan 1975.

${ }^{148}$ Once again, the Great Fifth takes a momentary detour to discuss minor variants of this event among different accounts. In particular, he notes how this is an intersection between Vaiśravana's mythos and Pehar's subjugation, an observation that Tucci (1999, p.735) reiterates; see Tā la'i bla ma 05 1991-1995, vol.5, p.29.2-4. There also appears to be some narrative overlapping, with Padmasambhava subduing Pehar several times in different contexts. This suggests diverse and even conflicting narrative strands being awkwardly tied together to form a whole.

${ }^{149}$ There has been some confusion over whether Dharmapāla was a man or a god. Ahmad himself seems to have oscillated on this point. In his translation of the Song of the Spring Queen, Ahmad states that Dharmapāa is a (human) king; see Nag-dBan Blo-bZan rGya-mTSHo 1995, p.166. However, in his translation of Sangyé Gyatso's Life of the Fifth Dalai Lama, Ahmad adds the interpolation that Dharmapāla is a deity; see Sañs-rGyas rGyamTSHo 1999, p.253. It seems clear from the Fifth Dalai Lama's account that he is a man of royal descent, and a particularly important one at that, as will be elaborated upon later.
} 
very affectionate toward Dharmapāla, so he appeared [before him] and took up his three [possessions]: a self-made turquoise statue of the Buddha, a sacred leather mask (Figure 17), ${ }^{150}$ and a crystal lion mount. [Then Pehar] said, "Since you have been invited to be a protector of Samyé Monastery, I will go with yougod and man together." Because he served [Dharmapāla], the sovereign spirit Pehar, riding on a bejeweled wooden bird, said, "To Samyé!" [Thus,] when the meditation center was conquered [by the Prince's army], being attached to Dharmapāla and his own sacred items, the sovereign spirit followed them [to Tibet]. ${ }^{151}$ The precious abbot Śāntarakșita offered Pehar stag horns and deer bladders as gifts in exchange for not harming any women. Dharmapāla offered Pehar tiger- and leopard-headed victory banners as gifts in exchange for not harming any men. The great Padmasambhava then placed a vajra on the sovereign spirit's forehead and bound him to his oath [to protect the Buddhist teachings]. Thus, to this day, when the sovereign spirit truly possesses [the Nechung Oracle], a trace of the vajra appears on his forehead. ${ }^{152}$

\section{Pehar Arrives at Nechung}

[Over time,] all Five Great Sovereign Spirits successively came to reside and remain at many monasteries [in Tibet]. Thus, the Great Dharma King [Pehar went] to reside at Yangön Monastery ${ }^{153}$ in the central region to the north. ${ }^{154}$

\footnotetext{
${ }^{150}$ Tib. zhal brnyan bse 'bag; this is a variant of bse 'bag smug chung. For more on the mystique surrounding this artifact, which has come to be associated with the Dharma protector Tsiu Marpo, see Nebesky-Wojkowitz 1998, pp.103-104.

${ }^{151}$ This sentence is a condensation of the original line, in which the Fifth Dalai Lama briefly notes the minor contradiction between Pehar taking his sacred items and agreeing to follow Dharmapāla versus Dharmapāla and the sacred items being led back to Tibet by Prince Muruk Tsenpo's army and Pehar following after them because he was attached to them. The Fifth Dalai Lama believes the latter scenario to be the correct one; however, that he includes both possibilities in his account is a vivid illustration of his continuing negotiation with the disparate and often conflicting elements of the narrative; see Tà la'i bla ma 05 1991-1995, vol.5, pp.29.1-30.1. Lin Shen-yu also examines this narrative conflict as it is presented in the Song of the Spring Queen; see Lin 2010, pp.17-18.

${ }^{152}$ While my goal here is to illustrate how the Fifth Dalai Lama understood Tibetan history with respect to Pehar, it is still worth noting those works that have discussed the actual historicity of this event. The most notable article is Heather Stoddard's "Nine Brothers of the White High," which reassesses and adds to past discussions; see Stoddard 1997. However, Stoddard's work should be tempered by observations and corrections made by Leonard van der Kuijp; see van der Kuijp 1998, pp.1148-1150. A new article by Roberto Vitali also discusses the historicity of the Bhatahor affair, suggesting that it is a conflation of Pehar's narrative with a later conquest; see Vitali 2011.

${ }^{153}$ Tib. Yang dgon gyi gtsug lag khang. No explanation is given for when or why Pehar went to Yangön Monastery in the Tsel region (Tib. Tshal). According to oral tradition, the eighth-century monk and translator Vairocana came to the site of Üling Monastery (Tib. Dbus gling dgon pa) near Yangön after he had a quarrel with one of King
} 
Due to the past karma [of] the myriarch lord of Tsel, Dönyö Dorjé, ${ }^{155}$ on the third day of the first month of the Earth-Ox year [1529], Pehar took possession [of an oracle] and prophesied, ${ }^{156}$ "When Gungtang [Monastery] is destroyed by fire, Dönyö Dorjé will pass on to the pure land ${ }^{157}$ [from] here. I, Pehar, will go to the land of Uḍdiyāna!" "158 Because of such prophecies, the master [Dönyö Dorjé] became very angry and said in reply, "[I will throw] Pehar and his sacred possessions ${ }^{159}$ into the middle of the $\left[\right.$ Kyichu] ${ }^{160}$ River!" His family and lineage holders pleaded [with him], saying, "[Pehar] is the protector of our ancestors, how can you throw him in the river? [If you do this] his power will bring great harm to our retinue and subjects!" Dönyö Dorjé said, "I will not die and Gungtang shall not be destroyed by fire! If he goes to Uḍ̣ịāṇa, I will perform destructive actions [against him]!” Then he said, “[Throw] Pehar and his sacred possessions into the Kyichu River ${ }^{161}$ [headed for] Dambak Marser

Trisong Deutsen's queens. He invited Pehar to go there with him and the deity stayed behind when the monk went on to Drak Yerpa (Tib. Brag yer pa); interview with Lodrö Samten (Tib. Blo gros bsam gtan), caretaker monk of Üling Monastery, November 3, 2011. See also Sørensen, Hazod, and Tsering Gyalbo 2007, vol.2, pp.611-613. There is no way to confirm that this was believed to be the case in the seventeenth century; however, this story resonates with mythic events surrounding Nechung Monastery's founding, discussed in chapter 3.

${ }^{154}$ By way of transition, these two brief sentences were drawn from Sangyé Gyatso's portion of the Nechung Register (see Appendix III, p.579). The remaining text is translated from the Hagiography of Jokpa Jangchup Penden, also composed by Sangyé Gyatso; see Appendix IV, ff.10a.5-14b.1.

${ }^{155}$ Tib. Don yod rdo rje. Other than the rank given here and a potential connection to the famed Rinpung (Tib. Rin spungs) lord Dönyö Dorjé (1462/1463-1512; TBRC: P375), little is known of this figure; see Sørensen, Hazod, and Tsering Gyalbo 2007, p.218n.576.

${ }^{156}$ Quoting the Gung thang dkar chag-which in turn summarizes content from the Hagiography of Jokpa Jangchup Penden - Sørensen and Hazod translate this event as Pehar taking possession of Dönyö Dorjé himself; see Sørensen, Hazod, and Tsering Gyalbo 2007, p.217. The lines in the original hagiography and the summary in the Gung thang dkar chag differ grammatically; the former text uses an instrumental case particle (Sangs rgyas rgya mtsho n.da., ff.10a.6-10b.1) while the latter uses a dative-locative particle (Sørensen, Hazod, and Tsering Gyalbo 2007, Appendix 6, Gung thang dkar chag, f.41b.2). This confusion is worsened by the unreliable spelling and poor syntax used throughout the manuscript of the hagiography. However, given that Pehar takes possession of an unnamed individual five more times in this text, I suggest that he possesses someone other than Dönyö Dorjé and is delivering the prophecy in the myriarch's presence.

${ }^{157}$ Tib. dag pa'i zhing du gshegs; this is an honorific euphemism for dying.

${ }^{158}$ According to Sørensen, Hazod, and Tsering Gyalbo (2007, pp.55, 112-113), the fire prophesied here is the great fire of 1546, the worst in Tsel Gungtang's history. Pehar is saying that when Tsel Gungtang is destroyed and Dönyö Dorjé dies, he will return to Padmasambhava's land of origin and abandon the clan and region he had presumably watched over for centuries.

${ }^{159}$ Tib. bskor [sic: dkor] rdzas lus g.yar [sic: g.yang].

${ }^{160}$ Tib. Skyid chu.

${ }^{161}$ Tib. Skye [sic: Skyid] chu. This word is preceded by a syllable that is difficult to read in the facsimile (Sangs rgyas rgya mtsho n.da., f.10b.5). At first glance it looks like $s k u$, but it seems to have a suffix letter too faded to recognize. Despite this, the meaning of the sentence is fairly clear. 
village!" ${ }^{162}$ His servants, subjects, and family [then] carried Pehar and his sacred possessions to the middle of the river in a coracle. ${ }^{163}$ When they began to do so, Pehar took possession [of a medium again], saying, "HRĪḤ! I, the evil spirit ${ }^{164}$ Pehar, have an inauspicious connection with the unintelligent master and his family. When my residence ${ }^{165}$ changes, this master ${ }^{166}$ [and his] retinue will fall into ${ }^{167}$ the ocean! My lama is the Vajrasattva [Jokpa Jangchup Penden]. I will clear away all adverse conditions for him." Having spoken such, [the deity] went into the river and proceeded to the lower valley of Dambak Marserchen [village]. ${ }^{168}$

Subsequently, the previous night ${ }^{169}$ [Jokpa Jangchup Penden] had an excellent dream. In it, a white man appeared from the sky and said, "Receive me! Receive me!" [He stood] within a canopy of rainbow light, had teeth like rows of [tiny] conch-shells and turquoise eyebrows, [rode] a young white horse, and had many attendants. He placed his head at lord [Jokpa Jangchup Penden's] feet. [The lord] cleared away all [of the white man's] physical defilements and offered him about a thousand human hearts. [The white man then] said, "Quite a few omens will arise and a guest will come today, so be prepared!" Around noon on the fifth day [of the month], Pehar and his sacred possessions ${ }^{170}$ came to rest on the banks of the Kyichu River [near] the lower valley of Dambak Marserchen. ${ }^{171}$ There was a rainbow canopy [as well as] a white rainbow. Master [Jokpa

\footnotetext{
${ }^{162}$ Tib. nas krongs ston glang dmar sad. This fragment is difficult to fully understand. I suggest that it is a highly misspelled variant for the village area around Nechung, called elsewhere in this text Dam/Dar 'bag dmar ser. This could explain the ston glang dmar sad; however, the nas krongs is still unclear. Perhaps it is a poorly written phonetic rendering for Gnas chung, since such phonetic misspellings are found elsewhere in this text. It is also possible that nas is a redundancy and krongs is a misspelling of grong, which is how I interpret it here. For a fuller discussion of Dambak Marser village and its significance, see Sørensen, Hazod, and Tsering Gyalbo 2007, p.217n.574.

163 Tib. ko ba.

${ }^{164}$ Tib. 'dre ngan.

${ }^{165}$ Tib. 'dre ngan gnas gzhi; lit. "the residence of the evil spirit."

${ }^{166}$ The original text has the following annotation here: 'khor sa bcas pas go dgos so/ 'dre ngan rdo rje'i tshig la 'gyur ba med/' 'dre ngan bskor rdzas bcas pa khyer nas 'gro gzugs med/ This can be translated as: "[Dönyö Dorjé] and those around him should have listened. The evil spirit's vajra verses are immutable. After the evil spirit and his possessions were carried [away], his form was no longer [present]." See Appendix IV, n.18.

${ }^{167}$ Tib. $d a$; read as $d u$.

${ }^{168}$ Tib. Dam 'bag dmar ser can. A variant spelling for the first part of this name is Dan 'bag, pronounced Denbak.

169 Tib. mdang gsum; read as mdang sum.

${ }^{170}$ Tib. bskor rdzas lus g.yang.

${ }^{171}$ Tib. Dar [sic: Dam] 'bag dmar ser can.
} 
Jangchup Penden's] attendants came [to his quarters]. He instructed ${ }^{172}$ his two attendants, Drakpa Gyentsen ${ }^{173}$ and Döndrup Rapten, ${ }^{174}$ saying, "My guest has arrived at the bottom of the valley and has also pitched [his rainbow] tent. Bring him [here]!"

The two attendants went quickly and saw [the deity]. He was neither man nor spirit ${ }^{175}$ and he wore silks and brocades, as well as a cloak of vulture feathers. ${ }^{176}$ He said, "HRĪH!! In an unfabricated divine palace [I] reside as the essence of non-duality. [However,] for the master, I am [here] in a conventional sense surrounded by young monks. The time has come to depend on me, the protector among the evil spirits! I seek an acceptable place for my [sacred] possessions!" [He then] prophesied, "[For] the master [and the monastic] assembly [I will be] a sentry during the day and a watchman during the three [watches of the] night. I will clear away adverse conditions, accomplish concordant [conditions], and am endowed with the power of good aspirations. I will properly bear [these responsibilities]!" The attendants ${ }^{177}$ said, "We are the attendants! We told our master we would come to receive [you] and return. Then [you can] pay homage to him and discuss [your] full history, the one who is neither man nor spirit. ${ }^{178}$ Therefore, it would be very good for us to invite [you] up!" And so the servants, [having] gone down, invited [the deity] up.

The master's fast dark-yellow horse had died, and its head, as well as a sheep's head, ${ }^{179}$ had been placed in front of him; they were bright white [skulls] lacking flesh or brains. Then Pehar and his sacred possessions arrived before the master. Pehar took possession [of a medium] and said, "HRĪḤ! The time has come for me, the spirit, to say [these] three statements to the master, who resides as the essence of Vajrasattva in the middle of this gathering consisting of the young monks' assembly, the eight male and female bodhisattvas, the patron [clans]

\footnotetext{
${ }^{172}$ Tib. mdzub rigs [sic: khrid] mdzad.

${ }^{173}$ Tib. Drags pa rgyan mtshan.

174 Tib. Don grub rab brtan.

175 Tib. $m a$ [sic: $m i]$ min 'dre min.

${ }^{176}$ Tib. bya rgyod pa'i spu thu le [sic: thul] ba.

177 Tib. drung grags seng. The etymology of this phrase is unclear; however, given that it appears again below in the variant drung seng, it appears to mean some type of attendant.

${ }^{178}$ Tib. mi min 'dre min.

${ }^{179}$ Tib. dbyangs [sic: g.yang] mgo.
} 
that flank [the master] — the Tak[dongpa] and Ngül[düpa ${ }^{180}$ —as well as sixteen attendants. $^{181}$

"[First,] The master, along with his retinue and subjects, must take notice of this evil spirit's small items for which there is no abode. ${ }^{182}$

"[Second, I] thoroughly illuminate the path, like the eight [auspicious] items ${ }^{183}$ glittering in the ground, the [eight] auspicious signs ${ }^{184}$ - [like] the white parasol-in the sky, and the seven ornaments ${ }^{185}$ in the intermediate space. The master, bodhisattvas, tutelary deities, dākiniss, and all the oath-bound protector deities have gathered like clouds. Accordingly, I feel the vajra on my forehead and the adamantine nectar of immortality on my tongue.

"[Third,] for the master, the Dharma lineage, and the spiritual community, [I will act as] a sentry during the three [watches of the] day and a watchman during the three [watches of the] night. Until I attain enlightenment, I will not transgress [my vows]. I will swiftly destroy the physical enemies and the formless obstructing spirits. [May] the master consider [this]! ${ }^{186}$

"[My] formless vajra verses are immutable! During the death anniversary of the lord's mother, Drölma Lhadzé, ${ }^{187}$ when he [built] a silver-plated reliquary ${ }^{188}$ [for her], he offered items topped with a thousand measures worth of turquoise and gold in order to dedicate them to her complete enlightenment. In

\footnotetext{
${ }^{180}$ Tib. yon bdag stag dang dngul gyi gzhogs pa can. The full names of the two patron clans given here are mentioned earlier in this text; see chapter 3, p.229.

${ }^{181}$ Tib. drung seng.

182 Tib. 'dre ngan gnas med rdzas chung 'di dag rnams slob dpon 'khor 'bangs bcas pas go dgos so/.

${ }^{183}$ Tib. [bkra shis] rdzas brgyad; these are [1] a mirror (Tib. me long), [2] curds (Tib. zho), [3] dūrvā grass (Tib. rtswa dur ba), [4] wood apple fruit (Tib. shing tog bil ba), [5] a right-coiling conch shell (Tib. dung g.yas 'khyil), [6] a bezoar (Tib. gi wang), [7] vermilion powder (Tib. li khri), and [8] white mustard seeds (Tib. yungs dkar).

${ }^{184}$ Tib. bkra shis rtags rdzas [sic: brgyad]; these are [1] the supreme parasol (Tib. gdugs mchog), [2] a pair of golden fish (Tib. gser nya), [3] a vase (Tib. bum pa), [4] a lotus (Tib. pad ma), [5] a right-coiling conch shell (Tib. dung g.yas 'khyil), [6] an eternal knot (Tib. dpal be'u), [7] a victory banner (Tib. rgyal mtshan), and [8] the wheel of Dharma (Tib. 'khor lo).

${ }^{185}$ Tib. nor bu cha bdun; these are [1] the king's earrings (Tib. rgyal po'i rna cha), [2] the queen's earrings (Tib. btsun mo'i rna cha), [3] the minister's earrings (Tib. blon po'i rna cha), [4] rhinoceros horn (Tib. bse ru'i rwa), [5] a branch of coral (Tib. byu ru'i sdong po), [6] an elephant tusk (Tib. glang chen mche ba), and [7] a triple-eyed gem (Tib. nor bu mig gsum).

${ }^{186}$ These three statements appear to be based on the Tibetan phrase go myong rtogs gsum, meaning the "threeunderstanding, experience, and realization." Here, the third concept is dgongs rather than rtogs, but the same progression is visible. Pehar is requesting his sacred items be attended to, and in exchange he offers his qualified experience as a protector for Master Jokpa Jangchup Penden to consider.

${ }^{187}$ Tib. Sgrol ma lha mdzes. Jokpa Jangchub Penden's mother is introduced near the beginning of this text; see Appendix IV, f.2b.1-2.

${ }^{188}$ Tib. dngul rdung; read as dngul gdung.
} 
addition to this, due to the master's practice, Drölma Lhadzé [indeed] passed into the Blissful Pure Land." ${ }^{\prime 189}$ After this was said, [the lord] expanded the practice ${ }^{190}$ of his dedication prayers. As [the lord] took turquoise and placed it on top of his horse's skull, he entrusted himself to [Pehar] and commanded, "Pehar, [your] supports, thread-crosses, and shrines have been inconsistent. I will establish a steadfast thanksgiving rite ${ }^{191}$ for the good [activities] that were entrusted in the past, and build a shrine on well-employed land. I praise the awesome prestige of the excellent outer [activities] that have been entrusted [to you]! May you accomplish ${ }^{192}$ all pacifying, augmenting, subjugating, and destructive activities that I [request]! May you perform activities that [cause] all monastic communities and monasteries to completely flourish! May you perform powerful activities that quickly liberate [through destruction all] physical enemies and formless obstructing spirits with wrong views!" The turquoise-adorned horse skull arose from this [meeting]. ${ }^{193}$

The lord [then] commanded the monastic disciplinarian of the Takdong clan as follows, "Build a small abode ${ }^{194}$ for my Dharma protector ${ }^{195}$ Pehar!" This was properly accomplished according to the lama's instructions. Afterward, they constructed body, speech, and mind supports, as well as a thread-cross support, topped by the lord's own horse skull. [The shrine] was consecrated with the glorious Cakrasamvara [practice] and the local ruler gave the benediction. Then flowers were strewn about and fell to the ground as far as an arrow can fly. The monastic disciplinarians of the Takdongpa and Ngüldüpa [clans], as well as the male and female patrons, [performed] their own ${ }^{196}$ songs and dances; the virtuous teachers [sang] vajra songs on experience and realization; the sons and daughters of the gods rained down flowers; and there was a canopy of rainbow light, as well

\footnotetext{
${ }^{189}$ Tib. Bde ba can; Skt. Sukhavatī.

${ }^{190}$ Tib. 'tshams [sic: mtshams] sbyor; lit. "connection."

${ }^{191}$ Tib. btang [sic: gtang] rag.

${ }^{192}$ Tib. sgrub; read as sgrubs.

${ }^{193}$ This interaction suggests that Jokpa Jangchup Penden took a personal item of his, his horse's skull, and decorated it with turquoise as an offering to Pehar, which bound them together.

194 Tib. gnas chung chung.

${ }^{195}$ Tib. chos gsung [sic: srung].

${ }^{196}$ Tib. dang nga rang gi; on its own this fragment means "and my own;" however, in the present context it makes no sense since there is no indication that the surrounding content is spoken, let alone by whom. I am reading this as a misspelling of rang rang gi.
} 
as [other] inconceivable and wondrous signs. Lord [Jokpa Jangchup Penden] supervised the blessing ${ }^{197}$ of each of the supports. Because of [all] this, [everyone] was graced with an actual vision of a white man riding a white horse, who was adorned with such items as a jeweled crown, and who was clothed in various silks. His teeth were like rows of conch shells and he had turquoise eyebrows. He carried a white conch shell in his right hand and a hundred[-bead] rosary in his left. He was surrounded by a retinue. Periodic support offerings were accordingly established [at the shrine] and it was indeed first given the name Nechung (Figure 18).

\section{Alternative Narratives}

The above account is an approximation of how the Fifth Dalai Lama understood Pehar's origins and his eventual appearance at the site that would come to be known as Nechung. However, many of the same sources cited above, all of which were known to the Great Fifth, also contain alternative and even conflicting narrative accounts of Pehar's past. This begs the question of why the Fifth Dalai Lama chose to promote the above account when expanding Nechung and composing its register. The following are a few examples of alternative narratives found in these same sources, which paint at times a very different picture of the deity.

The account above stems in part from the explanatory tantra of the White Crystal Rosary. However, a different account comes from the introductory chapter of the White Crystal Rosary's root tantra, and is cited verbatim in Amézhap's Symphony of the Captivating Gods: ${ }^{198}$

The title of this text in Sanskrit is Rudrarājabhabhitantraguhya; ${ }^{199}$ in Tibetan it is Dügyel Sheltreng Sangwé Gyü. ${ }^{200}$ I pay homage to Lord Yamāntaka, King of the Herukas!

\footnotetext{
${ }^{197}$ Tib. $b k a$ ' sgo [sic: bsgo]; while this term usually means "to command, order," here it appears to refer to prayers for protective blessings.

${ }^{198}$ A myes zhabs 2000, pp.407.2-411.5. It is clear that the White Crystal Rosary is cited verbatim because the tale is first presented in Amézhap's own prose language (see ibid, pp.402.2-407.2) before being given again in the poetic meter likely found in the original text. My translation is based on the latter poetic account in hopes of keeping close to the original. Moreover, as illustrated in the attendant translation, it appears this citation begins at the very beginning of the root tantra.

${ }^{199}$ The bhabhi here is meant to represent 'crystal rosary,' though the original Sanskrit word is difficult to ascertain.

${ }^{200}$ Tib. Bdud rgyal shel phreng gsang ba'i rgyud; lit. Secret Tantra of the Terrifying King's Crystal Garland. This English title translates the Sanskrit rudra (lit. "terrifying") rather than the Tibetan bdud (lit. "hindering spirit").
} 
Thus, I have heard: ${ }^{201}$ the fierce and terrifying Lord Padma Heruka manifested in a brilliant form. With confidence he overpowered the host of hindering spirits, laughing uproariously, "Haha! Hihi!" His body is adorned with charnel ground ornaments and he sits amid the burning flames of apocalyptic fire. He resides in a divine mansion of blazing and terrifying charnel grounds, where there are thickets, groves, and thorny trees, black flowers and poisonous woods, savage beasts fighting amongst themselves, and carrion birds crying out. It is surrounded by swelling oceans of blood... ${ }^{202}$ In this pure abode, Lord Padma Heruka achieved a deep meditative state that produced grand manifestations in order to tame the myriad hostile forces. Thus, the Master of Secrets Vajrapāni, as well as many fierce emanations, filled the sky. The Master of Secrets exclaimed, "Haha! Hihi! How wonderful!" and frightening warriors shook the world. Because of this, the haughty spirits all fainted, vomited blood, and were overpowered.

The Great Padma Heruka settled in the meditative state that liberates all from suffering, causing many of the haughty spirits to faint or be killed. They cried out in anguish and sought refuge, saying, "We will obey whatever the Glorious One commands! We will do whatever is ordered of us!" So Vajrapāni said, "Listen, all you haughty spirits! If you would be obedient to the Glorious One's commands, then tell me in what way each of your systems are practiced, from where your life-essences can be summoned, in which favorable substances you delight, how the ritual preparations for your mandalas are performed, and what actions please each of you! If you would be obedient, then be so here!" From among the crowd of haughty spirits, a great asura ${ }^{203}$ layman said to the fierce Lord Padma Heruka and his attendant the great Vajrapāni, "We haughty spirits, due to the karma of our past lives, are incomplete and born to kill. Among all these haughty spirits, my own lineage is as follows:

\footnotetext{
${ }^{201}$ Tib. 'di skad bdag gi thos pa'i dus cig na; this phrase is commonly found at the beginning of sütras, supposedly spoken by the Buddha's disciple Ānanda, who is relaying what he directly heard from the Buddha.

${ }^{202}$ Tib. yang rgyud de nyid las/; A myes zhabs 2000, pp.407.6. This is the equivalent of an ellipsis, signifying that after quoting the beginning of the tantra Amézhap is now quoting another portion.

${ }^{203}$ Tib. lha mi; read as lha min.
} 
"Along the highest peak of Mount Meru, at the base of the wish-fulfilling tree, within the nine-pointed castle of the hindering spirits, atop a throne made from the corpses of humans and horses, the king of the hindering spirits, Kingdefeater, ${ }^{204}$ resided. Along the northeast summit of Mount Meru, at the base of the wish-fulfilling tree, within Lake Manasarovar, the white female serpent spirit Gojokchen ${ }^{205}$ resided. She was a sister of the eight great serpent spirit kings, and she acted as the grandmother of the landlord spirits and plague spirits. Her desire for a man boiled like water, but she could not find a husband in all the three worlds and became despondent. She remained so until my father, the king of the hindering spirits, dispatched a humorless black hindering spirit with a letter for her, which said, 'Would it be improper if I were to fall in love with a female serpent spirit [such as yourself]?' She respectfully wrote back, 'It would also make me happy to fall in love! I have great desire and you have great anger. By combining my desire and your anger, we might produce many capricious spirits that would lay waste to the world. If so, what would you do?' My father the hindering spirit responded, 'I also desire a wasted world. Such barrenness would be my karma!' The hindering spirit and the serpent spirit [met and] made love on the peak of Mount Meru, and after five months thirteen eggs were produced from their union.

"The eggs shook and trembled ${ }^{206}$ and burst into flames, covering the world in cacophony and darkness. However my mother hungered for the eggs, so she swallowed them. But as soon as she did, flames burst from her body, blood poured from her mouth, lightening flashed from her nose, and tears of blood fell from her eyes. She felt like her body was falling apart. In the pure realm of the gods on the peak of Mount Meru, she went into the presence of the hindering spirit [king] endowed with a garland of skulls and vomited up the eggs before offering them to Glorious Vajrapāni. [She said,] 'Vicious and dangerous capricious spirits will be born from these eggs; I pray that you bless and subjugate them!' Vajrapāni took the eggs and placed them on top of the Amolika Stone

\footnotetext{
${ }^{204}$ Tib. Rā ja rgyal ba; lit. "One who Overcomes Kings."

205 Tib. Mgo cog [sic: lcog] can; lit. "She whose Head is Wreathed [with Flowers]."

${ }^{206}$ Tib. ldog; read as ldeg.
} 
within the pure realm of the gods. He struck each one with a rock and they burst open. From the first egg, the king of the hindering spirits, Köjé Drangkar, ${ }^{207}$ was born. When the next egg burst open, the planetary-hindering spirit Rāhula was born. Then came the savior spirit Mukha Zungnyi Dongchen. ${ }^{208}$ Then the eastern Shelging Karpo. ${ }^{209}$ Then the haughty spirit Guwangché, ${ }^{210}$ Padma Gargyi Wangchuk, ${ }^{211}$ Tsangpa Dunggi Khongsengchen, ${ }^{212}$ Sokpo Chakyi Marachen, ${ }^{213}$ Yekha Trülgyi Gyelpo, ${ }^{214}$ Sipa Zhidzin Norgyi Dagpo, ${ }^{215}$ and Yarshu Marpo. ${ }^{216}$ However, the seventh egg $^{217}$ flew up into the heavens. This enraged Glorious Vajrapāni, who pursued [the rogue egg]. He captured it and dashed it against the ground three times, causing it to crack open.

"What emerged from the egg was a being that did not look like the son of a hindering spirit, but rather like the son of a god. His body was incredibly white, his head was adorned with [a hat] that resembled Mount Meru surrounded by the four continents, and he marvelously exhibited all thirteen signs of royalty. [Everyone] was astonished. His name was King Pehar ${ }^{218}$ and he was born with the body of a human but the head of a garuda bird. Indra, the lord of the gods, gave him the name Khyungchen Lutrukdül, layman of the gods. When he led armies against the asuras, he rode a white lion, wore a white silk vest and a blue hat, ${ }^{219}$ and [brandished] a razor. When he surrounded and advanced on them, he defeated the asura army, and so was called the great layman of the gods. When he became famous in the land of the gods, he was entrusted to guard the gods' meditative concentration. When he entered meditative absorption [himself], he

\footnotetext{
207 Tib. Bskos rjes brang dkar; see note 98.

${ }^{208}$ Tib. Mu kha zung gnyis gdong can; lit. "Face Endowed with Two Mouths."

209 Tib. Shel ging dkar po; lit. "White Crystal Servant."

${ }^{210}$ Tib. Dgu dbang che; lit. "Great Ruler of All."

211 Tib. Padma gar gyi dbang phyug; lit. "Lord of the Lotus Dance."

212 Tib. Tshangs pa dung gi khong seng can; lit. "Brahma with the Conch-shell Crevice."

${ }^{213}$ Tib. Sog po lcags kyi sma ra can; lit. "Mongolian with an Iron Beard."

214 Tib. Ye kha 'phrul gyi rgyal po; lit. "Miraculous King of Yekha."

215 Tib. Srid pa gzhi 'dzin nor gyi bdag po; lit. "Lord of Wealth who Upholds the Foundation of the World."

216 Tib. Yar shu dmar po; this is likely a variant of Yam shud dmar po, lit. "Red One of Yamshü."

217 Tib. bdun tshigs pa; lit. "seventh interval." Since this is the middle of the thirteen eggs, it resonates strongly with Pehar's place in the story of the five eggs discussed below. Also, while this group of eggs was said to be thirteen, only twelve deity names are provided, including this final one.

${ }^{218}$ Tib. Spe dkar rgyal po.

${ }^{219}$ Tib. gling zhu; the context makes it clear that this is a hat, though it is unclear what type of hat.
} 
was called the Black Layman Dünringhar. ${ }^{220}$ As such, [this being, which is me,] has many names.

"However you summon me, I am the layman of the gods. My father is the hindering spirit king and my mother is the serpent spirit Düza Minkarmo. ${ }^{221}$ My retinue consists of great commanders and generals, as well as black lords of life with black hair and great black flags. My outer ministers are Hara ${ }^{222}$ and Langdra. $^{223}$ My internal minister is Putra Dorjé. ${ }^{224}$ There are also slaves, zinpa, and dompo. On my right there are a hundred archers and tiger-skin-clad warriors. On my left there are a hundred brigadiers and śrāvaka-arhats. In front of me is the vanguard of a hundred black women. Behind me is the rearguard of a hundred black monks. These are the servants that I have captured, as well as the four fox siblings. $^{225}$ This is the form in which I was born. These are the names of my emanations. I and my retinue will obey your command!”

This second origin story is significant for several reasons. First, it clearly provides a much shorter alternative to the first account offered above. That this tale is given at the very beginning of the White Crystal Rosary's root tantra also indicates that there is no preceding story. Second, there are a few similar elements, though they are presented differently or in a confused fashion. In the main account, Pehar is born to Köjé Drangkar in one of his past lives, while in this second tale they are brothers hatched from the same group of thirteen eggs. In both accounts Pehar has a mother named some variant of Minkarma, which is also the name of his consort in the iconography presented at the beginning of this chapter. In both stories Vajrapāni plays a large role in Pehar's subjugation, despite the latter's persistent mischief. Third, this story is not given at all in the Nechung Register even though it comes from a source with which the Fifth Dalai Lama was familiar. This indicates that he made a conscious choice to select one origin tale over the other. I will explore possible reasons for this choice below.

\footnotetext{
220 Tib. Dun ring har; lit. "Sudden Perserverance."

${ }^{221}$ Tib. Bdud gza' Smin dkar mo; lit. "Hindering-Planetary Spirit, White-Eyebrowed Woman."

${ }^{222} \mathrm{Tib}$. Ha ra; the literal meaning of this word is uncertain, perhaps it is a toponym.

${ }^{223}$ Tib. Lang dra; the literal meaning of this word is uncertain, perhaps it is a toponym.

224 Tib. Putra rdo rje; lit. "Adamantine Son."

${ }^{225}$ Tib. wa khyung spun bzhi; read as wa khyu spun bzhi.
} 
The next variant narrative stems from the Tantra of the Capricious Spirit Norlha Nakpo and is cited in Lelung's Ocean of Oath-Bound Guardians: ${ }^{226}$

Then Lekden $\mathrm{Nakpo}^{227}$ said to the capricious spirit Norlha Nakpo, ${ }^{228}$ "What is your family lineage?" The black lord of life, son of the hindering spirits, said, "Long ago, in the first eon, my father Yemé Trülgyel ${ }^{229}$ [resided] up high in the azure sky at the base of the wish-fulfilling tree, on the summit of Mount Meru. [My mother] Lunyen Minkarma Gojokchen ${ }^{230}$ [resided] on the banks of Lake [Manasarovar], on the northeast side of Mount Meru. My father was given to anger and my mother was a lustful serpent spirit. They had sex, and after seven months five eggs [were produced]. The first [egg] produced Köjé Drangkar; ${ }^{231}$ the second, Zadü Nakpo; ${ }^{232}$ third, Kyungchen Pehar; ${ }^{233}$ fourth, the lord of life Shelging, ${ }^{234}$ and fifth, Dorjé Lekpa. ${ }^{235}$

"Then, in my next life, my father was Mujé Tsenpo ${ }^{236}$ and my mother was Lumo Göngönma. ${ }^{237}$ Three eggs resulted from their union. The first produced Gönpo Nakpo; ${ }^{238}$ the second, Lutsen Nakpo; ${ }^{239}$ and the third, Dümo Jakang. ${ }^{240}$

Then, after transmigrating [yet again, my father] Dünak Yakșa Dringön ${ }^{241}$ and [my mother] Lumo Belgo Trakmikma ${ }^{242}$ mated. About nine months after their union, a black iron egg was produced. My parents discussed [what to do]

\footnotetext{
${ }^{226}$ See Sle lung rje drung 1976, pp.376.2-377.4. Aside from direct evidence that Lelung faithfully quotes verbatim the extant texts he cites, one strong indicator that this citation of the non-extant Tantra of the Capricious Spirit Norlha Nakpo is likewise verbatim is that almost the entirety of this material is given in seven-syllable verse format. ${ }^{227}$ The original text has Mgon po Legs ldan; see note 112.

${ }^{228}$ Tib. Nor lha nag po; lit. "Black Wealth God." This appears to be another, less common, epithet for Pehar.

${ }^{229}$ Tib. Ye med 'phrul rgyal; lit. "Victorious Manifestation of Nothingness."

${ }^{230}$ Tib. Klu gnyan Smin dkar ma mgo lcog can; lit. "Serpent-Plague Spirit, White-Eyebrowed Woman whose Head is Wreathed [with Flowers]."

${ }^{231}$ Tib. Skos rje 'brang dkar; see note 207.

${ }^{232}$ Tib. Gza' bdud nag po; lit. "Black Planetary-Hindering Spirit."

${ }^{233}$ Tib. Khyung chen Pe har; lit. "Great Garuda Pehar."

${ }^{234}$ Tib. Shel ging; see note 209.

${ }^{235}$ Tib. Rdo rje legs pa; lit. "Excellent Vajra." This is one of the most important Nyingma protectors; see NebeskyWojkowitz 1998, pp.154-159.

${ }^{236}$ See note 95.

${ }^{237}$ Tib. Klu mo Gos sngon ma; lit. "Sky-Clad Female Serpent Spirit."

${ }^{238}$ Tib. Mgon po nag po; lit. "Black Savior." This is a form of Mahākāla.

${ }^{239}$ Tib. Klu btsan nag po; lit. "Black Serpent-Imperial Spirit." This deity is presumably Pehar in this life.

${ }^{240}$ Tib. Bdud mo Bya rkang; lit. "Bird-Legged Female Hindering Spirit."

${ }^{241}$ Tib. Bdud nag Yaksha mgrin sngon; lit. "Black Hindering Spirit, the Blue-Necked Yakșa."

${ }^{242}$ Tib. Klu mo Sbal mgo khrag mig ma; lit. "Frog-Headed Female Serpent Spirit with Bloody Eyes."
} 
before splitting the egg open with a scorpion[-handled] sword. A black iron scorpion arose, and when it shot up into the sky even the gods became paralyzed [with fear]. When it came down even the serpent spirits fainted. Fearing the world's deterioration, my parents cursed, 'We, [his own] father and mother, are incapable [of stopping him] since his ferocity is greater than ours! Because of this, please [Brahmā] come subjugate him!' Glorious long-maned Brahma ${ }^{243}$ [thought], 'If I do not conquer the hindering spirit's son, the world will deteriorate.' $\mathrm{He}$ summoned me through meditation and $[\mathrm{I}]$, the young black scorpion of the hindering spirits, appeared. [Brahmā then] struck the center of the black scorpion's one eye [with] an adamantine three-pronged khatvāñga staff. [I,] the scorpion - the iron Mönpa - became very frightened, and my one eye gushed streams of blood. I brandished a corpse club and a razor in my right hand, and held a black lasso of the hindering spirits in my left. [Then] I transformed into the great untamed lord of life. I offered my life essence to this chief deity, Brahmā, and promised to act in accordance with his commands."

This narrative is an admixture of elements previously encountered. The significant difference here is that a number of Pehar's past lives are discussed rather than just one. Beyond this, the first life in this account mimics the alternative narrative drawn from the White Crystal Garland's root tantra. The biggest discrepancy is that five rather than thirteen eggs are produced by Pehar's parents. This number and the names of the five deities born from these eggs parallel the account of the deity's rebirth in Münpé Yungdrung, provided in the main narrative above. The second life is little more than a segue into the third life. Nonetheless, there is a pattern developing where Pehar's siblings dwindle by odd numbers - the first life had five eggs, the second life three, and the third just one, Pehar himself. In the third life, there are more elements reminiscent of the main account. Pehar takes on the form of a scorpion and he is summarily subjugated because he is too dangerous. It is striking, however, that the Indian god Brahmā subjugates him here rather than the Buddhist deity Vajrapāni.

\footnotetext{
${ }^{243}$ Tib. Tshangs pa shrī ral can. Per Sørensen provides an historical explanation for the etymology of this deity's name in his monumental study Thundering Falcon, relating it to the toponym rtsang and even to the origins of the Tibetan word for Tibet, bod; for a summary of this explanation, see Sørensen 2005, p.295.
} 
A third example also stems from Lelung's text, in which he cites the Black Iron Rosary Tantra: ${ }^{244}$

Thus, I have heard: the Blessed One Karma Heruka resided in nondualistic union with his consort-[surrounded] by the four continents, [eight] subcontinents, the sun and the moon - in the divine mansion of a blazing volcano, up in the azure sky southeast of the great Malaya mountains. ${ }^{245}$ Within the immeasurable palace of the gods and spirits there dwelled together the leader of the capricious spirits, Vajrapāni, as well as Lekden Nakpo, ${ }^{246}$ the layman Norlha Nakpo, ${ }^{247}$ the eight classes of male and female barbaric spirits, [Norlha Nakpo's] hindering spirit consort Śanti Rozen, ${ }^{248}$ his mother Düza Minkar[ma], the seven siblings_patra, putra, shadröl, kyidröl, ${ }^{249}$ zinpo, dompo, and mönpa-Shelging, Vaiśravana, Yamshü Marpo, ${ }^{250}$ Garwa Nakpo, ${ }^{251}$ the leader of the sky spirits, and the eight classes of gods and spirits.

Afterward, in particular, Vajrapāni subdued all the haughty spirits and dwelled impartially in meditation. Then Lekden Nakpo-wearing a garland of skulls and a black cloak, and holding a curved knife and a blood-filled skull cup_paid homage [to Vajrapāni] (Figure 19). He requested that [Vajrapāni] subdue the layman Norlha Nakpo, the son of the hindering spirits. ${ }^{252}$

This source establishes Vajrapāni, Lekden Nakpo, and Norlha Nakpo (Pehar) within the same celestial mansion under the authority of a tantric Heruka. However, beyond summarizing the later interaction between them, this account provides few new details. What is interesting to

\footnotetext{
${ }^{244}$ See Sle lung rje drung 1976, pp.375.3-376.1.

${ }^{245}$ Tib. ri bo chen po Ma la ya; this refers to the Malaya mountain range in southwest India along the Western Ghats.

${ }^{246}$ Once again, the fuller name provided here is Mgon po Legs ldan nag po.

${ }^{247}$ Both Sle lung rje drung 1976 (p.375.4) and 2003 (p.307.6) actually have Nor lha bdag po, lit. "Wealth God Lord." However, Sle lung rje drung 1978 (p.15.3) has Nor bu nag po, while Sle lung rje drung 1979 (p.41.15) has Nor lha nag po. I am choosing the latter variation, since Nor lha nag po appears to be the most standard form of this epithet.

${ }^{248}$ Tib. Shan ti ro zan. The first half of this name is likely the Sanskrit śänti, meaning "peace, tranquility." The literal translation of this name would then be "Tranquil Corpse-Eater;" compare with note 34.

249 The variant spelling spyi grol is given here.

${ }^{250}$ Tib. Yam shud dmar po; see note 216.

251 Tib. Mgar ba nag po; lit. "Black Ironsmith." This figure is a servant of the deity Dorjé Lekpa; see NebeskyWojkowitz 1998, pp.155-156.

${ }^{252}$ As an afterward, Lelung states the following: "It must be known that this savior spirit-wearing a garland of skulls and carrying a knife and skull — and the divine monk Lekden Nakpo discussed earlier are the same;" see Sle lung rje drung 1976, p.376.1-2. This is illustrated in the Meru Sarpa murals; see Figure 19.
} 
note about all of these variant narratives is the mention of other deities, which will be discussed further below. It is also significant that these three different sources-the White Crystal Rosary, the Tantra of the Capricious Spirit Norlha Nakpo, and the Black Iron Rosary Tantra-are all treasure texts believed to stem ultimately from Padmasambhava. ${ }^{253}$

These narrative discrepencies are further exacerbated by the numerous variations and outright conflicts found in other descriptions and iconographies. For instance, in the ThreadCross Ritual for the Six White [Possessions] of the Sovereign Spirit Pehar, the deity is given a number of names and epithets contingent on his location. Moreover, his parents are given names that differ from all of the above accounts:

The great sovereign spirit's father was named Great Namkhyi Karpo. ${ }^{254}$ His mother's name was Queen Shukcham Gyelmo. ${ }^{255}$ These two mated and through them a son was born named Gyajin Karpo. ${ }^{256}$ First he resided up in the sky, [where] he was called Namteu Karpo, ${ }^{257}$ the lord of life sovereign spirit, and the enemy-defeating god Pehar. He was the only son born ${ }^{258}$ from his parents' union. Then he went to the land of Mongolia. [There] he was called Namlha Karpo, ${ }^{259}$ Gelha Jangchup, ${ }^{260}$ and Horlha Tsering. ${ }^{261}$ [When] the meditation center in Bhatahor was conquered, he was called the great landlord spirit. ${ }^{262}$

Iconographically, there are a number of descriptions of Pehar that conflict with the three-headed, six-armed form described at the start of this chapter:

\footnotetext{
${ }^{253}$ See Tā la'i bla ma 05 1991-1995, vol.2, p.615.2-3.

${ }^{254}$ Tib. Gnam khyi dkar po; lit. "White Sky Dog."

255 Tib. Shugs lcam rgyal mo; lit. "Female Sovereign Spirit, Powerful Sister."

256 Tib. Brgya byin dkar po; lit. "White Indra."

257 Tib. Gnam the'u dkar po; lit. "White Sky Spirit."

258 Tib. skyes gcig bu; compare with note 43.

259 Tib. Gnam lha dkar po; lit. "White Sky God."

${ }^{260}$ Tib. Dge lha byang chub; lit. "Virtuous God of Enlightenment."

${ }^{261}$ Tib. Hor lha tshe ring; lit. "Mongolian God of Long-Life."

${ }^{262}$ Ra shag Gter ston 1976, pp.225.3-226.4: rgyal po chen po yab kyi mtshan/ya ni gnam khyi dkar po che/ ma dang de ni yum gyi mtshan/ ma ni shugs lcam rgyal mo btsun/ de gnyis srid cing sprul [sic: sbrum] pa las/ bu ni brgya byin dkar po 'byung/dang po gnam gyi sgeng du bzhugs/gnam the'u dkar po zhes kyang bya/ srog bdag rgyal po zhes kyang bya/ dpe har dgra lha zhes kyang bya/ de nyis bsrid gyi skyes gcig bu/bar du hor gyi yul du byon/gnam lha dkar po zhes kyang bya/ dge lha byang chub zhes kyang bya/ hor lha tshe ring zhes kyang bya/ bha ta hor gyi sgom grwa bcom [sic: bskos]/ sa bdag chen po zhes kyang bya/... This narrative continues with the story of Samyé Monastery's construction and Pehar's installation there; it can also be found in Ra shag Gter ston and Gra sgom Chos kyi rdo rje 1976-1980, pp.384.5-385.1. Another example of a divergent lineage can be found in Nyi ma 'od zer 1976-1980, p.309.5-6.
} 
You, the great Dharma-protecting sovereign spirit, ride a long-nosed elephant for a mount. Sometimes you ride a blue-maned lion. You wear a white silk cloak on your body and a black silk hat ${ }^{263}$ on your head. You carry in your hands a mendicant's staff and a small container. You are known as the sovereign spirit of Samyé. $^{264}$

The great sovereign spirit Pehar has a white body, one head, and two hands. He [holds] a vajra in his right hand and counts a crystal rosary with his left. He rides on an elephant. ${ }^{265}$

Different names and iconographies like these have a simple explanation in the Tibetan idiomthey are understood as different forms and emanations of the same deity. This concept is so engrained in the Tibetan imaginaire that they do not perceive such apparent discrepancies as a problem. When I have brought up Pehar's different forms to various Tibetan monks and laymen they all invariably say the same thing: a deity changes forms like we change clothes.

The contradictions in the various narratives, however, are more difficult to explain. Such processes are best understood through the lens of concepts like superscription, cogeneration, and reverberation, as described and utilized in Prasenjit Duara's "Superscribing Symbols" and Paul Katz's Demon Hordes and Burning Boats. ${ }^{266}$ Katz actually works off of Duara's concept of superscription, which is "a modality of symbolic evolution [whereby] cultural symbols are able to lend continuity at one level to changing social groups and interests even as the symbols undergo transformations. ${ }^{267}$ However, as Katz notes, superscription implies a linear acretion of mythic symbolism. His solution is cogeneration, a concept that accounts for the "simultaneous creation of various versions [of myths] by different people." ${ }^{268}$ Superscription and cogeneration are not mutually exclusive concepts, however, and the former will be revisited again in chapter 3

\footnotetext{
${ }^{263}$ Tib. rmog zhu; this is specifically a three-layered Chinese style hat.

${ }^{264}$ Ra shag Gter ston 1976, p.227.2-4: chos skyong rgyal po chen po khyod/chibs su ba glang sna ring chibs/res 'ga' seng ge mgo sngon chibs/sku la dar dkar 'jo [sic: 'jol] ber gsol/ dbu la rmog zhu dar nag gsol/ phyag na gseg shang par bu bsnams/ bsam yas rgyal po zhes su grags/.

${ }^{265}$ Rgyal sras Legs ldan pa 1976-1980, p.350.6: rgyal po chen po pe ha ra sku mdog dkar po zhal gcig phyag gnyis g.yas pa rdo rje dang g.yon pas shel phreng bsgrangs shing glang chen la bcibs pa/.

${ }^{266}$ See Duara 1988 and Katz 1995, pp.113-114.

${ }^{267}$ Katz 1995, p.113, citing Duara 1988, p.780.

${ }^{268}$ Katz 1995, pp.113-114.
} 
when discussing the state dominance of symbolic power that the Nechung cult will come to represent. In addition to these notions, there is reverberation, which Katz's describes as follows:

It is clear that there was a continuous exchange of ideas, values, and beliefs between different groups of people in late imperial China, something perhaps comparable to the richocheting back and forth of the echo of a yodel off the sides of a mountain. ...As the sound of the echo varies with each rebound, so do ideas, values, and beliefs change as they pass from person to person. However, as in the case of cogeneration, different beliefs prove able to coexist. ${ }^{269}$

Katz states that his notion of reverberation was inspired by Rolf Stein; it is also similar to Wendy Doniger's usage of "cross-fertilization." 270 While the above ideas were developed in the milieu of Chinese deity studies, they can be fruitfully applied to its Tibetan analogue.

The various texts discussed in this chapter present slightly divergent and even contradictory information on Pehar's name(s), origins, and iconography. However, because of the authority of their origins, which is reinforced through their citation by authoritative figures, they are equally valid representations. Cogeneration and reverberation provide an etic explanation for how divergent mythic accounts can be propagated simultaneously; but how are the contradictions resolved by Tibetans, emically? There are two potential solutions, both of which have been exhibited by sources already discussed. The contradictions openly posed a problem for Lelung, who included all major variations in his narrative account, presumably for the sake of comprehensiveness. His solution is an interpretation dependent on the classic Mahāyāna Buddhist notion of skillful means: ${ }^{271}$ "Because the actions of the Thus-gone Ones ${ }^{272}$ cannot be apprehended, I think they are revealed in different forms depending on the proclivities and character of the disciple."273

The Fifth Dalai Lama took a different approach when he composed his portion of the Nechung Register; he chose to highlight one particular narrative over all other alternatives. The main reason for this is revealed in the opening lines of the register. After the salutatory poems at

\footnotetext{
269 Ibid, p. 114.

${ }^{270}$ See Doniger 2009, p.6.

${ }^{271}$ Tib. thabs; Skt. upāya.

272 Tib. de bzhin gshegs pa; lit. tathāgata. This refers to the Buddhas.

${ }^{273}$ Sle lung rje drung 1976, p.385.3: de bzhin gshegs pa'i mdzad pa la tshad bzung med pa'i phyir gdul bya'i mos ngo la ltos nas rnam pa tha dad par bstan par sems so/.
} 
the beginning of the register, the Great Fifth immediately begins quoting scripture to make a convincing case for the worship of Dharma protectors. He cites an argument that calls for accepting the most logical doctrine, the implication being that the Buddha's doctrine is the most logical. He then quotes the great Buddhist sage Dharmakīrti, explaining that if the primary Buddhist scripture is infallible, then all secondary literature is likewise infallible. He proceeds to contract the focus of scripture to the superiority of Vajrayāna doctrine. He then quotes the tantras as saying that relying on Dharma protectors is necessary in order to overcome temporary hindrances and adverse conditions in one's practice. Dharma protectors are thus understood to be clearing the way for a smooth journey on the path to enlightenment. These beings are also described as emanating from the very wisdom of the Buddhas and are ultimately non-dualistic, so they are concordant with the deepest levels of tantric metaphysics. The Great Fifth concludes this argument by stating that the Five Sovereign Spirits headed by Pehar are the best Dharma protectors because they exist in the three highest tantras of Nyingma doxography; these are the Inner Tantras of Mahāyoga, Anuyoga, and Atiyoga. ${ }^{274}$ Furthermore, these deities are manifestations of the Five Buddha Families, a connection elaborated upon by Sangyé Gyatso in the second half of the register. ${ }^{275}$

The Fifth Dalai Lama is making a wholly Buddhist argument for why Pehar and the Five Sovereign Spirits are the most powerful and effective protector deities; to support this he must choose a narrative that represents Pehar in an equivalent fashion. Before giving the narrative, the Great Fifth continues to use Buddhist language to explain that Pehar's story exists only in a conventional sense, having just explained his ultimate nature. This resonates with the foundational Mādhyamika doctrine of the Two Truths. ${ }^{276}$ When we compare the narrative choices available above with those the Fifth Dalai Lama ultimately made, it is clear that he chose the most Tantric Buddhist version of Pehar's origins.

The master narrative above begins with Pehar in the Asura realm, one of the six realms of traditional Buddhist cosmology. He becomes ordained as a Buddhist monk and his monastic vows eventually deteriorate. He is reborn over the course of eons in accordance with the Buddhist notion of reincarnation; moreover, these rebirths take place in other Buddhist-

\footnotetext{
${ }^{274}$ See Appendix III, pp.560-563.

${ }^{275}$ See Appendix III, p.578.

${ }^{276}$ Tib. bden pa gnyis; Skt. satyadvaya. The two truths are [1] Conventional Truth (Tib. kun rdzob bden pa; Skt. samvrtisatya), which explains daily experiences and the objects that make up our seemingly concrete universe, and [2] Ultimate Truth (Tib. don dam bden pa; Skt. paramārthasatya), which explains that everything is ultimately empty (Tib. stong pa nyid; Skt. śünyatā) of inherent existence.
} 
recognized realms, such as hell and god realms. In a more tantric venue, Pehar is repeatedly subdued by the fierce Buddhist divinity Vajrapāni and eventually by the famed tantric exorcist Padmasambhava. Often this subjugation is achieved by the subduer, such as Lekden Nakpo and Padmasambhava, assuming the identity of the Buddhist deity Hayagrīva through tantric deity yoga. During his quarrel with Padmasambhava, Pehar was the protector deity of a meditation center-though its religious affiliation is never specified-before he was eventually entrusted with protecting Samyé Monastery, Tibet's first Buddhist monastery.

The Fifth Dalai Lama's master narrative also includes many indigenous Tibetan elements, such as an odd number of egg births, scorpion emanations, and ambivalent sky realms. Nonetheless, these parts are clearly overshadowed by the broader Buddhist structure and content. By contrast the alternative narratives illustrate weaker Buddhist elements. The first alternative account presents itself like a Buddhist tantra, providing a Sanskrit title followed by a Tibetan title and beginning with "Thus, I have heard." However, aside from the presence of Heruka and Vajrapāni, most of the attention is on the thirteen eggs and Pehar's mischievousness. The second variant account recognizes rebirth but adds little else, and the third is light on narrative details. It is clear that the narrative the Great Fifth promotes is stronger and fuller in terms of Buddhist associations.

On a structural level the master narrative also has one other powerful motif. It appears to have many of the same basic elements as the famous tantric tale of Rudra. This story is found in the fifth and sixth chapters of the Chronicle of Padmasambhava, and concerns the rise and fall of the fierce demon Rudra. A summary of this story will be necessary to highlight the similarities that Pehar's story shares with it. The following account paraphrases the translation and summary found in Matthew Kapstein's Tibetan Assimilation of Buddhism: ${ }^{277}$

In the land of Dujongtsam, ${ }^{278}$ there was a householder named Koukala ${ }^{279}$ who had a son named Kouküntri ${ }^{280}$ and a servant named Pramādeva. ${ }^{281}$ The son

\footnotetext{
${ }^{277}$ See Kapstein 2000, pp.170-174. I relied on the original Tibetan text to reinforce my presentation; see O rgyan gling pa 1996, pp.29-56. I also referred to a second translation to bolster the content of my summary; see Khandro.net 2013.

${ }^{278}$ Tib. 'Du ljongs mtshams; lit. "Where the Borderlands are Joined."

279 Tib. Ko’u ka la; lit. "Black Kou."

280 Tib. Ko'u kun dkris; lit. "All-Ensnaring Kou."

${ }^{281}$ Tib. Pra ma de ba; the normative Sanskrit is Pramādeva, meaning "Divine Understanding."
} 
and the servant became ordained under the monk Tupka Zhönnu, ${ }^{282}$ who is one of Padmasambhava's past lives. Kouküntri took the ordination name Tarpa $\mathrm{Nakpo}^{283}$ and Pramādeva took the name Denpak. ${ }^{284}$ Tarpa Nakpo had great faith, but he took Tupka Zhönnu's tantric teachings literally and became engrossed in evil deeds. The deportment of his body increased, while his mind deteriorated. Conversely, Denpak understood the definitive meaning of his master's teachings; the deportment of his body declined, while his mind expanded. After some time, Tarpa Nakpo and Denpak came to disagree over theory and practice and began to quarrel over the proper approach to primordial awareness. ${ }^{285}$ They went to Tupka Zhönnu to settle the dispute, who agreed with Denpak's understanding. Tarpa Nakpo became enraged; he verbally abused both Tupka Zhönnu and his servant Denbak, exiling the latter to a far off land. Over time, Tarpa Nakpo became a murderous drunkard and a whoremonger, spiraling down the realms of rebirth over countless lifetimes. He was eventually born in Hell, and then reborn in other lower forms for tens of thousands of lifetimes afterward.

Then, before Buddha Śākyamuni's teachings appeared in the world, in Lañkāpūrṇa, ${ }^{286}$ the land of the barbaric spirits, there was a whore named Küntugyu. ${ }^{287}$ At dusk she slept with a hindering spirit, at midnight she slept with an imperial spirit, ${ }^{288}$ and at dawn she slept with a god. Tarpa Nakpo was thus conceived in this life from three fathers. After eight months Tarpa Nakpo was born with three heads, six arms, four legs, and two wings. Each head had three eyes, making nine in all. Evil omens and calamities befell the land, and his mother died shortly after his birth. The people took the monstrous baby and Küntugyu's body to the charnel ground, leaving them under the tree where the boar of ignorance, the snake of hatred, and the bird of passion resided. To survive,

\footnotetext{
${ }^{282}$ Tib. Thub dka' gzhon nu; lit. "Youth who is Difficult to Defeat."

283 Tib. Thar pa nag po; lit. "Black Liberation."

284 Tib. Dan phag; lit. "Changeless Secret."

285 Tib. ye shes.

${ }^{286}$ This refers to the island of Sri Lanka, which was the site of Rāvana's demon kingdom in the Indian Epic the Rāmāyaṇa.

${ }^{287}$ Tib. Kun tu rgyu; lit. "She who Wanders Everywhere."

${ }^{288}$ Tib. btsan. Kapstein (2000, p.173) translates this as an abreviation of btsan po, meaning "king." However, it seems clear from the context of the other deities involved, as well as the red face among Rudra's three faces, that the imperial spirit type (Tib. btsan) is meant here.
} 
the baby sucked his mother's breast; this only produced puss, but it nurished him for a week. Then he sucked out his mother's blood and survived another week. Then he ate her breasts and lived a third week. He ate her entrails, surviving a fourth week. He ate her skin, surviving a fifth week. Finally, he ate her bone marrow, spinal cord, cartilage, and brains, surviving a sixth week. Having eaten his mother, the monstrous child feasted on other corpses and wrapped himself in the skins of humans and elephants. He ate tigers and wore their furs as a loincloth. This wrathful demon's three heads were each a different color; the right head was white, the left head was red, and the center head was dark blue. His body was gigantic and ashen in color. His hands and feets had the talons of a bird. He carried a staff and other weapons [with his right hands], and blood-filled skulls with his left, from which he would constantly drink. Afterward, he emerged from the charnel ground fully grown and even the gods were terrified of him. He was known as Matram ${ }^{289}$ Rudra and he became the lord of all demons, the scourge of all worlds.

In response to this terror that would engulf all of samsāra, the Buddhas and Bodhisattvas discussed how best to defeat Rudra. Among this gathering was Vajrasattva, who was in fact the current form of Tupka Zhönnu, and Vajrapāṇi, who had been Denpak long ago. These enlightened beings entreated Avalokiteśvara and his consort Tārā to defeat Rudra, which they set about doing by manifesting as the ferocious Hayagrīva and Vajravārāhī, respectively. The two did battle with Rudra, and to defeat him Hayagriva shrank to a miniscule size and entered the demon king's anus. Once inside, Hayagrīva expanded back to normal, filling Rudra's body, his horse head exploding from the demon's forehead. Rudra was subdued and Hayagrīva continued to wear his body thereafter, which explains Hayagrīva's appearance (Figure 20). In the end, Rudra promised to protect the Buddha's teachings from then on.

\footnotetext{
${ }^{289}$ This derives from the Sanskrit word mātr, meaning 'mother.' I agree with Kapstein's interpretation that in this context the term refers to Rudra causing the death of his mother; he thus translates this name as Matricide Rudra; see Kapstein 2000, p.170.
} 
Kapstein notes that a more extended version of this story can be found in the Sütra which Gathers All Intentions, ${ }^{290}$ which the Fifth Dalai Lama cites in the Nechung Register. ${ }^{291}$ Regardless, when comparing this classic tantric tale with the Pehar narrative that the Great Fifth favored, the similarities become immediately apparent.

Like Kouküntri, Mahābhūta, Pehar's earliest form, is the social superior, while Lekden Nakpo and Pramādeva were under their service; nevertheless, the two were friends. These friends are equally devout and take monastic ordination under the same religious master. Overtime, however, Mahābhūta and Kouküntri's vows degenerate, their friendships becomes strained, and they eventually become envious of their more spiritually successful colleague. These figures are reborn in lower and lower realms of samsāra over countless lifetimes, eventually ending up in a hell realm. Mahābhūta and Kouküntri are both eventually reborn as wrathful demons that become the lord of all fierce spirits. They are then subdued and made to serve the Buddha's teachings. There are also a number of cross-hatching elements. Rudra is subdued by Hayagrīva while Pehar is subdued by Padmasambhava in the form of Hayagrīva. There is even the subsumed presence of Padmasambhava throughout the tale of Rudra. Moreover, Rudra's old friend Denpak is reborn as Vajrapānin, while Pehar's old friend Lekden Nakpo and Vajrapāni develop a close relationship in the process of subduing the sovereign spirit.

The similarities between the two tales are too close to be coincidental. Yet there are still unique narrative elements in Pehar's tale. He is a shapeshifter that badgers his old friend over many lives, doing so in forms commonly found in Tibetan stories. Pehar is born from an egg in many accounts and usually among an odd-numbered collection, another uniquely Tibetan trait. Finally, while both stories take place in the distant mythic past, Pehar's tale converges on Tibetan history. He becomes an integral part of key hegemonic shifts, whether it's the eighthcentury military expansion of the Tibetan Empire, the sixteenth-century dissolution of the Tsel Hierarchy and the rise of the Dalai Lama lineage, or the seventeenth-century centralization of the Tibetan government under the Fifth Dalai Lama. In the process of developing a mythic narrative to place at the heart of Nechung Monastery as a religious lynchpin for his emerging government, the Fifth Dalai Lama chose a deity, and a specific narrative, that was both resolutely Tibetan and Buddhist in character.

\footnotetext{
${ }^{290}$ Tib. Mdo dgongs pa 'dus pa; see Kapstein 2000, pp.171, 268n.25. A translation of this longer version of the Rudra myth can be found in Dalton 2011, pp.159-206. I am grateful to Bryan Cuevas for drawing my attention to this source; email communication, July 22, 2013.

${ }^{291}$ See Appendix III, p.561.
} 


\section{Divine and Demonic Associations}

The myths and narrative variations above do not just paint a vivid picture of Pehar's character and past, they illustrate something of the vast network of other deities and higher beings with which he has close ties. This network can be seen in other contexts as well, such as ritual and iconography. With regards to the latter, it is surprising that the iconography and orientation of the Five Sovereign Spirits provided at the start of this chapter are not visible in the narratives about Pehar. In fact, there is no explicit mention of the Five Sovereign Spirits in these stories. This is odd when contrasted with the mythologies of other Tibetan protector deities. The other major Dharma protector of Samyé Monastery, Tsiu Marpo, leads a group of deities called the Seven Blazing Brothers, ${ }^{292}$ and his mythology explains that the other six deities emanated from the various parts of his body. ${ }^{293}$ Dorjé Lekpa, who was briefly mentioned in one of the alternative narratives above, has a team of nine warriors in his retinue called the Nine Masang Brothers ${ }^{294}$ mythological accounts likewise explain how these nine deities came to be associated with Dorjé Lekpa. ${ }^{295}$ The tales above mention a vast retinue under Pehar's control, but nothing is said about his four other hierarchically-superior forms. What then should we make of the singular Pehar we encounter in the mythology and the multiple forms of Pehar we encounter in rituals and iconography?

The solution to this inconsistency may be hidden deeper in the iconography itself. At various points in the Great Fifth's master narrative, as well as in the variant accounts, there are names and descriptions that resonate with the images of the Five Sovereign Spirits presented to us. The deities' names appear at various and seemingly arbitrary points in the mythology. Pehar is a given. Gyajin is one of the many names under which Pehar was known at various times according to the Thread-Cross Ritual for the Six White [Possessions] of the Sovereign Spirit Pehar. Mönbuputra is listed as a type of spirit, a hundred of which act as Pehar's internal ministers. ${ }^{296}$ Shingjachen, "the one possessing a wooden bird," stems from Pehar riding one of his possessions - a bejeweled wooden bird—-to Samyé after the meditation center in Bhatahor

\footnotetext{
${ }^{292}$ Tib. 'Bar ba spun bdun.

${ }^{293}$ See Nebesky-Wojkowitz 1998, pp.170-171. For a fuller discussion of Tsiu Marpo, see Bell 2006.

${ }^{294}$ Tib. Ma sangs spun dgu.

${ }^{295}$ See Nebesky-Wojkowitz 1998, p.156.

${ }^{296}$ See note 122. This also reverberates with the role the sovereign spirit Mönbuputra appears to have among the five deities - he guides both Pehar's and Gyajin's mounts.
} 
was conquered. $^{297}$ Kyechik Marpo, also known as Kyechikpu, the "sole-born son," was subtly mentioned as a descriptor for Pehar likewise in the Thread-Cross Ritual for the Six White [Possessions]. ${ }^{298}$

In addition to these descriptions that became names, traces of each deity's appearance can be found throughout the above stories. Gyajin is the most vivid example, with alternative descriptions of Pehar matching many of his features. ${ }^{299}$ Moreover, Gyajin's emanation is a young layman with a crystal rosary, the same form Pehar takes when he submits to Padmasambhava at Crystal Cave. The esoteric form of Pehar known as Jeché Keru also holds a crystal rosary, though he is much more wrathful in appearance. ${ }^{300}$ Shingjachen's image is often accompanied by a garuda hovering over his head; this speaks to the time when Pehar turned into such a winged creature in an attempt to escape Vaiśravaṇa at Bhatahor. Pehar, Mönbuputra, and Gyajin's minister all ride lions for mounts, which is reminiscent of Pehar taking on the form of a lion when attacking both Dünting Nakpo and Padmasabhava.

Pehar is white in color, as he is commonly described. However, Shingjachen and Mönbuputra are black, which may be traced back to Pehar's epithet Norlha Nakpo, the "black wealth god." Gyajin is dark blue, which is a common variant of black. Kyechik Marpo's red body color stands out; however, the fact that his color is given in his name ${ }^{301}$ suggests that it was established either by oral tradition or through a non-extant source. Perhaps it was a means to establish uniform symmetry with Pehar's three heads, which are black (in some sources dark blue), white, and red. Pehar's appearance stands out the most, since he is the only one of the Five Sovereign Spirits that has three heads and six arms. The reason for this is never explained, but I suggest that it is yet one more correspondence Pehar's mythos holds with the tale of Rudra-Pehar is not just an analogue of Rudra, he looks like Rudra. They have the same number of heads and arms, with the same colors, and they both wear human and tiger skins for clothes. As for the number of sovereign spirits being five, this resonates with the Five Brother Commanders among whom Pehar was born in a past life. Finally, some of the consorts have names we have seen before. Gyajin's consort Shantinma Marpo, who is alternatively called

\footnotetext{
${ }^{297}$ See also Appendix III, p.565.

${ }^{298}$ See note 258.

${ }^{299}$ See notes 264 and 265 above.

300 See note 57.

301 Tib. dmar po, lit. "red."
} 
Śānti Rozan elsewhere in the Ten-Chapter Sādhana, ${ }^{302}$ appears as Norlha Nakpo's consort in the Black Iron Rosary Tantra. ${ }^{303}$ Likewise, Pehar's consort Düza Minkarma appears as his mother in several of the accounts above. ${ }^{304}$

These numerous reverberations suggest that the Five Sovereign Spirits came about as a means of iconographically standardizing the disperate and sometimes contradictory accounts surrounding Pehar's mythology. Once again emanation plays an important interpretive role in making sense of these discrepencies. Pehar has different apperances because they are all different forms of a powerful shapeshifting deity. This standardization must have occurred early on, given that these established descriptions of the Five Sovereign Spirits appear in the latetwelfth-century Ten-Chapter Sädhana. This also illustrates that iconography is mythology devoid of chronology.

Mythic and iconographic associations can also be traced to other deities. As noted above, no deity is an island and Pehar is part of an extensive network of other deity cults, which can be observed iconographically, ritually, and institutionally, as the following chapters will illustrate. For now, I would like to mention a few of the deities connected to Pehar in various contexts. In the stories recounted earlier, there are already noticeable mythic connections to important Tibetan Buddhist figures such as Padmasambhava, Vajrapāṇi, Hayagrīva, Vaiśravaṇa, and even Mahākāla. ${ }^{305}$ Other significant protector deities appear, if only briefly, such as Rāhula, ${ }^{306}$ Yamshü Marpo, and Dorjé Lekpa, all of whom are born as Pehar's siblings in accounts of his past lives. Indian deities like Indra and Brahmā also make an appearance; they are both involved in taming Pehar in alternative narratives. ${ }^{307}$

A unique iconographic reverberation can be observed with Shingjachen's consort, Sergyi Putrima. This deity is described as having four arms, a lion for a right earring and a snake for a left earring, a necklace of severed heads, an elephant-skin cloak, and iron shackles around her

\footnotetext{
${ }^{302}$ See Appendix IIa, n.1429.

${ }^{303}$ See note 248.

${ }^{304}$ For other tantric contexts in which this comparison of iconographic elements and symbols was fruitfully applied, see Heller 1997, and Linrothe 2000a and 2000b.

${ }^{305}$ There are strong implications that Pehar's old friend and nemesis Lekden Nakpo is either a form of, or otherwise connected to, Mahākāla. The most overt example is that Lekden Nakpo is called Mahākāla's son in the White Crystal Rosary; see Sle lung rje drung 1976, 373.5-6. His various names also suggest a connection. For more information on this complex and multifaceted protector deity, see Nebesky-Wojkowitz 1998, pp.38-67.

${ }^{306}$ For an extensive study of Rāhula, see Bailey 2012.

${ }^{307}$ This also resonates with the life of the Buddha Śākyamuni, in which Indra and Brahmā play important roles; see Ruegg 2008, p.19.
} 
feet. This imagery is remarkably parallel to a form of Penden Lhamo ${ }^{308}$ called "Queen of the Desire Realm Known as Dhūmāvatî." ${ }^{309}$ Given that a chapel at Nechung Monastery is dedicated to this form of Penden Lhamo (see chapter 3), it is quite likely that Sergyi Putrima is another name for Dhūmāvatī. The unique earring configuration is also found on another form of Penden Lhamo, called Makzor Gyelmo, ${ }^{310}$ who is an important Dharma protector of the Sakya and Geluk sects, as well as the other major protector of the Dalai Lamas' lineage and government alongside Nechung. ${ }^{311}$

There are other deities not found in the mythology or immediate iconography of the Five Sovereign Spirits, but they can be seen in the pantheon array of statues and murals found in monasteries, temples, and chapels connected to these five deities. Examples include Makzor Gyelmo, Tsiu Marpo, the Twelve Tenma Goddesses, ${ }^{312}$ the Eight Sädhana Deities, ${ }^{313}$ and the tantric tutelary deity Vajrabhairava. ${ }^{314}$ These and other deities appear in unique configurations with the Five Sovereign Spirits at various sacred sites, creating a visual record of institutional interconnection. Such individually distinct pantheons therefore speak to the tradition of each institution and provide an iconographic means of identifying important lineage connections, an observation that will be explored in greater detail in chapter 3. For the moment it is necessary to highlight this divine network and the more significant deities that make it up because they will reappear throughout this work. Within the intricate intersections of mythic elements, iconographic details, and deity identities we can observe numerous reverberations and cogenerations of powerful narratives, images, and symbols.

\footnotetext{
308 Tib. Dpal ldan lha mo; lit. "Glorious Goddess."

${ }^{309}$ Tib. Dud gsol mar grags pa 'Dod khams dbang phyug ma. Dud gsol [sic: sol] ma is Dhūmāvatī in Sanskrit, both of which mean "Smoky Woman; see Nebesky-Wojkowitz 1998, p.24.

310 Tib. Dmag zor rgyal mo; lit. "Queen of Army[-Repelling] Sorcery."

311 See Nebesky-Wojkowitz 1998, p.26.

312 Tib. Brtan ma bcu gnyis.

${ }^{313}$ Tib. Sgrub pa bka' brgyad; this refers to the eight central Heruka deities of the Nyingma Mahāyoga scriptural tradition. These deities are [1] Yamāntaka, deity of the body (Tib. 'Jam dpal sku gshin rje shed), [2] Hayagrīva, deity of speech (Tib. Pad ma gsung rta mgrin), [3] Viśuddha, deity of the mind (Tib. Yang dag thugs), [4] Vajrāmṛta, deity of good qualities (Tib. Rdo rje bdud rtsi yon tan; variant: Che mchog yon tan), [5] Vajrakīlāya, deity of activities (Tib. Rdo rje phur ba 'phrin las), [6] Mātara, deity of invoking and dispatching (Tib. Ma mo rbod gtong), [7] Lokastotrapujanātha, deity of mundane offerings and praise (Tib. 'Jig rten mchod bstod), and [8] Mantrabhīru, deity of wrathful mantras (Tib. Dmod pa drag sngags). The details of these deities are found in the treasure collection discovered by Nyangrel Nyima Özer entitled the Assembly of the Sugatas of the Eight Proclamations (Tib. Bka' brgyad bde gshegs 'dus pa; TBRC: W22247).

${ }^{314}$ Tib. Rdo rje 'jigs byed.
} 


\section{Ontology and Emanation}

One final word should be said about the ontological status of the Five Sovereign Spirits. The anthropologist Urmila Nair was the first to extensively discuss the ontology of the Nechung deities in her master's thesis, The Sociological Inflection of Ontology. ${ }^{315}$ As the title indicates, Nair uses a sociological, as well as a linguistic, approach in order to understand how Tibetans in Dharamsala perceive Pehar and Dorjé Drakden. ${ }^{316}$ She concludes that the status of the deities is not standardized, but changes depending on the person. Some monks consider Pehar to be a supramundane protector, while others consider him a mundane protector. ${ }^{317}$ Nair states that ultimately the ontological status of these deities is not as important as other factors, ${ }^{318}$ though she recognizes that she presents a synchronic rather than historical argument. ${ }^{319}$ To remedy this, and to relate this issue of ontology back to the late seventeenth-century expansion of Nechung Monastery, I will explore here how Pehar's ontology was understood by the Fifth Dalai Lama and his regent Sangyé Gyatso. As noted above, their representation of Pehar and the Five Sovereign Spirits would have significant repercussions later since it became the dominant model of the Nechung cult.

David Ruegg describes the supramundane/mundane dichotomy as a structured contrastative opposition, ${ }^{320}$ and provides a detailed examination of its Indian origins and tantric uses. He observes that 'mundane' has come to refer to deities and practices identifiable with the ambient surrounding culture, whether Indian or Tibetan, while the 'supramundane' refers explicitly to Buddhist deities endowed with a soteriological function. ${ }^{321}$ We know that this dichotomy has been recognized in Tibet at least since the late eight century, because it appears on the inscribed pillar at Samyé Monastery (Figure 21). ${ }^{322}$ While it is beyond the scope of this work to chronicle the evolution of these terms in Tibetan religious thought, it is important to understand their meaning in the context of Pehar and the Nechung deities. Pehar has always had

\footnotetext{
${ }^{315}$ See Nair 2004.

${ }^{316}$ Nair notes that both deities are referred to as the Nechung Chökyong (Tib. Gnas chung chos skyong), the "Nechung Dharma protector;" see ibid, p.8.

${ }^{317}$ See ibid, p.13. Such differences of opinion are also observable along sectarian lines. According to NebeskyWojkowitz (1998, p.177), the Five Long-Life Sisters (Tib. Tshe ring mched lnga) are considered mundane deities by Gelukpas, but supramundane deities by Nyingmapas and Kagyüpas.

${ }^{318}$ See Nair 2004, p.34.

${ }^{319}$ See ibid, p.36.

${ }^{320}$ See Ruegg 2008, p.viii.

${ }^{321}$ See ibid, pp.42, 93.

${ }^{322}$ See Richardson 1985, pp.28-31.
} 
close ties with Samyé, yet he does not appear in the context of the inscribed pillar, which invokes the mundane and supramundane deities simply as witnesses to the edict established by King Trisong Deutsen.

As noted above, the Fifth Dalai Lama discusses Pehar's ultimate and conventional natures in the Nechung Register. He explains that reliance on Pehar accords with the various doxographical levels of tantra, and then provides the conventional understanding of the deity's mythology. However, the Great Fifth presents a more explicit discussion of Pehar's ontological status near the end of his autobiography: $:^{323}$

It is said that before, on the third day [of the month], God Day, ${ }^{324}$ Namlha Jangchup ${ }^{325}$ would be invoked to descend into the body of the medium. Accordingly, he descended into a woman ${ }^{326}$ and changed clothing. Additionally, according to the definitive Ultimate Truth, Namlha Jangchup does not exist, his

\footnotetext{
${ }^{323}$ Tā la'i bla ma 05 1991-1995, vol.7, pp.445.5-447.4: lha tshes gsum gyi nyin sngon la gnam lha byang chub kyi sku rten par sku phebs yong rgyu bos tshar bgyis gsung ba ltar bud med la phab grub par chas gos rnams bsgyur zin thog don dam nges pa'i gnam lha byang chub ni gzugs sku chos dbyings su thim nas med/ kun rdzob bcos ma'i gnam lha byang chub kyi tshul 'dzin de ni da nas khog la yong rgyu med/ da lam khog la yongs [sic: yong] pa 'di'i pha ni lha bu tshangs pa dkar po yin/ ma ni srin mo nag mo yin/ bu ni dge bsnyen dkar po yin pas sems can kun la gnod 'tshe dang / gdug rtsub shin tu che ba zhig yong rgyu yin/ mdo sde lo gsar gnyis las sngar lugs bzhin snang bar gshar gyis bos yong chog rgyu min/ mang la'ang dge bsnyen dkar po las gzugs can gzugs med kun gyis gnam lha byang chub dang chos rgyal chen po sogs zer dbang yong gin min/zhes sogs gsungs tshul gyi slar yang tha' $i$ ji' $i$ yi ge 'byor/ de dag la mchog dman bar ma kun yid gnyis su gyur cing / ma nas phal cher chos skyong chen por phrag dog gis phebs ma med pa dang / la la gzhung la cung zad 'khangs te rten 'brel slog [sic: zlog] thabs yin 'dra sogs brjod rigs sna tshogs byung ba dang / sne'u sdong rtse nas sde pa blo bzang sbyin pas chos skyong rang la dri ba dang / gzhan yang lho rgyud kyi lha 'dre phal mo cher dri ba re mdzad 'dug kyang 'di yin gyi gsal ma byung par snang / gnas chung chos skyong chen po dang tshangs pa dung theng [sic: thor] can la sde pas dri ba mdzad par gnyis ka mthun par gzugs med de gar dri ba gyis dang gsal yong gsungs 'dug/ de skor la sde pas nged la'ang brtag pa dgos zer pa lha 'dre'i brtag pa 'di 'khrugs pa'i gsal dka'gshas [sic: gsha'] ma byas/ de ltar pe kar chos dbyings su thim nas chab [sic: tshab] ma byung na rgyal po'i skye rgyus sogs gter kha [sic: ga] re mang na bzhugs par de bzhin 'byung 'gyur gyi gsal kha mi snang / de bden na dpal 'dzin sogs kyis ma dregs drag gsum bod [sic: rbod] mar smra ba'i grogs su song ba dang / mnga' ris pan chen sku mched sogs snga 'gyur ba phal cher nges ngor bde gshegs rigs lnga la rnam pa gdul bya gdug pa can 'dul ba'i phyir 'jig rten dregs pa'i tshul bzung bar bshad pas na gdul bya ma rdzogs par yal ba ga la srid lta bu'i blor chud dka' ba'i mi srid pa dang / yang chos dbang rin po che'i gter byon mkha' ri'i zhus lan sogs kyi dbang du btang na/ khyod dang gang bzang dpal dang gsum: lo ni da dung brgyad brgya thub: de nas zangs mdog dpal ri'i rtsar [sic: rtser]: srin phrug gsum du skyes nas byang chub thob: yang phyi ri bo po ta lar: byang chub thob par gdon mi za: sogs dang mtshungs par ngo bo rigs lnga'ang snang ngor sprul pa'i rigs su 'byon pa dang 'dra bar yal ba sogs med pa'i nges pa'ang med tsam e yin snyam pa'i the tshom gyi dra bar chud cing gang ltar dpyad dka' ba'i dus rtags khyed [sic: khyad] par can zhig yin par sems/. Samten Karmay paraphrases the main argument of this discussion, stating that the Great Fifth adopted a Nyingma stance on the Five Sovereign Spirits: they originate from the Five Buddha Families but take on the form of worldly deities; see Karmay 1998c, p.361.

${ }^{324}$ Tib.lha tshes; the significance of this day will be discussed in the next chapter.

${ }^{325}$ Tib. Gnam lha byang chub; lit. "Enlightened Sky God." This is yet another epithet for Pehar, and it appears to contain elements from other names associated with the deity cited earlier.

${ }^{326}$ Tib. bud med la phab grub par... In this context the meaning of this line is difficult to ascertain; it may be that Pehar did descend into female mediums before an official (male) state oracle was established at Nechung.
} 
physical body ${ }^{327}$ having dissolved into the Dharma body. ${ }^{328}$ According to the fabricated Conventional Truth, [he] appears in the form of Namlha Jangchup and then spontaneously possesses [a medium].

Recently, I again received a letter from [Dalai Hung?] Taiji, ${ }^{329}$ which said something like, "The father of this possessing deity is [considered] to be the divine prince, White Brahmā. ${ }^{330}$ His mother is the Black Female Barbaric Spirit $^{331}$ and their son is [this] White Layman. ${ }^{332}$ Because of this, he will bring harm upon all sentient beings and is incredibly ferocious. According to ancient tradition, other than [during] the second New Year [celebration of] Dodé, ${ }^{333}$ no one should be allowed to invoke him to appear over and over again. Also, for many people, other than the White Layman, no physical and formless beings are capable of controlling such [deities] as Namlha Jangchup and the Great Dharma King." 334 These [words] gave everyone-superior, middling, and inferiorsecond thoughts. Basically, this came [about] not without an abundance of jealousy toward the great Dharma protector. A few people were [even] a little hostile toward the government and there were various excuses ${ }^{335}$ like, "[the deity] repels karmic connections."

The governor of Nedong Tse[tang], ${ }^{336}$ Lozang Chinpa, said that he asked a question to the Dharma protectors themselves. He also asked a question each to

${ }^{327}$ Tib gzugs sku; Skt. rūpakāya.

${ }^{328}$ Tib. chos dbyings; Skt. dharmadhātu; lit. "the expanse of the Dharma."

${ }^{329}$ Tib. Tha' $\mathrm{iji}$; it is unclear to whom this refers, but it is likely a seventeenth-century minister; see Shakabpa 2010, p.365.

330 Tib. Tshangs pa dkar po.

${ }^{331}$ Tib. Srin mo nag mo; here we encounter yet another variant account of Pehar's family lineage.

${ }^{332}$ Tib. Dge bsnyen dkar po.

${ }^{333}$ Tib. Mdo sde lo gsar gnyis. Mdo sde most likely refers to the Mdo sde mchod pa holiday, the 'Offering of the Sütras.' This is sometimes also called Mdos sde mchod pa, mdos referring here to thread-crosses. Its alternative name is 'Dzam gling spyi bsang, 'Universal Incense Day,' which is celebrated on the fifteenth day of the fifth Tibetan month. The three days around this time commemorate Padmasambhava's taming of all the autochthonous spirits of Tibet, and is particularly important for Pehar. However, calling it the second New Year seems unusual. More details on this holy day will be mentioned in the next chapter.

${ }^{334}$ Tib. Chos rgyal chen po; this is likely another epithet for Pehar, or specifically Dorjé Drakden, as it is used often by the Great Fifth in his rituals; see Tā la'i bla ma 05 1991-1995, vol.11, pp.129-591. The relationship between these figures is unclear here.

${ }_{335}$ Tib. brjod rigs.

${ }^{336}$ Tib. Sne'u sdong rtse [thang]; this region is southeast of Lhasa and was the seat of the Pakmodru (Tib. Phag mo gru) polity from the mid-fourteenth to mid-fifteenth century. 
most of the gods and spirits of the south. ${ }^{337}$ Nevertheless, it appears they did not clarify his query. The governor [then] asked questions to the great Nechung Dharma protector and to Brahmā with the conch-shell topknot, ${ }^{338}$ and they were both in agreement. He asked questions to these formless beings and they were clarified. Regarding this, the governor said to me, "This must be investigated!" This investigation of the gods and spirits was distressing and genuinely difficult to elucidate. In short, if Pehar ${ }^{339}$ dissolved into the Dharma body and arose as a representative of [the ultimate Dharma], why are there many treasure texts discussing such [prosaic] things as the sovereign spirit's legends? As such, this matter lacked clarification. If this were true, then it would be helpful for [people] like Peldzin ${ }^{340}$ to incite [through sorcery such troublesome spirits as] the maternal spirits, haughty spirits, and wrathful spirits. ${ }^{341}$

In most Nyingma texts - such as [the works of] Ngari Panchen and his brother $^{342}$ - it is explained that, with regards to Ultimate [Truth], manifestations of the Five Buddhia Families took on the forms of worldly haughty spirits in order to tame all the pernicious beings that need taming. Therefore, they exist wherever [such] tamable beings have not completely vanished. They exist [where] there are people that have difficulty understanding such things. Moreover, to present an example from such [a work] as the Sky Mountain Replies, ${ }^{343}$ a treasure text revealed by the precious [Guru] Chöwang: ${ }^{344}$

\footnotetext{
${ }^{337}$ These questions were likely posed to various mediums possessed by Dharma protectors and lesser spirits.

${ }^{338}$ Tib. Tshangs pa dung theng [sic: thor] can; this is an abbreviation for Tshangs pa dung gi thor tshugs can. This likely refers to the Lamo Tsangpa Oracle, another important state oracle, who was traditionally stationed at Lamo Monastery (Tib. La mo dgon pa), 49 kilometers northeast of Lhasa and not far from Ganden Monastery (Tib. Dga' ldan dgon pa). According to Glen Kelley, Lamo Monastery was significantly damaged during the Cultural Revolution, but the main temple appears to have been salvaged and some restoration work had been done as of 1993; see Kelley 1993, p.34.

${ }^{339}$ Tib. Pe kar; this is standardized to Pehar.

${ }^{340}$ Tib. Dpal 'dzin; it is unclear to whom this refers.

${ }^{341}$ Tib. ma dregs drag gsum. This is an abbreviation for ma mo dregs pa drag po gsum.

${ }^{342}$ Tib. Mnga' ris pan chen sku mched; This refers to the sixteenth-century Nyingma treasure-revealer Ngari Panchen Padma Wangyel (Mnga' ris pan chen Padma dbang rgyal, 1487-1542; TBRC: P1699) and his younger brother, the surprisingly long-lived Lekden Dorjé (Legs ldan rdo rje, 1512-1625?; TBRC: P1701). These siblings are associated with the Northern Treasures tradition and promoted the cult of Tsiu Marpo. Lekden Dorjé, in particular, became an important lineage figure for the Fifth Dalai Lama.

${ }^{343}$ Tib. Mkha' ri'i zhus lan.

${ }^{344}$ Tib. Chos dbang rin po che; this refers to Guru Chökyi Wangchuk (Gu ru Chos kyi dbang phyug, 1212-1270; TBRC: P326), one of the five great Nyingma treasure-revealers.
} 
You three [mountains-Sky Mountain,] Gangzang, and [Gyala] Pelri ${ }^{345}$-lived for more than eight hundred years. Then, after you were born as the three children [of] barbaric spirits on the peak of the Glorious Copper-colored Mountain, you attained enlightenment. Upon [your] grandmother, Mount Potala, there is no doubt you attained enlightenment.

Similarly, even though [the Five Sovereign Spirits] are in essence the Five Buddha Families, in appearance they come in a variety of emanations. As such, they are not evanescent and so forth.

I was caught in a web of doubt, thinking only that this [issue] might even be incomprehensible, and no matter how I approached it the examination was difficult. When this happened, I remembered that [these texts] were extraordinary proof!

This detailed rumination illustrates that Pehar's status, and indeed his efficacy as a protector deity, was not a foregone conclusion. Clearly there was a lot of disagreement and consternation in the seventeenth century about protector deities and spirits, and where exactly they stood ontologically. Some people, such as Dalai Hung Taiji, felt that beings like Pehar should only be invoked on special occasions because they were too dangerous. Others, like the governor of Nedong, felt that only certain deities were efficacious, specifically the state oracles of Nechung and Lamo. The Fifth Dalai Lama notes that this was even a contentious issue within the government, though he chalks it up to jealousy. Nonetheless, the Great Fifth recognized the seeming contradiction. If Pehar was an enlightened being, what about all of the myths suggesting quite the opposite? Conversely, if worldly spirits were completely beneficial, then invoking them would never be a problem, when it seems that more often than not it was.

The Fifth Dalai Lama's solution was to cite important Nyingma treasure-revealers. For him these sources prove that the Five Sovereign Spirits are actually enlightened emanations of the Five Buddha Families simply taking on worldly wrathful forms in order to tame particularly troublesome beings. With regards to the supramundane/mundane dichotomy, this interpretation

${ }^{345}$ Tib. dpal; I am reading this as an abbreviation for Rgya la dpal ri, an important mountain range five hundred kilometers east of Lhasa. 
provides an interesting caveat. Pehar and his group belong to the mundane category in a conventional sense but are aligned with the supramundane category in an ultimate sense. ${ }^{346}$ This resolution is akin to having one's cake and eating it too; Pehar is legitimized as a Buddhist deity in keeping with the highest tantras, yet he acts like a fierce worldly deity to combat forces - both human and supernatural-considered detrimental to the Dharma broadly and to the Tibetan government specifically. This strongly suggests that Dharma protectors play an important role in the sacralization and religious justification of state-sponsored violence.

The Great Fifth's regent Sangyé Gyatso not only agreed with this stance but stated it even more explicitly in his section of the Nechung Register. Each of the Five Sovereign Spirits is described as an emanation of a specific Buddha, and equated to their type of wisdom and the mental affliction it is meant to combat. ${ }^{347}$ Nevertheless, this issue was far from settled since even Sangyé Gyatso offers conflicting information. In the Hagiography of Jokpa Jangchup Penden, which the regent may have composed, Pehar possesses a medium and is quoted as saying, "Until I attain enlightenment, I will not transgress [my vows]." This hardly seems like the kind of thing an enlightened being would say; perhaps it is meant to keep up appearances along with the rest of the deity's mythos. Regardless, the matter of the Nechung deities' ontology remains ambiguous, but such an ambiguity can be a kind of power, one that allows for multiple interpretations to exist simultaneously in order to support different claims and positions.

Pehar may be a complicated god, but it is still possible to compehend the important aspects of his nature and mythology. To understand the way this deity came to be represented at Nechung and related institutions, it was necessary to ascertain how the Fifth Dalai Lama viewed him. Given the abundance of diverse and even contradictory mythologies surrounding these sovereign spirits, it was important to parse out which mythologies were central to the Great Fifth's representation of Pehar and which were not. Interpretative tools like reverberation and cogeneration provide useful explanations for the multitude of narrative accounts, but they are not enough to explain motivation. By contrasting the myths familiar to the Great Fifth, I have shown that he wished to proffer a very Buddhist image of Pehar, yet one not completely divested of his

\footnotetext{
${ }^{346}$ Along these lines, Ruegg (2008, pp.160-161) discusses how mundane deities tamed by supramundane deities are sometimes considered emanations of Buddhas and Bodhisattvas.

${ }^{347}$ See Appendix III, p.578. Karmay (1998c, pp.361-362) notes that Sangyé Gyatso refers to Pehar as a transcendental wisdom deity (Tib. ye shes $p a$ ). The regent explains away any deaths that were attributed to Pehar by claiming that they were actually caused by the petty worldly deities in the sovereign spirit's entourage; an oracle even died because of these deities.
} 
central Asian origins and qualities. This hybrid deity has many important connections to other deities both mundane and supramundane, the institutional significance of which will be discussed in chapter 3. Finally, Pehar's own ontological status is found to be ambiguous, since he skirts both mundane and supramundane strata depending on one's perception. Yet this ambiguity allows the deity to be accessible on multiple levels, making him available through different contexts. This characterization of the Five Sovereign Spirits and their mythic past provides the foundation upon which Nechung's ritual structure will be built in the next chapter. 

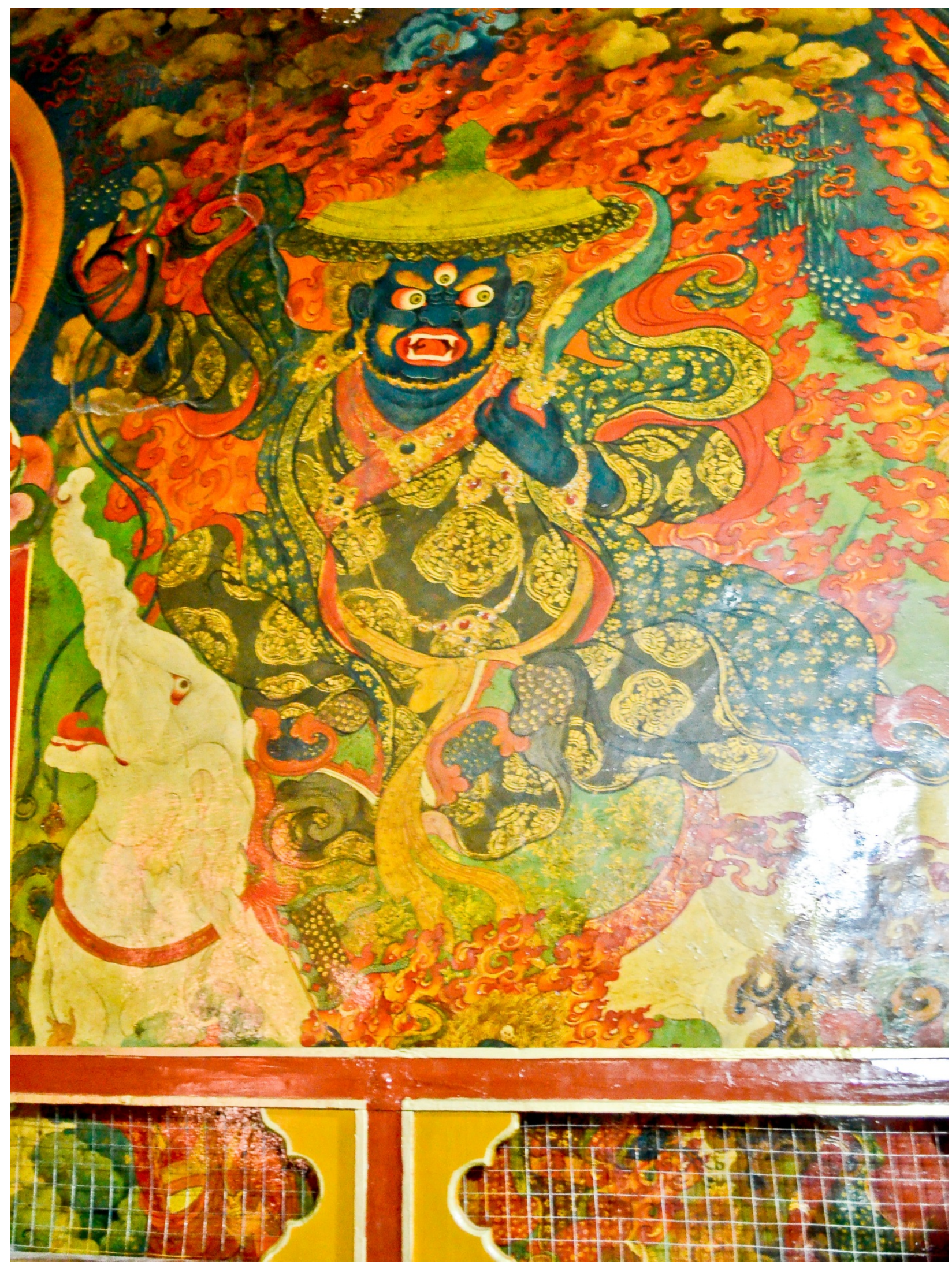

Figure 1: Gyajin, the central sovereign spirit of the mind; Nechung Monastery Assembly Hall, Lhasa.

(Photo: Cecilia Haynes, 2011) 


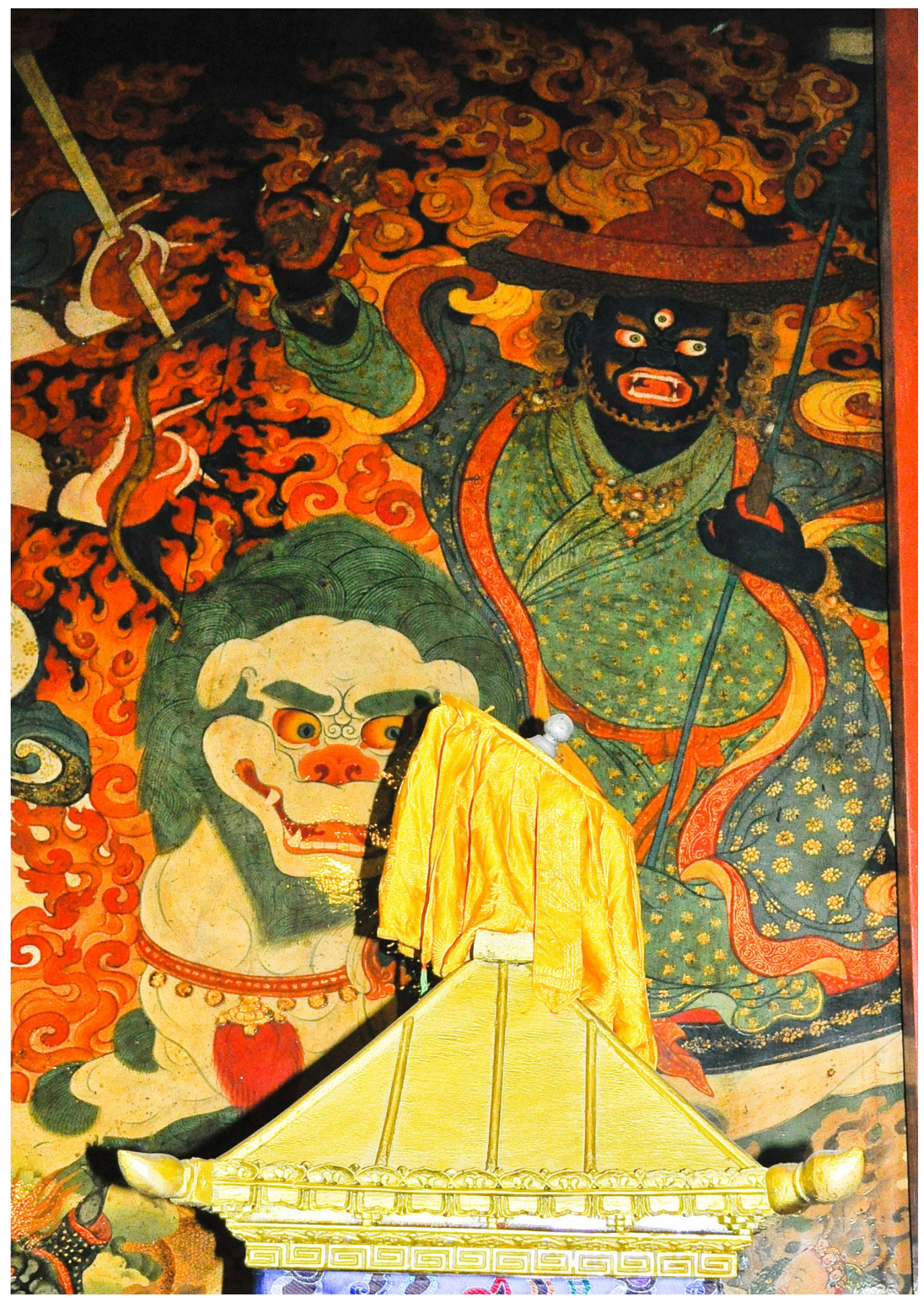

Figure 2: Mönbuputra, the eastern sovereign spirit of the body; Nechung Monastery Assembly Hall, Lhasa. (Photo: Cecilia Haynes, 2011) 


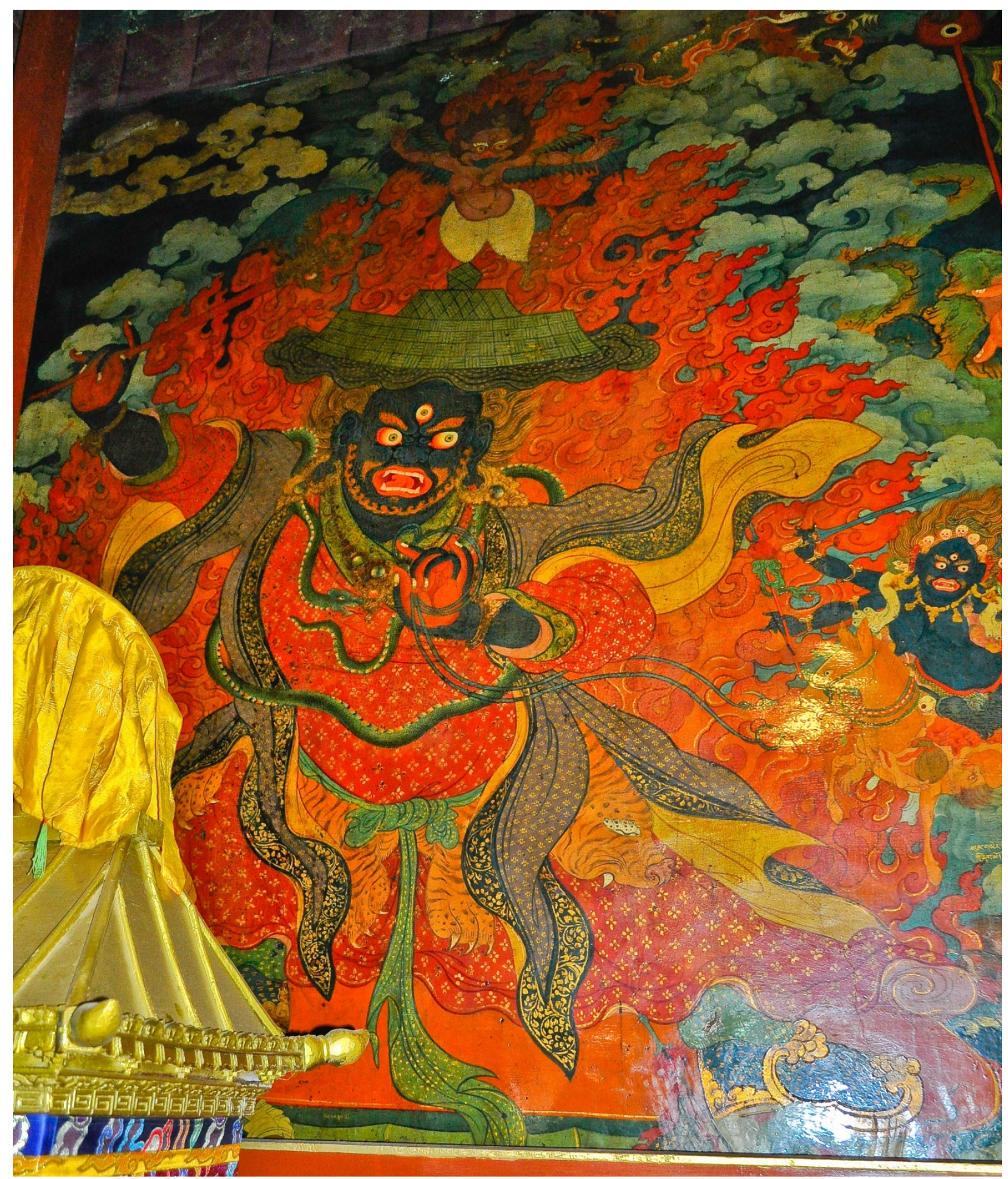

Figure 3: Shingjachen, the southern sovereign spirit of good qualities; Nechung Monastery Assembly Hall, Lhasa. (Photo: Cecilia Haynes, 2011) 


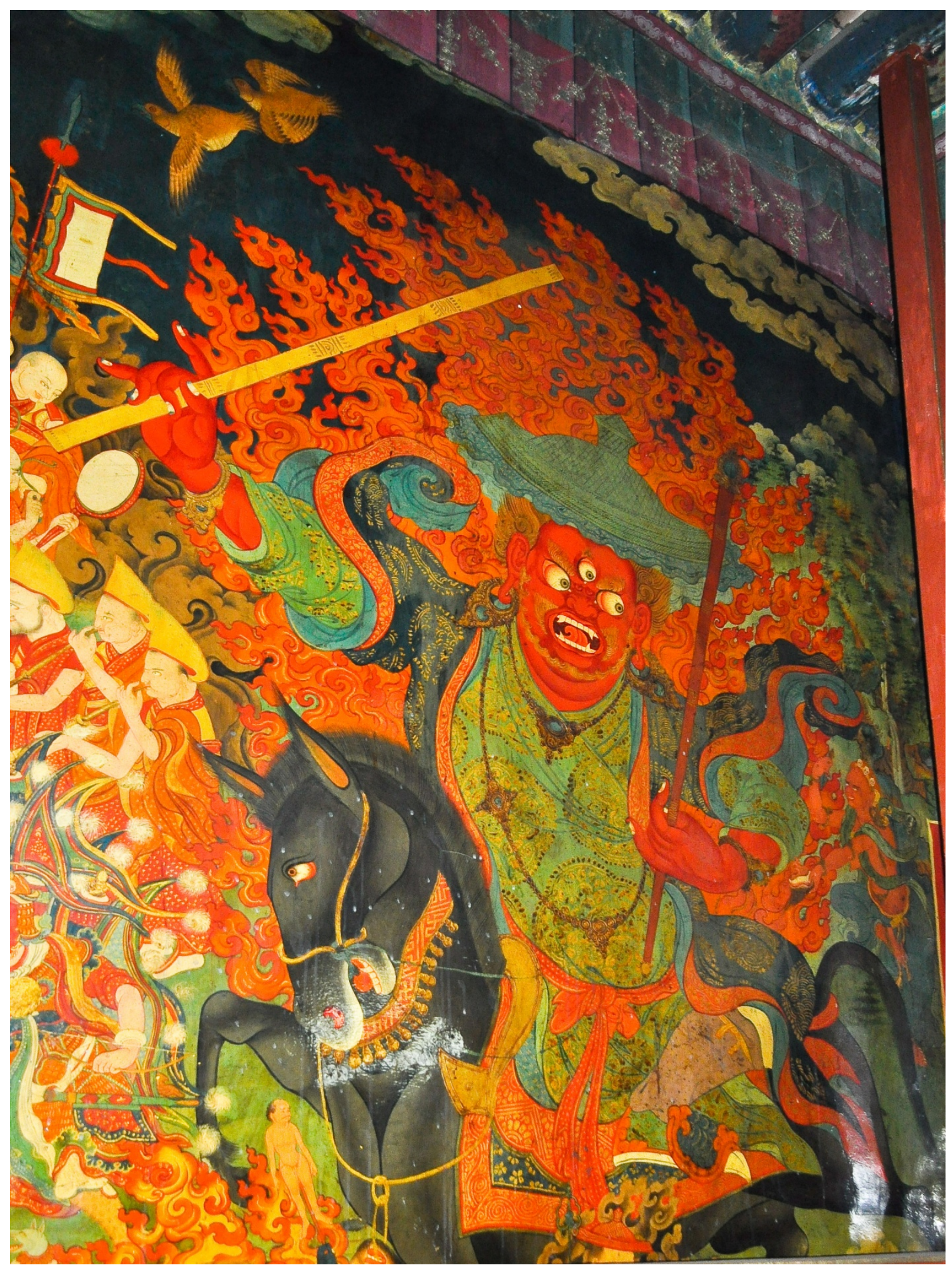

Figure 4: Kyechik Marpo, the western sovereign spirit of speech; Nechung Monastery Assembly Hall, Lhasa. (Photo: Cecilia Haynes, 2011) 

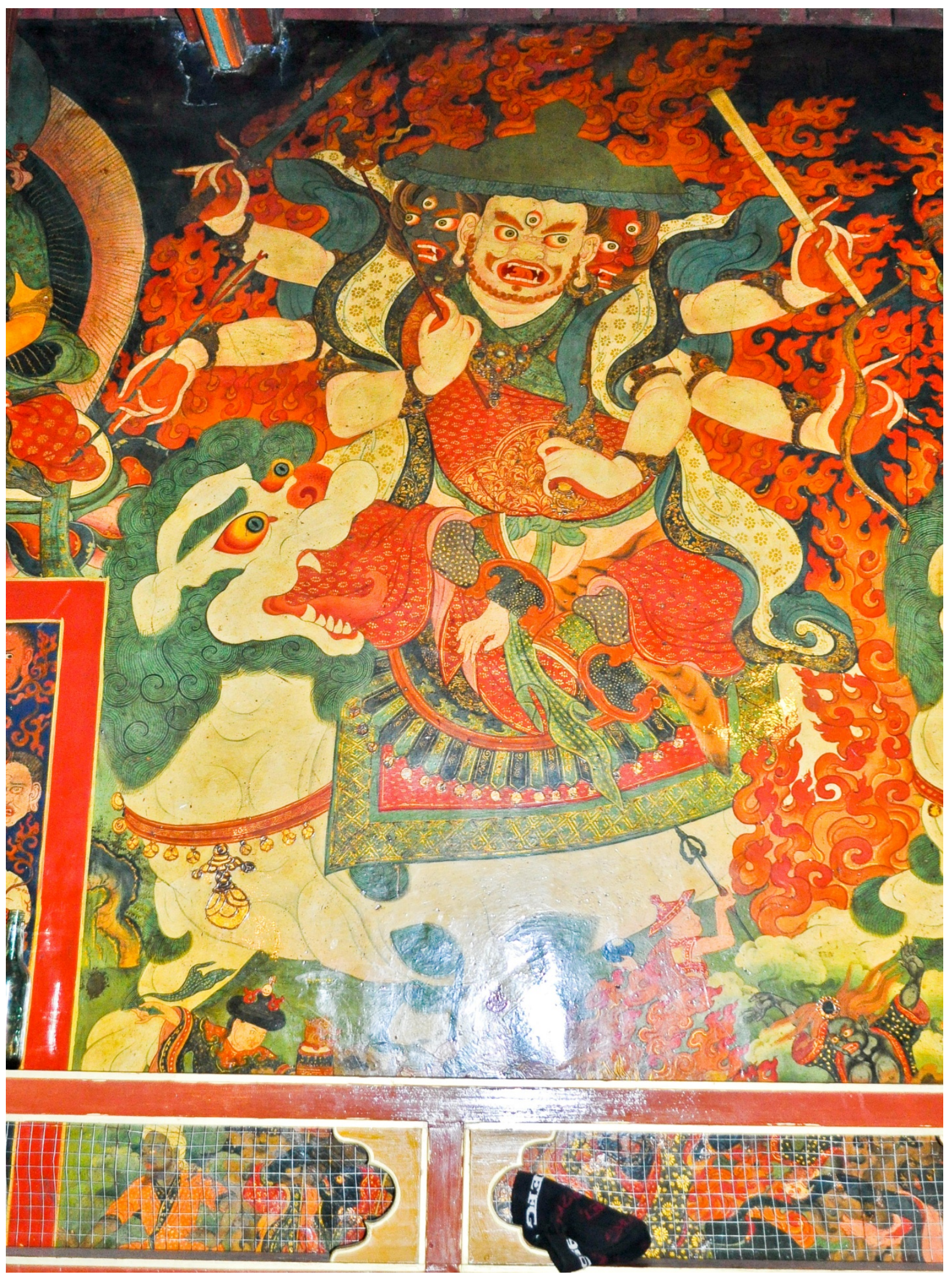

Figure 5: Pehar, the northern sovereign spirit of activities; Nechung Monastery Assembly Hall, Lhasa.

(Photo: Cecilia Haynes, 2011) 


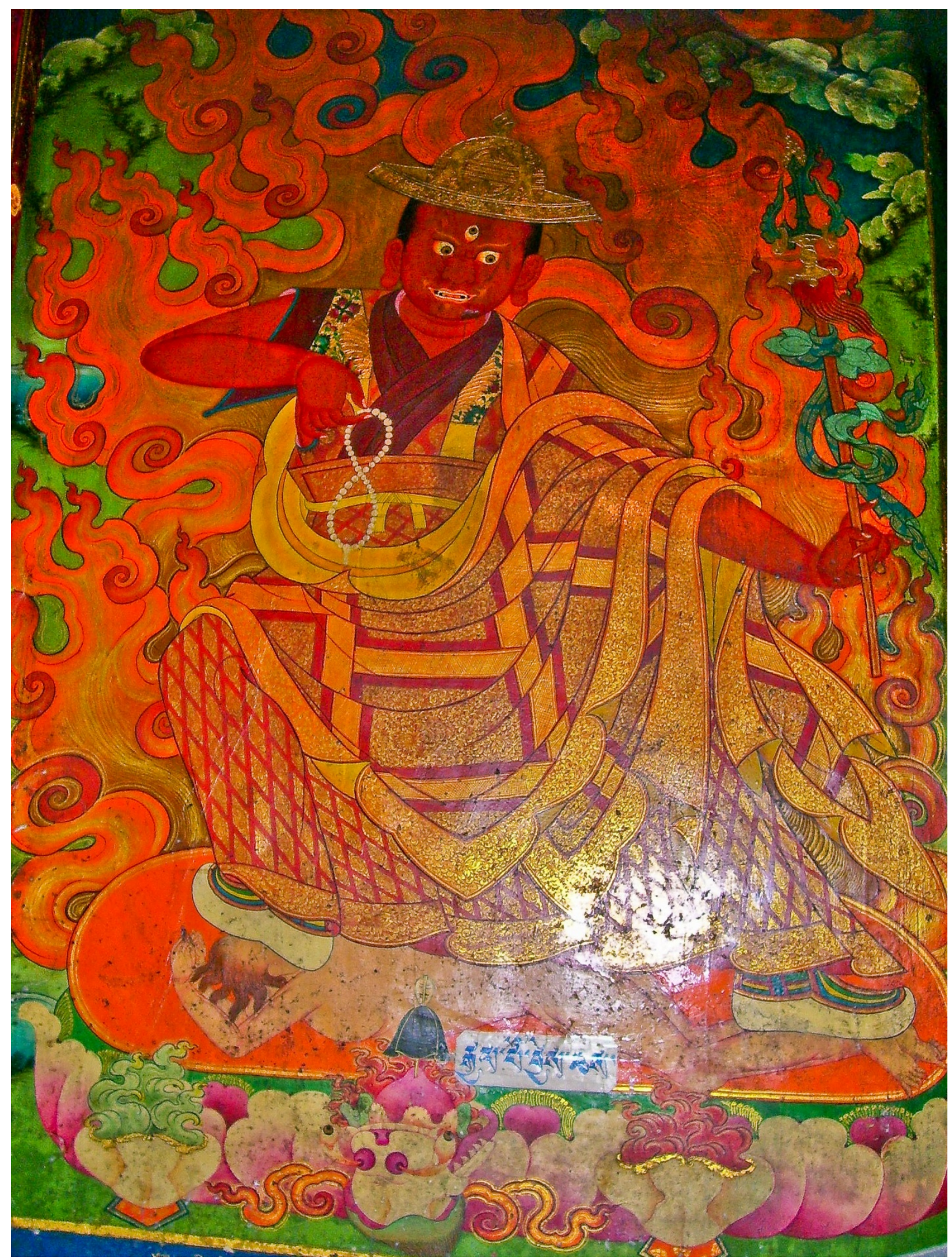

Figure 6: The sovereign spirit Jeché Keru; Nechung Monastery Central Chapel, Lhasa.

(Photo: Christopher Bell, 2007) 


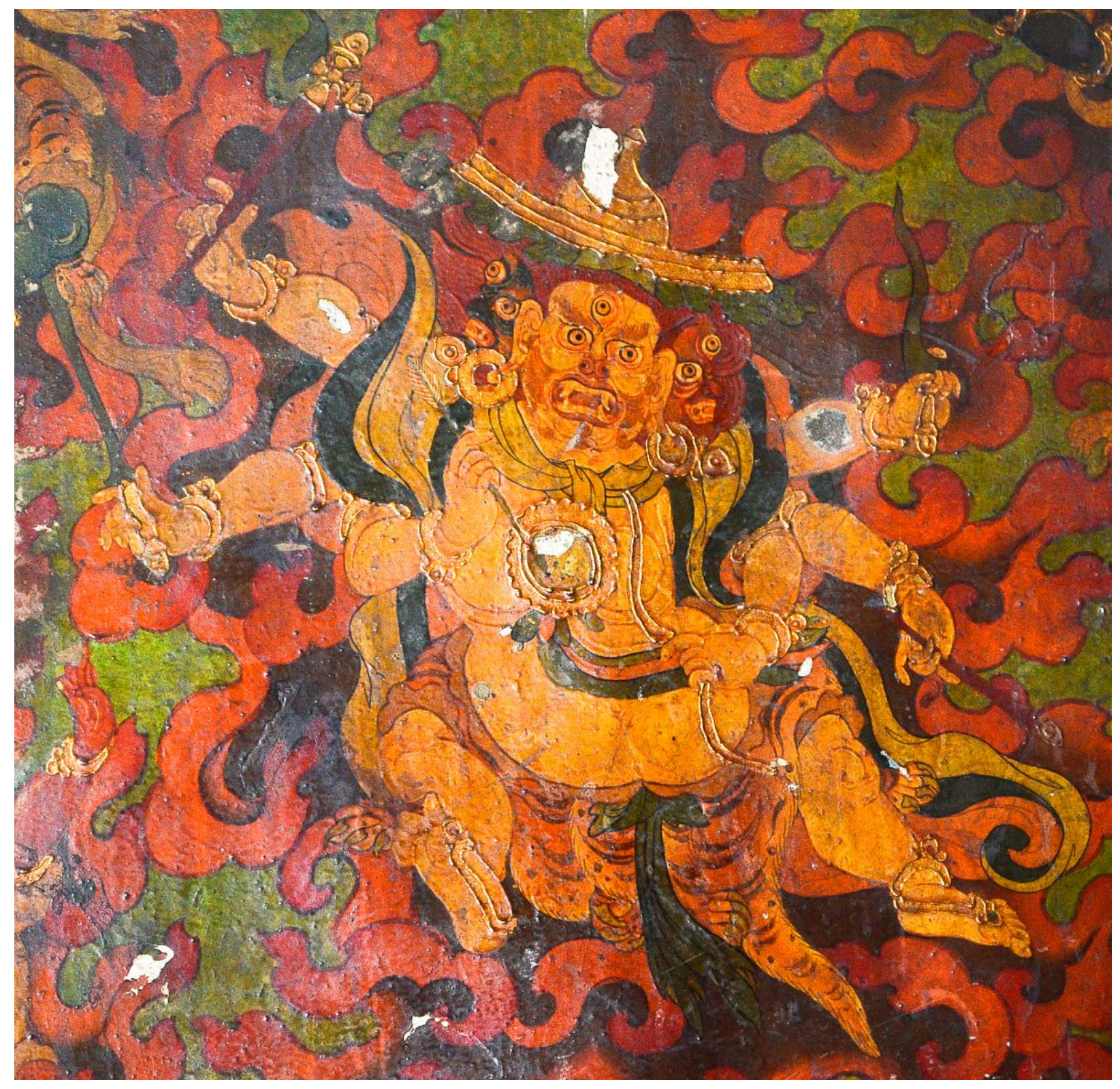

Figure 7: Mudü Dramkarjé; Meru Sarpa Tsangpa Chapel. (Photo: Christopher Bell, 2011)

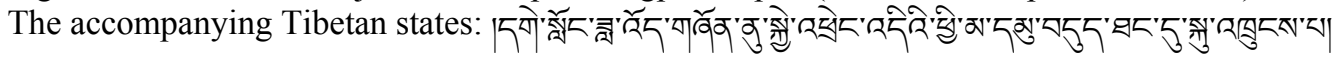

Translation: In the next life in this series of incarnations, the monk Daö Zhönnu was born as Mudü Tang [sic: Drang]. 


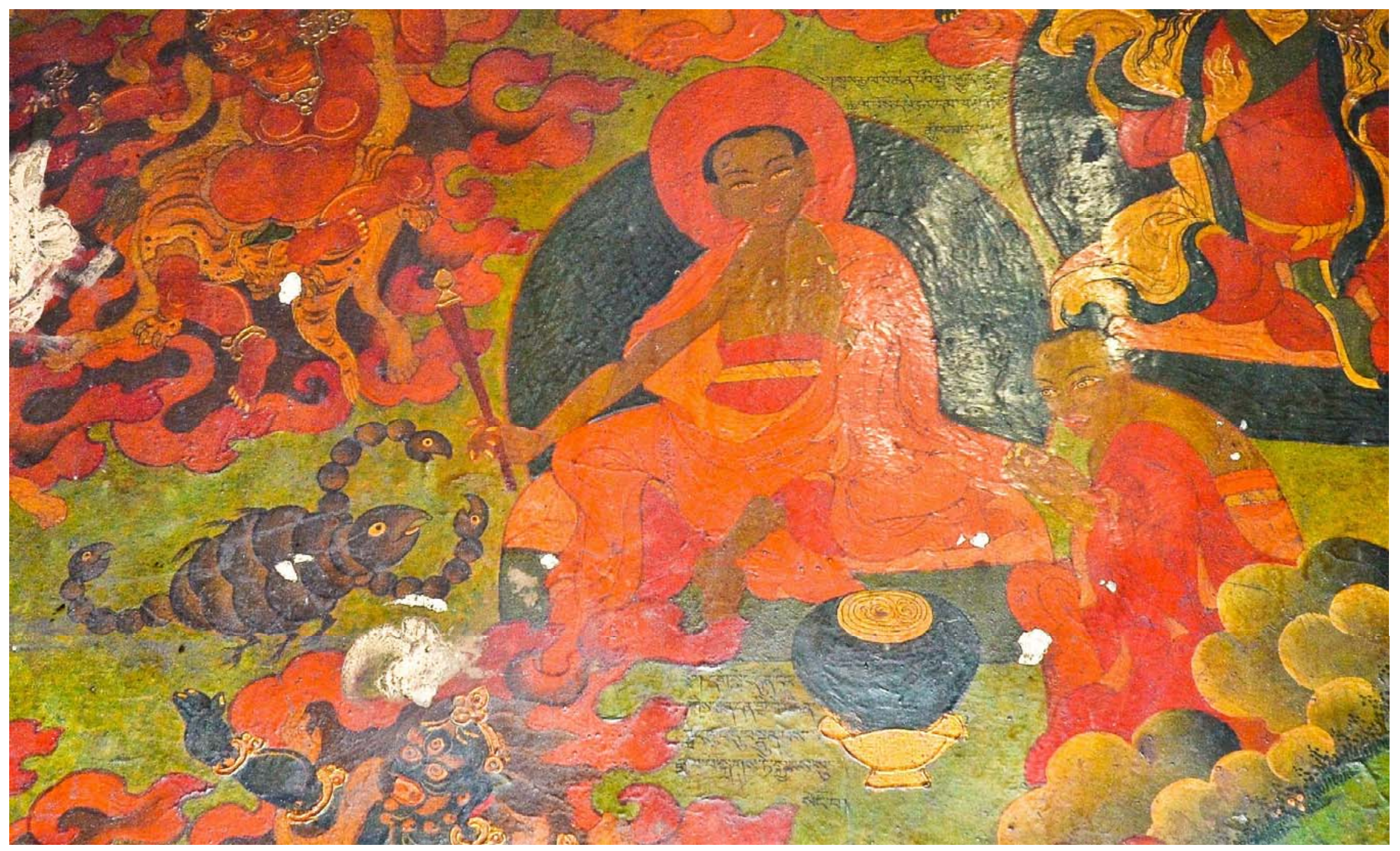

Figure 8: Dünting Nakpo defeats Mudü Dramkarjé; Meru Sarpa Tsangpa Chapel. (Photo: Christopher Bell, 2011)

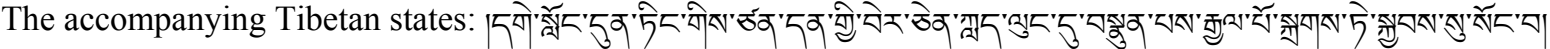

Translation: The fully-ordained monk Dünting [Nakpo], endowed with a sandalwood club, struck [Mudü Dramkarjé] on the head. Then the sovereign spirit became frightened and took refuge in him. 


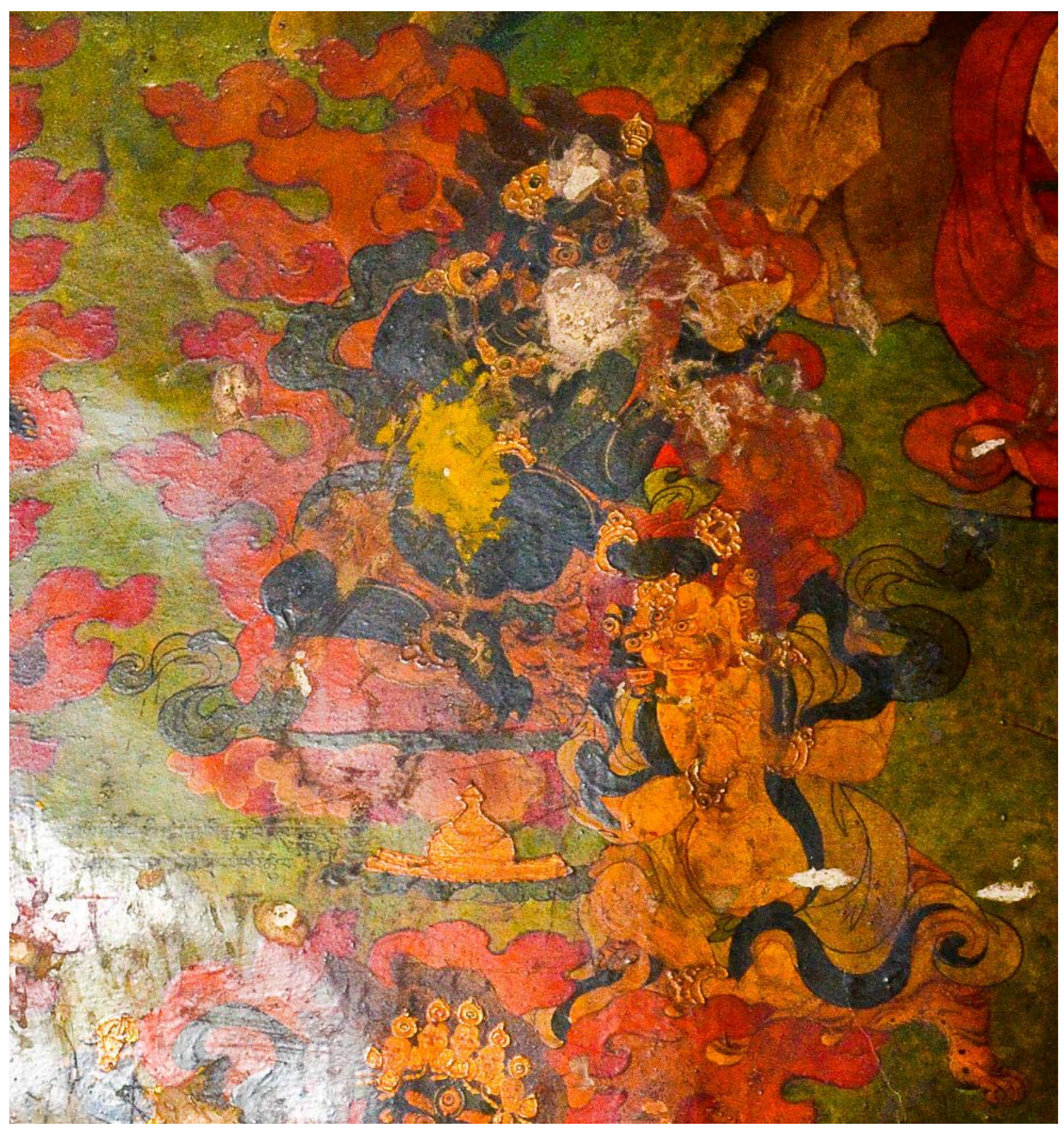

Figure 9: Vajrapāni binds Mudü Dramkarjé; Meru Sarpa Tsangpa Chapel. (Photo: Christopher Bell, 2011)

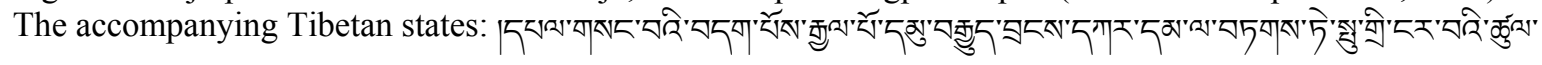
অুু전

Translation: The Master of Secrets [Vajrapāṇi] bound King Mugyü [sic: Mudü] Drangkar under oath, and so he bore the name Putri Ngarwa [sic: Barwa]. 


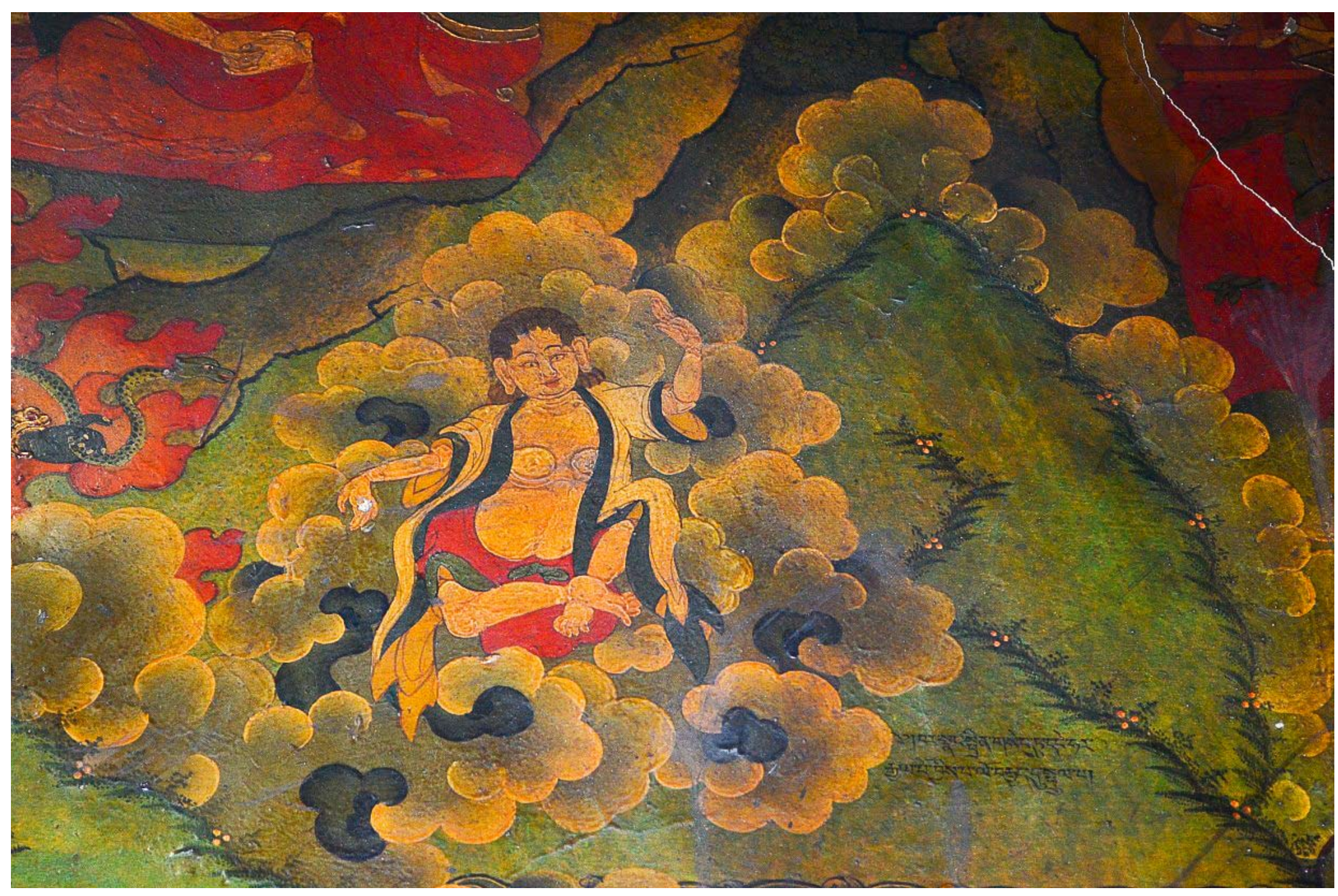

Figure 10: Pehar as an Eight-Year-Old Boy; Meru Sarpa Tsangpa Chapel. (Photo: Christopher Bell, 2011)

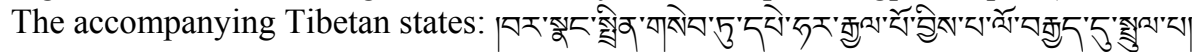

Translation: Among the clouds in the sky, the sovereign spirit Pehar emanated as an eight-year-old boy. 


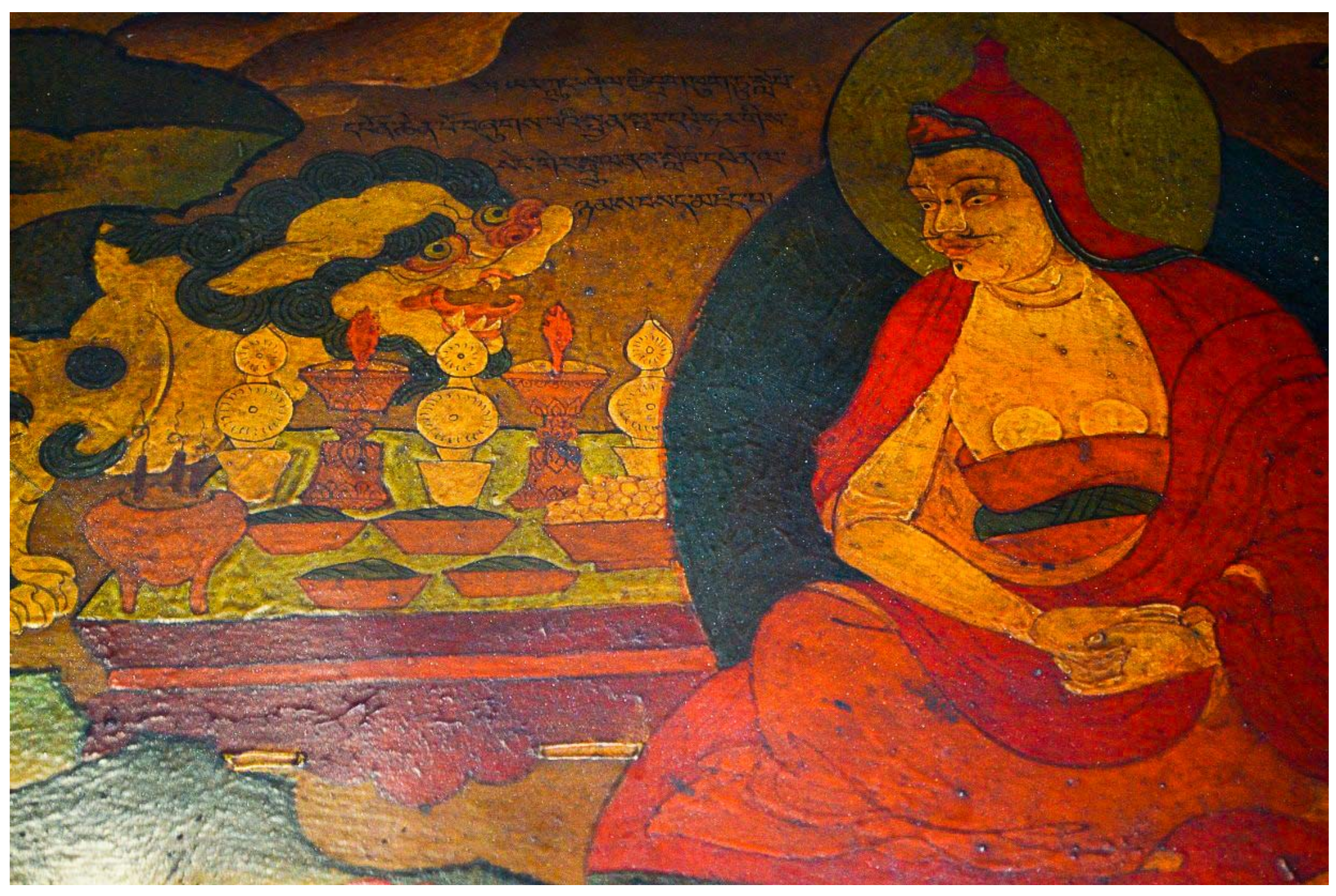

Figure 11: Pehar Tests Padmasambhava; Meru Sarpa Tsangpa Chapel. (Photo: Christopher Bell, 2011)

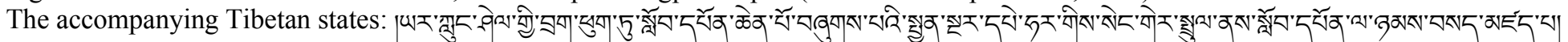

Translation: The Great Master [Padmasambhava] was residing at the Crystal Cave of Yarlung, and Pehar came before him in the guise of a lion to test him. 


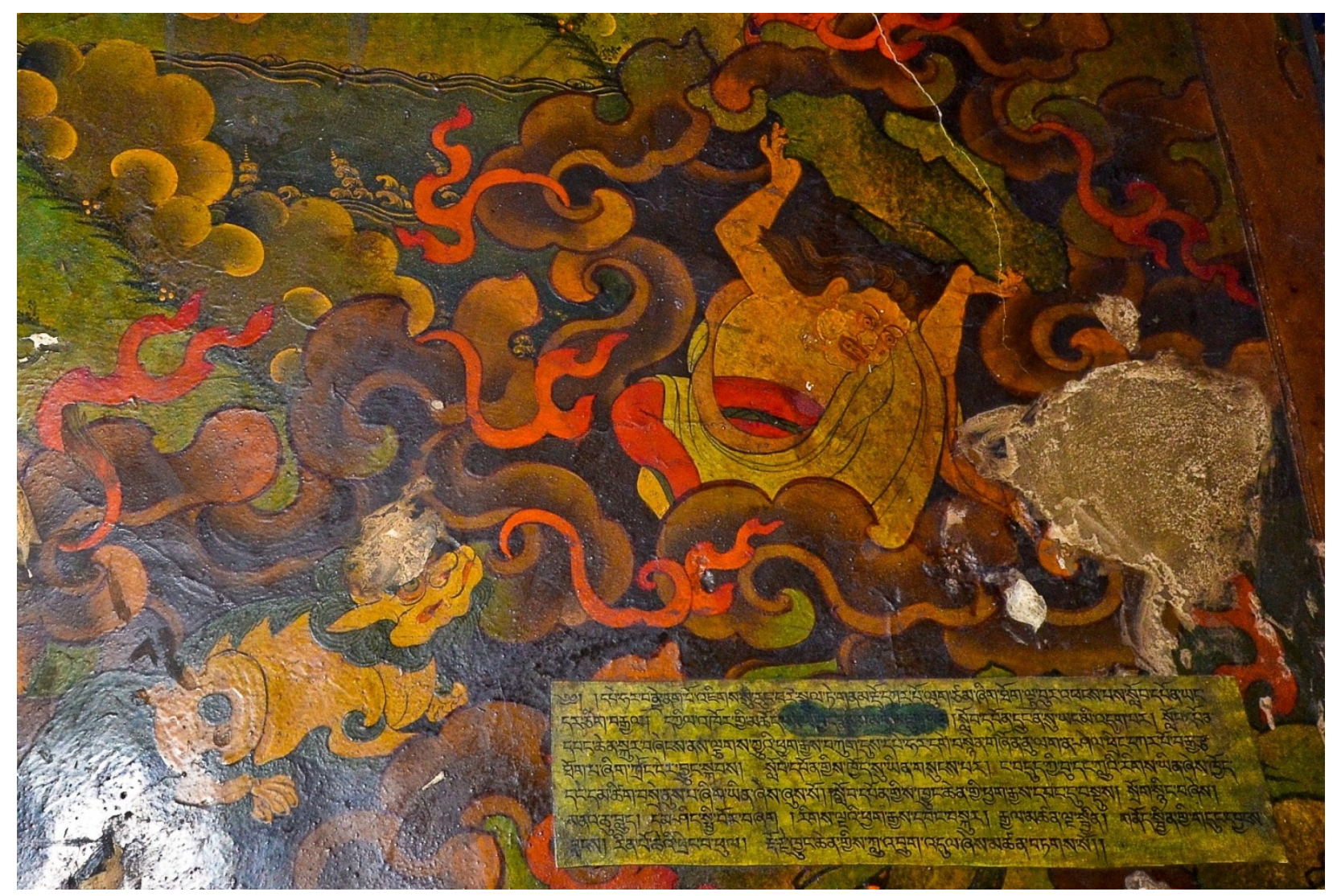

Figure 12: Pehar Transforms into a Black Monk; Meru Sarpa Tsangpa Chapel. (Photo: Christopher Bell, 2011)

The accompanying Tibetan states:

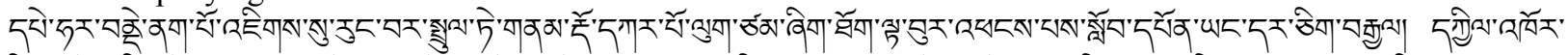

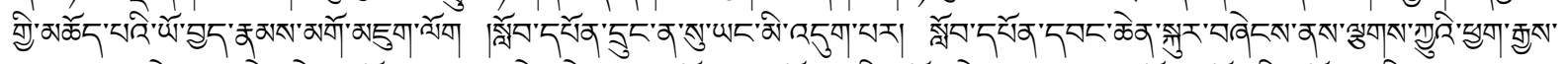

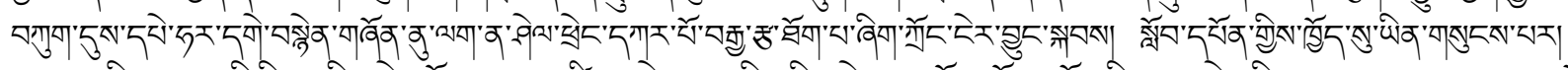

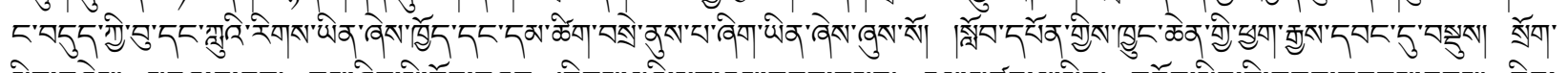

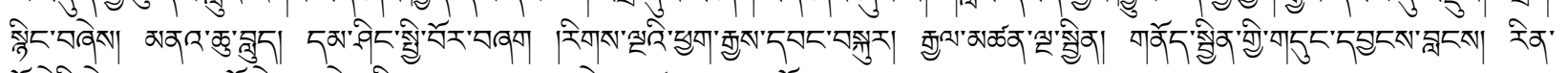

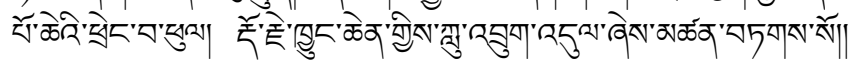

Translation:

Pehar transformed into a frightening black monk and threw down a white meteor, about [the size of] a sheep, like a thunderbolt. Because of this, even the master fainted for a moment [and] the offering materials for the mandala were upended. [When the master revived,] there was no one in front of him. The master took on the form of Hayagrīva and seized [Pehar] with the Iron Hook mudrā. When [this happened], Pehar stood upright [before the master] as a young layman holding a hundred[-bead] white crystal rosary in his hands. The master asked, "Who are you?" [Pehar answered,] "I am the son of a hindering spirit and I was born of a serpent spirit." [The master replied,] "I have the power to integrate [my] samaya vow with yours." [And so] the master subjugated him with the Great Garuda mudrā, took his life essence, gave him holy water to drink, placed a holy branch on the crown of his head, conferred empowerments on him using the mudrā of the Five [Buddha] Families, and bestowed on him five victory banners. [Pehar] sang a sad song to him about the capricious spirit's lineage and offered him precious garlands. [In response, the master] gave him the name Dorjé Khungchengyi Ludrukdül. 


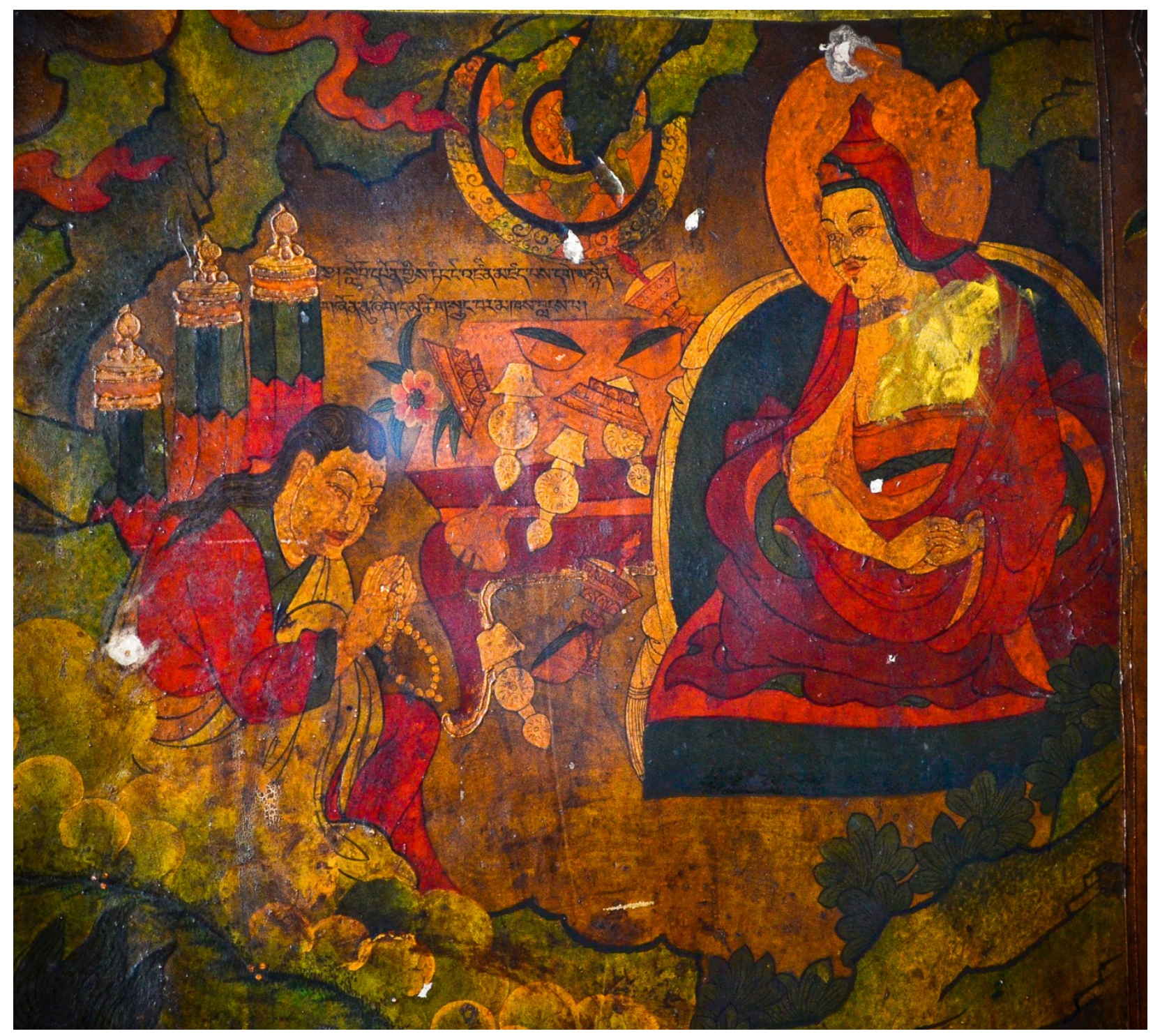

Figure 13: Pehar Transformed into a Young Layman; Meru Sarpa Tsangpa Chapel. (Photo: Christopher Bell, 2011)

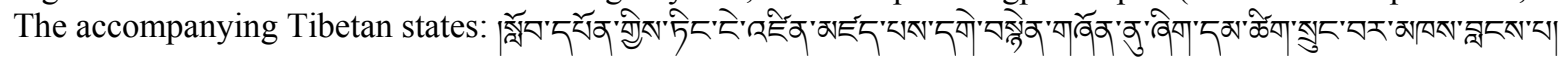
Translation: Because the master performed meditation, the young layman promised to observe his samaya vow. 


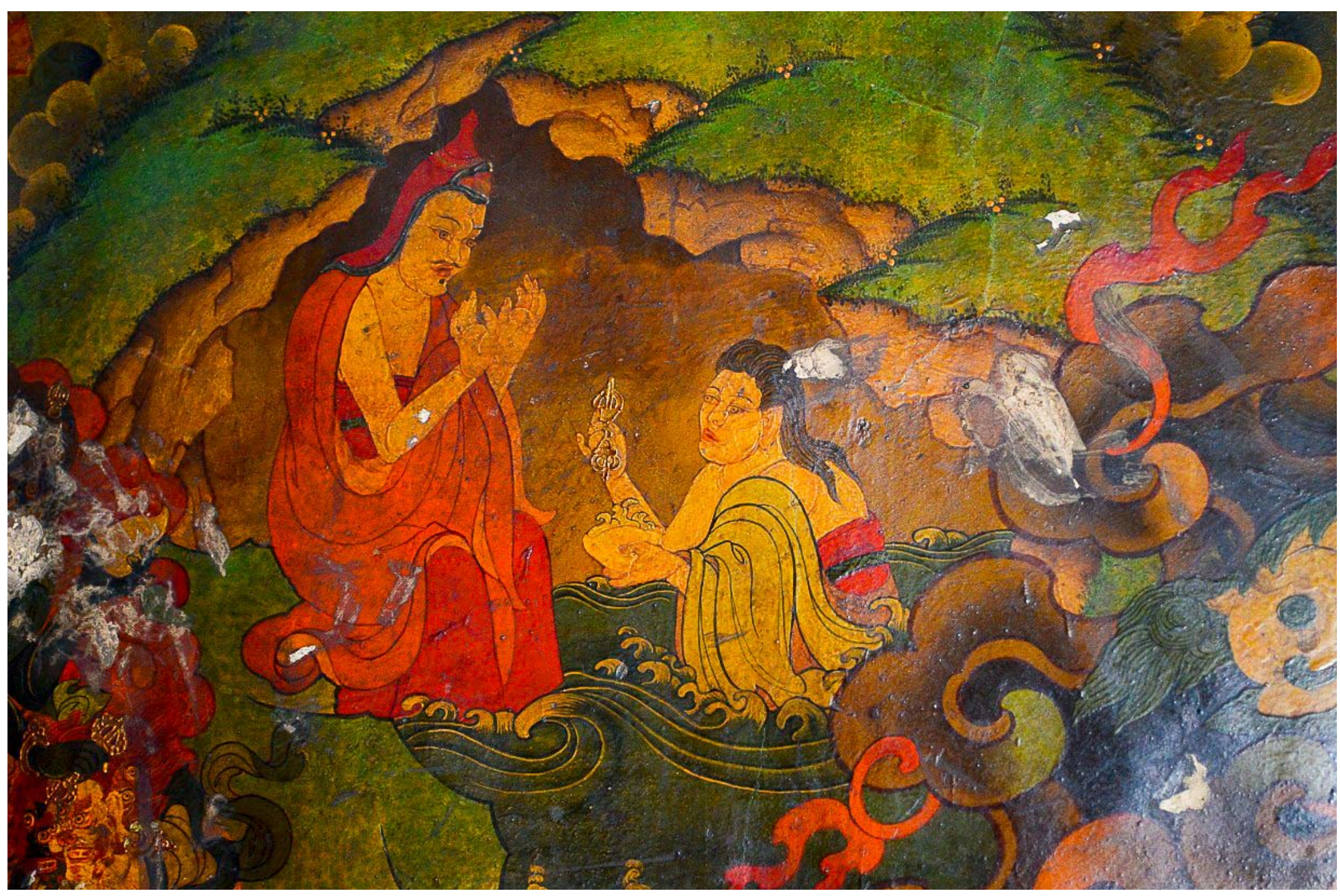

Figure 14: Padmasambhava Subjugates Pehar; Meru Sarpa Tsangpa Chapel. (Photo: Christopher Bell, 2011)

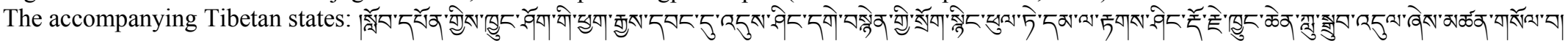
Translation: The master conquered [Pehar] with the Garuda's Wing mudrā and the layman offered up his heart essence. [The master] bound him to oath and gave him the name Dorjé Khyungchen Ludrupdül. 


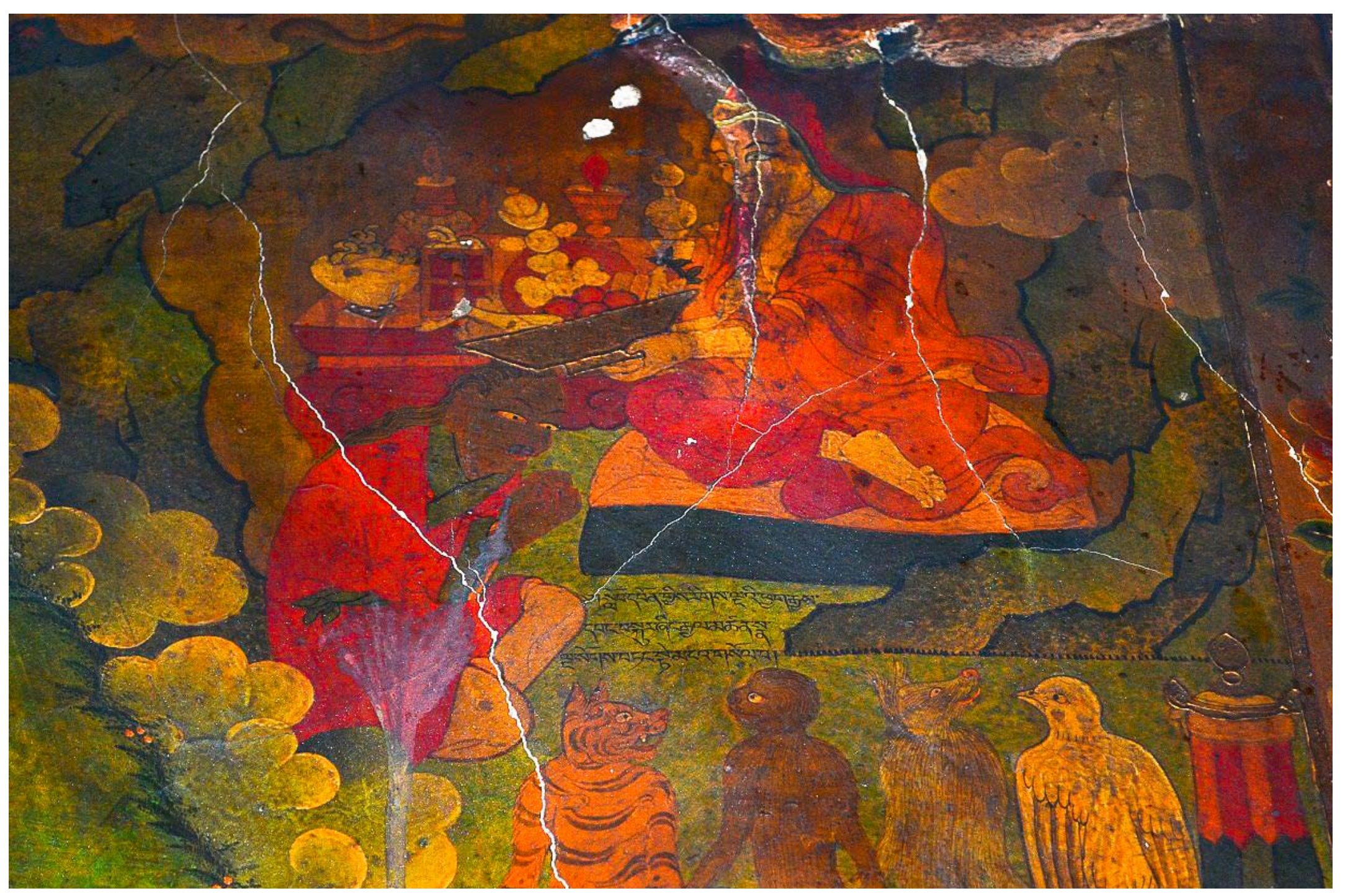

Figure 15: Padmasambhava Confers Empowerments; Meru Sarpa Tsangpa Chapel. (Photo: Christopher Bell, 2011)

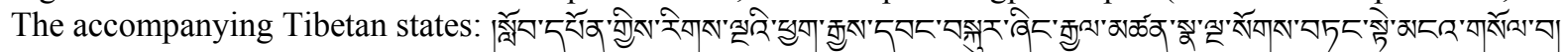

Translation: Using the mudrā of the Five [Buddha] Families, the master conferred empowerments on [Pehar], bestowed on him such [items] as five different kinds of victory banners and invested him with power. 


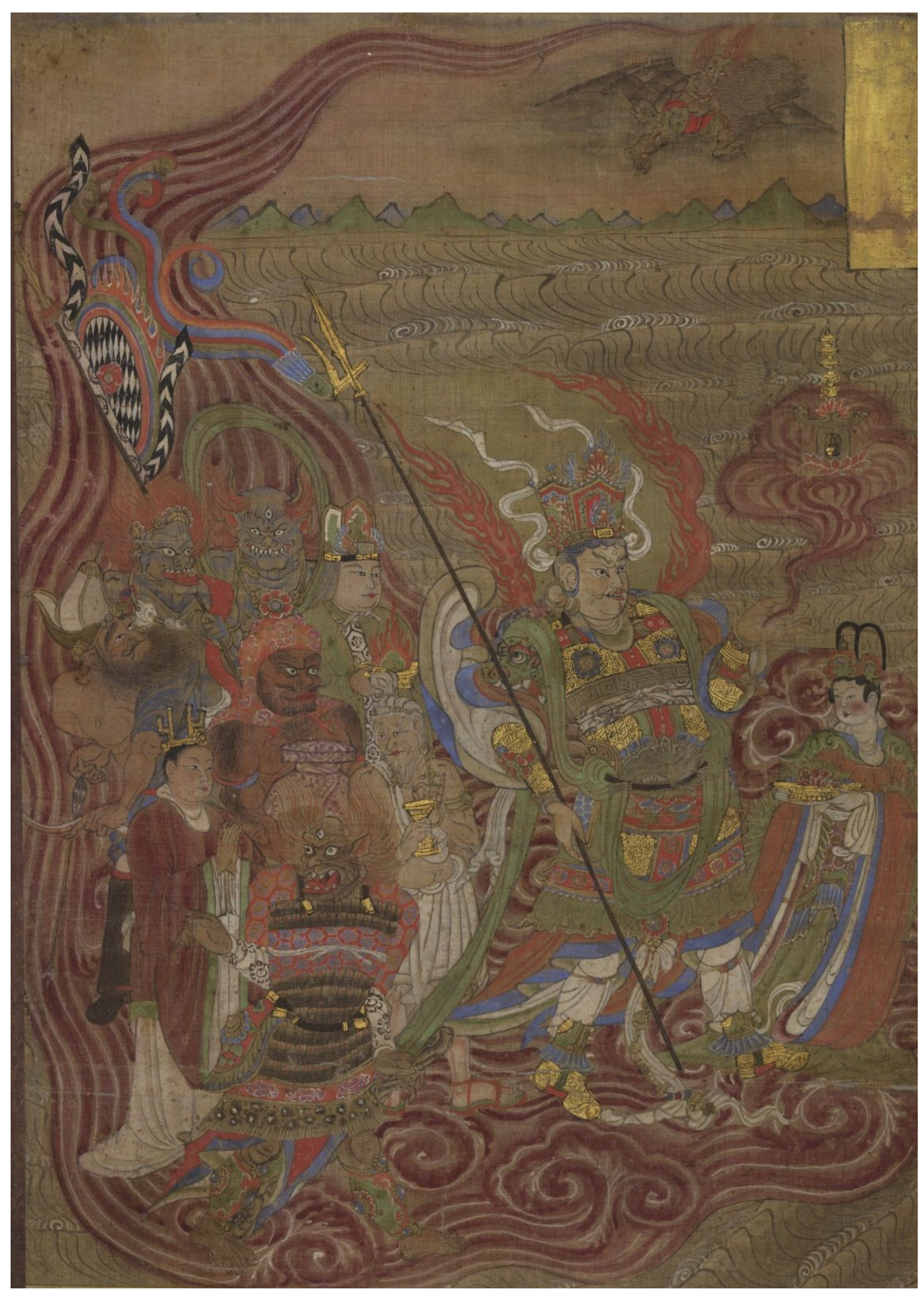

Figure 16: A Central Asian painting of "Vaiśravana in Jang" (Tib. Rnam sras ljangs), $9^{\text {th }}$ century. In the upper right register is the bat-winged vulture - or garuda, according to other accounts - into which Pehar transformed. In the middle left register one of Vaiśravana's spirit soldiers is readying an arrow to shot the vulture down. (C) Trustees of the British Museum. 


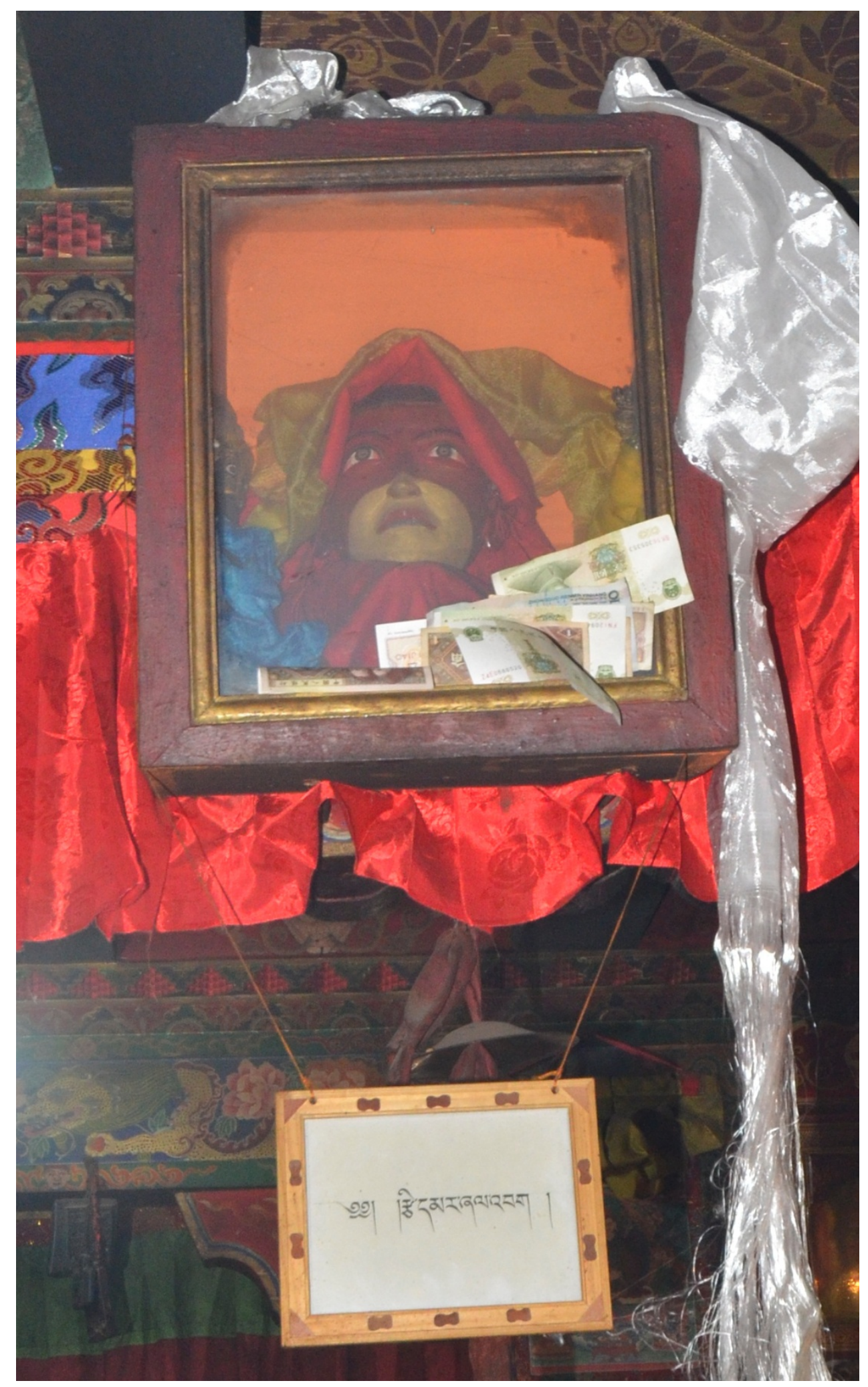

Figure 17: A replica of Pehar's sacred leather mask (Tib. bse 'bag smug chung), held at the Pehar Kordzöling, Samyé Monastery (Photo: Cecilia Haynes, 2011). Intriguingly, the Tibetan underneath says "the mask [of] Tsiu Marpo" (Tib. Rtsi dmar zhal 'bag). The real mask is said to be either destroyed or in Dharamsala, in the possession of the Fourteenth Dalai Lama. 


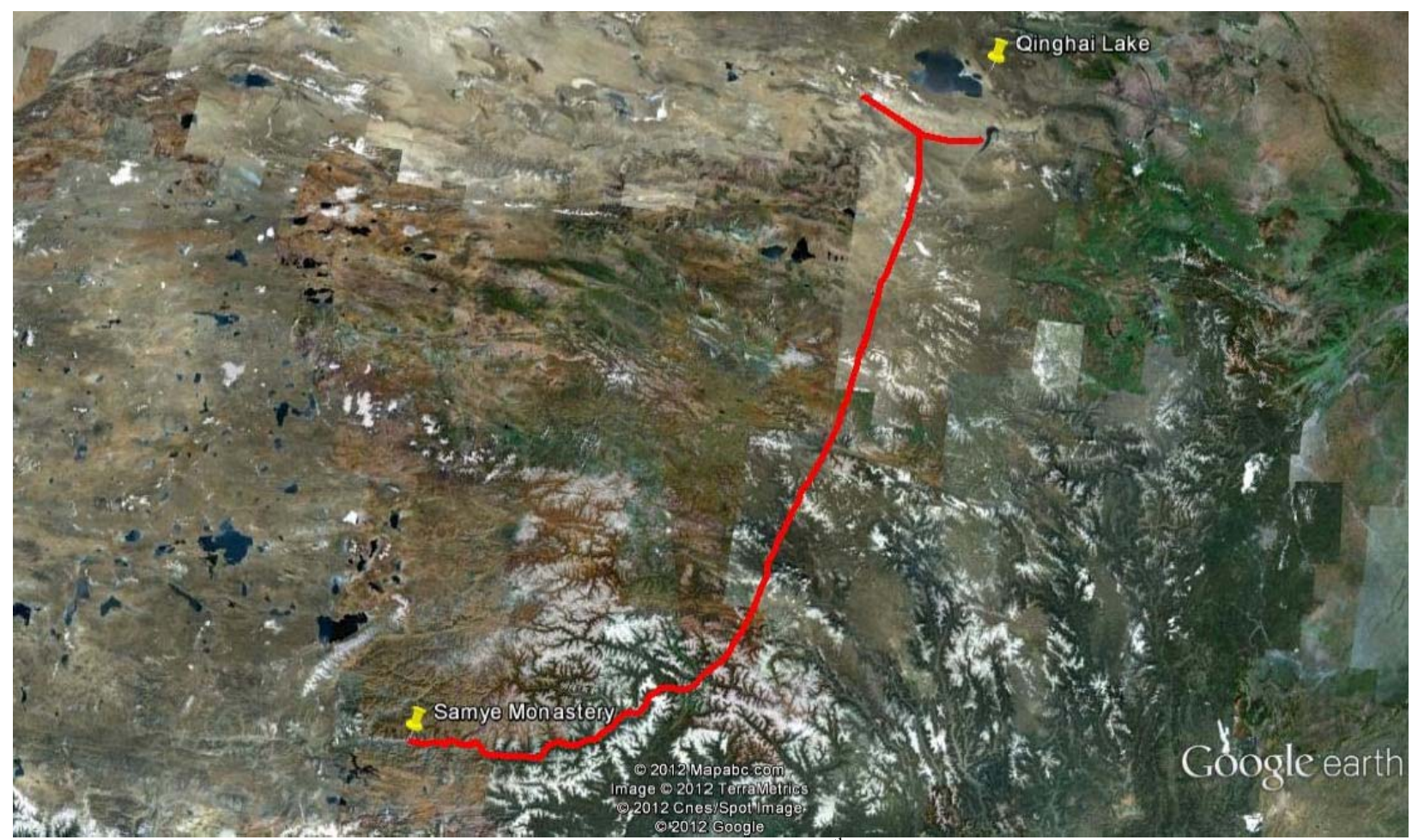

Figure 18a: An approximation of Pehar's journey to Tibet in the $8^{\text {th }}$ century. Pehar was residing at a meditation center in Bhatahor, somewhere near Qinghai Lake, when it was conquered by Prince Muruk Tsenpo's army. The sovereign spirit was captured by Vaiśravaṇa, brought to Samyé Monastery by the prince's army, and eventually assigned as the guardian of the monastery's treasury by Padmasambhava. (C) 2012 Google.

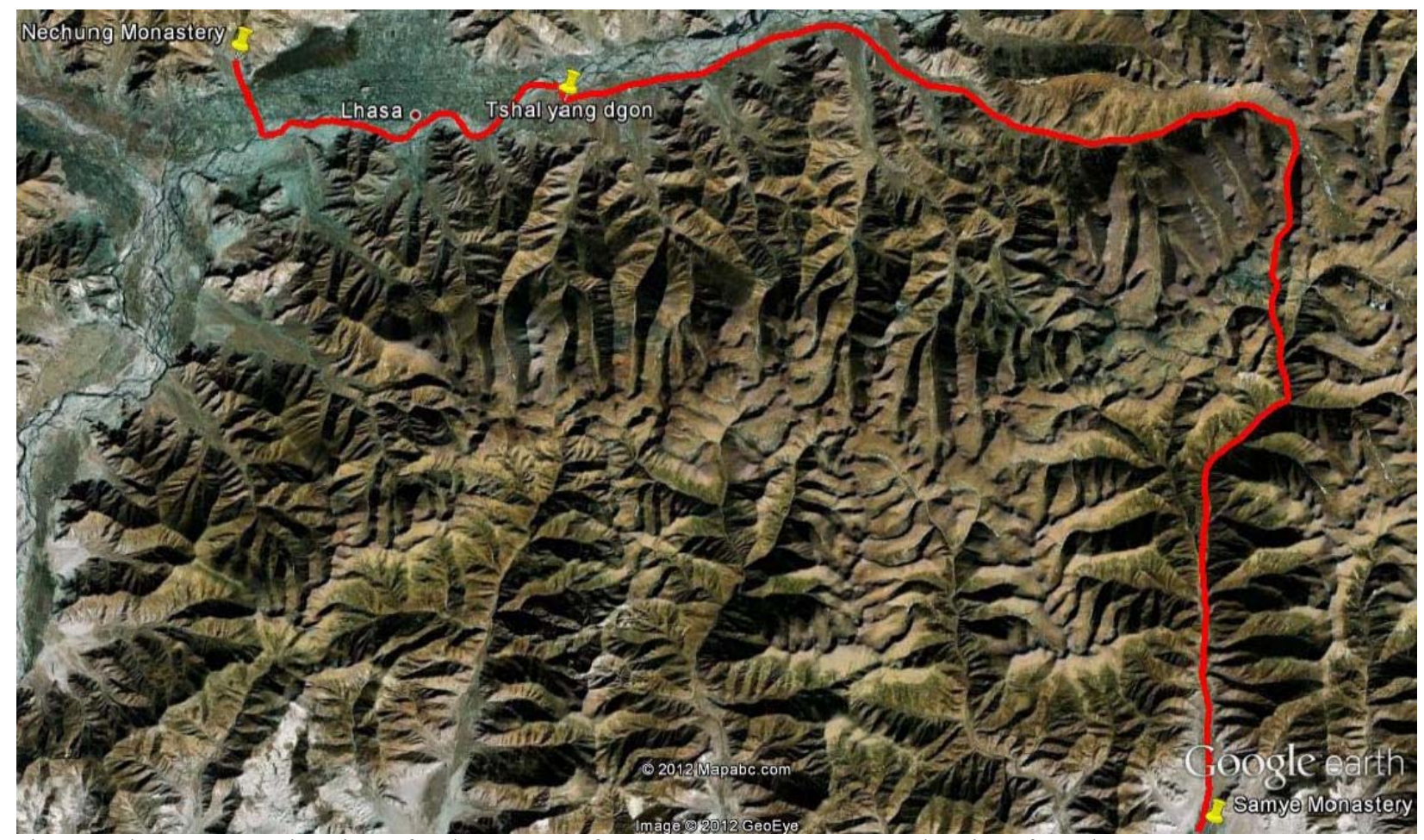

Figure 18b: An approximation of Pehar's route from Samyé Monastery to the site of Nechung Monastery. At some point the sovereign spirit traveled to Tsel Yangön from Samyé before he was unceremoniously dumped into the Kyichu River in 1529. Nechung Monastery was then founded for him at Dambak Marser Village. (C) 2012 Google. 


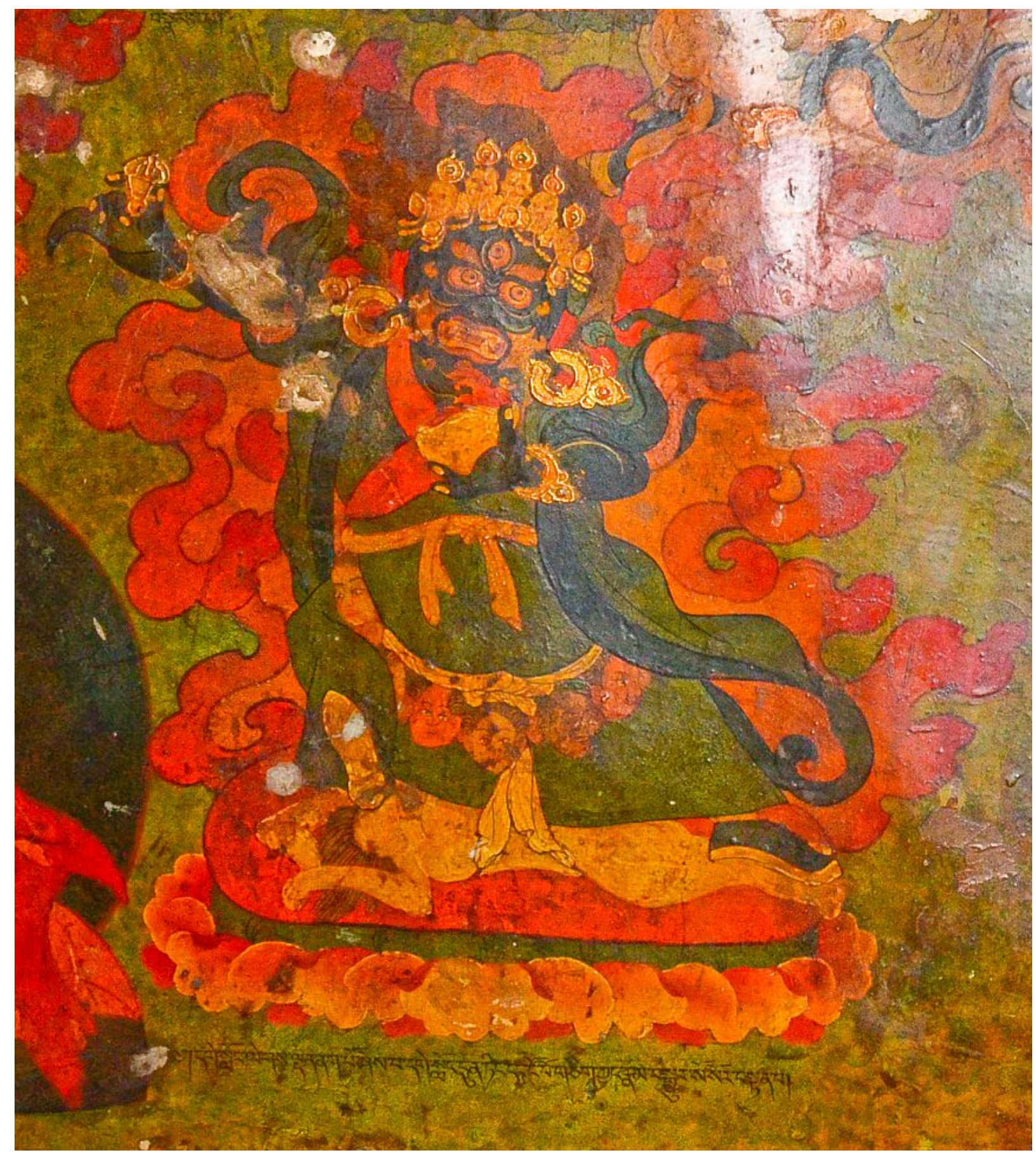

Figure 19: Lekden Nakpo and Dünting Nakpo are the Same; Meru Sarpa Tsangpa Chapel.

(Photo: Christopher Bell, 2011)

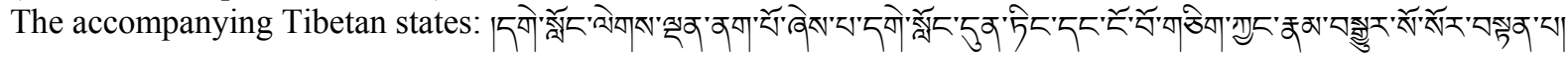
Translation: Athough the monk called Lekden Nakpo and the monk Dünting [Nakpo] were the same being, they appeared in distinct forms. 


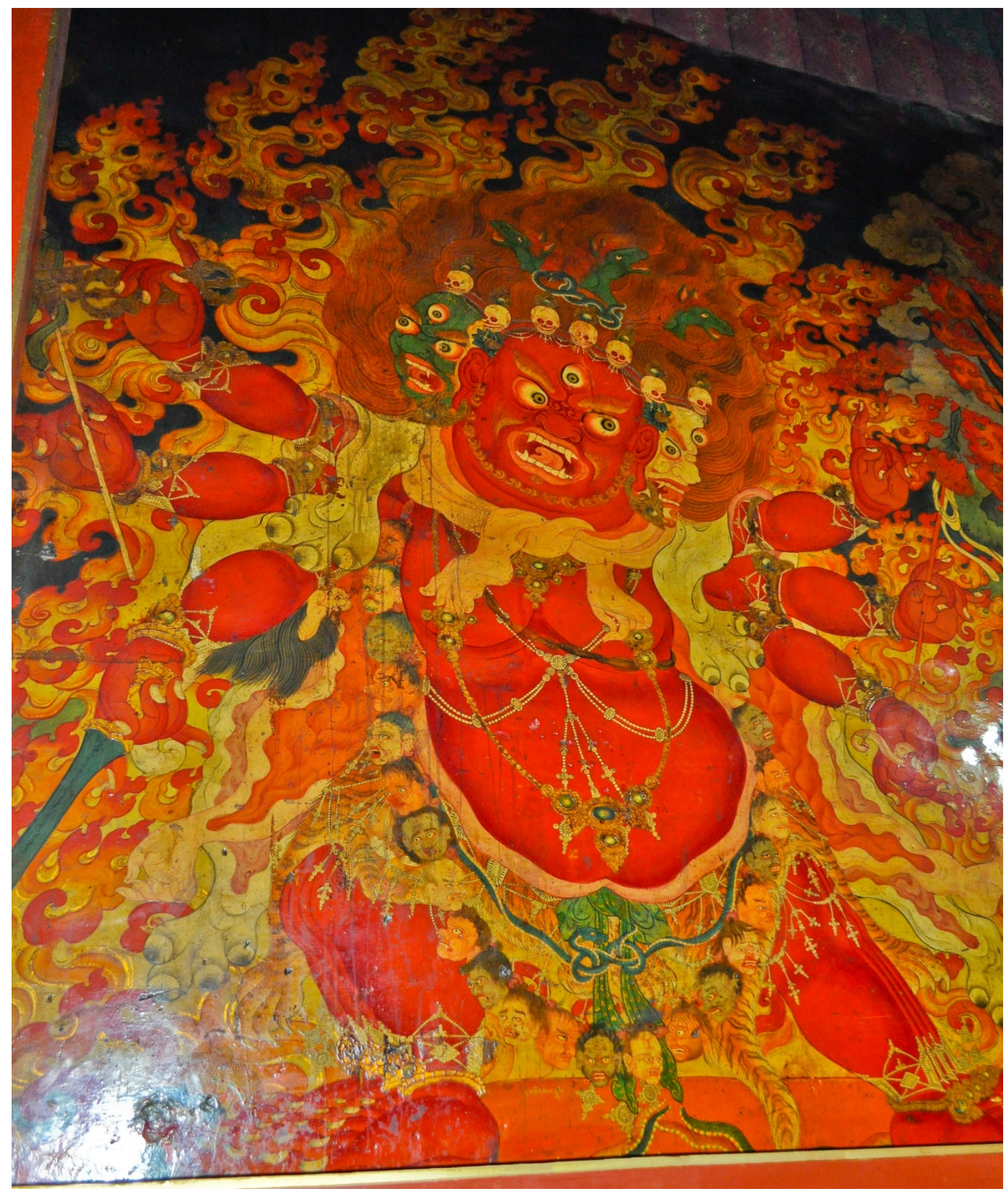

Figure 20: Hayagrīva, with his horse head(s) bursting forth from Rudra's forehead; Nechung Monastery Assembly Hall. (Photo: Christopher Bell, 2011) 


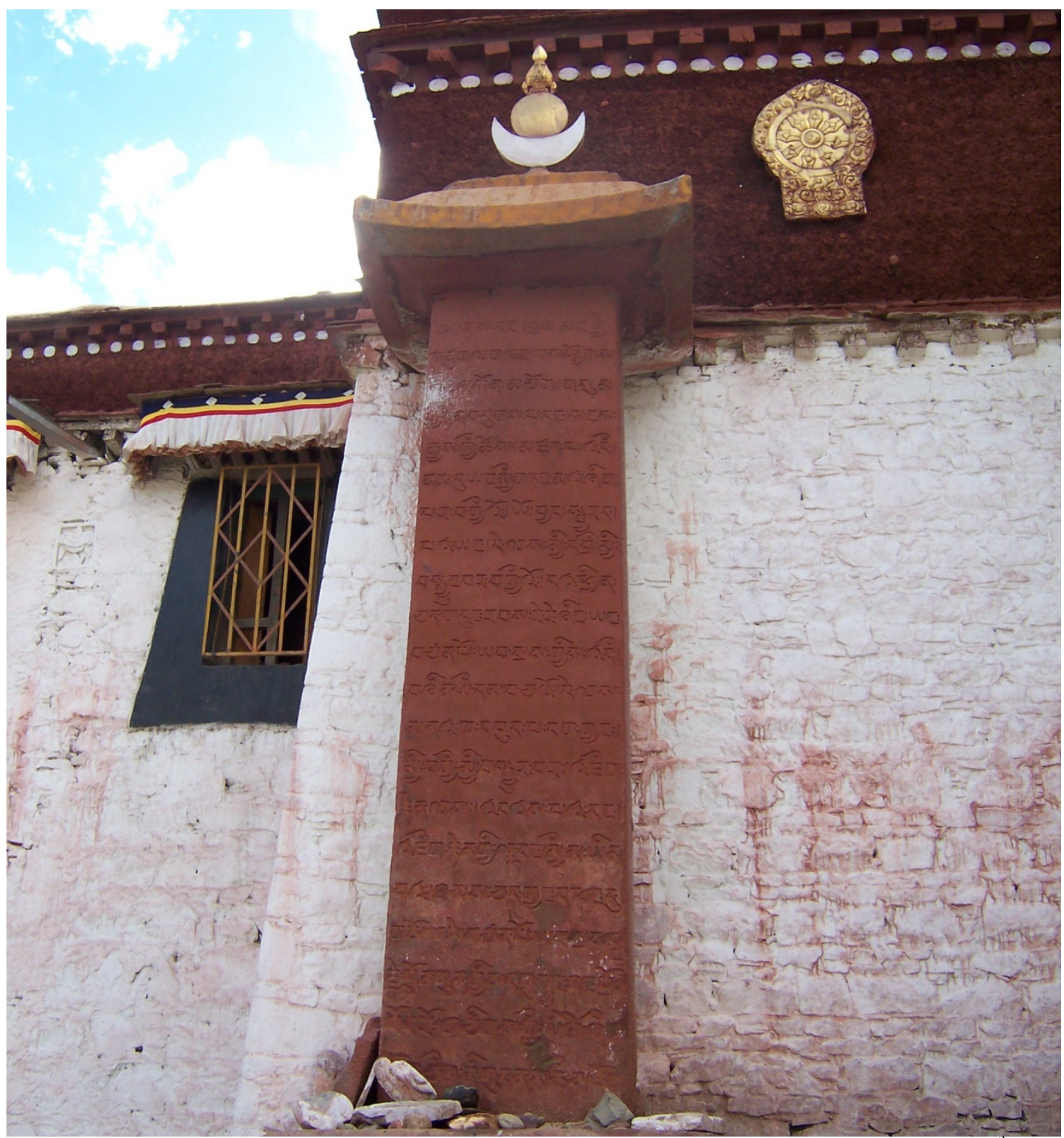

Figure 21a: Samyé Monastery inscribed pillar (Tib. rdo ring), erected at the monastery's founding (late $8^{\text {th }}$ century).

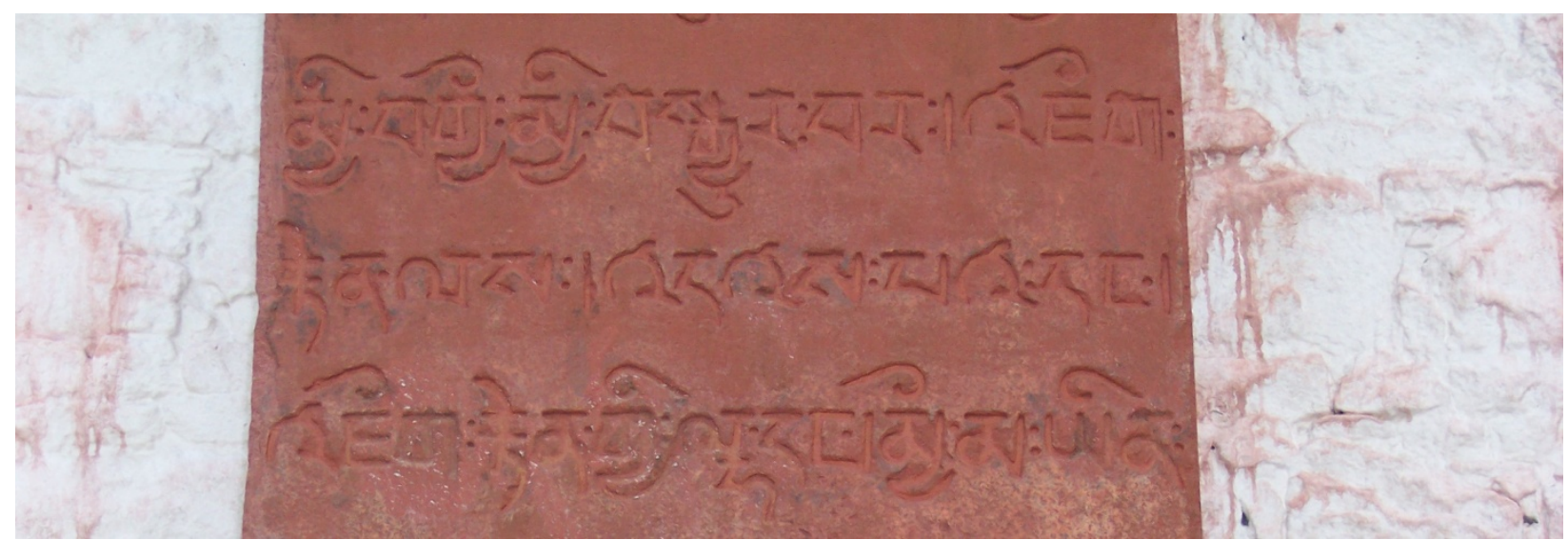

Figure 21b: Close-up of inscription mentioning supramundane and mundane deities. (Photos: Christopher Bell, 2005) 


\section{Chapter 2: Nechung's Ritual Pedigree}

Throughout the seventeenth century, the Fifth Dalai Lama engaged with Pehar and promoted his cult at Nechung through ritual. The Great Fifth not only performed various rituals for the deity, as recorded in his autobiography, he composed the text of several such rites over the course of his reign. These rituals were not written at random, but were requested by regents and monks, and the vast majority by Pehar himself via the Nechung Oracle. These works are at the heart of Nechung Monastery's liturgical collection and ritual calendar, both of which have accrued in content since the seventeenth century. The most important of the Great Fifth's Nechung rituals, the Adamantine Melody, was requested by his first regent, Sönam Rapten, sometime around 1650. However, the ritual was composed quickly at the behest of the Nechung Oracle. Moreover, this lengthy ritual is the culmination of 500 years of accumulated material, beginning with a twelfth-century treasure text entitled the Ten-Chapter Sädhana that was 'rediscovered' by the treasure-revealer Nyangrel Nyima Özer (1124-1192). To this day, the TenChapter Sädhana and the Adamantine Melody are the two central rituals at Nechung Monastery. Like the mythic narrative presented last chapter, the Great Fifth relied on ancient Nyingma texts to support and justify his advancement of the Nechung cult, which he used to ritually buttress the power and authority of his Gelukpa government.

From the seventeenth century onward, the Nechung Oracle also impacted the growth of the monastery's ritual corpus, requesting or inspiring ritual texts through successive human mediums. Of great confusion, however, is what deity possessed the Nechung Oracle in the course of this textual development. As will be discussed below, Tibetan oracles can be possessed by multiple deities despite being known for one in particular. In the case of the Nechung Oracle, he can be possessed not only by Pehar but by several of his emanations as well. Specifically, it appears that from the turn of the eighteenth century onward the deity Dorjé Drakden, a minister of one of the Five Sovereign Spirits, would come to possess the Nechung Oracle far more than Pehar. The exact timing and reason for this shift in the primary possessing deity is unknown, and no known sources discuss it directly, but it had far-reaching consequences. Despite Pehar's mythic and historical primacy at Nechung, as well as Dorjé Drakden's meager 
origins, the latter eventually usurped the former's centrality. Now the monastery's chief deity is Dorjé Drakden, who represents Nechung at other sacred sites.

In examining these developments, the present chapter offers a gradual contraction of focus on, and temporal range for, Nechung's ritual activities and texts. The chapter begins with a discussion of the various methods used at Nechung Monastery for invoking Dharma protectors. It is through such means that wrathful guardians are entreated to guard monasteries and the state alike. This is followed by a bird's-eye view of Nechung's yearly ritual activities. This ritual calendar is a twentieth-century record that illustrates how much ritual activity has accrued at Nechung since the seventeenth century. Some of these rituals synchronize with grander citywide activities while others are only practiced at Nechung. Next there is a detailed discussion of the liturgical collection on which Nechung's ritual practices are based. This Nechung Liturgy was compiled in the mid-nineteenth century at the request of the Nechung Oracle and vividly illustrates the oracle's 200-year influence over the monastery's ritual corpus. The chapter's focus condenses to offer a deeper examination of the two key texts of the Nechung Liturgy, the Ten-Chapter Sädhana and the Adamantine Melody, as well as a collection of rites composed by the Second Dalai Lama, in order to illuminate the intricate ritual accretion that has taken place between these works. Beyond expanding the institutional and cosmic significance of the cult of Pehar, this accretion also exemplifies how the worship of other deities, like Tsiu Marpo and Makzor Gyelmo, can merge into other cults or shift their affiliation through the process of emendation. The chapter concludes with a detailed exploration of Dorjé Drakden's iconographic origins, as well as his curious and expanding place within Nechung's pantheon.

\section{Methods for Invoking Dharma Protectors}

Like many religious sites in Tibet, Nechung Monastery has historically been the center of a rich variety of ritual activity. These activities include daily, monthly, and annual recitations, torma offerings, ${ }^{1}$ statue consecrations, thread-cross mansions, ${ }^{2}$ ritual dances, ${ }^{3}$ oracle possessions, and festivals. Despite this diversity of execution, all of these rituals are concerned with engaging the Five Sovereign Spirits and the deities of their entourage. While it is not the purpose of this

\footnotetext{
${ }^{1}$ Tib. gtor ma.

2 Tib. mdos; an alternative is nam mkha'.

${ }^{3}$ Tib. 'cham.
} 
dissertation to examine the historical evolution of each of these kinds of ritual, it is nonetheless important to briefly discuss their nature and significance.

Periodic ritual recitation has been a mainstay of Nechung Monastery at least since its 1682 renovation, though likely before then as well. Such recitations are also at the core of every other major ritual performance, from thread-cross construction to oracle possession, since each of these activities requires a vocal invocation to consecrate the sacred object or summon the monastery's central deities. The number of monks, the length of the recitation, and the degree to which it is accompanied by offerings or musical instrumentation may change depending on the circumstance and occasion, but these basic goals are the same (Figure 22). The primary ritual collection for Nechung Monastery from which these recitations are drawn is the Nechung Liturgy, which will receive a more detailed discussion below.

Torma offerings consist of colored and molded dough cakes and often accompany ritual recitations, especially lengthier ceremonies. Such offerings are presented to the monastery's deities in the course of a ritual and in elaborate configurations consistent with the spirit category to which the deities belong. ${ }^{4}$ Tormas made and offered for specific occasions are usually discarded after the ritual is complete. However, there are also year-long or continuous tormas ${ }^{5}$ constructed and preserved near or on the altars of the deities. These tormas represent constant offerings to the monastery's deities and are replaced only once a year, usually as part of the New Year festivities (Figure 23). Temporary and continuous tormas must be consecrated with mantras provided in the pertinent ritual manuals before they can be presented to deities, whose presence is believed to be made manifest through the ritual process as well as within the locus of their statues and murals. Beyond tormas, other offerings such as incense, beer, milk, yogurt, and butter lamps are occasionally presented at the altar in front of or near the deities' statues by monastics and laity alike.

Nechung Monastery is home to numerous images of its central deities and their retinue, as well as other important deities and figures that illustrate a strong Nyingma-Geluk fusion-a characteristic that extends back to its restoration. ${ }^{6}$ Indeed, this vast collection of murals and statues is one of the unique characteristics of the monastery. ${ }^{7}$ To this day the courtyard walls are

\footnotetext{
${ }^{4}$ For lists and drawings of specific tormas and the spirit types to which they are generally offered, see NebeskyWojkowitz 1998, pp.343-354; and Beer 2004, pp.320-335.

5 Tib. lo gtor.

${ }^{6}$ See Appendix III.

${ }^{7}$ See Ricca 1999.
} 
covered in murals of the deities' retinue, its assembly hall walls have images of the Five Sovereign Spirits and the Eight Sādhana Deities, and its inner chapels house statues of the Five Sovereign Spirits and other deities to which they have a close connection. Like all sacred statues, the images housed at Nechung have all been consecrated through ritual recitation and mantric invocation. ${ }^{8}$ The completion of this process is the 'eye-opening ceremony,' ${ }^{9}$ which involves painting the eyes of the thangka image, mural, or statue in order to sacralize the object. Consecration allows the statue to act as a suitable offering and vessel for the deity that it represents, which in turn makes it a fitting locus to which tormas and other offerings can be presented (Figure 24). These images represent spatial manifestations of the deities in contrast to their temporal manifestations exhibited during periodic ritual recitations; both forms are an invitation to the deity. This constant visual presence is also used by the monks to aid their mental visualization of the deities during ritual performances.

In keeping with this desire for deities like the Five Sovereign Spirit to be ever-present, monks at Nechung Monastery also once constructed thread-cross mansions in which to house Pehar, Dorjé Drakden, and the Five Sovereign Spirits more broadly. ${ }^{10}$ A thread-cross mansion is a cubic structure made of sticks and colored thread. This geometric construction is a small model of the deity's divine mansion, which can stand two to six feet in height and vary in intricacy (Figure 70). ${ }^{11}$ Just as statues act as a spatial manifestation of the deity, these threadcross mansions act as a spatial manifestation of their divine abode and are built in order to invite the deity into them. A number of rituals that concern the construction and consecration of these mansions were referred to in the last chapter. It is clear that thread-cross mansions have been utilized at Nechung at least since its renovation, since they are mentioned throughout the Nechung Register as well as in the ritual calendar given below.

Ritual dances have been an important element of the religious life of all major Tibetan monasteries. The practice has been severely diminished in Tibet since the mid-twentieth century, but it is still done today at historically important sacred centers, such as Samyé Monastery.

\footnotetext{
${ }^{8}$ For the most detailed examination of this consecration process as it pertains to images and reliquaries, see Bentor 1996.

${ }^{9}$ Tib. spyan dbye ba'i cho ga.

${ }^{10}$ This practice may still be present at Nechung Monastery in Lhasa today, though I saw no signs of it. By contrast, a continuously present thread-cross mansion for Penden Lhamo is kept in the back-right Desire Realm Chapel at Nechung Monastery today. This thread-cross mansion is kept locked inside a large cabinet until it is needed for ceremonial purposes.

${ }^{11}$ For a full discussion of these and other Tibetan thread-cross structures, see Nebesky-Wojkowitz 1998, pp.369-397.
} 
These dances reenact the great mythic stories of Padmasambhava and other tantric exorcists in their efforts to subdue the local gods and spirits, and also represent the play of the higher Buddhist gods and enlightened beings. During these narrative performances, which can last for many hours over many days, monks wear masks and dress in costumes representing various gods, exorcists, and tutelary deities. As representations of important protector deities, like the Five Sovereign Spirits, the monks perform specific dance routines around or for a central figure. These routines are accompanied by music and tell a story of conflict, subjugation, and ultimately liberation. Sometimes the dances are performed before effigies of the Dharma protectors, acting as a gift of entertainment for them (Figure 25). In either case, the dancers dressed as these deities momentarily embody them and act as yet another conduit for their presence. ${ }^{12}$ As mentioned in the ritual calendar below, the monks of the four monasteries connected to Tsel Gungtang ${ }^{13}$ have traditionally been responsible for organizing the ritual dances at Nechung Monastery, and at Drepung Monastery on one occasion. This speaks to the historical relationship between Tsel Yangön Monastery and Nechung Monastery, and may symbolize Pehar's migration from the Tsel region to the area around Dambak Marserchen village, which was discussed last chapter.

Perhaps the most significant and concrete instance whereby a monastery's deity manifests is through the medium of an oracle. A Tibetan oracle is a human being who periodically and ritually becomes possessed by a Tibetan protector deity in order to provide prophecies or advice on anything from personal matters of health and well-being to state matters of national security. Not every monastery has an oracle and not all oracles are tied to monasteries. Nevertheless, Nechung Monastery's oracle is arguably the most famous and certainly one of the most important in Tibetan history. Nowadays the Nechung Oracle is most often possessed by Dorjé Drakden, the minister of Kyechik Marpo, the western sovereign spirit of speech; however, he has been known to become occasionally possessed by Pehar himself, as well as other members of the Five Sovereign Spirits and their retinue. The institutional idiosyncrasies of the Nechung Oracle will be given greater attention in the next chapter, but for now it is necessary to offer some general information on Tibetan oracles as a ritual focus and category.

\footnotetext{
${ }^{12}$ The two best studies on Tibetan ritual dances are Nebesky-Wojkowitz 1976 and Kohn 2001.

${ }^{13}$ Tib. Tshal Gung thang.
} 
There are a number of Tibetan words that refer to oracles, such as kuten ("bodily receptacle"), ${ }^{14}$ lhabap ("descended god"), ${ }^{15}$ and lhaka ("god speaker"). ${ }^{16}$ These words are descriptive enough, yet a number of other terms exist with varying degrees of popular usage and which carry greater cultural significance. Pawo ${ }^{17}$ and pamo, "warrior" and "woman warrior" respectively, focus more on the aggressive qualities of these figures. Hildegard Diemberger argues that these terms also tie oracles to the epic bard traditions of Tibet and draw attention to the dangerous experiences that are commonly found in the life narratives of oracles. ${ }^{19}$ NebeskyWojkowitz makes a distinction between terms used for oracles that channel low-ranking deities—lhapa ("god person") ${ }^{20}$ — and those used for high-ranking, state-recognized oracleschöjé ("Dharma lord"). ${ }^{21} \mathrm{~A}$ term that was shared with me personally is chökyong ("Dharma protector"), ${ }^{22}$ which is confusing since it is more commonly applied to the deities themselves. A degree of conflation appears to be occurring where the individual identity of the oracle is so subsumed within that of the possessing deity as to be indistinguishable. The oracle simply is the Dharma protector while under possession - there is no difference. In practice, the latter term is used to refer to the oracle while under possession of the deity, while other terms, such as kuten and koktu zhukpa ("the internally entered"), ${ }^{23}$ refer to the individual who becomes possessed. I have adopted this indigenous distinction in my own usage; 'medium' refers to the individual who periodically becomes possessed by the deity and 'oracle' refers to the human medium while under possession as the mouthpiece of the deity. ${ }^{24}$

The origins of the oracle tradition in Tibet are unknown, though it is generally thought to have been a pre-Buddhist practice that was later incorporated into the Buddhist cosmological structure. ${ }^{25}$ Only worldly deities are generally believed to possess mediums, since transcendental deities are beyond the worldly concerns that oracles are requested to resolve and also beyond the need for a human basis to speak directly. Rare instances where oracles claim to be possessed by

\footnotetext{
${ }^{14}$ Tib. sku rten.

${ }^{15}$ Tib. lha 'bab.

${ }^{16}$ Tib. lha bka'.

${ }^{17}$ Tib. dpa' bo. Per-Arne Berglie (1976) is especially fond of this epithet.

${ }^{18}$ Tib. dpa'mo.

${ }^{19}$ See Diemberger 2005, p.128; also see Stein 1959.

${ }^{20}$ Tib. lha pa.

${ }^{21}$ Tib. chos rje.

${ }^{22}$ Tib. chos skyong; personal correspondence with Lodrö Gyeltsen (Tib. Blo gros rgyal mtshan), lama of Tengyéling (Tib. Bstan rgyas gling) monastery, Lhasa; July 24, 2005. See also Tewari 1987, p.140.

${ }^{23}$ Tib. khog tu zhugs pa; see Tà la'i bla ma 05 1991-1995, vol. 5, p.274.4.

${ }^{24}$ See also Nair 2004, p.38n.8.

${ }^{25}$ See Nebesky-Wojkowitz 1998, p.428; Peter 1978b, p.288; and Tewari 1987.
} 
transcendental deities are usually met with suspicion. ${ }^{26}$ A medium is commonly renowned for being the vessel of a specific deity; yet most mediums can channel multiple deities in a single trance, with each deity providing further insight into a communal crisis or prophetic declaration. $^{27}$

When a deity descends into a medium it results in a trance state. This trance state of possession shows a marked change in the behavior of the medium. As the deity begins to take over the medium's body, he or she will begin to shake and tremble, breathe faster and with heavy breaths, and even puff out air or wag their tongue. The medium's complexion also changes, with his or her face turning red or yellow, depending on the disposition of the deity. ${ }^{28}$ The disposition of the deity is important, since a medium can channel a wrathful or peaceful deity. A medium possessed by a wrathful deity will grow red-faced and become very violent in his or her movements; a passive deity will cause the medium to act more subdued. It is generally held that mediums of wrathful deities do not live very long because of the intense strain and pain they endure during trances. ${ }^{29}$ The medium will also start to exhibit the specific attributes of the particular deity possessing them. Nebesky-Wojkowitz provides a vivid account of this feature:

\begin{abstract}
Many mediums, mostly at the beginning of the trance, show also a behaviour characteristic of the deity who took possession of their body. Thus a medium of $r$ Do rje shugs ldan [Dorjé Shugden] produces the gurgling sound of a man in the agony of suffocation - said to be the voice of the abbot bSod nams grags pa [Sönam Drakpa] who killed himself by stuffing a ceremonial scarf into his throat-; the oracle-priest of $s K a r$ ma shar [Karmasha], who sometimes becomes possessed by Bya khri mig gcig po [Jatri Mikchikpo], "the one-eyed with the bird-throne", will keep only one eye open for the duration of his trance; the spirit of Slob dpon [Lopön], the crippled adversary of the
\end{abstract}

\footnotetext{
${ }^{26}$ See Nebesky-Wojkowitz 1998, p.409; and Diemberger 2005, p.130. By contrast, there are instances were enlightened beings are believed to possess and deliver prophesies through the medium of sacred objects. At Tradruk Temple (Tib. Khra 'brug), southeast of Lhasa, there is a statue of Padmasambhava that supposedly has the ability to speak; see Dowman 1988, p.178. For a complete monograph of Traduk, see Sørensen, Hazod, and Tsering Gyalbo 2005. There is a speaking image of Tara (Tib. Gsung sgrol ma) at Langtang Drolma Temple (Tib. Glang thang sgrol ma lha khang) in Kham, west of Derge (Tib. Sde dge); see Dorje 2004, pp.510-511. There is also a talking painting of Penden Lhamo in the Potala Palace; see Pommaret 2003, p.98.

${ }^{27}$ See Havnevik 2002, pp.276-277; and Nebesky-Wojkowitz 1998, p.421. See in particular Nebesky-Wojkowitz 1998, pp.433-437, for a detailed account of a single trance that involved four deities.

${ }^{28}$ This process has been well documented. See Nebesky-Wojkowitz 1998, pp.418-419, 429-431; Havnevik 2002, pp.271-272; Day 1989, pp.435-476; Day 1990, pp.213-218; Berglie 1976, pp.99-103; Schenk 1993; and Diemberger 2005, pp.136-138.

${ }^{29}$ See Nebesky-Wojkowitz 1998, pp.418, 435; and Havnevik 2002, p.272.
} 
former state magician [Nechung Oracle] rGyal mtshan mthar phyin [Gyentsen Tarchin], makes his medium limp; the Drung yig chen mo [Drungyik Chenmo], as soon as he had entered the body of an oracle-priest, will remind all those present of the events which led eventually to his incorporation among the dharmapālas by saying the sentence "I killed the ninety-nine horses of my master but left one for my lady-love"; the spirit of the las dpon [foreman], who once served the bDe legs rabs ldan [Delek Rapden] family of Shigatse, always complains about the heavy grain-tax which had been collected at his time, etc. ${ }^{30}$

Hanna Havnevik likewise describes a scenario in which the female oracle Lobsang Tsedrön channeled a male warrior spirit and accordingly dressed, walked, and drank beer like a man; she never drank beer in any other circumstance. Patrons claim that, once out of the trance, nobody could smell beer on her breath. ${ }^{31}$

Supernatural qualities are a significant attribute of the trance state and help authenticate the sacred activity that surrounds the oracle tradition. These abilities include shows of super strength, such as being able to bear the heavy crown associated with the position of the oraclesaid to be so heavy that two or three men are needed to hoist it onto the oracle's head - and twisting swords into knots. This twisted sword, called the 'knotted thunderbolt, ${ }^{32}$ is considered a prized possession among Tibetans, and those honored enough to obtain one hang it above doorways to ward off demonic influences. Another supernatural ability gained under trance includes an oracle thrusting a sword into his or her chest and removing it to show no sign of injury; oracles vomiting coins has also been recorded. ${ }^{33}$ Such miraculous exhibitions accompany the oracle's primary skills of clairvoyance and prophecy that are the impetus for their trances. ${ }^{34}$

The goal of oracle trances is to provide a service to the community on multiple levels. This service involves eliciting the supernatural knowledge of the deity as expressed through the oracle to provide prophetic advice concerning the future of the community. With village oracles the concern is more local, while state oracles like Nechung offer advice on a greater political scale. An oracle can be consulted by individual patrons regarding personal crises, such as family problems or wealth and love issues, or for communal concerns, such as unsolved crimes and

\footnotetext{
${ }^{30}$ Nebesky-Wojkowitz 1998, p.418.

${ }^{31}$ See Havnevik 2002, p.271.

${ }^{32}$ Tib. rdo rje mdud pa.

${ }^{33}$ See Rock 1935, p.477; and Nebesky-Wojkowitz 1998, pp.440-441.

${ }^{34}$ For a detailed discussion of the Buddhist understanding of clairvoyance, see Nair 2010, p.26n27.
} 
legal matters. ${ }^{35}$ Furthermore, oracles—-specifically on the local level-act as healers, using their powers of divination to assess an individual's illness and respond with appropriate advice as to its remedy. Nebesky-Wojkowitz explains an action called 'releasing the obstructing spirit, 36 where an oracle will beat a sick individual with his or her sword in order to drive away the harmful forces causing the illness. ${ }^{37}$

Diemberger states that the success of an oracle is in his or her ability to mediate at times of personal and public crisis; an oracle's reputation is dependent on his or her efficacy. ${ }^{38}$ Indeed, oracles have been known to tarnish their reputation by offering bad or incorrect advice. On a political level, this can be especially hazardous. Nebesky-Wojkowitz explains an incident where the Nechung Oracle in 1904 predicted a Tibetan victory against the British Expeditionary Force. This did not occur, so the oracle fled with the Dalai Lama to Mongolia when the British reached Lhasa. Upon their return, the Nechung Oracle was dismissed from his office. ${ }^{39}$ The punishment incurred on oracles for their inadequacy or insubordination has been known to come from the possessing deity as well. Such wrath is usually retaliation for the medium's disobedience to the deity. In one instance, recounted by Joseph Rock, an oracle was requested by his possessing deity not to marry, yet did so anyway. In response, the deity, during a fit of trance, caused the medium to disembowel himself and hang his entrails on the statues in his private chapel. ${ }^{40}$

Mediums can appear among the monastic or lay community. The Nechung mediums have mostly been monks, ${ }^{41}$ while the Gadong medium has always been a layman, and the lineage is hereditary. ${ }^{42}$ In most cases an individual is chosen by a deity for his or her own mysterious reasons, though Tibetans speculate that there is a moral element to this choice. Some claim that an oracle must live a blameless and virtuous life in order to be a vessel pure enough for a deity to inhabit temporarily. ${ }^{43}$ This is not universally held, however, since it is also claimed that oracles tend to be of low moral quality. This may be specific only to local oracles where a distinction is drawn between the aristocratic and lower class laity, the latter being from whence oracles

\footnotetext{
${ }^{35}$ See Diemberger 2005, pp.115-116, 139; and Havnevik 2002, p.271.

${ }^{36}$ Tib. bgegs dkrol.

${ }^{37}$ See Nebesky-Wojkowitz 1998, p.441.

${ }^{38}$ See Diemberger 2005, pp.138-140.

${ }^{39}$ See Nebesky-Wojkowitz 1998, p.451.

${ }^{40}$ See Rock 1935, p.478. Nebesky-Wojkowitz (1998, p.421) also cites this example.

${ }^{41}$ According to the Gadong Medium of the 1990s, the Nechung mediumship started out as lay, but this lineage broke early and became monastic instead; see Kelley 1993, p.20.

42 See Kelley 1993, p.29. Havnevik 2002 explicitly examines another hereditary oracle lineage.

${ }^{43}$ See Rock 1935, p.478; and Nebesky-Wojkowitz 1998, p.418.
} 
generally come. ${ }^{44}$ Diemberger argues that oracles have a comfortable relationship with defilement, having experienced it in their own lives and routinely dealt with it in healing practices. This familiarity gives oracles a degree of insight afforded by their ambiguous social status. Such ambiguity allows oracles to resolve personal and public crises that generally develop from liminal moments of life such as birth, marriage, sickness, and death, all of which are fraught with impurities. ${ }^{45}$ Nonetheless, oracles are expected to maintain a degree of bodily purity by abstaining from tobacco and alcohol, and by following any prohibitions requested by the possessing deity. ${ }^{46}$ Regarding medium recognition on a political level, there are some instances in which a potential medium is chosen from a series of candidates, with various tests administered to aid the selection process. Nebesky-Wojkowitz details this process and explains that a successful candidate is installed in his position during a ceremony called tendrel, ${ }^{47}$ which involves gift-giving and the conferring of titles on the newly-appointed medium. ${ }^{48}$

Nebesky-Wojkowitz attended a number of trance sessions firsthand and his account of oracle possession - though nearly sixty years old - continues to be the most descriptive and organized. ${ }^{49}$ The ceremony involves considerable preparation. The special attire worn by the medium during a trance is laid out on a throne or seat in the specific order in which the medium dresses before the trance. The clothes in this ensemble are indicative of the possessing deity and also include various weapons associated with him or her. ${ }^{50}$ Another important item that oracles-particularly state oracles-wear is a small shield with a mantric seed syllable ${ }^{51}$ inscribed on it, which hangs around the neck and rests upon the medium's chest. Seed syllables are single syllables of great power and many deities of all ontological statuses are associated with a particular seed syllable. As for the oracular shield, it is called a mirror ${ }^{52}$ because it is reflective and convex at the center and sometimes has a gold or silver rim.

Once the preparations are complete, the monks attending the trance session begin a series of invocatory chants inviting the deity to come and possess the medium. This invocation can

\footnotetext{
${ }^{44}$ See Havnevik 2002, p.277; and Day 1990, p.208.

${ }^{45}$ See Diemberger 2005, pp.141-150.

${ }^{46}$ See Havnevik 2002, p.280n.115.

47 Tib. rten 'brel; lit. "interdependent connection."

${ }^{48}$ See Nebesky-Wojkowitz 1998, pp.419-421.

${ }^{49}$ For a more recent anthropological account of the Nechung Oracle's trance state, observed in Dharamsala, see Sidky 2011.

${ }^{50}$ See Nebesky-Wojkowitz 1998, pp.410-414.

${ }^{51}$ Tib. sa bon.

52 Tib. me long.
} 
include musical accompaniment from thigh-bone trumpets and drums. Havnevik provides an example in which the oracle herself chants the invocations and thus prompts the deity to descend of her own accord without the aid of monks. ${ }^{53}$ This stage of the ceremony also includes detailed iconographic descriptions of the deity and his or her abode. As the chanting continues, the deity is said to descend gradually upon the oracle, forcing him or her to fall deeper into a trance state. This transition is punctuated by huffing breath and violent movements that become steadily exaggerated. For the Nechung Oracle, the face assumes a dark red color and his assistants place the heavy helmet upon his head, fastening it with belts under his chin. Assistants are available during the entire ceremony to help dress the oracle, hold him up, and catch him when he collapses at the end of the trance. ${ }^{54}$ Havnevik explains that for the female state oracle Lobsang Tsedrön, her own husband was her assistant during trances. ${ }^{55}$ When the assistants step back and the oracle bears the helmet alone, the deity is believed to have fully descended (Figure 26).

Several explanations exist for where exactly the deity comes from to possess the oracle. For Nebesky-Wojkowitz, the answer most commonly provided is that the deity originates from the seed syllable at the center of the mirror that the oracle wears. ${ }^{56}$ By contrast, Havnevik explains that deities enter the oracle through the fingers or toes by way of their subtle channels, according to yogic tradition. ${ }^{57}$ At this point in the trance, praise is sung to the oracle, the deity embodied, and he or she is ready to attend to the needs of those present. Tea and sometimes tormas are offered to the oracle now. If the ceremony takes place within the actual throne room of the deity, such as with the Nechung Oracle, then the oracle takes his seat on his own throne. However, even if the ceremony takes place within the home of a client, the deity is treated like an honored guest. Even retired oracles continue to be revered by monks and patrons. ${ }^{58}$

Once praise has been offered, the oracle is asked various questions by the surrounding monks or present members of the community. The answers to these questions are in most instances quite cryptic and must be translated by the assistants, thus showing a further act of mediation. The trance session is an engaged process. The esoteric and mumbled advice of the oracle is clarified by the interpreting assistants and then enacted by the individual or members of

\footnotetext{
${ }^{53}$ See Havnevik 2002, p.274.

${ }_{55}^{54}$ See Nebesky-Wojkowitz 1998, pp.409-410, 429.

${ }_{55}^{55}$ See Havnevik 2002, ibid.

${ }^{56}$ See Nebesky-Wojkowitz 1998, p.411.

${ }^{57}$ See Havnevik 2002, p.280. She also cites Berglie and Diemberger, who state that the top of the head is another entry point.

${ }^{58}$ See Havnevik 2002, p. 274.
} 
the community. ${ }^{59}$ In effect, the oracle is only one element - though an important one - in a complex system of communal decision-making. The oracle's answers are also sometimes provided in verse. In some instances, the answer is framed by moments of wild frenzied dances performed by the oracle, as well as the various shows of superhuman ability previously discussed.

After all questions have been answered, the oracle may provide an extra service of offering blessings either by blowing on seeds or inscribing prayers on tied ribbons, both of which are then offered to members of the audience. The service ends abruptly when the oracle collapses. The deity departs, the human faculties of the medium return, and sometimes he or she passes out; the medium has no recollection of the proceedings of the session. ${ }^{60}$ Several trance sessions may occur during one ceremony, with each trance signifying the descent of another god into the medium. Usually the first to enter is the central god with whom the oracle is most associated. This god is called the 'lord of the channels, ${ }^{61}$ and is the one who allows other deities to enter the medium. ${ }^{62}$ At the conclusion of the ceremony, prayers of thanksgiving are usually recited. The medium then strips off the oracular attire and replaces it in proper order on the throne with the help of his or her assistants. The normal garments of the medium, which are worn beneath this attire, are often drenched in sweat after a ceremony. ${ }^{63}$

This summary of an oracle trance ceremony is by necessity both generic and synchronic. Multiple variations of the ceremony exist at various points in Tibetan history and differ by locale. Much of this variation is unknown to us given the absence of firsthand detailed reports in the historical record. One important note should be made on the diachronic nature of the majority of the sources cited here. Nebesky-Wojkowitz, writing in the early 1950s, provides a detailed examination of the oracle tradition as it existed in the midst of Chinese occupation but before the Cultural Revolution. His focus is also strongly directed toward important male state oracles. This observation is the same for Joseph Rock and Prince Peter of Greece and Denmark, both of whom conducted preliminary research on the oracle tradition as it existed before or just after Chinese occupation. Hanna Havnevik and Hildegard Diemberger, however, conducted their research well after the Cultural Revolution, a time when the practices of many oracle lineages

\footnotetext{
${ }^{59}$ See Diemberger 2005, p. 137.

${ }^{60}$ For a video of an oracle trance undertaken by the current medium of the Nechung Oracle, Tupten Ngödrup (Tib. Thub bstan dngos grub), see Delicateear 2012.

${ }^{61}$ Tib. rtsa bdag.

${ }^{62}$ See Diemberger 2005, p.130.

${ }^{63}$ For the full accounts of oracle trances from which this summary draws, see Nebesky-Wojkowitz 1998, pp.429439; Havnevik 2002, pp.270-272; and Diemberger 2005, pp.136-138.
} 
were forcefully cut off. This also resulted in the destruction of many oracle costumes and ritual implements. In these studies the majority of oracles do not change into ceremonial garments and their only ritual implement consists of a mirror that they use for divination purposes, though it is difficult to assess whether this is a change or if it also relates to the social setting and scale. Havnevik and Diemberger, as well as Sophie Day, provide useful studies on the state of the oracle tradition as it exists in recent times, and all three of their works show an increase in members of the tradition, mainly in villages and on the local level. Since the Nechung Oracle escaped to India with the Fourteenth Dalai Lama in 1959, state-recognized oracles no longer exist in Tibet; even the one female state oracle, Lobsang Tsedrön, is now retired. ${ }^{64}$

Ultimately, the purpose of the various rituals at Nechung Monastery, and most especially the trance sessions of the Nechung Oracle, is to bring the Nechung deities into the presence of the monks, the community, and the Dalai Lama's government. The ritual recitations, statue consecrations, thread-cross mansions, and ritual dances all summon the Five Sovereign Spirits. Once offerings are made to them as part of the ritual program, they are asked to aid the monastery, the government, and Tibet at large. The Nechung Oracle represents the most explicit example of this relationship. One or more of the monastery's deities descend into the Nechung medium, respond to questions, and provide prophetic advice to those present. Like the other rituals discussed above, oracular possession is a means of maintaining an active relationship with the deities of institutions like Nechung. ${ }^{65}$

It is important to note that these different ritual activities are not mutually exclusive but are often found together on many occasions - they are mutually reinforcing. Oracle sessions are accompanied by ritual recitations and often include torma offerings; likewise for statue consecrations, thread-cross mansion constructions, and ritual dances. The timing and configuration of these ritual programs are established over the course of the Tibetan year and make up Nechung Monastery's unique ritual calendar, to which we now turn.

\footnotetext{
${ }^{64}$ For a lengthy discussion of oracles within a larger South Asian context, see Smith 2006.

${ }^{65}$ For an excellent recent exploration of Tibetan rituals that offers diverse methodological approaches, see Cabezón 2010.
} 


\section{The Many Rites of Nechung}

Nechung Monastery is at the center of an intricate network of rituals. This network includes broad city-wide ritual activities, such as the Great Prayer Festival ${ }^{66}$ and the Gungtang Flower Offering, ${ }^{67}$ as well as rites specific to Nechung. These two levels are intertwined, which can be observed in the following presentation of the monastery's ritual calendar. This calendar was composed by Lingön Padma Kelzang in the mid-1980s and represents what Nechung's yearly ritual cycle looked like prior to the 1950 s. $^{68}$ Such periodic activities are what give Nechung its character since these practices and their timing are particular to the monastery. These numerous rites also point to Nechung's ecumenical constitution, given its practice of the Geluk tutelary deity Thirteen-Deity Bhairava, the Sakya form of Vajrayoginī, and, of course, its constant engagement with Nyingma treasure texts like the Ten-Chapter Sädhana. These rituals likewise evince the numerous multivalent relationships Nechung has with other deity cults. Finally, the following list illustrates how Nechung's ritual practices have gradually accrued over time since the seventeenth century:

\section{$\underline{\text { First Month }}$}

Every year, on the morning of the first day of the first month, [the Nechung monks] must perform the ritual for Thirteen-Deity Bhairava, ${ }^{69}$ and then perform the communal amending and restoring rites for the Dharma protectors five times. ${ }^{70}$ Afterwards, when the general assembly ${ }^{71}$ [gathers] at dawn for the morning tsok offering, ${ }^{72}$ they perform the amending and restoring rites for the [Nechung] Dharma protector. Then the general assembly performs the amending and restoring rite of the Ten-Chapter Sädhana, Ngadak Nyang[rel]'s treasure text. On top of this, they perform the Incense Offering to Worldly Deities. ${ }^{73}$ At noon,

\footnotetext{
${ }^{66}$ Tib. Smon lam chen mo.

${ }^{67}$ Tib. Gung thang me tog mohod pa.

68 The following is a translation of the text found in Tibetan Academy of Social Sciences 2009, pp.460-467.

${ }^{69} \mathrm{Tib}$, 'Jigs byed lha bcu gsum. This ritual involves propitiating the tutelary deity [Vajra]bhairava surrounding by his twelve attendants, making thirteen deities total.

${ }^{70}$ The amending and restoring rites refer to the rituals collected in the Nechung Liturgy, discussed below.

${ }^{71}$ Tib. rgyun tshogs.

${ }^{72}$ Tib. tshogs. This refers to an offering of many colored tormas.

${ }^{73}$ Tib. Rgyags brngan lha bsangs. This Northern Treasures text is found in the Lho brag mkhar chu bdud 'joms gling gi 'don cha'i skor (See Lhodrak Kharchu Monastery 1999, pp.675-778.) and is attributed to Gökyi
} 
part of the general assembly separates the chapters from the Dharma protector's amending and restoring rite entitled the [Adamantine] Melody, ${ }^{74}$ and prepares to perform it. [These] rituals are chanted the entire day on the first day. Thus, when the ritual chanting is performed the manner of doing it is [usually] slow.

On the second day, from the morning onward, [the monks perform] the [Adamantine] Melody and the Incense Offering to Worldly Deities. Then, when the sun rises on [Gepel] Utse, ${ }^{75}$ they begin performing the invitation to the Dharma protector, [who possesses the Nechung Oracle]. All the lamas, reincarnate lamas, and abbots, as well as the [entire] monastic community, must come [to Nechung] from Drepung to have an audience with the Dharma protector [Nechung Oracle]. According to oral tradition, they come in accordance with a vow made in Jamyang Chöjé Tashi Penden's ${ }^{76}$ time. It is tradition that the Drepung monastic community comes [to Nechung], as mentioned above, on the second day of each month.

On the third day, there is an assembly session for a tsok offering, as well as ritual chanting similar to the second day. Traditionally, most of the monastic and lay officials from the government come to [make] an elaborate offering, and to invite and have an audience with the Dharma protector [Nechung Oracle]. In the evening, at dusk, there is another offering.

From the fourth day [onward], the eight best monks [from Nechung] chapel, ${ }^{77}$ as well as most of the monastic community, must go to the [Great] Prayer Festival [in] Lhasa and stay at the [holy] residence of Meru Nyingpa. Amid the extensive gathering of the Great Prayer Festival, Nyang[rel]'s root treasure text, within the textual lineage of the [Adamantine] Melody, must be recited on the basis of the secret sädhana of the tutelary deity Hayagrīva.

Demtruchen (Rgod kyi ldem 'phru can, 1337-1409; TBRC: P5254); for the citation of a modern edition published in Xining, see Tenzin Samphel 2008, p.271. My English translation of this work's title is aided by the description in the Bod rgya tshig mdzod chen mo; see Zhang 1985, p.540. A portion of this text also appears in the Nechung Liturgy, see Appendix I, text 24.

74 Tib. Sgra dbyangs ma.

75 Tib. Dge 'phel dbu rtse. This is the mountain on which the monasteries of Drepung and Nechung sit; see Havnevik 2002, p.264.

${ }^{76}$ Tib. 'Jam dbyangs chos rje Bkra shis dpal ldan, 1379-1449; TBRC: P35. This important Geluk figure founded Drepung Monastery.

77 Tib. $l \log$. 
Supplications must also be offered, such as giving prayers and offerings to the Black and Red Protectors. ${ }^{78}$ Along with [enjoying] tea and noodle soup, such [things] as this are commonly done in similar fashion among the monastic community of the Great Prayer Festival that gathers at the [Jokhang] Temple.

During the [Great] Prayer Festival, on the tenth day of the first month, the officials traditionally perform an elaborate offering at Meru Nyingpa [in the style of] the nobility.

On the fifteenth day, [the full moon day,] the Dharma protector [of Nechung] traditionally descends into the body [of the medium] and the [chief] abbot of Ganden Monastery has an audience with him in the Sungchörawa. ${ }^{79}$ Afterwards, they come to the dry assembly ${ }^{80}$ in the [Jokhang] courtyard with the monks. At that time, the local monks ${ }^{81}$ must go as a 'golden procession ${ }^{82}$ [in] a series of four middle-sized groups.

The twenty-fourth day is, as above, the time to go offer tormas [to] the [Nechung] Dharma protector.

On the morning of the twenty-fifth day, during the [Ceremonial] Invitation of Maitreya, ${ }^{83}$ the Dharma protector [Nechung Oracle] must follow along with [his attendant] group. ${ }^{84}$ Then, in the evening, the monks return to [Nechung] Monastery.

From the twenty-sixth day [onward, the monks celebrate] the New Year holiday at [Nechung] Monastery for seven days; the general assembly gathers two times each day. The monastic college [then] makes an [offering] of elegant teas and foods.

\footnotetext{
${ }^{78}$ Tib. srung ma dmar nag. This refers to the two deities assigned as protectors of the Dalai Lama's lineage and government. Penden Lhamo Makzor Gyelmo is the black one and Dorjé Drakden is the red one, though the later identification has been historically ambivalent and subject to controversy; see Heller 1992a.

${ }^{79}$ Tib. gsung chos ra ba; lit. "enclosure for religious discourse." According to Robert Barnett, this refers to "the open area on the southwest side of the Jokhang temple that traditionally was used for public talks by lamas;" see Barnett 2006, p.199. Hugh Richardson (1993, p.132) confirms this.

${ }^{80}$ Tib. skam tshogs; this is a literal translation and refers to a prayer assembly of monks where food and tea are not served, hence the name. According to Richardson (1993, p.26), these dry assemblies do have tea but not food and are usually in the afternoon, while wet assemblies are in the morning.

${ }^{81}$ Tib. gnas grwa.

${ }^{82}$ Tib. serw sbreng; this is a procession of monks, the color referring to their religious garments.

${ }^{83}$ Tib. Byams pa gdan 'dren. This refers to a silver image of Maitreya, housed in the Jokhang Temple, that would be placed on a cart and drawn in clockwise circumambulation around the Jokhang; see Richardson 1993, p.52.

${ }^{84}$ Tib. ru sbreng; read as a misspelling of $r u$ 'bring.
} 
In volume $G a$ of the Duküla, ${ }^{85}$ the Fifth Dalai Lama writes, "Although there was no New Year's custom at Nechung until recently, when the New Year's offering was established [at Nechung], the Regent (Sangyé Gyatso) said, 'the extraordinary ${ }^{86}$ enemy-defeating god of Ganden Palace ${ }^{87}$ has an excellent disposition!' Accordingly, during the offerings of the New Year holiday (for the Iron-Monkey year [1680]), while there were older practices - such as the New Year's offerings of various district governors, chief lamas, regional leaders, [citizens of] districts and estates, and [members of] religious centers-the [Nechung] oracle went into trance ${ }^{88}$ and [everyone] made offerings one after another."

\section{$\underline{\text { Second Month }}$}

On the first day of the second month, preparations must be made for creating the sacred medicine of [immortal] nectar. ${ }^{89}$

From the second to the fifteenth day, the sädhana for the sacred medicine of [immortal] nectar is performed in the tradition of the treasure-revealer Sögyel. ${ }^{90}$ This is [from] the time of the Thirteenth Dalai Lama (1876-1933). Traditionally, the expenditures for the sacred medicine sādhana were provided by the government office that conducted long-life prayer services [for the Dalai Lama], ${ }^{91}$ and a monk official [from the government] came [to] manage the medicine offering. Regarding the sacred medicine sädhana, in a year that Nechung [Monastery] offers a wet performance, ${ }^{92}$ Namgyel College ${ }^{93}$ must offer

\footnotetext{
${ }^{85}$ This refers to the third volume of the Fifth Dalai Lama's autobiography. The quoted passage can be found in Tā la'i bla ma 05 1991-1995, vol.7, p.367.4-5.

${ }_{86}^{86}$ Tib. gzhan dang $m a$ 'dra; lit. "unlike any other." See Goldstein 2001, p.940 for comparison.

${ }^{87}$ Tib. Dga' ldan pho brang; this refers to the site of the Tibetan government at Drepung Monastery established by the Fifth Dalai Lama.

${ }^{88}$ Tib. sku phebs; lit. "[the deity] descended into the body."

${ }^{89}$ Tib. bdud rtsi sman sgrub; this also refers to the sädhana practice performed in the process of making these medicine pellets.

${ }^{90}$ Tib. Gter ston Bsod rgyal (1856-1926). This figure, also known as the treasure-revealer Lerap Lingpa (Gter ston Las rab gling pa), is a disciple of the famous late nineteenth-century polymath Mipam Gyatso (Mi pham rgya mtsho, 1846-1912; TBRC: P252); see Dudjom Rinpoche 1991, vol.1, p.879. The treasure-revealer Sögyel was also "responsible for uncovering the 1899 [sorcery] plot against the Thirteenth Dalai Lama" (see ibid, vol. 2, p.84n.1196).

${ }^{91}$ Tib. Zhabs brtan las khungs.

92 Tib. rlon sgrub; this likely refers to the inclusion of tea and food during the ritual ceremony.

${ }^{93}$ Tib. Rnam rgyal grwa tshang.
} 
a dry performance. ${ }^{94}$ In the next year, Nechung must offer a dry performance and Namgyel a wet performance; it alternates annually in this manner. Consequently, when there is a dry performance, the sacred medicine itself will be produced; when there is a wet performance, the sacred medicines that were produced the previous year must be prepared and offered again.

During the prayer [festival] for the [Great] Assembly Offering, ${ }^{95}$ in addition to the three monastic centers [of] Sera, Drepung, and Ganden [being present] equally, [the monks of Nechung Monastery] must accordingly participate as a group in the Golden Procession of the Assembly Offering. ${ }^{96}$

\section{Third Month}

On the second and third days of the third month, the offering for amending the life-force ${ }^{97}$ is established. Regarding the ritual of amending the life-force, it is said that it was newly established by the [Nechung] medium Ngawang Gyatso. ${ }^{98}$

From the fourth day [onward], once the chanting ritual for amending the life-force is established, the amending and restoring rites to the Dharma protector are performed from among the usual amending and restoring rites [the Nechung Liturgy]. Even though [the rites] concerning the planetary and imperial spirits are usually condensed, during the life-force amending [ritual], the visualized supports, ${ }^{99}$ invitation, request to remain, ${ }^{100}$ restrictions, ${ }^{101}$ amending rite, confession, praise, entrustment, and enthronement ${ }^{102}$ must be done for the planetary and imperial spirits.

\footnotetext{
${ }^{94}$ Tib. skam sgrub; see note 80 .

${ }^{95}$ Tib. tshogs mchod [chen mo]. This is a holiday that commemorates the death of the Fifth Dalai Lama, and likely subsequent Dalai Lamas; it begins on the nineteenth day of the second lunar month and continues until the end of the month; see Richardson 1993, pp.60-61.

${ }^{96}$ Tib. tshogs mchod serw sbreng; this is a significant ceremony, performed on the 30th or new moon day of the second month, where a procession of monks carries offerings from the Jokhang to the Potala; see Zhang 1985, p.2291. This ceremony is said by Richardson to have been instituted by Regent Sangyé Gyatso, having been inspired by a vision beheld by the Fifth Dalai Lama; see Richardson 1993, pp.74-81.

${ }^{97}$ Tib. srog bskang gi mchod.

${ }^{98}$ Tib. sku rten Ngag dbang rgya mtsho. According to Tupten Püntsok, this figure was installed as the Nechung Oracle in 1747; see Thub bstan phun tshogs 2007, p.138.

${ }^{99}$ Tib. rten skyed.

${ }^{100}$ Tib. bzhugs gsol.

${ }^{101}$ Tib. dam sgrags.

102 Tib. mnga' gsol.
} 
On the fifteenth day, during the incense offerings and prayers to the image of the deity, ${ }^{103}$ each monk from the college offers fourteen square toffees ${ }^{104}$ and pastries.

On the sixteenth day, the general assembly routinely [gathers].

On the twenty-fifth day, when the Dharma protector is invited to [receive] gifts, the Nechung Oracle wears such things as Heruka's attire ${ }^{105}$ and bone ornaments. On this day, there are no prophecies and the like.

On the twenty-ninth day, [there is a] torma-throwing rite for restoring the life-force, and then a tapestry that has a variety of protector deities [on it] is spread out in front of the courtyard. ${ }^{106}$ Because the height of the tapestry is taller than the height of the monastery's portico, a little bit of the tapestry cloth must be rolled up at the bottom. [The tapestry's] width fits approximately between the two stone lions. ${ }^{107}$ A monk of the place named Honorable ${ }^{108}$ Jampa Tapkhé $^{109}$ is said to have made [this tapestry] and offered [it to the monastery].

On the thirtieth day, [there is] a thanksgiving service and a restoring and amending rite for the Dharma protector.

\section{Fourth Month}

On the first day of the fourth month, [the monks perform] a supplement to the ritual for amending the life-force [as well as] the Secret Assembly of the Masters [cycle]. ${ }^{110}$ They also offer a thanksgiving service for the Subjugator of the Three Realms [form of] the tutelary deity Hayagrīva. ${ }^{11}$

\footnotetext{
103 Tib. skam gsol.

104 Tib. bu ram sgar ma; my translation is based on Goldstein 2001, p.722.

${ }^{105}$ Tib. he ru ka'i chas; for a description of this attire, see Zhang 1985, p.3069.

106 Tib. rdo gcal.

107 These are the two stone lions at the entrance to Nechung Monastery's assembly hall; see Figure 41.

108 Tib. sku zhabs.

109 Tib. Byams pa thabs mkhas.

${ }^{110}$ Tib. Bla ma gsang 'dus; this is an important cycle of treasure texts rediscovered by the treasure-revealer Guru Chöwang (Gu ru Chos kyi dbang phyug, 1212-1270; TBRC: P326).

${ }^{111}$ Tib. Yi dam Rta mgrin Khams gsum zil gnon. Samten Karmay (1988, p.74) explains that the "[Fifth] Dalai Lama received the teachings of this ritual cycle in 1659 from Lokeśvara in a vision. Hayagriva was his tutelary deity from the age of ten and the form of Khams-gsum zil-gnon is believed to be particularly effective in dealing with the damsri spirits;" italics in the original.
} 
From the second to the fourth day, there is a burnt offering ritual for amending the life-force.

From the fifth day to the sixth or seventh day, the thread-cross support ${ }^{112}$ of the Dharma protector must be threaded and offered, and the thread-cross ritual ${ }^{113}$ within the amending and restoring rites must be performed.

From the fourth day of the third month to the seventh day of the fourth month, the extensive communal offerings for amending the life-force must be made [between] dawn and dusk.

On the eighth day of the fourth month, the [long-]life ritual ${ }^{114}$ for the Five Sovereign Spirits must be performed.

On the ninth day, four [monks from] the general assembly come together and gather twice.

On the tenth day, in accordance with the time of the monastic college's new year summer offering, ${ }^{115}$ [the monks] assemble and invite the Dharma protector [Nechung Oracle]. At this time, no others traditionally come except for the monks of the place and the government treasurer. ${ }^{116}$ On that day, even the usual general assembly must gather.

On the eleventh and twelfth days, all day long, [the monks perform] the Incense Offering to Worldly Deities [ritual] and have a general assembly.

On the thirteenth day, [the monks] must prepare to go to the Flower Offering [Festival] at Gungtang Monastery. ${ }^{117}$

On the fourteenth day, twenty-two local monks must go to Gungtang Monastery along with the medium of the Dharma protector. They conduct offerings and assemblies within Tsel Yangön College. ${ }^{118}$

On the fifteenth day, during the procession of the Drip Dzongtsen ${ }^{119}$ and Pen[den] Lhamo [statues] within Gungtang's enclosure, the [Nechung] Oracle-

\footnotetext{
112 Tib. brten mdos.

${ }^{113}$ Tib. mdos chog.

${ }^{114}$ Tib. tshe chog.

${ }^{115}$ Tib. dbyar gsol.

${ }^{116}$ Tib. bla phyag; an abbreviation of bla brang phyag mdzod.

${ }^{117}$ Tib. Gung thang me tog mchod pa; see Richardson 1993, pp.87-89.

${ }^{118}$ Tib. Tshal Yang dgon.

${ }^{119}$ Tib. Grib gdong btsan; this is a variant spelling of Grib rdzong btsan.
} 
while in a trance - traditionally performs an elaborate offering ceremony in the company [of these two deities].

On the sixteenth day, those who went to Gungtang Monastery return to [Nechung] Monastery.

From the seventeenth to the nineteenth, the usual general assembly gathers four times.

[Starting] from the twentieth day and lasting nine days, [the monks perform] the secret ritual text entitled the Secret Speech, ${ }^{120}$ and the torma makers ${ }^{121}$ go on a picnic. Here there is no specific expenditure from the college, so each [monk] pools [his own resources] and offers them.

\section{$\underline{\text { Fifth Month }}$}

From the second day of the fifth month throughout the full extent of the month, [the monks] perform the summer offering. Even during this the usual general assembly must gather. On top of this, on the third day of each month, the high abbot official ${ }^{122}$ - a representative from the Tibetan government ${ }^{123}$ - comes to make an offering to the image of the Dharma protector. And on each day, each office must come and do this [offering]; for example, the Council of Ministers ${ }^{124}$ comes on the fourth day. Besides this, from time to time during the summer offering about two or three bureaus together must come in particular; even a few aristocrats $^{125}$ come.

On the fifteenth day of the fifth month, [monks] traditionally come from Namgyel College to make an offering to the image [of the Dharma protector].

\footnotetext{
${ }^{120}$ Tib. Gsung gsang $b a$; it is uncertain to which text this is referring. Perhaps it is the Gsung gsang ba bsam gyis mi khyab pa la bsngags pa padma dkar po'i chun 'phyang composed by Orgyan Jikmé Chökyi Wangpo (O rgyan 'Jigs med chos kyi dbang po, 1808-1887; TBRC: P270); see Dpal sprul rin po che 1970.

${ }^{121}$ Tib. mchod gshom pa; this is a variant of mchod bzhengs $p a$.

${ }^{122}$ Tib. spyi khyab mkhan po.

${ }^{123}$ Tib. sa gnas srid gzhung; lit. "local government." This term is used in modern China to refer to the pre-modern Tibetan government; see Goldstein 2001, p.1117.

${ }^{124}$ Tib. bka'shag.

${ }^{125}$ Tib. sger khag; lit. "private sector."
} 
At day-break on the tenth day of the monkey month ${ }^{126}$ of the monkey year, every kind [of oracle from] all over central Tibet becomes possessed by the three [spirits]_-gods, plague spirits, and imperial spirits ${ }^{127}$ — [and] gathers at Nechung Monastery. On top of this, [they] must perform the 'Comparison of the Gods' 128 in front of the chief of the haughty spirits [Pehar], a secondary emanation of the Wisdom Drongmin, ${ }^{129}$ the Exalted Mighty Lotus [Hayagrīva]. Then those allowed to be possessed record [their] gods in a book, ${ }^{130}$ and every year [they] must pay a ' $\operatorname{god} \operatorname{tax}^{, 131}$ to the [Tibetan] courts. ${ }^{132}$

\section{$\underline{\text { Sixth Month }}$}

From the fourth day of the sixth month to the eighth day, [the monks] must perform the consecration to Thirteen-Deity Bhairava along with the burnt offering. [During] the length of this, eighteen monks must participate, led by the chant leader responsible for the ritual chanting. Also, eighteen shrine keepers must participate, led by the shrine master responsible for the [shrine] offerings. Then a sand mandala with four pillars must be created.

At the end of the sixth month, [the monks] perform the Incense Offering to Worldly Deities ritual for the various surrounding estates, such as Mara, ${ }^{133}$ Bokma, ${ }^{134}$ Kadruk, ${ }^{135}$ Gyamo Jangma, ${ }^{136}$ and Gönpasar. ${ }^{137}$ Furthermore, [the monks] traditionally lead the servants from the monastic college and go [to

\footnotetext{
${ }^{126}$ According to the Bod rgya tshig mdzod chen mo, this is the seventh lunar month; see Zhang 1985, p.1690. However, according to its placement in this catalogue of monthly rituals, it is the fifth month. The office manager of Nechung Monastery in Dharamsala likewise states that it is the fifth month. See also Nechung Monastery 2004.

127 Tib. lha gnyan btsan gsum.

${ }^{128}$ Tib. lha bsdur. Richardson (1993, p.92-93) places this ceremony on the eighth day of the month; this is confirmed by Tupten Puntsok; see Thub bstan phun tshogs 2007, p.175.

129 Tib. ye shes 'drong min; the latter two words are difficult to translate in this context and may be a misspelling. In considering Pehar's ontological status last chapter, it is interesting to note that here he is referred to as an emanation of Hayagrīva.

${ }^{130}$ Tib. Iha deb tu bkod; an alternative translation could be, "are recorded in the book of gods," though it is unclear just what book this would be.

${ }^{131}$ Tib. Iha khral. John Avedon (1984, pp.201-202) explains that the god tax was collected annually by the district governors of Tibet and given to Nechung Monastery.

132 Tib. bsher khang las khungs.

133 Tib. Ma ra.

134 Tib. 'Bogs ma. See Thub bstan phun tshogs 2007, p.30 for a similar list of these estates. In this latter source, this location is spelled 'Brog mo.

135 Tib. Ka drug.

136 Tib. Rgya mo byang ma.

${ }^{137}$ Tib. Dgon pa gsar.
} 
Nechung] together with those who serve the Dharma protector-the Nechung head teacher, ${ }^{138}$ the chant master, ${ }^{139}$ the shrine master, ${ }^{140}$ the caretaker of the Eastern Shrine Room, ${ }^{141}$ the secretary, ${ }^{142}$ and the personal attendants. ${ }^{143}$

On the twenty-seventh day, those who went to perform the Incense Offering to Worldly Deities, as discussed above, return [to the monastic college].

On the twenty-eighth day, [monks] traditionally come to Nechung every year from the four monastic [colleges at Gungtang]-Tsel Yangön, Önlönpa, Zimkhang Sharpa, and Chudré ${ }^{144}$ - to perform ritual dances. Furthermore, the retinue of the Dharma protector [Nechung Oracle] — such as the glorious simulacra, ${ }^{145}$ fully-ordained monks, ${ }^{146}$ black hat [dancers], ${ }^{147}$ demonesses, ${ }^{148}$ spiritual teachers, ${ }^{149}$ sword-dancing warriors, ${ }^{150}$ and skeleton dancers ${ }^{151}$-must

${ }^{138}$ Tib. slob dpon.

${ }^{139}$ Tib. dbu mdzad.

${ }^{140}$ Tib. mchod dpon.

${ }^{141}$ Tib. mchod khang shar gyi dkon gnyer.

142 Tib. drung yig.

${ }^{143}$ Tib. sku mdun pa.

${ }^{144}$ Tib. tshal yang dgon dang / dbon blon pa/ gzim khang shar pa/ chu 'bras bcas dgon pa bzhi; Per Sørensen and Guntram Hazod discuss the "'Four grva tshang of Gung-thang Bla-ma Zhang': gZims-khang shar-ba/ma...Chos-khri grva-tshang...Chos-'khor-gling...and Yang-dgon grva-tshang;"' see Sørensen, Hazod, and Tsering Gyalbo 2007, vol.1, p.228n.616. The first and last college names have clear parallels and strongly imply that these are the same four colleges mentioned in this text. Unfortunately, the other names do not match well. It is possible that chu 'bras is a radical misspelling of "Chos-khri [grva-tshang]," since their central Tibetan pronunciations are homophonous. However, dbon blon pa has no conceivable connection to "Chos-'khor-gling," and so it may be an alternative name for the college, one that I have not yet encountered elsewhere. For another variant list, see Bshes gnyen tshul khrims 2008 , p.30.

${ }^{145}$ Tib.dpe 'dra; this is apparently a misspelling of dpal 'dra. Nebesky-Wojkowitz (1976, p.29) translates this term as 'those similar to the noble one.' By his account, these are dancers dressed like the Nechung Oracle, or whoever the central deity is; see ibid, p.53, for these dancers dressed as the Karmasha (Tib. Kar ma shag) Oracle. Richardson (1993, p.102) speculates that this term is short for Pe har 'dra, given the context. He provides no evidence for this, however, so I am inclined to trust Nebesky-Wojkowitz's spelling. Richardson (ibid) provides a photograph of the Karmasha Oracle, which includes two distinctly masked dancers that may be these very figures.

${ }^{146}$ Tib. dge slong. Nebesky-Wojkowitz $(1976$, p.18) defines these as dancers "in lama dress with flat golden hats as worn by higher-ranking members of the lamaistic clergy."

${ }^{147}$ Tib. zhwa nag; see Nebesky-Wojkowitz 1976, p.18. As their namesake suggests, these figures wear widebrimmed black hats; see Figure 25a. See also Nebesky-Wojkowitz 1976, pp.80, 94-98.

${ }^{148}$ Tib. bdud mo; Nebesky-Wojkowitz $(1976$, p.18) states that these dancers possess "long black hair and [are] dressed in black gowns."

${ }^{149}$ Tib. a tsa ra; Skt. ācārya. Nebesky-Wojkowitz (1976, p.82) states that these dancers "represent Hindus. Accordingly their masks are dark brown or black, with prominent noses, often bearded and with long hair or with a hair-knot on top, as customarily worn by Indian mendicants. ...It seems [they] are figures designed to holds the [sic] ridicule the priesthood of Hinduism..." See also Kohn 2001, p.226.

${ }^{150}$ Tib. skyes pa gri gar. Skyes pa literary means 'man,' but I agree with Nebesky-Wojkowitz's (1976 p.80) translation of 'warrior' considering their "dress usually consists of coats of mail, helmets, often decorated with flags, high boots, etc." For more information on their involvement in sword dances, see ibid, pp.22-23, and Kohn 2001, pp.228-230. 
present a ritual dance. At this time, the oldest chanting monks, ${ }^{152}$ along with ordinary monks and drummers, ${ }^{153}$ must go there from Nechung Monastery as representatives of the chant master.

On the twenty-ninth day, the various incumbents ${ }^{154}$ - such as the Nechung medium, the Nechung estate officer, the secretary, and the chant master-must go to Drepung Monastery. Then, they must go to the Tantric College ${ }^{155}$ to pray to the image [of the] Dharma protector and throw a tantric torma [for him]. ${ }^{156}$ After that, while they rest at Deyang College, the local monks from the college traditionally greet those who came [from Nechung] with tea and rice. In the evening, after they return to Nechung, the Tashi Zhölpa ${ }^{157}$ and Nyemo ${ }^{158}$ opera dancers traditionally perform the first section of the [Ache] Lhamo opera ${ }^{159}$ at Nechung Monastery. ${ }^{160}$

On the thirtieth day, the Jungpa ${ }^{161}$ opera dancers perform an opera all day [for the Yogurt Festival], and the Nechung medium, monastic officials, and all the local monks go to watch.

\section{$\underline{\text { Seventh Month }}$}

On the first day of the seventh month, similar to that mentioned above, the Nyemo dancers present an [Ache] Lhamo opera performance all day long.

Starting from the second day, the amending and restoring rite entitled Nyakdra ${ }^{162}$ is performed for seven days. The expenditure is issued from the

\footnotetext{
${ }^{151}$ Tib. thod skam; lit. "dry skull." The significance of this term is difficult to decipher, though the context heavily suggests that it is a type of ritual dancer. Neither Nebesky-Wojkowitz nor Kohn mention this term; however, Nebesky-Wojkowitz (1976, pp.29, 36, 53, 57) mentions a type of skeleton dancer called thod go dkar ril. I speculate that thod skam is a misspelling of an abbreviation of this term, which would be thod dkar.

${ }^{152}$ Tib. gsung gsang pa; given the context, this is clearly a variant spelling of gsung bzang ba, literally "person with a good voice," which here likely refers to those chanting monks that are led by the chant master.

${ }^{153}$ Tib. rnga pa $b a$; the $b a$ seems to be an unintentional addition.

${ }^{154}$ Tib. las 'khri; this is read as a variant spelling of las khri; see Goldstein 2001, p.1070.

${ }^{155}$ Tib. Sngags pa grwa tshang.

${ }^{156}$ Tib. sku gsol zhus nas sngags pa'i gtor rgyab la chos skyong; the word order seems a little out of sorts at the end, but otherwise the meaning is clear.

${ }^{157}$ Tib. Bkra zhis zhol pa; this is a specific opera troupe. See Attisani and Ludbrook 1999, p.5. For a fuller study of Tibetan opera, see Lobsang Dorje 1984. See also Richardson 1993, p.98.

${ }^{158}$ Tib. Snye mo; this refers to a district in central Tibet that lies west of Lhasa.

${ }^{159} \mathrm{Tib}$. [a che] lha mo. This is a famous folk opera founded in the fifteenth century by Tangtong Gyelpo (Tib. Thang stong rgyal po, 1361-1485; TBRC: P2778).

${ }^{160}$ This coincides with the beginning of the Yogurt Festival (Tib. Zho ston) in Lhasa; see Richardson 1993, p.99.

${ }^{161}$ Tib. gcung $p a$.
} 
monastic college and must be collected [again] for the amending and restoring rites. There's an oral tradition that [says] this was established after the Nyakrong battles. ${ }^{163}$ At this time, sometimes a hundred thousand tsok and ten thousand tsok are offered through the policy of the college steward, and sometimes even the government bestows an offering tsok on the seventh day.

On the seventh day, the Dharma protector's implements are carried into the Lubum [Room] ${ }^{164}$ inside Drepung Monastery's great assembly hall. The local monks must come and carry four hand-held battalion banners; people from $\operatorname{Dambak}^{165}$ [also] come and then return [home]. At this time, the local monks give them an overture with four long trumpets and clarinets on top of the great assembly [hall]. Then those on the Drepung governing committee of lamas ${ }^{166}$ must offer provisions to those who stay the day.

On the eighth day, the high [government officials] that [usually] go to Drepung, in addition to the local monks, go to Drepung. Then [monks] from the Petup $^{167}$ regional house offer tea and rice to ${ }^{168}$ such [figures] as the [Nechung] medium, and offer tea and noodle soup to the [Nechung] monastic community. The Dharma protector is invited [to possess the Nechung medium] within the assembly, and both the abbatial governing committee and the monastic disciplinarian have an audience with the Dharma protector [Nechung Oracle]. Then the [Nechung] medium, and so forth, go to Deyang College's main hall and the Dharma protector is invited [again]. After consecrating the image in the main hall, they return to Nechung. ${ }^{169}$

\footnotetext{
162 Tib. Nyag sga; if read as a misspelling of nyag sgra, it is possible this refers to the army that pillaged many areas of Kham in the nineteenth century; see the following note.

${ }^{163}$ Tib. nyag rong sde gzar. This likely refers to the troubles that accrued in Nyakrong, and surrounding regions of Kham, in the 1860s; see Shakabpa 2010, vol. 2, pp.606-608.

164 Tib. klu bum; this is a misspelling of klu 'bum. For a discussion of this room and its contents, see note 169 below. For a fuller description of this reliquary, see Tibetan Academy of Social Sciences 2009, p.57.

165 Spelled Dan bag.

166 Tib. bla ma rig gra ba; I am reading this as a misspelling of bla ma rigs grwa ba.

${ }^{167}$ Tib. Dpe thub; this is a variant spelling for Spe thub. According to Jim Valby's Tibetan dictionary, this is a village in western Tibet. This regional house belongs to Loseling College (Tib. Blo gsal gling grwa tshang) in Drepung Monastery; see Tibetan Academy of Social Sciences 2009, p.293.

168 Tib. lad; given the context, this is clearly a simple misspelling of la.

169 This holiday is explained within the greater context of Drepung Monastery earlier in this work. Tibetan Academy of Social Sciences 2009, p.43: "The eighth day of the seventh month is the Drepung Lubum Holy Day (Tib. 'Bras spungs klu 'bum dus chen). On the western side of the great assembly hall there is the Lubum Room. Inside this there are two white reliquaries made of clay, and [devotees] are permitted to see them. Except for this
} 
From the ninth day [on], the general assembly routinely [gathers].

On the twentieth day, [the monks perform] the chanting ritual for the Medicine Buddha. ${ }^{170}$

From the twenty-first to the twenty-eighth, [the monks perform] the [Vajra]yoginī chanting ritual of the Sakya tradition. ${ }^{171}$

From the fifteenth day of the six month [onward], the entire monastic community gathers [from their] summer retreat and performs the vow-purifying ceremony. ${ }^{172}$ On the sixth day [of the sixth month], [the monks] accept the summer retreat. The fourteenth day of the seventh month is the ceremony for releasing the summer retreat rules, ${ }^{173}$ so the monks have a picnic ${ }^{174}$ for the festival that ends the summer retreat. ${ }^{175}$ On that day, such [things] as the main provisions are given by all the monastic colleges and, in addition to this, ${ }^{176}$ the expenditures are further provided by others.

\footnotetext{
day, people are not allowed to visit this shrine room to make offerings. Although the main [items] to see are the two Lubum reliquaries, there are also in this shrine room three two-storey tall silver reliquaries; these are the three reliquaries of the Third Dalai Lama Sönam Gyatso [Bsod nams rgya mtsho, 1543-1588; TBRC: P999], the Fourth Dalai Lama Yöntan Gyatso [Yon tan rgya mtsho, 1589-1616; TBRC: P177], and one of the Fifth Dalai Lama's regents, Trinlé Gyatso ['Phrin las rgya mtsho, d. 1667; TBRC: P3649]. On this day, all the temple halls throughout Drepung Monastery - such as [those in] the great assembly, the monastic colleges, regional houses, and local dormitories - open their doors and [devotees] can visit them to make offerings. Early in the morning the Nechung medium, with his entourage arrayed [on] good horses, go to Drepung from Nechung. At this time, those who blow the long trumpets and clarinets of Deyang College from atop the great assembly hall's balcony play for them. This is traditionally done now and is called 'Auntie's Clarinet Words' (Tib. rgya gling gi tshig zhang dga' ma)."

The last term carries interesting connotations. Rgya gling gi tshig means 'words of the clarinet;' however, zhang $d g a$ ' ma requires further discussion. Zhang here means "maternal uncle," while $d g a$ ' ma means "wife," the phrase as a whole meaning "maternal uncle's wife;" hence "aunt" - or the affectionate "auntie," as I chose. I speculate that this stems from the filial terminology often used in Tibetan to refer to institutional ties. In this case, Drepung Monastery as a whole would be the "maternal uncle" to Nechung Monastery, while Deyang College - with which these instrumentalist monks are associated - would be the "wife" of the monastery, or more accurately one of its "wives," since Drepung has a number of colleges. The understanding then is that this is a clarinet overture presented by Deyang College that speaks to their institutional relationship to Nechung.

${ }^{170}$ Tib. Sman bla; Skt. Bhaișjyaguru.

${ }^{171}$ Tib. sa skya'i lugs kyi rnal 'byor ma'i gsung chog.

${ }^{172}$ Tib. gso sbyong; Skt. poșadha.

${ }^{173}$ Tib. dgag dbye.

${ }^{174}$ Tib. gling gtong; this is an abbreviation for gling ga gtong.

175 Tib. chab zhugs; according to Richardson (1993, p.109), this is a bathing festival. This would explain the etymology of the Tibetan term, which means "to enter water."

${ }^{176}$ Tib. de' $i$ khar; this is a variant of de khar.
} 


\section{Eighth Month}

On the first day of the eighth month, [the monks] prepare to go to the festival that ends the summer retreat.

From the second day to the thirtieth, all the monks go have a picnic for the end of the summer retreat festival at Tshakur Park. ${ }^{177}$ During this, such [things] as the main provisions are offered from all the monastic colleges and, in addition to this, there are also those few others who further provide the expenditures. ${ }^{178}$

On the eighth day, an elaborate banquet conferred by the Thirteenth Dalai Lama is traditionally offered to all the local monks during the day. On this day, the entire assembly [of monks] must perform an incense offering to the gods.

Amidst the five days near the conclusion of the festival for the end of the summer retreat, with regards to the administrators, two monks rotate taking a turn every two years acting [as] the caretakers of the Eastern Shrine Room. ${ }^{179}$ Every day during the five days of the festival that ends the summer retreat, these two [monks] must give to all the [other] monks expenditures of tea six times, noodle soup [and] porridge ${ }^{180}$ two times, and tsampa soup ${ }^{181}$ two times.

The income for the above-mentioned administrators - the two caretakers of the Eastern Shrine Room - is drawn [from] the shares of the local monks' tea and noodle soup [given] during the [Great] Prayer Festival, the daily eight copper ornaments, and the usual beverages and gifts [for] the anniversary of both the Birch Tree Chapel ${ }^{182}$ and the Desire Realm Chapel. ${ }^{183}$ Nevertheless, it is [still]

\footnotetext{
${ }^{177}$ Tib. Tsha khur gling kha; I am uncertain as to where this is located.

${ }^{178}$ Except for some differences in word choice, this line is clearly reiterating what was said a few lines above at the end of the seventh month.

179 Tib. mchod khang shar ma; for details on the contents of this room, see Tibetan Academy of Social Sciences 2009, pp.450-451. For the room's physical location, see Figure 42, number 9.

${ }^{180}$ Tib. tha zhis; this is a difficult word to translate. Given the context it is clearly some kind of food. Tupten Püntsok spells this word tha zhib and connects it with noodle soup (Tib. bzhes thug); see Thub bstan phun tshogs 2007, p.221.

${ }^{181}$ Tib. 'jam thug.

182 Tib. Gro sdong lha khang; a variant of this is Sgro sdong lha khang. This is the northwestern chapel that houses the famous tree of Nechung. For further details on this important chapel, see chapter 3, p.181; see also Tibetan Academy of Social Sciences 2009, pp.448-449.

${ }^{183} \mathrm{Tib}$. 'Dod khams lha khang; this is the northeastern chapel dedicated to Dhūmāvatī. For further details on this chapel, see chapter 3, p.184, and ibid, pp.449-450.
} 
difficult to successfully balance revenue and expenses. ${ }^{184}$ Because of this, as an indemnity, after acting as the caretakers of the Eastern Shrine Room for two years, [these monks] act as the caretakers of the Western Shrine Room ${ }^{185}$ for three years. And so, at this time they do not need to give expenditures and their income is produced [from] the offering tormas and offering grains of the individual rituals for making offerings. This is merely supplementary [income].

From the twenty-first day to the twenty-third, the annual field output ${ }^{186}$ of the different estates and the different livestock leasers ${ }^{187}$ of the monastic college are individually calculated at Tshakur Park.

On the thirtieth day, the [statue of] Maitreya is invited to Tshakur Park. Together with this, there is a spectacle of performances, such as effigies of yaks, tigers, and lions — called Asing Takseng ${ }^{188}$ — and foot races; dancing boys are [also] present. ${ }^{189}$ On this day, the festival for the end of the summer retreat is adjourned.

\section{Ninth Month}

From the second day of the ninth month to the third, there is a dry assembly called the 'manifest $t$ sok.' 190

On the fifth day, monks who have made a tantric vow must prepare the [ritual] expenditures. [These] are placed within the fourth dönchen ${ }^{191}$ in accordance with the above tradition [of] making tantric vows.

On the twenty-ninth day, the majority of the monks must go to wash the wooden planks where the offerings made of various continuous tormas ${ }^{192}$ are arranged.

\footnotetext{
${ }^{184}$ Tib. gtong yong gab thub; I am reading this as a typographical error resulting in the shortening of the phrase gtong yong kha 'thab thub.

${ }^{185}$ Tib. mchod khang nub ma; for further details on this shrine room, see ibid, p.450. For the room's physical location, see Figure 42, number 8.

${ }^{186}$ Tib. thon skor.

${ }^{187}$ Tib. she ma khag; Goldstein (2001, p.1101) defines this term as "a person who leases other people's livestock."

${ }^{188}$ Tib. a sing stag seng; this is a variant of a zing stag seng. Stag and seng mean "tiger" and "lion," respectively. A zing is difficult to translate, though given the context it likely means "yak."

${ }^{189}$ Tib. zhal ngo; in this context, this term is difficult to translate. I am reading it here to mean "presence."

${ }^{190}$ Tib. bzhengs tshogs.

${ }^{191}$ Tib. don chen; given this context, this appears to refer to a vessel of some sort, but I am uncertain as to what kind.

${ }^{192}$ Tib. 'dzugs gtor. These are the tormas that are kept inside the shrine rooms throughout the year as constant offerings to the gods.
} 
From the thirtieth day [onward], five people from among the eighteen chief torma makers must annually go and create [new] year-long tormas for the shrine rooms within the top and bottom floors of Nechung Monastery, continuous tormas for the [Nechung] medium Tā Lama, vow ${ }^{193}$ tormas for the supreme reincarnate lama of Nechung [Nechung Tülku], ${ }^{194}$ and continuous tormas for Meru Nyingpa. On the fifteenth day of the eleventh month, the creation of all [the tormas] must be completed. Creating [these] continuous tormas comes to about eight hundred measures ${ }^{195}$ of butter. ${ }^{196}$

\section{Tenth Month}

From the thirtieth day of the previously mentioned [ninth month] until the eighteenth day of the tenth month, [the monks] perform the sädhana ritual for Avalokiteśvara who Liberates All Beings ${ }^{197}$ in the central assembly.

On the nineteenth day [of the tenth month], [the monks] lay out a mandala of colored sand in order to establish the mandala and make offerings.

From the twenty-first to the twenty-fourth, the chanting monks ${ }^{198}$ and chant master must practice the liturgical music. ${ }^{199}$

On the twenty-fifth day-the '[Twenty-]Fifth [Day] Offerings' ${ }^{200}$ - [the monks] must play the music for the ritual chant in the central assembly.

From the twenty-sixth to the twenty-seventh, [the monks perform] the empowerment ritual for Bhairava and [produce] his cloth-painted mandala.

\footnotetext{
${ }^{193}$ Tib. thugs dam; Skt. samaya.

${ }^{194}$ Tib. Gnas chung mchog sprul; this is the reincarnate lama, usually called Nechung Rinpoche (Tib. Gnas chung rin po che), who has been associated with Nechung Monastery since the latter half of the nineteenth century.

${ }^{195} \mathrm{Tib}$. khal; this is a standard Tibetan unit of measure equal to around 25-30 pounds.

${ }^{196}$ Tib. mar lha khal. The lha makes this fragment difficult to translate; given the context, I have decided to read this as a gross spelling error and believe the intention was mar gyi khal.

${ }^{197}$ Tib. Thugs rje chen po 'gro ba kun grol; this form of Avalokiteśvara relates to a cycle of texts belonging to the Northern Treasures tradition. According to Rangjung Yeshe, this is a specific treasure text revealed by the fourteenth-century treasure-revealer Gökyi Demtruchen; see note 73.

${ }^{198}$ Tib. gsung gsang; see note 152.

${ }^{199}$ Tupten Püntsok provides the added detail that there are eighteen such monks involved in this rehearsal; see Thub bstan phun tshogs 2007, p.224.

${ }^{200}$ Tib. lnga mchod. My translation is drawn from Richardson 1993, p.114. This day commemorates the death of Tsongkhapa. For more details on this holy day as it pertains to Nechung Monastery, see Thub bstan phun tshogs 2007, pp.225-226.
} 
On the twenty-eighth day, [the monks perform] a Tārā ritual ${ }^{201}$ and the general assembly routinely [gathers].

\section{Eleventh Month}

On the fifth day of the eleventh month, in addition to the general assembly, [the monks] must read out loud an official notice given by the Thirteenth Dalai Lama, as well as an official notice given by Regent Sangyé Gyatso.

From the sixth day to the seventh, the Conjunction of Nine Evils ${ }^{202}$ is observed in each [monk's] dwelling.

From the eighth to the fifteenth, [there are] eighty-eight different melodies for the amending and restoring rites, [and] two, three, or four melodies each are performed for every session; it must be completed on the fifteenth day. Every day during this [time], there is a general assembly for four sessions each.

On the ninth day of the eleventh month, eight monks are specially selected and must build the thread-crosses of the sovereign spirits, imperial spirits, and maternal spirits [for] the solstice general ritual.

On the twenty-second day, [the monks] must perform the rituals for the Vajrakilaya Razor of Innermost Essence ${ }^{203}$ cycle in the central assembly.

From the twenty-third day [onward], during the time when the Gyelpo Jeché ritual (also called Jeché Ketu ${ }^{204}$ ) is performed, the government provides an estate and the monastic college provides the [ritual] expenditures. For the length of seven days, [the monks] in the central assembly perform the ritual of crushing, burning, and discarding [evil influences].

On the twenty-ninth day, [the monks] must perform a torma-throwing [ceremony].

\footnotetext{
${ }^{201}$ Tib. sgrol chog.

${ }^{202}$ Tib. ngan pa dgu 'dzoms; see Richardson 1993, p.115, for an explanation of this day. In contrast to the days given here, Richardson ascribes this event to the fourth and fifth days of the month.

${ }^{203}$ Tib. Phur pa yang snying spu gri; this is a cycle of treasure texts retrieved by the treasure-revealer Sögyel (see note 90) in 1895, and subsequently adopted by the Thirteenth Dalai Lama in 1898 at the behest of the Nechung Oracle; see Rigpa Shedra 2012.

${ }^{204}$ Tib. Byes chas ke tur [sic: tu]; this rare form of Pehar is discussed in chapter 1.
} 
From the thirtieth day onward, the monks of intermediate training take turns going to visit [their] parents, departing regimentally_first, second, third, and so forth.

\section{$\underline{\text { Twelfth Month }}$}

On the ninth day of the twelfth month, the monastic college treasurer provides the expenditures, and eight monks perform the Four Hundred [Offerings ritual $]^{205}$ of the Mindröling Southern Treasures tradition. ${ }^{206}$

From the tenth day to the twelfth, for three days, a group of eight monks performs rites for invoking prosperity ${ }^{207}$ by means of the King of Supreme Jewels prosperity rite, ${ }^{208}$ the Dākini and the Wealth God [rite], ${ }^{209}$ and the Five Sovereign Spirits $[\text { rite }]^{210}$ of the Mindröling Southern Treasures tradition.

On the nineteenth day, the entire Four Hundred [Offerings ritual] of the monastic college [is performed]. ${ }^{211}$

For the length of three days, starting on the twentieth, a group of eight monks [performs] the [prosperity] rituals mentioned above, as well as the Appeasing the Turbulence of the Maternal Spirits [ritual] ${ }^{212}$ during one day in

\footnotetext{
${ }^{205}$ Tib. brgya bzhi; for a detailed discussion of this ritual in a Sherpa context, see Ortner 1999, pp.91-127.

${ }^{206}$ Tib. lho gter smin grol gling lugs; this refers to the Southern Treasures tradition of treasure texts instituted by Terdak Lingpa (Gter bdag gling pa, 1646-1719; TBRC: P7) at Mindröling Monastery, which was established in 1676 under the auspices of the Fifth Dalai Lama; see Berzin 2003.

${ }^{207}$ Tib. g.yang 'gug.

${ }^{208}$ Tib. G.yang 'gug nor bu phyogs brgyad. According to Tupten Püntsok this type of ritual is called g.yang sgrub rather than g.yang 'gug, which are synonymous in meaning as rituals that 'attract' or 'acquire' prosperity; see Thub bstan phun tshogs 2007, p.233. If read as the variant G.yang sgrub nor bu phyogs brgyad, then this is most likely a misspelling of G.yang chog nor bu mchog rgyal, since two similarly titled texts are found on TBRC: [1] a Kagyüpa text entitled G.yang sgrub nor bu mchog rgyal (TBRC: W00EGS1016770), and [2] a Northern Treasures text entitled Phywa 'phrin nor bu mchog rgyal (TBRC: W27295). Since the text mentioned here is from the Southern Treasures tradition, neither of these texts are likely the one mentioned here, though the latter may be a close parallel. I am translating this text according to the latter work titles.

${ }^{209}$ Tib. Mkha' 'gro nor lha.

${ }^{210}$ Tib. rgyal po sku lnga; this likely refers to a cycle of rites pertaining to these deities traditionally used at Mindröling Monastery.

${ }^{211}$ According to Tupten Püntsok, more rites take place on this day; see Thub bstan phun tshogs 2007, p.234. Specifically, the Dharma protector is invited (the oracle goes into trance) at Yangön Monastery and at Gungtang Monastery's Mantra College, which is Üling Monastery; see Sørensen, Hazod, and Tsering Gyalbo 2007, vol.1, pp.233-250.

${ }^{212}$ Tib. Ma mo'i 'khrugs bskong; according to Rangjung Yeshe, a similarly-titled ritual was composed by the Thirteenth Karmapa Düdül Dorjé (Karma pa 13 Bdud 'dul rdo rje, 1733/1734-1797/1798; TBRC: P828). However, there is also a Geluk text entitled Ma mo'i 'khrugs bskong bya tshul nyes brgya'i tsha gdung sel ba'i chu shel dbang
} 
order to attract prosperity [to] the monastic college. The torma makers [make] the necessary New Year's offerings ${ }^{213}$ and the eight-colored butter for the sheep's head. [Also,] the community of monks [gathers] four times for the routine general assembly.

On the twenty-eighth day, [monks] coming [from] the four monastic colleges of Gungtang ${ }^{214}$ perform a ritual dance like the one during the Yogurt Festival.

On the twenty-ninth day, the [Nechung] Dharma protector's long prayer flags are tied up in the Western Shrine Room. ${ }^{215}$ Then about sixty people are drawn from among those who dwell in Zhöl [Village], ${ }^{216}$ those who are government workers [from] Dambak, those from the monastic college, and also those from under the monastic manager [to act as] carriers for the long prayer flags. After that, [monks] from the four previously mentioned monastic colleges [at Gungtang] and the bearers of the long prayer flags must go to the Drepung Tantric College and perform ritual dances. On this day, the torma-throwing [ceremony] of [Drepung] Tantric College is performed. The Dharma protector must also come enter the body [of the Nechung medium] ${ }^{217}$ in order to throw the torma. Then, after auspicious tea and rice is served at Deyang College, everyone returns [home]. On this day, the local monks perform the longevity dhâran $\bar{l}^{218}$ as well as the three [exorcism rites of] Sìtâtapatra, the Heart Sutra, and the Dākinī Simhamukha, ${ }^{219}$ in their central assembly. Moreover, [the monks] must also go perform [these] 'stability of life' rites ${ }^{220}$ on both sides [of the monastery].

po, composed by Panyül Pökar Tülku Ngawang Tsultrim Namgyel ('Phan yul spos dkar sprul sku Ngag dbang tshul khrims rnam rgyal, 19th century; TBRC: P3172); see Toyo Bunko 2002.

${ }^{213}$ Tib. rtse sgro. This is a more detailed object; according to Goldstein (2001, p.862), this is a "wooden slab with butter decorations that are put on an offering plate (at the New Year celebration)."

${ }^{214}$ Tib. mtshal dgon khag bzhi. Tupten Püntsok has tshal dgon khag bzhi; see Thub bstan phun tshogs 2007, p.234. Bshes gnyen tshul khrims 2008, p.30, has [tshal] gung thang dgon par dgon khag bzhi. When we compare these phrase variants, and given the close relationship previously illustrated between Nechung and Gungtang, it is likely that the latter monastery's four colleges (see note 144) are meant here.

${ }^{215}$ Tib. chos khang nub ma; this is clearly a misspelling of mchod khang nub ma.

${ }^{216}$ Tib. zhol pa. This village was located at the foot of the Potala Palace in pre-modern Tibet.

${ }^{217}$ Tib. sku gsol gyis. Tupten Püntsok has sku gsol zhus; see Thub bstan phun tshogs 2007, p.234. This is a variant expression for entreating the deity to enter the body of the medium.

${ }^{218}$ Tib. tshe gzungs; I am uncertain as to which dhärañ $\bar{t}$ this is, though it likely pertains to the Buddha Amitayus. It may be the 'Phags pa tshe dang ye shes dpag tu med pa'i snying po zhes bya ba'i gzungs.

${ }^{219}$ Tib. gdugs sher seng gsum. According to Zhang (1985, p.1346), this is an abbreviation for three exorcism rites used to turn back evil influences. Each of the three syllables indicates one of the three rites. The first pertains to 
Furthermore, as stated above, every year in the tenth month, nine monks must go and take turns [performing rituals] for twenty-one days in order to attract prosperity [to] the Dalai Lama's treasury. ${ }^{221}$ Regarding the prosperity rituals [performed] at this time, [the monks] perform prosperity rites by means of the King of Supreme Jewels prosperity rite, the Dākini and the Wealth God [rites], the Five Sovereign Spirits [rite], and the Íśvara Mahādeva [rite]. ${ }^{222}$ These are performed in accordance with the root scriptures of the rituals along with their supplemental burnt offerings. In addition to this, after the master talks about the system of prosperity rites originating from treasure texts, he also provides a small prosperity banquet. In the tenth month, nine monks [perform] the previously discussed prosperity rites in the government treasury office [for] thirty-one days. However, there is no [rite] concerning Mahādeva.

In the eleventh month, over [the course of] four days, five local monks perform prosperity rites ${ }^{223}$ — by means of such [rituals] as the King of Supreme Jewels and the Five Sovereign Spirits—-for Drepung's overseer of tea. ${ }^{224}$ [Then] five local monks perform the prosperity rites of the Kangyur Labrang ${ }^{225}$ over [the course of] seven days at Lhasa Peling. ${ }^{226}$ [Then] five local monks [perform] the prosperity rites of the Petup regional house of Drepung [over the course of] three days, [and] five local monks similarly [perform] the prosperity rites at Lhalung Hermitage $^{227}$ [over the course of] three days. [Also], a group of four [monks] must take turns every six months [as] supplicators of the Meru Nyingpa protector

Gdugs dkar (Skt. Sittātapatra), which means 'White Parasol;' this is a Buddhist goddess and a form of Avalokiteśvara that protects against obstacles. The second is Shes rab snying po, the ever-ubiquitous Heart Sutra. The third is $m k h a$ ' 'gro ma Seng ge'i gdong pa can (Skt. dākinī Simhamukha), which means the 'Lion-faced dākinī', ${ }^{220}$ Tib. zhabs rim; According to Goldstein (2001, p.924), this is a variant of zhabs brtan. Presumably, this refers to the rites mentioned in the previous sentence.

${ }^{221}$ Tib. rtse phyag.

${ }^{222}$ Tib. Dbang phyug ma hā de ba. Nebesky-Wojkowitz (1998, p.269), describes the iconography of Lha chen nam dbang phyug Mahādeva. He may also be on ibid, p.94, where a wealth god named Dbang phyug chen po (Skt. Mahā-Ívara) is discussed. Given the concern for prosperity in these rites, the latter is more likely this deity, though it may be that these are simply the same figure. Regardless, I am not certain to which ritual text this refers.

${ }^{223}$ Tib. g.yang 'gug.

${ }^{224}$ Tib. 'bras spungs bkra shis khang gsar; lit. 'New Auspicious House of Drepung.' According to Goldstein (2001, p.35), this is an "official in Drepung appointed by the traditional Tibetan government to oversee the daily morning tea that the government provided the monks."

${ }^{225}$ Tib. bka' 'gyur bla brang; I am uncertain as to what specific institution this refers, though it likely concerns a building or room that houses a copy of the Tibetan Kangyur (Tib. Bka' 'gyur) Buddhist canon.

${ }^{226}$ Tib. lha sa pad gling; I am uncertain as to which place this refers.

${ }^{227}$ Tib. Lha lung ri khrod. 
deities. For six months, [these] four local monks must perform longevity rituals $^{228}$ — by means of the Vajrakilaya Razor of Innermost Essence cycle-in the sovereign spirit sanctum ${ }^{229}$ on top of the firewood enclosure.

Among these numerous activities, there are two holy days of great significance to Nechung Monastery. The first, which was briefly noted above, is called 'God Day' and it is celebrated on the second or third day of every month. ${ }^{230}$ God Day honors the Nechung protectors as well as the center's historic relationship with Drepung Monastery:

On the second day of every month the Drepung governing council and monastic community traditionally went to Nechung for God Day. In particular, on the second day of the first Tibetan month the entire assembly of Drepung Monastery went to Nechung Monastery. After gathering in the courtyard of Nechung Dorjé Drayangling, the monastic assembly also traditionally had an audience with the Dharma protector [Nechung Oracle]. ${ }^{231}$

Moreover, the Fifth Dalai Lama's ritual for the Nechung deities, the Adamantine Melody, was and continues to be performed on this day at Nechung Monastery. ${ }^{232}$

The other important holiday is called by various names - such 'Monkey-Year MonkeyMonth, ${ }^{233}$ 'Tenth Day of the Monkey Month, ${ }^{, 234}$ and 'Nechung Monkey Month' ${ }^{235}$ —and is practiced around the middle of the fifth Tibetan month. This holiday was briefly mentioned in the above calendar and is listed on the fifteenth day of the month. However, there appears to be some disagreement on when it actually took place. Modern Tibetan accounts place the holiday

\footnotetext{
${ }^{228}$ Tib. tshe bsgrub.

${ }^{229}$ Tib. rgyal po lcog; here I am translating lcog as 'sanctum' since the context implies a smaller structure than the main hall. Drawing on André Alexander's Temples of Lhasa, I speculate that this specifically refers to the sanctum (4) on level 2 of Meru Nyingpa that is above the storage room (22) on level 1, which may have been used to hold firewood, given its function; see Alexander 2005, p.110.

${ }^{230}$ Tib. lha tshes. In the last chapter (p.79), a quote by the Fifth Dalai Lama places this holy day on the third day, while modern accounts place it on the second day.

${ }^{231}$ Tibetan Academy of Social Sciences 2009, p.43.

${ }^{232}$ See Mig dmar tshe ring 2010, p.54.

${ }^{233}$ Tib. sprel lo sprel zla.

${ }^{234}$ Tib. sprel zla'i tshes bcu; see Tā la'i bla ma 05 1991-1995, vol.7, p.373.6.

${ }^{235}$ Tib. gnas chung sprel zla.
} 
on the fifteenth day of the fifth month, which is called 'Universal Incense Offering Day. ${ }^{236}$ Hugh Richardson discusses this latter holiday, which is still celebrated in Lhasa and at Samyé today. During 'Universal Incense Offering Day,' Tibetans would visit their preferred oracles, who would all be active on this day, and then make offerings of incense to the innumerable protector deities. Richardson states that major oracles like Nechung, Gadong, ${ }^{237}$ Karmasha, ${ }^{238}$ and Darpoling ${ }^{239}$ took part in this celebration, as did many other minor oracles. This holiday is particularly important at Samyé, where it is believed to be presided over by Pehar. ${ }^{240}$ Given that the fifteenth of the month is taken up by 'Universal Incense Offering Day,' Richardson places 'Nechung Monkey Month' on the eighth day, calling it 'the Comparison of the Gods at Nechung., ${ }^{241}$ The Fifth Dalai Lama placed the holiday on the tenth day of the month, as one of the alternative names above illustrates. Regardless of the exact monthly date, the significance of this holiday is that it was only practiced once every twelve years, in the monkey year of Tibetan calendrics. This day celebrates the birth of Padmasambhava and is notable for the large group of Tibetan oracles that traditionally gathered at Nechung Monastery. The contemporary Tibetan scholar Mikmar Tsering offers a more detailed description:

The tradition is that, [on this day] temple oracles, such as the Nechung Dharma protector, Gadong, Tenma, ${ }^{242}$ Pushar, ${ }^{243}$ Denbak Zhangkho, ${ }^{244}$ Yelné Lutsen, ${ }^{245}$ Pari Tsenkhang, ${ }^{246}$ Gyangkhar, ${ }^{247}$ and Dongkar Aril, ${ }^{248}$ come and gather at Nechung Monastery. Then the statue of master Padmasambhava that resides at

\footnotetext{
${ }^{236}$ Tib. 'Dzam gling spyi bsang. It should be noted that this holiday is celebrated annually. This day commemorates Padmasambhava taming the Tibetan gods and spirits before founding Samyé Monastery in the eighth century; it is marked by Tibetans burning juniper incense for the protector deities, especially Pehar and Tsiu Marpo.

237 Tib. Dga' gdong.

${ }^{238}$ Tib. Karma shag.

239 Tib. Dar po gling.

${ }^{240}$ See Richardson 1993, pp.94-95.

${ }^{241}$ Tib. gnas chung lha bsdur; see ibid, pp.92-95.

${ }^{242}$ Tib. Bstan ma. This refers to the leader of the Twelve Tenma Goddesses.

${ }^{243}$ Tib. Phu shar.

${ }^{244}$ Tib. Dan bag zhang kho. Tupten Püntsok has the alternative spelling, Dan bag zhang po; see Thub bstan phun tshogs 2007, p.176.

${ }^{245}$ Tib. Yal sna'i klu btsan. Tupten Püntsok has two other names, neither of which are likely variants of this name: Dpa' ri dgon shar and Ba smad btsan khang; see ibid. This suggests either different names for the same deity or it indicates other oracles involved in this event.

${ }^{246}$ Tib. Pa ri btsan khang. Tupten Püntsok has the alternative spelling, Spa ri thog btsan; see ibid.

247 Tib. Rgyang mkhar. Tupten Püntsok has the alternative spelling, Rgyang dkar; see ibid.

${ }^{248}$ Tib. Gdong dkar a ril. Tupten Püntsok has the alternative spelling, Gdong dkar ab ri; see ibid.
} 
the Rasa Trülnang temple complex ${ }^{249}$ in Lhasa is invited to Nechung Monastery. The oracles enter into trance and circumambulate Nechung Monastery, following after both the statue of master Padmasambhava and the Nechung Oracle. According to tradition, the Dalai Lama also comes to Nechung Monastery at this time. Traditionally, the ceremony on that day is principally [performed] in order to observe whether or not deities are in fact actually able to descend into the twelve or so oracles there, who [act as] mediums ${ }^{250}$ in the vicinity of Lhasa. Thus, it is like testing the authenticity ${ }^{251}$ of the gods. ${ }^{252}$

One final ceremony that merits mentioning is the 'Ransom for the Demon-King, ${ }^{253}$ traditionally celebrated on the $29^{\text {th }}$ day of the $2^{\text {nd }}$ Tibetan month. This elaborate event is believed to have been started in the time of the Fifth Dalai Lama. Though no longer celebrated, the rite involved two men carrying off ransom offerings that drew malignant spirits away from Lhasa, as well as "breath bags, ${ }^{254}$ that held the life breath or souls of spirits and enemies. These men were then driven out of the city, in part by the Nechung Oracle himself, taking these baneful items with them to ensure the Dalai Lama's safety and the country's prosperity. One of these men goes to Samyé Monastery and deposits the ransom offerings and life breaths within the 'breath house ${ }^{255}$ of the Pehar Kordzöling, which houses the souls of the dead guarded over by Pehar. ${ }^{256}$ In this way, the central Tibetan government and the Nechung Oracle continue to have a relationship with Pehar's former residence at Samyé.

A close reading of Nechung Monastery's ritual calendar reveals how fairly modern it is in terms of clear references to founding dates for specific elements. More accurately, it illustrates how much accretion is involved in an institution's ritual programs and activities over time. For instance, in the second and eleventh months rituals were performed that were drawn from

${ }^{249}$ Tib. Ra sa 'phrul snang gtsug lag khang; this is the more ancient name for the Jokhang Temple.

${ }^{250}$ Tib. lha phebs mkhan; lit. "those into whom deities descend."

${ }^{251}$ Tib. rgyugs tshad len pa; tshad here is being read as an abbreviation for tshad ma.

${ }^{252}$ Mig dmar tshe ring 2010, pp.54-55. This holiday is still celebrated in exile every twelve years today, though it is severely diminished. The Nechung Oracle, as well as the Gadong and Tenma Oracles are present for the festivities and even go into trance. However, it appears that a competition between multiple oracles no longer takes place; see Tsepak Rinzin 1992. For a fuller discussion of this holiday, see Nechung Monastery 2004. See also Thub bstan phun tshogs 2007, pp.175-178, which is a contracted but updated version of material from the latter source.

${ }^{253}$ Tib. glud 'gong rgyal po.

${ }^{254}$ Tib. dbugs rkyal.

${ }^{255}$ Tib. dbugs khang.

${ }^{256}$ The other man returns to his village, to deposit his cargo at a temple there. For a greater historical discussion of this significant ceremony and its ties to Pehar, see Karmay 1998c and Richardson 1993, pp.61-71. 
treasure texts revealed by Lerap Lingpa (1856-1926), in the time of the Thirteenth Dalai Lama. In the third month a life-force amending rite was performed, which was instituted by the Nechung medium Ngawang Gyatso after his installation in 1747. The Nyakdra amending and restoring rites performed in the seventh month were established most likely after the $1860 \mathrm{~s}$. The banquet given at the end of the summer retreat was instituted by the Thirteenth Dalai Lama. Finally, the practice of making torma offerings for the Nechung Tülku, also known as Nechung Rinpoche, could not have been established until the time of the Thirteenth Dalai Lama, since the office did not exist prior to the late nineteenth century. ${ }^{257}$ The Padmasambhava statue involved in the Nechung Monkey Month ceremony described above also stems from this later period, having been rediscovered by Lerap Lingpa. ${ }^{258}$

Many other rites and ceremonies listed above are difficult to date with certainty, so tracing them back to the late seventeenth century is not possible at this time. Nonetheless, a few of these rituals are believed to extend back to the time of the Fifth Dalai Lama. The Nechung Oracle's involvement in the New Year festivities was apparently requested by Regent Sangyé Gyatso. The regent also instituted the second month Golden Procession of the Assembly Offering, having been inspired by one of the Fifth Dalai Lama's visions. Hayagrivva, in the form of the Subjugator of the Three Realms, was established as Nechung Monastery's tutelary deity because this form of Hayagrīva was the Great Fifth's tutelary deity. Lastly, the Four Hundred [Offerings] ritual performed in the twelfth month was established by Fifth Dalai Lama, based on the Mindröling Southern Treasures tradition.

While God Day is clearly discussed by the Great Fifth, there is no direct evidence that the contest of oracles that took place during Nechung Monkey Month extended back to his time. However, it is clear from his autobiography that the holiday held great significance and even then concerned the involvement of many institutions, rituals, and oracles. ${ }^{259}$ If the Comparison of the Gods was established at Nechung during the time of the Great Fifth, it would have been the perfect opportunity to control all regional oracles around Lhasa; their authenticity was judged by state oracles like Gadong, Lamo, and Samyé, presided over by the head state oracle, Nechung. Regardless of its precise beginnings, this ritual ceremony quickly became the best solution to the conundrum posed by the Nechung Oracle, as well as other oracles, discussed at the end of the

\footnotetext{
${ }^{257}$ See Tsepak Rinzin 1992, p.30.

258 See ibid.

${ }^{259}$ See Tā la’i bla ma 05 1991-1995, vol.7, pp.16.6-20.3.
} 
last chapter. Nechung Monkey Month was a means of both promoting and legitimizing the Nechung Oracle and provided a state apparatus for monitoring potentially dangerous oracular activity in a newly created hierarchy of oracles, which was reevaluated every twelve years.

At the center of all this thick ritual activity is the liturgical collection practiced at Nechung Monastery. In Tibetan such collections are referred to as 'fulfilling and amending rites ${ }^{260}$ because they fulfill the promises to a monastery's protector deities and amend the promises these deities made to protect the sacred center. Another common name for these liturgical compilations is 'Dharma services' ${ }^{261}$ and every Tibetan monastery has one, though they vary dramatically in size and detail. These ritual texts have been and continue to be recited during torma offerings, thread-cross rites, ritual dances, and oracular invitations at the Lhasa and Dhasa Nechung Monasteries. They are the foundational documents used to invite the Five Sovereign Spirits into the presence of the Tibetan government, monastic community, and laity, and we will explore the evolution of their contents presently.

\section{Liturgical Accretion}

The collection of Nechung Monastery's fulfilling and amending rites is entitled $A$ Marvelous Garland of Jewels that Adorns the Neck of the Fortunate Youth: A Collected Series of Prayers and Mending Rituals for the Palace of Adamantine Melody, Exalted in the Three Realms (see Appendix I). ${ }^{262}$ This compilation, which I refer to as the Nechung Liturgy for convenience, was compiled in 1845 at the request of the Nechung medium of that period, Kelzang Tsültrim; ${ }^{263}$ it is approximately 90 folios long and consists of 42 texts. Most of the texts in the Nechung Liturgy are the liturgical manuals used in the ritual recitations and performances described above. However, the collection also includes deity iconographies, reincarnation lists, and prophecies by the Nechung Oracle.

\footnotetext{
260 Tib. bskang gso.

261 Tib. chos spyod.

${ }^{262}$ Tib. Sa gsum na mngon par mtho ba rdo rje sgra dbyangs gling gi zhal 'don bskang gso'i rim pa phyogs gcig tu bsgrigs pa'i ngo mtshar nor bu'i ’phreng ba skal bzang gzhon nu'i mgul rgyan. Appendix I provides bibliographic details.

${ }^{263}$ Tib. Bskal bzang tshul khrims. He served as the Nechung medium from 1837-1856; see Thub bstan phun tshogs 2007, p.138.
} 
Among these texts, the Fifth Dalai Lama composed the most-10 of them are by his hand. $^{264}$ At a close second is the Seventh Dalai Lama Kelzang Gyatso (1708-1757), ${ }^{265}$ with 9 texts to his name. ${ }^{266}$ In far third is the Nechung Oracle, with different mediums of the oracle composing 5 texts over the course of two centuries, either in or out of trance. ${ }^{267}$ A few works are an expansion of the Second Dalai Lama's writings, which has implications for the discussion in the next section of this chapter. ${ }^{268}$ The remaining works consist of one or two texts by individual authors. For instance, Regent Sangyé Gyatso and Ngari Pạ̣chen Padma Wangyel ${ }^{269}$ both contributed two works. $^{270}$ Other authors, such as the Fourth Panchen Lama Lobzang Chökyi Gyentsen, ${ }^{271}$ Terdak Lingpa, ${ }^{272}$ and Lelung Jedrung Zhepé Dorjé ${ }^{273}$ have only one text present in the collection. Nyangrel Nyima Özer also has only one text present; however, it happens to be one of the most important works in the collection and will be discussed below.

With 22 texts composed by a Dalai Lama, more than half of the collection, it appears that this monolithic figure dominates the Nechung Liturgy. However, a closer examination of this work's contents, especially the colophons of its texts, reveals an equally significant figure underlying its compilation. Many of the texts composed by the Dalai Lamas were either prophetically requested or encouraged by the Nechung Oracle. Six of the Fifth Dalai Lama's texts were requested by the oracle. ${ }^{274}$ Three of the Seventh Dalai Lama's texts were likewise requested, ${ }^{275}$ while another one of his texts was requested by Trichen Dorjé Chang after the latter was inspired by the Nechung Oracle in trance. ${ }^{276}$ Moreover, upon the death of the Seventh Dalai Lama, the regent Demo Ngawang Jampel Delek Gyatso ${ }^{277}$ was asked by the Nechung Oracle to

\footnotetext{
${ }^{264}$ See texts 1, 2, 4, 7, 8, 9, 10, 11, 27, and 39 of Appendix I. Furthermore, text 14 could be counted as another work by the Fifth Dalai Lama; its colophon explains that it was (mentally) transferred from the Fifth to the Sixth Dalai Lama through rebirth.

${ }^{265}$ Tib. Skal bzang rgya mtsho; TBRC: P179.

${ }^{266}$ See texts 12, 16, 17, 18, 19, 20, 21, 22, 23 of Appendix I.

${ }^{267}$ See texts $3,13,25,36$, and 37 of Appendix I. Texts 13, 36, and 37 were composed by the $18^{\text {th }}$ century Nechung medium Ngawang Gyatso while out of trance. Texts 3 and 25 were composed in trance, and thus by the 'deity.'

${ }^{268}$ See texts 4, 26, and 39 of Appendix I.

${ }^{269}$ Tib. Mnga' ris pan chen Padma dbang rgyal, 1487-1542; TBRC: P1699.

${ }^{270}$ See texts 15,41 , and 29, 38 of Appendix I, respectively.

${ }^{271}$ Tib. Pan chen 04 Blo bzang chos kyi rgyal mtshan, 1570-1662; TBRC: P719.

${ }^{272}$ Tib. Gter bdag gling pa 'Gyur med rdo rje, 1646-1714; TBRC: P7.

${ }^{273}$ Tib. Sle lung rje drung Bzhad pa'i rdo rje, 1697-1740; TBRC: P675.

${ }^{274}$ See texts 7, 8, 9, 10, and 11 of Appendix I. Text 4 was requested by the Fifth Dalai Lama's regent Sönam Rapten (Bsod nams rab brtan, 1595-1658; TBRC: P4436), but was further encouraged by the Nechung Oracle; see Appendix IIc, p.520.

${ }^{275}$ See texts 12, 18, and 22 of Appendix I.

${ }^{276}$ Tib. Khri chen Rdo rje 'chang; see text 19 of Appendix I.

${ }^{277}$ Tib. De mo 07 Ngag dbang 'jam dpal bde legs rgya mtsho (d.1777; TBRC: P1788); see text 40 of Appendix I.
} 
compose a ritual. Finally, the last text of the Nechung Liturgy was composed as an extensive colophon for the entire collection, which was compiled at the behest of the Nechung Oracle in 1845. The result is that 17 texts - more than any individual Dalai Lama-were either composed or requested by the Nechung Oracle. Along with the Dalai Lama, the Nechung Oracle had an equally strong hand and consistent involvement in the Nechung Liturgy.

The Nechung Liturgy illustrates an even more vivid historical accretion than the monastery's ritual calendar discussed in the previous section. The collection is dated to the midnineteenth century, but the slow addition of texts prior to this time is clearly visible. There is a noticeable ebb and flow to the corpus, with the greatest activity centering around the Fifth and Seventh Dalai Lamas. These works are then surrounded by oracular prophecies from their respective eras, as well as texts by contemporaries, with occasional intrusions by more ancient works. The text is broadly chronological in arrangement, but there are non-contemporary texts spread throughout, suggesting a thematic orientation. This is a work rooted in the hundred years between the mid-seventeenth and mid-eighteenth century, with some notable forays into the following century. However, while there are only a few hints at agency in the accretion of the ritual calendar, such as Lerap Lingpa or the Thirteenth Dalai Lama, here the Dalai Lama and the Nechung Oracle have a much stronger presence. The bodhisattva and the god molded the Nechung Liturgy, revealing their constant presence in the evolution of Nechung Monastery's fundamental ritual programs. This presence, and the relationship it embodies, is most explicit in the two primary ritual manuals of Nechung Monastery-the Ten-Chapter Sädhana and the Adamantine Melody.

\section{The Central Nechung Rituals and Their Evolution}

Of all the texts in the Nechung Liturgy, the Ten-Chapter Sädhana and the Adamantine Melody are the most important. These two texts are also the longest works in the collection by far; the vast majority of the other texts are less than three folios long, and some are only a few lines in length. These two ritual manuals are the only ones that we know with certainty were practiced at Nechung Monastery around the time of its 1682 renovation. Even today, these rites are practiced at least once a month during God Day, as well as during other important occasions, 
at both the Lhasa and Dhasa Nechung Monasteries. If the Nechung Liturgy represents the core of all ritual activity at Nechung, then these works represent the core of the liturgy.

The Ten-Chapter Sädhana and the Adamantine Melody are treated as two separate texts, but in fact they represent a ritual and mental continuum spanning five hundred years. The full title of the Ten-Chapter Sädhana is the Ten-Chapter Sädhana: A Supplication Offering to the Five Great Sovereign Spirits. ${ }^{278}$ Four extant editions of this text are available and in varying sizes, though the Nechung Liturgy edition is more than 11 folios long. ${ }^{279}$ As previously noted, this work is a treasure text that was rediscovered by the famous twelfth-century treasure-revealer Nyangrel Nyima Özer, who is believed to be a reincarnation of both Padmasambhava and King Trisong Deutsen. ${ }^{280}$ The text itself explains in its colophon that it was originally composed by Padmasambhava, ${ }^{281}$ and according to the Fifth Dalai Lama it originated from the primordial Buddha himself, Samantabhadra. ${ }^{282}$ It is the earliest known ritual document to describe the Five Sovereign Spirits.

The structure of the text is given in the title itself - it consists of ten chapters. ${ }^{283}$ Three of the work's extant editions have a lengthy prepatory or introductory segment, which will be examined below, but the heart of the text is clearly comprised of ten chapters. The outline of these chapters is not drastically different from most rituals dedicated to protector deities and is as follows: [1] requesting the deities to manifest; [2] inviting the deities; [3] requesting the deities to reside; [4] making prostrations to the deities; [5] integrating one's samaya vow with the deity's; [6] presenting offerings of the medicinal nectar of immortality to the tantric scholars and deities; [7] presenting body, speech, and mind offerings to the deities; [8] praising the deities; [9] reasserting the deities' oath and entrusting them with protective activities; and [10] compelling the deities to act on the activities entrusted to them. Appendix IIa provides a Tibetan transcription and translation of this text.

The full title of the Adamantine Melody is the Unceasing Adamantine Melody: A Sādhana for Presenting Prayers and Offerings to the Five Great Sovereign Spirits. ${ }^{284}$ At about

\footnotetext{
${ }^{278}$ Tib. Rgyal po chen po sku lnga'i gsol mchod 'phrin las don bcu ma. This is text 5 of Appendix I.

${ }^{279}$ See the preface of Appendix IIa for details on these editions. The length of this text is in part due to the divergent introductory segments.

${ }^{280}$ Tib. Mnga' bdag Nyang ral Nyi ma 'od zer, 1124-1192; TBRC: P364. See Saṅs-rGyas rGya-mTSHo 1999, p.viii.

${ }^{281}$ See Appendix IIa, p.439.

${ }^{282}$ See Tà la'i bla ma 05 1991-1995, vol.2, p.615.4.

${ }^{283}$ Tib. don bcu; lit. "ten topics."

${ }^{284}$ Tib. Rgyal po chen po sde lnga la gsol mchod 'bul tshul 'phrin las 'gags med rdo rje'i sgra dbyangs. This is text 4 of Appendix I.
} 
20 folios long, this is the longest text in the Nechung Liturgy; there are four extant editions of this text available. ${ }^{285}$ This work was composed by the Fifth Dalai Lama sometime around 1650, having been requested by his regent and encouraged by the Nechung Oracle. ${ }^{286}$ For the 1682 renovation of Nechung, the monastery was given the grander name Nechung Dorjé Drayang Ling, ${ }^{287}$ which was drawn from the title of this ritual text. Nechung was not only expanded, it became the central locus for this rite.

The Adamantine Melody is about twice as long as the Ten-Chapter Sädhana and is much more extensive in content. Its basic structure is based on the latter text, but additional material has warped its arrangement, which is not so easily numbered. For the sake of simplicity, here is a preliminary outline: [1] a preface of panegyric verses to Padmasambhava and the Fives Sovereign Spirits; [2] preparations and mantras; [3] the foundational principal practice; ${ }^{288}$ [4] the invitation, request to reside, and offerings and praises for the deities, drawn from the Second Dalai Lama; [5] invocations and iconography for visualizing the deities; [6] more rites of invitation and requesting to reside, as well as praises and the integration of the oaths, drawn from Nyangrel Nyima Özer; [7] bestowing offerings on the deities; [8] praises and entrusting of the activities, drawn from the Second Dalai Lama; [9] confession of faults; [10] blessing the offerings, inviting higher deities, and serving them the offerings; [11] amending and restoring rites; [12] more praises for the deities; [13] entrusting activities to the deities; [14] final invocations, offerings, and covenant; [15] a visualized ritual dance; [16] the enthronment of the deities in their office; and [17] the benediction. It is worth noting that there is some redundancy in the ritual content of this text regarding praises, invitations, and requests for the deities to reside, which is indicative of its multiple influences. Furthermore, this numerical scheme is linear but otherwise arbitrary; many of these segments have multiple rituals within them. Nonetheless, my goal was to provide a basic outline of the key rites within the larger text. Appendix IIc provides a Tibetan transcription and translation of this text.

\footnotetext{
${ }^{285}$ See the preface of Appendix IIc for details on these editions.

${ }^{286}$ The colophon of this ritual explains that it was requested by the Fifth Dalai Lama's regent Sönam Rapten (see note 274 above), who served as regent from around 1642 until his death in 1658. As explained above, the ritual was further encouraged by the Nechung Oracle, suggesting that the Great Fifth did not dally in composing the text once it had been requested; see Appendix IIc, p.520. Given the lack of an exact date in the colophon, I am splitting the difference of the two decades Sönam Rapten acted as regent and suggest that the text was composed around 1650.

${ }^{287}$ Tib. Gnas chung Rdo rje sgra dbyangs gling; lit. "The Small Abode-Palace of the Adamantine Melody."

${ }^{288}$ Tib. dngos gzhi.
} 
Chronologically nestled between these two texts is a third that is not found in the Nechung Liturgy, but which is integral to its evolution. This work is entitled the Offerings and Praises to such [Deities] as the Great Dharma Kings, the Five Long-Life Sisters, Dorjé Drakmogyel, Dorjé Yudrönma, Chölha, Kongtsün Demo, and Odé Gungyel-from the Miscellaneous Writings of the Venerable Omniscient One's Collected Works. ${ }^{289}$ I refer to this text as the Offerings and Praises for the sake of simplicity; it is 23 folios long and was composed by the Second Dalai Lama. ${ }^{290}$ While we can safely assign the text to the first half of the sixteenth century, there is no single date of composition. Like the Nechung Liturgy or the Fifth Dalai Lama's own collection of rituals, ${ }^{291}$ this is not one text but a collection of several texts composed over time. As the title indicates, this compilation contains propitiatory texts dedicated to several deities, though it is the rituals concerning the Five Sovereign Spirits-referred to in the title as the Great Dharma Kings - that are important for the present study. There are six rituals in this work that focus on the Five Sovereign Spirits, making up 9 folios total, or $40 \%$ of the entire work. None of these texts has a title but they do have colophons with varying degrees of detail.

Structurely, most of the rites in the Offerings and Praises dedicated to the Five Sovereign Spirits are so short that they only consist of offerings and/or praises. Some include rudimentary iconographic visualizations and the entrustment of activities. The first and longest text is a lengthy torma offering rite and has the following outline: [1] preparations and mantras; [2] a panegyric description of Padmasambhava and the Five Sovereign Spirits; [3] iconography of the deities drawn from Nyangrel Nyima Özer and further expanded upon; [4] detailed visualized offerings for the deities; [5] exaltations to the deities; [6] reasserting the samaya vow of the deities; and [7] entrusting activities to the deities. Appendix IIb provides a Tibetan transcription and translation of this text.

These three ritual documents are deeply interconnected despite the centuries that separate their compositions. To illustrate this, I will discuss their relationship in the process of providing an exegetical assessment of each work chronologically. The Ten-Chapter Sädhana will receive our closest attention because of the rich information provided by the discrepancies visible between the four extant editions we have of the text. As listed in the preface of Appendix IIa,

\footnotetext{
${ }^{289}$ Tib. Rje btsun thams cad mkhyen pa'i gsung 'bum thor bu las chos rgyal chen po tshe ring mched lnga rdo rje grags mo rgyal rdo rje g.yu sgron ma 'phyos lha kong btsun de mo 'o de gung rgyal sogs kyi gsol kha bstod pa dang bcas pa rnams.

${ }^{290}$ Tã la'i bla ma 02 Dge 'dun rgya mtsho, 1476-1542; TBRC: P84.

${ }^{291}$ See Tā la’i bla ma 052007.
} 
these editions are labeled BPLC, BCPC, GRSD, and RGC62 for convenience and ease of reference. The two oldest editions, BPLC and BCPC, stem from the seventeenth century and have clear ties to the Northern Treasures tradition. The third edition, GRSD, is from the Nechung Liturgy, dated to 1845. Finally, the fourth edition, RGC62, is found in the Great Treasury of Precious Termas, placing it in the second half of the nineteenth century.

I have created a diplomatic edition of these four versions, which has yielded some notable findings. First, RGC62 is the latest edition and also the shortest. While the other three editions have an elaborate introduction preceding the first chapter, RGC62 lacks such a segment. Moreover, each of the three other editions has a distinct introductory section despite the general similarity found in the ten chapters themselves across all four editions. The introduction in the BPLC and GRSD editions are the most similar, but they nonetheless have a few differences peppered throughout their content. The BPLC edition adds material not found in the other editions. $^{292}$ As for the BCPC edition, it has an introductory section completely distinct from BPLC or GRSD. ${ }^{293}$ It echoes many of the basic ideas but is not as detailed, and it even has some contradictory information. These differences indicate that only the ten chapters themselves make up the original text of the Ten-Chapter Sädhana. It is clear that the unique introductions of each edition were added later under the institutional authority of Dorjé Drak Monastery, the center of the Northern Treasures tradition (BPLC and BCPC), as well as Nechung Monastery (GRSD).

While these trends and divergences require a close reading of the editions, additions are much more obvious. The BPLC edition in particular has two additional folios in its text, which are noticeable not only because their content is missing from the other editions, but because the folios actually disrupt the content of the surrounding text. ${ }^{294}$ The extraneous folios break into the folio pagination of the work with their own singular numbering of jikpuo, ${ }^{295}$ meaning 'one' (Figure 27).

Perhaps the most striking addition, however, is the deity Tsiu Marpo, the other major Dharma protector of Samyé Monastery (Figure 28). His name and iconography appear in only two of the editions of the Ten-Chapter Sädhana - the BPLC and BCPC - those produced by the Northern Treasures tradition. This connection itself is not very surprising; it was Ngari Panchen Padma Wangyel who revealed Tsiu Marpo's root treasure texts, and who subsequently

\footnotetext{
${ }^{292}$ See for example Appendix IIa, pp.401-406

${ }^{293}$ See Appendix IIa, pp.413-416.

${ }^{294}$ See Appendix IIa, pp.431-432, 437.

${ }^{295}$ Tib. gcig pu'o.
} 
propagated the deity's cult in the sixteenth century with his younger brother, the Second Dorjé Drak Rikzin Lekden Dorjé. ${ }^{296}$ That the other two editions of the Ten-Chapter Sädhana lack any information on Tsiu Marpo indicates that he was interpolated into the text by the early seventeenth century. Indeed, the previously-mentioned extraneous folio in the BPLC edition exclusively concerns Tsiu Marpo's iconography, referring to him by his epithet Yangleber. ${ }^{297}$ This extra folio in BPLC actually cuts into the content of chapter 9 in the core text; a similar interpolation is found in chapter 10 as well. ${ }^{298}$ Yet another description of Tsiu Marpo is provided earlier in the BPLC edition, interrupting Gyajin's iconography. ${ }^{299}$ The BCPC edition mentions this deity as well, but only once. ${ }^{300}$ This may be the historical point in which Tsiu Marpo's cult merged with Pehar's, and it was through the interpolation of seventeenth-century material via the Northern Treasures tradition; the two deities have been inseparable every since (Figures 28 and 29). Such textual interpolation is a vivid example of how ritual emendation can combine deity cults, forever altering the significance of rituals and impacting their future use.

One final observation about the Ten-Chapter Sädhana is that throughout these multiple editions, mantras are added and subtracted, and their spelling and pronunciations change. If the proper recitation of mantras is important to the successful completion of a ritual, ${ }^{301}$ then these differences carry certain implications about the nature of error within Tibetan ritual architecture. Regardless, the Ten-Chapter Sädhana is representative of how treasure texts are not static texts but are always evolving in usage, significance, and even content well after they have been discovered.

As noted above, the Second Dalai Lama's Offerings and Praises is a collection of rituals dedicated to multiple deities. The Five Sovereign Spirits are just one group of deities among others in this work, although they receive the most attention. The first text is about 6 folios

\footnotetext{
${ }^{296}$ Rdo rje brag rig 'dzin 02 Legs ldan rdo rje (1512-1625?; TBRC: P1701). See Bell 2006 for an extensive study of this root treasure text and other texts concerned with Tsiu Marpo. See also Macdonald 1978a and 1978b for a detailed discussion of the sixteenth- and seventeenth-century politics surrounding Pehar and Tsiu Marpo at Samyé Monastery.

${ }^{297}$ See Appendix IIa, pp.431-432; see also Bell 2006, pp.147-149. See Appendix IIa, pp.411, 428, where the deity is called more explicitly Tsiu Marpo.

${ }^{298}$ See Appendix IIa, pp.431-432, 437.

${ }^{299}$ See Appendix IIa, pp.405-406.

300 See Appendix IIa, p.415.

${ }^{301}$ Many extensive ritual performances conclude with a prayer begging for the deity's tolerance for any mistakes made in the course of the rite; see Beyer 1973, p.223.
} 
long - the longest in the collection- ${ }^{302}$ and is followed by three other rites to the Five Sovereign Spirits; the other two rites are later in the work. This indicates that the Five Sovereign Spirits had not only successfully transitioned into the Geluk pantheon by the sixteenth century, but into the lineage of the Dalai Lamas as well. They were important enough to have a presence in this collection noticeably larger than any other deity. The most significant point, however, is that the first and longest of these rites copies verbatim most of chapter 2 and a few lines from chapter 3 of the Ten-Chapter Sädhana. ${ }^{303}$ The Second Dalai Lama was certainly familiar with the text and used it as a basis for his largest ritual. None of the other five works, however, contain material from Nyangrel Nyima Özer's treasure text. Regardless, all six works have been translated in Appendix IIb because they, along with the Ten-Chapter Sädhana, provided the foundation, directly or indirectly, for the Fifth Dalai Lama's Adamantine Melody. These rites from the Offerings and Praises may not be recorded in the Nechung Liturgy, but material from them is present nonetheless. They provide a suitable transition into the richness of the Great Fifth's ritual edifice.

In composing the Adamantine Melody, the Fifth Dalai Lama drew extensively from the Ten-Chapter Sädhana and the Five Sovereign Spirit rites within the Offerings and Praises. ${ }^{304}$ He further summarized elements from the Assembly of the Quintessential Mind Attainment, ${ }^{305}$ an important cycle of treasure texts rediscovered by the fifteenth-century treasure-revealer Ratna Lingpa. ${ }^{306}$ The result is a dynamic ritual accretion (Figure 30). ${ }^{307}$ Starting with the Ten-Chapter Sädhana, most of its chapter 2 and a portion of chapter 3 made its way into the Second Dalai Lama's Offerings and Praises (Figure 30: blue lines). Then the whole of both chapters, as well as chapter 4 , most of chapter 5 , and the concluding mantras of chapter 7 , became the foundation for the Fifth Dalai Lama's Adamantine Melody (Figure 30: blue and red lines). It is immediately clear that the Ten-Chapter Sädhana was a more significant source to the Fifth Dalai Lama than it was to the Second. Around this core the Great Fifth built a grander ritual program, inserting

\footnotetext{
${ }^{302}$ Indeed, this first text is twice as long as the next largest rite in the collection, a three-folio work dedicated to Dorjé Drakmogyel; see Tā la’i bla ma 02 2006, pp.184.2-189.4.

303 Compare Appendix IIa, pp.419-420 and Appendix IIb, pp.454-455.

${ }^{304}$ The Fifth Dalai Lama copied from three of the six rites in the Offerings and Praises; I translated the other three to provide further context from the Second Dalai Lama's time. See Appendix IIb.

${ }^{305}$ Tib. Thugs sgrub yang snying 'dus pa. The colophon of the Adamantine Melody specifically has Bla ma' $i$ las byang thugs bsgrubs yang snying 'dus pa, which refers to the Precious Garland Practice Manual (Tib. Las byang rin chen phreng ba); see Appendix IIc, pp.490-492, 520, and Ratna gling pa 1976.

${ }^{306}$ Ratna gling pa, 1403-1479; TBRC: P470.

307 See the preface to Appendix II.
} 
additional panegyric segments written by the Second Dalai Lama in his Offerings and Praises (Figure 30: orange lines). Finally, the Fifth Dalai Lama based the principal practice of the ritual on Ratna Lingpa's Assembly of the Quintessential Mind Attainment (Figure 30: purple lines). He adorned the composition with generation phase instructions and mantras, and filled in the rest with his own material, though the colophon suggests other sources were used as well (Figure 30: black lines).

The principal practice drawn from Ratna Lingpa's treasure text is unique because it is not copied verbatim like the verses taken from the Ten-Chapter Sädhana and the Offerings and Praises. Instead, the Great Fifth presents the details and hierarchy it illustrates in his own words. While the Ten-Chapter Sädhana and the Offerings and Praises only mention Hayagriva once or twice, and very briefly at that, here he and his consort Vajravārāhī are described in great detail. Moreover, these lines provide a broader mandalic cosmology in which the Five Sovereign Spirits are now included. This is the mandala of Hayagrīva embracing Vajravārāhī, who are then transmuted into Lama Vajradhara and his consort, the Dākinī Tsogyé. ${ }^{308}$ Surrounding them, on lotus petals in the four cardinal directions, are emanations of Padmasambhava. Then, on lotus petals further out, there are eight more of Padmasambava's emanations. Dākinīs and Dharma protectors then fill the mandala's surrounding courtyard (Figure 31). Thus, through the Fifth Dalai Lama, the Five Sovereign Spirits have come to be nested within a larger and more detailed Buddhist universe, one where Padmasambhava reigns supreme.

The Adamantine Melody's evolution also returns us to Tsiu Marpo. We saw earlier how Tsiu Marpo was inserted into the retinue of the Five Sovereign Spirits within the Ten-Chapter Sädhana through a seventeenth-century emendation. Furthermore, we know that the TenChapter Sädhana came to the Fifth Dalai Lama via the Northern Treasures tradition. ${ }^{309}$ While it appears that he used an edition of the Ten-Chapter Sädhana different from any of the extant editions we have today, it seems closest to the BPLC edition. The Great Fifth included Tsiu Marpo in his Adamantine Melody and used an iconographic description of the deity only found in this edition. ${ }^{310}$ This is an example of how a deity can be retroactively inserted into one ritual

\footnotetext{
${ }^{308}$ This is the famous spiritual consort of Padmasambhava. It is worth noting that Tsögyel's iconography in this work matches that of the ultimate Buddha Vajradhara's consort, Prajn̄āpāramitā; see Appendix IIc, p.490, and Getty 1962 , pp.2-5.

309 The Great Fifth's Record of Received Teachings explains that he received the Ten-Chapter Sädhana from Zur Chöying Rangdröl (Zur Chos dbyings rang grol, 1604-1669; TBRC: P650), who transmitted other texts of the Northern Treasures tradition to the Fifth Dalai Lama; see Tā la'i bla ma 05 1991-1995, vol.2, p.615.6.

${ }^{310}$ Compare Appendix IIa, pp.405-406 and Appendix IIc, p.498.
} 
text (the Ten-Chapter Sädhana), and then standardized by another (the Adamantine Melody), thus showing one mechanism for how deity cults merge.

The edition of the Adamantine Melody used in this study also has a number of extra folios not found in the other editions. ${ }^{311}$ As with the BPLC edition of the Ten-Chapter Sädhana, these folios are clearly interpolations. The text's content and pagination are interrupted, and moreover the actual writing style is distinct from that of the surrounding text (Figure 32). The second of these extra folios is particularly telling; it continues the trend of making offerings to past lineage holders, including not only the Fifth Dalai Lama himself but masters that came after him. ${ }^{312}$ As yet another example of ritual accretion, the contents of this text and the ritual performance it directs was updated at a later time, perhaps during the era of the Thirteenth Dalai Lama. The ritual has continued to evolve along with the institution.

One final observation is that the edition of the Adamantine Melody found in the Nechung Liturgy has three short rites appended to it that are not found in other editions of the text. ${ }^{313}$ All three are dedicated to the Five Sovereign Spirits; however, they are drawn from other sources. The first was composed by the Great Fifth and was part of a larger ritual for Penden Lhamo. The second text was composed by the Fourth Panchen Lama, Lobzang Chökyi Gyentsen, ${ }^{314}$ and it states explicitly that it was taken from a sādhana dedicated to Penden Lhamo Makzor Gyelmo and changed into a rite for the Five Sovereign Spirits. As the other major institutional protector alongside Nechung, Makzor Gyelmo's importance to the Dalai Lama's and to the Tibetan government cannot be overstated. Her presence in this text-as well as elsewhere in the Nechung Liturgy ${ }^{315}$ - speaks to her presence at Nechung Monastery, and to the relationship between the two deities overall. The third text is a generic thanksgiving offering ${ }^{316}$ focused on the Five Sovereign Spirits. Once more we see other texts being adapted and adopted into larger ritual structures. Through a close exegetical reading, each of these three grand works - the TenChapter Sädhana, the Offerings and Praises, and the Adamantine Melody-reveals how rituals can be used, reused, and amended, how deities like Tsiu Marpo and Makzor Gyelmo can change

\footnotetext{
${ }^{311}$ See Appendix IIc, pp.494-496, 504-505. See also the preface to Appendix I, which explains how one edition of the Nechung Liturgy has extraneous folios not found in the other.

${ }^{312}$ See Appendix IIc, pp.504-505.

${ }^{313}$ See Lobzang Tondan 1983, vol.1, pp.49.5-53.1. Since my focus here is exclusively on the Adamantine Melody, a transcription and translation of these short rites is not included in Appendix IIc.

${ }^{314}$ Tib. Pan chen 04 Blo bzang chos kyi rgyal mtshan, 1570-1662; TBRC: P719.

${ }^{315}$ See text 27 in Appendix I.

${ }^{316}$ Tib. gtang rag mchod pa.
} 
institutional affiliation, and how deity cults, like that of the Five Sovereign Spirits, can become nested within greater cosmologies.

\section{Dorjé Drakden}

In the course of examining these core ritual texts that are so central to Nechung Monastery, one figure stands out for being surprisingly absent. This is Dorjé Drakden, the protector who has come to be synonymous with Nechung. As stated above, Dorjé Drakden is the deity that most often takes possession of the Nechung Oracle. Despite this, the name Dorjé Drakden appears only a few times in the Ten-Chapter Sädhana and Adamantine Melody. In the iconography of the Five Sovereign Spirits, the descriptions of the deities are followed by that of their consorts, ministers, and emanations. The western sovereign spirit of speech, Kyechik Marpo, we are told, has a minister named Dorjé Drakden, who wears monastic robes, brandishes a mendicant's staff, and rides a camel (Figure 33). ${ }^{317}$ Other than this minor appearance, there is no attention given to this deity. This is a far cry from the Dorjé Drakden we see today (Figure $34):^{318}$

The great enemy-defeating god is the capricious spirit Dorjé Drakden! His body is intensely red, like a Mount Meru-sized heap of lotus rubies bathed in [the light] of ten million suns. He has one head and two arms. His right hand raises to the sky a leather military standard with which he crushes the horde of

\footnotetext{
${ }^{317}$ See chapter 1, p.35.

${ }^{318}$ This work is text 6 in Appendix I and follows immediately after the Ten-Chapter Sädhana. Lobzang Tondan 1983, vol.1, pp.75.4-76.5: dgra lha chen po gnod sbyin rdo rje grags ldan sku mdog padma rä ga'i lhun po la nyi ma bye bas 'khyud pa lta bu rab tu dmar bal zhal gcig phyag gnyis pa/ phyag g.yas bse'i ru mtshon namkha' la 'phyar bas bgegs dpung thal bar rlog cing / g.yon sdigs mdzub kyis btsan zhags dmar po bzung bas gnod byed dam nyams dgra bo 'gugs par mdzad pa/ zhal gdangs shing ljags klog ltar 'khyug pa/ mche ba rnon po bzhi gtsigs shing khro gnyer shin tu bsdus pa/ sma ra dang smin ma me ltar 'bar zhing / bse khrab dang bse rmog gyon pa/ rin po che dang rus pa'i rgyan gyis brgyan pa/ zhabs la sag lham gsol zhing / g.yas bskum g.yon brkyang gis bskal pa'i me dpung 'bar ba'i klong dkyil na gar dgu'i nyams kyis bzhugs pa'i rol du phar spyang bya 'ug dgyed [sic: 'gyed] pa/ pho nyar gnam lcags thog dang rlung nag 'tshub ma 'khrid pa/ sprul pa rab tu byung ba'i cha byad can/chos gos ngur smrig dang dar zhu ser po gsol ba/ g.yas beng dbyug dang g.yon lcags kyi 'phreng bas dgra bo rtsis la 'debs pa/ dor stabs kyi phag nag steng na 'gying ba/ yum gzi brjid chen mo dkar la dmar mdangs chags pa mdzes shing yid du 'ong ba/ rtse ber nyis brtsegs gsol zhing me tog gi thod bcings dang rin po ches spung ba g.yas rtse gsum dang g.yon thod pa bdud rtsis gang ba 'dzin pa/ blon po bdud nag mi sdug pa'i gzugs can ral pa brdzes pa/ g.yas dar mdung dang g.yon rgyu zhags bsnams pa/ dar dmar gyi ber gyon zhing / snang srid lha srin sde brgyad sogs 'khor du dam can rgya mtsho'i dmag tshogs dpag tu med pas bskor ba'o//. Interestingly, a second iconography of Dorjé Drakden makes up the remainder of the text, though it does not appear to be drastically different.
} 
obstructing spirits. His left hand makes the tarjani mudra and holds the red lasso of the imperial spirits; with this he captures the maleficent enemies who violate the samaya vow. His mouth is gaping and his tongue flashes like lightning. He bares his four sharp fangs and [his face] is clenched into a wrathful grimace. His beard and eyebrows blaze like fire. He wears leather armor and a leather helmet. $\mathrm{He}$ is adorned with jewelry and bone ornaments, and wears leather boots on his feet. With his right leg bent and his left extended, ${ }^{319}$ he resides amid the roiling blaze of apocalyptic fire, performing the nine dance modes. ${ }^{320} \mathrm{He}$ is accompanied by wild dogs and owls, and dispatches thunderbolts and black blizzards as heralds.

Dorjé Drakden's emanation takes on the guise of an ordained monk. He wears saffron-colored monastic robes and a silk yellow hat. He [holds] a large club in his right hand and an iron rosary in his left, with which he keeps account [of all] the enemies. He assumes a strident posture atop a black boar. Dorjé Drakden's consort is a great majestic woman. She is beautiful, with a lovely white complexion and a tinge of red. She wears two layers of monastic cloaks as well as a turban of flowers stacked with jewels. She holds in her right hand a trident, and in her left a skull cup filled with the nectar of immortality. Dorjé Drakden's minister appears in the form of a repulsive black hindering spirit, his long hair streaming upward. He brandishes a spear with a silk flag in his right hand and a lasso of intestines in his left, and wears a red silk cloak. Regarding the retinue, they are surrounded by the immeasurable army of the ocean of oathbound protectors, such as the eight classes of gods and spirits of the phenomenal world.

This is the earliest known description of Dorjé Drakden, and it is from another text available in the Nechung Liturgy that was composed by the Fifth Dalai Lama's own student, the treasure-revealer Terdak Lingpa. ${ }^{321}$ Nothing else beyond this fierce iconography is provided in

\footnotetext{
${ }^{319}$ Tib. g.yas bskum g.yon brkyang; Skt. pratyālị̈ha. This refers to an aggressive posture commonly found in the iconography of wrathful deities.

${ }^{320}$ Tib. gar dgu'i nyams. These are the nine modes wrathful deities express through ritual dance; they are [1] erotic (Tib. sgeg pa), [2] heroic (Tib. dpa' ba), [3] repulsive (Tib. mi sdug pa), [4] humorous (Tib. dgod pa), [5] furious (Tib. drag shul), [6] terrifying (Tib. 'jigs su rung ba), [7] compassionate (Tib. snying rje), [8] magnificent (Tib. rngam pa), and [9] tranquil (Tib. zhi ba).

${ }^{321}$ Gter bdag gling pa 'Gyur med rdo rje (1646-1714; TBRC: P7); see Dudjom Rinpoche 1991, vol.1, pp.825-834.
} 
his short work, so there is no textual reconciliation offered for this conflict in the two descriptions. While at the Dhasa Nechung Monastery, I asked one monk why Dorjé Drakden has two appearances, one as Kyechik Marpo's minister and the other as the fierce red Nechung protector. The monk said they were actually two different deities, just with the same name - one was Minister Dorjé Drakden ${ }^{322}$ and the other was Nechung Dorjé Drakden. ${ }^{323}$ No other monks could confirm this interpretation, however, nor do any historical documents. The most common interpretation I have heard is that the minister form of Dorjé Drakden is his peaceful guise, while the red form is his wrathful guise; this too does not have historical backing.

I agree with Amy Heller that this fierce description of Dorjé Drakden was perhaps influenced by Begtse, an equally important protector deity for the Dalai Lamas and one with an older history. ${ }^{324}$ It is also possible, as Heller implies, ${ }^{325}$ that Dorjé Drakden's wrathful appearance was inspired by the Nechung Oracle's demeanor while in trance. As she first observed, there is in the Nechung Liturgy a short panegyric composed by the Fifth Dalai Lama in 1651 at the behest of the Nechung Oracle, which describes the oracle in a trance. He wears armor and a helmet, holds a lasso, lance, sword, and other weapons, and has a fierce comportment. ${ }^{326}$ In many of the relevant ritual colophons within the Nechung Liturgy, the oracle and the deity are conflated, since both are referred to as the Great Dharma Protector, the Great Sovereign Spirit, or the Great Dharma King. ${ }^{327}$ The name Dorjé Drakden itself appears in a few of the text colophons of the Nechung Liturgy, particularly those pertaining to the Seventh Dalai Lama, and specifically in the context of possessing the oracle. ${ }^{328}$ It seems from at least the early eighteenth century Dorjé Drakden and the oracle were considered one and the same. Moreover, many murals and statues visible today depict the Nechung Oracle possessed by Dorjé Drakden (Figures 26, 35, and 36). Regardless of the specifics, whether through treasure text revelation, iconographic borrowing, or oracular inspiration, Dorjé Drakden has taken on a different appearance than he possesses in the Ten-Chapter Sädhana and the Adamantine Melody. He has even come to be viewed as the central deity of Nechung Monastery, over and above the Five

\footnotetext{
322 Tib. blon po Rdo rje grags ldan.

323 Tib. Gnas chung Rdo rje grags ldan; personal communication, February 20, 2012.

${ }^{324}$ See Heller 1992a.

${ }^{325}$ See ibid, pp.487-488.

${ }^{326}$ See text 7 of Appendix I; see in particular Lobzang Tondan 1983, vol.1, p.79.5-6.

${ }^{327}$ See texts 3, 4, 7, 8, 9, 10, 11, 19, 25, 40, and 42 of Appendix I.

${ }^{328}$ See texts 18,22 , and 40 of Appendix I.
} 
Sovereign Spirits from which he sprang. A brief return to the full content of the Nechung Liturgy may reveal why this is the case.

As discussed above, while the Nechung Oracle penned very few of the rituals contained in the Nechung Liturgy, he was nonetheless responsible for more texts being composed than any other figure, mostly through requesting them. He was likewise responsible for the liturgy's compilation in 1845 . The Dalai Lama, when considered as a unity across multiple lifetimes, may have composed more texts in this collection than anyone else, but he was motivated by the deity's constant encouragement via the Nechung Oracle. With these details in mind, I suggest that Nechung Monastery was originally the abode of the Five Sovereign Spirits, while the Nechung Oracle was the "abode" of Dorjé Drakden. The core rituals of Nechung hardly mention Dorjé Drakden while giving prominence to the Five Sovereign Spirits. The Nechung Register ${ }^{329}$ also mentions the Five Sovereign Spirits constantly; there are praises to them throughout the text and, as we know, it contains a summary account of Pehar's former lives. The handful of references in the Nechung Register to Dorjé Drakden clearly put him in a secondary position. Before and up to its 1682 renovation, Nechung Monastery was meant to be the special palace of the Five Sovereign Spirits led by Pehar. However, it was also the home of the Nechung Oracle, who-as the embodiment of the Five Sovereign Spirit's emanation, Dorjé Drakden-became more important over the centuries following his promotion to state oracle. This deity was active in history in a fairly consistent manner, and he continues to be so today.

We can observe through the colophons of the Nechung Liturgy that the institution of the Nechung Oracle reshaped the cosmology of Nechung Monastery. The Five Sovereign Spirits are still an essential part of the Nechung hierarchy, but rather than one of them being at its centerlike Pehar - there is instead Dorjé Drakden (Figure 36). Even the deity's origins have been retroactively reformed. On numerous occasions monks of both Dhasa and Lhasa Nechung Monasteries have told me that Dorjé Drakden is the combined emanation of the Five Sovereign Sprits. Some monks have even said the Five Sovereign Spirits actually emanated from Dorjé Drakden, challenging Pehar's emanational primacy. It seems that even as Pehar's cult at Nechung was being articulated in the late seventeenth century, another deity began to usurp it. This illustrates a divine social mobility, where deities can rise up from obscurity and become

\footnotetext{
${ }^{329}$ See Appendix III.
} 
dominant, while the dominance of other deities can be challenged or even wane, all through ritual evolution.

Ritual accretion works on multiple levels, from a single text, to a lineage of texts, to an entire corpus, and even within an institution's ritual calendar. Multiple editions of the TenChapter Sädhana illustrate important details on how a twelfth-century treasure text can take on new institutional significance in the seventeenth century. This text, as well as several rites composed by the Second Dalai Lama, were then reinvigorated within a larger ritual program and cosmology systematized by the Fifth Dalai Lama. Given that the Great Fifth is considered a reincarnation of both Nyangrel Nyima Özer and the Second Dalai Lama, ${ }^{330}$ this can be seen as an act of amendment performed by the same author - across reincarnated lifetimes - over the course of five centuries. The full collection of the Nechung Liturgy is a more obvious example of accretion, with rituals and prayers being added to the core texts over two centuries. Likewise, Nechung's ritual calendar exhibits similar forms of performative accretion. Examining these ritual layers has yielded significant historical information on how deity cults evolve. Deities can be added to other pantheons through interpolation, couched within greater cosmologies through ritual expansion, and promoted in status through institutional clout. By analyzing ritual texts as historical documents, we uncover more of the factors involved when Tibetan institutions harness ritual programs for their own advancement over the course of centuries.

In his seminal work To Take Place, Jonathan Z. Smith offers a distinct understanding of ritual. ${ }^{331}$ For Smith, the place in which a ritual is performed is just as important as the ritual itself, if not more so. All of the rituals discussed above are viewed as tools for imbuing a specific sacred site with the presence of a deity to varying degrees and for diverse ends. Still, this is not to suggest that a particular ritual is limited to a specific place. As Smith explains, "place is not best conceived as a particular location with an idiosyncratic physiognomy or as a uniquely individualistic node of sentiment, but rather as a social position within a hierarchical system." ${ }^{332}$ Wherever a ritual is conducted, the site is important for the position it holds within a grander scheme. In terms of hierarchy, we observed above how from the late seventeenth century onward the Nechung Oracle became head of a newly defined hierarchy of Tibetan

\footnotetext{
${ }^{330}$ Sañs-rGyas rGya-mTSHo 1999, pp.viii-ix.

${ }^{331}$ See Smith 1987.

${ }^{332}$ Ibid, p. 45 .
} 
oracles, how other deities like Tsiu Marpo and Makzor Gyelmo shifted in affiliation through rituals that came to define Nechung, and how a deity like Dorjé Drakden advanced in status-all through the rituals that have been emplaced at Nechung as well as other sacred centers.

Where a ritual is performed is just as important for understanding its significance as it is to comprehend its textual arrangements or know when in the year it is conducted. This is explicit in the next chapter, which explores the other major monasteries and temples with which Nechung has a close relationship. A number of these centers were briefly mentioned in the ritual calendar above, but require further discussion. However, first we must introduce ourselves to the history of Nechung Monastery itself and the institution of the Nechung Oracle. The foundation of mythology has been set and the framework of ritual has been constructed. All that remains is to lay the brick and mortar of Nechung's history and adorn it with other sacred sites. 


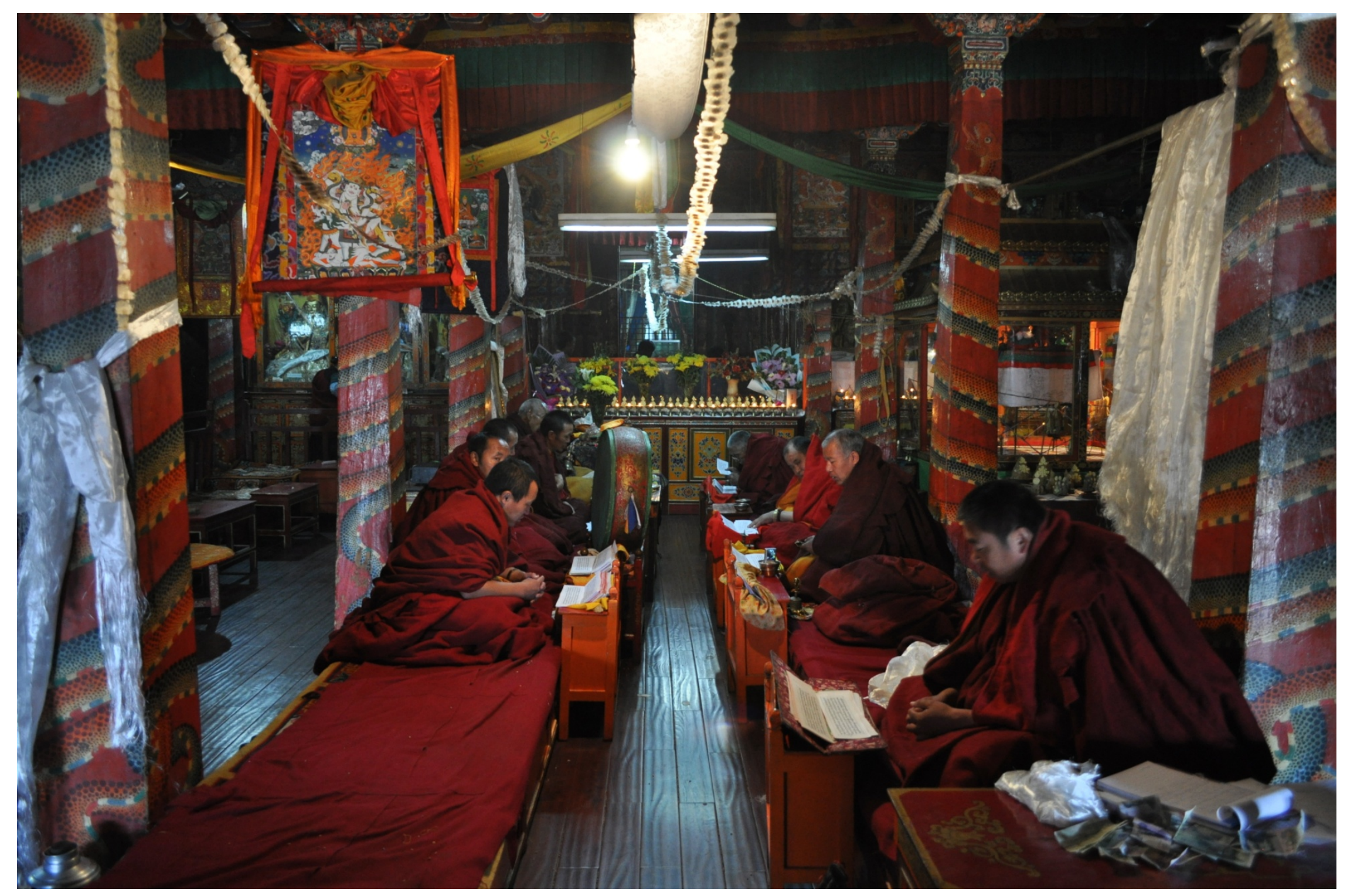

Figure 22: Nechung monks reciting verses for the tenth month ritual to four-armed Avalokiteśvara who Liberates All Beings; Nechung Monastery Assembly Hall, Lhasa. (Photo: Christopher Bell, 2011) 


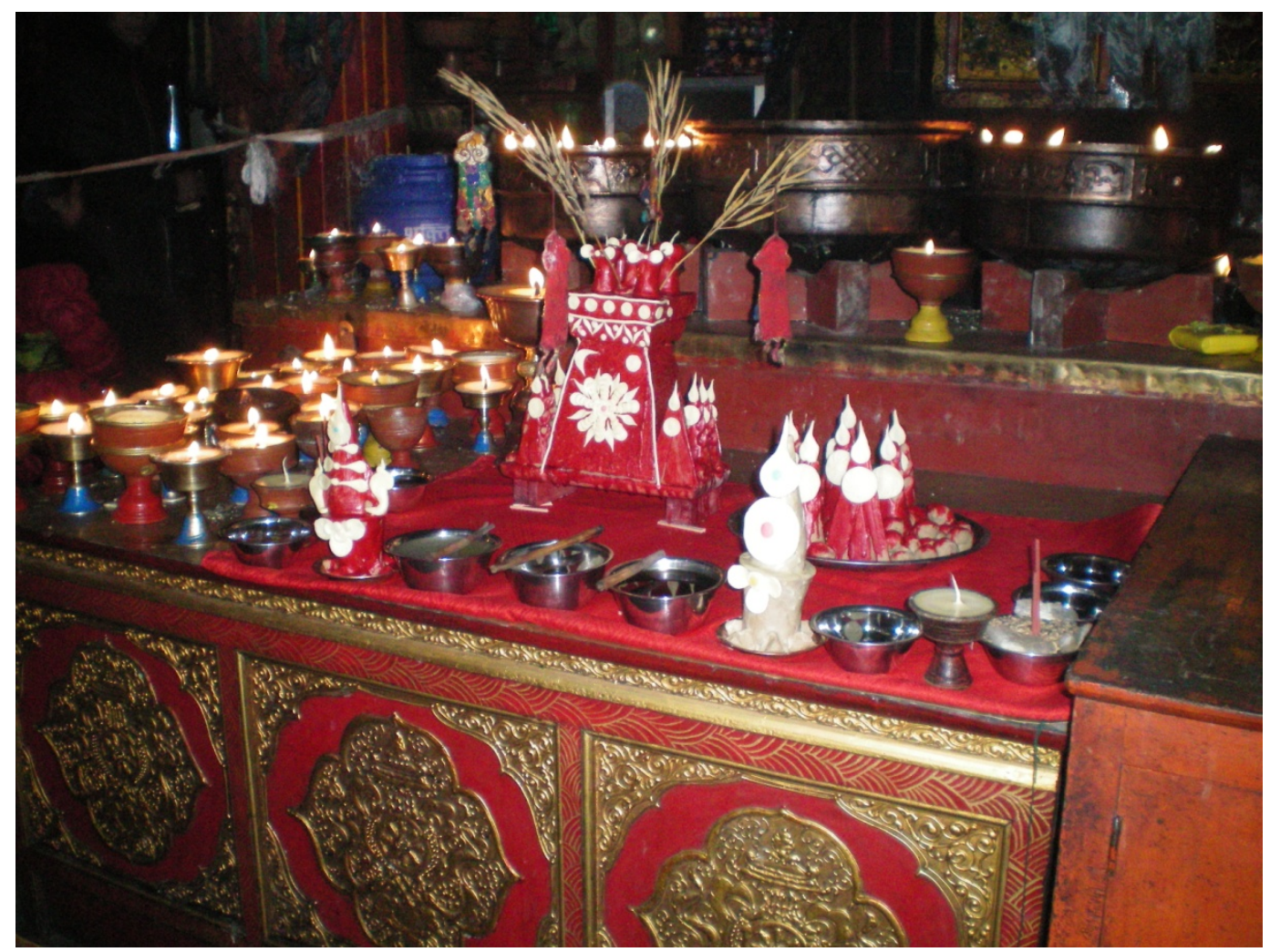

Figure 23a: Torma offerings presented to the Five Sovereign Spirits and their retinue during a ritual performance of the Ten-Chapter Sādhana; Meru Nyingpa Monastery Assembly Hall, Lhasa. (Photo: Christopher Bell, 2011)

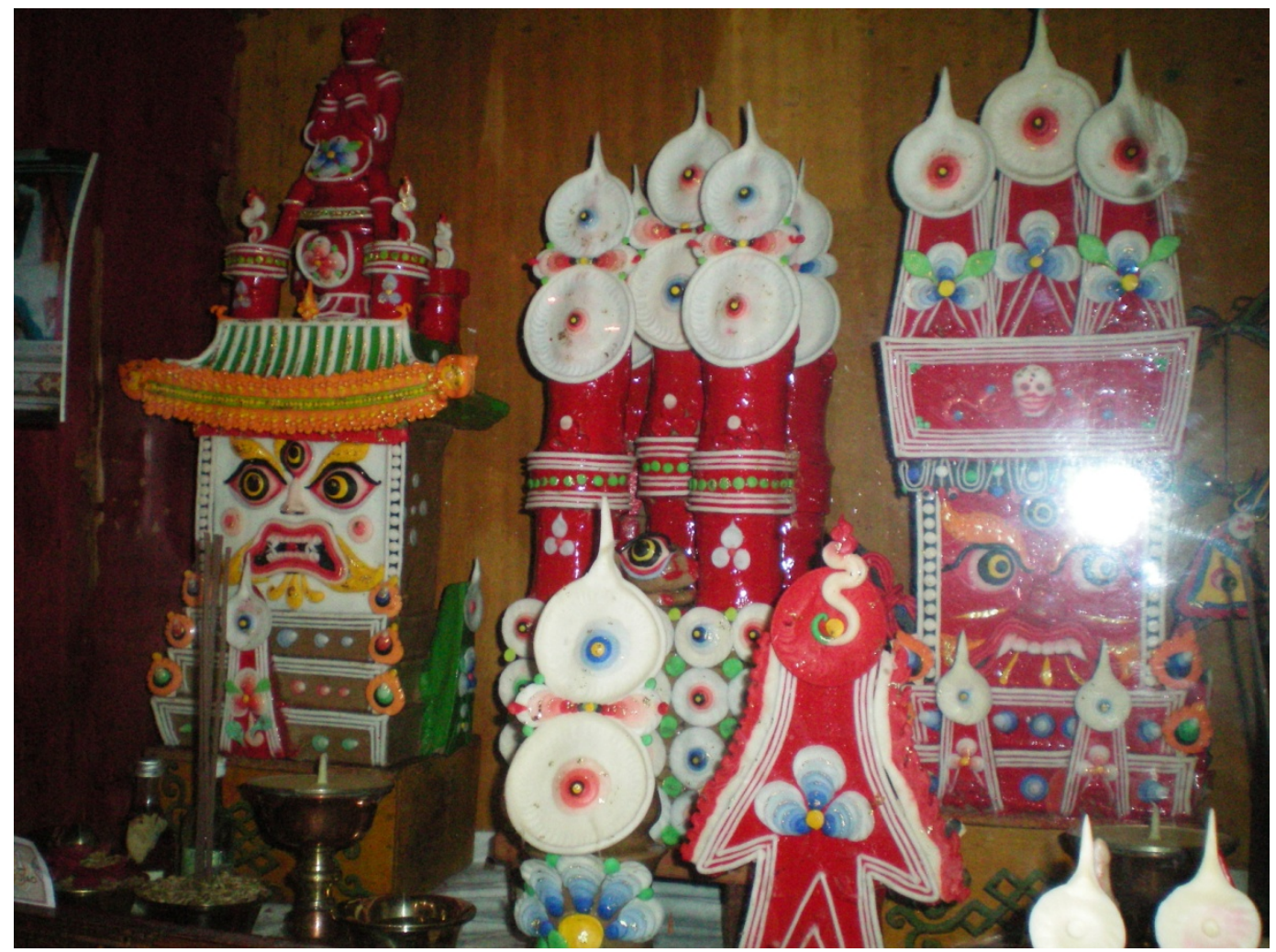

Figure 23b: Glass-encased continuous tormas for Pehar, the Five Sovereign Spirits, and Tsiu Marpo; Tengyeling (Tib. Bstan rgyas gling) Monastery Central Chapel, Lhasa. (Photo: Christopher Bell, 2011) 


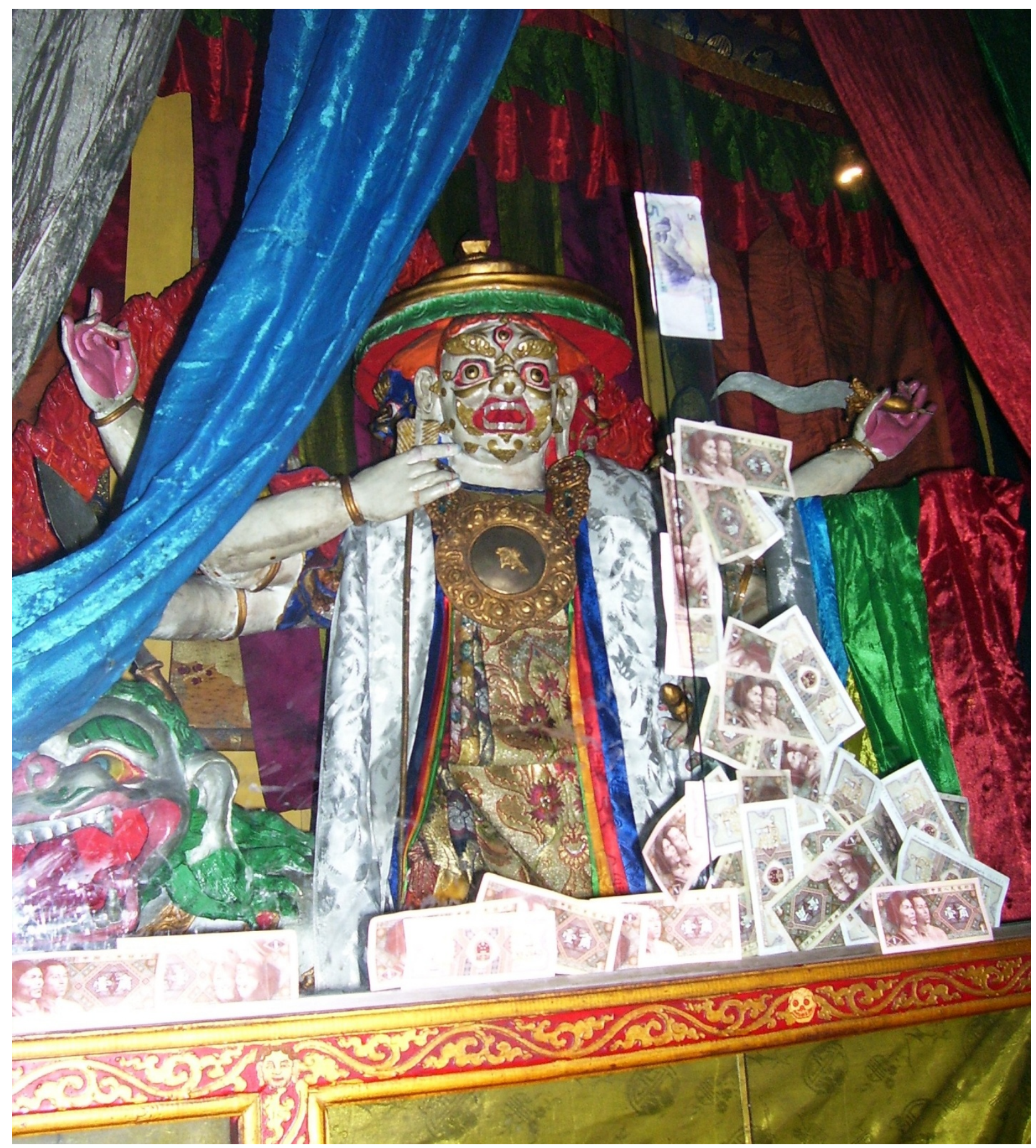

Figure 24: Glass-encased image of Pehar, to which Chinese jiao have been offered. This image is surrounded by similar statues of the four other sovereign spirits (see Figures 60, 67, and 68) and a trough for butter offerings is nearby at the chapel entrance; Nechung Monastery Central Chapel, Lhasa. (Photo: Christopher Bell, 2007) 


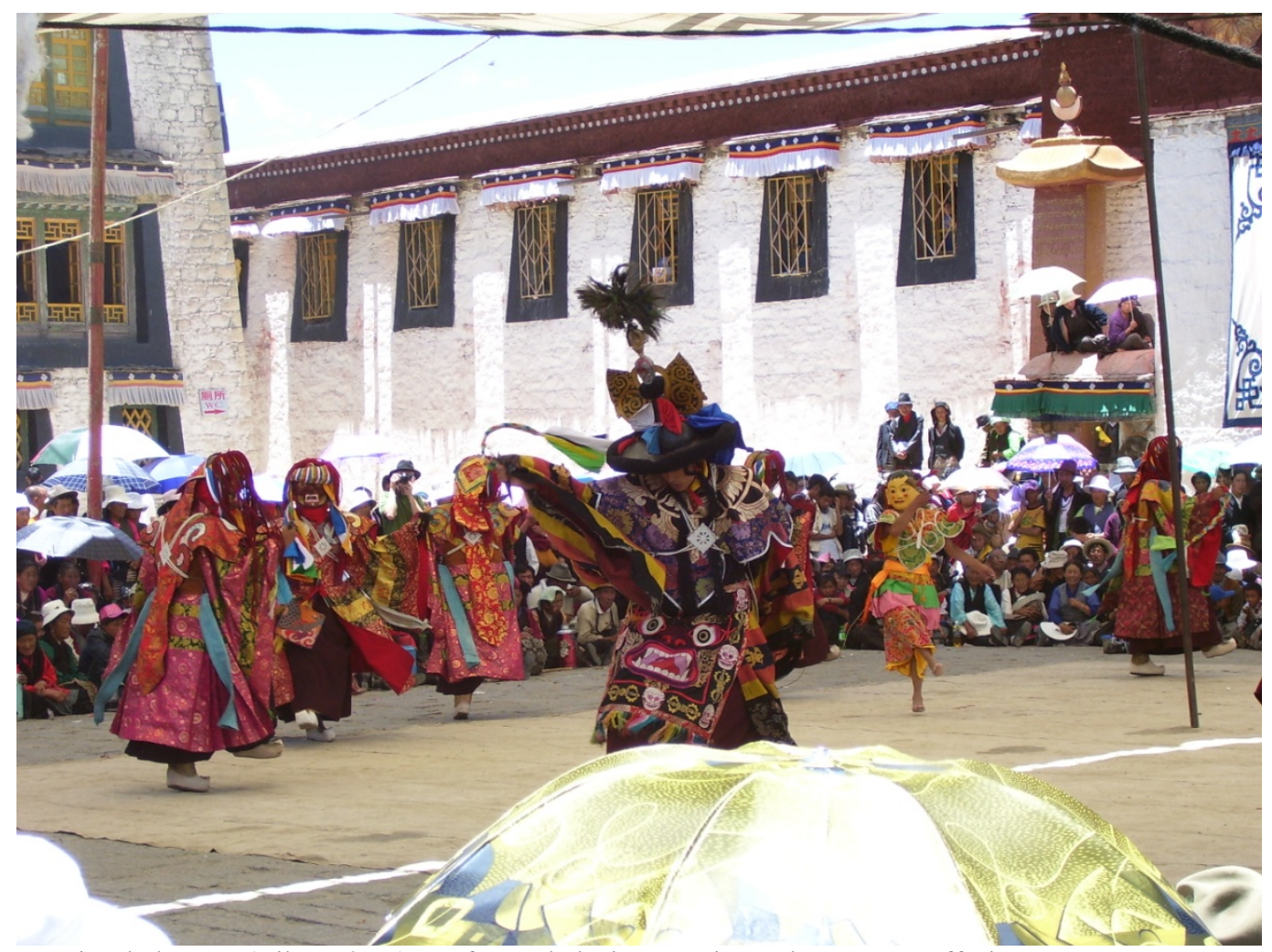

Figure 25a: Ritual dances (Tib. 'cham) performed during 'Universal Incense Offering Day.' Samyé Monastery, Central Temple (Tib. dbu rtse) courtyard, Tibet. (Photo: Christopher Bell, 2007)

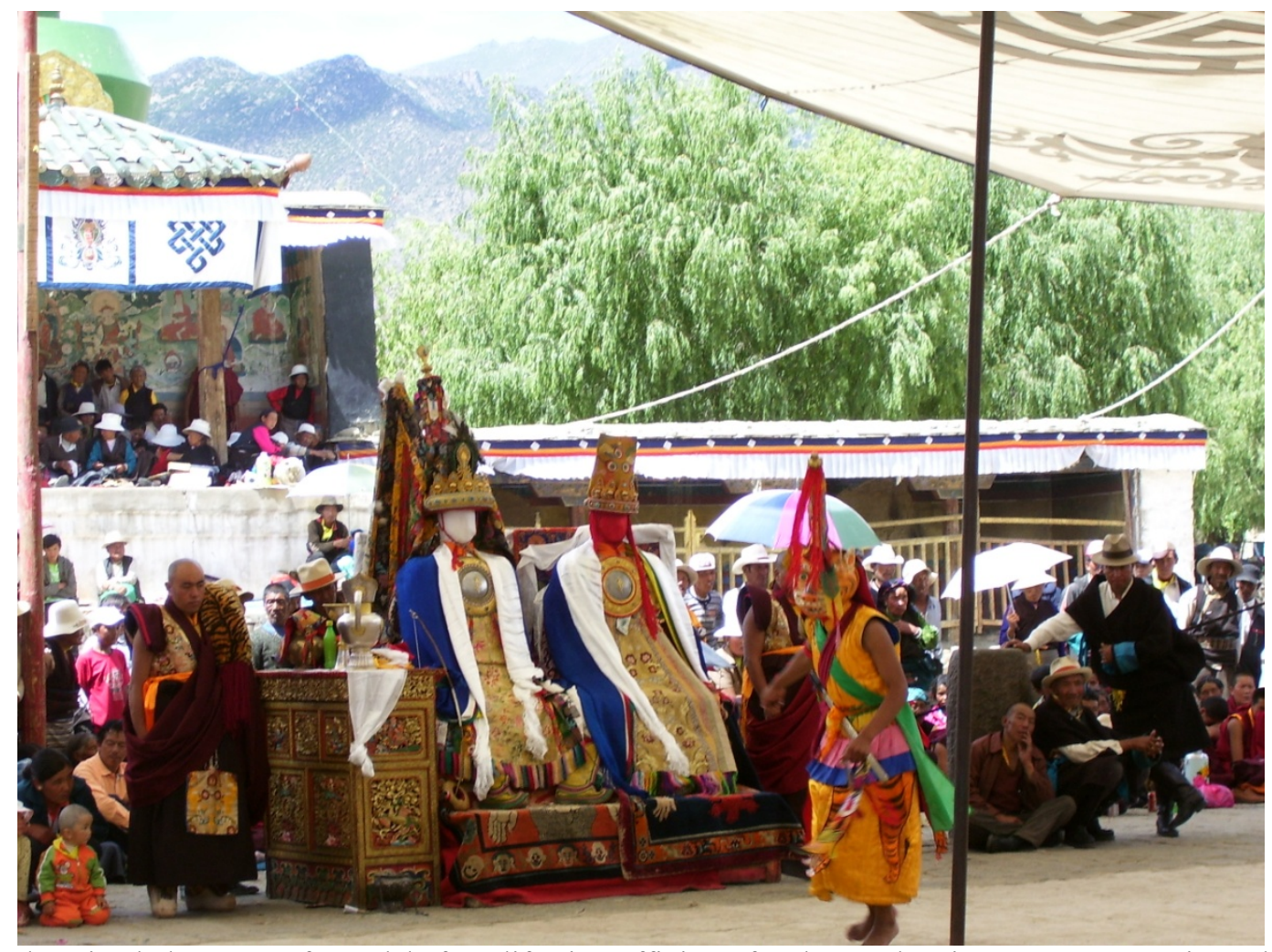

Figure 25b: Ritual dances performed before life-size effigies of Pehar and Tsiu Marpo on 'Universal Incense Offering Day.' Samyé Monastery, Central Temple (Tib. dbu rtse) courtyard, Tibet. (Photo: Christopher Bell, 2007) 


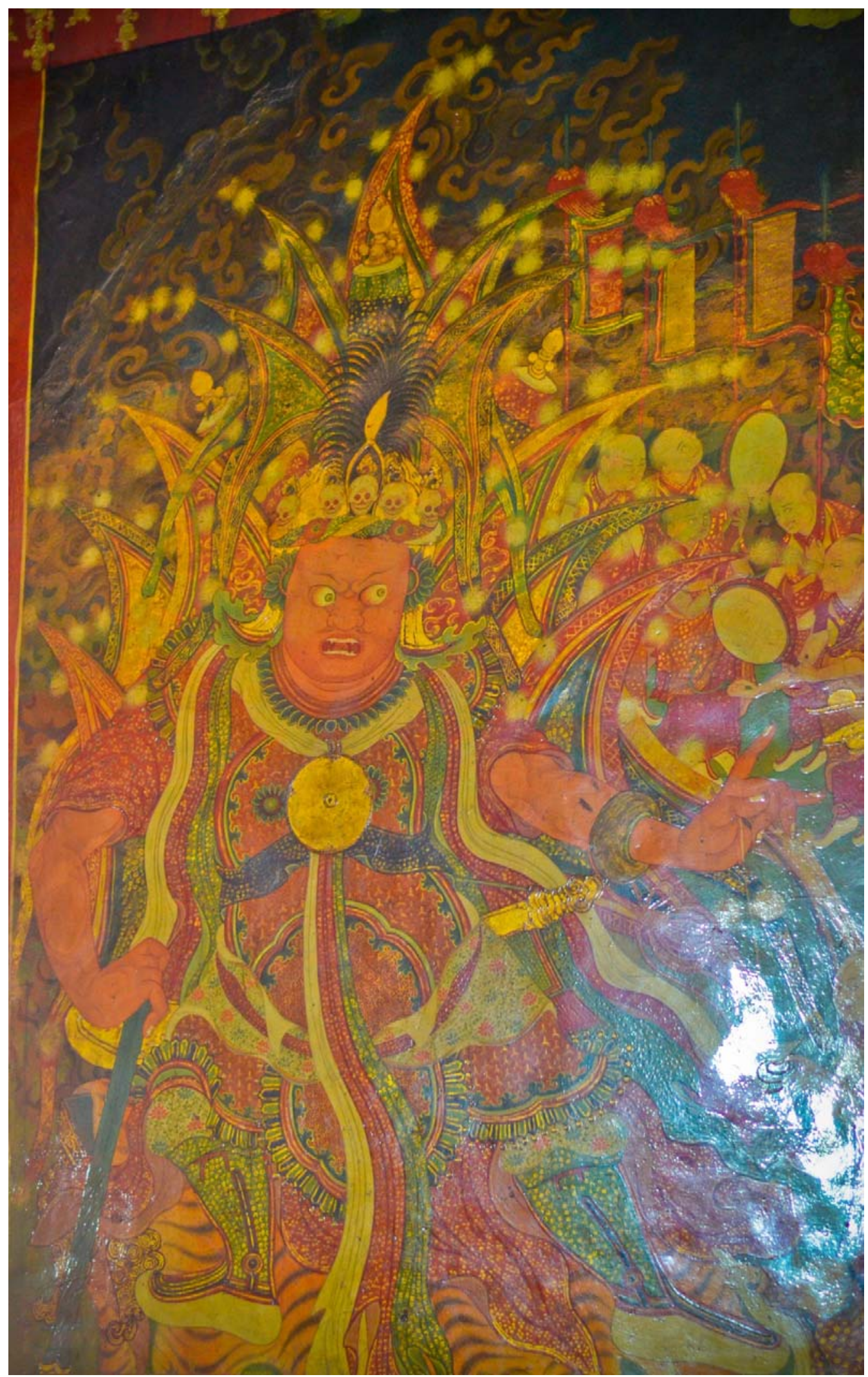

Figure 26: Mural of the Nechung Oracle in a trance. This is an image of Lobzang Lekjor (Tib. Blo bzang legs 'byor), who was installed as the medium of Nechung in 1690 (see Thub bstan phun tshogs 2007, p.84); Nechung Monastery Assembly Hall, Lhasa. (Photo: Cecilia Haynes, 2011) 


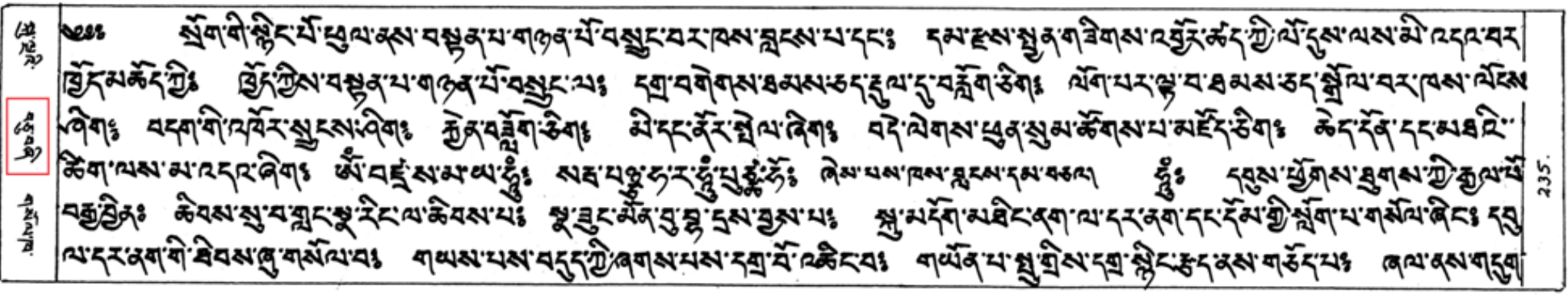

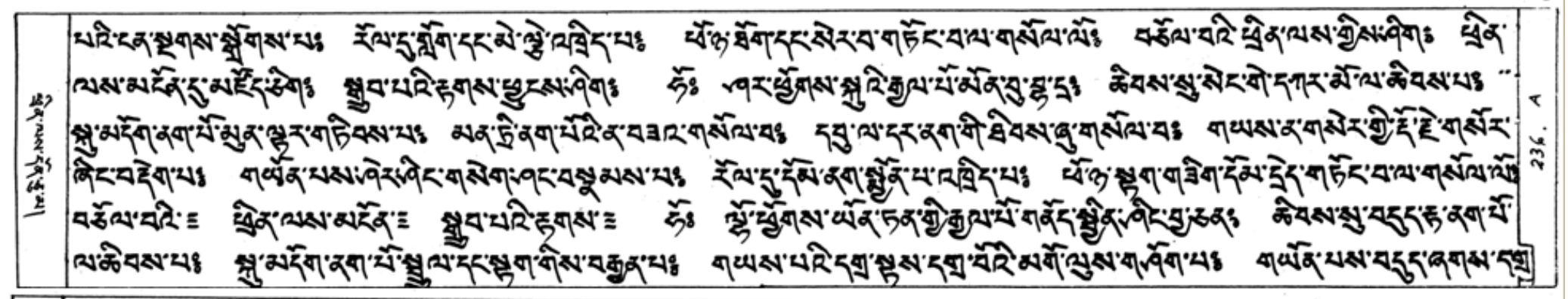

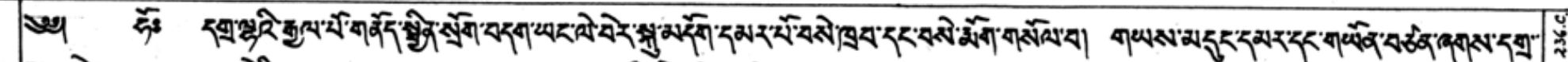

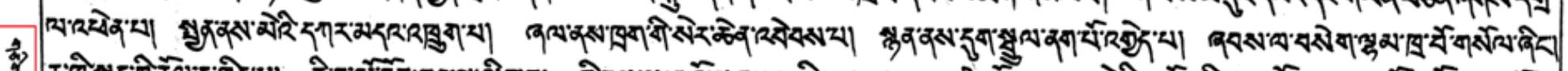

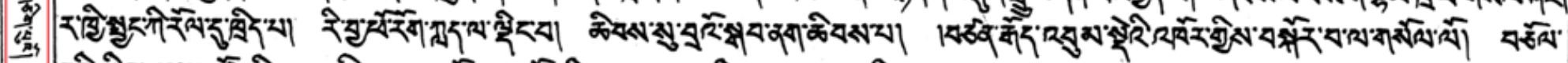

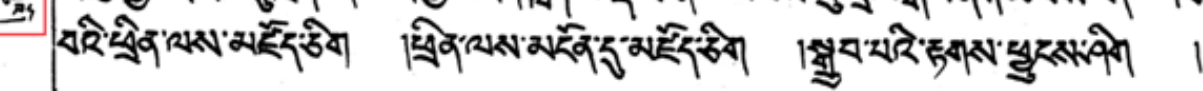

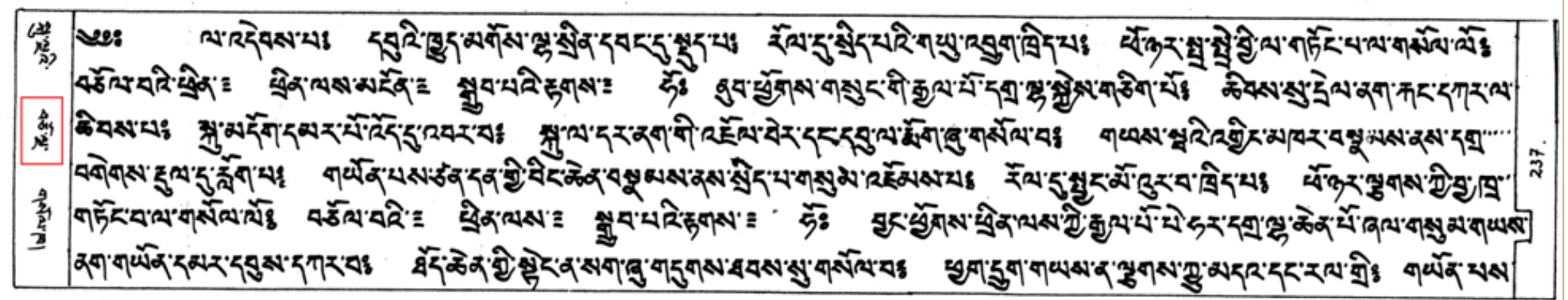

Figure 27: Digitized scans of four folio sides from the original BPLC Tibetan manuscript; this illustrates one of the extraneous folios in the text. The Tibetan pagination progresses from 14 (recto and verso) to 1 (recto; verso is blank) to 15 (recto), as highlighted by the red boxes; Nyi ma 'od zer 1994, pp.235-237. 


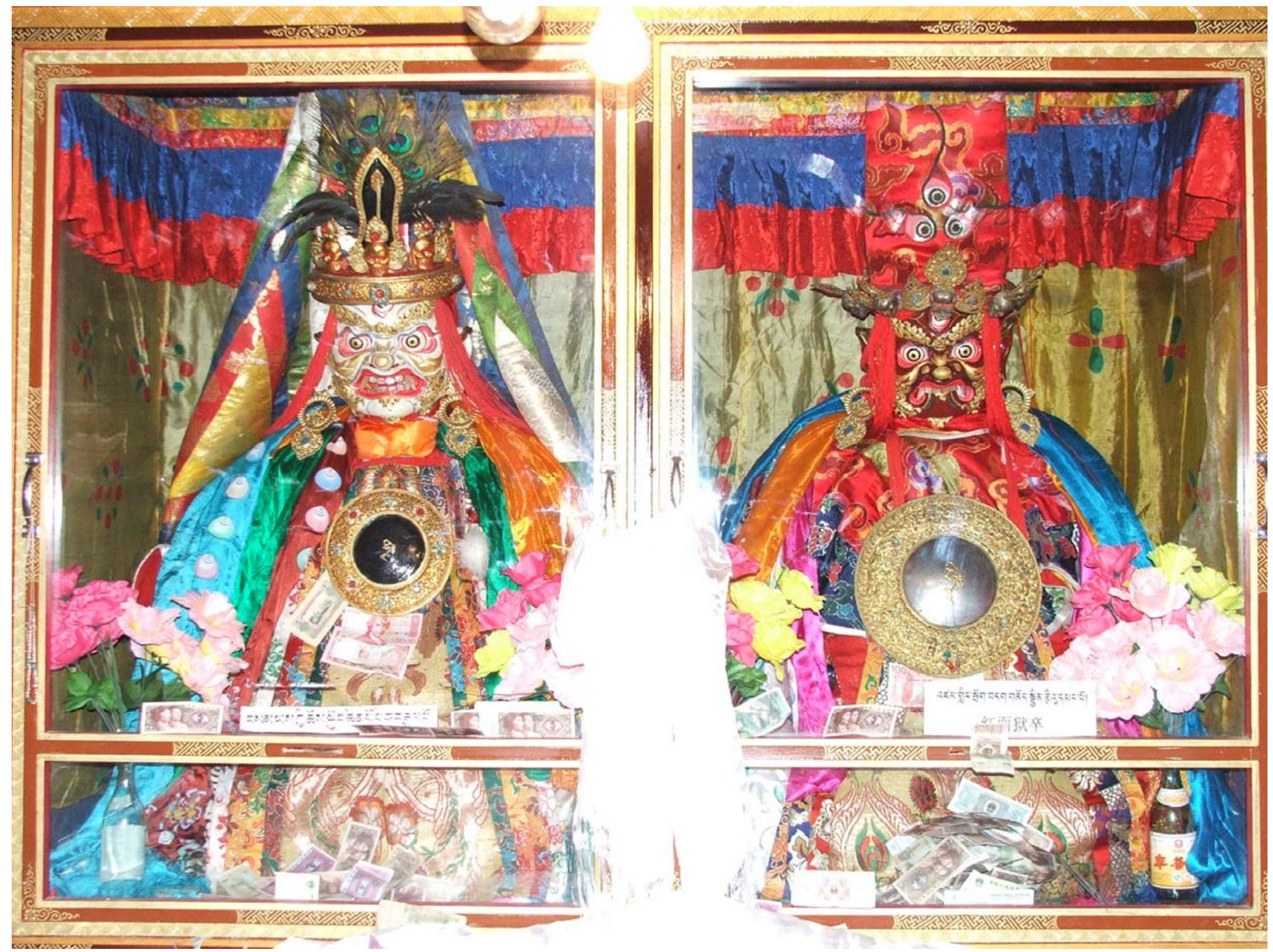

Figure 28: Central images of Pehar and Tsiu Marpo at the Pehar Kordzöling (Tib. Dpe har dkor mdzod gling); Samyé Monastery, Tibet. (Photo: Lindsay Sekreve, 2007) 


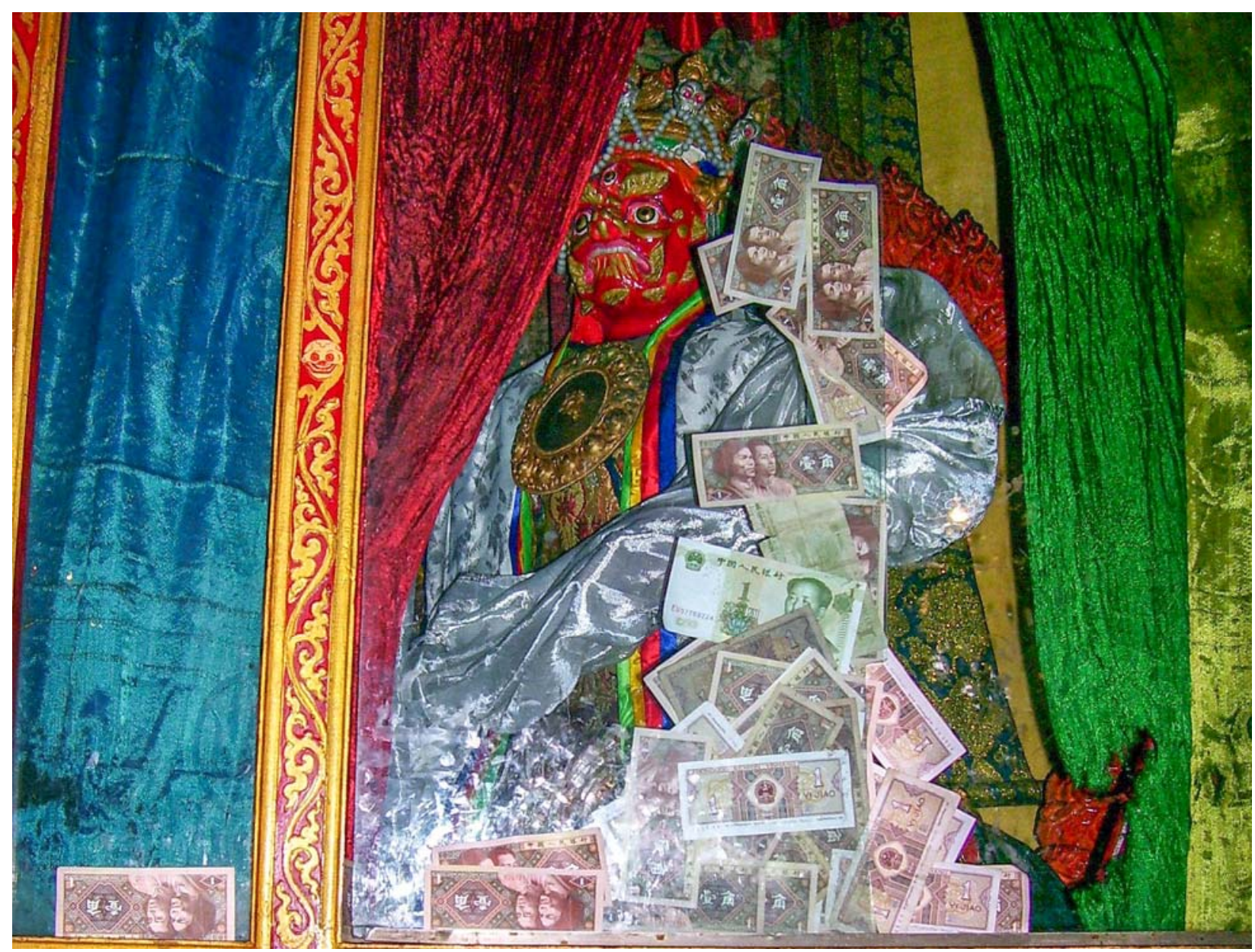

Figure 29a: Statue of Tsiu Marpo in the company of the other central statues at Nechung; Nechung Monastery Central Chapel, Lhasa. (Photo: Christopher Bell, 2007)

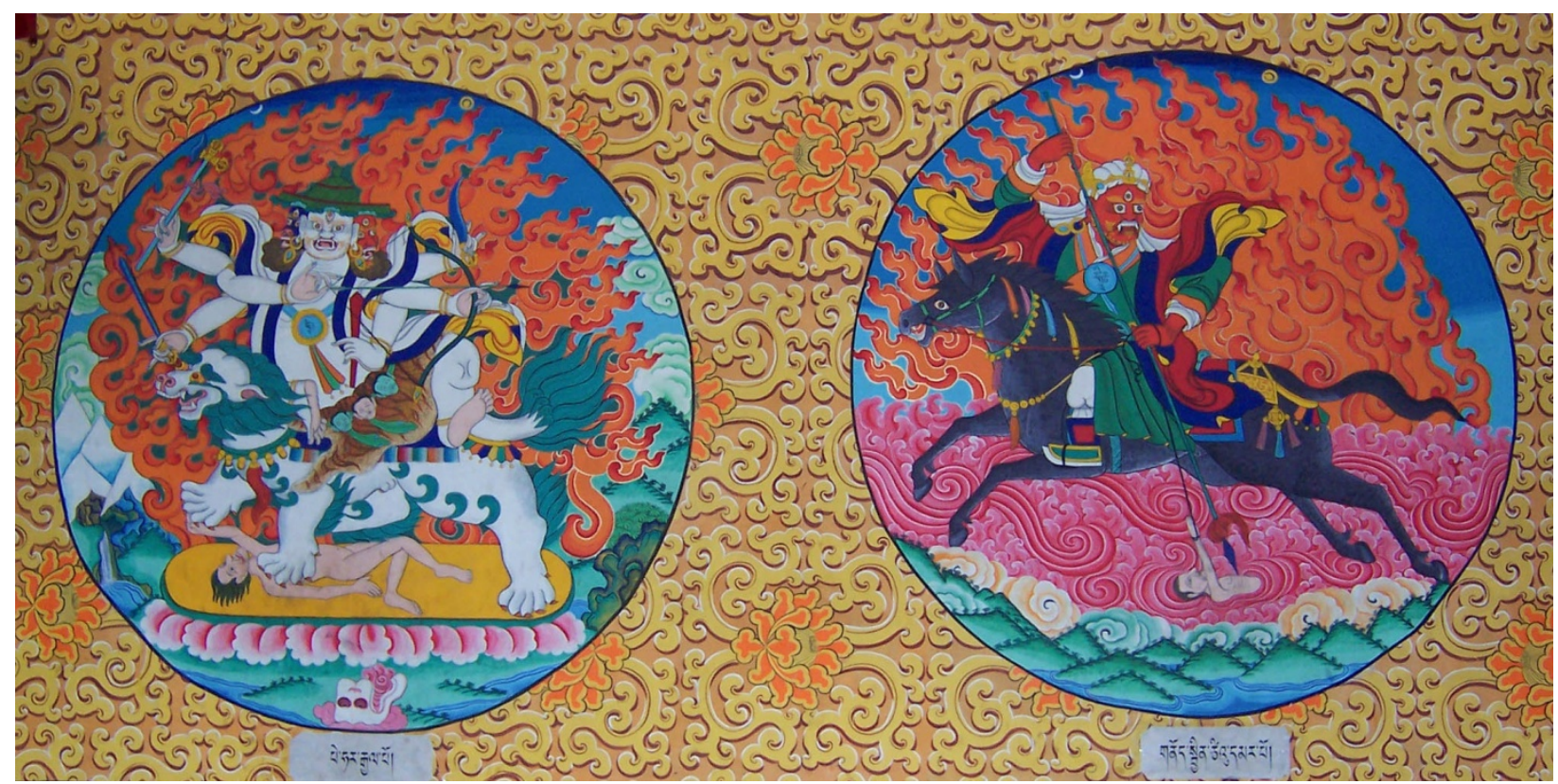

Figure 29b: Murals of Pehar and Tsiu Marpo; Tengyeling Monastery Side Chapel, Lhasa.

(Photo: Christopher Bell, 2007) 


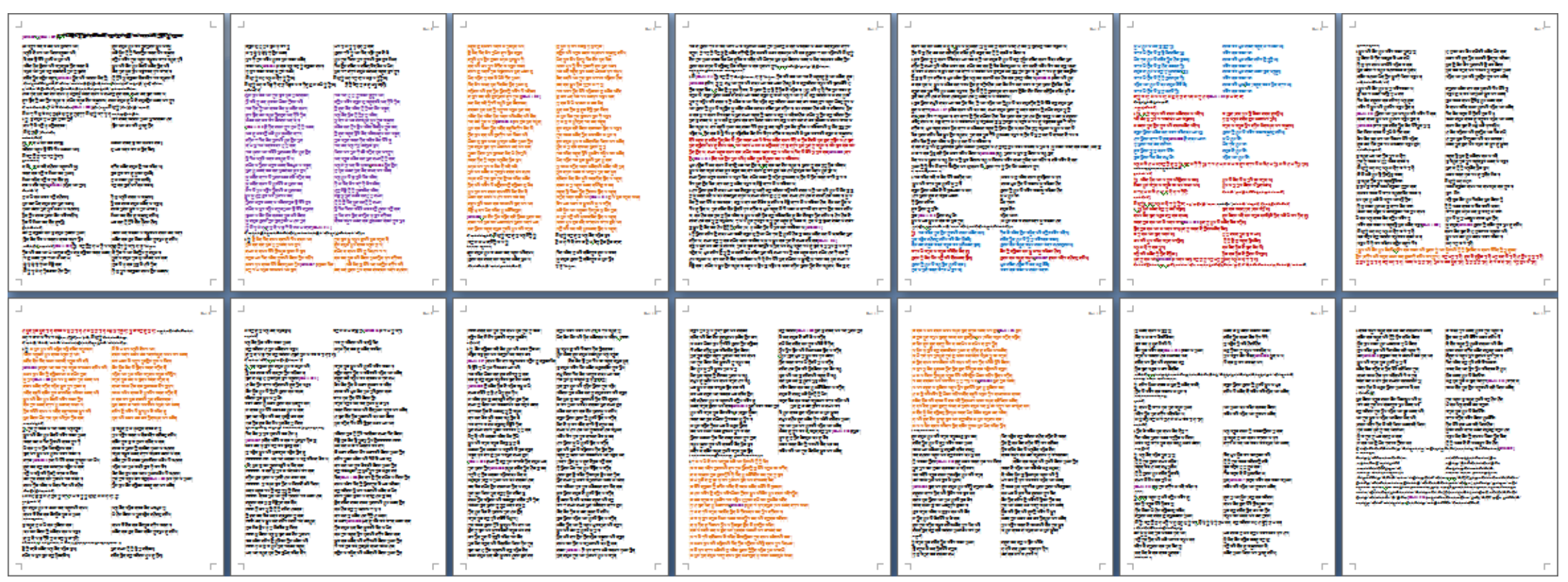

Figure 30: A transcription of the full Tibetan text of the Fifth Dalai Lama's Adamantine Melody. Contents copied from different sources are indicated by colors to illustrate a sense of growth and perspective. The blue lines indicate material from Nyangrel Nyima Özer's Ten-Chapter Sädhana, which was subsequently used in the Second Dalai Lama's Offerings and Praises; red lines are more material drawn from the Ten-Chapter Sädhana; orange is material from the Offerings and Praises; purple is material from Ratna Lingpa's Assembly of the Quintessential Mind Attainment; and black is the Great Fifth's own material, though it is likely some of it was drawn from other sources. 


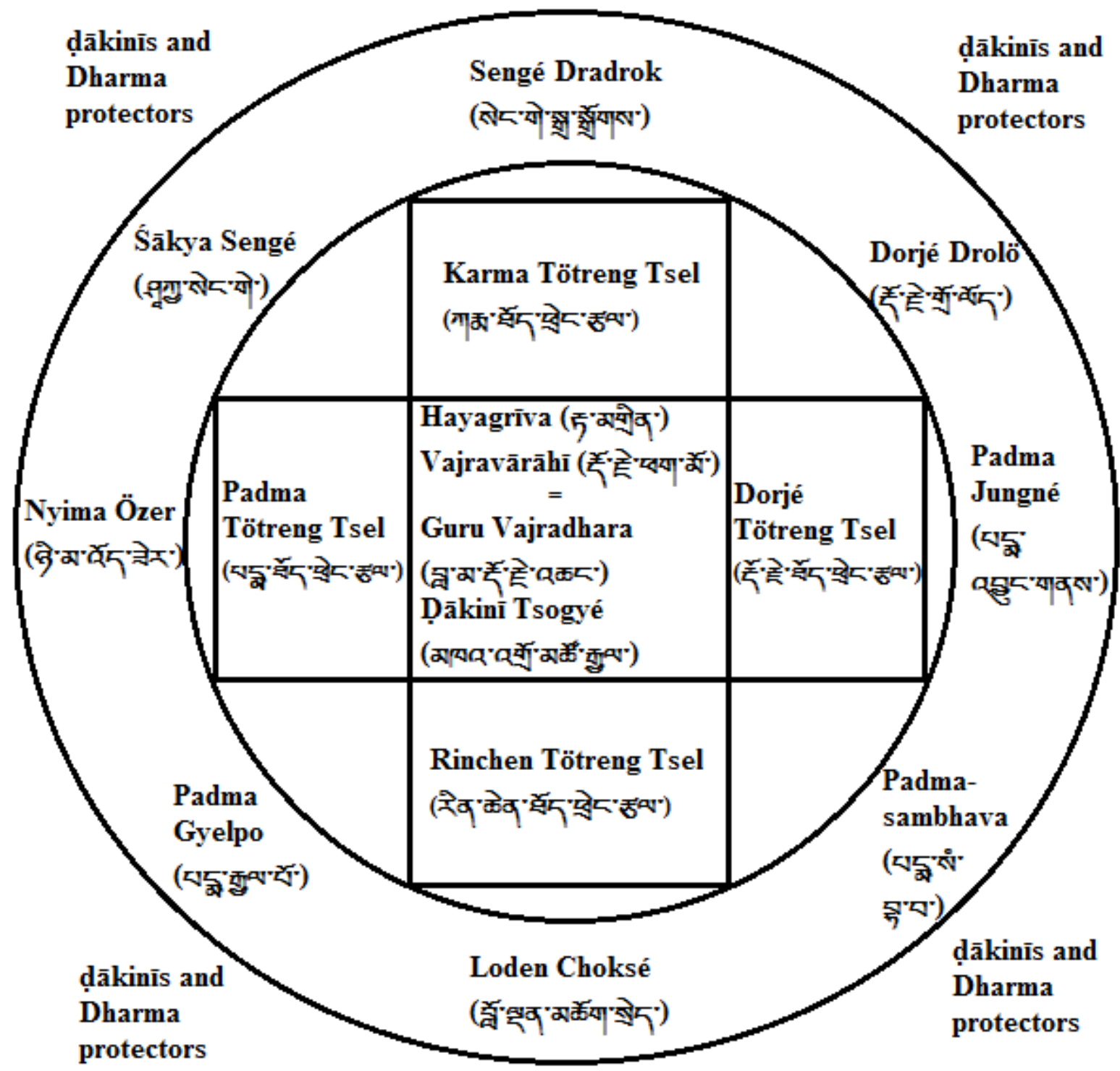

Figure 31: Ratna Lingpa's Assembly of the Quintessential Mind Attainment cosmology adopted by the Fifth Dalai Lama in the Adamantine Melody. 


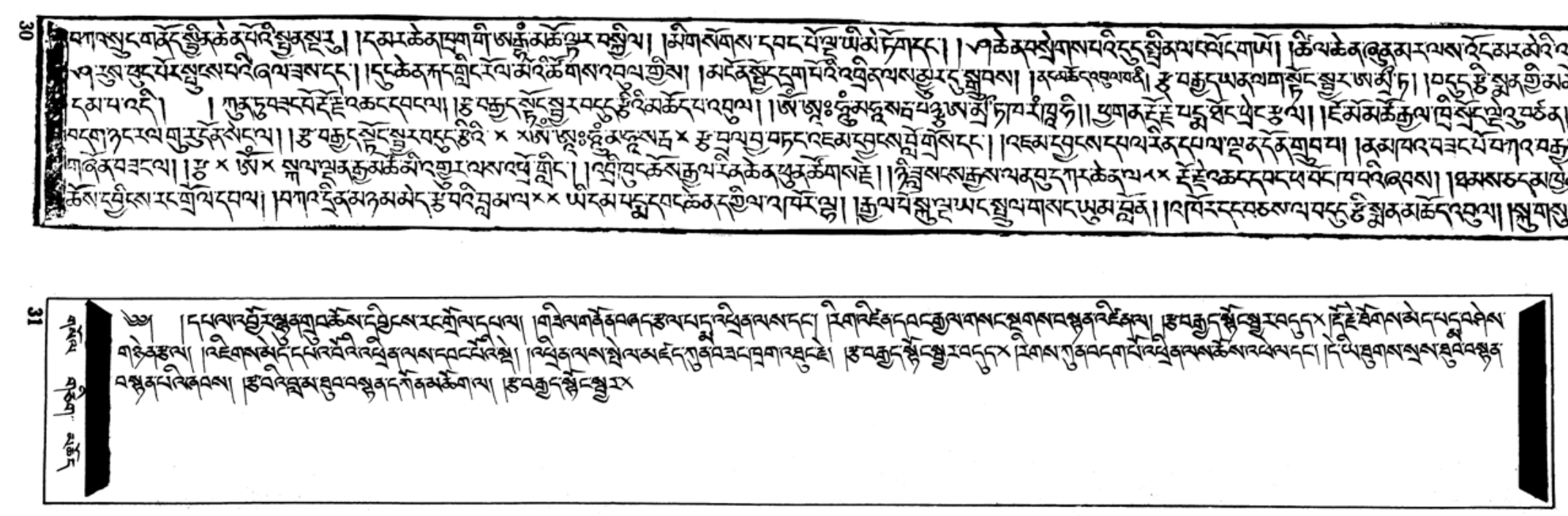

Figure 32: Digitized scans of two folio sides from the original Adamantine Melody manuscript in the Nechung Liturgy. Notice how the writing style and even the folio design is different between the folios; Lobzang Tondan 1983, pp.30-31. 


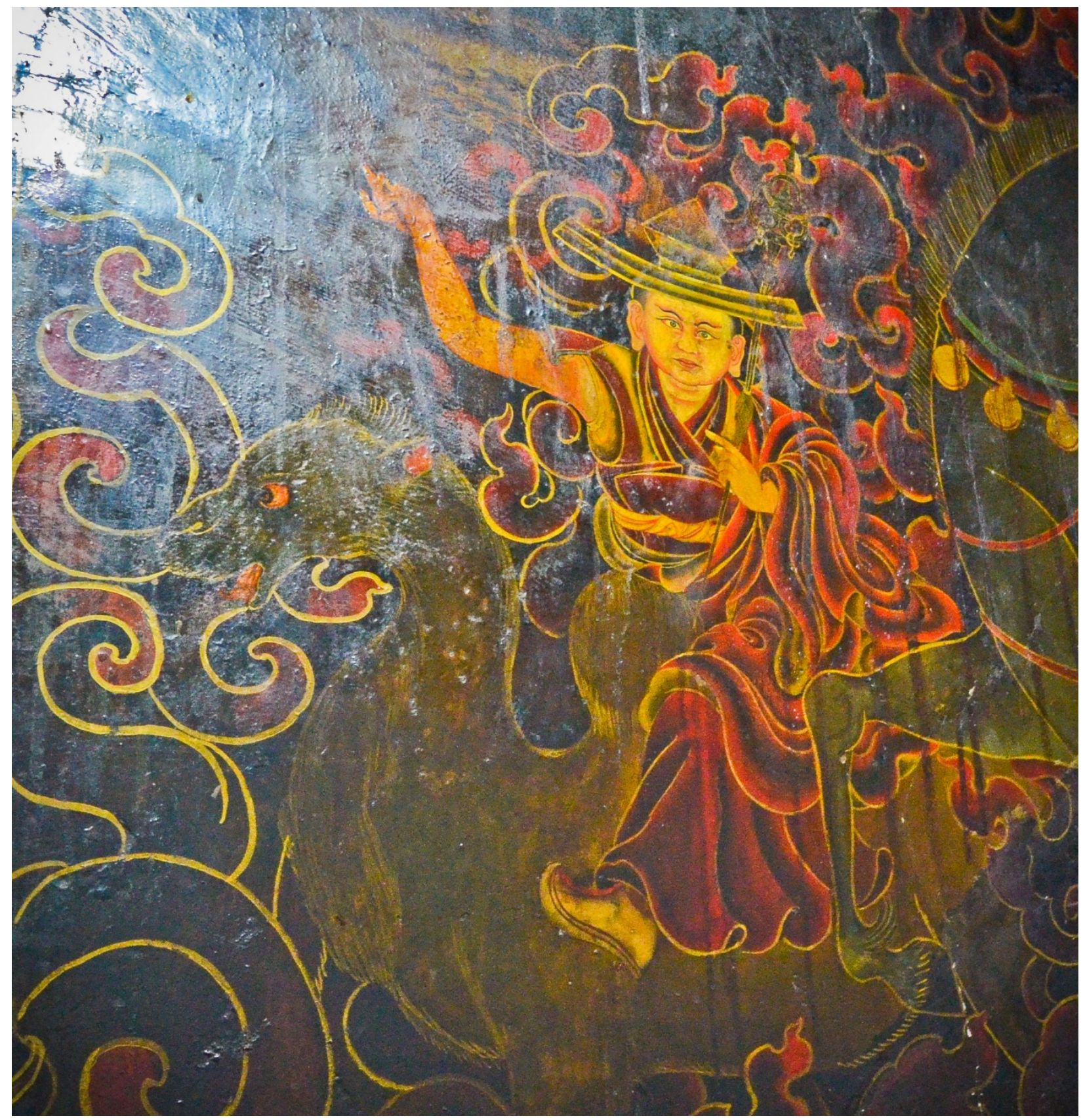

Figure 33: Mural of Dorjé Drakden as the minister of Kyechik Marpo, the western sovereign spirit of Speech; Meru Nyingpa Monastery Assembly Hall, Lhasa. (Photo: Cecilia Haynes, 2011) 


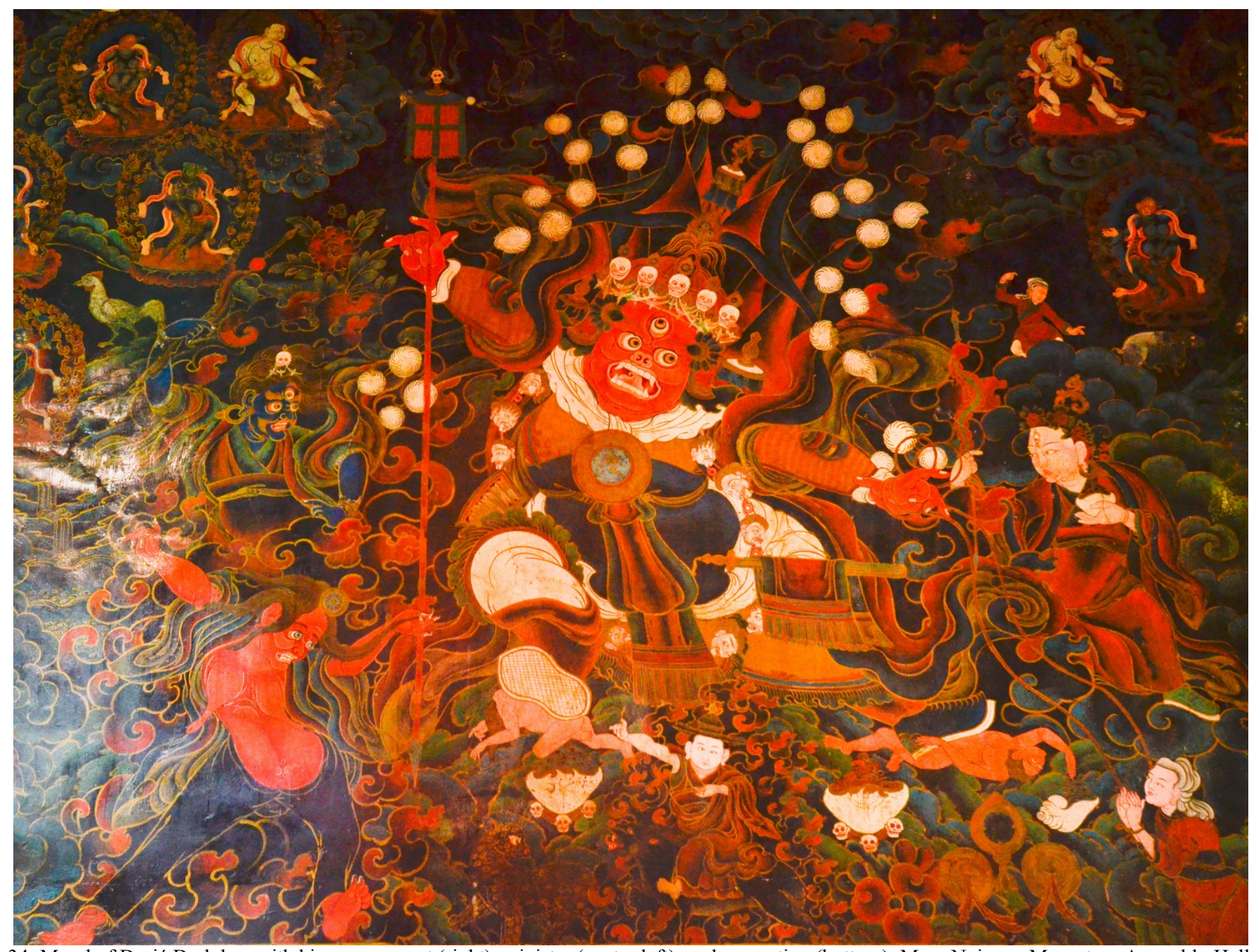

Figure 34: Mural of Dorjé Drakden, with his own consort (right), minister (center left), and emanation (bottom); Meru Nyingpa Monastery Assembly Hall, Lhasa. (Photo: Cecilia Haynes, 2011) 


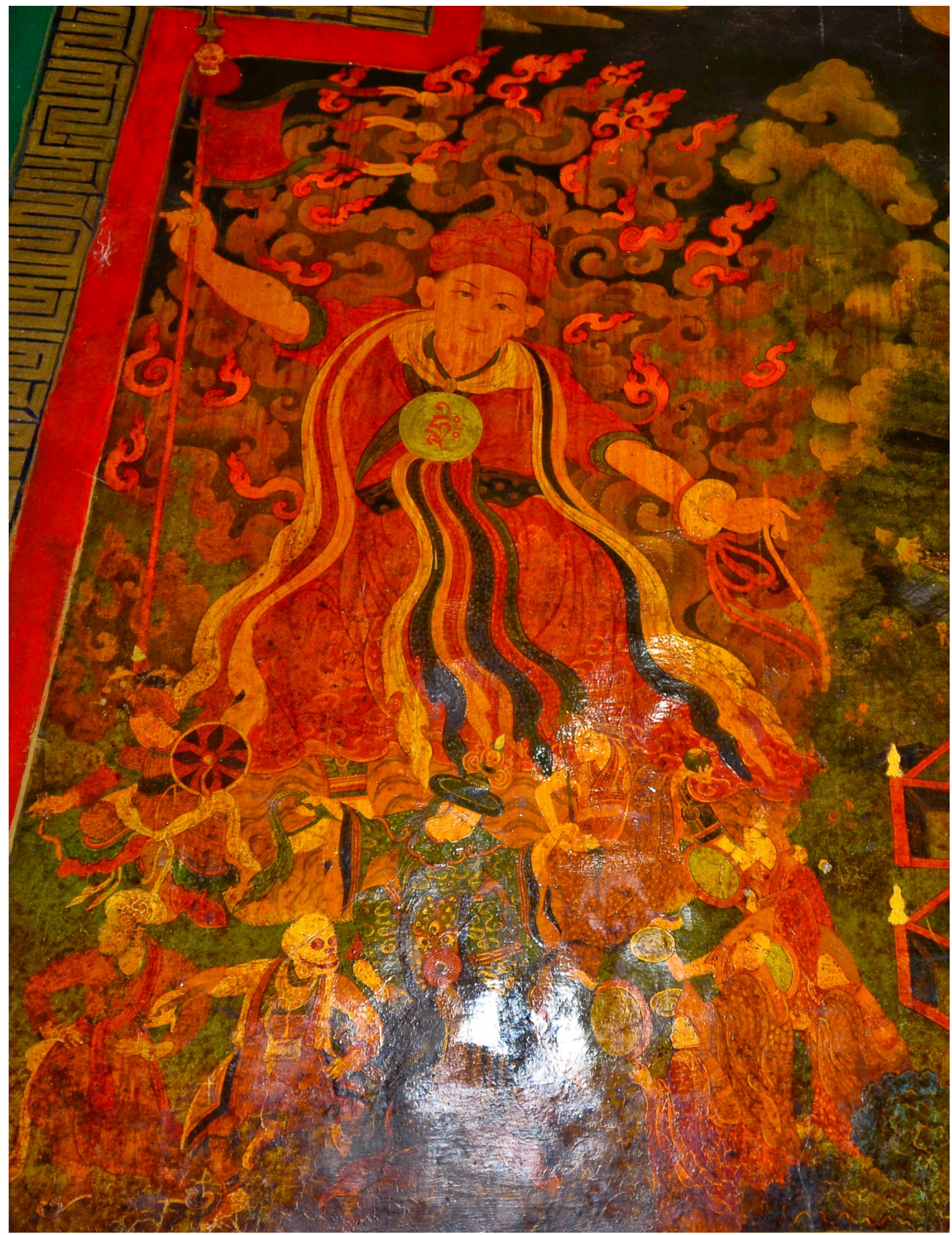

Figure 35: Mural of the Nechung Oracle in a trance surrounded by his retinue, who are performing ritual dances. This is said to be an image of Śākya Yarpel (Tib. Shākya yar 'phel), who acted as the Nechung medium from 18561900; Drepung Monastery, Deyang College Assembly Hall, Lhasa. (Photo: Cecilia Haynes, 2011) 


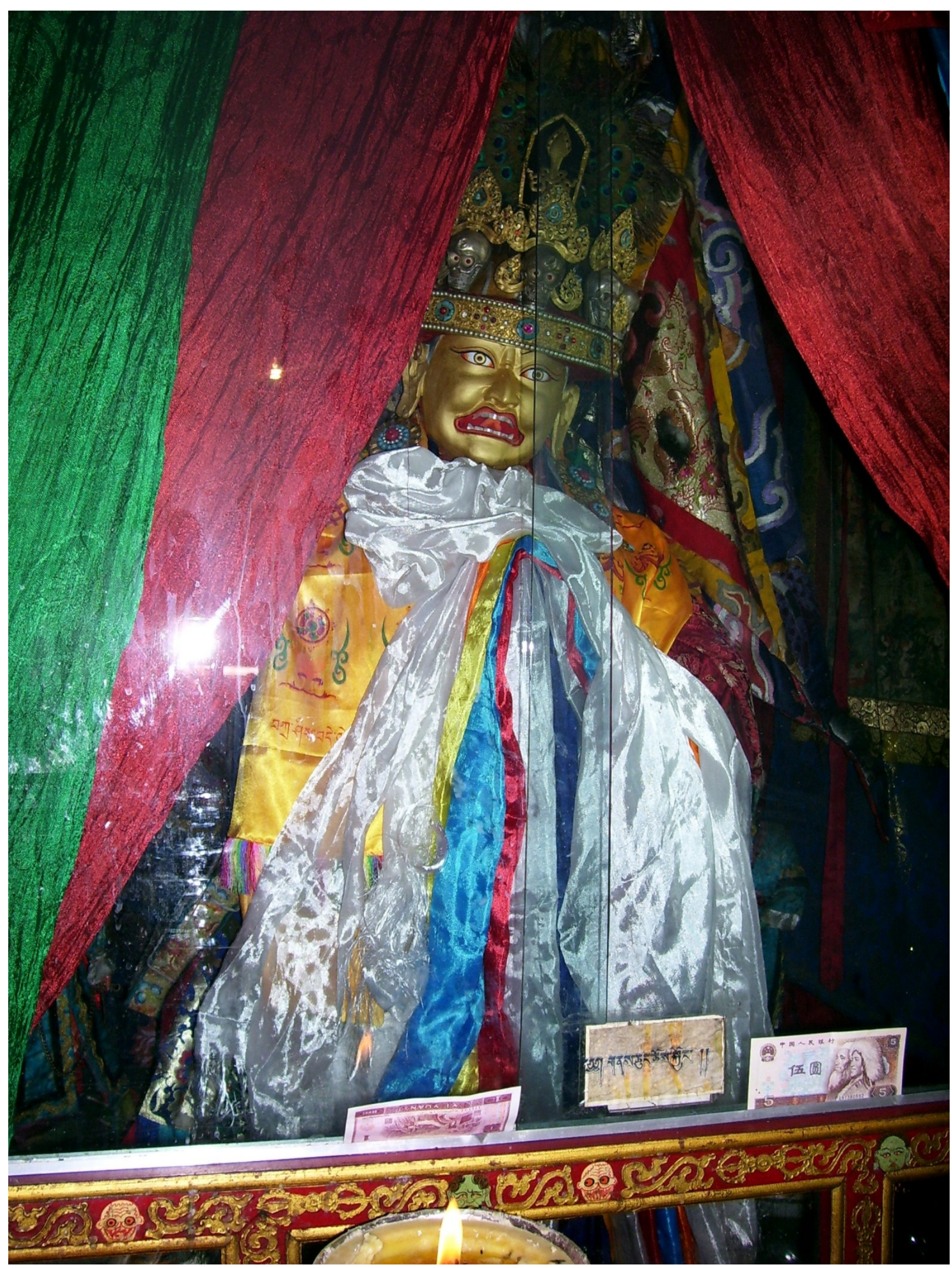

Figure 36: Statue of the Nechung Oracle, the central statue of Nechung Monastery. This image is likewise said to be a representation of the Nechung medium Sākya Yarpel; Nechung Monastery Central Chapel, Lhasa. (Photo: Christopher Bell, 2007) 


\section{Chapter 3: Nechung's Institutional Development}

The Fifth Dalai Lama built up Pehar's mythic and ritual presence at Nechung in the decades following his 1642 assumption of power. In tandem with this, the Nechung Oracle's involvement in the Great Fifth's affairs became more pronounced and Nechung Monastery was slowly built up. These activities came to a head in the early $1680 \mathrm{~s}$ when, after decades of stalled efforts, the monastery was fully renovated and expanded through the initiative of Regent Sangyé Gyatso. The regent coauthored the Nechung Register - the monastery's official narrative-with the Fifth Dalai Lama and gave Nechung the additional name of Palace of Adamantine Melody, based on the title of the Great Fifth's central ritual text. After the Dalai Lama's death in 1682, Sangyé Gyatso continued to support the Nechung cult and embellished the monastery until its full completion in 1690 .

As an institution, Nechung had a growing population of resident monks, an established narrative identity and ritual corpus, an oracle who acted as an ever-ready conduit for the Five Soverein Spirits, and a broadening array of affiliations with other monastic centers. The symbolic power of ancient Samyé Monastery, as embodied by Pehar, had been successfully wrested from Central Tibet's other major power brokers, the Tselpa Kagyüpa, transplanted to the Gelukpa monastery of Drepung, and intimately linked to the lineage of the Dalai Lamas through mythic, ritual, and institutional engineering. These efforts relied on preexisting sacred texts and sites, and were part of a larger program of legitimation that related the Fifth Dalai Lama's government back to King Trisong Deutsen's dominion. As reincarnations of key eighth-century figures, the Great Fifth, Sangyé Gyatso, and others in their cotorie presented themselves quite literally as the rebirth of Tibet's imperial past. Pehar, as an extension of that past, validated and bolstered the Great Fifth's rule through ritual invocation and oracular prophesy.

As the site of much of this activity, this final chapter introduces Nechung Monastery itself. First I describe the physical monastery in detail and analyze its symbolic dimensions based on observations made in situ. The mural and statue iconographies are especially indicative of Nechung's strong Nyingma origins, while still evincing solid historical ties to Geluk lineageholders and institutions. This is followed by a detailed exploration of Nechung's history, which is complicated by a dearth of sources and conflicting accounts. Nonetheless, I examine what 
materials there are and present a chronological presentation of the monastery's evolution. I then discuss the institution of the Nechung Oracle, which likewise had vague beginnings. From the available accounts, it is clear that Pehar was the dominant deity to possess the Nechung Oracle in the seventeenth century. Nonetheless, Dorjé Drakden still appears occasionally and a subtle shift is tangible by the turn of the eighteenth century. Both the Fifth Dalai Lama and Sangyé Gyatso refer to the possessing deity ambiguously as the "emanated Dharma protector of Nechung," making identification uncertain. However, Sangyé Gyatso refers to Kyechik Marpo and Dorjé Drakden in his writings far more than the Great Fifth does, shifting the focus from the Five Sovereign Spirits as a whole to the western sovereign spirit in particular. Nechung remains the special abode of the Five Sovereign Spirits, yet Kyechik Marpo and his minister became its primary residents, leaving most of the other sovereign spirits free to migrate to other sacred centers. The chapter ends by exploring this diffusion of the Nechung cult to monasteries and chapels in and around Lhasa, creating a ritual hegemony and securing the supremacy of the Dalai Lama's state cult. This process began in the seventeenth century but continued up to the twentieth century. The exact dates for when these sites were converted to the cult of the Five Sovereign Spirits are unknown. However, the change in their institutional affiliation is clearly evident in the transplantation of the cult's iconography, the distribution of its ritual corpus and related texts, and the employment of oracles that channel its deities at these sites. Nechung Monastery was expanded in the seventeenth century by the Fifth Dalai Lama and Sangyé Gyatso; however, they laid the groundwork for future Dalai Lamas to extend Nechung's cult until it encompassed all of Lhasa.

\section{Physical and Symbolic Architecture}

Nechung Monastery is nestled among the foothills of Gepel Utsé Mountain, ${ }^{1}$ about half a mile downhill from Drepung Monastery and less than five miles northwest of the Jokhang Temple (Figure 37). In pre-modern times Nechung was situated outside the boundaries of the city of Lhasa. Even by the early twentieth century Lhasa was little more than a large town situated around the Jokhang and Ramoché temples. ${ }^{2}$ However, in the last fifty years Lhasa has

\footnotetext{
${ }^{1}$ Tib. Dge 'phel dbu rtse.

${ }^{2}$ See Pommaret 2003, p.26. The Potala Palace used to be considered outside of Lhasa as well, and it had its own small village called Zhöl (Tib. Zhol) settled at its base; see ibid, pp.43-44.
} 
grown dramatically and exponentially under Chinese control. As a prefectural-level city, Lhasa's jurisdiction has spread well beyond the Potala Palace and Norbulingka Park, and easily extends to and beyond Dambak Marserchen, the village just below Nechung Monastery. For this reason, Nechung now sits comfortably at the outskirts of Lhasa and can be easily reached from the city center by car, cab, or bus.

Architecturally, Nechung Monastery is comprised of a single building that is about 68 meters long, 50 meters wide, and 23 meters high. The monastery has four floors, though the first one is generally unused except perhaps for storage. This minor floor is notable only for the central gate on its southern wall. According to oral tradition, this gate remains perpetually closed to bar the deity Dorjé Shugden from entering Nechung, either to usurp the monastery or to replace Pehar when the latter is officially promoted to a supramundane deity. ${ }^{3}$ The two main entrances to Nechung are instead on the east and west sides of its second and primary floor. The west gate is the principal entrance and it consists of a small veranda at the head of a flight of stairs. This threshold is flanked by murals of fierce deities known as the Black Butcher and Red Butcher (Figure 38). ${ }^{4}$

Past this entrance is Nechung Monastery's famous and expansive courtyard. The walls along the courtyard's colonnade are covered in extensive and highly detailed murals of the Five Sovereign Spirits' retinue (Figure 39). ${ }^{5}$ The important exception to this parade of deities is the wall inscription of the Nechung Register recorded on the courtyard's southern wall (Appendix III, Figure 98). At the north end of the courtyard is the monastery proper, which is three stories high (Figure 40). Stairs flanked by two Chinese guardian lions lead up to the monastery's portico and main entrance. This entrance consists of six high doors covered in gruesome paintings of flayed human skins. Like the western gateway to the courtyard, these doors are also surrounded by murals of the black and red threshold protectors, as well as other deities (Figure 41). The two central doors make up a single wide threshold, resulting in five entrances - representing the Five Sovereign Spirits. These two central doors are kept closed most of the year because only Pehar or Dorjé Drakden may pass through them; this was also the traditional point of entry for the Nechung Oracle when in trance. ${ }^{6}$

\footnotetext{
${ }^{3}$ See Nebesky-Wojkowitz 1998, p.445, and Dorje 2004, p.115.

${ }^{4}$ Tib. Bshan pa nag po and Bshan pa dmar po, respectively.

${ }^{5}$ Franco Ricca provides a comprehensive list of the deities within this painted retinue in his detailed monograph on Nechung's architecture and iconography; see Ricca 1999, pp.94-97.

${ }^{6}$ Personal correspondence with the Nechung chant master Pasang; Nechung Monastery, November 17, 2011.
} 
The main entrance leads into the monastery's sizeable 16-pillared assembly hall from which the other chapels and shrine rooms are accessible (Figure 22). Figure 42 provides a modified version of the Nechung Monastery floor plan created by Franco Ricca in his Il Tempio Oracolare di gNas-chun; it will be a useful reference point for the murals and sacred objects mentioned below. ${ }^{7}$ While the courtyard contains images of the Five Sovereign Spirits' retinue, the assembly hall has the deities themselves, as well as a number of others. Moving clockwise along the wall from the main entrance, the life-size murals of the assembly hall are as follows: ${ }^{8}$
a. Nechung Oracle (Figure 26)
b. Kyechik Marpo (Figure 4)
c. Gyajin (Figure 1)
d. Mantrabhīru (Figure 43)
e. Guru Vidyādhara ${ }^{9}$ (Figure 44)
f. Vajrakīlāya (Figure 45)
g. Yamāntaka (Figure 46)
h. Vajrāmṛta (Figure 47)
i. Master Padmākara (Figure 48)

j. Secret Sādhana Hayagrīva ${ }^{10}$ (Figure 20)

k. Viśuddha (Figure 49)

1. Lotus Speech Hayagrīva (Figure 50)

m. Mātara (Figure 51)

n. Lokastotrapujanātha (Figure 52)

o. Pehar (Figure 5)

p. Mönbuputra (Figure 2)

q. Shingjachen (Figure 3)

r. Nechung Oracle Tokbep Dzepa ${ }^{11}$ (Figure 53)

There are two primary groups of deities in this assembly hall pantheon: the Five Sovereign Spirits (b, c, o, p, and q), accompanied by their consorts, ministers, and emanations, and the Eight Sãdhana Deities of the Mahāyoga tantric system (d, f, g, h, k, 1, m, and n), represented in

\footnotetext{
${ }^{7}$ Ricca (1999, pp.43-68) provides the most extensive discussion of Nechung Monastery's architectural structure and design. Nebesky-Wojkowitz (1998, pp.445-448) offers a rudimentary floor plan and architectural discussion of the monastery; however, it is not nearly as extensive as Ricca's, nor is his floor plan as exact. Having never visited Lhasa, Nebesky-Wojkowitz relied on indirect sources and descriptions for his account. For a detailed discussion of Nechung's various chapels and their contents, see Tibetan Academy of Social Sciences 2009, pp.443-457.

${ }^{8}$ The following letters coincide with the assembly hall arrangement illustrated in Figure 42.

${ }^{9}$ Tib. Rig 'dzin slob dpon. Guru Vidyādhara is also a cosmic form of Padmasambhava. He is similar in iconography to Guru Vajradhara, who is at the center of the grand Buddhist universe to which the Five Sovereign Spirits were appended by the Fifth Dalai Lama in his Adamantine Melody; see Figure 31.

${ }^{10}$ Tib. Rta mgrin gsang sgrub. This form of Hayagrīva stands without his consort and is not part of the Eight Sädhana Deities.

${ }^{11}$ Tib. chos skyong chen po Thog 'bebs mdzad pa; lit. "the great Dharma protector, Lightning-Striker." This mural represents the Nechung Oracle possessed by Dorjé Drakden. Nechung monks have told me this is an image of Sākya Yarpel (Tib. Shākya yar 'phel), who acted as the Nechung Medium from 1856-1900. A variant of this name is thog phebs, which likewise refers to falling lightning, and it appears to be an epithet associated with Śākya Yarpel; see Tibetan Academy of Social Sciences 2009, p.446. The oracle here is surrounded by Tsiu Marpo's group of deities, the Seven Blazing Brothers.
} 
sexual union with their consorts. ${ }^{12}$ Added to the later group is Guru Vidyādhara (e), who is at the center of the Eight Sädhana Deities' mandala. The remaining figures are two Nechung Oracles (a and r), Padmākara (i), and another Hayagrīva standing apart from his placement among the Eight Sädhana Deities (j).

The positioning of these monolithic figures is as important as the figures themselves. Moving south to north, we have the murals of two Nechung Oracles flanking the main entrance and then the Five Sovereign Spirits spanning out from there. Beyond them are Guru Vidyādhara and the Eight Sädhana Deities. Finally, there is Padmākara, a form of Padmasambhava, and Secret Sädhana Hayagrīva, who are in mirrored positions at the north end of the walls. This represents a symbolic movement through different levels of tantric power. The deepest point of the assembly hall (north) signifies the highest level, the secret tantric power of Padmasambhava and the form of Hayagriva that he channeled to subjugate Pehar. Moving down (south), there is the inner tantric power of Guru Vidyādhara and the Eight Sädhana Deities, and then the outer tantric power of the Five Sovereign Spirits. Finally, there is the gross embodiment of such spirits in the form of oracles. Martin Mills makes an analogous observation of embodied architecture in Ladakh. The vertical axis of Ladakhi monasteries and homes, from the entrance to the back, represents a hierarchy of ritual purity and sacrality. The purest and most sacred area is the back, referred to as the 'head,' which is why the highest lamas sit there and on the highest seats. The seat height and religious status of individuals diminishes when one moves toward the entrance, the 'bottom,' which is why the laity sit closer to the entrance and polluting shoes are left at the door. $^{13}$ In a similar fashion, the 'head' of Nechung is clearly the most sacred, not only for its higher tantric murals but also because the monastery's three main chapels are located there, as are its sacred statues. The assembly hall murals embody this hierarchy with tantric power and ritual purity acting in tandem.

Before discussing Nechung's three major chapels, I will make a few final observations on the assembly hall's cosmography and institutional relationships. There are a few other smaller but significant murals in the assembly hall located above the chapel doors. Above the door to the Western Shrine Room are [1] Amitābha ${ }^{14}$ and [2] Amoghasiddhi ${ }^{15}$ (Figure 54a). Above the door

\footnotetext{
${ }^{12}$ See chapter 1 , note 313 .

${ }^{13}$ See Mills 2003, pp.48-52.

${ }^{14}$ Tib. Snang ba mtha' yas; this is the Western Buddha of the Padma Family.

${ }^{15}$ Tib. Don yod grub pa; this is the Northern Buddha of the Karma Family.
} 
to the Desire Realm Chapel are [3] White Tārā, ${ }^{16}$ Vairocana's consort, and [4] Vairocana himself ${ }^{17}$ (Figure 54b). Above the door to the Eastern Shrine Room are [5] Akșobhya ${ }^{18}$ and [6] Ratnasambhava ${ }^{19}$ (Figure 54c). These figures make up the heads of the Five Buddha Families, with the addition of White Tara, the consort of the central Buddha Vairocana. It is fitting that these figures are placed primarily around the Five Sovereign Spirits, since the latter deities are their emanations, as Regent Sangyé Gyatso explains. ${ }^{20}$ These images reveal yet another layer of Buddhist cosmology present within Nechung.

The Birch Tree Chapel also has small murals above its entrance representing the Dharma Lord Mönlampel, ${ }^{21}$ Lord Lodrö Tenpa, ${ }^{22}$ and Baso Chökyi Gyentsen ${ }^{23}$ - the eighth, seventh, and sixth abbots of Ganden Monastery, respectively (Figure 55). This progression suggests that murals of the remaining lineage of the seven Ganden abbots who followed after Tsongkhapa ${ }^{24}$ continue behind the statue casement covering the wall next to the Birch Tree Chapel. Murals of Tsongkhapa, the First Panchen Lama, and the First Dalai Lama ${ }^{25}$ are also likely behind this casement. ${ }^{26}$ While the murals of the Five Sovereign Spirits and Eight Sädhana Deities speak to the Nyingma origins of Nechung's rituals, this lineage of Ganden abbots indicates the monastery's deep connection to the Geluk school of Tibetan Buddhism.

This affiliation is strengthened by the six life-size statues encased at the northern end of the assembly hall. The first casement, situated against the wall between the Birch Tree Chapel and the Central Chapel, contains statues of the Seventh Dalai Lama, the Buddha Śākyamuni, and Tsongkhapa. The case against the wall between the Central Chapel and the Desire Realm Chapel contains statues of the Fifth Dalai Lama, Padmasambhava, and Regent Sangyé Gyatso. ${ }^{27}$ Last

\footnotetext{
${ }^{16}$ Tib. Sgrol dkar.

${ }^{17}$ Tib. Rnam par snang mdzad; this is the Central Buddha of the Buddha Family.

${ }^{18}$ Tib. Mi bskyod pa; this is the Eastern Buddha of the Vajra Family.

${ }^{19}$ Tib. Rin chen 'byung ldan; this is the Southern Buddha of the Ratna Family.

${ }^{20}$ See Appendix III, p.578.

${ }^{21}$ Tib. chos rje Smon lam dpal (1414-1491; TBRC: P451), the eighth abbot of Ganden Monastery.

${ }^{22}$ Tib. rje Blo gros brtan pa (1402-1476; P4636), the seventh abbot of Ganden Monastery.

${ }^{23}$ Tib. Ba so Chos kyi rgyal mtshan (1402-1473; TBRC: P432), the sixth abbot of Ganden Monastery and younger brother of Khedrupjé Gelek Pelzang (Tib. Mkhas grub rje Dge legs dpal bzang, 1385-1438; TBRC: P55), the first Panchen Lama.

${ }^{24}$ Tib. 'Jam dbyangs gtsang pa bdun brgyud; lit. "Lineage of the Seven Men of Tsang who are [like] Mañjughoṣa [Tsongkhapa]."

${ }^{25}$ Tib. Tã la'i bla ma 01 Dge 'dun grub pa (1391-1474; TBRC: P80). Together these three figures are known as 'the Three- - the Lord and his [two] Spiritual Sons' (Tib. Rje yab sras gsum).

${ }^{26}$ See Tibetan Academy of Social Sciences 2009, p.445.

${ }^{27}$ This last statue is unlabelled and I am grateful to Mikmar Tsering for identifying it for me; email correspondence, February 18, 2013.
} 
chapter we saw how important the Fifth and Seventh Dalai Lamas were in Nechung's ritual expansion; it seems they continue to have a strong physical presence at the monastery as well.

As previously noted, Nechung's three most important chapels are located at the back north end of the monastery's assembly hall. In the northwest corner is the Birch Tree Chapel, ${ }^{28}$ in the northeast corner is the Desire Realm Chapel, ${ }^{29}$ and between these two is the Central Chapel, ${ }^{30}$ the sanctum sanctorum. The Birch Tree Chapel is four pillars in size and is the oldest part of Nechung, representing the original Pehar shrine before its grand 1682 expansion (Figure 56). In the northwest corner of this chapel is Pehar's soul tree, ${ }^{31}$ into which he dissolved in the form of a bird and around which his original chapel was subsequently built (Figure 57). ${ }^{32}$ The historical and mythic details of this event will be elaborated upon below. The tree itself is encased and nearly obscured by other casements, but a thick branch protrudes from between two statues and is almost completely covered in Tibetan prayer scarves. ${ }^{33}$ The statue left of the tree branch is of Dorjé Drakden, though his wrathful face is constantly covered. The statue on the right is a smaller representation of the Nechung Oracle. In front of the branch and these images is an altar where devotees come to make offerings of Tibetan beer, milk, and yogurt, as well as prayer scarves. This area is surrounded by framed photographs of the current and previous Nechung Oracles. Other statues are arrayed along the walls of this small room, representing Tsongkhapa, the Seventh Dalai Lama, Padmasambhava, and various bodhisattvas.

While the Birch Tree Chapel is the historical heart of Nechung Monastery, the Central Chapel is its ritual heart. This chapel is also four pillars in size, though it has four major doors. Like the main entrance, the two middle doors are really one wide threshold and only the deity/oracle are allowed to pass through it. The Central Chapel is a smaller microcosm than the assembly hall, since it only contains the Five Sovereign Spirits and a few other related protector deities. Nevertheless, this room is the most sacred chapel on the first floor of the monastery because it was once the throne room for the Nechung Oracle himself. ${ }^{34}$ Prior to the Nechung medium's exile, this is the room in which he would go into trance on all the major monthly and annual occasions discussed in the previous chapter. If the oracle's presence was required in

\footnotetext{
${ }^{28}$ Tib. Gro sdong lha khang.

${ }^{29}$ Tib. 'Dod khams lha khang.

${ }^{30}$ Tib. Gtsang khang dbus ma.

${ }^{31}$ Tib. bla shing.

${ }^{32}$ For the physical location of this tree in relation to the monastery, see Figure 42, letter $\mathrm{x}$.

${ }^{33}$ Tib. kha btags.

${ }^{34}$ See Nebesky-Wojkowitz 1998, p.447; and Tibetan Academy of Social Sciences 2009, p.447.
} 
Nechung's courtyard, such as during Nechung Monkey Month, then he would pass through the two-door central entrance of the chapel and then through the two-door central entrance of the monastery. This axis is Nechung's central channel, representing the manifestation of the Five Sovereign Spirit's power and movement out into the world. Though the Nechung Oracle is no longer present, an encased life-size statue of the oracle stands in the middle of the chapel—it is the central image of this chapel and of the monastery as a whole (Figure 36). Other statues line the chapel's walls and two murals are visible on both sides of the entrance. Moving clockwise around the central statue from the entrance, the images of the Central Chapel are as follows: ${ }^{35}$
A. great enemy-defeating god ${ }^{36}$
I. Goddess of the Five Long-Life Sisters ${ }^{39}$ (Figure 58) (Figure 65)
B. Toktsen $^{37}$ (Figure 59)
J. Kyechik Marpo ${ }^{40}$
C. Gyajin (Figure 60)
K. Goddess Nyima Zhönnu ${ }^{41}$ (Figure 66)
D. Pehar (Figure 24)
L. Shingjachen (Figure 67)
E. Dorjé Drakden (Figure 61)
M. Mönbuputra (Figure 68)
F. Goddess Drakgyelma ${ }^{38}$ (Figure 62)
N. Tsiu Marpo (Figure 29a)
G. Makzor Gyelmo (Figure 63)
O. Jeché Keru ${ }^{42}$ (Figure 6)
H. Hayagrīva with consort (Figure 64)

\footnotetext{
${ }^{35}$ The following letters coincide with the Central Chapel arrangement illustrated in Figure 42.

${ }^{36}$ Tib. dgra lha chen po. This is a mural of a nameless enemy-defeating god, though it is a form or emanation of Pehar. This image is a classic representation of Tibetan horse-riding chthonic deities who act as guardians of the land. The following Tibetan quatrain is found beneath this mural: dgra lha chen po khyed rnams kyi/ bdag cag chos bzhin spyod pa la/ mi mthun rgyen rnams mi 'byung zhing / bsam don lhun gyi sgrub par mdzod//. This can be translated as: "May all you great enemy-defeating gods act [toward] us in accordance with the Dharma! Do not bring about discordant causes [but rather] accomplish spontaneously whatever we desire!"

${ }^{37}$ Tib. Thog btsan; this deity is an officer in Pehar's retinue and a threshold protector like the Black and Red Butchers. A medium of this deity had close ties to the family of the Nechung medium Gyentsen Tarchen (Tib. Rgyal mtshan mthar phyin), who was installed in 1913; see Nebesky-Wojkowitz 1998, p.132.

${ }^{38}$ Tib. lha mo Grags rgyal ma; a variant of this name is Dorjé Drakmogyel (Tib. Rdo rje grags mo rgyal), who was briefly encountered last chapter as one of the deities in the Second Dalai Lama's Offerings and Praises. This goddess is the leader of the Twelve Tenma Goddesses; she is also a central protector of Drepung Monastery and resides on Gepel Mountain above Drepung.

${ }^{39}$ Tib. lha mo Tshe ring mched lnga; there is only one statue representing these five goddesses, though it is unclear which of these deities it is.

${ }^{40}$ Unfortunately, no image of this statue is available due to it being consistently covered by curtains.

41 Tib. lha mo Nyi ma gzhon nu.

${ }^{42}$ This is the second mural in the chapel. The following Tibetan quatrain is found beneath it: 'dod [sic: gdod] nas sgrib bral ngo bo byang chub byang / rang bzhin lhun grub ma 'gags snang cha'i rtsal/ las shar chos rgyal byes chas ke ru yi/ lag len 'khrigs su sdebs par gnang ba stsol/. This can be translated as: "The Dharma King Jeché Keru manifests through the power of the unobstructed apparent aspect of spontaneously self-existing, primordial, untainted, and perfected enlightened nature. May we be given permission to properly arrange his practices!"
} 
Even more than in the assembly hall, Dorjé Drakden and the Five Sovereign Spirits are the central deities of this array $(\mathrm{C}, \mathrm{D}, \mathrm{E}, \mathrm{J}, \mathrm{L}$, and $\mathrm{M})$. The nameless great enemy-defeating god and Jeché Keru (A and O) usher the devotee into the sanctum, while Toktsen and Tsiu Marpo (B and $\mathrm{N}$ ) act as door guardians. The remaining protector deities are goddesses with significant historical ties to the Five Sovereign Spirits. Drakgyelma and the Five Long-Life Sisters (F and I) have been part of the Dalai Lamas' lineage since the Second Dalai Lama, given their presence in the Offerings and Praises. Makzor Gyelmo (G), as previously discussed, is the other major protector of the Tibetan government alongside the Nechung protector; she has been tied to the Dalai Lamas since at least the Great Fifth.

The last goddess is Nyima Zhönnu (K), who is unique for being comparatively late. This deity was a personal protector of the eighteenth-century Geluk master Lelung Jedrung Zhepé Dorjé, who composed the Ocean of Oath-Bound Guardians. The Nechung Liturgy contains one ritual by this author and it is dedicated to the deity Nyima Zhönnu. This short text was composed in 1728 in recognition for the deity having aided the Seventh Dalai Lama when he had health issues. ${ }^{43}$ Considering the Seventh Dalai Lama's involvement in the evolution of Nechung's ritual corpus, this ritual for Nyima Zhönnu was likely added shortly after its composition and the deity herself subsequently installed at the monastery. When I have asked about Nyima Zhönnu, Nechung monks have told me that she is the protector of the land on which Nechung Monastery rests. This deity illustrates the potential anacronism that can creep in with an analysis of a monastery's deity pantheon. Like rituals, pantheons accrete. One must be cautious of the history at work in these arrays without presuming that such arrangements are static or have always been present since their establishment. This is especially the case in the Central Chapel, given that it was once the throne room for the Nechung Oracle. Fortunately, the Nechung Register is fairly explicit about the monastery's contents at the time of its renovation. ${ }^{44}$

The most powerful deities in the Central Chapel are Hayagrīva and his consort $(\mathrm{H})$. Unsurprisingly, these two entwined figures are also the central deities of the array, positioned as they are at the exact center back of the chapel and with seven protectors on each side. There is a simpler reduplication of the sacred vertical axis observed in the assembly hall. The lesser deities are present near the bottom of the chapel, at the entrance; the higher protector deities, such as the

\footnotetext{
${ }^{43}$ See text 30 of Appendix I, and Lobzang Tondan 1983, vol. 1, p.130.

${ }^{44}$ See Appendix III, pp.566-573. For a discussion of the Central Chapel's pre-modern contents, see Tibetan Academy of Social Sciences 2009, pp.447-448.
} 
Five Sovereign Spirits, Five Long-Life Sisters, and Makzor Gyelmo, span out along the sides; and finally Hayagriva, the high tantric deity in union with his consort, lords over the others from the sacred head of the chapel.

The third major chapel of Nechung Monastery's first floor is the Desire Realm Chapel, which is also four pillars in size. This name is a literal translation of the Tibetan, though it would perhaps be more accurate to call it the Dhūmāvatī Chapel, since it is named for this goddess who is the 'Queen of the Desire Realm.' This deity was noted in chapter 1 for having eerily similar iconography to Shingjachen's consort, Sergyi Putrima. The chapel's name is also indicative of the form of Penden Lhamo at Tsel Gungtang, who is likewise called 'Queen of the Desire Realm,' one of the three daughters of Penden Lhamo Makzor Gyelmo. ${ }^{45}$ This is likely where the chapel's name derives from, since it maintains a connection to Pehar's former abode in Tsel. Regardless, this chapel is dedicated to Penden Lhamo more broadly and goddesses dominate the contents of the room. The west and north walls are mostly covered with a large long casement that contains the year-long torma offerings. The cases are all wood and kept closed most of the year, though they are beautifully painted (Figure 69). These paintings illustrate the iconographic qualities and possessions of Tsiu Marpo, Drakgyelma, the Goddess of the Five Long-Life Sisters, Nyima Zhönnu, Makzor Gyelmo, Dorje Drakden, and the Five Sovereign Spirits - most of the same figures found in the Central Chapel. There are no other murals to speak of and the remaining wall space of the room is obscured by encased statues. On the remainder of the north wall there is the Buddha Śākyamuni and Hayagrīva with his consort. Along the east wall moving clockwise, there are the goddesses Ekajațā, Makzor Gyelmo, and Nyima Zhönnu. The chapel is also notable for housing a large thread-cross mansion for Penden Lhamo, taken out only once a year for ritual purposes (Figure 70).

On the second floor of Nechung Monastery, above the assembly hall and just as large, there is the "world chamber, ${ }^{46}$ in which the Dalai Lama would reside during teachings and

\footnotetext{
${ }^{45}$ See Sørensen, Hazod, and Tsering Gyalbo 2007, p.594.

${ }^{46}$ Tib. 'dzam gling gzim chung. There is some disagreement over where and what this space is. Ricca (1999, pp.63-64) places it over the area of the Central Chapel and refers to it as the residence of the Dalai Lama while at Nechung. This seems unlikely, given the small space and the presence of a giant Padmasambhava statue there, to be discussed below. It is possible this space was the Dalai Lama's apartment once; however, there is another building just north of Nechung, but part of the monastery's grounds, that Nechung monks have told me was the Dalai Lama's former apartment. Lingön Padma Kelzang places the 'world chamber' directly above the assembly hall, since it is 16-pillars large; see Tibetan Academy of Social Sciences 2009, p.452. I was unable to visit the room myself, so I could not confirm; however, I accept Lingön Padma Kelzang's assessment given that his is the older and more direct
} 
meetings with the Nechung Oracle. North of this area, taking up two floors and sitting right above the Central Chapel, there is a two-story tall statue of Guru Nangsi Zilnön, ${ }^{47}$ a fierce form of Padmasambhava (Figure 71). This statue was installed in 1981 over the course of renovating the monastery after it was damaged during the Cultural Revolution. ${ }^{48}$ Except for the large statue's enclosure, and a small chapel facing it, the third floor is uncovered and acts as the roof for the rest of the monastery. These other spaces of the monastery illustrate a more overt hierarchy. The Dalai Lama, as Avalokiteśvara incarnate, is spiritually and thus physically higher on the second floor than the Five Sovereign Spirits on the first floor. Likewise, Padmasambhava, who is often called the Second Buddha ${ }^{49}$ or the Buddha of the Three Times, ${ }^{50}$ is represented by the largest statue in the monastery. This image starts on the second floor but rises up to the outcropping third and final floor, thus making him higher than the Dalai Lama.

Nechung Monastery presents us with a complex cosmology that resonates with multiple registers in the Tibetan Buddhist pantheons. On a two-dimensional plane, there is an axis of tantric power moving from the head of the monastery to the bottom. The central figure of Nechung Monastery is the Nechung Oracle, who embodies Dorjé Drakden and the Five Sovereign Spirits, and whose presence is still remembered at the monastery in the form of its central statue. This image is at the heart of Nechung, and from it the Five Sovereign Spirits and other important protector deities emanate while being under the control of Hayagrīva. These deities reverberate out into the assembly hall, joining Padmasambhava and the Eight Sädhana Deities. Moreover, the lords of the Five Buddha Families make an appearance, situated above the Five Sovereign Spirits as a reminder of their ultimate origins. The lesser deities of the Five Sovereign Spirits' retinue then radiate out through the courtyard murals. Three-dimensionally, there is a hierarchy of enlightenment. The worldly deities of ambiguous enlightened ontology reside on the first floor; the enlightened bodhisattva embodied by the Dalai Lama presides over them from the second floor; and the tantric Buddha Padmasambhava watches over it all from the third floor. ${ }^{51}$

source. Nevertheless, I agree with Ricca's description of this larger space above the assembly hall; see Ricca 1999, p.63. Also see Ricca 1999, Plate (Tav.) 20, for a photograph of this space.

${ }^{47}$ Tib. Gu ru Snang srid zil gnon.

${ }^{48}$ See Ricca 1999, p.64, and Tibetan Academy of Social Sciences 2009, p.455.

${ }^{49}$ Tib. sangs rgyas gnyis pa.

${ }^{50} \mathrm{Tib}$. dus gsum sangs rgyas.

${ }^{51}$ For a parallel with Ladakhi household cosmology, see Mills 2003, pp.153-164. 
Lastly, Nechung's iconographic and architectural configuration is interspersed with reiterations. Images of the Five Sovereign Spirits and other deities are found in several chapels as well as the assembly hall. There are numerical iterations, such as the Five Buddha Families, Five Sovereign Spirits, and Five Long-Life Sisters. There are also replications in relationships, such as Hayagrīva ruling over the deities of the Central Chapel, Padmasambhava and Hayagrīva ruling over the deities of the assembly hall, and Padmasambhava ruling over the monastery's entire divine population. An especially notable reduplication is found in the images of deities with their consorts: Guru Vidyādhara and the Eight Sädhana Deities, Vairocana and White Tara, and Hayagriva with his consort in the Central Chapel. The assembly hall murals of the Five Sovereign Spirits are also accompanied by their consorts, alongside their ministers and emanations. I contend that the very structure of the monastery duplicates this relationship. The Birch Tree Chapel in the northwest corner represents Pehar, perhaps in his most ancient form as Shingjachen, and the Desire Realm Chapel in the northeast corner represents Dhūmāvatī, a counterpart to Shingjachen's consort Sergyi Putrima.

However, it is interesting that Dhūmāvatī is not actually present in her own chapel. Rather it is Makzor Gyelmo and other goddesses tied to the Dalai Lamas that are prominently placed within this room. Given that both Dhūmāvatī and Makzor Gyelmo are considered forms of Penden Lhamo, it is easy enough to mix the two, allowing one form to eventually dominate. The chapel's name reveals its origins while its contents reveal its evolution. It appears that Dorjé Drakden and Penden Lhamo Makzor Gyelmo were eventually established as central figures at Nechung - over and above Pehar and Dhūmāvatī - due to their growing importance to the Dalai Lama's government. Indeed, it is a ritual to Makzor Gyelmo, not Dhūmāvatī, that has been appended to the edition of the Fifth Dalai Lama's Adamantine Melody found in the Nechung Liturgy. This subtle transition is especially noteworthy at Meru Nyingpa Monastery, where Dorjé Drakden and Makzor Gyelmo are much more clearly the central figures, as will be shown below. When discussing this matter with Nechung monks, the answer has usually been that Dhūmāvatī and Makzor Gyelmo are the same, just as Pehar and Dorjé Drakden are often conflated. Yet this overlaying of deity identities elides the slow historical change that takes place whenever a deity gets more ritual attention, becomes the greater focus of oracular pronouncements, or is promoted in status through the visions and dreams of authority figures.

We have seen how rituals and pantheons accrete; in our discussion of Dorjé Drakden last chapter, we also observed how deities can do the same. A similar process no doubt took place 
with Makzor Gyelmo, though given our focus on Nechung we can only discuss her briefly here. Nechung Monastery illustrates divine relationships synchronically as well as diachronically. The significance, forms, and names of deities change gradually over time, and sacred centers like Nechung are one of the cauldrons where this alchemy takes place. Nechung Monastery represents the intersection of particular myths, rituals, devotional acts, prophesies, and divine contact, all of which converge to create a distinct institutional character. The architecture and shifting contents of Nechung are important, but they all extend from its unique history.

\section{The Many Histories of Nechung Monastery}

The history of Nechung Monastery is not well-documented. In fact, the Nechung Register presently stands as the only history of Nechung from the seventeenth century, and it is fairly light on Nechung's activities prior to the renovation. The second most explicit resource is the Hagiography of Jokpa Jangchup Penden (Appendix IV), composed within a century after 1682. This work refers to events that occurred over a century before Nechung's renovation. Prior to this period, there is no known mention of Nechung in the Tibetan historical record. ${ }^{52}$ Given this paucity of materials, our only recourse is to rely on oral tradition in tandem with the few historical documents we have at our disposal. Oral history is important in its own right; however, its limitation is that it is difficult to trace to specific centuries without textual or archeological references. Fortunately, some of the important elements in Nechung's history have topographical or artifactual support, which will be cited below.

There are three modern Tibetan accounts of Nechung's oral history, as well as one English account. Lingön Padma Kelsang's Tibetan account is the oldest, having been culled in the 1980s. ${ }^{53}$ Tupten Püntsok's Tibetan account was published much more recently; ${ }^{54}$ nonetheless, this account is at least two decades old since it was the basis for the English account published in $1992 .{ }^{55}$ Moreover, in many instances Tupten Püntsok's wording is exactly the same as Lingön Padma Kelsang's, strongly suggesting that the former had access to and copied material from the latter-unless there is an unknown common source that both used. The newest

\footnotetext{
${ }^{52}$ See Mig dmar tshe ring 2010, pp.13-14.

${ }^{53}$ See Gling dbon Padma skal bzang 1988, pp.33-38. This material was reprinted in Tibetan Academy of Social Sciences 2009, pp.439-443.

${ }_{55}^{5}$ See Thub bstan phun tshogs 2007 , pp.3-5, 10-12.

${ }^{55}$ See Tsepak Rinzin, et al. 1992, pp.20-22.
} 
Tibetan account is from Mikmar Tsering's book on Nechung Monastery, material for which was drawn from Lingön Padma Kelsang's text in addition to new research. ${ }^{56}$ These accounts are consistent with one another and have very few discrepancies, likely because they all primarily stem from Lingön Padma Kelsang's materials and are also based on interviews conducted at Nechung. The following disjointed narrative predominantly draws from Lingön Padma Kelsang's work, given its primacy, though it still refers to the other sources when necessary: ${ }^{57}$

\section{Nechung Yulokö Shrine}

According to tradition, Nechung Monastery began with a prophecy. In the time of King Trisong Deutsen, the translator Vairocana once went to the place where Nechung Monastery would come to be located. There he saw various miraculous signs manifest around a birch tree, so he told master Padmasambhava about it. ${ }^{58}$ The master prophesied, "That birch tree is Pehar's soul tree (Figure 57), and the pond nearby is Pehar's soul lake (Figure 72). ${ }^{59}$ In the future a monastery will appear at this place.” Later, Prince Muné Tsenpo ${ }^{60}$ established a small monastery at this site and placed four monks there. Samyé was known as the 'Great Abode' (Nechen) ${ }^{61}$ and so this area was called the 'Small Abode' (Nechung). Ba Penyang ${ }^{62}$ was appointed abbot, and he brought a sacred image of Tārā from Samyé and installed it there. Thus, this place was given the name Nechung Yulokö. ${ }^{63}$ Afterward, a village arose in the vicinity of the monastery and was

\footnotetext{
${ }^{56}$ See Mig dmar tshe ring 2010, pp.12-21.

${ }^{57}$ See Tibetan Academy of Social Sciences 2009, p.439; Thub bstan phun tshogs 2007, p.3; Tsepak Rinzin, et al. 1992, p.20; and Mig dmar tshe ring 2010, p.12.

${ }_{58}^{58}$ For another oral tradition connecting the monk Vairocana with Pehar, see chapter 1, note 153.

${ }^{59}$ Tib. bla mtsho. After the Cultural Revolution this small pond was apparently filled in and lay housing was built on top of it. In effort to regain some of the sacredness of the site, the house is no longer in use and is locked against outsiders. The now-enclosed site of the soul lake is just northwest of the monastery proper, a minute walk uphill. See Figure 42 for further orientation.

${ }^{60}$ Tib. Mu ne btsan po, b.774. This was the first of King Trisong Deutsen's sons to succeed him, though his reign did not last long; see Sørensen 1994, pp.404-407.

${ }^{61}$ Tib.gnas chen; presumable this name implies the 'great abode' of Pehar.

${ }^{62}$ Tib. Sba dpal dbyangs. This figure appears to be the famous Dba' dpal dbyangs, who was one of the first Tibetan Buddhist monks. He was also one of the major figures who espoused the gradual school of Indian Buddhism during the great debate at Samyé Monastery; see van Schaik and Doney 2007, pp.190-193.

${ }_{63}^{63}$ Tib. Gnas chung g.yu lo bkod; lit. "Small Abode, [Paradise] Arrayed in Turquoise Petals." This refers to the name of Tārā's Buddha land (Tib. G.yu lo bkod pa'i zhing).
} 
named after it. To this day the village of Yulokö still exists (Figure 73). ${ }^{64}$ This legend is very well-known.

None of this information is corroborated by eighth-to-ninth-century Tibetan documents, the Dunhuang materials, or even the standardized histories written after the eleventh century. However, it is known that Prince Muné Tsenpo, during his brief kingship, was involved in a number of social projects that included the establishment and expansion of religious institutions. ${ }^{65}$ For its part, this narrative contains a deceptive degree of verisimilitude that makes it difficult to immediately falsify. Here I am using verisimilitude in the manner that Elizabeth Clarke defines it, as a practice meant "to convince an audience that the deed or the speech might have been done or said as represented." ${ }^{66}$ Clarke elaborates on this notion as it has been developed by historians of Greek historiography:

"Verisimilitude," [Torry James] Luce asserts, for the Greek historians "was equivalent to veracity." ${ }^{, 67}$ Particularly important in this rhetorical context was the role of the inventio, the elaboration of events or speech by the historian, the only test for which was its probability. A prime example is Thucydides' history of the Peloponnesian War: despite the author's being hailed as a forerunner of Leopold von Ranke, for sections of his history there remain no other sources with which to compare his narrative. ${ }^{68}$

I should add that, in the Tibetan case, the authority of high lamas and religious masters who assert or support these narratives buttresses the convincing quality of verisimilitude. Inventio is also legitimized as a form of memory, maintained and recovered over lifetimes not unlike treasure texts. Here the origin of Nechung is given an elaboration not wholly contradictory to the origin story posited in the narrative of chapter 1. The monastery is thus called Nechung, the 'Small Abode,' in contrast to Pehar's 'Great Abode' of Samyé Monastery. Nonetheless, there is no way to know with certainty that this was how Nechung's origins were understood by the Fifth Dalai Lama and his regents; it is possible this was a later elaboration created as the monastery's

\footnotetext{
${ }^{64}$ Today a small collection of modern houses make up the remnants of this village, which is situated about a hundred yards east of Nechung and is separated by a meandering brook.

${ }^{65}$ See Sørensen 1994, ibid.

${ }^{66}$ Clarke 2004, p.168; emphasis in the original.

${ }^{67}$ Quoting T.J. Luce's The Greek Historians (London: Routledge, 1997), p.3.

${ }^{68}$ Clarke 2004, ibid; emphasis in the original.
} 
prestige grew. Oral tradition does not revisit Nechung again until Pehar's prophesied arrival, and when it does it is fraught with historical discrepancies.

\section{Nechung Chapel ${ }^{69}$}

We have already discussed the story of Pehar's arrival at Nechung in $1529 .^{70}$ According to the Hagiography of Jokpa Jangchup Penden, Pehar is evicted from Tsel by the region's myriarch Dönyö Dorjé. He then arrives on the shores of the Kyichu River below Drepung Monastery and is invited there with great fanfare by Jokpa Jangchup Penden. A small abode is later built near Dambak Marserchen village for the deity and his sacred items. This account is detailed and likely dates to the late seventeenth century, yet it is virtually unknown compared to a much more popular and convoluted version of events. The British explorer L.A. Waddell composed the oldest English version of this legend in 1895:

[T]he spirit of Pehar entered into a resident of Ts'al-gun-t'an [Tsel Gungtang], and said to a Lāma named Z'añ [Lama Zhang], "Let us go to Udyāna [Uḍ̣̣iyāṇa] (the country of Padma-sambhava)." The Lāma then shut up the possessed man in a box, which he flung into the river Kyi[chu]. Now the abbot of De-pung [Drepung] had prophesied the previous day to his pupils, saying, "A box will float down the river, go find it and seize it." The pupils found the box and brought it to the spot where the Nä-ch'un [Nechung] temple now stands, namely, about one mile to the S.E. of De-pung, and there they opened it, and lo! a great fire came out and disappeared into a tree, and the dead body of a man was found in the box; but by the prayers of the abbot the spirit consented to return to the body. And the resuscitated corpse, refusing to enter the pure monastery of De-pung on the plea of being uncelibate, requested to be granted "a small dwelling" where he stoodhence the name of the place Nä-ch'un or "the small dwelling.,"71

\footnotetext{
${ }^{69}$ Tib. Gnas chung lcog. This term was used for Nechung before its 1682 renovation, and sometimes it is still used in shorthand. The term $l \operatorname{cog}$ refers to a particular Tibet structure akin to a turret. One of the definitions Goldstein provides is "a smaller edifice on top of [a] larger building; see Goldstein 2001, p.347. This basic structure is visible at Nechung today, with the highest and smallest part of the monastic building protruding above the rest. This same design is also visible at the Pehar Kordzöling of Samyé Monastery. The term generally refers to a chapel and is applied in some instances to small structures that lack such a protruding level.

${ }^{70}$ If the dates for Jokpa Jangchup Penden are late by 60 years, then the earliest date for Pehar's arrival would be 1469 ; see chapter 1 , note 79 .

${ }^{71}$ Waddell 1895, p.479n.1; Nebesky-Wojkowitz (1998, pp.106-107) cites this account as well, though he misrepresents it somewhat.
} 
There are striking dissimilarities between this account and the one given in chapter 1, indicating a great deal of confusion about what took place when Pehar's and Nechung's mythic histories intersected. The immediate discrepancy in this account is the appearance of Lama Zhang $^{72}$ — the famed twelfth-century warlord and founder of the Tselpa Kagyü sect ${ }^{73}$ —alongside Drepung Monastery, which was not founded until 1416. Beyond this, the above account has a few elements in common with the narrative given in chapter 1. There is mention of going to Uḍḍiyāṇa, though, in this instance, Waddell (mis)understands it to mean Pehar wants Lama Zhang to go with him to Padmasambhava's realm. A similar origin for the name Nechung is also given, though there is an interesting elaboration on Pehar needing the small dwelling because he felt too impure to enter Drepung. The most striking feature, however, is the resurrected human medium at the center of this event. The Hagiography of Jokpa Jangchup Penden states that a coracle, rather than a box, was used to transport the deity to Nechung. ${ }^{74}$ It is possible that a living medium was banished from Tsel via a boat along with the deity's belongings. If this were the case, the speeches given by Pehar in chapter 1, both to Dönyö Dorjé as well as to Jokpa Jangchup Penden and his disciples, may have been delivered through an actual, if otherwise unknown, medium. Perhaps the lineage of the Nechung Oracles did not begin at Nechung but extended back to Tsel. ${ }^{75}$

Writing in the mid-1950s, Nebesky-Wojkowitz provides a more colorful and detailed account that supplements Waddell's tale:

After residing at Samye for many centuries, Pe har is supposed to have moved to the monastery of Tshal gung thang (chos 'khor gling) or shortly Gung thang, an establishment of the rNying ma pa sect [sic] lying on the bank of the Kyichu (sKyid chu) river, about half a stage to the east of Lhasa (lHa sa). During his stay at Tshal gung thang, Pe har began to quarrel with a learned priest of this monastery named Bla ma zhang...who for some reason had taken a strong antipathy towards this dharmapāla. It thus happened that, when a new monastery was built under the direction of Bla ma zhang, the latter ordered the painters, who were designing the frescoes inside the new shrine, not to paint a single picture of Pe har. The god, angered by this insult, decided to take

\footnotetext{
${ }^{72}$ Tib. bla ma Zhang Brtson 'grus grags pa, 1121/1123-1193; TBRC: P1857.

${ }^{73}$ Tib. Tshal pa bka' brgyud. For more information on this figure, see Yamamoto 2009, as well as Sørensen, Hazod, and Tsering Gyalbo 2007, pp.30-39.

${ }^{74}$ See chapter 1, p.54. The Nechung Register makes a similar claim; see Appendix III, p.579.

${ }^{75}$ See chapter 1 , note 156.
} 
revenge and, assuming the form of a boy, began to assist the painters in their work in a most obliging way. The artists were very pleased with their young helpmate, and when their work neared completion, they asked the boy how they could reward him for his help. The boy then replied that his only wish would be that they should paint somewhere on a wall of the shrine the small figure of a monkey holding a burning incense-stick in its hand. The painters readily complied with this strange request. One night, after all the work in the temple had been finished, Pe har slipped into the shape of the painted monkey, and with the burning incense-stick he set the whole sanctuary on fire. ${ }^{76}$

Infuriated by the destruction of the shrine, Bla ma zhang performed a special magic rite and thus succeeded in bringing Pe har into his power. He compelled then the dharmapala to enter a rgyal mdos, a thread-cross made for deities of the rgyal po class. Having caught the god in this contraption, the lama locked the thread-cross in a box, which he threw into the nearby Kyichu river. The box was quickly swept away by the current, and when reaching the neighbourhood of Drepung, one of the four abbots of this greatest Tibetan monastery espied the casket which was just drifting past. As he recognized by means of his supernatural powers that $P e$ har had been imprisoned in this box, he ordered a priest to pull it out of the water and to bring it immediately into the monastery. The lama succeeded in retrieving the casket, but while carrying it became overwhelmed by curiosity and lifted its lid. At once the imprisoned dharmapāla escaped, and assuming the shape of a beautiful white dove flew to a nearby birch (gro ba shing), where he vanished. Later the Nechung monastery was built around this tree. Pe har began to manifest himself from now on at this place, assuming possession of the body of a priest, who was eventually appointed to the office of a state oracle by the fifth Dalai Lama. $^{77}$

Nebesky-Wojkowitz also notes a few other alternative accounts. In one variant it is the Fifth Dalai Lama himself who spied the box floating down the Kyichu and sent the abbot after it. In another it is Dorjé Drakden, not Pehar, who is trapped in the box. Both of these versions appear to be later conflations. ${ }^{78}$ Regardless of who actually carried the load, it is said to have become

\footnotetext{
${ }^{76}$ Pehar taking the form of a monkey in this story may very well be the reason why, even today, a live monkey is chained to a pole on the grounds of Nechung Monastery, in the garden of the Dalai Lama's former apartment just north of the monastery proper. There is another live monkey chained up at Pehar Kordzöling Temple in Samyé Monastery. I have not seen such a sight at any other monasteries.

${ }_{77}^{77}$ Nebesky-Wojkowitz 1998, pp.104-105.

${ }^{78}$ See ibid, pp.105-106.
} 
preternaturally heavier as it was brought up the mountain. In all of these instances, the unnamed abbot is no doubt Jokpa Jangchup Penden.

We encounter Lama Zhang's anachronistic presence again in Nebesky-Wojkowitz's account. Some works that recount this event take Lama Zhang's mention at face value, at the expense of Drepung Monastery, and place it in the twelfth century. ${ }^{79}$ Others attempt to redress the discrepancy by illustrating a strong historical connection between Lama Zhang and Pehar. ${ }^{80}$ Then there are those sources that fully recognize the discrepancy but are uncertain of what to make of it. ${ }^{81}$ I agree with Guntram Hazod's assessment that Lama Zhang is not actually meant in this mythic event, but rather he personifies the community of Tsel and their rejection of Pehar. ${ }^{82}$ It is most likely that the kernel of fact behind this narrative took place in the sixteenth century, and that two important historical moments_-Lama Zhang founding Tsel Gungtang and Pehar's transfer to Nechung-were simply conflated. ${ }^{83}$ Considering the potential fusion of Pehar's arrival at Samyé and a later conquest, ${ }^{84}$ as well as the Fifth Dalai Lama's involvement in this event according to one variant noted above, conflation is not an uncommon characteristic of Tibetan historiography.

The details of Pehar's escape from the box have also been embellished over the intervening centuries. According to current lore, when the abbot's steward put the box down, either out of fatigue or curiosity, he placed it on a large stone. Though he was told not to, the steward opened the box and Pehar flew out in the form of a white dove. ${ }^{85}$ The bird landed on the famed birch tree, his soul tree, and dissolved into it. Out of regret or excitement, the steward is said to have cried out, "Master, think of me!"86 This exclamation then miraculously appeared on the large stone, which is still visible today, situated between Pehar's soul tree and his soul lake

\footnotetext{
${ }^{79}$ See Tsepak Rinzin, et al. 1992, p.21, and Dorje 2004, p.115.

${ }^{80}$ See Thub bstan phun tshogs 2007, pp.4, 6-9. While it is beyond the scope of this work, there is a potential connection between Lama Zhang and Pehar that deserves attention; see ibid.

${ }^{81}$ See Tibetan Academy of Social Sciences 2009, p.439, and Mig dmar tshe ring 2010, p.14.

${ }^{82}$ See Sørensen, Hazod, and Tsering Gyalbo 2007, p.627n.116.

${ }^{83}$ One variant that Lingön Padma Kelsang provides also places this event in the sixteenth century. This account states that Pehar was expelled from Tsel by Tselpa Jampa Künga (Tib. Mtshal pa Byams pa kun dga') after the Gungtang revolt (Tib. Gung thang gling log). It is unclear to what the Gungtang revolt refers, but Jampa Künga is likely Jampa Künga Jungné (Tib. Byams pa kun dga' 'byung gnas; TBRC: P5720), the $16^{\text {th }}$-century abbot of Sangpu Neutok Monastery (Tib. Gsang phu ne'u thog); see Sørensen, Hazod, and Tsering Gyalbo 2007, pp.687-688. See also Tibetan Academy of Social Sciences 2009, p.439.

${ }^{84}$ See chapter 1 , note 152 .

${ }_{85}^{85}$ According to Tupten Püntsok, the box even became too heavy to lift; see Thub bstan phun tshogs 2007, p.5.

${ }^{86}$ Tib. bla ma mkhyen.
} 
(Figure 74). ${ }^{87}$ The steward went to tell the abbot what happened and the abbot replied, "Although the circumstance [of this karmic connection] is a little unsuitable, a small abode will appear there in the future." ${ }^{\prime 8}$ Thus, a small chapel ${ }^{89}$ was built around the birch tree, and a small college of eight monks was established there. ${ }^{90}$ Despite the conflict between the detailed account in chapter 1 and this alternative account, the latter correlates with the artifactual presence of the birch tree, the site of Pehar's soul lake, and the miraculous stone.

The oldest historical document to discuss Pehar's arrival at Nechung is Sangyé Gyatso's portion of the Nechung Register, written in 1682. It explicitly dates the deity's transfer during the time of the Second Dalai Lama. However, it also contradicts all of the accounts mentioned above, as well as the events in the Hagiography of Jokpa Jangchup Penden. In the Nechung Register, the Second Dalai Lama visits Yangön Monastery and encounters Pehar. The two have a karmic connection and leave the monastery together by way of a coracle. This account is drastically different from the others because it involves the Dalai Lama himself retrieving the deity from his former residence. It is also the account that has a sense of primacy above all others because it was recorded on the wall of Nechung Monastery. This version casts into doubt the authorship of the Hagiography of Jokpa Jangchup Penden. If these two narratives conflict with one another on so fundamental an event, how could they both have been written by Regent Sangyé Gyatso? This confusion remains unresolved, but it is possible that the Second Dalai Lama was added to the original narrative in order to strengthen the historical tie between the deity and the Dalai Lama.

What all of these stories have in common is Pehar's transfer from the region of Tsel to the vicinity of Drepung, his rejection by important Tsel lords, like Lama Zhang, Dönyö Dorjé, and Jampa Künga, and his acceptance by important Drepung masters, like Jokpa Jangchup

\footnotetext{
${ }^{87}$ See Tibetan Academy of Social Sciences 2009, pp.439-440. The stone on which Pehar's box was placed, and upon which the words "Master, think of me!" appeared, was painted to heighten the wording by the time of my fieldwork at Nechung. However, Mikmar Tsering has an older photo of the stone without paint and the inscribed words are vaguely visible; see Mig dmar tshe ring 2010, page 8 of the frontispiece photos. See Figure 42, letter Z.

${ }^{88}$ Tibetan Academy of Social Sciences 2009, p.440: rten 'brel cung ma 'grig kyang ma 'ongs pa na der gnas chung chung zhig chags yong. Tupten Püntsok provides yet another variation on the origin of Nechung's name. When the steward told the abbot about Pehar escaping from the box and residing in the birch tree, the abbot responded, "The god is big, but the place is [too] small!" Thub bstan phun tshogs 2007, p.11: lha de che/ gnas de chung.

${ }^{89}$ Tib. $l \operatorname{cog}$.

${ }^{90}$ Presumably, if the original eighth-century Yulokö Shrine actually existed, it was likely built near the birch tree rather than around it, and had deteriorated or been destroyed in the intervening centuries long before this new chapel was built. The lineage of four monks maintaining the old temple would likewise have been discontinued long ago. That the number of monks assigned to the new Nechung Chapel was eight is according to modern-day senior Nechung and Drepung monks; see Thub bstan phun tshogs 2007, p.5.
} 
Penden, the Second Dalai Lama, and the Fifth Dalai Lama. The account from the Nechung Register illustrates the power of the Dalai Lama's lineage more directly. Not only did the Second Dalai Lama retrieve Pehar from Yangön Monastery, he spread the Geluk teachings while he was there. In all of these instances, important Tselpa power brokers are cutting ties with the deity, allowing the burgeoning Drepung hegemony to adopt him as their own. This event ultimately symbolizes the passing of the torch from the waning Tselpa Kagyü hierarchy to the waxing Geluk government, which was first established by the Second Dalai Lama at Drepung. ${ }^{91}$

\section{Nechung Dorjé Drayangling Monastery}

The above accounts illustrate Nechung's development under different institutions- the ancient Yarlung dynasty, the Tselpa hierarchy, and Drepung Monastery. However, even under the management of the Fifth Dalai Lama and his regents, Nechung went through several phases. The full renovation of Nechung Chapel began in 1681 under the direction of Regent Sangyé Gyatso; yet the foundation for the newly enlarged monastery was actually laid in the 1660s, during the regency of Trinlé Gyatso. ${ }^{92}$ A tantric temple was built on the site shortly thereafter at the request of the Nechung Oracle, who also prophesied the monastery's later expansion. ${ }^{93}$ Nechung's expansion was intentionally begun in the $3^{\text {rd }}$ month of 1681 , which celebrates when the Buddha turned the Dharma wheel of the Kălacakra at the great reliquary of Glorious Dhānyakațaka. ${ }^{94}$ Drepung Monastery was named after this ancient Indian Buddhist site, so it was only fitting that the expansion of a monastery with strong ties to Drepung would begin in this month. More than a year-and-a-half later, on the $14^{\text {th }}$ day of the $9^{\text {th }}$ month in 1682 , a temporary consecration took place at Nechung, signifying its completion. ${ }^{95}$ The monk Jamyang Drakpa $^{96}$ acted as the vajra master, presiding over monks from the Dalai Lama's Namgyel

\footnotetext{
${ }^{91}$ The Ganden Podrang Palace (Tib. Dga' ldan pho brang) at Drepung, the original site of the Dalai Lama's government, was constructed by the Second Dalai Lama in 1518; see Tibetan Academy of Social Sciences 2009, p.380. The argument that Pehar represented Drepung's political inheritance of the once great Tselpa hegemony was first put forward by Guntram Hazod; see Sørensen, Hazod, and Tsering Gyalbo 2007, p.628.

${ }^{92}$ Tib. 'Phrin las rgya mtsho, b. $17^{\text {th }}$ cent.; TBRC: P3649. Trinlé Gyatso was the Fifth Dalai Lama's second regent, after Sönam Rapten, and he served from 1660 until his death in 1668. See Tibetan Academy of Social Sciences 2009, p.442.

${ }_{93}$ See Appendix III, p.575.

${ }_{94}^{94}$ Tib. Dpal ldan 'bras spungs; see Appendix III, p.582.

${ }^{95}$ Lingön Padma Kelsang places this event in 1683; see Tibetan Academy of Social Sciences 2009, p.442. This is incorrect since the Nechung Register clearly states that this event took place in the Water-Dog year (Tib. rnga chen; 1682); see Appendix III, p.588. Mikmar Tsering likewise has 1683 since he quotes Lingön Padma Kelsang; see Mig dmar tshe ring 2010, p.20.

${ }_{96}$ 'Jam dbyangs grags pa, b.17th cent.
} 
Monastery and consecrating the sacred site with the mandala of the wrathful heruka Vajrakumāra. ${ }^{97}$ The Nechung medium at the time, Tsewang Pelwar, also went into trance and the oracle expressed his joy at the auspicious circumstances taking place. ${ }^{98}$ This event occurred nearly nine months after the Fifth Dalai Lama's passing. ${ }^{99}$ The monastery would also not be completely established until the $25^{\text {th }}$ day of the $3^{\text {rd }}$ month in 1690 , likely because the full array of statues and ritual contents were still being added in the decade following its expansion. According to Sangyé Gyatso, by this time the monastic community had been increased to 101 monks. ${ }^{100}$

The Nechung Register provides a fairly detailed list of the monastery's contents after its renovation. Like today, the courtyard contained murals of the sovereign spirits' retinue. The assembly hall, however, is generically described as containing murals of lamas, buddhas, bodhisattvas, peaceful and wrathful tutelary deities, dākiniss, and Dharma protectors. One chapel, the name of which is too damaged in the inscription to confidently identify, contains bas-relief statues of eighteen deities, though it is uncertain to which deities this refers. Another chamber, in the top floor, has statues of Padmasambhava and his 25 disciples. These 25 disciples are no longer present at Nechung today, but their original inclusion at the monastery indicates a strong connection with Samyé Monastery, where these first Tibetan monks were ordained. Like the giant statue of Padmasambhava that now sits on the second floor of Nechung today, the original statue of the tantric master in the upper floor signifies his superiority to and control over Peharthis initial orientation illustrates multiple interconnected registers.

In the Yellow Beryl: A Religious History of the Geluk Tradition, ${ }^{101}$ Sangyé Gyatso's famous 1698 monograph on Gelukpa monasteries and sacred centers, the regent provides further details on Nechung's possessions:

At the temple of Nechung Pehar, a very important guardian of the [Buddha's] teachings, in the Central Chapel, there [are statues of] the superior subjugating

\footnotetext{
${ }^{97}$ Tib. Rdo rje gzhon nu; this is a form of Vajrakīlāya.

${ }^{98}$ See Appendix III, p.589.

${ }^{99}$ The Fifth Dalai Lama passed away on the $30^{\text {th }}$ day of the $2^{\text {nd }}$ Tibetan month in 1682; see Sanis-rGyas rGya-mTSHo 1999, p.xi. I am grateful to Kurtis Schaeffer for referring me to this source.

${ }^{100}$ See Sangs rgyas rgya mtsho 1980, vol.2, p.332.5-6, which will be discussed below. According to Tupten Püntsok, Nechung Monastery had about 50 monks when the expansion was completed in 1682; see Thub bstan phun tshogs 2007, pp.82-83.

${ }^{101}$ Tib. Dga' ldan chos 'byung baidūurya ser po; see Sangs rgyas rgya mtsho 1980.
} 
tutelary deity [Hayagrīva] and the Five Sovereign Spirits, as well as Dorjé Drakden in particular. To the right of that, in the Birch [Tree] Chapel, there are statues of the lineage lamas. To the left [of the Central Chapel] there is the inner secret support of the thread-cross mansion, together with thoroughly completed ritual substances. Above, [on the second floor,] there is a chapel with [statues of] the Eight Bodhisattvas and the Five Dalai Lamas. Together with the Chapel of the Sixteen Arhats, both [chapels] possess offering materials. [Finally,] there are murals along the assembly hall and courtyard. All together, [this monastery] was made from [materials and labor worth] more than $179,247 \mathrm{kel}^{102}$ of grain. ${ }^{103}$

The basic structure of the monastery after its expansion has been maintained up to today; however, the Desire Realm Chapel is noticeably absent. Rather, its location is an unnamed chapel housing the sovereign spirits' thread-cross mansion and other sacred materials. This suggests that the goddess, whether Dhūmāvatī or Makzor Gyelmo, may have been a later addition. Moreover, we find that the historical heart of the monastery, the sacred birch tree, is surrounded by statues of lineage lamas, the details of which Sangyé Gyatso supplies elsewhere in the Yellow Beryl:

With respect to the newly built Nechung Chapel, [it includes] support statues of Padmasambhava in the Zahor style — surrounded by his eight manifestations - the Buddha, Dromtön, ${ }^{104}$ the venerable Tsongkhapa, and, above all, the fifth emanation of the saffron-robed monk [the Fifth Dalai Lama]. ${ }^{105}$

While Sangyé Gyatso does not specify that these statues are situated in the Birch Tree Chapel, this is likely the case given the clear lineage of Buddhist masters it illustrates. This configuration

\footnotetext{
102 Tib. khal; this is a standard Tibetan unit of measure equal to 20 bre. A khal equates to 25-30 pounds.

${ }^{103}$ Sangs rgyas rgya mtsho 1980, vol.2, p.323.3-5: bstan srung 'gangs chen gnas chung pe har lcog tu btsan khang dbus mar gong gnon gyi yi dam dang / rgyal po sku lnga khyad par rdo rje grags ldan dang bcas pa/ g.yas sgro khang du bla ma'i sku rigs dang / g.yon du rten mdos kyi nang gsang ba'i rten rdzas ma tshang ba med pa dang bcas pa/ steng du bde gshegs brgyad rje bla ma na rim lnga dang bcas pa'i lha khang / gnas bcu lha khang dang bcas pa gnyis kyi mchod rdzas skor/'du khang dang bde yangs su ldebs ris dang bcas par 'bru khal chig 'bum bdun khri dgu stong nyis brgya zhe bdun lhag bcas las grub pal.

${ }^{104}$ Tib. 'Brom; an abbreviation for 'Brom ston (1004-1064), Atīśa's chief disciple.

${ }^{105}$ Sangs rgyas rgya mtsho 1980, vol.2, p.255.5-6: gnas chung lcog gsar rgyag ngos/ brten pa orgyan za hor ma la mtshan brgyad kyis bskor ba/ thub dbang / 'brom/ rje btsun btsong kha pa/ ngur smrig gar rol lnga pa yan gyi sku rnams/. This line is quoted in Mig dmar tshe ring 2010, p.20.
} 
brings the chapel housing Pehar's soul tree, and the monastery as a whole, under the direct control of the Geluk sect.

\section{Later Milestones}

Since its renovation in the late seventeenth century, Nechung Monastery has expanded ritually, institutionally, and geographically. The monastery's ritual repertoire has grown in the intervening centuries, as illustrated in the last chapter. Institutionally, the Thirteenth Dalai Lama was a significant patron of Nechung Monastery, strengthening the relationship between the bodhisattva and the god. He added 14 more monks to Nechung, bringing the total monastic population to 115 around the turn of the twentieth century. ${ }^{106}$

Another significant figure is the reincarnating Nechung Rinpoche. In the 1880s, Orgyan Trinlé Chöpel ${ }^{107}$ came to Nechung from Mindröling Monastery ${ }^{108}$ in order to act as a spiritual guide for the Nechung medium, Śākya Yarpel, and to transmit tantric practices to the monastic community. In 1891, in accordance with one of the Nechung Oracle's prophesies, he went to eastern Tibet to retrieve from Jamyang Kyentsé Wangpo ${ }^{109}$ a treasure statue of Padmasambhava that had been revealed by Lerap Lingpa. This image was brought to Lhasa on the $22^{\text {nd }}$ day of the $9^{\text {th }}$ month - the day of the Buddha's divine descent from Tuṣita heaven ${ }^{110}$ — and installed at the Jokhang Temple. Prior to 1959, it was this statue that was invited to Nechung every twelve years during Nechung Monkey Month. Orgyan Trinlé Chöpel also brought back to Nechung treasure texts revealed Lerap Lingpa, which the monastery subsequently practiced.

Orgyan Trinlé Chöpel was the first in the Nechung Rinpoche incarnation line, or first Nechung Tülku. ${ }^{111}$ At Mindröling he had also been recognized as a reincarnation of Langdro Könchok Jungné, ${ }^{112}$ as well as of the treasure-revealer Ratna Lingpa. ${ }^{113}$ Sometime after being granted the title, Nechung Rinpoche was given an estate at Nechung, built along the eastern side

\footnotetext{
${ }^{106}$ See Tsepak Rinzin 1992, p.21.

${ }^{107}$ Tib. O rgyan 'phrin las chos 'phel, b. $19^{\text {th }}$ cent.

${ }^{108}$ Tib. Smin grol gling; this is one of the six main Nyingma monasteries, located southeast of Lhasa in Lhoka (Tib. Lho kha). Mindröling Monastery was founded in 1676 by Terdak Lingpa and is the main institution for the Southern Treasures tradition (Tib. Lho gter lugs); see Dowman 1988, pp.165-167.

${ }^{109}$ Tib. 'Jam dbyangs mkhyen brtse'i dbang po; 1820-1892; TBRC: P258. Jamyang Kyentsé Wangpo was a leading figure of the nonsectarian (Tib. Ris med) movement that swept through eastern Tibet in the nineteenth century.

${ }^{110}$ See Richardson 1993, p.109.

111 Tib. Gnas chung sprul sku.

112 Tib. Lang gro Dkon mchog 'byung gnas, $8^{\text {th }}$ cent.; this figure was one of King Trisong Deutsen's ministers and one of Padmasambhava's 25 disciples.

${ }^{113}$ Tib. Ratna gling pa, 1403-1479; TBRC: P470.
} 
of the monastery. This estate suffered damage during the Cultural Revolution, but it has been partially rebuilt and is still visible today (Figure 75). After Orgyan Trinlé Chöpel's death, the Thirteenth Dalai Lama recognized Tupten Könchok ${ }^{114}$ as his reincarnation, making him the second Nechung Rinpoche. Tupten Könchok taught Tibetan language in Beijing from 1956 to 1959. Upon his return to Tibet, however, he was arrested and imprisoned for a few months. In 1962, he escaped to India, bringing with him into exile the sacred leather mask that had been brought to Samyé with Pehar in the eighth century. ${ }^{115}$ In 1964 the second Nechung Rinpoche became a professor in Delhi, and in 1973 he founded a satellite temple for Nechung Monastery in Hawaii. ${ }^{116}$ On August 31, 1982, Tupten Könchok passed away. On May 20, 1985, Tenzin Losel $^{117}$ was born, and in 1993 he was recognized as Tupten Könchok's reincarnation, becoming the third Nechung Rinpoche. He currently resides at the Nechung Monastery in Dharamsala. ${ }^{118}$

Nechung Monastery took on extensive damage before and during the Cultural Revolution (1966-1976). In 1987, Franco Ricca and Erberto Lo Bue were commissioned by CESMEO to assess the magnitude of the damage inflicted on the monuments of south-central Tibet during this time. Ricca worked on Nechung Monastery and made the following assessment:

The temple was in fact occupied by the Chinese army at the time of the attack that overpowered the great monastery of 'Bras-spuns [Drepung], during the fierce repression of the 1959 uprising in Lhasa. On this occasion the gilded copper roof, typical of many Tibetan temples of that era, was removed along with the Oracle's great silver throne, and all the statues were destroyed. At the time of the Cultural Revolution, the monastery was turned into an agricultural farm and the galleries of the courtyard were sealed with masonry infill from the interstices of the pillars, making rooms used for the provisions of the Red Guard, as stores for fodder, and as shelter for livestock....

[By 1996,] the infill had been removed and replaced with a long series of prayer wheels, and the paintings were freed from the layer of soot that covered them and vigorously restored (restoration criteria in Tibet are quite far from our own concepts and

\footnotetext{
114 Thub bstan dkon mchog, 1918-1982.

115 See chapter 1, note 150, as well as Figure 17.

116 This US center, named Nechung Dorje Drayang Ling, was established in Pahala, Hawaii. According to their website (http://www.nechung.org/), their temple was founded in 1973. According to Tsepak Rinzin, it was founded in 1974; see Tsepak Rinzin 1992, p.30.

117 Tib. Bstan 'dzin blo gsal.

118 This information on Nechung Rinpoche was drawn from Tsepak Rinzin 1992, p.30, and Thub bstan phun tshogs 2007, pp.139-145.
} 
often translate into effective repainting). In many cases it was still possible for me to find an adherence to the pre-existing work and its conservation when it seemed clearly visible; the repainting itself was conducted with a strict observance of the original iconography and with a faithful tracing of the manner and techniques that characterized it, as evidenced by a comparison with the 1987 photographic documents. ${ }^{119}$

Efforts to restore Nechung Monastery to its former glory were permitted by 1981, when the twostory statue of Guru Nangsi Zilnön was installed on the second floor. Ricca states in his work that the process of reinforcing architectural structures, restoring murals, and installing statues has been ongoing since the 1980s. Today the monastery's modern restoration is complete, though there continue to be minor changes or additions. For instance, sometime after 1999 thin wooden fences have been constructed and placed in front of the lower register of the courtyard murals for protection. Since 2005 similar fences have been placed in front of the lower register of the assembly hall murals. According to Pasang, ${ }^{120}$ the monastery's chant master, there are now only 19 monks at the Nechung Monastery in Lhasa, with two residing at Meru Nyingpa.

Due to the monastery's desecration and the escape of the Nechung Oracle from Tibet in 1959, Nechung was reestablished in exile. The institution was temporarily located in an Indian house in Dharamsala before land was granted by the Tibetan Government-in-Exile. Residences for the monks were built in the late 1970s, and construction of the monastery proper began in May of 1981. The Indian Nechung Dorjé Drayangling, ${ }^{121}$ as it is called, was built within the compound of the Central Tibetan Government, the Gangchen Kyishong, ${ }^{122}$ situated between the city of Dharamsala and the suburb of McLeod Ganj. The Dhasa Nechung was completed in March of 1984, and formally consecrated by the Fourteenth Dalai Lama on March 31, 1985 (Figure 76). The monastery is only a one-minute walk downhill from the Library of Tibetan Works and Archives, past the Nechung Cafe. According to the senior Nechung monk Yeshé Söpa, ${ }^{123}$ there are 96 monks at the monastery in Dharamsala today. ${ }^{124}$

\footnotetext{
${ }^{119}$ Ricca 1999, p.7; the English translation is my own.

${ }^{120}$ Tib. Pa sangs. Personal communication; Nechung Monastery, Lhasa, November 19, 2011.

${ }^{121}$ Tib. 'Phags yul Gnas chung rdo rje sgra dbyangs gling.

122 Tib. Gangs can skyid gshongs; lit. "Delightful Valley of the Snowy Land."

${ }^{123}$ Tib. Ye shes bsod pa. Personal correspondence; Nechung Monastery, Dharamsala, February 29, 2012.

${ }^{124}$ For more on the Dhasa Nechung Monastery, see Tsepak Rinzin 1992, pp.31-32, and Thub bstan phun tshogs 2007, pp.153-170.
} 
The institution of Nechung Monastery now exists in two distinct locations. The Nechung on the outskirts of Lhasa is the historical sacred center, the place where Pehar came to reside after being expelled from Tsel. It is here that the power of place is strongest, since Pehar's soul tree and soul lake are still present, as is the miraculous stone engraved with the words "Master, think of me!" After the disruption of the Cultural Revolution the monastery has become once again active, though it is severally diminished. Monks perform the original rituals of the monastery, such as the Ten-Chapter Sädhana and Adamantine Melody, and participate in daily monastic duties. Nonetheless, the site's full sacrality has been greatly weakened by the loss of the Nechung Oracle and Nechung Rinpoche, as well as the absence of the Dalai Lama. These figures, so central to Nechung's activities, now reside in Dharamsala. Although the new Nechung Monastery in India lacks the powerful mythic history and terroir of the original, the Nechung Oracle is active there. He regularly gives prophecies in the company of the Fourteenth Dalai Lama and others during important events or on auspicious holy days. The ritual corpus and calendar have also been reestablished at the Dhasa Nechung. Both Nechung Monasteries are simultaneously ritually active today; however, power and place have been split and the institution of Nechung is now divided.

\section{The Nechung Oracle}

The Nechung Oracle has been active since the time of the Second Dalai Lama, and he has had a close relationship with the Dalai Lamas since then as well. The only extensive history ever published on the Nechung Oracle is a chapter found in Tupten Puntsok's Nechung History. ${ }^{125}$ The chapter ends with a useful chart listing all seventeen known oracles up to the present. This oracle history is mostly a collection of quoted passages drawn from other primary sources, such as the various biographies of the Dalai Lamas, but it is indispensible as a reference as well as for its occasional clarifications and commentary.

The earliest dated reference to the Nechung Oracle is 1542, when he is consulted after the death of the Second Dalai Lama:

\footnotetext{
${ }^{125}$ See Thub bstan phun tshogs 2007, pp.79-138.
} 
Then one day the Great Dharma King of Nechung came. Kugyak ${ }^{126}$ and the novice monks said, "All the volumes of the holy Dharma have caught on fire! ${ }^{127}$ Do you have insight? Because [this] great and vast country is without a ruler, what do we do? Do you have insight?" [The Oracle] said, "Offer to the lama ${ }^{128}$ a ceremony [requesting him] to firmly remain [in the world]." He [then] appeared to exhort the lama's [reincarnation] lineage. ${ }^{129}$

This strongly implies that the Nechung Oracle was functioning during the life of the Second Dalai Lama, though no specific date is mentioned for when the first Nechung Oracle became active. ${ }^{130}$ The source of this quote is from a biography detailing the latter half of the Second Dalai Lama's life. This work was composed by a figure named Konjokgyap, ${ }^{131}$ whose dates are unknown, making this text likewise difficult to date. The colophon of the text states that it was composed in the Iron-Monkey year. The earliest Iron-Monkey year after the Second Dalai Lama's death is 1560; however, it could also refer to the next Iron-Monkey year, 1620. If this is a mid-sixteenth-century work, it would be the earliest mention of the Nechung Oracle.

Another early text to mention the Nechung Oracle is the Jewel Translucent Sütra, a history of Altan Khan and the Mongols in the sixteenth century. Likely composed in 1607, this work has been translated into English by Johan Elverskog. ${ }^{132}$ According to this account, in 1575 the Third Dalai Lama was invited to Mongolia by Altan Khan in order to preach the Dharma in his land. ${ }^{133}$ Upon receiving the invitation from the Khan's envoys, the Nechung Oracle was entreated, and he offered the following prophecy:

\footnotetext{
${ }^{126}$ Tib. Khu brgyag; this appears to refer to an individual, though it is unclear who it is.

${ }^{127}$ Tib. me thigs phog; the meaning of this wording is difficult to fully ascertain.

${ }^{128}$ This refers to the Second Dalai Lama.

${ }^{129}$ Sku sger yig tshang 1977, vol.1, pp.621.20-622.3: de nas nyin gcig gnas chung gi chos rgyal chen po phebs te/ khu brgyag cing / ban chung tsho/ dam pa'i chos kyi glegs bam thams cad la me thigs phog 'dug pa e mthong / yangs pa'i rgyal khams chen po mi mgo med kyis gang 'dug pa e mthong / bla ma la brtan bzhugs phul/ ces bla ma' $i$ sku rim la bskul bar snang \%. While the day itself is not specified, it occurs between the $8^{\text {th }}$ and $18^{\text {th }}$ day of the $3^{\text {rd }}$ month of the Water-Tiger year (1542); for the year, see ibid, p.617.16. The Second Dalai Lama himself passed away on the night between the seventh and eighth day of this same month and year; see ibid, p.628.6-13.

${ }^{130}$ Tsepak Rinzin states that the first Nechung Oracle became active in 1544; see Tsepak Rinzin 1992, p.23. However, he provides no source for this claim and it is clearly contradicted by the above account.

${ }^{131}$ Tib. Dkon cog skyabs.

${ }^{132}$ See Elverskog 2003, p.46.

${ }^{133}$ For the date, see ibid, p.140n.233.
} 
"By decree of the Crown Jewel Master Padmasambhava, Which reveals the prophecy of the Superior Horse-headed Powerful King [Hayagrīva]. Entirely, the words of me, Pehar Khan, should be seen as conventional and ultimate truth, The ultimate truth is particularly beyond comprehension. The conventional truth is visualizing the deeds of the Eight Names [of Padmasambhava] and Five Bodies [of the Buddha]. I see that the helpful Dalai Lama, who by sight knows all conditions, And the virtuous Bodhisattva Altan Khan, when we were there, all together striving, Took a vow in front of Padmasambhava on the summit of the Glorious Copper Colored Mountain. By the power of the blessings of the merits vowed by them together, The incarnation of Bodhisattva Avalokiteśvara, meritorious Dalai Lama was born in the West. The Blessed Altan Khan was born in the East in the land of the Mongols. A sign that the religion of the Blessed Ones will spread like the sun.

"For this reason, you, the Dalai Lama, whom to behold is completely beneficial, You should go there according to the decree of the Mongol Khan. Evenly all living beings will be enlightened and the sun of the jewel religion will rise."134

The Third Dalai Lama agreed to this advice, but it took two more years of correspondence and gift exchanges before the trip to Mongolia would occur. However, in the latter half of 1577, when the time finally came to travel, many Tibetan lords - as well as the nominal Tibetan ruler at the time, Pakmodrupa Zhapdrung Ngawang Drakpa ${ }^{135}$ —attempted to discourage the Dalai Lama from going. They felt that Mongolia was too savage a land for his teachings to be useful, and that his time would be better served continuing to teach in Tibet. Nonetheless, the Third Dalai Lama wanted to honor his friendship with Altan Khan and spread Buddhism to Mongolia. To resolve this conflict he repeatedly consulted the Nechung Oracle, who proffered the following advice:

"If the wise Dalai Lama goes to Mongolia without delay, You will spread Buddhism vastly! You will lead the mistaken ones! You will enlighten like the sun the darkness of the disgraceful defilements! I will be with you, Holy One! Go without hindrance!"136

\footnotetext{
${ }^{134}$ Ibid, pp. 143-145, lines 678-692. I should note that the medium discussed in this work is not explicitly called the Nechung Oracle. However, given that the medium channels Pehar, that the prophecy is delivered in Lhasa, and that this figure has a close relationship with the Dalai Lama, it is clear that this is indeed the Nechung Oracle; see ibid, p.143n.240.

${ }_{135}^{13}$ Tib. Phag mo gru pa Zhabs drung Ngag dbang grags pa.

${ }^{136} \mathrm{Ibid}, \mathrm{p} .151$, lines 781-785.
} 
The Nechung Oracle's words galvanized the Dalai Lama to finally travel to Mongolia. As a result an important relationship was forged between Altan Khan and the Dalai Lama, which would have important repercussions in the future.

Beyond these two sources there is little to no mention of the Nechung Oracle, or the sense of his character as a prophet, until the writings of the Fifth Dalai Lama. It is of course in the Great Fifth's works that the Nechung Oracle becomes markedly present. In 1646, the Fifth Dalai Lama composed the biography of the Third Dalai Lama, and in this work there is a noticeable advancement in the relationship between the Dalai Lama and Pehar. Indeed, according to the Great Fifth, the friendship between the bodhisattva and the deity strengthened significantly immediately following the Second Dalai Lama's death. While in the intermediate state, before being reborn as the Third Dalai Lama, the Second Dalai Lama visited many heavenly realms. At one point he even came into the presence of the great master Padmasambhava. It is here that the Second Dalai Lama encountered a red form of Pehar, perhaps Kyechik Marpo or Dorjé Drakden, along with Penden Lhamo. This meeting is significant enough that it is quoted almost verbatim in Sangyé Gyatso's section of the Nechung Register:

When he was close to being born in the direction of Tölung Tsega ${ }^{137}$ for the benefit of all beings, [the Second Dalai Lama] was slightly delayed by a hindrance. At this time, he deliberately went to the glorious Copper-colored Mountain ${ }^{138}$ because he was exhausted from benefiting beings. When [he arrived], the great master was teaching the profound Dharma to an assembly of knowledgebearing dākas and dākinīs. There were two protector deities-one large and one small - in front of where he was sitting. The [large] one had a black body and white plaited locks of hair, and held a sword and a blood-filled skull-cup. The [small] one had a red body and wore leather armor and a leather helmet, the top of which was adorned with silk ribbons. He brandished in his hands a red spear and a lasso. He possessed a tiger-skin quiver and a leopard-skin bow case, and wore red leather boots. The [two deities] stood as such with Padmasambhava above

\footnotetext{
${ }^{137}$ Tib. Stod lung rtse dga'. The full name of the Third Dalai Lama's birth place is Stod lung rtse dga' khang gsar, located in the Töling valley just west of Lhasa.

${ }^{138}$ Tib. Zangs mdog dpal ri; this is Padmasambhava's pure land.
} 
and behind them. [The Dalai Lama] asked the great master Padma[sambhava], "Who are these two protectors?" [The master replied,] "These two are my attendants and they will accompany [you] as companions. Go to Tibet in order to benefit the [Buddha's] teachings and sentient beings!" Accordingly, they were entrusted as [the Dalai Lama's] servants to accomplish all [desired] activities. As requested, [the Dalai Lama,] together with the two protectors, came to this land in order to benefit [all] tamable beings. ${ }^{139}$

The scene of Padmasambhava with the red and black protectors is also visually represented at Meru Sarpa Monastery (Figure 77).

This connection between the Third Dalai Lama and Pehar is reaffirmed early in the Dalai Lama's life. According to the Great Fifth's biography of the Third Dalai Lama, the Nechung Oracle was consulted at the beginning of 1556, well before the exchange with Altan Khan, when the Dalai Lama was around twelve years old. This lengthy consultation is the first detailed glimpse we have of Pehar's personality, through the conduit of the oracle:

In tandem with the Gutor ceremony, ${ }^{140}$ [the Third Dalai Lama] went before the great Dharma protector's mandala table ${ }^{141}$ and [the Nechung Oracle] said the following: "In general, Padmasambhava is a tiny grain in the hearts of the Thousand Buddhas, [and] I am the servant of Padmasambhava. I have never transgressed Padmasambhava's command, even by a fraction of a horse's tail cut into a thousand pieces. Padmasambhava bestowed on me the Buddha's teachings to guard for my allotted work, and gave me the enemies' flesh, blood, and life breath for my allotted food. Now, in front of every monastery, from the foundation ${ }^{142}$ on up, there is King Pehar. ${ }^{143}$ In front of every precious shrine

\footnotetext{
${ }^{139}$ See Appendix III, p.580; see also Tā la'i bla ma 05 1982, pp.16-17, and Sku sger yig tshang 1977, vol.2, p.7.

${ }^{140}$ Tib. dgu bgtor. This refers to a lengthy festival on the $29^{\text {th }}$ day of the $12^{\text {th }}$ lunar month that involves ritual dances and torma-throwing ceremonies performed to expiate the community's defilements, which have accumulated over the year; see Richardson 1993, pp.116-123. This event takes place in the Wood-Rabbit year (1555); see Sku sger yig tshang 1977, vol.2, p.56.8. However, since this event is at the very end of the Tibetan lunar year, this would place it within the first month or two of 1556.

${ }^{141}$ Tib. dkyil 'khor; in this context this refers to a table of offerings, which includes the mandala pyramid of rice often found on elaborate shrine tables.

${ }^{142}$ Tib. 'bre zhabs; lit. "bottom measure."
} 
support, from the tsatsa ${ }^{144}$ as small as a mustard seed [on up], there is King Pehar. In front of [the scripture of] the Holy Dharma, from a single syllable on up, there is King Pehar. I eat the flesh and drink the blood of the enemies and obstructing spirits that harm these sacred supports! The Ganges River-like stream of the enemies' life breaths flows into my mouth without interruption. Nevertheless, I never stray from great compassion even for an instant.

"Do these two things contradict? For me there is no conflict! Even though the cause was that I had been born of a fierce seed and the effect was that I belonged to the eight classes of the haughty spirits of the conventional world, I did not remain forever in that same state. This is akin to the legend of Rudra Tarpa Nakpo, for example. Specifically, the present time is the age of degeneration - unruly beings are difficult to discipline, monks are incapable of ethical conduct, tantric practitioners cannot [keep] their samaya vows, and kings deviate from imperial laws and abandon them. The result of [all] this is that there is no time for happiness, since there is war and strife, disease among people and cattle, crop failures and famine, etc. In such an era as this, in order to benefit tamable beings, Padmasambhava exhorted [me] and subdued me peacefully with the taming Dharma. Then the Incarnate One who is Meaningful to Behold ${ }^{145}$ came, and I descended [with him] in order to accomplish those activities that he [entrusts to me] and to wrathfully subdue unruly beings. Moreover, I have never before freed an enemy and I continue to not let [enemies go free].

"In particular, the number and series of subjugation [rites] that were accordingly imparted from the Tantra Class by the Blessed One [the Buddha] are authentic ritual practices. Because I have seen such things, [I know that] the warrior spirits, $d \bar{a} k i n \bar{s}$, Dharma protectors, guardians, and wisdom deities that are above me also reside here and there, such as in the environment, sacred sites, and charnel grounds. However, they must come from their respective realms in order to [give] a delightful and gently drifting dance [and] to care for their ancient

\footnotetext{
${ }^{143}$ Tib. Pe dkar; though this spelling would be phonetically rendered as Pekar, I am rendering it as Pehar for the sake of uniformity.

${ }^{144}$ Tib. sAtstsha; this is a variant spelling for the miniature clay icons of Buddhas, enlightened beings, and gods often found at monasteries.

${ }^{145}$ Tib. sprul sku mthong ba don ldan. This is an epithet for the Dalai Lama often used by the Nechung Oracle; see Nair 2010, p.123.
} 
samaya vows. There are also protective gods, local deities, landlord spirits, and worldly spirits that are below me; however, they must be reminded of their respective samaya vows before coming. By contrast, I joyfully came today to offer a 'Well done!'

"Some people act [with] a false knowledge that is not knowledge, a false understanding that is not understanding, and a false realization that is not realization. They say, 'Substitute that with this! Replace this with that!' Among those who believe in foolishness, people who are fraudulent, lazy, and deceitful claim that they have attained spiritual accomplishments and are exceptional. Regarding the leaders, their lives are blotted out. When I see these things, I, King Pehar, become very sad. Nevertheless, as it stands, the river of subjugation [rites] that were imparted from the precious Tantras is not muddied by errors. The series of waves of authentic rituals are densely gathered. Whoever tastes [its waters] will quickly vanquish Māra, the Lord of Death, and they will be filled with the elixir of great wisdom. When I see such things, I, King Pehar, [become] supremely happy. It is very good! Furthermore, may the remaining [Dharma teachings] thoroughly and properly bring [sentient brings] to complete perfection!

"Now I will also go to the torma-throwing [ceremony]. This exhortation is not insignificant!" Having spoken thus, [the Nechung Oracle] went [to the ceremony]. ${ }^{146}$

\footnotetext{
${ }^{146}$ Sku sger yig tshang 1977, vol.2, pp.66.3-68.2: dgu gtor dang 'grig pa'i chos skyong chen po dkyil 'khor gyi drung du byon tel 'di skad ces gsungs/ spyir sangs rgyas stong gi thugs kyi zi'u 'bru de padma 'byung gnas/ padma 'byung gnas kyi bka' sdod de nga yin/ ngas padma 'byung gnas kyi bka' las rta rnga dum bu stong du gshags pa'i cha tsam yang 'da' ma myong / padma 'byung gnas kyis nga'i las skal du sangs rgyas kyi bstan pa bsrung ba dang / zas skal du dgra bo'i sha khrag srog dbugs rnams phog pa yin pas/ da ni gtsug lag khang bre zhabs yan chod/ dkon cog gi rten mchod sātstsha yungs 'bru tsam dang / dam pa'i chos yig 'bru gcig yan chod kyi drung na pe dkar rgyal po re re yod/ rten de dag la gnod pa'i dgra bgegs kyi sha za khrag 'thung / dgra bo'i srog dbugs chu bo gangga'i rgyun tsam zhig nga'i kha na rgyun mi 'chad par 'gro yang / snying rje chen po dang skad cig kyang 'bral ma myong / de gnyis e 'gal/ nga ni mi 'gal ba zhig yin/ yang gal te rgyu sa bon rtsub mos bskyed pa'i 'bras bu 'jig rten rang rgyud kyi dregs pa sde brgyad du gtogs pa zhig yin pa'i tshe na'ang / de rtag tu de ka'i ngang du sdod pa ma yin tel dper na ru tra thar pa nag po'i gtam rgyud la ci 'dra zhig 'dug /khyad par du deng sang snyigs ma'i dus su yod/sems can dmu rgod gdul dka'/ ban dhes tshul khrims mi thub/ sngags pas dam tshig mi thub/ rgyal bos rgyal khrims 'chol par btang / de'i 'bras bu 'thab rtsod/ 'khrug long / mi nad/ phyugs nad/ lo nyes/ mu ge sogs kyis bde ba'i skabs med pa 'di yin/ de 'dra'i dus 'dir/ gdul bya sems can gyi don byed pa la/ padma 'byung gnas kyis bka' bsgos nas/gdul bya chos dang zhi bas 'dul ba la/ sprul sku mthong ba don ldan byon/ de'i 'phrin las bsgrub pa dang / gdul bya dmu rgod drag pos 'dul ba de nga la babs pa yin/sngar yang dgra bo yan par gtong ma myong / da dung mi gtong ngo / /khyad par bcom ldan 'das kyis rgyud sde las ji ltar gsungs pa'i dbang gi grangs dang / go rim cho ga lag len rnam par dag pa 'di lta bu mthong tsa na/ nga yan chad kyi dpa' bo mkha' 'gro chos skyong srung ma ye shes pa rnams kyang / yul dang / gnas dang / dur khrod sogs gang na bzhugs kyang / so so'i zhing khams nas
} 
A few days later, the Nechung Oracle would come from Nechung to request a life-size statue of Padmasambhava. ${ }^{147}$

This prolonged exhortation reveals a lot about the character of the Nechung Oracle. First, there is no ambiguity as to who speaks through the oracle-again and again Pehar reveals himself as the deity possessing the medium. Pehar was also recorded as the possessing deity in the Jewel Translucent Sütra, making him the primary deity of the Nechung Oracle up through the mid-seventeenth century. Second, though it is not apparent in translation, the oracle occasionally uses archaic terms and syntax, which illustrates Pehar's ancient character. Third, Pehar stresses his reliability as Padmasambhava's servant. He also remarks on his relationship with the Third Dalai Lama; he alludes to their earlier meeting in the intermediate realm before they descended into the world during the Dalai Lama's rebirth. Fourth, Pehar recognizes that there is a potential contradiction between his wrathful activities and enlightened calling. However, he argues that this conflict does not truly exist, stating that his fierce services are needed during such a degenerate age when there is so much strife in the world. Moreover, he explicitly compares his origins with that of Tarpa Nakpo, whose legend was discussed in chapter 1 as being a possible model for Pehar's story. Fifth, Pehar makes a claim for his special status by comparing himself to other types of deities. He states that higher deities are generally far away and must be called from their individual realms. By contrast, lower deities are closer, but their excessively worldly natures require that they be constantly reminded of their samaya vows. Pehar, however, suggests that he does not require such a reminder, and he comes willingly from anywhere since he can be found everywhere the Dharma requires protection (e.g., monasteries, shrine objects, scriptures). Finally, Pehar is clearly distressed by charlatans and individuals that meddle with ritual affairs, which may be a veiled reference to those who oppose his advice. However, he is cheered by those who practice the authentic tantric rites and he encourages his

dgyes pa'i gar stabs ling nge sngon gyi dam tshig rjes su skyong ba'i phyir 'byon dgos shing / nga man chad kyi lha srung yul lha gzhi bdag 'jig rten pa rnams kyang rang rang gi dam tshig dran nas 'ong dgos pa yin la/ de ring nga yang legs so 'bul bar dga' bzhin du 'ongs pa yin/la la zhig gis mi shes pa'i shes rdzu/ ma go ba'i go rdzu/ ma rtogs pa'i rtogs rdzu byed cing / de'i tshab 'dis 'ong / de'i dod 'dis gyis zer zhing / zog dang las sla dang / g.yo sgyu 'ba' zhig gis blun po dad pa can gyi khrod du/ grub pa thob pa'i khyad par can zhig yin pa skad byas shing / mi mgo bskor nas tshe 'byid pa dag mthong tsa na/ nga pe dkar rgyal po yang shin tu skyo bar 'ong gi 'dug kyang / 'di ltar rgyud sde rin po che rnams las gsungs pa'i dbang gi chu bo nor 'khrul gyi rnyog pa med cing / phyag len rnam par dag pa'i rlabs 'phreng 'khrigs pa/ gang gis myong ba de dag myur du 'chi bdag gi bdud las rgyal nas/ ye shes chen po'i bdud rtsis khyab par 'gyur ba 'di lta bu dag mthong tsa na/ nga pe dkar rgyal po yang mchog tu dga'o/ /shin tu legs so/ /da dung 'phro mus rnams nan tar legs por yongs su rdzogs par mdzod cig /da nga yang gtor rgyab la 'gro'o/ /bka' bsgo ma zhan cig/ces gsungs nas thegs so/. This prophecy is paraphrased and incredibly contracted in the Nechung Register; see Appendix III, pp.581-582.

${ }^{147}$ See ibid, p.68.2-7. 
audience to do so. He concludes his proclamation by stressing its importance before participating in the day's ceremonies.

Given that the Fourth Dalai Lama (1589-1616) lived a short life, there are no known records of the Nechung Oracle's prophecies during his lifetime. There is only one meaningful mention of the oracle in the Fourth Dalai Lama's biography, which was also composed by the Fifth Dalai Lama. This brief account states that the Nechung Oracle prophesied that the Dalai Lama's fourth rebirth would be in Mongolia. ${ }^{148}$ This is true, though at the time of this work's composition it was a foregone conclusion.

This brings us to the Fifth Dalai Lama, whose autobiography illustrates a profound efflorescence of activity by several Nechung mediums over the course of his lifetime. The first medium of the Nechung Oracle who is introduced by name is Nangso Gönor, and it is on the occasion of his death:

In the spring, the medium of the Nechung Dharma King, Nangso Gönor, passed away. New mediums came [but] they didn't say much, so what good were they? However, the regent [Sönam Rapten] said, "Ritually arrange an extensive supplication for the sovereign spirit!" [The mediums] began to do so. After a brief interval, there was a good omen [and] the best arose [from among the mediums]. ${ }^{149}$

This is the earliest reference that discusses the transition from one medium to another, and it appears that the process was not a clean one. Several mediums appeared, all vying for the position of the Nechung Oracle, perhaps due to the office's new prestige within the nascent government. The Fifth Dalai Lama's regent at the time, Sönam Rapten, had to devise a method for ascertaining which medium was authentic. He chose a supplication rite to Pehar, presumably because it would reveal which of the candidates had a special connection to the deity. The name

\footnotetext{
${ }^{148}$ See ibid, p.175.6-7.

149 Tā la'i bla ma 05 1991-1995, vol.5, p.272.5-6: so ga gnas chung chos rgyal gyi sbu khog nang so dgos nor 'das pa'i khog gsar rnams la phebs kha sra ba byung bas de la phan re yin nam gang ltar sde pas rgyal gsol rgyas ba zhig chog sgrigs gyis gsung ba ltar dbu btsugs mtshams myur du grub na lags [sic: legs] pa'i mtshan ma zhig gyad byung ba. This competition between mediums took place in the $9^{\text {th }}$ month of the Fire-Pig year (1647); see ibid, p.282.2, for the next year, which is the Earth-Mouse year (1648). Thus, Nangso Gönor died in the early months of 1647 and the next medium was installed later that same year.
} 
of the newly selected medium is given the following year and it appears he was quite successful as the Nechung Oracle:

\begin{abstract}
During the Yogurt Festival, the Great Emanated Dharma Protector possessed Sepo Sönam, and faithfully related past and present events as well as prophecies. ${ }^{150}$
\end{abstract}

Nearly a decade later, Sepo Sönam was still active as the Nechung Oracle. During a ceremony at Deyang College, the oracle provided valuable prophecies and even offered insight into a former medium:

On the $19^{\text {th }}$ day, auspicious verses were uttered and flowers scattered in the monk's quarters of Deyang College, as well as in front of the Maitreya [statue] within the shrine hall. In the assembly hall, the monks arranged a longevity ceremony. ${ }^{151}$ The Great Dharma Protector also took possession of [Sepo Sönam] and many extraordinary things were said, such as an account of the medium Jampa Gyatso's time. ${ }^{152}$

Other than a name, nothing is known of the medium Jampa Gyatso. Since Nangso Gönor was the previous medium, the understanding is that Jampa Gyatso preceded him.

There is a curious incident that occurred during Sepo Sönam's tenure as the Nechung medium. The Fifth Dalai records that in 1653 he had a vision of Dorjé Drakden in full oracle regalia. A few days after the vision, the Great Fifth received word that a monk at Chökorling Monastery ${ }^{153}$ named Chöpel Zangpo ${ }^{154}$ became possessed by Dorjé Drakden at the same time he

\footnotetext{
${ }^{150}$ Ibid, p.287.4: zho ston la sprul pa'i chos skyong chen po sras po bsod nams kyi khog tu zhugs te phebs pa'i sngon byung da ltar gyi lo rgyus dang lung bstan yid ches pa mdzad/. This event took place on the $30^{\text {th }}$ day of the $6^{\text {th }}$ month, 1648.

${ }^{151}$ Tib. ring 'tsho'i rten 'byung; see Karmay 2005a, p.84.

${ }^{152}$ Tā la'i bla ma 05 1991-1995, vol.5, pp.481.6-482.1: tshes bcu dgu la bde yangs gra tshang gi gra khang / gtsang khang gi byams pa dang bcas par shis pa brjod cing me tog gtor/'du khang du gra dmangs kyas [sic: kyis] ring 'tsho'i rten 'byung bsgrigs shing chos skyong chen po'ang khog tu babs sku khog byams pa rgya mtsho'i dus kyi lo rgyus sogs ngo mtshar mang du gsung \%. This event took place on the $19^{\text {th }}$ day of the $4^{\text {th }}$ month of the WoodSheep year (1655); see ibid, p.471.6, for the year.

${ }^{153}$ Tib. Chos 'khor gling.

${ }^{154}$ Tib. Chos 'phel bzang po.
} 
experienced his vision. ${ }^{155}$ This does not indicate that there was a different Nechung medium than Sepo Sönam, since this monk was at a different monastery; rather it illustrates that deities can possess multiple individuals at any given time. Moreover, Dorjé Drakden is explicitly mentioned as the possessing deity, indicating that this important emanation of Pehar was already descending into mediums as early as the $1650 \mathrm{~s}$.

Regardless of such oddities, Sepo Sönam faithfully acted as the Nechung Oracle for the majority of the Fifth Dalai Lama's rule. However, at his death the transition to a new medium was once again fraught with difficulties:

The medium Sepo Sönam - whose nature had become that of the enemydefeating god of the Ganden Podrang - had passed away. Since then, a monk of the college who acted as an attendant and secretary became possessed several times. However, he did not say much and flaws [in his possession] would arise, such as getting lost in the process and becoming embarrassed. This raised doubts [about his efficacy]. The caretaker Lobzang Jinpa prepared him [and] gradually [the deity was able to] enter [the medium] to be beseeched without interruption. Nevertheless, [the deity] would not enter a vessel [again] until a full year later. Because of this, the three [oracles of] Samyé, Lamo, and Tsongdü ${ }^{156}$ acted for him.

When asked one day about [the Nechung Oracle], the Lamo [Oracle] had prophesied to the monk Jamyang Drakpa, ${ }^{157}$ "There is no need for you to search far or long; he will come from within the vicinity of the [Ganden] Podrang." Since last year, the middle son of Lemawa, [named] Tseten, became possessed. Afterward, it gradually became clear [that he was the new medium]. He was not dismissed by Möndrupa Rinchen Tashi, [the medium] of Samyé, Gyitang Norbu, [the medium] of Lamo, or [the medium] of Tsongdü. Those who were asked

\footnotetext{
${ }^{155}$ See Karmay 1988, pp.35, 183f.6.2-5. This event was recorded in the Fifth Dalai Lama's visionary autobiography and was composed no later than 1663 ; see ibid, p.14.

${ }^{156}$ This oracle channeled the deity Jatri Mikchikpu, the minister of the eastern sovereign spirit Mönbuputra; see Tā la'i bla ma 05 1991-1995, vol.5, p.685.5. As for the location of Tsongdü, the Great Fifth later refers to this area as Dra Tsongdü (Tib. Gra Tshong 'dus; see ibid, vol.6, p.58.3), indicating that this is Drachi Tsongdü Tsokpa (Tib. Gra phyi Tshong 'dus tshogs pa), a Sakya Monastery in the Drachi valley just southwest of Samyé Monastery, on the southern banks of the Brahmaputra River (Tib. Gtsang po); see Dowman 1988, pp.160-161, and Dorje 2004, pp.175176.

${ }^{157}$ This figure was heavily involved in Nechung Monastery's expansion and presided over its 1682 consecration; see Appendix III, p.588 and passim.
} 
about this [thought] it was probably a favorable [sign]. I [the Fifth Dalai Lama] am an adherent of the great Dharma King of Nechung and [so] it was said that I also needed to examine [him], which I did. Although there was a great quarreling among the gods and spirits and it was difficult to examine him, I thought auspiciousness would come about. Accordingly, he later performed faithfully, doing such things as tying a sword into a knot and giving advice.

On the third day [of this year], an auspicious star day, [the Nechung Oracle] went down to the Sovereign Spirit Chapel ${ }^{158}$ and went to its roof. At first the possession was not pure and his speech was obstructed, and because of this his recitation was uncomfortable. The gateways of the medium's subtle channels were also narrow. Because of this, circumstances arose that were very different from those of Sepo Sönam. I had quite a few discussions with [individuals on the matter], such as with the cook Döndrup Gyatso. However, whenever [the deity] would enter into [the medium], it looked as if the formless one was truly possessing [him]. Thus, a [light of] great extraordinary brilliance appeared [when we] placed on his head the splendid soul stone of Wangpödé ${ }^{159}$ - the vajra-holder of Lady Karchen [Yeshé Tsogyel], leader of the gathering of ten million dākinis - and his disciples, and poured onto his tongue the medicine that liberates through taste. He expounded the names of those who transmitted the oral lineage: the Blessed One Samantabhadra, the Five Buddha Families, Vajrapāṇi, Hayagrīva, and the Five Noble Ones; as well as, specifically, the vajra-holder of Uḍdiyāṇa [Padmasambhava], his body emanation Nyang[rel] Nyima Özer, his speech emanation Chökyi Wangchuk, ${ }^{160}$ his mind emanation Ngari [Paṇchen] Padma Wangchen (1487-1542) and his brother [Lekden Dorjé (1512-1625?)], his good qualities emanation the Dharma King Tashi Topgyel Wangpödé, the benevolent

\footnotetext{
${ }^{158}$ Tib. rgyal po lcog; this likely refers to Nechung Monastery before its renovation.

${ }^{159}$ This refers to Tashi Topgyel Wangpödé (Bkra shis stobs rgyal Dbang po'i sde, 1550?-1603; TBRC: P646), an important transmitter of the Northern Treasures tradition and an incarnation of Ngari Panchen.

${ }^{160}$ Gu ru Chos kyi dbang phyug, 1212-1270; TBRC: P326.
} 
Chöying Rangdröl, ${ }^{161}$ the great universal lord Tratsangpa, ${ }^{162}$ and up to the knowledge-bearer Terdak Lingpa. ${ }^{163}$

He was commanded again to accomplish the deeds of the four activities in order to spread, more and more, the happiness and well-being of the general and specific teachings. While proclaiming the samaya vow, he accepted it eagerly and became happy and extremely resplendent. [The deity] had descended into his body and it was wonderful! He was dressed up and I praised all of his excellent belongings that were gathered together, such as the cymbals, teas, garments, and silks. ${ }^{164}$

The year of Sepo Sönam's death is unknown, though it was likely around 1677 given the above series of events. It appears that there was a nameless medium active shortly after Sepo Sönam's death, but he was so ineffective that the other major oracles had to act in his stead. This medium does not appear in Tupten Püntsok's list, likely due to his inadequacy and brief term in office. A

${ }^{161}$ This figure transmitted the Ten-Chapter Sädhana to the Fifth Dalai Lama; see chapter 2, note 309.

${ }^{162}$ Khra tshang pa Blo mchog rdo rje, 1595-1671; TBRC: P2668. This is another master of the Northern Treasures tradition who transmitted teachings to the Fifth Dalai Lama alongside Chöying Rangdröl.

${ }^{163}$ See chapter 2 , note 321.

${ }^{164}$ Tā la'i bla ma 05 1991-1995, vol.7, pp.212.6-214.4: dga' ldan pho brang pa'i dgra lhar sad [sic: song] gshis sku rten sras po bsod nams 'das pa nas bzung mgron gnyer dang [sic: drung] pa btang ba'i gra tshang gi gra pa kha shas kyis sku phebs zhus kyang phebs kha sra ba de lam du lus pa skyengs pa lta bu'i skyan [sic: skyon] byung dogs/ gnyer pa blo bzang sbyin pa bcas rim par mu 'thud zhu bcug kyang khog zhugs lo skor bar ma byung bar brten bsam yas/ la mo/ tshong 'dus gsum du yang nge [sic: de] pa btang ba de skor zhus skabs shig dge slong 'jam dbyangs grags par la mo bas phar tshol [sic: 'tshol] ba sogs ring khad [sic: khyad] mi dgos pho brang gi nye skor nas yong bar lung bstan/ lo sngon ma nas sle ma ba'i bu 'bring po tshe brtan la khog zhugs shig byung 'dug pa rjes su rim par gsal du song ba bsam yas su smon grub pa rin chen bkra shis/ la mor sgyad [sic: sgyid] thang nar [sic: nor] bu dang tshong 'dus su'ang ma [sic: mi] btang ste dri skor zhus pa phal cher mthun par gnas chung chos rgyal chen po'i phyogs gtogs yin tshul dang / da [sic: nged] la'ang brtag pa dgos zer ba ltar bgyis pa lha 'dre' $i$ skor 'khrugs ches sa' [sic: sa 'i] dpyad dka' na'ang bdag byas pa bzang ba shar ba bzhin rjes su ral grir mdud pa dang bslab ston sogs yid ches su gyur pa tshes gsum skar ma bza' [sic: bzang] bar rgyal po lcog tu phab pa'i rtser phebs pa thog mar khog ma byang pa'i gsung 'gags kyis 'don mi bde zhing sku khog gi rtsa sgo yang dog stabs nas gnar [sic: gnas] lugs rnams sras po bsod nams dang 'dra min sna tshogs byung ba ja ma don grub rgya mtsho sogs kyis gleng gzhi mang tsam byas 'dug rung nang du byon pa'i tshe gzugs med dngos su zhugs nyams kyis dkyus ma dang mi 'dra pa'i bkag [sic: bkrag] zil che bar snang ba mkha' 'gro bye ba'i tshogs dpon mkhar chen bza'i phyag rdor dbang po'i sde yab sras kyi bla rdo rngam can de dbur bzhag/myong grol gyi sman ljags steng blud/ bcom ldan 'das dpal kun tu bzang po/ rigs lnga/ gsang bdag/rta mgrin/dam pa'i rigs can dra ma lnga/ khyad par o rgyan rdo rje 'chang / sku sprul nyang nyi ma 'od zer/ gsung sprul chos kyi dbang phyug/ thugs sprul mnga' ris padma dbang chen sku mched/ yon tan rnam sprul chos rgyal bkra shis stobs rgyal dbang po'i sdel dran [sic: drin] can chos dbyings rang grol dang khyab bdag khra tshang pa chen po/ rigs 'dzin gter bdag gling ba'i bar du byon pa' $i$ bka' babs brgyud pa'i mtshan rnams brjod da [sic: de] bstan pa spyi bye brag gi bde skyid gong nas gong du spel phyir las bzhi'i 'phrin las sgrub par yang bskyar bka' bsgos dam tshig bsgrags pa bzhin dang blangs kyi spro nyams dang byin shin tu chags pa byung / sku phebs pa'i legs sor bzabs [sic: gzab] mchor gyi sku chas legs pa cha tshang / sbug chol ja gos dar sogs spams bstod/. These events culminated on the $3^{\text {rd }}$ day of the $1^{\text {st }}$ month of the Earth-Sheep year (1679). 
year after his faulty term began a new medium was discovered near the Ganden Podrang. This figure is named Tseten, the son of Lemawa, and his mediumship was equally troubled at the beginning. Nevertheless, the other oracles supported him, as did the Fifth Dalai Lama, despite a few false starts. Tseten showed promise, and on the $3^{\text {rd }}$ day of the New Year, 1679, his abilities eventually blossomed. Miraculous activities surrounded Tseten's possession, and he recited the names of the lineage-holders of the Northern Treasures tradition from their primordial origins up to the seventeenth century. It seems that Sepo Sönam's mediumship lacked these kinds of problems, but despite the initial difficulty a successful possession had finally occurred and a new Nechung Oracle was found.

Tseten, who was also called Tsewang Pelwar, was recognized as the next Nechung medium in 1678 , but his abilities did not come to fruition until 1679. He was also Nechung's medium at the time of the monastery's expansion. Indeed, it was later in 1679 that the decision to renovate Nechung began to be discussed in earnest after previous talks had stalled:

Although a six-pillar monastic estate had been previously [offered] to the great Nechung Oracle, from the time of Sanön Sepo Sönam there was much discussion [about expanding it]. [However,] because he never went into trance at a suitable time, it remained at a postponed stage [until] recently [when] the medium Tsewang Pelwar became possessed. Together with this, the regent [Sangyé Gyatso] talked well about a monastic estate. He thought that if there was a Dharma protector and a medium at each [monastery], like [at] Samyé, even if he's too wrathful, this Nechung is no different from them. Because of this, [since Nechung] also has its own medium, it is not good that establishing [a monastery] has been [so] difficult.

Moreover, according to the regent's wishes, [offerings] were given in the presence of Lawatrang. ${ }^{165}$ However, it seemed inappropriate for the La[wa]trang

\footnotetext{
${ }^{165}$ Tib. La ba 'phrang; the context strongly suggests that this is a place name, though its location is uncertain. This place is mentioned in the Blue Annals (see Roerich 1996, p.889) as well as in Tsepon Shakabpa's One Hundred Thousand Moons (see Shakabpa 2010, vol.1, p.398, note j), where it is spelled La ba 'phreng. While unidentified, the name suggests that it is a narrow gorge or stream. Moreover, the contexts of both this current quote and Shakabpa's history strongly indicate that it is located just south of Drepung, perhaps next to Nechung, on the way to Kyormolung Monastery (Tib. Skyor mo lung dgon pa) west of Lhasa. Given this, I propose that Lawatrang is the name of the gorge that cuts down Gepel Utsé Mountain between Drepung and Nechung. This gorge must be crossed to get to Nechung from Drepung.
} 
serpent-hindering spirit to possess [a medium], so his land was expropriated by the government. ${ }^{166}$ Frankly, there was no need to conceal [the fact] that the Great Dharma Protector [Pehar] was replacing this [local deity]. ${ }^{167}$

Tsewang Pelwar's eventual success as a medium cleared the obstacles for Nechung Monastery's expansion, which had plagued the development during Sepo Sönam's tenure. Before Nechung could be expanded, however, the nearby land needed to be acquired by the government and ritually cleansed of the local god that had previous inhabited it.

Tsewang Pelwar continued to act as the Nechung Oracle during the monastery's renovation, as well as through the death of the Fifth Dalai Lama. Shortly after the Great Fifth's death, early in 1682, the Nechung Oracle secretly offered the following lamentation and prophecy in verse to Sangyé Gyatso:

HRIH! It is good that you ask [this] question of me- the evil spirit. The formless ones are even more tormented [by the Fifth Dalai Lama's passing] than those with form! [Oh] Manidhārin, ${ }^{168}$ who is the rebirth of Mutri Tsenpo! The master [the Fifth Dalai Lama] has abandoned his vessel in your [life]time. Regarding this, the teachings that he previously realized are faultless and eternal. Maṇidhārin, if [he] were to arise in another [place], the religious and secular [government] would be incomplete, [which] would greatly harm the [government]. Although the emanation of the master sheds his skin, the emanation does not fade

\footnotetext{
${ }^{166}$ Given that Nechung Monastery was built along the banks of the gorge that I suspect is Lawatrang, it makes sense that the deity of the gorge would be propitiated before Nechung was expanded in order to ensure the project's success. This deity's land was then confiscated in order to build Nechung on it.

${ }^{167}$ Tā la'i bla ma 05 1991-1995, vol.7, pp.310.6-311.2: gnas chung chos skyong chen por snga sor mchod gzhis ka drug kyang sa bsnon sras po bsod nams dus nas gleng gzhi mang du yod 'dug rung bar skabs su sku la phobs [sic: ma phebs] par brten rim 'gyangs su lus pa nye lam sku rten tshe dbang dpal 'bar la sku phebs byung ba dang bcas/ sde pas mchod gzhis shig legs chul glang [sic: tshul gleng] pa bsam yas lta bu'i chos skyong ngang [sic: dang] sku rten pa so sor yin na drag na'ang gnas chung 'di sngar nas dbye ba med gshis sku rten rang yang byed dka' bcas dge med 'dra snyam yang sda [sic: sde] pa'i 'dod pa ltar la ba 'phrang gdong phul ba yin kyang la 'phrang klu bdud sku khog la mi 'phrod nyams kyis gzhung len ngos chos skyong chen pos de dod par bkab mi dgos/. This discussion took place on the $25^{\text {th }}$ day of the $9^{\text {th }}$ month of the Earth-Sheep year (1679).

${ }^{168}$ Tib. Nor bu 'dzin; lit. "Jewel-Bearer." This is the name of one of Avalokiteśvara's attendants, especially found in images of Four-Armed Avalokiteśvara (Tib. Phyag bzhi pa; Skt. Caturbhuja); see Himalayan Art Resources 2013a. This name refers here to Sangyé Gyatso, given that it states this figure is a reincarnation of Mutri Tsenpo; see Appendix III, p.575, and Lobzang Tondan 1983, vol.1, p.7.5. Just as Manidhārin is the servant of Four-Armed Avalokiteśvara, Sangyé Gyatso is the servant of the bodhisattva's incarnation. Manidhārin is also sometimes considered the son of Avalokiteśvara, which strengthens this connection, since Sangyé Gyatso is the reincarnation of several sons of the Dalai Lama's past lives; see Appendix I, text 2.
} 
away. Previously the master returned swiftly in succession. This is good for the religious and secular [government] and is due to the power of non-attachment. Recently [his] radiance has ripened in the southeast. ${ }^{169}$ Because there are so many unruly degenerate beings, they increase in [just] a day [and create] hardship after a short while. However, I, the sovereign spirit Pehar, promise that [the Dalai Lama] will quickly come without delay!

Paint images of the eight terrifying ones, ${ }^{170}$ fierce Hayagriva and Vajrapāṇi, the master ${ }^{171}$ himself, as well as White and Green Tārā. For a week the monks of the Tantric College ${ }^{172}$ [should] single-mindedly perform the Prayer that Spontaneously Fulfills All Wishes ${ }^{173}$ [and] give offering tormas to the host of the formless haughty spirits. Then, because [you] were placed on the master's right side, there is a great necessity for [good] omens and a positive karmic connection [between us]. In the past, the Tibetan ${ }^{174}$ Mutri Tsenpo established [Nechung]; ${ }^{175}$ it seems that [you] are his reincarnation of late. Therefore, do not be bound by sorrow - the iron shackles of delusion — rather, protect [all] sentient beings by being carefree and cheerful! If you are very depressed it will attract external obstructions. This protective knot has a large sigil ${ }^{176}$ on it; it would be good if you kept it in the middle of your house unimpaired. ${ }^{177}$

\footnotetext{
169 The Sixth Dalai Lama was born southeast of Lhasa in Tawang (Tib. Rta dbang), which is located in the modernday Indian state of Arunachal Pradesh.

${ }^{170}$ Tib. 'Jigs pa brgyad; this likely refers to the Eight Sādhana Deities.

${ }^{171}$ Tib. slob dpon; in the context of the current prophecy this title refers to the Fifth Dalai Lama, though it generally refers to Padmasambhava.

${ }^{172}$ Tib. sngags grwa; given that a Tantric house had been built by this time on Nechung's land (See Appendix III, p.575), this likely refers to this building rather than to Drepung Monastery's Tantric College.

${ }^{173}$ Tib. Bsam pa lhun grub; this refers to the seventh chapter of the famous Seven-Chapter Supplication (Tib. Le'u bdun $\mathrm{ma}$ ) dedicated to Padmasambhava and rediscovered as a treasure text by the fourteenth-century treasurerevealer Zangpo Drakpa (Tib. Bzang po grags pa); see TBRC: W27513.

174 Tib. shing sgo; lit. "wooden door." This is an ancient term for Tibet as the land of wooden doors.

${ }^{175}$ Given the context, this refers to the first construction of Nechung by Muné Tsenpo around the turn of the eighth century. The oracle is confusing Sangyé Gyatso's incarnations here.

176 Tib. rtags gzhi; lit. "fundamental sign." According to Tsepak Rigzin, this refers to symbolic drawings that oracles make on various objects; see Tsepak Rigzin 1993, pp.50-51.

${ }^{177}$ Sangs rgyas rgya mtsho 2007, p.60: hrih 'dre ngan nga la 'dri ba byas pa legs/ /gzugs can rnams las gzugs med 'dod gdungs chel /mu khri btsan po'i skye ba'i nor bu 'dzin//khyod dus slob dpon khog pa bskyur ba ni/ /sngon nas dgongs pa'i bstan pa mi nyams rtags [sic: rtogs]/ /nor bu 'dzin pa gzhan la byung srid na/ /bstan srid mi zin 'di la shin tu gnod//slob dpon sbrul [sic: sprul] skogs bskyur kyang sbrul [sic: sprul] ma yal//snga sor slob dpon na rim myur 'byon ni/ /bstan srid legs par ma chags dbang gis yin//da lam 'od zer shar lto [sic: lho] phyogs su smin/ /snyigs ma'i sems can dmu rgod ches pa yis/ /zhag tu spar ba cung zhig dka' ba 'dug /'on kyang 'gyangs med myur du 'byon pa yi//khas len pe har rgyal po nga yis byed//jigs pa brgyad dang rta mgrin phyag rdor gtum//slob dpon nyid dang sgrol ma dkar sngon bcas//sku bris sngags grwa'i 'dus tshogs zhag bdun du/ /bsam pa lhun grub rtse
} 
There are a number of important observations provided by this prophecy. First, we see that by 1682 Pehar is still the main deity possessing the Nechung Oracle. We are also given another glimpse into Pehar's character, who is clearly pained by the Great Fifth's death and who further bemoans the unruly beings of this degenerate age. Second, this proclamation acts as a suitable example of the standard two-part structure of the Nechung Oracle's prophesies. The first part is a prophecy, which in this case concerns the Fifth Dalai Lama's rebirth, preceded by the deity's thoughts on the latter's death. The second part consists of commands or advice, usually in relation to the prophecy. Here Pehar, through the Nechung Oracle, wishes to establish a closer relationship with Sangyé Gyatso in the wake of the Great Fifth's death. The deity highlights the regent's karmic connection with the monastery, since the latter first established the institution in a previous incarnation. Pehar ends by stressing the need for Sangyé Gyatso to be in a positive frame of mind during these tough times, and he offers the regent a protective cord for his benefit. The Nechung Oracle, and Tibetan oracles in general, conclude the trance by offering such blessed substances or materials to their audience. It merits noting that many of the images the oracle requested to be painted are still present on the walls of Nechung Monastery today; this includes the Eight Sādhana Deities, Hayagrīva, and White Tārā. A statue of the Fifth Dala Lama is also currently present at Nechung, though it is likely newer.

The medium Tsewang Pelwar, having lived through the Great Fifth's death and Nechung Monastery's expansion, passed away in 1689, a decade after his installation. The next medium, Kongpo Lobzang Lekjor, was installed in 1690. Sangyé Gyatso, in his Yellow Beryl, describes these events and provides a fitting conspectus on Nechung's deity, monastery, and oracle as they were understood by the Tibetan government by the end of the seventeenth century:

gcig gsol ba bdebs//gzugs med dregs pa'i tshogs la mchod gtor byin//de nas slob dpon g.yas zur bzhag pa yis//ltas dang rten 'brel dgos ba che ba yod//sngar yang shing sgo mu khri btsan pos btsugs//slad char de yi skye ba yin yod pas/ /rmongs gab lcags sgrog yid gdung ma bcing bar/ llhod yangs dga' spro'i sgo nas sems can skyongs/ lyid gdung ches na rang la phyi gegs 'jug /srung ba'i mdud 'dir rtags gzhi che yod pas/ /gnas khang dbus su ma nyams bzung na legs/. The first half of this prophecy is quoted in Thub bstan phun tshogs 2007, p.83. This prophecy was recorded by the Fifth Dalai Lama's scribe, Changkyim Ngawang Kyentsé (Tib. Chang khyim Ngag dbang mkhyen rtse, b.17th cent.; TBRC: P5334), on the $26^{\text {th }}$ day of the $2^{\text {nd }}$ month of the Water-Dog year (1682); for the year, see Sangs rgyas rgya mtsho 2007, p.32. This date conflicts with the one given in Sangyé Gyatso's biography of the Fifth Dalai Lama, which places the latter's death on the $30^{\text {th }}$ day of the $2^{\text {nd }}$ month; see note 99 above. 
The Great Emanated Dharma Protector of Nechung-the essence of the wisdom of discriminating awareness, the purification of desire ${ }^{178}$ - does not waver from the body of the Victorious Lord of the Dance. ${ }^{179}$ However, in order to subjugate all kinds of savage beings, the sovereign spirit of speech, the enemydefeating god Kyechik [Marpo], and his emanated minister Dorjé Drakden appear to be indistinguishable [from such savage beings]. They [also] have an inconceivable [number of] physical appearances and names in order to protect the general and specific teachings of the Buddha.

Likewise, the Omniscient [Second Dalai Lama] Gendün Gyatso appointed [this deity] as guardian of Glorious Drepung [Monastery]. Thus, he is called the Nechung Dharma protector. In particular, numerous times after the lord's [the Dalai Lama's] illusory body of wisdom, the enjoyment body, separated from the coarse vessel of his emanation body, he went into the infinite ocean of the pure land. [This time,] at the Cāmara Lotus Light Palace, ${ }^{180}$ the Great Vajradhara of Uḍḍiyāna [Padmasambhava] repeatedly proclaimed their samaya vow. Furthermore, [Padmasambhava] assigned [the Nechung Dharma protector] as the guardian of the teachings for the Supreme Emanation Body, the Omniscient Sönam Gyatso [the Third Dalai Lama]. ${ }^{181}$ Accordingly, this servant of the successive emanations of the saffron-robed monk [the Dalai Lama] became the enemy-defeating god of the Ganden Podrang. ${ }^{182}$ It is known that [this deity] is different from [all] others.

I myself built the [Nechung] temple, distinquished by eight kinds of craftworks. ${ }^{183}$ After such things [as discussed above, but] before some of the countless $^{184}$ tumultuous activities [that recently] occurred, the [Nechung] Dharma protector was observed within a series of mediums and acted reliably in the

\footnotetext{
${ }^{178}$ In Sangyé Gyatso's portion of the Nechung Register, this coincides with the description of Kyechik Marpo-the western sovereign spirit of speech — as an emanation of Amitābha; see Appendix III, p.578.

${ }^{179}$ Tib. Rgyal ba Gar gyi dbang po; this is an epithet for Avalokiteśvara.

${ }^{180}$ Tib. Rnga yab pad ma 'od; this is Padmasambhava's palace. The Rnga yab refers to Cāmara, one of the eight subcontinents in traditional Buddhist cosmology.

${ }^{181}$ This refers to the event discussed above in the intermediate state between the Second Dalai Lama's death and the Third Dalai Lama's birth.

${ }^{182}$ Tib. Dga' ldan phyogs thams cad las rnam par rgyal ba'i pho brang; lit. "the Joyous Palace that is Completely Victorious in All Directions."

${ }^{183}$ See Appendix III, pp.589-591.

${ }^{184}$ Tib. nam mkha' dang mnyam; lit. "as infinite as the sky."
} 
material [world]. [However,] whatever wrathful deity possesses [the medium] as the wisdom deity, ${ }^{185}$ the [excessive] attachment of the [deity's] pernicious retinue would inevitably result in [the medium's] death, ${ }^{186}$ and those who bestow offerings would also be unsatisfied! Recently, in the Earth-Snake year [1689], Lema Tsewang Pelwar died due to [the Dharma protector's] anger. ${ }^{187}$ In the IronHorse year [1690], [the Nechung deity] sincerely possessed Kongpo Lobzang Lekjor, and due to this he spoke on whatever was pertinent [regarding] ancient history and the present. Because he is not dependent on the disorderly unseen [world], he speaks sufficiently on anything in the past or the future, in accordance with Manidhārin's [my] wishes. Even the medium himself is incapable of being distracted by worldly matters. Along with this, all kinds of offerings by myself and others, [rituals for] perfecting the [two] accumulations [of merit and wisdom], and especially [the deity's] past fulfilling and amending rites [are performed] for the great Dharma protector.

On top of this, there is [the deity's] monastery Dorjé Drayangling, newlybuilt [in accordance with] the diviners. It has 101 monks and was [fully] established on the $25^{\text {th }}$ day of the $3^{\text {rd }}$ month of the Iron-Horse year [1690]. Generally, the entire set of the correct central rites, such as the Adamantine Melody, the work of the Great Fifth - the excellent lama who is the crown ornament of samsāra and nirvāna - are chiefly recited. Specifically, the entreaties to the sovereign spirits are recited. Outside of this, the Samantabhadracaryāpranidhānarāja ${ }^{188}$ and the Amitāyus Dhāranii ${ }^{189}$ are performed, [as well as other] methods for whatever is best for sentient beings.

All of the great Dharma protector's activities cannot be apprehended! He also [acts] at Drokmo, ${ }^{190}$ Gönpasar, ${ }^{191}$ Kyormolung, Kadruk, ${ }^{192}$ and Rampa, ${ }^{193}$ which were established around Nechung, along with any remaining areas. ${ }^{194}$

\footnotetext{
${ }^{185}$ Tib. ye shes pa; this is the formless being that takes possession of the medium during a trance session.

${ }^{186}$ Tib. tshe'i bar chad; lit. "the interruption of life."

${ }^{187}$ Tib. khu [sic: 'khu] ldog; lit. "backfired malice." Goldstein $(2001$, p.158) suggests that this word is used primarily in reference to the anger of a protector deity. The word's etymology favors this understanding, since it implies that the deity's anger turns back on the person to whom the deity is connected.

${ }_{188}$ Tib. Bzang spyod; this is an abbreviation of Bzang po'i spyod pa'i smon lam kyi rgyal po.

${ }^{189}$ Tib. Tshe [dpag med] gzungs.

${ }^{190}$ Tib. 'Brog mo.

${ }^{191}$ Tib. Dgon pa gsar; this refers to a hermitage near Sera Monastery.
} 
Writing sixteen years after the Nechung Register's composition, Sangyé Gyatso reinforces the notion that the Five Sovereign Spirits are emanations of enlightened beings that have taken on wrathful forms to subjugate savage beings. This elaborates on the claim made earlier by Pehar himself in the Third Dalai Lama's biography, when he reconciled his wrathful activities with his ultimately compassionate nature. Notably, it is not Pehar but rather the sovereign spirit Kyechik Marpo and his minister Dorjé Drakden who are given here as the central Nechung deities. These deities appear together again in Sangyé Gyatso's biography of the Fifth Dalai Lama. In this work's prefatory section discussing the Second Dalai Lama, Sangyé Gyatso explains that "the sovereign spirit of speech, the enemy-defeating god Kyechik [Marpo], came from Yangön by way of a coracle because of his previous karmic connection [to the Second Dalai Lama] and his samaya vow." "195 In his biography of the Sixth Dalai Lama,

192 Tib. Ka drug.

193 Tib. Ram pa.

${ }^{194}$ Sangs rgyas rgya mtsho 1980, vol.2, pp.331.4-333.1: gnas chung sprul pa'i chos skyong chen po 'dod chags rnam par dag pa sor tog [sic: rtog] ye shes kyi ngo bo rgyal ba gar gyi dbang po'i sku las ma g.yos bzhin du/ rnam pa skye bo mi bsrun pa rnams 'dul ba'i phyir gsung rgyal dgra lha skyes gcig dang 'phrul blon rdo rje grags ldan tha mi dad pa'i tshul bstan te sangs rgyas kyi bstan pa spyi dang bye brag skyong bar sku'i rnam 'gyur dang mtshan gyi rnam grangs bsam gyis mi khyab kyang / thams cad mkhyen pa dge 'dun rgya mtshos dpal ldan 'bras spungs kyi srung mar bskos pas gnas chung chos skyong du grags shing / lhag par rje 'di nyid sprul sku rags pa'i za me [sic: ma] tog las longs sku ye shes sgyu ma'i sku logs su phye nas dag zhing rab 'byams rgya mtshor phebs pa'i du mal rnga yab padma 'od du ogyan rdo rje 'chang chen pos yang bskyar gyis dam bsgrags te slar yang mchog gi sprul sku thams cad mkhyen pa bsod nams rgya mtsho'i bka'i srung mar gnyer gtad mdzad pa bzhin/ ngur smrig gar rol na rim gyi bka' sdod dga' ldan phyogs thams cad las rnam par rgyal ba'i pho brang gi dgra lhar gyur pa gzhan dang mi 'dra bar go ste nged rang nas gtsang khang bzo sna brgyad kyis 'phags pa bzhengs pa sogs nas zang zing gi 'phrin las nam mkha' dang mnyam la lar babs sngar nas sku khog na rim nas chos skyong la dmigs pa'i dngos por spyod ches pa/ ye shes par khro ba ci la mnga' yang 'khor gdug pa can gyi 'khren chas tshe'i bar chad du song ba nyag gcig dang / 'bul ba po dag kyang blo kha mi rdzogs pa zhig 'dug pa/ nye lam sa sprul [sic: sbrul] sle ma tshe dbang dpal 'bar khu [sic: 'khu] ldog gis 'das shing / lcags rta kod [sic: kong] po blo bzang legs 'byor la sku phebs yid ches byung bar brten/snga sor gyi lo rgyus dang da sgos ci 'gab zhus par/ gzugs med zang zing la bltos pa ma yin pas 'das ma 'ongs gang la yang nor bu 'dzin pa'i blo dang bstun chog gsung pa dang / sku rten pa rang nas kyang 'jig rten phyogs kyi g.yeng ba mi yong tshul byung ba dang bcas chos skyong chen por rang gzhan gyis phul rigs rnams tshogs rdzogs khyad bkang [sic: bskang] gso ba sngon ma'i steng du tho btsun gsar rgyag gi gra tshang rdo rje sgra dbyangs gling gra pa brgya dang gcig yod/lcags rta zla ba gsum pa'i tshes nyer lnga la tshugs/ rje bla ma srid zhi'i gtsug rgyan lnga pa chen po'i bka' rdo rje sgra dbyangs sogs las byang gzhung bsrangs kyi sde dgu spyi dang khyad par rgyal gsol gtsor bton ngos/ bzang spyod dang tshe gzungs 'gro gang che byed pa'i thabs chos skyong chen po' $i$ 'phrin las [thams] cad bzung dang bral yang / 'brog mo/ dgon pa gsar/ skyor lung ka drug/ ram pa/ gnas chung skor bcas 'khrol 'khyil dang bcas pa/. The latter half of this fragment is quoted in Thub bstan phun tshogs 2007, pp.29-30.

${ }^{195}$ Sangs rgyas rgya mtsho n.db., vol.1, f.124a.4: gsung rgyal dgra lha skyes gcig yang dgon nas rta mgo'i tshul gyis sngon gyi las 'brel dam tshig gis phebs. This text was composed sometime after the Nechung Register but before the Yellow Beryl. Zahiruddin Ahmad misunderstands this line, believing it to refer to three different deities: the 'Oracle King' (gsung rgyal; referring to the Nechung Oracle), a 'Foe God' (dgra lha), and 'Ekajāta' (skyes gcig; a fierce goddess). Ahmad appears to be interpreting the last term as an exact translation of the goddess's Sanskrit name as he has it spelled. However, the normative Sanskrit spellings for this goddess's name are Ekajațā or Ekajațī, both of which mean 'one lock of hair' rather than 'one birth,' as 'Ekajāta' and the Tibetan term mean. In Tibetan, Ekajațā's name is usually given as Ral gcig ma (lit. "Woman with a Single Lock of Hair”) or Sngags srung ma (lit. "Female Guardian of the Mantras"); see Sańs-rGyas rGya-mTSHo 1999, p.210. 
Sangyé Gyatso also explicitly states that Kyechik Marpo or Dorjé Drakden possess the Nechung Oracle. ${ }^{196}$ Sangyé Gyatso's portion of the Nechung Register likewise mentions Dorjé Drakden, suggesting that the 1780s was a transitional period for the possessing deity of the Nechung Oracle. Given that Dorjé Drakden is prominent in eighteenth-century accounts of the Nechung Oracle,${ }^{197}$ the late seventeenth century may be the period when Pehar possessed the oracle less and less and Dorjé Drakden took over. In the above account, Sangyé Gyatso also summarizes key moments in the relationship between the Dalai Lama and the central Nechung deities, and provides some additional information on Tsewang Pelwar's untimely death. It seems the next medium, Kongpo Lobzang Lekjor, was very successful, since a mural of him in trance is still visible at Nechung Monastery today (Figure 26). This medium's installation occurred the same year Nechung Monastery was fully completed - all of its murals painted, statues installed, and shrine offerings established; he is the last Nechung Oracle of the seventeenth century.

Tupten Püntsok was the first to produce a chronology of the various Nechung mediums. The first medium on his list is an obscure figure named Lobzang Penden; ${ }^{198}$ however, he cites no source for this name, suggesting that it is known only through oral tradition. The second oracle on his list is Jampa Gyatso, who is mentioned only once in a proclamation delivered by Sepo Sönam. ${ }^{199}$ The third medium is Nangso Gönor and the fourth is Sepo Sönam, at which point we begin to have solid dates. Strangely, Tupten Püntsok does not provide an end date for Nangso Gönor, who died in 1647. Sepo Sönam was installed as the next oracle the same year, which is also not given in Tupten Püntsok's list. While a solid lineage can be constructed from the third medium onward, the enumeration of the first two mediums is more problematic. Aside from the lack of any historical references to Lobzang Penden, the long time span suggests that there were more than two mediums before Nangso Gönor. There has been a Nechung Oracle since the mid-sixteenth century, the twilight years of the Second Dalai Lama. With the average oracle being active for $10-30$ years ${ }^{200}$ it is likely that one or two unnamed oracles may be missing from Tupten Püntsok's list. If this is the case, Jampa Gyatso's placement is also

\footnotetext{
${ }^{196}$ Sangs rgyas rgya mtsho 1989, pp.397.1-2, 606.1; this work was composed in 1701.

${ }^{197}$ See the citations of the Nechung Liturgy colophons in chapter 2.

${ }^{198}$ Tib. Blo bzang dpal ldan; see Thub bstan phun tshogs 2007, p.79.

${ }^{199}$ Tupten Püntsok also states that there is another medium named Ringangpa (Tib. Rin sgang pa), which he claims is another name for Jampa Gyatso. He provides no citations for this name or his assertion; see ibid, pp.79-80.

${ }^{200}$ See the chart below; the notable exception is Śākya Yarpel, who acted as the Nechung Oracle for nearly fifty years.
} 
uncertain. However, it is also possible that there were periods of time when there was no active Nechung Oracle.

Regardless, the early history of the Nechung Oracle is clearly difficult to ascertain. Historical accounts of the lineage of mediums begin to emerge in the seventeenth century, with detailed and consistent data not appearing until the Fifth Dalai Lama's writings. Currently, the list compiled by Tupten Püntsok is the standard list accepted by the Tibetan Government-inExile. While this section is primarily concerned with seventeenth-century Nechung Oracles and their prophecies, I provide below Tupten Püntsok's full list of Nechung mediums in English, with emendations made to account for some of the issues discussed above. I have retained Tupten Püntsok's numbering as well, since there is no solid evidence that there were more than two mediums preceding Nangso Gönor. A number of these mediums were mentioned in the previous chapter: ${ }^{201}$

\begin{tabular}{|c|c|c|c|}
\hline & Nechung Mediums & Installation & Resignation \\
\hline 1. & Lobzang Penden (Tib. Blo bzang dpal ldan) [?] & unknown & unknown \\
\hline 2. & Jampa Gyatso (Tib. Byams pa rgya mtsho) & unknown & unknown \\
\hline 3. & Nangso Gönor (Tib. Nang so dgos nor) & unknown & 1647 \\
\hline 4. & $\begin{array}{l}\text { Sepo Sönam (Tib. Sras po bsod nams) } \\
\text { Note: Chosen from among several mediums. }\end{array}$ & 1647 & $1677[?]$ \\
\hline $5 a$. & Unnamed medium, monastic secretary & $1677[?]$ & 1678 \\
\hline $5 b$. & Tsewang Pelwar (Tib. Tshe dbang dpal dbar) & 1678 & 1689 \\
\hline 6. & $\begin{array}{l}\text { Kongpo Lobzang Lekjor } \\
\text { (Tib. Kong po Blo bzang legs 'byor) }\end{array}$ & 1690 & unknown \\
\hline 7. & $\begin{array}{l}\text { Tsangyang Tamdrin } \\
\text { (Tib. Tshangs dbyangs rta mgrin) }\end{array}$ & 1725 & 1747 \\
\hline
\end{tabular}

\footnotetext{
${ }^{201}$ For an English-language discussion of Nechung Oracles, particularly those active in the first half of the twentieth century, see Nebesky-Wojkowitz 1998, pp.444-454. For an even older account, see Waddell (1895, pp.478-481), who refers to the Nechung Oracle as the the Necromancer-in-Ordinary to the Government. For the following list in the original Tibetan, see Thub bstan phun tshogs 2007, p.138.
} 


\begin{tabular}{|c|c|c|c|}
\hline 8. & Ngawang Gyatso (Tib. Ngag dbang rgya mtsho) & 1747 & unknown \\
\hline 9. & Yuloköpa (Tib. G.yu lo bkod pa) & unknown & unknown \\
\hline 10. & Kelzang Tsultrim (Tib. Bskal bzang tshul khrims) & 1837 & 1856 \\
\hline 11. & Śākya Yarpel (Tib. Śākya yar 'phel) & 1856 & 1900 \\
\hline 12. & Lobzang Sönam (Tib. Blo bzang bsod nams) & 1901 & unknown \\
\hline 13. & Gyentsen Tarchin (Tib. Rgyal mtshan mthar phyin) & 1913 & $1915^{202}$ \\
\hline 14. & $\begin{array}{l}\text { Lobzang Sönam } \\
\text { Note: Installed as the Nechung Oracle a second time. }\end{array}$ & unknown & 1936 \\
\hline 15. & Lobzang Namgyel (Tib. Blo bzang rnam rgyal) & 1936 & 1944 \\
\hline 16. & Lobzang Jikmé (Tib. Blo bzang 'jigs med) & 1945 & 1984 \\
\hline 17. & Tupten Ngödrup (Tib. Thub bstan dngos grub) $)^{203}$ & 1987 & present \\
\hline
\end{tabular}

Nebesky-Wojkowitz provides an oral account for exactly why the Nechung Oracle was elevated to the status of state oracle. Apparently during the time of the Fifth Dalai Lama, "members of the Nepalese community intended to kill the inhabitants of Lhasa by poisoning the public wells." ${ }^{204}$ The Nechung Oracle revealed this plot through his clairvoyant powers and the plan was foiled. As dramatic as this story is, it is surprisingly absent from the Fifth Dalai Lama's autobiography and related sources. There was a brief dispute in 1661 when Nepalese forces invaded Tibet's borders, ${ }^{205}$ which may have produced ethnic tensions within Lhasa. However, there is no solid evidence that Nepalese citizens in Lhasa reacted to such tensions by attempting to poison the city. How is it that the most important event in the development of the Nechung Oracle's institution is not mentioned once in any of the primary sources discussed above? In this case, a complete absence of evidence is evidence of absence. This story was likely a later embellishment to provide a specific reason for the Nechung Oracle's promotion.

\footnotetext{
${ }^{202}$ See Nebesky-Wojkowitz 1998, p.452.

${ }^{203}$ Photographs of the last three Nechung mediums are available in Thub bstan phun tshogs 2007, pp.286-288 (these pages are unnumbered and are found in the photographs section at the end of the book).

${ }^{204}$ Nebesky-Wojkowitz 1998, p.449. Waddell 1895, p.479, provides the earliest recounting of this legend, though he likewise provides no sources beyond oral tradition.

${ }^{205}$ See Shakabpa 2010, vol.1, p.362.
} 
If this is the case, then when was the Nechung Oracle established as the state oracle? Perhaps this is an instance where an English term distorts the Tibetan reality. While most English works that discuss the Nechung Oracle-including this one-use the phrase 'state oracle, ${ }^{206}$ this does not translate a specific Tibetan term. There are words for 'oracle' and 'medium,' as discussed last chapter, but when specifying the political import of an oracle such as Nechung, accounts simply append qualifiers like 'god of the Ganden Podrang.' There is no specific position called 'state oracle' in Tibetan because it did not exist before the Fifth Dalai Lama established his administration and made oracles a part of it. As with the story about poisoned wells, there is no specific moment found in the literature when the Nechung Oracle was established as a state oracle. He was clearly important to the Fifth Dalai Lama throughout his life. Indeed, according to Sangyé Gyatso, the Nechung Oracle went into trance on the occasion of the Fifth Dalai Lama's entry into Drepung Monastery at the age of six. ${ }^{207}$ Furthermore, as discussed above, the relationship between the Dalai Lamas and Pehar had been established well before then.

There is a consistently detailed focus on the transition between mediums starting in 1647, early in the Fifth Dalai Lama's rule. This detail betrays an anxiety about maintaining an effective Nechung Oracle over the course of the Great Fifth's newly secured governance. Special attention is given to when these transitions are completed successfully. For instance, although Tsewang Pelwar began showing signs of possession in 1678, efficacious possessions did not start until the following year, at which point there was much relief. Members of the government were also involved in aiding these transitions. The Fifth Dalai Lama's regent, Sönam Rapten, was instrumental in Sepo Sönam's recognition, and the Great Fifth himself was involved in Tsewang Pelwar's eventual installation. It seems that these successful moments act as inaugurations, emphasizing the medium's entry into the office. This suggests that, rather than one moment of promotion, these periodic inaugurations renewed and reinforced the oracle's relationship to the government. Nechung Monastery had been a work in progress since Trinlé Gyatso's regency, before its expansion in 1682 and completion in 1690. Likewise, the Nechung Oracle's rise was not a single event but a gradual advancement, beginning in the 1640s at the latest and coming to fruition by the 1680 s.

\footnotetext{
${ }^{206}$ The use of this term in English extends back to at least the late nineteenth century; see Waddell 1895, p.246. Nebesky-Wojkowitz elaborated on the concept in his 1948 German article, "Das tibetische Staatsorakel;" see Nebesky-Wojkowitz 1972.

${ }^{207}$ See Sangs rgyas rgya mtsho 1980, vol.2, p.200.4-6.
} 
The mediums of the Nechung Oracle had vague beginnings, and even during the Fifth Dalai Lama's rule medium transitions were difficult. Yet along with Nechung Monastery's full establishment, the lineage of its mediums also became standardized. Chapter 2 showed that the Nechung Oracle was instrumental in the development of Nechung's liturgy; now we see that the oracle was equally and intimately linked to the institution's expansion.

\section{Monastery and Chapel Networks}

No monastery is an island, and this is especially the case with Nechung Monastery. In Sangyé Gyatso's Yellow Beryl, cited above, he mentions a series of monasteries where the Nechung deities were also active. These sites include Drokmo, Gönpasar, Kyormolung, Kadruk, and Rampa. The histories of these sacred centers are difficult to trace, but their listing indicates broader inter-institutional ties between Nechung and other places. From the seventeenth century onward, a number of historically significant monasteries and chapels in and around Lhasa became tied to the Five Sovereign Spirits. Whatever their earlier histories, these institutions were subjugated by the Dalai Lama's government and their liturgical repertoires were aligned with Nechung's central rites. The ritual programs implemented at these centers were then employed in service to the Dalai Lamas' expanding political control. The mural iconographies and deity arrays of these various sacred sites were also changed to reflect the Nechung pantheon. These rituals and iconographies linked the institutions together through a common state deity cult in which the Five Sovereign Spirits were propitiated to protect the Dalai Lama and the Tibetan government, as well as to defeat their enemies.

This network of sites includes Tsel Yangön Monastery, ${ }^{208}$ Deyang College ${ }^{209}$ at Drepung Monastery, Meru Nyingpa Monastery, Gadong Monastery, ${ }^{210}$ Karmasha Chapel, ${ }^{211}$ and Banakzhöl Chapel. ${ }^{212}$ Each of these sacred centers has a historical and ritual connection to Nechung and the Five Sovereign Spirits, and they will be individually explored below. I have visited all of these sites and have gathered much of the following information in situ, as well as

\footnotetext{
208 Tib. Tshal Yang dgon.

${ }^{209}$ Tib. Bde yangs grwa tshang.

210 Tib. Dga' gdong dgon.

${ }^{211}$ Tib. Kar ma shag btsan khang.

212 Tib. Sbra nag zhol rgyal khang. While Karmasha and Banakzhöl are called 'chapels,' the Tibetan meaning is slightly distinct between the two. Karmasha is a btsan khang, which means 'house of an imperial spirit,' while Banakzhöl is a rgyal khang, meaning 'house of a sovereign spirit.'
} 
from contemporary sources, so there is a potential for anachronism. However, while it is beyond the scope of this study to examine in detail the historical nuances of each place, it is hoped that by presenting their basic histories and current characteristics it will reveal something about the relationship they have had with Nechung.

\section{Tsel Yangön Monastery}

Tsel Yangön Monastery has been discussed before as the likely site of Pehar's residence after Samyé but before Nechung (Figure 78). The monastery is located in the region of Tsel, just southeast of Lhasa on the southern banks of the Kyichu River. Yangön sits just outside the border of modern-day Lhasa and is only a 6-mile drive from the Jokhang Temple. This monastery was founded in 1175 by Lama Zhang-who would establish Tsel Gungtang twelve years later - and it is the oldest continuous monastery in Tsel. The monastery's establishment was requested by Dakgöm Tsultrim Nyingpo. ${ }^{213}$ The popular oral account of Pehar antagonizing Lama Zhang has the deity living at Yangön before burning down Tsel Gungtang; this resulted in Lama Zhang tossing the deity into the Kyichu.

According to oral tradition, Lama Zhang was meditating at the Jakar hermitage ${ }^{214}$ one day when a whirlwind suddenly passed through the sky. A piece (Tib. tshal bu) of Lama Zhang's robe was carried away by the wind and fell into the river valley below. Thus, the area where the cloth fragment fell was called 'Tsel."215 Lama Zhang said, "This is a good sign and omen that the Buddha's serene teachings and sentient beings must gather at this place. In this pure land that has accumulated merit, a monastery - a foundation for the teachings — should be founded." Having developed a priest-patron relationship with Gar Gyelwé Jungné, ${ }^{216}$ Lama Zhang built Yangön Monastery and established a group of monks there in the Earth-Sheep year (1175). From that day forth, the monastery was part of the four great Kagyü traditions, though it was entrusted to the Tselpa Kagyü tradition first. ${ }^{217}$ With the rise of the Gelukpa sect, Yangön

\footnotetext{
${ }^{213}$ Dwags sgom Tshul khrims snying po, 1116-1169; see Sørensen, Hazod, and Tsering Gyalbo 2007, vol. 1, pp.32, 94.

${ }^{214}$ Tib. Bya 'khar ri khrod. This hermitage is located on Jakar Mountain, southeast of Tsel Gungtang, and is an important meditation site for Lama Zhang; see ibid, p.81n.40.

${ }^{215}$ A version of this story is given in ibid, p.84n.52.

216 Tib. 'Gar Rgyal ba'i 'byung gnas. This figure was an important patron for Lama Zhang; see ibid, p.145.

217 These details were paraphrased from Bstan pa mkhyen rab 1993, pp.12-13. See this work for a fuller discussion of this monastery's structure and contents. For a detailed history of Yangön's lineage of lords, see Sørensen, Hazod, and Tsering Gyalbo 2007, vol.1, pp.91-116; a more compact list is also found in Sangs rgyas rgya mtsho 1980, vol.1, p.247.1-6.
} 
Monastery and the other major centers of Tsel were converted into Geluk centers around the sixteenth century, though the specific date for Yangön's conversion is unknown. ${ }^{218}$

In pre-modern times, Pehar's relationship with the Tsel region was renewed annually during the fourth-month Gungtang Flower Offering festival. As discussed last chapter, the Nechung Oracle and other Nechung monks would go to Tsel Gungtang and make offerings at Tsel Yangön. The Nechung Oracle would also participate in the procession of Penden Lhamo and Drip Dzongtsen. ${ }^{219}$ This event would acknowledge Pehar's past while reaffirming the passing of the political torch from Tsel to the Ganden Podrang. Outside of this holiday, Nechung's relationship to Gungtang also became permanently situated at Nechung Monastery. As stated above, Sangyé Gyatso's Yellow Beryl does not include the Desire Realm Chapel in his description of Nechung. While the chapel space was first used to house Pehar's thread-cross mansion, it seems it was converted into a chapel for Dhūmāvatī, the 'Queen of the Desire Realm,' sometime in the eighteenth century in order to strengthen ties with Tsel Gungtang's central deity. As for Yangön Monastery, the specific site of Pehar's arrival in Tsel, which is referred to as his 'birthplace' by Guntram Hazod, is located just southeast of the monastery proper. ${ }^{220}$ As of 1993 there had been an ancient chapel dedicated to Pehar on the grounds of Yangön, located just beyond the northeast corner of the monastery. ${ }^{221}$ It has since been torn down, along with a nearby chapel for the Twelve Tenma Goddesses, and the area was converted into lay housing (Figure 79). ${ }^{222}$

Today Yangön Monastery is the site of very little religious activity; it currently has only one caretaker monk. The monastery is two-stories tall and consists of an assembly hall, a doorless inner sanctum, and monks' apartments on the second floor. It has a spaceous enclosed courtyard, which is generally accessed from the west gate. There is a legible register inscribed on the north-facing western wall of the monastery's vestibule. To my knowledge this is the only copy of the register available. The faded murals of the vestibule include images of the Wheel of Existence $^{223}$ and the Four Great Kings. ${ }^{224}$ The murals within the assembly hall are much newer,

\footnotetext{
${ }^{218}$ See Sørensen, Hazod, and Tsering Gyalbo 2007, vol.1, pp.115-116.

${ }^{219}$ For more information on this holiday and the history behind it, see ibid, vol.2, pp.573-596.

${ }^{220}$ For a map, see Sørensen, Hazod, and Tsering Gyalbo 2007, vol.1, p.237, graph 5; see also ibid, vol. 2, p.629.

${ }^{221}$ See Bstan pa mkhyen rab 1993, pp.16-17.

${ }^{222}$ A photo of this chapel's site, taken a decade earlier, is also found in Sørensen, Hazod, and Tsering Gyalbo 2007, vol.1, p.327, image 35 .

${ }^{223}$ Tib. srid pa'i 'khor lo.

${ }^{224}$ Tib. rgyal chen bzhi.
} 
though they primarily consist of hundreds of images of Amitāyus. ${ }^{225}$ The main exceptions are two murals flanking the main entrance. The mural on the wall west of the entrance is of Tsiu Marpo; on the wall east of the entrance is Dorjé Yudrönma, ${ }^{226}$ who is by some accounts considered the head of the Twelve Tenma Goddesses. ${ }^{227}$ Other notable images in the assembly hall include an encased photograph of the current Nechung Oracle as well as a statue of the central Drikung Kagyü ${ }^{228}$ protector deity Achi Chökyi Drölma. ${ }^{229}$ Within Yangön's inner sanctum there are the following major statues, presented in clockwise fashion: [1] a reliquary, [2] Vajrapāṇi, [3] Lama Zhang, [4] Avalokiteśvara, [5] Guru Nangsi Zilnön, [6] Padmasambhava (central image), [7] Pehar (Figure 80), [8] Makzor Gyelmo, [9] Dorjé Yudrönma, and [10] Toktsen. $^{230}$ Every one of these figures has been encountered in Pehar's mythos or they are present at Nechung Monastery and other monasteries tied to Nechung. Moreover, according to Guntram Hazod, Tsiu Marpo is the chief protector deity of Yangön; local lore states that he was once retrieved from the Kyichu River in a fashion not unlike Pehar's retrieval at Nechung. ${ }^{231}$

The current ritual corpus for Yangön Monastery includes the Nechung Liturgy as well as a Drikung Kagyü amending and restoring rite. Also found in Yangön's repertoire is a 53-folio text entitled, A Lengthy Chanting Arrangement for the Supplications of the Palace of Adamantine Melody [Nechung], Exalted in the Three Realms, and the Ten-Chapter Sädhana. ${ }^{232}$ This work contains excerpts from the Ten-Chapter Sädhana as well as from other works dedicated to the Five Sovereign Spirits, a number of which were composed by several of the Dalai Lamas. The monastery's caretaker informed me that occasionally monks from Nechung

\footnotetext{
${ }^{225}$ Tib. Tshe dpag med.

${ }^{226}$ Tib. Rdo rje G.yu sgron ma.

${ }^{227}$ Other accounts give Dorjé Drakgyelma as the head of the Twelve Tenma Goddess; see Nebesky-Wojkowitz 1998, p.190, and Figure 62.

${ }_{228}^{22}$ Tib. 'Bri gung bka' brgyud.

229 Tib. A phyi chos kyi sgrol ma. I was informed by Mikmar Tsering that this deity is at Yangön Monastery because the current caretaker monk belongs to the Drikung Kagyü sect; personal correspondence, November 20, 2011. For more information on this deity, see Muldowney 2011.

${ }^{230}$ Sørensen and Hazod compiled a similar list of Yangön's threshold murals and inner sanctum statues; see Sørensen, Hazod, and Tsering Gyalbo 2007, vol.1, p.237, graph 4. Some of images provided in this list are different, suggesting that they have been replaced or added over the last decade. The main discrepancy is that they claim the western-side entrance mural is of Toktsen while the statue of the red imperial spirit within the sanctum is of Tsiu Marpo. However, the iconography of each image suggests it is the other way around, and the caretaker monk confirmed this; personal correspondence with Sönam Tsering (Tib. Bsod nams tshe ring), Yangön caretaker monk, November 3, 2011.

${ }^{231}$ See Sørensen, Hazod, and Tsering Gyalbo 2007, vol.2, p.597.

${ }^{232}$ Tib. Sa gsum na mngon par mtho ba rdo rje sgra dbyangs gling gi zhal 'don 'phrin las don bcu ma'i gton [sic: 'don] bsgrigs rag rig. The rag rig is being read as an uncommon variant for khrag khrig, meaning 'a great number.'
} 
would come to Yangön to perform these rituals. ${ }^{233}$ Beyond the Drikung Kagyü rituals, which appear to be for the current caretaker's own use, Yangön Monastery's liturgical heritage has been clearly synchronized with Nechung's. Not only does Yangön's history have an important place in Pehar's mythography, the legacy of the Five Sovereign Spirits has been iconographically and ritually maintained at the monastery since its conversion into a Geluk center.

\section{Deyang College}

Like Yangön, Deyang College also played an instrumental role in Pehar's mythic history (Figure 81). After being cast out of Tsel, Pehar floated down the Kyichu River in a coracle before ending up on the banks of the river below Drepung Monastery. It was the founder and abbot of Drepung's Deyang College, Jokpa Jangchup Penden (Figure 82), who became presciently aware of the deity's arrival and eventually established the Nechung Chapel for Pehar in 1529. Deyang College itself was founded nearly thirty years earlier, on the $10^{\text {th }}$ day of the $12^{\text {th }}$ month of a Monkey year (early 1501), ${ }^{234}$ when Jangchup Penden was 37 years old. ${ }^{235}$ The events surrounding the college's construction and consecration are detailed in the Hagiography of Jokpa Jangchup Penden:

[Deyang's construction was patronized by] more than 16 high geshés ${ }^{236}$ and 50 monks, as well as the patron clans of the Ngüldüpa and Takdongpa. The monasteries beyond [Drepung that surround Deyang in a mandalic configuration] are Orgyan Chödzongpa in the upper valley [to the north], Böngön Garpa College to the east, Mengön to the west, and the monastery of Dambak Marserchen in the lower valley [to the south]. ${ }^{237}$ When this Dharma center was established, the empowerments for all the cycles of the one hundred thousand Vajrayāna tantras were performed. [This included] the Vajramā $\bar{a}^{238}$ empowerments, the

\footnotetext{
${ }^{233}$ Personal correspondence with Sönam Tsering, November 21, 2011.

${ }^{234}$ See chapter 1 , note 79 , for a discussion of this problematic date.

${ }^{235}$ See Appendix IV, ff.8b.5-9a.1.

236 Tib. drung rab 'byams pa.

${ }^{237}$ See Sørensen, Hazod, and Tsering Gyalbo 2007, vol.1, p.217n.572. Could this last monastery be referring to the ancient monastery built in Dambak Marserchen by Muné Tsenpo around the turn of the eighth century?

${ }^{238}$ Tib. Rdo rje phreng ba; lit. "Vajra Garland." This is an important explanatory tantra for the Guhyasamaja tantric system.
} 
Kälacakra ${ }^{239}$ the Zhalu system of the Hevajra Tantra, ${ }^{240}$ the Mahāmāy $\bar{a},{ }^{241}$ the Guhyasamajja, ${ }^{242}$ the Chak system of [Vajra]bairava surrounded by Eight Zombies,${ }^{243}$ the Glorious Cakrasamvara ${ }^{244}$ the One Hundred [Cycles] of Mitra, ${ }^{245}$ the One Hundred [Cycles] of the Siddhas, ${ }^{246}$ the [practice for] Black and White Acala, ${ }^{247}$ the Homage to the Twenty-One $\left[\right.$ Tärās] ${ }^{248}$ and the [practice for] Red and Black [Mahākāla] with the Curved Blade. ${ }^{249}$ Through such limitless Dharma teachings and general doctrines of the Kadampa School, sentient beings were brought to the path of ripening and liberation.

The best of the clans made offerings. [This included] the Revered Lekden Düdjom, Norbu Wangyel, and their sister Drönmakyé, as well as their servants; the descendants of Prince Namgyelö; ${ }^{250}$ and from the Takdongpa clan, Nangso Sönam Dargyé, Nangso Tseten, Lady Tsering Wangmo, and their son Sönam Tsering, as well as their servants. The ancient samaya vow [was fulfilled] through the quality and quantity of the patrons as well as through the chief tutelary deity Cakrasamvara, [with whom there is] a continuous sacred bond. Each of the throne[-holders made] extensive offerings of dedication tormas and samaya tormas. Inseparable from the secret essence within all moral conduct, this fearless lion [Jokpa Jangchup Penden] sat atop [Deyang's] throne.

Regarding the Wheel of the Dharma of the profound, vast, and unsurpassed vehicle, it liberates fortunate beings, [bringing] them to ripening and liberation, and completes all the activities of tamable beings. Supplications were performed [by] disciples who gathered faithfully, led by the Revered Rinchen Zangpo, the Learned Drapa Gyentsen, and the Learned Rapten Döndrup-heads of meditation centers, Dharma colleges, and monasteries, etc. [The disciples also]

${ }^{239}$ Tib. Dus 'khor; lit. "Wheel of Time."

${ }^{240}$ Tib. Zhwa lugs Skyes [sic: kye] rdor.

${ }^{241}$ Tib. Mahā ma ya; lit. "Great Illusion."

242 Tib. Gsang 'dus; lit. "Secret Assembly."

${ }^{243}$ Tib. Chags lugs 'Jigs byed ro lang brgyad bskor; it is unclear what the Chak system is, though it may refer to Chak Jangchupling Monastery (Tib. Chag Byang chub gling).

${ }^{244}$ Tib. Bde mchog; lit. "Wheel of Great Bliss."

${ }^{245}$ Tib. Mi tra brgya rtsa.

${ }^{246}$ Tib. Grub thob brgya rtsa.

247 Tib. Mi g.yo ba dkar nag.

248 Tib. Phyag 'tshal nyer gcig.

${ }^{249}$ Tib. Gri gug dmar nag.

${ }^{250}$ Tib. lha sras Rnam rgyal 'od. This figure is a member of the Gugé (Tib. Gu ge) royal line; see Vitali 1996 , p.506. 
recited prayers and offerings for each of the Dharma protectors, such as Brahmā. ${ }^{251}$ Furthermore, it is said that [the Dharma protectors] guard [the monastery] and come quickly [when needed] because of their great karmic connection. Through both the Dharma and material wealth [the above individuals] came to aid this monastery. ${ }^{252}$

Deyang College is located roughly in the center of Drepung's large monastic complex, situated east of Loseling College ${ }^{253}$ and just downhill from Gomang College. ${ }^{254}$ Since it is part of Drepung it is already a Geluk center, and several registers are inscribed on the walls of its veranda. ${ }^{255}$ The college is active today and houses a handful of monks. It has been noted before that Deyang and Nechung have maintained a special relationship, given their historical connection. The monks of Deyang traditionally greeted the oracle and monks of Nechung when they would visit in the sixth, seventh, and twelfth months of the Tibetan year. Murals and statues inside the college reveal this close connection. There are murals of the Nechung Oracle within the assembly hall flanking the entrance (Figure 35$),{ }^{256}$ as well as a large portrait of the Five Sovereign Spirits surrounding Hayagrīva (Figure 83). In fact, there has been a mural of the Nechung Oracle in Deyang College's assembly hall since the late seventeenth century. ${ }^{257}$

Moreover, Deyang's top floor is called the Pehar Chapel, ${ }^{258}$ and its ritual corpus and images are exclusively dedicated to the Five Sovereign Spirits and related deities. Inside this chapel are life-size statues of figures like Tsiu Marpo, Dorjé Yudrönma, and members of the Five Sovereign Spirits. The chapel's inner sanctum houses a bust of Dorjé Drakden for its central image, surrounded by Guru Nangsi Zilnön and Makzor Gyelmo. The sanctum also possesses a miraculous self-created (Tib. rang byung) mural of the Nechung Oracle. The chapel's ritual text is entitled, Series of Deyang Chapel's Prayers and Offerings for the Two-the

\footnotetext{
${ }^{251}$ Tib. Gdong bzhi pa; lit. "Four-headed One."

${ }^{252}$ See Appendix IV, ff.8b.5-10a.5. The events of Pehar's arrival at Nechung, which were translated in chapter 1, immediately follow this description. For a list of Deyang Monastery's abbots, see Pan chen Bsod nams grags pa 2007, p.146. For a brief modern history of Deyang, see Tibetan Academy of Social Sciences 2009, pp.340-353.

253 Tib. Blo gsal gling grwa tshang.

254 Tib. Sgo mang grwa tshang.

${ }^{255}$ Unlike Yangön Monastery, the registers of Deyang College have been transcribed and published in the original Tibetan; see ibid, pp.646-659.

${ }^{256}$ There is another mural of the Nechung Oracle in Deyang Monastery's assembly hall, on the other side of the entrance, though its face is covered.

${ }^{257}$ See Sangs rgyas rgya mtsho 1980, vol.2, p.253.5. This list also mentions Makzor Gyelmo and the goddess Drakgyelma (referred to by the variant Drakmogyel [Tib. Drak mo rgyal]) among Deyang's murals.

258 Tib. Dpe har lcog.
} 
Five Sovereign Spirits in General, the Leaders of the Haughty Spirits, and the Imperial Spirit Kyechik [Marpo in Particular], Nechung's Enemy-defeating God. ${ }^{259}$ It is immediately clear that the Nechung deities, especially Kyechik Marpo, are at the heart of this corpus. The Five Sovereign Spirits as they are practiced at Nechung pervade the imagery and ritual of Deyang College, which has continued to nurture the memory of Pehar's arrival during Jokpa Jangchup Penden's time. Deyang is Pehar's home within the walls of Drepung Monastery, located just a few doors down from the Ganden Podrang.

\section{Meru Nyingpa Monastery}

Meru Nyingpa Monastery is located in the center of the Barkhor circuit, situated right behind the Jokhang Temple on its eastern face (Figure 84). This monastic complex is one of the most ancient sacred sites in Tibet. There are three centers within this complex, which is accessed from an alleyway to the north. The oldest part of Meru Nyingpa is a small chapel dedicated to the wealth god Jambhala, ${ }^{260}$ a form of Vaiśravana. This chapel was founded in the ninth century during the reign of King Relpachen (806-841), ${ }^{261}$ the last of the three great Buddhist Kings of Tibet. The Jambhala Chapel $^{262}$ is the first chapel one encounters when entering the complex grounds; it is on the west end of the courtyard behind a line of prayer wheels. Oral tradition claims that the chapel was built next to a boulder, now walled over, that was sacred to the first Tibetan Buddhist King Songtsen Gampo. ${ }^{263}$ On the floor above the Jambhala Chapel is the Bramzé Chapel, ${ }^{264}$ dedicated to the deity Bramze and built in the nineteenth century. This chapel is managed by Sakya monks from Gongkar Chödé Monastery, ${ }^{265}$ southwest of Lhasa.

Like the Jambhala Chapel, the monastery's name is also believed to stem from the ninth century. At that time two protector chapels were thought to have been constructed in each of the four cardinal directions surrounding the Jokhang Temple. A white chapel and a red chapel were built east of this sacred temple. The white chapel was called "the white one" in ancient Tibetan (Tib. dkar ru or ka ru) and the red chapel was called "the red one" (Tib. dmar ru or rme ru). The

\footnotetext{
${ }^{259}$ Tib. Dregs pa'i sde dpon sku lnga spyi dang gnas chung dgra lha skyes gcig rgyal btsan gnyis bcas bde yang lcog gi gsol mchod bya ba'i rim pa rnams.

${ }^{260}$ Tib. Dzam bha la.

${ }^{261}$ See Sørensen 1994, pp.410-411n.1420.

${ }^{262}$ Tib. Dzam bha la lha khang.

${ }^{263}$ See Alexander 2005, p.105.

${ }^{264}$ Tib. Bram ze mgon khang.

${ }^{265}$ Tib. Gong dkar chos sde.
} 
red chapel, Meru, referred to the building that is now known as the Jambhala Chapel. ${ }^{266}$ When Meru Sarpa ("New Meru”) was founded centuries later, this sacred center came to be called Meru Nyingpa ("Old Meru”). ${ }^{267}$ As the name implies, the new Meru monastery has historical ties to the old one.

The site of Meru Nyingpa was dramatically enlarged in the nineteenth century, at which time a monastic assembly hall was established. This monastery was founded in the 1880 s by the Nechung medium Śākya Yarpel, and it has been a satellite of Nechung Monastery and housed members of Nechung's monastic community ever since. ${ }^{268}$ Meru Nyingpa and Nechung did have a connection prior to the late nineteenth century, though there is disagreement on just when it began. André Alexander places the start of this institutional relationship in the seventeenth century, ${ }^{269}$ while Tsering Gyalbo dates it to the eighteenth century, when the site was apparently renovated. $^{270}$ A partially damaged register is visible in the monastery's portico, though its contents have yet to be transcribed. Otherwise, the complex as a whole suffered comparatively little damage during the Cultural Revolution. The monastery faces south and is three stories high; it has storage rooms on the first floor, the assembly hall and inner sanctum on the second, and the former apartments for the Dalai Lama and Nechung Oracle on the third. As discussed last chapter, the Nechung Oracle and other Nechung monks would reside at Meru Nyingpa during most of the first month of the Tibetan New Year for festivities and rituals.

Murals of the Black and Red Butchers cover the threshold to Meru Nyingpa's portico, within which there are murals of the Four Great Kings flanking the entrance to the assembly hall. Inside the assembly hall there are grand murals of the Nechung protectors and related deities. These murals are the originals, though they were retraced and varnished in the mid-1990s. ${ }^{271}$ Moving clockwise from the entrance, the divine array is as follows: [1] Tsiu Marpo, [2] Nyenchen Tanglha, ${ }^{272}$ [3] Pelgön Bramzé, ${ }^{273}$ [4] Nyima Zhönnu, [5] an enemy-defeating god, ${ }^{274}$

\footnotetext{
${ }^{266}$ See Tshe ring rgyal po 2005, p.395.

${ }^{267}$ For more on Meru Sarpa, see Alexander 2005, pp.124-140; this monastery is called Meru Dra-tsang in this work.

${ }^{268}$ See ibid, p. 105 .

${ }^{269}$ See ibid.

${ }^{270}$ See Tshe ring rgyal po 2005 , p.395.

${ }^{271}$ See Alexander 2005, p.109.

${ }^{272}$ Tib. Gnyan chen thang lha. For more on this popular mountain god, see Nebesky-Wojkowitz 1998, pp.205-209.

${ }^{273}$ Tib. Dpal mgon bram ze; this is the central deity of the Sakya chapel within this complex. I was informed by one of Meru Nyingpa's monks that this deity is a manifestation of Avalokiteśvara; personal correspondence, July 23, 2007.

${ }^{274}$ This is the same figure painted on the wall of Nechung Monastery's Central Chapel; see note 36 above and Figure 58.
} 
[6] Kyechik Marpo, [7] Shingjachen, [8] Dorjé Drakden, [9] Pehar, ${ }^{275}$ [10] Hayagrīva (flanked by Rāhula and Ekajațā), [11] Vajrabhairava, [12] unknown, ${ }^{276}$ [13] Makzor Gyelmo, [14] Gyajin, [15] Mönbuputra, [16] Dorjé Yudrönma (surrounded by the Twelve Tenma Goddesses), [17] Dorjé Yudrönma (alone), [18] Dorjé Lekpa, [19] the Two Lords of the Charnel Grounds, ${ }^{277}$ and [20] Toktsen. The Five Sovereign Spirits and Dorjé Drakden are accompanied by their consorts, ministers, and emanations, and all of these monolithic figures are surrounded by numerous smaller deities.

The entrance into Meru Nyingpa's inner sanctum is situated between murals 10 and 11 . Flanked by encased statues of Dorjé Drakden (Figure 85) and Makzor Gyelmo, this inner sanctum is in a distinct chapel accessed by stairs. Approached clockwise, the sanctum's pantheon of statues is: [1] Shingjachen, [2] Nyima Zhönnu, [3] Kyechik Marpo, [4] Hayagrīva, [5] Padmasambhava (central image), [6] Pehar, [7] Gyajin, [8] Mönbuputra, and [9] Toktsen. A thread-cross mansion is locked in a case next to this last statue, which is opened only once a year for Universal Incense Offering Day. There is a door in the sanctum that leads to a stairwell, which in turn leads to the second floor apartments. This apartment space is now a chapel dedicated to Dorjé Drakden and it displays a life-size statue of the deity. Meru Nyingpa's structure clearly mimicks Nechung Monastery's - in both centers the assembly hall has murals of the Five Sovereign Spirits and related deities, the inner sanctum reduplicates these deities as statues, and the second floor has the oracle's apartment. Meru Nyingpa is also syncretistic like Nechung; the Jambhala Chapel is Nyingmapa, the Bramzé Chapel is Sakyapa, and the central monastery is Gelukpa. ${ }^{278}$ Moreover, it appears that at the time of Meru Nyingpa's construction, Dorjé Drakden and Makzor Gyelmo were well established as the two protectors of the Tibetan government, since they have symbolically equal footing in this monastery. This illustrates a subtle historical and iconographic distinction from the murals at Nechung, where the relationship between the two deities is not as clear.

\footnotetext{
${ }^{275}$ In recent years, this painting has been blocked by a large encased statue of Thousand-Armed Avalokiteśvara. For a photograph of this mural before it was covered, see Ricca 1999, p.156, Plate (Tav.) 6.

${ }^{276}$ Like Pehar, this painting is blocked by statues. The first image is an encased statue of Four-Armed Avalokiteśvara; the second is a model of the Mahabodhi Temple in Bodh Gaya, India.

${ }^{277}$ Tib. Dur khrod bdag po gnyis; these two distinct figures are macabre skeletons intertwined in dance.

${ }^{278}$ See Alexander 2005, pp.102-123, for a detailed discussion of Meru Nyingpa's architecture. For more historical background, see Tshe ring rgyal po 2005; Bshes gnyen tshul khrims 2008, pp. 24-26; and Chos 'phel 2009, pp.26-27. For an English introduction to this monastery that includes an interactive map and panorama photographs of the assembly hall, see Tibetan and Himalayan Library 2013.
} 
Today there are less than ten monks at Meru Nyingpa, two of which are Nechung monks. The ritual corpus for the monastery is the Nechung Liturgy, and the Ten-Chapter Sädhana is especially important since it is performed every Wednesday. Likewise, the torma offerings presented during these ceremonies are the same as those offered at Nechung Monastery. Iconographically, structurally, and ritually, Meru Nyingpa is Nechung's satellite within Lhasa's old city.

\section{Gadong Monastery}

Gadong - which literally means 'Happy Face'-is the oldest of the monasteries tied to Nechung (Figure 86), at least according to oral tradition. The monastery is located in the Tölung valley just west of Lhasa and is on the other side of Gepel Utsé Mountain. It is less than 9 miles west of the Jokhang Temple. Despite its antiquity and its proximity to Drepung Monastery, substantial historical data on Gadong is lacking. According to an 1820 Tibetan geography, the Extensive Explanation of the World, ${ }^{279}$ Gadong was founded by Zhikpo Sherap ( $11^{\text {th }}$ century). ${ }^{280}$ Sangyé Gyatso also states that Zhikpo Sherap was the monastery's founder, ${ }^{281}$ and there is a statue of this figure within the monastery's central chapel. However, there is a brief contemporary history of Gadong that hangs over the monastery's entrance, which claims that it was establisheded by the vinaya master Wangchuk Tsültrimbar. ${ }^{282}$ The Blue Annals places this figure primarily in the eleventh century, explaining that he went to Gadong and spent most of his life there; ${ }^{283}$ it does not state that he founded the monastery, nor does it explain who did. Perhaps Zhikpo Sherap and Wangchuk Tsültrimbar are one and the same, or the latter was the disciple of the former.

Regardless, the history posted over Gadong's entrance discusses Wangchuk Tsültrimbar, and it is the most complete history of the monastery so far available. This short history is entitled, A Brief Introduction to the History of Gadong Monastery-Palace of Illumination; ${ }^{284}$ it is framed by two poems and its author is unknown. A translation of its central prose section is as follows (Figure 87):

\footnotetext{
${ }^{279}$ Tib. 'Dzam gling rgyas bshad; for an English translation of this work, see Wylie 1962.

${ }^{280}$ See ibid, p.150n.333.

${ }^{281}$ See Sangs rgyas rgya mtsho 1980, vol.1, p.256.5.

282 Tib. Dbang phyug tshul khrims 'bar, 1047-1131.

${ }^{283}$ See Roerich 1996, pp.78-79.

${ }^{284}$ Tib. Dga' gdong gsal byed gling dgon gyi lo rgyus ngo sprod mdor nsdus.
} 
The founder of this monastery [was] the vinaya master of Gya, Wangchuk Tsültrimbar. He was born in the Fire-Pig year of the first Tibetan rabjung (1047) into the sublime family lineage of the Mangrel of Upper Nyang. ${ }^{285}$ Having become learned in the general sütras and mantras, and in the vinaya especially, he acted diligently to benefit the [Buddha's] teachings and [all] sentient beings. $\mathrm{He}$ founded this monastery and made it his own principal dwelling place. $\mathrm{He}$ peacefully passed away at the age of 85 , in the Iron-Pig year of the second Tibetan rabjung (1131). This monastery was founded in the middle of the eleventh century, in the Iron-Monkey year of the first Tibetan rabjung (1080). In the past, before Sera, Drepung, and Ganden were founded, there were six Kadampa monastic centers in Ü. These [places] are known as the three-Gadong, Kyormolung, and Zülpu ${ }^{286}$ — and the [other] three-Sangpu Neutok, Dewachen, ${ }^{287}$ and Tsel Gungtang. ${ }^{288}$ [It is from these centers that] bearers of the Kadampa tradition, and the exposition and study of the five-volume teachings, ${ }^{289}$ were greatly disseminated.

In the seventh Tibetan rabjung, in 1390, Lama Umapa Tsöndrü Senge ${ }^{290}$ and Lord Tsongkhapa came together, drew the sacred boundaries of retreat, and resided there. The two masters each dwelled in a meditation room, and sometimes gathered [together] to drink tea, etc. First the Precious Lord [Tsongkhapa] entrusted Lama Umapa [with] translating. Then he listened to many Dharma [teachings delivered through visions] by the Venerable Mañjuśrīi, ${ }^{291}$ and he asked many questions about the Mantra[yāna], specifically Emptiness. He performed, in a very diligent [manner], the approach and accomplishment of his tutelary deity, and in no time at all he directly perceived the face of Mañjughoșa. ${ }^{292}$ Furthermore, he understood [that this place was] an

\footnotetext{
${ }^{285}$ Tib. Myang stod mang ral; Myang stod is located in Tsang.

${ }^{286}$ Tib. Zul phu. The Tibetan expression that refers to these monasteries is dga' skyor zul gsum.

${ }^{287}$ Tib. Bde ba can; This monastery is today referred to as Ra stod; personal correspondence, Mikmar Tsering, November 13, 2011.

${ }^{288}$ The Tibetan expression that refers to these monasteries is gsang bde gung gsum.

${ }^{289}$ Tib. bka' pod lnga; these are [1] logic (Tib. tshad ma), [2] Mādhyamika (Tib. dbu ma), [3] Prājñapāramita (Tib. phar phyin), [4] Abhidharmakośa (Tib. mngon pa mdzod), and [5] Vinaya (Tib. 'dul ba).

${ }^{290}$ Tib. Bla ma Dbu ma pa Brtson 'grus seng ge, b. $14^{\text {th }}$ cent.

${ }^{291}$ Tib. 'Jam dpal dbyangs.

292 Tib. 'Jam dbyangs.
} 
extraordinarily sacred site, [where] such things as outer, inner, and secret visions of the tutelary deities Vajrabhairava ${ }^{293}$ and Dharmarāja ${ }^{294}$ occur. Nowadays, things like a sacred painting of Mañjughoșa can be seen in the Mañjughoșa Temple. The plaster meditation cave underneath that is the Precious Lord's meditation room. Then, after about the ninth Tibetan rabjung [early- to midsixteenth century] the monastery deteriorated, and the exposition and study of theory and practice gradually disappeared [from there].

Later, during the time of the Fifth Dalai Lama, the [monastery] was restored. Along with this, the Great Fifth appointed the southern sovereign spirit of good qualities [Shingjachen] as the lord and protector of the place. [This deity's] medium came to reside there and his tradition flourished. The [Gadong] protector is similar to the protector deities of the successive Dalai Lamas and the previous Tibetan government. He guards the virtuous forces and is very famous, such as being the protector of Gomang College at Drepung. Traditionally, [monks] would come [to the monastery] from Drepung every year for the summer offering. The chief care and protection of this monastery was conducted by Gomang College at Drepung Monastery, and its monastic community [consisted of] about 50 monks. There were [also] many amazing supports, such as the three supports of [sacred] deity statues. Tantric ritual was emphasized and elaborate religious duties were performed, such as [rituals dedicated to] the tutelary deities Secret Sädhana Hayagrīva, the Thirteen-Deity Bhairava, and the Omniscient One [Vairocana], ${ }^{295}$ as well as fasting, ritual dances, and torma-throwing ceremonies.

Nevertheless, during the Cultural Revolution, apart from the assembly hall, [the monastery] disappeared without a trace. Furthermore, in the Fire-Tiger year of the sixteenth Tibetan rabjung (1985 [sic: 1986]), [the monastery] was renovated through the approval of the higher authorities [and] with the support of patrons like Chakdor-la ${ }^{296}$ and the masses of devotees... ${ }^{297}$

\footnotetext{
${ }^{293}$ Tib. Rdo rje 'jigs byed.

${ }^{294}$ Tib. Chos rgyal.

${ }^{295} \mathrm{Tib}$. Kun rig; this likely refers to Kun rig Rnam par snang mdzad.

${ }^{296}$ Tib. Phyag rdor lags.

${ }^{297}$ The last two-and-a-half lines of this history have been censored. The line before the censored portion begins to explain that, prior to the 1986 renovation, two monks named Ngawang Lekshé-la (Tib. Ngag dbang legs bshad lags) and Jampa Zangpo-la (Tib. Byams pa bzang po lags), took on teaching duties, presumably at Gadong. There are two
} 
A plaque at the entrance to Gadong's courtyard states that the monastery's modern renovation and religious revivification was completed in 2009.

Sangyé Gyatso confirms some of the above historical points, such as the time spent at Gadong by Lama Umapa and Tsongkhapa, as well as the latter's visions of Mañjuśrī. The regent also briefly discusses the relationship between Drepung and Gadong, though he says nothing of its central protector. ${ }^{298}$ The practice of householder monks had also been active at the monastery from at least the late seventeenth-century, ${ }^{299}$ which may explain how the Gadong Oracle lineage developed as a hereditary line. ${ }^{300}$ At the time of the Yellow Beryl's composition, Gadong had 80 monks and nuns. ${ }^{301}$

If the other details of the above account are otherwise accurate, it reveals significant facts about Gadong's historical nature. The monastery started out as a Kadampa center before being imbued with further sacred character by Tsongkhapa's presence. According to the Fifth Dalai Lama's autobiography, he had to have taken over the monastery and appointed Shingjachen as its main protector by 1640, shortly before he assumed political power; this work also records the Gadong Oracle going into trance over a decade later, in $1654 .^{302}$ The connection to Drepung's Gomang College cannot be as confidently traced, but it is clear that the Gadong deity has a relationship with the college today-Gomang's protector chapel possesses a life-size statue of the deity. ${ }^{303}$ Just as Deyang College is Nechung's home within Drepung, so it seems Gomang College is Gadong's Drepung satellite. When Keith Dowman visited the monastery in the mid1980s, he claimed that it and the cave where Tsongkhapa meditated had disappeared. ${ }^{304}$ However, according to the above historical account the assembly hall was not destroyed, and the current state of the monastery appears to bear that out.

Architecturally, Gadong resembles Nechung, though it is smaller and less grandiose. Like Nechung, the monastery has an enclosed courtyard accessed from the west gate, which is

other modern Tibetan sources that provide brief historical outlines for Gadong Monastery and their information coincides with the information presented here; see Bshes gnyen tshul khrims 2008, pp.247-248, and Chos 'phel 2009, pp.98-99.

${ }^{298}$ See Sangs rgyas rgya mtsho 1980, vol.1, pp.256.5-257.1.

${ }^{299}$ See ibid, p.256.6; see also Wylie 1962, p.78.

${ }^{300}$ See chapter 2 , note 42 .

${ }^{301}$ See Sangs rgyas rgya mtsho 1980, vol.1, p.257.1.

${ }^{302}$ For the 1640 mention of the Gadong protector, which may actually be referring to the oracle, see Tā la'i bla ma 05 1991-1995, vol.5, p.195.6. Later, the Gadong Oracle went into trance on the $25^{\text {th }}$ day of the $9^{\text {th }}$ month of the Wood-Horse year (1654); see ibid, p.462.2. The current Gadong Oracle, Tenzin Wangdak, believes that Gadong's oracle lineage extends as far back as the Third Dalai Lama; see Kelley 1993, p.29.

${ }^{303}$ See Tibetan Academy of Social Sciences 2009, p.206.

${ }^{304}$ Dowman 1988, p.132. 
flanked by the Black and Red Butchers. The newly built courtyard has no murals and is lined instead with more than a dozen monks' quarters. The monastery's central building, which is much older in appearance, is similar to Nechung's; it has an assembly hall with three chapels situated along its northern end. The entrance to the central building is flanked by murals of Dorjé Lekpa and Tsiu Marpo. Inside the assembly hall there are murals of the Gadong Oracle, Dorjé Yudrönma, Makzor Gyelmo, and other smaller wrathful gods and goddesses. These images are painted in the wrathful style of gold outlined over a black background. ${ }^{305}$

The protector chapel in the northwest corner of the assembly hall has been newly renovated and the walls recently painted. There is a single mural on the wall depicting the head of the Twelve Tenma Goddesses, either Dorjé Yudrönma or Dorjé Drakgyelma-the iconography is unusual for both. ${ }^{306}$ This chapel also has statues of Padmasambhava, Makzor Gyelmo, Shingjachen, and Pehar. The casement for the central deity is empty, though a Gadong monk informed me that a statue of Hayagriva will be placed there in the near future.

The central chapel can be entered from the protector chapel, though it also has two entrances leading in from the assembly hall. Inside this chapel the entrance is flanked by murals of the Tenma Goddess - likely Dorjé Yudrönma — and Shingjachen. On a table below the latter painting a sacred treasure stone is on display. The walls of the chapel are lined with statues of the following figures, presented in a clockwise fashion: [1] Śāntarakṣita, [2] Padmasambhava, [3] King Trisong Deutsen, [4] Four-Armed Avalokiteśvara, [5] Tārā, [6] Lama Umapa, [7] Zhikpo Sherap, [8] the Fifth Dalai Lama, [9] Vajrapāṇi (with smaller statues of Tsongkhapa, the First Panchen Lama, and the First Dalai Lama), [10] the Buddha Śākyamuni, [11] Hayagrīva, [12] Mañjuśrī, [13] Pehar, [14] Gyajin, [15] Mönbuputra, [16] Shingjachen, and [17] Kyechik Marpo. $^{307}$ In the center of the chapel, setup in a fashion similar to Nechung Monastery's central image, there is an encased life-size statue of the Gadong Oracle (Figure 88). ${ }^{308}$ This chapel array vividly illustrates Gadong Monastery's historical allegiences - it simultaneously pays tribute to the monastery's Kadampa origins, Tsongkhapa's vision of Mañjuśrī, the Fifth Dalai Lama's consolidation, and the Five Sovereign Spirits, with one of the latter acting as the site's chief deity.

\footnotetext{
305 Tib. nag thang.

${ }^{306}$ The identification of this goddess can be difficult because, in many of the monasteries where she is found, she is simply called 'Tenma' by the monks.

${ }^{307}$ There is also an eighteenth casement but it was empty at the time of my visit, October 27, 2011.

${ }^{308}$ There is an intriguing gold-over-black mural on the back of the casement for this central statue. It features a portrait of wild animals, with a large bird in the center acting as the clear focus of the scene. This is no doubt Pehar in his fowl form.
} 
Gadong's northeast chapel is dedicated to the future Buddha Maitreya and there is a large encased statue of the deity at its center. There are also smaller statues of the Eight Bodhisattvas and hanging thangkas of holy masters. Right next to the monastery proper there is the cave in which Tsongkhapa meditated and had a vision of Mañjuśrī. Statues of both figures have been installed within the cave, which is accessed through a small temple.

Gadong Monastery's ritual repertoire consists of a 46-folio manuscript with the lengthy title, A Liturgical Arrangement of All the Periodic Recitations for Gadong Monastery, such as the Garland of Lotus Rubies: the Sädhana for Secret Sädhana Hayagrīva, the Lama's Ritual Manual, a Torma Offering for [Penden] Lhamo, the Ten-Chapter Sädhana: A Supplication Offering to the Five Dharma Kings, the Joyful Laughter of the Chief of the Haughty Spirits: the Individual Amending Rite for the Great Sovereign Spirit of Good Qualities, the Individual Supplication for the Dharma King Shingjachen, the Individual Supplication for Nechung, and a Tsok Offering for Hayagriva. ${ }^{309}$ This collection was organized, and many parts composed, in the nineteenth century by the Third Reting Rinpoche, Ngawang Yeshé Tsültrim Gyentsen. ${ }^{310}$ The title of this work is a list of the various rituals performed at Gadong, most of which have a clear liturgical affinity with Nechung. The Ten-Chapter Sädhana itself is included, as is a rite to Nechung specifically. As a monastery and ritual center, Gadong is very much within the sphere of Nechung's larger cultic activity.

This is also true of Gadong Monastery's oracle tradition. The Gadong Oracle became a state oracle like Nechung during the time of the Fifth Dalai Lama. Since then he would participate in the Comparison of the Gods ceremony and has been one of the major oracles consulted by the Dalai Lamas. The oracle would become periodically possessed by the sovereign spirit Shingjachen or his minister, directly connecting him to the cult of the Five Sovereign Spirits. The Gadong Oracle was also traditionally entreated for weather-related concerns, such as bringing rain or preventing hail. ${ }^{311}$ While the Nechung Oracle lineage was monastic, the Gadong lineage was lay and hereditary. The current Gadong medium, Tenzin Wangdak, was born in the late 1930s and went into exile in India in 1956. In the 1980s he

\footnotetext{
${ }^{309}$ Tib. Rta mgrin gsang sgrub kyi sgrub thabs padma rā ga'i phreng ba/ bla ma'i las byang / lha mo'i gtor 'bul/ chos rgyal sku lnga'i gsol mchod 'phrin las don bcu/ yon tan rgyal po chen po'i sger bskang dregs pa'i sde dpon dgyes pa'i bzhad sgra/ chos rgyal shing bya can gyi sger gsol/ gnas chung sger gsol/ rta mgrin gyi tshogs mchod sogs dga' gdong grwa tshang gi 'don rgyun cha tshang nags 'gros su bkod pa.

${ }^{310}$ Tib. Rwa sgreng A chi thu ho thog thu Ngag dbang ye shes tshul khrims rgyal mtshan, 1816-1863; TBRC: P191.

${ }^{311}$ See Nebesky-Wojkowitz 1998, pp.123-124.
} 
reestablished Gadong Monastery within the Gangchen Kyishong complex of Dharamsala. ${ }^{312}$ The Dhasa Gadong Monastery is just past the Gangchen Kyishong entrance, and is only a five-minute walk from the Dhasa Nechung Monastery. Given the relationship between Nechung and Gadong, one can find in Lhasa's old city markets today photographs depicting the current Nechung and Gadong Oracles sitting next to each other in trance. Of the sacred centers discussed in this section, Gadong is the only one that could be called the second Nechung.

\section{Karmasha Chapel}

Karmasha Chapel is located within Lhasa's old city, just a 5-minute walk east of the Barkhor circuit (Figure 89). There are few written histories that concern this chapel, though a number of oral accounts exist. This site is commonly believed to extend back to the seventh century, having acted as a protector chapel for the Jokhang Temple. ${ }^{313}$ Beyond that, its historical status is unknown until the sixteenth century. According to one oral account, the Zhamarpa ${ }^{314}$ built a monastery near Lhasa's old city called Karma Gönsar, ${ }^{315}$ which acted as a newer residence than the older monastery of Yangpachen. ${ }^{316}$ However, Karma Gönsar was destroyed during the Fifth Dalai Lama's time when the Karma Kagyü school lost its foothold in Lhasa. ${ }^{317}$ This angered the monastery's protector deity, so a new monastery was built to appease him. This monastery was called Karmasha, meaning 'the Karma[pa]'s Residence.' 318 A brief contemporary history claims that Karma Gönsar was actually destroyed by the Dzungar Mongols when they invaded Lhasa, placing the destruction in 1717; the protector chapel was then built as a replacement. ${ }^{319}$ This same source suggests that the name comes from the site's former association with the Tibetan government's council of ministers, the Kasha (Tib. Bka' shag). ${ }^{320}$ Regardless, after the old monastery was destroyed its gilded roof was given to Sera Monastery, and since then the rebuilt chapel has been a Geluk monastery under the control of Sera. ${ }^{321}$

\footnotetext{
${ }^{312}$ This and other information on Gadong's modern circumstances are provided in Kelley 1993, pp.28-31, 84-89.

${ }^{313}$ See Alexander 2005, p.183.

${ }^{314}$ Tib. Zha dmar pa; this religious figure is an important lineage-holder of the Karma Kagyü school.

${ }^{315}$ Tib. Karma dgon gsar; lit. "New Karma[pa] Monastery." The name comes from being a residence for the Karmapa on his visits to Lhasa; see ibid.

${ }^{316}$ Tib. Yang pa can; this monastery was the Zhamarpa's original monastery, located west of Lhasa.

${ }^{317}$ See ibid.

${ }^{318}$ This oral account was relayed to me by Mikmar Tsering; personal correspondence, December 31, 2011.

${ }^{319}$ See Chos 'phel 2009, p.27; for the historical context, see Shakabpa 2010, vol.1, p.419. A lot of the following information drawn from Chos 'phel 2009 was copied verbatim in Thub bstan yar 'phel 2009, pp.119-120.

${ }^{320}$ See Chos 'phel 2009, p.27.

${ }^{321}$ See ibid, p.28.
} 
The central protector deity of Karmasha is Mönbuputra's minister Jatri Mikchikpu (Figure 90). The contemporary history of Karmasha provides a popular explanation for the deity's origin and name:

Images of this deity normally show him with his two eyes closed and an eye of wisdom bulging from his forehead. It is said that even if ten thousand birds are flying in the sky, he can vividly and flawlessly see the color of all their feathers. Regarding this, because Jatri Chenchik ${ }^{322}$ was too turbulent, Guru Rinpoche [Padmasambhava] tore out his two eyes and said, "Now what do you see?" [The deity] replied, "My one eye sees ten thousand birds flying in the sky!" Thus, this protector was given the name Jatri Chenchik (“10,000 Birds, One Eye"). ${ }^{323}$

This chapel also had its own oracle, who was believed to be a guardian of the Jokhang Temple as well as the local protector of Lhasa itself. ${ }^{324}$ According to Nebesky-Wojkowitz, this oracle was primarily possessed by the eastern sovereign spirit himself, Mönbuputra, with Jatri Mikchikpu being a secondary possessing deity. ${ }^{325}$ However, it is commonly believed that the main possessing deity for the Karmasha Oracle was Jatri Mikchikpu, along with his attendant the Great Wild Imperial Spirit. $^{326}$ This oracle was particularly popular with corpse cutters, guardsmen, craftsmen, and Lhasa's opera dancers, who would propitiate him on a monthly basis. Low caste people like the corpse cutters would also participate in the oracle's parades and dances. Because of this association, this protector deity was given the epithet 'the beggars' spirit. ${ }^{327}$ Aside from the monthly visits of devotees, the Karmasha Oracle would also deliver prophecies

\footnotetext{
${ }^{322}$ See chapter 1 , note 37.

${ }^{323}$ Chos 'phel 2009, p.28: lha de'i snang brnyan rgyun gtan gyi spyan gnyis btsums shing / dpral ba'i ye shes kyi spyan 'bur tshugs su gzigs pa des nam mkhar bya khri gcig 'phur kyang thams cad spu mdog ma nor bar khra lam mer gzigs thub ces zer/ de'ang bya khri spyan gcig sku shin tu 'tshub pas gu ru rin po ches spyan gnyis bton gnang ste "da khyod kyis ci mthong ngam” zhes gsungs par "nga'i mig gcig gis nam mkhar bya khri gcig 'phur ba mthong byung” zhes zhus pa bcas kyis srung ma de'i mtshan la bya khri spyan gcig ces gsol/.

${ }^{324}$ See Alexander 2005, p.184.

${ }^{325}$ See Nebesky-Wojkowitz 1998, p.122. Nebesky-Wojkowitz spells this chapel's name sKar ma shar; Hugh Richardson gives a similar spelling; see Richardson 1993, p.130.

326 Tib. Btsan rgod chen mo.

327 Tib. sprang po'i lha; see Alexander 2005, p.184.
} 
on special occasions, like the New Year holiday, Universal Incense Offering Day, and the Yogurt Festival. $^{328}$ This oracle lineage is no longer active today.

Since Karmasha Chapel is a satellite of Sera Monastery, the Karmasha Oracle acted as Sera's oracle and would go into trances there on occasion, such as during the Yogurt Festival. ${ }^{329}$ The college at Sera that is associated with Karmasha is Mé College. ${ }^{330}$ This college's central deity is named Taok Chögyel, ${ }^{331}$ who is ambiguously connected to the Five Sovereign Spirits. Some accounts claim this deity refers to Shingjachen, while others state he is Pehar's minister Putra Nakpo. ${ }^{332}$ One monk at Mé College said that Jatri Mikchikpu is Taok Chögyel's minister, ${ }^{333}$ which would make the latter a form of Mönbuputra. In all of these instances, this deity is associated with Pehar's cult. A short ritual dedicated to Taok Chögyel composed by the Fifth Dalai Lama reveals that the deity's cult has been present at Mé College since the seventeenth century; however, it does not otherwise indicate an explicit connection to the Five Sovereign Spirits. ${ }^{334}$ Moreover, Taok Chögyel's origin story has nothing to do with Pehar. In a past life this deity had been a monk at Nālandā University in India; he lived a sinful life and was reborn as an evil spirit as a result. Despite being ritually subdued, in the sixteenth century this spirit ordered a monk to help him kill the Second Demo Rinpoche, ${ }^{335}$ the regent of Tibet, before killing the monk in turn. Taok Chögyel has since been subdued again, but he is known for his cruel nature. ${ }^{336}$ The lack of any connection with Pehar in this story could suggest that Taok Chögyel, for reasons unknown, was absorbed into the cult of the Five Sovereign Spirits after the seventeenth century. Regardless, Jatri Mikchikpu is the other major Dharma protector of Mé College, and the ritual corpus practiced in the college's protector chapel is the same one practiced at Karmasha Chapel.

Karmasha Chapel is active today, though it is severally diminished. While the threestory building has been renovated, most of its rooms were converted into lay housing.

\footnotetext{
${ }^{328}$ See Chos 'phel 2009, p.28. For a fuller description of the activities in which the Karmasha Oracle participated, see ibid, pp.28-29; see also Alexander 2005, p.184, and Waddell 1895, pp.481-482.

${ }^{329}$ See Richardson 1993, pp.100-102; see also Nebesky-Wojkowitz 1998, pp.422, 424.

330 Tib. Smad grwa tshang.

331 Tib. Tha 'og chos rgyal.

332 See Nebesky-Wojkowitz 1998, pp.130-131.

${ }^{333}$ See Tibetan and Himalayan Digital Library 2007, minute 13:16.

${ }^{334}$ See Tā la'i bla ma 05 1991-1995, vol.11, pp.572.3-575.1.

335 Tib. De mo 02 Dpal 'byor bkra shis, 1507-1571; TBRC: P5456.

${ }^{336}$ See Nebesky-Wojkowitz 1998, pp.131-132.
} 
Nonetheless, the assembly hall and inner sanctum have retained their devotional character. ${ }^{337}$ The walls of the assembly hall are covered in gold-over-black murals of deities like Dorjé Yudrönma, Rāhula, and the Five Sovereign Spirits. On the hall's eastern wall are encased statues of the following deities, listed in clockwise order: [1] Makzor Gyelmo, [2] Nechung Oracle, [3] Jatri Mikchikpu, [4] Taok Chögyel, [5] Jatri Mikchikpu (again), [6] Tsiu Marpo, and [7] a deity named Damchen Garnak. ${ }^{338}$ On a pillar near these statues there hangs a 'breath bag,' which is used mythically by deities, and ritually by oracles, to hold the life breath of spirits and enemies (Figure 91). This is one of the bags traditionally used during the 'Ransom for the Demon-King' ceremony to transport life breaths to the Pehar Kordzöling at Samyé. ${ }^{339}$ Karmasha's inner sanctum is distinguished from the assembly hall by pillars and is also raised a level. The sanctum contains encased statues of lineage masters - e.g., Padmasambhava, Tsongkhapa, and the First Dalai Lama-and enlightened beings-e.g., Four-Armed Avalokiteśvara, White Tara, Vajrapāṇi, and the Buddha.

Karmasha's ritual repertoire consists of three manuals. The first is dedicated to the tutelary deity Vajrabhairava. The second rite, which is also practiced at Sera Monastery's Mantric College, is dedicated to several protector deities: Six-Armed Mahākāla, ${ }^{340}$ the Five Sovereign Spirits, ${ }^{341}$ Kșetrapāla, ${ }^{342}$ Makzor Gyelmo, Vaișravaṇa, Begtse, ${ }^{343}$ Serzhünma, ${ }^{344}$ and Brahmā. The third rite is specifically dedicated to Jatri Mikchikpu and is entitled, Amending and Restoring Rite for the Great Jatri [Mikchikpu], Guardian of the Victorious One's Teachings. ${ }^{345}$ According to its colophon, this rite was composed in 1977. Once more, many of the deities that appear in these ritual titles have been encountered before. Karmasha may be affiliated with Sera Monastery rather than Drepung, but it is closely tied to the cult of the Five Sovereign Spirits.

\section{Banakzhöl Chapel}

Banakzhöl Chapel is also located in Lhasa's old city, situated northeast of the Barkhor circuit (Figure 92). This chapel is the most mysterious out of all these sacred centers, since

\footnotetext{
${ }^{337}$ For a detailed discussion of Karmasha Chapel's architecture, see Alexander 2005, pp.183-189.

${ }^{338}$ Tib. Dam chen gar nag; lit. "Great Holy Black Dancer." The identity of this deity is uncertain.

339 See Alexander 2005, p.188; this ceremony was discussed last chapter.

340 Tib. Mgon po phyag drug pa.

${ }^{341}$ Referred to collectively here as Chos rgyal.

${ }^{342}$ Tib. Kșe tra pā la.

${ }^{343}$ Referred to here by his epithet Lcam sring.

${ }^{344}$ Tib. Gser zhun ma; lit. "Molten Gold." The identity of this deity is uncertain.

${ }^{345}$ Tib. Rgyal ba'i bstan srung bya khri chen po'i bskang gso.
} 
almost nothing is known of its historical circumstances. Locals claim that the chapel was founded by the Second Dalai Lama, and that it took on its present appearance during the first Gorkha war (1788-1792). ${ }^{346}$ The central deity of Banakzhöl Chapel is the southern sovereign spirit Shingjachen. Banakzhöl also had its own oracle who channeled Shingjachen, though the last one died many years ago. ${ }^{347}$ The chapel is currently maintained by two monks from Drak Yerpa ${ }^{348}$ though André Alexander explains that this task was performed by Meru Sarpa monks in the past. ${ }^{349}$

While Banakzhöl Chapel was reopened in the 1990s and restored in 2000, its murals were almost completely destroyed. The chapel is one-storey tall and very small, consisting of only four pillars. ${ }^{350}$ There is no distinct inner sanctum; however, against the far eastern wall facing the entrance there is a large encased statue of Four-Armed Avalokiteśvara. This image is surrounded by smaller statues of the Fifth Dalai Lama, Tsongkhapa, Mañjuśrī, and Guru Nangsi Zilnön. Against the southern wall there are small statues of Tsongkhapa, the First Panchen Lama, and the First Dalai Lama. The central Dharma protector takes up the northern wall. The main statue is of Shingjachen on his horse, flanked by Tsiu Marpo and another smaller statue of Shingjachen without his mount (Figure 93). Since all of these figures are found at Gadong Monastery as well, Banakzhöl is reproducing this specific monastery's lineage. Other notable items include a sacred treasure stone akin to the one at Gadong, as well as fierce masks and breastplate mirrors hanging from two of the pillars; the mirrors were once worn by the chapel's oracle. $^{351}$ Finally, the willow tree in the chapel's courtyard is said to be the home of a local serpent spirit. ${ }^{352}$ Banakzhöl Chapel is a satellite temple for Gadong Monastery, and as such it shares the monastery's ritual corpus.

\section{Other Monasteries and Chapels}

In addition to these sacred sites with direct ties to the cult of Nechung, there are other monasteries and chapels with indirect ties. These centers exhibit some degree of relation to the

\footnotetext{
${ }^{346}$ See Alexander 2005, p.201.

${ }^{347}$ See ibid, pp.201, 203.

${ }^{348} \mathrm{Tib}$. Brag yer pa. This was told to me by one of the caretaker monks; personal correspondence, November 23, 2011. See also Alexander 2005, p.202.

${ }^{349}$ See ibid.

${ }^{350}$ See ibid, pp.200-203, for a detailed discussion of Banakzhöl Chapel's architecture.

${ }^{351}$ See Alexander 2005, p.200.

${ }^{352}$ See ibid, p.202.
} 
Five Sovereign Spirits and their retinue, either through institutional, iconographic, or oracular affiliation. The first of these is Tengyeling Monastery, ${ }^{353}$ located just west of the Jokhang Temple. This site is Samyé Monastery's satellite in Lhasa and Tsiu Marpo is its central protector deity, given his sixteenth-century rise in popularity at Samyé. ${ }^{354}$ Nevertheless, Tengyeling recognizes Pehar's continued importance at Samyé and a statue of him is situated next to the central image of Tsiu Marpo (Figure 94). Moreover, Pehar's iconography at this monastery matches his Ten-Chapter Sädhana form as opposed to the one-headed, two-armed form found at Samyé.

Dorjé Drak Monastery, located west of Samyé, shares some important institutional history with Nechung. The very cult of the Five Sovereign Spirits as it is practiced at Nechung extends from Dorjé Drak's Northern Treasures tradition. Despite the monastery's diminished size, these deities continue to have a presence at Dorjé Drak (Figure 95). This monastery has also continued to be involved in Nechung's ritual affairs. In November of 2011, the abbot of Dorjé Drak presided over the tenth-month ritual dedicated to Avalokiteśvara who Liberates All Beings at Nechung Monastery. This ritual stems from Dorjé Drak's repertoire ${ }^{355}$ and it involves building an elaborate sand mandala, which had not been built at Nechung in a decade (Figure 96). The relationship between these two monasteries has been maintained even after 1959 .

Other centers are less connected but are on the periphery of the Nechung cult. Darpoling Chape $^{356}$ in Lhasa's old city had an oracle that would occasionally be possessed by Pehar, ${ }^{357}$ and its assembly hall murals include members of the Five Sovereign Spirits. ${ }^{358}$ Meru Sarpa has historical ties to Meru Nyingpa and offers an extensive mural account of Pehar's past lives, as discussed in chapter 1. Namgyel Monastery, the Dalai Lamas' personal monastery, was involved in Nechung's consecration after its renovation. ${ }^{359}$ Finally, Nechung Rinpoche originated from the Nyingma monastery of Mindröling, a ritual from which is performed at Nechung in the twelfth Tibetan month. This monastery was also founded by Terdak Lingpa, who composed the iconography of Dorjé Drakden provided in the Nechung Liturgy and discussed last chapter.

\footnotetext{
${ }^{353}$ Tib. Bstan rgyas gling.

${ }^{354}$ For more information on Tengyeling Monastery, see ibid, pp.209-221.

355 See Chapter 2, note 197.

${ }^{356}$ Tib. Dar po gling btsan khang; see Alexander 2005, pp.175-181.

${ }^{357}$ See Richardson 1993, pp.94-95.

${ }^{358}$ Strangely enough, all of the Five Sovereign Spirits are present in Darpoling's assembly hall murals except for Pehar. Nonetheless, one corner does have a prominent white bird that likey refers to Pehar; its appearance resonates with the painting of Pehar as a white bird found at Samyé Monastery's central temple (Tib. dbu rtse).

${ }^{359}$ See Appendix III, p.588.
} 
Nechung's own ritual calendar exhibits strong connections with many of the above institutions. Ritual activities in the first Tibetan month tie Nechung to Meru Nyingpa Monastery and the Jokhang temple complex at large during the Great Prayer Festival. The second and fifth months are connected with Namgyel Monastery. The fourth, sixth, and twelfth months emphasize Nechung's historic relationship with Tsel Gungtang, Tsel Yangön, and Tsel Üling. The sixth, seventh, and twelfth months reinforce ties to Drepung Monastery, and Deyang College in particular. The tenth and eleventh months further bind Nechung to Drepung and the Ganden Podrang government overall. The twelfth month relates Nechung to Mindröling Monastery, the center of the Southern Treasures tradition. Finally, the important holy day called God Day maintains Nechung's relationship with Drepung on a monthly basis, while Nechung Monkey Month - which is connected to Padmasambhava's birthday and his subjugation of deitiesperiodically reminds devotees of the monastery's ancient ties to Samyé Monastery.

All of these sacred sites symbolically surround Nechung in a mandala of expanding relationships. An institutional hierarchy is visible through the degree to which a sacred center is affiliated with Nechung, and this is iterated either through ritual commonality, deity arrays, or oracular connection. The locations of these centers do not necessarily accord with appropriate cardinal directions; however, their proximity to certain areas is intentional. Nechung Monastery's satellite, Meru Nyingpa, was chosen for its location behind the Jokhang Temple, the sacred center of Lhasa. Nechung's other branch chapel is in Drepung Monastery's Deyang College, maintaining not only a historical connection but also a proximity to the Ganden Podrang. Gadong Monastery likewise has a branch chapel in Drepung close to the Tibetan government, Gomang College, and it has a satellite near the Jokhang, Banakzhöl. Karmasha is in the city center and has a branch in Sera Monastery. Outlying monasteries like Samyé, Tsel Gungtang, and Dorjé Drak retain their connection through annual rituals. Samyé even has its own satellite near the Jokhang, Tengyeling Monastery. The pantheon arrays for each of these sites are also unique despite the repetition of deities encountered between them; they all include local gods of the vicinity, lineage masters of the larger school, deities of the state cult, and enlightened beings from the pan-Buddhist tradition.

The Five Sovereign Spirits themselves have expanded beyond their original home at Nechung Monastery. While Pehar was still the main possessing deity of the Nechung Oracle in the mid-seventeenth century, Kyechik Marpo and Dorjé Drakden took over shortly thereafter. Sangyé Gyatso's accounts confirm this, making Nechung the western sovereign spirit's domain. 
After Dorjé Drakden's cultic rise in the eighteenth century, he annexed Meru Nyingpa a century later through the Nechung Oracle. Gadong Monastery became the home of the southern sovereign spirit, Shingjachen, and Banakzhöl his Lhasa chapel. Karmasha Chapel came under the control of the eastern sovereign spirit, Mönbuputra, through his minister Jatri Mikchikpu. This leaves Pehar himself, the northern sovereign spirit, and Gyajin, the central sovereign spirit. Deities may migrate in myth, but ritually they emanate. Despite moving to Nechung, Pehar is still iconographically and ritually present at Tsel Yangön Monastery. This would imply that Yangön remains the northern sovereign spirit's domain. Pehar is also still very much present at Samyé Monastery's Pehar Kordzöling. Of these deities, Gyajin appears to be the only one without a distinct monastery or chapel. Nebesky-Wojkowitz claims that this deity had oracles through which he was channeled, but they were of minor importance and never consulted by the government. ${ }^{360}$ This uneven popularity, or lack thereof, suggests local histories and cultic movements, the details of which are still unknown.

Regardless, the state promotion of the Nechung cult gave the Dalai Lama's burgeoning government control over a powerful source of cultural capital. This control did not necessarily grow at the expense of local representations of Pehar's cult, but it did give a political character to the deity, which was utilized to advance the government's ritual agendas. As Prasenjit Duara explains when discussing the imperial recognition and endorsement of the Guandi cult: "The state could not, and in most cases did not even seek to, erase local versions of the gods; rather, it sought to draw on their symbolic power even while it established its dominance over them." By advocating a popular cult and controlling its narrative, ritual, and institutional representations, the Fifth Dalai Lama's government tapped into a strategic means of unification through standardizing popular beliefs and practices.

In previous chapters we have explored mythic and ritual accretion, while here we observe institutional accretion. In his exquisite discussion of theory, To Take Place, Jonathan Z. Smith argues for greater attention to be paid to the importance of place in ritual. Concentrating on this argument, Smith examines the establishment of sacred hierarchy in the Jewish temple complex, the reinvention of Christian sacred space under Emperor Constantine, and the replication of

\footnotetext{
${ }^{360}$ See Nebesky-Wojkowitz 1998, p.122.

${ }^{361}$ Duara 1988, p.783. See also Hansen 1990, which examines the imperial standardization and promotion of Chinese deity cults during the Song Dynasty.
} 
emplaced rituals outside of Christian Jerusalem. Smith defines a temple as a 'built ritual environment'- "marked-off space...in which, at least in principle, nothing is accidental; everything, at least potentially, demands attention. The temple serves as a focusing lens, establishing the possibility of significance by directing attention, by requiring the perception of difference." 362 This definition certainly applies to Nechung as well as to the numerous chapels and temples that came under its ritual control. This control and temple expansion was connected to the 'kingship' of the Dalai Lamas in the guise of cosmology. ${ }^{363}$ Furthermore, the relationship Nechung's ritual corpus and calendar had with the broader rites and festivals of Lhasa allowed the monastery's practices to be repackaged and replicated to sites outside of Nechung. Smith explains this process succinctly when discussing the exportation of liturgical activity from the Church of the Holy Sepulchre:

While the locus [of the Church] was left behind, the system of "days" and the correlation of the loci of scripture to those days could be maintained. Through a concentration on the associative dimensions of place together with the syntagmatic dimensions of narrative, a system was formulated that could be replicated away from the place. ...With few exceptions, the hymns, prayers, scripture lessons, and gestures tied to particular places in the indigenous Jerusalem liturgy could be expropriated and exported. The sequence of time, the story, the festal calendar, have allowed a supersession of place. It is the apta diei that will be endlessly replicable, rather than the aptus locus. ${ }^{364}$

This process occurred with Nechung as well, with the additional element that each new place where the monastery's cult was applied gained new divine significance through the emanations of the Five Sovereign Spirits. Pehar's various forms were emplaced at each of the sites described above, reinventing their previous sacred character regardless of whether it was originally a Kadampa or Kagyüpa center. Such politics of emanation were implemented by the Dalai Lama's government to enforce the state cult at significant sites, strengthening and centralizing its control over the region. This observation can be extended to Dhasa Nechung and its global satellites as well, where the cult of Nechung was wholly transported after the Dalai Lama and Nechung Oracle escaped to India.

\footnotetext{
${ }^{362}$ Smith 1987, p.104.

${ }_{364}^{363}$ See ibid, pp.20-21.

${ }^{364}$ Ibid, p. 94 .
} 
Nechung Monastery's history is believed to extend back to the turn of the ninth century, but it did not achieve notable prestige until its 1682 expansion and renovation. In tandem with this, the monastery's oracle was endorsed and promoted by the nascent Tibetan government. Through this institutional legitimation Nechung's cult proliferated. Starting in the seventeenth century, certain ancient monasteries were absorbed by the Dalai Lama's government while others were newly founded, and over the course of centuries the cult of the Five Sovereign Spirits expanded beyond Nechung. This expansion pervaded significant political arenas like Tsel and the Ganden Podrang, religious centers like Drepung, Sera, and the Karmapa's former abode, and historically rich domains like Lhasa's old city. Nechung maintained its control over these institutions through iconographic and ritual hegemony, observed in their pantheon arrays and ritual corpora. In pre-modern Tibet, control was also reinforced through the Comparison of the Gods ceremony celebrated every twelve years, when the oracles of these and other chapelstheir charismatic heart-would be reevaluated at Nechung Monastery by state oracles like Nechung, Gadong, and Lamo. This historical network of sites offers us a lucid geographic configuration for the Lhasa mandala of the Five Sovereign Spirits as it reverberated from Nechung (Figure 97). Though it is beyond the scope of this work, Nechung's cultic network has also been extended to monasteries and sacred sites outside Lhasa and across the Tibetan plateau. With the mythic foundation laid and the ritual framework built, the veneer of Nechung's history and institutional network has been set and varnished. Like the Palace of Adamantine Melody itself, this metaphoric structure of Nechung's cult was built by the Fifth Dalai Lama and his regent Sangé Gyatso. The final question to consider is why they did so to begin with. 


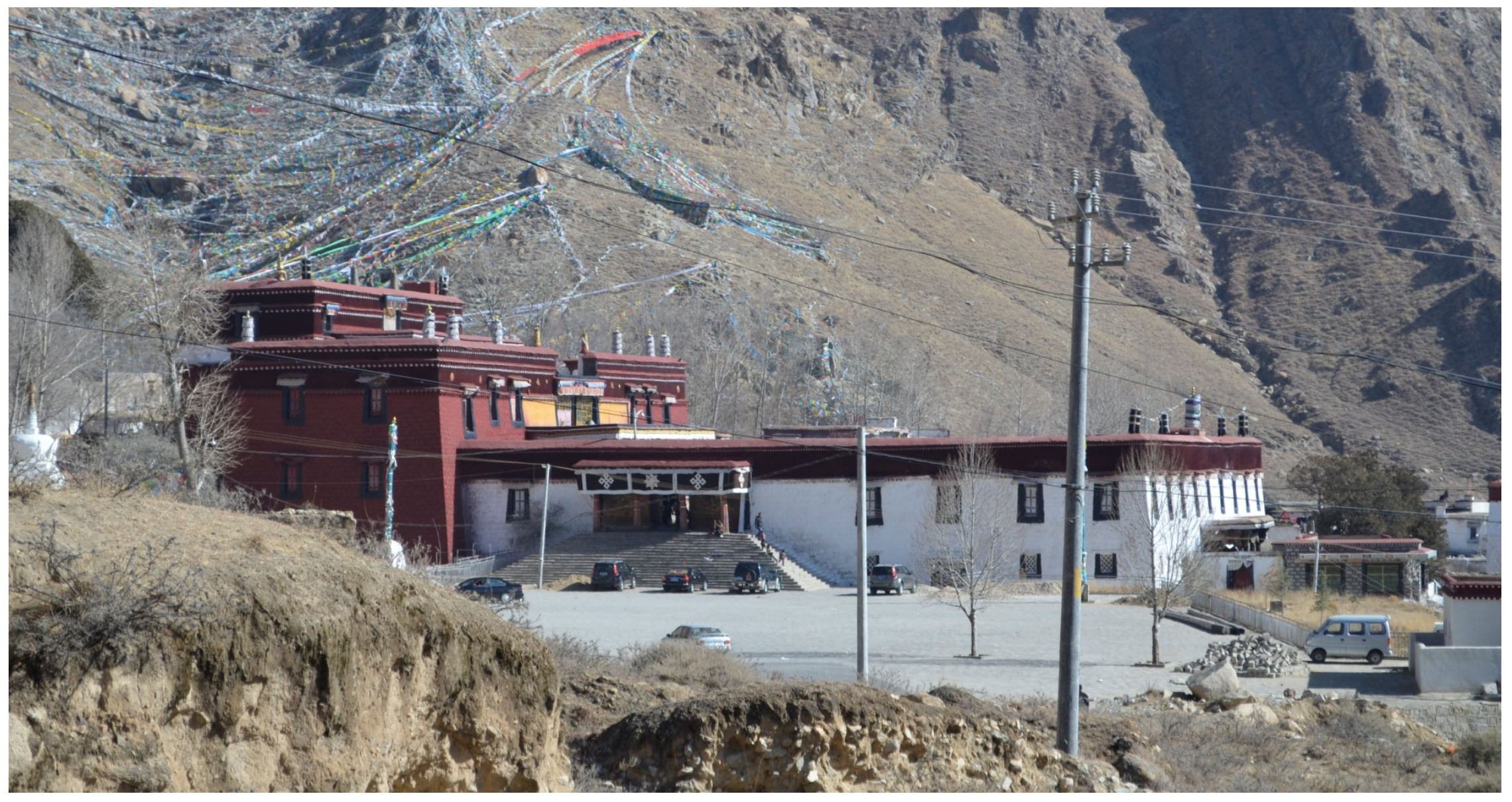

Figure 37: Nechung Dorjé Drayangling Monastery (Tib. Gnas chung rdo rje sgra dbyangs gling), Lhasa. (Photo: Cecilia Haynes, 2011) 


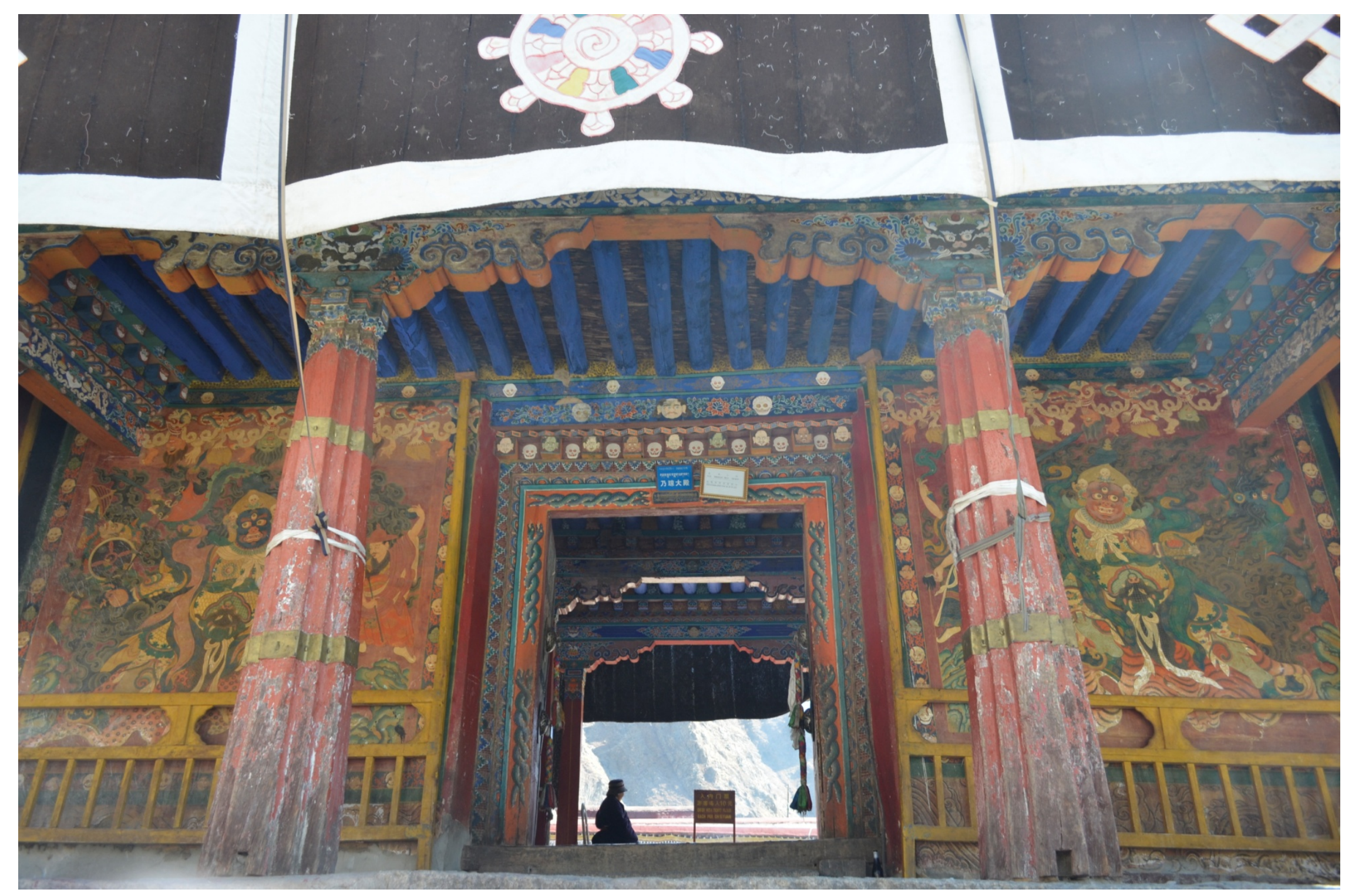

Figure 38: West Gate entrance of Nechung Monastery, Lhasa. Murals of the Black Butcher (Tib. Bshan pa nag po) and Red Butcher (Tib. Bshan pa dmar po) are visible on either side of the entrance. (Photo: Cecilia Haynes, 2011) 


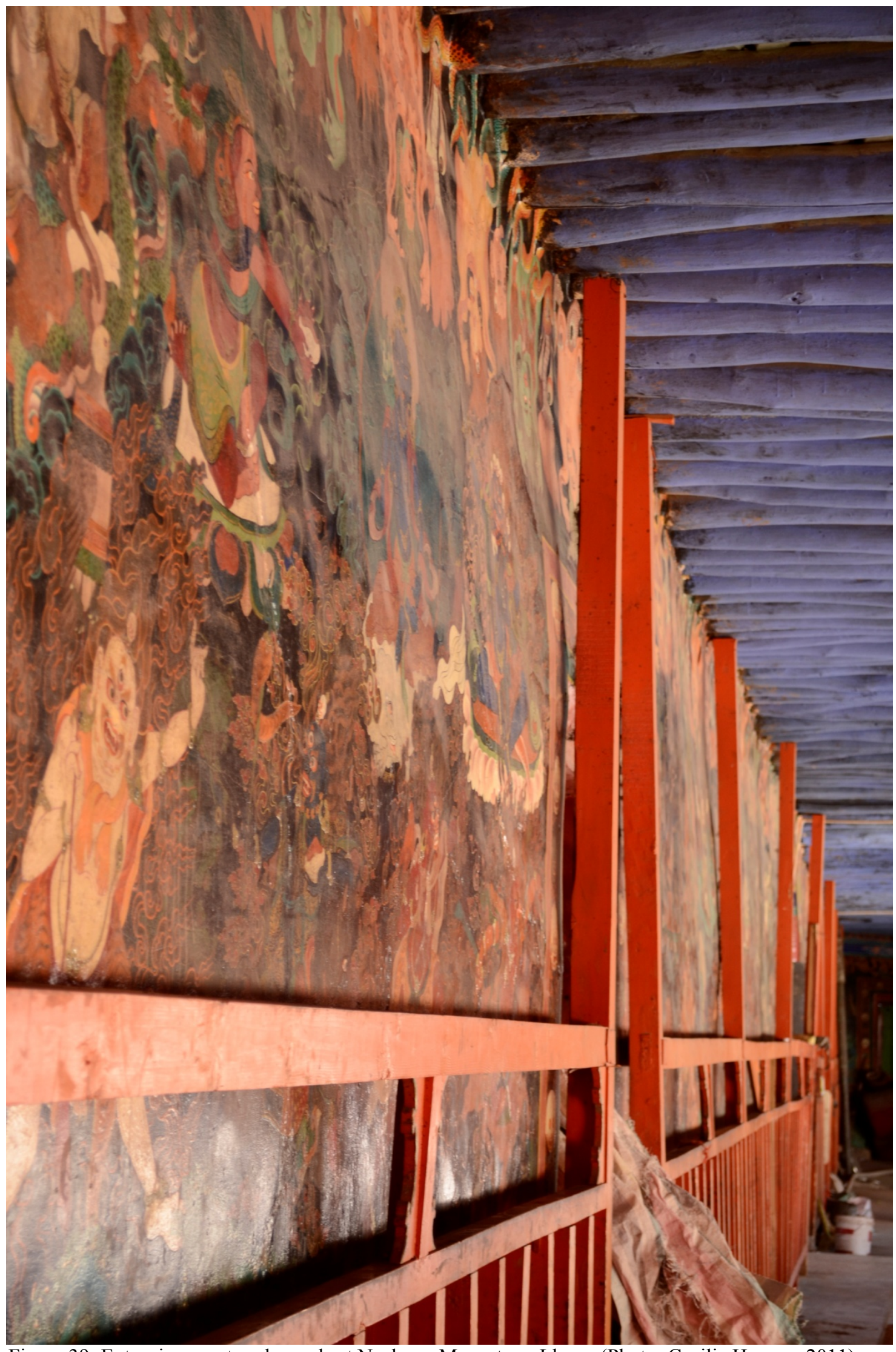

Figure 39: Extensive courtyard murals at Nechung Monastery, Lhasa. (Photo: Cecilia Haynes, 2011) 


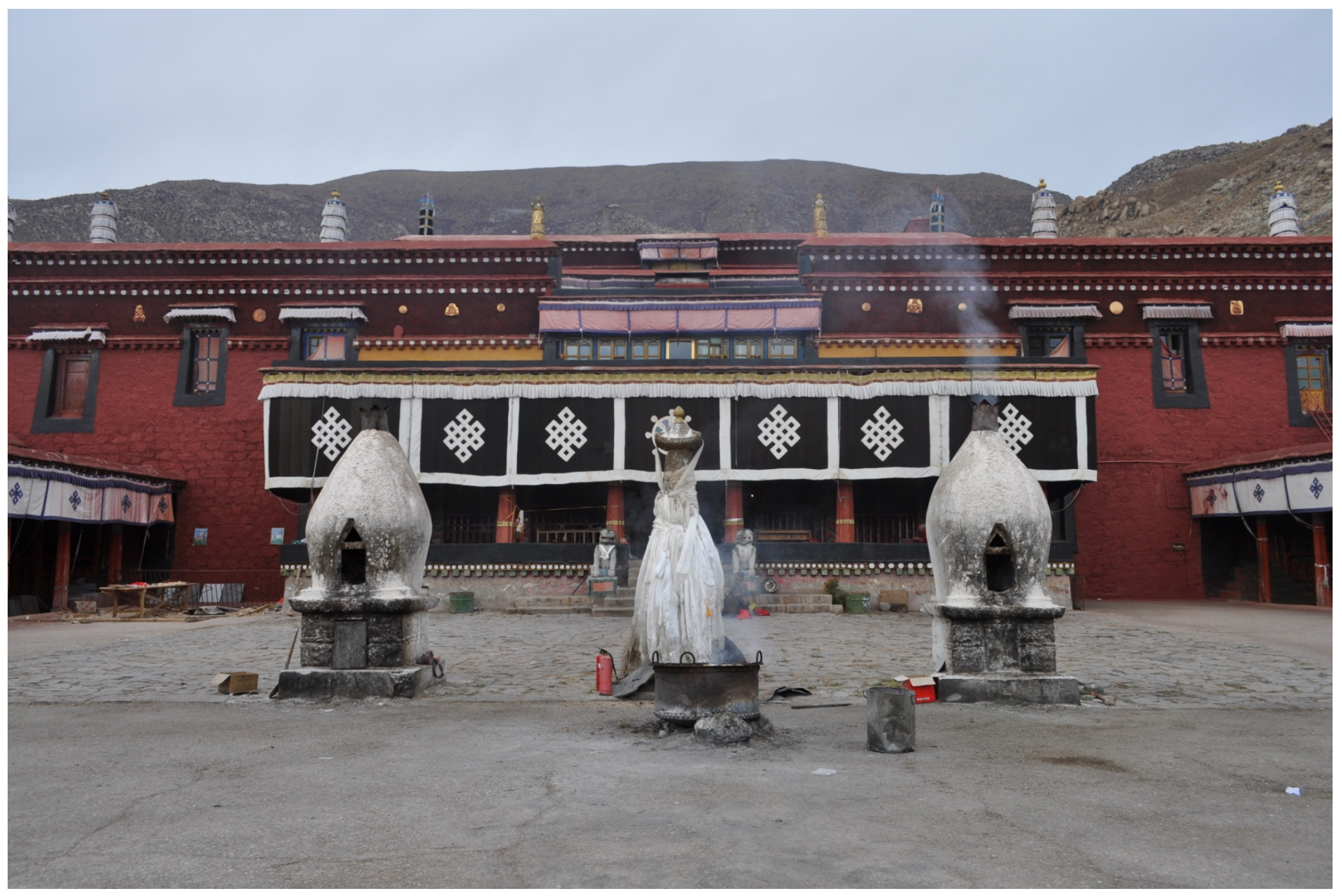

Figure 40: Central building of Nechung Monastery, Lhasa. (Photo: Cecilia Haynes, 2011) 

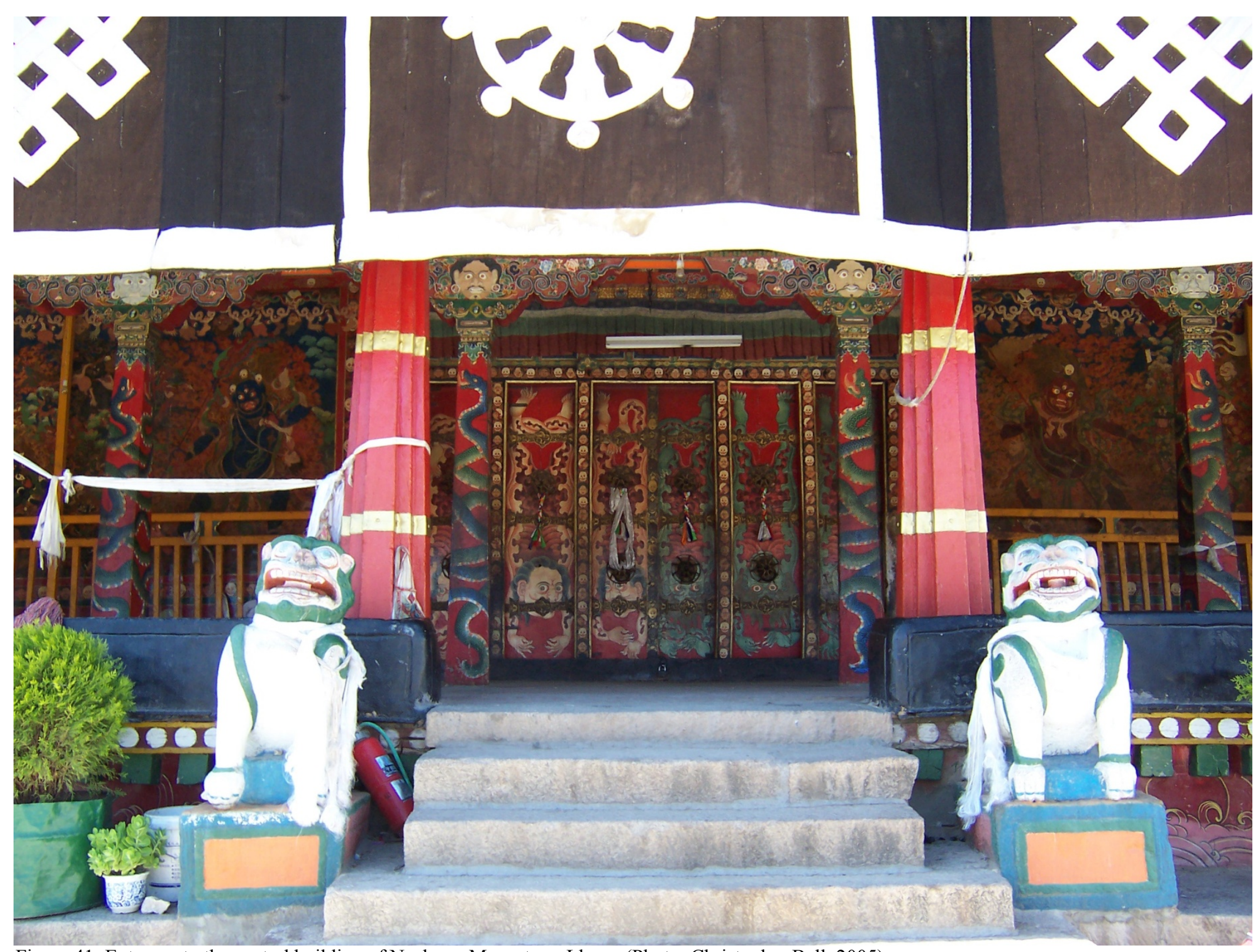

Figure 41: Entrance to the central building of Nechung Monastery, Lhasa. (Photo: Christopher Bell, 2005) 


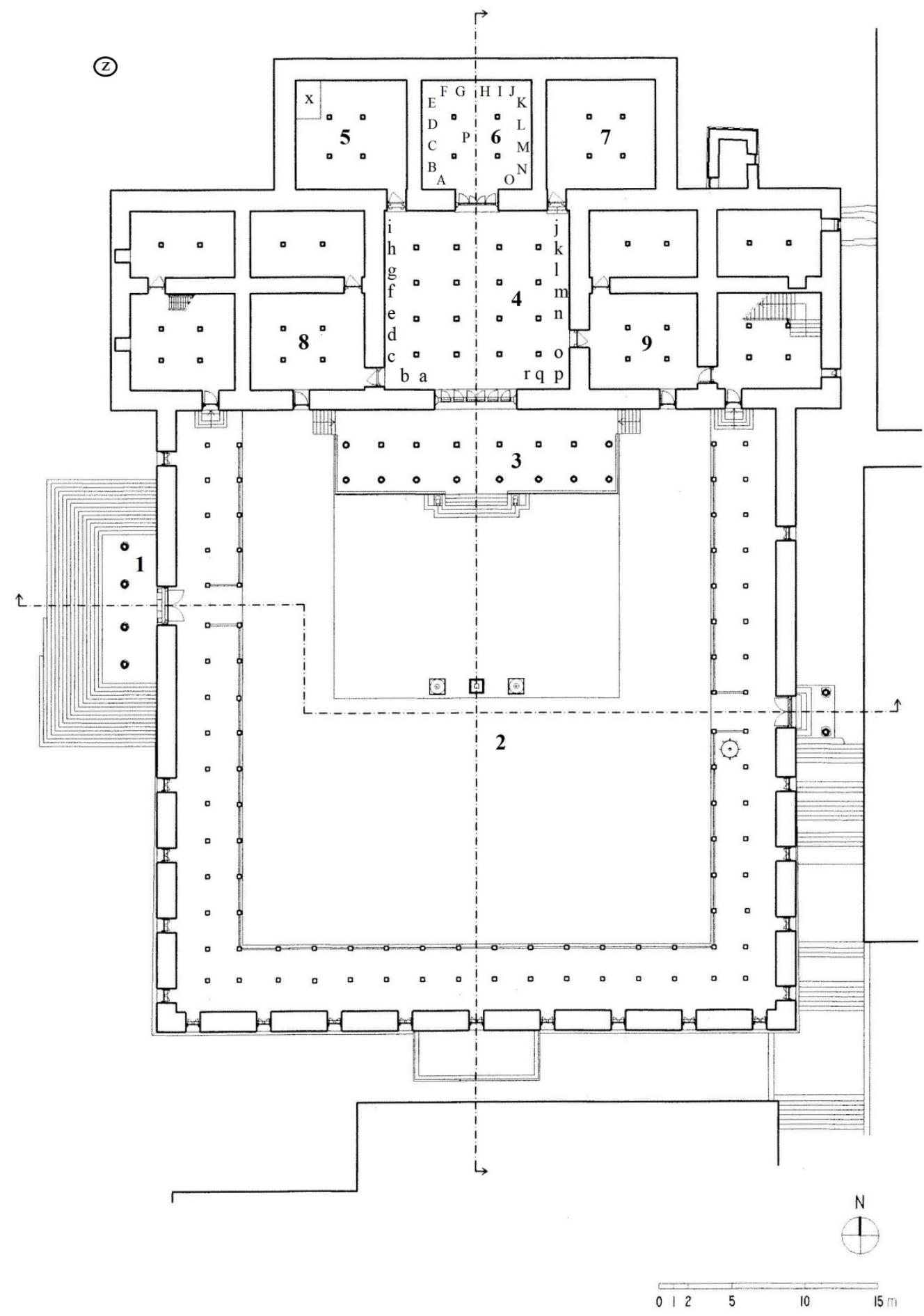

Figure 42: Floor plan of Nechung Monastery, Lhasa. The following areas are of particular importance: [1] Western Gate, [2] Courtyard, [3] Entrance Portico, [4] Assembly Hall (Tib. 'du khang), [5] Birch Tree Chapel (Tib. Gro sdong lha khang), [6] Central Chapel (Tib. Gtsang khang dbus ma), [7] Desire Realm Chapel (Tib. 'Dod khams lha khang), [8] Western Shrine Room (Tib. Mchod khang nub ma), and [9] Eastern Shrine Room (Tib. Mchod khang shar ma). (C) Franco Ricca \& Edizioni dell'Orso, Alessandria/CESMEO, Torino; see Ricca 1999, p.47, Fig.4. Alterations made to image with the author's permission; email correspondence with Franco Ricca, January 28, 2013. 


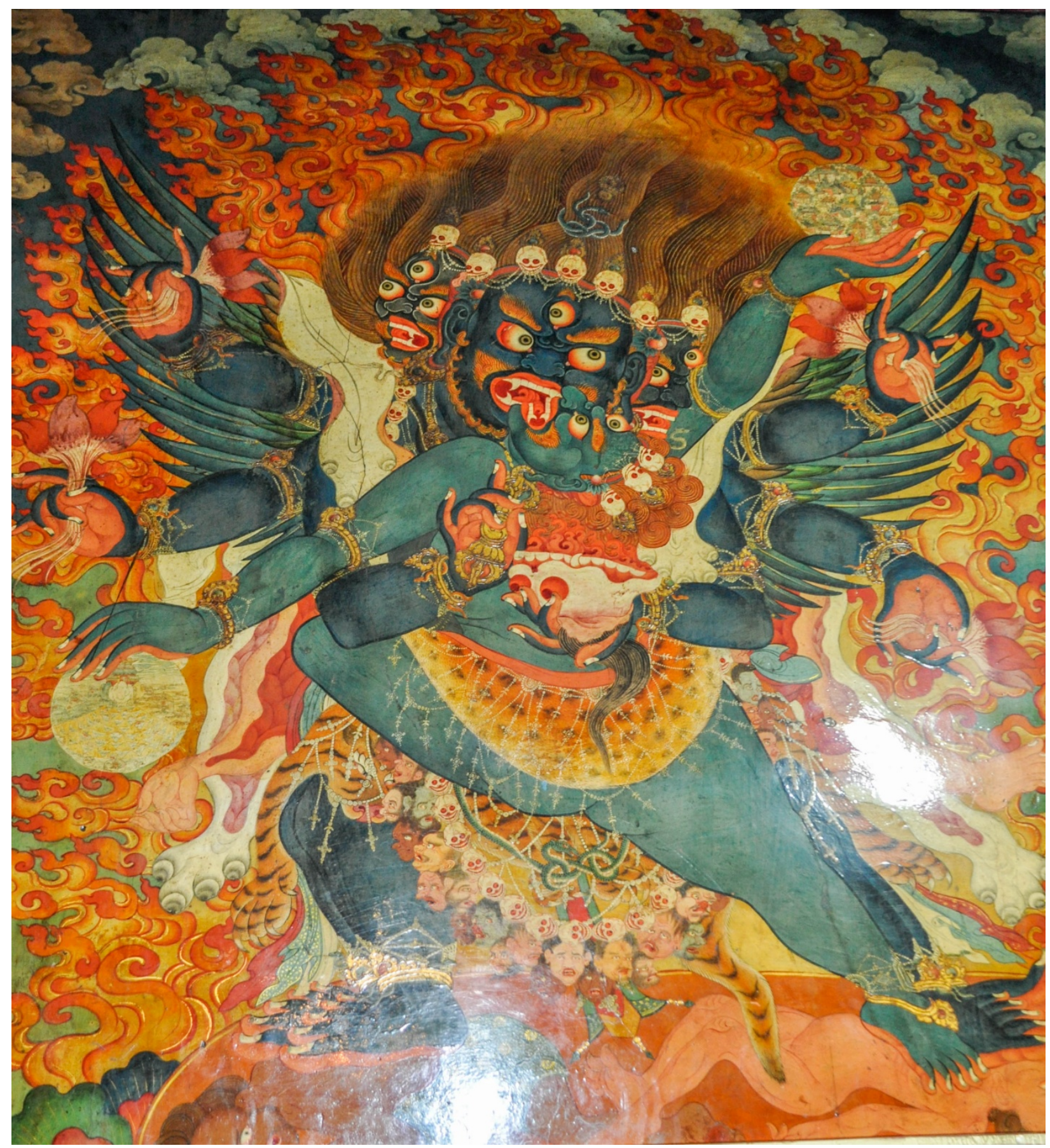

Figure 43: Mantrabhīru (Tib. Dmod pa drag sngags) in union with his consort (Tib. yab yum); Nechung Monastery Assembly Hall, Lhasa. (Photo: Christopher Bell, 2011) 


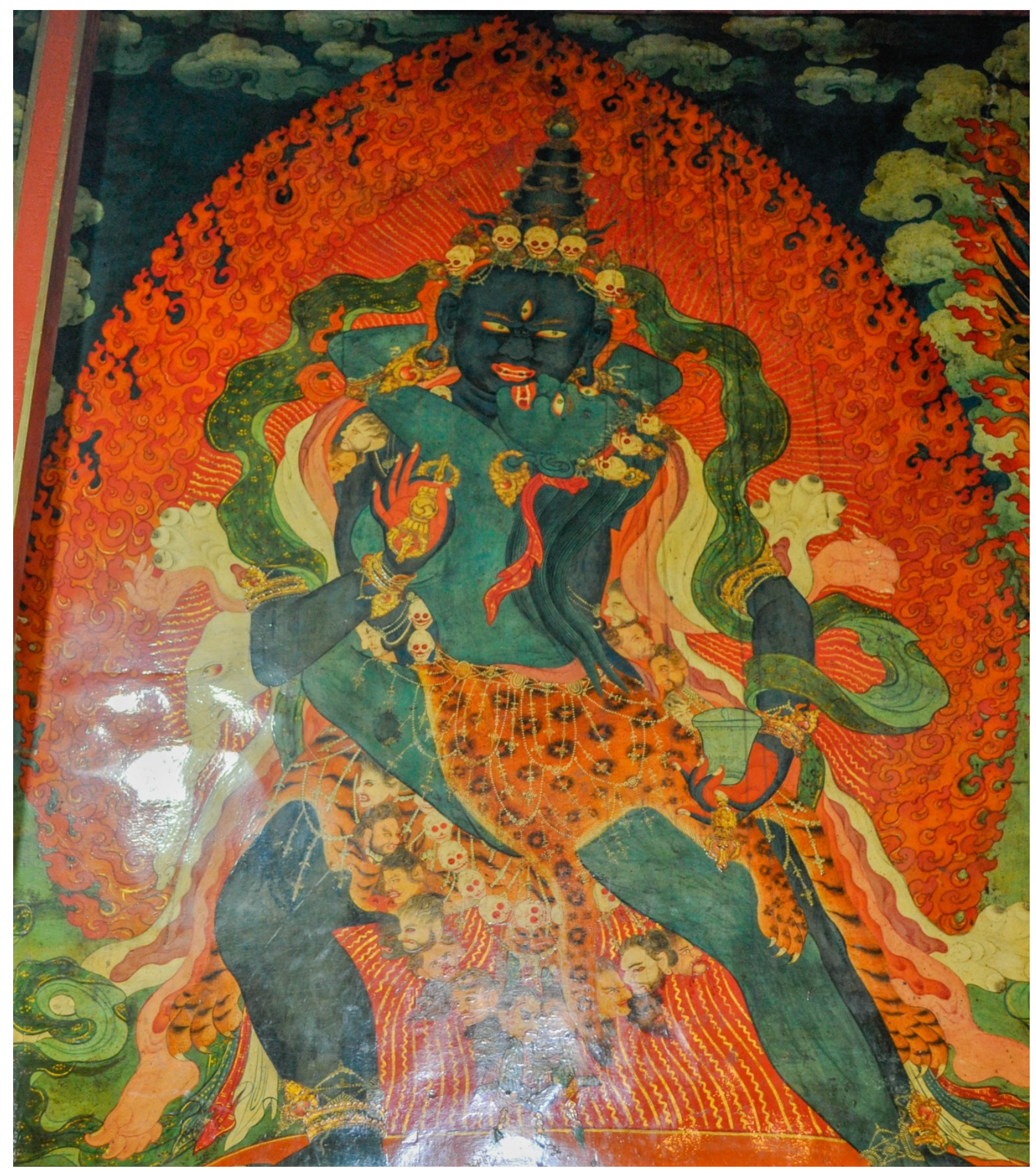

Figure 44: Guru Vidyādhara (Tib. Rig 'dzin slob dpon) in union with his consort; Nechung Monastery Assembly Hall, Lhasa. (Photo: Christopher Bell, 2011) 


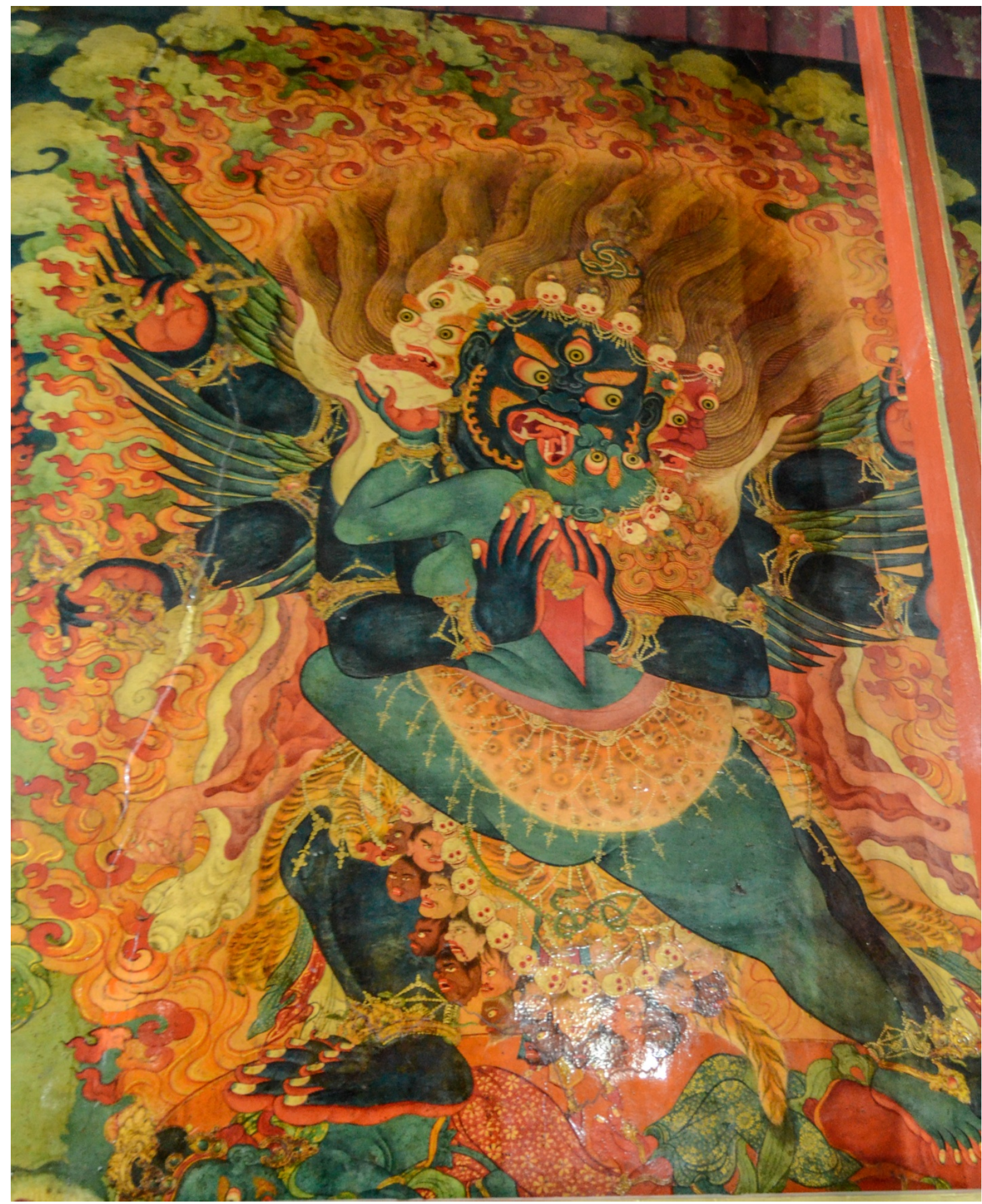

Figure 45: Vajrakīlāya (Tib. Rdo rje phur ba 'phrin las) in union with his consort; Nechung Monastery Assembly Hall, Lhasa. (Photo: Cecilia Haynes, 2011) 


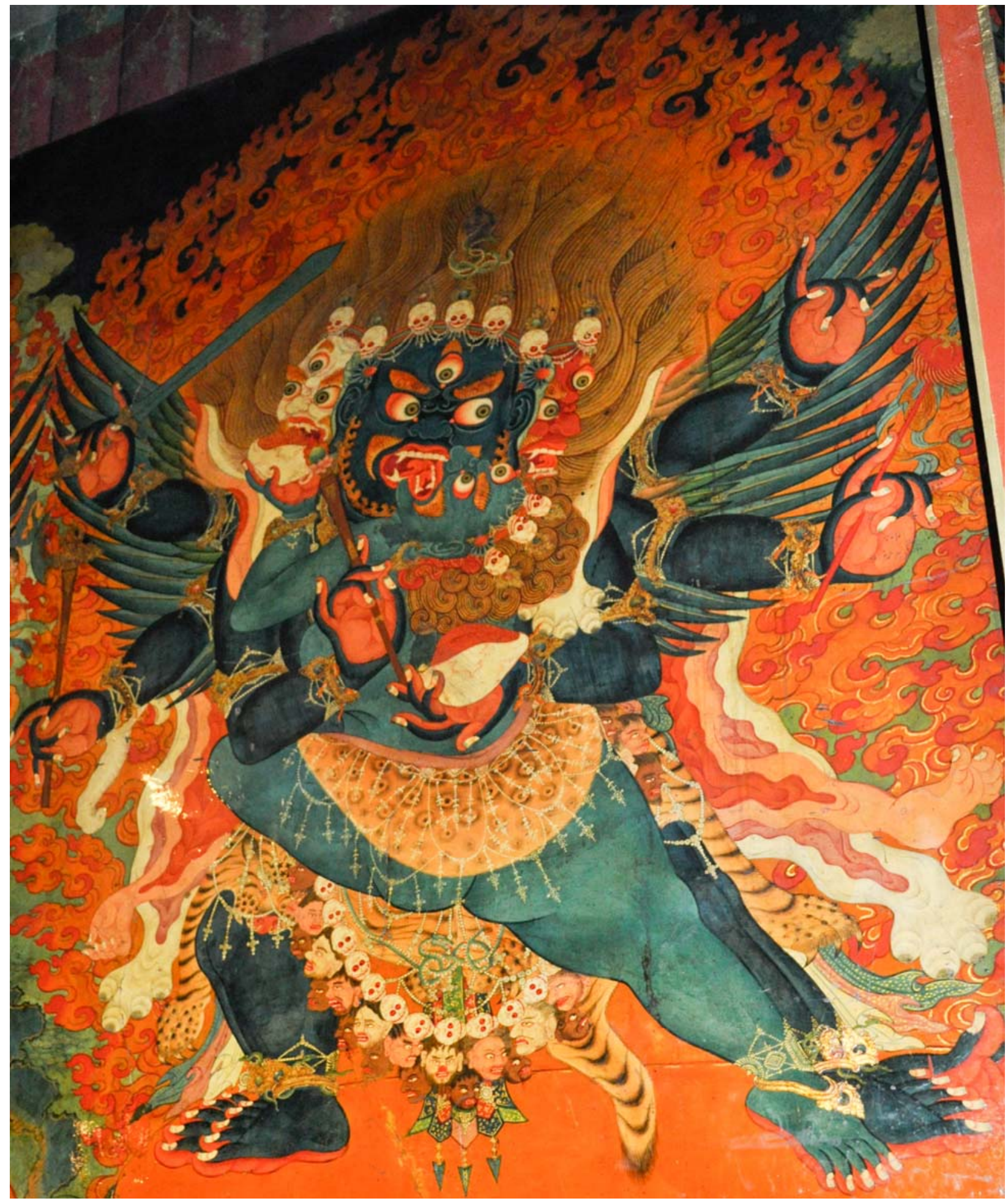

Figure 46: Yamāntaka (Tib. 'Jam dpal sku gshin rje shed) in union with his consort; Nechung Monastery Assembly Hall, Lhasa. (Photo: Christopher Bell, 2011) 


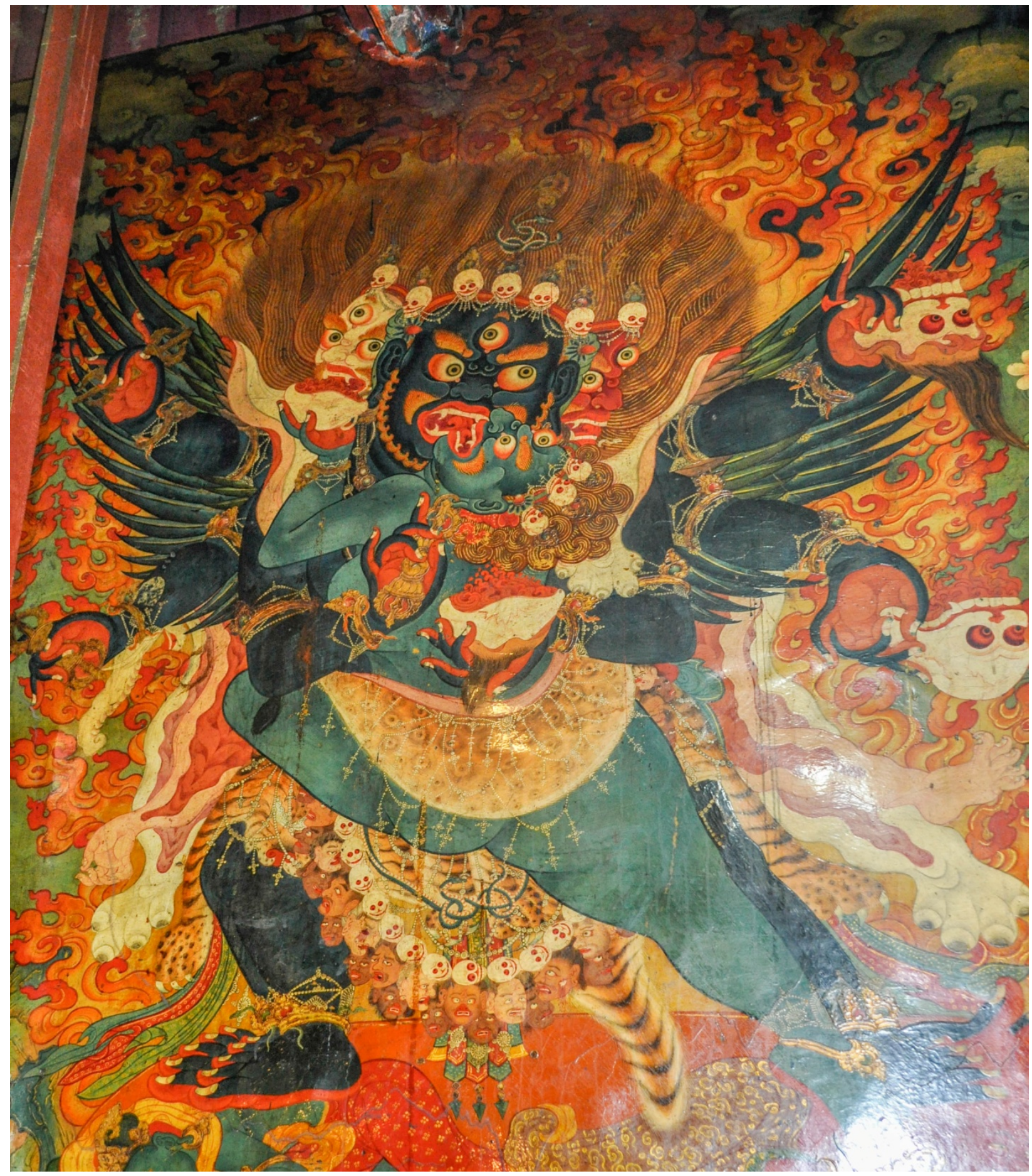

Figure 47: Vajrāmrtta (Tib. Rdo rje bdud rtsi yon tan) in union with his consort; Nechung Monastery Assembly Hall, Lhasa. (Photo: Christopher Bell, 2011) 


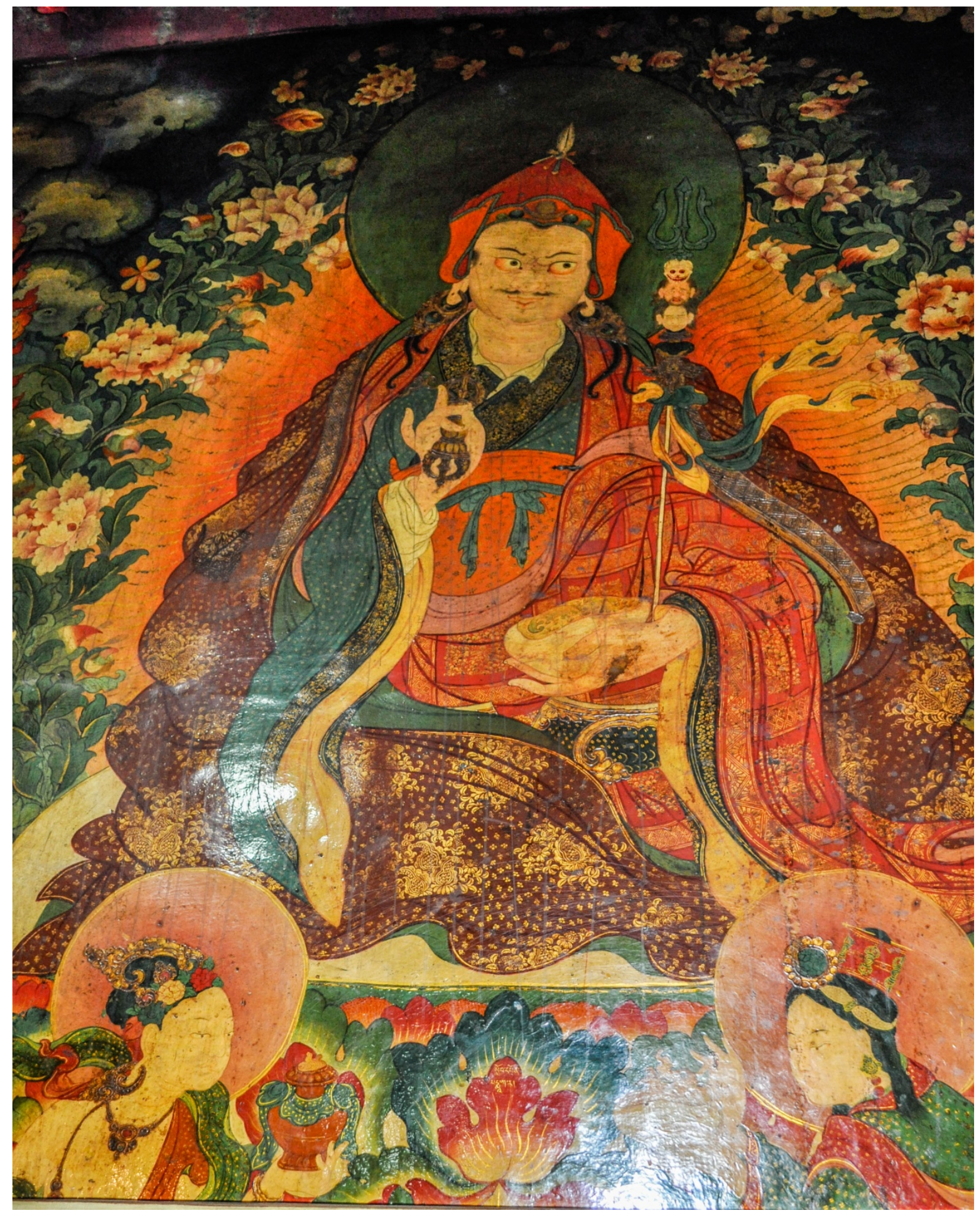

Figure 48: Master Padmākara (Tib. slob dpon Padmā ka ra; lit. "Lotus-born"), a form of Padmasambhava; Nechung Monastery Assembly Hall, Lhasa. (Photo: Christopher Bell, 2011) 


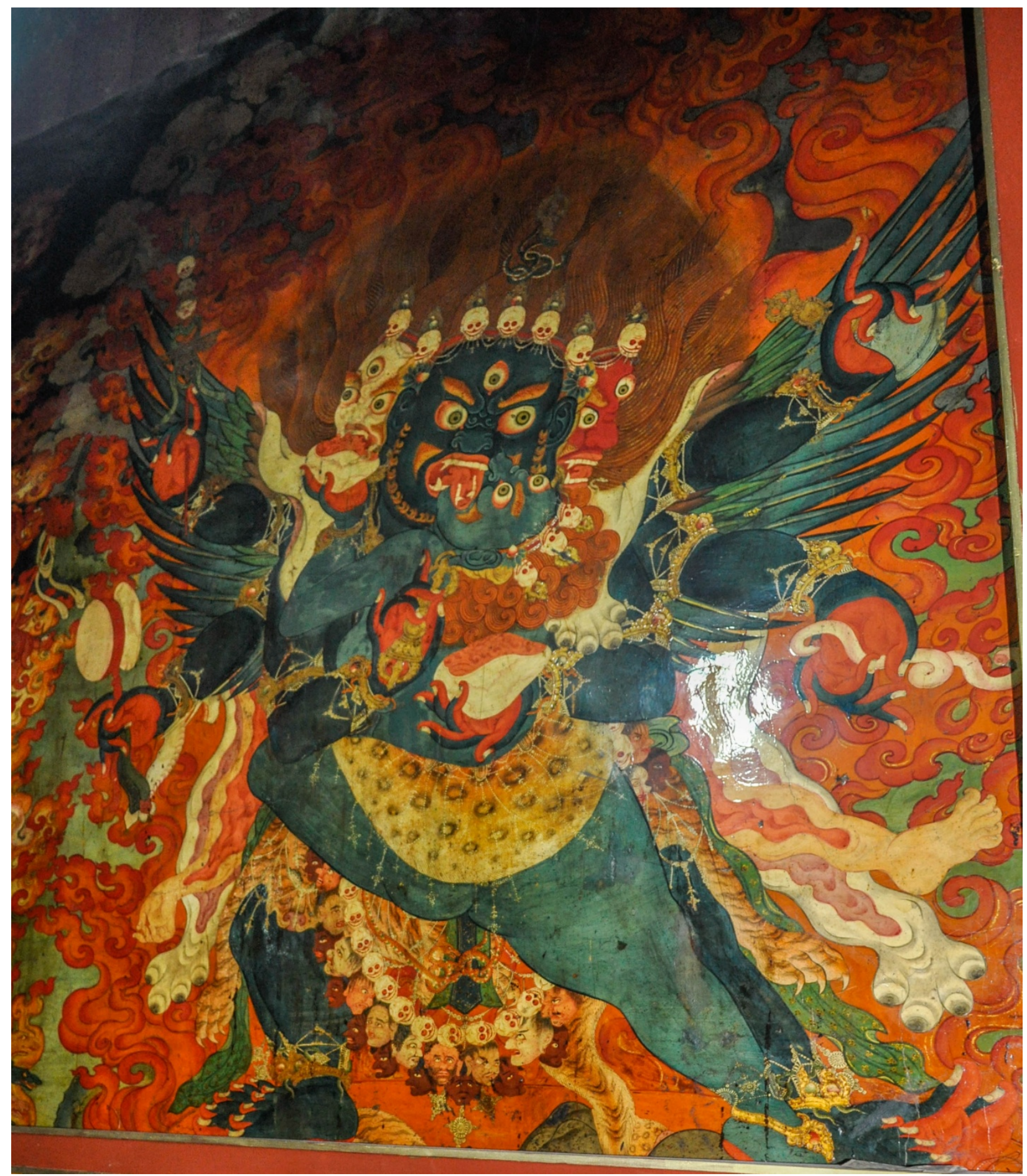

Figure 49: Viśuddha (Tib. Yang dag thugs) in union with his consort; Nechung Monastery Assembly Hall, Lhasa. (Photo: Christopher Bell, 2011) 


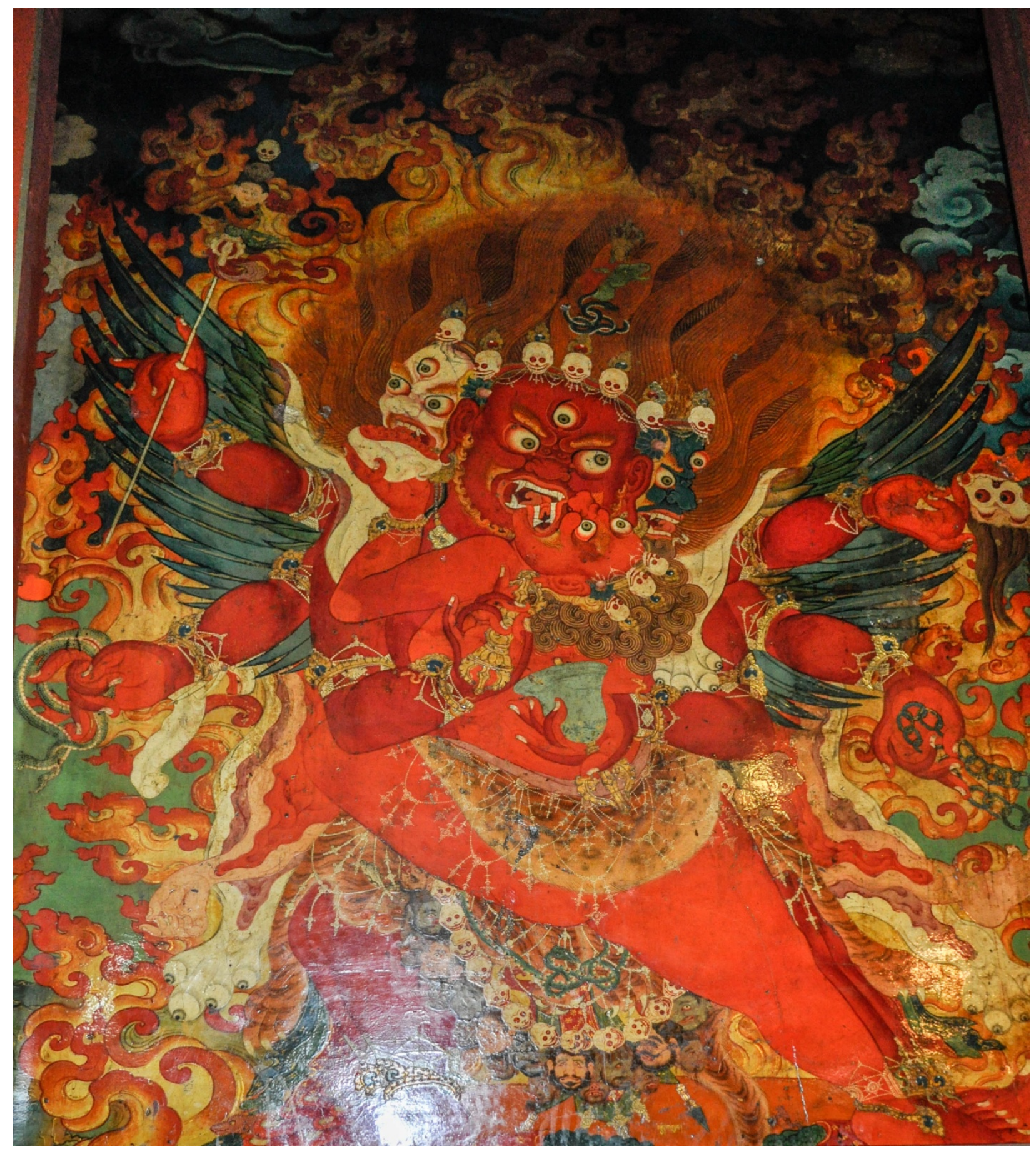

Figure 50: Lotus Speech Hayagrīva (Tib. Pad ma gsung rta mgrin) in union with his consort; Nechung Monastery Assembly Hall, Lhasa. (Photo: Christopher Bell, 2011) 


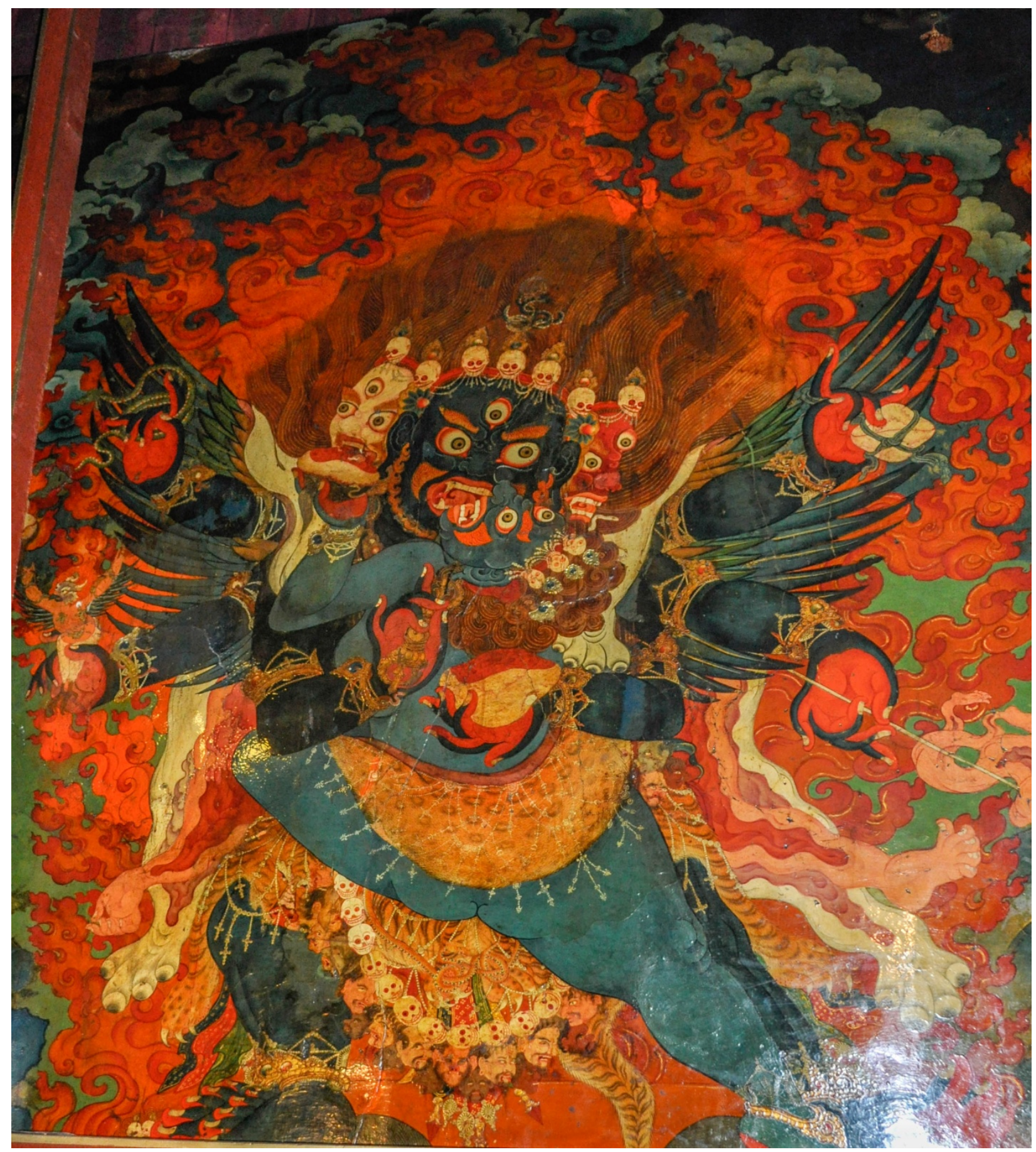

Figure 51: Mātara (Tib. Ma mo rbod gtong) in union with his consort; Nechung Monastery Assembly Hall, Lhasa. (Photo: Christopher Bell, 2011) 


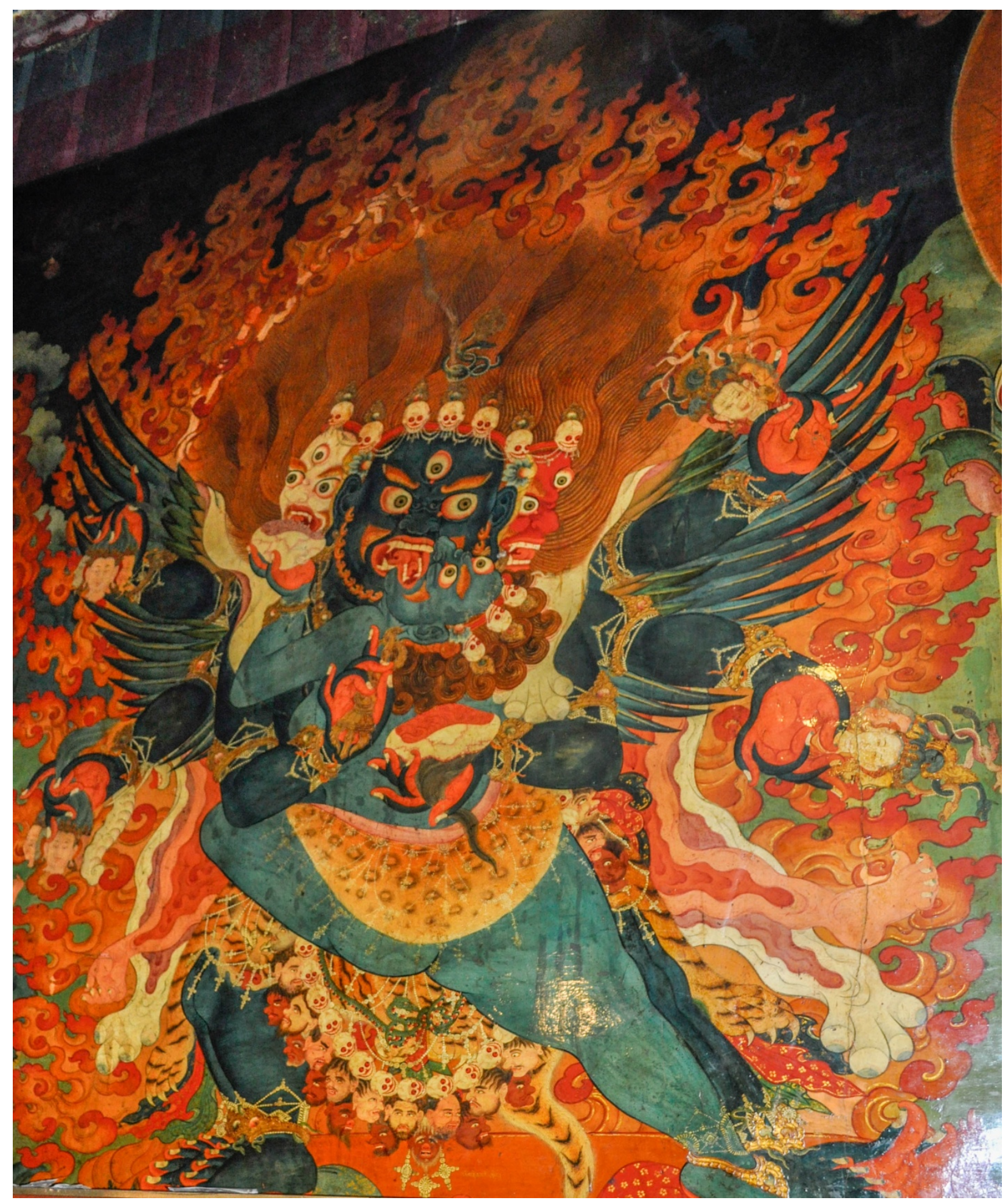

Figure 52: Lokastotrapujanātha (Tib. 'Jig rten mchod bstod) in union with his consort; Nechung Monastery Assembly Hall, Lhasa. (Photo: Christopher Bell, 2011) 


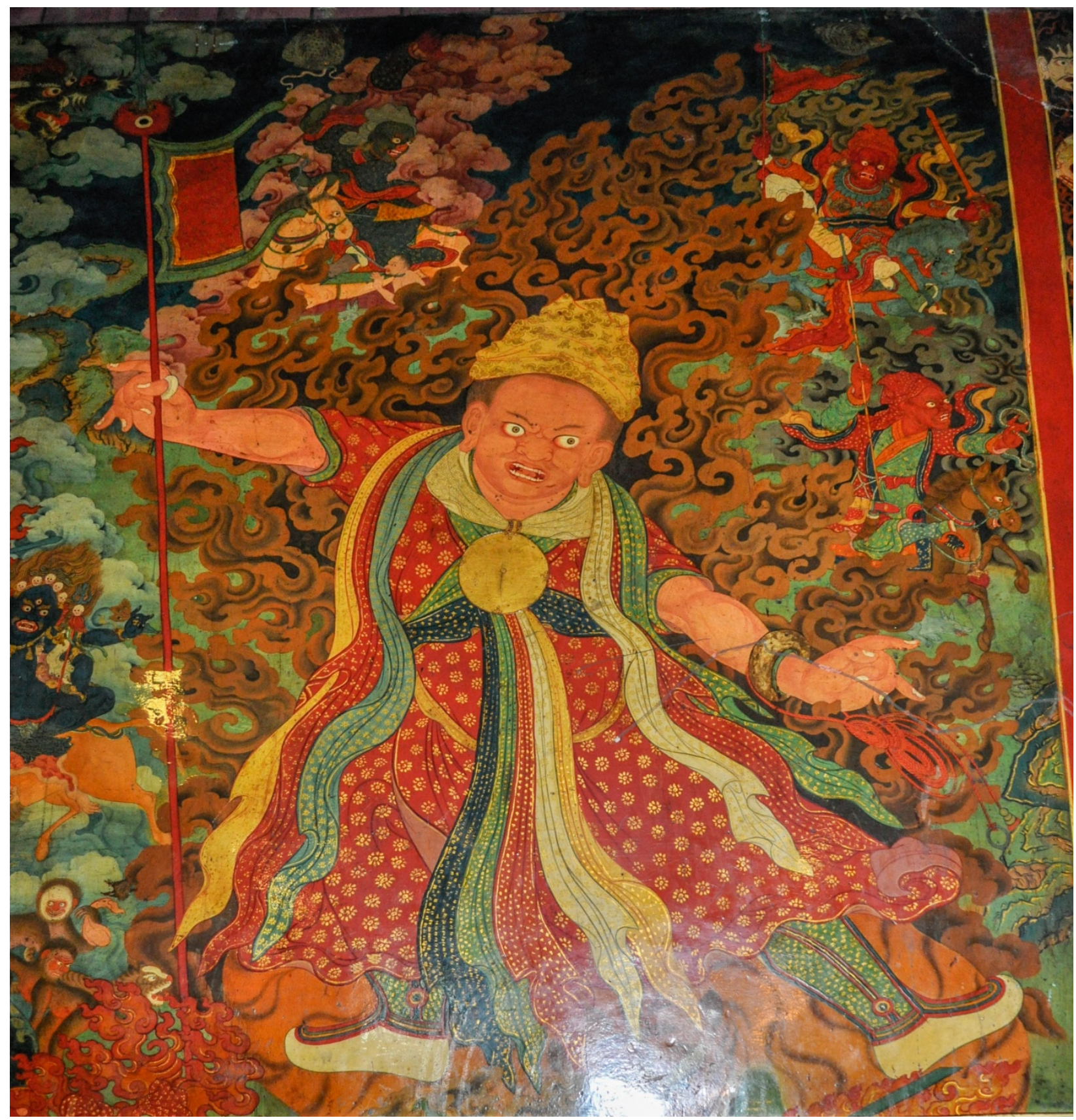

Figure 53: The Nechung Oracle Tokbep Dzepa (Tib. chos skyong chen po Thog 'bebs mdzad pa). This is said to be an image of Śākya Yarpel (Tib. Shākya yar 'phel), who acted as the Nechung Medium from 1856-1900; Nechung Monastery Assembly Hall, Lhasa. (Photo: Christopher Bell, 2011) 


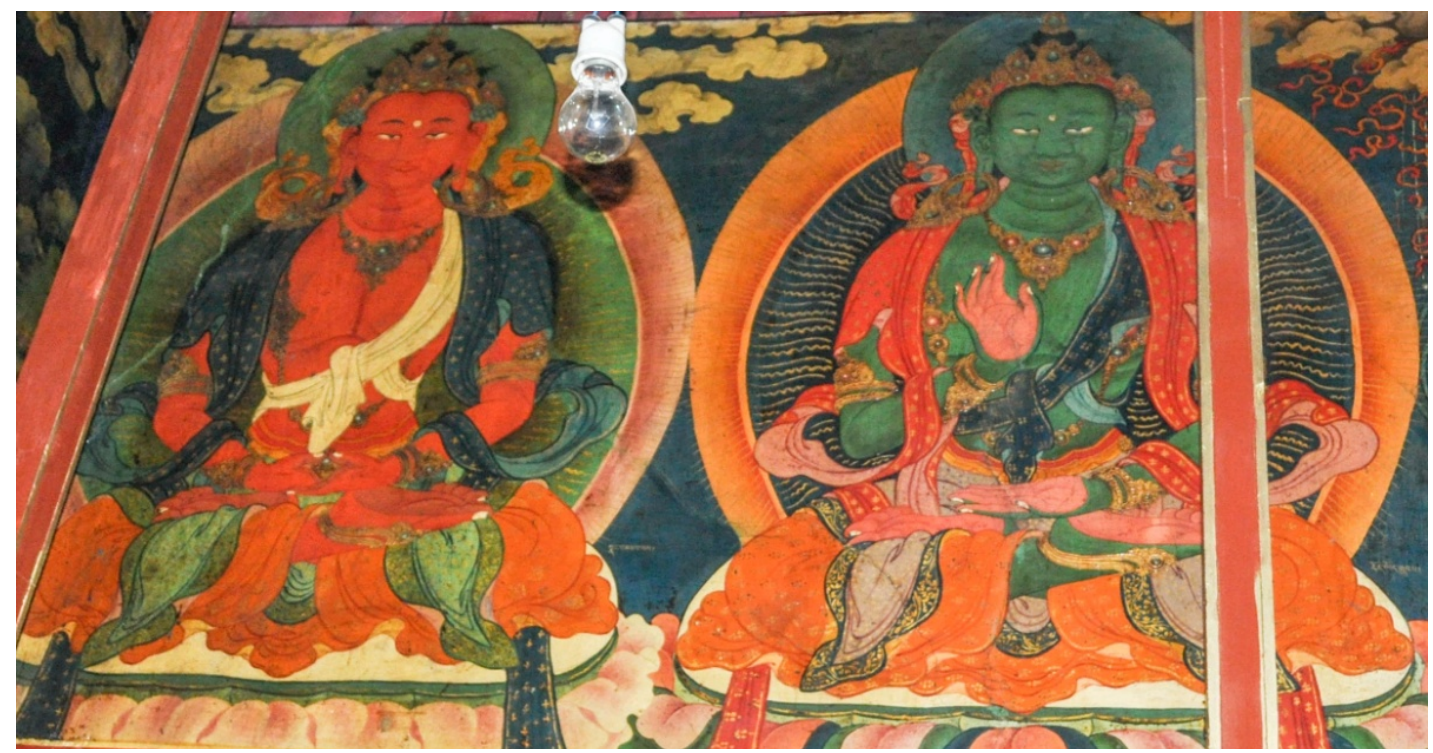

54a: [1] Amitābha (Tib. Snang ba mtha' yas), the Western Buddha of the Padma Family, and [2] Amoghasiddhi (Tib. Don yod grub pa), the Northern Buddha of the Karma Family; Nechung Monastery Assembly Hall, Lhasa.

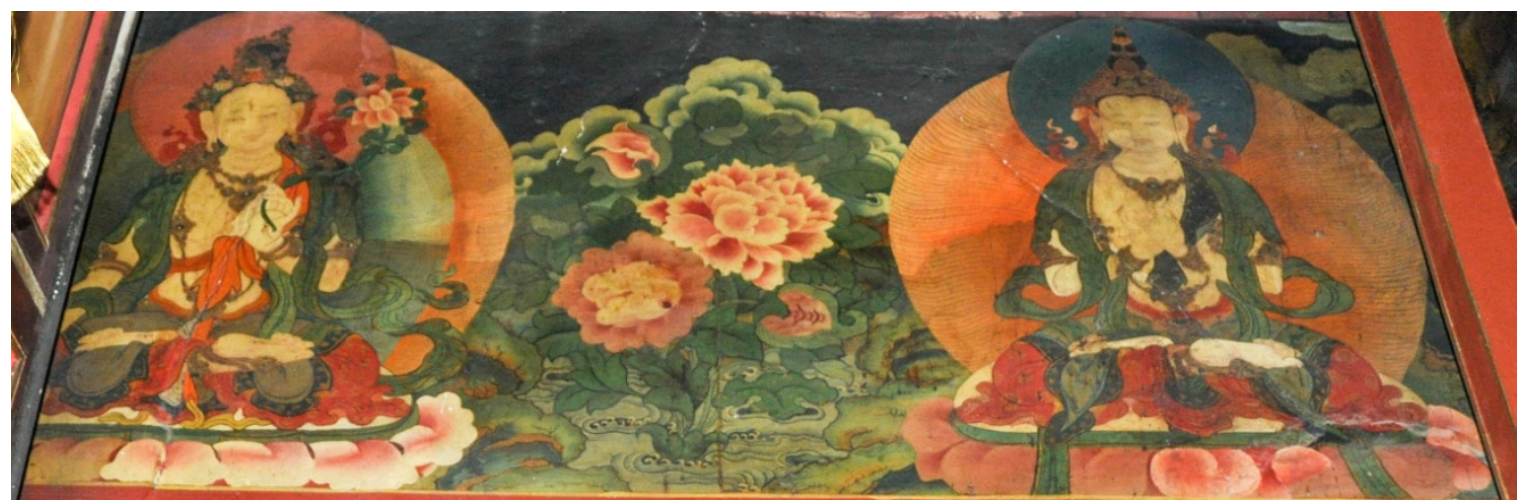

54b: [3] White Tārā (Tib. Sgrol dkar), Vairocana's consort, and [4] Vairocana (Tib. Rnam par snang mdzad), the Central Buddha of the Buddha Family; Nechung Monastery Assembly Hall, Lhasa.

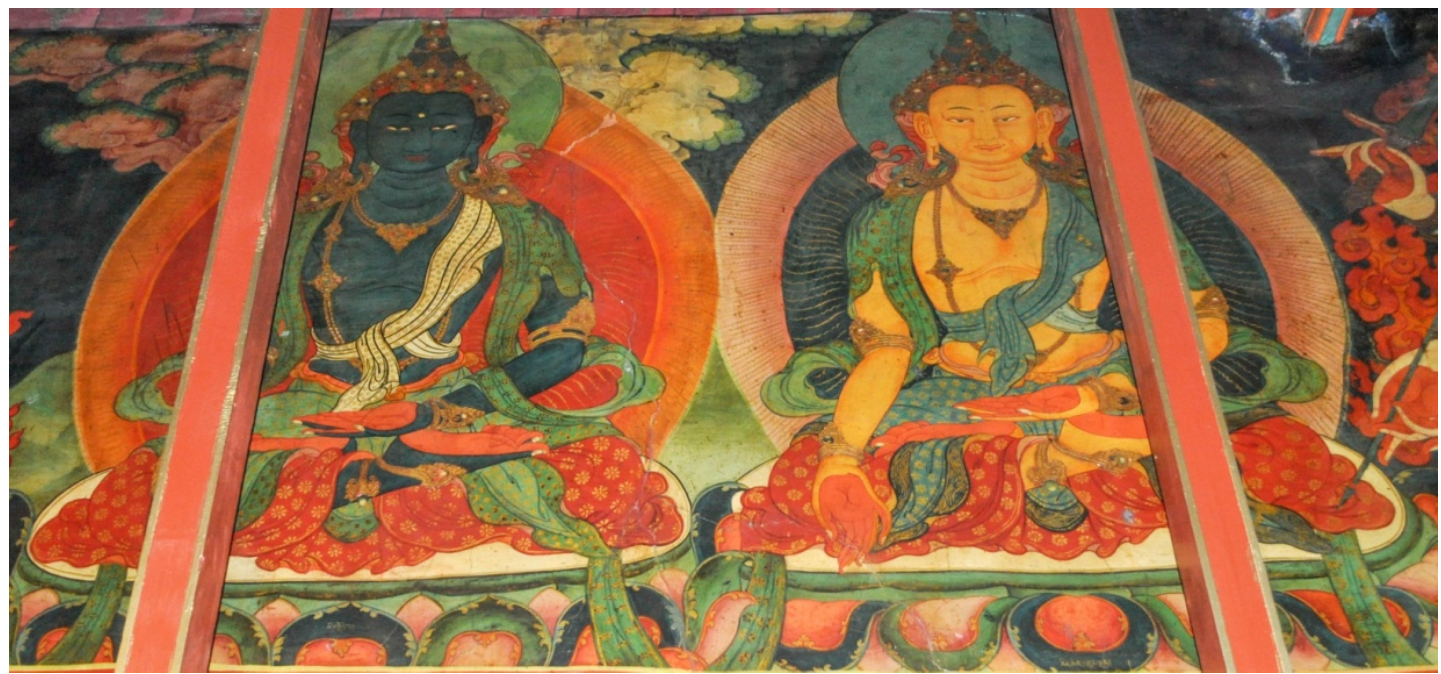

54c: [5] Akșobhya (Tib. Mi bskyod pa), the Eastern Buddha of the Vajra Family, and [6] Ratnasambhava (Tib. Rin chen 'byung ldan), the Southern Buddha of the Ratna Family; Nechung Monastery Assembly Hall, Lhasa. (Photos: Christopher Bell, 2011) 


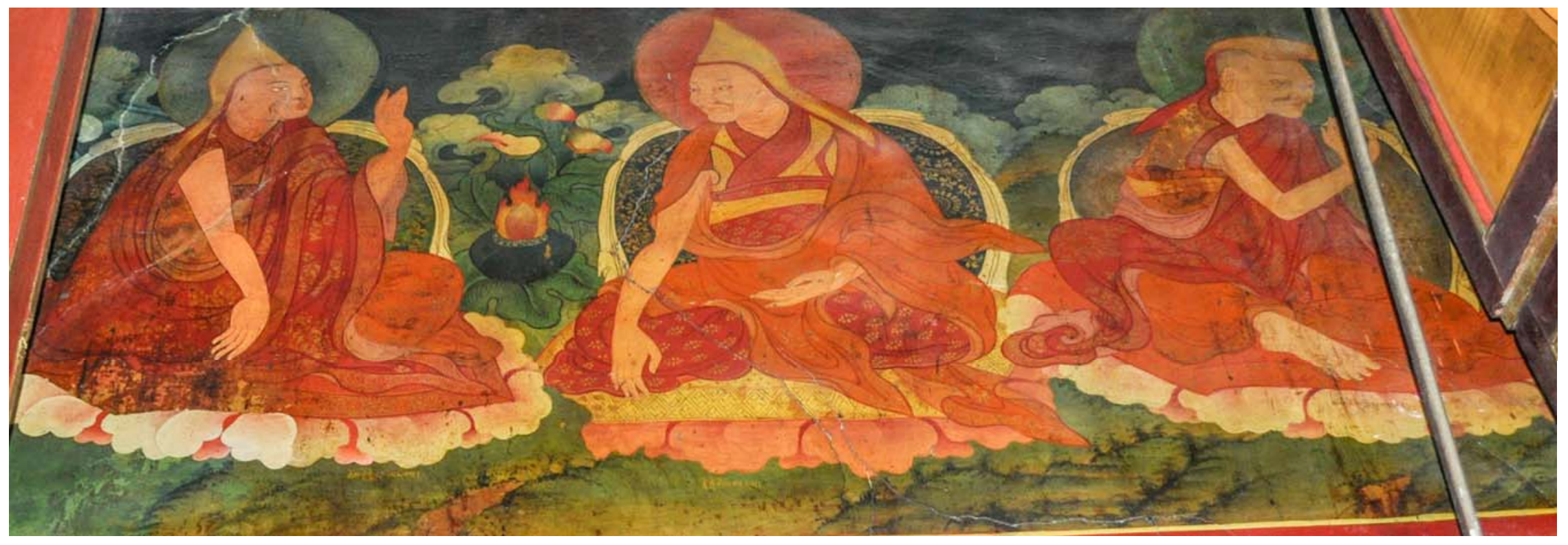

Figure 55: [1] the Dharma Lord Mönlampel (Tib. chos rje Smon lam dpal, 1414-1491), the eighth abbot of Ganden Monastery, [2] Lord Lodrö Tenpa (Tib. rje Blo gros brtan pa, 1402-1476), the seventh abbot of Ganden Monastery, and [3] Baso Chökyi Gyentsen (Tib. Ba so Chos kyi rgyal mtshan (1402-1473), the sixth abbot of Ganden Monastery; Nechung Monastery Assembly Hall, Lhasa. (Photo: Christopher Bell, 2011) 


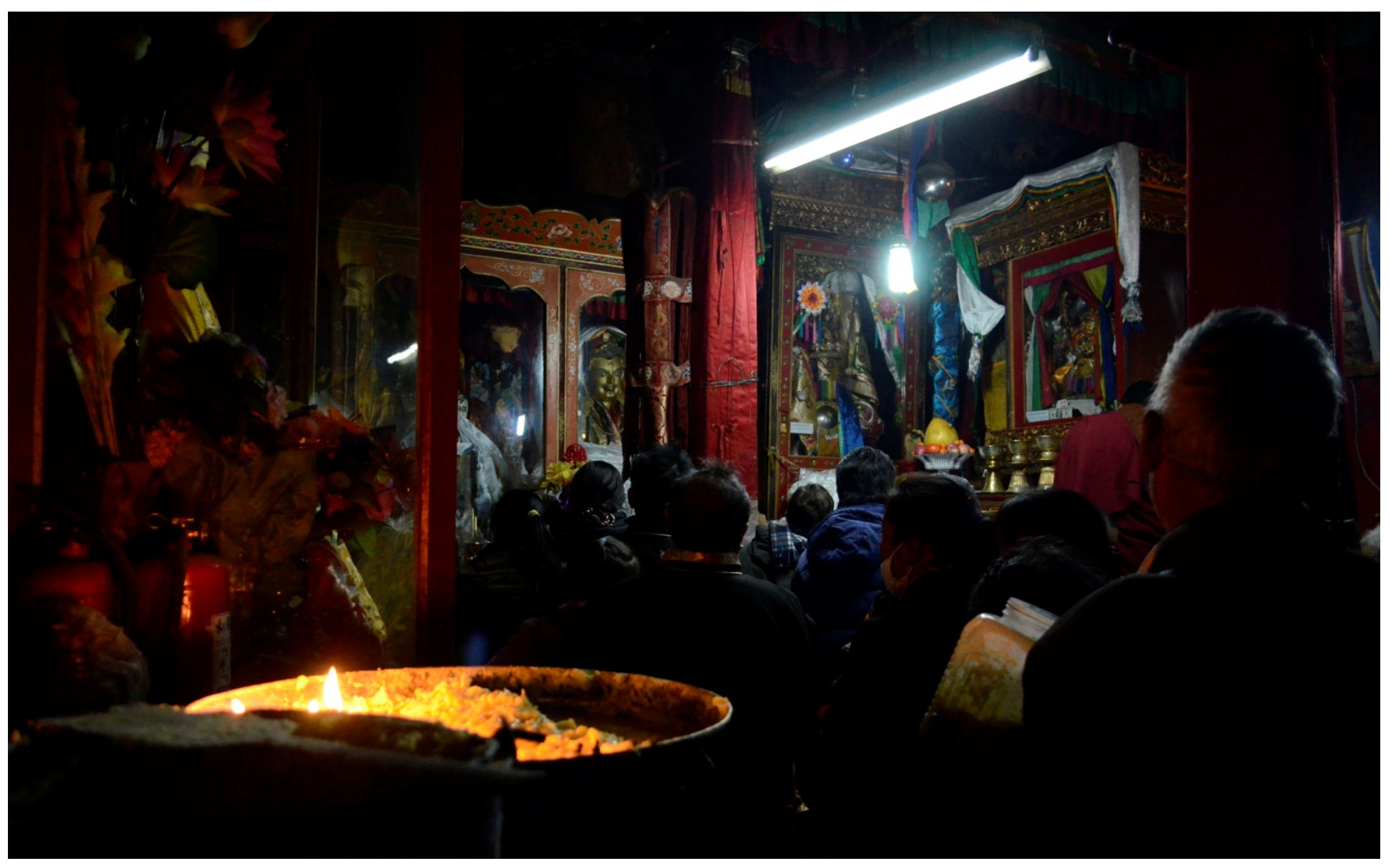

Figure 56: Tibetan devotees making offerings in the Birch Tree Chapel; Nechung Monastery Assembly Hall, Lhasa. (Photo: Cecilia Haynes, 2010) 


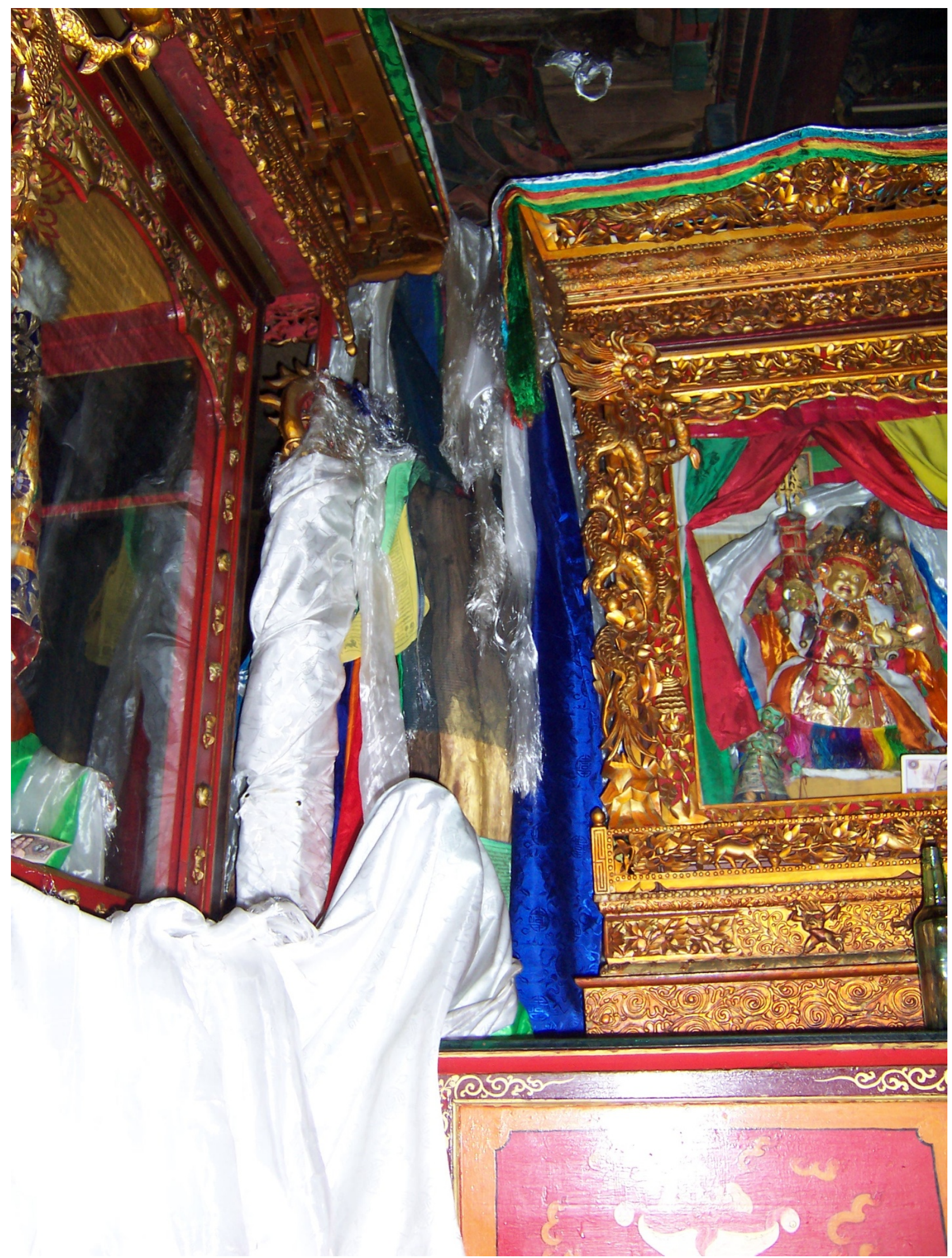

Figure 57: Pehar's soul tree (Tib. bla shing) within the Birch Tree Chapel; Nechung Monastery Assembly Hall, Lhasa. (Photo: Christopher Bell, 2005) 


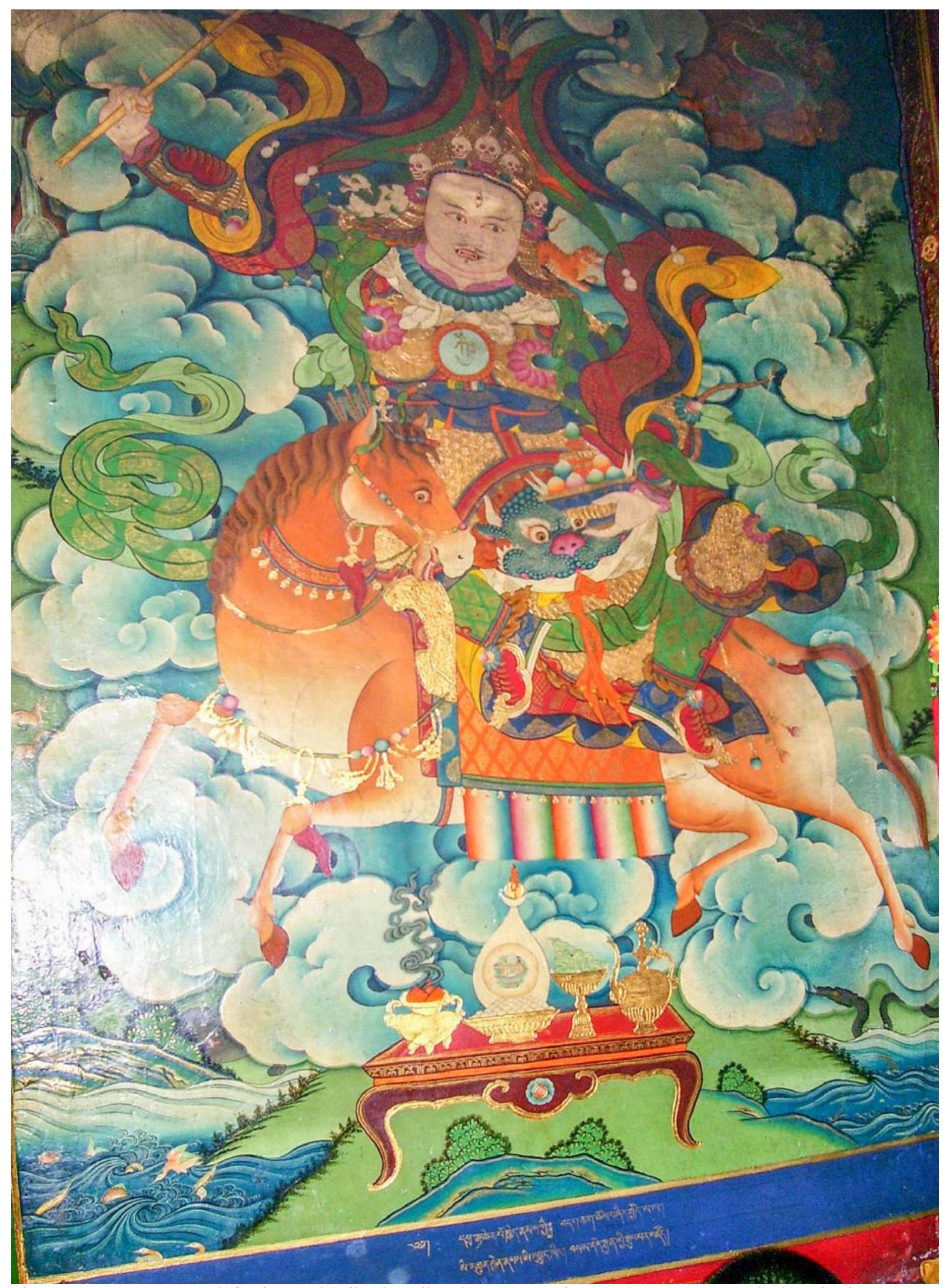

Figure 58: Great enemy-defeating god (Tib. dgra lha chen po); Nechung Monastery Central Chapel, Lhasa. (Photo: Christopher Bell, 2007) 


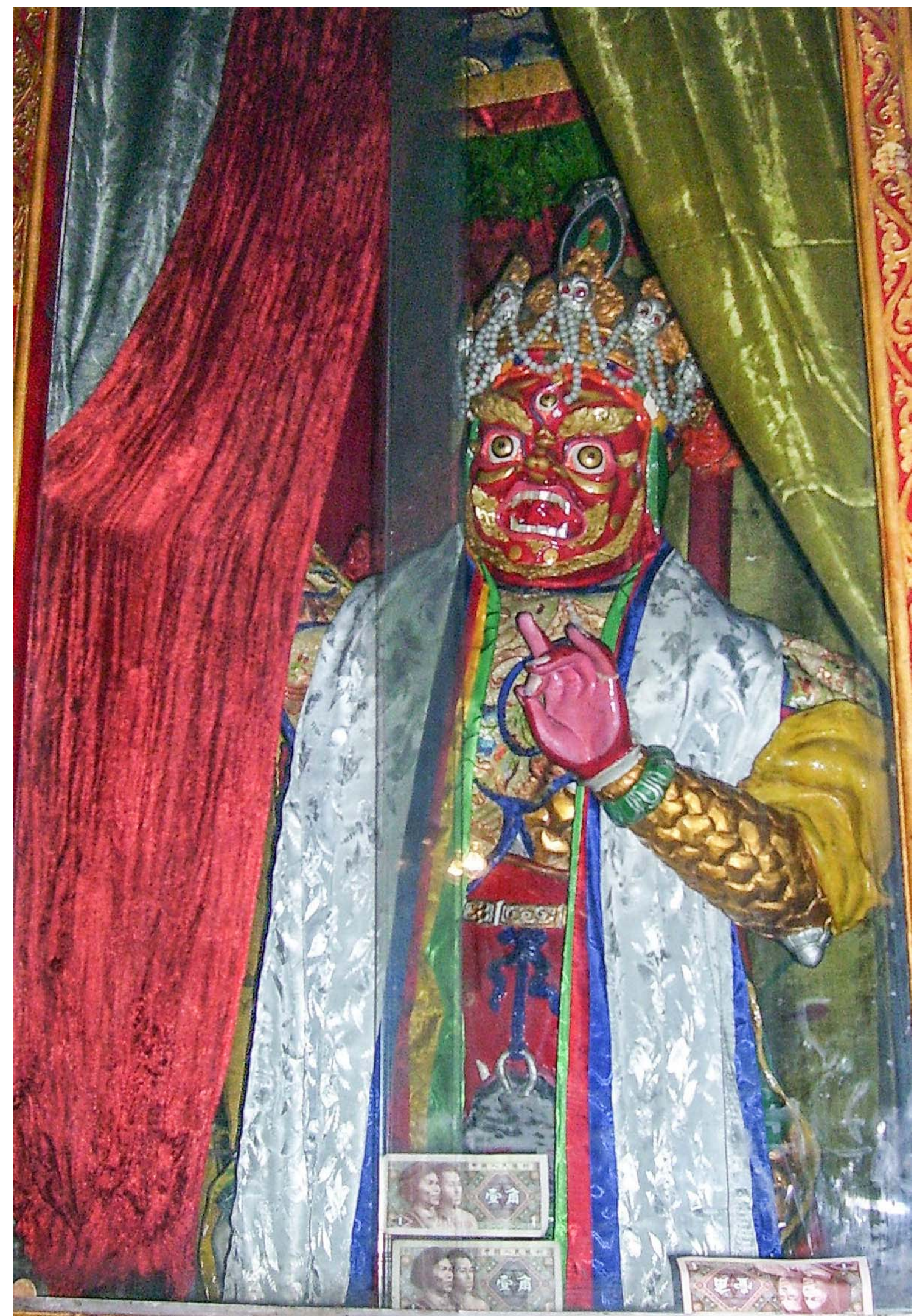

Figure 59: Toktsen (Tib. Thog btsan), a door guardian; Nechung Monastery Central Chapel, Lhasa. (Photo: Christopher Bell, 2007) 


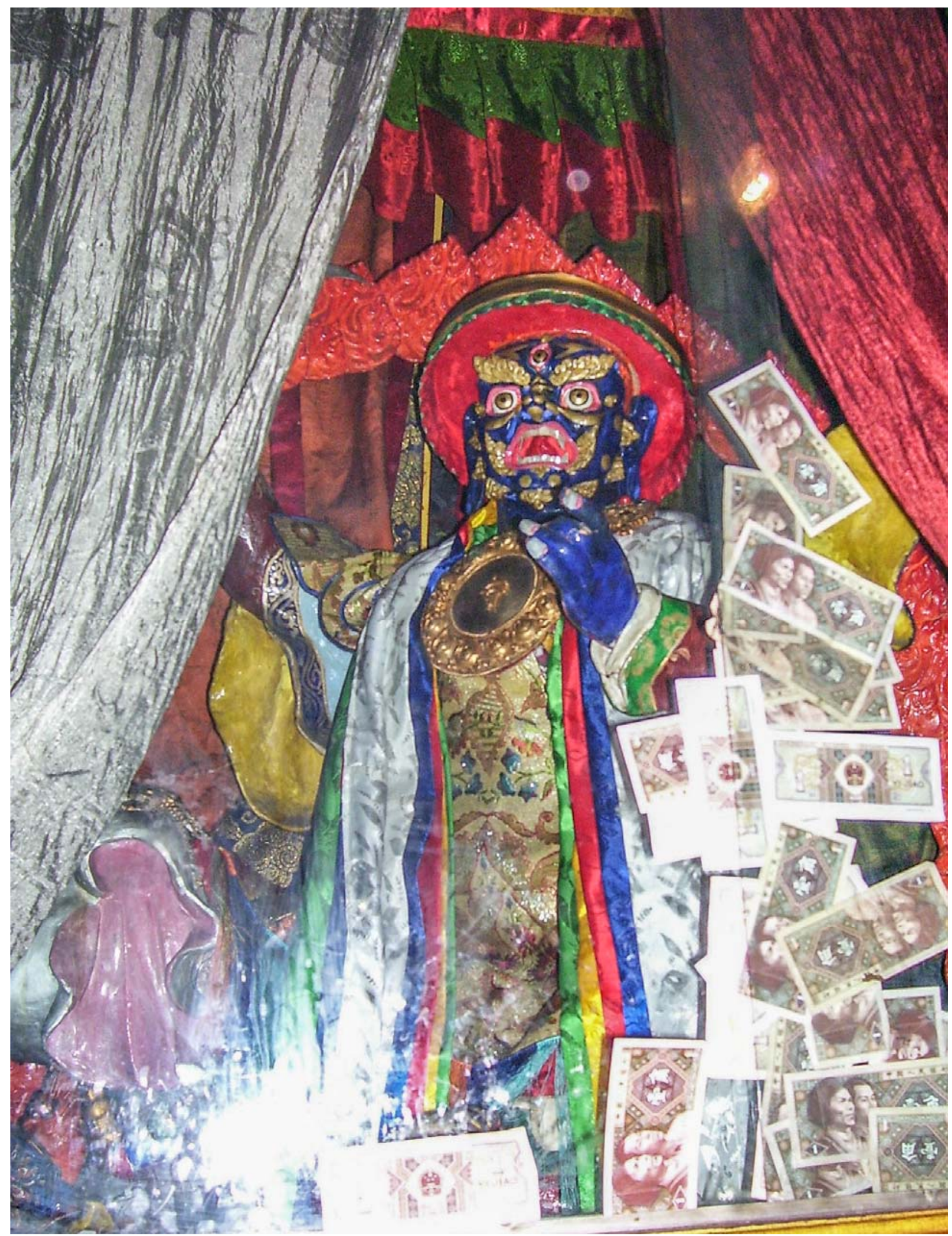

Figure 60: Gyajin; Nechung Monastery Central Chapel, Lhasa. (Photo: Christopher Bell, 2007) 


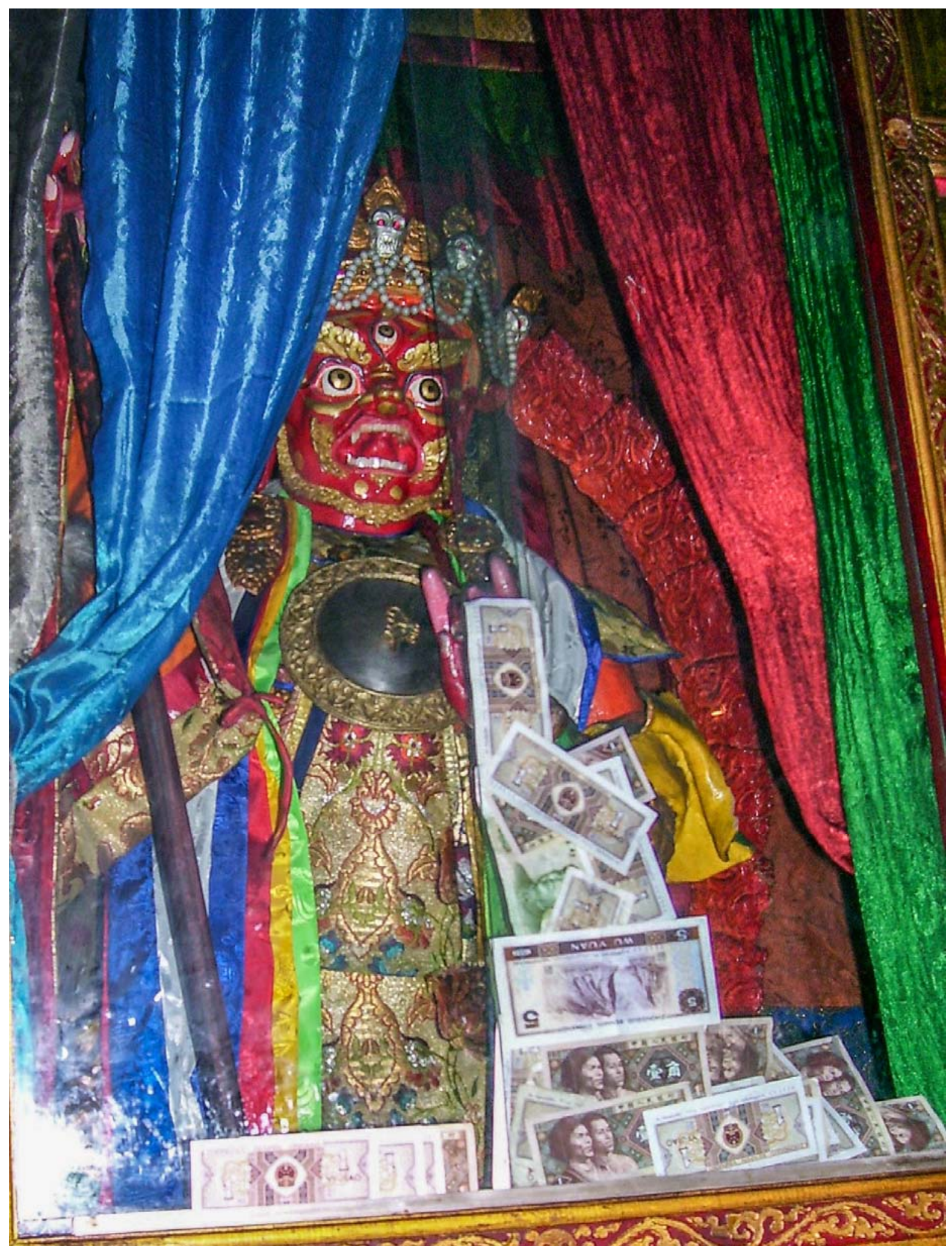

Figure 61: Dorjé Drakden; Nechung Monastery Central Chapel, Lhasa. (Photo: Christopher Bell, 2007) 


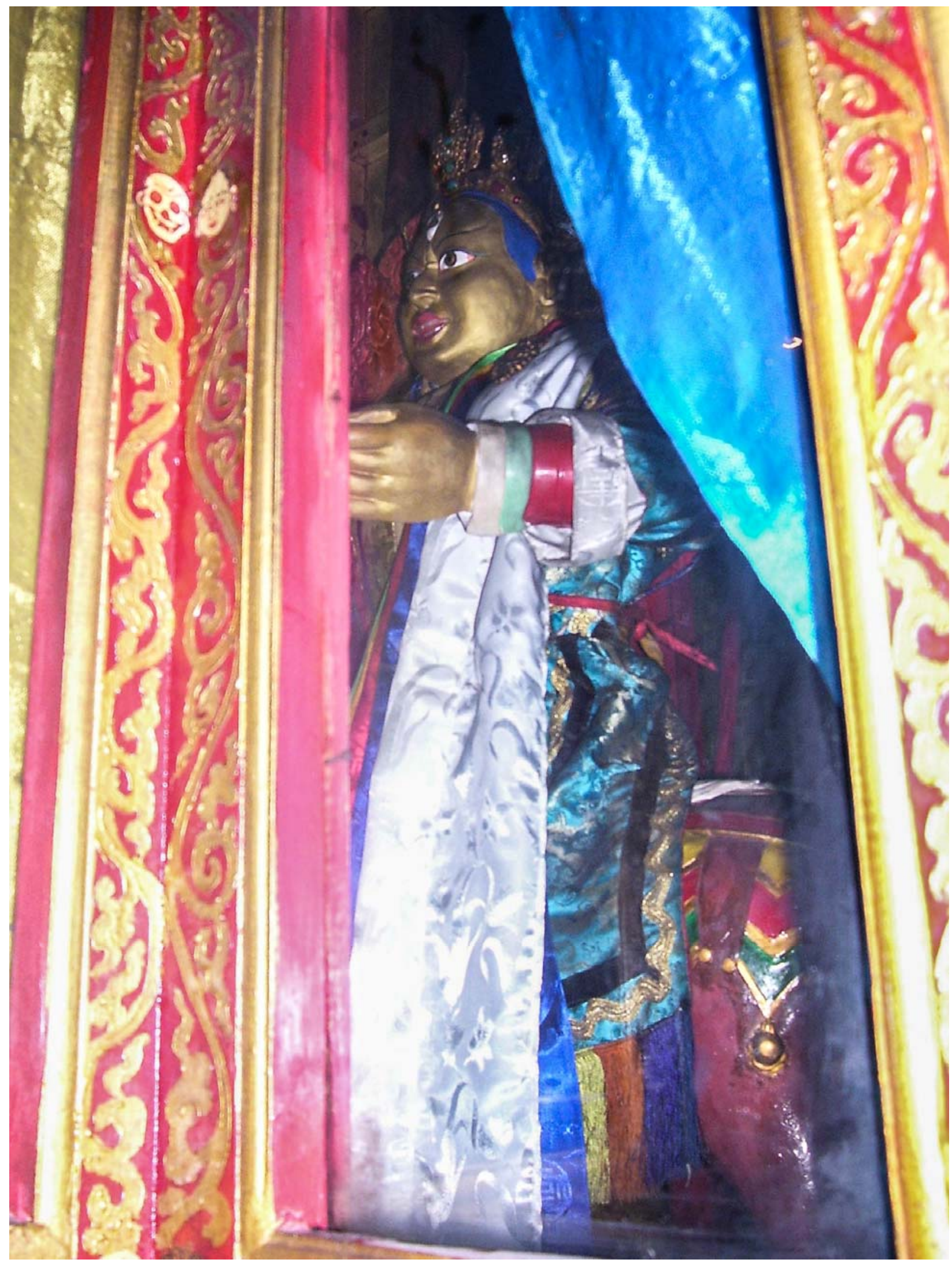

Figure 62: Goddess Drakgyelma (Tib. lha mo Grags rgyal ma), the leader of the Twelve Tenma Goddesses; Nechung Monastery Central Chapel, Lhasa. (Photo: Christopher Bell, 2007) 


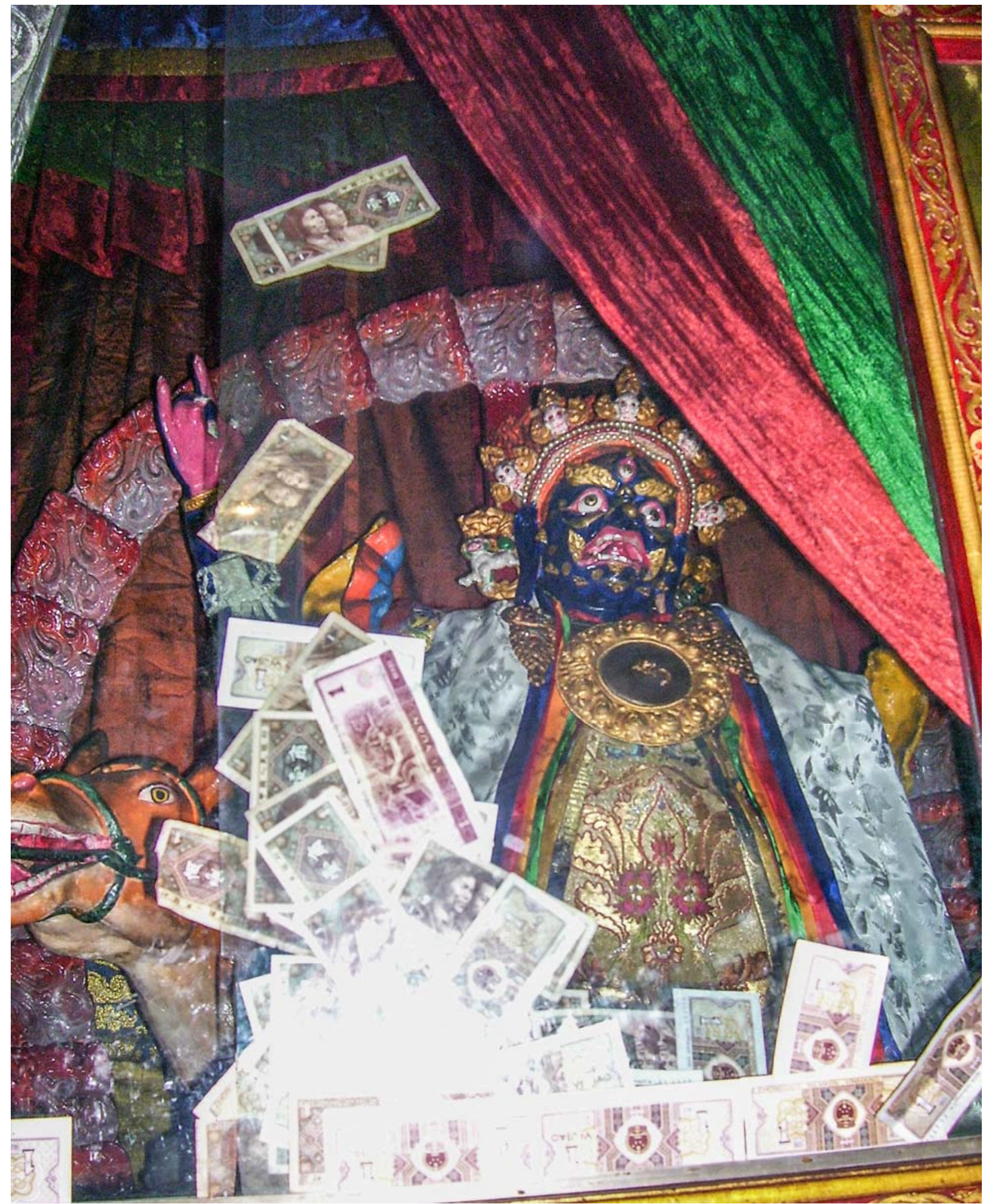

Figure 63: Goddess Makzor Gyelmo; Nechung Monastery Central Chapel, Lhasa. (Photo: Christopher Bell, 2007) 


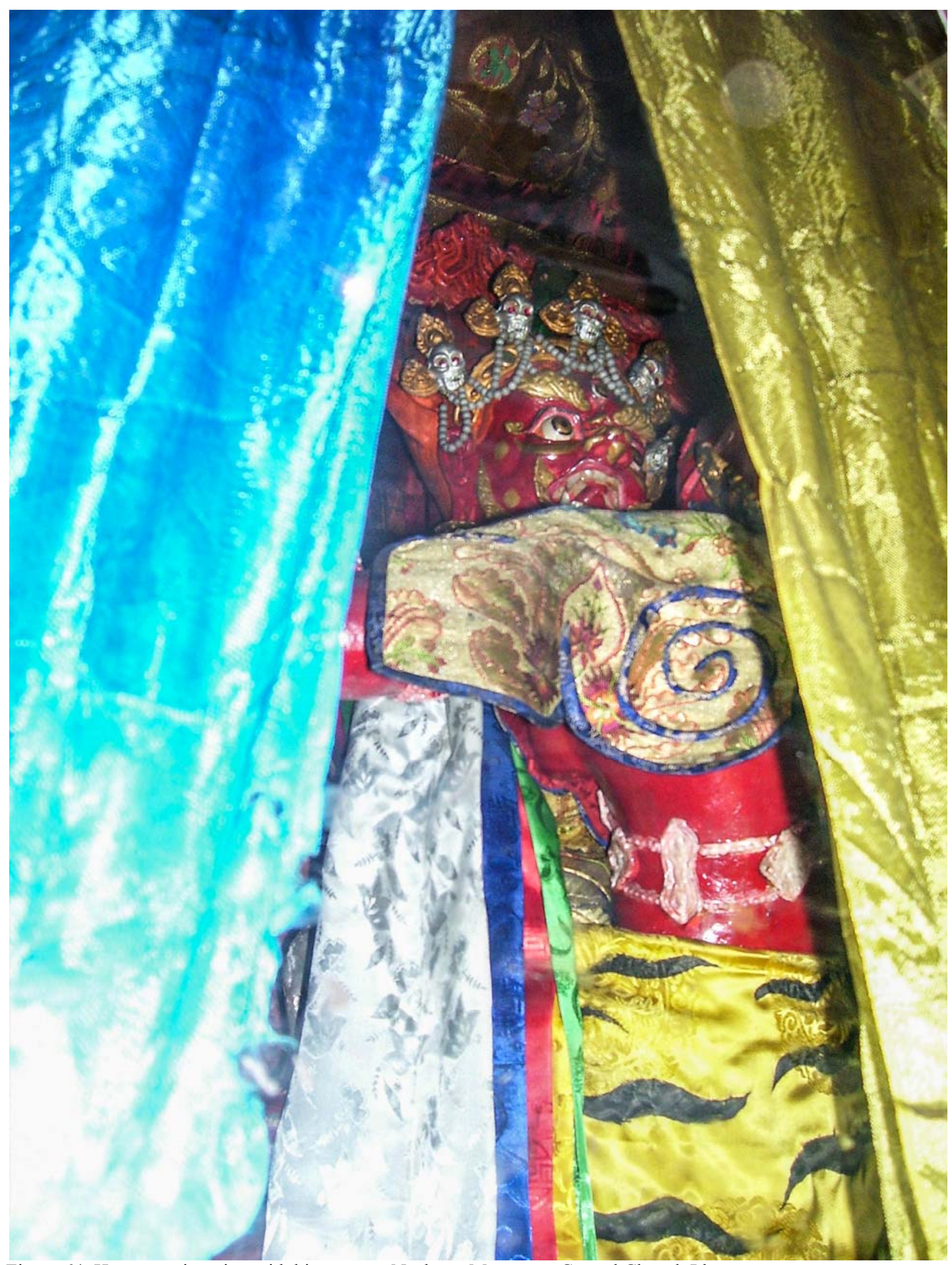

Figure 64: Hayagrīva in union with his consort; Nechung Monastery Central Chapel, Lhasa. (Photo: Christopher Bell, 2007) 


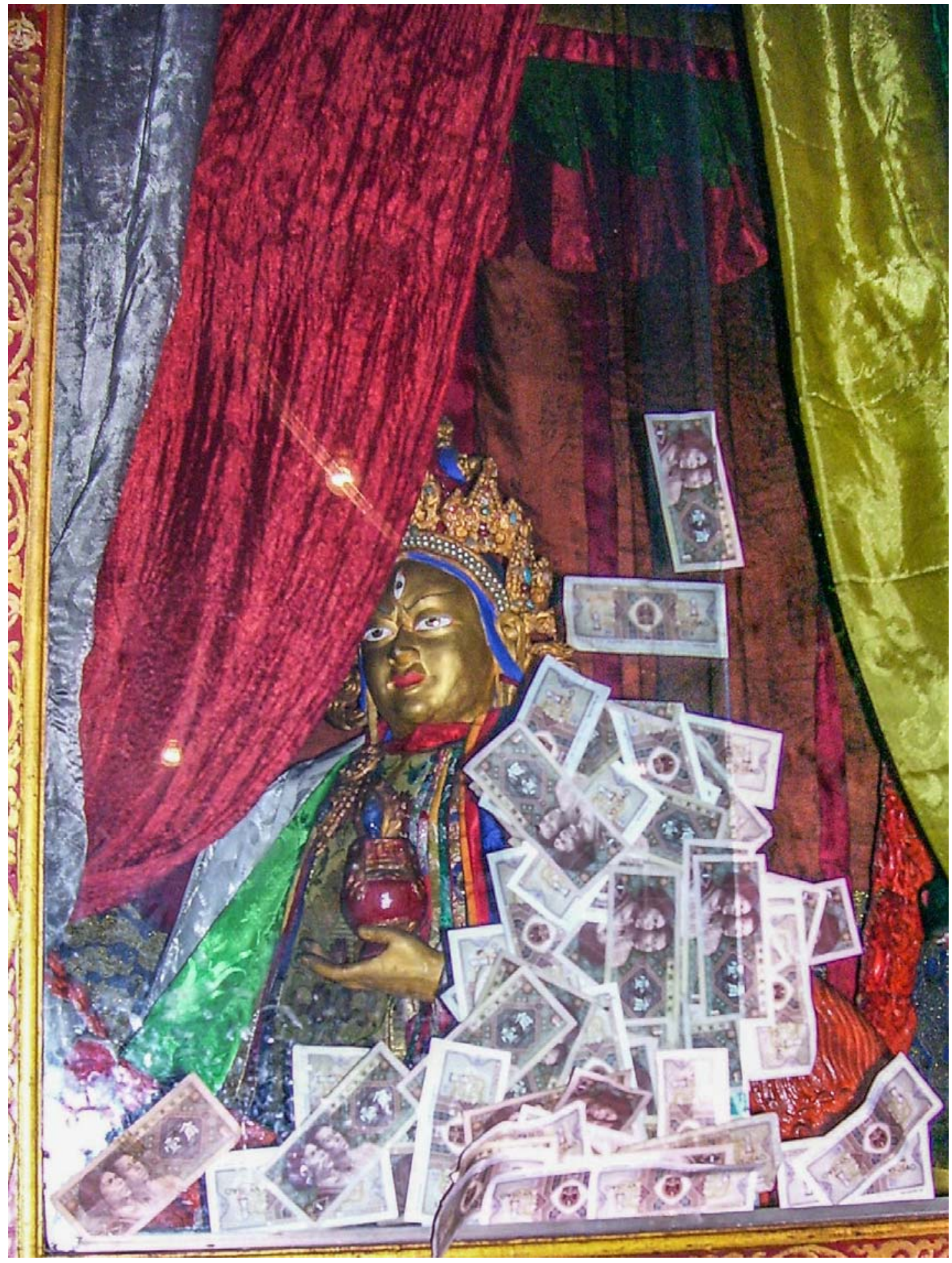

Figure 65: Goddess of the Five Long-Life Sisters (Tib. lha mo Tshe ring mched lnga); Nechung Monastery Central Chapel, Lhasa. (Photo: Christopher Bell, 2007) 


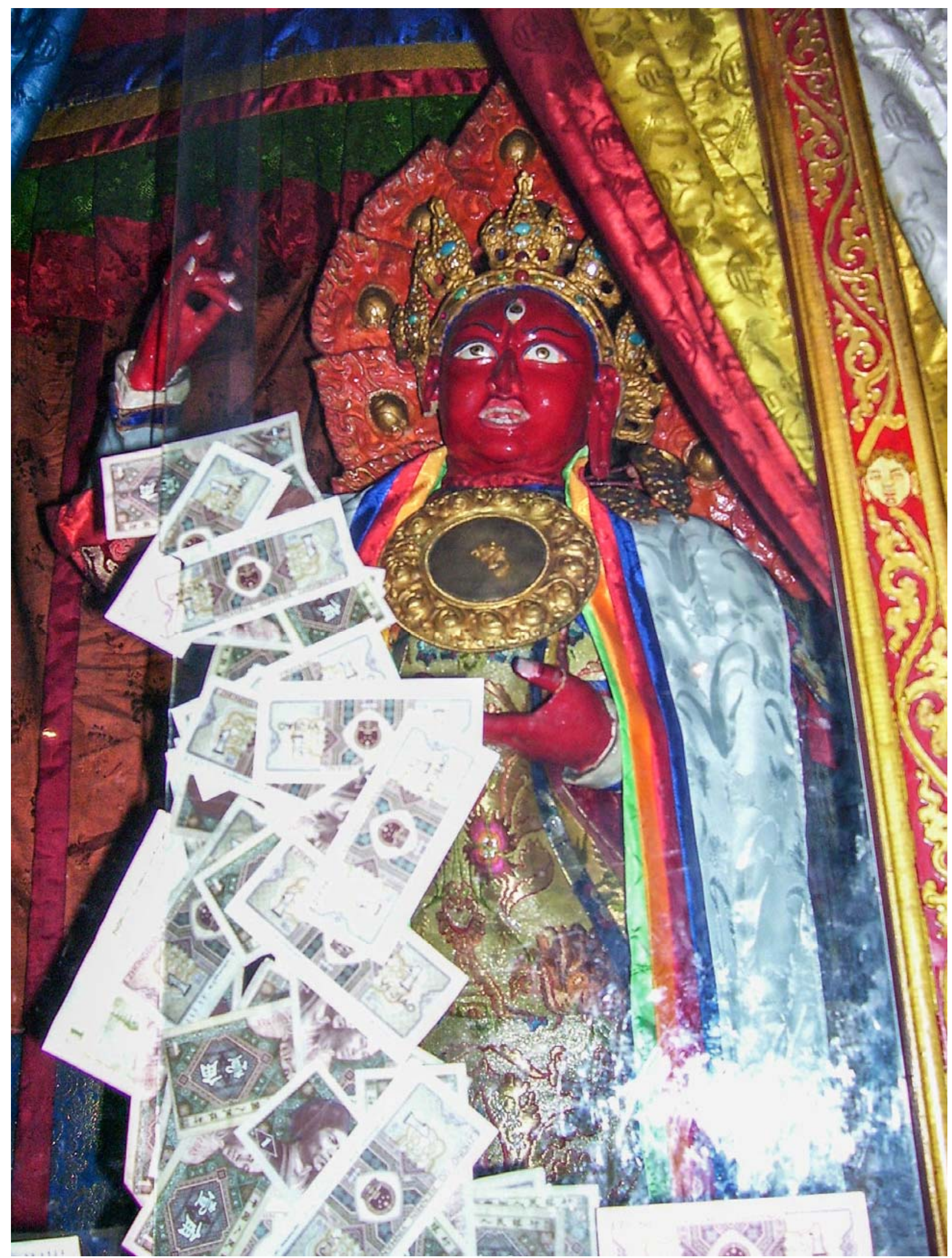

Figure 66: Goddess Nyima Zhönnu (Tib. lha mo Nyi ma gzhon nu); Nechung Monastery Central Chapel, Lhasa. (Photo: Christopher Bell, 2007) 


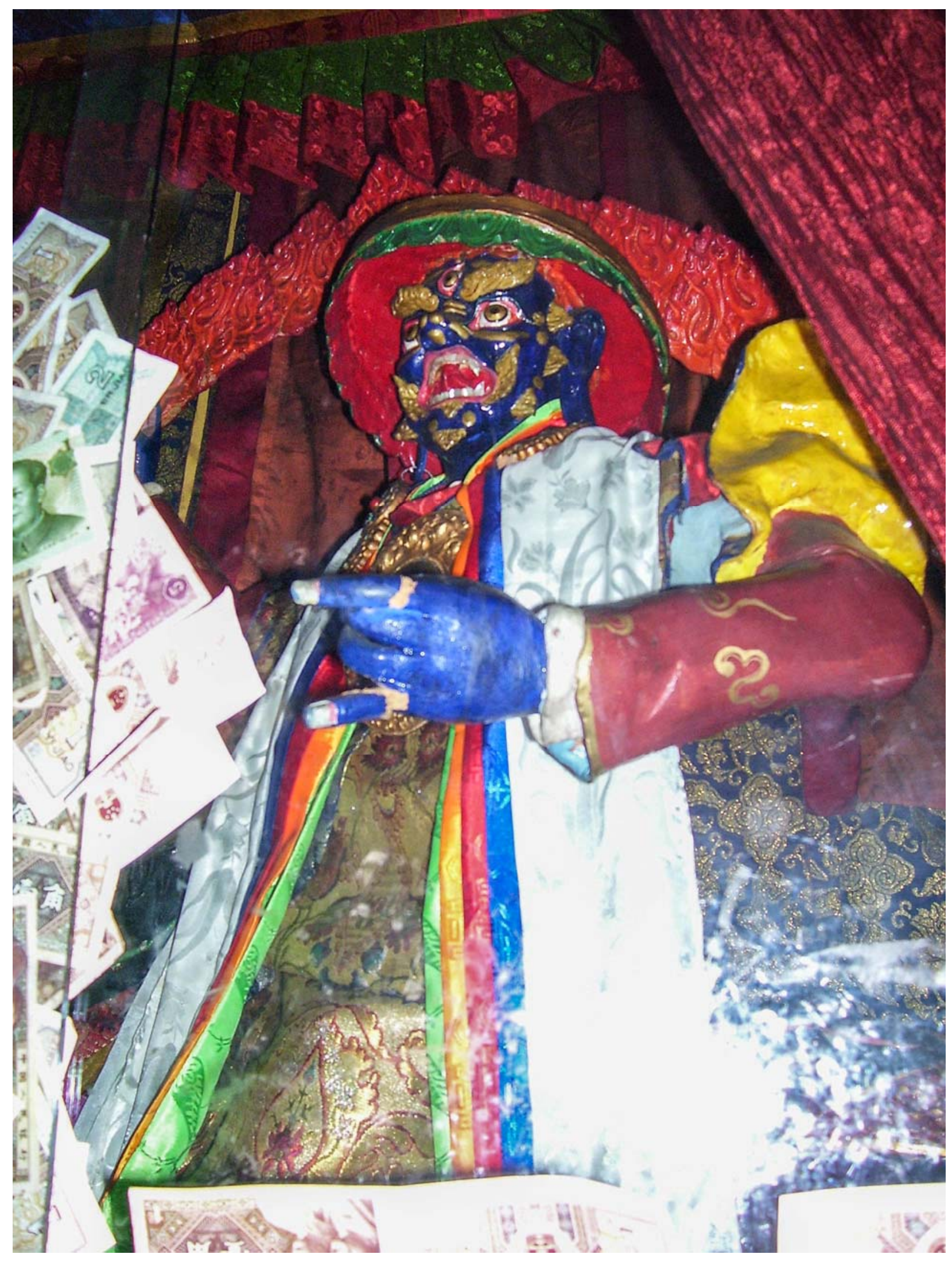

Figure 67: Shingjachen; Nechung Monastery Central Chapel, Lhasa. (Photo: Christopher Bell, 2007) 


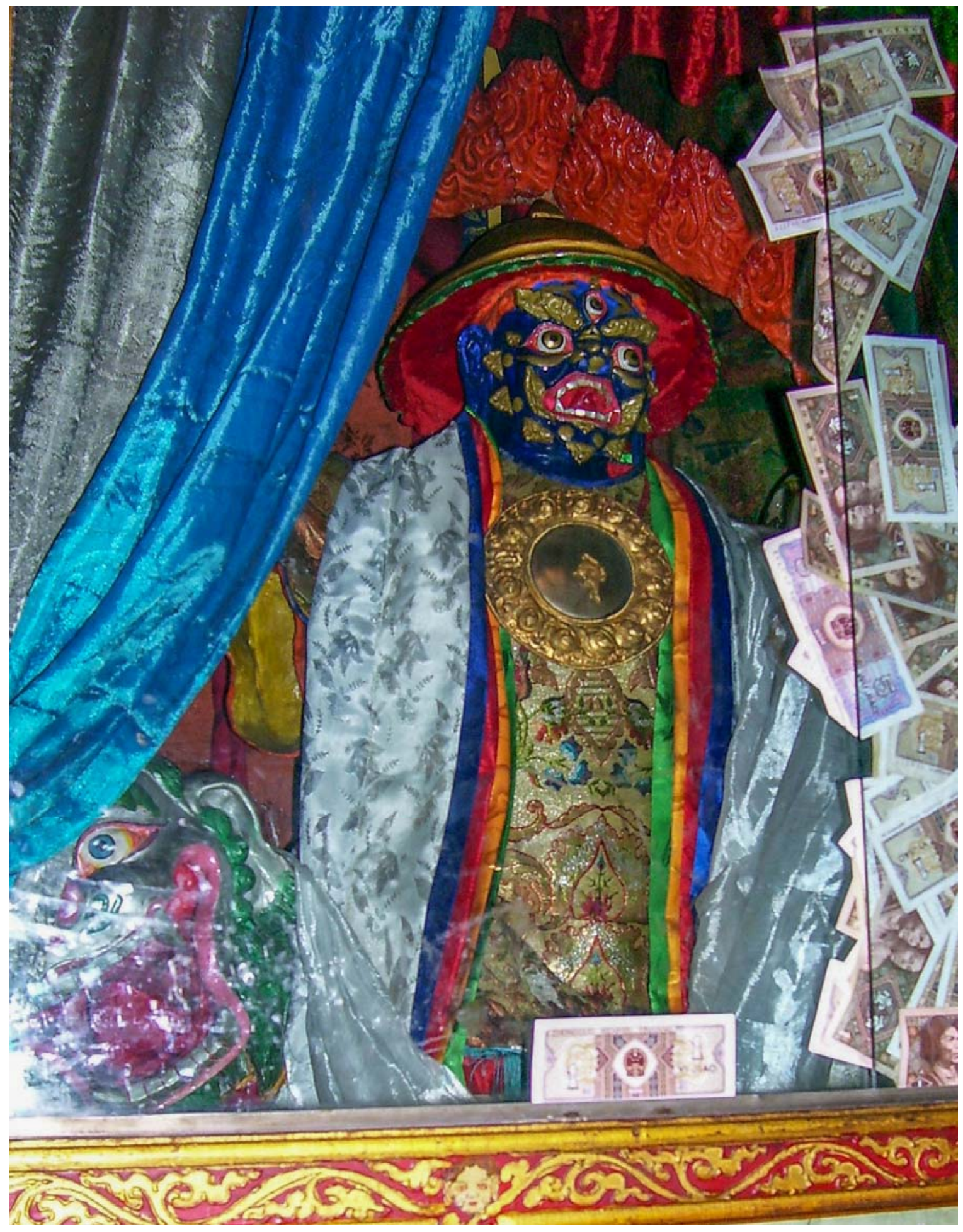

Figure 68: Mönbuputra; Nechung Monastery Central Chapel, Lhasa. (Photo: Christopher Bell, 2007) 


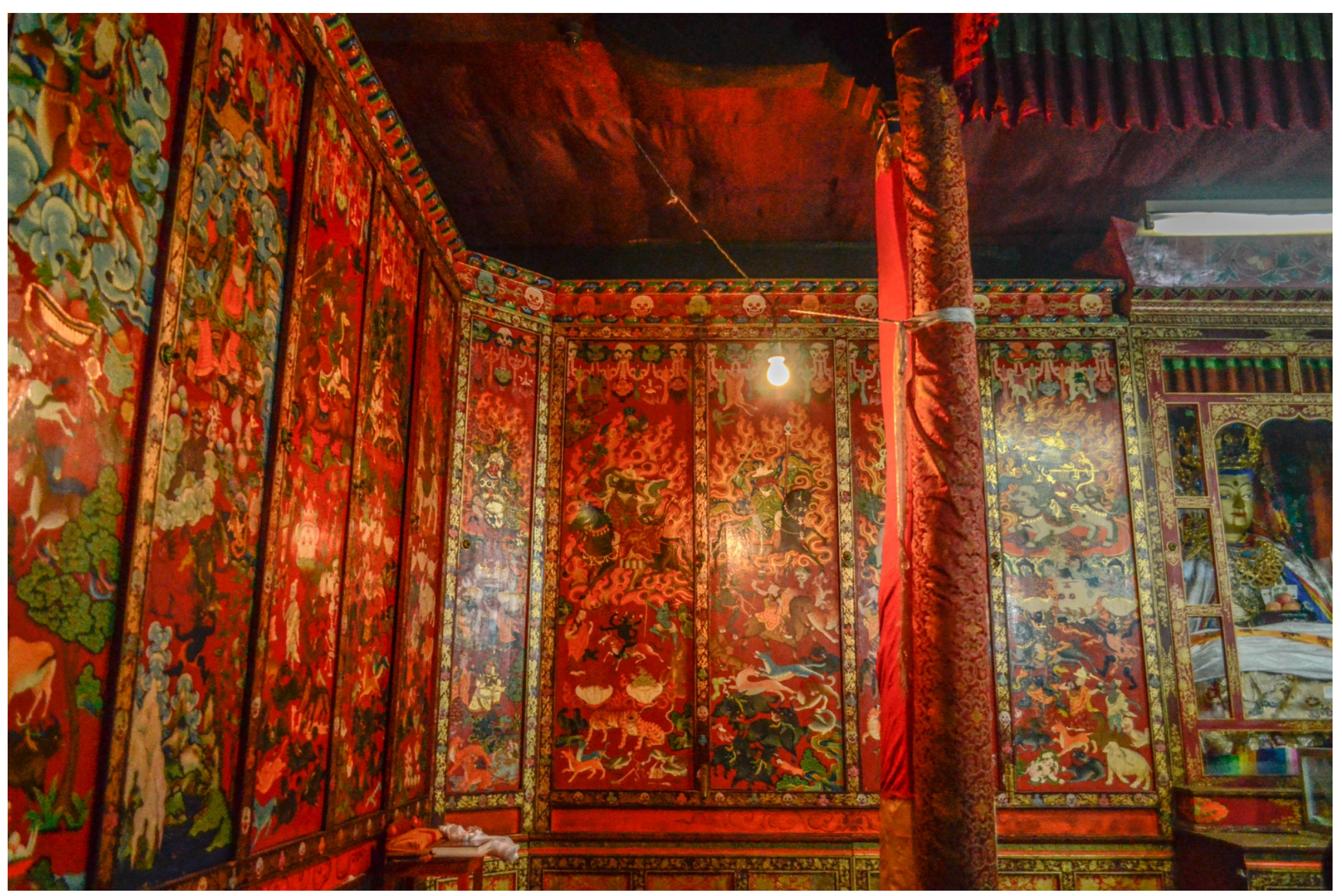

Figure 69: Decorated year-long torma casement; Nechung Monastery Desire Realm Chapel, Lhasa. (Photo: Cecilia Haynes, 2011) 


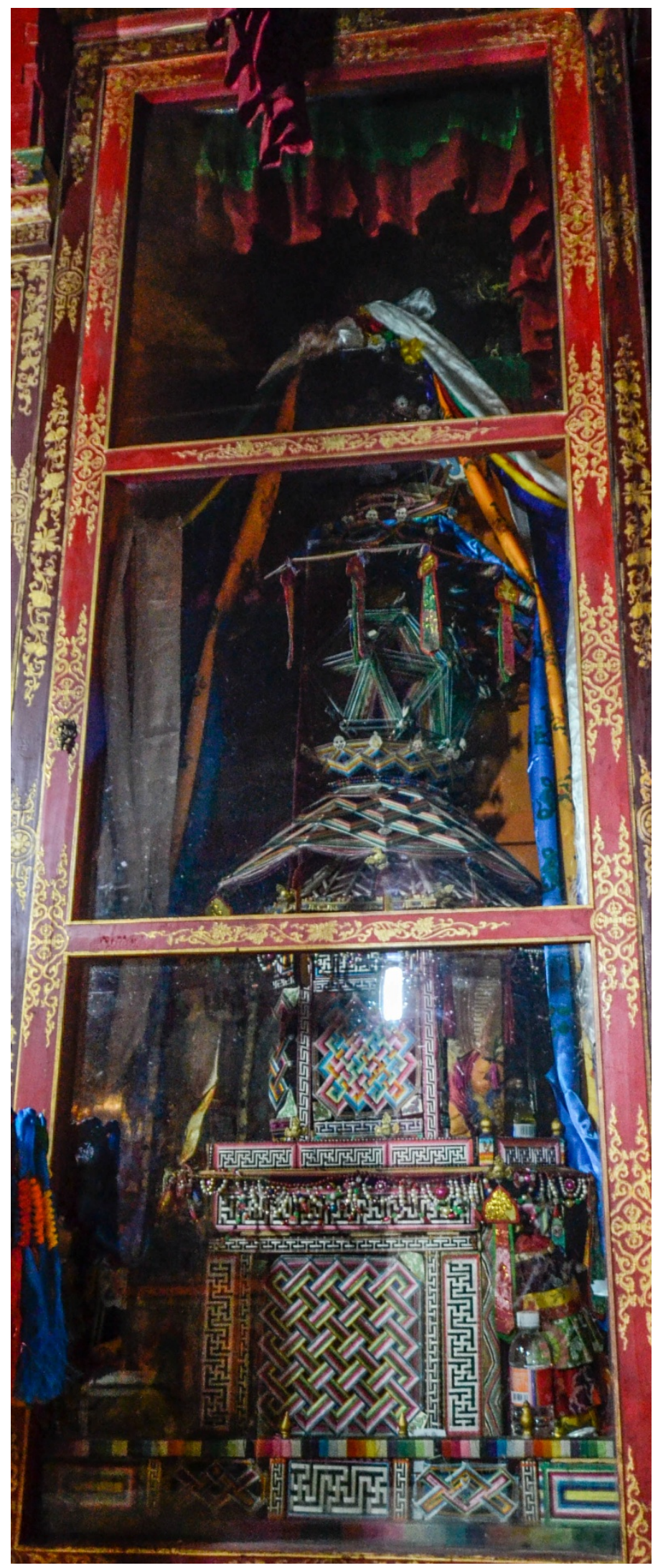

Figure 70: Penden Lhamo thread-cross mansion; Nechung Monastery Desire Realm Chapel, Lhasa. (Photo: Cecilia Haynes, 2011) 


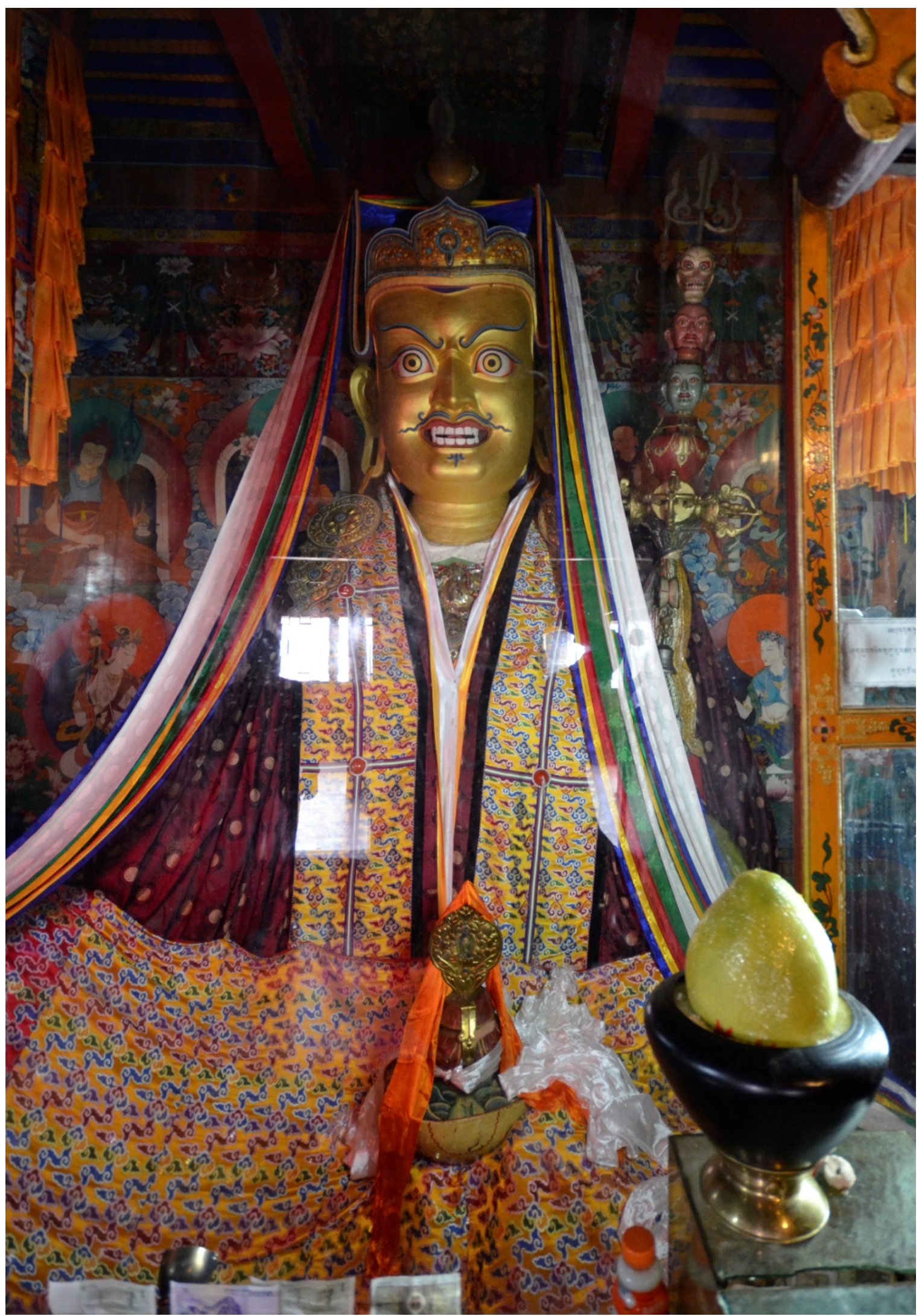

Figure 71: Guru Nangsi Zilnön; Nechung Monastery Guru Nangsi Zilnön Chapel, Lhasa. (Photo: Cecilia Haynes, 2011) 


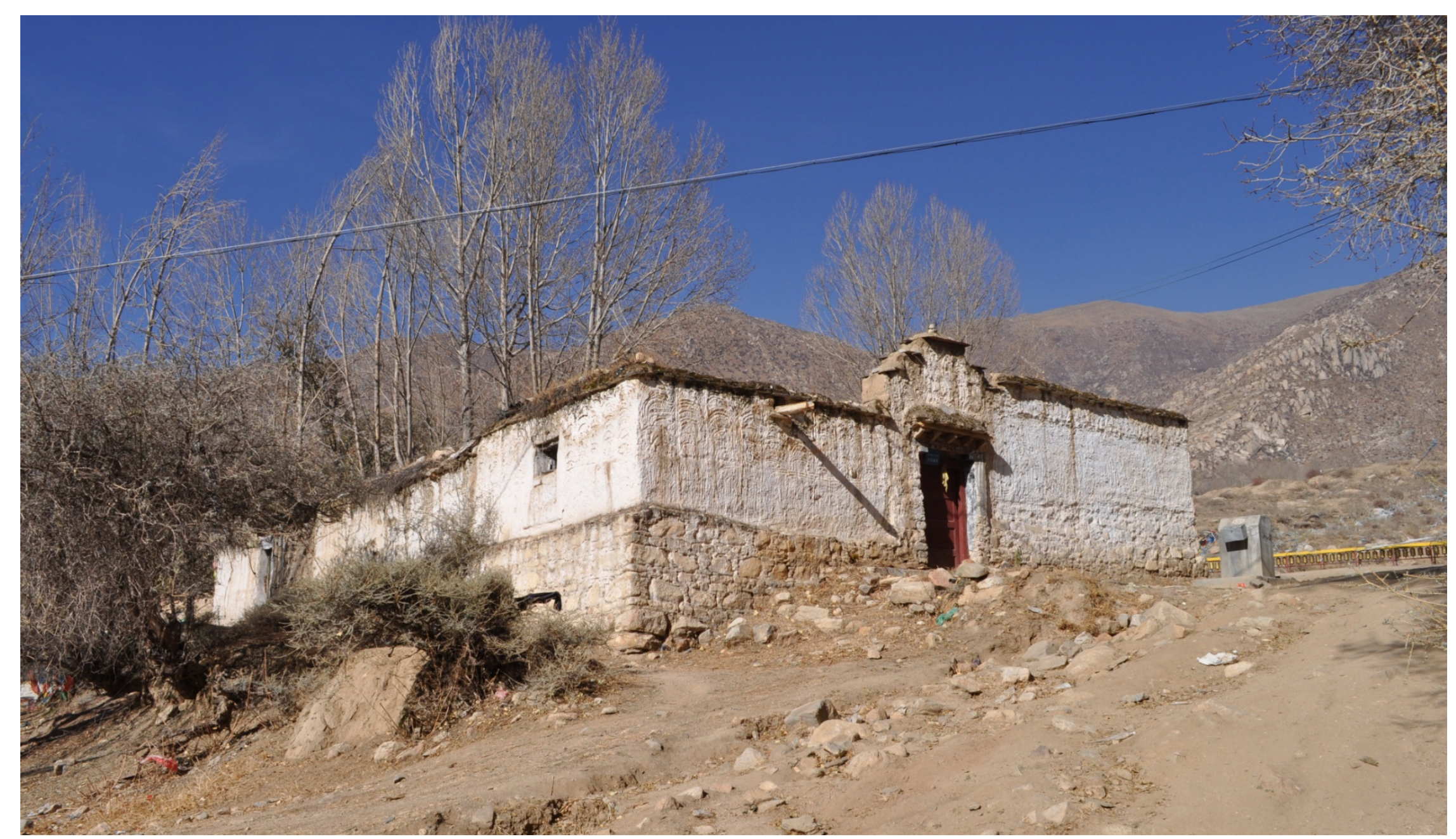

Figure 72: Former site of Pehar's soul lake (Tib. bla mtsho); Nechung Monastery grounds, Lhasa. (Photo: Christopher Bell, 2011) 


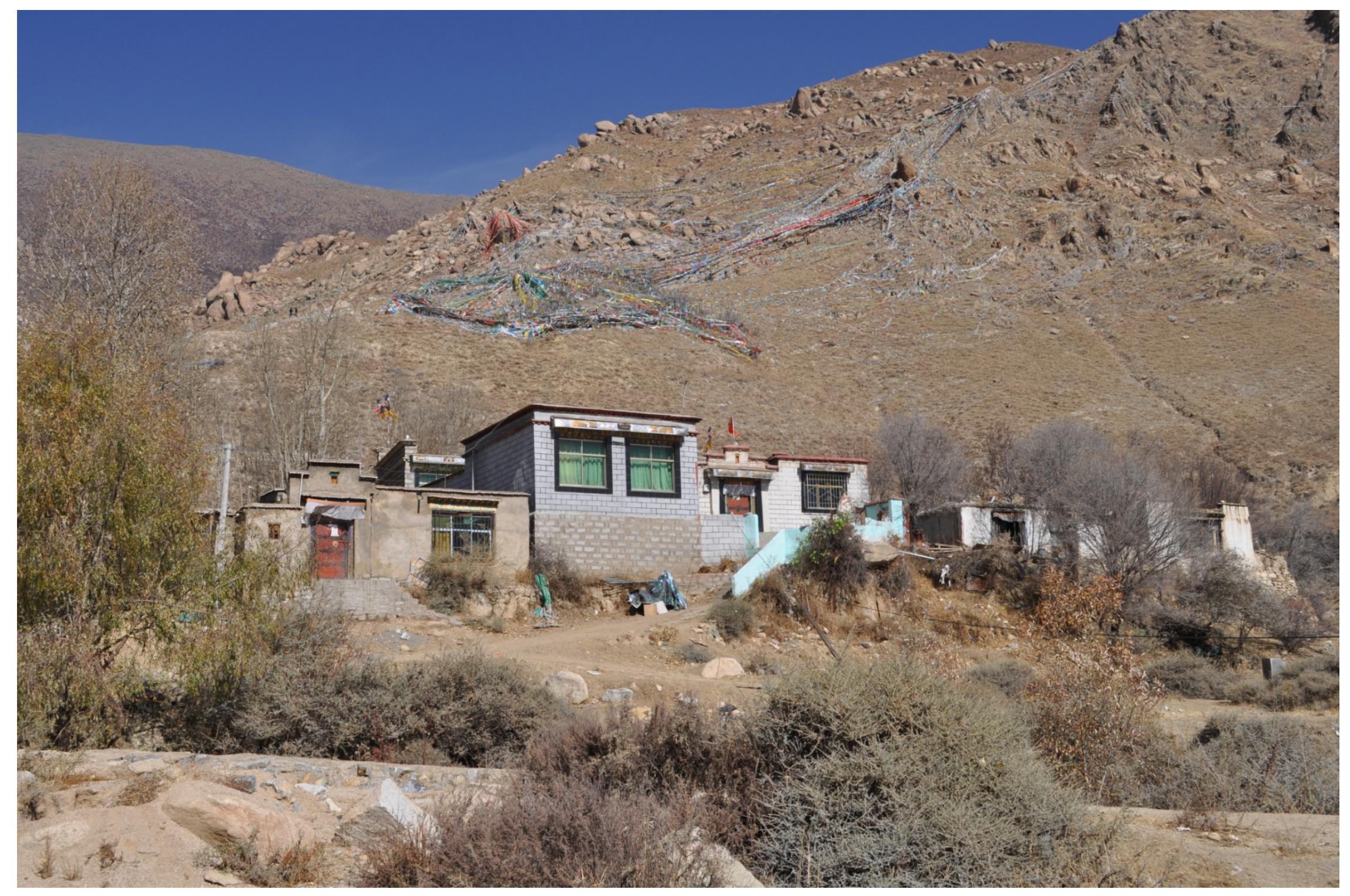

Figure 73: Modern-day site of Yulokö village (Tib. G.yu lo bkod); near Nechung Monastery, Lhasa. (Photo: Christopher Bell, 2011) 


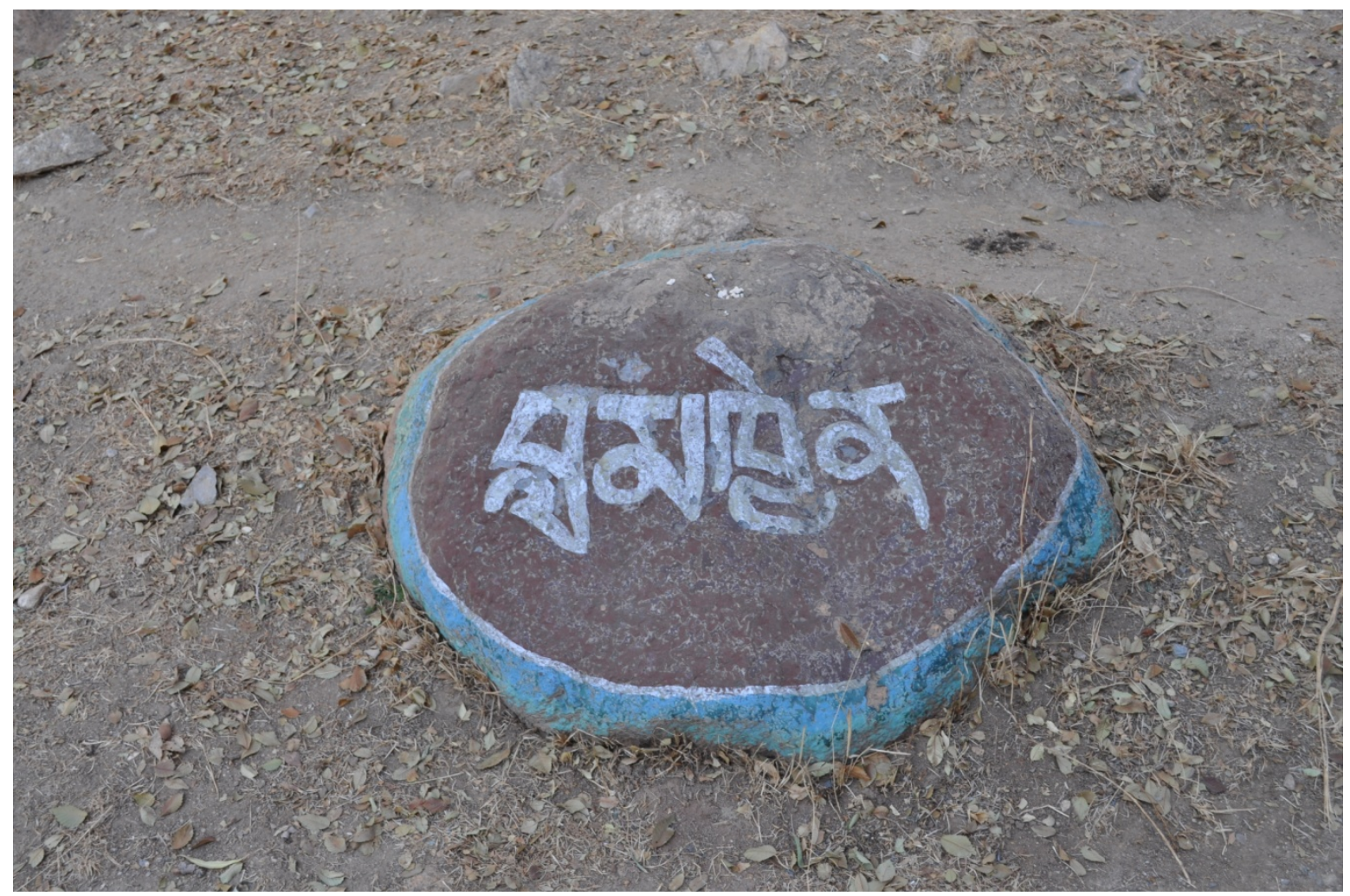

Figure 74a: The stone on which Pehar's box was placed. The miraculous Tibetan inscription, "Master, think of me!" (Tib. bla ma mkhyen), is embossed with paint; Nechung Monastery grounds, Lhasa. (Photo: Christopher Bell, 2011)

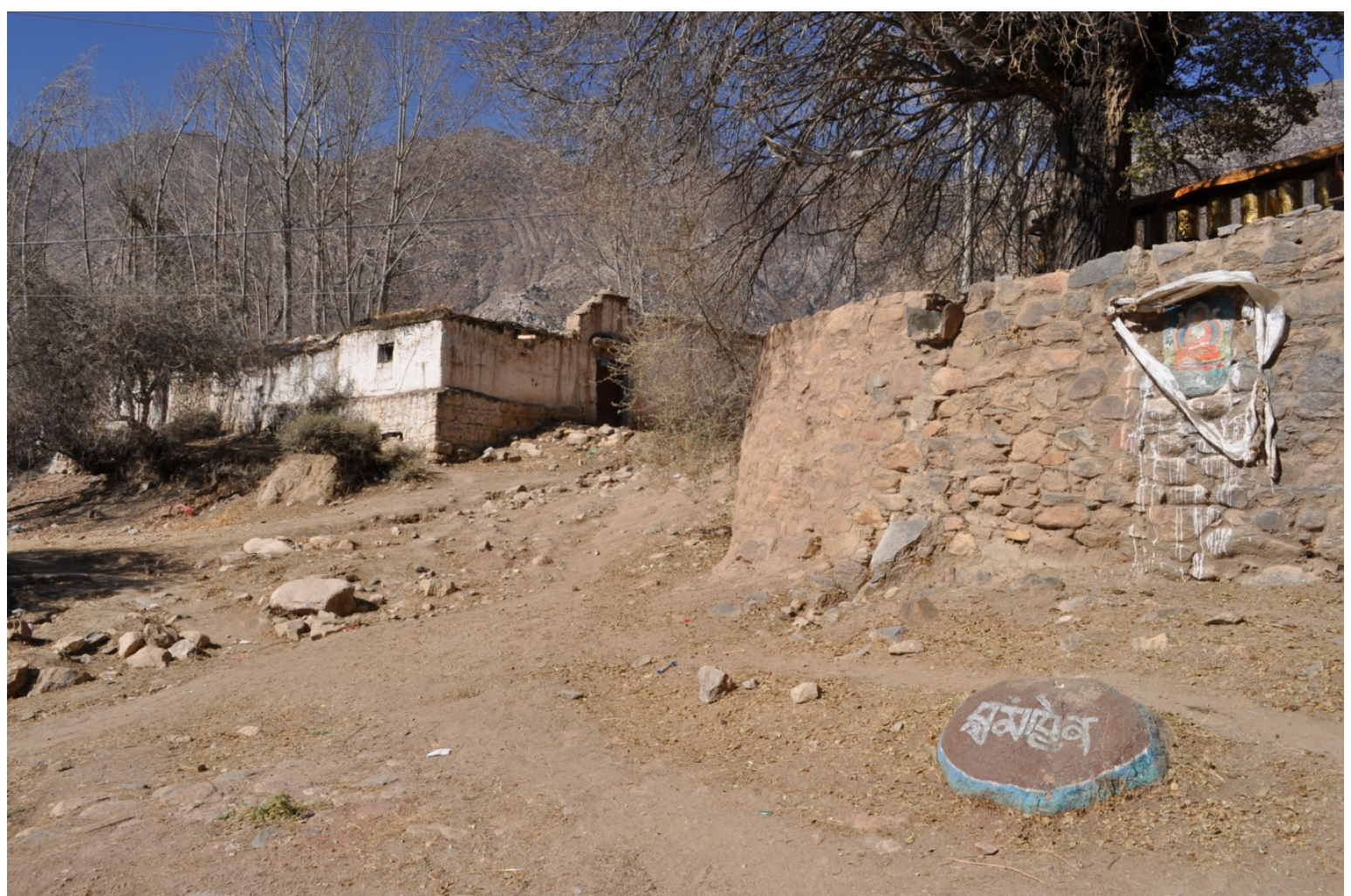

Figure 74b: The miraculous stone (bottom-right) in relation to Pehar's enclosed soul lake (upper-left); Nechung Monastery grounds, Lhasa. (Photo: Christopher Bell, 2011) 


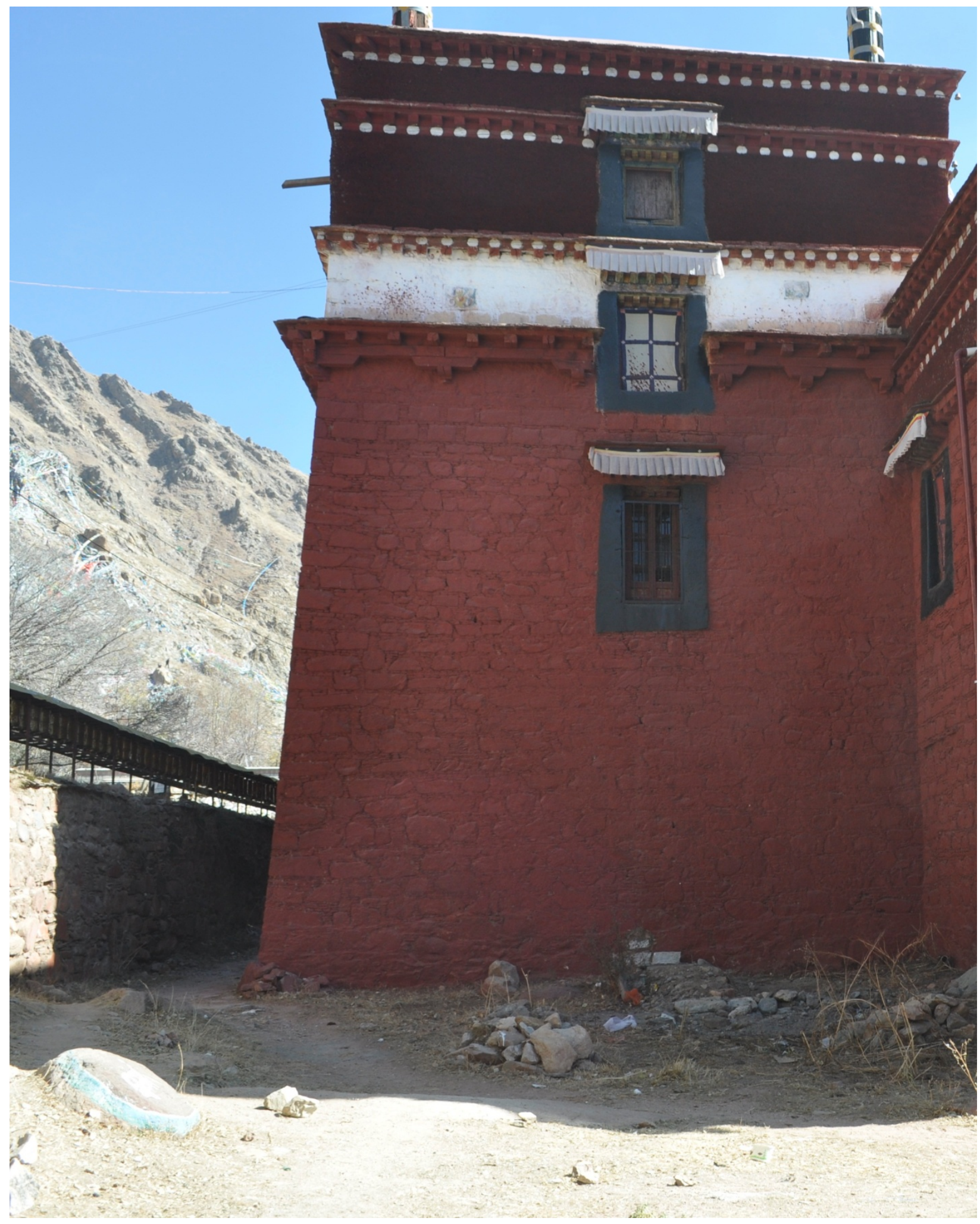

Figure 74c: The miraculous stone (bottom-left) near the outer wall of the monastery's northwest corner, containing the birch tree on which Pehar landed; Nechung Monastery grounds, Lhasa. (Photo: Christopher Bell, 2011) 


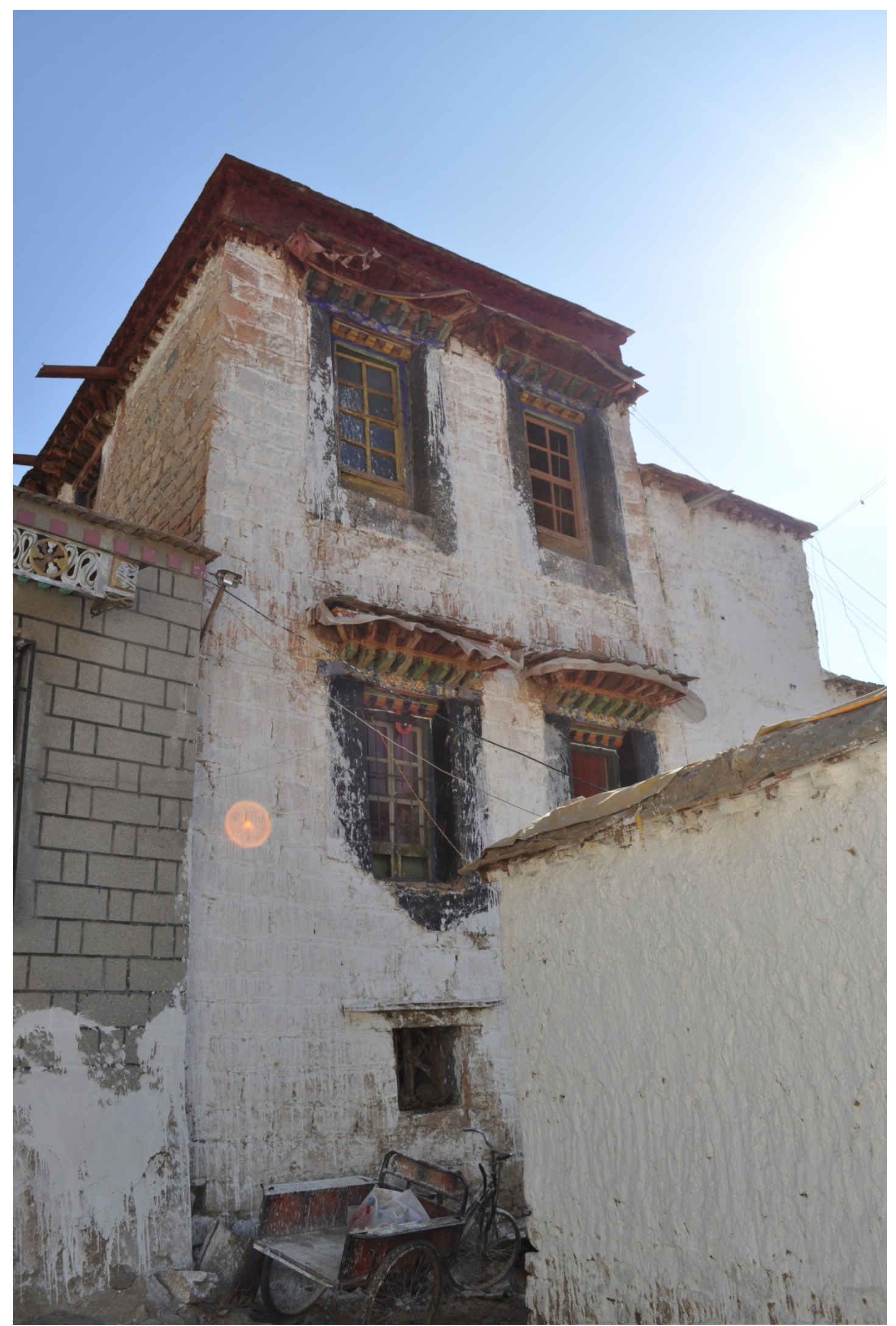

Figure 75: The estate (Tib. bla brang) of Nechung Rinpoche; Nechung Monastery grounds, Lhasa. (Photo: Christopher Bell, 2011) 


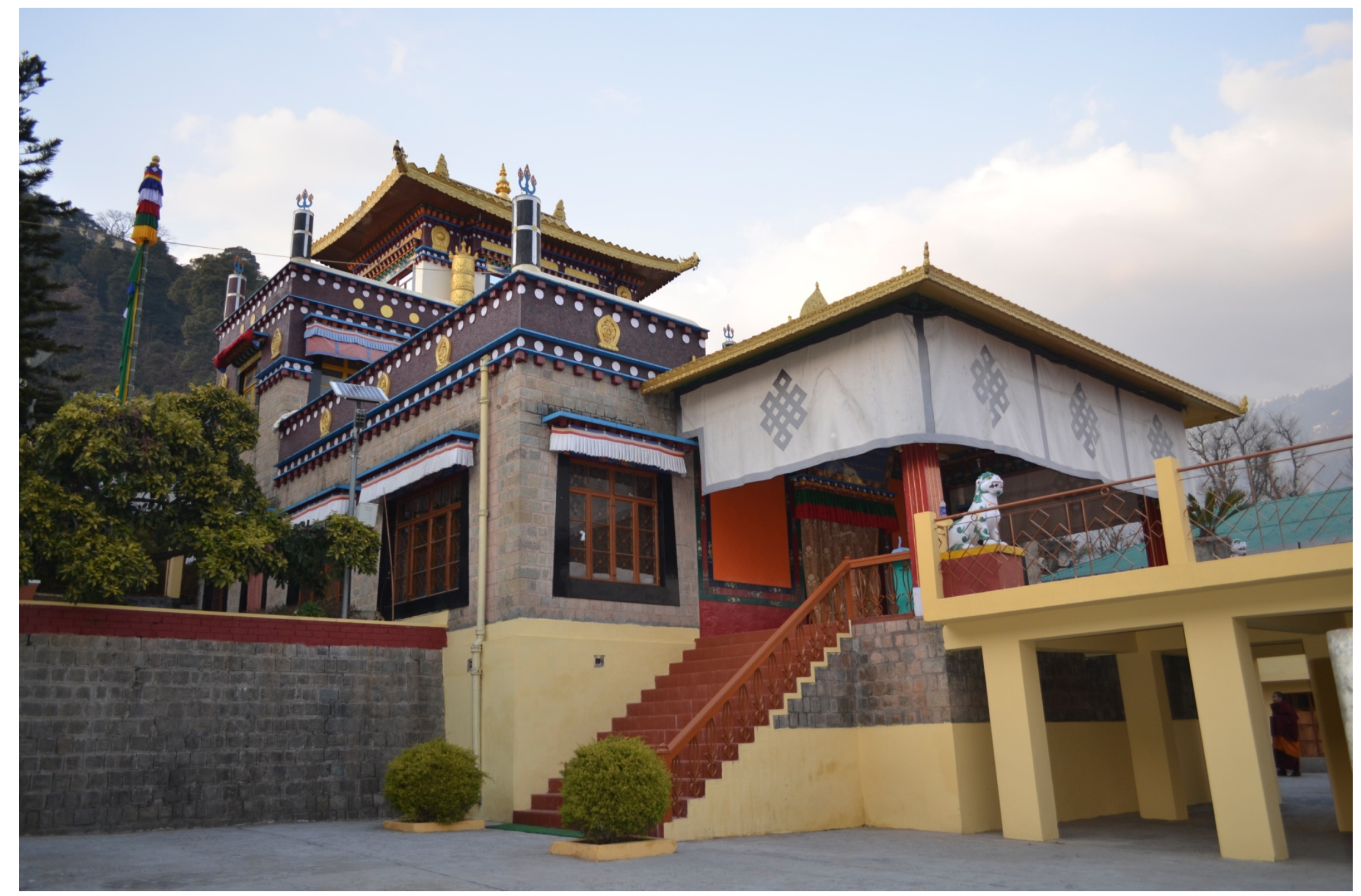

Figure 76: Nechung Monastery, Gangchen Kyishong, Dharamsala. (Photo: Cecilia Haynes, 2012) 


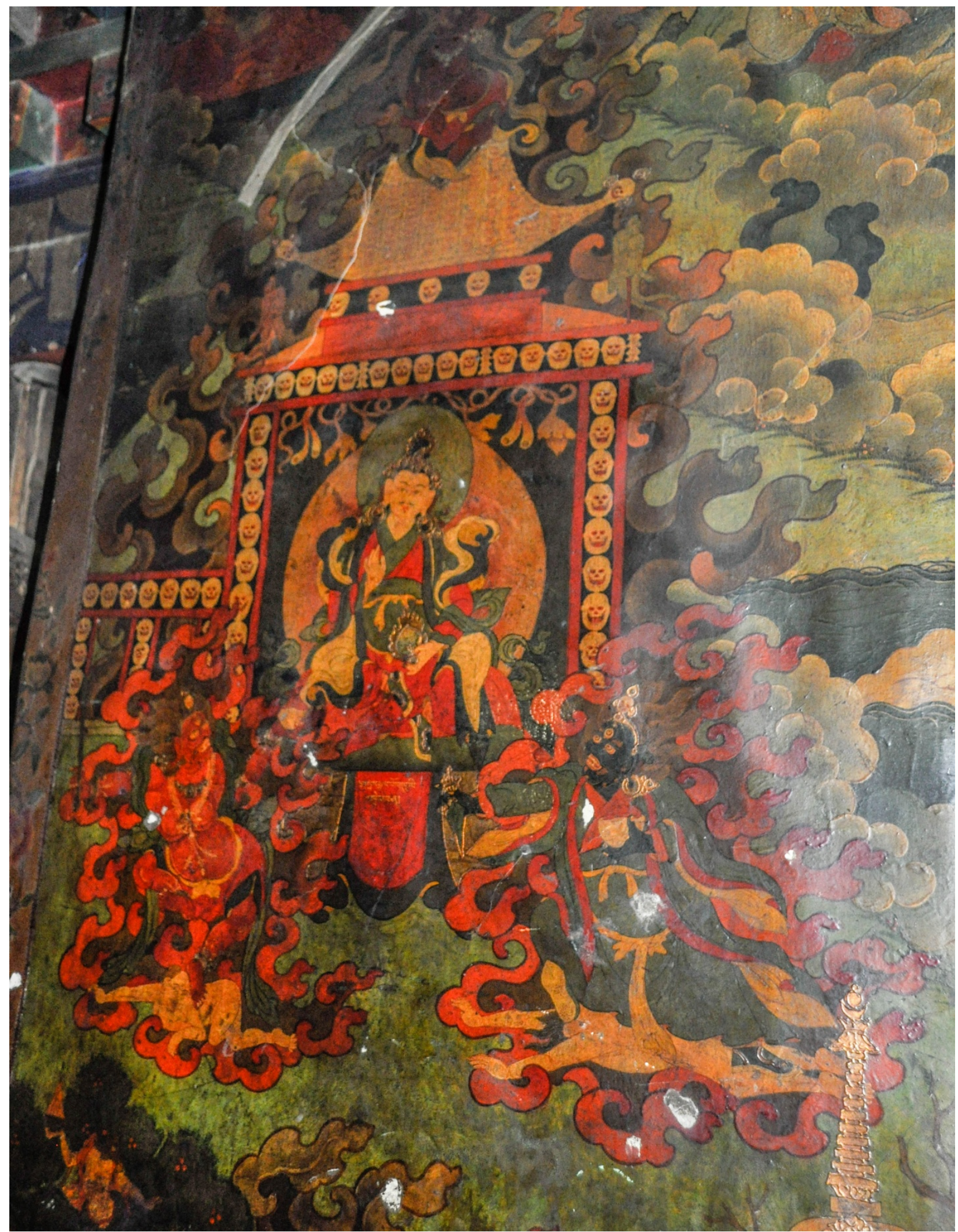

Figure 77: Padmasambhava with the red and black protectors (Tib. srung ma dmar nag); Meru Sarpa Tsangpa Chapel. (Photo: Christopher Bell, 2011) 


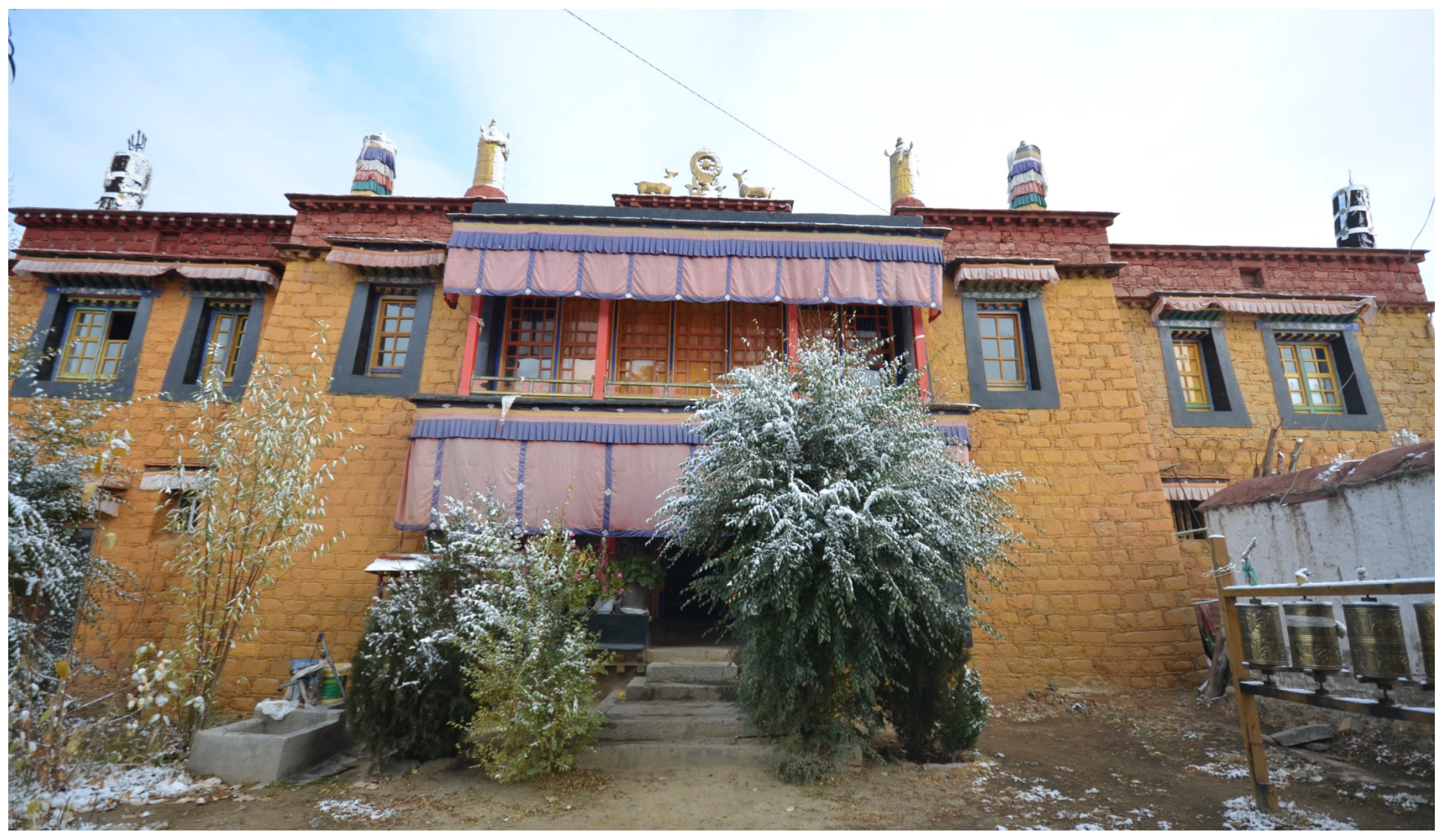

Figure 78: Tsel Yangön Monastery (Tib. Tshal Yang dgon dgon pa), southeast of Lhasa. (Photo: Cecilia Haynes, 2011) 


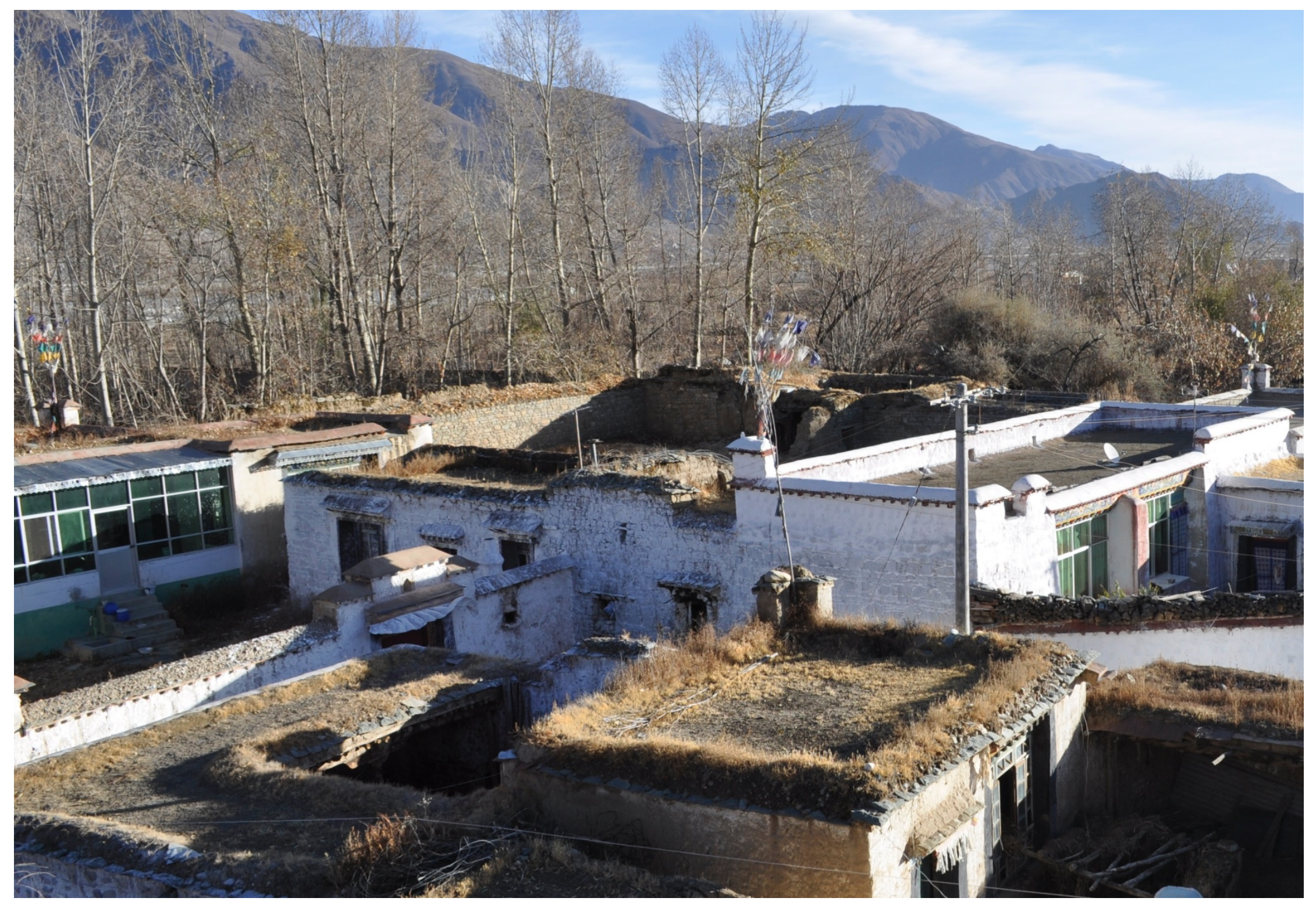

Figure 79: Site of Yangön's Pehar Chapel (Tib. Pe har lcog), now in ruins, surrounded by lay housing; Tsel Yangön Monastery. (Photo: Christopher Bell, 2011) 


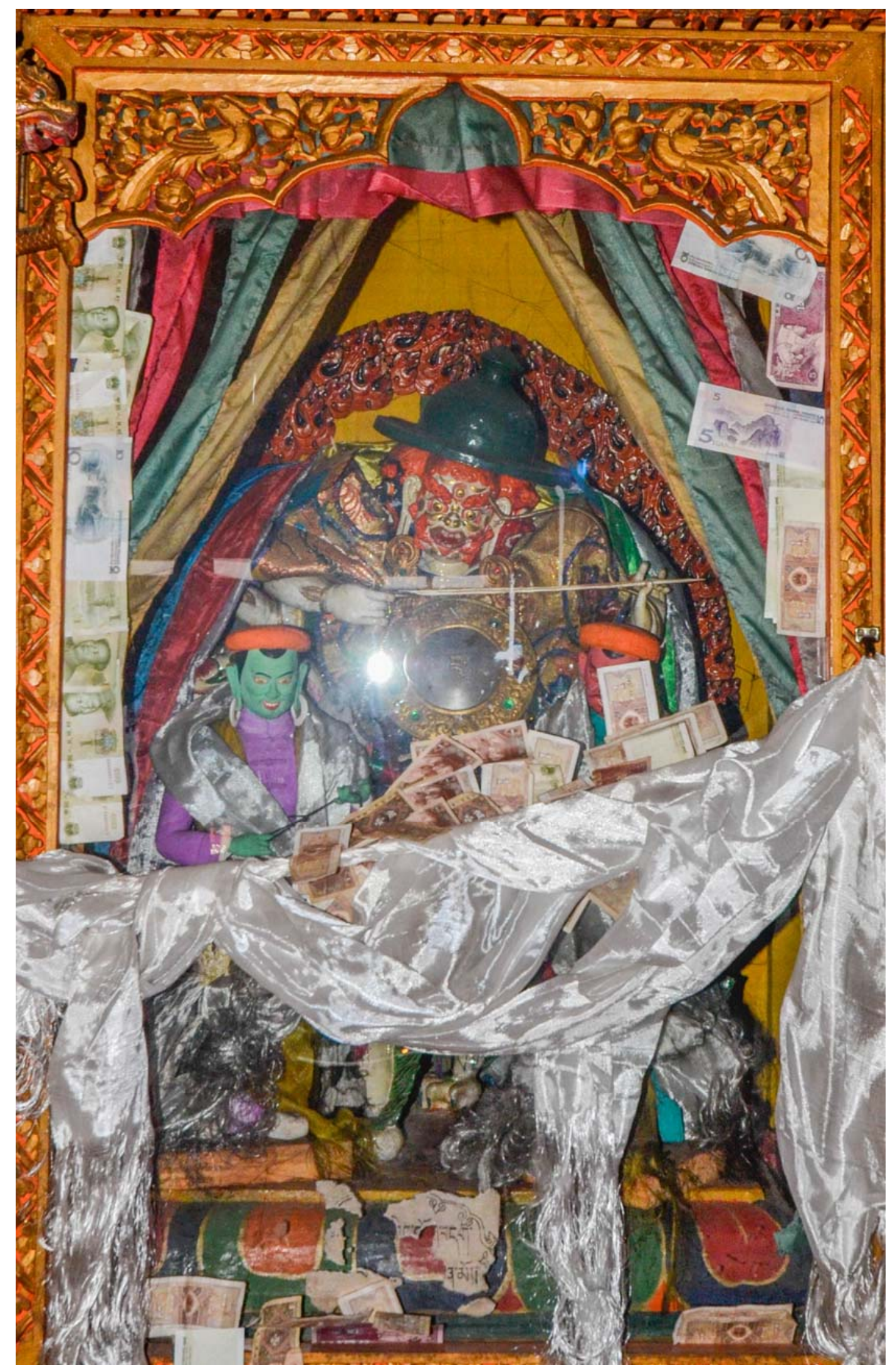

Figure 80: Statue of Pehar; Tsel Yangön Monastery Inner Sanctum. (Photo: Cecilia Haynes, 2011) 


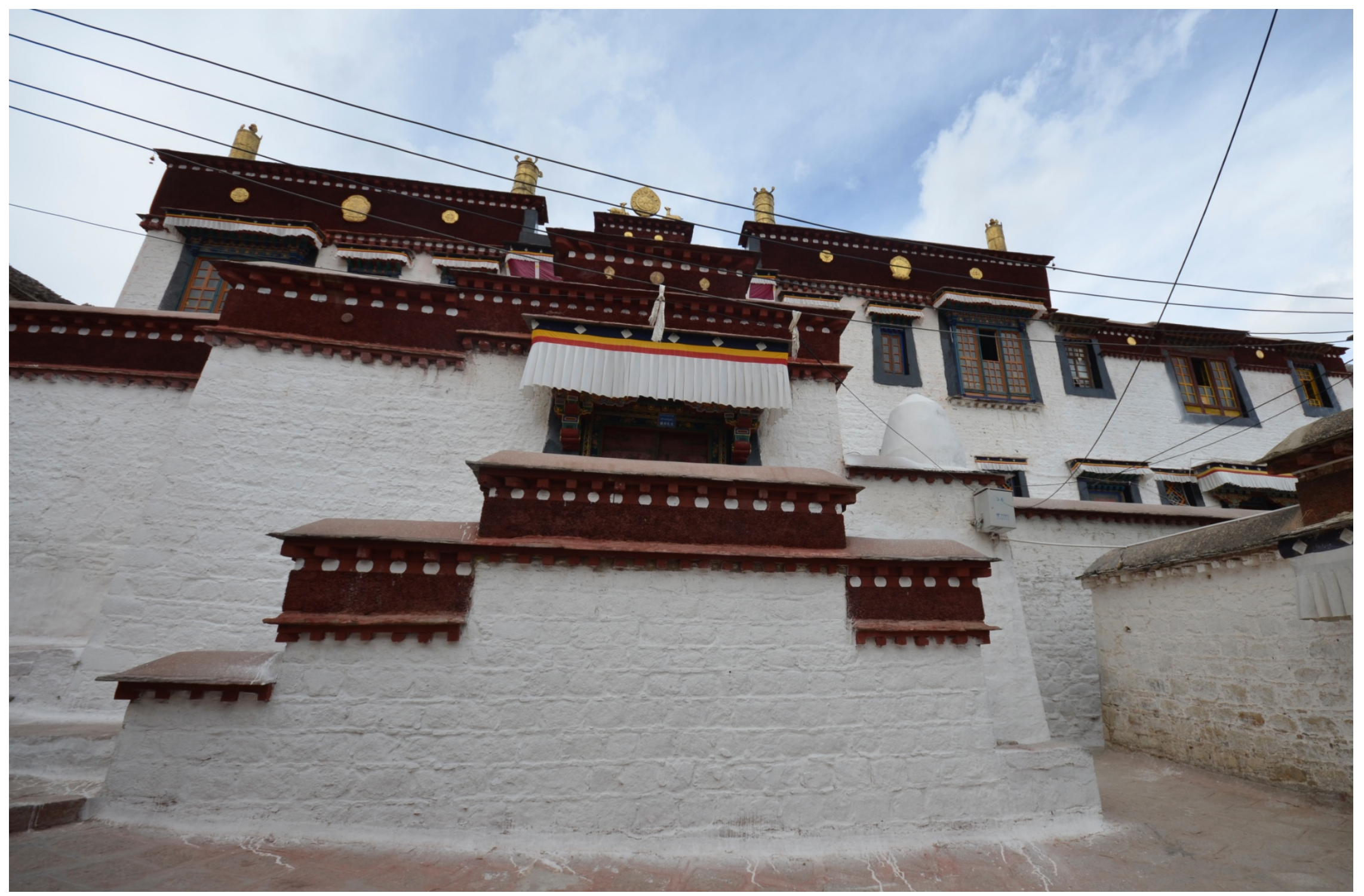

Figure 81: Deyang College (Tib. Bde yangs grwa tshang), Drepung Monastery. (Photo: Cecilia Haynes, 2011) 


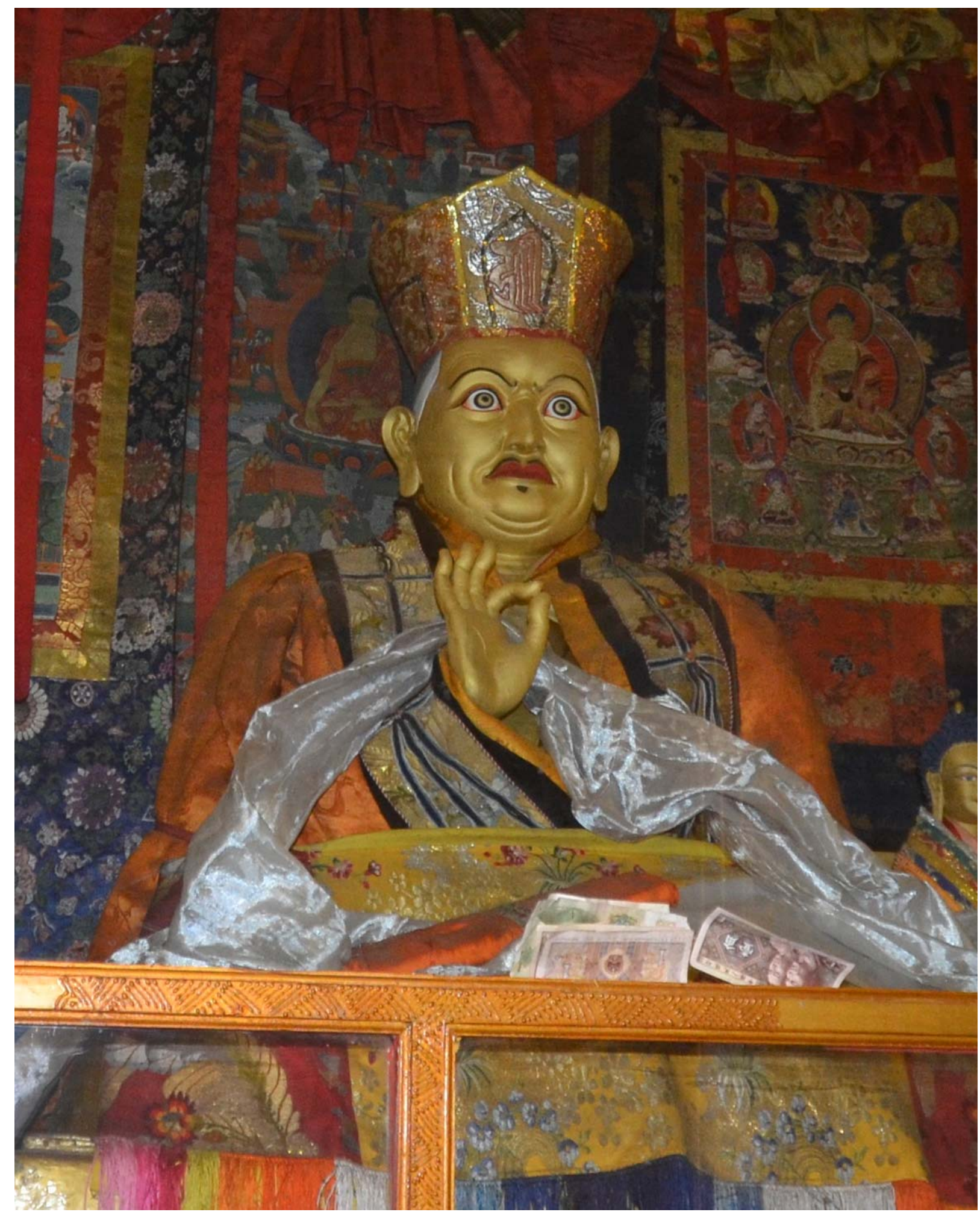

Figure 82: Statue of Jokpa Jangchup Penden (1464-1531); Deyang College Assembly Hall, Drepung Monastery. (Photo: Cecilia Haynes, 2011) 


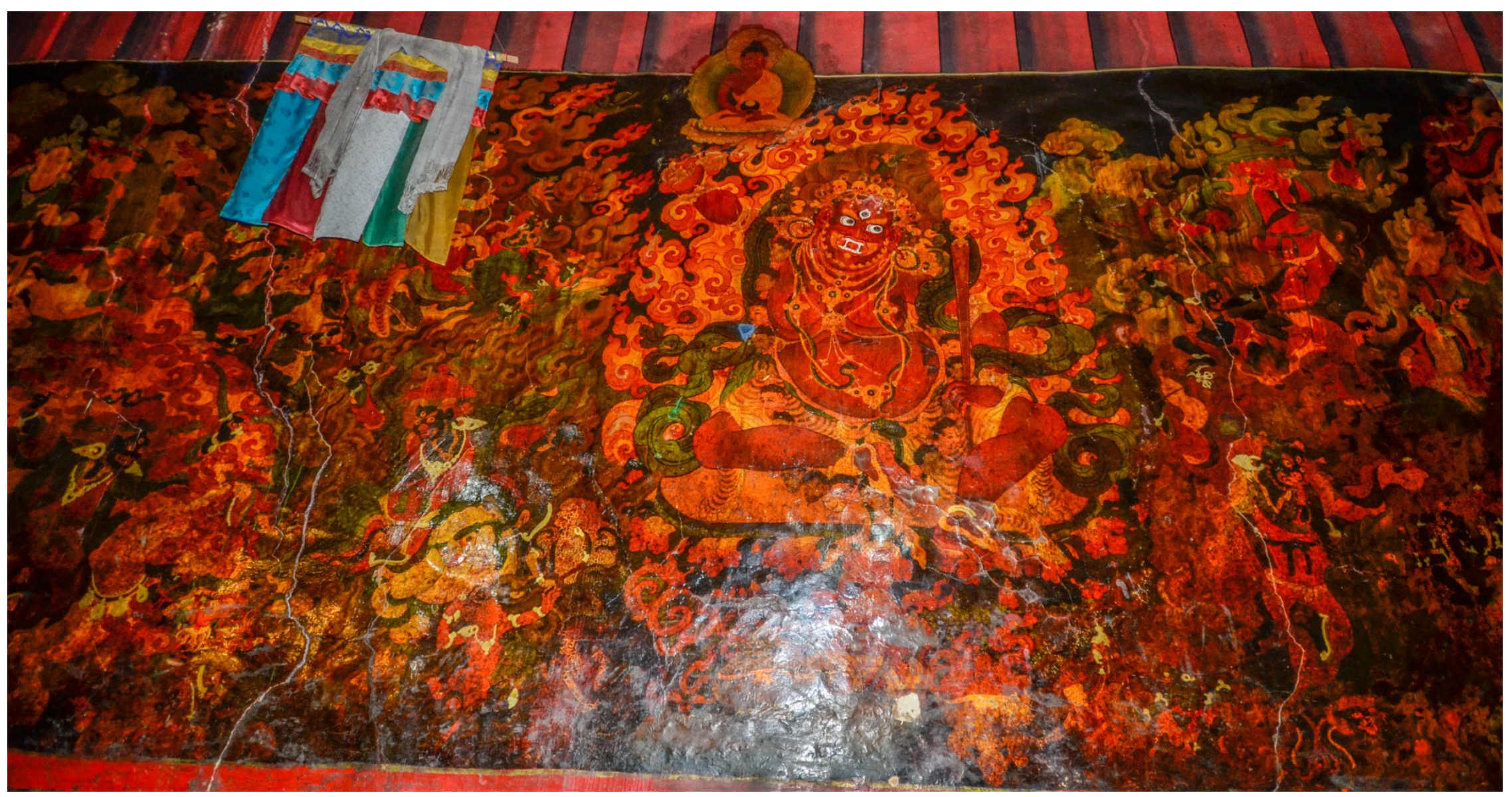

Figure 83: Murals of the Five Sovereign Spirits surrounding Hayagrīva. From left to right: [1] Pehar (top left, face covered), [2] Gyajin, [3] Mönbuputra, [4] Hayagrīva (large cental image), [5] Kyechik Marpo (top right), and [6] Shingjachen; Deyang College Assembly Hall, Drepung Monastery. (Photo: Cecilia Haynes, 2011) 


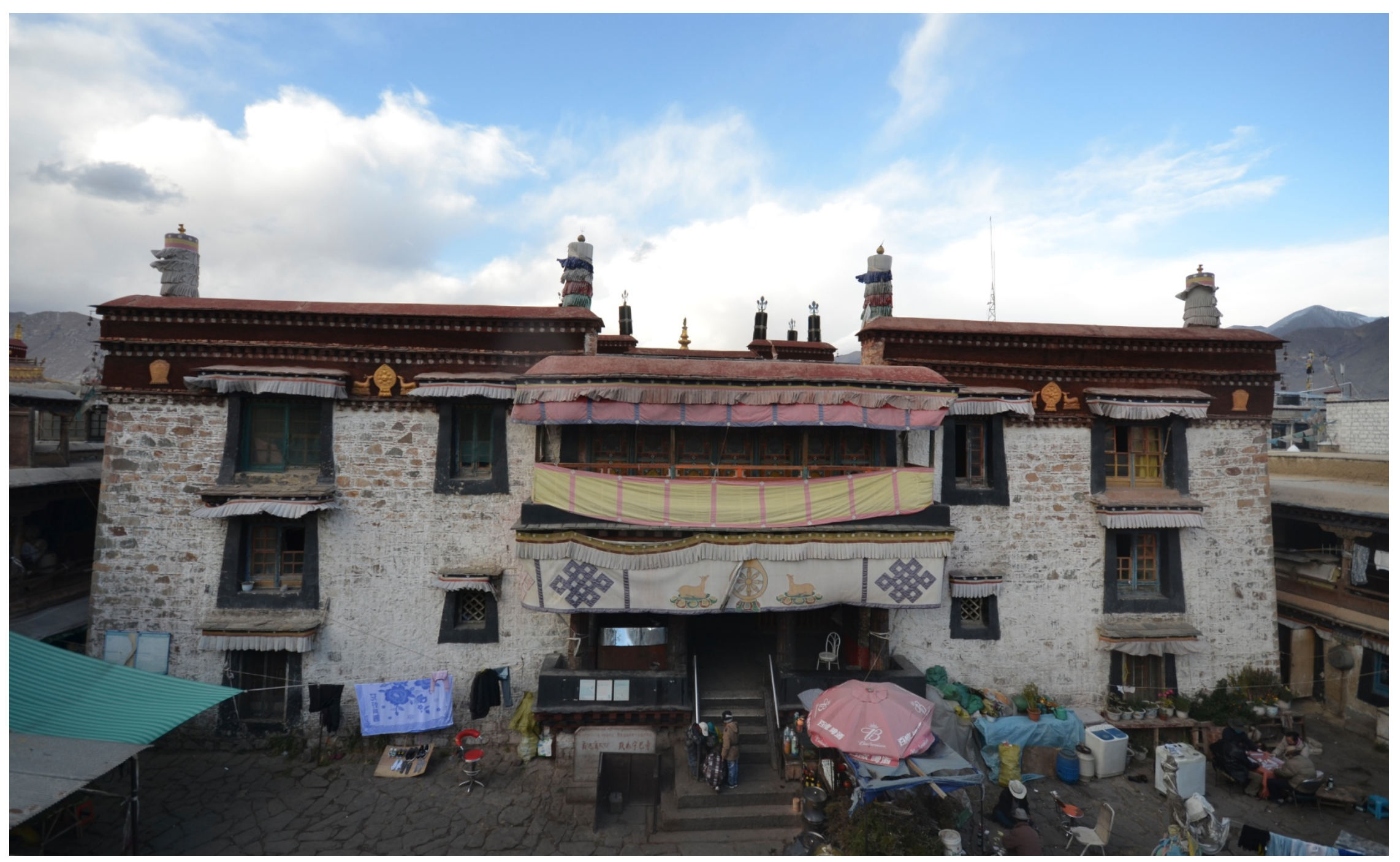

Figure 84: Meru Nyingpa Monastery (Tib. Rme ru snying pa). (Photo: Cecilia Haynes, 2011) 


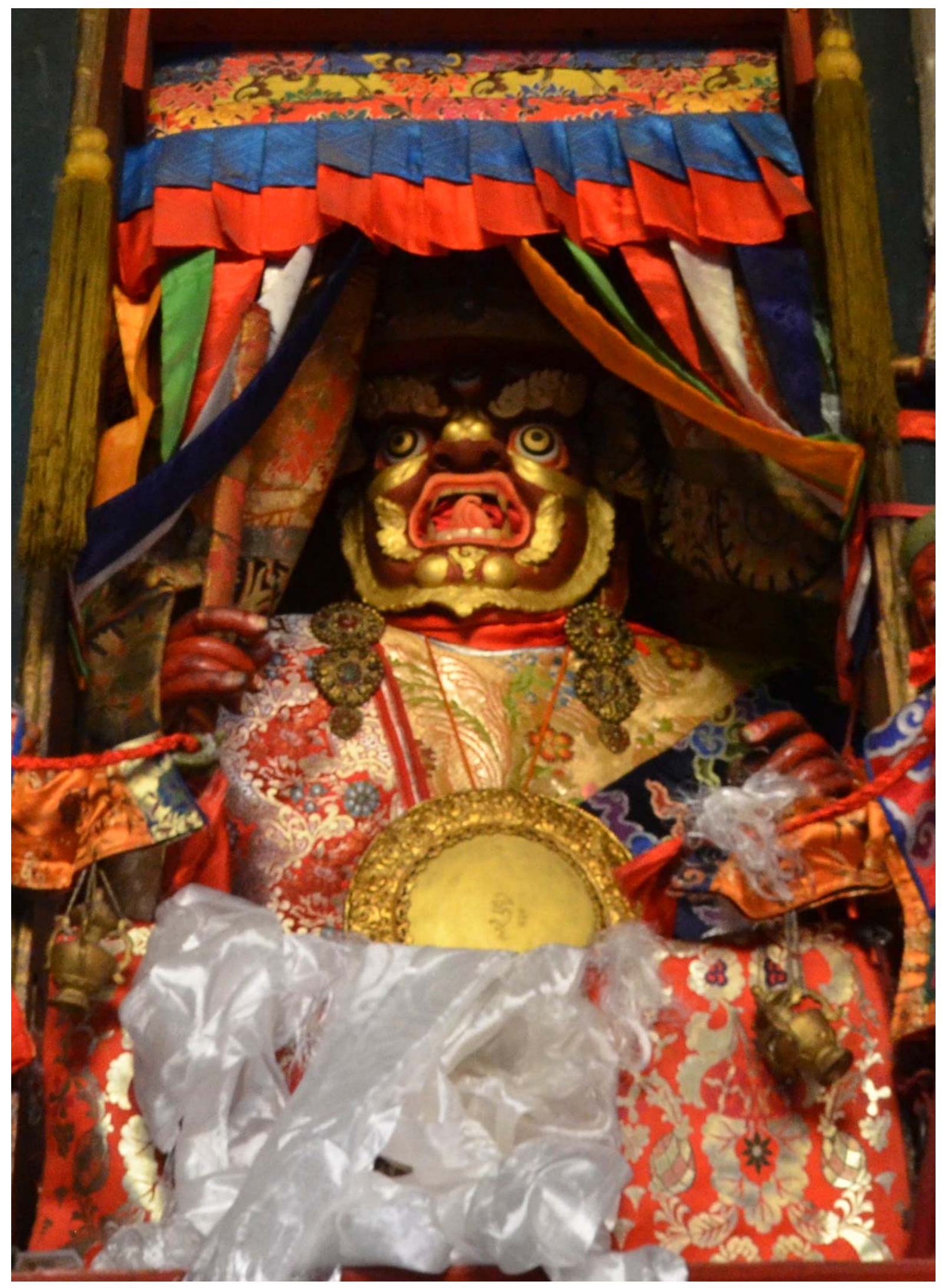

Figure 85: Statue of Dorjé Drakden; Meru Nyingpa Monastery. (Photo: Cecilia Haynes, 2011) 


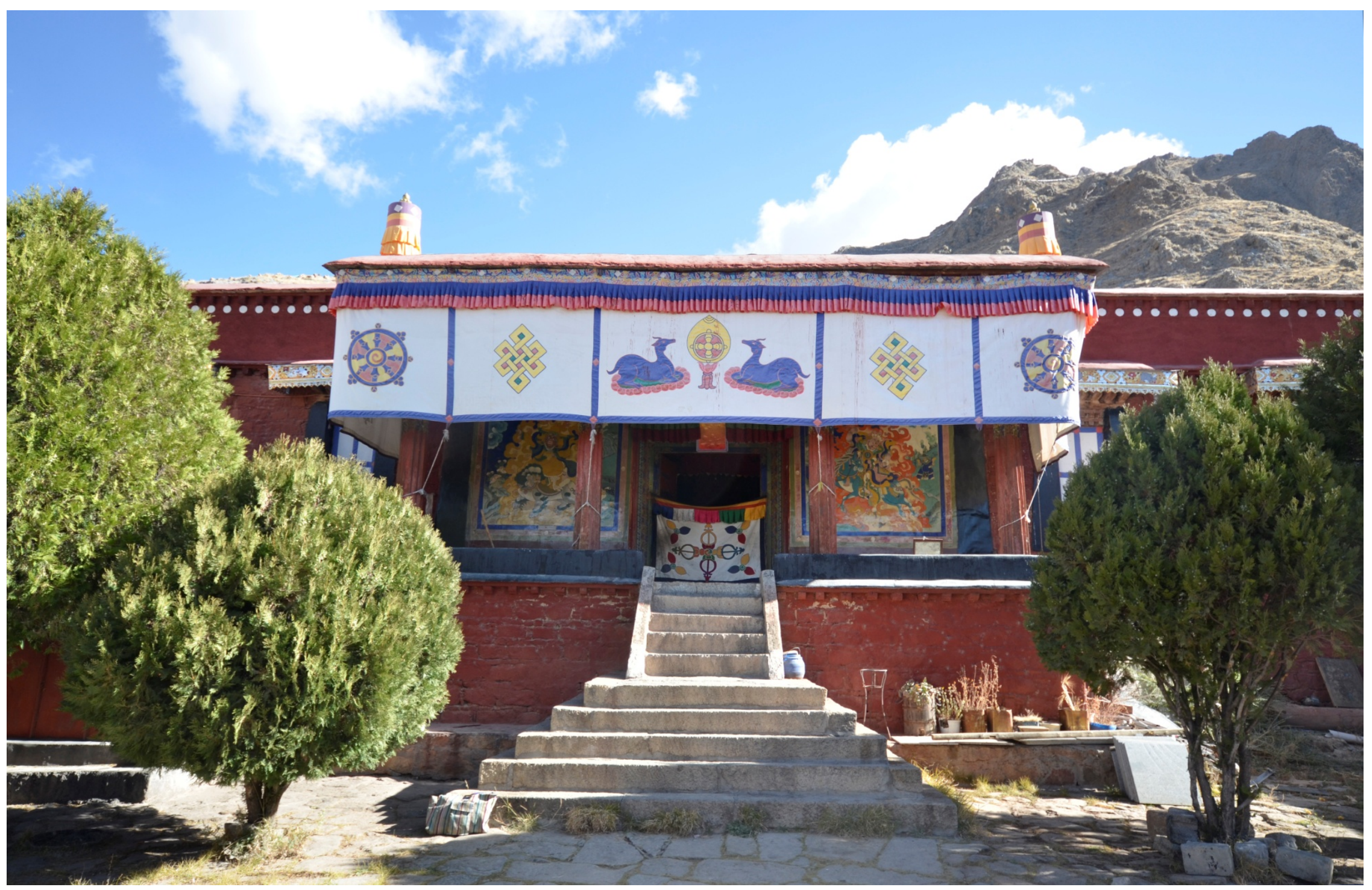

Figure 86: Gadong Monastery (Tib. Dga' gdong dgon pa). (Photo: Cecilia Haynes, 2011) 


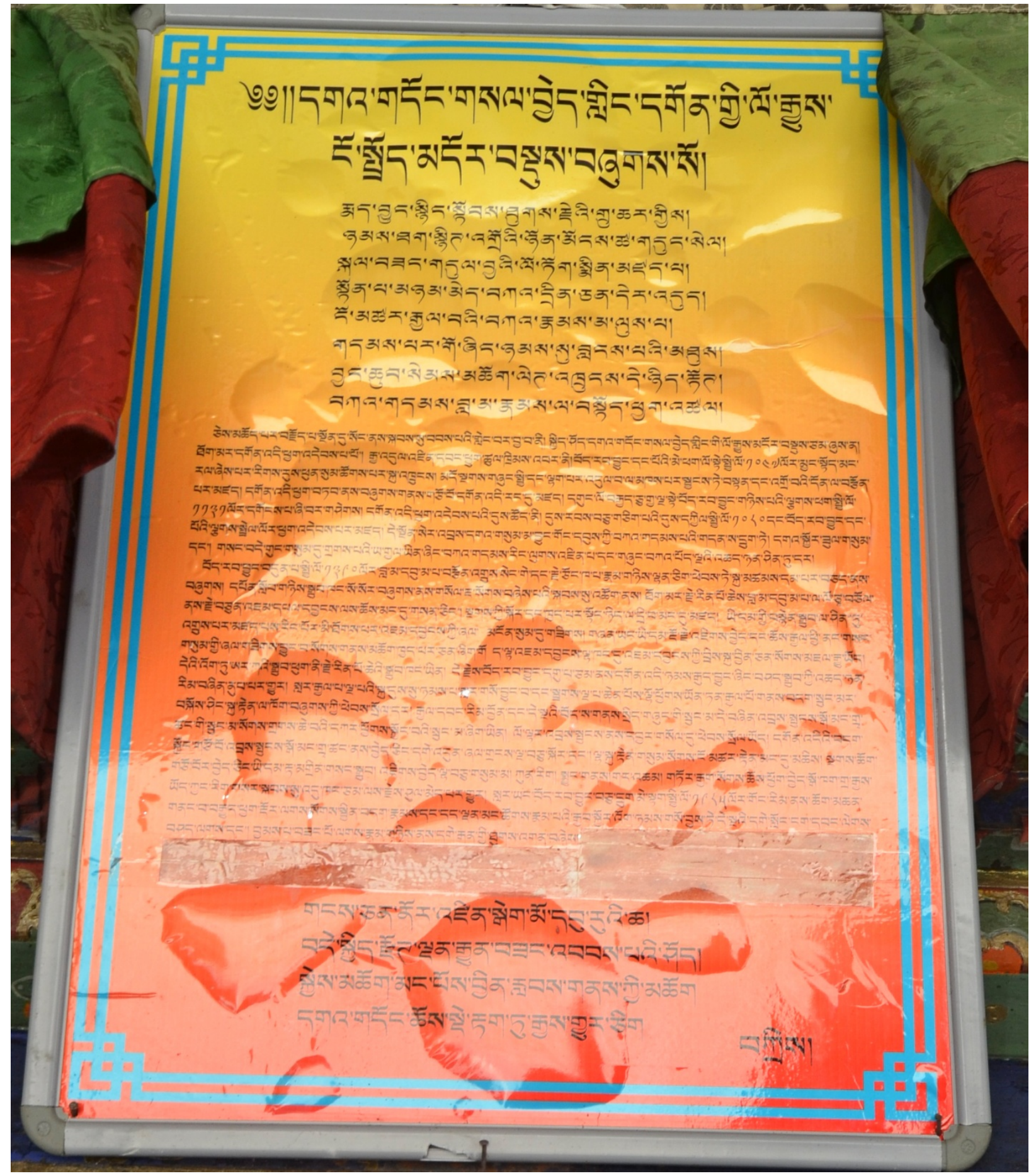

Figure 87: A brief history of Gadong hanging over the monastery's entrance; Gadong Monastery. (Photo: Cecilia Haynes, 2011) 


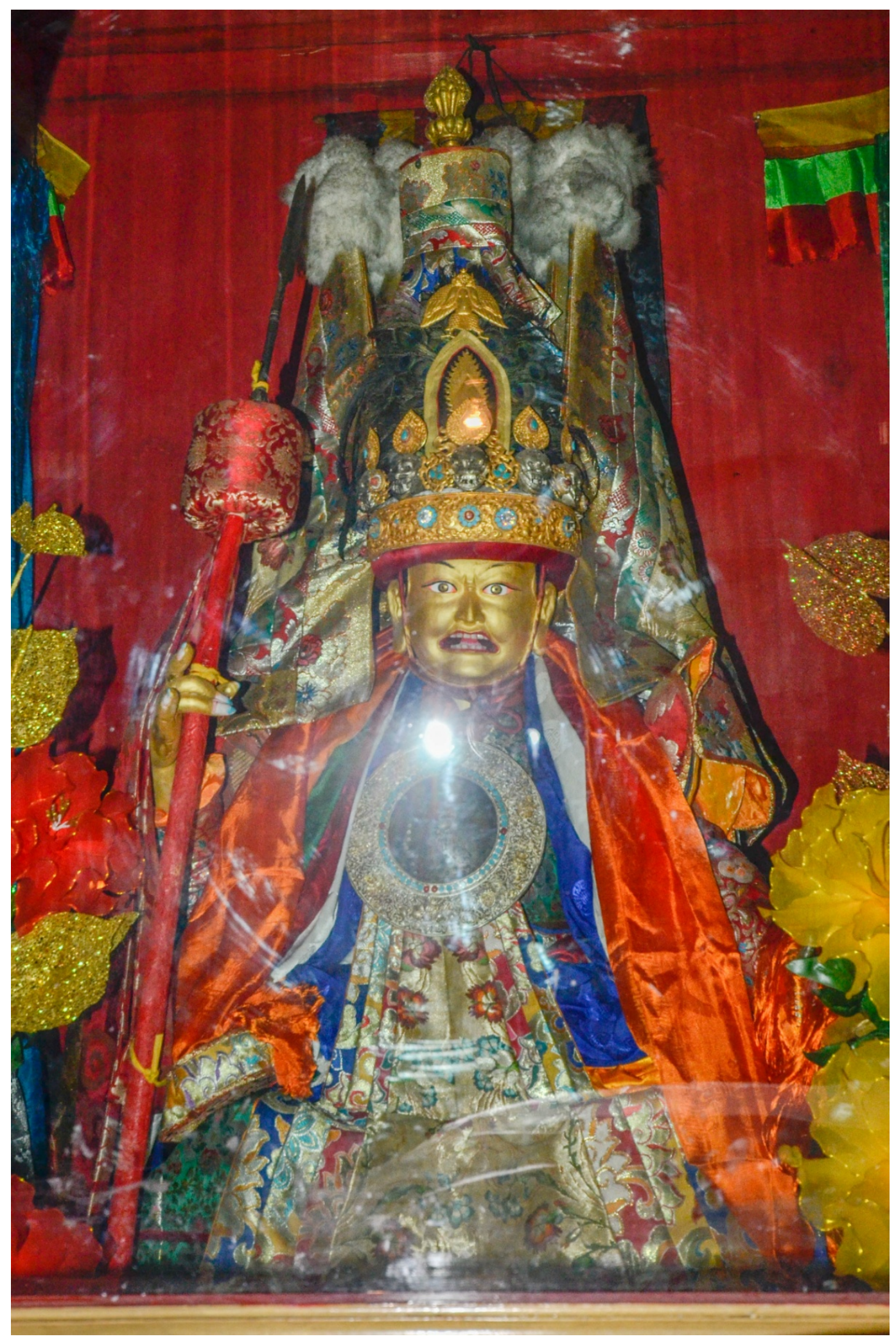

Figure 88: Life-size statue of the Gadong Oracle; Gadong Monastery Central Chapel. (Photo: Cecilia Haynes, 2011) 


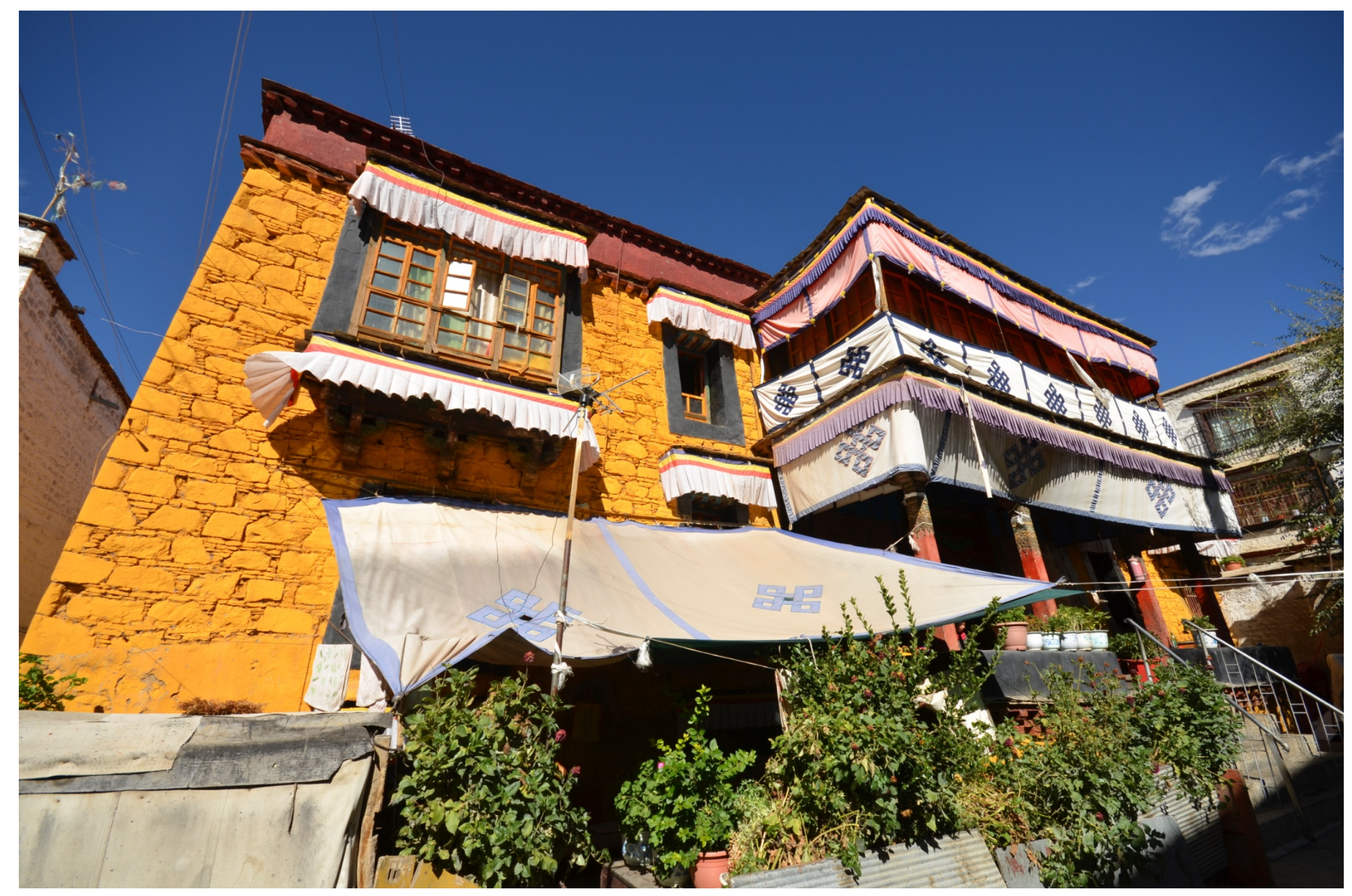

Figure 89: Karmasha Chapel (Tib. Karma shag btsan khang). (Photo: Cecilia Haynes, 2011) 


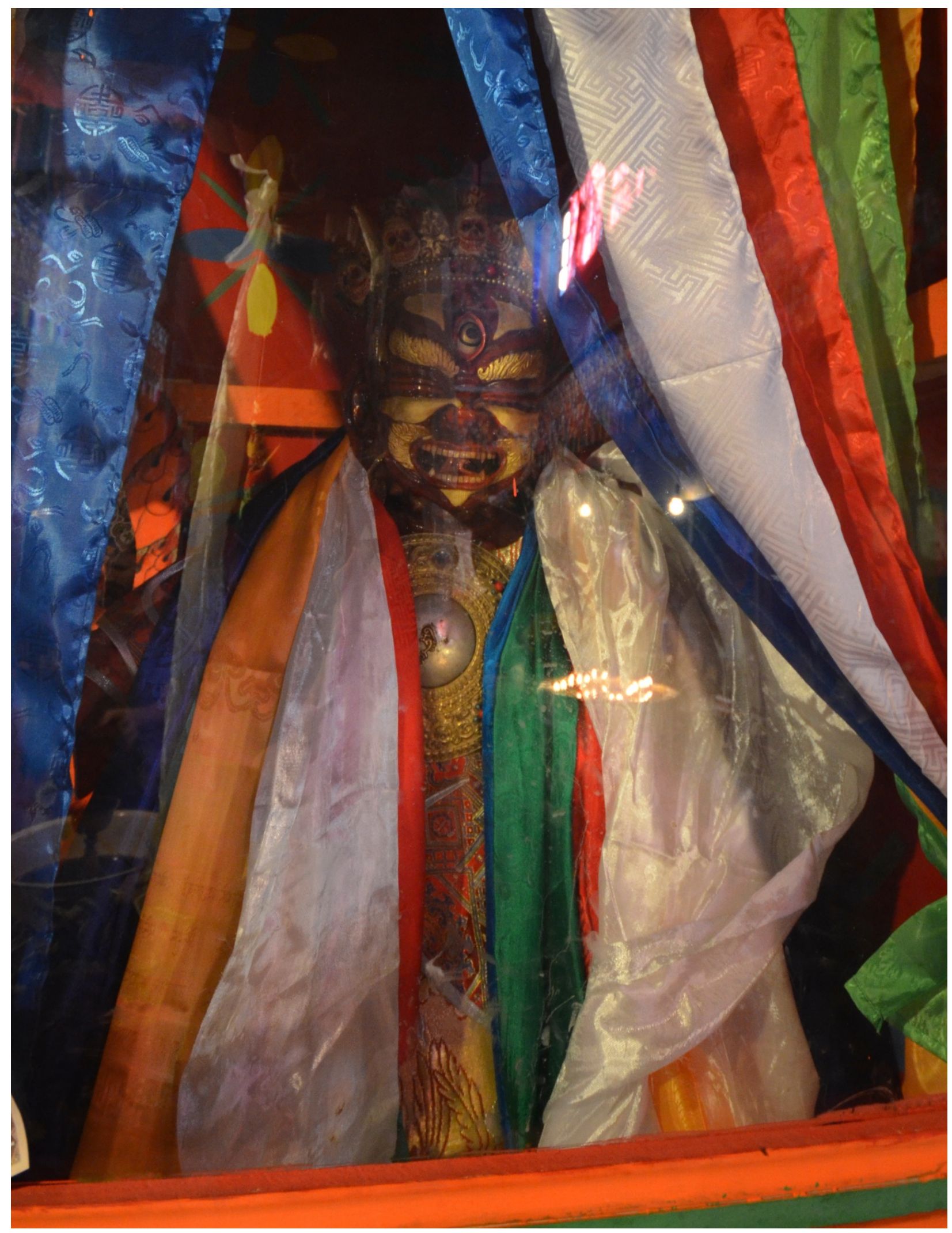

Figure 90: Statue of Jatri Mikchikpu; Karmasha Chapel. (Photo: Cecilia Haynes, 2011) 


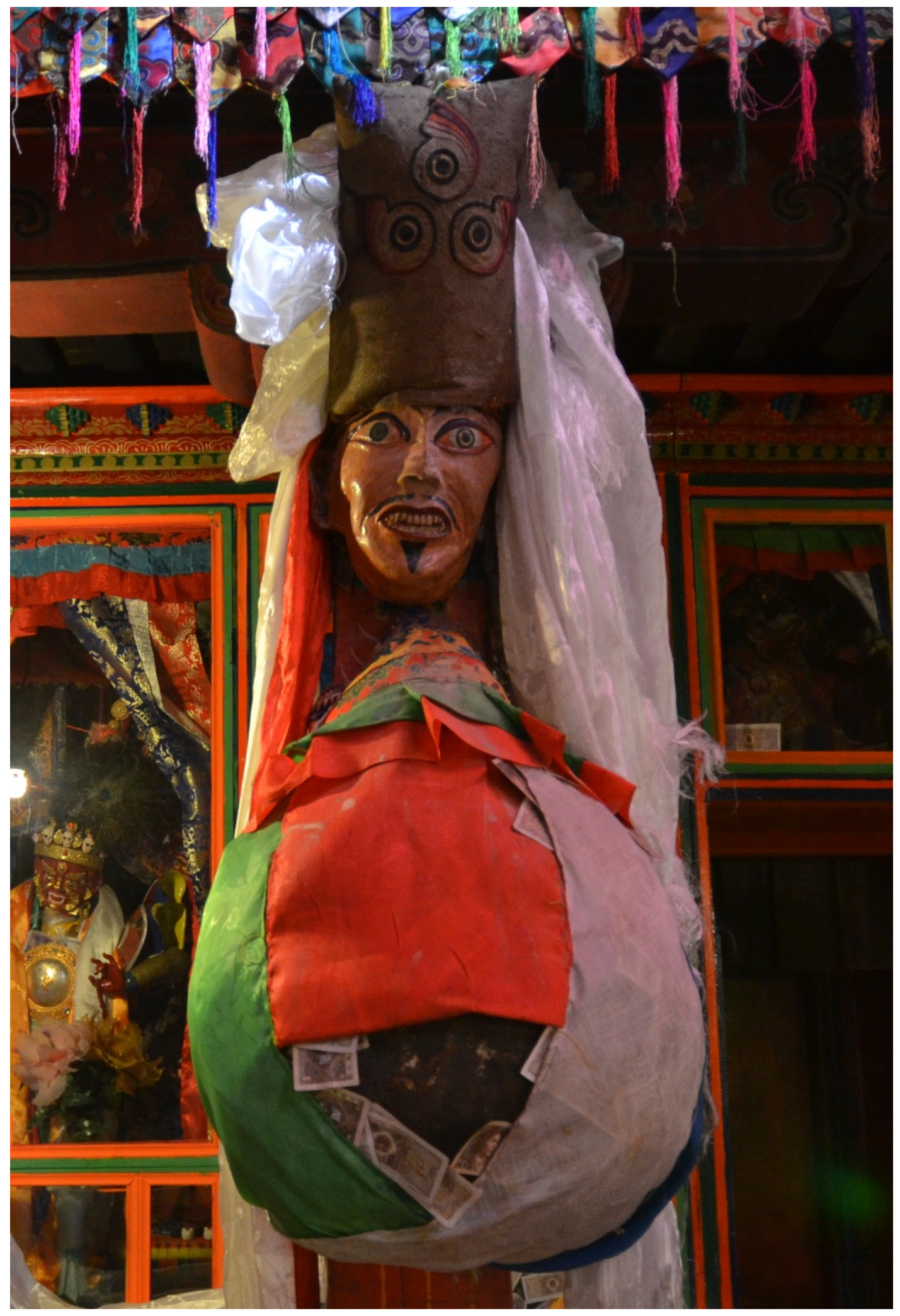

Figure 91: A 'breath bag' (Tib. dbugs rkyal) used to hold the life breath or souls of beings; Karmasha Chapel. (Photo: Cecilia Haynes, 2011) 


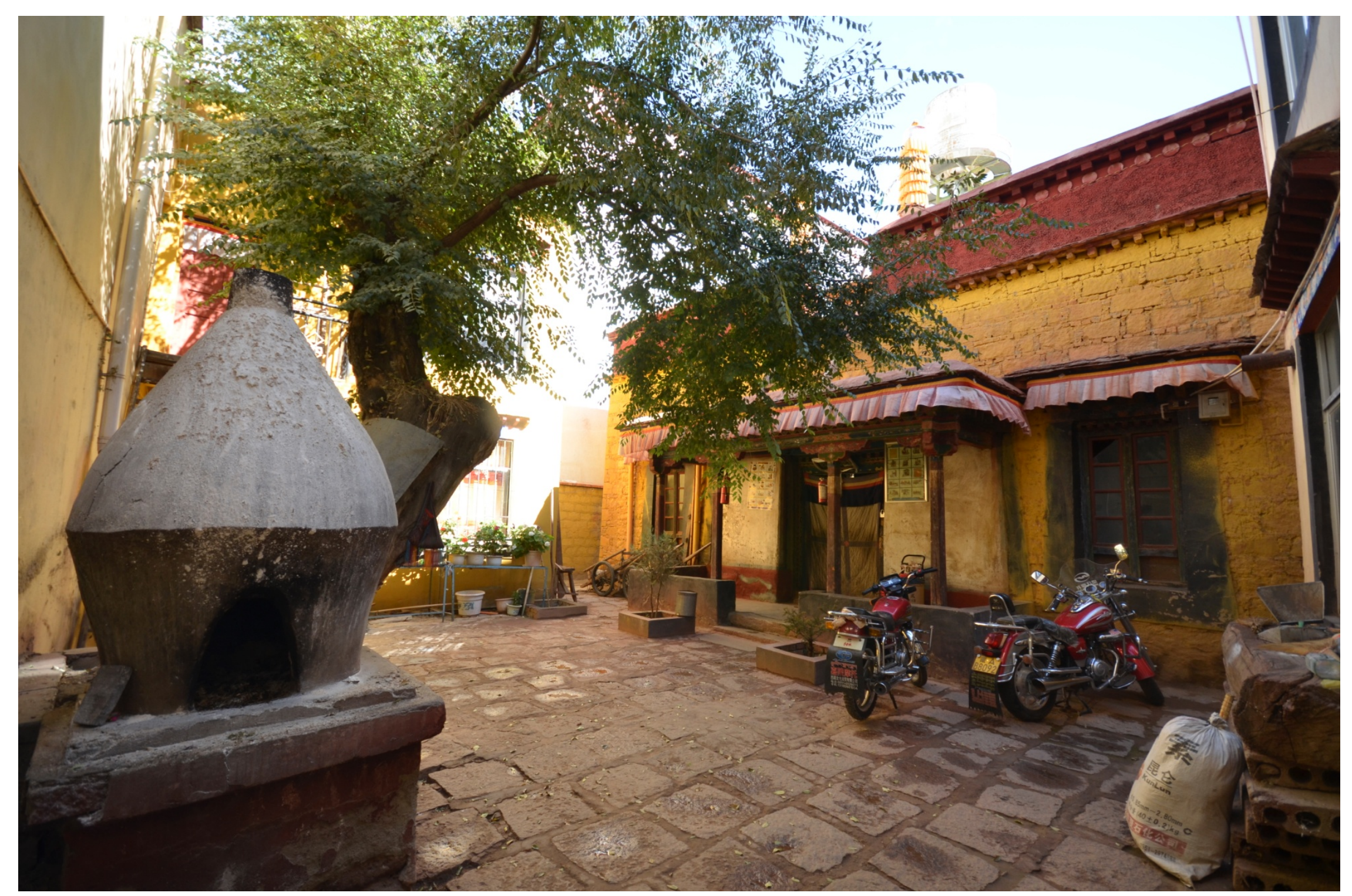

Figure 92: Banakzhöl Chapel (Tib. Sbra nag zhol rgyal khang). (Photo: Cecilia Haynes, 2011) 


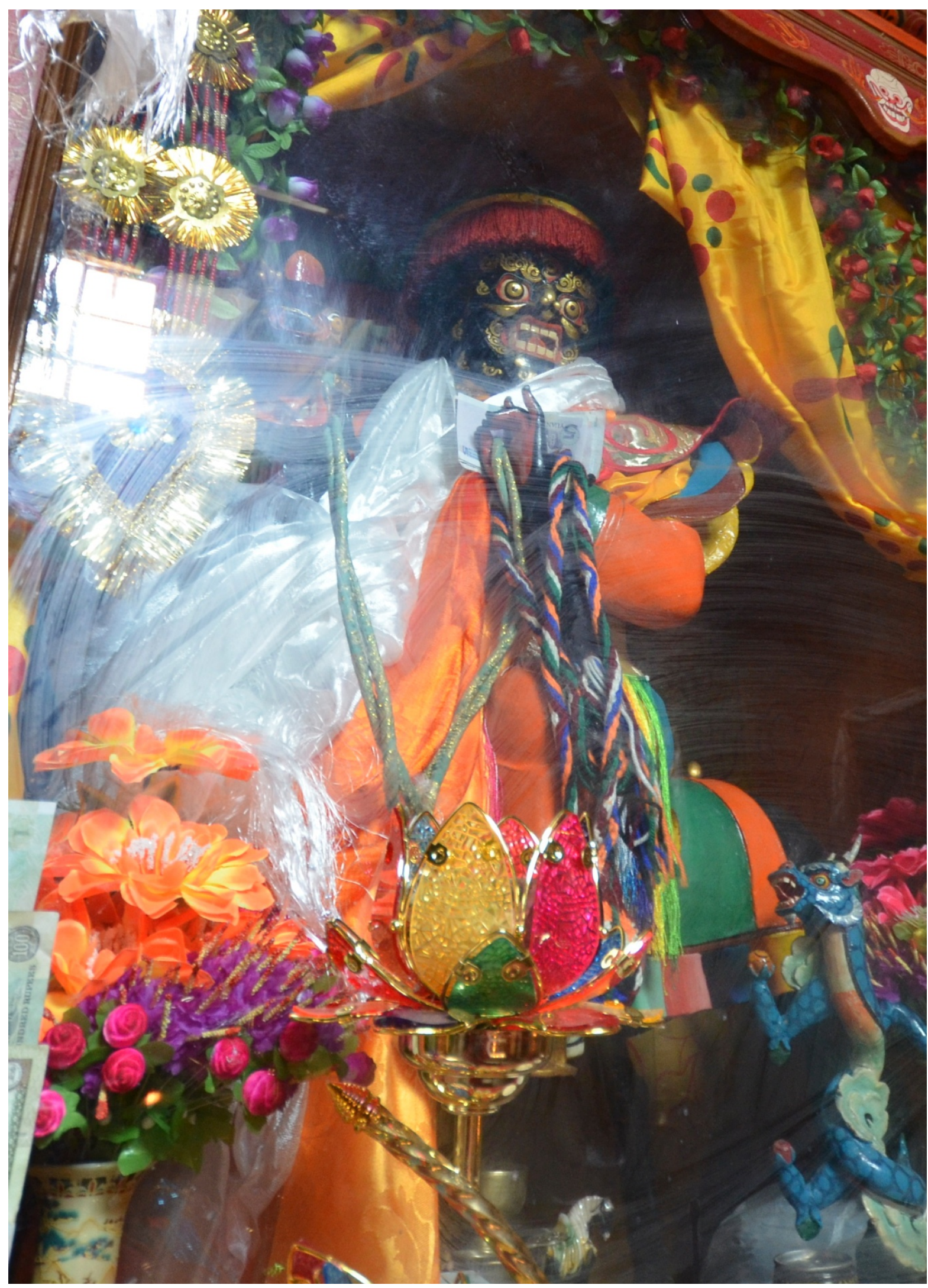

Figure 93: Central statue of Shingjachen; Banakzhöl Chapel. (Photo: Cecilia Haynes, 2011) 


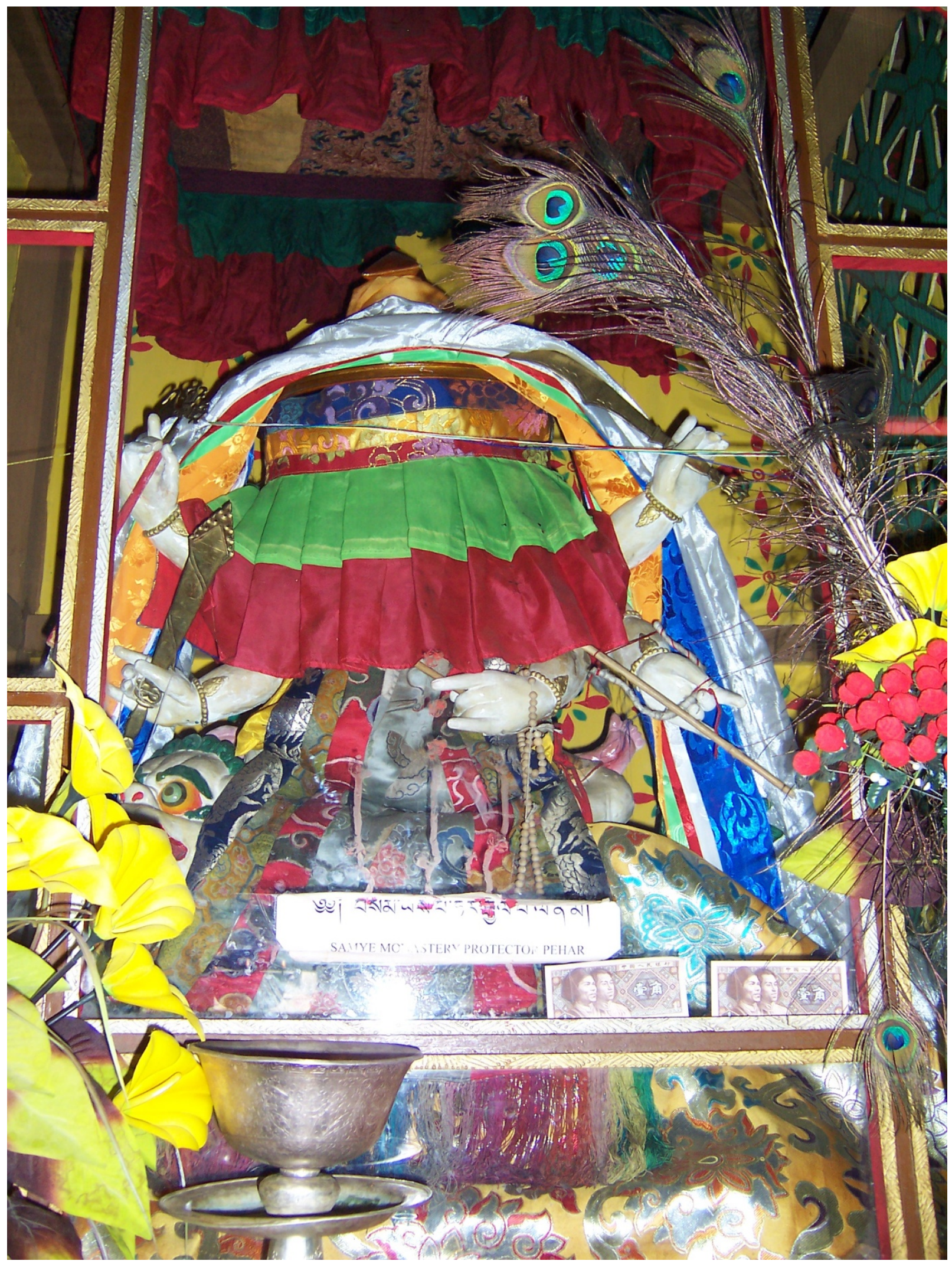

Figure 94: Statue of Pehar next to the central image of Tsiu Marpo; Tengyeling Monastery Main Chapel (Tib. Bstan rgyas gling dgon pa). (Photo: Christopher Bell, 2005) 


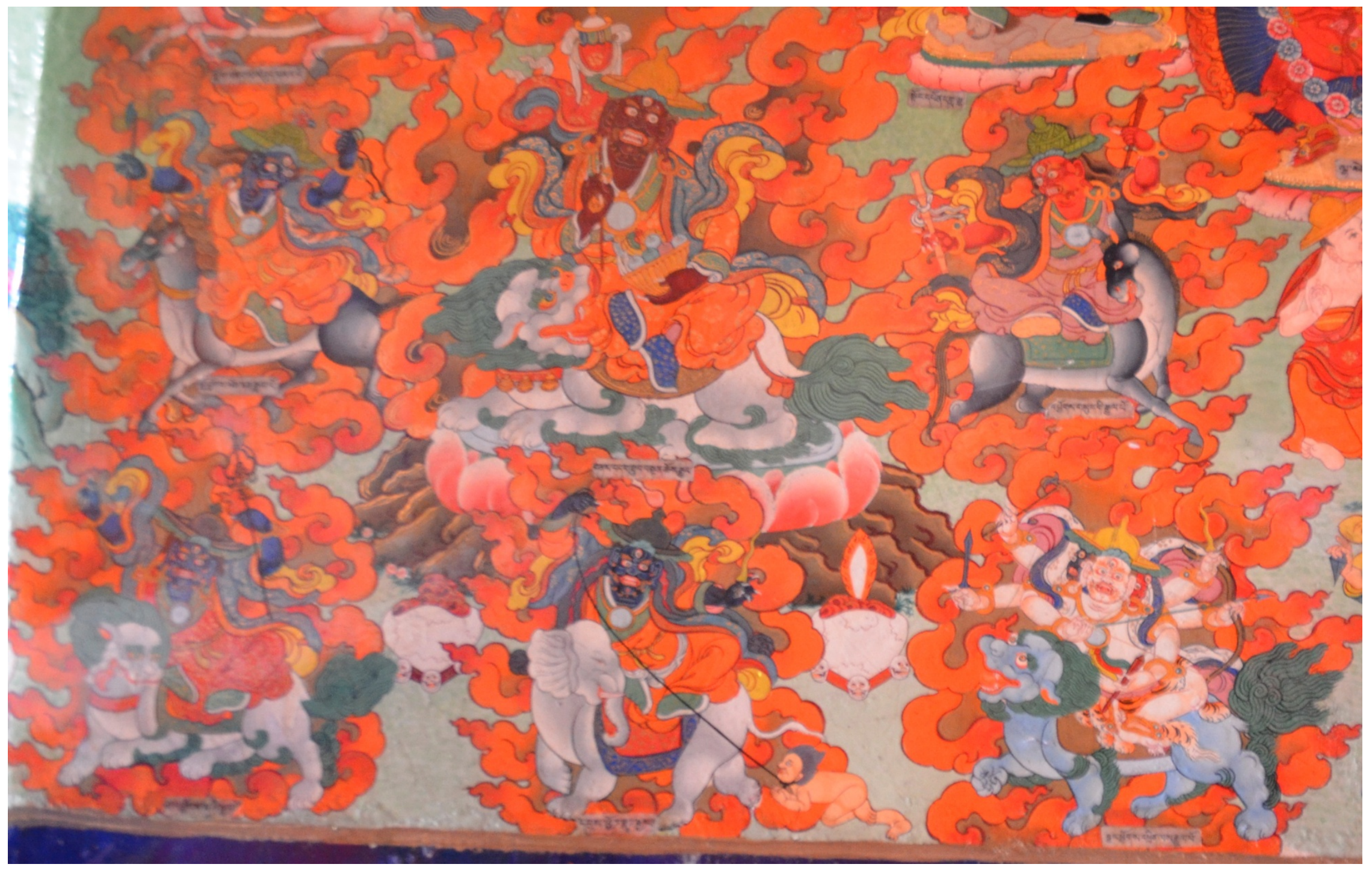

Figure 95: Mural of the Five Sovereign Spirits surrounding the monastery's local protector, Tupten Chögyel (Tib. gnas bdag Thub bstan chos rgyal). Given his own connection to Dorjé Drak, Tsiu Marpo is situated next to these figures just off frame; Dorjé Drak Monastery (Tib. Rdo rje brag dgon pa) Assembly Hall. (Photo: Cecilia Haynes, 2011) 


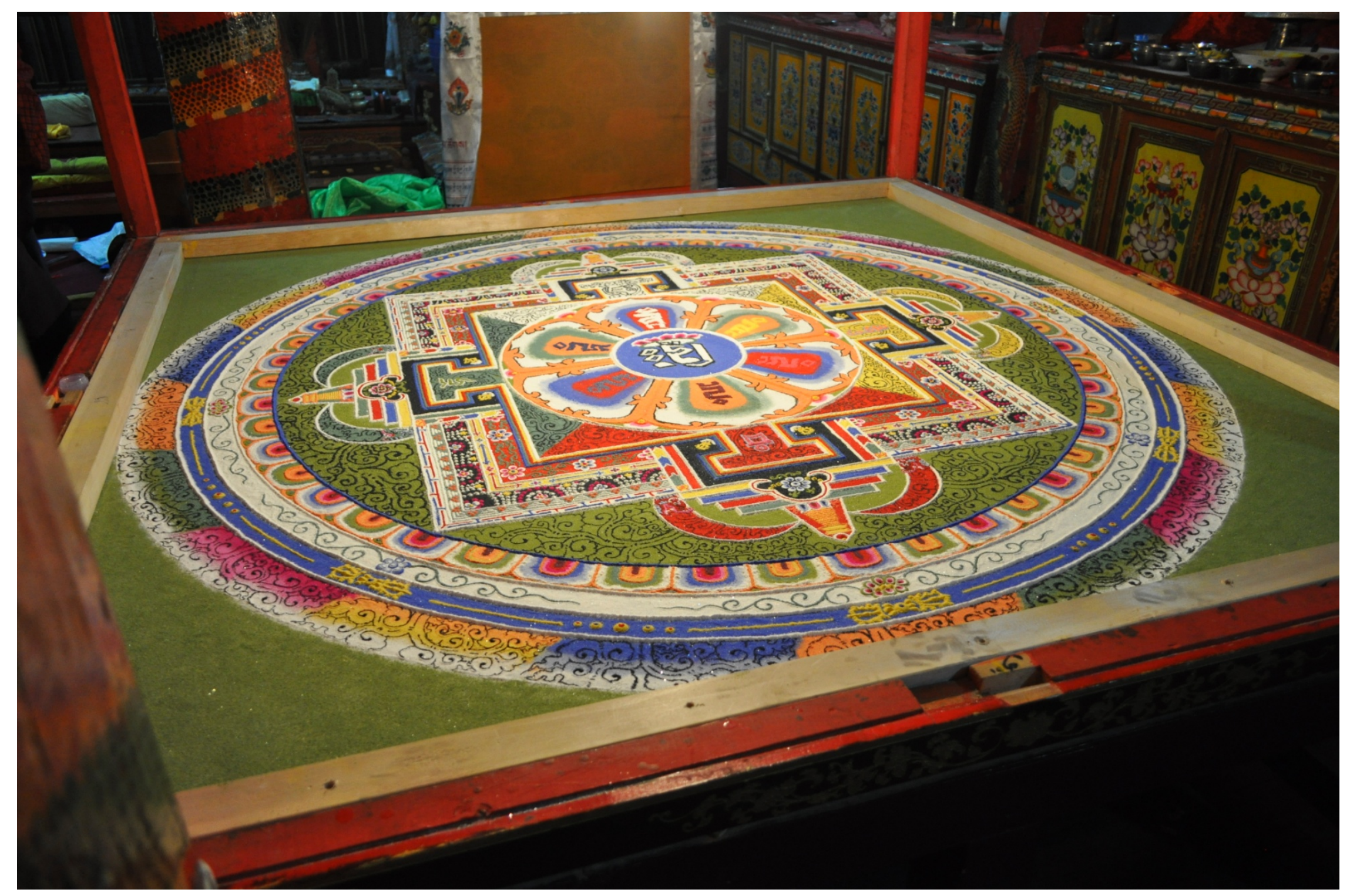

Figure 96: Mandala for Avalokiteśvara who Liberates All Beings, November 23, 2011; Nechung Monastery Assembly Hall. (Photo: Christopher Bell, 2011) 


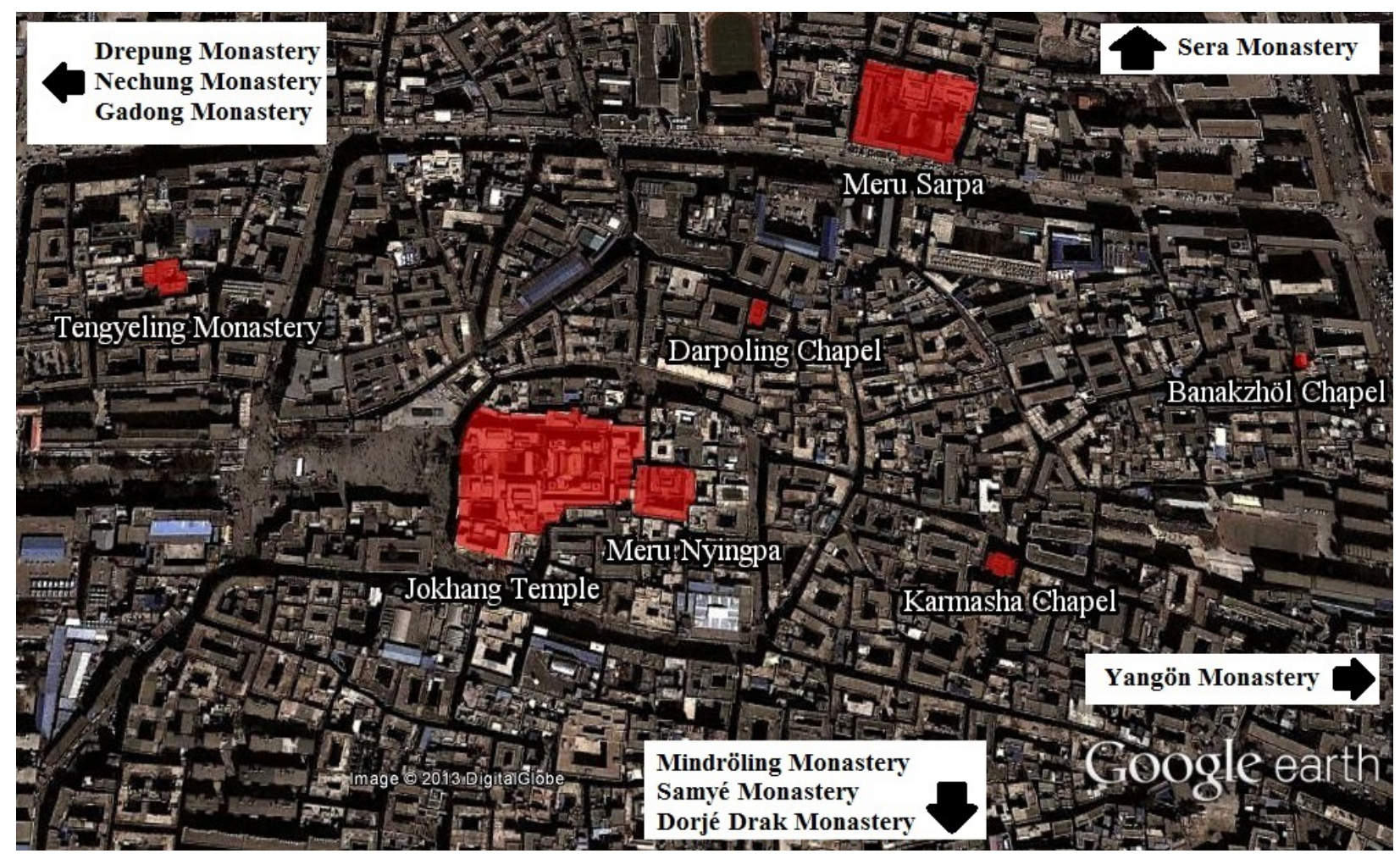

Figure 97a: Modern-day map of Lhasa's old city. The monasteries and chapels pertinent to the cult of the Five Sovereign Spirits are highlighted and labeled. The placement of these sacred sites was drawn from the map produced by the Tibet Heritage Fund; see Alexander 2005, p.20. (c) 2012 Google

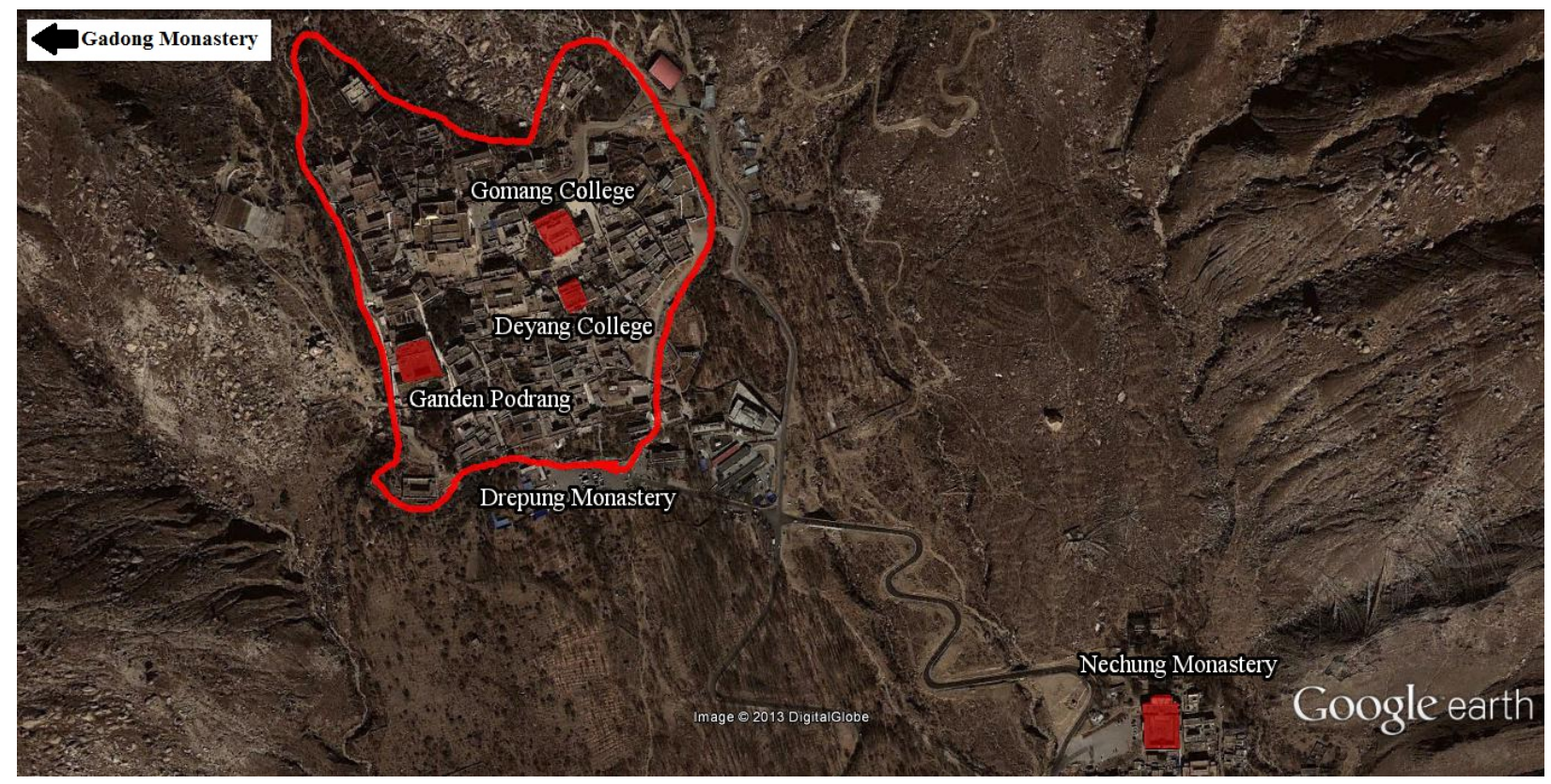

Figure 97b: Modern-day map of Drepung and Nechung Monasteries, illustrating the proximity between the two. Drepung's complex is outlined, and the buildings pertinent to the cult of the Five Sovereign Spirits are highlighted and labeled. The placement of the sites within Drepung was drawn from an interactive map developed by Georges Dreyfus; see Dreyfus 2006b. C 2012 Google 


\section{Conclusion}

The Fifth Dalai Lama, with the diligent assistance of his regent Sangyé Gyatso, was the architect of Nechung Dorjé Drayangling and its newly articulated deity cult, which were the lynchpin for his new government's religious and political agenda. First, the mythology, iconography, and ritual system of the Five Sovereign Spirits came down to the Great Fifth primarily through the Northern Treasures tradition of the Nyingma sect. Drawing from this material, he codified an account of Pehar's life and eventual arrival at Nechung. The Fifth Dalai Lama was selective in this process; he crafted a narrative that spoke most to the grand Buddhist history of Tibet's past, and to a sense of manifest destiny regarding Tibet's unification under his government. Sangyé Gyatso aided this standardization with his contribution to the Nechung Register, which provides an official history for the deity and his monastery.

Second, the Fifth Dalai Lama nurtured the cult of Nechung by composing his own ritual manual for the Five Sovereign Spirits, one that built on and complemented the foundational TenChapter Sädhana. This ritual augmentation was not arbitrary; it had been built over centuries of intertextual evolution, from Nyangrel Nyima Özer and the Second Dalai Lama to the Great Fifth. Nechung's ritual pedigree was secured in the seventeenth century, but the monastery's corpus continued to expand over the following centuries due to the Nechung Oracle's continuous involvement. This involvement, and the growth of the monastery's ritual repertoire, saw a tertiary form of Pehar named Dorjé Drakden take on a more prominent role, eventually becoming the dominant deity of Nechung.

Third, the physical monastery itself was renovated and greatly expanded in 1682, at the end of the Fifth Dalai Lama's life. This project had been planned - and partially starteddecades before Sangyé Gyatso finally championed the construction's completion. The final piece of the new complex was oracular possession, and so the Nechung Oracle gradually grew to prominence within the Dalai Lama's nascent government. By the end of the seventeenth century, the oracle's close relationship with the Dalai Lama had been solidified as he came to head a newly established hierarchy of state and local oracles intertwined with deities, rituals, and narratives. With Nechung's cult firmly ensconced, other institutions soon came under the ritual and iconographic hegemony of this state cult. Members of Nechung's deity cult were 
strategically installed at historically important religious and political centers, satellites situated around Lhasa's sacred center, and chapels located at Drepung and Sera monasteries. Through these mythic, ritual, and institutional mechanisms, the cult of Pehar flourished at Nechung and other sacred places under the Great Fifth and subsequent Dalai Lamas.

Once established, the state cult of the Five Sovereign Spirits served multiple purposes. The ritual invocations at Nechung and related sites were performed to ensure the continuous involvement of these powerful deities in protecting the Dalai Lama, the Tibetan government, and Tibet itself from natural and supernatural threats. The Nechung deities were summoned not only to destroy pernicious spirits and keep lesser divinities in line, but also to protect against more worldly threats like damaging weather, Mongolian incursions, and civil discord. These roles can be perceived along the spectrum of the four activities (Tib. 'phrin las rnam bzhi) that Pehar and his group are often called upon to perform. Pacifying activities involve quelling local deities and detrimental forces. An example of this took place during the 1682 consecration of Nechung. A snowstorm settled over the monastery and workers had portentous dreams, indicating that the regional spirits were displeased with their activity. Once the Five Sovereign Spirits were fully invited to reside at Nechung, the storms, and the pernicious deities who caused them, were pacified. ${ }^{1}$ For augmentation, Pehar's nature as a wealth deity comes to the fore. He was the protector of Samyé Monastery's treasury, has mythic ties to the wealth god Vaiśravana, and is even called a wealth god himself in some of his ritual texts. ${ }^{2}$ Rituals tied to wealth were performed at Nechung Monastery during the twelfth Tibetan month, and the god tax collected during Nechung Monkey Month further supplemented the government's coffers. It is clear that the Five Sovereign Spirits were propitiated in part to augment the wealth of the Dalai Lama's government. The deities of Nechung were also marshaled when powerful deities or enemies needed to be subjugated. The Karma Kagyü's geopolitical control over central Tibet was destroyed by Güshi Khan and his Khoshut forces, but the tension that resulted needed to be suppressed. As a result, Karmasha, the Karmapa's monastery in Lhasa, was subjugated and absorbed into the cult of the Five Sovereign Spirits. ${ }^{3}$ In instances where enemies or malevolent forces are deemed too dangerous to be pacified or subjugated, destruction is the final recourse. This is an activity that Pehar particularly enjoys since he consumes the flesh, blood, and life

\footnotetext{
${ }^{1}$ See Appendix III, p.589.

${ }^{2}$ See Appendix III, p.569; see also chapter 1, notes 114, 228.

${ }^{3}$ See chapter 3, pp.241-244.
} 
breath of enemies and obstructing spirits for his allotted food. ${ }^{4}$ The Five Sovereign Spirits were, and continue to be, entreated to perform the above four activities. In so doing, these deities act to calm forces that are detrimental to the government, enrich its treasury, overpower its opponents, and destroy recalcitrant enemies and spirits. By implementing these ritual invocations and standardizing their practice at sacred centers across Lhasa, the state cult of Nechung was actively involved in a program of unification. Given the extant of Tibet's fragmentation before the Fifth Dalai Lama's ascension, the evolution of the Nechung cult was an important part of the Tibetan government's national consolidation.

\section{The Many Lineages of the Fifth Dalai Lama}

The Five Sovereign Spirits were, and continue to be, of central importance to the Dalai Lama's government. Nevertheless, there are many other Dharma protectors that can be propitiated to perform the four activities, and the Fifth Dalai Lama had close personal ties to such deities. ${ }^{5}$ Moreover, we have also been introduced to many other protector deities associated with Nechung and its gods. Tsiu Marpo, the other major guardian of Samyé Monastery, is important to the Northern Treasures tradition like Pehar; he even seems to have ridden into the latter's cult on his coattails. Penden Lhamo is equally important and ontologically superior to Pehar; she has ties to the former Tsel hegemony and the form of the goddess named Makzor Gyelmo is the other major Dharma protector of the Tibetan government. Other goddesses, such as the Five Long-Life Sisters and the Twelve Tenma Goddesses, have had significant connections to the lineage of the Dalai Lamas since the second incarnation. Dorjé Drakgyelma, in particular, as the head of the Twelve Tenma Goddesses, is a central deity of Drepung Monastery. Still other protectors make noteworthy appearances, such as Begtse, another major deity in the Dalai Lamas' cultic repertoire, Tsangpa, the god of the Lamo oracle, and Vaiśravana, the wealth god involved in Pehar's eighth-century capture. Given this abundance of deities, why did Pehar take on such salience for the Fifth Dalai Lama and the Tibetan government in the seventeenth century?

\footnotetext{
${ }_{5}^{4}$ See chapter 3, p.206, and Appendix IIc, p.514.

${ }^{5}$ For other deities that are entreated to perform the four activities, see Heller 1992b, p.279n.79; Bell 2006, pp.166, 172; and Tà la'i bla ma 05 1992b. For the Fifth Dalai Lama's visionary engagement with such deities, see Karmay 1988, pp.36, 60, 62, and passim.
} 
Although many of these other deities had connections to the Fifth Dalai Lama, none of them were as close to him as Pehar. There are four major lineages by which the bodhisattva and the god were connected, all of which are significant: [1] Ancestral - the Fifth Dalai Lama stressed an ancient family connection to Pehar; [2] Transmissional - the Fifth Dalai Lama received the teaching transmissions of Pehar's key treasure texts; [3] Incarnational - the Fifth Dalai Lama's incarnation lineage extended back not just to the Second Dalai Lama but to Nyangrel Nyima Özer, both of whom were active promoters of Pehar's cult; and [4] Institutional - Pehar already had pre-existing ties not just to the Gelukpa sect but to Drepung Monastery in particular. Along with these, an important Mongolian connection will also be discussed below. While the Fifth Dalai Lama inherited the cultic practices of many other protector deities through one or two of these lineages, only Pehar can boast a significant connection to all of them.

\section{Ancestral Connection}

In chapter 1 we explored Pehar's mythic origins. Once the deity entered world history by arriving in Mongolia, he developed a relationship with a mysterious Indian figure named Dharmapāla. As previously noted, ${ }^{6}$ the account of Pehar's entrance into Tibet is drawn from the Fifth Dalai Lama's autobiography and was likely composed around 1666 . However, the Great Fifth first composed this narrative 23 years prior in his history of Tibet, the Song of the Spring Queen. In both works this section is part of a larger accounting of the Chongyé lineage, the Fifth Dalai Lama's own family line. Prior to describing the events of Pehar's capture in these two sources, the Great Fifth outlines the genealogy of the Zahor royal bloodline, from which the Chongyé descended. For our purposes, we will start the lineage with the King of Zahor, Indrabhūti, ${ }^{7}$ who begat Śakraputa, who begat Vihāradhāra. ${ }^{8}$ Vihāradhāra, in turn, had two sons, Dharmarāja and the famous abbot Śāntarakṣita, as well as a daughter named Mandārava, who became one of Padmasambhava's consorts. Dharmarāja then had three sons, Dharmapāla, Śākyadeva, and Mahādeva. The Great Fifth then explains where exactly Dharmapāla came from:

\footnotetext{
${ }^{6}$ See chapter 1 , note 130 .

${ }^{7}$ This figure is an important legendary king for Vajrayāna Buddhism in general and has his own conflicting mythic narratives; see Karmay 1998a.

${ }^{8}$ Tib. Gtsug lag 'dzin.
} 
It is written in the old records of the family genealogy that Dharmapāla himself came to Tibet from India, ${ }^{9}$ and that the meditation center where Pehar resided was probably located in the land of Zahor. [However,] according to Lama Sokdokpa's ${ }^{10}$ Refutations to Criticisms of the Nyingma School, ${ }^{11}$ the Zahor lineage of the Taktse ${ }^{12}$ [princes] is not the Zahor in India. This implies that there was another Zahor in China. [Regardless,] both accounts are merely foolish talk that lack foundation. If one accepts the tradition that the meditation center where Pehar resided was in India, it would contradict the story of Vaiśravana in the land of Jang. There are no records whatsoever that have a story [saying] there is another Zahor in China different from the Zahor in Bengal. Bengal, in eastern India, and China are closely connected, and there are many travelers, like merchants, who cross the ocean with ships. Therefore, Dharmapāla [must have] gone to China and [then] settled at the meditation center in Bhatahor. ${ }^{13}$

This argument is not found in the Song of the Spring Queen, where the Fifth Dalai Lama states unequivocally that Pehar was initially in the land of Zahor. ${ }^{14}$ In the two decades between this latter statement and its revision in the mid-1660's, the Great Fifth clearly became troubled by the contradicting narratives. ${ }^{15}$ To combat this he engaged with the narratives directly, negotiating the conflicts in order to produce a newer, clearer account. In contrast to his previous opinion, the Fifth Dalai Lama came to believe that Pehar's meditation center was in Mongolia, specifically around Qinghai Lake. He states this explicitly in the Nechung Register, ${ }^{16}$ which

\footnotetext{
${ }^{9}$ Tib. rgya gar. Tucci (1999, p.734) has China, which is incorrect.

${ }^{10}$ Sog bzlog pa Blo gros rgyal mtshan, 1552-1624; TBRC: P645.

${ }^{11}$ Tib. Rnying ma'i rtsod bzlog. The full title of this work is Sngags rnying ma'i rtsod spong 'bri khung dpal 'dzin gyi brtsod lan, which is found in a larger collection of refutations entitled, Gsang snangs snga 'gyur la bod du rtsod pa snga phyir byung ba rnams kyi lan du brjod pa nges pa don gyi 'brug sgra; see Sog bzlog pa 1975.

${ }_{12}$ Tib. Stag rtse; this is a historically significant region just east of Lhasa. It contains both Tsel Gungtang and Ganden (Tib. Dga' ldan) Monastery further east.

${ }^{13}$ Tà la'i bla ma 05 1991-1995, vol.5, pp.26.5-27.3.

${ }^{14}$ See ibid, vol.19, p.187.5. For a deeper discussion of where Tibetan scholars and traditions have placed Zahor, see Tucci 1999, p.736.

${ }^{15}$ These contradictions can be found in other Tibetan historical accounts of which the Fifth Dalai Lama was no doubt aware. For example, in the Mirror Illuminating the Royal Genealogies (Tib. Rgyal rabs gsal ba'i me long) by the Sakyapa lama Sönam Gyeltsen (Bsod nams rgyal mtshan, 1312-1375; TBRC: P1226), Pehar is said to come from Zahor (Bengal); see Sørensen 1994, p.385. However, in Nyangrel Nyima Özer's Honey Nectar from the Heart of the Flower: A History of the Dharma (Tib. Chos 'byung me tog snying po sbrang rtsi'i bcud), the meditation center is said to be in Bhatahor (Mongolia); see Nyi ma 'od zer 1988, p.344. The Padma bka' thang also associates Pehar with Mongolia; see Douglas and Bays 1978, pp.391-392.

${ }^{16}$ See Appendix III, p.565.
} 
explains that Pehar was "invited" from Drugu. ${ }^{17}$ It is clear that the route taken by Prince Muruk Tsenpo's army, explained in the chapter 1 account, refers to a region in or near Qinghai. The issue is then how to reconcile the two possible entry points for Pehar. For the Great Fifth the answer is Dharmapāla, his forefather from Zahor. ${ }^{18}$ In the fragment above, the Fifth Dalai Lama responds to two different claims: [1] that Pehar resided in Zahor, India, with Dharmapāla, and [2] that Zahor is not in India, but presumably in China. The Great Fifth disagrees with both claims and makes the definitive statement that Dharmapāla must have traveled from India through China, and then came to reside at the meditation center in Bhatahor, Mongolia. Pehar was the tutelary deity of this center at that time and the two developed a favorable rapport, which would later impact Pehar's decision to come to Tibet.

In this account, Pehar has been connected to the Fifth Dalai Lama's family as far back as Dharmapāla, who the Great Fifth believes migrated from Zahor to Bhatahor and then to Tibet. The Great Fifth's autobiography even begins with Pehar's arrival at Samyé because it is discussed within the broader context of the Dalai Lama's family lineage. This is important for how the Great Fifth identified himself, since he usually signed the colophons of his texts with some variation of the epithet, "the monk born of the Zahor line."19 It is also significant that Dharmapāla was the nephew of Śāntarakșita, the famed first abbot of Samyé Monastery. With these family connections, a multifaceted relationship between Pehar, Samyé, and the Fifth Dalai Lama was established.

\section{Transmissional Connection}

Over 1500 folios of text — consisting of four volumes of the Fifth Dalai Lama's collected works - make up the Great Fifth's vast Record of Received Teachings. Listed in this collection are the transmission lineages through which the Fifth Dalai Lama received the major texts concerning Pehar. These transmission records are an important means of validating the

\footnotetext{
${ }^{17}$ See chapter 1 , note 146.

${ }^{18}$ The Fifth Dalai Lama's lineage extends back to Dharmapāla through his father; see Sañs-rGyas rGya-mTSHo 1999, p.253. For the details of this lineage, see Tā la'i bla ma 05 1991-1995, vol.5, pp.24.4-40.2; ibid, vol.19, pp.186.6-186.2; Nag-dBañ Blo-bZan rGya-mTSHo 1995, pp.165-173; and Tucci 1999, pp.643-644. In his translations, Tucci clearly shows that Dharmapāla is the forefather of the Zahor line transitioning into Tibet; however, his table of the Chongyé genealogy (Table VII) incorrectly shows the line descending from Dharmapāla's brother Mahādeva.

${ }^{19}$ Tib. za hor gyi rigs las byung ba'i ban de. For a historical discussion of Zahor and its connection to the Fifth Dalai Lama's lineage, see van der Kuijp 2013.
} 
authenticity of these works, and they secure the Great Fifth's right to practice and transmit them himself. The lineage of the works most significant to Nechung's cult, such as the White Crystal Rosary and the Ten-Chapter Sädhana, are recorded as not only deriving from Indian originals but from primordial origins as well. The following list is presented in the second volume of the Record of Received Teachings:

The Great Oral Instruction Tantra of the White Crystal Rosary-also known as the twenty-chaptered Explanatory Tantra of the Black Wealth God-the sevenchaptered Blue Turquoise Rosary Tantra, and the nine-chaptered Black Iron Rosary Tantra: History of the One-Eyed [Hindering Spirit] were [respectively] translated [from Sanskrit] by the three-Master Padma[sambhava], Nup Namkhé Nyingpo, and the great translator Vairocana. Along with the Ten-Chapter Sädhana: A Supplication Offering [to the Five Great Sovereign Spirits and their Retinues], the transmission lineage by which [these texts] were acquired is as follows: Samantabhadra, Vajradhāra, Vajrapāṇi, the precious [master of] Uḍ̣̣iyāṇa [Padmasambhava], Queen [Yeshé] Tsögyel, [King] Trisong Deutsen, Ngadak Nyang[rel Nyima Özer], Guru Dönseng Gyentsen, Tsadrel Jatang Chöjé, Tsungmé Jamyang Lodrö, Jamyang Pelrin, Guśrī Penden Döndrup [1382-1466; TBRC: P3600], Tsungmé Namkha Zangpo, Kagyepa Zhönnu Pelzang, the Tantric scholar Kelden Gyatso, Mingyur Künga Pelzang, Drigung Zurpa Rinpoché [15091557; TBRC: P399], Chöjé Nyida Sangyé, Ekarchen Lenbu Ami, Vajradhāra Pabongkapa Penjor Lhündrup [1561-1637; TBRC: P647], the Omniscient Zur Chöying Rangdröl [1604-1669; TBRC: P650], and through him-me, the monk of Zahor. $^{20}$

\footnotetext{
${ }^{20}$ Tā la'i bla ma 05 1991-1995, vol.2, pp.615.2-6: shel 'phreng dkar po man ngag gi rgyud chen le'u nyi shu pa nor lha nag po'i bshad rgyud du 'ang grags so/g.yu 'phreng sngon po'i rgyud le'u bdun pa/ lcags 'phreng nag po mig gcig sngon byung gi rgyud le'u dgu pa rnams slob dpon pad ma/ gnubs nam mkha'i snying po/ lo chen bai ro gsum gyis bsgyur ba/gsol kha 'phrin las don cu ma dang bcas thob pa'i brgyud pa ni/ kun tu bzang po/ rdo rje 'chang/ phyag na rdo rjel o rgyan rin po chel jo mo 'tsho rgyal/ khri srong lde btsan/ mnga' bdag nyang / gu ru don seng rgyal mtshan/ rtsa bral bya btang chos rje/ mtshungs med 'jam dbyangs blo gros/ 'jam dbyangs dpal rin/ gu shri dpal ldan don grub/ mtshungs med nam mkha' bzang po/ bka' brgyad pa gzhon nu dpal bzang/sngags 'chang skal ldan rgya mtsho/ mi 'gyur kun dga' dpal bzang/ 'bri gung zur pa rin po che/ chos rje nyi zla sangs rgyas/ e dkar chen lan bu a mi/rdo rje 'chang pha bong kha pa dpal 'byor lhun grub/zur kun mkhyen chos dbyings rang grol/des bdag za hor bande la'o/l.
} 
In the next volume, the transmission lineage for more specific instructions related to the Kama and Terma ${ }^{21}$ corpus of the sovereign spirit Jeché is listed. These instructions include exhortations, offerings, and diagrams for protective circles and lingas, all of which came down through the Nup (Tib. Gnubs) family line. This transmission is as follows:

The Second Buddha Master [Padmasambhava], the Divine Lord Nup Sangyé Yeshé, the Divine Lord Nup Lönten Gyatso, the Divine Lord Nup Yeshé Gyatso, Nup Padma Wangyel, Nup Lhajé Jampel, Nup Gyagar Dorjé, the Divine Lord Chökyi Yeshé, Chögo Kenchenpa, the Tantric scholar Tashi Rinchen, Lama Jangchup Pelwa, Lama Drakpa Lhaö, the Tantric scholar Drakpa Samdrup, Lord Penjor Drakpa, the great lama Jamyang Drakpa, Drigungpa Rinchen Püntsok [1509-1557; TBRC: P399], his son Drigungpa Chögyel Püntsok, the Tantric scholar Tashi Topgyel [1550?-1603; TBRC: P646]—from the lineage of Minyak Tongkün Gyelpo, the Vidyādhara Ngagi Wangpo [1580-1639], the Universal Lord Chöying Rangdröl, and through him—me, the monk of Zahor. ${ }^{22}$

Immediately following this list, a second lineage pertaining specifically to the White Crystal Rosary and its practices is provided. The description preceding the following transmission clarifies that this tantra was hidden by Padmasambhava in a pillar at Samyé Monastery:

The great Nup [clan members] mentioned above, as well as the treasure-revealer Dorjé Öbar. $^{23}$ [Then,] from Nup Lhajé Jampel to Lord [Drigungpa] Chögyel Püntsok it is the same [as above]. Then Lama Jinpa Püntsok, Urnyön Tukyi Dorjé,

\footnotetext{
${ }^{21}$ Tib. bka' gter; this refers to the orally transmitted teachings (Tib. bka' $m a$ ) and treasure texts (Tib. gter ma) of the Nyingma tradition.

${ }^{22}$ Tà la'i bla ma 05 1991-1995, vol.3, pp.96.1-4: slob dpon sangs rgyas gnyis pa/ lha rje gnubs sangs rgyas ye shes/ lha rje gnubs lon tan rgya mtsho/ lha rje gnubs ye shes rgya mtsho/ gnubs padma dbang rgyal/ gnubs lha rje 'jam dpal/ gnubs rgya gar rdo rje/ lha rje chos kyi ye shes/ chos sgo mkhan chen pa/ sngags 'chang bkra shis rin cen/ bla ma byang chub dpal ba/ bla ma grags pa lha 'od/sngags 'chang grags pa bsam grub/rje dpal 'byor grags pa/ bla chen 'jam dbyangs grags pa/ 'bri gung pa rin cen phun tshogs/ de sras 'bri gung pa chos rgyal phun tshogs/ mi nyag stong 'khun rgyal po'i brgyud las sngags 'chang bkra shis stobs rgyal/ rigs 'dzin ngag gi dbang po/ khyab bdag chos dbyings rang grol/ des bdag za hor bande la'o//. The specific practices drawn from the corpus of the sovereign spirit Jeché are listed just prior to this lineage; see ibid, pp.95.4-96.1.

${ }^{23}$ This figure is also known as Gyazhangtrom (Tib. Rgya zhang khrom) and is an incarnation of Nup Sangyé Yeshé.
} 
the scholar-adept Könchok Lhündrup, Tratsangpa Dorjé Mitoktsel, and through him-me. ${ }^{24}$

Other than the involvement of cosmic figures like Samantabhadra and Vajradhāra, the transmission lineage for the practices associated with the White Crystal Rosary, and the sovereign spirit Jeché overall, extend back to the eighth century. This era represents both the height of Tibet's imperial expansion as well as the establishment of monastic Buddhism in Tibet, signified by the founding of Samyé Monastery by Padmasambhava. Members of the Nup clan figure prominently and for good reason. Nup Sangyé Yeshé was a disciple of Padmasambhava and was among the first 25 monks ordained at Samyé. The Nup line as a whole became renowned for the spiritual prowess of its members. ${ }^{25}$ Nup Namkhé Nyingpo, another of Padmasambhava's disciples and a Samyé monk, is said here to have aided in the translation of the root texts behind these practices alongside Padmasambhava and Vairocana. Centuries later, Nyangrel Nyima Özer understandably became part of this tantric lineage. Drigungpa Rinchen Püntsok also appeared later on. This sixteenth-century Kagyü treasure-revealer had close ties to Ngari Paṇchen Padma Wangyel and his brother Lekden Dorjé, early purveyors of the Northern Treasures tradition; together these three reconsecrated Samyé Monastery. ${ }^{26}$ This series eventually transitioned into other important keepers of the Northern Treasures tradition, such as Ngagi Wangpo, Chöying Rangdröl, and Tratsangpa Dorjé Mitoktsel, from whom the Fifth Dalai Lama received these tantric systems. It is noteworthy that this transmission came down through predominantly Nyingma and Drigung Kagyü channels. This unbroken link to imperially important figures like Padmasambhava and members of the Nup clan, as well as to great treasure-revealers of the past, testifies to the authenticity of the tantric cycles upon which Nechung Monastery's ritual pedigree was founded. These records also stress the Fifth Dalai Lama's involvement in maintaining these transmission lineages as well as his centrality in validating the Mahāyoga system practiced at Nechung Monastery.

\footnotetext{
${ }^{24}$ Tā la'i bla ma 05 1991-1995, vol.3, pp.96.6-97.1: gnubs chen yan gong ltar la/gter ston rdo rje 'od 'bar/gnubs lha rje 'jam dpal nas/ rje chos rgyal phun tshogs kyi bar 'dra ba la/ de nas bla ma sbyin pa phun tshogs/dbur smyon thugs kyi rdo rje/ mkhas grub dkon cog lhun grub/khra tshang pa rdo rje mi rtog rtsal/ des bdag la'o//. The specific practices for the White Crystal Rosary are listed just prior to this lineage; see ibid, p.96.4-6.

${ }^{25}$ See Sørensen 1994, p.446n.1611. For a fuller discussion of the Nup lineage, see Dudjom Rinpoche 1991, vol.1, pp.607-616.

${ }^{26}$ See Gu ru bkra shis 1990, p.536; see also ibid, pp.541-544.
} 


\section{Incarnational Connection}

In chapter 2 we examined the roots of Nechung Monastery's ritual lineage. Specifically, by exploring the intertextual relationship between the Ten-Chapter Sädhana, the Offerings and Praises, and the Adamantine Melody, it was shown that this textual transmission was part of a centuries-long process of emendation. Even more significant is that this evolution was conducted by the same author, as it were, through the process of reincarnation.

According to its own colophon, the Ten-Chapter Sädhana was composed by Padmsambhava in the eighth century and subsequently revealed by Nyangrel Nyima Özer in the twelfth century. Nyangrel Nyima Özer, aside from being an important treasure-revealer, was believed to be the body reincarnation of both King Trisong Deutsen and Padmasambhava. He had many visionary experiences in his youth and received many teachings from emanations of Padmasambhava and his consort Yeshé Tsogyel. Furthermore, he retrieved several treasure texts prior to encountering Padmasambhava himself in a hidden land, which is not unlike the Second Dalai Lama meeting the great exorcist in his Buddha realm between lives:

While experientially cultivating the Guru as the Attainment of Mind (bla-ma thugs-sgrub) at Mutik Shelgi Pagong, Yeshe Tshogyel actually arrived and bestowed on him the text of the Hundredfold Dialogue of the Dākinī (mkha'-'gro'i zhu-lan brgya-rtsa). She led Nyang-rel to the Siitavana charnel ground, where the master Guru Rinpoche and the eight awareness-holders who were successors to the transmitted precepts gave him, separately, the empowerments of the Eight Transmitted Precepts (bka'-brgyad), in general and in particular. They also gave him the tantras and the esoteric instructions in their entirety. ${ }^{27}$

This of course refers to when Nyangrel Nyima Özer received the tantric system of the Eight Sädhana Deities, murals of whom grace the walls of Nechung's assembly hall. Nyangrel Nyima

\footnotetext{
${ }^{27}$ Dudjom Rinpoche 1991, vol.1, p.757. The eight awareness-holders (Tib. rig 'dzin brgyad; Skt. aștavadyādhara) mentioned here are [1] Mañjuśrīmitra (Tib. 'Jam dpal bshes gnyen), who taught the Yamāntaka cycle; [2] Nāgārjuna (Tib. Klu sgrub), who taught the Hayagrīva cycle; [3] Vajrahūṃkāra (Tib. Rdo rje hūṃ mdzad), who taught the Viśuddha cycle; [4] Vimalamitra (Tib. Dri med bshes gnyen), who taught the Vajrāmṛta cycle; [5] Prabhahasti (Tib. 'Od kyi glang po), who taught the Vajrakîlāya cycle; [6] Dhanasamıskrta (Tiv. Nor gyi legs sbyar), who taught the Mātara cycle; [7] Guhyacandra (Tib. Zla gsang), who taught the Lokastotrapujanātha cycle; and [8] Sāntigarbha (Tib. Zhi ba'i snying po), who taught the Mantrabhïru cycle. Also see chapter 1, note 313.
} 
Özer later married Jobuma, ${ }^{28}$ a reincarnation of Yeshé Tsogyel, and their two sons, as well as his disciples, carried on his teaching lineages after his death. ${ }^{29}$

The Second Dalai Lama, who composed the Offerings and Praises, was familiar with Nyangrel Nyima Özer's Ten-Chapter Sädhana and quoted from it to create the foundation for his lengthiest ritual to the Five Sovereign Spirits. Of the first four Dalai Lamas, the Great Fifth identified most with the second and it shows within the context of Nechung. The Adamantine Melody extensively quotes the Second Dalai Lama's rituals to Pehar-more than it quotes even the Ten-Chapter Sädhana. The Great Fifth refers to Pehar as the 'Great Emanated Dharma King,' based on the Second Dalai Lama's phrasing. Finally, contrary to the account given in the Hagiography of Jokpa Jangchup Penden, the Nechung Register states that the Second Dalai Lama was responsible for Pehar's arrival at Nechung. The register likewise mentions the Second Dalai Lama encountering the sovereign spirit—either as Kyechik Marpo or Dorjé Drakden - in the intermediate state before being reborn. Clearly the Great Fifth modeled his approach to the Nechung deities on the Second Dalai Lama's representation of their cult.

The Fifth Dalai Lama's incarnational connection to the Second Dalai Lama is selfexplanatory, and it is referred to in several contexts to highlight the long-term association between the Dalai Lama and Pehar. The connection to Nyangrel Nyima Özer is less overt. In Sangyé Gyatso's biography of the Fifth Dalai Lama, the twelfth-century treasure-revealer is listed alongside several other important incarnations tied to the Great Fifth's mental continuum. This list presents a dramatic chain of lifetimes extending back to King Trisong Deutsen and Padmasambhava, and still further back to the previous Indian incarnations of Avalokiteśvara. ${ }^{30}$ This lineage validates the Fifth Dalai Lama as an emanation of the Bodhisattva of Compassion and offers a cosmic vision of the interplay between gods and enlightened beings within the world. The mental continuums of the Great Fifth and the immortal god Pehar have crossed paths numerous times in the past. In the eighth century, this relationship took on the form of Padmasambhava subjugating and installing the deity as the protector of Samyé's treasury. In the twelfth-century, Nyangrel Nyima Özer discovered the root tantric cycle dedicated to Pehar and composed by Padmsambhava. In the sixteenth century, the Second Dalai Lama was involved in

\footnotetext{
${ }^{28}$ Tib. Jo 'bum ma.

${ }^{29}$ For two biographies of Nyangrel Nyima Özer, see ibid, pp.755-759, and Saṅs-rGyas rGya-mTSHo 1999, pp.154159. There is a collection of nineteenth-century thangkas that illustrate the incarnations of the Dalai Lamas with the Great Fifth acting as the central portrait. Incarnations prior to the Dalai Lama lineage are also included, and Nyangrel Nyima Özer can be found in the portrait of the Third Dalai Lama; see Himalayan Art Resources $2013 \mathrm{~b}$.

${ }^{30}$ See Saṅs-rGyas rGya-mTSHo 1999, pp.vii-x.
} 
the deity's arrival within the sphere of Drepung Monastery. Finally, in the seventeenth century, the Fifth Dalai Lama standardized and expanded Nechung's mythic, ritual, and institutional significance, making the monastery an important part of his secular and religious government.

\section{Institutional Connection}

While Pehar's place at Nechung Monastery has been the focus of this work, the Vairocana prophecy described in chapter 3 suggests that a more ancient association exists between the deity and Dambak Marserchen valley. Indeed, it appears that Pehar had been present in this valley in some fashion prior to even the 1529 founding of Nechung Chapel. Although Waddell's account of Pehar's arrival at Nechung claims that the deity was too impure to enter Drepung, ${ }^{31}$ a more ancient and authoritative Tibetan source states that he was partially responsible for the founding of the monastery itself. The famed Geluk hierarch Paṇchen Sönam Drakpa, ${ }^{32}$ who was abbot of both Drepung and Ganden Monastery, composed an important history of the Kadampa and early Geluk traditions in the early sixteenth century. This work is a precursor to Sangyé Gyatso's Yellow Beryl, and it understandably discusses the founding of Drepung Monastery by Jamyang Chöjé Tashi Penden. ${ }^{33}$ In the following account from Paṇchen Sönam Drakpa's text, Jamyang Chöjé encounters Pehar in a dream, though the deity is called by an older name:

Wonderful omens arose in a dream that [Jamyang] Chöjé [experienced], such as [the following]: the god called Namdé Karpo ${ }^{34}$ showed him a place for the monastery and said, "[If] you build a monastery here, I will give you 5,000 monks." Immediately, [Jamyang Chöjé] walked up from lower Denbak [Dambak] Valley and saw that there were many ponds of 'spiritually enriching water.' In particular, at the foot of Elephant Mountain, the Precious Lord [Tsongkhapa] sat near many of [these] ponds and said, "Because these are the ponds of hearing and contemplating [the Buddha's teachings], [you should] drink [from them]." From the combination of both [this dream and previous requests to establish a

\footnotetext{
${ }^{31}$ See chapter 3, p.190.

32 Pan chen Bsod nams grags pa, 1478-1554; TBRC: P101.

33 'Jam dbyangs chos rje Bkra shis dpal ldan, 1379-1449; TBRC: P35.

${ }^{34}$ For a variant spelling of this name, see chapter 1, note 257.
} 
monastery], [Jamyang Chöjé] founded the great Dharma center of Glorious Drepung in the Fire-Male-Monkey year [1416], at the age of $38 .^{35}$

After being requested several times by Tsongkhapa himself to build a monastery, this auspicious dream helped to galvanize Jamyang Chöjé's resolve. Drepung's construction was then patronized by Namkha Zangpo, ${ }^{36}$ the wealthy leader of Neudzong, ${ }^{37}$ at Tsongkhapa's advice. ${ }^{38}$ Pehar's involvement illustrates that the deity was already believed to have a strong connection to Drepung even by the early fifteenth century, if not earlier.

This connection was further strengthened during the lifetime of Jokpa Jangchup Penden. As discussed in the last chapter, Jangchup Penden founded Drepung's Deyang College, the smallest of the monastery's colleges. Decades later this figure established Nechung Chapel downhill from Drepung, and from that time on the college and chapel have been closely linked. While there is textual disagreement as to how Pehar came to Nechung-whether the Second Dalai Lama brought Pehar back to Drepung, as the Nechung Register claims, or Jangchup Penden had Pehar retrieved from the Kyichu River, as his hagiography claims - in either case an important Drepung throne-holder was responsible for establishing the deity in the valley.

The Ganden Podrang was established at Drepung by the Second Dalai Lama in 1518, a little over a century after the monastery's founding. From that time on the lineage of the Dalai Lamas has been intimately linked to the institution of Drepung. The Fifth Dalai Lama resided at Drepung Monastery since he was a child and he inherited the Ganden Podrang through his incarnation lineage; both institutions took on vastly greater political significance in his lifetime. Since Pehar already had preexisting ties to Drepung through the monastery's founding myth, as well as through Jokpa Jangchup Penden and the Second Dalai Lama, this made him an excellent

\footnotetext{
${ }^{35}$ Pan chen Bsod nams grags pa 2007, p.119: chos rje ba'i rnal lam du'ang lha rnam lde dkar po yin zer ba zhig gis dgon pa'i sa yul bstan tel 'dir khyod kyis dgon pa gcig thob/ngas btsun pa stong phrag lnga 'bul zer/ de ka'i mod la dan 'bag mda' nas yar byon pas longs spyod kyi chu yin zer ba'i rdzing bu mang po 'dug pa gzigs cing khyad par glang chen ri gdong du rdzing bu mang po'i 'gram na rje rin po che bzhugs nas 'di rnams thos bsam gyi rdzing bu yin pas 'thung gsung ba sogs kyi bltas ya mtshan can byung pa gnyis tshogs las/ nyid kyi dgung lo so brgyad pa me pho spre'u'i lo la dpal ldan 'bras dpungs kyi chos sde chen po btab/. This dream is elaborated upon in Sangyé Gyatso's Yellow Beryl, which states that it took place at Neudzong in the Wood-Sheep year (1415). This account further interprets Namdé Karpo to refer to the "sovereign spirit of speech, the enemy-defeating god Kyechik [Marpo] and his minister [Dorjé Drakden] (Tib. gsung rgyal dgra lha skyes gcig dpon blon); see Sangs rgyas rgya mtsho 1980, vol.1, pp.168.4-169.2. See also Thub bstan phun tshogs 2007, pp.67-69, and Mig dmar tshe ring 2010, pp.7073.

${ }^{36}$ Tib. Nam mkha' bzang po.

${ }^{37}$ Tib. Ne'u rdzong.

${ }^{38}$ See Pan chen Bsod nams grags pa 2007, pp.118-119.
} 
candidate for the protector deity of the government that spread out from this monastery. Though the deity's origins were in Nyingma rituals and the Tselpa Kagyü polity, Pehar's early association with Drepung brought him into the Geluk sphere of influence just as much as the Second Dalai Lama's Offerings and Praises did, if not more so. Rather than needing to forge an institutional bond, the Fifth Dalai Lama was able to tap into one that already existed between Pehar and Drepung.

\section{Mongolian Connection}

Although not a distinct lineage, one final connection concerns Mongolia. As discussed in the introduction, Güshi Khan, the leader of the Khoshut Mongols, was responsible for the Fifth Dalai Lama's rise to power. Having effectively ended the civil war in Tibet, the Mongolian prince gave the Great Fifth full religious authority over the Land of Snows, with secular authority following not long after. ${ }^{39}$ Güshi Khan and the Fifth Dalai Lama had a close relationship, which was strengthened by historical precedence. The doner-donee relationship (Tib. yon mchod) established between this Mongol Khan and the Great Fifth was likened to the thirteenth-century relationship between the Sakya hierarch Pakpa Lodrö Gyentsen ${ }^{40}$ and Kublai Khan (1215-1294), the grandson of Genghis Khan. ${ }^{41}$ Moreover, this relationship reflected more recent lineal associations, namely the connection between Altan Khan and the Third Dalai Lama, as well as the Fourth Dalai Lama, who was Altan Khan's great grandson. As discussed in chapter 3, the alliance between Altan Khan and the Third Dalai Lama was prompted by the Nechung Oracle's persistent advice. Furthermore, Pehar had come to Tibet from Mongolia in the eighth century, having resided in an area close to Qinghai Lake - called Kökönor in Mongolian - which is where Güshi Khan would establish his base in $1637 .^{42}$ This account placing Pehar in Mongolia became the preferred narrative in the Fifth Dalai Lama's autobiography, as discussed above. This added connection buttressed ties between the Gelukpa and the Khoshut Mongols and made Pehar's cult especially valuable. One could even perceive Pehar as a divine personification of the Mongol Khan - he is a skilled Warrior King that leads an

\footnotetext{
${ }^{39}$ See Yamaguchi 1995.

${ }^{40}$ Tib. 'Phags pa Blo gros rgyal mtshan, 1235-1280; TBRC: P1048.

${ }^{41}$ See Schaeffer 2005a, p.68.

${ }^{4}$ See Pommaret 2003, p.71.
} 
army yet he is religiously-oriented, defeating the Dalai Lama's enemies to protect and propagate the Dharma.

As Giuseppe Tucci rightly observed, Pehar's various geomythological allegiances allowed the Great Fifth to have his cake and eat it too. The deity's Mongolian past made him ideal for strengthening political ties to Güshi Khan while his former relationship with Dharmapāla, the Fifth Dalai Lama's royal ancestor, connected Pehar to India, the preeminent source of Buddhist religious legitimation. ${ }^{43}$ Although the Great Fifth engaged with a large and diverse pantheon of deities, with each being important in their respective contexts, ${ }^{44}$ Pehar was elevated to a particularly high status of state worship at Nechung because of the several lineal and historical connections the deity shared with the Dalai Lama. This multilayered relationship made the sovereign spirit a more suitable choice than other deities with whom the Great Fifth had only one or two connections. Pehar was one deity-from which others emanated-who embodied and promoted the ancestral, transmissional, incarnational, institutional, and geopolitical justifications for the Fifth Dalai Lama's grand unification of Tibet.

\section{Institution-building and the Power of People}

In his famous treatise on charisma and institution-building, Max Weber defines charisma as "a certain quality of an individual personality by virtue of which he is set apart from ordinary men and treated as endowed with supernatural, superhuman, or at least specifically exceptional powers or qualities. These are such as are not accessible to the ordinary person, but are regarded as of divine origin or as exemplary, and on the basis of them the individual concerned is treated as a leader." 45 Although the term has since been secularized, this original meaning for charisma involved an overtly preternatural characteristic. Weber explains that in order to maintain and stabilize the organization or group that is formed through the charismatic efficacy of a leader, this power must be routinized. Weber himself already perceived the lineage of the Dalai Lama as embodying this routinized charisma, so this argument is not new. ${ }^{46}$ Nonetheless, I posit that

\footnotetext{
${ }^{43}$ See Tucci 1999, vol.2, p.736.

${ }^{44}$ See Heller 2005b.

${ }^{45}$ Weber 1968, p.48.

${ }^{46}$ See ibid, p.55. For Weber's principles by which 'pure charisma' is transformed into 'routinized charisma,' see ibid, pp.54- 58 .
} 
this understanding can be extended not just to the Nechung Oracle but to several religious and government officials who were part of the Fifth Dalai Lama's court, and whose authority and legitimation likewise drew from previously established charisma.

Weber's sociological conception of the 'prophet'-though predominantly JudeoChristian in orientation - maps fairly well onto both the Dalai Lama and the Nechung Oracle. For Weber, as a 'bearer of charisma,' a prophet 'proclaims a religious doctrine or divine commandment" as either a 'renewer of religion' or a 'founder of religion. ${ }^{47}$ The key qualities of a charismatic prophet are that they "do not receive their mission from any human agency," 48 they are "closer to that of the popular orator (demagogue) or political publicist than to that of the teacher," apply to both the Dalai Lama and the Nechung Oracle, though perhaps in different capacities. The Fifth Dalai Lama was a renewer of religion while the Nechung Oracle's abilities drew primarily from a divine source. Both were believed to receive their mandates from a higher order, and the Nechung Oracle's principal duty was to offer divine injunctions. The Dalai Lama and the Nechung Oracle epitomize routinized charisma, since the former has been recognized in a chain of over a dozen individuals while the latter has been recognized in numerous mediums spanning several centuries.

The Fifth Dalai Lama may have executed the seventeenth-century growth of the Nechung cult, but like all great executives he did not act alone. Along with the Nechung Oracle-acting through several mediums - the Regent Sangyé Gyatso was the Great Fifth's second-in-command near the end of the leader's life. When the Dalai Lama passed away, the regent secretly ruled Tibet in his stead and cemented the Great Fifth's legacy with his copious writings. ${ }^{51}$ The second text of the Nechung Liturgy details Sangyé Gyatso's past lives, the most significant of which is the son of King Trisong Deutsen, Prince Muné Tsenpo, after whom the text is titled. Since the Fifth Dalai Lama was a reincarnation of Trisong Deutsen, through Nyangrel Nyima Özer, it is fitting that his spiritual son Sangyé Gyatso was the king's biological son in a past life. ${ }^{52}$ As discussed last chapter, Muné Tsenpo was also responsible for building the first small Nechung

\footnotetext{
${ }^{47}$ See ibid, p.253.

${ }^{48}$ Ibid, p. 258.

${ }^{49}$ Ibid, p. 261.

${ }^{50}$ Ibid, pp.261-262.

${ }^{51}$ See Schaeffer 2005a, pp.72-73.

${ }^{52}$ This text lists several of Sangyé Gyatso's past lives, most of which were the sons of the Fifth Dalai Lama's former incarnations; see chapter 3, note 168 .
} 
Monastery as a shrine for the deity who would later inhabit it. By expanding and completing the monastery, Sangyé Gyatso was simultaneously 'reliving' and fulfilling his past self's obligation toward Nechung.

The regent was not the only one to harness the power of the mythic past. Terdak Lingpa, the treasure-revealer who composed the first known description of Dorjé Drakden, was considered a reincarnation of the translator Vairocana. ${ }^{53}$ It will be recalled that Prince Muné Tsenpo built Nechung in response to the miraculous visions Vairocana beheld at the site of its future location. Padmasambhava then interpreted these visions, associating the nearby birch tree and small pond with Pehar. Terdak Lingpa also founded Mindröling Monastery, the main center for the Southern Treasures tradition, giving his charismatic authority an institutional base. The Buddhist concept of rebirth has allowed significant past events to be literally embodied by these figures and several other contemporary reincarnations.

Other important figures associated with the Fifth Dalai Lama evoke a grand cosmic vision of Tibet, where divine beings play out epic narratives in human form. For example, while the Dalai Lama is an emanation of the Bodhisattva Avalokiteśvara, the Panchen Lama is an emanation of the Buddha Amitābha; the latter lineage held the throne at Tashi Lhünpo Monastery ${ }^{54}$ near Shigatse. Sangyé Gyatso was likewise referred to as Maniidhārin, the divine son of Avalokiteśvara. Furthermore, lineages of legitimation continue to have a strong presence, acting as constant tethers to the past. The Fifth Dalai Lama had visions of, and dream encounters with, Lekden Dorjé and Tashi Topgyel Wangpödé- two important transmitters of the Northern Treasures tradition based at Dorjé Drak Monastery—and they would give him empowerments or advice in these states. ${ }^{55}$ The Great Fifth's initiations into this and related traditions were overseen by important contemporary upholders of the lineage, such as Chöying Rangdröl and Tratsangpa.

Most of these figures have been encountered in previous chapters as important members of the Dalai Lama's circle, and each possessed significant religious and/or political authority in their respective domains. By their combined charisma, as well as through the powerful mythos in which they were bound up, these individuals made up a larger institutional enterprise that drew on Tibet's imperial past for legitimation. This efficacious network not only bolstered

\footnotetext{
${ }^{53}$ See Sangs rgyas rgya mtsho 1980, vol.2, p.204.6.

${ }^{54}$ Tib. Bkra shis lhun po dgon pa.

${ }^{55}$ See Karmay 1988, pp.30, 37.
} 
Nechung's heritage and authority, but also that of the nascent Tibetan government as a whole. This was a necessary mechanism for instilling greater power in a government, the supremacy of which was not a foregone conclusion in the latter half of the seventeenth century. ${ }^{56}$

Mythic, lineal, and institutional networks were constructed and maintained by this alliance of charismatic individuals. These networks were, in turn, reinforced by a constellation of intersecting and overlapping ritual mandalas. The numerous sacred sites discussed in this work, whether directly or indirectly associated with Nechung, create a ritual map of Lhasa that began to flourish in the seventeenth century and which continued to grow for centuries afterward. This network is ultimately a series of overlapping mandalas, each with different representations of emplaced power. For instance, there is the Nechung mandala, where Nechung symbolically resides at the center of other institutions that serve Pehar's emanations; the government's mandala, with which Nechung is closely affiliated and serves several important functions; and the Jokhang mandala during the Tibetan New Year, when the Nechung Oracle and monks must come into the city and reside at Meru Nyingpa, playing second fiddle to the larger Buddhist cosmos being enacted during the Great Prayer Festival.

Nechung's growth vividly illustrates how religious beliefs, actions, and institutions accrue over time. Historical individuals, like the Fifth Dalai Lama, are motivated by their devotion to ahistorical figures, like the Nechung deity; through their charismatic authority, such individuals then enhance or create new sacred centers, ritual programs, and institutional affiliations. Deities like Nechung, in turn, are believed to continually act in history by becoming temporarily incarnate in oracles. These incarnate deities then propagate and promote their own cult by requesting new rituals and chapels; by their very presence they expand on their evergrowing mythos. Belief in deities spurs action, which creates history. History is then viewed through the lens of divine involvement, maintaining belief in deities in a cyclical and mutually reinforcing fashion. Contrary to popular conceptions in the Euro-American sphere, myth and history are not mutually exclusive, and rooting out the former will not necessarily bring one closer to the latter. Using the Nechung cult as a case study, the present work offers one method for approaching and understanding the historical impact of Tibetan deity cults, as well as the worship of divinities in other religious traditions more broadly.

\footnotetext{
${ }^{56}$ See Yamaguchi 1995.
} 


\section{A Modern Encounter}

The Fifth Dalai Lama used his relationship with Pehar to help legitimate his rule, strengthening symbolic and spiritual connections between his burgeoning government and Tibet's imperial past through several venues. Regardless of this utilitarian dimension, it is clear from the Great Fifth's numerous writings that his devotion and connection to Pehar was an earnest one. The Dalai Lama wrote his autobiography, quickly completed the Adamantine Melody, composed several other rituals, and made political decisions all based on the Nechung Oracle's advice. As far as the Great Fifth was concerned, he was acting just as much for Pehar as Pehar was acting for him - the two maintained a mutually-beneficial friendship.

Although the deity's cult was propelled to the level of state cult under the Fifth Dalai Lama's rule, Pehar was clearly a popular, if capricious, deity prior to this. Unfortunately, it is difficult to ascertain the characterization of the Nechung cult among the populace during the seventeenth century, since writings from this era on the Five Sovereign Spirits and related deities are of a predominantly institutional nature. Nevertheless, modern oral narratives could reveal something of how the lay populace interacted with the Nechung deities, and other spirits and oracles, in the past. To conclude, I would like to present an ethnographic account that demonstrates how divinities and spirits affect Tibetans on a regular basis today, and which have no doubt acted as such in bygone eras. The following account was relayed to me by a Tibetan man who is a native of Lhasa and it concerns the health problems his father experienced. This narrative was recorded on November 24, 2011, and the names have been changed to protect the identities of those involved:

Jikmé's father was having heart problems in the summer of 2011. He tried modern medical help but it failed him. Jikmé's mother recommended seeking the advice of a former monk in Chongyé, Lhoka, where Jikmé's mother and family were from. When they consulted the ex-monk, he advised them to enlist the help of the local Nyima Zhönnu oracle. This was a woman in her early thirties who had only been to Lhasa once and she had a strong Lhoka dialect. They discussed the situation with the oracle while she was in trance and her demeanor changed to that of an old Tibetan woman - she even spoke in a Lhasa dialect. The oracle ascertained that the cause of the father's illness was that a spirit had taken up residence in his chest. This was not just any spirit either, but that of Jikmé's uncle, his father's younger brother Döndrup. Döndrup 
had been tragically murdered a few years ago. Determining this to be the cause, the oracle agreed to come to Lhasa and help Jikmé's father.

Tibetans generally believe that an individual's soul (Tib. srog) is under the care of whoever is the landlord spirit of the place in which they were born. Jikmé's landlord spirit was King Chugyü ${ }^{57}$ at Karngadong ${ }^{58}$ near Lhasa. As for Jikmé's father and uncle, their landlord spirit was Jatri Chenchik at Karmasha Chapel. Because of this, the Nyima Zhönnu medium had to go to Karmasha and beseech Jatri Chenchik to give her temporary control over the souls of these two men before she could attempt to cure them. While the medium entreated the deity, Jikmé and his family offered the deity butter lamps and other items. After the request was made, Jatri Chenchik fortunately gave the medium permission to control the souls-presumably she could clairvoyantly hear his response. The medium used a 'soul bag' to hold Uncle Döndrup's spirit before proceeding to the family's home where the ailing father was. This exchange was conducted without the medium being possessed.

At the family home the medium went into trance, with an older man accompanying her and reciting a ritual text to incite the possession. Once under control of Nyima Zhönnu, the oracle proceeded to have a conversation with the uncle's spirit inside Jikmé's father. She confirmed that he had two daughters and requested that he leave so as not to cause anymore harm. According to Jikmé, Uncle Döndrup was stuck in the intermediate state and needed to move on to one of the other six Buddhist realms of rebirth. Eventually the uncle's spirit agreed to leave, but only if the father promised to conduct certain religious services after he left. It was not clear to Jikmé what all of these services were, but one apparently involved renovating a Buddhist reliquary. After accepting the uncle's demands, the work was done and the oracle left. Within a week the father's heart problems were gone and he was healthy again.

This account illustrates several noteworthy points. It vividly shows an oracle as a healer rather than just a soothsayer; the Nyima Zhönnu oracle used her powers of divination to assess an illness and responded with the appropriate remedy. It also illustrates just how many different types of spirits Tibetans interact with on a daily basis, and how these divinities interact with each other. In this narrative alone there is an oracle-possessing deity, a monastery protector deity who is also a landlord spirit, a ghost, and the souls of sick individuals. Most significantly, the main deities in this account are Nechung deities. Jatri Chenchik is the minister of Mönbuputra, the

\footnotetext{
${ }^{57}$ Tib. Chu rgyud rgyal po.

${ }^{58}$ Tib. Mkhar rnga gdong.
} 
eastern sovereign spirit of the body, and Nyima Zhönnu has been an important protector at Nechung since her adoption by the Seventh Dalai Lama in the eighteenth century. Clearly the institution-building activities of the seventeenth century had repercussions that reverberated to today. Finally, this account intimates that while Pehar and the other Nechung Dharma protectors are historically, politically, and ritually significant, they represent only a small part of the vast ocean of deities, spirits, and ghosts that Tibetans regularly contend with.

By exploring mythology, history, and biography—all of which converge at ritual — this work has shed light on why and how Pehar's cult at Nechung expanded rapidly in the seventeenth century and has flourished since then. Pehar was chosen to protect the Tibetan government, over and above other deities, because of his many close connections to the Fifth Dalai Lama. Furthermore, Pehar was ideally placed considering his former ties to Samyé, Tibet's first Buddhist monastery, and to the Tselpa Kagyü hierarchs, the previous political power brokers of central Tibet. He likewise had preexisting ties to Drepung Monastery, the Fifth Dalai Lama's home institution. The deity's ambiguous origins also aided his propagation by associating him with both Mongolia and India. His Mongolian origins made him a suitable symbol to reinforce the relationship between the rising Geluk hegemony and Güshi Khan's Mongolian forces. His Indian origins made him a legitimate Buddhist deity to revere, given the strong validating force India has always been in Tibetan Buddhism. In this instance, the belief in Pehar's Indian and Mongolian roots is more important than whatever his actual origins may have been-narrative trumps historicity.

The Nechung cult was promoted and expanded through several mechanisms - mythology, ritual, prophecy, dreams and visions, and architectonics. These mechanisms required the performance and interpretative power of charismatic and influential authority figures like the Fifth Dalai Lama, members of his administration, and affiliated religious leaders. This elaborate orchestration, taking place over decades and even centuries, illustrates that no deity stands alone and that rising cults require strong mythological, institutional, and interpersonal networks to support and propagate them. In the Tibetan imaginaire, this work has concerned the centurieslong friendship of two immortals: one a bodhisattva that reincarnates every lifetime, the other a god that possesses a human medium each generation-ultimately, they both represent the play (Tib. rol pa) of the Buddhas. 


\title{
Appendix I
}

\section{An Outline of the Nechung Liturgy}

The Nechung Liturgy is available in the following two editions:

\begin{abstract}
Bskal bzang rin chen (19th cent.). 1969. Sa Gsum Na Mngon Par Mtho Ba Rdo Rje Sgra Dbyangs Gling Gi Zhal 'Don Bskang Gso’i Rim Pa Phyogs Gcig Tu Bsgrigs Pa'i Ngo Mtshar Nor Bu'i 'Phreng Ba Skal Bzang Gzhon Nu'i Mgul Rgyan: The collected liturgical texts of Gnaschung Rdo-rje-sgra-dbyangs-gling, the residence of the State Oracle of Tibet. Gangtok: Sonam Topgay Kazi.
\end{abstract}

Lobzang Tondan, ed. 1983. The Collected Works of Liturgy of the Gnas-chun Rdo-rje-sgradbyañs-glin Monastery, 3 vols. Delhi: Lobzang Tondan. TBRC: W00EGS1016248.

The 1969 edition is a reproduction of the original 1845 xylographic collection entitled $A$ Marvelous Garland of Jewels that Adorns the Neck of the Fortunate Youth: A Collected Series of Prayers and Mending Rituals for the Palace of Adamantine Melody, Exalted in the Three Realms (Tib. Sa gsum na mngon par mtho ba rdo rje sgra dbyangs gling gi zhal 'don bskang gso'i rim pa phyogs gcig tu bsgrigs pa'i ngo mtshar nor bu'i 'phreng ba skal bzang gzhon nu'i mgul rgyan). This work is approximately 90 folios long and consists of 42 distinct texts. The 1983 edition contains the same 1969 edition of $A$ Marvelous Garland of Jewels while adding 54 more texts, making the collection three volumes long and consisting of several hundred folios. This supplemental content was added in the late-nineteenth to early-twentieth century, during the time of the Thirteenth Dalai Lama, and is a further example of liturgical accretion (see chapter 3).

For the purposes of this work, the Nechung Liturgy refers only to the self-contained 42text collection, A Marvelous Garland of Jewels. Additionally, there are 4 extra folios of content in the 1983 edition of the Nechung Liturgy that are not found in the 1969 edition. These extra folios are discussed in chapter 3 and translated in Appendix IIc. For this reason, the edition cited in this dissertation and indexed below is the 1983 edition. It should be noted, though, that both Lhasa and Dhasa Nechung Monasteries currently use the 1969 edition of the Nechung Liturgy in their ritual performances. 
The structure of the below outline is divided into three columns and forty-two rows. The first column assigns a number to each text, the second provides the text title in the Wylie Tibetan transliteration scheme, and the third gives the page numbers for each text according to the 1983 edition pagination. If provided in the original text, each text title is also accompanied by a summary of significant provenance data, such as author, scribe, date of composition, and location of composition, as well as significant notes.

\#

1 sa gsum na mngon par mtho ba rdo rje sgra dbyangs gling gi zhal 'don bskang gso'i rim pa phyogs gcig tu bsgrigs pa'i ngo mtshar nor bu'i 'phreng ba skal bzang gzhon nu'i mgul rgyan A Marvelous Garland of Jewels that Adorns the Neck of the Fortunate Youth: A Collected Series of Prayers and Mending Rituals for the Palace of Adamantine Melody, Exalted in the Three Realms

\section{Pages}

$1-5.5$

Author: Fifth Dalai Lama (1617-1682; TBRC: P37)

Scribe: Dpal grong sngags rams pa Ngag dbang dge legs

Note: This is the collection title and its textual material acts as a preface to the content that follows

2 lha sras mu ne'i zlos gar mi dbang sangs rgyas rgya mtsho'i ('khrungs $5.5-11.4$ rabs gsol 'debs) thog med bskal pa ma

Author: Fifth Dalai Lama (1617-1682; TBRC: P37) explaining to Regent Sangye Gyatso (1653-1705; TBRC: P421)

3 gangs can mgon po thams cad mkhyen gzigs chen po rgyal mchog na $\quad 11.4-12.4$ rim gyi zhabs brtan nub phyogs bde ldan ma

Author: Nechung Oracle prophesy

$4 \quad$ rgyal po chen po sde lnga la gsol mchod 'bul tshul 'phrin las 'gags $12.4-53.1$ med rdo rje'i sgra dbyangs

Author: Fifth Dalai Lama (1617-1682; TBRC: P37)

Note: Based on Nyangrel Nyima Özer's Ten-Chapter Sādhana, the Second Dalai Lama's Offerings and Praises, and Ratna Lingpa's Assembly of the Quintessential Mind Attainment. Transcribed and translated in Appendix IIc. Rites to Makzor Gyelmo are appended to the end of the text (pp.49.5-53.1) 
Author: Composed by Padmasambhava, rediscovered by Nyangrel Nyima Özer (1124-1192; TBRC: P364)

Note: Transcribed and translated in Appendix IIa.

$6 \quad$ rdo rje grags ldan gyi mngon rtog gong 'og gnyis

$75.4-77.5$

Author: Gter bdag gling pa 'Gyur med rdo rje (1646-1714; TBRC: P7)

7 chos rgyal chen po'i gsol kha rgyal pa mkhyen brtse ma

$77.5-80.5$

Author: Fifth Dalai Lama (1617-1682; TBRC: P37)

Scribe: Blo bzang nor bu

Date of composition: 3rd month of the Iron-Rabbit year [1651] (lcags yos nag pa zla ba)

Note: Composed at the behest of the Nechung Oracle after the Dalai Lama offered an image on the God Day of the $3^{\text {rd }}$ month.

8 gsol kha ’jam dpal gshin rje ma

$80.5-83.4$

Author: Fifth Dalai Lama (1617-1682; TBRC: P37)

Scribe: Dge slong 'Jam dbyangs grags pa (b. $17^{\text {th }}$ cent; TBRC: P2277)

Date of composition: 15th day of the 6th (Mongolian) month of the Earth-Sheep year [1679] (sa lug hor zla drug pa'i tshes bco lnga'i nyin)

Note: Composed at the request of the Nechung Oracle.

9 chos rgyal chen po'i spyan 'dren gung sngon ma

$83.4-84.2$

Author: Fifth Dalai Lama (1617-1682; TBRC: P37)

Scribe: Dpal grong Sngags rams pa (Ngag dbang dge legs)

Note: Composed at the request of the Nechung Oracle as a pithy supplication to supplement the Don-bcu-ma.

10 rgyal po chen po'i mdos bsngo rgyas pa dngos grub chang 'bebs ma

$84.2-91.5$

Author: Fifth Dalai Lama (1617-1682; TBRC: P37)

Scribe: Rgya mtsho

Note: Composed at the request of the Nechung Oracle, during the establishment of a thread-cross at Nechung.

11 mdos gsol 'bring po gyeng gzhung bsam don lhun grub ma 91.6-94.2

Author: Fifth Dalai Lama (1617-1682; TBRC: P37)

Scribe: Sngags ban ngag dbang 'phrin las

Note: Composed at the request of the Nechung Oracle during the establishment of a new thread-cross support at Nechung. 
12 chos rgyal chen po'i mdos bsngo rgyun 'khyer las bzhi lhun grub

Author: (?) Tā la'i bla ma 07 Skal bzang rgya mtsho (1708-1757;

TBRC: P179)

Site of composition: Se ra theg chen gling

Note: Requested by the Nechung medium Blo bzang bkra shis, as well as the Nechung head chanter Blo bzang bsod nams

13 mdos chog bsags skabs mdos bsngo bsdus pa

$98.3-98.4$

Author: Nechung medium Ngag dbang rgya mtsho (installed 1747)

14 'dod gsol bod yul lha gcig ma

$98.4-99.6$

Note: Essence of words transferred from the Fifth to the Sixth Dalai Lama (involving consciousness transference)

15 chos rgyal chen por bstod bskul bshags tshig dam tshig rdo rje ma

$99.6-102.2$

Author: Regent Sangye Gyatso (1653-1705; TBRC: P421)

16 gtang rag gdod nas sangs rgyas ma

$102.2-104.4$

Author: Tā la'i bla ma 07 Skal bzang rgya mtsho (1708-1757; TBRC: P179)

Site of composition: Namgyel Monastery (Phan bde legs gshad gling)

Date of composition: starting from the auspicious astrological juncture of the sun and Jupiter (Tib. mi [sic: me] bzhi) on the 4th day of the 7th month of the Wood-Pig year [1754]

Note: The lengthy colophon details how this rite was composed.

17 chos rgyal chen po'i gsol kha lhun grub bde chen ma

$104.4-109.5$

Author: Tā la'i bla ma 07 Skal bzang rgya mtsho (1708-1757; TBRC: P179)

Site of composition: A place above Minyak [Likely Li thang or Mgar tar]

Date of composition: 1728-1735 (The period of the Seventh Dalai Lama's exile in Khams)

Scribe: Secretary (drung yig) Tshangs skyes blo ldan

Note: Requested by Bsod nams dar rgyas

18 sger gsol ye shes lnga ldan ma

$109.5-111.3$

Author: Tā la'i bla ma 07 Skal bzang rgya mtsho (1708-1757; TBRC: P179)

Site of composition: Glorious Drepung Monastery 
Date of composition: the 3rd day of an autumn month of the FireSheep year [1727]

Note: Requested by Dorjé Drakden, who took visible form by possessing an individual [likely the Nechung Oracle], and whose vajra speech required that it be a concise expression of what was previously said (not sure what this refers to)

19 gsol kha dngos grub kun mkhyen ma

$111.3-112.3$

Author: Tā la'i bla ma 07 Skal bzang rgya mtsho (1708-1757; TBRC: P179)

Date of composition: Fire-Rabbit year [1747]

Note: Requested by Khri chen rdo rje 'chang, when Gnas chung chos rgyal chen po entered the Kuten's core and they became indistinguishable.

20 gsol mchod stong khams dregs pa ma

$112.3-112.6$

Author: Tā la'i bla ma 07 Skal bzang rgya mtsho (1708-1757; TBRC: P179)

Note: Requested by the translator (lo ts + tsha ba) Sbyin pa rgya mtsho

21 bshags pa bsam pa'i re bskong ma

$112.6-113.5$

Author: Tā la'i bla ma 07 Skal bzang rgya mtsho (1708-1757; TBRC: P179)

Author: Tā la'i bla ma 07 Skal bzang rgya mtsho (1708-1757; TBRC: P179)

Date of composition: 13th day of the [unknown] month of the WoodSnake year [1725]

Rough Colophon translation: This is the manner of calling upon the samaya commitment of and entrusting the activities to the great leader of the haughty spirits (dregs pa'i sde dpon chen po) Dorjé Drakden. Because there were many various mediums for the great Dharma Protector, the cabinet ministers by necessity determined that there should be [only] one medium, as in the past. In accordance with this determination, on the 13th[?] day of the X month of the Wood-Snake year [1725], they offered balls of dough in front of the self-arise statue of Avalokitesvara [in the Jokhang]. Then, when the medium Tshangs dbyangs rta mgrin (served 1725-1747) came to Nechung, [the deity] manifested and said, "a ritual must [be written]!" The cabinet ministers and others requested this and, accordingly, the Seventh Dalai Lama composed it. 
23 mnga' gsol yon tan lhun rdzogs ma

$114.4-115.5$

Author: Tā la'i bla ma 07 Skal bzang rgya mtsho (1708-1757; TBRC:

P179)

24 lha bsang rgyags rngan grangs bsogs skabs las gzhung tshar gcig 115.5-116.1 sngon du song nas

\section{No colophon}

25 chos rgyal chen po'i gsol kha 'phrin las dang bcas pa dus gsum rgyal $116.1-118.2$ ba ma

Author: Recited by the Nechung Oracle

Scribe: Second Dalai Lama (1476-1542; TBRC: P84)

Site of composition: Jokhang Temple

26 bstan skyong rdo rje drag mo rgyal gyis gsol mchod gangs ri'i 'phreng $118.3-123.3$ ba ma

Note: Improved and arranged with a few parts taken from the writings of the Second Dalai Lama (1476-1542; TBRC: P84)

27 'dod khams dbang phyug dmag zor rgyal mo'i gsol mchod rlung nag $123.3-126.6$ gur phub ma

Author: Fifth Dalai Lama (1617-1682; TBRC: P37)

Scribe: 'Phyong rgyas lkog pa Phun tshogs dbang po

Note: Composed out of samaya commitment to [Dorje Drak?]

Rig 'dzin sprul sku rin po che

28 lha mi'i 'dren mchog pan chen blo bzang chos rgyan gyi gsung lha mi'i 126.6 - 128.1 bshags pa rdo rje 'chang dbang ma

\section{No colophon}

Author: Spoken by Pan chen 04 Blo bzang chos kyi rgyal mtshan (1570-1662; TBRC: P719)

29 bstan ma bcu gnyis kyi spyi gsol na mo bzhin mi ma

$128.2-130.3$

Author: Collected by Mnga' ris Pan chen Padma dbang rgyal (14871542; TBRC: P1699)

Author: Sle lung rje drung bzhad pa'i rdo rje (1697-1740; TBRC: P675) 
Date of composition: After 30th day of the 7th month of the EarthMonkey year of the 13th rabjung [1788; corrected to 12th rabjung: 1728]

Note: On the $25^{\text {th }}$ he came to the Jokhang and received teachings; on 30th day, he went to the Dga' ldan khang gsar of Pholhaba Sonam Topgyal, (1698-1747), then Potala to meet with Dalai Lama and ministers.

31 gsol kha snang med bde chen ma

$137.1-140.2$

\section{No colophon}

32 dpe har chos kyi rgyal po'i bskang gso dregs pa'i sde dpon mnyes 140.3-151.4 phyed zla ba gsar pa dam nyams dgra dpung 'joms byed

Author: Rwa sgreng A chi thu No mon han Blo bzang ye shes bstan pa rab rgyas (1759-1815; TBRC: P304)

Site of composition: his own dwelling, Lnga ldan 'od snang, at Pha bong kha

Note: Requested by Lcang skya 04 Ye shes bstan pa'i rgyal mtshan (1787-1846; TBRC: P3610). For another version of this text see TBRC: W7335, vol. 4.

33 rtsa gsum bskang gso dgyes pa'i rol gar

Author: Revealed by Rgyal sras Rdo rje gling pa (1346-1405; TBRC: P6164)

Author: Gnubs sangs rgyas ye shes ( $8^{\text {th }}$ century)

Note: This brief recitation is apparently meant to precede all other ritual components

35 snang srid dregs pa ma

$158.3-159.3$

Author: De mo 08 Blo bzang thub bstan 'jigs med rgya mtsho (17781819; TBRC: P1812)

Date of composition: Fire-Ox year [1817]

Author: Spoken by the Nechung medium Ngag dbang rgya mtsho (installed 1747) 
Author: Arranged by the Nechung medium Ngag dbang rgya mtsho (installed 1747) during a feast and mending ritual (Tib. tshogs bskong) for the Five Great Sovereign Spirits

38 btsan gsol mnga' ris pa pan chen sku mched kyi gter gzhung lhad med

Author: Mnga' ris Pạn chen Padma dbang rgyal (1487-1542; TBRC: P1699)

Note: This work is available in six other collections.

39 (dge 'dun rgya mtsho'i gsung [nas]) ja mchod 'dren pa mnyam med ma $164.2-165.2$ dang / 'khor 'das rgyal po ma

Author: Fifth Dalai Lama (1617-1682; TBRC: P37)

Note: Based on the writings of the Second Dalai Lama (1476-1542;

TBRC: P84)

40 mnga' gsol don gnyis sku gsum ma

$165.2-167.2$

Author: De mo 07 Ngag dbang 'jam dpal bde legs rgya mtsho (d.1777;

TBRC: P1788)

Date of composition: the 9th day of the 12th month of the Earth-Tiger [1758]

Site of composition: Potala, Gzims chung Kun bzang bde chen

Note: A longer alternative title is provided in the colophon: Gnas chung sprul pa'i chos rgyal chen po rdo rje grags ldan 'khor bcas dbu 'phangs bstod cing mnga' gsol ba'i 'phrin bcol kun gsal shis pa brjod pa'i sgra dbyangs

41 gong sa mi dbang chen po sangs rgyas rgya mtsho nas thugs smon $167.2-167.6$ bden tshig gnang ba bdud bzhi rab bcom ma

Author: Regent Sangye Gyatso (1653-1705; TBRC: P421)

Compiler: Ku sa li Drung gnas Bskal bzang rin chen Requested by: the Nechung medium Bskal bzang tshul khrims (served 1837-1856), the master chanter, the instructor, and monastic officials. Date of compilation: the 4th day of the 6th month of the Wood-Snake year of the 14th rabjung [1845], after a failed attempt in the WaterTiger year [1842] (p.175)

Note: This text has no title, being the final verses for the collection as a whole. 


\section{Appendix II}

\section{The Central Nechung Rituals}

This appendix is by far the largest of the four appendices. It is in truth three appendices in one, since it consists of Tibetan transcriptions and English translations of the following three Tibetan ritual manuals:

Appendix IIa: The Ten-Chapter Sädhana: A Supplication Offering to the Five Great Sovereign Spirits and their Retinues (Rgyal po chen po sku lnga'i gsol mchod 'phrin las don bcu ma). This is a treasure text believed to have been composed by Padmasambhava and 'rediscovered' by the treasure-revealer Nyangrel Nyima Özer (1124-1192). This sub-appendix provides a critical edition of the Tibetan text followed by my English translation.

Appendix IIb: Selections from the Offerings and Praises to such [Deities] as the Great Dharma Kings, the Five Long-Life Sisters, Dorjé Drakmogyel, Dorjé Yudrönma, Chölha, Kongtsün Demo, and Odé Gungyel-from the Miscellaneous Writings of the Venerable Omniscient One's Collected Works (Tib. Rje btsun thams cad mkhyen pa'i gsung 'bum thor bu las chos rgyal chen po tshe ring mched lnga rdo rje grags mo rgyal rdo rje g.yu sgron ma 'phyos lha kong btsun de mo 'o de gung rgyal sogs kyi gsol kha bstod pa dang bcas pa rnams). This is a collection of short rites dedicated to several Dharma protectors composed by the Second Dalai Lama (1476-1542). I have only transcribed and translated the six propitiatory rites in this collection that focus on Pehar and the Five Sovereign Spirits. These texts are not technically present in the Nechung Liturgy; however, they play a central role in the evolution of Nechung's central rituals, the Ten-Chapter Sädhana above and the Adamantine Melody below.

Appendix IIc: The Unceasing Adamantine Melody: A Sādhana for Presenting Prayers and Offerings to the Five Great Sovereign Spirits (Tib. Rgyal po chen po sde Inga la gsol mchod 'bul tshul 'phrin las 'gags med rdo rje'i sgra dbyangs). Composed by the Fifth Dalai Lama (1617-1682), this lengthy ritual manual draws heavily from the content of the previous two texts. Along with the Ten-Chapter Sädhana, this is the most important ritual text at Nechung Monastery. 
Each of these three sub-appendices is prefaced by an introduction that elaborates on their significance and my presentation of the text. These works exhibit an extensive degree of intertextuality, which is illustrated in the following transcriptions and translations by color-coded words. Orange represents material shared between Appendices IIb and IIc; red represents material shared between Appendices IIa and IIc; and blue represents text shared between all three works. There are no textual portions exclusively shared between Appendices IIa and IIb. Lastly, purple text signifies the adoption of content from a work beyond the above three, which will be explained when encountered. This color coding vividly illustrates the degree of sharing that exists between these three texts, as well as the contextual evolution that these particular ritual fragments experienced over the course of their composition. 


\section{Appendix IIa}

\section{The Ten-Chapter Sädhana}

The Ten-Chapter Sädhana: A Supplication Offering to the Five Great Sovereign Spirits and their Retinues (Tib. Rgyal po chen po sku lnga'i gsol mchod 'phrin las don bcu ma) is the foundational ritual of this study. It is the oldest known ritual to discuss the Five Sovereign Spirits at length, it is one of the central rituals at Nechung Monastery, and it is the basis for the Fifth Dalai Lama's Adamantine Melody, the other central Nechung ritual. For these reasons, I have given the most attention to the text of this ritual. There are four extant editions of the TenChapter Sädhana, and the abbreviations and bibliographic details for each are as follows:

BPLC Nyi ma 'od zer, Mnga' bdag Nyang ral (1124-1192). 1994. Rgyal po sku lnga 'khor bcas kyi gsol kha phrin las don bcu ma. In Byang gter phur pa lha nag gi chos tshan. Yol mo sprul sku 03 Bstan 'dzin nor bu (1589-1644), ed. Gangtok: Tingkey Gonjang Rinpoche, pp.209-247. TBRC: W1KG3566.

BCPC Nyi ma 'od zer, Mnga' bdag Nyang ral (1124-1192). n.d. Rgyal po sku lnga 'khor bcas kyi gsol kha phrin las don bcu ma. In Bla ma mchod pa'i cho ga nor bu'i phreng ba sogs chos tshan khag cig. Pad ma 'phrin las, Rdo rje brag rig 'dzin 2 (1641-1717), ed. Ladakh: La dwags brag thog dgon, pp.405-442. TBRC: W1KG3707.

GRSD Nyi ma 'od zer, Mnga' bdag Nyang ral (1124-1192). 1983. Rgyal po chen po sku lnga'i gsol mchod 'phrin las don bcu ma. In The Collected Works of Liturgy of the Gnas-chun Rdo-rje-sgra-dbyains-glin Monastery: Reproduced from blockprints from Gnas-chun and other Tibetan establishments, vol. 1. Delhi: Lobzang Tondan, pp.53-75.

TBRC: W00EGS1016248.

RGC62 Nyi ma 'od zer, Mnga' bdag Nyang ral (1124-1192). 1976. Rgyal po sku lnga 'khor bcas kyi gsol kha phrin las don bcu ma. In Rin Chen Gter Mdzod Chen Mo: A reproduction of the Stod-lun Mtshur-phu redaction of 'Jam-mgon Kon-sprul's great work on the unity of the gter-ma traditions of Tibet: With supplemental texts from the Dpal-spuns redaction and other manuscripts, vol.62. Paro: Ngodrup and Sherab Drimay, pp.275-298.

TBRC: W20578. 
I have created a critical edition of the Ten-Chapter Sädhana that combines the above four editions of this text. The Tibetan transcription and my English translation of this critical edition are provided below. Since the GRSD edition is the one used at Nechung Monastery - both in Lhasa and in Dharamsala - I have used it as the basis for my Tibetan transcription, with differences between editions noted in footnotes. However, the English translation is a critical edition that uses all four editions in an attempt to produce the best possible reading. Nonetheless, given the GRSD edition's primacy in this context, I rely on it first and foremost. This is evident in the footnotes, where I illustrate relevant differences between the editions, as well as in the body of the text. Whenever two or more of the editions diverge, I note it visually by splitting the variant translations and placing them side-by-side. The GRSD edition is provided on the left in 12-point font, while the other edition's content is on the right and provided in bolded 10-point font. In some instances the other editions provide extra content, and this is visually indicated with a blank left side and a right side full of material from the other editions. This format allows the reader to engage the text as the GRSD edition alone if they so choose, while also providing all the content from the other editions so that a full understanding of the ritual outside the context of Nechung is possible.

A final note about the relationship between the editions: On average the GRSD and BPLC editions are most similar to one another, while the same can be said for the RGC62 and BCPC editions. However, in many instances the RGC62, BPLC, and BCPC editions will have something in common that is otherwise different in the GRSD edition. Finally, the BPLC edition is the longest of the four because it has two extraneous folios added to it, as well as some additional content within the ritual text itself. 


\section{Ten-Chapter Sädhana Transcription}

[GRSD:53][RGC62:275][BPLC:209][BCPC:405]

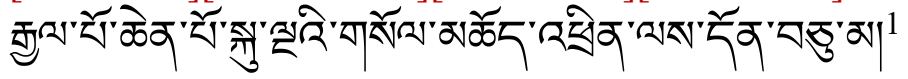

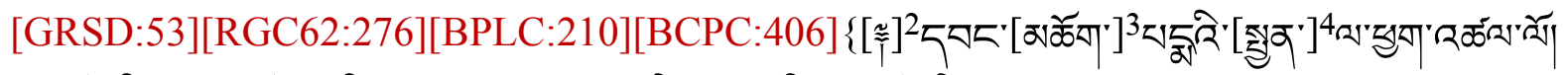

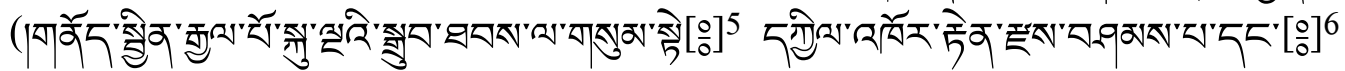

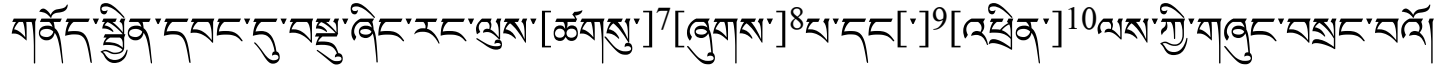

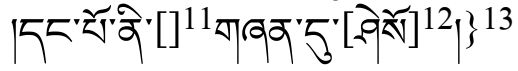

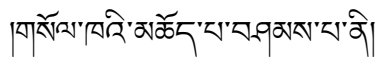

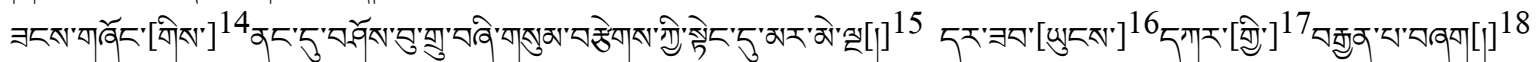

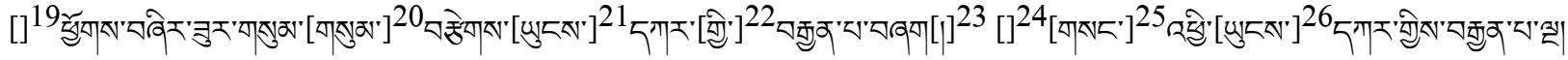

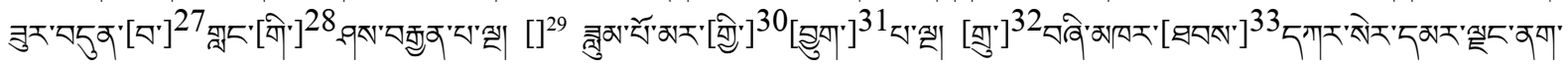

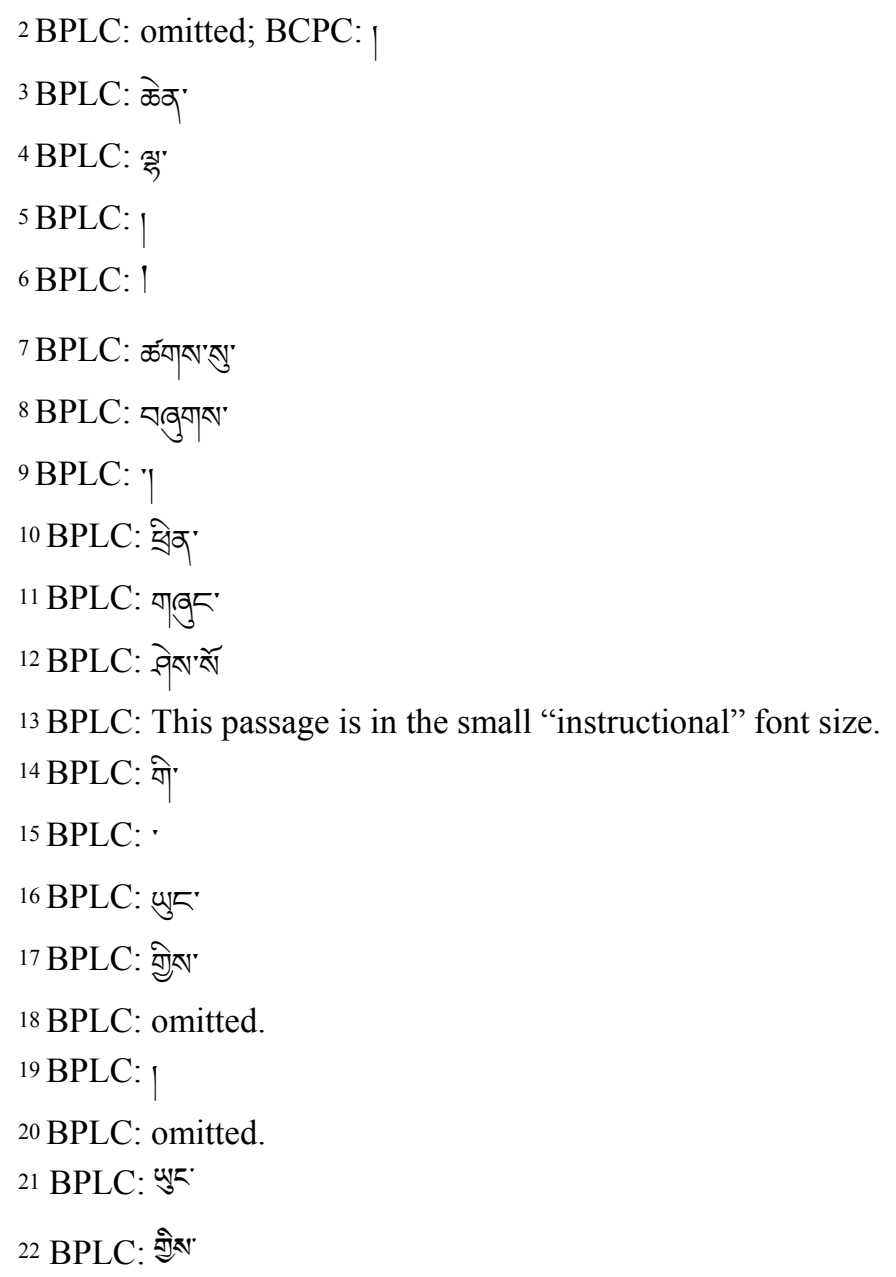




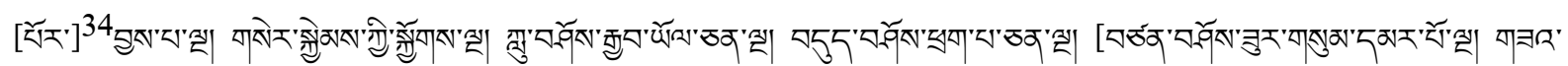

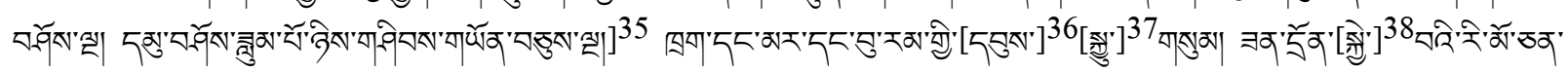

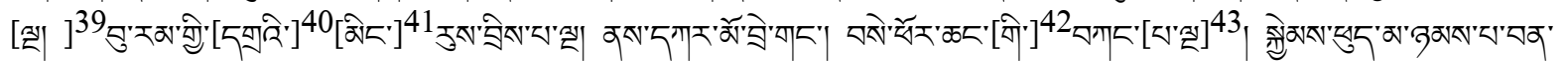

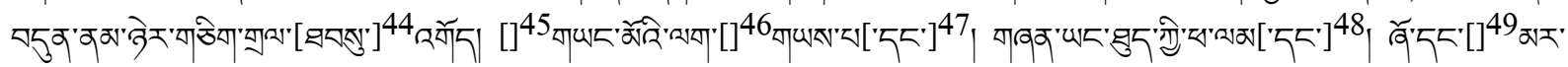

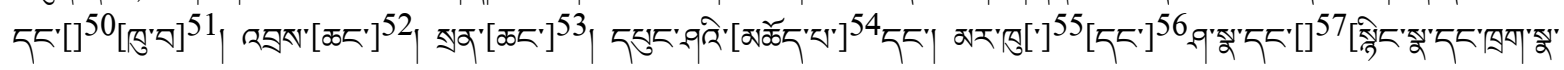

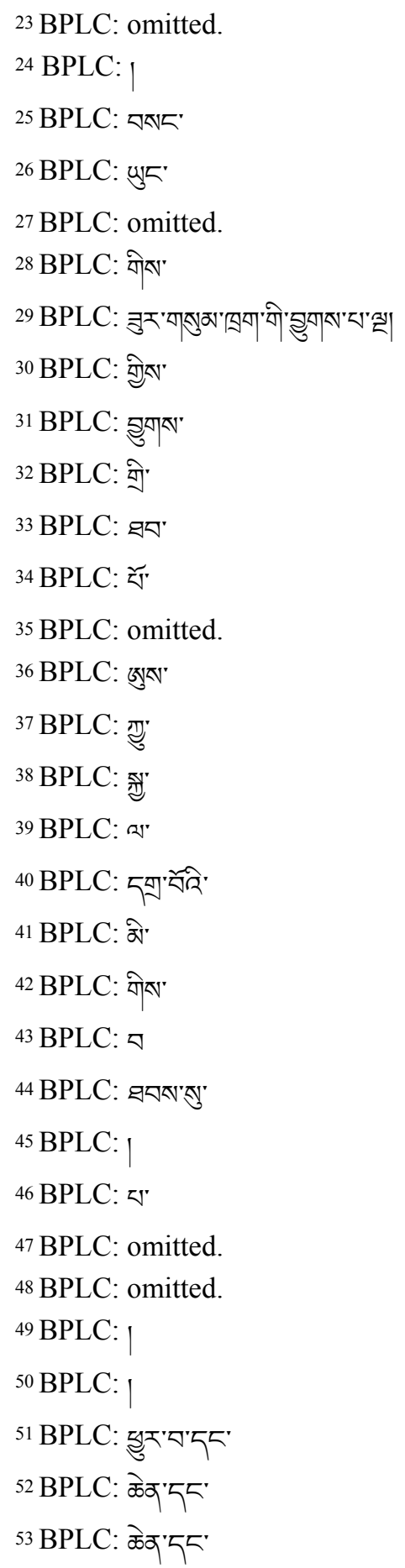




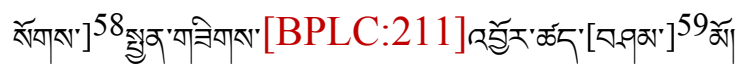

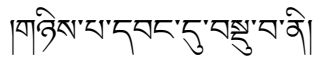

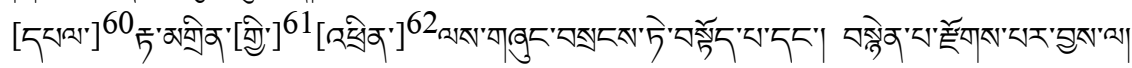

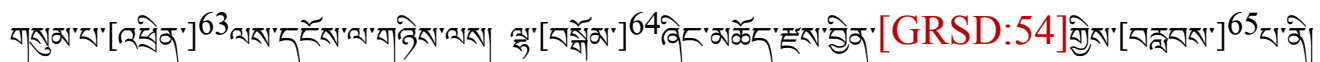

\section{GRSD:}

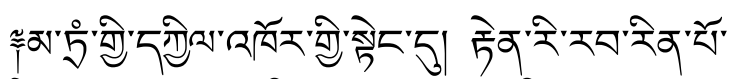

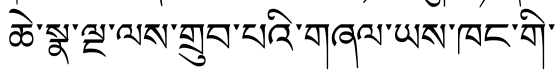

\section{BPLC:}

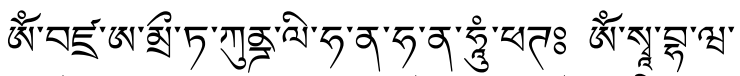

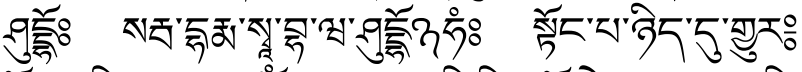

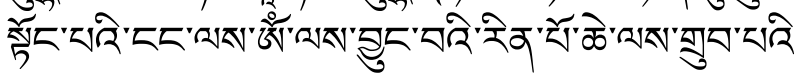

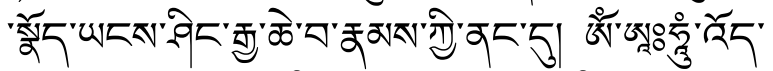

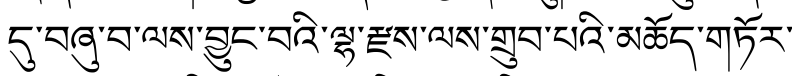

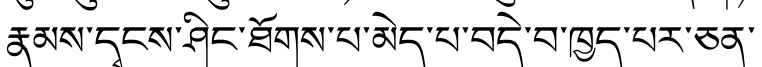

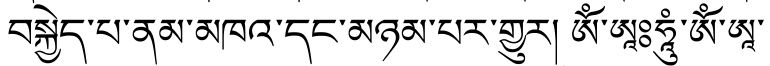

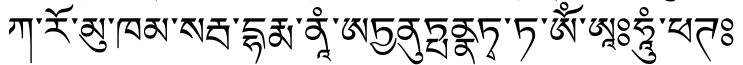

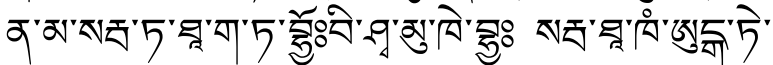

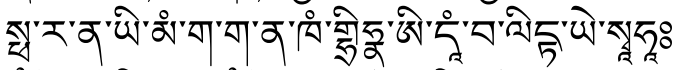

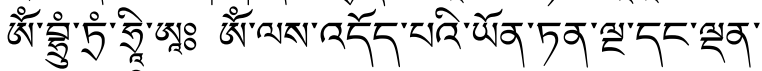

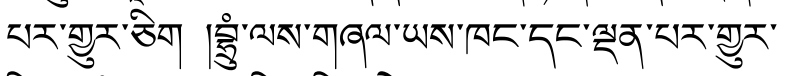

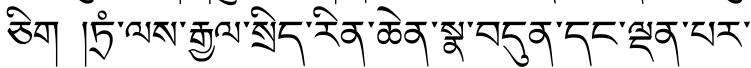

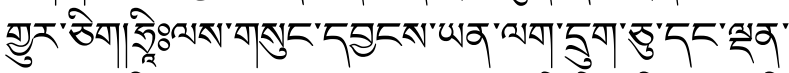

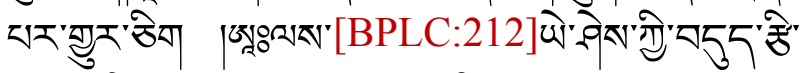

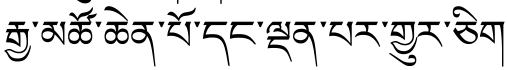

\footnotetext{
54 BPLC: ๘ॅॅ'অ"

55 BPLC:

56 BPLC: omitted.

57 BPLC:

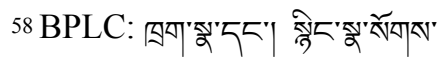

59 BPLC: Ђ-Яনतः

60 BPLC: omitted.

61 BPLC: ब्रेत

62 BPLC: छ्जेव

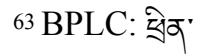

${ }^{64}$ BPLC: 취지

65 BPLC: অ্মৃনে
} 


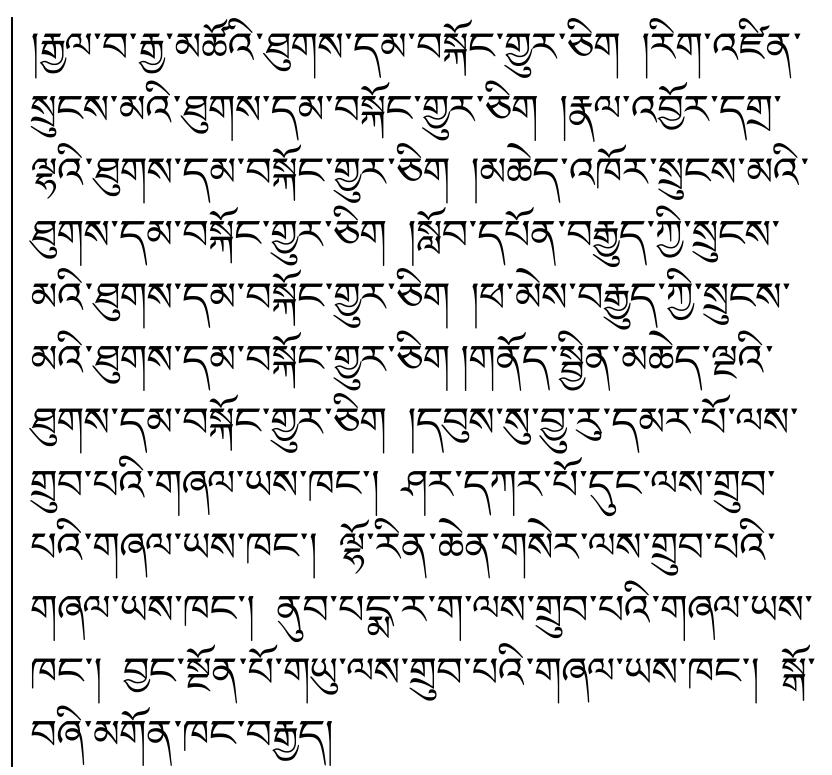

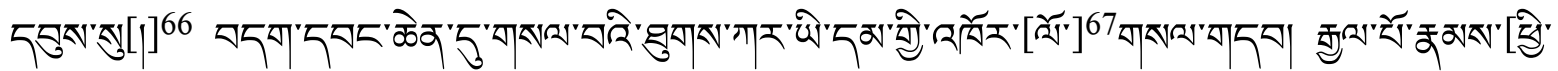

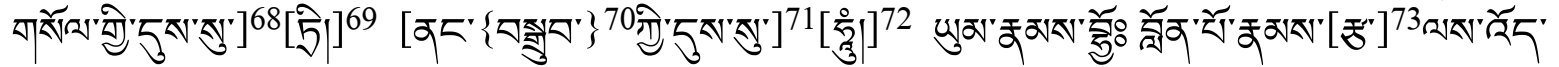

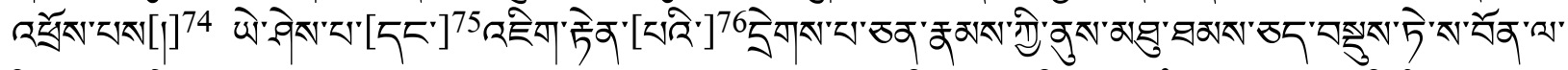

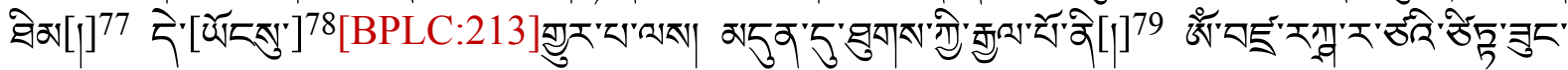

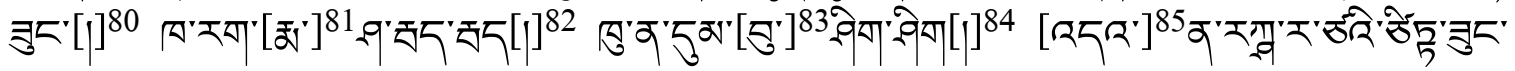

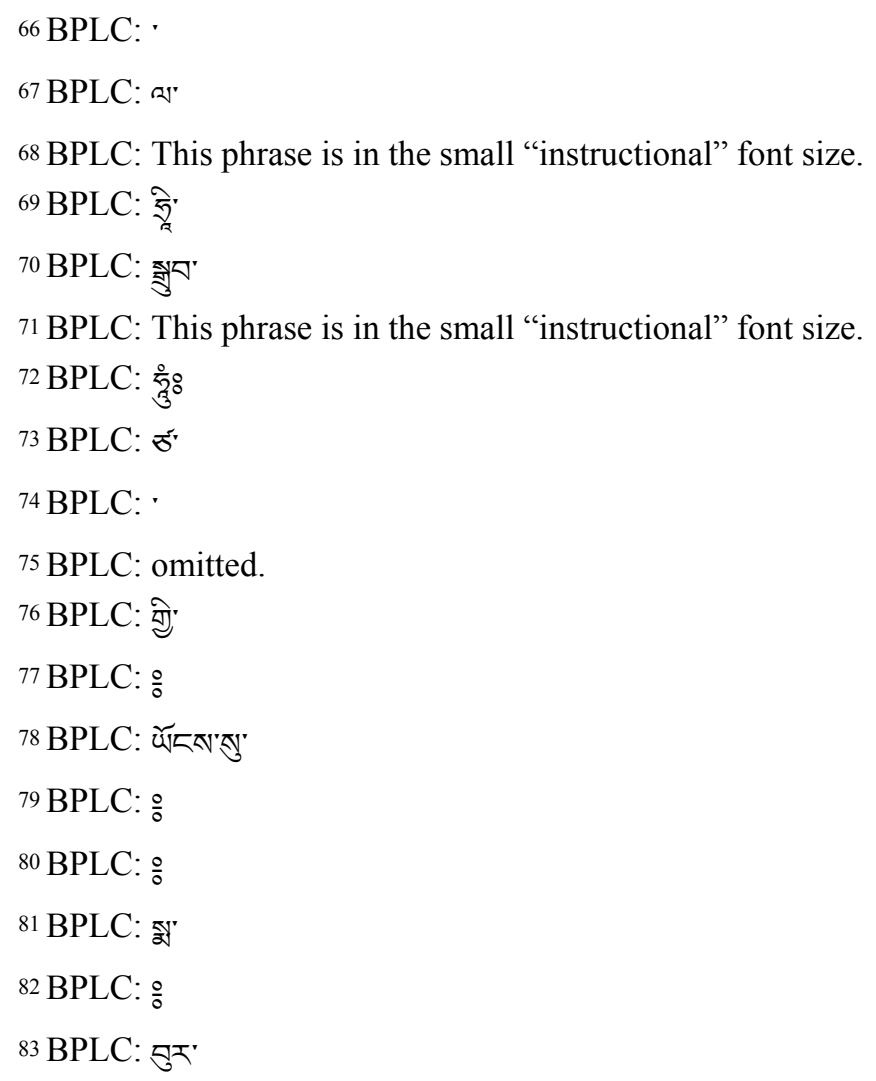




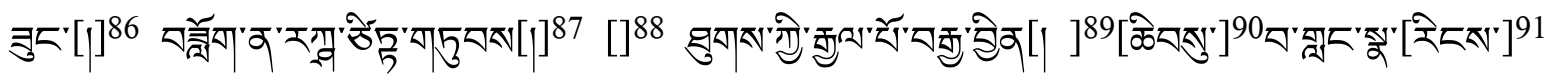

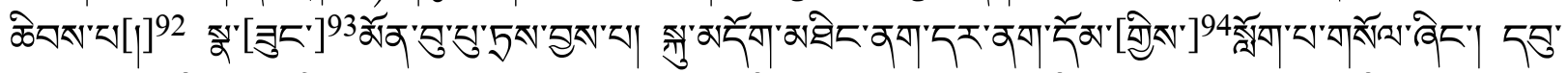

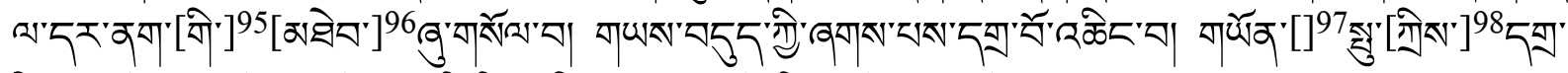

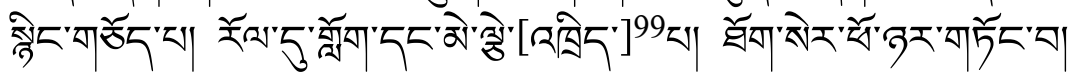

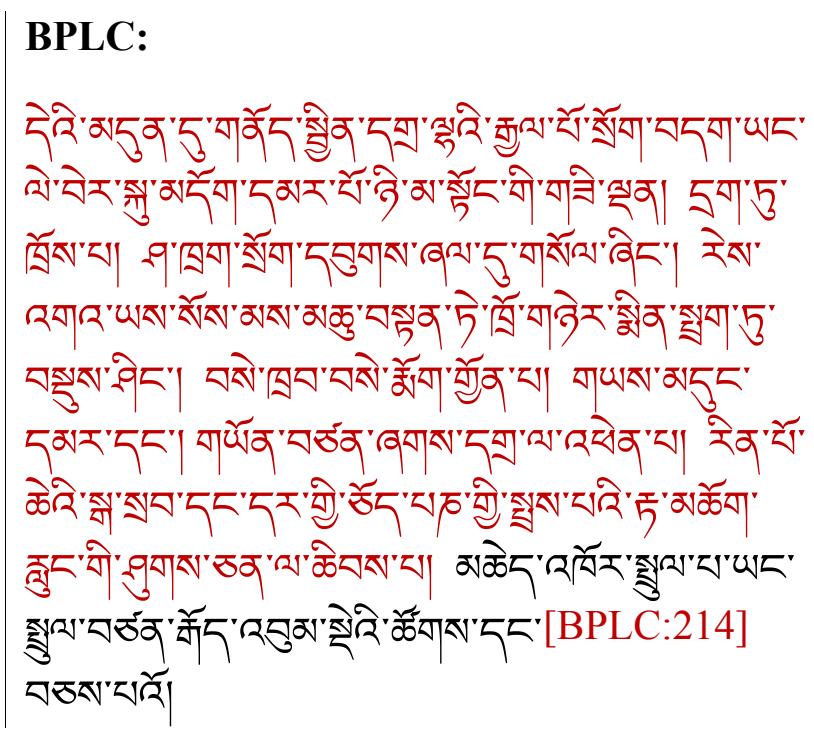

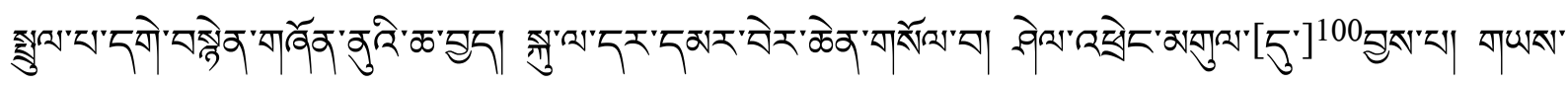

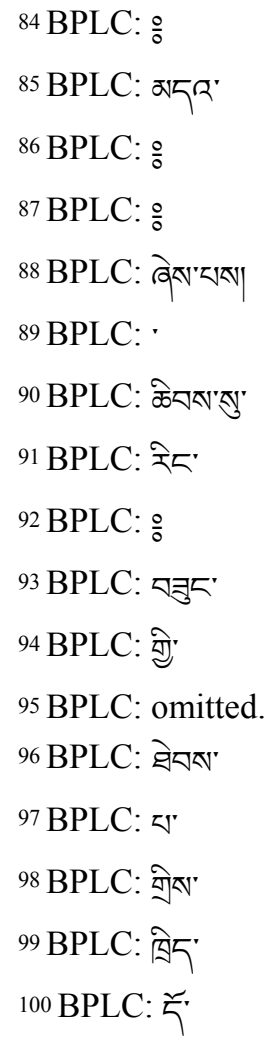




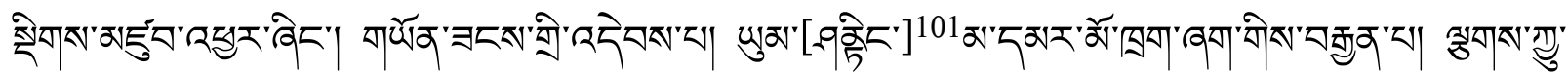

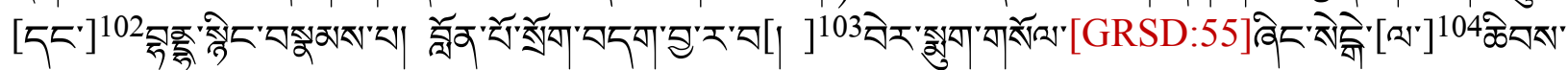

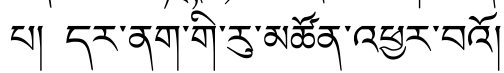

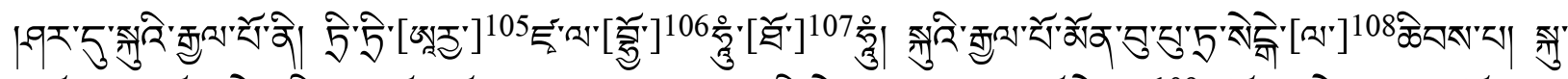

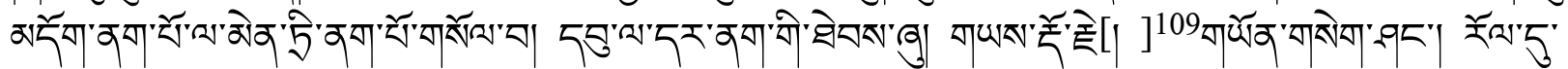

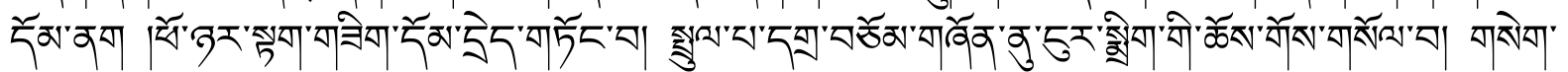

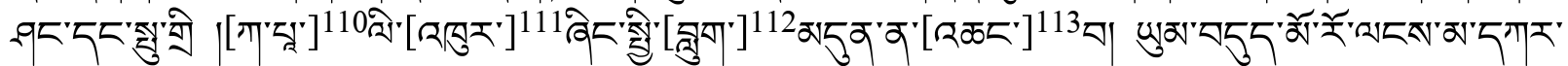

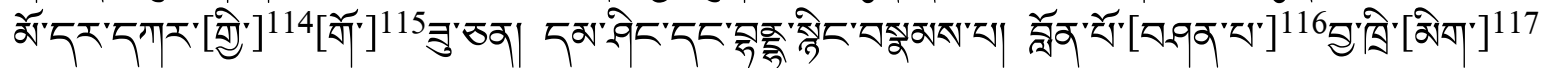

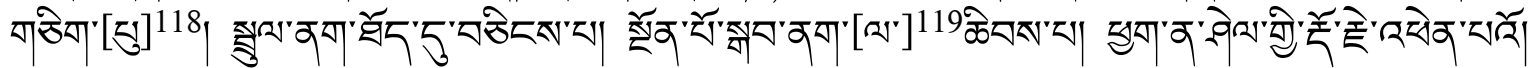

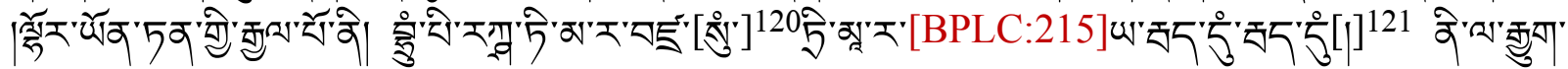

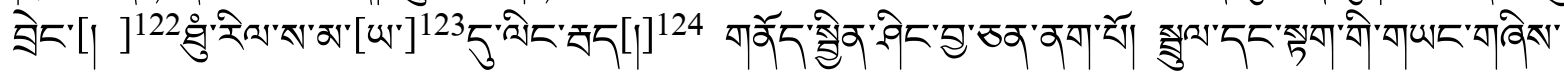

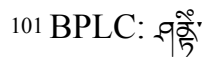

102 BPLC: omitted.

103 BPLC: '

104 BPLC: omitted.

105 BPLC: खाइ

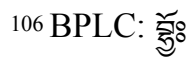

107 BPLC: 范。

108 BPLC: omitted.

109 BPLC: '

110 BPLC: गू'ख

111 BPLC: 宺工

112 BPLC: 정제

113 BPLC: शद्यू

114 BPLC: omitted.

115 BPLC: 제'

116 BPLC: omitted.

117 BPLC: ஓे

118 BPLC: 芹

119 BPLC: omitted.

120 BPLC: הু'

121 BPLC: $\%$

122 BPLC: omitted.

123 BPLC: omitted.

124 BPLC: 응
} 


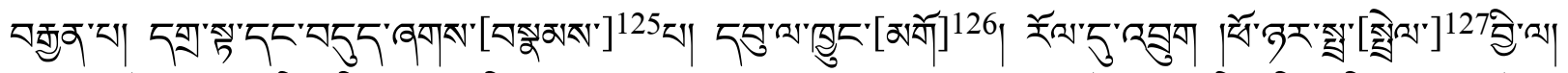

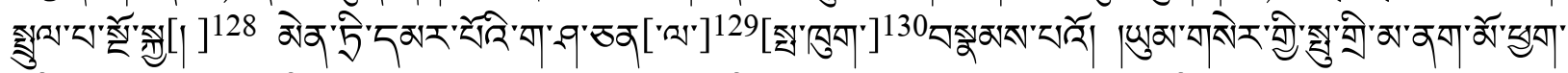

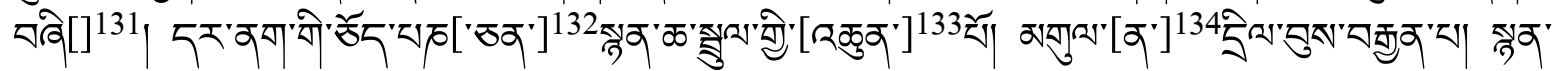

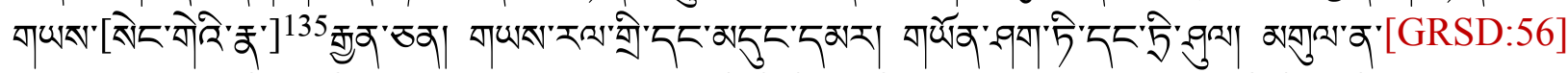

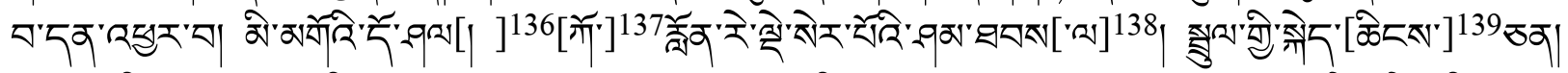

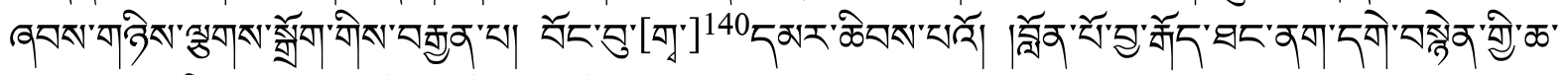

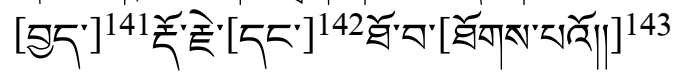

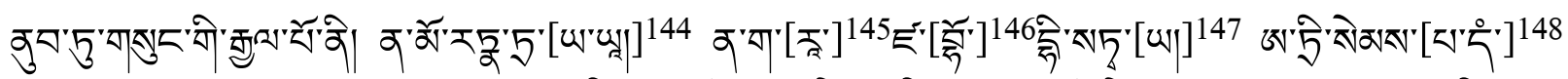

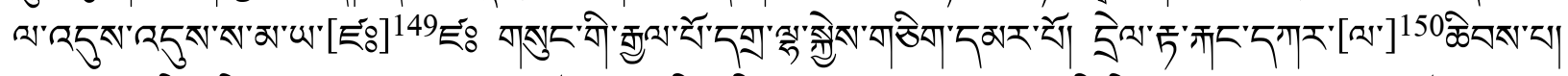

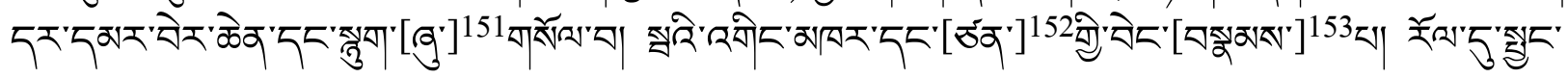

\footnotetext{
125 BPLC: Ђశ్원

126 BPLC: वे'

127 BPLC: श्रें

128 BPLC: '

129 BPLC: |

130 BPLC: 적'মुगु"

131 BPLC: 'व

132 BPLC: |

133 BPLC: कुण

134 BPLC: ॠ

135 BPLC: तोड्जेरें बूरे"

136 BPLC: '

137 BPLC: 并

138 BPLC: omitted.

139 BPLC: केవస

140 BPLC: बा

141 BPLC: इ્डे

142 BPLC: omitted.

143 BPLC: 近可|

144 BPLC: ్ㄻㅃㅇ

145 BPLC: $x$

146 BPLC: 芩"

147 BPLC: ঋ๐

148 BPLC: Гपर इव'
} 


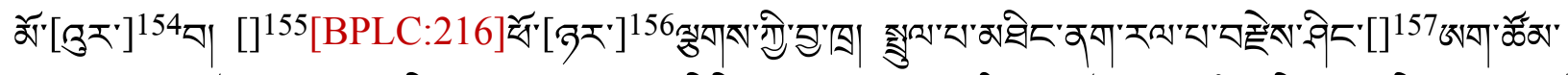

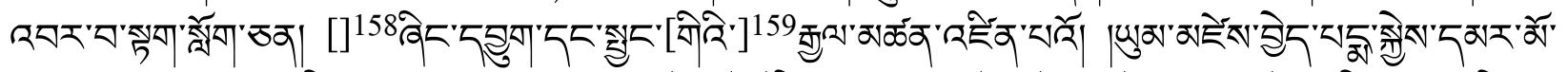

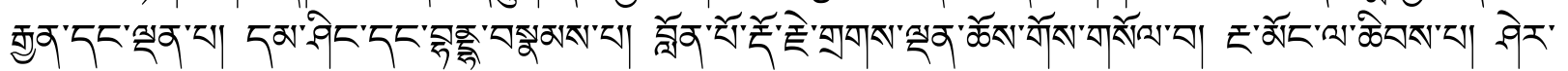

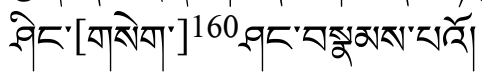

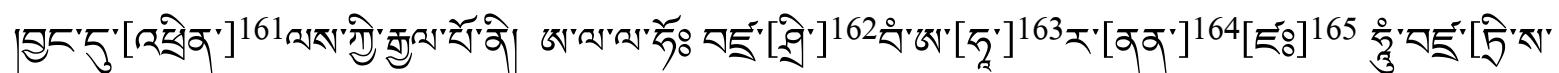

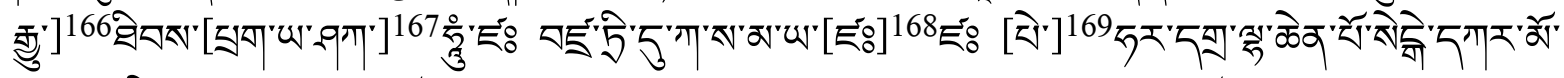

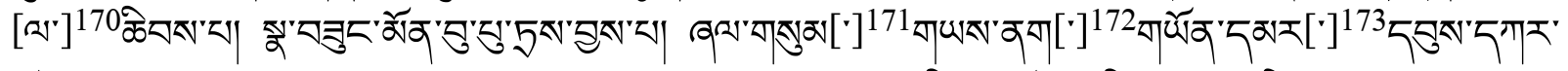

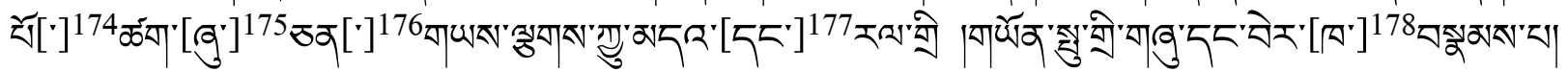

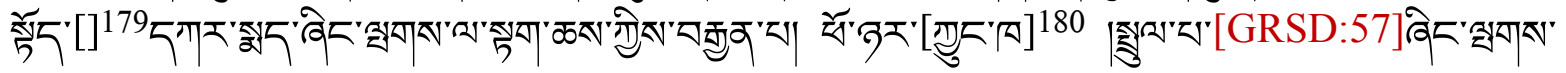

\footnotetext{
149 BPLC: Е“

150 BPLC: omitted.

151 BPLC: gु

152 BPLC: उँक्र

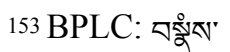

154 BPLC: 25 रू $^{\circ}$

155 BPLC: |

156 BPLC: శ’

157 BPLC:

158 BPLC: |

159 BPLC: गोरें

160 BPLC: बो "बासेर"

161 BPLC: द्रेव

162 BPLC: श्रें

163 BPLC: 5

164 BPLC: ववः

165 BPLC: E"

166 BPLC: 재ำ

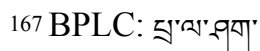

168 BPLC: Е"

169 BPLC: 5चे

170 BPLC: omitted.

171 BPLC: |

172 BPLC: |

173 BPLC: |
} 


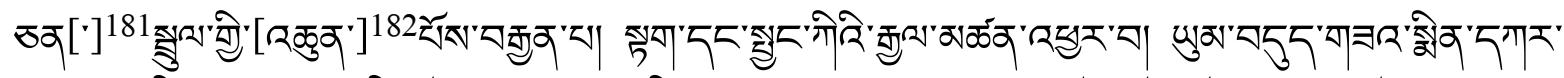

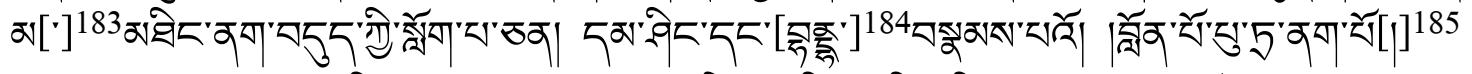

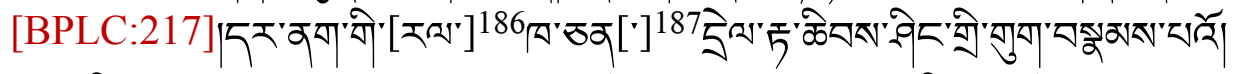

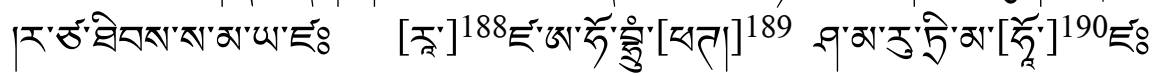

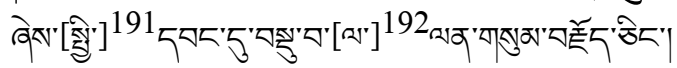

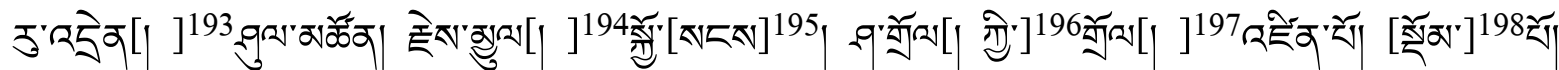

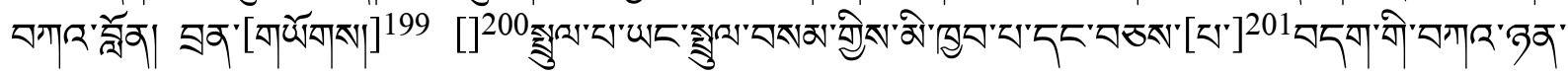

\footnotetext{
174 BPLC: |

175 BPLC: q

176 BPLC: |

177 BPLC: $5^{\mathbf{x}}$

178 BPLC: गा

179 BPLC: $5^{\mp}$

180 BPLC: 줮'ग

181 BPLC: |

182 BPLC: कुळ्

183 BPLC: |

184 BPLC: 可可”

185 BPLC: omitted.

186 BPLC: ХNत

187 BPLC: |

188 BPLC: ₹"

189 BPLC: 跨

190 BPLC:

191 BPLC: त्रेख

192 BPLC: omitted.

193 BPLC: '

194 BPLC: '

195 BPLC: వনজइ

196 BPLC: 'हैं

197 BPLC: '

198 BPLC: ज्रेक

199 BPLC: बार्थाया

200 BPLC: |
} 


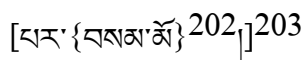

\section{GRSD:}

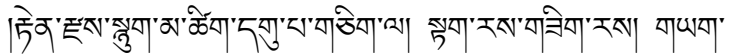

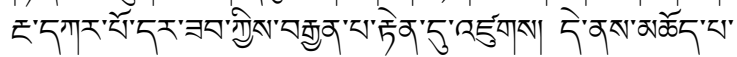

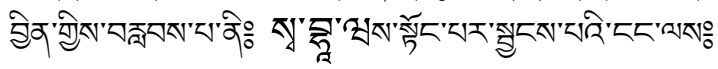

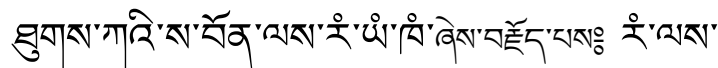

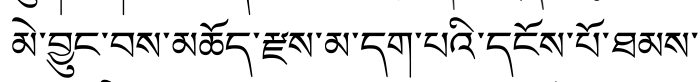

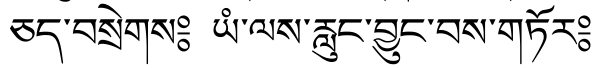

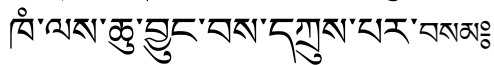

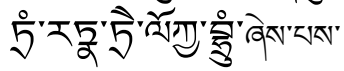

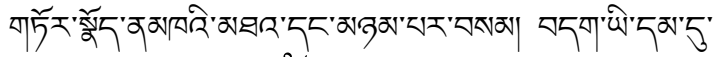

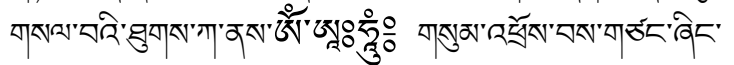

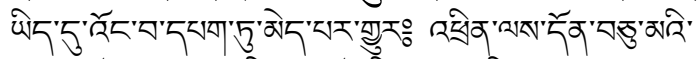

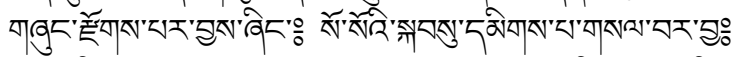

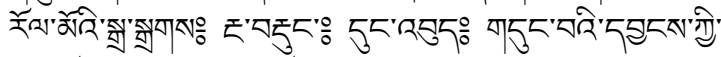

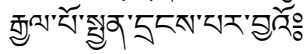

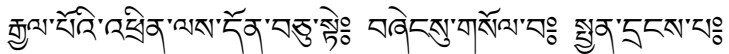

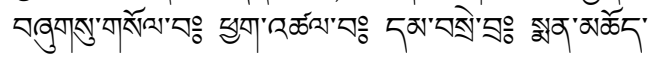

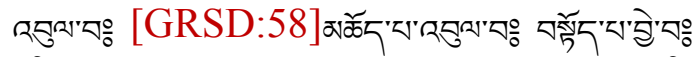

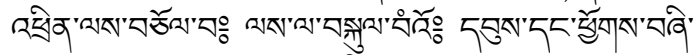

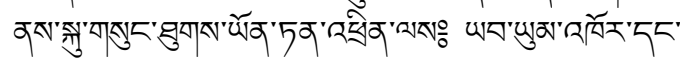

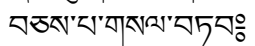

\section{BPLC:}

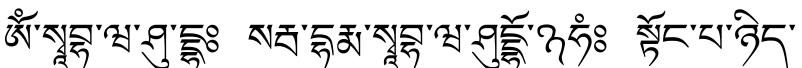

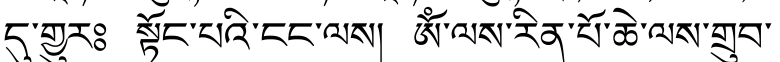

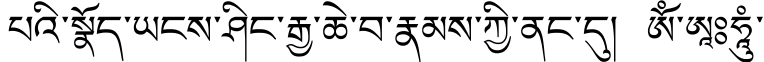

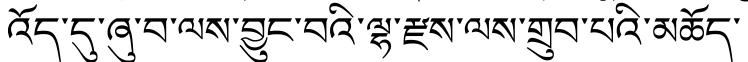

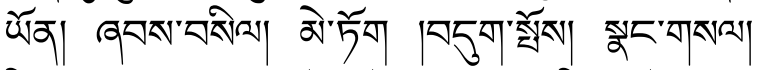

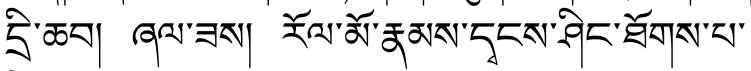

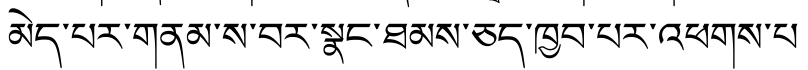

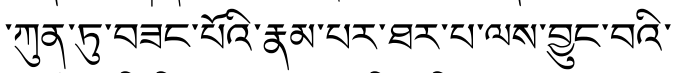

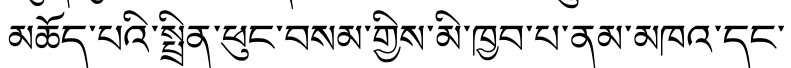

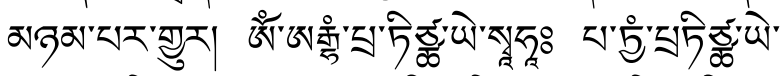

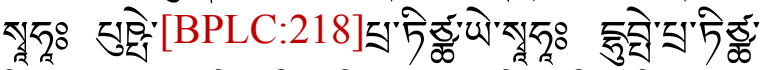

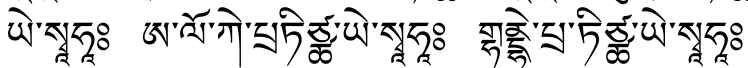

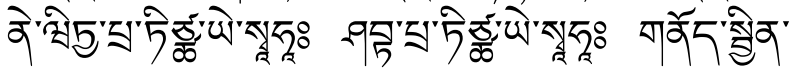

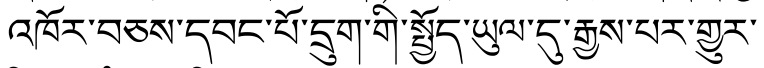

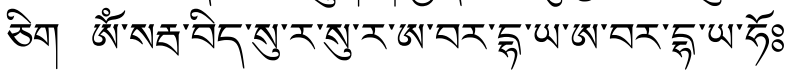

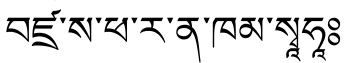

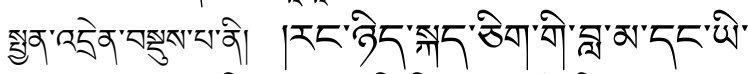

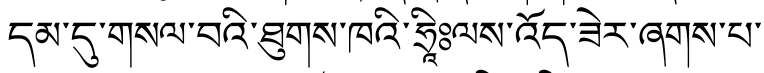

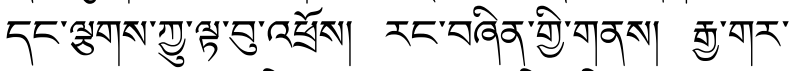

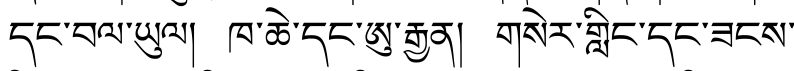

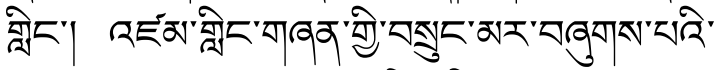

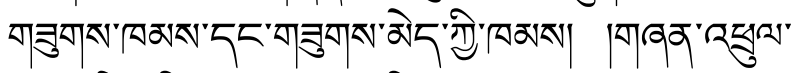

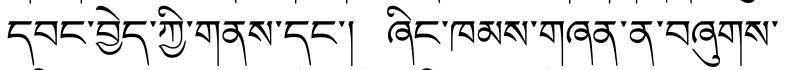

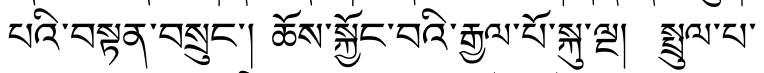

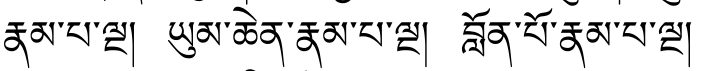

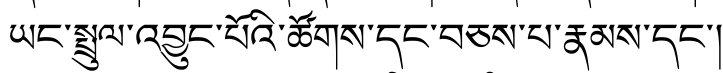

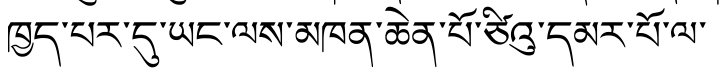

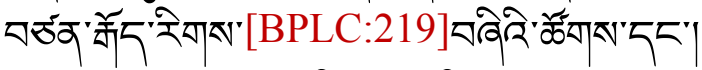

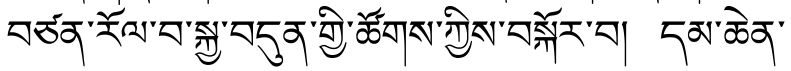

\footnotetext{
201 BPLC: 뗑

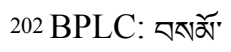

203 BPLC: This phrase is in the regular "recitational" font size.
} 


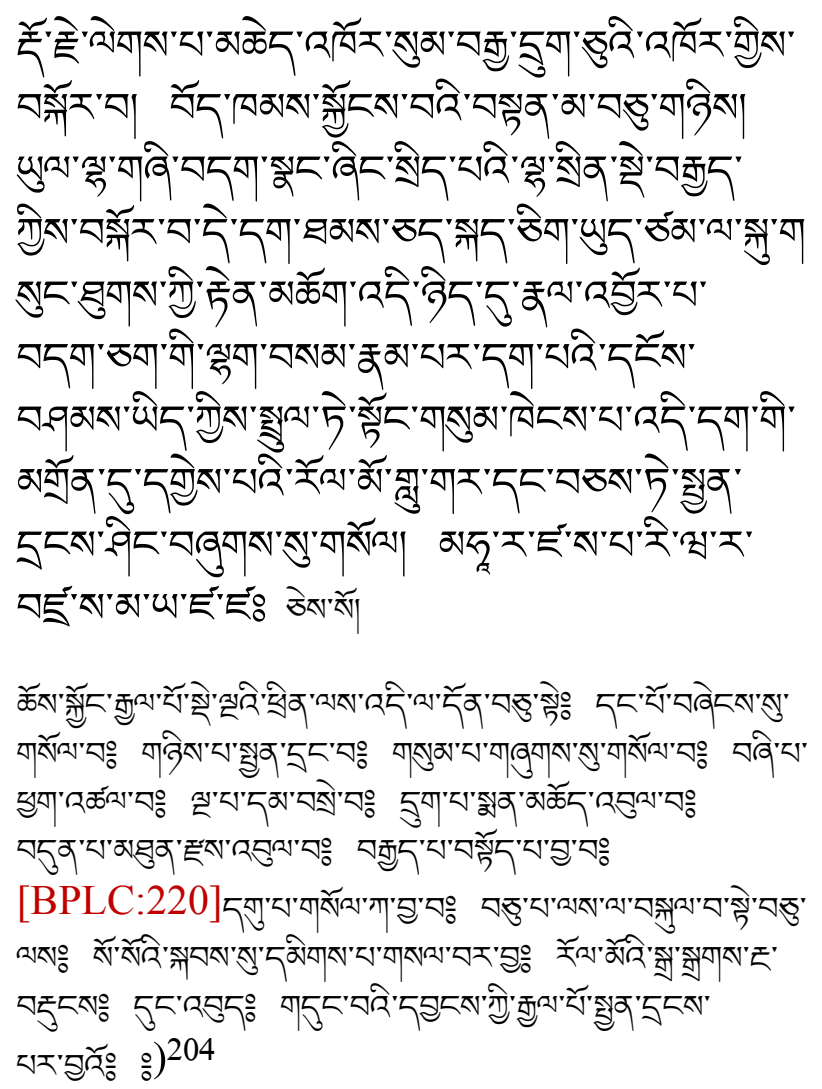

\section{BCPC:}

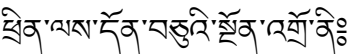

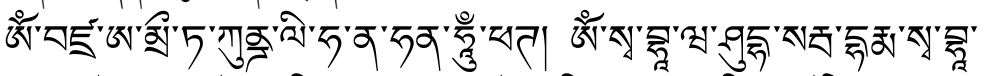

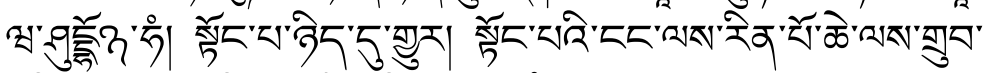

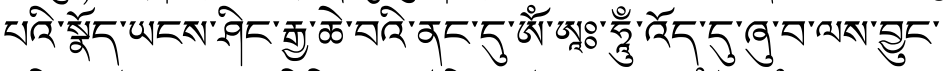

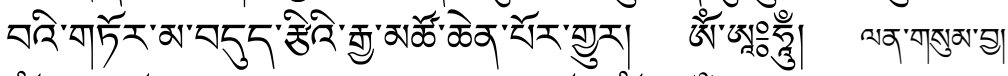

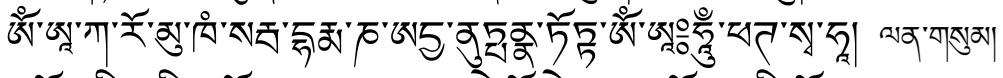

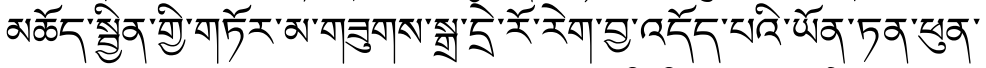

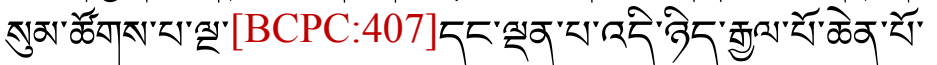

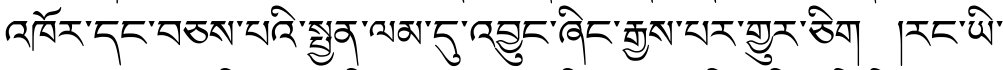

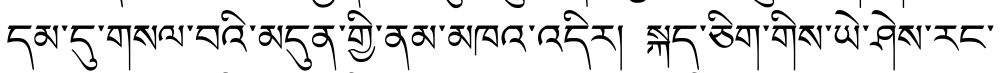

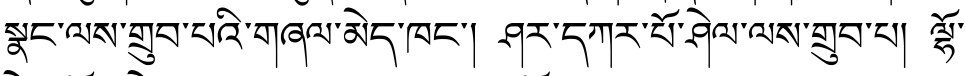

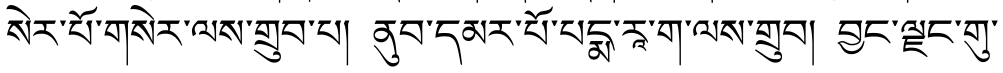

204With the exception of the opening homage, this text from the first page until now has only existed in the GRSD

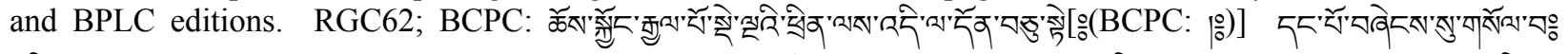

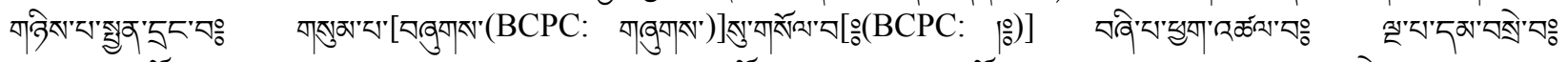

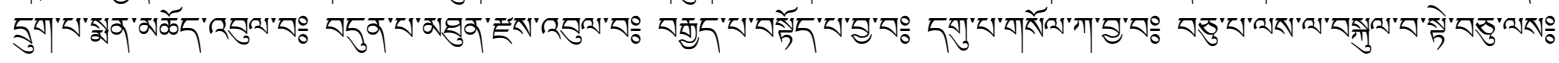




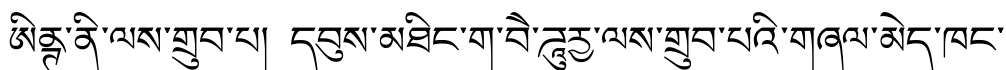

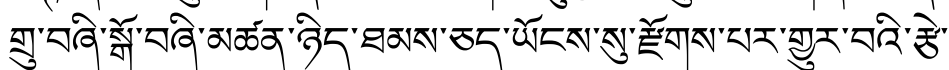

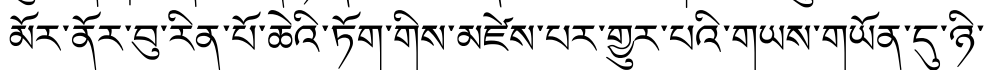

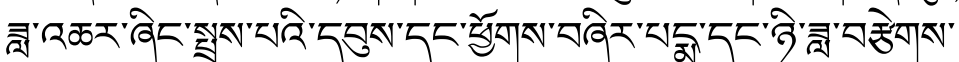

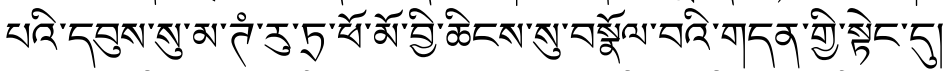

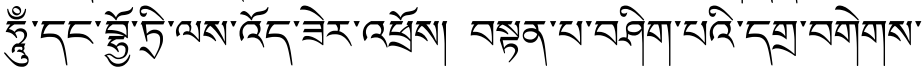

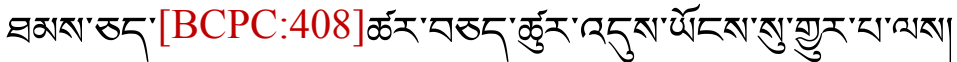

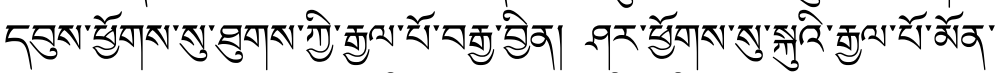

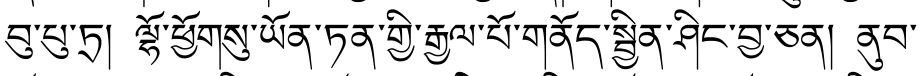

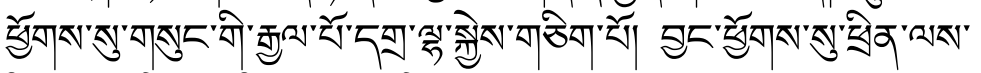

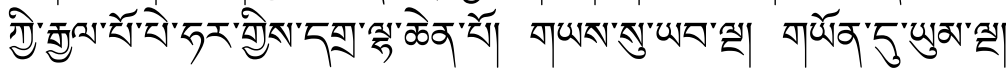

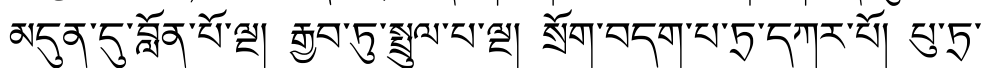

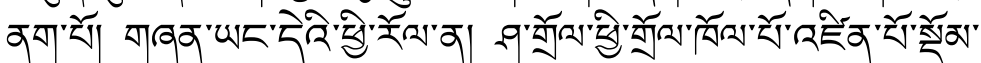

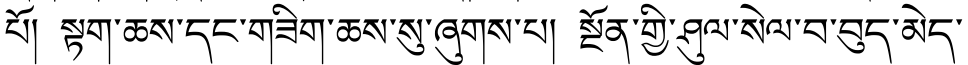

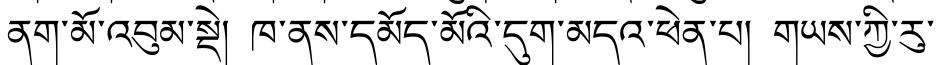

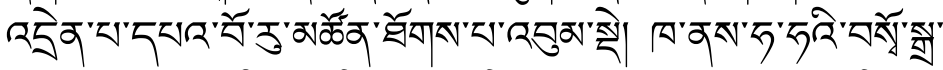

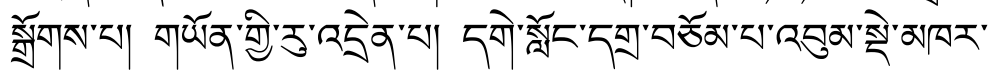

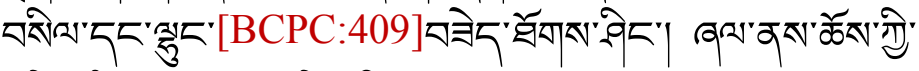

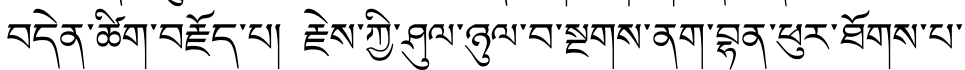

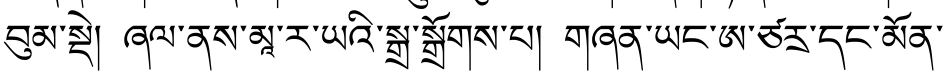

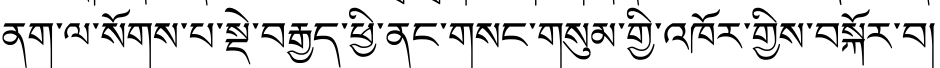

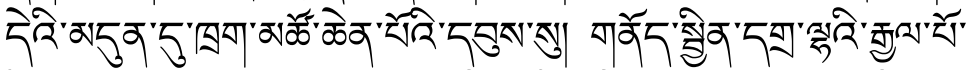

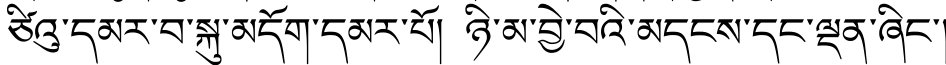

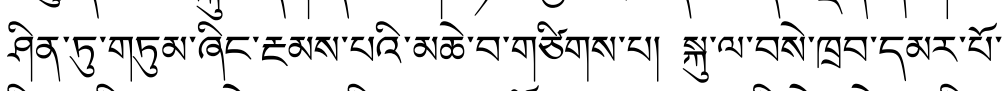

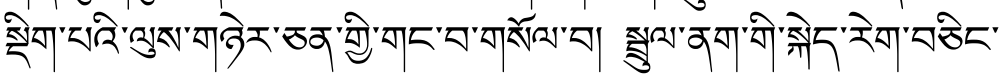

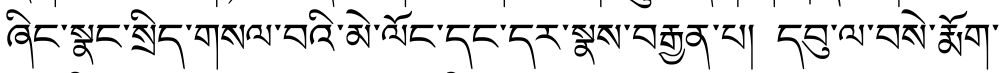

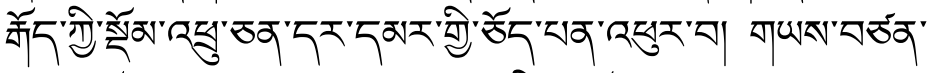

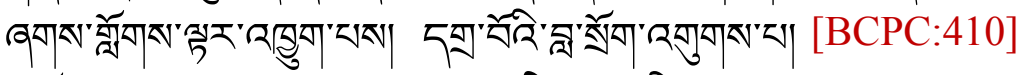

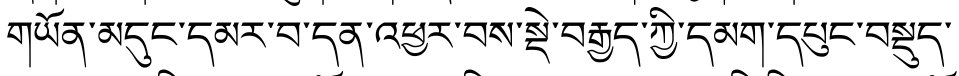

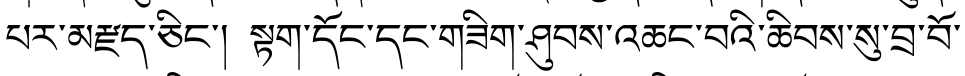

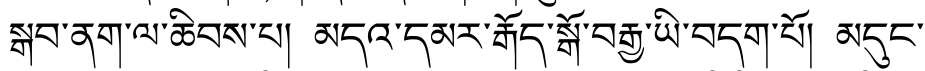

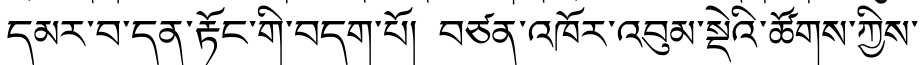

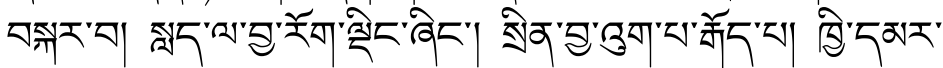

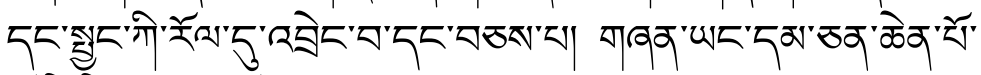

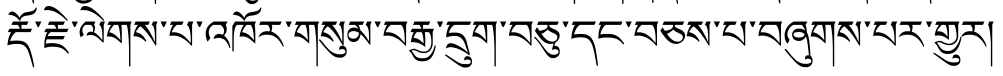




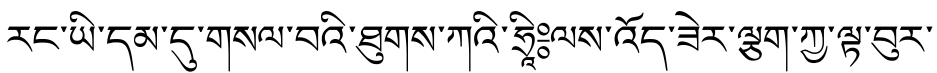

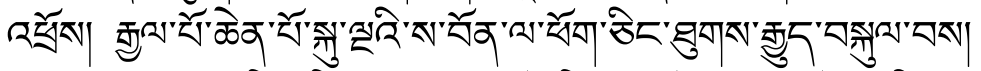

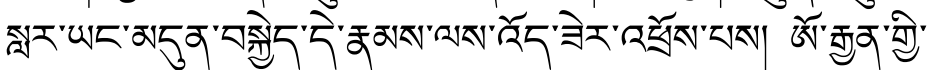

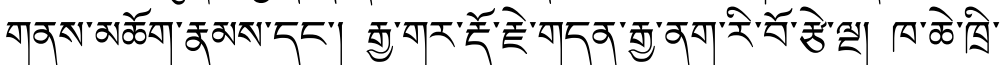

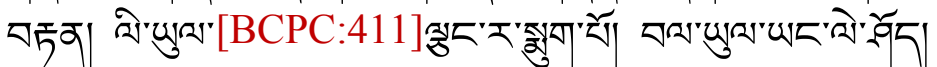

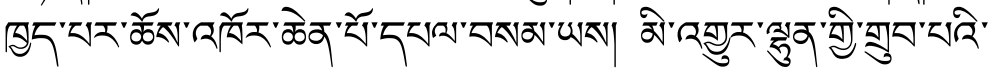

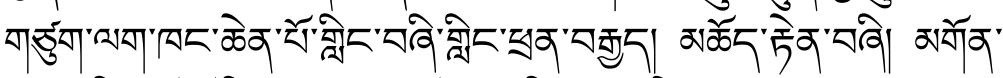

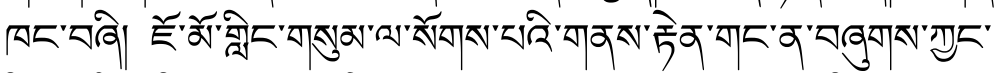

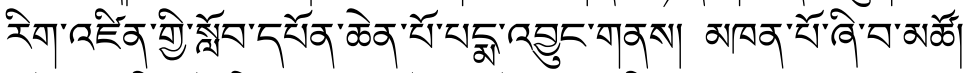

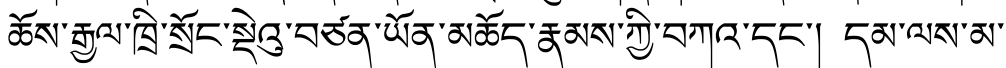

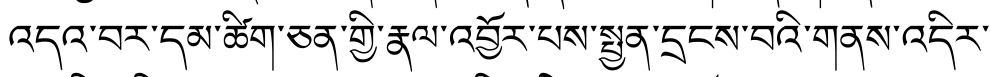

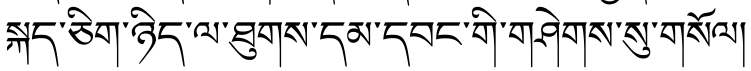

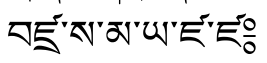

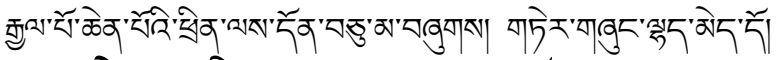

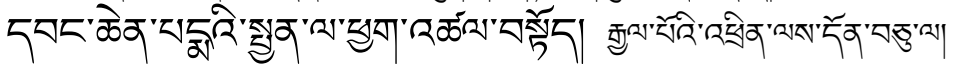

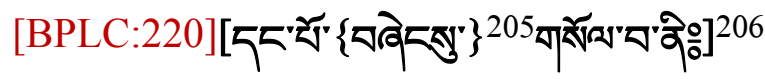

[극गㅠ: $]^{207}$

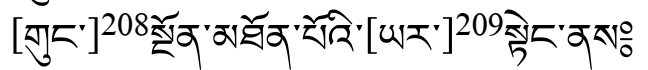

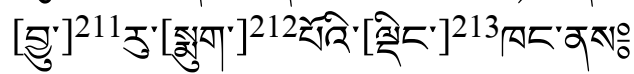

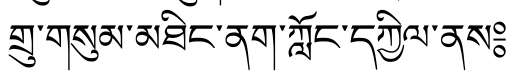

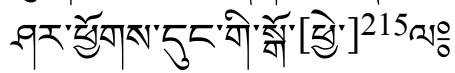

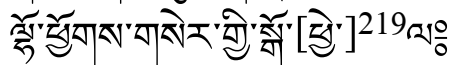

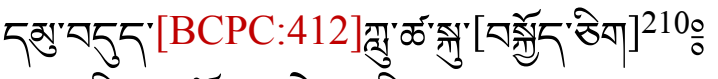

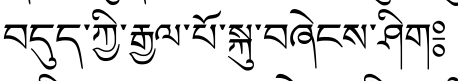

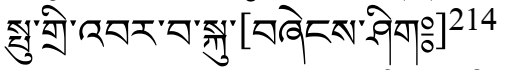

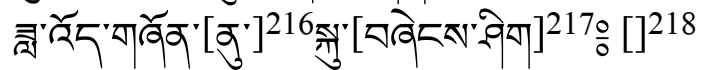

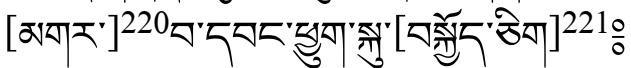

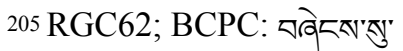

206 GRSD; BPLC: omitted.

207 RGC62; BCPC: 뀌응 ; BPLC: 낑

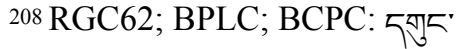

209 BCPC: याइ

210 RGC62; BPLC: వबेटत्रेण

211 BCPC: इे दें

212 BCPC: इसर

213 BCPC: श्रेद

214 BCPC: :

215 RGC62; BPLC; BCPC: ఫ్ ఫेत 


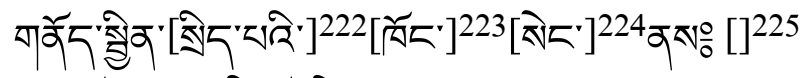

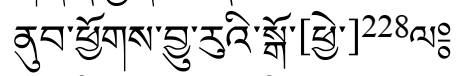

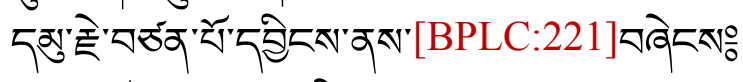

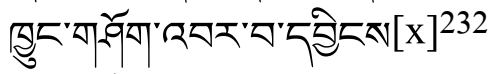

[वषासेके

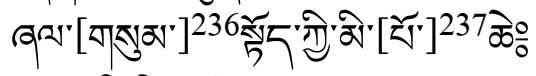

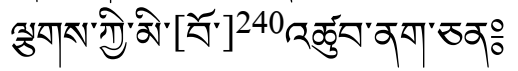

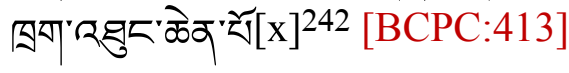

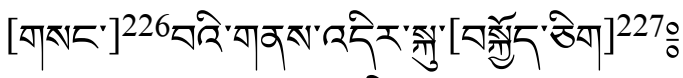

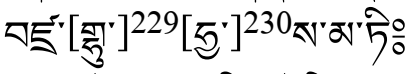

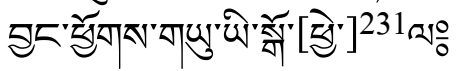

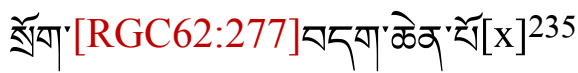

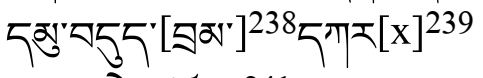

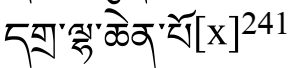

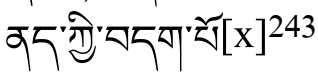

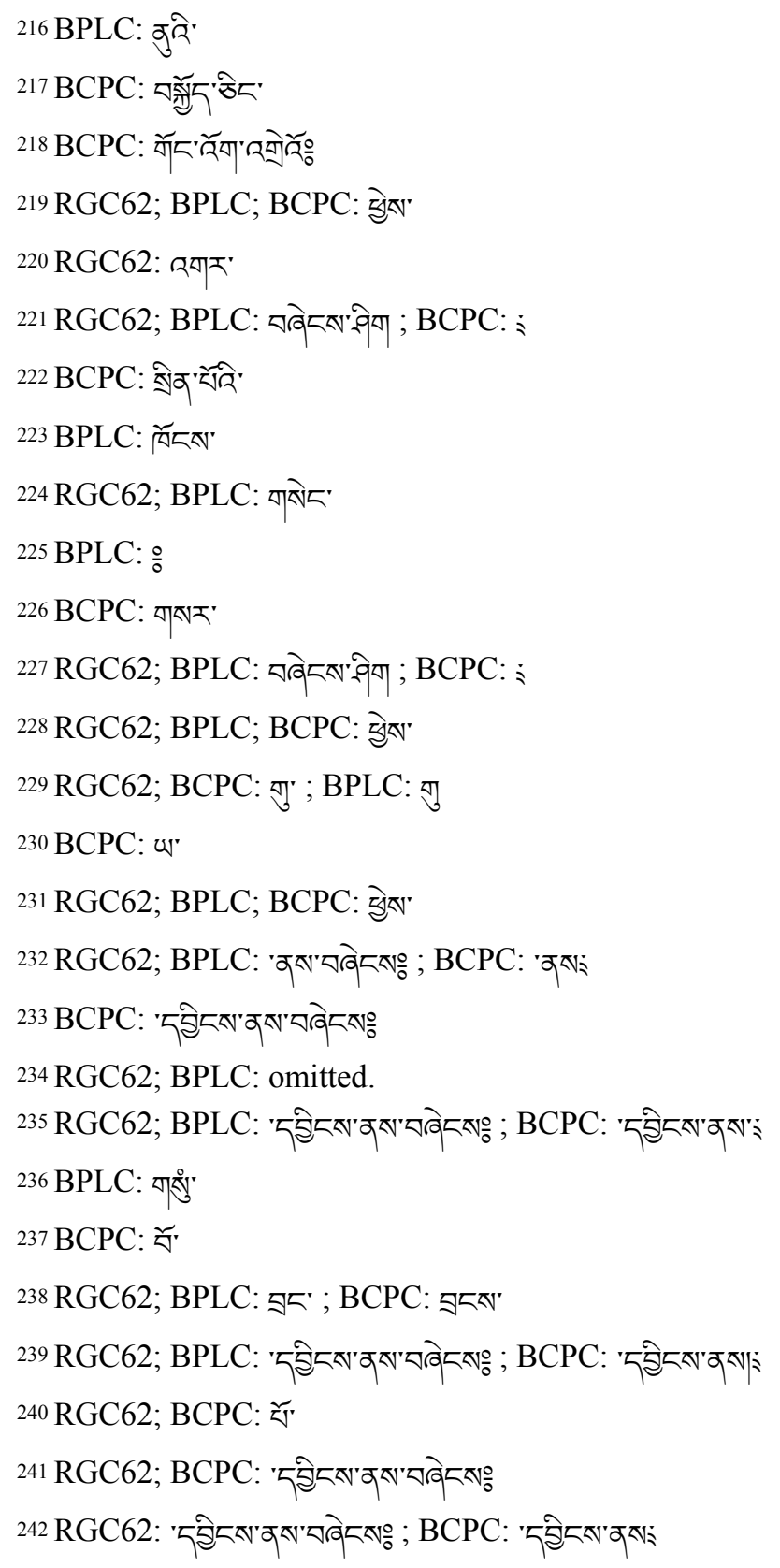




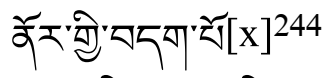

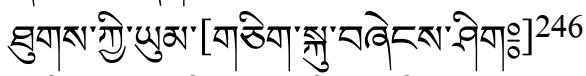

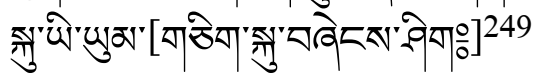

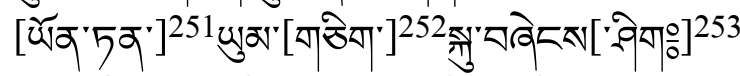

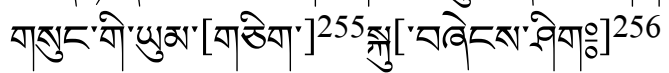

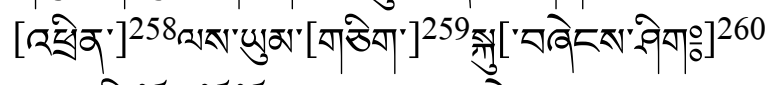

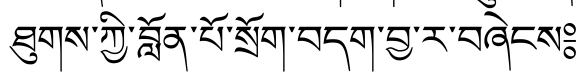

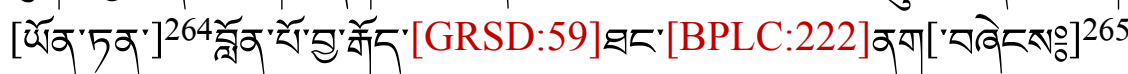

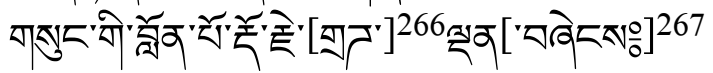

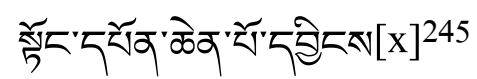

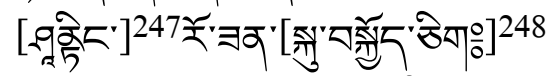

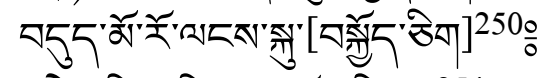

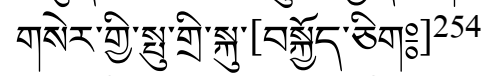

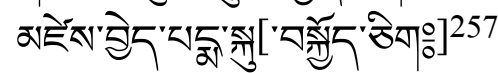

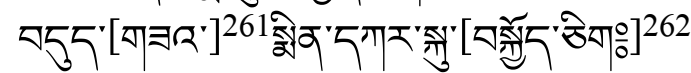

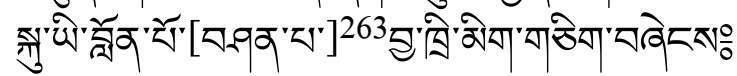

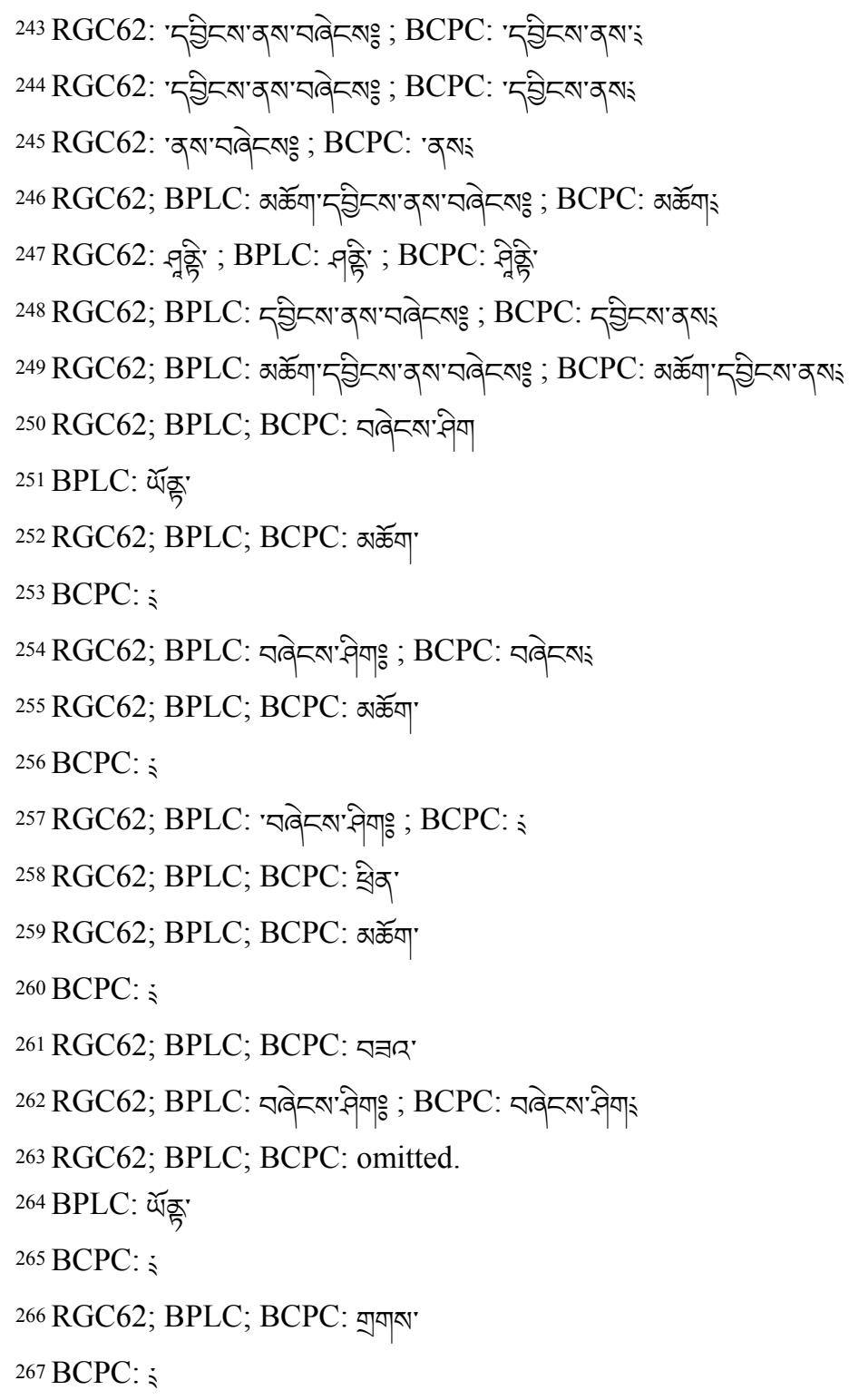




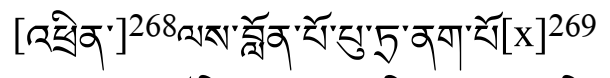

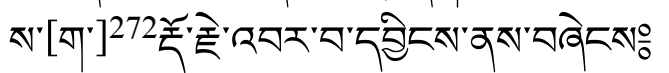
[BCPC:414] [] ${ }^{274}$

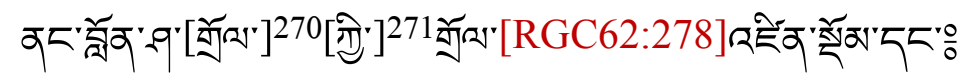

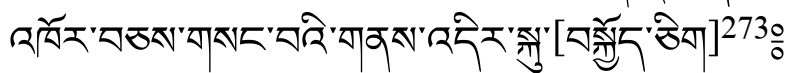

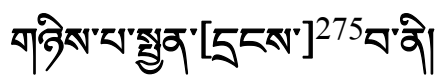

[긍 $\left.\{1\}^{276}\right]^{277}$

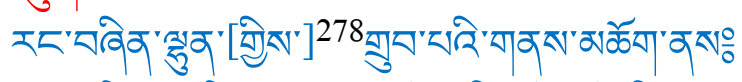

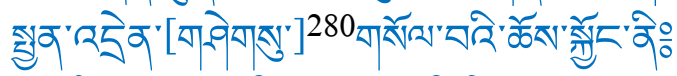

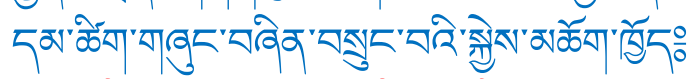

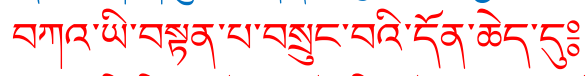

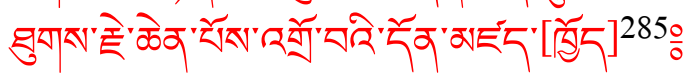

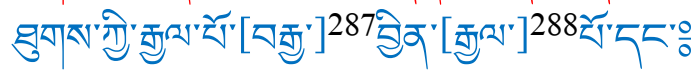

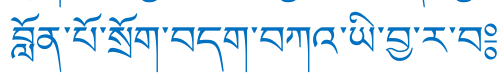

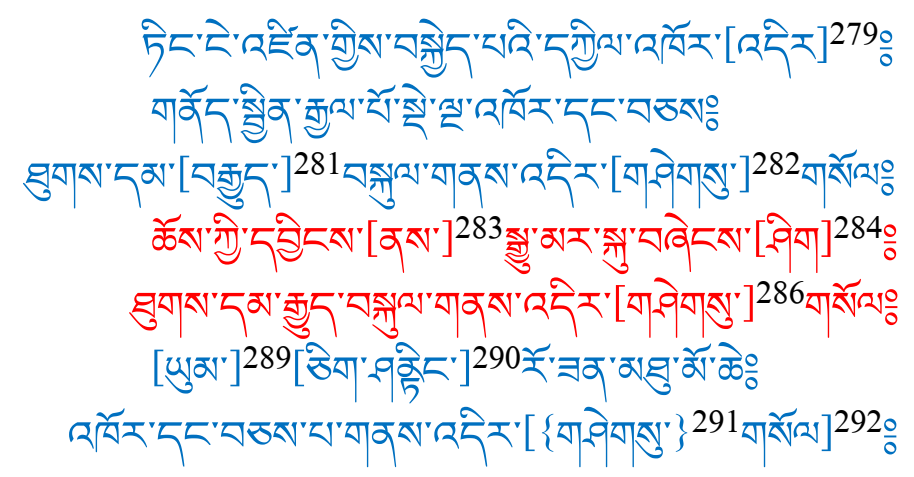

268 RGC62; BPLC; BCPC: ఫ్ఫेवे

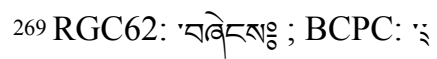

270 BCPC: 玄”

271 RGC62; BPLC: के ; BCPC: बें

272 RGC62; BPLC: ग" ; BCPC: $₫ 5$ गा"

273 RGC62; BPLC; BCPC: Ђवेटसे वेषा

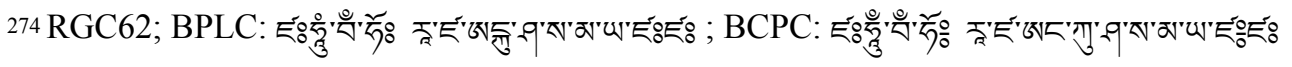

275 RGC62; BPLC; BCPC: Ђॅ॰

276 RGC62; BPLC: 응

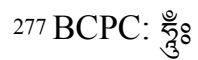

278 BCPC: प्रें

279 RGC62; BPLC; BCPC: वस्त

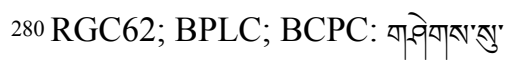

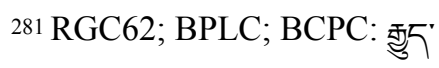

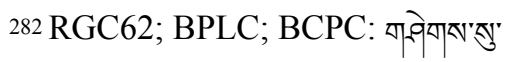

283 RGC62; BPLC; BCPC: खस"

284 RGC62; BPLC; BCPC: v

285 RGC62; BPLC; BCPC: $\longleftarrow$

286 RGC62; BCPC: गाशेयास'तु'; BPLC: गाशेत'

287 BCPC: 讶

288 RGC62; BPLC; BCPC: ळेव 


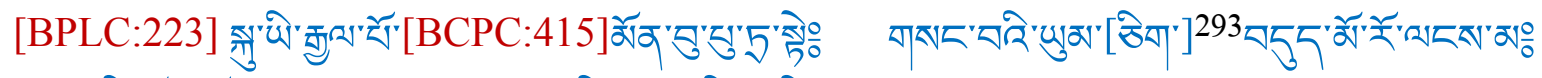

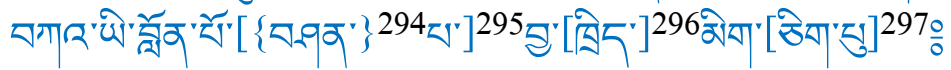

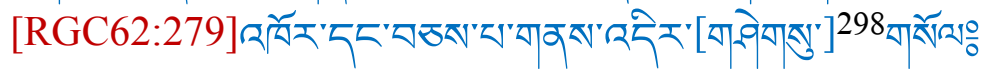

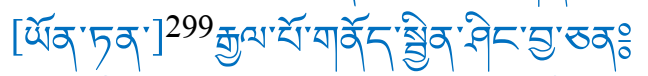

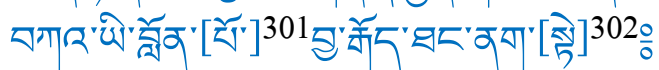

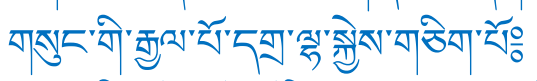

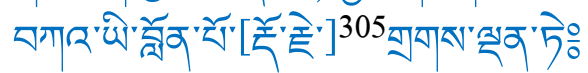

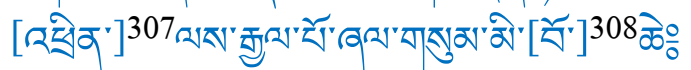

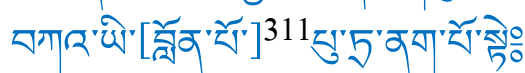

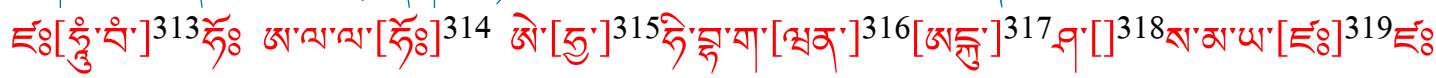

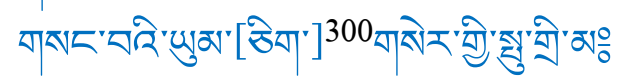

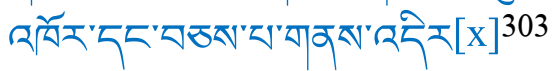

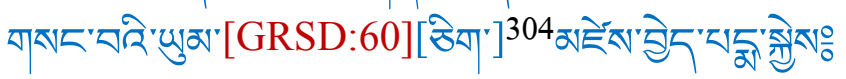

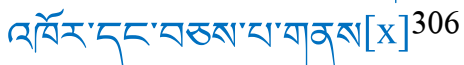

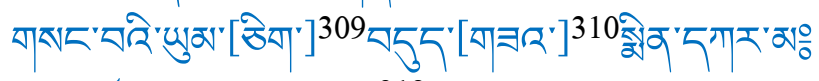

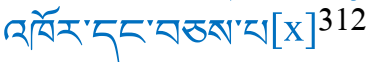

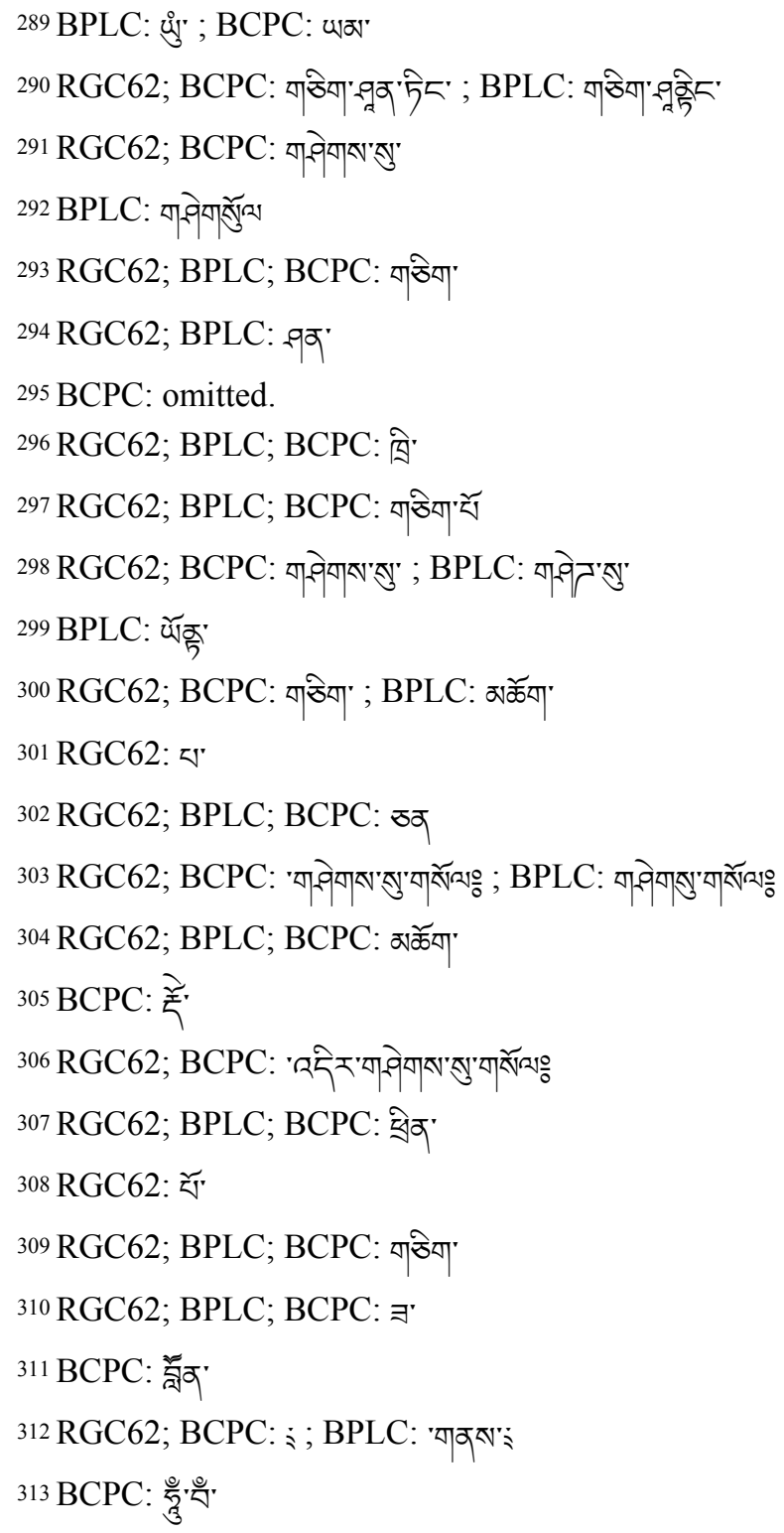




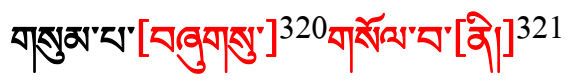

[궁응 $]^{322}$

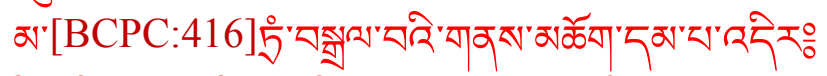

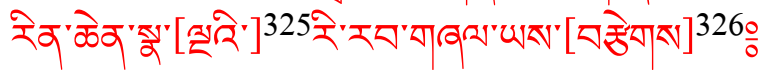

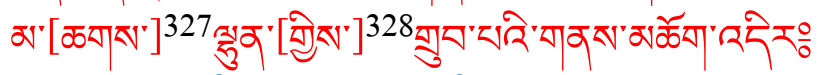

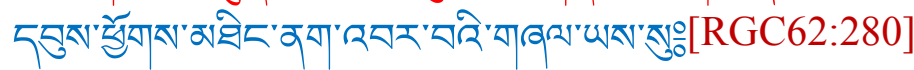

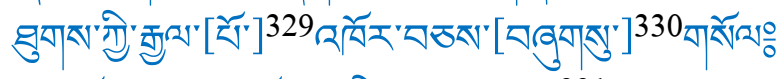

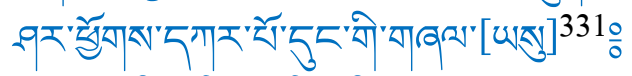

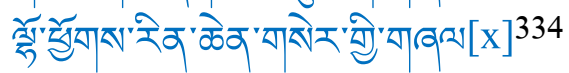

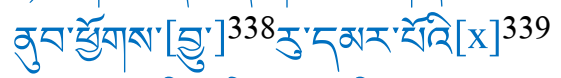

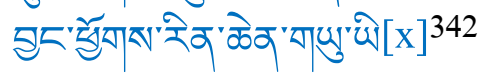

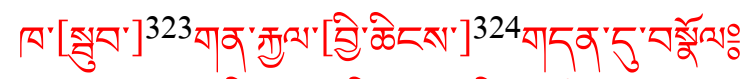

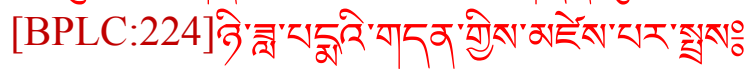

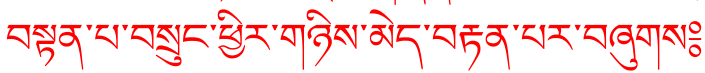

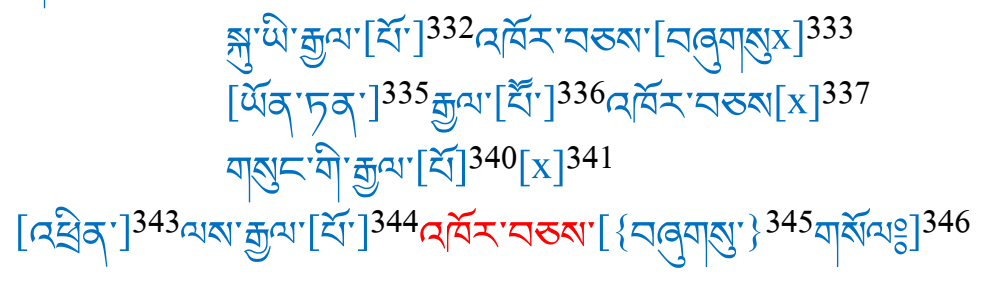

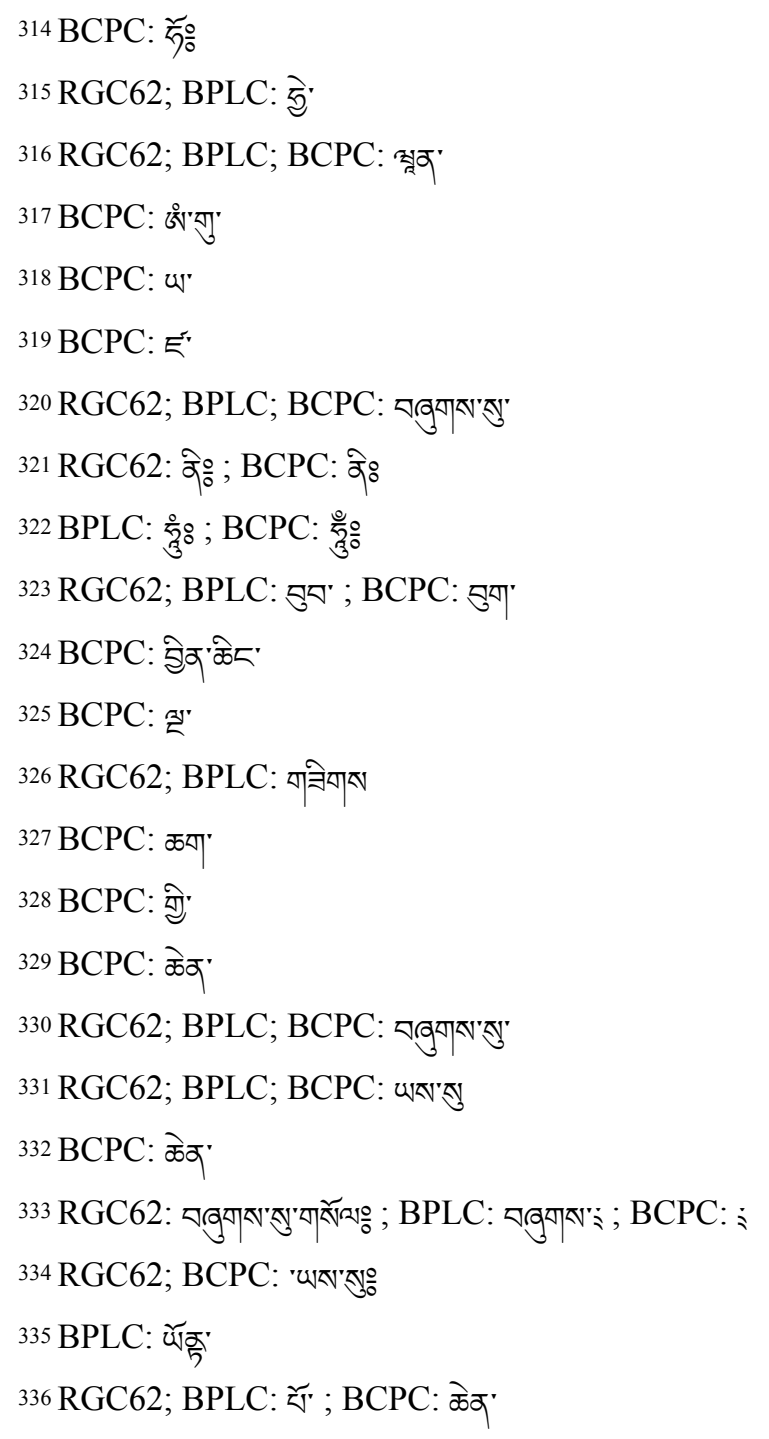




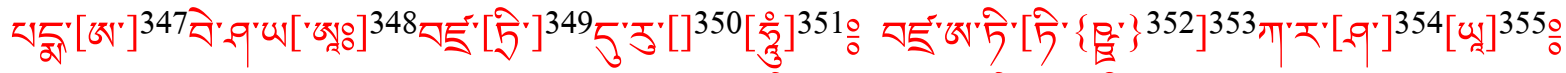

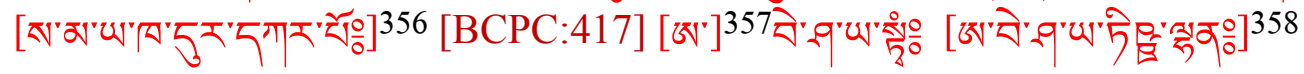

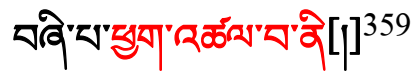

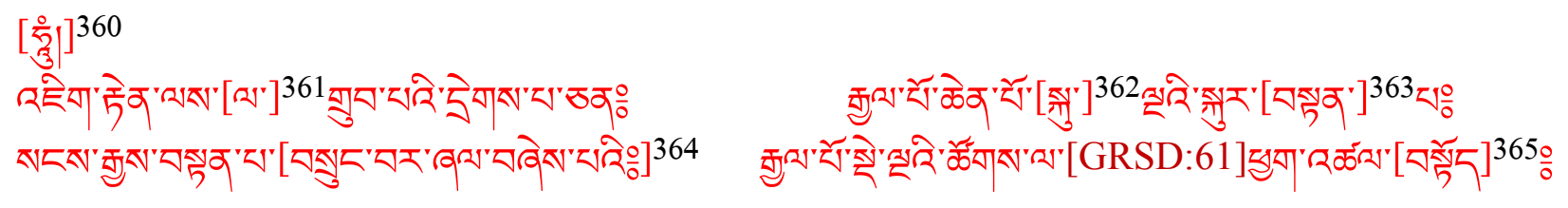




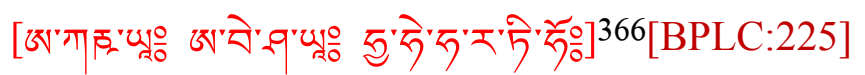

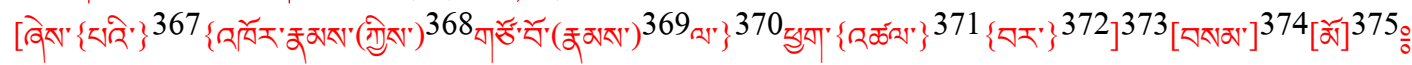

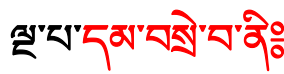

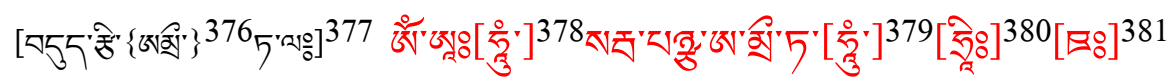

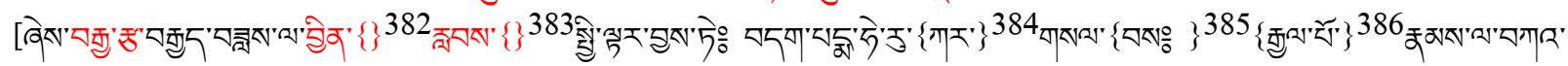

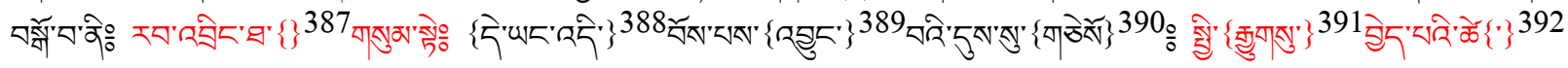

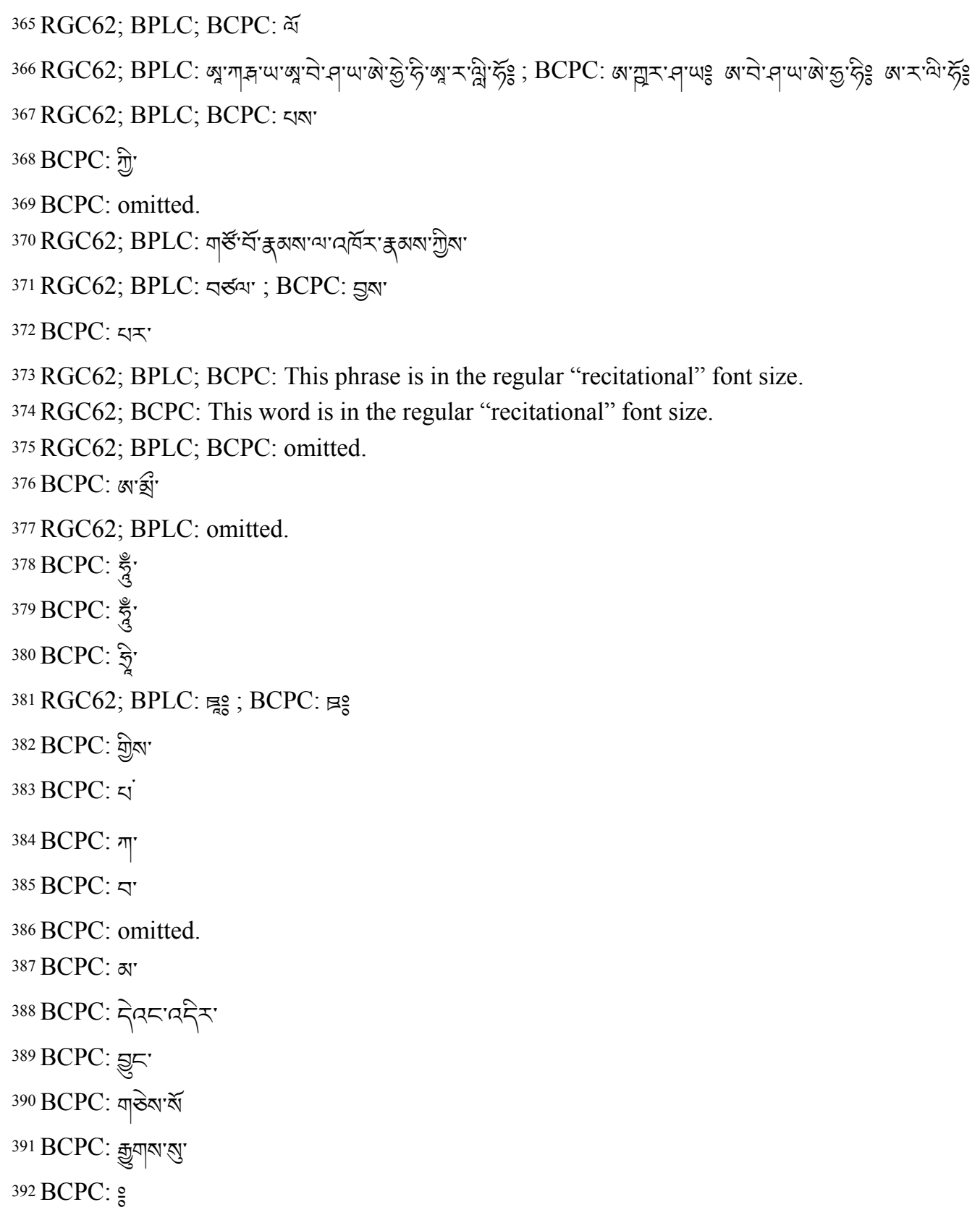




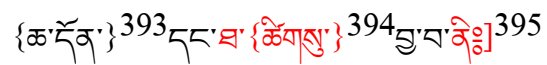

[RGC62:281][궂응 $]^{396}$

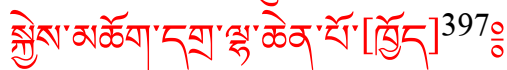

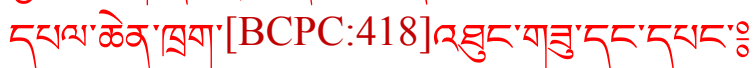

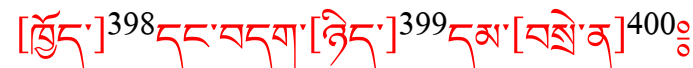

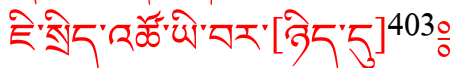

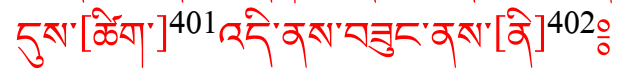

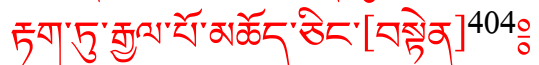

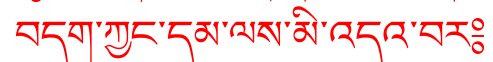

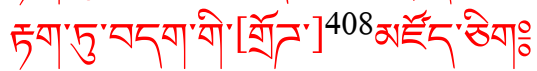

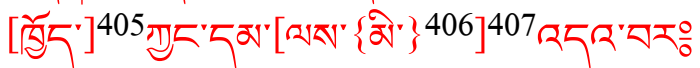

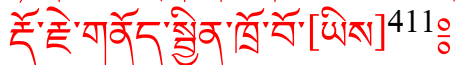

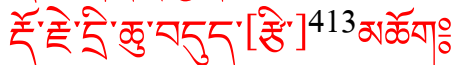

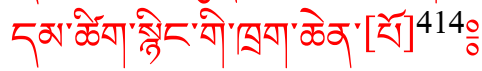

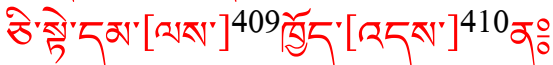

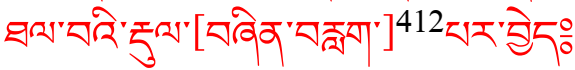

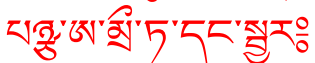

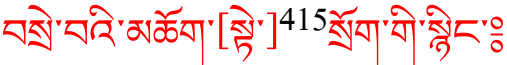

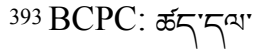

394 BCPC: केषा एरेंके॰

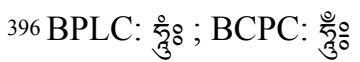

397 RGC62; BPLC: ف्रेद

398 RGC62; BPLC: ف्डे5;

399 RGC62; BPLC: वें

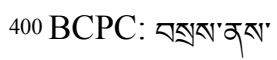

401 RGC62; BPLC: केస్

402 BCPC: 자

403 RGC62; BPLC: 5ग7]

404 RGC62; BPLC: ஏईव ; BCPC: వईेव

405 RGC62; BPLC: ف्डेट" ; BCPC: क्ड5

406 BCPC: §ं

407 RGC62; BPLC: బ'वं

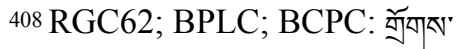

409 RGC62; BPLC:

410 RGC62; BPLC: R5R०

411 RGC62; BPLC: џे

412 RGC62; BPLC: Гु'㸎"

413 RGC62; BPLC: ₹ेंें

414 BCPC: 袞

415 BCPC:
}

395 RGC62: बेस' 


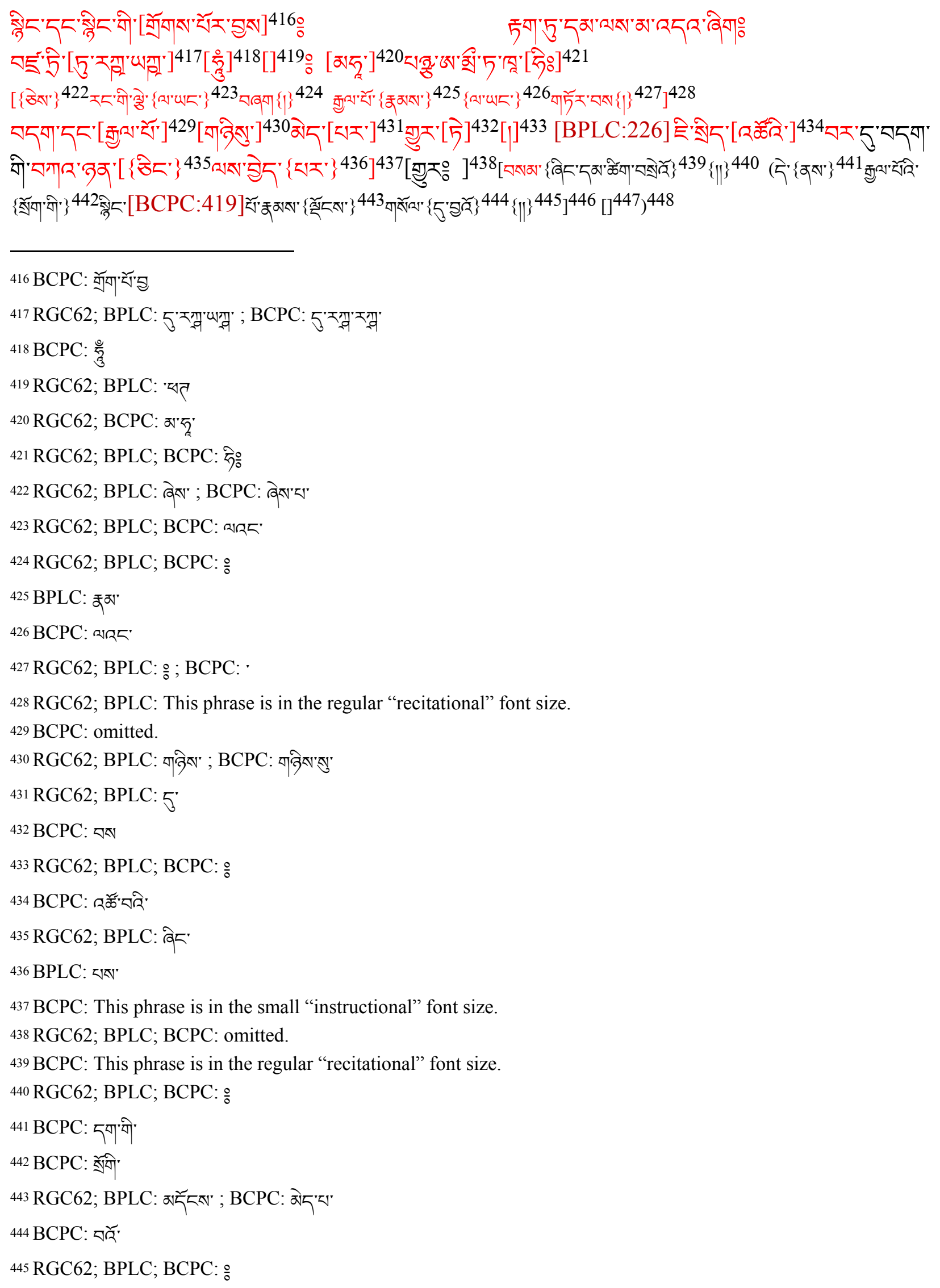




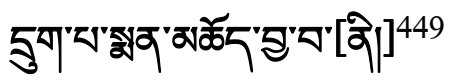

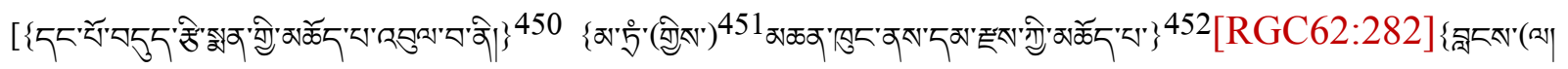

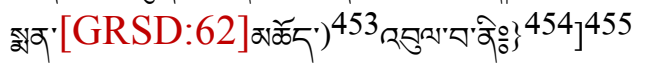

[]$^{456}$

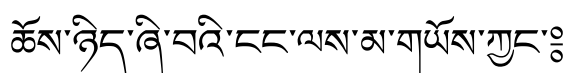

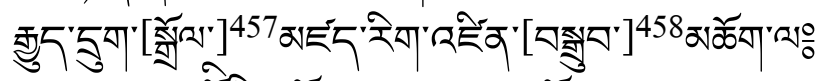

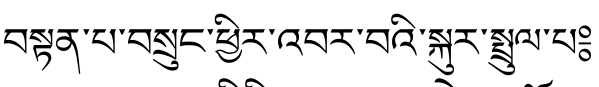

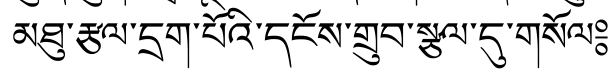

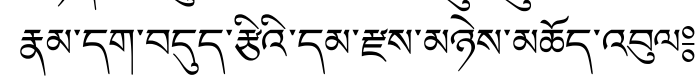

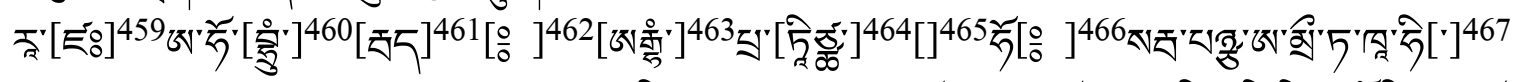

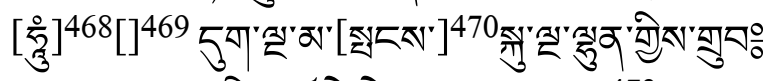

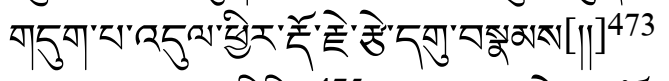

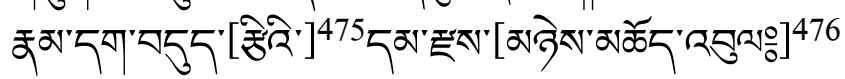

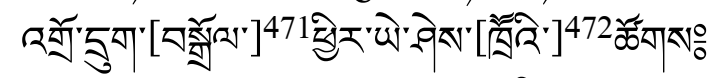

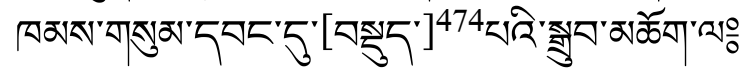

446 RGC62; BPLC: This phrase is in the regular "recitational" font size.

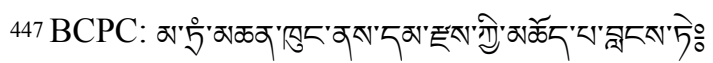

448 BCPC: This passage is in the regular "recitational" font size.

449 RGC62; BCPC: वे०े ; BPLC: वे०

450 RGC62; BPLC: omitted.

451 RGC62; BPLC: ब्रें

452 RGC62; BPLC: This phrase is in the regular "recitational" font size.

453 RGC62; BPLC: नें

${ }^{454}$ BPLC: This phrase is in the regular "recitational" font size.

455 BCPC: omitted.

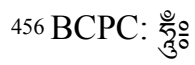

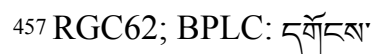

458 RGC62; BPLC: 젝' ; BCPC: 깾'

459 RGC62: ङ゙ ; BPLC; BCPC: Еँ

460 RGC62; BPLC: ন্তু

461 BCPC: অत्र

462 RGC62; BPLC: '

463 BCPC: खाश्रों

464 BCPC: Ђे हूँ

465 RGC62; BPLC: ऐे

466 RGC62; BPLC: ·

467 RGC62; BCPC: ㅇ ; BPLC: The character is too faded, but it is likely

468 BCPC: 蒿.

469 RGC62; BPLC: 응 


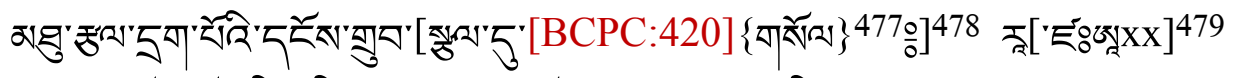

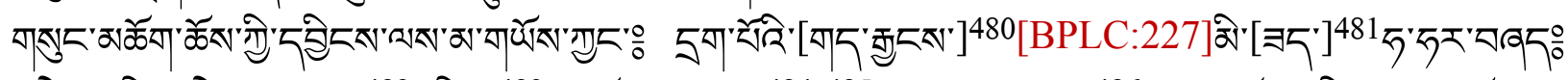

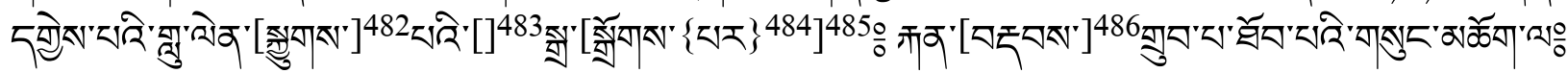

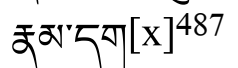

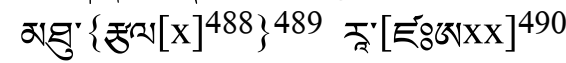

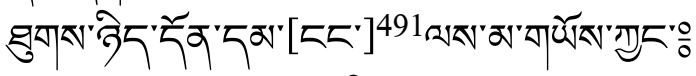

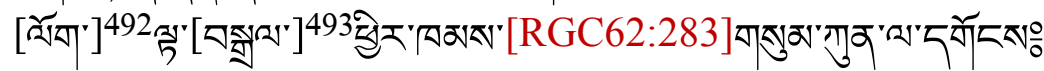

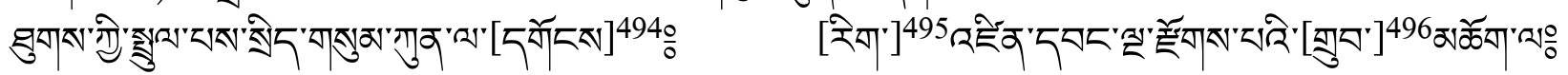

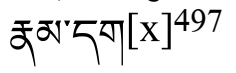

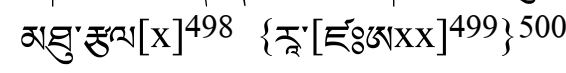

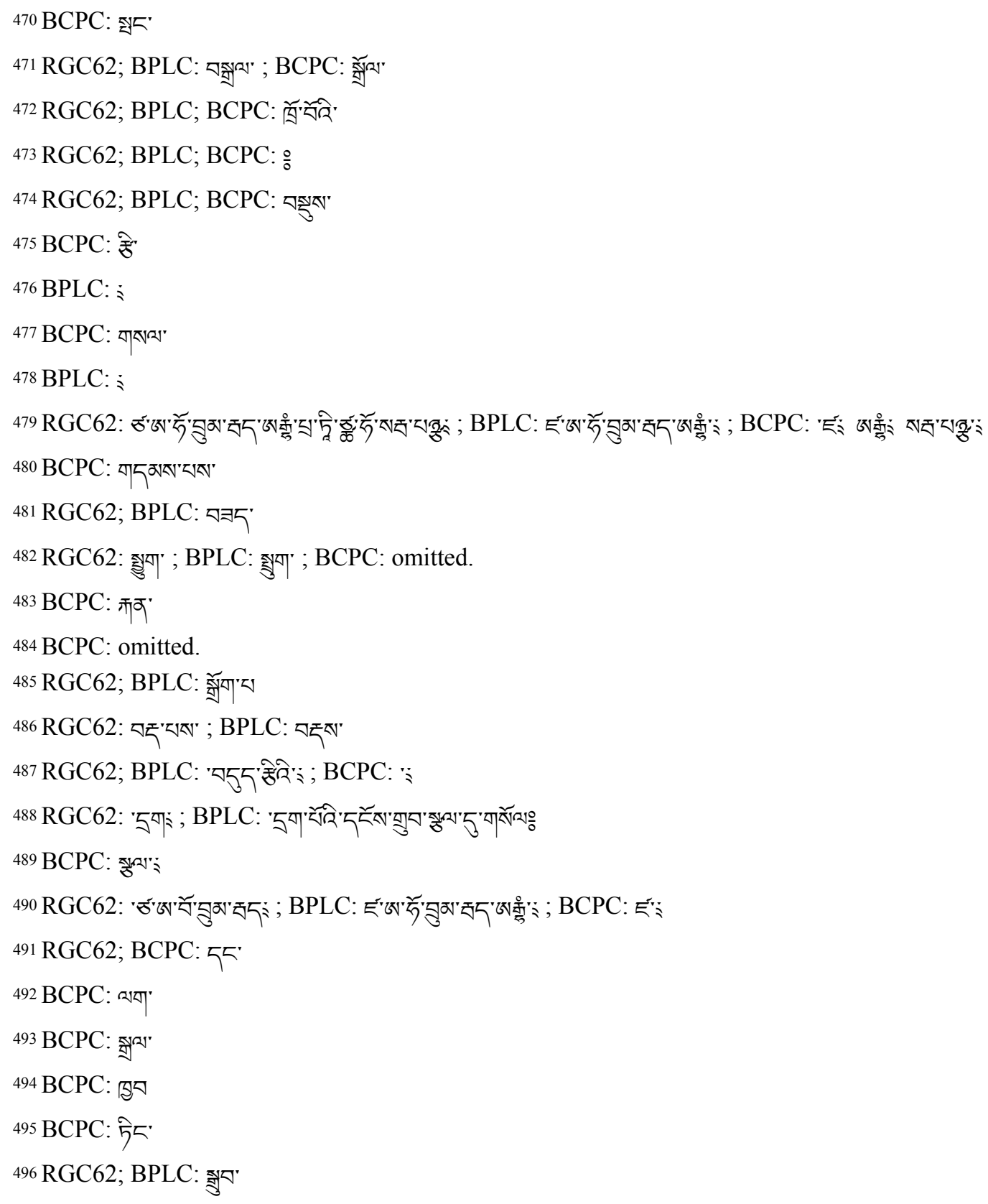




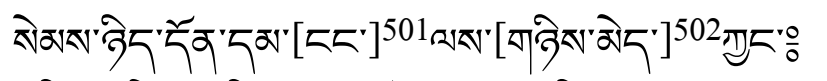

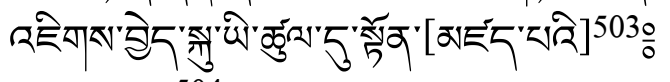

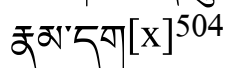

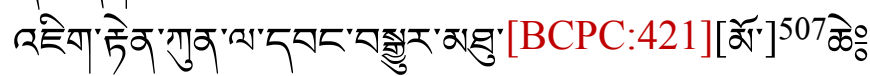

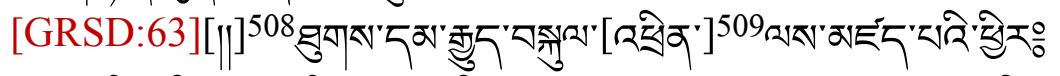

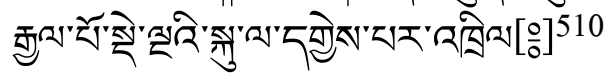

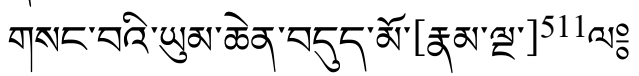

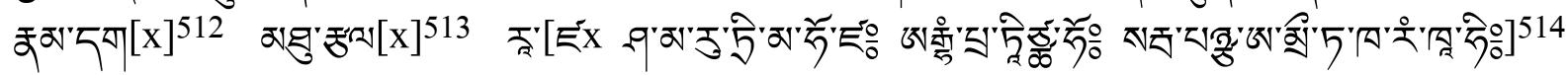

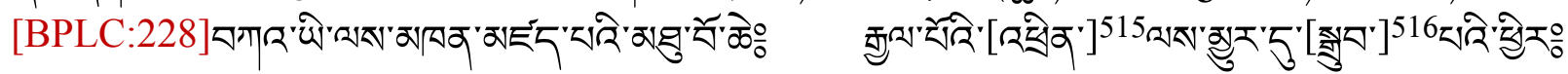

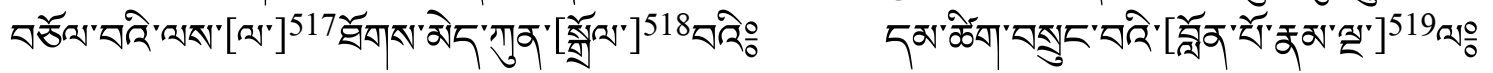

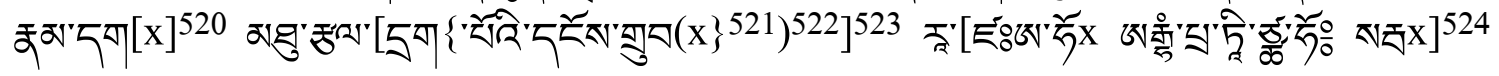

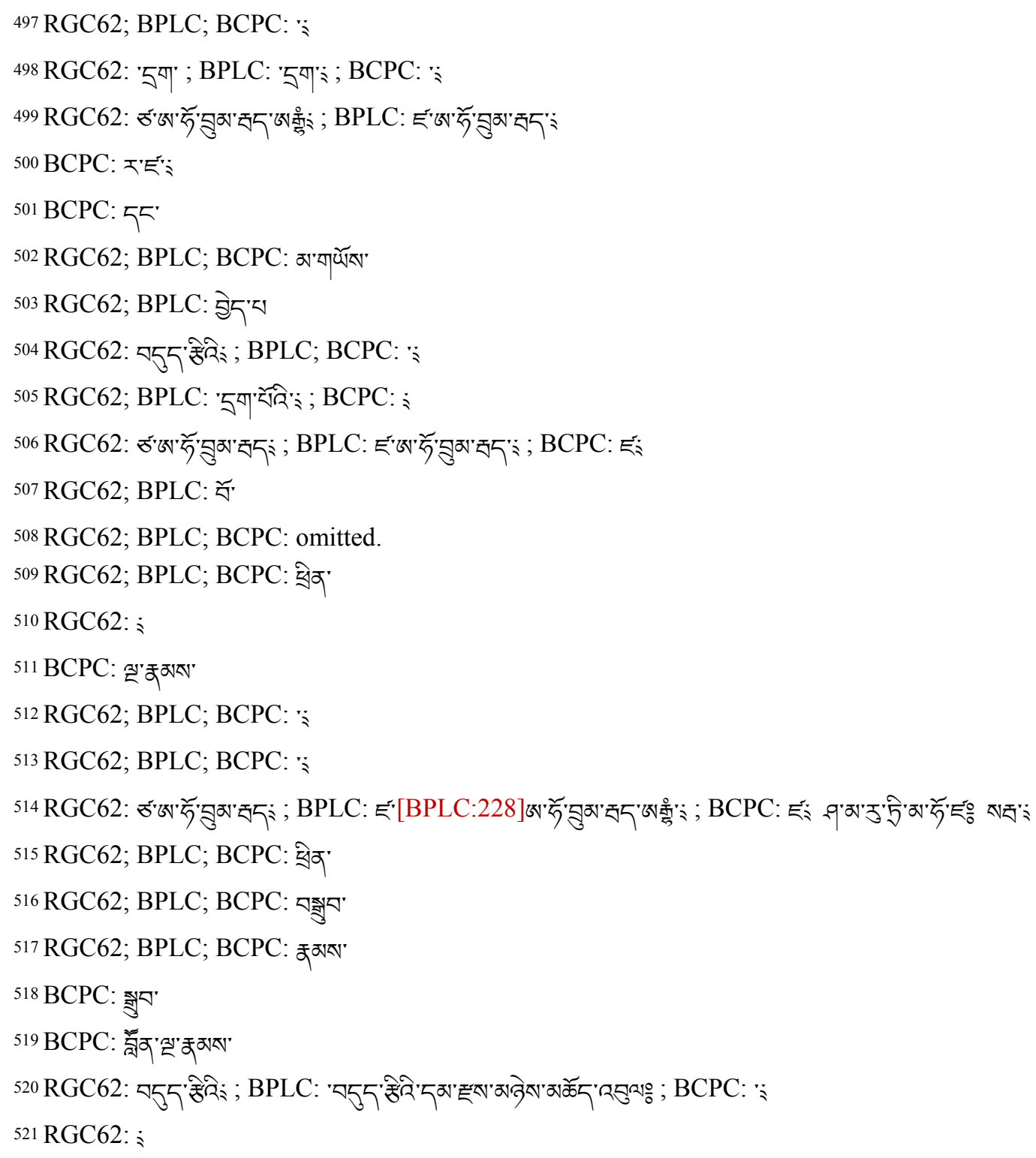




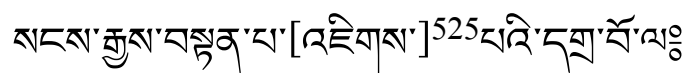

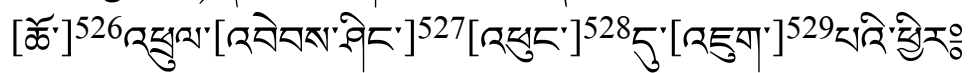

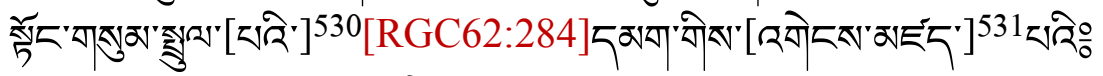

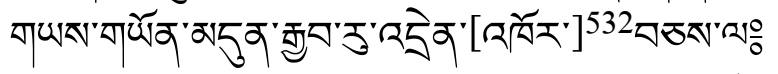

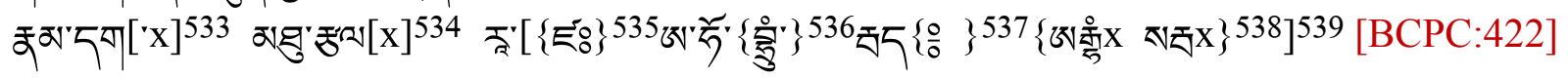

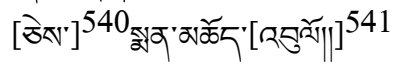

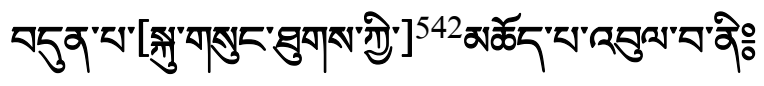

[] 543 [ूे०

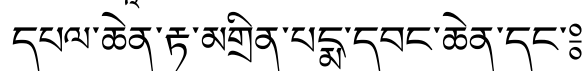

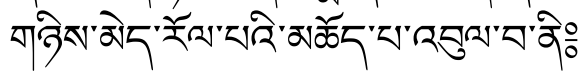

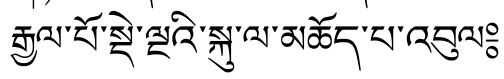

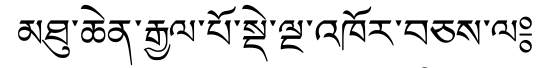

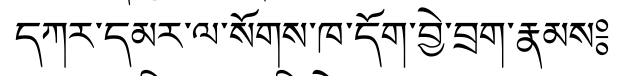

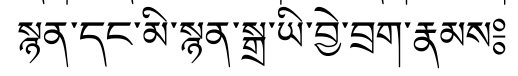

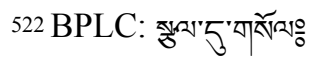

523 BCPC: :

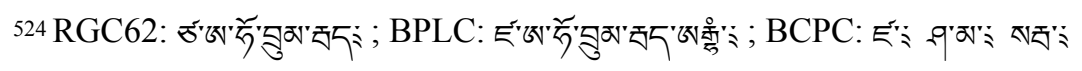

525 RGC62; BPLC: रहेगा ; BCPC: Ђशेषा"

526 BCPC: केते

527 BCPC: इचव'ठेट

528 RGC62; BPLC; BCPC: चुॅ'

529 RGC62; BPLC; BCPC: ग|बुग"

530 BCPC: 5

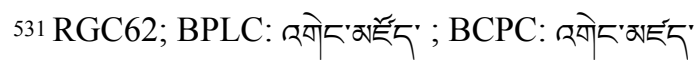

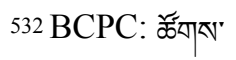

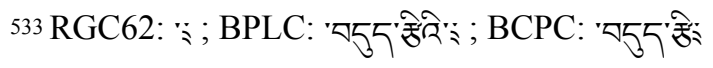

534 RGC62; BPLC: : ; BCPC: '万可炎官:

535 RGC62: ซ゙ ; BPLC: Е゙

536 RGC62; BPLC: ন্তুक'

537 BPLC: '

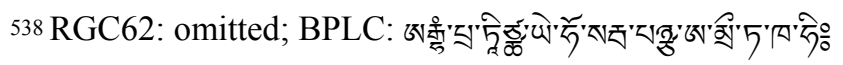

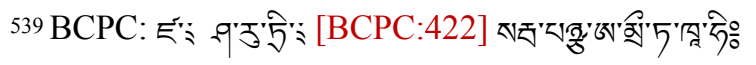

540 RGC62; BPLC; BCPC: बेते

${ }^{541}$ RGC62; BPLC; BCPC: RБुख्य त्रे०

542 RGC62; BPLC; BCPC: omitted.

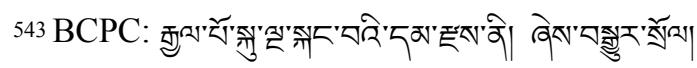




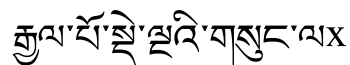

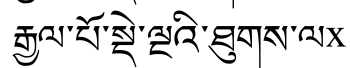

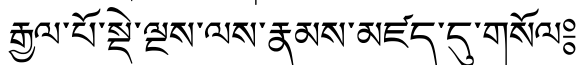

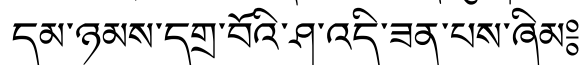

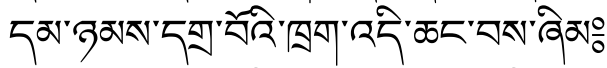

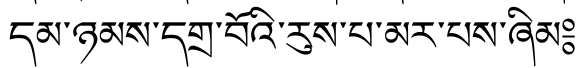

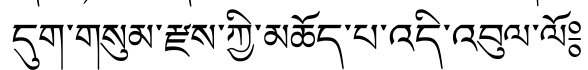

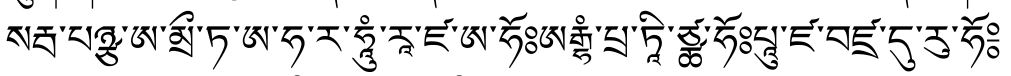

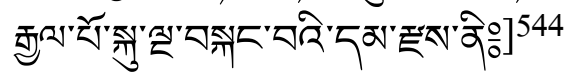

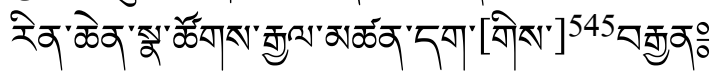

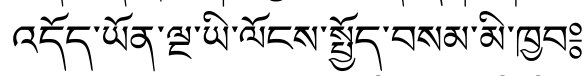

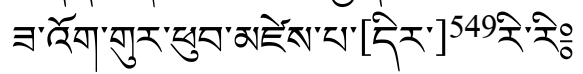

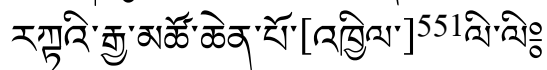

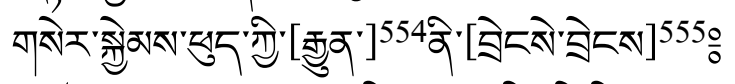

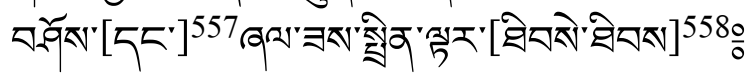

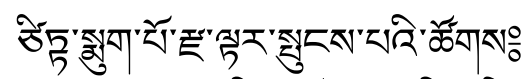

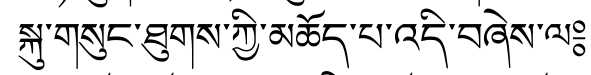

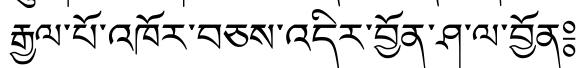

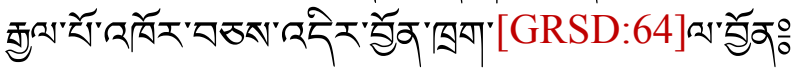

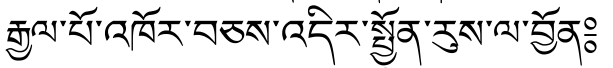

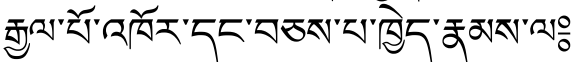

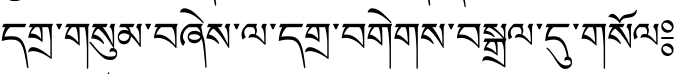

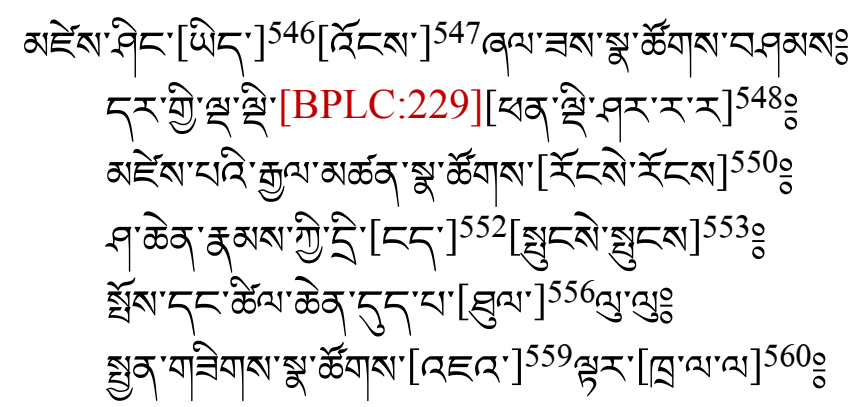

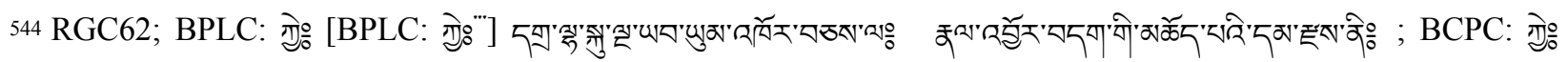

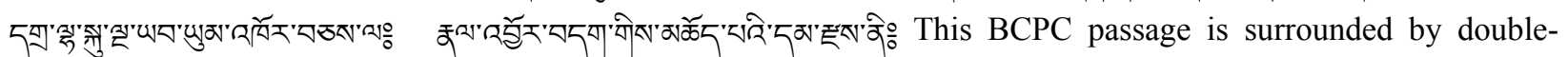
parentheses, and the previous line (note 543) is added after the ग刃्रे०े as an interlinear annotation, suggesting that it should replace or is on par with this line.

545 BCPC: बों

546 BCPC: Щें

547 RGC62; BPLC; BCPC: К̌ॅ

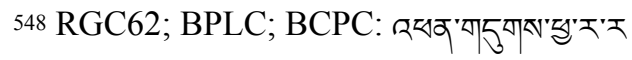

549 RGC62; BPLC: Һे; ; BCPC: शें

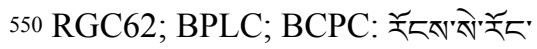

551 BCPC: के

552 BCPC: 55

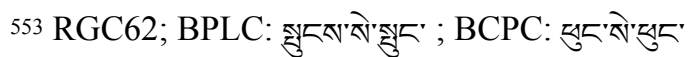

554 BCPC: 武;

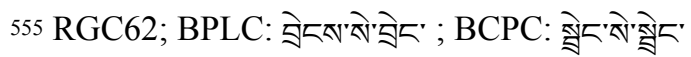

556 RGC62; BPLC; BCPC: Яู'

557 RGC62; BPLC; BCPC: गार์

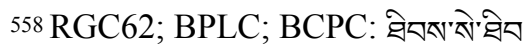

559 RGC62; BPLC; BCPC: Æ゙

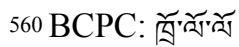




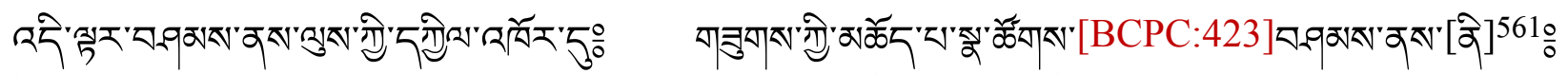

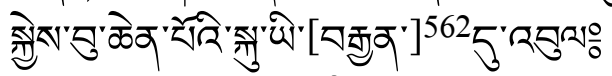

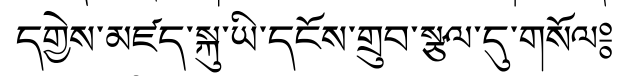

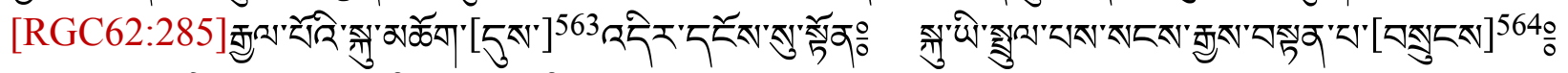

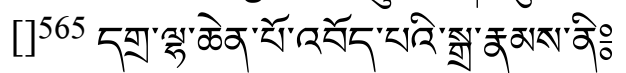

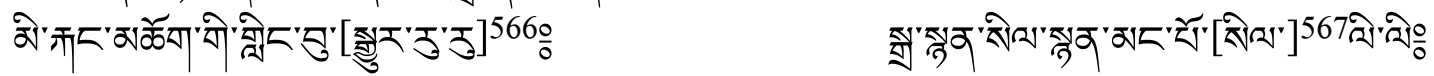

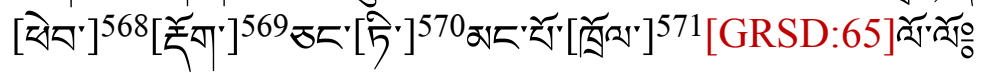

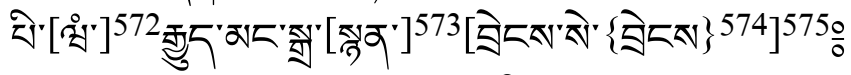

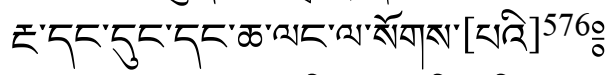

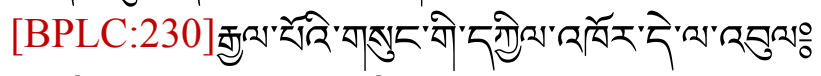

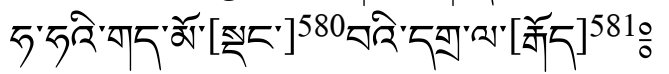

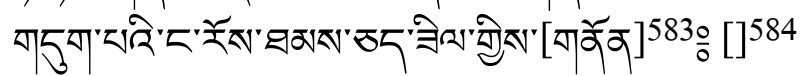

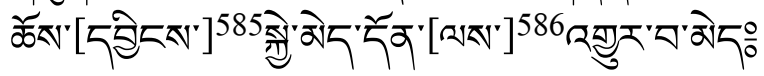

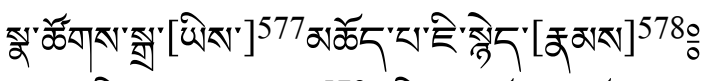

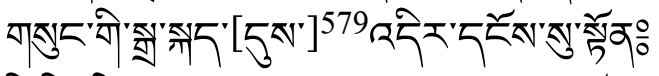

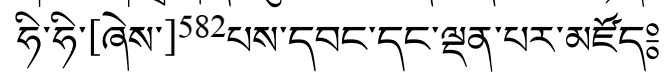

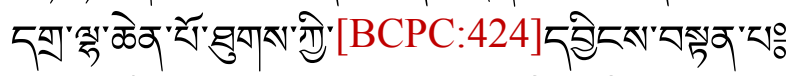

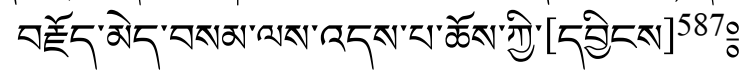

\footnotetext{
561 RGC62; BPLC; BCPC: 저

562 RGC62; BPLC; BCPC: ఫ్రুव

563 RGC62; BPLC: خَّ'

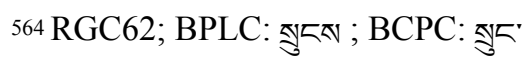

565 RGC62; BPLC; BCPC: ग्रे०

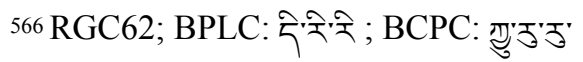

567 RGC62; BPLC; BCPC: సें

568 BCPC: छोषसे

569 RGC62; BPLC; BCPC: 草

570 RGC62; BPLC: Ђิ乃ु' ; BCPC: நิ乃

571 RGC62; BPLC; BCPC: 茴

572 BCPC: ชํํ

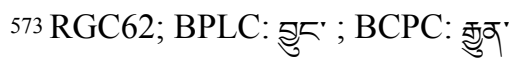

574 RGC62; BPLC: ఫेГ'

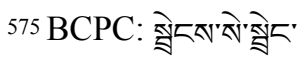

576 RGC62; BPLC; BCPC:

577 RGC62; BPLC; BCPC: ঋे

578 BCPC: $\longleftarrow$

579 RGC62; BPLC: خૅ

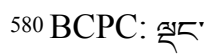

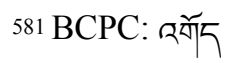

582 RGC62; BPLC; BCPC: $\square 95$
} 


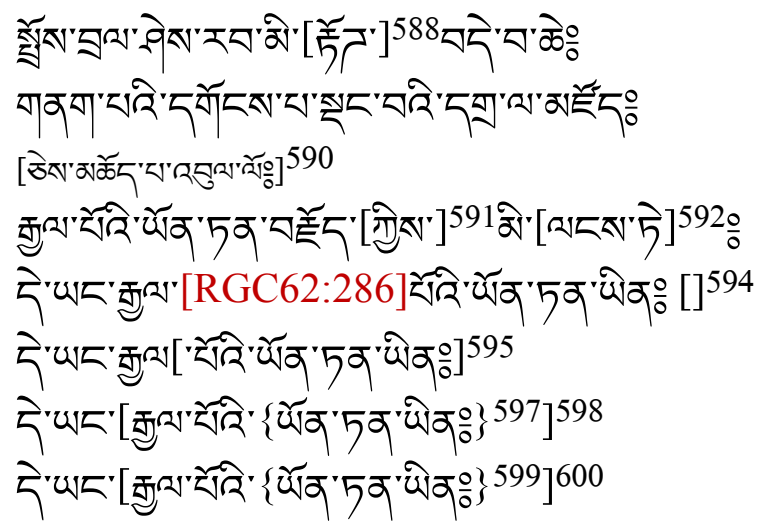

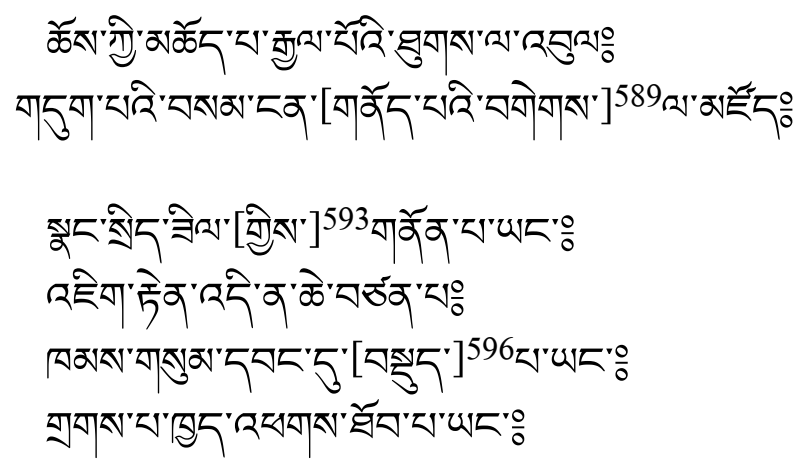

\section{BPLC:}

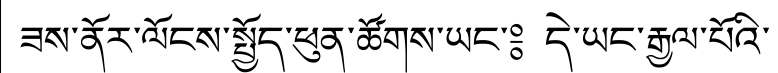

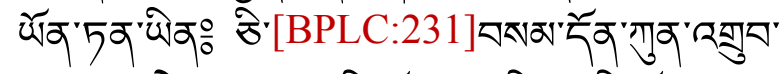

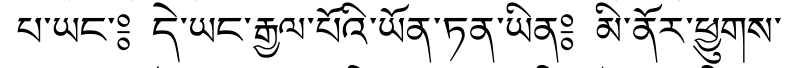

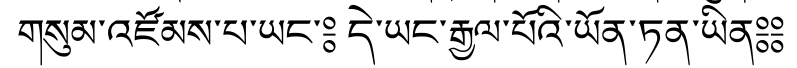

\footnotetext{
583 BCPC: गाव

584 BCPC: 끙으

585 BCPC: नेॅ

586 RGC62; BPLC: 『

587 RGC62; BPLC: 获

588 RGC62; BPLC; BCPC: 芌可

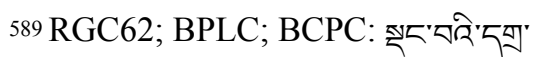

590 RGC62; BPLC; BCPC: omitted.

591 BCPC: गें'

592 RGC62; BPLC; BCPC: ख్ त्रे

593 BCPC: ग्रे'

594 BCPC: रेषासर बचेत्रे।

595 RGC62: : ; BCPC: “خेशे":

596 RGC62; BPLC: 25ुतें

597 RGC62: :

598 BCPC: :

599 RGC62: :

${ }^{600} \mathrm{BCPC}$ : :
} 


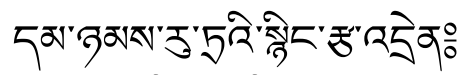

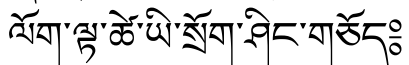

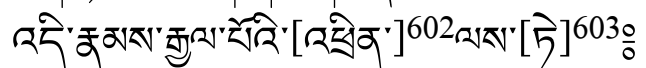

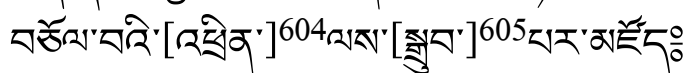

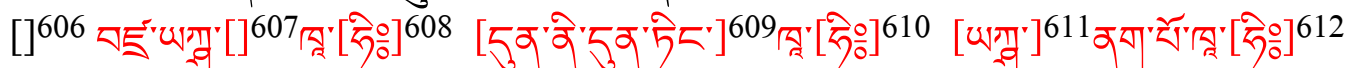

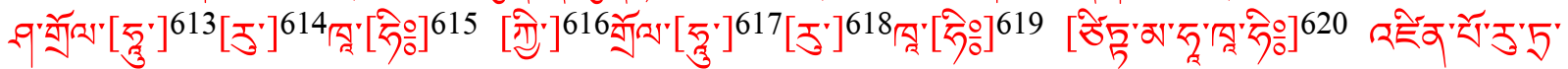

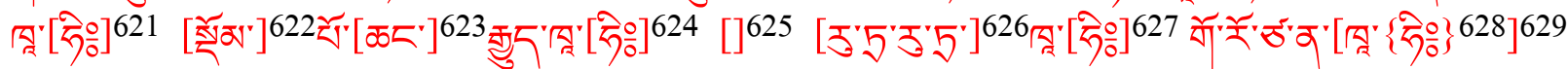

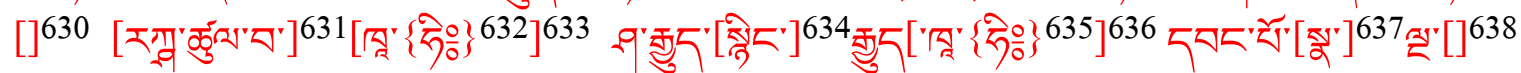

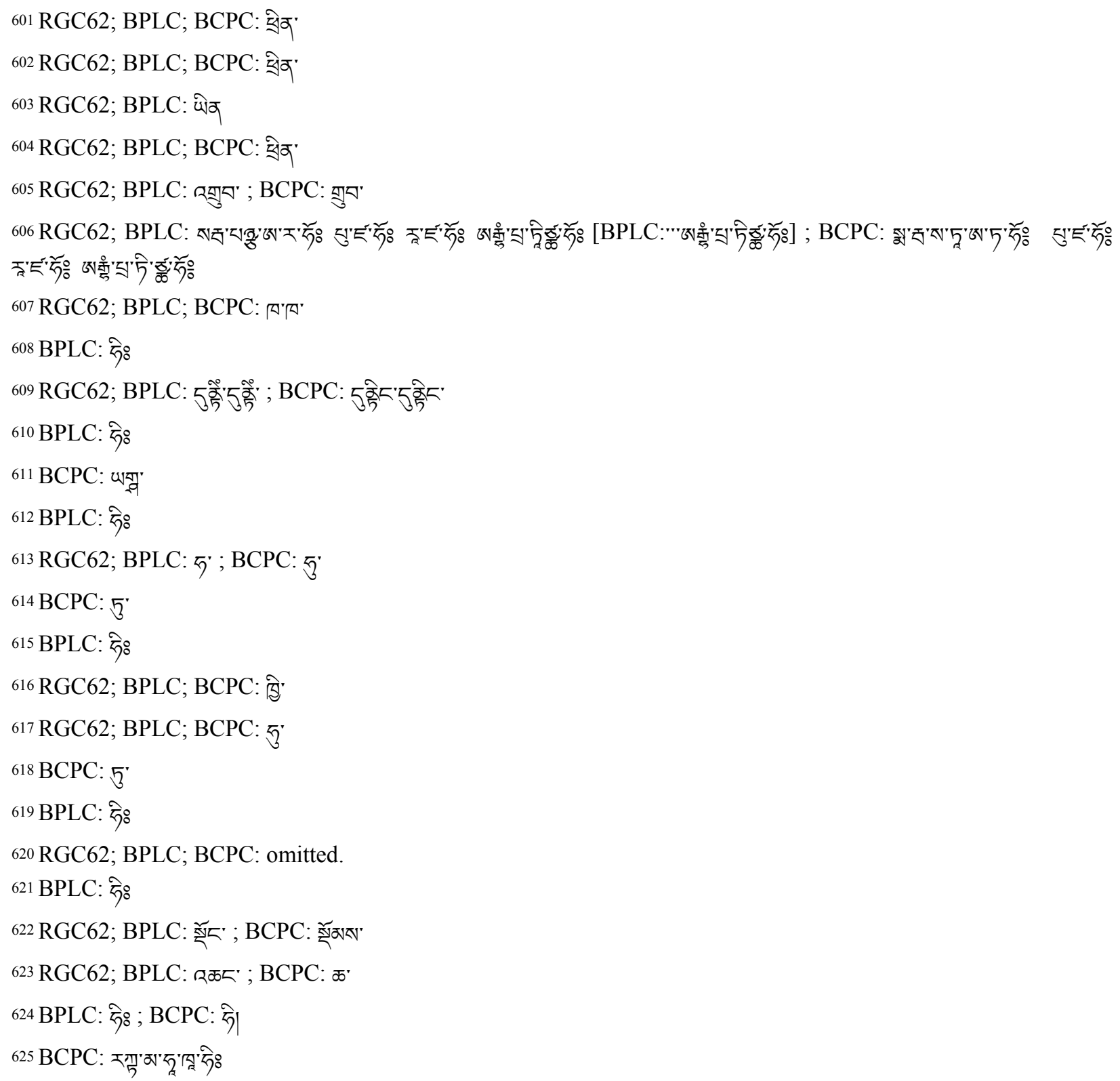




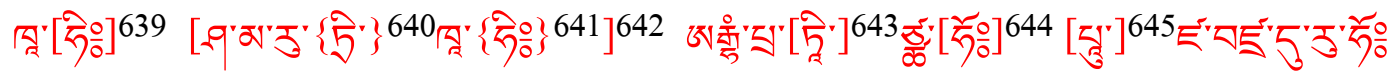

\section{BPLC:}

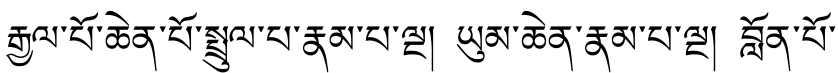

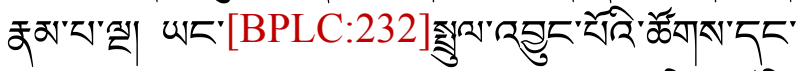

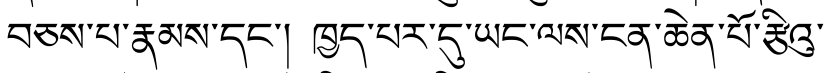

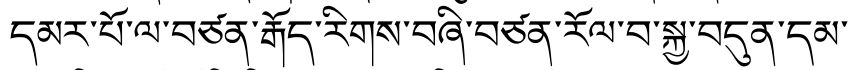

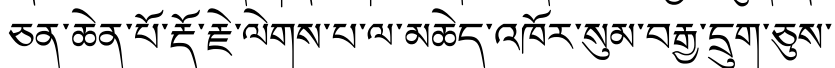

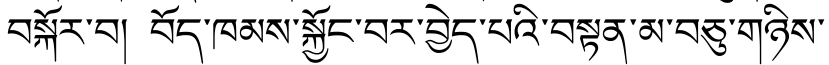

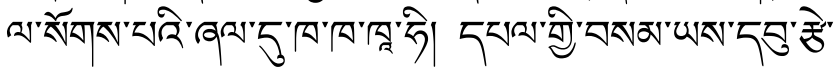

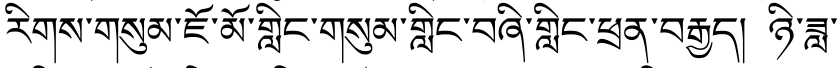

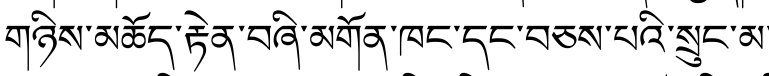

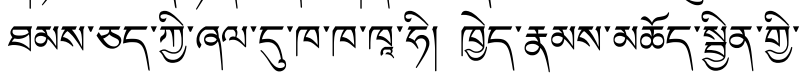

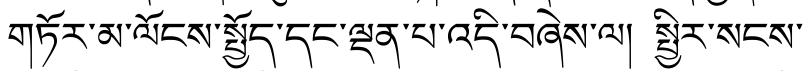

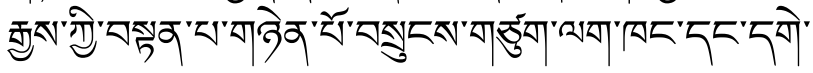

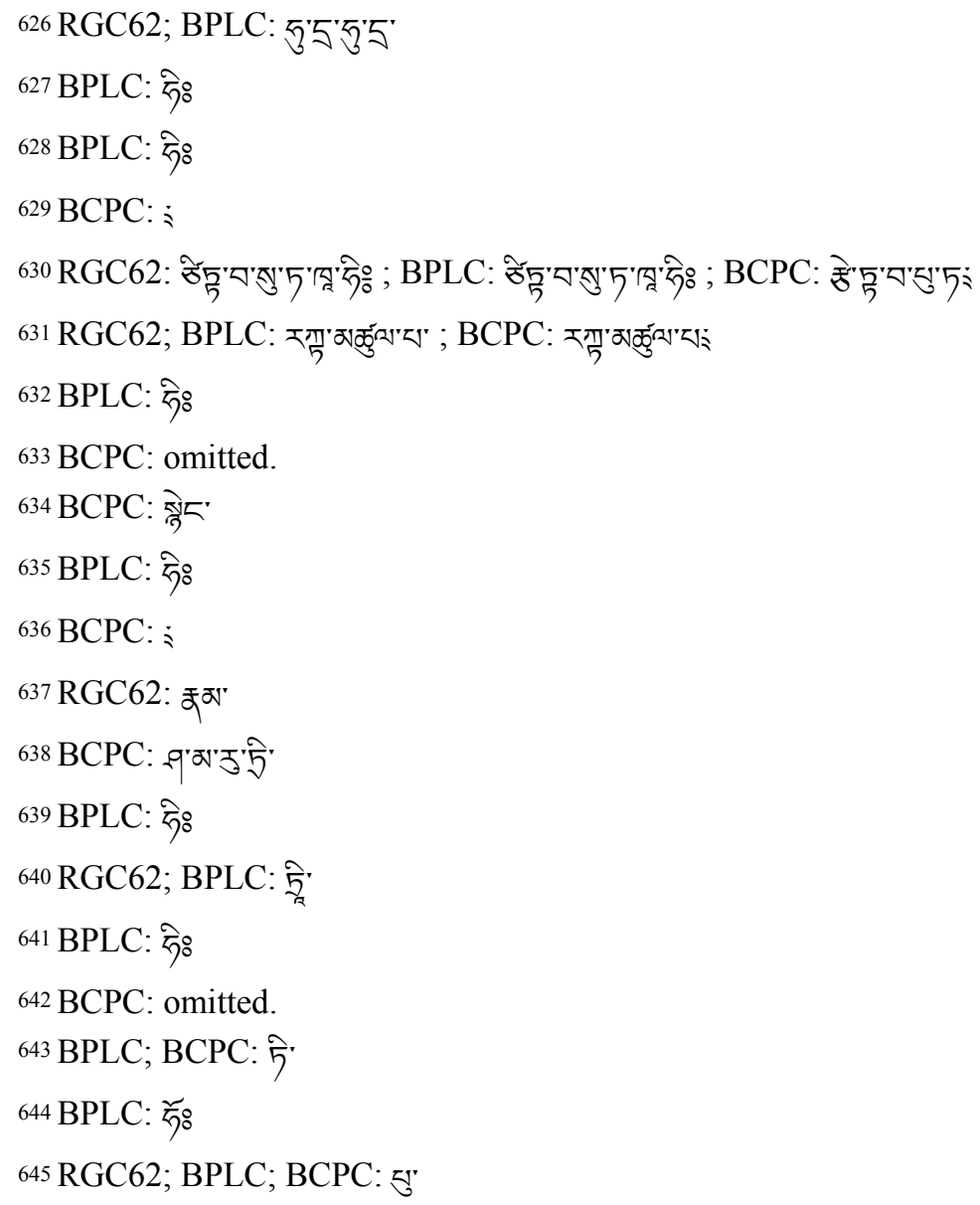




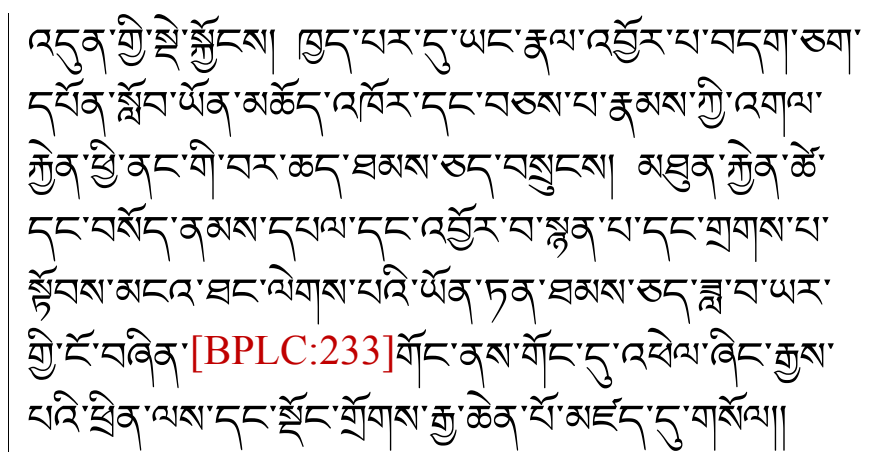

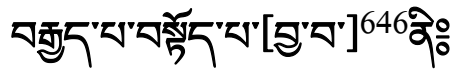

[귱유 647

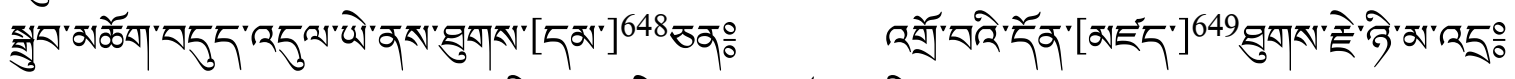

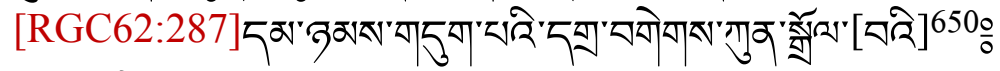

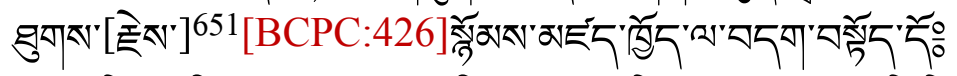

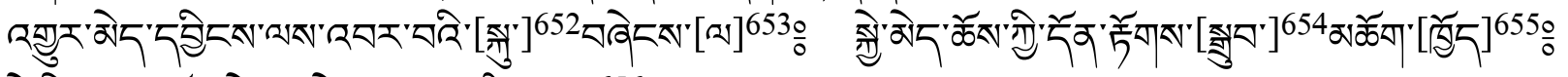

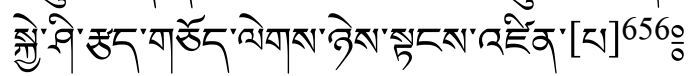

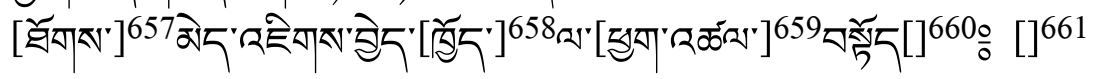

\footnotetext{
646 BPLC: omitted.

${ }^{647}$ RGC62: 귝응 ; BCPC: 뀨응

648 BCPC: 로'

649 BCPC: 5

650 RGC62; BPLC: \

651 RGC62; BPLC; BCPC: 골

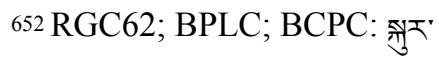

653 RGC62; BPLC; BCPC: ㄴ

654 BCPC: ब्ञुॅन

655 BCPC: ब्डे

656 BCPC: परिे

657 RGC62; BPLC: 浇ा

658 BCPC: ब्रेॅ"

659 RGC62; BPLC; BCPC: $\square 5 \sqrt{7}$

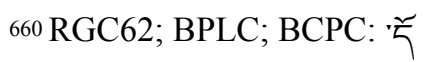

${ }^{661} \mathrm{BCPC}$ : रेषासर 2 ब्रेया।
} 


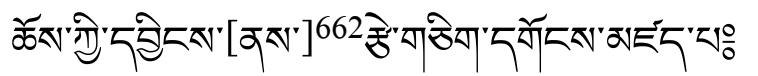

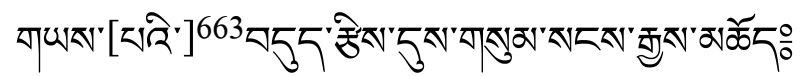

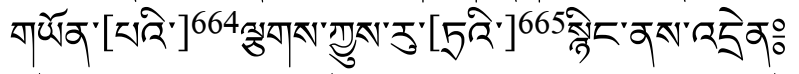

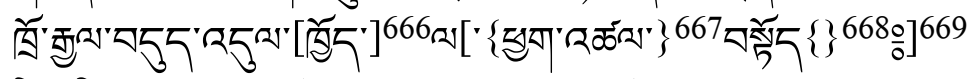

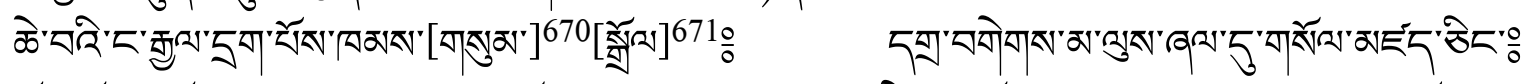

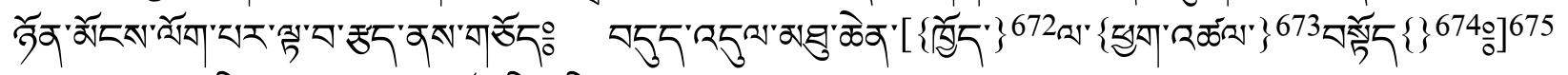

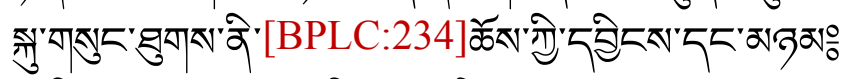

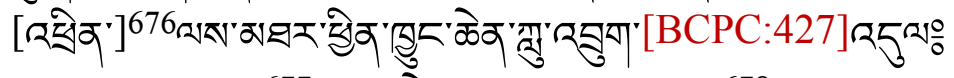

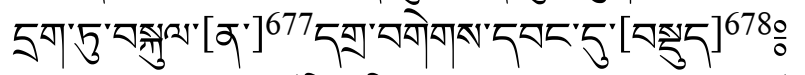

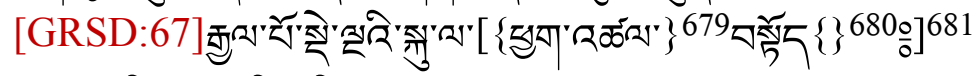

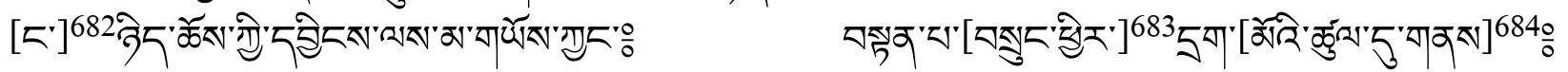

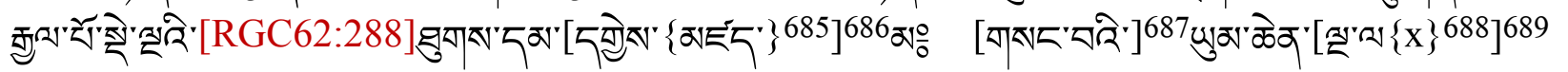

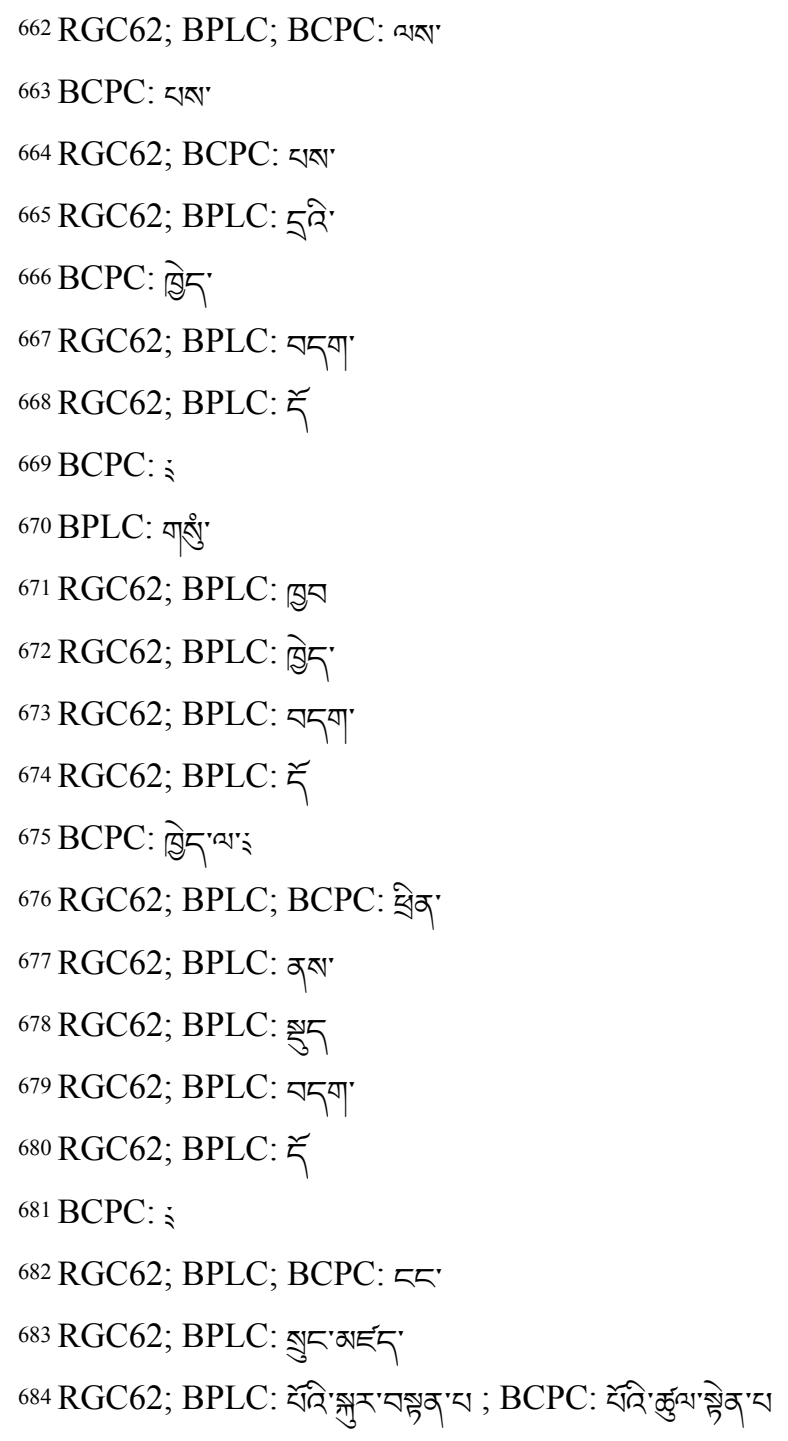




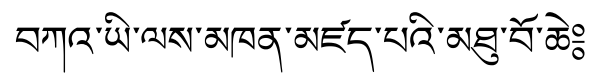

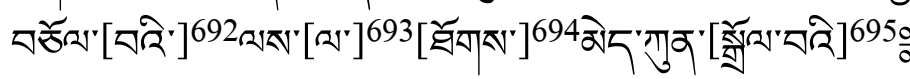

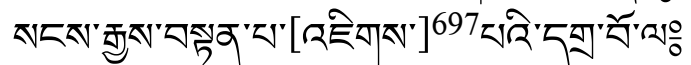

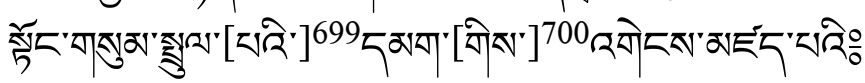

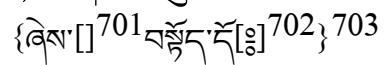

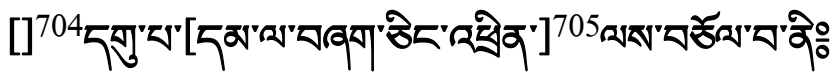

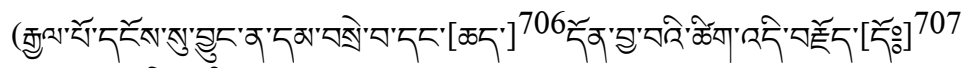

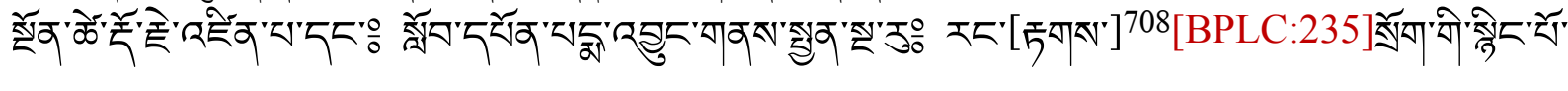

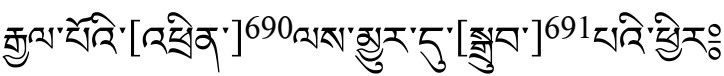

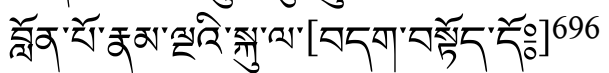

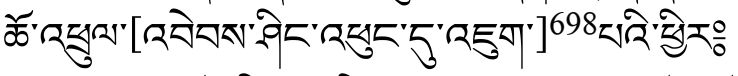

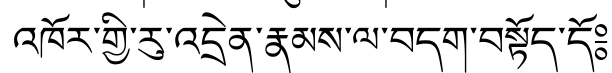

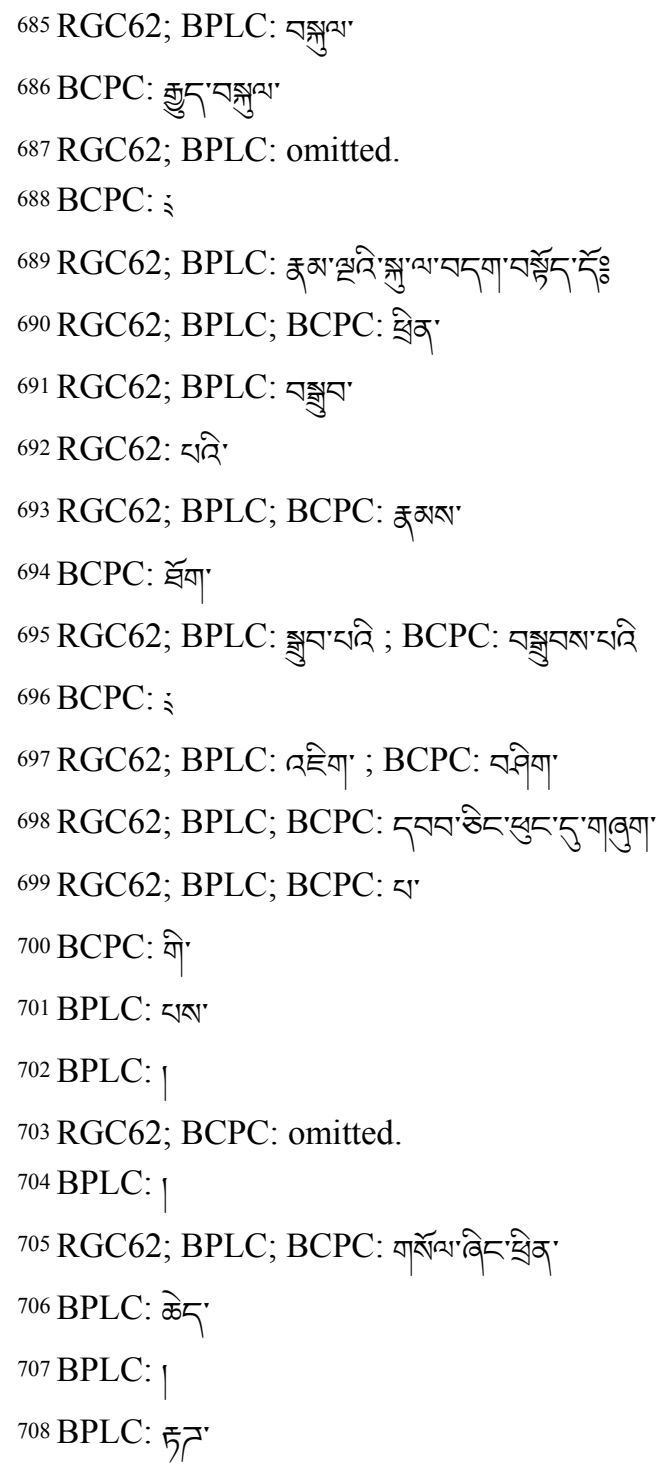




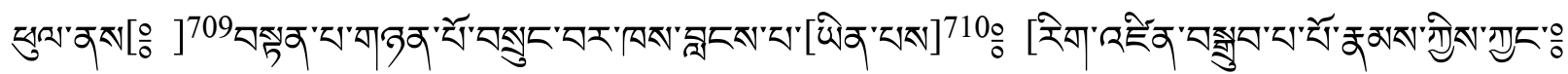

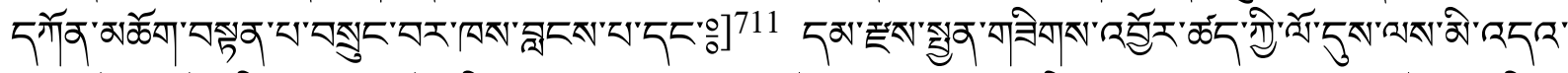

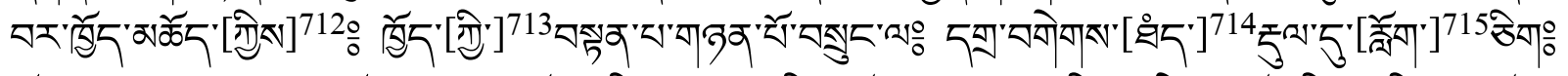

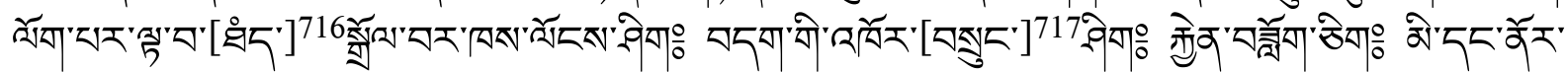

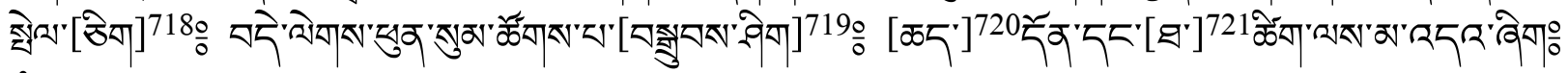

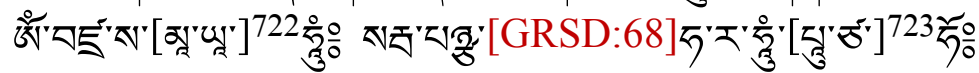

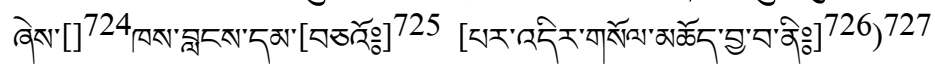

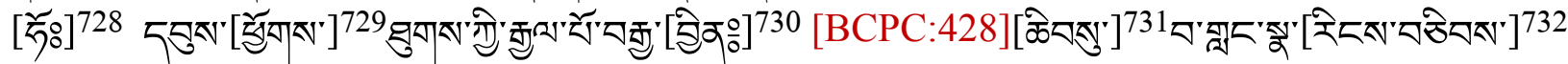

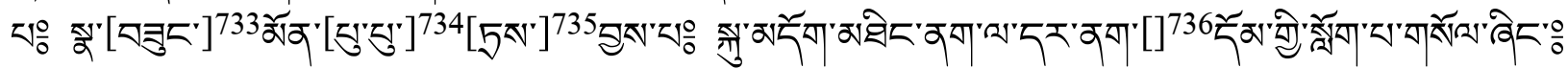

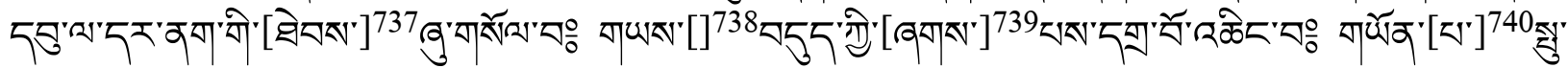

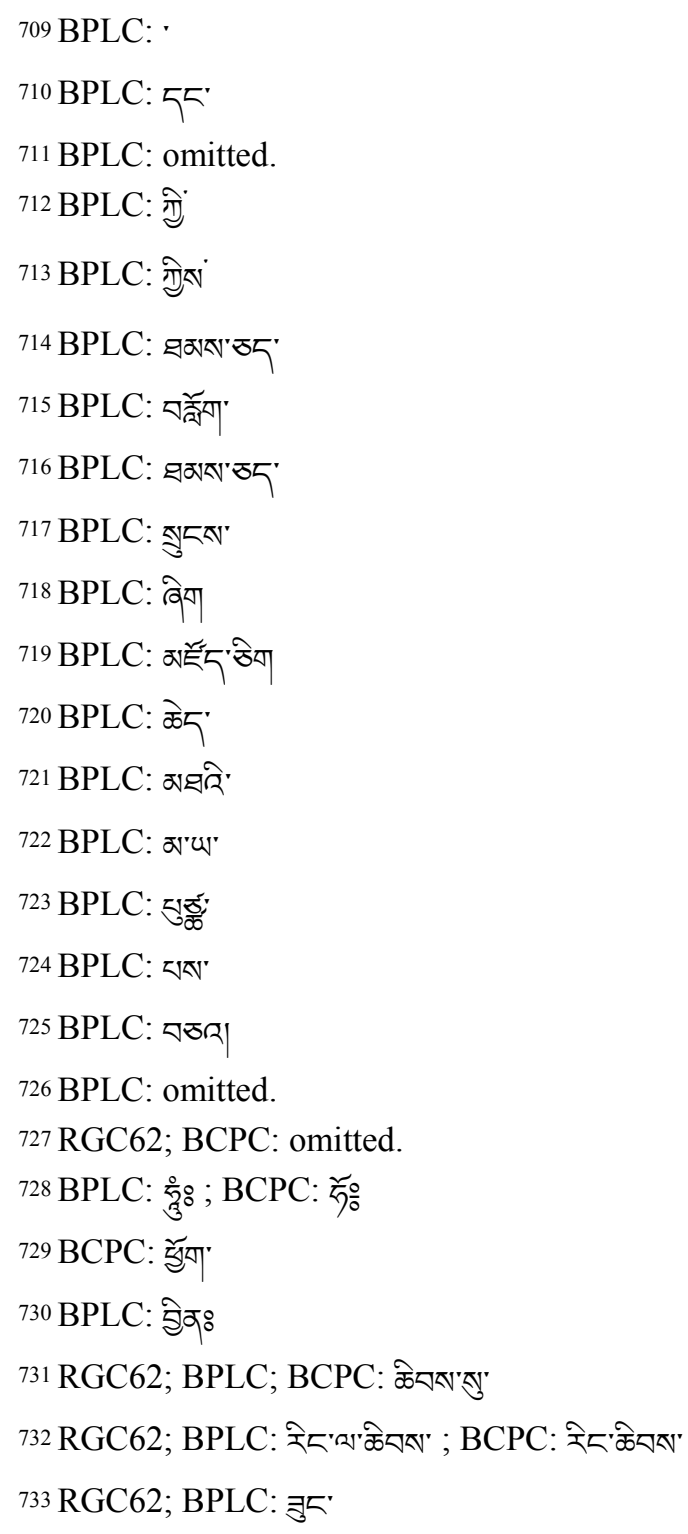




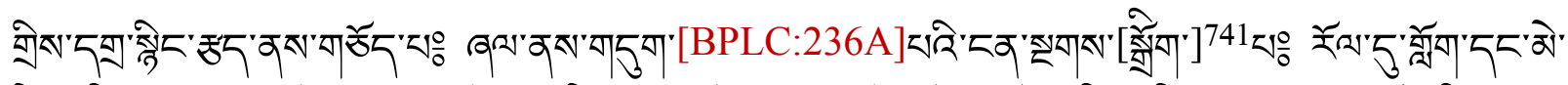

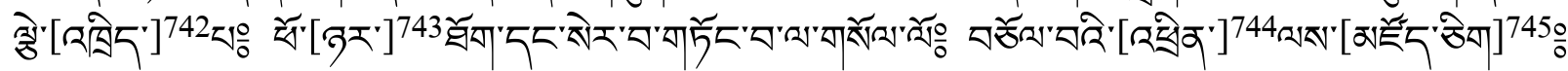

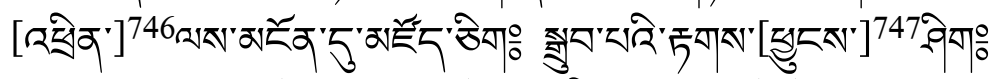

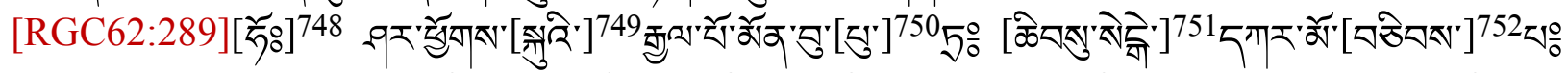

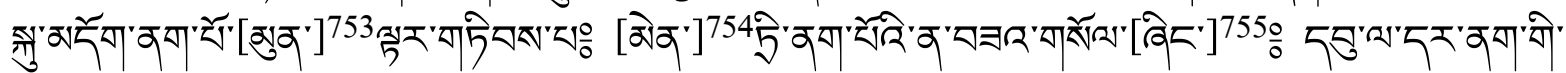

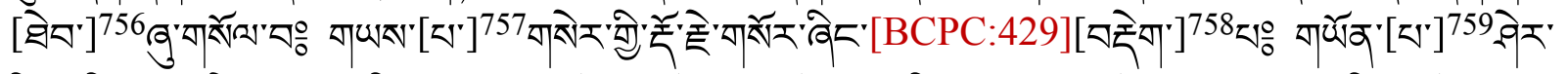

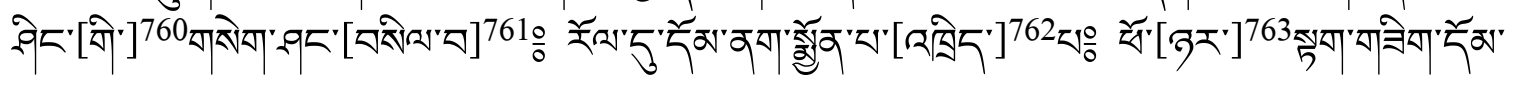

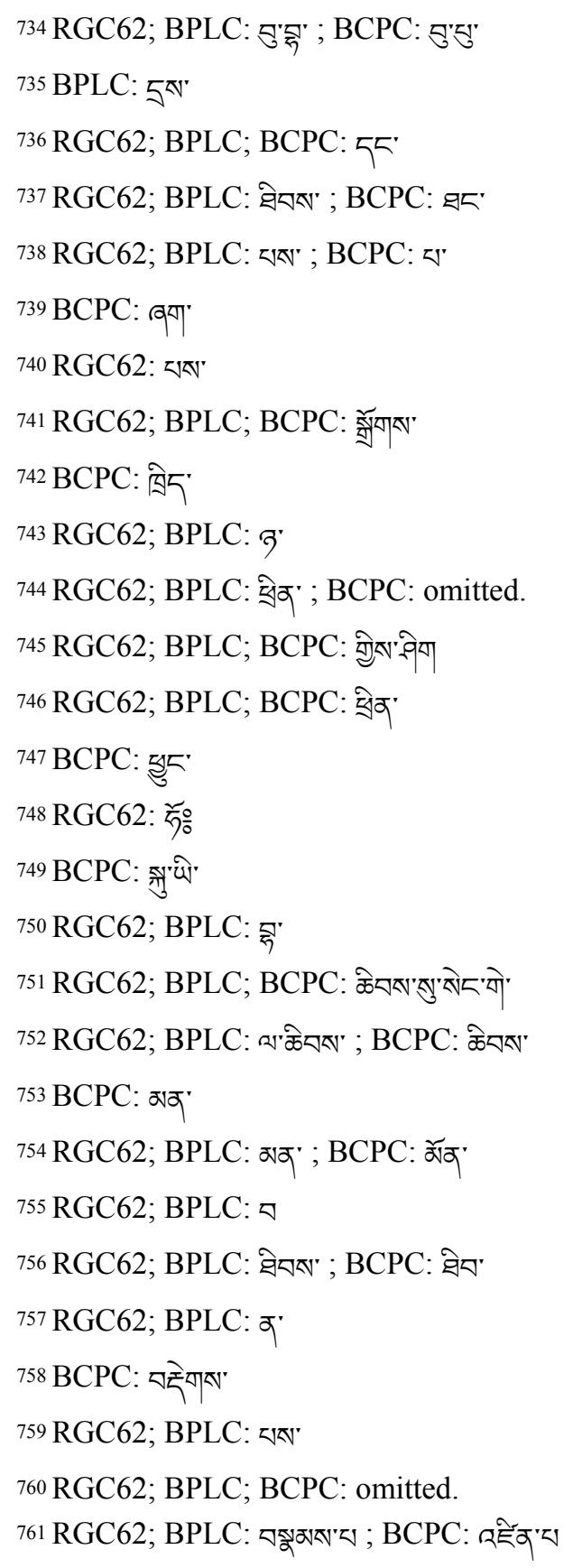




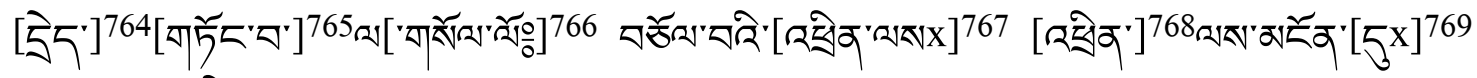

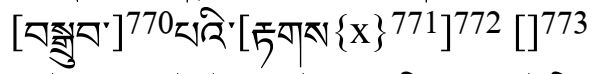

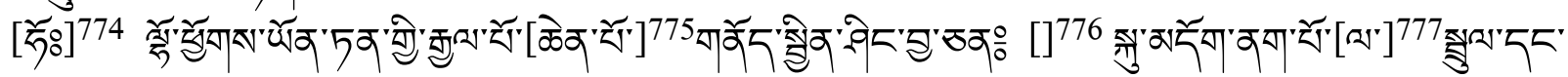

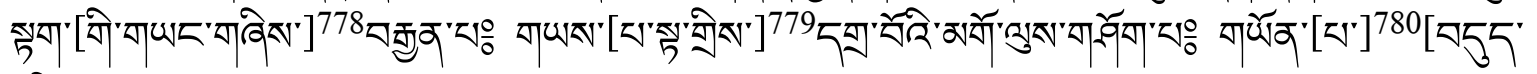

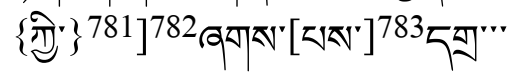

\section{BPLC: ${ }^{784}$}

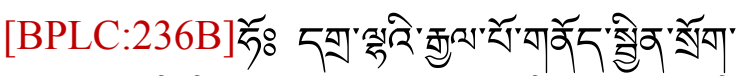

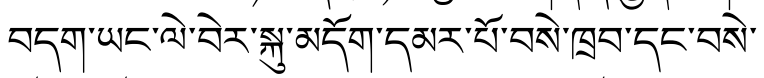

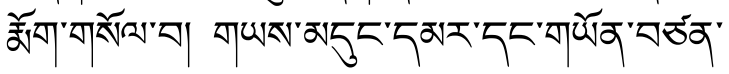

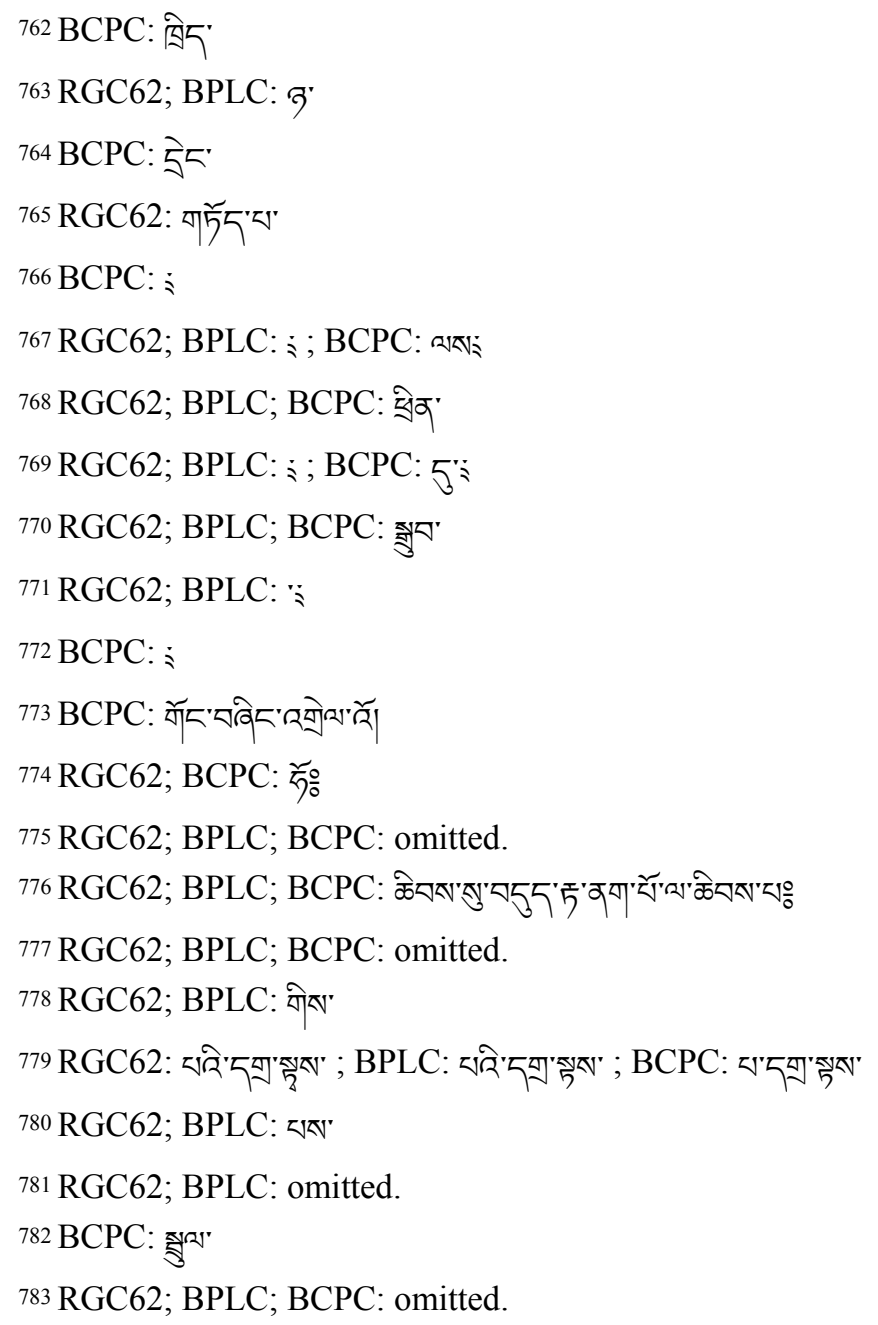

784 This is an extraneous folio that does not continue the content nor follow the same Tibetan numbering as the rest of the text; the text itself continues past this folio. This is a brief additional text of one folio, which is numbered in

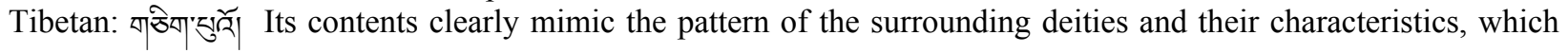
explains its placement at this juncture. 


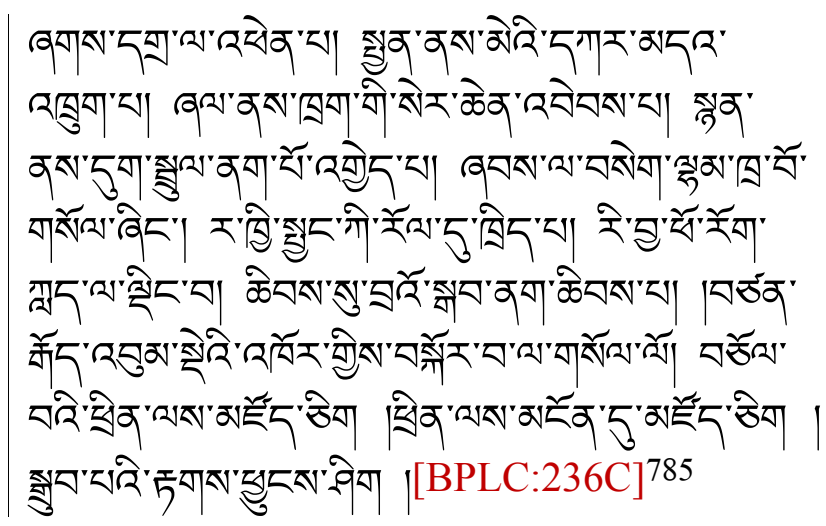

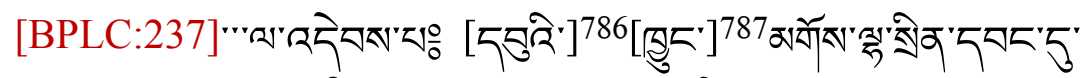

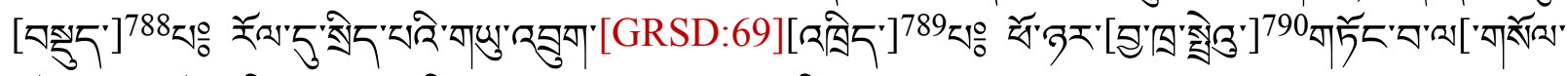

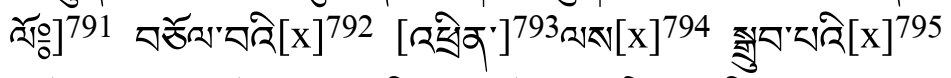

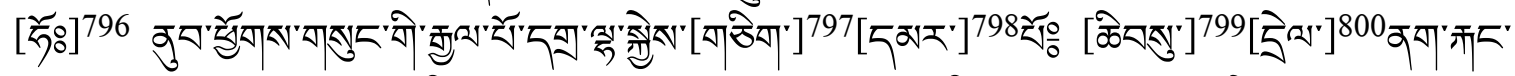

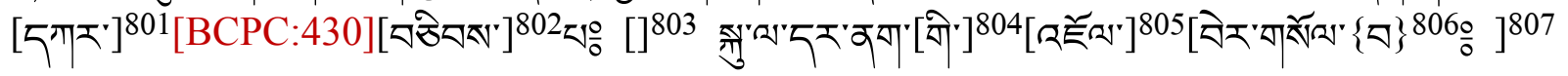

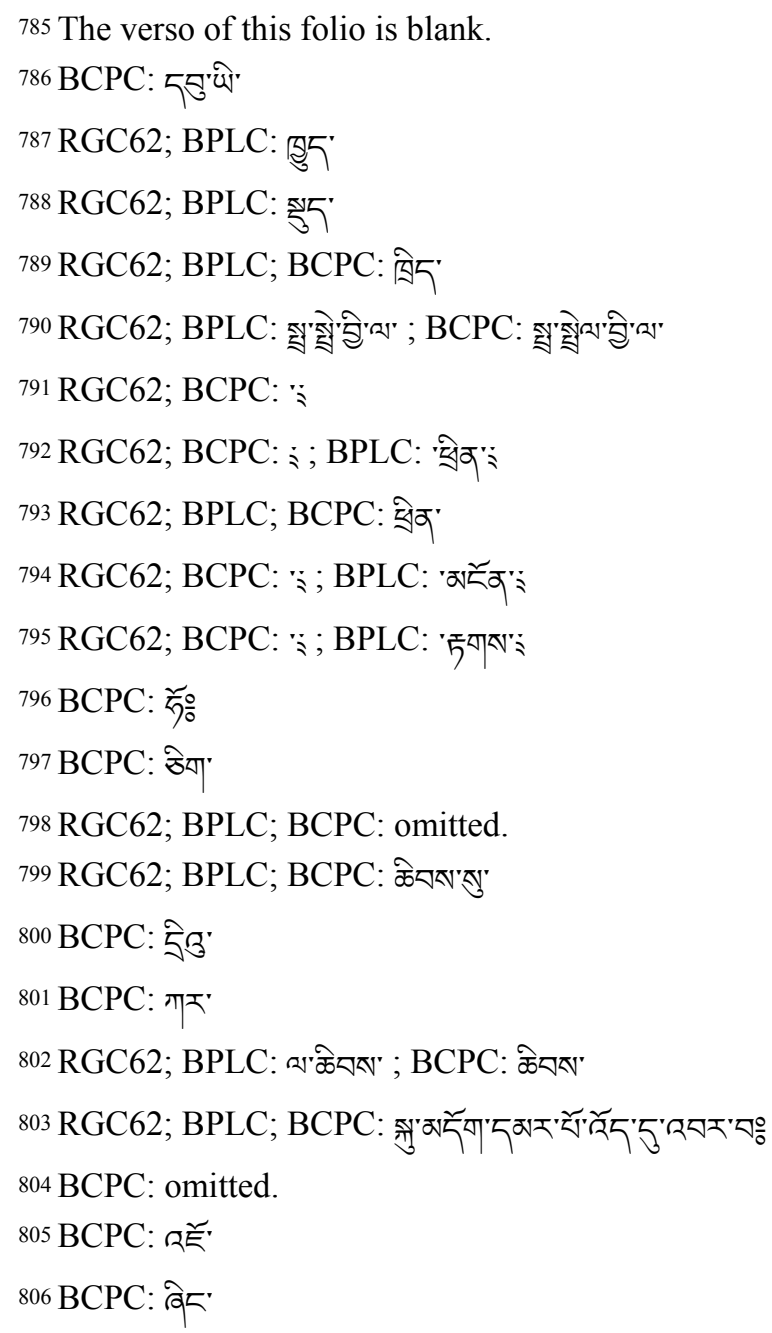




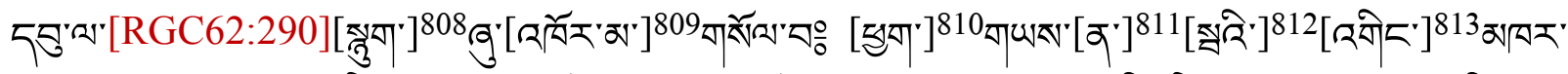

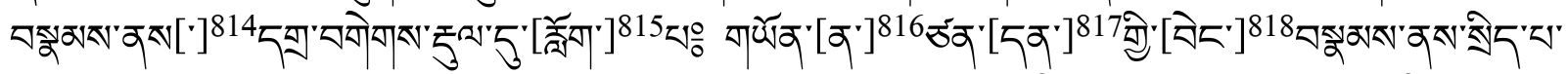

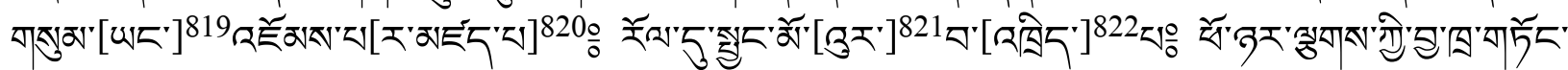

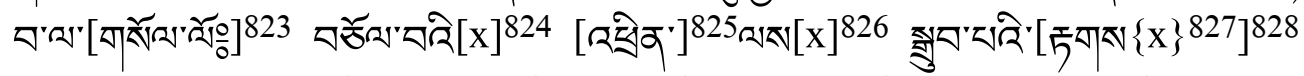

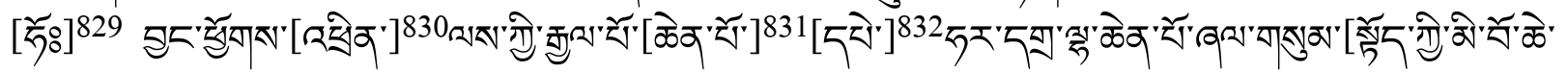

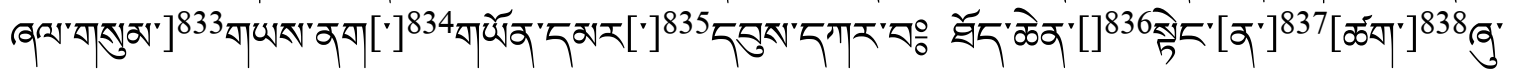

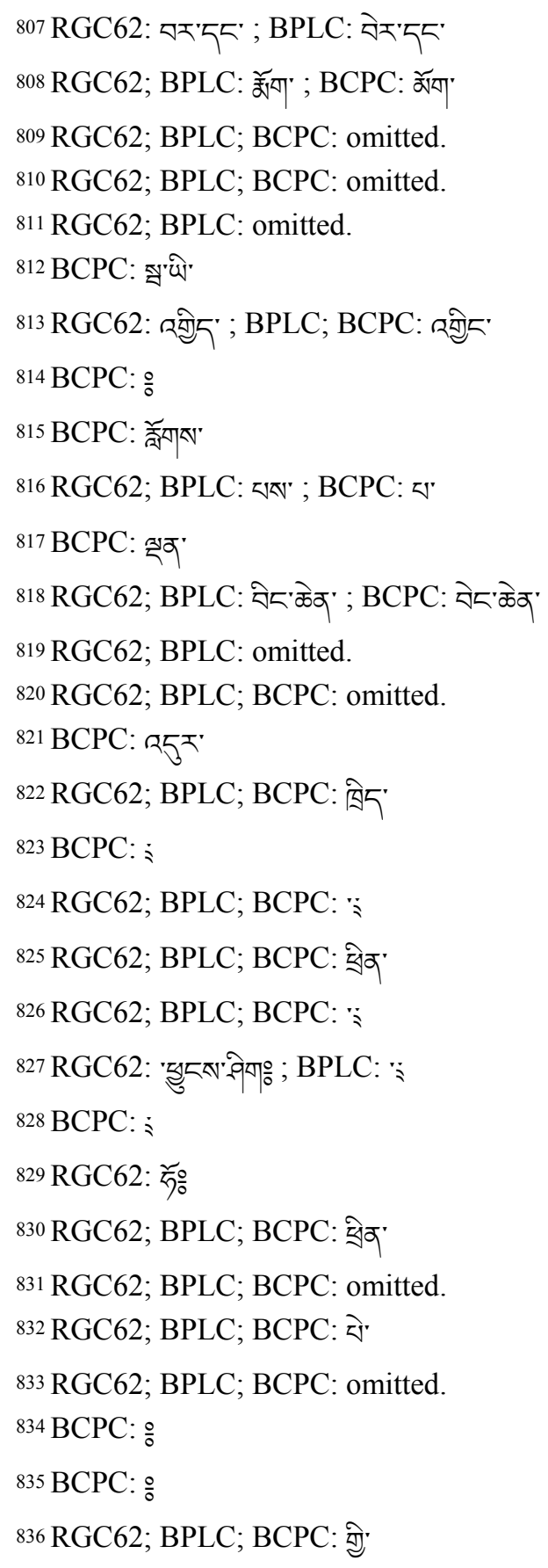




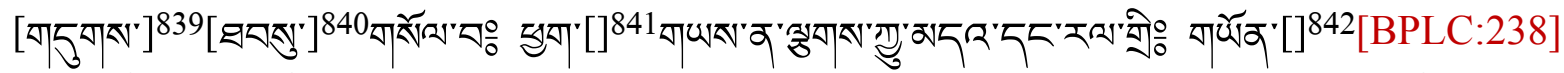

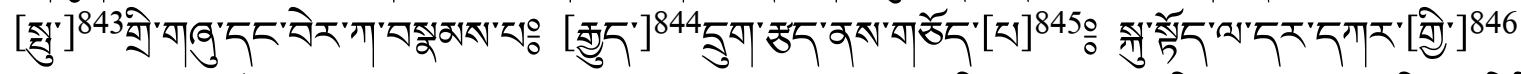

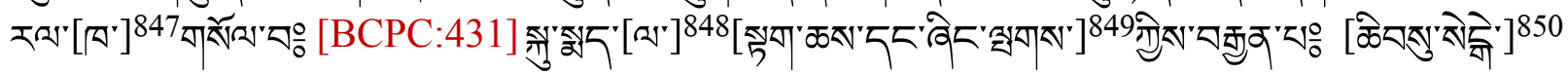

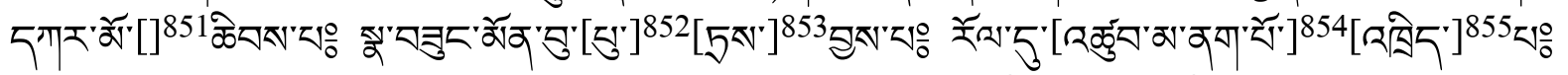

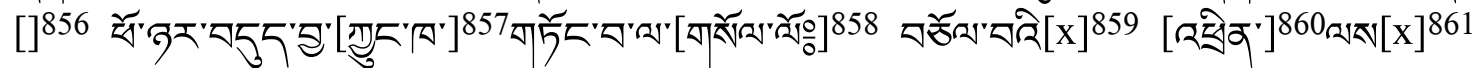
त्रुपद दरि $[\mathrm{x}]^{862}$

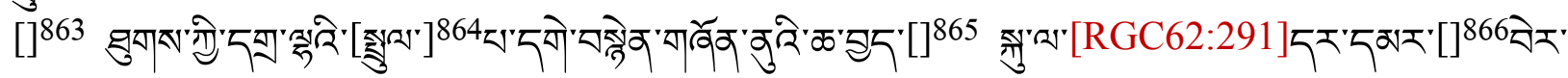

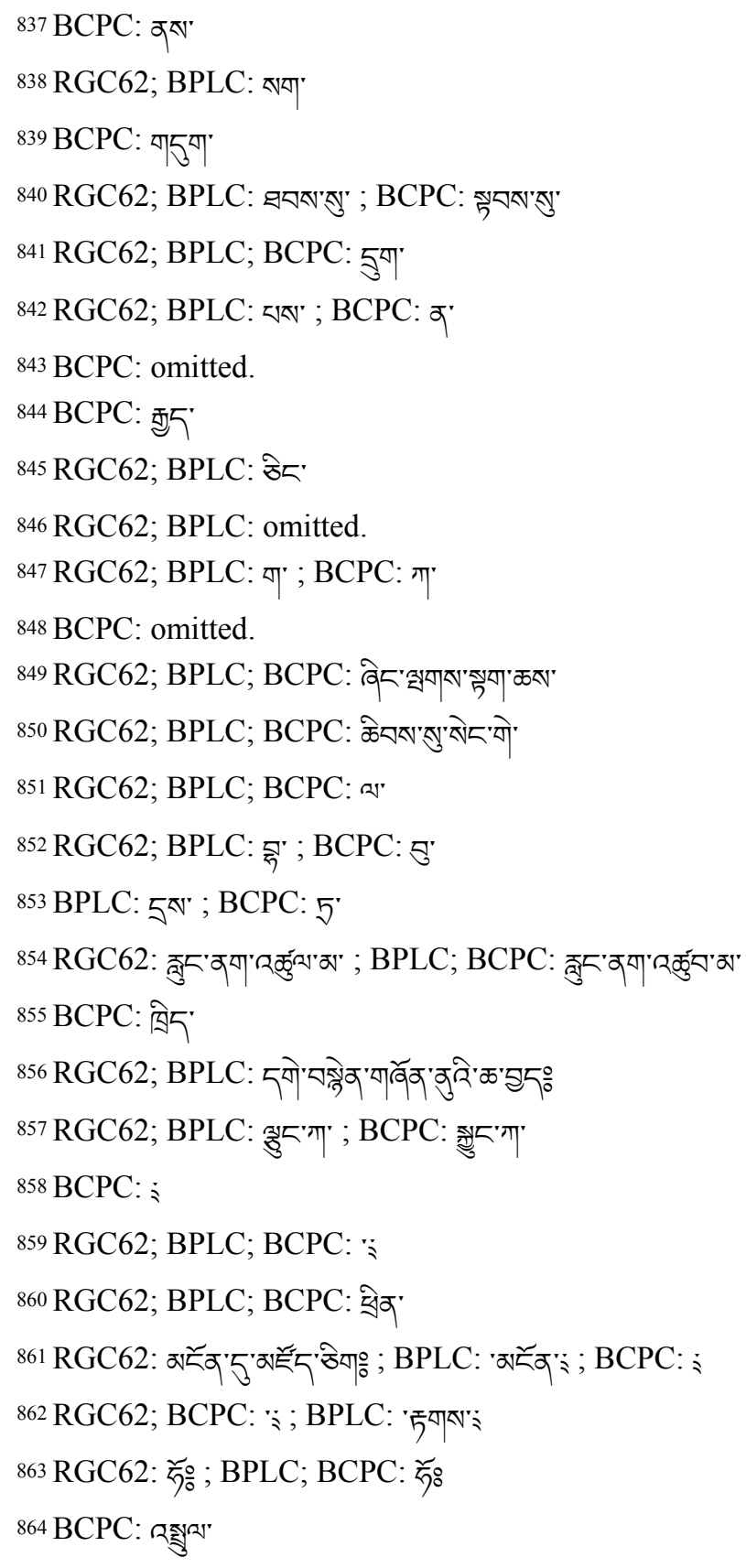




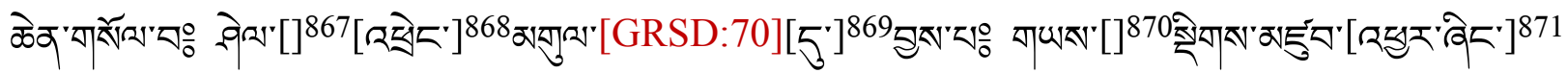

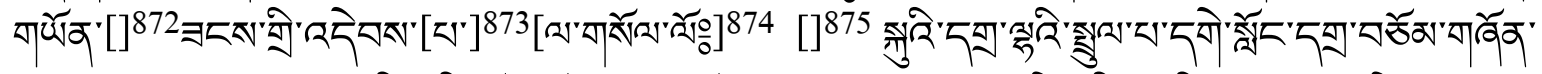

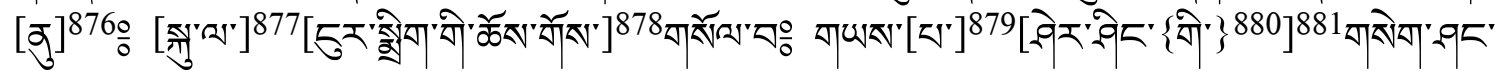

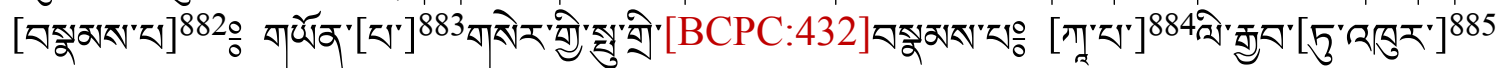

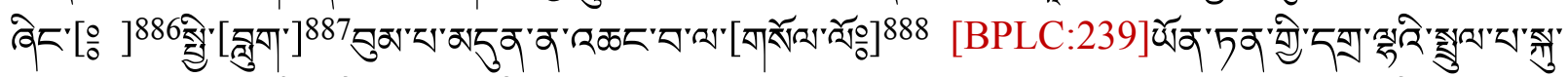

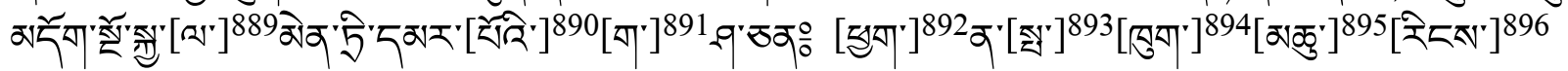

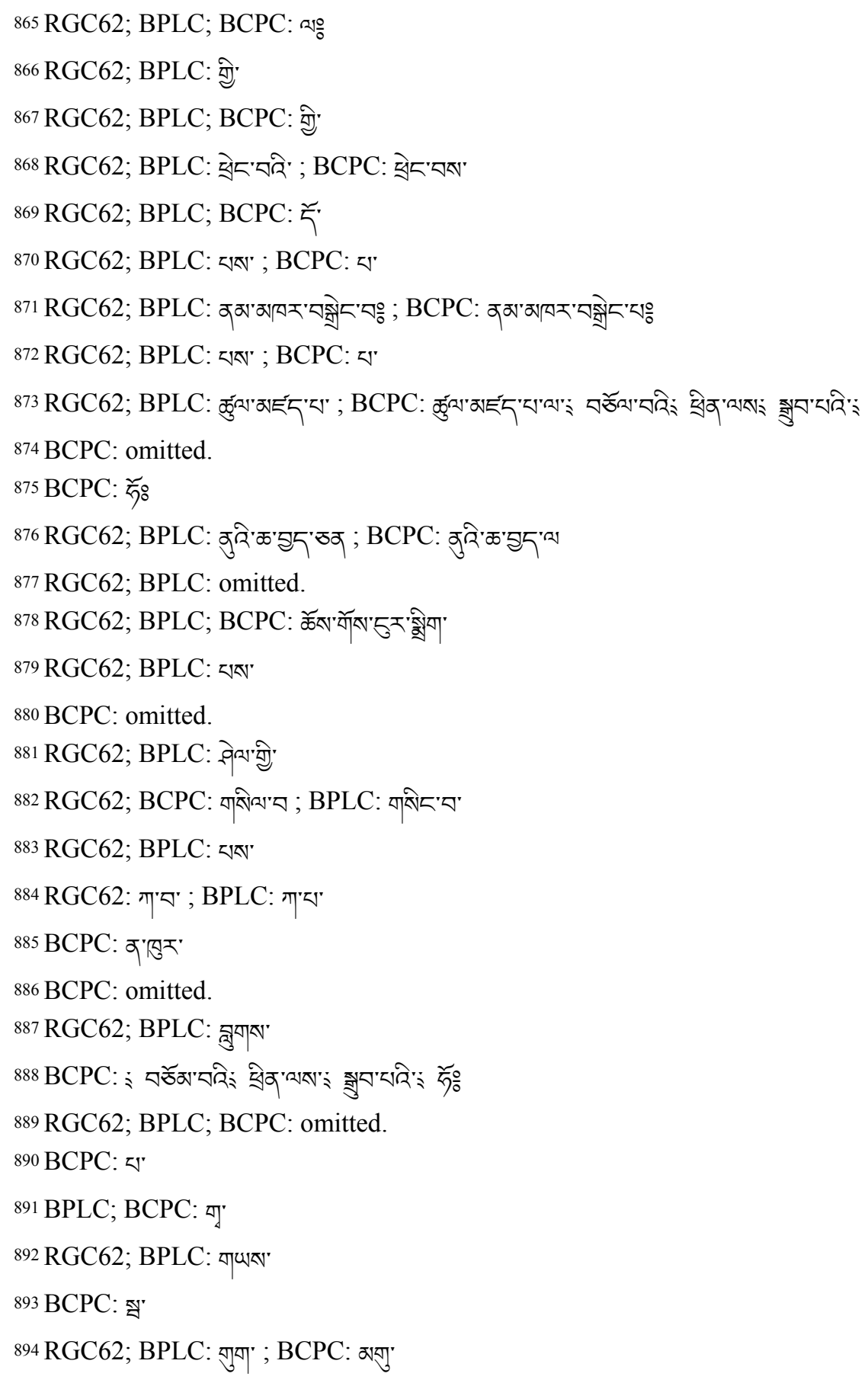




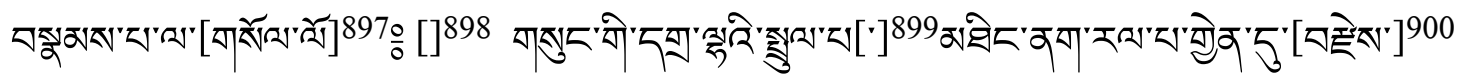

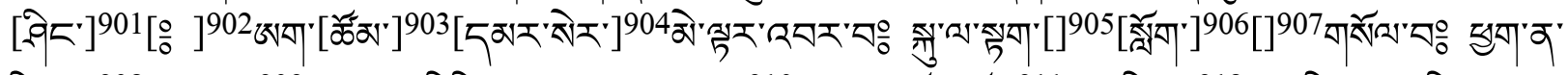

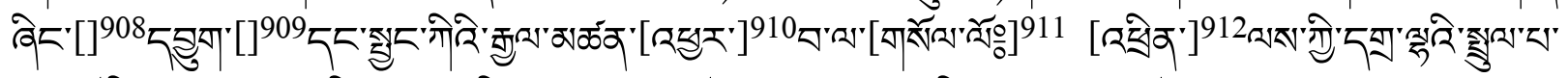

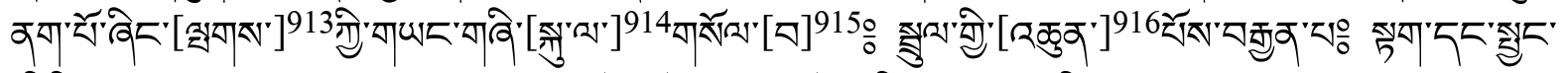

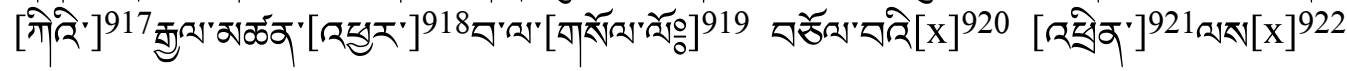

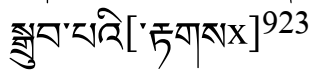

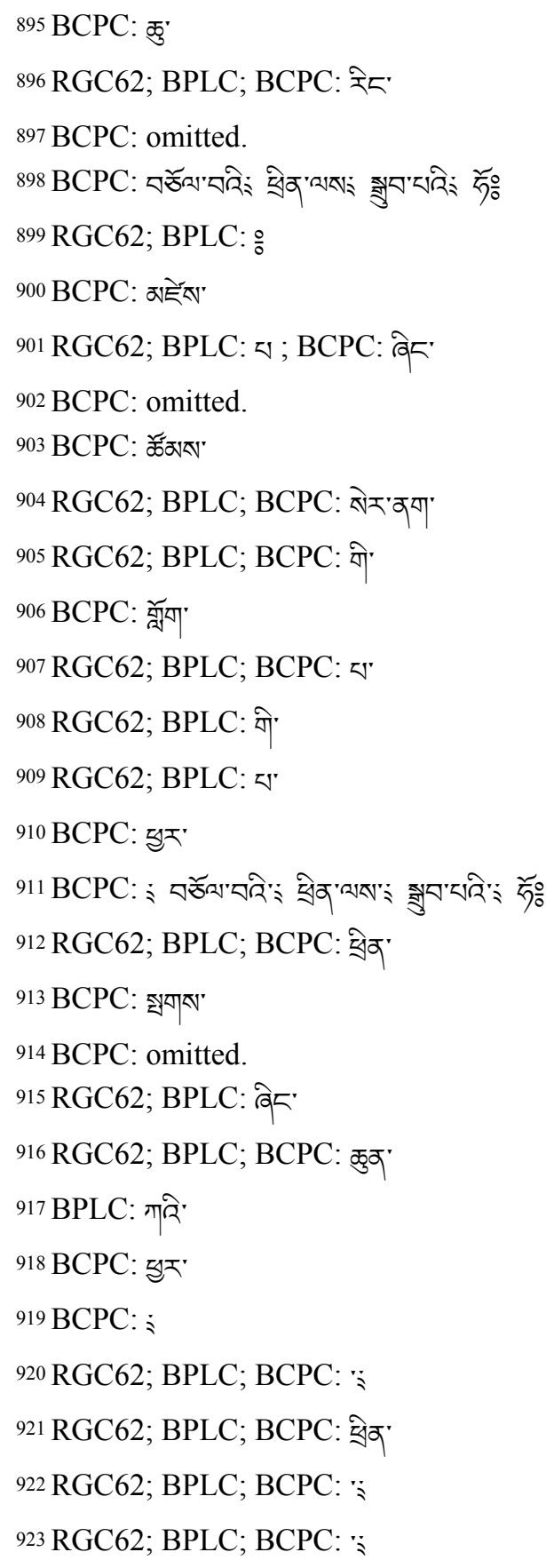




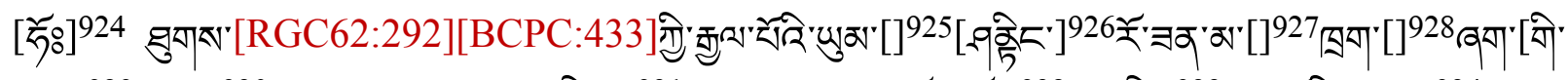

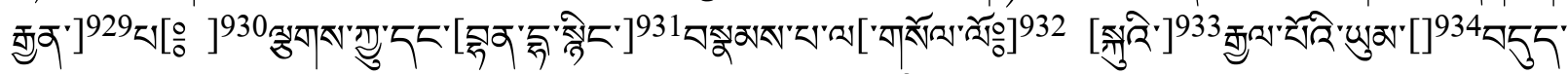

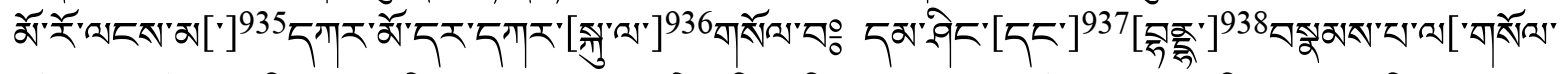

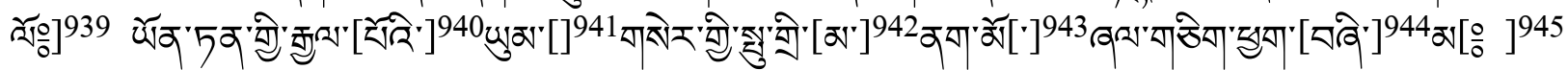

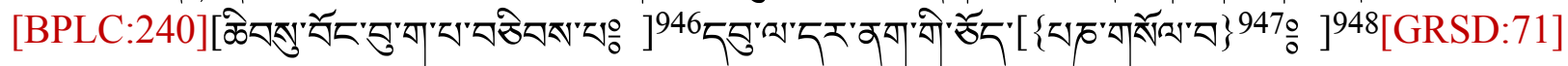

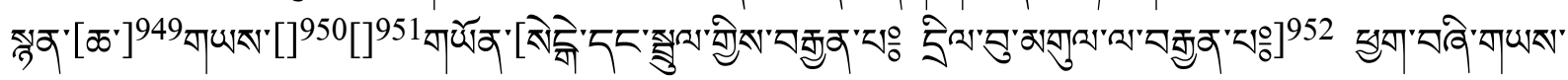

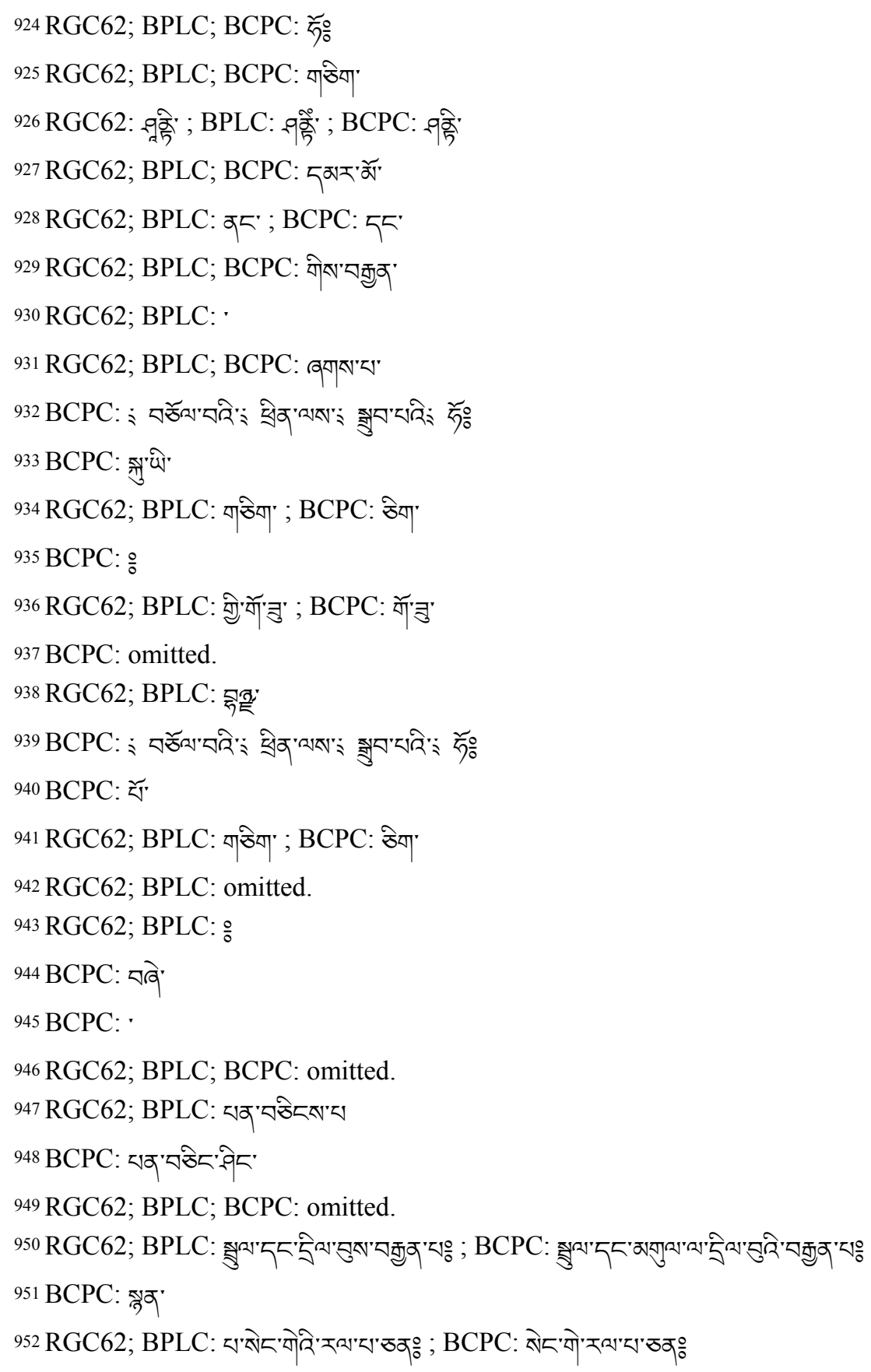




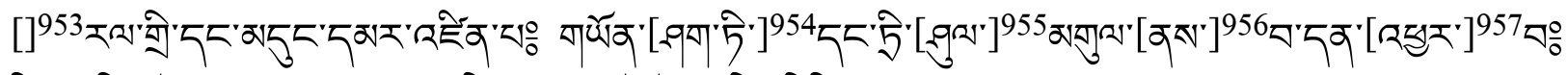

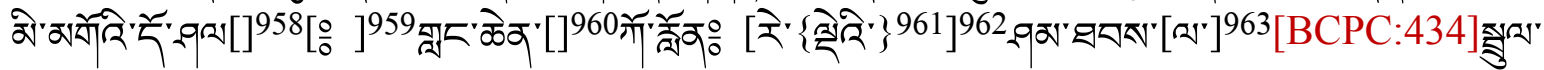

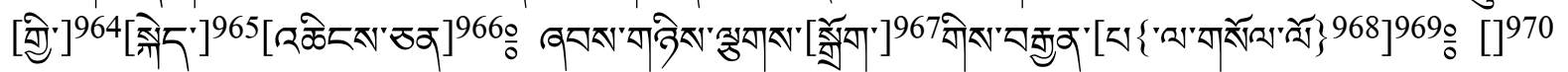

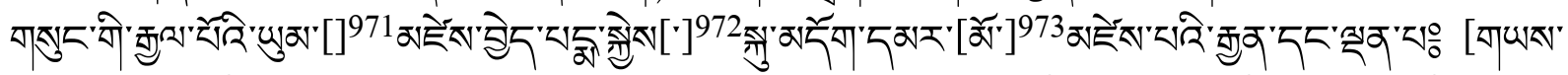

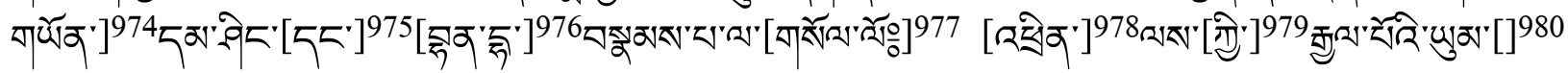

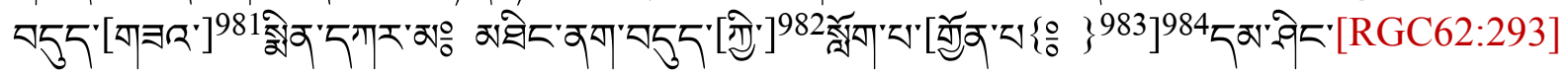

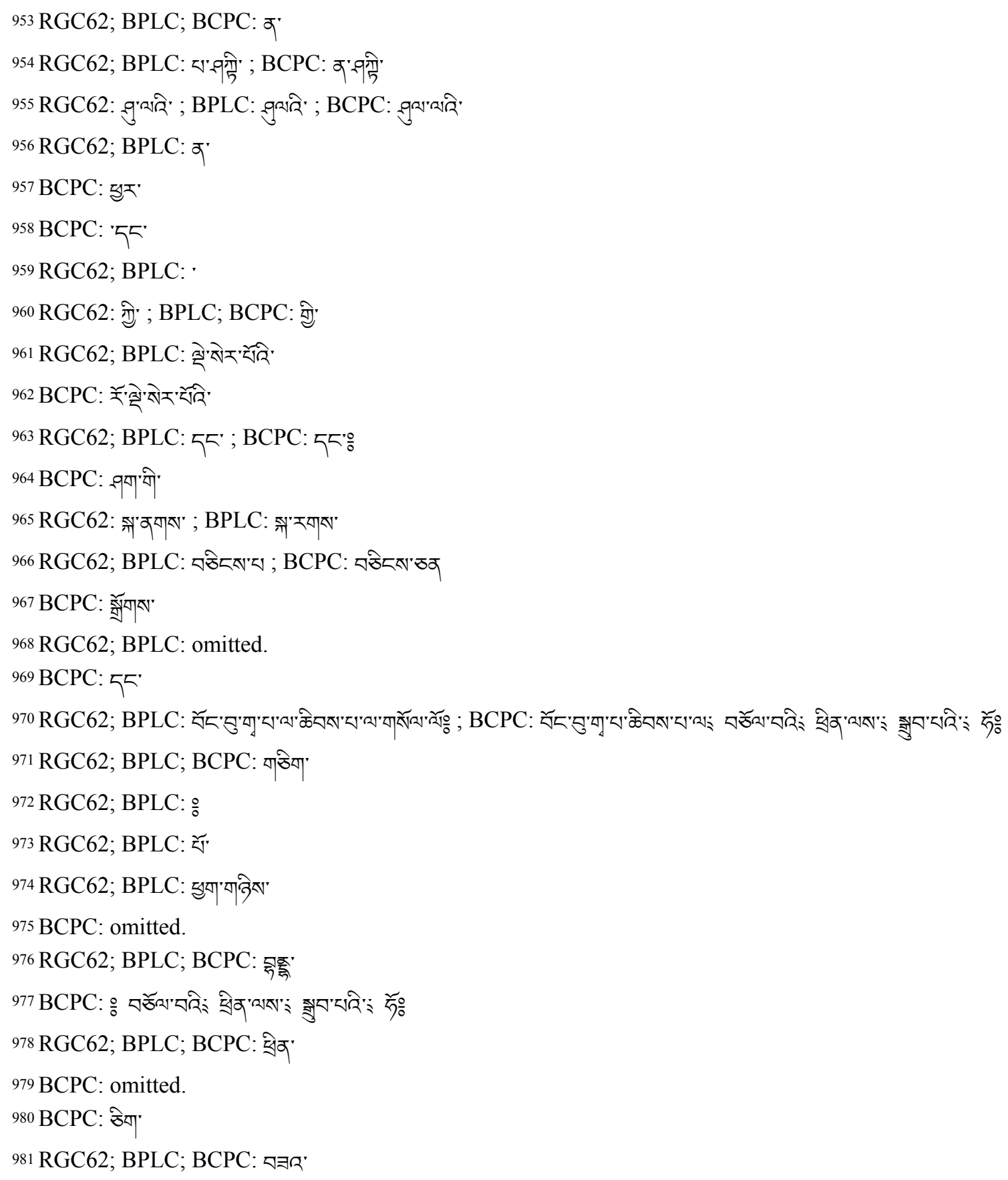




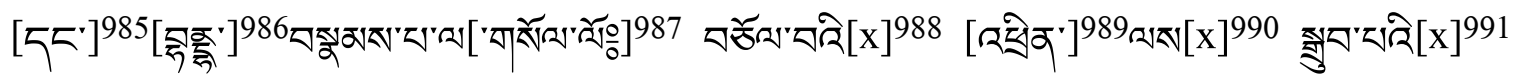

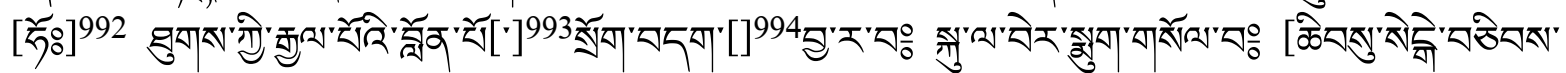

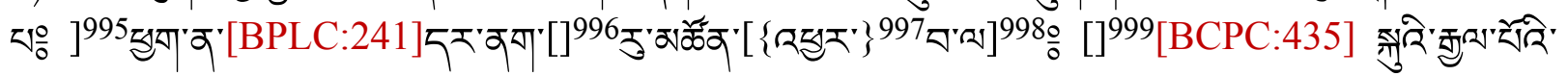

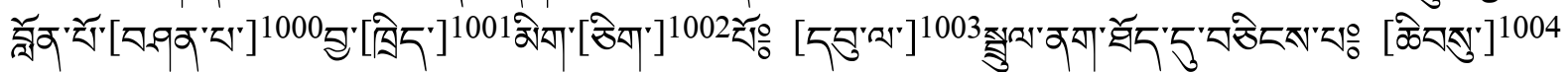

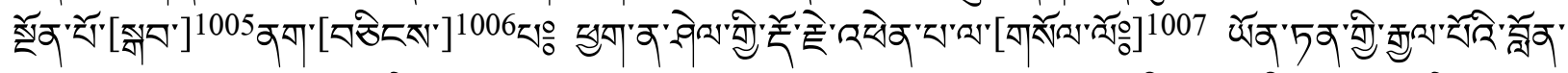

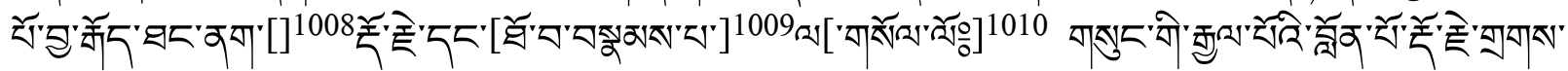

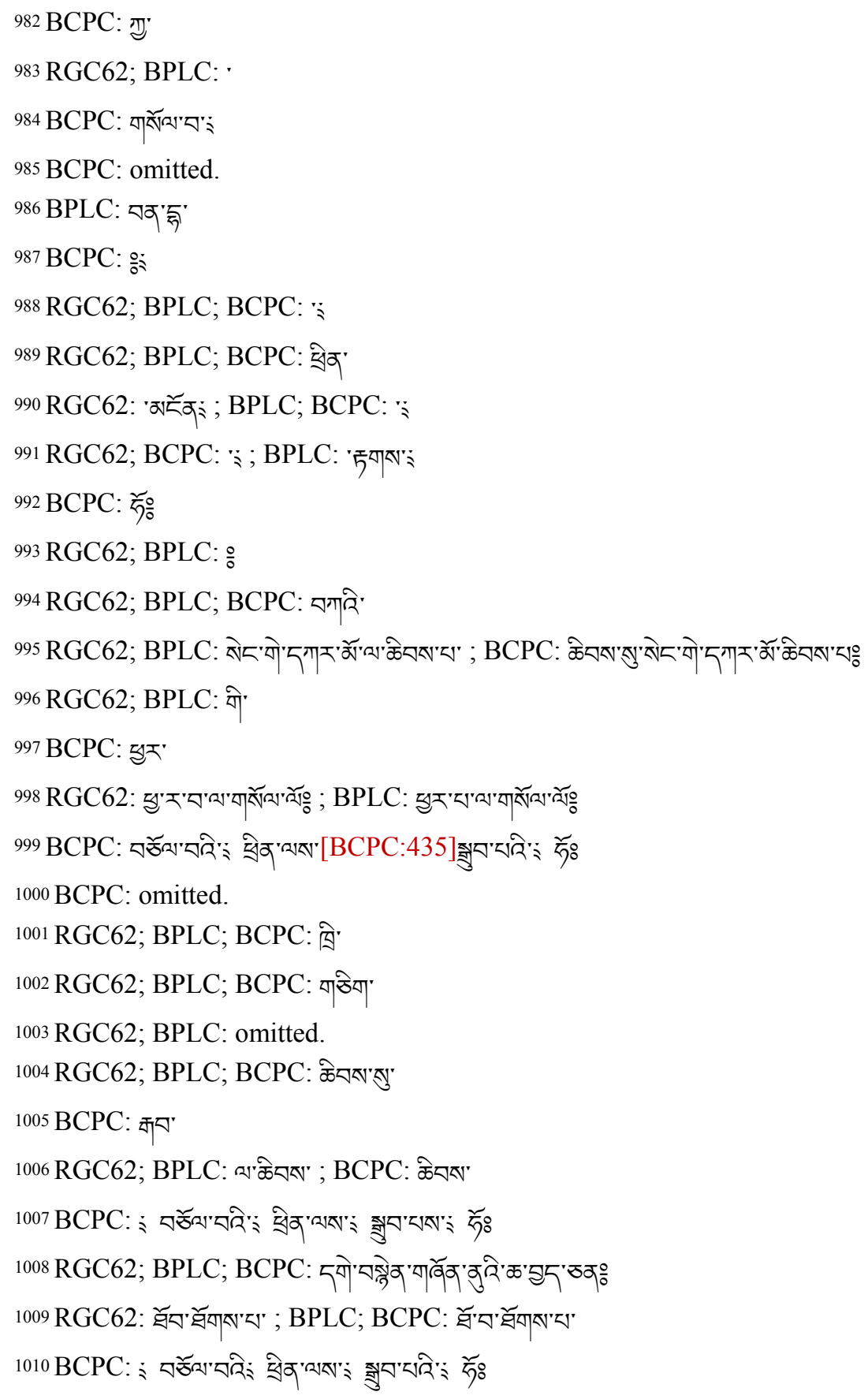




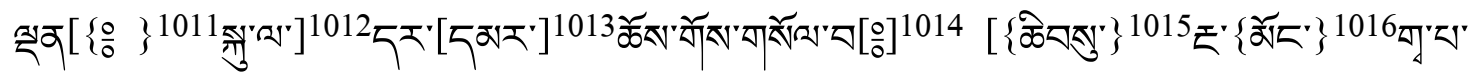

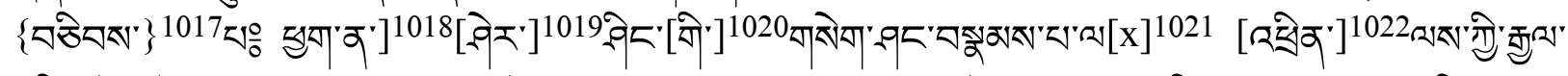

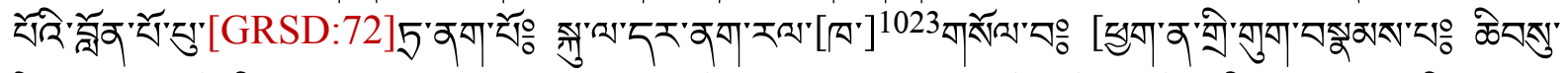

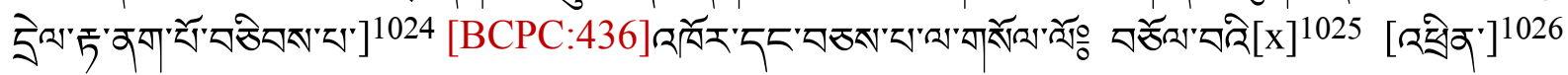

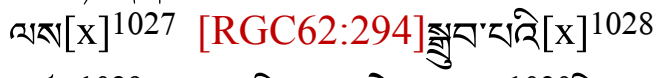

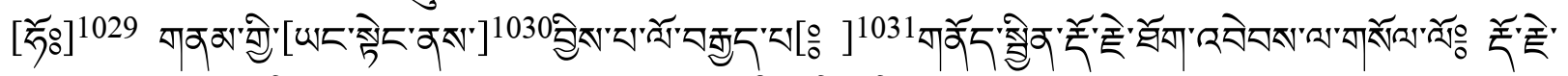

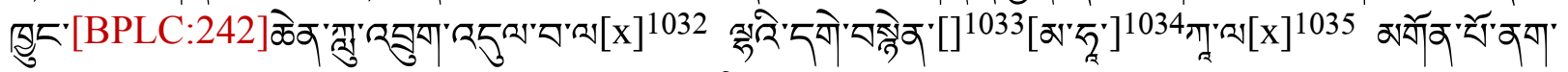

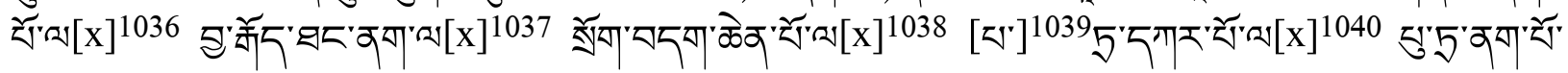

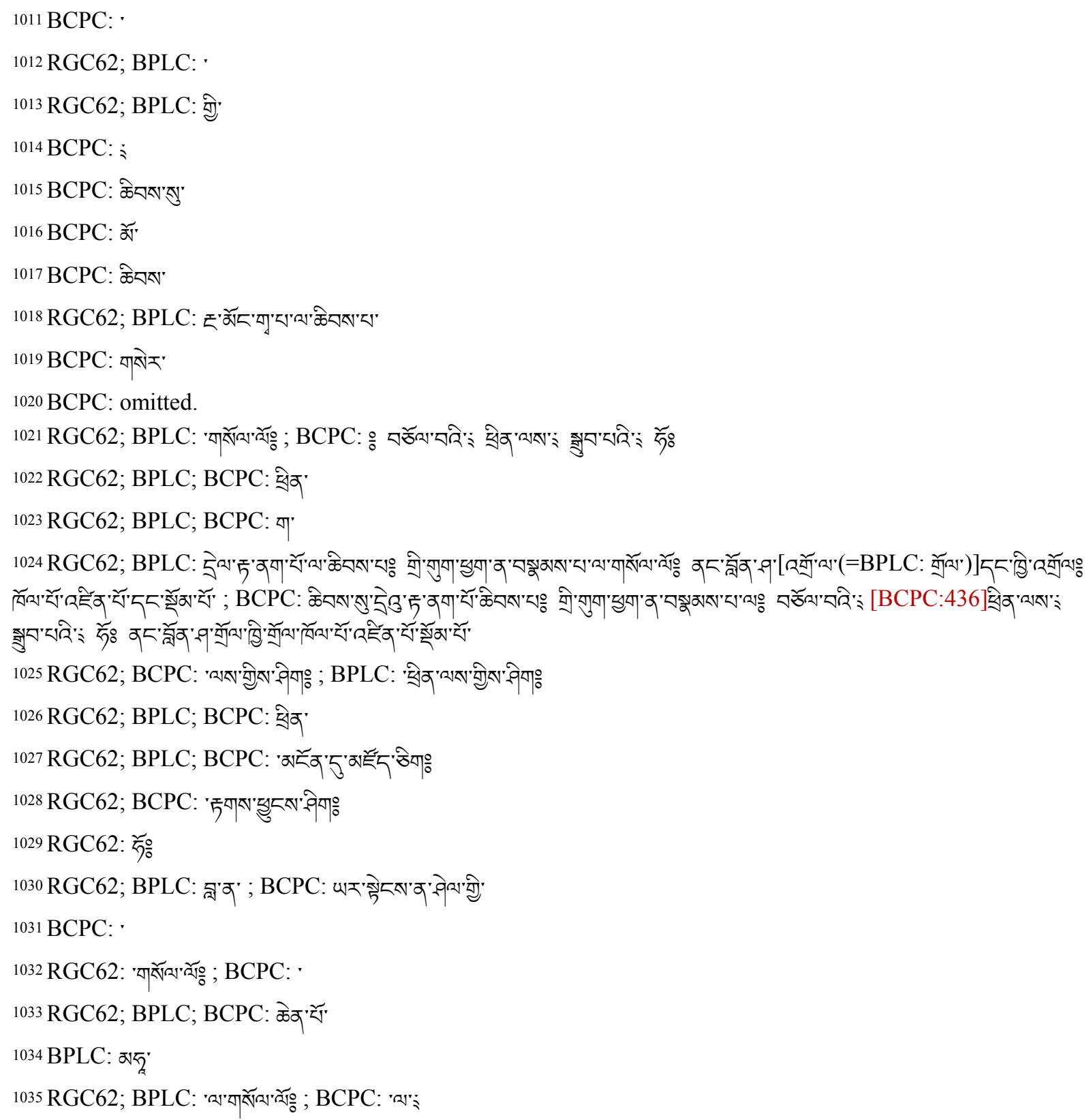




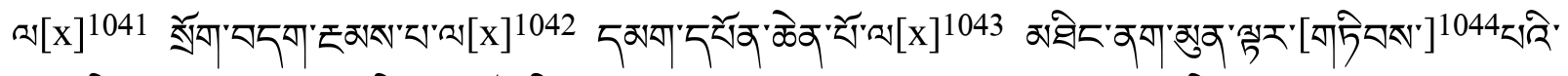

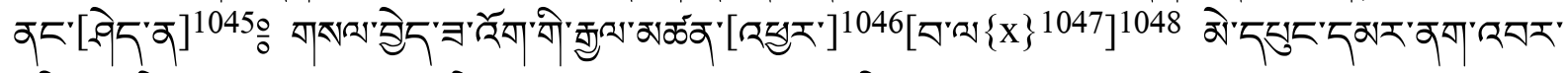

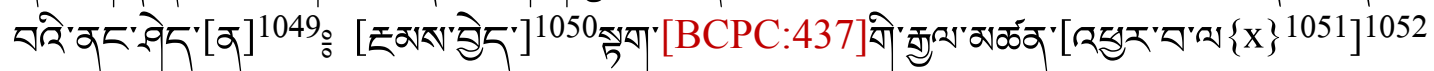

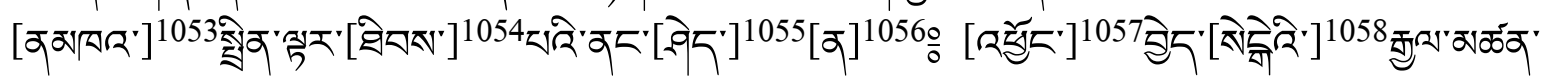

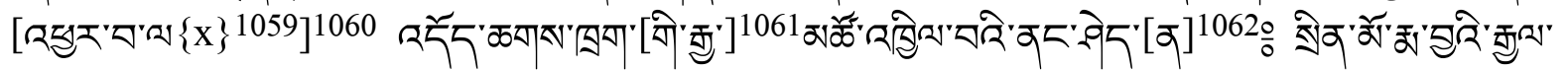

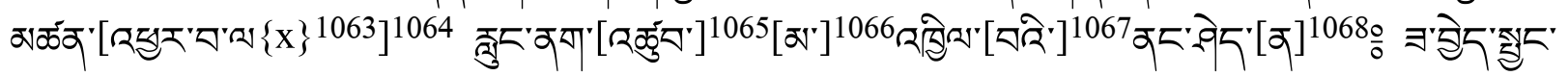

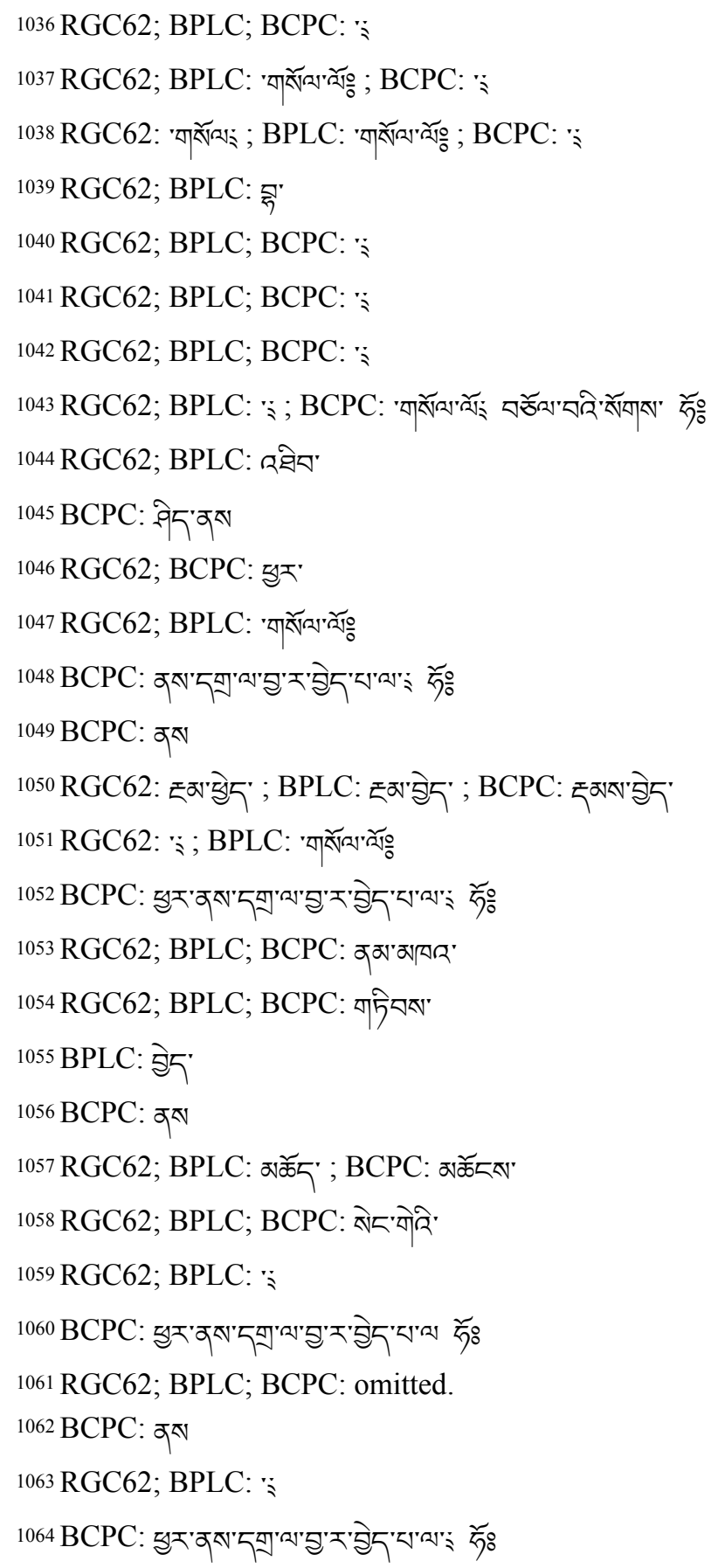




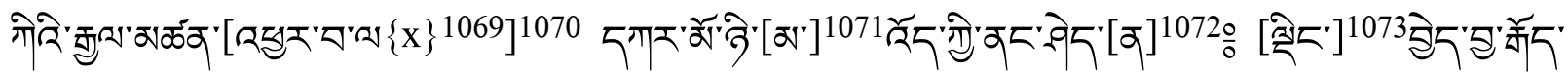

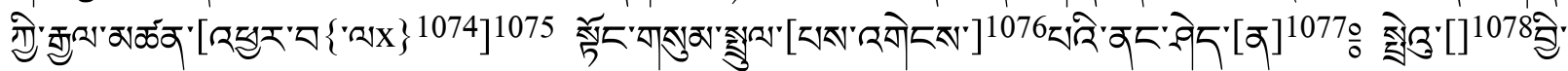

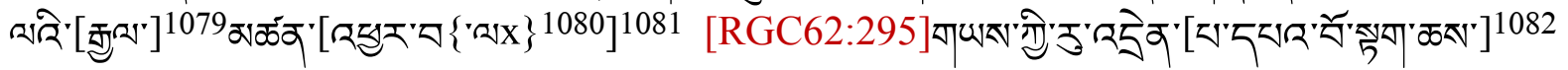

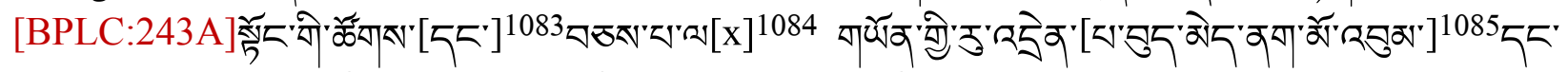

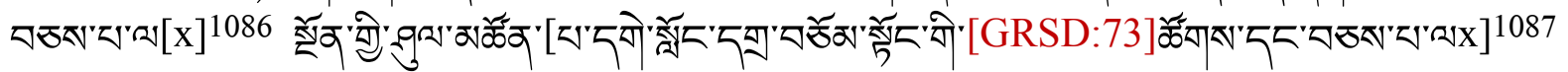

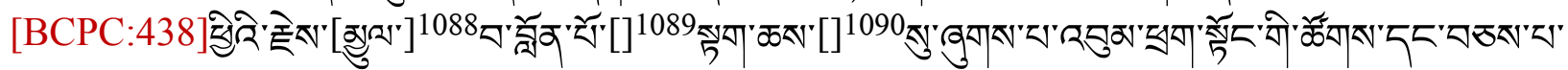

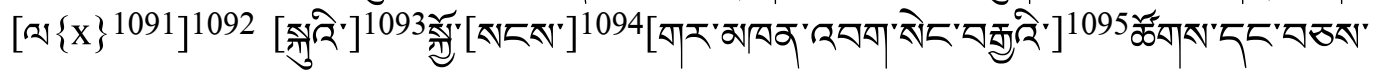

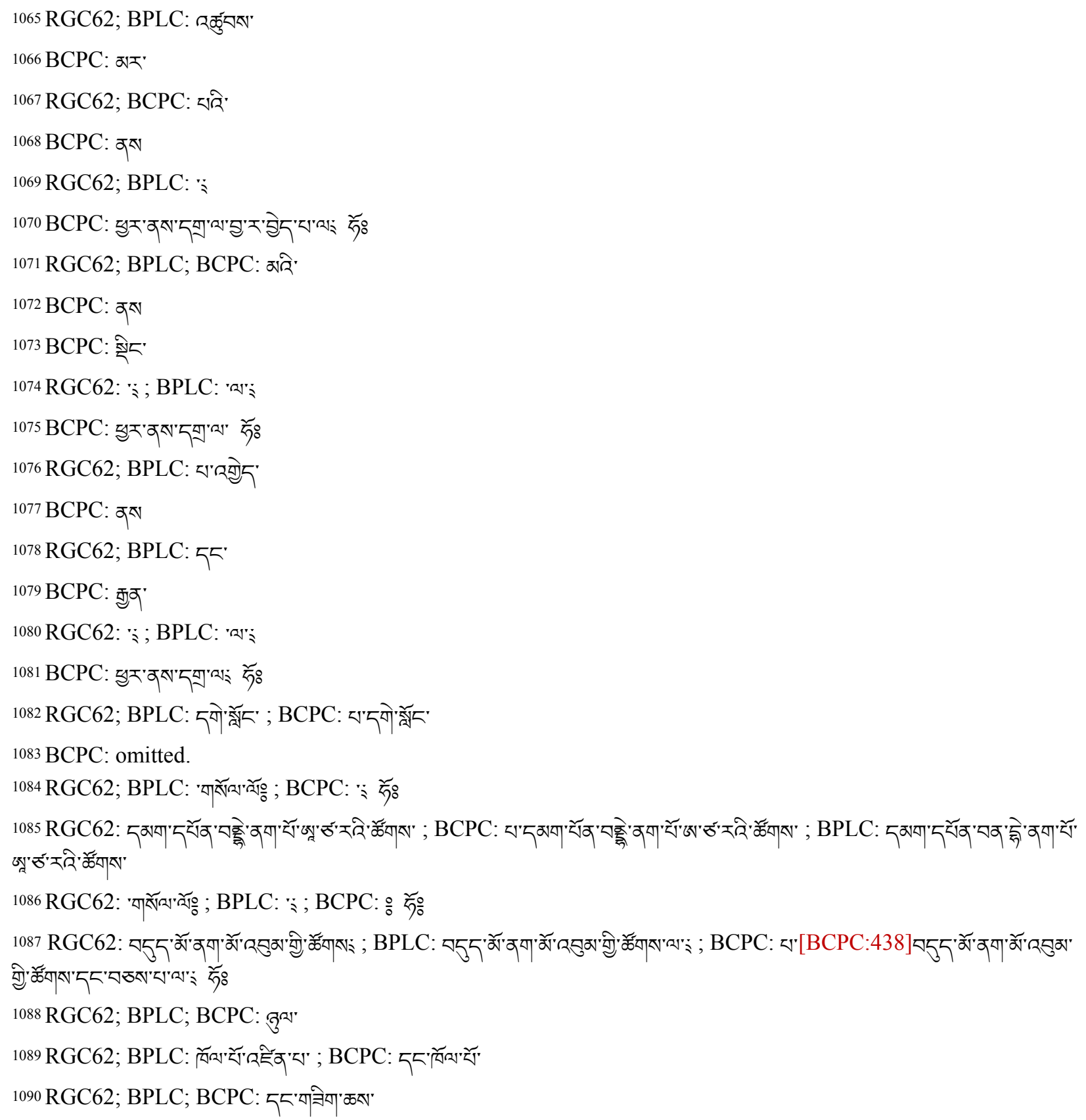




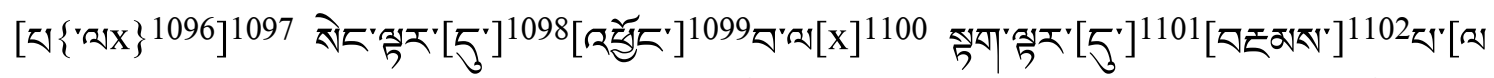

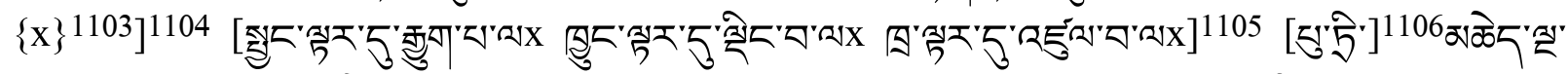

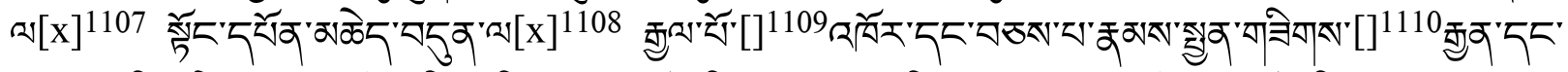

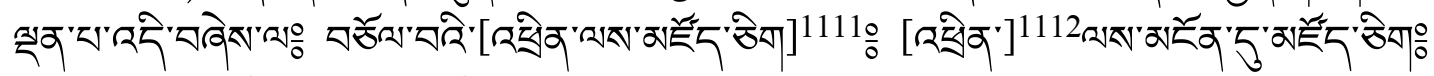

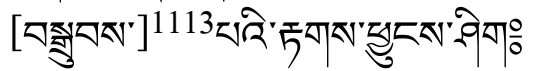

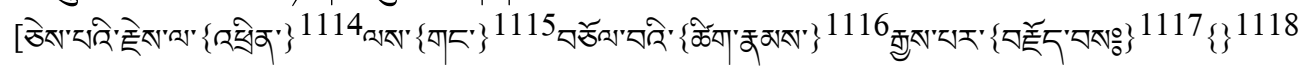

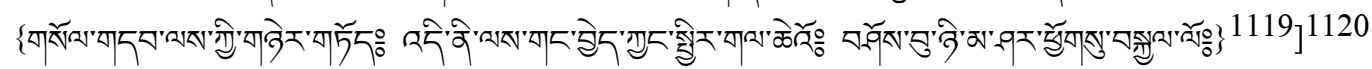

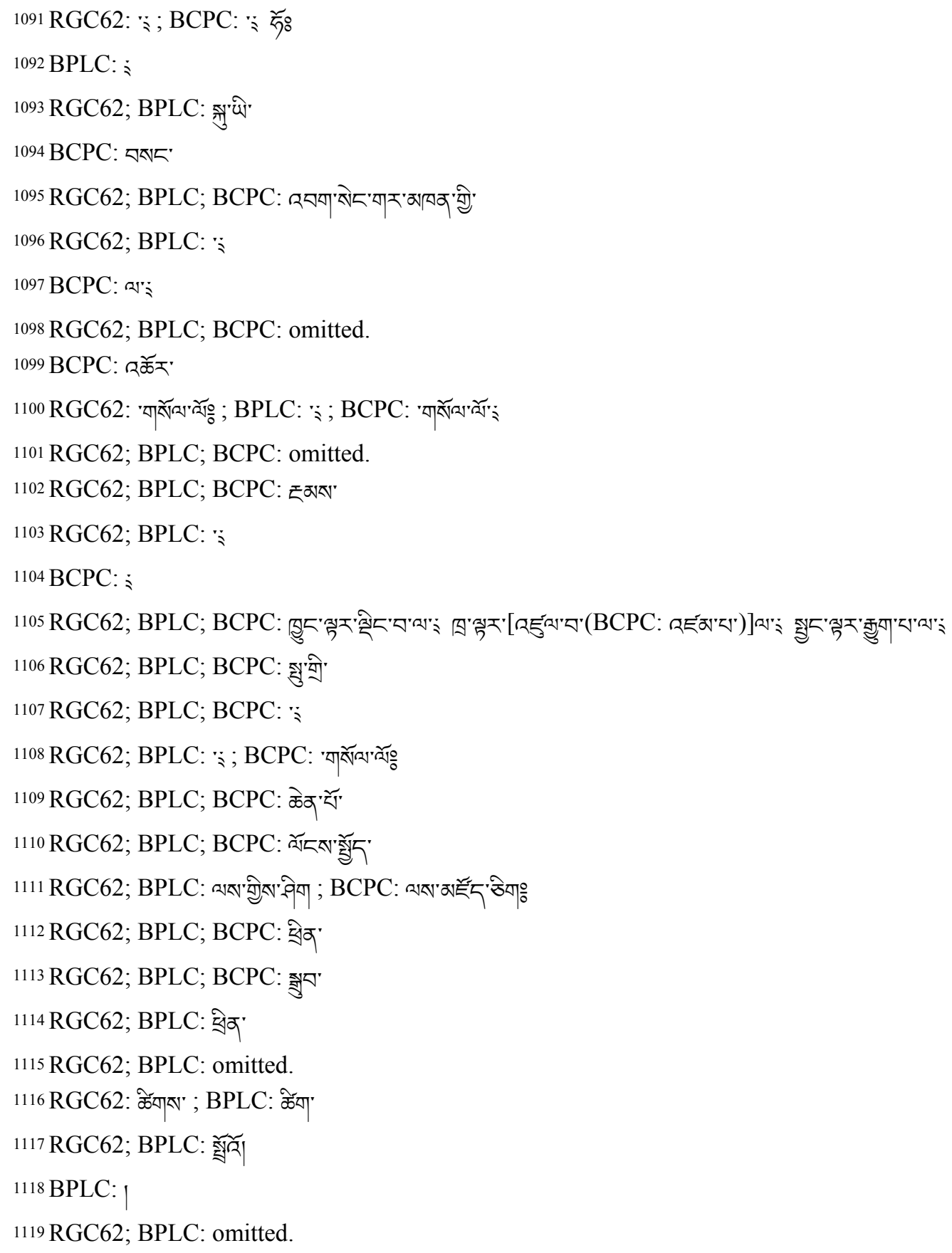




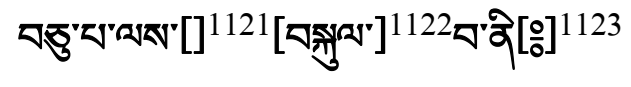

[궁유 ${ }^{1124}$

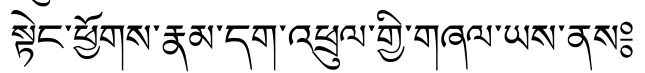

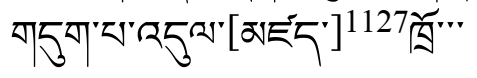

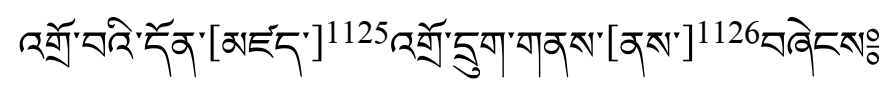

BPLC: 1128

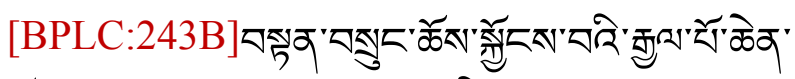

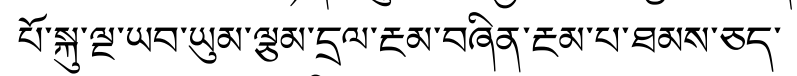

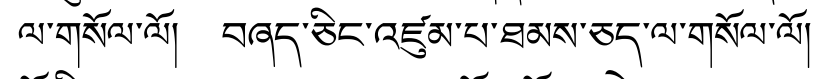

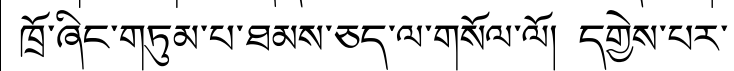

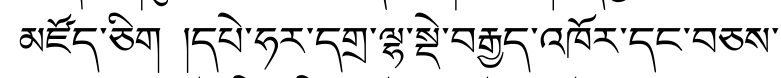

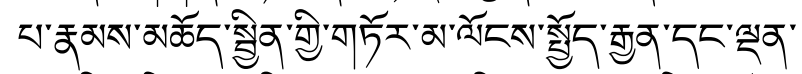

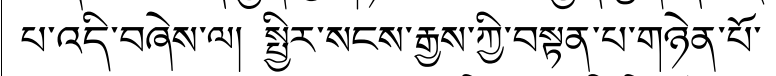

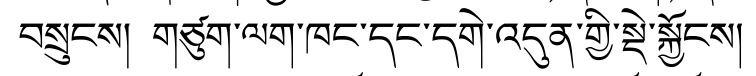

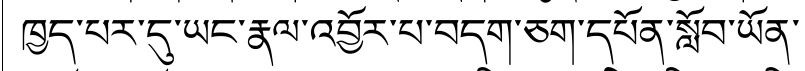

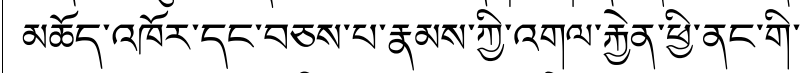

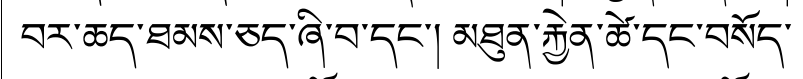

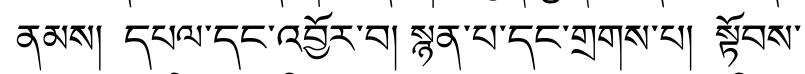

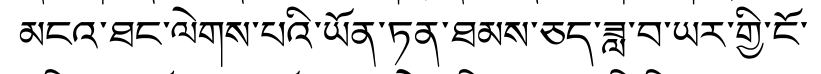

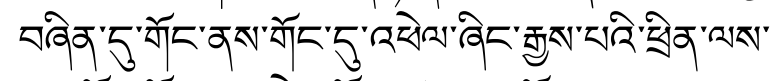

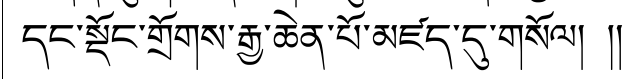

[BPLC:243C]1129

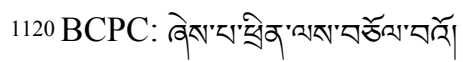

1121 RGC62; BPLC; BCPC: खv

1122 BCPC: অ젰

1123 RGC62; BPLC: |

1124 RGC62: 귱응 ; BCPC: 즁으

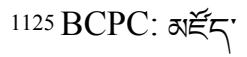

1126 RGC62; BPLC: Rלेच'

1127 RGC62; BPLC: ఫ्डेर्र

1128 BPLC: There is an extraneous folio at this point that does not continue the content nor follow the same Tibetan numbering as the rest of the text; the text itself continues past this folio. This is a brief additional text of one folio,

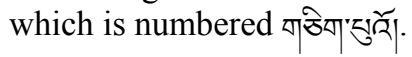

1129 The verso of this folio is blank.
} 


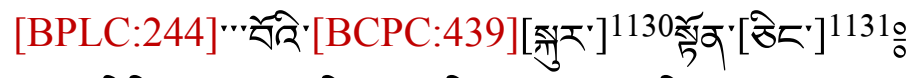

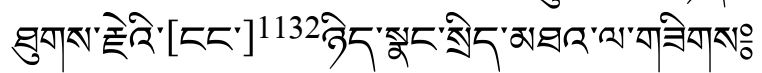

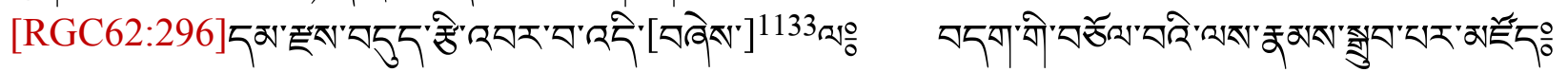

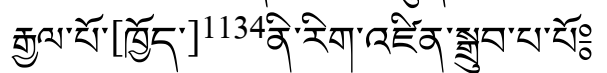

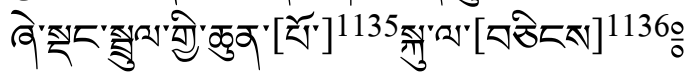

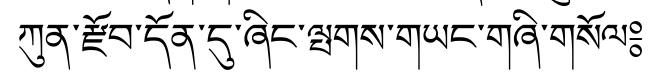

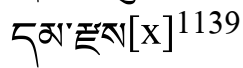

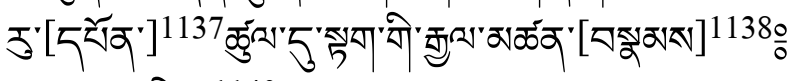
$\left.[\square 5 \nabla]^{\circ} \mathrm{x} x\right]^{1140}$

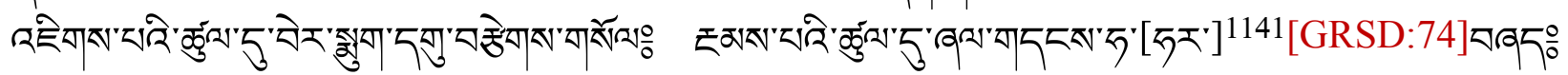

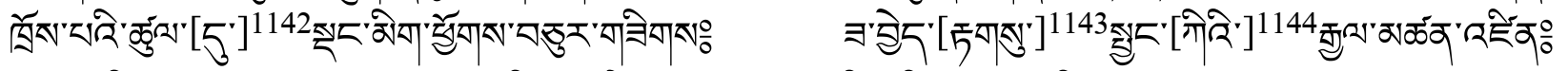

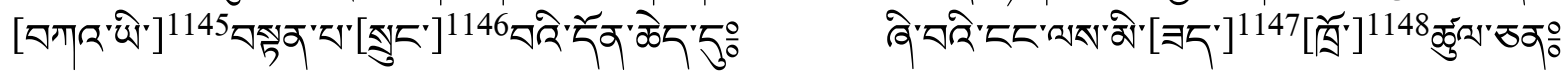

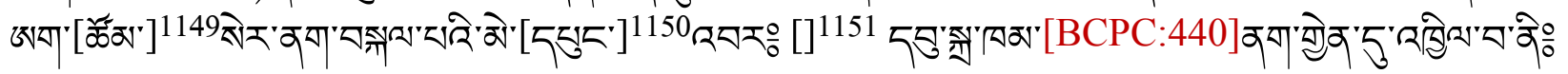

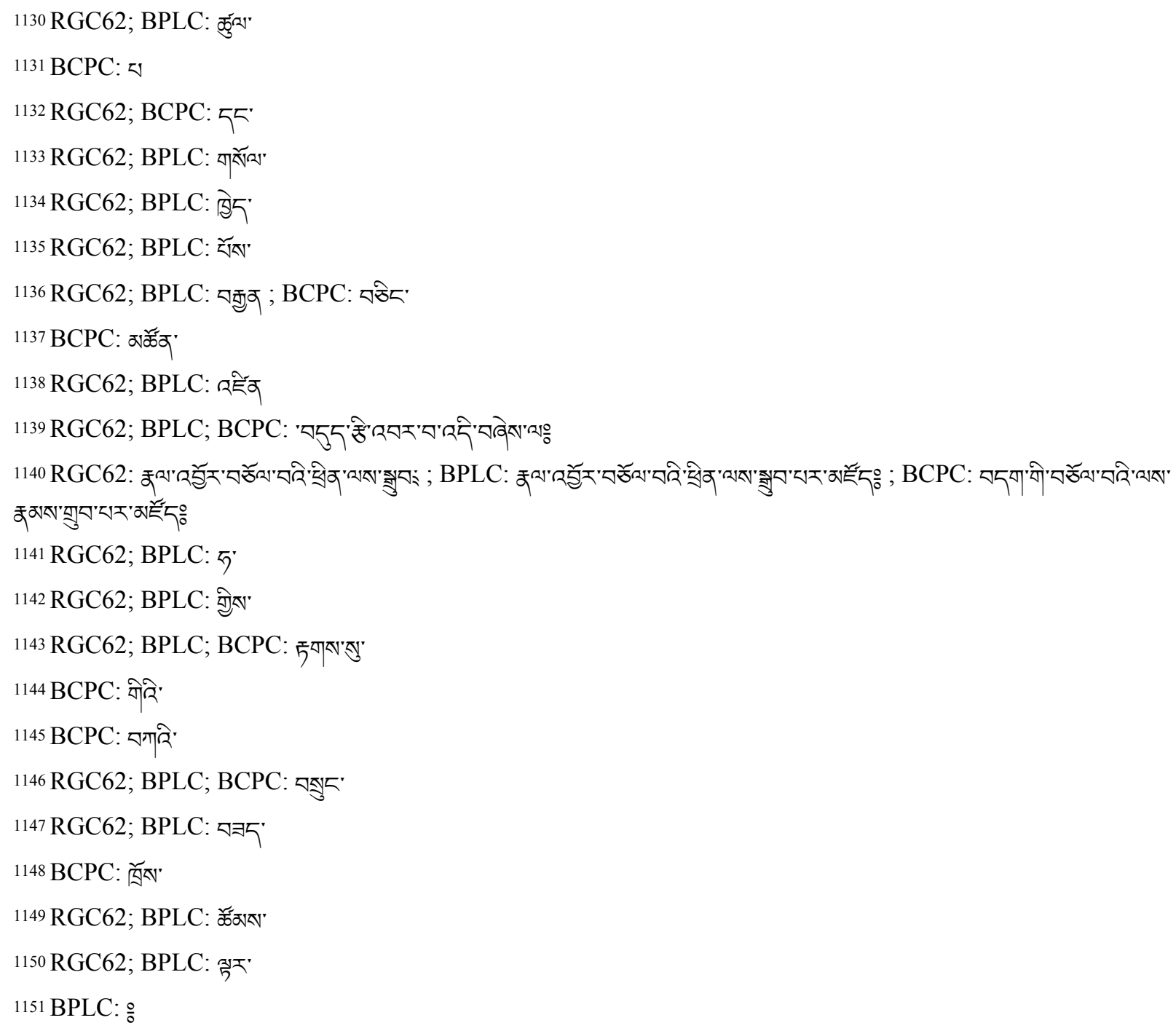




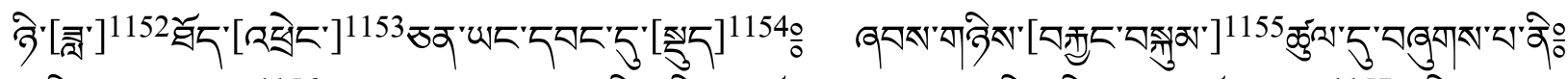

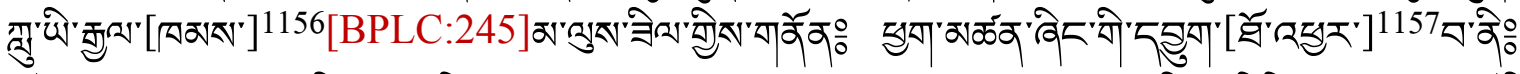

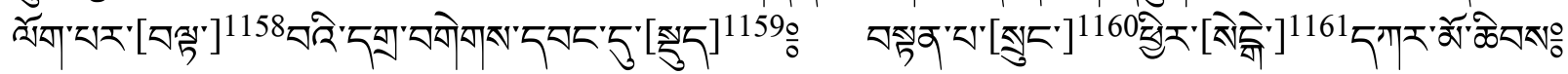

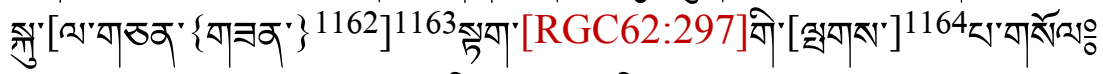

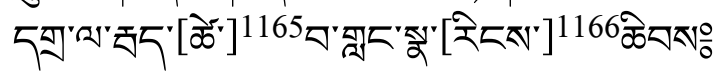

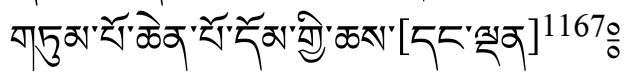

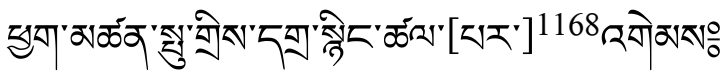

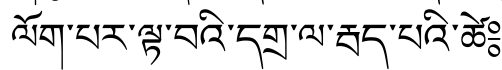

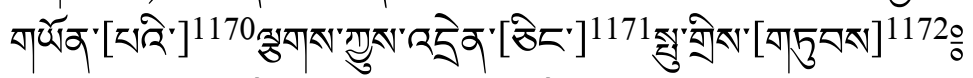

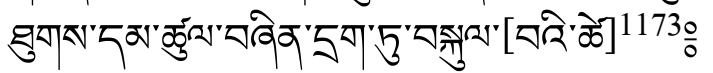

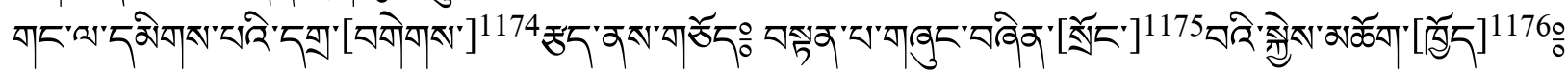

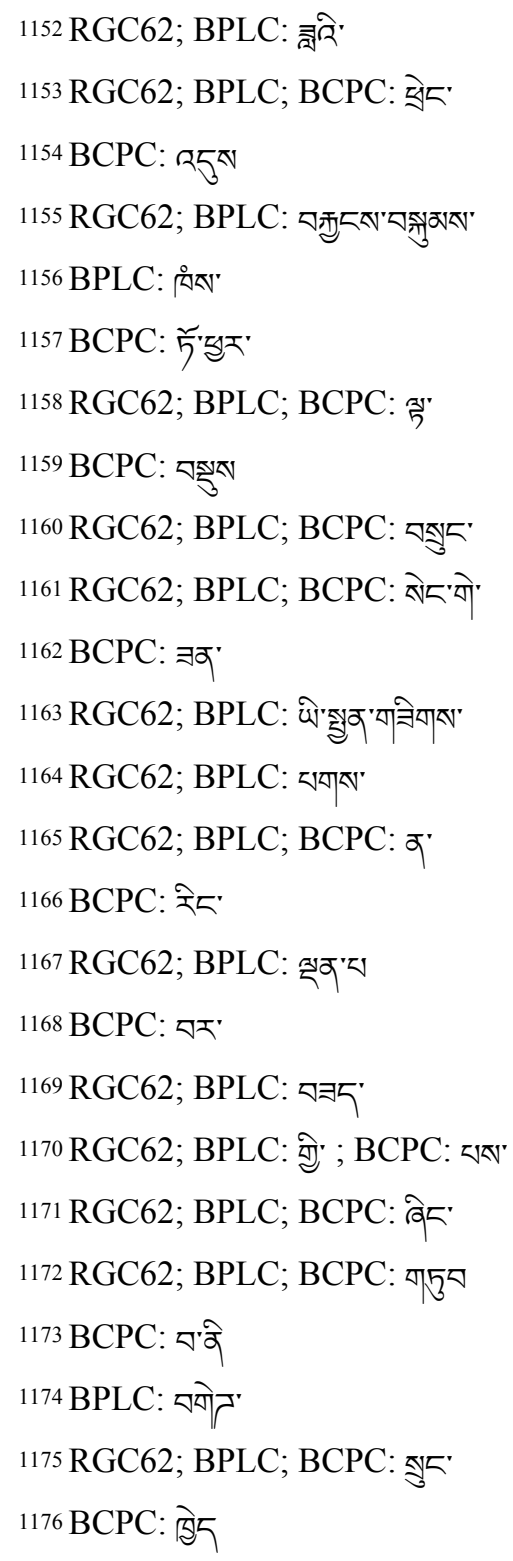




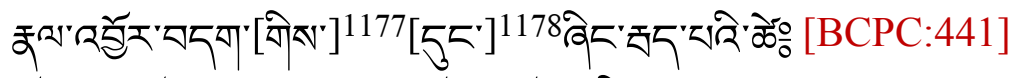

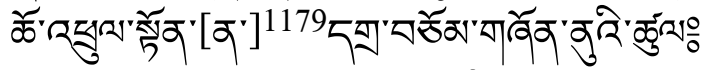

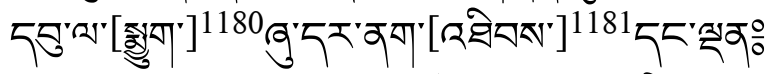

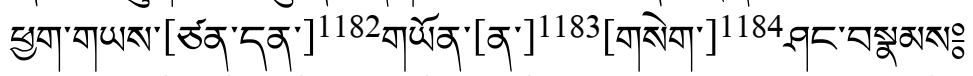

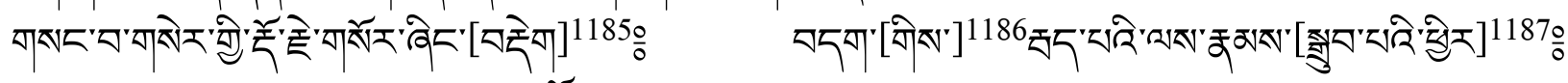

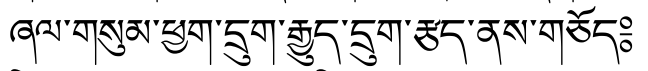

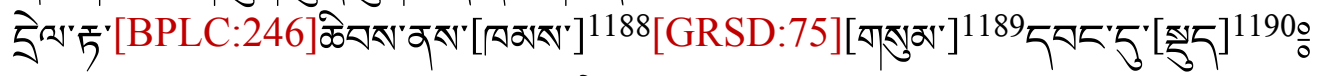

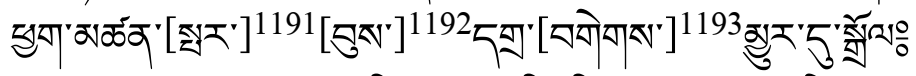

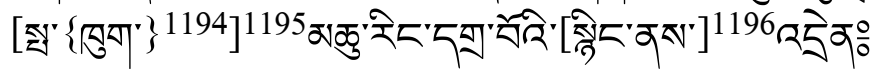

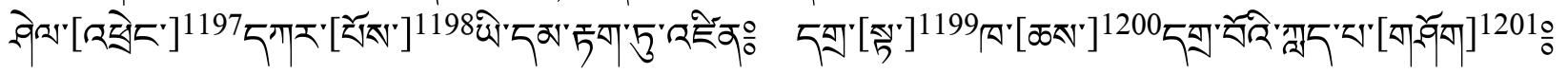

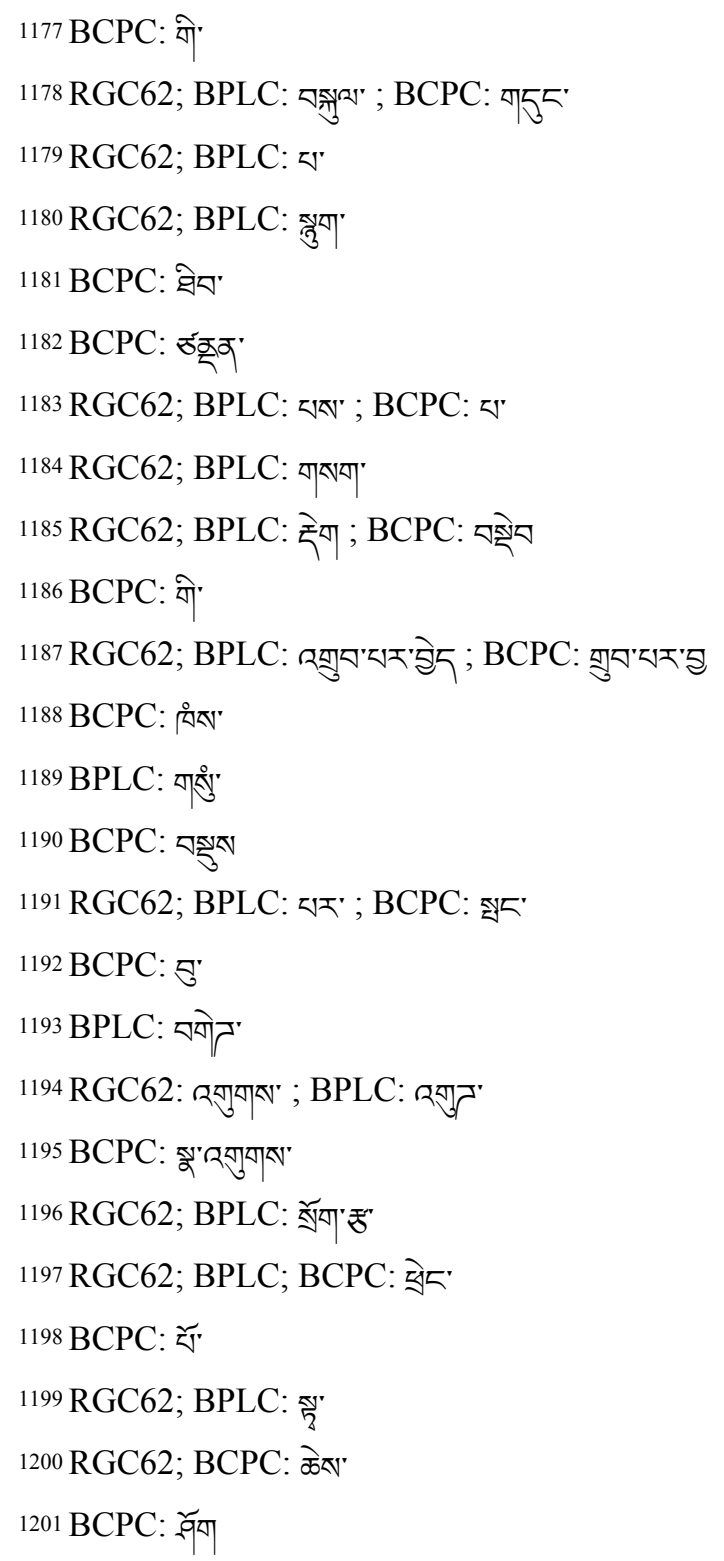




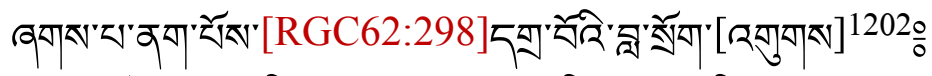

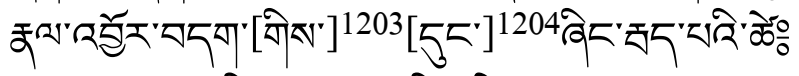

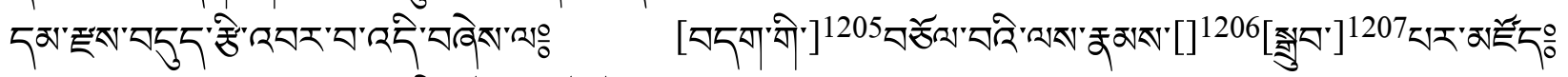

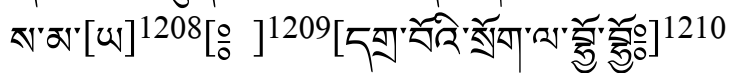

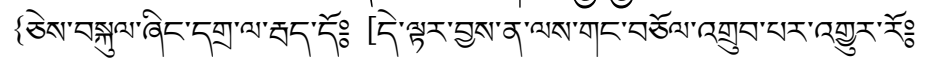

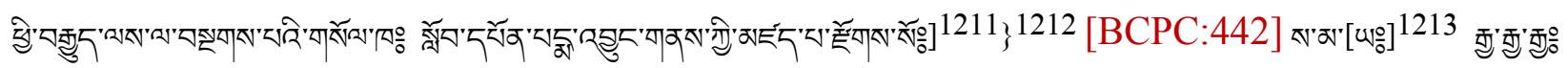

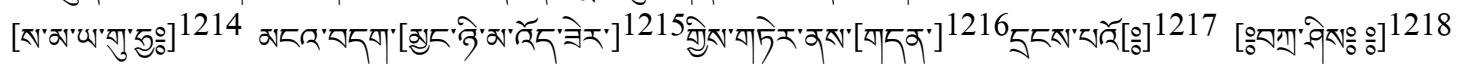

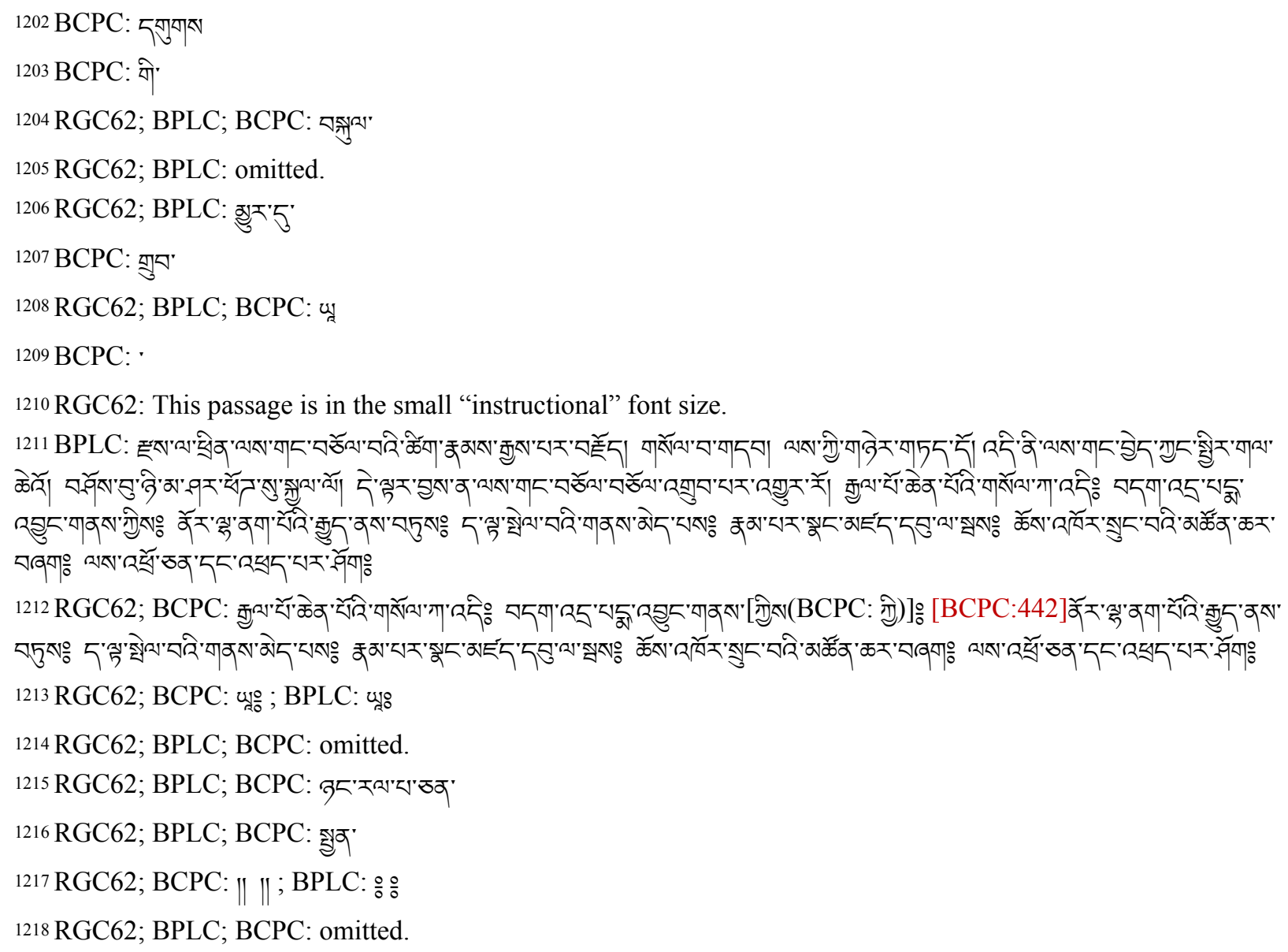




\title{
A Supplication Offering to the Five Great Sovereign Spirits 1220 and their Retinues 1221
}

\author{
[RGC62:276][BPLC:210][BCPC:406]I pay homage to Utpala Padmanetra! 1222
}

\section{[Preface]}

This sādhana for the Five Capricious Spirits and Sovereign Spirits has three parts: [1] Arranging the supporting ritual items for the mandala, [2] subjugating the capricious spirits and establishing one's own body as provisions [for the spirits], and [3] performing correctly the main practice of the [core] sädhana.

In addition to the core [sädhana], you [should] know [the following]:

\section{[Part I:] Arranging the Supplication Offerings}

Inside a copper basin — in addition to a small square three-layered torma1223 — place five butter lamps, silk brocade, and white mustard seeds [as] adornments. In the four cardinal directions place white mustard seeds, [arranged like] triangles [in] three layers, [as] adornments.

Skillfully arrange [the following] in rows: five sangchi 1224 adorned with white mustard seeds; five zurdün 1225 adorned with ox meat; five triangles smeared with blood; five circles smeared with butter; five square mansions that

1219 The Sanskrit word sādhana (ritual practice manual), while more commonly translating the Tibetan word sgrub thabs, is here translating the word 'phrin las; aside from meaning "enlightened activity," the latter can also mean a practice manual, and given the context this seems the more likely meaning here. Moreover, I have chosen to use the Sanskrit word sädhana in place of an English equivalent in order to highlight that there are different types of ritual manuals composed and employed for different purposes. A sādhana, specifically, is used for rituals meant to summon or invoke deities in order to supplicate and make offerings to them for reciprocal benefits and goals. Regarding ontological status, the deities who are the focus of such ritual manuals run the gamut from enlightened beings - such as tantric tutelary deities and bodhisattvas - to unenlightened worldly spirits - a fair amount of which become bound and assigned as protector deities.

1220 Tib. Rgyal po chen po sku lnga; a more literal translation would be, "the Five Forms of the Great Sovereign Spirit." For the sake of a smoother translation, I have chosen not to translate $s k u$, meaning 'form, body,' but it is significant to note that the honorific term for 'body' is used rather than the nonhonorific alternative, lus.

1221 This translation combines the titles of all four editions, among which there are only two variants: Rgyal po chen po sku lnga'i gsol mchod 'phrin las don bcu ma and Rgyal po sku lnga 'khor bcas kyi gsol kha phrin las don bcu ma. 1222 Tib. Dbang mchog Padma'i spyan; lit. "Blue Lotus-eyed One." According to the Monier-Williams SanskritEnglish Dictionary (Monier-Williams 1993, p.584), this is the name of a future Buddha, though no other information is provided.

1223 Tib. bshos bu; this is a small torma (Tib. gtor $m a$ ), which refers to a ritual item commonly found in most Tibetan rites. A torma is a colored dough cake usually decorated with butter medallions. They can vary greatly in structure, detail, and significance depending on the focus of the ritual. Generally, they act as offerings to a variety of deities.

1224 Tib. gsang 'phyi; the meaning of this term is obscure.

1225 Tib. zur bdun; the meaning of this term is obscure. 
are white, yellow, red, green, and black; five goblets of golden libations; five tormas with silken backs for the serpent spirits; five tormas with shoulders for the hindering spirits; five red triangular tormas for the imperial spirits; five tormas for the planetary spirits; five tormas [each] with two [butter] circles in a row [and] a distorted left side for the savage spirits; three pastries [made] of blood, butter, and molasses; five warm [loaves] of barley dough with drawings of humans on them; five bones of the enemy painted with molasses; ${ }^{1226}$ one measure of white barley; five leather bowls filled with barley beer; seven or twenty-one pitchers of the choicest, untainted beverages.

Whatever offerings [there are] for the protector deities to receive [should] be arranged - such as the right leg of a sheep; diamonds of sweet cheese; yoghurt, butter, and cheese; ${ }^{1227}$ steamed rice ${ }^{1228}$ [and] soybeans; ${ }^{1229}$ offerings of shoulder meat; and clarified butter, as well as various meats, hearts, and kinds of blood. [BPLC:211]

\section{[Part II:] Subjugating [the Capricious Spirits]}

After correctly performing the main sādhana to Glorious Hayagrīva, praise him and complete the [ritual] practice of approaching [him].

\section{[Part III:] The Actual Sädhana}

\section{[Introduction]}

After [completing the above] two [parts], meditate on [your] tutelary deity 1230 and bless the ritual items [as follows]: [GRSD:54]

GRSD: 1231

On top of the Matram ${ }^{1232}$ mandala [there is] a divine mansion made of the five precious

\section{BPLC:}

\author{
OṂ VAJRĀMṚTAKUṆ̣ALI 1234 HANA HANA 1235 \\ HŪṂ1 1236 PHAṬ1 1237
}

1226 Tib. bu ram gyi dgra bo'i mi rus bris pa lnga. This translation is based on the BPLC edition, which has mi in place of the ming that the other three editions have. Given the context, this seems to make more sense, since the alternative would yield a very different translation: "five transcriptions [of] the names and clans of enemies [written] with molasses."

1227 Tib. phyur ba; this translation is based on the BPLC edition. The other three editions have khu ba, meaning 'semen.' Given the context of dairy-based products, I chose to use the BPLC edition's variant word.

1228 Tib. 'bras chen; this is based on the BPLC edition, while the other three editions have 'bras chang, which is rice wine. Since this section of offerings seems to be mostly about food, I chose the BPLC variant.

1229 Tib. sran chen; this is based on the BPLC edition, while the other editions have sran chang, meaning lentil beer.

1230 Tib. lha bsgom; here the word lha, which generically means 'deity,' here refers to the tutelary deity (Tib. yi dam; Skt. iștadevatā); this refers to the specific individual tantric deity with which one has developed a relationship in the course of tantric practice, and with whom one identifies during deity yoga.

1231 The GRSD and BPLC editions, as well as the BCPC edition, have an extended ritual exposition at the beginning of the text that is not found in the RGC62 edition. However, the BPLC elaborates on this exposition the most. Relegating this different set of ritual expositions to footnotes would be cumbersome. Instead, I am placing them here next to each other in the body of the text. Since the GRSD is the central focus of this translation, I am using a smaller font size and bolded letters to distinguish the BPLC exposition.

1232 This likely refers to Matram Rudra, a great demon representative of ignorance and Buddhist evils; see Kapstein 2000, pp.163-177. 
treasures 1233 - a representation of Mount Meru.

\section{OṂ SVĀBHAVA 1238 ŚUDDHOḤ 1239 SARVA 1240 DHARMA ${ }^{1241}$ SVĀBHAVA ŚUDDHO 'HAṂ1242}

All becomes emptiness. From within the continuum of emptiness, OM [arises]. From [OM], vast and spacious jeweled vessels arise. Within [these vessels], OM Ā HŪṂ dissolve into light. From [these mantric syllables], offering tormas made of divine substances arise. [These tormas] are visualized [as] pure, unobstructed [by material hindrances], and exceptionally pleasing; and they become as limitless as the sky. 1243 OṂ ĀḤ HŪṂ1244

\section{$\begin{array}{lllllll}\text { OM } & \bar{A} & \text { KARO } & 1245 & \text { MUKHAM } & 1246 & \text { SARVA }\end{array}$ DHARMANĀṂ 1247 ATYANUTPANNATVAT 1248 OṂ ĀḤ HŪṂ PHAT}

1234 The normative Sanskrit is Vajrāmṛtakuṇụlī; Tib. Rdo rje bdud rtsi 'khyil ba; lit. “Adamantine Nectar Swirler.” This is the name of a wrathful deity invoked to dispel negative influences; see Nebesky-Wojkowitz 1998, pp.321322.

1235 Lit. "slaughter, kill."

1236 This mantric syllable means, “absorb!”; see Beyer 1973, p.101.

1237 Like OM, both of these syllables tend to be defined as untranslatable mantric seed syllables, though the latter, PHAT, could be understood as an onomatopoeic command for "Crack!" or "Disperse!" It thus acts as a final statement that actualizes the mantra. PHAT is also usually used in fierce mantras; see Beyer 1973, p.145. This line can be translated as: "OM Adamantine Nectar Swirler-Kill! Kill! HŪM PHAṬ!"

1233 Tib. rin po che sna lnga; the five precious treasures are gold (Tib. gser), silver (Tib. dngul), turquoise (Tib. g.yu), coral (Tib. byu ru), and pearl (Tib. mu tig).

1238 The normative Sanskrit spelling is svabhāva; lit. "essence, nature, condition." The BCPC edition has this spelling, see BCPC:406, line 3.

1239 This word is often rendered ŚUDDHĀḦ; lit. "to be purified, cleansed, freed."

1240 Lit. "all."

1241 Here dharma refers to the irreducible unit of existence for an object or event. This is a complex term with a rich history, but for simplicity's sake I am translating it here as "phenomena."

1242 The individual Sanskrit word is aham, meaning "I, me." This line can be translated as: "OM All Phenomena are Purified of Essence! I am Purified of Essence!"

1243 For further discussion of these mantras and visualizations, and their contextual use in Tibetan Buddhist rituals, see Beyer 1973, pp.143-144; and Bentor 1996, p.156.

1244 The order of these mantras coincides with the preliminary rituals for offering torma to hindering spirits discussed by Beyer (1973, p.143) and Bentor (1996, pp.156-157). Beyer (ibid) elaborates on their significance: the OM VAJRĀMRTAKUṆDALI mantra cleanses the offerings; the OM SVABHĀVA mantra purifies the offerings, making them one with emptiness; and the OM ĀH HŪM helps to empower the offerings.

1245 The normative Sanskrit is kāro, based on kāra, meaning "letter, syllable."

1246 This is the accusative case for mukha, meaning "door, opening, entrance."

1247 The normative Sanskrit is dharmānām, which is the genitive plural for dharma, here meaning 'phenomena.'

1248 The normative Sanskrit is ādyānutpannatvād, meaning 'unproduced from the beginning.' This line can be translated as: "OM The Syllable $\overline{\mathrm{A}}$ is the entrance to [the insight that] all phenomena are unproduced from the beginning!" This refers to the first letter of the Arapacana alphabet. This mantra, as well as the mantras elaborating on the next four letters of this alphabet, are discussed and translated in Conze 1975, pp.21-22. See also Beyer 1973, p.146, for a brief discussion of this mantra. 


\author{
NAMA 1249 SARVA TATHĀGATABHYOḤ 1250 \\ VIŚVA 1251 MUKHEBHYAḤ 1252 SARVATHĀ 1253 \\ KHAM 1254 UDGATE 1255 SPHARANA 1256 IMAṂ 1257 \\ GAGANA 1258 KHAṂ GHṚHNA 1259 IDĀṂ 1260 \\ BALING'1261 TAYE1262 SVĀHĀḤ 1263 \\ OM BHRUM TRAM HRĪ ĀH \\ From OM, may those imbued with the five desirable \\ qualities 1264 arise! \\ From BHRUM, 1265 may those possessing divine \\ mansions 1266 arise! \\ From TRAM, may those endowed with the seven \\ precious attributes of royalty 1267 arise!
}

1249 This derives from the Sanskrit namas, meaning "to pay homage, worship."

1250 The normative Sanskrit is tathāgatebhyo, which is the dative plural for tathāgata, meaning "One who has Gone Thus." This is a common appellation for the Buddha, latter extended to all Buddhas and Bodhisattvas in Mahāyāna Buddhism.

1251 Lit. "all, whole, entire."

1252 This is the dative plural for mukha, which in this context means "direction, quarter."

1253 Lit. "all, throughout, entirely."

1254 This is the accusative singular for kha, meaning "empty space, air, sky."

1255 This is the present tense conjugation for udgata, meaning "to appear, arise."

1256 The normative Sanskrit is spharana, which is equivalent to sphurana and means "manifestation, to expand forth, to spring forth." A closely related word is sphära, which means "extensive, abundant." The latter is found in some variants of this mantra, so I have used both understandings to inform my translation.

1257 This is a variant of idam, meaning "here, to this place, now."

1258 Lit. "sky, atmosphere."

1259 The normative Sanskrit is grhṇa, which derives from grah and means "to take, accept, receive, seize."

1260 The normative Sanskrit is idam, meaning "this, here."

1261 The normative Sanskrit is balim, which is the accusative singular for bali, meaning "offering, torma."

1262 The normative Sanskrit is tāye, which is the present tense for tāy and means "to spread, proceed in a continuous stream or line."

1263 This mantric word is commonly used when making oblations to deities. This line can be translated as: "Pay Homage to All the Thus-Gone Ones pervading all the directions throughout space! Come forth and abundantly manifest in the space here! Accept these offerings that are spread out in a continuous stream! SVĀHĀH!" As Bentor (1996, p.157n.220) laments, while portions of this mantra are understandable, it is difficult to make sense of the whole. This is my attempt at a translation, which is partially informed by Beyer 1973, p.339, and Hodge 2003, p.177. Moreover, it's unclear who is being addressed in this mantra. Viewed alone, it would seem the Thus-Gone Ones were the focus of this recitation. However, when compared to Beyer (1973, p.415) and Bentor (1996, p.157), it appears this is the mantra recited when the offerings are actually presented to the ghosts and hindering spirits as bribes to ensure they do not defile the rest of the ritual proceedings. It almost seems that a small line referencing these spirits is missing from the mantra presented here. Given this, it is likely this mantra is a directed at the aforementioned spirits, commanding them to pay homage to the Buddhas and Bodhisattvas, to come into the presence of the ritualists, and then to accept the offerings prepared for them before they depart.

1264 Tib. 'dod pa'i yon tan lnga; these are qualities that are pleasing to the five physical senses.

1265 Beyer (1973, p.145) explains that this mantric seed syllable is generally used to visualized the palaces of deities. 1266 Tib. gzhal yas khang; lit. "immeasurable house." 
From HRĪḤ, may those imbued with the sixty qualities of a melodious voice ${ }^{1268}$ arise!

From ĀH, [BPLC:212] may those possessing the great ocean of wisdom nectar arise! 1269

May the samaya 1270 vows of the ocean of Victorious Ones 1271 be fulfilled!

May the samaya vows of the protectors of the tantric scholars 1272 be fulfilled!

May the samaya vows of the enemy-defeating gods of the yogins be fulfilled!

May the samaya vows of the protectors of relatives and retinues 1273 be fulfilled!

May the samaya vows of the protectors of the masters' transmissions 1274 be fulfilled!

May the samaya vows of the protectors of the ancestors' lineages be fulfilled!

May the samaya vows of the Five Capricious Spirit Siblings 1275 be fulfilled!

In the Center [there is] a divine mansion made of red coral.

In the East [there is] a divine mansion made of white conch shell.

In the South [there is] a divine mansion made of precious gold.

In the West [there is] a divine mansion made of lotus[like] rubies.

In the North [there is] a divine mansion made of blue turquoise.

[They each have] four gates [and] eight protector deity chapels.

1267 Tib. rgyal srid rin chen sna bdun; these are [1] chariots (Tib. 'khor lo), [2] jewels (Tib. nor bu), [3] queens (Tib. btsun mo), [4] ministers (Tib. blon po), [5] elephants (Tib. glang po), [6] excellent steeds (Tib. rta mchog), and [7] generals (Tib. dmag dpon).

1268 For a list of all sixty of these qualities, see Dung dkar Blo bzang 'phrin las 2002, pp.2097-2098.

1269 According to Beyer (1973, p.145), "OṂ HŪṂ TRAṂ HRỊ̣̄ ĀḤ collectively represent the five families of Buddha." With the exception of BHRUṂ (in place of HŪM), these five seed syllables match this pattern exactly.

1270 The samaya (Tib. dam tshig) is a sacred commitment. In this context it binds a deity to their vow to protect the Buddhist teachings, and specifically reinforces their relationship with the ritual practitioner. Such vows also instill a connection between a lama and his disciples.

1271 Tib. rgyal ba; Skt. jina. This is another common appellation for Buddhas.

1272 Tib. rig 'dzin; Sky. vidyādhara; lit. "knowledge-bearer."

1273 Tib. mched 'khor; the translation offered is a literal rendering of these two words, though it is possible that it is an abbreviation of skye mched (Skt. äyatana) 'khor lo (Skt. cakra) drug, meaning 'the [twelve] sense faculties and sense objects, and six chakras [of the subtle body].'

1274 Tib. slob dpon brgyud.

1275 Tib. Gnod sbyin mched lnga. It is unclear to which group of deities this is referring; however, given the context and the previous conflation of capricious and sovereign spirits in the preface, it is likely this is an uncommon variant name for the Five Sovereign Spirits. 
At the center of this, visualize the [protective] circle of the tutelary deity in [your] heart, which manifests as great self-empowerment. During the outer invocation the sovereign spirits radiate from TRI, ${ }^{1276}$ during the inner sādhana practice they radiate from HŪM; their consorts radiate from BHYOH; [and] their ministers radiate from RTSA. 1277 Then all the abilities and powers of the wisdom deities and mundane haughty spirits gather together and dissolve into the seed syllables. From this transformation, [BPLC:213] [the following appear] in front of you:

\section{Regarding the [central] sovereign spirit of the mind, [recite] OM} VAJRARAKȘARAJÉCITTA ZUNG ZUNG! 1278 Incite the karak masha!1279 Destroy the kuna dumbu! 1280 If he transgresses [his vow], the guardian king's heart—Seize it! Seize it! 1281 If he regresses, the guardian's heart—Cut it into Pieces!1282 Gyajin, ${ }^{1283}$ the sovereign spirit of the mind, rides a long-trunked elephant as a mount, which is led 1284 by Mönbuputra. ${ }^{2285}$ His body color is dark blue, [and] he wears black silk and a bear-skin coat. On his head he wears a thumb[-shaped] hat 1286 with black silk [fringe]. In his right hand is the lasso of the hindering spirits, with which he binds the enemy. In his left hand is a razor, with which he cuts out the enemy's heart. Lightening and flames accompany his reveling. He sends forth hail and thunderbolts as heralds.

\section{BPLC:}

In front of [Gyajin, there is] the capricious spirit, the king of the enemy-defeating gods, the lord of life Yangleber.1287 His body color is red [and has] the brilliance of a thousand suns. He is fiercely wrathful.

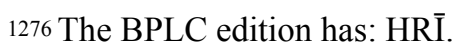

1277 The BPLC edition has: TSA.

1278 This mantra is an interesting hybrid of Sanskrit and Tibetan, with the Tibetan — rather than Sanskrit-genitive being employed between RAJA and CITTA, and the ending command being the Tibetan zung, which is the imperative of 'dzin pa, meaning "to lay hold of, seize." The translation would be: "OM Heart of the Adamantine Guardian King-Seize it! Seize it!”

1279 Tib. kha rag rma sha; the meaning of this term is obscure.

1280 Tib. khu na dum bu; the meaning of this term is obscure.

1281 This repeats the hybridization discussed in note 69 above.

1282 This short section threatening the deity to be complicit is unique; three of the four descriptions of the deities that follow lack this, but otherwise mimic the structure of the rest of this description.

1283 Tib. Brgya byin; Skt. Indra.

1284 Tib. sna bzung byas; lit. "to hold the nose."

1285 Tib. Mon bu pu tra; lit. "Son of the Mön." This name suggests some cross-linguistic reiteration; the Tibetan word pu means 'son,' as does the Sanskrit word putra. The word mon refers to an ethnic group indigenous to the southern Himalayas, though its exact semantic parameters are unclear; see Nebesky-Wojkowitz 1998, pp.8-9.

1286 According to iconographic representations of this deity found at Nechung (Tib. Gnas chung) Monastery and Meru Nyingba (Tib. Rme ru snying ba) Temple, this hat looks similar to the broad-brimmed hat commonly worn by Pehar in most representations, the one difference being a conical rather than rounded bowl.

1287 Tib. Yang le ber; this is another, less common name for Tsiu Marpo (Tib. Rtsi'u dmar po). See Bellezza 2005, p.291, and Bell 2006, pp.147-149. 
He eats and drinks flesh, blood, and life-breath. 1288 Sometimes he bites 1289 his lower lip with his upper teeth, and his eyebrows and forehead 1290 are contorted into a wrathful grimace. He wears a coat of armor and a leather helmet. He throws at the enemy the red lance in his right hand and the lasso of the imperial spirits in his left hand. He rides an excellent horse that is as fast as the wind, [and is] decorated with a jeweled saddle and bridle, and silken head ornaments. He is accompanied by a multitude of his siblings and retinue, emanations and secondary emanations, and a hundred thousand wild imperial spirits. 1291 [BPLC:214]

His emanation [takes] the guise of a young layman wearing a large cloak of red silk on his body and a crystal rosary around his neck. He raises the tarjani mudrāa ${ }^{1292}$ with his right [hand] and wields a copper knife in his left [hand]. His consort is Shantinma Marpo;1293 adorned with blood and fat, she brandishes an iron hook and a heart[-filled] skull cup. His minister is the lord of life Jarawa.1294 He wears a maroon cloak [GRSD:55] and rides a lion, holding aloft a military standard of black silk.

Regarding the eastern sovereign spirit of the body, [recite] TRI TRI ĀRYA JVALA 1295 BHYO ${ }_{1296}$ HŪM THO${ }_{1297}$ HŪM! Mönbuputra, the sovereign spirit of the body, rides a lion. He wears a black mentri1298 [coat] on his black-colored body, [and] a thumb[-shaped] hat with black silk [fringe] on his head. In his right hand is a vajra and in his left is a mendicant's staff. 1299 Black bears [accompany] his reveling, and he sends forth tigers, leopards, and [black] bears and grizzly bears as heralds. His emanation is a young arhat wearing saffron-colored religious robes. He carries a mendicant's staff, a razor, and a

1288 According to Nebesky-Wojkowitz (1998, p.108), this is the flesh, blood, and life-breath of the enemy, though the text he cites (Ibid, p.562) makes no mention of this.

1289 The BPLC edition has the word bstan here, but this seems incorrect in contrast to the word cited by NebeskyWojkowitz (1998, p.562), which is mnan. The latter word is also used in the GRSD edition's quote of this passage (see Appendix IIc, note 11). Given the context, I have chosen to substitute mnan for this translation.

1290 Both the BPLC edition and the text cited by Nebesky-Wojkowitz (1998, p.562) have sprag here. Given the context, this seems to be a misspelling of dpral, which is how I am translating it here.

1291 This description is found, with very little variation, in Nebesky-Wojkowitz 1998, pp.108, 562.

1292 Tib. sdigs $m d z u b$; Skt. tarjanī; this is a threatening mudrā known as the 'scorpion gesture.'

1293 Tib. Shanting ma dmar po; lit. "Red Tranquility."

1294 Tib. Bya ra ba; lit. "Watchman."

1295 Beyond the surrounding mantric seed syllables, these two Sanskrit words are the only ones with definitive definitions. ĀRYA means "noble" and JVALA means "flame." If we accept that the following BHYO declines JVALA, then it simply makes it dative plural: "to the noble flames!" In either case, it is not entirely clear how this relates to this deity.

1296 The BPLC edition has BHYOH.

1297 The BPLC edition has BHYOH.

1298 Tib. men tri; the meaning of this term is obscure. Nebesky-Wojkowitz (1998, p.109) leaves this term untranslated, though he implies that it is some kind of animal.

1299 Tib. gseg shang; Skt. khakkhara. 
skull cup, and an anointing vase hangs down his front. His consort is the female hindering spirit Rolangma Karmo. 1300 Endowed with a white silk dress, she brandishes a holy branch 1301 and a heart[-filled] skull cup. His minister is Jatri Mikchikpu 1302 the butcher. He wears black snakes for a turban and rides a black-bottomed blue [horse].1303 He flings a crystal vajra from his hand.

Regarding the southern sovereign spirit of good qualities, [recite] BRŪM VIRAKȘA TIMARA VAJRA SUM TRIMĀRA [BPLC:215] YA BÉ1304 DUM BÉ DUM! 1305 He moves quickly [like] indigo! 1306 Incite [the spirit to be] inseparably and completely bound to the samaya vow. The capricious spirit Shingjachen Nakpo,1307 [the sovereign spirit of good qualities,] is adorned with snakes and tiger-skins, and brandishes a battle axe and the lasso of the hindering spirits. [There is] a female khyung1308 over his head. Dragons [accompany] his reveling, [and he sends forth] apes, monkeys, and cats 1309 as heralds. His emanation is light blue, endowed with a bandoleer of red mentri [fur], and he brandishes a long hooked cane. ${ }^{1310}$ His consort is the four-armed Sergyi Putrima Nakmo.1311 She is endowed with a black silk diadem, is adorned with a bundle of snakes [as] an earring, and has a bell around her neck. Her right ear has a lion earring.1312 In her right hands are a

1300 Tib. Ro longs ma dkar mo; lit. "White Female Zombie."

1301 Tib. dam shing.

1302 Tib. Bya khri mig gcig pu; lit. "One-eyed Bird Throne.”

1303 While this text is not explicit about the animal, the text that Nebesky-Wojkowitz (1998, p.109) cites states that it is a horse. The iconography of the deity at Meru Nyingpa also has him riding a horse.

1304 Tib. rbad; lit. "to incite." This word is often used synonymously with the mantric syllable PHAT; see note 1237. 1305 This mantra is exceptionally difficult to decipher.

1306 Tib. ni la rgyug bring; the word ni la is clearly derived from the Sanskrit nïla, meaning "indigo, sapphire." However, the full meaning of this sentence and its odd placement in this description is a little obscure. The translation I offer is an attempt to make sense it.

1307 Tib. Shing bya can nag po; lit. "The Black One with a Wooden Bird."

1308 Tib. khyung mo; Skt. garudī, the feminine of garuda, an auspicious mythical bird. I'm am drawing on the BPLC edition, which appears to closely match the iconography of the deity presented in Nechung Monastery's assembly hall. The GRSD has khyung mgo, meaning "garuda head."

1309 Tib. byi la. Nebesky-Wojkowitz (1998, p.109) translates byi alone, which means "rat." This is a possibility if the $l a$ is understood as a particle. However, previous sections discussing heralds (Tib. pho nya) do not show this pattern, so I am choosing to read byi la as a single word.

1310 Tib. spa khug/'gugs; this term is somewhat obscure so I am drawing on the translation from Nebesky-Wojkowitz (1998, p.110), who likewise seems uncertain of its meaning. Moreover, later context and etymology, as well as mural iconography, imply that this is a crooked or hooked implement.

1311 Tib. Gser gyi spu gri ma nag mo; lit. "The Black Woman with a Golden Razor."

1312 The text cited by Nebesky-Wojkowitz (1998, pp.110, 563) is more explicit, stating that this consort's right earring is a lion and her left earring is a snake. With this unique earring orientation - along with her four arms, the necklace of severed heads, the elephant-skin cloak, the iron shackles on her feet, and other similarities-the iconography of this goddess is remarkably parallel to a form of Penden Lhamo (Tib. Dpal ldan lha mo) named “Queen of the Desire Realm Renowned as Dhūmāvatî̀” (Tib. Dud gsol mar grags pa 'dod khams dbang phyug ma; Dud gsol [sic: sol] ma is Dhūmāvatī in Sanskrit, both of which mean "Smokey Woman."); see Nebesky-Wojkowitz 1998, p.24. Given that a chapel at Nechung Monastery is dedicated to this form of Penden Lhamo, it is quite likely that this consort is an emanation or another form of this deity. This same earring configuration is found with another important form of Penden Lhamo named Makzor Gyelmo (Tib. Dmag zor rgyal mo; lit. "Queen [who uses] Sorcery [to Repel] Armies"), who is an important protectress of the Geluk sect and the other major protector of the Dalai Lamas' lineage alongside Nechung; see Nebesky-Wojkowitz 1998, p.26. 
sword and a red lance; in her left are a scimitar1313 and a trident. [GRSD:56] A banner flaps around her neck, and she [wears] a necklace of human heads. She possesses an [elephant-skin] cloak, a petticoat of yellow yak-hair felt, and a belt of snakes. Her two feet are adorned with iron shackles. She rides a donkey with a red spot on its forehead. His minister Jagö Tangnak 1314 has the appearance of a layman, and brandishes a vajra and war hammer.

Regarding the western sovereign spirit of speech, [recite] NAMO RATNATRAYĀYA 1315 NAGARĀJA BODHISATWAYAH! 1316 Reflect on ATRI and gather the oaths! 1317 SAMAYA JAH'1318 JAH! The enemy-defeating god Kyechik Marpo, ${ }^{1319}$ the sovereign spirit of speech, rides a white-heeled mule. He wears a red silk cloak and a bamboo hat; and he brandishes a cane staff 1320 and a sandalwood club. Roaring 1321 she-wolves [accompany] his reveling, [BPLC:216] and [he sends forth] iron hawks as heralds. His emanation is dark blue, has locks of hair that flow [upward] and a blazing beard, and is endowed with a tiger-skin garment. He holds aloft a corpse club and a victory banner [adorned with] a wolf's [head]. His consort Dzejé Padmakyé Marmo'1322 is endowed with ornaments. She brandishes a holy branch and a skull cup. His minister Dorjé Drakden 1323 wears monastic robes and rides a camel. He brandishes a mendicant's staff [made from] a red tree. 1324

Regarding the northern sovereign spirit of activities, [recite] ALALA HOH! 1325 Seize the VAJRAŚRIVAṂAHĀRA 1326 JAH HŪM! ! Surrounded by VAJRATRISA 1327

\footnotetext{
1313 Tib. shag ti; Skt. śakti; this is a fairly ambiguous weapon, with both the Tibetan and Sanskrit words being defined as a sword or a lance. Nebesky-Wojkowitz (1998, p.24) chose to even leave it untranslated. I have decided to rely on the iconography of this goddesses as it is presented in the Meru Nyingpa assembly hall. Here it is clearly a curved sword in her hand, so I have chosen to translate this term as "scimitar."

1314 Tib. Bya rgod thang nag; lit. "Black Pine Vulture."

1315 This is the dative singular of ratnatraya, the "Three Jewels."

1316 The normative Sanskrit is bodhisattvāya, which is the dative singular for bodhisattva. This rendition of the mantra is based mainly on the BPLC edition. Lit. "I Pay Homage to the Three Jewels and the Bodhisattva King of the Serpent Spirits!"

1317 Tib. a tri sems pa dam la 'dus 'dus s ma ya dzah dzah; this is an especially obscure hybrid mantra and it is difficult to translate; I am offering an attempt here.

1318 This mantric syllable means, "summon!”; see Beyer 1973, p.101.

1319 Tib. Skyes gcig dmar po; lit. "the Sole-Born Red One." The deity's body color is in his name, so it does not explicitly appear in the description.

1320 Tib. sba' $i$ 'ging mkhar; this is a difficult word to translate, so the definition I offer was drawn from NebeskyWojkowitz (1998, p. 110) and the iconography of the deity in Meru Nyingpa's assembly hall.

1321 Tib. 'ur ba; the BPLC edition has 'dur ba, which means "trotting." Either translation would seem feasible, though given the terrifying nature of these deities and their retinue, I have chosen the GRSD edition's variant.

1322 Tib. Mdzes byed padma skyes dmar mo; lit. "Beautiful Red Lotus-born Woman."

1323 Tib. Rdo rje grags ldan; lit. "Renowned Vajra."

1324 Tib. sher shing; I am reading this as gsher shing; an alternative would be tsher shing, meaning "thorn bush."

1325 According to Beyer (1973, p.101), this mantric syllable signifies the dissolution of the visualization.

1326 The normative Sanskrit is vajraśrīvāmahāra, which means "a garland of glorious and splendid vajras."

1327 Lit. "a three-fold fence of vajras."
} 
PRAGAYAŚAK ${ }^{1328}$ HŪM JAḤ! VAJRATRIDUKA-SAMAYA 1329 JAH JAḤ! The great enemy-defeating god Pehar, 1330 [the sovereign spirit of activities,] rides a white lioness, which is led by Mönbuputra. [He has] three faces: the right one is black, the left one is red, and the middle one is white. He possesses a bamboo hat. His right hands brandish an iron hook, an arrow, and a sword. His left hands brandish a razor, a bow, and a club. His upper body is adorned with white silk [garments] and his lower with human- and tigerskin [garments]. [He sends forth] jackdaws as heralds. His emanation [GRSD:57] possesses a human-skin [garment] and is ornamented with a bundle of snakes. He holds aloft victory banners [adorned with] tiger and wolf [heads].1331 His consort is Düza Minkarma, ${ }^{1332}$ who is dark blue and wears the fur-lined coat of the hindering spirits. She brandishes a holy branch and skull cup. His minister is Putra Nakpo.1333 [BPLC:217] He possesses a black silk robe, ${ }^{1334}$ rides a mule, and brandishes a curved knife.

Recite this three times, subjugating all:

\section{RAJA1335 THIBS SAMAYA JAḤ!!1336 RĀJA AHO1337 BHRUM PHAṬ! ŚAMARUTRI MAHŌ JAḤ!1338}

Contemplate the following:

The [Five Sovereign Spirits'] brigadiers, 1339 pathfinders, 1340 rear patrol,1341 entertainers, ${ }^{1342}$ shadröl, kyidröl, zinpo, dompo, 1343 ministers, servants and attendants, along with their inconceivable emanations and secondary emanations are obedient to me!

\footnotetext{
1328 This is a difficult mantra to decipher. If we abide by the GRSD edition, then one way of rendering this line in normative Sanskrit is pragayaśa $k$, which means something like "attaining power; advancing power," or alternatively, pragaiśa $k$, "resounding power; extolling power." If we abide by the BPLC edition, which has pra la shag, then this may be a redundant hybrid mantra, with the Sanskrit prala meaning "to dissolve; reabsorb," and the Tibetan shag deriving from bshag, "to break down." If this is the correct reading, then perhaps it refers to the last stage of these visualization processes, which is their ritual dissolution. This would seem to coincide with the JAH and HŪM that precede this description; however, both of these interpretations are speculative. See Beyer 1973, p.101.

1329 I am interpreting the normative Sanskrit as vajratriduhkhasamaya, and translating it as, "[Remember Your] Oath [to Protect Against] the Three Kinds of Suffering [with] Adamantine [Resolve.]" The Three Kinds of Suffering (Tib. sdug bsngal gsum; Skt. triduhkha) are [1] the suffering of physical and mental pain (Tib. sdug bsngal gyi sdug bsngal; Skt. duhkhaduhkhatāa); [2] the suffering of change (Tib. 'gyur ba'i sdug bsngal; Skt. viparināmaduhkhatā); and [3] the suffering of conditioned existence (Tib. khyab pa 'du byed kyi sdug bsngal; Skt. samskāraduhkhatāa).

1330 Tib. Pe har dgra lha chen po.

1331 See Nebesky-Wojowitz 1998, p.111.

1332 Tib. Bdud gza' smin dkar ma; lit. "Female Hindering-Planetary Spirit with White Eyebrows."

1333 Tib. Pu tra nag po; lit. "Black Son." This is a hybrid name, since putra is Sanskrit for "son, child."

1334 Tib. dar nag gi ral kha; John Bellezza (2005, p.357, n.49), defines ral kha/ga as "[a] kind of cloth robe that appears to have had wide sleeves and long tassels."

1335 The normative Sanskrit is rāja.

1336 Lit. "The Samaya[-bound] Kings who are Widespread—Summon Them!"

1337 Lit. "Oh, Kings!"

1338 Lit. "Summon the Great Peaceful and Wrathful [Ones]!"

1339 Tib. ru 'dren.

1340 Tib. shul mtshon. Bellezza (2008, p.425) translates this term as "beacon of the way." Given the anthropomorphic nature of the terms in this section, I have chosen to translate it as "pathfinder."

1341 Tib. rjes myul.
} 


\section{GRSD}

Establish as [your] support the [following] ritual object: a nine-part bamboo cane [thread-cross mansion] 1344 decorated with a tiger-skin cloth, a leopard-skin cloth, a white yak tail, and silk brocade.

Then, regarding the consecrated offerings:

From within a state purified in emptiness [with the] SVABHĀVA [mantra],1345 recite:

RAM YAM KHAM [arise] from the seed syllable of the heart!

Contemplate [the following]:

Fire arises from RAM and burns up all the impure elements of the ritual offerings!

Wind arises from YAM and scatters [all the impure elements of the ritual offerings]!

Water arises from KHAM and washes away [all the impure elements of the ritual offerings]!

Recite the following:

TRAM RATNATRAILOKYA BHRUM! 1346

\section{BPLC:}

\section{OM SVĀBHAVA ŚUDDHOḤ SARVADHARMA} SVĀBHAVA ŚUDDHO 'HAṂ!

All becomes emptiness. From within the continuum of emptiness, OM [arises]. From [OM], vast and spacious jeweled vessels arise. Within [these vessels], OM ĀH HŪM dissolve into light. From [these mantric syllables], there arise offering water, feetwashing water, flowers, incense, lamps, perfumed water, food offerings, and music made of divine substances. [These offerings] become an inconceivable pile as limitless as the sky, a cloud of offerings that arise from the liberating [activities] of the noble Samantabhadra, 1347 pervading all the sky, the earth, and the space between, clearly and without obstruction.

\section{OṂ ARGHAṂ 1348 PRATICCHAYE 1349 SVĀHĀḤ!}

PATYAṂ 1350 PRATICCHAYE SVĀHĀH!

PUȘPE 1351 [BPLC:218] PRATICCHAYE SVĀHĀḤ!

DHUBPE 1352 PRATICCHAYE SVĀHĀḤ!

ALOKE 1353 PRATICCHAYE SVĀHĀH!

GHANDHE 1354 PRATICCHAYE SVĀHĀḤ!

NEVITYA 1355 PRATICCHAYE SVĀHĀḤ!

1342 Tib. skyo sangs; lit. "removers of grief." This may refer to a kind of harlequin figure whose job it was to amuse the king and his court.

1343 Tib. sha grol kyi grol 'dzin po sdom po; this series of four terms often appears in descriptions of Pehar's retinue; however their meaning is obscure. Literally they mean 'flesh-liberator,' 'dog[?]-liberator,' 'apprehender,' and oathbearers,' respectively. These figures clearly make up members of Pehar's entourage, but their exact significance is unknown. Nebesky-Wojkowitz $(1998$, pp. 111, 564) translates sha grol as 'hangman.' Likewise, I would translate kyi grol as 'houndkeeper,' 'dzin po as 'administrator,' and sdom po as 'retainer.' Nevertheless, because the accuracy of these speculative translations cannot be ascertained, I choose to keep the terms untranslated.

1344 Tib. snyug ma tshig dgu pa gcig; a monk at Meru Nyingpa (Tib. Rme ru snying pa) explained to me that this was a type of large thread-cross structure (Tib. mdos) made out of bamboo shafts that are nine sections long; personal communication, October 5, 2011.

1345 This refers to the mantra, OM SVABHĀVA ŚUDDHOH SARVADHARMA SVABHĀVA ŚUDDHO 'HAM. This is "the mantra of purifying into dharma nature" (Tib. chos nyid rnam par dag pa'i sngags) see Bentor 1996, p.86.

1346 Lit. "TRAM Precious Three-Worlds BHRUM.",

1347 Tib. Kun tu bzang po; lit. "the Ever-Excellent One."

1348 Lit. "face-washing water."

1349 The normative Sanskrit is the imperative praticcha, meaning "accept!"

1350 The normative Sanskrit is pādyam ; lit. "feet-washing water."

1351 Lit. "flowers."

1352 The normative Sanskrit is dhūpe; lit. "incense."

1353 The normative Sanskrit is āloke; lit. "lamps."

1354 The normative Sanskrit is gandhe; lit. "perfume." 
Then imagine that the container of tormas is as extensive as the sky. Manifest as your tutelary deity and purify [the vessel and its contents] by emanating the three [seed syllables] OM ĀH HŪM from your heart; they become beautiful and boundless.

The [core] text of the Ten-Chapter Sädhana has been perfected and the objects of visualization for each occasion are clarified. One should invite the sovereign spirits by making the sounds of the cymbals resound, beating the drums, blowing the horns, and singing a melodious song of longing.

\section{ŚABTA 1356 PRATICCHAYE SVĀHĀḤ! 1357}

May the capricious spirits 1358 and their retinue extensively arise in the realm of the six senses!

\section{OM SARVAVID SURA SURA AVARDHAYA AVARDHAYA HOH! 1359 VAJRA SPHARANA KHAM SVĀHĀḤ̂ 1360}

Regarding the abridged invitation, recite [the following]: Manifesting as your lama and tutelary deity — who are simultaneously oneself - such [things] as light rays, a lasso, and an iron hook emanate from the HRĪH on [your] heart.

The guardians who reside in the realm of inherent nature, in India and Nepal, in Kashmir and Uḍ̣̣iyāṇa, in Sumatra 1361 and Sri Lanka, 1362 and in other worlds; the guardians of the teachings who reside in the form realm and formless realm, in the abode of the gods who enjoy pleasures provided by others, 1363 and in other regions; the Five Sovereign Spirits who protect the Dharma, [their] five emanations, five consorts, five ministers, and their secondary emanations, along with a host of spirits; in particular, the great servant Tsiu Marpo 1364 surrounded by a group of the four types of wild imperial spirits 1365 [BPLC:219] and a group of the Seven Emanated Imperial Spirit Riders, 1366 the great

1355 The normative Sanskrit is naivedye; lit. "food offerings."

1356 The normative Sanskrit is śabda; lit. "music."

1357 See Beyer 1973, p.380 for similar instructions and mantras. See ibid, p.148 for the individual definitions of these words for offerings; Beyer also offers here some discussion of the odd Sanskrit grammar present in this recitation.

1358 As before, the context suggests that this refers to the Five Sovereign Spirits despite the use of another spirit type. 1359 The only parallel I have been able to find of this mantra is provided by Beyer (1973, p.203), which states, “...OM SARVA-VID PŪRA PŪRA AVĀRHEBHYAH..." It is conceivable, though speculative, that a non-extant cursive edition of this ritual text could account for the misspelling of püra as sura, since the Tibetan pa and sa look very similar in cursive. As for avardhaya, this appears to be a simple misspelling. The word that Beyer provides, avārhebhyah, is clearly the dative plural compound of ava-arha, meaning "to the worthy ones." Drawing on Beyer, a possible translation of the mantra in this text is, "Omniscient OM is Satisfying to [All] the Worthy Ones HOH!"

1360 Lit. "The Vajras Abundantly Manifest in Space SVĀHĀ!"

1361 Tib. Gser gling; Skt. Suvarṇadvīpa; lit. "the Golden Isle."

1362 Tib. Zangs gling; Skt. Tāmradvīpa; lit. "the Copper Isle."

1363 Tib. Gzhan 'phrul dbang byed; Skt. Paranirmitavaśavartin; this refers to the sixth heaven in the desire realm (Tib. 'Dod khams; Skt. Kāmadhātu).

1364 Tib. Tsi'u dmar po.

1365 Tib. Btsan rgod rigs bzhi.

1366 Tib. Btsan rol ba skya bdun. 
Oath-bound One Dorjé Lekpa ${ }^{1367}$ surrounded by his retinue of 360 siblings and attendants, the Twelve Tenma Goddesses 1368 who protect Tibet, and the local gods 1369 and lords of the ground 1370 surrounded by the eight classes of gods and spirits in the phenomenal world 1371 - we the yogins, in an instant, visualize in our minds the manifest display of our pure motivation as all of these supreme supports of body, speech, and mind. Accompanied by music, song, and dance that are pleasing to these [spirit] guests [who] fill the billion-world system, 1372 we invite [you all] and request that you reside here!

\title{
MAHĀRAJA 1373 SAPARIVARA 1374 VAJRA SAMAYA JA JAḤ! 1375
}

\begin{abstract}
1376 The Ten-Chapter Sädhana of the [Five] Sovereign Spirits [includes]: [1] Requesting to Manifest; [2] Invitation; [3] Requesting to Reside; [4] Prostration; [5] Integrating the Oaths; [6] Presenting the Medicine Offering; [GRSD:58] [7] Presenting Favorable Offerings; 1377 [8] Exaltation; [BPLC:220] [9] Entrusting the Activities;1378 and [10] Compelling into Action.
\end{abstract}

\section{GRSD:}

Clearly visualize the Father and Mother 1379 [of] Body, Speech, Mind, Good Qualities, and Activities within the center and the four [cardinal] directions, together with their retinues.

1367 Tib. Rdo rje legs pa; lit. "Excellent Vajra."

1368 Tib. Bstan ma bcu gnyis.

1369 Tib. yul lha.

1370 Tib. gzhi bdag.

1371 Tib. snang zhing srid pa'i lha srin sde brgyad.

1372 Tib. stong gsum.

1373 The normative Sanskrit is mahārāja; lit. "great king."

1374 The normative Sanskrit is saparivāra; lit. "attended by a retinue."

1375 A possible translation is, "The Great Kings attended by their Retinue [and with] Adamantine Vows-Summon Them! Summon Them!"

1376 Except for the prayer to Utpala Padmanetra at the beginning, the text of the sädhana up to this point is only in the GRSD and BPLC editions, it is not found in the RGC62 and BCPC editions.

1377 The GRSD edition has mchod pa 'bul ba, while the other three editions have mthun rdzas 'bul ba; I have created a translation that acknowledges both concepts.

1378 The GRSD edition has 'phrin las bcol ba, while the other three editions have gsol ka bya ba, meaning "Performing the Supplication." Given the primacy of the GRSD edition, I have opted to provide the translation for its terminology.

1379 This refers to each deity and his consort.

1380 This is matches exactly the end of the GRSD edition's introduction on its p.57, line 6. In the BPLC edition is follows the chapter list rather than precedes it. 
BCPC: 1381

Regarding the preliminary preparation for the Ten-Chapter Sädhana:

Recite [the following] three times:

OM VAJRĀMRTAKUṆ@ALI HANA HANA HŪM
PHAṬ! OṂ SVABHĀVA ŚUDHA SARVA
DHARMA SVÄBHĀVA ŚUDDHO 'HAM!!

All becomes emptiness. From within the continuum of emptiness, vast and spacious jeweled vessels arise. Within [these vessels], OM ĀḤ HŪM dissolve into light. The tormas that arise from [these mantric syllables] become a great ocean of nectar.

OṂ ĀḤ HŪṂ!

[Recite the following] three times:

OM A A KARO MUKHAM SARVA DHARMANA ADYANUTPANNATOTTA! OM ĀḤ HŪM PHAT SVAHĀ!

May offering tormas that possess the five sublime sensory pleasures [of] sight, sound, smell, taste, and touch [BCPC:407] appear before the great kings and their retinues, and become extensive!

Manifest as your tutelary deity; here in the space before you [there appear], in an instant, divine mansions made of selfarisen wisdom. In the East [there is] a divine mansion made of white crystal. In the South [there is] a divine mansion made of yellow gold. In the West [there is] a divine mansion made of red lotus[-like] rubies. In the North [there is] a divine mansion made of green sapphire. 1382 In the Center [there is] a divine mansion made of blue cymophane. [They each have] four sides and four gates, [and] all of their attributes are entirely complete. Their peaks are beautifully [adorned] with tips of precious jewels. The sun and the moon manifest and adorn their left and right sides. In the center and in the four [cardinal] directions there are lotuses with the sun and the moon piled on top. In the middle of this, on top of a divan where Mațam Rudra and his consort are

1381 The BCPC edition's lengthy introduction appears to be an amalgamation of elements from both the GRSD and BPLC editions, yet it also possesses a number of unique characteristics and additions. Most notably, it provides a lengthy description of the protector Tsiu Marpo and his retinue. For these reasons, I have chosen to include it in the body of the translation, despite noticeable but minor redundancies. As with the BPLC edition, I am also using a smaller font size and bolded letters to distinguish the BCPC edition from the GRSD edition.

1382 Tib. inda ni; this is an abbreviation of in dra ni la, which derives from the Sanskrit indranila. 
bound together [like] adulterers, 1383 rays of light emanate from HŪṂ, BHYO, and TRI.

Having completely annihilated and reabsorbed all of the [human] enemies and [non-human] obstructions that destroy the [Buddhist] teachings: [BCPC:408]

Gyajin, the sovereign spirit of the mind [who resides] in the Center.

Mönbuputra, the sovereign spirit of the body [who resides] in the East.

The capricious spirit Shingjachen, the sovereign spirit of good qualities [who resides] in the South.

The enemy-defeating god Kyechikpu, the sovereign spirit of speech [who resides] in the West.

The great enemy-defeating god Pehar, 1384 the sovereign spirit of activities [who resides] in the North.

On the right [are] the five male [deities], on the left [are] their consorts, in front of them [are] their five ministers, [and] behind them [are] their five emanations, [together with] the lords of life Patra Karpo 1385 and Putra Nagpo. 1386 Furthermore, on the outside they are attended by hangmen, kyidröl, ${ }^{1387}$ servants, zinpo, [and] dompo [dressed in] tigerskin and leopard-skin garments.

Preceding [them all] are a hundred thousand black women who clear the path; they spew curses from their mouths [like] poisonous arrows. On the right [of them all] there are a hundred thousand brigadier heroes brandishing military standards; they shout from their mouths the war cry of "Ha ha!" On the left [of them all] there are a hundred thousand brigadier arhat monks brandishing mendicant staffs and begging bowls; [BCPC:409] they speak dharmic truths from their mouths. Following [them all] are a hundred thousand skullcup- and dagger- 1388 bearing black mantra [sorcerers] who wander the path; they proclaim from their mouths,

1383 Tib. ma tam ru dra pho mo byi chings su bsnol ba. The meaning of this line is obscure; a longer variant of it can be found below at the start of chapter 3 .

1384 Tib. Pe har gyis dgra lha chen po; I am reading gyis as gyi.

1385 Tib. Pa tra dkar po; Pa tra possible derives from the Sanskrit pātra, meaning "adept." If this is the case, this deity's name would be translated as "White Adept."

1386 Tib. Pu tra nag po; as with the previous footnote, this deity's name is also a hybrid, the first part deriving from the Sanskrit putra, meaning "son." Lit. "Black Son."

1387 This has the variant spelling, phyi grol.

1388 Tib. bhan phur; this is an abbreviation of bhan dha dang phur pa. 
"Māraya!"'1389 Moreover, they are surrounded by a retinue of the eight outer, inner, and secret classes [of spirits], such as $\bar{a} c \bar{a} r y a s^{1390}$ and Black Mön [spirits]. ${ }^{1391}$

In front of this [assembly of spirits], in the middle of a great ocean of blood, [there is] the capricious spirit Tsiu Marpo, 1392 king of the enemy-defeating gods. His body is red in color and possesses the radiance of ten million suns. He is very wrathful and bears ferocious fangs. He wears on his body red armor covered in scorpion shells. 1393 A belt of black snakes is tied [around his waist], and he is adorned with silken ribbons and a mirror that illuminates the phenomenal world. He wears on his head a leather helmet endowed with an aigrette of vulture feathers 1394 and [adorned with] red silk ribbons. In his right hand the lasso of the imperial spirits, flashing like lightening, snatches the enemy's life essence. [BCPC:410] In his left hand he brandishes a red spear [with a] banner 1395 on it. He amasses 1396 the armies of the eight classes [of spirits]. He bears a tiger-skin quiver and a leopard-skin bow case; and he rides for a mount a black horse with white around the mouth and eyes. $1397 \mathrm{He}$ is surrounded by a host of a hundred thousand imperial spirit attendants-a hundred lords possessing red arrows with vulture feathers, [and] a thousand 1398 lords possessing red spears with banners. 1399 They are followed by soaring crows, wild owls, and packs of red dogs and wolves. The great Oath-bound One Dorjé Lekpa and his 360 attendants have also come to reside here.

Manifesting as your tutelary deity, such [things] as light rays and an iron hook 1400 emanate from the HRĪH on [your] heart.

\footnotetext{
1389 Tib. $m \bar{a}$ ra $y a$; this derives from the Sanskrit māra, meaning "death" and referring to both the concept itself and its personification in the evil deity Māra.

1390 Tib. a tsarra; while this Sanskrit-derived word usually means "spiritual guide," here it clearly refers to a type of spirit.

1391 Tib. mon nag; Mön refers to a Himalayan region south-southwest of Tibet.

1392 Here the variant Tsi' $u$ dmar ba is used; for purposes of standardization, I am transcribing it as Tsiu Marpo.

1393 Tib. lus gnyer; lit. "wrinkled body." This translation was informed by Nebesky-Wojkowitz 1998, p.166.

1394 Tib. sdom 'phru; this is likely a misspelling of sgro 'phru; this understanding and the accompanying translation is drawn from Nebesky-Wojkowitz 1998, p.166.

1395 Tib. dan; I am reading this as a misspelling of dar.

1396 Tib. bsdud par mrdzad; this is read as a misspelling of sdud par mdzad.

1397 Tib. bra bo sgab nag; this translation is based on Goldstein 2001, p.458, and Zhang 1985, p.1060. This description differs slightly from the one provided by Nebesky-Wojkowitz (1998, p.167), who describes Tsiu Marpo's mount as "a black horse with white heels."

1398 Tib. rtong; this is read as a misspelling of stong.

1399 Tib. dan; this is read as a misspelling of dar.

1400 Tib. lcag kyu; this is read as a misspelling of lcags kyu.
} 
Bestow the seed syllable of the Five Great Sovereign Spirits and invoke their mental continuum. Furthermore, rays of light emanate from the generations in front [of you]. Thus, regardless of where in the world [the Five Sovereign Spirits] reside - such as the holy sites of Uḍdiyāṇa, Bodhgaya 1401 in India, Wutaishan 1402 in China, Triten 1403 in Kashmir, the maroon willow grove 1404 in Khotan, [BCPC:411] Yangleshö 1405 in Nepal, or, in particular, the great Dharma center of Glorious Samyé, changeless and spontaneously perfected, [with its] grand central temple, four continents and eight subcontinents, four reliquaries, four protector chapels, and three mansions for the queens-yogins who possess the samaya vow and do not transgress it or the pronouncements of the great master of the tantric scholars, Padmasambhava, the abbot Śāntarakṣita, and the Dharma-king Trisong Deutsen, ${ }^{1406}$ [can] invite [the deities]. By the power of your samaya vow, 1407 request [that the deities] approach this place in an instant!

VAJRA SAMAYA JA JAḤ 1408

The Ten-Chapter Sädhana of the [Five] Great Sovereign Spirits [is an] unadulterated root treasure text.

I pay homage to and praise the Mighty Padmanetra! 1409

The Ten-Chapter Sädhana of the [Five] Sovereign Spirits:

1401 Tib. Rdo rje gdan; lit. "Diamond Throne."

1402 Tib. Ri bo rtse lnga; Ch. 五台山; lit. "Five-peak Mountain.”

1403 Tib. Khri brtan; the location of this site is uncertain.

1404 Tib. lcang ra smug po. These places are holy sites with ties to various Buddhas; see Martin 2001, p.37. It is also worth noting that this particular place in Khotan is the birth place of the protector Tsiu Marpo in his previous incarnation.

1405 Tib. Yang le shod.

1406 In the text, these three are followed by the Tibetan word yon mchod, meaning "priest and patron," and referring to Padmasambhava and Śantarakșita as the priests and Trisong Deutsen as their patron. I have left it out of the translation proper to reduce confusion.

1407 Tib. thugs dam; this is the honorific form of the word, as opposed to the non-honorific form (dam tshig) used in the third person in the previous sentence. This is due to the practitioner manifesting as his tutelary deity, as stated at the beginning of this introduction and restated at the beginning of this paragraph; see also Nair 2010, p.180.

1408 Lit. "The Adamantine Samaya Vow-Summon it! Summon it!"

1409 Tib. Dbang chen Padma'i spyan; compare to note 1222 above. 


\section{Chapter 1: Requesting to Manifest}

\section{HŪM KYAIḤ!}

Mudü Lutsa, 1410 come [here]1411 from up above the high azure sky! [BCPC:412]

King of the hindering spirits, come [here] from a canopy of maroon coral!

Putri Barwa,,$^{1412}$ come [here] from within the vast dark-blue triangular expanse!

Opening the conch-shell door of the east, arise [from the Source,] Daö Zhönnu! 1413

Opening the golden door of the south, arise [from the Source,] Garwa Wangchuk! 1414

Come to this secret place from the recesses of the capricious spirits and barbaric spirits!

Opening the coral door of the west, arise from the Source, 1415 Vajraghuhyasamati1416 [and]

Mujé Tsanpo! 1417 [BPLC:221]

Opening the turquoise door of the north, arise from the Source, Khyungshok Barwa! 1418

Nakpo Tsedü, 1419 arise from the Source! 1420 Great lord of life, 1421 [RGC62:277] arise from the Source! Great three-faced celestial man ${ }^{1422}$ [and] Mudü Drangkar,1423 arise from the Source! Wicked and restless iron man 1424 [and] great enemy-defeating god, arise from the Source! Great blood-drinker, ${ }^{1425}$ arise from the Source! [BCPC:413] Lord of disease, 1426 arise from the Source! Lord of wealth, ${ }^{1427}$ arise from the Source! Great general, 1428 arise from the Source!

1410 Tib. Dmu bdud klu tsha; lit. "The Hot Savage-Hindering-Serpent Spirit."

1411 The editions of this text present two verbs used interchangingly here: sku bzhengs, which means "to arise, appear, manifest," and sku bskyod, which means "to approach, come, arrive;" both terms are in honorific form. Given the constant, and at times confusing, juxtaposition of these terms between the editions of this chapter, I have decided to translate both in this context as "to come [here]" in order to maintain a sense of uniformity. The one instance where the two words must be distinguished will be found below during the invocation to the consorts of the Five Sovereign Spirits. Likewise, I have selectively drawn from the various editions in effort to produce a uniform translation.

1412 Tib. Spu gri 'bar ba; lit. "Blazing Razor."

1413 Tib. Zla 'od gzhon nu; lit. "Young Moonbeam."

1414 Tib. Mgar ba dbang phyug; lit. "Powerful Blacksmith."

1415 Tib. [chos] dbyings; Skt. [dharma]dhätu. In Buddhist cosmology, this is the primordial ground from which all existence springs.

1416 I suggest that the normative Sanskrit for this name is Vajraguhyasamādhi, meaning "Secret Adamantine Meditation."

1417 Tib. Dmu rje btsan po; lit. "Sovereign of the Savage Spirits."

1418 Tib. Khyung gshog 'bar ba; lit. "Blazing Garuda Wings."

1419 Tib. Nag po tshe bdud; lit. "Black Life-Hindering Spirit."

1420 This line is not found in the RGC62 edition.

1421 Tib. srog bdag chen po.

1422 Tib. zhal gsum stod kyi mi po che; this is an epithet for Pehar.

1423 Tib. Dmu bdud brang dkar; lit. "White-chested Savage-Hindering Spirit." The GRSD edition has Dmu bdud bram dkar, in which case it's possible to read the second name as bram ze dkar, which means "White Brahmin."

1424 Tib. lcags kyi mi po 'tshub nag can.

1425 Tib. khrag 'thung chen po.

1426 Tib. nad kyi bdag po.

1427 Tib. nor gyi bdag po.

1428 Tib. stong dpon chen po. 
Supreme consort of the mind, arise from the Source! Sānti Rozan, ${ }^{1429}$ approach! Supreme consort of the body, arise from the Source! Female hindering spirit Rolang, ${ }^{1430}$ approach!

Supreme consort of good qualities, arise [from the Source]! Sergyi Putri, 1431 approach!

Supreme consort of speech, arise [from the Source]! Dzejé Padma, 1432 approach!

Supreme consort of activities, arise [from the Source]! Düza Minkar, ${ }^{1433}$ approach!

Minister of the mind, lord of life Jara, 1434 come [here]!

Minister of the body, Jatri Mikchik the butcher, 1435 come [here]!

Minister of good qualities, Jagö [GRSD:59] Tangnak, [BPLC:222] come [here]!

Minister of speech, Dorjé Drakden, come [here]!

Minister of activities, Putra Nakpo, come [here]!

Cabinet ministers, shadröl, kyidröl, [RGC62:278] zin[po], dom[po], Saga, 1436 and Dorjé Barwa, 1437 arise from the Source! [You all] together with your retinue, come to this secret place! [BCPC:414]

\section{RGC62, BPLC, BCPC: 1438}

\section{JAḤ HŪṂ BAṂ HOḤ! 1439 RĀJA AÑKUŚA SAMAYA JAḤ JAḤ! 1440}

1429 Tib. Shānti ro zan; lit. "Tranquil Corpse-eater." This deity is called Shantinima Marpo in the introduction; the names thus carry different meanings upon comparison. The GRSD edition also gives her first name as Shantinma in this instance.

1430 This deity is called Rolangma Karmo in the introduction above.

1431 This deity is called Sergyi Putrima Nakmo in the introduction above.

1432 This deity is called Dzejé Padmakyé Marmo in the introduction above.

1433 This deity is called Düza Minkarma in the introduction above.

1434 This deity is called lord of life Jarawa in the introduction above.

1435 This deity is called Jatri Mikchikpu the butcher in the introduction above.

1436 Tib. Sa ga. This likely refers to the 14th of the 28 stellar deities (Tib. rgyu skar nyi shu rtsa brgyad). However, the BCPC edition has landlord spirit (Tib. sa bdag). If the latter is the case, then this may simply be an epithet for the following deity.

1437 Tib. Rdo rje 'bar ba; lit. "Blazing Vajra."

1438 The RGC62, BPLC, and BCPC editions all have an additional mantra that completes this chapter and which is not found in the GRSD edition. Except for very minor typographical differences, the mantra is exactly the same between the three editions.

1439 While some of these individual mantric syllables have been previously discussed, this is the first time this specific configuration has appeared. Beyer (1973, p.101) describes these four syllables as representing, respectively, the summoning, absorbing, binding, and dissolving of the knowledge being (Tib. ye shes sems dpa') into the symbolic being (Tib. dam tshig sems $d p a^{\prime}$ ). The former is the divinity as it arises from the Source, while the latter is the visualization of the deity - a representation of the yogin's own mind - that then becomes embodied by the former. It is at this moment that the yogin becomes one with his tutelary deity. For a lengthier discussion of this process, see ibid.

${ }_{1440}$ Lit. "The Samaya[-bound] King [with the] Iron Hook-Summon Him! Summon Him!” This likely refers to Pehar, who is the only one of the Five Sovereign Spirits that brandishes an iron hook. 


\section{Chapter 2: Invitation}

HŪM!!

The Dharma protectors that I invite from the supreme realm-which is changeless and spontaneously perfected-and request to come to this mandala-which is generated through meditative concentration1441 - are the Five Capricious-Sovereign Spirits together with their retinue. You, supreme beings that protect according to your fundamental samaya commitment, I request [that you] come to this place [where] I have invoked [your] samaya vow. For the benefit of protecting the teachings of the [Buddha's] Word, arise from the Source of the Dharma as an illusion! You, who act with great compassion for the sake of [all] beings, I request [that you] come to this place [where] I have invoked [your] samaya vow.

Great Gyajin, sovereign spirit of the mind, [your secret] consort, the powerful Shantin Rozan, and [your council] minister, the lord of life Kayi Jarawa, 1442 together with [your] retinue-I request [you all] to come to this place. [BPLC:223]

Mönbuputra, sovereign spirit of the body, [BCPC:415] [your] secret consort, the female hindering spirit Rolangma, and [your] council minister, Jatri Mikchikpu the butcher, [RGC62:279] together with [your] retinue-I request [you all] to come to this place.

The capricious spirit Shingjachen, sovereign spirit of good qualities, [your] secret consort, Sergyi Putrima, and [your] council minister, Jagö Tangnak, together with [your] retinue-I request [you all] to come to this place.

Enemy-defeating god Kyechikpo, 1443 sovereign spirit of speech, [your] secret consort, [GRSD:60] Dzejé Padmakyé, and [your] council minister, Dorjé Drakden, together with [your] retinue-I request [you all] to come to this place.

Great three-faced man, sovereign spirit of activities, [your] secret consort, Düza Minkarma, and [your] council minister, Putra Nakpo, together with [your] retinue-I request [you all] to come to this place.

\section{JAH HŪM BAM HOH! $\quad$ ALALA HOH! 1444 \\ EHYEHI 1445 BHAGAVAN1446 AÑKUŚA SAMAYA JAH JAḤ! 1447}

1441 Tib. ting nge 'dzin; Skt. samädhi.

1442 Tib. Bka' yi bya ra ba; lit. "Watchman of the [Buddha's] Word."

1443 This deity is called Kyechik Marpo in the introduction above.

1444 This mantric fragment was first seen in the introduction above as part of Pehar's mantra.

1445 The GRSD and BCPC editions have EHYAHI, while the RGC62 and BPLC editions have EHYEHI. I have chosen to use the latter since it appears to be the more normative. This is a difficult term to decipher, but I suspect that it is the reiteration of the Sanskrit word ehi, which means "come near!" When placed together as ehi ehi, it would be rendered as ehyehi according to the rules of sandhi.

1446 This is a popular Sanskrit term used to refer to high Hindu, Buddhist, and Jain deities. It is often translated as "Lord," "Venerable," and "Almighty."

${ }_{1447}$ Lit. "Come Near, Come Near, Samaya[-bound] Lord with the Iron Hook-I Summon You! I Summon You!” As noted above (see note 1440), this mantra likely refers to Pehar. 


\section{Chapter 3: Requesting to Reside}

HŪM!

[BCPC:416] In this supreme holy place where Matram [Rudra] was liberated [through destruction], on a divan [made of] a [male and female] adulterer bound together-one laid facedown, the other in a supine position1448 - I have erected a measureless Mount Meru [made] of the five precious objects, [BPLC:224] and beautifully adorned it with the sun, the moon, and a lotus divan. In this supreme place where non-attachment is spontaneously perfected, reside firmly without duality in order to protect the teachings!

I request that [you,] sovereign spirit of the mind, along with [your] retinue, reside in the blazing dark-blue divine [mansion] in the center. [RGC62:280]

I request that [you,] sovereign spirit of the body, along with [your] retinue, reside in the white conch-shell divine [mansion] in the east.

I request that [you,] sovereign spirit of good qualities, along with [your] retinue, reside in the precious golden divine [mansion] in the south.

I request that [you,] sovereign spirit of speech, along with [your] retinue, reside in the red coral divine [mansion] in the west.

I request that [you,] sovereign spirit of activities, along with [your] retinue, reside in the precious turquoise divine [mansion] in the north.

PADMA ĀVEŚAYA 1449 ĀḤ! 1450 VAJRATRIDURUȘA 1451 HŪM!

VAJRA ATITIȘṬA 1452 KARAŚSAYĀ! 1453 White Bridle1454 SAMAYA JAḤ JAḤ!

[BCPC:417] ĀVEŚAYA STVAM!! 1455 AVEŚAYA TIṢṬA1456 LHAN! 1457

1448 Tib. kha sbub gan rkyal byi chings gdan du bsnol; phyi encompasses phyi pho and phyi mo. This imagery is visible in the murals of the Eight Sädhana Deities within Nechung Monastery's assembly hall. Many of these deities trample a small supine figure with their left foot and another facedown figure with their right; see Figures 43, 45, and 47. This iconography represents the supramundane conquering the mundane; see Ruegg 2008, pp.vii-viii.

1449 Lit. "to enter, take possession of;" from the root $\bar{a} v i s$.

1450 Lit. "Enter the Lotus! ĀḤ!

1451 The meaning of this term is difficult to decipher. According to Beyer (1073, p.349), DURU means "burn." If we accept ȘA as meaning "excellent, best," then one possible translation of this mantric phrase is: "Excellent Burning Three[-pointed] Vajra!"

1452 The normative Sanskrit is atidișta, meaning "influenced, attracted, inferred."

1453 The RGC62, BPLC, and BCPC editions have karaya, which derives from the root $k r$, meaning either "to do" or "to purify." In this case, this mantra could be translated as "Act in Accordance with the Vajra!" or "Purify in Accordance with the Vajra!"

1454 Tib. kha dur; this is read as a variant of kha mthur. The RGC62, BPLC, and BCPC editions have kha sgyur.

1455 This appears to be a variant of stavam, meaning "praise, hymn, prayer." Thus, one possible translation for this short mantra is, "Praise the Entrance [of the Deities]!"

1456 The normative Sanskrit is dișta, meaning "command, order."

1457 Tib. lhan; lit."together." One possible translation of this short hybrid mantra - which is only found in the GRSD edition-is, "[I] Command [You All] to Enter [Here] Together!" 


\section{Chapter 4: Prostration}

HŪM! !

The haughty spirits that accomplish mundane activities appear in the forms of the Five Great Sovereign Spirits. Prostrate and praise the assembly of the Five Sovereign Spirits, who promise to protect the Buddha's teachings! [GRSD:61]

$$
\text { ĀKARȘAYĀ } 1458 \text { ĀVEŚAYĀ EHYEHI ĀRALLI HO! 1459[BPLC:225] }
$$

Having recited this, imagine [the] retinues prostrating to the principal [deities].

\section{Chapter 5: Integrating the Oaths}

Perform the consecration as usual, reciting [the following] 108 times into the amrta, the nectar [of immortality]: OM ĀH HŪM!! SARVAPAÑCĀMRTA 1460 HŪM HRT̄H ȚHĀ! 1461

Because I [the yogin] appear as Padma Heruka, the commands issued to the sovereign spirits are three-foldsuperior, moderate, and inferior. Moreover, since [the yogin] calls out the [command], the time when [the deities] arise is crucial. At the time of performing the usual [ritual] quickly, the activities regarding the promise 1462 and the oath 1463 are as follows:

[RGC62:281] HŪM!!

You, supreme beings, great enemy-defeating gods-when [we] integrate the oath [between] you and myself, the Great Glorious One, the blood-drinking [Heruka], [BCPC:418] will be our mediator and witness. From this time onward, for as long as I live, may I not transgress my oath, and may I always give offerings to and rely upon [you,] the sovereign spirits. May you also not transgress your oath, and may you always act as my friends. However, if you do transgress your oath, Dorjé Nöjin Trowo1464 will crush you into particles of dust. The best integration is of the finest nectar [of immortality], adamantine urine-combined with the pañcāmrta 1465 -with the great heart's blood of the samaya vow; [this is] the essence of life. May [you] act as the quintessential friends of my heart, and may [you] never transgress your vow.

1458 This derives from ākarșa, meaning "to attract, draw toward oneself."

1459 This last mantric fragment is drawn from the RGC62, BPLC, and BCPC editions since the fragment in the GRSD edition appears to be a corruption. This assumption is based on the appearance of this form in other sources; see Beyer 1973, p.317, and Kohn 2001, p.220. The meaning of this mantra is obscure, though Beyer (ibid) implies that it relates to the summoning of deities. Indeed, this entire line of mantras seems to contain various synonyms for ordering the deities to enter into the ritual space.

1460 Lit. "All Five Nectars of Immortality." The five nectars (Tib. bdud rtsi lnga; Skt. pañcāmrta) are urine (Tib. dri chu), excrement (Tib. dri chen), blood (Tib. rak ta), semen (Tib. byang sems) and flesh (Tib. sha chen).

1461 According to William Stablein (1973, p.200), in this context, the HŪM represents the symbolic being and HRĪH the knowledge being (see note 1439), which are then united with ȚHĀ. Ritual medicine pills (Tib. ril bu) sometimes produced with this mantra signify this unification.

1462 Tib. cha don; I am reading this as a misspelling of chad don.

1463 Tib. tha tshigs.

1464 Tib. Rdo rje gnod sbyin khro bo; lit. "Wrathful Vajra Capricious Spirit."

1465 See note 1460 . 


\section{VAJRA TRIDURAKȘA YAKȘA 1466 HŪṂ PHAṬ! MAHĀPAÑCĀMRTTA KHĀHIH!!!1467}

Place this [nectar] on one's tongue [and] also distribute it to the sovereign spirits.

Contemplate [the following]:

I and the sovereign spirits have become inseparable. [BPLC:226]

For as long as I live, [you] will obey me and be my servants.

Integrate the samaya vows. Then, one should request that the life essences of the sovereign spirits appear.

[BCPC:419]

\section{Chapter 6: Presenting the Medicine Offering}

First, regarding presenting the offering of the medicinal nectar [of immortality]:

Take the offerings blessed by mantras from Matram [Rudra]'s armpit1468 [RGC62:282] and present the medicine offering [as follows]:1469 [GRSD:62]

HŪM! 1470

Even though [your] true nature does not waver from a peaceful state, [you] emanate a blazing body in order to protect the [Buddha's] teachings. I present a delightful sacramental offering of pure nectar to the most accomplished tantric scholars that liberate [beings in] the six transmigrations. I request that you bestow [on me] attainments ${ }^{1471}$ of fierce power.

\section{RĀJA AHO BHRUM BÉ! ARGHAM PRATĪCCHAYE HOH!! SARVAPAÑCĀMRTA KHĀHI HŪṂ!}

The five spontaneously perfected bodies that renounce the five poisons 1472 gather [as] fierce wisdom in order to liberate the six classes of beings, and brandish nine-pointed vajras in order to subdue pernicious forces. I present a delightful sacramental offering of pure nectar to the most accomplished ones that subjugate the three worlds. I request that you bestow [on me] attainments of fierce power. [BCPC:420]

\footnotetext{
1466 Lit. "Adamantine Capricious Spirit with Three Evil Eyes!"

1467 Lit. "Consume the Five Great Nectars of Immortality!" The mantric word KHĀHIH is synonymous with the Tibetan gsol cig; see Beyer 1973, p.159.

1468 This line is found at the end of chapter 5 in the BCPC edition.

1469 Medicine here refers to the nectar of immortality; see note 1460.

1470 This mantric syllable is only found in the BCPC edition; I am including it here for the sake of uniformity.

1471 Tib. dngos grub; Skt. siddhi; This refers to supernatural powers and abilities attained through advanced yogic practice.

1472 Tib. dug lnga; the five poisons are [1] desire (Tib. 'dod chags), [2] hatred (Tib. zhe sdang), [3] ignorance (Tib. gti mug), [4] pride (Tib. nga rgyal) and [5] envy (Tib. phrag dog).
} 


\section{RĀJA AHO BHRUṂ BÉ! ARGHAṂ PRATĪCCHAYE HOH!! SARVAPAÑCĀMRTA KHĀHI HŪṂ!}

Though [your] supreme speech does not waver from the Source of the Dharma, you burst out with "Ha ha!"- a fierce, inexhaustible, far-reaching laughter-[BPLC:227] and sing a resounding song of delight. I present a delightful sacramental offering of pure nectar to the supreme speech of the accomplished ones that strike their palates [with their tongues]. I request that you bestow [on me] attainments of fierce power.

\section{RĀJA AHO BHRUM BÉ! ARGHAṂ PRATĪCCHAYE HOḤ! SARVAPAÑCĀMRTA KHĀHI HŪṂ!}

Though [your] primordial nature1473 does not waver from the state of ultimate [truth], you concentrate on all the three worlds in order to liberate wrong views [through destruction]. [RGC62:283] Your mental emanations pervade1474 all the three spheres of existence. I present a delightful sacramental offering of pure nectar to the supreme accomplished ones that have perfected the five powers 1475 of the tantric scholars. I request that you bestow [on me] attainments of fierce power.

\section{RĀJA AHO BHRUM BÉ! ARGHAṂ PRATĪCCHAYE HOH!! SARVAPAÑCĀMRTTA KHĀHI HŪṂ!}

Though [your] mental nature 1476 does not waver 1477 from the state of ultimate [truth], you reveal [yourselves] in terrifying 1478 forms in order to liberate all poisonous wrong views [through destruction]. I present a delightful sacramental offering of pure nectar to the Five Great Capricious Spirits and Sovereign Spirits. I request that you bestow [on me] attainments of fierce power.

\section{RĀJA AHO BHRUM BÉ! ARGHAM PRATĪCCHAYE HOH!! SARVAPAÑCĀMRTTA KHĀHI HŪṂ!}

The great powerful ones that have dominion over the entire world [BCPC:421] [GRSD:63] delightfully embrace the forms of the Five Sovereign Spirits in order to perform the activity of invoking the samaya vow. I present a delightful sacramental offering of pure nectar to the five female hindering spirits, the great secret consorts. I request that you bestow [on me] attainments of fierce power.

\footnotetext{
1473 Tib. thugs nyid.

1474 Tib. khyab; this reading is based on the BCPC edition. The other three editions have dgongs, meaning "to consider, reflect, concentrate on." Given the context, the BCPC edition's alternative seemed more suitable.

1475 Tib. dbang lnga; the five powers are [1] faith (Tib. dad pa), [2] diligence (Tib. brtson 'grus), [3] mindfulness (Tib. dran pa), [4] meditative concentration (Tib. ting nge 'dzin), and [5] wisdom (Tib. shes rab).

1476 Tib. sems nyid.

1477 Tib. ma g.yos; this is drawn from the RGC62, BPLC, and BCPC editions. The GRSD edition has gnyis med, meaning "nonduality;" in this context it means being inseparable from the state of ultimate truth.

1478 Tib. 'jigs byed; this is also the name of an important tantric deity known in Sanskrit as Bhairava. However, the context in this case suggests an adjectival descriptor rather than a name.
} 


\section{RĀJA AHO BHRUṂ BÉ! ARGHAṂ PRATĪCCHAYE HOH!! SARVAPAÑCĀMṚTA KHĀHI HŪṂ! 1479 [BPLC:228]}

The great powerful ones that act as servants of the [Buddha's] Word completely accomplish 1480 the entrusted actions without obstruction in order to quickly establish the activities of the sovereign spirits. I present a delightful sacramental offering of pure nectar to the five ministers that protect the samaya vow. I request that you bestow [on me] attainments of fierce power.

\section{RĀJA AHO BHRUM BÉ! ARGHAṂ PRATĪCCHAYE HOH!! SARVAPAÑCĀMRTA KHĀHI HŪṂ!! 1481}

[You] fill the billion-world system with an army of [your] emanations in order to rain down magical illusions on, and bring about disaster for, the enemies that destroy the Buddha's teachings. [RGC62:284] I present a delightful sacramental offering of pure nectar to the right, left, front, and back brigadiers together with their attendants. I request that you bestow [on me] attainments of fierce power.

\section{RĀJA AHO BHRUṂ BÉ! ARGHAṂ PRATĪCCHAYE HOḤ!} SARVAPAÑCĀMRTTA KHĀHI HŪṂ!!1482 [BCPC:422]

\section{Chapter 7: Presenting the Favorable Offerings of the Body, Speech, and Mind}

\section{HRĪH!}

Regarding the presentation of offerings that are the play of non-duality to the great glorious Hayagrīva - the mighty lotus - and the great powerful ones - the Five Sovereign Spirits along with their retinue:

I present [as] offerings a variety of colors, such as white and red, to the bodies of the Five Sovereign Spirits.

I present [as] offerings a variety of sounds, pleasant and unpleasant, to the speech of the Five Sovereign Spirits.

I present [as] offerings maroon hearts, heaped together like clay, to the minds of the Five Sovereign Spirits.

Accepting these offerings of body, speech, and mind, I request that the Five Sovereign Spirits perform the [requested] actions.

1479 For this particular instance of the mantra, the GRSD edition has the following variation: RĀJA AHO BHRUM BÉ! ŚAMARUTRI MAHO JA! ARGHAM PRATĪCCHA HO! SARVAPAÑCĀMRTA KHARAM KHĀHI! The BCPC edition has a shorter variant of this alternative mantra. KHARAM likely means "pungent" here, and is simply added onto the mantra repeated several times in this chapter.

1480 Tib. sgrub; this is drawn from the BCPC edition. The other three editions have sgrol, meaning "to liberate;" given the context, the BCPC edition's alternative seemed more suitable.

1481 The version of this mantra in the BCPC edition mimics its appearance in the previous mantra, though the GRSD edition remains the same.

1482 See note 1481. 
Sovereign spirits along with your retinue, come here and approach the flesh. The flesh of the enemies that violate the samaya vow is more delicious than cooked barley.

Sovereign spirits along with your retinue, come here and approach the blood. [GRSD:64] The blood of the enemies that violate the samaya vow is more delicious than barley beer.

Sovereign spirits along with your retinue, come here and approach the bones. The bones of the enemies that violate the samaya vow are more delicious than butter. I present these material offerings of the three poisons ${ }^{1483}$ to you, the sovereign spirits along with your retinue.

I request that you consume the three enemies and liberate [through destruction] the enemies and obstructing [spirits].

\section{SARVAPAÑCĀMRTA AHARA 1484 HŪM! RĀJA AHOH! ARGHAM PRATĪCCHA HOH!! PŪJA1485 VAJRA DURU HO! 1486}

Regarding the sacred items that appease the Five Sovereign Spirit:1487

Arrange the various beautiful and attractive food offerings, 1488 ornamented with different kinds of jewels and victory banners. Arrange the inconceivable pleasures of the five senses 1489 like this: [BPLC:229] streaming silken tassels, ribbons, and canopies; flapping beautiful pitched satin tents; row after row of various beautiful victory banners; a swirling great ocean of blood; the billowing fragrance of human flesh; a continuous flowing stream of the choicest golden libations; the wafting smoke [from] incense and [burning] human fat; a dense, cloud-like gathering of provisions and food offerings; and the swaying, rainbowlike [colors] of the various deity offerings. Then, having arranged the various material offerings in the body mandala, [BCPC:423] present [them] as ornaments of the great beings' bodies.

1483 Tib. dug gsum; the three poisons are [1] desire (Tib. 'dod chags), [2] hatred (Tib. zhe sdang), and [3] ignorance (Tib. gti mug).

1484 The normative Sanskrit is āhara, meaning "seizing, offering."

1485 The normative Sanskrit is $p \bar{u} j \bar{a}$, meaning "to honor, worship, pay homage."

1486 One possible translation of this last mantric phrase is: "Burn, Venerated Vajra HO!"

${ }_{1487}$ All of the lines in chapter 7 up to this point are only found in the GRSD edition. By contrast, the following line is found in the RGC62, BPLC, and BCPC editions at the start of the chapter: "KYE! Regarding the sacred items that I, the yogin, offer to the five enemy-defeating gods, their consorts, and their retinue." Moreover, the BCPC edition has the following extra line added between the KYE! and the rest of this short sentence: "According to custom [it should] be changed to, "Regarding the sacred items that appease the Five Sovereign Spirits." The implication is that this line should replace or amend the previous one.

1488 Tib. zhal zas; this refers to a type of torma.

1489 Tib. 'dod yon lnga; the five sensual objects are [1] visible form (Tib. gzugs), [2] sound (Tib. sgra), [3] smell (Tib. $d r i$ ), [4] taste (Tib. ro), and [5] touch (Tib. reg bya). 
I request that you bestow [on me] the attainment of a delightful body. 1490 [RGC62:285] Supreme forms of the sovereign spirits, reveal [yourselves] in reality at this time and protect the Buddha's teachings with [your] physical emanations!

${ }_{1491}$ Regarding the utterances that summon the great enemy-defeating gods:

In the speech mandala of the sovereign spirits, I present all kinds of offerings of the various sounds - such as the trilling flutes of the best human thigh bones; the reverberating of many lutes and cymbals; the chiming and beating of many small cymbals and hand-drums; [GRSD:65] the continuous melody of the piwang 1492 lute; and drums, conch-shells, and a pair of cymbals. [BPLC:230]

Reveal the sound of [your] speech in reality at this time! [You] expel a laugh of "Ha ha!" at the hateful enemies. With a "Hi hi!", [you] act endowed with power. [You] overpower all with your vicious roar, display the source of the great enemy-defeating gods' minds, [BCPC:424] [and] do not veer from the ultimate uncreated Source of the Dharma.

To the minds of the sovereign spirits, I present offerings of the Dharma-the inexpressible, unimaginable Source of the Dharma, 1493 the great bliss of non-conceptual wisdom free from elaboration. You act against the hateful enemies [with] vicious intentions, [and] against the harmful obstructing [spirits with] cruel and malicious thoughts. Speaking thus, present the offerings.

The good qualities of the sovereign spirits are inexpressible. Even subjugating the phenomenal world is, moreover, a good quality of the sovereign spirits. [RGC62:286] [Even] greatness and power in this world is, moreover, a good quality of the sovereign spirits. Even having dominion over the three realms is, moreover, a good quality of the sovereign spirits. Even obtaining extraordinary renown is, moreover, a good quality of the sovereign spirits.

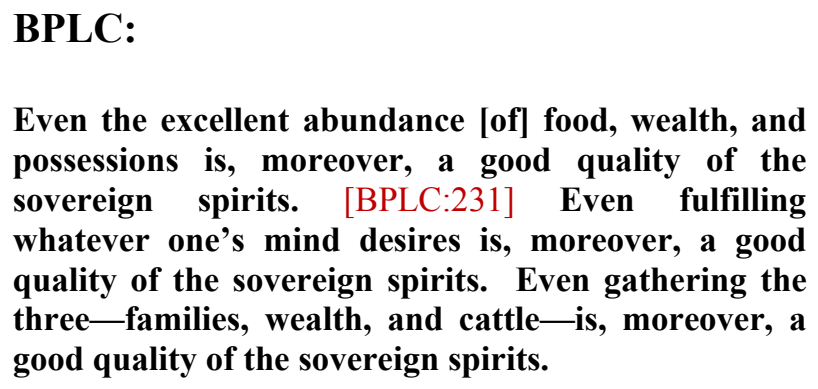
possessions is, moreover, a good quality of the sovereign spirits. [BPLC:231] Even fulfilling whatever one's mind desires is, moreover, a good quality of the sovereign spirits. Even gathering the three-families, wealth, and cattle-is, moreover, a good quality of the sovereign spirits.

1490 Tib. dgyes mdzad sku; dgyes mdzad is also a epithet for the tantric deity Hevajra; however, in this context it is likely an adjectival descriptor.

1491 The RGC62, BPLC, and BCPC editions start this section of this chapter with KYE! This is absent from the GRSD edition.

1492 Tib. pi wam; Ch. 必班; a Chinese stringed instrument.

1493 The RGC62 and BPLC editions have chos kyi sku (Skt. dharmakāya); lit. "Dharma body." 
The unobstructed activities of the sovereign spirits pull out the heart veins of Rudra, [who] violated his samaya vow; conquer the chief heretics [with] wrong views; chop down the life tree of the lifespan [that has] wrong views; [BCPC:425] and destroy the physical bodies of the yogin's enemies. These are the activities of the sovereign spirits.

Accept these sacred items and tormas, [GRSD:66] and accomplish [your] entrusted activities!

\title{
RGC62, BPLC, and BCPC: 194
}

\section{SARVAPAÑCĀRA 1495 HOḤ! PUJA HOḤ! RĀJA HOḤ! ARGHAṂ PRATĪCCHA HOḤ!}

\author{
VAJRAYAKȘA 1496 KHĀHI! 1497 DUNTIṂ1498 DUNTIṂ KHĀHI! YAKȘA Black1499 \\ KHĀHI! Shadröl HŪRU1500 KHĀHI! Kyidröl HŪRU KHĀHI! CITTAMAHĀA 1501 \\ KHĀHI! 1502 Zinpo RUDRA KHĀHI! Lineage of Dompos and Upholders 1503 \\ KHĀHI! 1504 RUDRA RUDRA KHĀHI! GOROCANA 1505 KHĀHI! 1506 RAKTA \\ Lips and Nose1507 KHĀHI! 1508 Streams of Flesh and Streams of Hearts KHĀHI! The \\ Five Senses1509 KHĀHI! ŚSAMARUTRI KHĀHI! ARGHAM PRATİCCHA HO! \\ PŪJA VAJRA DURU HO!
}

1494 These first mantric lines below are not found in the GRSD edition, but are in the RGC62, BPLC, and BCPC editions, with minor variations between them. What I present here is an attempted normative transliteration.

1495 Lit. "all five spokes [of a wheel]." Ara means the spoke of a wheel or of an altar formed like a wheel; thus, this may be a visual reference to the manner in which these offerings to Five Sovereign Spirits are displayed.

1496 Lit. "Adamantine Capricious Spirits."

${ }_{1497}$ In the RGC62, BPLC, and BCPC editions, KHĀHI is preceded by KHA KHA, which may be reiterative and mean "mouth" in this context. As such, one possible translation of this mantric phrase is: "Adamantine Capricious Spirits, Consume [with your] Mouth!"

1498 The meaning of this word is obscure.

1499 Lit. "black capricious spirits."

1500 The meaning of this word is obscure.

1501 Lit. "Great Heart."

1502 This mantric line is not found in the RGC62, BPLC, or BCPC editions.

1503 This spelling is drawn from the RGC62 and BPLC editions. I am reading "chang as "to uphold" and rgyud as a variant of brgyud, meaning "lineage;" nonetheless, the meaning of this phrase is not entirely clear.

1504 In the BCPC edition, this line is followed by an extra one not found in the other three: RAKTAMAHĀ KHĀHIH!! Lit. "Consume the Great Quantity of Blood!"

1505 The normative Sanskrit is gorocanā, lit. bezoar, synonymous with gi wang; see Pasang Yonten Arya 1994, p. 36.

1506 In the RGC62, BPLC, and BCPC editions, this line is followed by an extra one not found in the GRSD edition: CITTAVASUTA KHĀHI! If we accept that the normative Sanskrit for the first word is CITTAVASUDA, then one possible translation is: "Consume the Wealth-granting Heart!" There are slight typographical differences between the three editions, so I have presented here a normative transliteration.

1507 Tib. mtshul pa; this is drawn from the BPLC, BCPC, and RGC62 editions. In the GRSD edition this line is RAKȘA TSHUL BA, meaning "manner of guarding." Given the context, the former appears more fitting.

1508 Lit. "Consume [so that your] Lips and Nose are Bloody!"

1509 Tib. dbang po rnam lnga; this is drawn from RGC62 edition. At this point, the BCPC edition has the added phrase: ŚAMARUTRI, seemingly combining this and the next mantric line, which is not in the BCPC edition. 


\section{BPLC:}

Great Sovereign Spirits, [your] five emanations, five great consorts, five ministers, [BPLC:232] and secondary emanations, along with a host of spiritsin particular, such [deities] as the great servant 1510 Tsiu Marpo surrounded by the four types of wild imperial spirits [and] the Seven Emanational Imperial Spirit Riders, the great Oath-bound One Dorjé Lekpa surrounded by his retinue of 360 siblings and attendants, [and] the Twelve Tenma Goddesses who protect Tibet-please consume 1511 [these offerings]! 1512

All the protectors of glorious Samyé Monastery[with its] three-story central temple, three mansions for the queens, four continents and eight subcontinents, sun [temple] and moon [temple], four reliquaries, and protector chapels-please consume [these offerings]! 1513

All of you accept these enjoyable sacrificial tormas. In general, preserve the curative 1514 teachings of the Buddha, and protect the monastery and its community of monks. In particular, protect us, the yogins, the masters and disciples, the monks and patrons, along with our attendants, from all adverse conditions [and] inner and outer obstacles.

I request that you [Five Sovereign Spirits] perform the actions of increasing and expanding more and more-like the waxing of the moon-all the excellent qualities [of] favorable conditions and [long] life, merit and wealth, fame and prestige, and power and influence, [BPLC:233] and that you act extensively as my friends.

1510 Tib. las ngan; I am reading this as a misspelling of las mkhan.

1511 Tib. zhal du kha kha khā hi; this is a hybrid Tibetan-Sanskrit phrase that appears to have some redundancy, possibly as a means show greater respect or urgency. The zhal $d u$ and kha kha are synonymous in this context, both meaning "in one's mouth;" zhal is in the honorific form. The last word is the mantric entreaty KHĀHI.

1512 Except for minor variations, this is similar to the description of these deities provided at the end of the BPLC edition's introduction, pp.218-219.

1513 Except for minor variations, this is similar to the description of the monastery provided at the end of the BCPC edition's introduction, p.411.

1514 Tib. gnyen po; this may be a misspelling of gnyan po, meaning "awesome, powerful." 


\section{Chapter 8: Exaltation}

[Recite the following] praise:

HŪṂ!

I praise you who practices equanimity with compassion - supreme accomplished one who subdues the hindering spirits [and] is endowed with the primordial samaya vow, who acts for the sake of [all] beings like a sun of compassion, [RGC62:287] and who liberates all pernicious enemies and obstructing [spirits] that violate their samaya vows. [BCPC:426]

I prostrate to 1515 and praise you, unimpeded 1516 and terrifying one-supreme accomplished one who manifests as a blazing body from the immutable Source, who comprehends the meaning of the unproduced Dharma, who seeks out birth and death, and who grasps the distinction between good and evil.

I prostrate to and praise you, wrathful king that subdues the hindering spirits-who acts from the Source of the Dharma with single-minded intention, who offers the nectar [of immortality] to the Buddhas of the three times with his right [hand], and who pulls out Rudra's heart with an iron hook in his left [hand].

I prostrate to and praise you, great powerful one that subdues the hindering spirits-who liberates 1517 the three realms with great wrathful arrogance, who consumes [all] the enemies and obstructing [spirits] without exception, and who cuts off afflictive emotions and wrong [views] at the root.

[BPLC:234] I prostrate to and praise the forms of the Five Sovereign Spirits, whose body, speech, and mind is equal to the Source of the Dharma - who carry out their [entrusted] actions to the end and subdue the great khyungs, serpent spirits, and dragons, [BCPC:427] and who subjugate the enemies and obstructing [spirits] when fiercely provoked. [GRSD:67]

I prostrate to and praise the forms of the five great secret consorts-even though you do not waver from the natural Source of the Dharma, you abide in the manner of wrathful goddesses in order to protect the [Buddha's] teachings, and you delightfully invoke1518 the samaya vow of the Five Sovereign Spirits. [RGC62:288]

1515 Tib. phyag 'tshal; in the RGC62, BPLC, and BCPC editions, this word is substituted with bdag, meaning "I," as with the previous four-line verse. This is true of the next four verses.

1516 Tib. thogs med; the RGC62 and BPLC editions have thog med, meaning "beginningless."

1517 Tib. sgrol; the RGC62 and BPLC editions have khyab, meaning "to permeate."

1518 Tib. bskul; this is drawn from the RGC62, BPLC, and BCPC editions. The GRSD edition has mdzad, which is the honorific form for "to do, make, practice." 
I praise the forms of the five ministers-powerful ones that act [as] servants of the [Buddha's] Word, and who completely accomplish 1519 the entrusted actions without obstruction in order to quickly fulfill the activities of the sovereign spirits.

I praise the brigadiers of the retinue, who fill the billion-world system with an army of emanations in order to rain down magical illusions on, and bring about disaster for, the enemies that destroy the Buddha's teachings.

\section{Chapter 9: Placing Under Oath ${ }_{1520}$ and Entrusting the Activities}

When the sovereign spirits arise in reality, recite these words that integrate the oaths and enact the promise.

The promise and oath [are as follows]:

In a former life, in the presence of Dorjé Dzinpa1521 and the master Padma Jungné 1522 [BPLC:235] [you] offered up your true character [and] life essence, and promised to protect the awesome teachings. Even accomplished tantric scholars promised to protect the precious teachings and offer sacred deity offerings for you to accept every year without transgressing the [proper] time. Therefore, may you protect the awesome teachings and crush into dust all the enemies and obstructing [spirits]! May you promise to liberate [through destruction] all wrong views! May you protect my attendants! May you ward off [adverse] conditions! May you augment my family and wealth! May you establish plentiful auspiciousness! May you not transgress your promise and oath!

\section{OM VAJRA SAMĀYĀ HŪM!! \\ SARVAPAÑCA [GRSD:68] HARA1523 HŪM! PŪJA HO!}

Regarding the supplications and offerings to be performed [from] this print:1524

$\mathrm{HOH}$ !

I supplicate Gyajin — central sovereign spirit of the mind [BCPC:428]—who rides a longtrunked elephant as a mount, which is led by Mönbuputra; he whose body color is dark blue; he who wears black silk and a bear-skin fur coat, and who wears a thumb-shaped hat with black silk [fringe] on his head; he who binds the enemies with a lasso of the hindering spirits [in his] right hand; he who cuts out the root of the enemy's heart with a razor [in his] left hand; [BPLC:236A] he who shouts harmful evil mantras; he who has

\footnotetext{
1519 Tib. sgrub pa; this is drawn from the RGC62, BPLC, and BCPC editions. The GRSD edition has sgrol ba, meaning "to liberate."

1520 Tib. dam la bzhag. The RGC62, BPLC, and BCPC editions simply have gsol, meaning "to supplicate, request." 1521 Tib. Rdo rje 'dzin pa; Skt. Vajradhara; lit. "Vajra-holder." This is an important Buddhist deity who is a central figure in Vajrayāna cosmology.

1522 Tib. Padma 'byung gnas; Skt. Padmakara; lit. "Lotus-born One.” This is a common epithet of Padmasambhava.

1523 This may be an abbreviation of SARVAPAÑCĀMRTTA AHARA, which is found in chapter 7 above. Otherwise, HARA means "to receive, bear."

${ }_{1524}$ All the lines in chapter 9 up to this point are only found in the GRSD and BPLC editions; however, this last explanatory line is not in the BPLC edition.
} 
lightening and flames accompany his reveling; [and] he who sends forth hail and thunderbolts as heralds.

May you perform the entrusted activities! May you actually perform the activities!

May you cause signs of accomplishment to appear! [RGC62:289]

$\mathrm{HOH}$ !

I supplicate Mönbuputra - eastern sovereign spirit of the body-who rides a white lioness as a mount; he whose body color is black [and] as densely gathered as darkness; he who wears a robe of black mentri, and who wears a thumb-shaped hat with black silk [fringe] on his head; he who brandishes and strikes [with] a golden vajra [in his] right hand; [BCPC:429] he who brandishes a mendicant's staff [made from] a red tree [in his] left hand; he who has crazed black bears accompany his reveling; [and] he who sends forth tigers, leopards, and grizzly bears as heralds.

May you perform the entrusted activities! May you actually perform the activities! May you cause signs of accomplishment to appear!

$\mathrm{HOH}$ !

I supplicate the great capricious spirit Shingjachen - southern sovereign spirit of good qualities - who rides a black horse of the hindering spirits as a mount; 1525 he whose body color is black and who is adorned with snakes and tiger-skin [garments]; he who splits the head and body of the enemies with a battle axe [in his] right hand; he who throws at the enemies a lasso of the hindering spirits1526 [in his] left hand;1527 [BPLC:237] he who has the head of a khyung, with which he subjugates the gods and spirits; he who has cosmic turquoise dragons accompany his reveling, [GRSD:69] [and] he who sends forth hawks and monkeys 1528 as heralds.

May you perform the entrusted activities! May you actually perform the activities! May you cause signs of accomplishment to appear!

\section{BPLC: \\ [BPLC:236B] HOH!! \\ I supplicate Yangleber-the king of the enemy- defeating gods, the capricious spirit, and lord of life - whose body color is red, and who wears a coat of armor and a leather helmet; he who throws at the enemies a red spear [in his] right hand and the lasso of the imperial spirits [in his] left hand; he who has fiery shooting stars spring}

1525 Tib. chibs su bdud rta nag po la chibs pa; this line is not found in the GRSD edition, but it is in the RGC62, BPLC, and BCPC editions.

1526 Tib. bdud; the BCPC edition has sbrul, meaning "snake." Thus, in this edition this deity throws a snake lasso.

1527 At this point in the text-indeed, in the middle of this line - there is in the BPLC edition an extraneous folio that does not continue the content nor follow the same Tibetan numbering as the rest of the text; the text itself continues past this folio. This is a brief one-page folio numbered in Tibetan as gcig pu'o, meaning "solitary, single [text]." Its contents clearly mimic the pattern of the surrounding deities and their characteristics, which explains its placement at this juncture. For the sake of clarity, I am including it in the body of the text after this section.

1528 Tib. bya khra spre'u; the other three editions have spra spre[l] byi la, meaning "monkeys and cats." 
from his eyes; he who has bloody hailstones fall from his mouth; he who has black poisonous snakes emerge from his ears; he who wears multicolored curved boots 1529 on his feet; he who has goats, dogs, and wolves accompany his reveling; he who has mountain birds and crows soar overhead; he who rides a black horse with white around the mouth and eyes as a mount; [and] he who is surrounded by a retinue of a hundred thousand wild imperial spirits.

May you perform the entrusted activities! May you actually perform the activities! May you cause signs of accomplishment to appear! [BPLC:236C]1530

$\mathrm{HOH}$ !

I supplicate the enemy-defeating god Kyechik Marpo-western sovereign spirit of speech — who rides a white-heeled black mule as a mount; [BCPC:430] he whose body color blazes a radiant red;1531 he who wears a cloak of black silk on his body [RGC62:290] and a coiled bamboo hat 1532 on his head; he who, brandishing a cane staff in his right hand, crushes into dust the enemies and obstructing [spirits]; he who, brandishing a sandalwood club in his left hand, also conquers the three spheres of existence; he who has roaring she-wolves accompany his reveling; [and] he who sends forth iron hawks as heralds.

May you perform the entrusted activities! May you actually perform the activities! May you cause signs of accomplishment to appear!

$\mathrm{HOH}$ !

I supplicate the great enemy-defeating god Pehar-northern sovereign spirit of activities - the great three-faced celestial man, the right one black, the left one red, and the middle one white; he who wears a parasol-shaped bamboo hat on top of his great forehead; he who, [regarding his] six hands, brandishes an iron hook, an arrow, and a sword in his right hands, [BPLC:238] and a razor, a bow, and a club in his left hands; he who cuts off the six transmigrations at the root; he who wears a white silk robe on his upper body; [BCPC:431] he who is adorned with tiger- and human-skin garments on his lower body; he who rides a white lioness as a mount, which is led by Mönbuputra; he who has black storms accompany his reveling; [and] he who, in the guise of a young layman, ${ }^{1533}$ sends forth the jackdaws of hindering spirits as heralds.

May you perform the entrusted activities! May you actually perform the activities! May you cause signs of accomplishment to appear!

1529 Tib. bseg lham; I am reading this as gseg lham.

1530 The verso side of this folio is blank.

1531 Tib. sku mdog dmar po 'od du 'bar ba; this line is not found in the GRSD edition, but it is in the other editions.

1532 Tib. snyug zhu. The word rmog zhu is given as the variant in the RGC62 edition, which is a helmet with specific royal and military significance and iconography. This type of helmet is also worn by Pehar's medium; see NebeskyWojkowitz 1998, pp. 411-412. See also Bellezza 2005, p.31, n.32, and Bellezza 2008, pp.221, 227, $240,450$.

1533 Tib. dge bsnyen gzhon nu'i cha byad; this line is not found in the GRSD edition, but it is in the RGC62 and BPLC editions. 
$\mathrm{HOH} ! 1534$

I supplicate the emanation of the enemy-defeating god of the mind, who-in the guise of a young layman — wears a large red silk robe on his body; [RGC62:291] he who wears a crystal rosary around his neck; [GRSD:70] [and] he who raises the tarjani mudrā with his right hand, and strikes [with] a copper knife in his left hand.

I supplicate the emanation of the enemy-defeating god of the body, who-possessing the guise of a young arhat monk - wears saffron-colored religious robes on his body; he who brandishes a mendicant's staff [made from a] red tree with his right hand; he who brandishes a golden razor with his left hand; [BCPC:432] [and] he who carries a skull cup on his back, and has an anointing vase hang down his front.1535 [BPLC:239]

I supplicate the emanation of the enemy-defeating god of good qualities, who wears a bandoleer of red mentri [fur] on his light blue-colored body, [and] brandishes a long hooked cane in his right hand.

I supplicate the emanation of the enemy-defeating god of speech, whose [body color is] dark blue, whose locks of hair flow upward, and whose beard blazes reddish-yellow like fire; he who wears a tiger-skin garment on his body; [and] he who holds aloft in his hands a corpse club and a victory banner [adorned with] a wolf's [ head].

I supplicate the emanation of the enemy-defeating god of activities, who wears flayed human-skin on his black body; he who is adorned with a bundle of snakes; [and] he who holds aloft a victory banner [adorned with] tiger and wolf [heads].

May you perform the entrusted activities! May you actually perform the activities! May you cause signs of accomplishment to appear!

HOH! 1536 [RGC62:292][BCPC:433]

I supplicate Shanti Rozanma Marmo - consort of the sovereign spirit of the mind - who is adorned with blood and fat, [and] who brandishes an iron hook and a heart[-filled] skull cup. 1537

I supplicate the female hindering spirit Rolangma Karmo-consort of the sovereign spirit of the body - who wears a white silk dress on her body, and who brandishes a holy branch and a skull cup.

I supplicate one-headed, four-armed Sergyi Putrima Nakmo-consort of the sovereign spirit of good qualities [BPLC:240]—who rides a donkey with a [red] spot on its

\footnotetext{
1534 This mantric syllable is not found in the GRSD edition, but it is in the other three editions, with minor typographical variations between them. This is true of the next four verses as well, but only for the BCPC edition.

1535 In the BCPC edition, this verse ends with, "May you perform the entrusted activities! May you actually perform the activities! May you cause signs of accomplishment to appear!" This is true of the next two verses as well.

1536 For the next four verses, this mantric syllable is only found at the start of each verse in the BCPC edition.

1537 Tib. bhan dha snying; in place of this phrase, the RGC62, BPLC, and BCPC editions have zhags pa, meaning "lasso." In the BCPC edition this verse ends with, "May you perform the entrusted activities! May you actually perform the activities! May you cause signs of accomplishment to appear!" This is also true of the next three verses.
} 
forehead; 1538 she who wears a diadem of black silk on her head; [GRSD:71] she who is adorned with a lion [for her] right earring and a snake [for her] left earring, and who wears a bell around her neck; she who, [regarding] her four arms, grasps a sword and a red spear in her right hands, and a scimitar and a trident in her left hands; she who holds a banner aloft on her neck; she who is endowed with a necklace of human heads, a cloak of elephant skin, a petticoat of yellow felt, [BCPC:434] and a belt of snakes; [and] she whose two feet are adorned with iron shackles. ${ }^{1539}$

I supplicate Dzejé Padmakyé - consort of the sovereign spirit of speech-whose body color is red; she who is endowed with beautiful ornaments; [and] she who brandishes a holy branch and a skull cup in her left and right hands.

I supplicate Düza Minkarma - consort of the sovereign spirit of activities - whose [body color] is dark blue; she who wears a fur coat of the hindering spirits; [RGC62:293] [and] she who brandishes a holy branch and skull cup.

May you perform the entrusted activities! May you actually perform the activities! May you cause signs of accomplishment to appear!

$\mathrm{HOH} ! 1540$

I supplicate the lord of life Ké Jarawa1541 - minister of the sovereign spirit of the mindwho wears a maroon cloak on his body; he who rides a white lion as a mount; [BPLC:241] [and] he who holds aloft a military standard of black silk in his hands.1542 [BCPC:435]

I supplicate Jatri Mikchikpo 1543 the butcher-minister of the sovereign spirit of the body - who wears a black snake on his head as a turban; he who rides a black-bottomed blue [horse] as a mount; [and] he who flings a crystal vajra from his hands.

I supplicate Jagö Tangnak - minister of the sovereign spirit of good qualities - who is endowed with the appearance of a young layman, and who brandishes a vajra and war hammer.

I supplicate Dorjé Drakden-minister of the sovereign spirit of speech-who wears monastic robes of red silk on his body; he who rides a camel with a white spot on its forehead as a mount; [and] he who brandishes a mendicant's staff [made from a] red tree in his hand.

\footnotetext{
1538 Tib. chibsu bong bu ga pa bcibs pa; in the RGC62, BPLC, and BCPC editions, this line is provided at the end of the invocation with minor variations.

1539 All four editions provide different variations for some of this deity's attributes, though they all describe the same things.

1540 For the next five verses, this mantric syllable is only found at the start of each verse in the BCPC edition.

1541 Tib. Bka'i bya ra ba.

1542 In the BCPC edition, this verse ends with, "May you perform the entrusted activities! May you actually perform the activities! May you cause signs of accomplishment to appear!" This is true of the next four verses as well.

1543 Tib. Bya khrid mig cig po.
} 
I supplicate Putra Nakpo-minister of the sovereign spirit of activity — [GRSD:72] who wears a black silk robe on his body; he who brandishes a curved knife in his hand; [and] he who rides a black mule as a mount.

I supplicate the cabinet ministers, shadröl, kyidröl, servants, zinpo, and dompo,1544 along with their retinue.

May you perform the entrusted activities! [BCPC:436] May you actually perform the activities! [RGC62:294] May you cause signs of accomplishment to appear!

$\mathrm{HOH}$ !

I supplicate the eight-year-old child from up above the sky, the capricious spirit Dorje Tokbep! 1545 [BPLC:242]

I supplicate the great indestructible khyung Ludruk Dulwa!1546

I supplicate the great divine layman Mahākāla! I supplicate Gönpo Nakpo!1547

I supplicate Jagö Tangnak! I supplicate the great lord of life [Jarawa]!

I supplicate Patra Karpo! I supplicate Putra Nakpo!

I supplicate the majestic Lord of Life! I supplicate the great warlord!

I supplicate the one who holds aloft a victory banner of illuminating satin, within a darkblue [expanse] densely gathered like darkness! 1548

I supplicate the one who holds aloft a victory banner [adorned with] a majestic tiger's [head], within a mass of flames blazing dark red! [BCPC:437]

I supplicate the one who holds aloft a victory banner [adorned with] a haughty1549 lion's [head], within a sky densely packed with clouds!

I supplicate the one who holds aloft a victory banner [adorned with] a demonic peacock's 1550 [head], within a swirling ocean of blood [representing] attachment!

I supplicate the one who holds aloft a victory banner [adorned with] a devouring wolf's [head], within a swirling black tempest!

I supplicate the one who holds aloft a victory banner [adorned with] a soaring vulture's [head], within white sunrays!

I supplicate the one who holds aloft a victory banner [adorned with] a monkey's [head] and a cat's [head], within a billion-world system filled with emanations! [RGC62:295]

I supplicate the right-side brigadier together with a host of a thousand heroes clad in tiger-skin garments! 1551 [BPLC:243A]

\footnotetext{
1544 Tib. nang blon sha 'gro la dang khyi 'grol: khol po 'dzin po dang sdom po; these two lines are not found in the GRSD edition, but they are found in the other editions with minor variations.

1545 Tib. Rdo rje thog 'bebs; lit. "Vajra Lightning Strike."

1546 Tib. Klu 'brug 'dul ba; lit. "Subduer of Serpent Spirits and Dragons."

1547 Tib. Mgon po nag po; lit. "Black Savior." This is a form of Mahākāla.

1548 In the BCPC edition, this verse, as well as the following six verses, end with the line, nas dgra la bya ra byed pa la gsol lo/ hoh. This can be translated as: "... and [who] guards against the enemies! HOH!"”

1549 Tib. 'phyong byed; I am reading this is a variant of 'phyongs rgyas.

1550 Tib. srin mo rma bya.
} 
I supplicate the left-side brigadier together with a hundred thousand black women! 1552 I supplicate the preceding pathfinders together with a host of a thousand arhat monks!1553 [GRSD:73][BCPC:438]

I supplicate the rear patrol together with a host of a billion trailing 1554 ministers and [their] servants [wearing] tiger- and leopard-skin garments!

I supplicate the entertainers of the body together with a host of a hundred lion-masked dancers!

I supplicate the one who is haughty like a lion!

I supplicate the one who is majestic like a tiger!

I supplicate the one who runs like a wolf!

I supplicate the one who soars like a khyung!

I supplicate the one who glides like a hawk!

\section{I supplicate the Five Putri1555 Siblings! \\ I supplicate the Seven Commander Siblings!1556}

Great Sovereign Spirits along with your retinue, accept these enjoyable offerings endowed with ornaments!

May you perform the entrusted activities! May you actually perform the activities! May you cause signs of accomplishment to appear!

Following this, state in detail the verses for entrusting whatever actions [you desire over the ritual items], recite the supplications, [and] entrust the actions. Regarding this, whatever actions one does are also generally important. Carry the small tormas 1557 in the direction of the rising sun. 1558

1551 Tib. dpa' bo stag chas; the RGC62, BPLC, and BCPC editions have the alternative term, dge slong, meaning "fully-ordained monk." In the BCPC edition, this verse, as well as the next four verses, ends with HOH!

1552 Tib. bud med nag mo 'bum. The RGC62, BCPC, and BPLC editions have, with minor variants, the alternative phrase, dmag dpon ban dhe nag po à tsa ra'i tshogs, meaning "a host of warlords, black priests, and $\bar{a} c \bar{a} r y a s . "$

1553 Tib. dge slong dgra bcom stong gi tshogs. The RGC62, BCPC, and BPLC editions have, with minor variants, the alternative phrase, bdud mo nag mo 'bum gyi tshogs, meaning "a host of a hundred thousand black female hindering spirits."

1554 Tib. su zhugs pa; I am reading this as an abbreviation of rjes su zhugs pa.

1555 Tib. $p u$ tri; this term is obscure. One possibility is that it is a variant of putra, meaning "son" in Sanskrit. Possibly because of this ambiguity, the RGC62, BPLC, and BCPC editions give the homophonous spu gri instead, which means "razor." In this case, this group of deities would be the "Five Razor Siblings." In either case, the identity of this group is uncertain if it does not refer to the Five Sovereign Spirits themselves.

1556 Tib. stong dpon mched bdun.

1557 Tib. bshos bu.

1558 Tib. gsol gdab las kyi gnyer gtod: 'di ni las gang byed kyang spyir gal che'o: bshos bu nyi ma shar phyogsu bskyal lo:; these lines are not found in the RGC62 edition, and are found at the end of chapter 10 in the BPLC edition; see note 1566 below. In the BCPC edition, this entire instructional section is abbreviated to, zhes pa phrin las bcol ba'o/ This can be translated as: "[After] reciting [the above supplications], entrust the [requested] actions." 


\section{Chapter 10: Compelling into Action}

HŪṂ!

From a pure and miraculous divine mansion above, come to this place [within] the six transmigrations to act for the welfare of [all] beings! Display a wrathful body in order to subdue pernicious forces, 1559 [BPLC:244][BCPC:439] and watch over the extent of phenomenal existence [from] a compassionate state [of mind]! [RGC62:296]

Accept these sacred items [and] the blazing nectar [of immortality], and accomplish my entrusted actions!

\footnotetext{
1559 Again, at this point in the text-and in the middle of this line - there is in the BPLC edition an extraneous folio that does not continue the content nor follow the same Tibetan numbering as the rest of the text; the text itself continues past this folio. The details are the same for this extra folio as those of the one discussed above in note 326. For the sake of clarity, I am including it in the body of the text after this section.

1560 See note 1514 .

1561 The last two paragraphs reiterate supplications that appeared earlier in the BPLC edition (pp.232-233), with minor variations.

1562 The verso side of this folio is blank.
}

\begin{abstract}
BPLC:
[BPLC:243B] I supplicate the Five Great Sovereign Spirits who are guardians of the [Buddha's] teachings and protectors of the Dharma, [as well as your] consorts and retinue-all of whom are resplendent and majestic! I supplicate all the laughing and smiling [protector deities]! I supplicate all the fierce and violent [protector deities]! May [you all] be satisfied! [May] Pehar, the enemydefeating gods, [and] the eight classes [of spirits], together with their retinue, accept these enjoyable sacrificial tormas endowed with ornaments!

In general, preserve the curative 1560 teachings of the Buddha, and protect the monastery and its community of monks. In particular, pacify all the adverse conditions [and] inner and outer obstacles [that affect] us, the yogins, the masters and disciples, the monks and patrons, along with our attendants.

I request that you [Five Sovereign Spirits] perform the actions of increasing and expanding more and more-like the waxing of the moon-all the excellent qualities [of] favorable conditions and [long] life, merit and wealth, fame and prestige, and power and influence, and that you act extensively as my friends. 1561 [BPLC:243C] ${ }^{1562}$
\end{abstract}


You sovereign spirits are tantric scholar-practitioners, who- for the sake of conventional truth - wear human-skin garments, tie bundles of angry snakes to [your] bodies, [and] brandish victory banners [adorned with] tiger [heads] in the manner of brigade commanders.

Accept these sacred items [and] the blazing nectar [of immortality], and accomplish my entrusted actions! 1563

You wear nine-layered maroon cloaks in a frightening manner!

You laugh, "Ha ha," [with] a gaping mouth in a majestic manner! [GRSD:74]

You watch over the ten directions, glaring in a wrathful manner!

You bear victory banners [adorned with] wolves' [heads] symbolizing devourers!

You are endowed with an inexhaustibly wrathful manner, from within a peaceful state, in order to protect the teachings of the [Buddha's] Word!

You [have] dark yellow beards that blaze like the fires at the end of the eon!

[BCPC:440] You—whose dark yellow hair curls upward—subjugate even those endowed with a skull garland of the sun and the moon! 1564

You - who sit in a manner where one leg is stretched out and the other drawn inoverpower the kingdom of the serpent spirits without exception! [BPLC:245] You—who hold aloft a corpse club [as your] implement—subjugate the enemies and obstructing [spirits] with wrong views!

You ride a white lioness in order to protect the teachings [of the Buddha], and wear on your body the skin of a carnivorous tiger! [RGC62:297]

You ride a long-trunked elephant when sent out toward the enemies, are endowed with a great, fierce bear[-skin] garment, and cut into pieces the enemies' hearts with a razor [as your] implement!

When sent out toward the enemies with wrong views, you are a terrifying man covered in tiger[-skin] garments; you pull with an iron hook in your left hand and cut with a razor [in your right]!

When violently incited in accordance with your samaya vow, you cut to the core those enemies and obstructing [spirits that work against] whatever your goals are! You are the supreme being who protects according to the central teachings [of the Buddha]!

When I, the yogin, entreat and incite you, [BCPC:441] you [take on] the manner of a young arhat [who] displays magical illusions, [and] who wears on your head a bamboo hat covered in black silk!

You brandish a sandalwood [club] with your right hand and a mendicant's staff with your left! You brandish a secret golden vajra and strike [with it]!

Your three faces and six arms cut at the root [of] the six transmigrations in order to accomplish the actions that I incite [you to do]!

[BPLC:246] Riding a mule, you subjugate the three worlds! [GRSD:75]

You quickly liberate [through destruction] the enemies and obstructing [spirits] with a small vessel [as your] implement!

1563 The RGC62 and BPLC editions have the following alternative line: rnal 'byor bcol ba' $i$ phrin las sgrub=, which means "...accomplish the yogins' entrusted actions!"

1564 Tib. nyi zla'i thod phreng. 
You pull out the enemy's heart [with] a long hooked cane!

You always apprehend the tutelary deity with your white crystal rosary!

You cleave the enemy's brain with a Kashmiri battle axe!

You snatch the enemy's vital essence with a black lasso! [RGC62:298]

When I, the yogin, entreat and incite you, accept these sacred items [and] the blazing nectar [of immortality], and quickly1565 accomplish my entrusted actions!

\section{SAMAYA! [Take] the enemies' vital force! BHYO! BHYO!}

Invoke [the sovereign spirits like so] and incite them against [your] enemies. ${ }^{1566}$ If one performs [the ritual] in this way, whatever actions one entrusts will be accomplished.

\section{[Colophon]}

[This] supplication offering that praises the activities [of] the outer tantras was composed [and] perfected by Master Padma Jungné. 1567 [BCPC:442]

SAMAYA! GYA GYA GYA!1568 SAMAYA GUHYA!1569

[This] treasure text was revealed by Ngadak Nyang Nyima Özer.1570 [May all be] Auspicious!1571

\footnotetext{
1565 Tib. myur $d u$; this word is only found in the RGC62 and BPLC editions.

1566 The instructions at the end of chapter 9 in the GRSD edition are found here instead in the BPLC edition, with minor variations.

1567 The colophon up to this point is only found in the GRSD edition. The RGC62, BPLC, and BCPC editions have the following alternative lines: rgyal po chen po'i gsol ka 'di: bdag 'dra padma 'byung gnas kyis: [BCPC:442] nor lha nag po'i rgyud nas btus: da lta spel ba'i gnas med pas: rnam par snang mdzad dbu la sbas: chos 'khor srung ba'i mtshon char bzhag: las 'phro can dang 'phrad par shog: This can be translated as: "This supplication offering for the great sovereign spirits was compiled from the Black Wealth God Tantra by me, Padma Jungné, and those like me. Because it is not suitable to propagate [this text] now, I will conceal it in the head of the Nampar Nangdzé [statue] (Skt. Vairocana; this likely refers to the statue of Vairocana that was installed at Samyé Monastery when it was first established). Thus, I have put weapons in place to protect the wheel of Dharma. May someone with the proper karmic connection happen upon [this text]!"

1568 Tib. rgya rgya rgya; lit. "Seal! Seal! Seal!"

1569 Tib. sa ma ya gu hya; lit. "Secret samaya vow." This line is not found in the other three editions.

1570 Tib. Mnga' bdag Myang Nyi ma 'od zer, 1124-1192; TBRC: P364. The other three editions give the alternative epithet, Nyang Ral pa can.

1571 Tib. bkra shis; this final exclamation of good fortune is not found in the other three editions.
} 


\section{Appendix IIb}

\section{The Offerings and Praises}

The Offerings and Praises to such [Deities] as the Great Dharma Kings, the Five LongLife Sisters, Dorjé Drakmogyel, Dorjé Yudrönma, Chölha, Kongtsün Demo, and Odé Gungyelfrom the Miscellaneous Writings of the Venerable Omniscient One's Collected Works (Tib. Rje btsun thams cad mkhyen pa'i gsung 'bum thor bu las chos rgyal chen po tshe ring mched lnga rdo rje grags mo rgyal rdo rje g.yu sgron ma 'phyos lha kong btsun de mo 'o de gung rgyal sogs kyi gsol kha bstod pa dang bcas pa rnams) is a collection of texts composed by the Second Dalai Lama. Though not part of the Nechung Liturgy, this work contains six texts dedicated to the Five Sovereign Spirits, the longest of which has material drawn from the Ten-Chapter Sädhana. This long text, as well as two others, contain material that was then copied into the Fifth Dalai Lama's Adamantine Melody. This appendix consists of a transcription and translation of these six texts. The first four of the below texts follow one after the other, while the fifth and sixth texts appear later in the larger work. There are three extant editions of this work:

DL206 Tā la'i bla ma 02 Dge 'dun rgya mtsho (1476-1542). 2006. Rje btsun thams cad mkhyen pa'i gsung 'bum thor bu las chos rgyal chen po tshe ring mched lnga rdo rje grags mo rgyal rdo rje g.yu sgron ma 'phyos lha kong btsun de mo 'o de gung rgyal sogs kyi gsol kha bstod pa dang bcas pa rnams. In The Collected Works of the Second Dalai Lama Dge 'dun rgya mtsho, vol.6. Dharamsala: Library of Tibetan Works and Archives, pp.167-179. TBRC: W1CZ2857.

Tā la'i bla ma 02 Dge 'dun rgya mtsho (1476-1542). n.d. Rgyal dbang dge 'dun rgya mtsho'i gsung 'bum (根敦嘉措文集), 6 vols. Beijing: Krung go'i bod rig pa'i dpe skrun khang. TBRC: W1PD137878.

Tā la'i bla ma 02 Dge 'dun rgya mtsho (1476-1542). 199X. Dge 'dun rgya mtsho'i gsung 'bum, 3 vols. Dkar mdzes; s.n.

The following translation is based solely on the 2006 Dharamsala edition (DL206), since the other two collections were unavailable to me at the time of this writing. 


\section{Offerings and Praises Transcription}

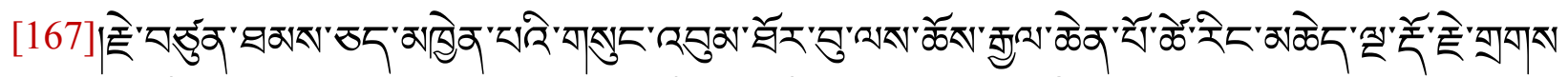

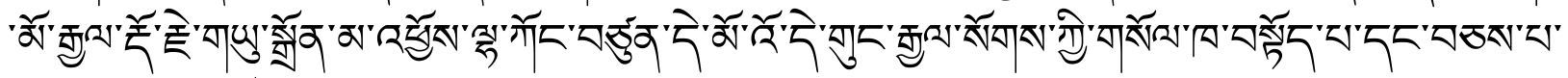

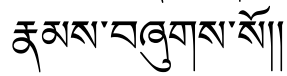

\section{[Text 1]}

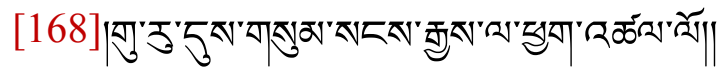

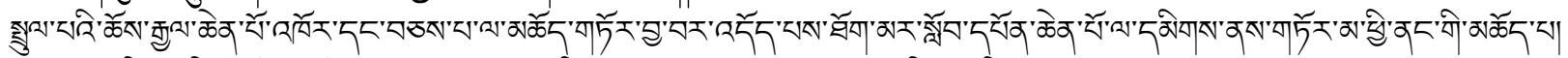

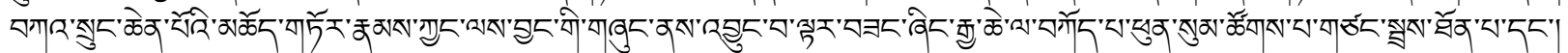

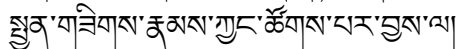

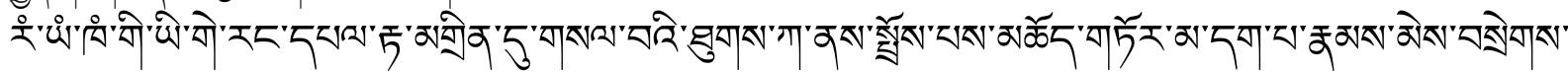

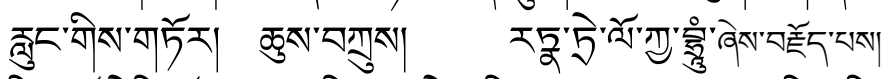

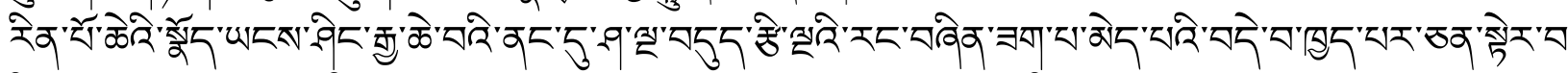

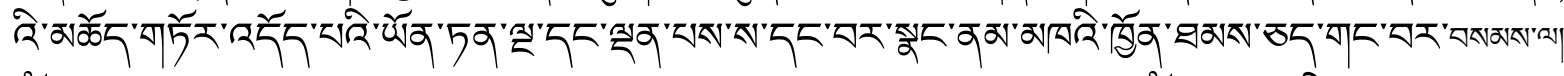

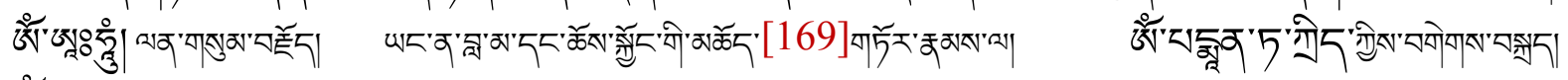

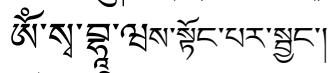

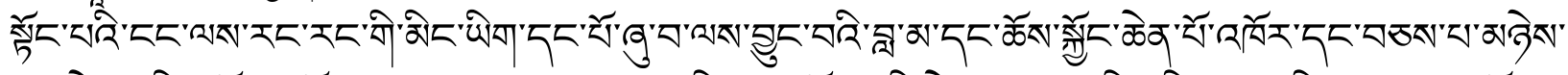

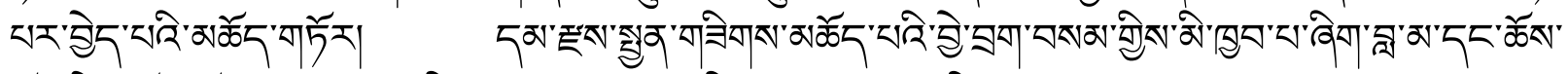

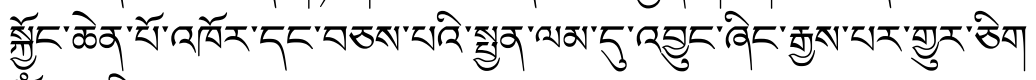

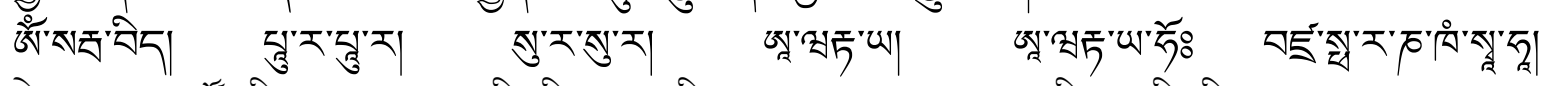

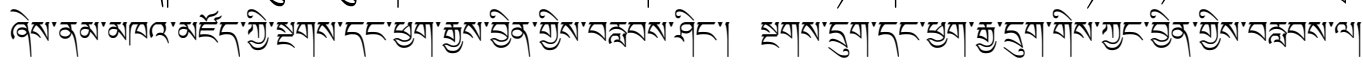

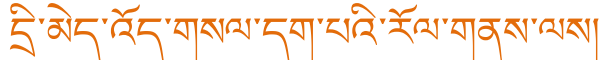

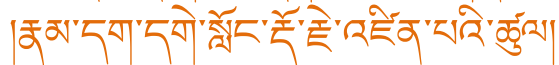

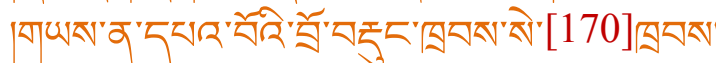

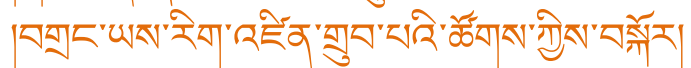

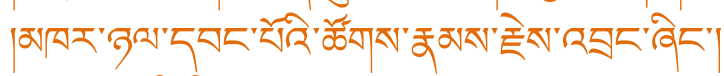

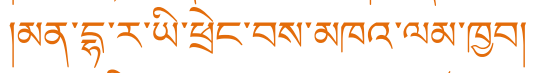

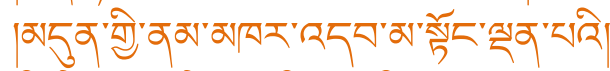

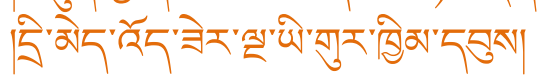

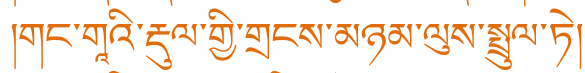

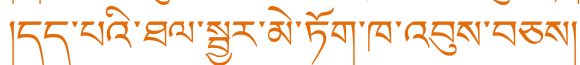

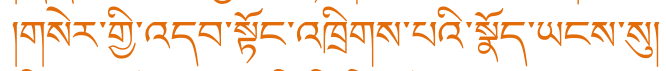

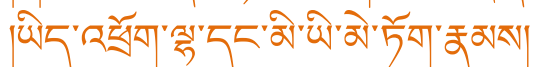

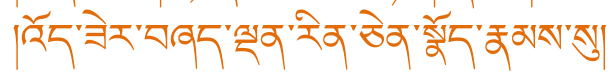

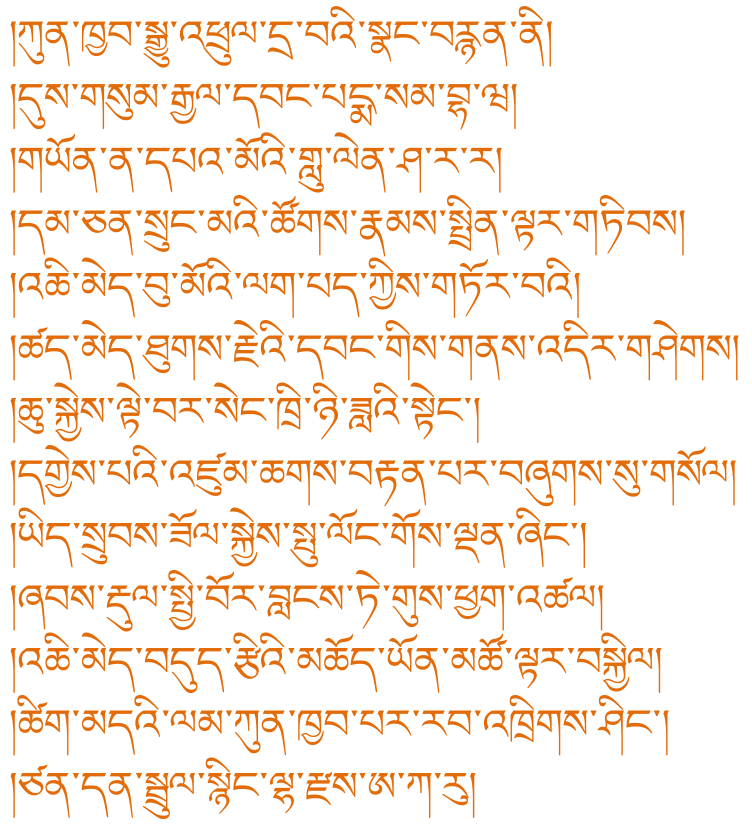




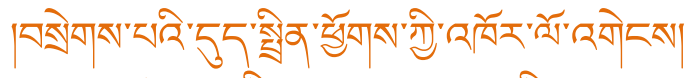
ब"মुহ"

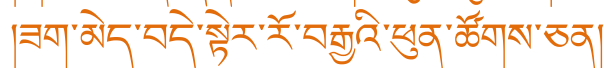

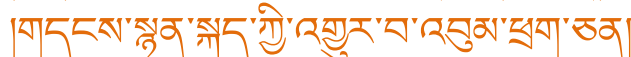

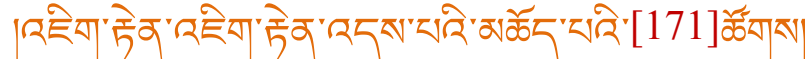

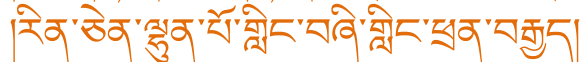

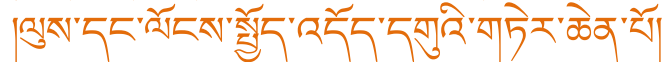

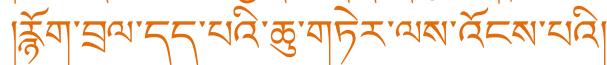

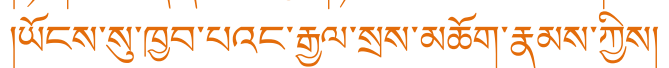

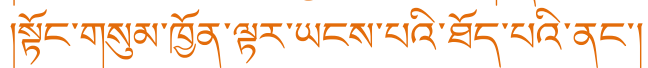

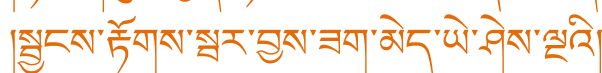

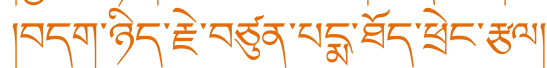

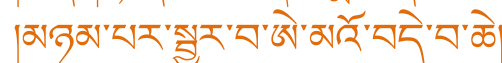

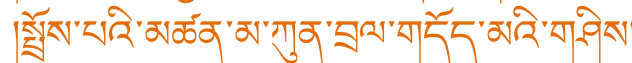

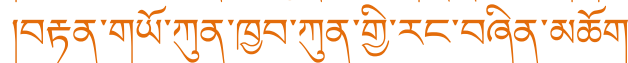

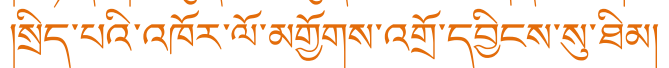

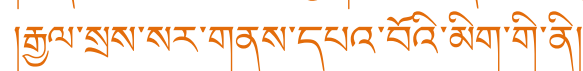

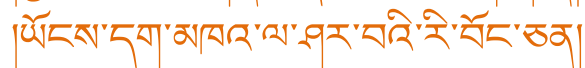

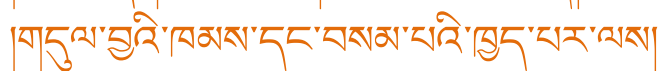

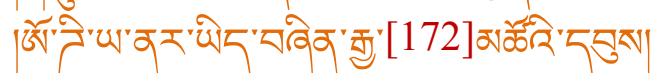

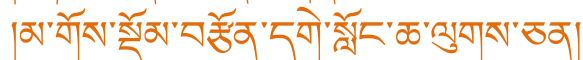

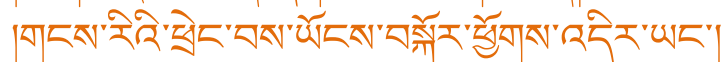

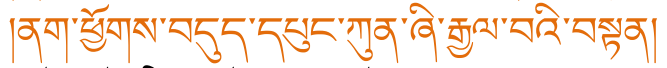

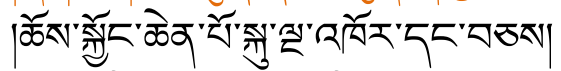

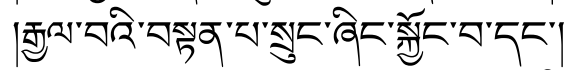

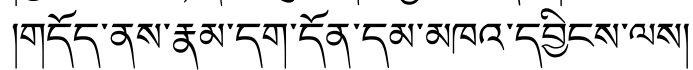
ज्ञायर

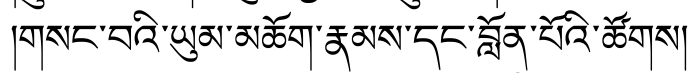

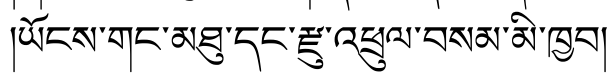

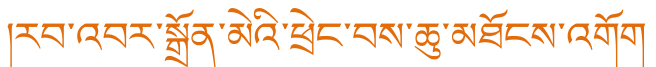

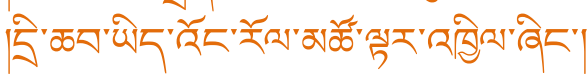

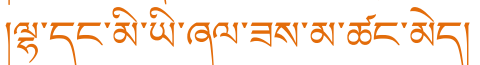

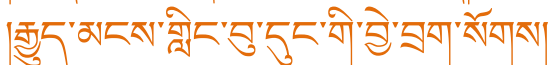

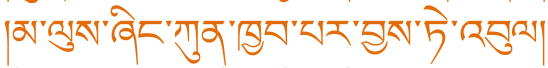

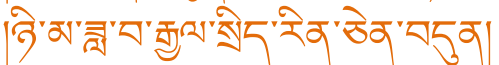

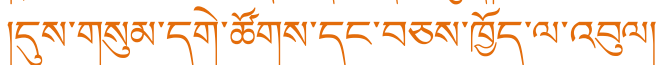

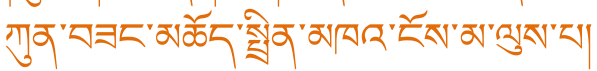

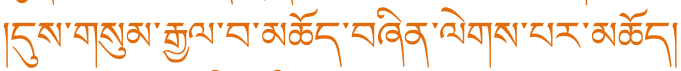

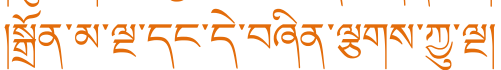

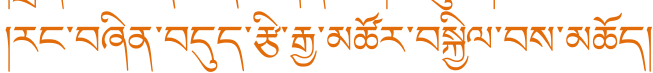

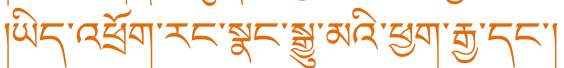

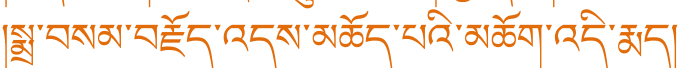

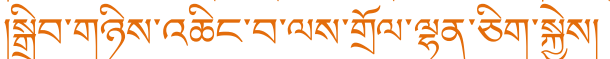

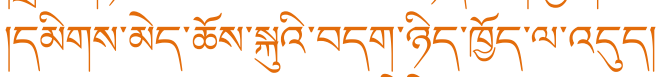

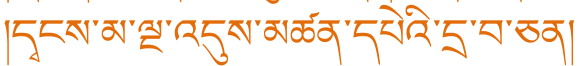
1

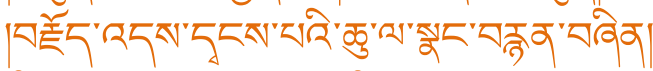

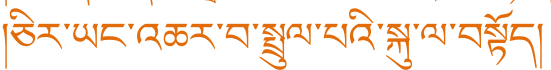

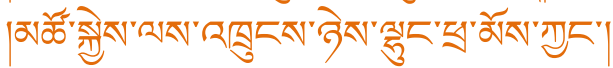

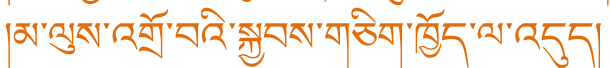

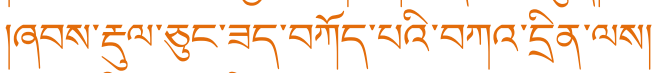

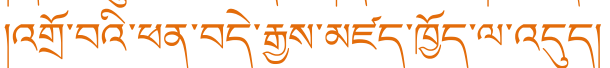

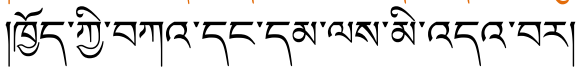

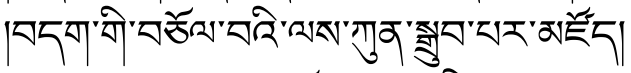

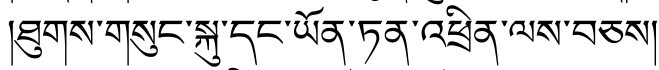

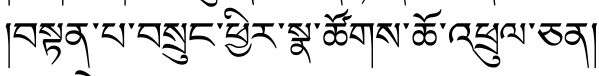

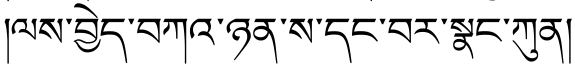

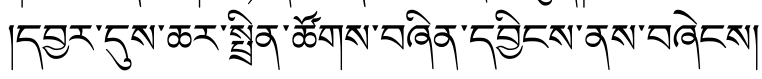

[The below quatrains are derived from most of chapter 2 of the Ten-Chapter Sädhana, sans framing mantras] ${ }^{1}$

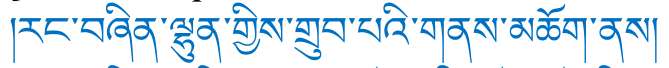

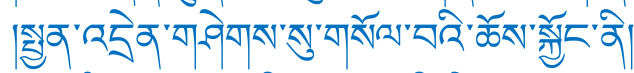

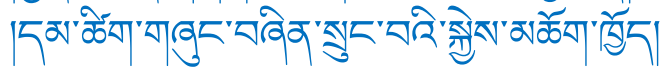
[1 quatrain is skipped]

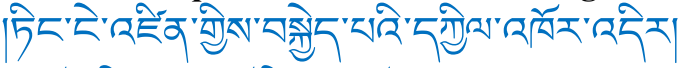

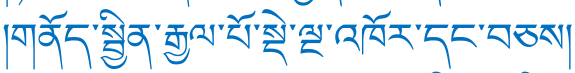

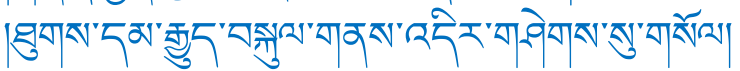

${ }_{1}^{1}$ See Appendix IIa, pp.361-362. 


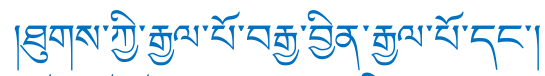

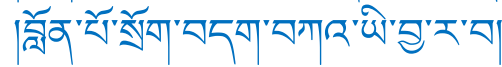

[The following 4 quatrains are given

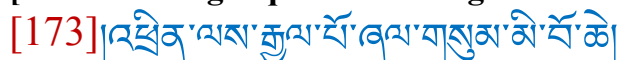

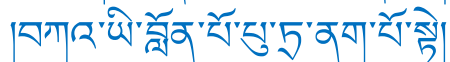

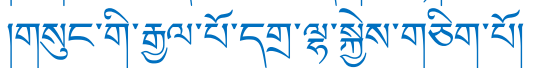

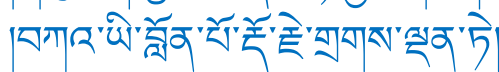

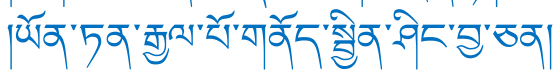

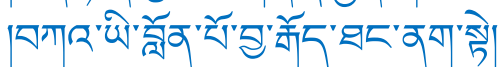

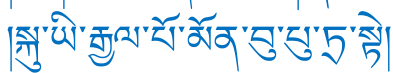

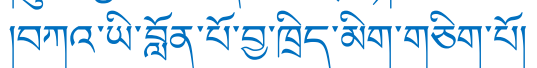

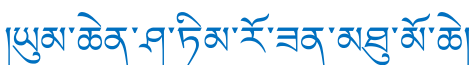

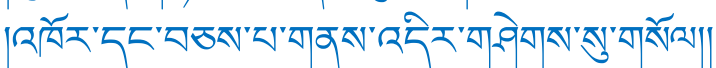

[The below quatrains expand upon content found in chapter 3 of the Ten-Chapter Sädhana] ${ }^{3}$

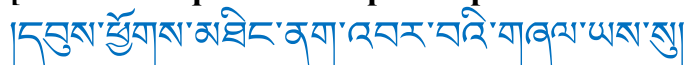

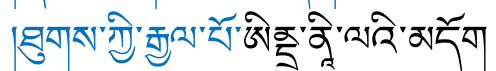

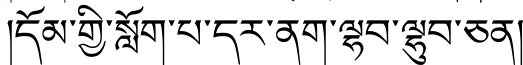

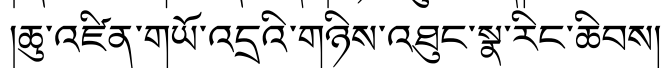

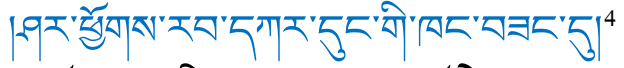

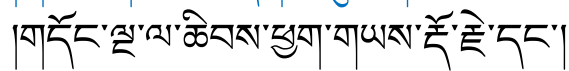

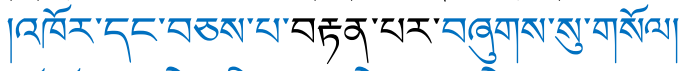

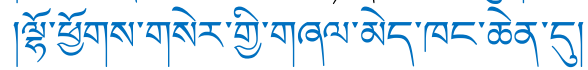

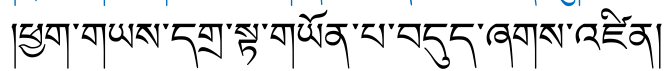

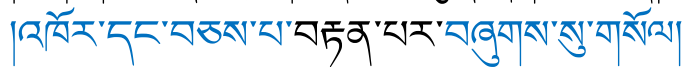

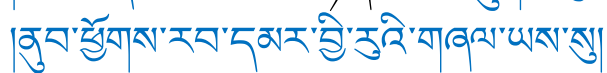

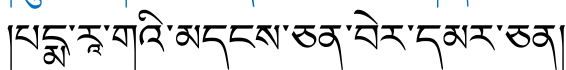

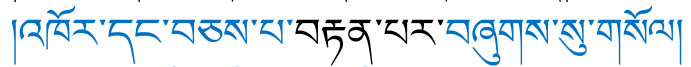

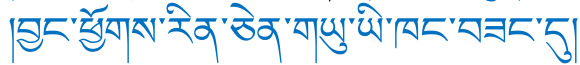

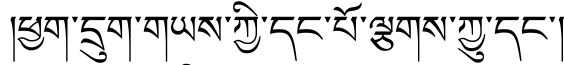

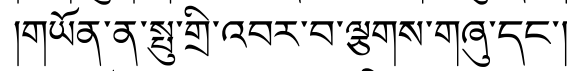

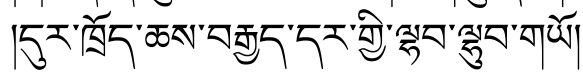

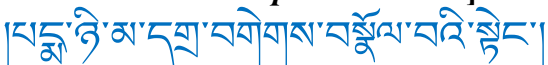

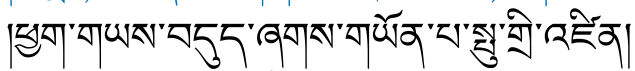

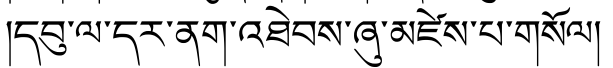

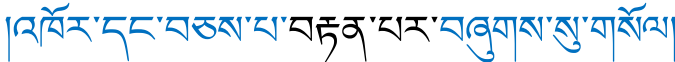

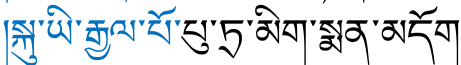

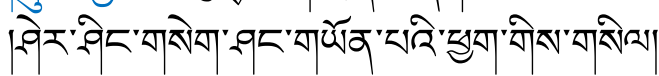

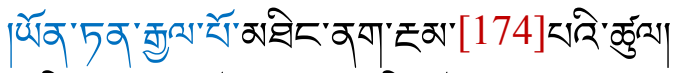

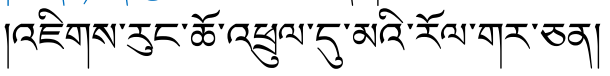

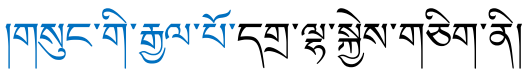

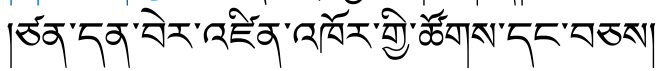

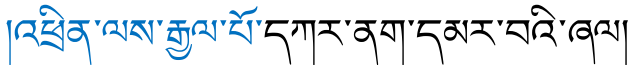

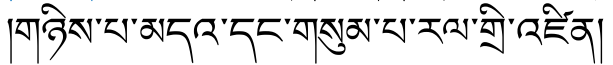

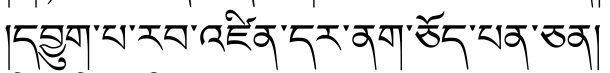

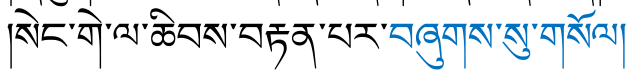

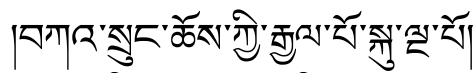

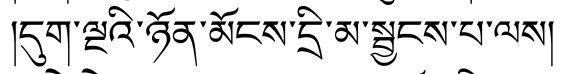

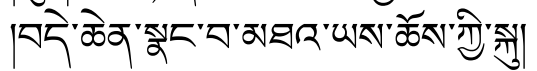

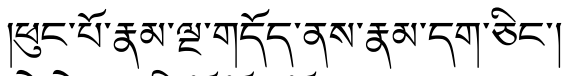

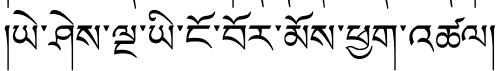

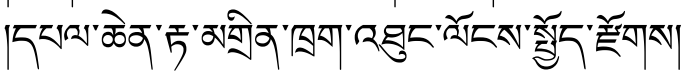

2 The extant editions of the Ten-Chapter Sädhana have [g]cig, meaning "single," rather than chen.

3 See Appendix IIa, p.363.

4 This phrasing for this mansion, and those immediately following, differ slightly from what is found in the extant editions of the Ten-Chapter Sädhana; compare Appendix IIa, ibid. 


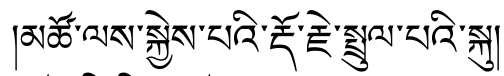

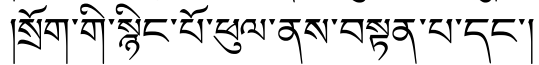

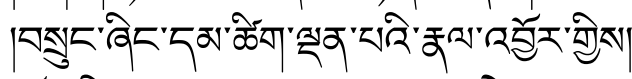

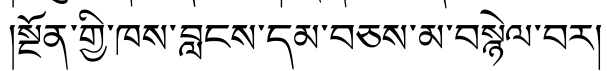

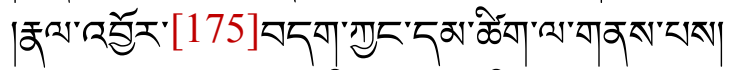

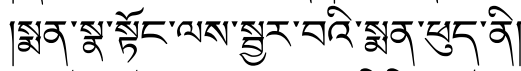

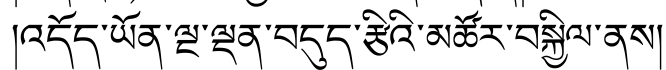

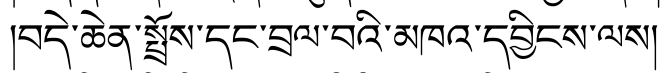

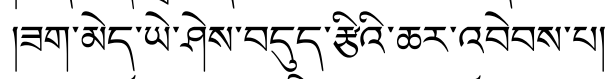

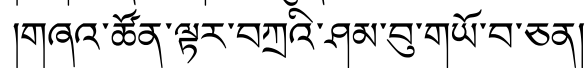

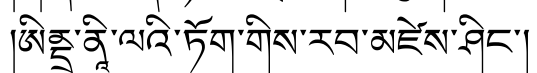
शिवे खेव ' बुु

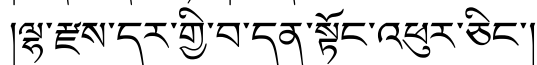

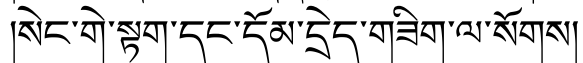

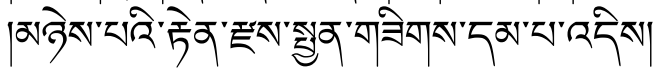

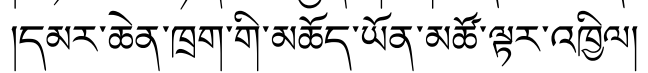

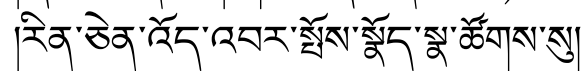

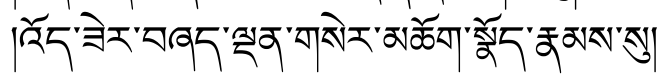

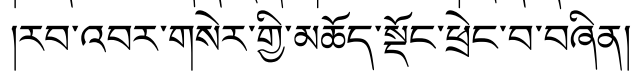

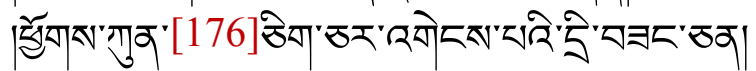

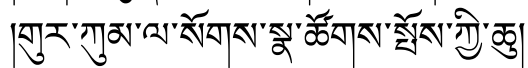

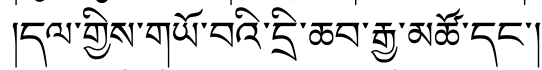

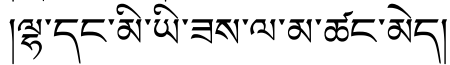

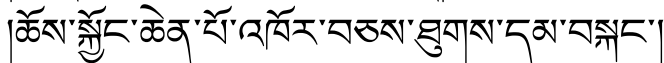

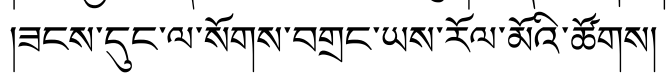

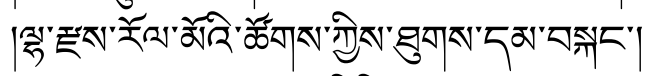

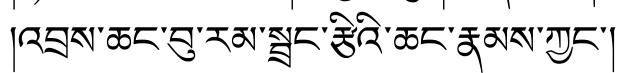

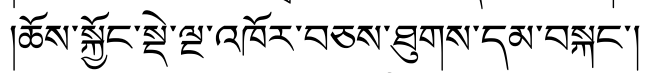

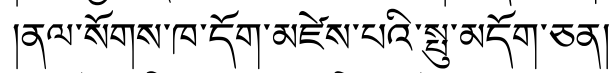

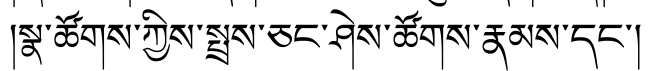

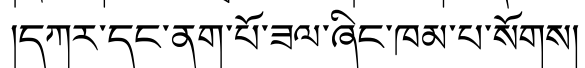

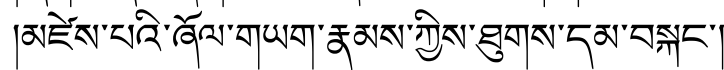

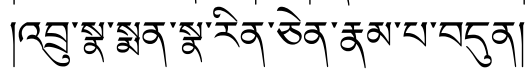

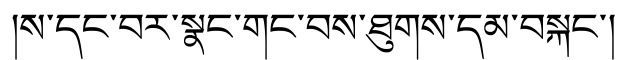

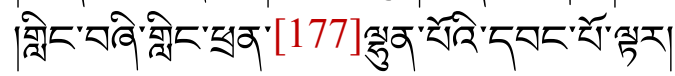

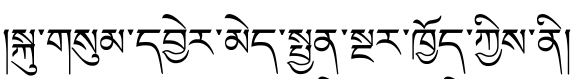

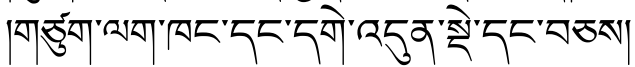

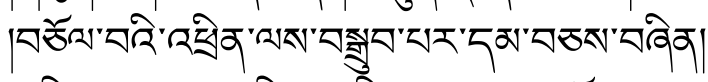

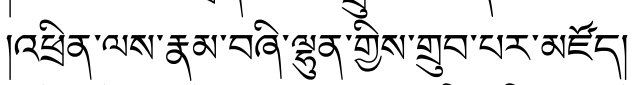

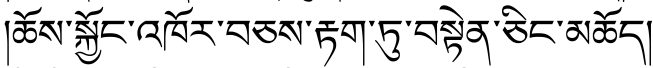

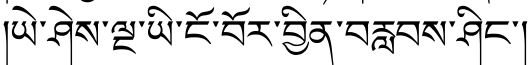

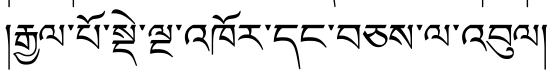

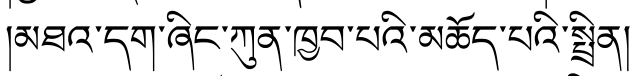

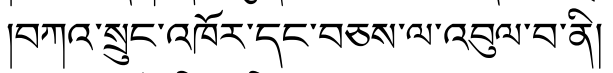

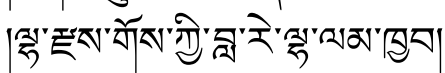

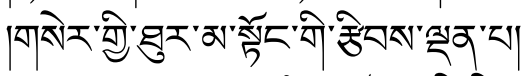

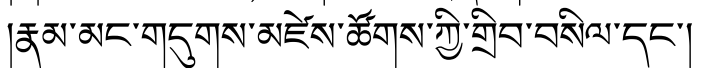

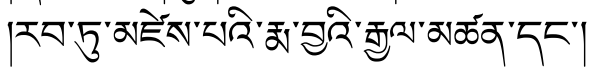

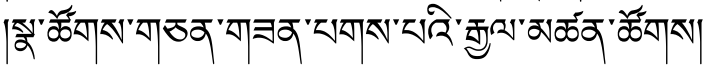

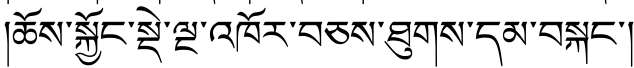

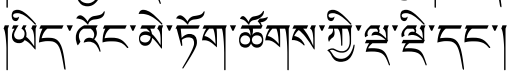

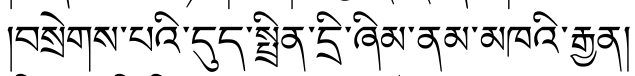

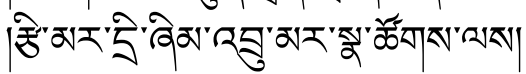

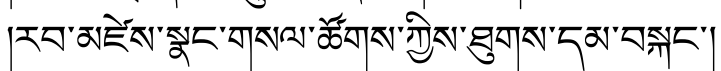

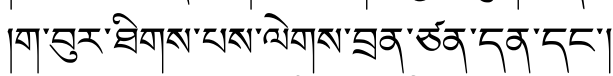

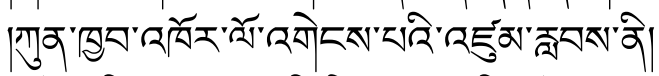

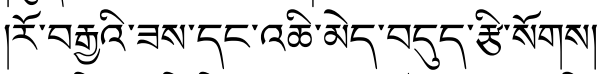

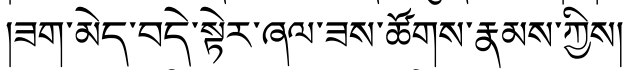

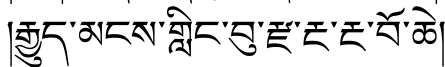

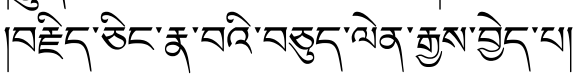

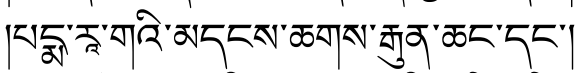

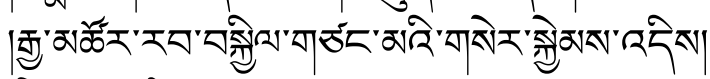

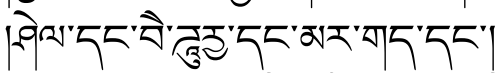

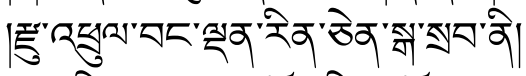

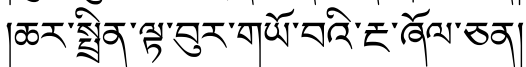

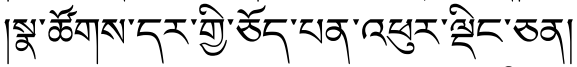

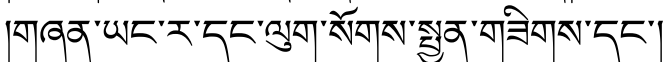

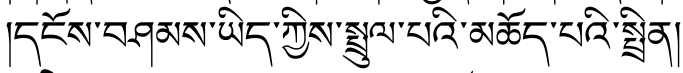

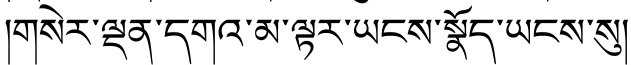

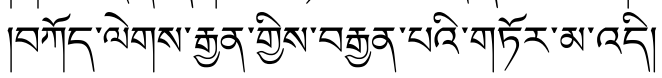




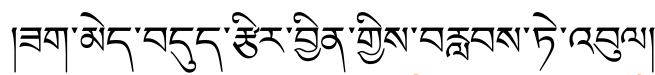

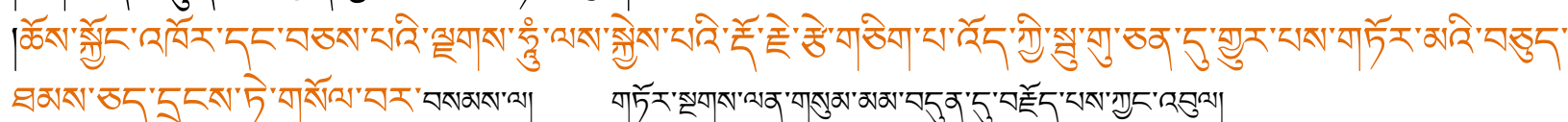

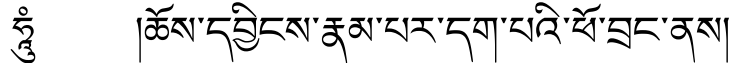

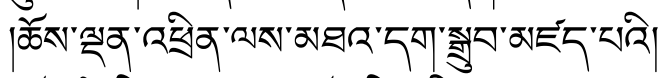

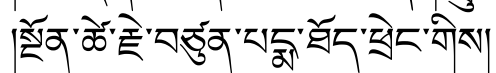

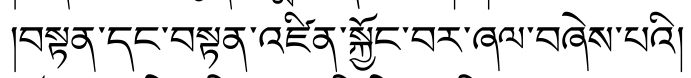

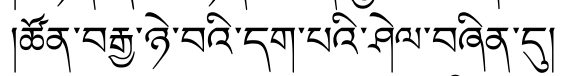

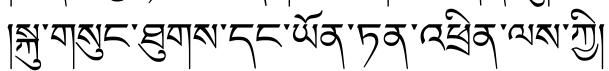

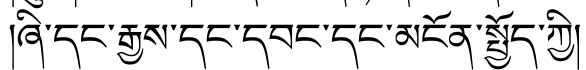

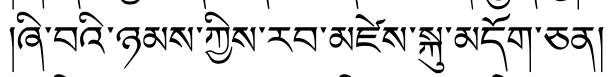

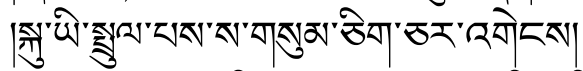

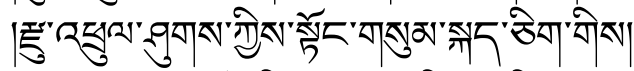

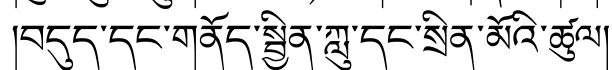

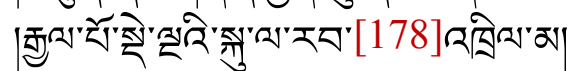

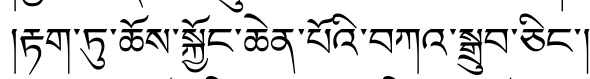

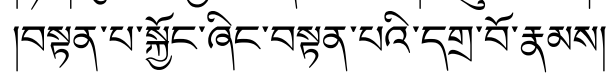

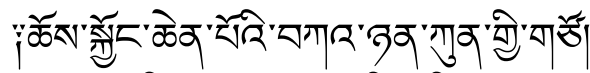

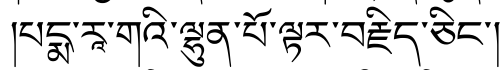

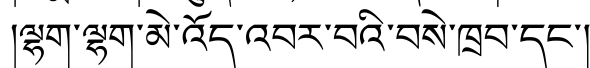

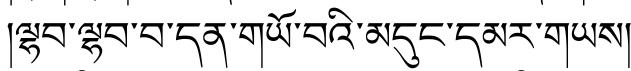

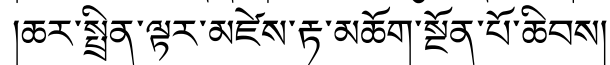

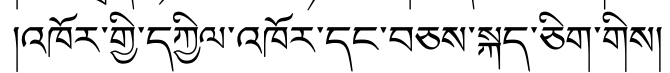

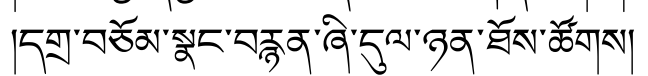

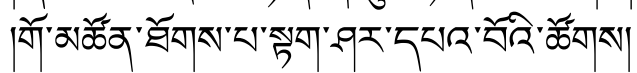

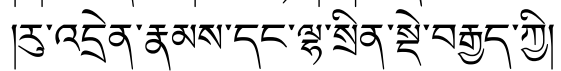

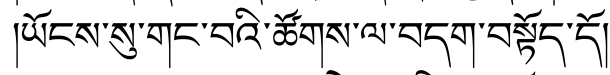

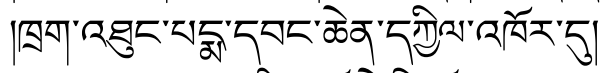

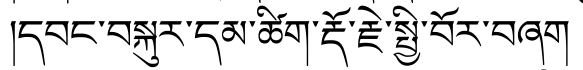

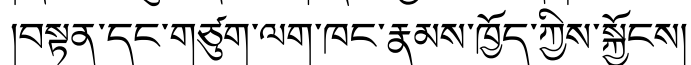

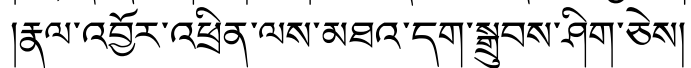

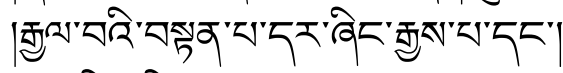

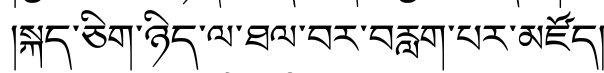

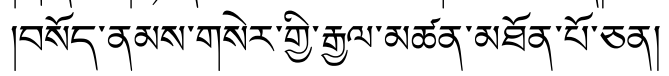

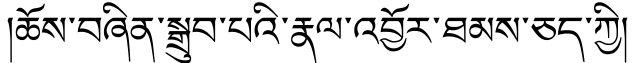

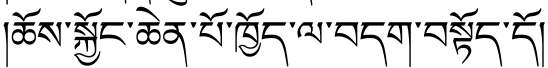

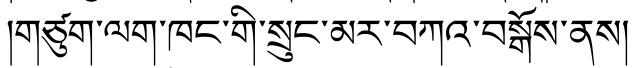

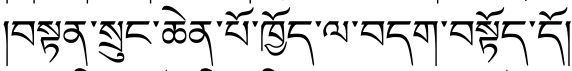

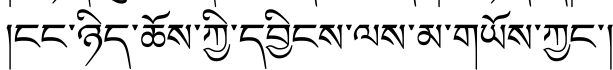

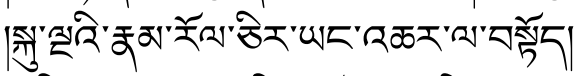

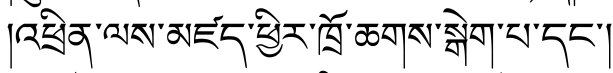

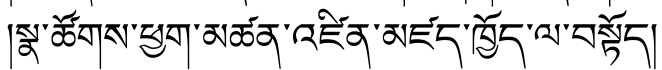

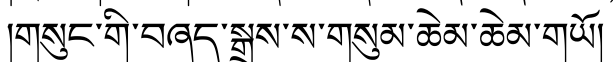

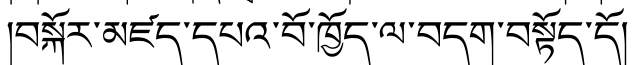

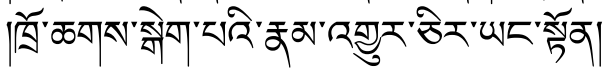

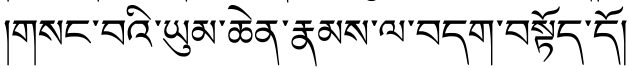

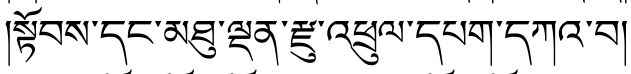

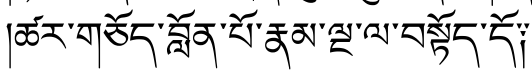

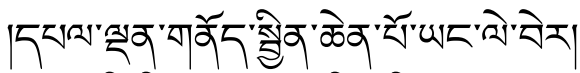

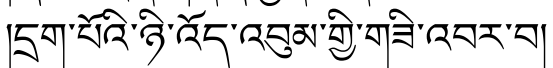

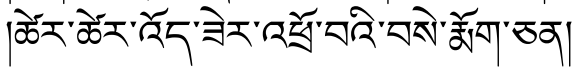

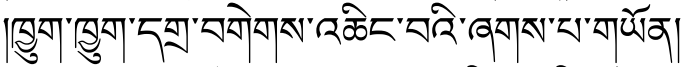

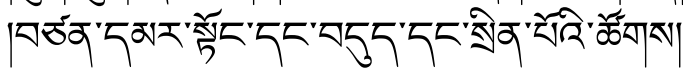

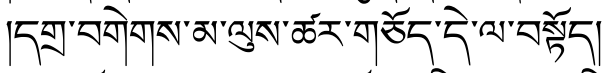

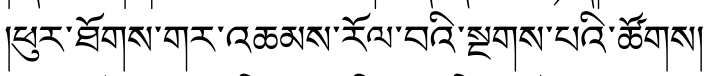

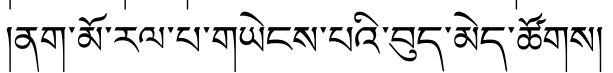

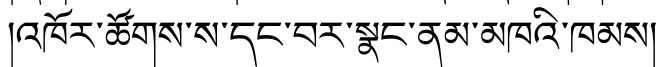

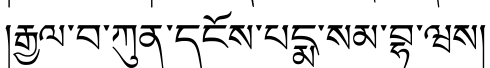

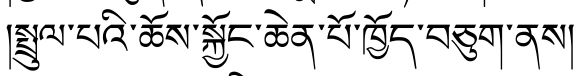

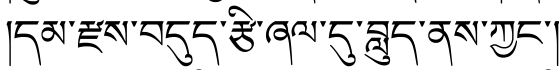

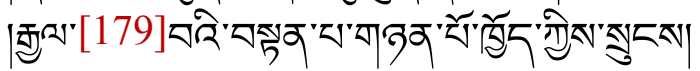

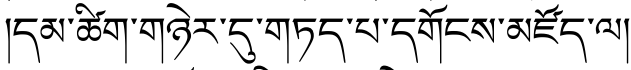

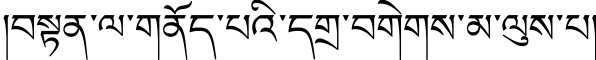

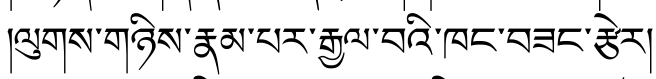

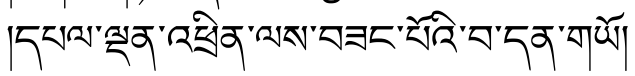




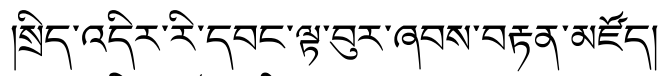

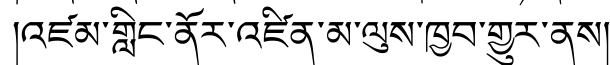

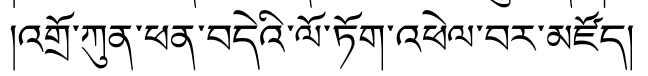

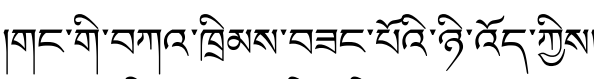

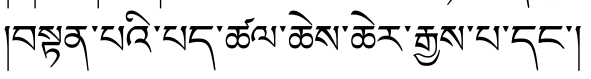

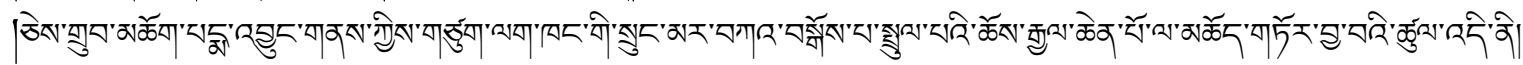

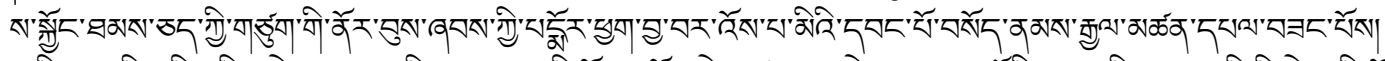

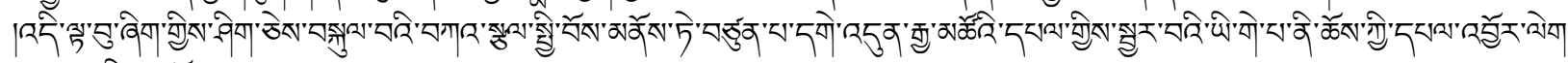

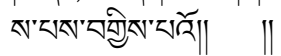

\section{[Text 2]}

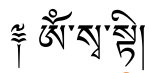

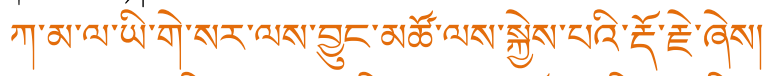

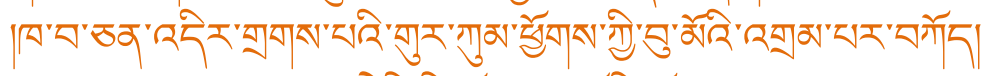

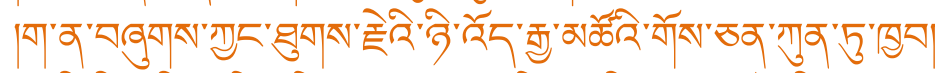

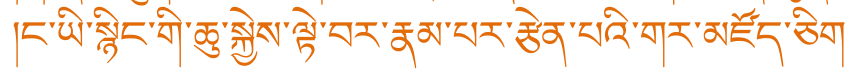

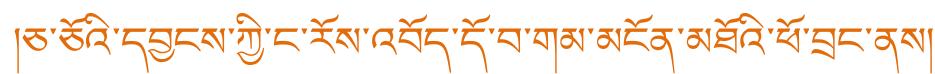

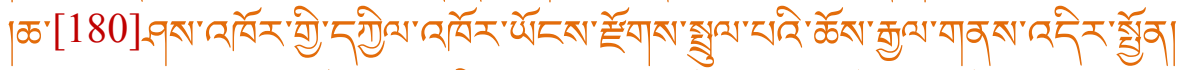

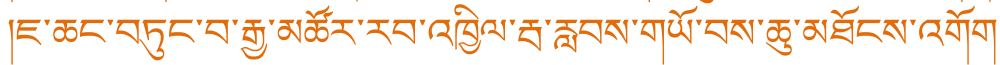

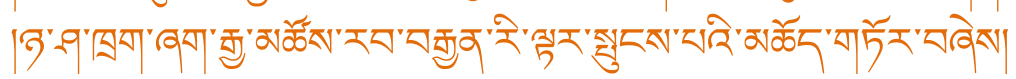

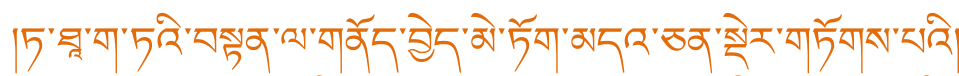

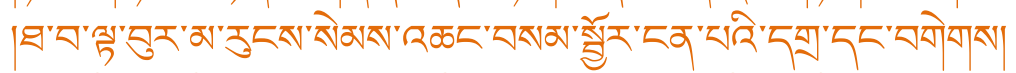

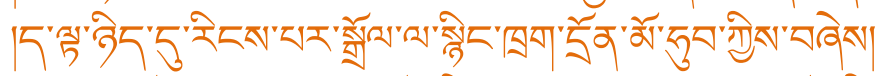

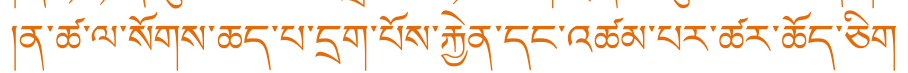

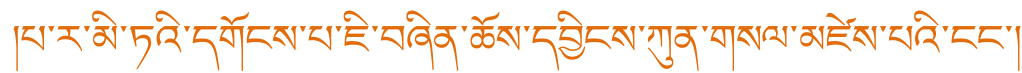

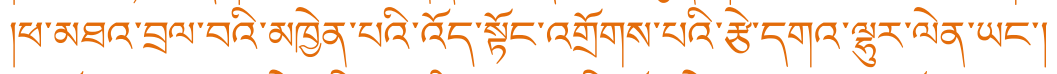

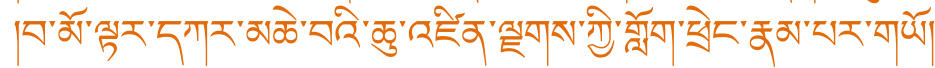

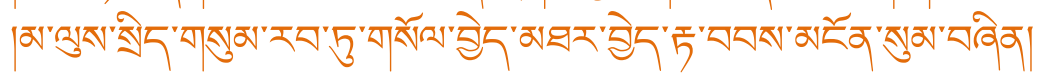

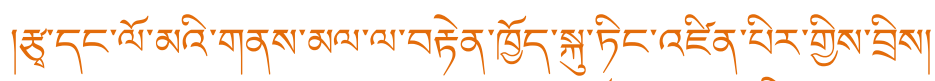

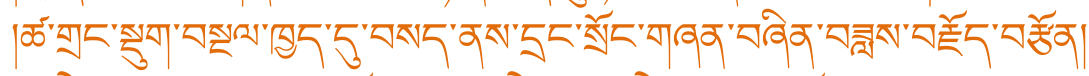

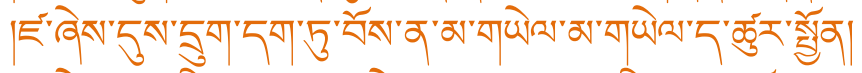

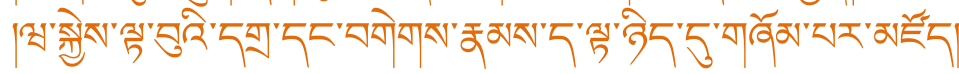

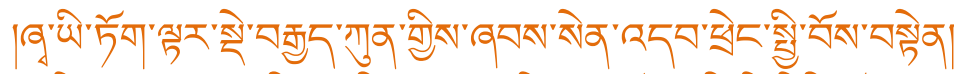

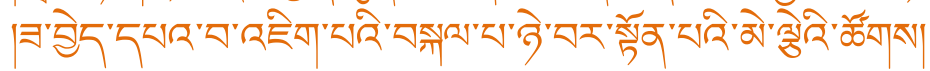




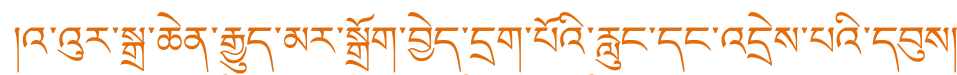

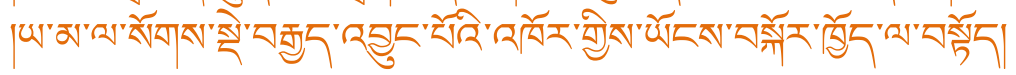

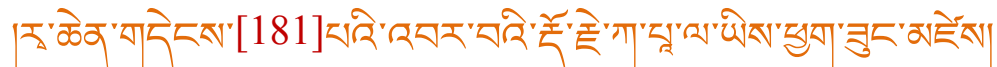

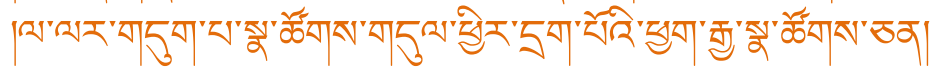

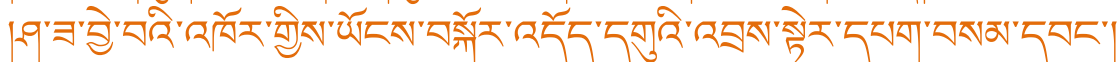

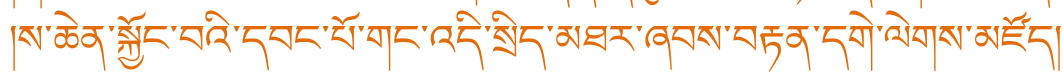

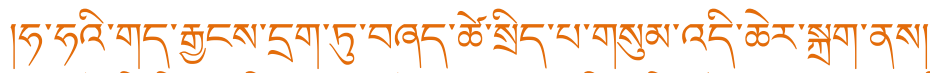

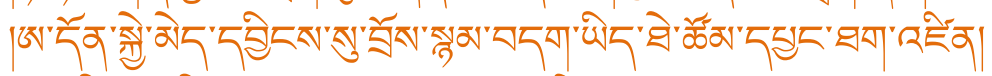

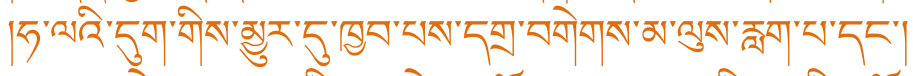

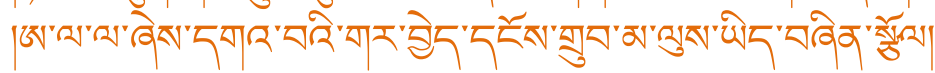

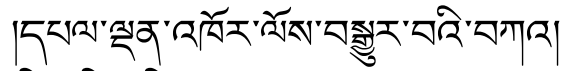

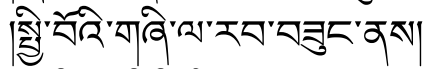

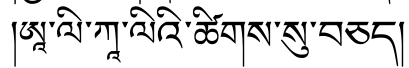

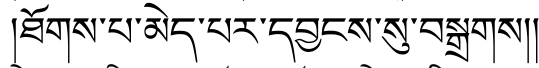

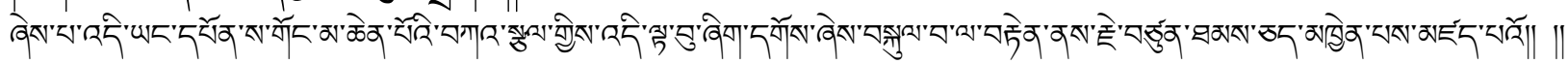

\section{[Text 3]}

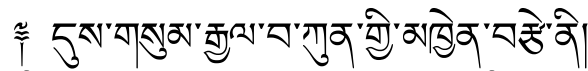

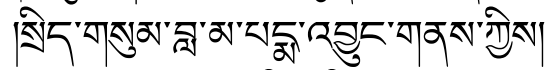

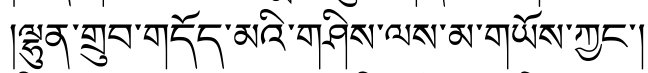

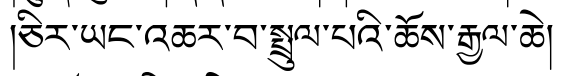

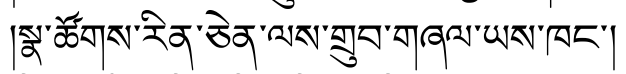

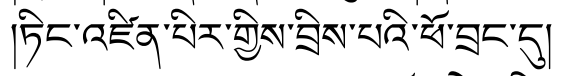

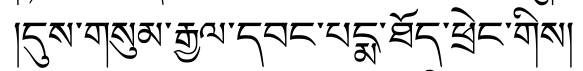

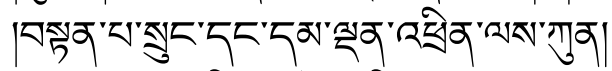

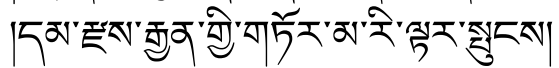

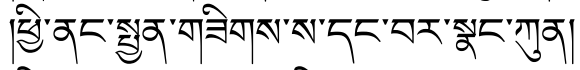

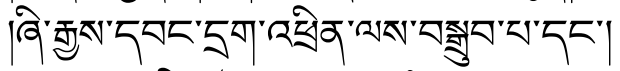

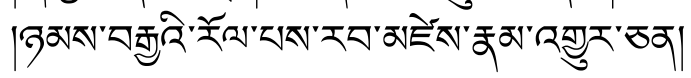

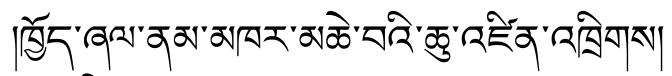

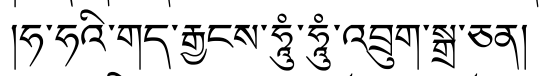

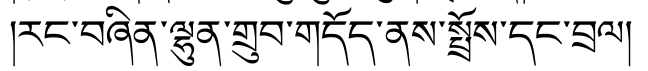

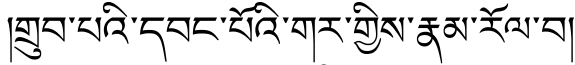

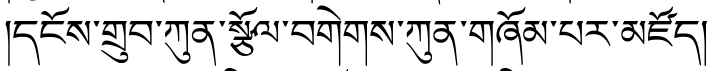

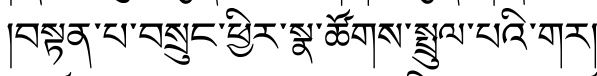

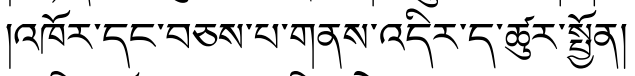

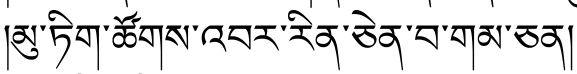

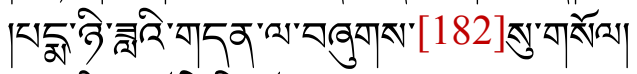

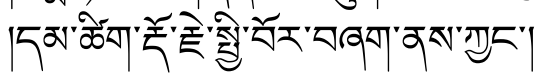

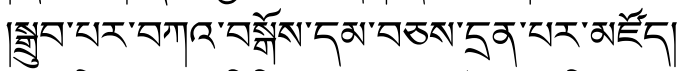

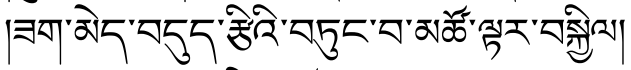

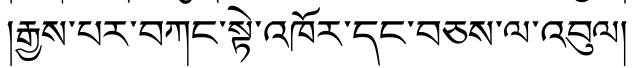

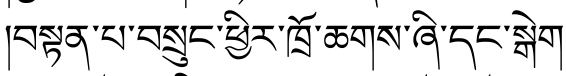

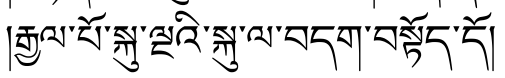

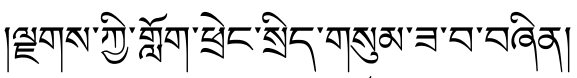

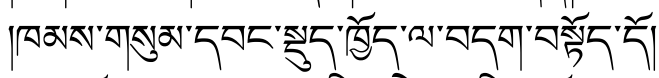

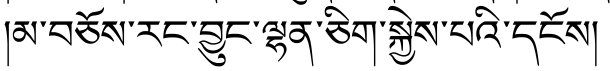




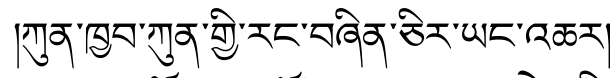

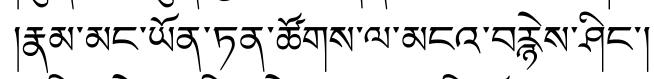

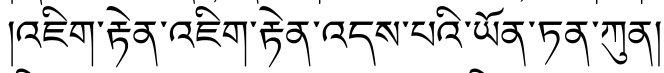

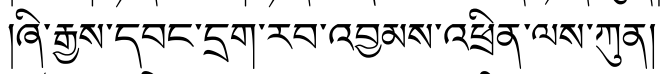

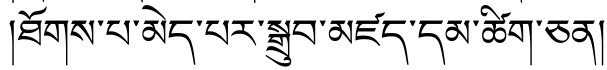

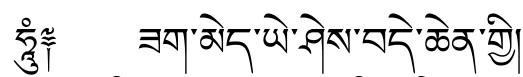

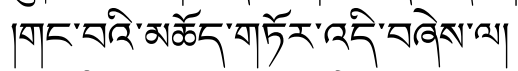

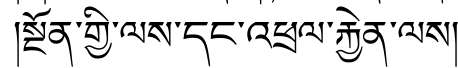

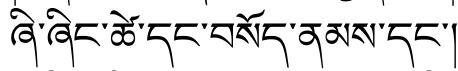

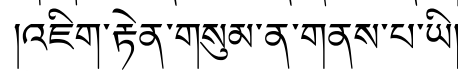

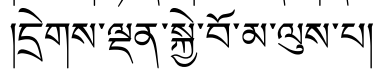

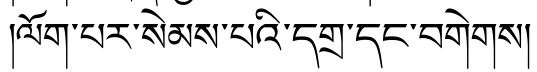

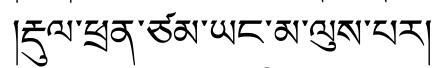

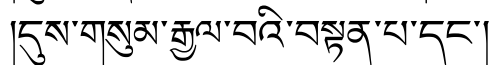

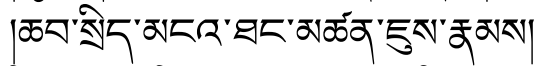

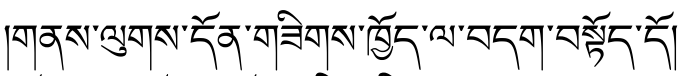

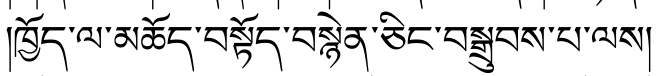

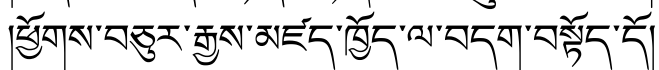

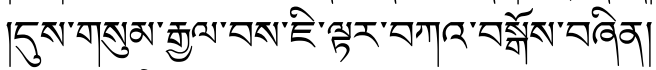

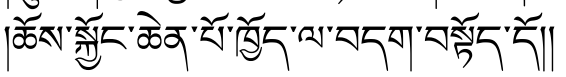

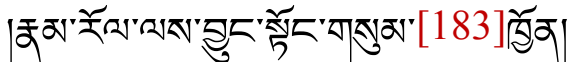

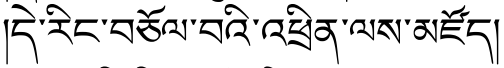

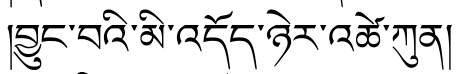

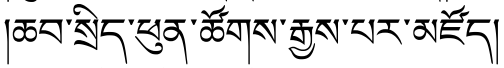

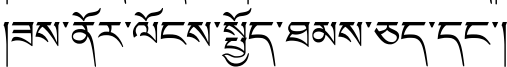

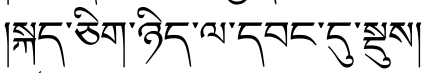

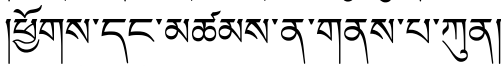

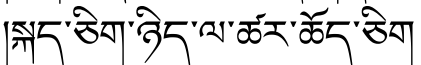

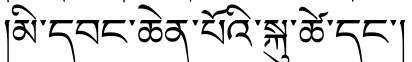

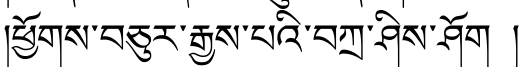

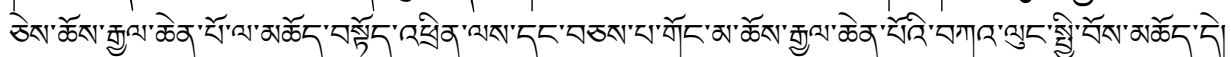

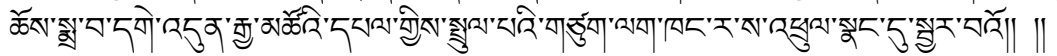

\section{[Text 4]}

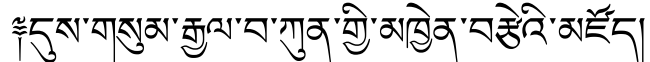

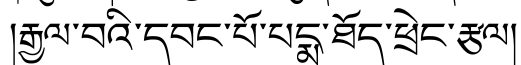

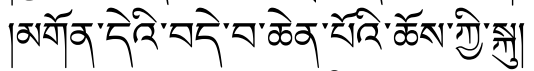

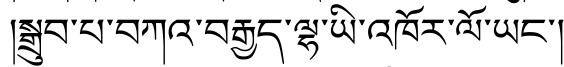

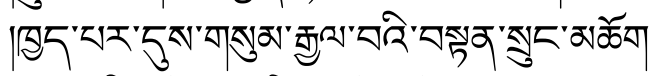

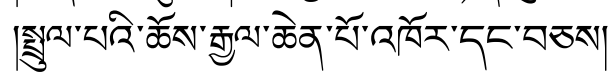

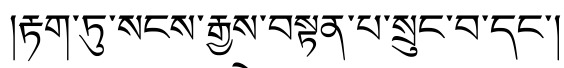

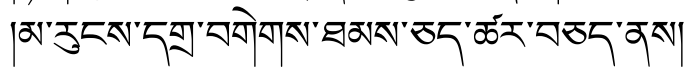

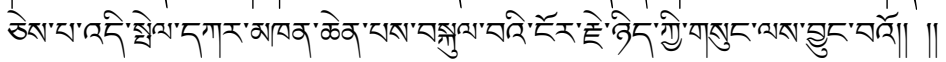

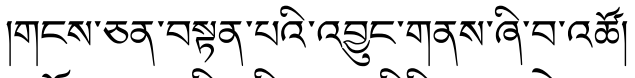

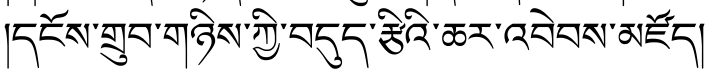

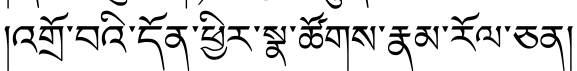

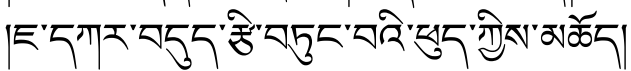

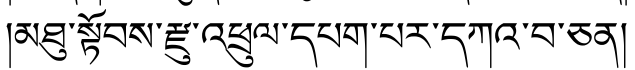

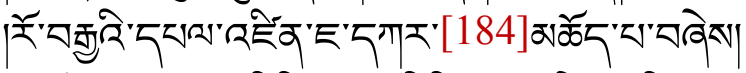

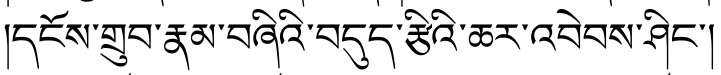

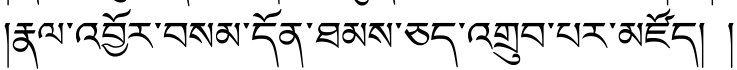

\section{[Text 5]}

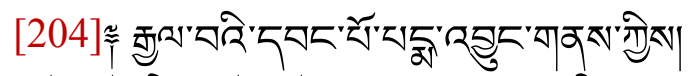

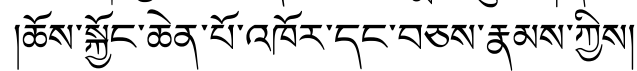

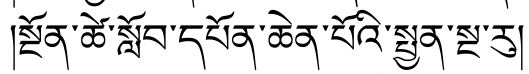

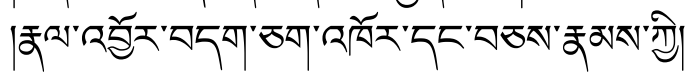

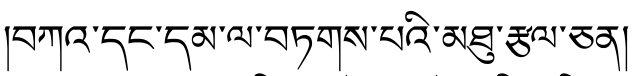

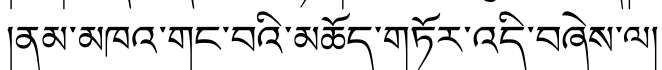

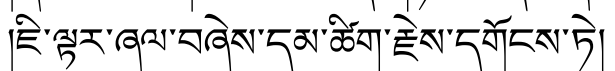

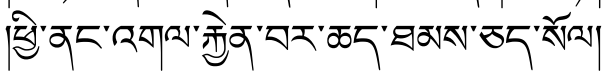




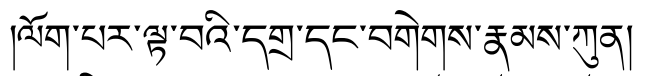

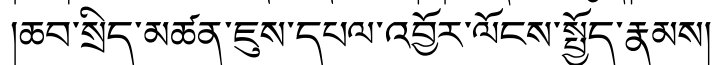

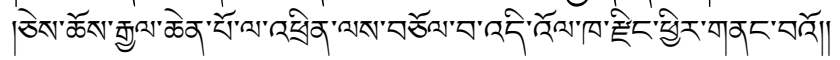

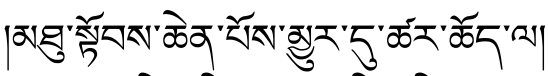

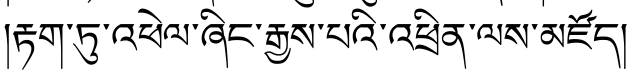

\section{[Text 6]}

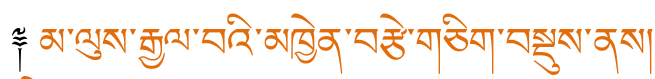

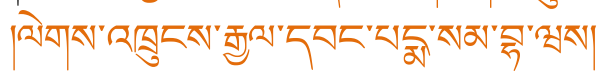

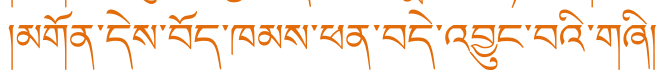

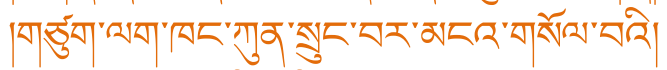

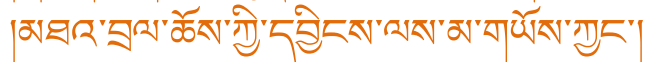

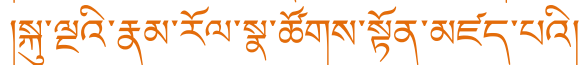

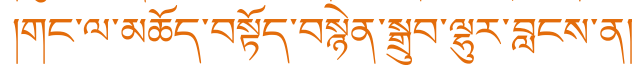

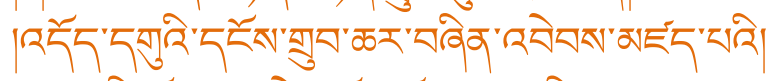

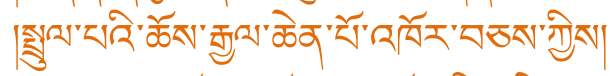

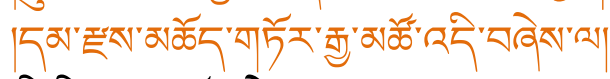

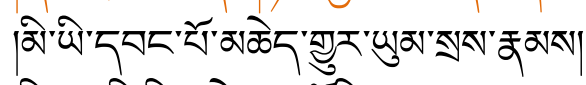

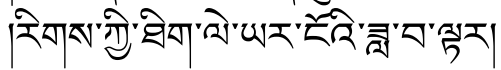

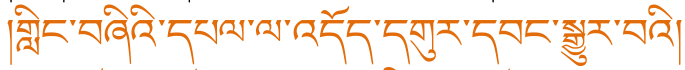

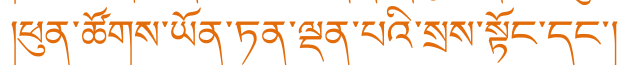

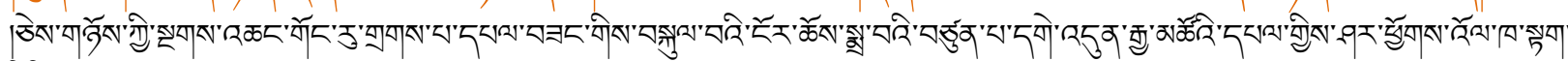

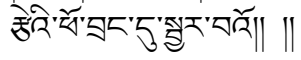

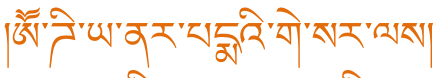

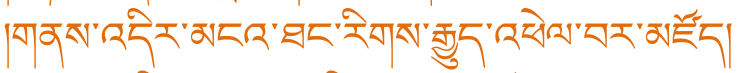

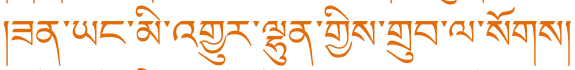

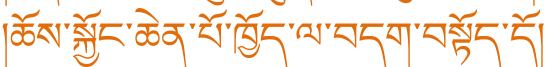
R丨

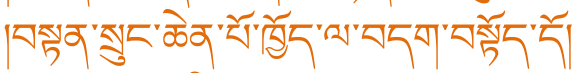

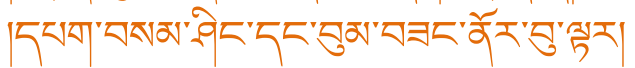

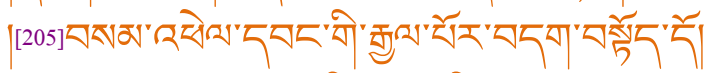

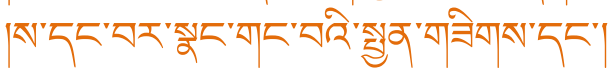

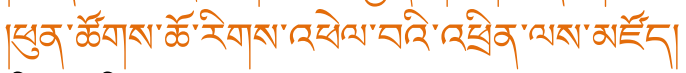

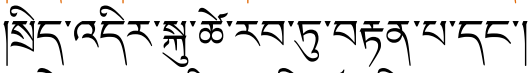

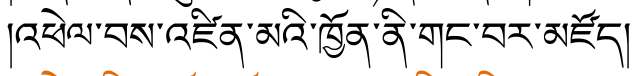

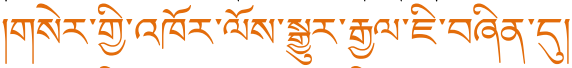

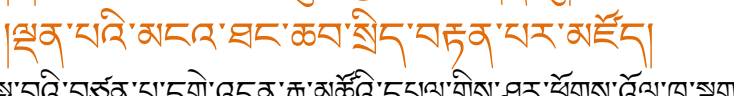




\title{
[167]Offerings and Praises to such [Deities] as the Great Dharma Kings, the Five Long-Life Sisters, 5 Dorjé Drakmogyel, 6 Dorjé Yudrönma, 7 Chölha, 8 Kongtsün Demo, 9 and Odé Gungyel 10 - from the Miscellaneous Writings of the Venerable Omniscient One's Collected Works
}

\author{
[Selections Pertaining to the Five Sovereign Spirits]
}

\section{[Text 1]}

[168] I pay homage to Guru [Rinpoche], the Buddha of the Three Times!

Because I wanted to make a torma offering to the great emanational Dharma Kings along with [their] retinue, ${ }^{11}$ first I made the outer and inner torma offerings after visualizing the great master [Padmasambhava]. Then I produced 12 with perfect purity [this] excellent and extensive composition derived from the sādhana text [for] the torma offerings to the great guardians of the [Buddha's] Word.13 [Finally,] I gathered the gifts for the deities.

Recite the following: The letters RAM, YAM, and KHAM emanate from my heart, having manifested as glorious Hayagrīva himself. Because of this, I burn with fire, scatter with the wind, and wash away with water the pure torma offerings.

RATNATRELOKYA ${ }^{14}$ BHRŪM!

Imagine the following: Within a vast and spacious jeweled vessel, the entire earth, intermediate space, and expanse of the sky are filled with torma offerings endowed with the five desirable qualities 15 that bestow extraordinary and undefiled bliss - the very nature of the five meats 16 and five nectars. 17

\footnotetext{
5 Tib. Tshe ring mched lnga; for more on these goddess, see Nebesky-Wojkowitz 1998, pp.177-181.

6 Tib. Rdo rje grags mo rgyal; lit. "The Victorious and Famous Adamantine Woman."

7 Tib. Rdo rje g.yu sgron ma; lit. "Adamantine Turquoise Lamp Woman."

8 Tib. 'phyos lha; the meaning of 'phyos here is not entirely clear. Barring the possibility that this is a misspelling, I am reading this as the past tense of "phyo, meaning "to fly, soar, glide." The meaning of this name would then be the 'Soaring God.' One of the colophons in this text gives the fuller name of the deity as Jo bo 'phyos lha dkon pa (DL206:212). Other than this, very little is known about the deity.

9 Tib. Kong btsun de mo; lit. "Venerable [Goddess] of Demo, Kongpo." For more on this goddess, as well as Dorjé Drakmogyel and Dorjé Yudrönma, all of whom are among the Twelve Tenma Goddesses, see Nebesky-Wojkowitz 1998, pp.181-198.

${ }^{10}$ Tib. 'O de gung rgyal. This is the name of a mountain range in Lokha, south of Lhasa, as well as the mountain god that resides there; see ibid, pp.208-209.

11 This refers to Pehar and the Five Sovereign Spirits, as well as their retinue.

12 Tib. thon $p a$; this is actually a past tense intransitive verb, meaning "emerged, came forth." This is a significant distinction because it suggests that the composition came about, seemingly of its own accord, with the Second Dalai Lama composing it in an inspired manner.

13 This refers to the Ten-Chapter Sädhana; see Appendix IIa.

14 The normative Sanskrit is ratnatrailokya; lit. "The Three Precious Worlds."

15 Tib. 'dod pa' $i$ yon tan lnga; pleasing form, taste, touch, sound, and scent.
} 
Recite three times: OM ĀH HŪM! Alternatively, for the torma offerings to the lamas and Dharma protectors, dispel the obstructing [spirits] with: [169] OM PADMĀNTA KRIDA! 18 Cultivate Emptiness with the OM SVABHĀVA [mantra].

From within emptiness, the first letter of the name of one's own [deity arises, then] dissolves. From that, torma offerings that please the lamas and the great Dharma protectors, along with their retinue, arise. May an inconceivable variety of sacred offerings appear in abundance before the lamas and the great Dharma protectors, along with their retinue!

OM SARVAVID PŪRA PŪRA SURA 19 SURA ĀVARTAYA ĀVARTAYA HOH VAJRA SPHARAN়A KHAM SVĀHĀ!20

[Having recited this,] bless [the offerings] with the mantra and mudra of the Sky Treasury,21 and further bless [them] with the six mantras and six mudras.22

Within a lucid and pure sky23 of immaculate light, a representation of the omnipresent Gyutrül Drawa24 [resides]. [This is] Padmasambhava - king of the victorious ones of the three eras[possessing] the manner of a completely pure vajra-bearing 25 monk.

On his right, heroes stomp about in a dance, [170] [and] on his left, heroines sing an endless stream of songs. He is surrounded by an assembly of countless accomplished tantric scholars, [and] all the oath-bound guardians billow around him like clouds.

All the chiefs of the gods follow after [him], and garlands of mandära26 [flowers] - which were strewn about by the hands 27 of Chimé Bumo 28 - fill the skies. 29 By your 30 immeasurable compassion, come to this place!

16 Tib. sha lnga; the flesh of a human, dog, elephant, horse, and ox or peacock.

17 Tib. bdud rtsi lnga; excrement, urine, blood, semen, and human flesh.

18 The normative Sanskrit for the last word is possibly krta. A potential translation for the whole mantra is: "OM [May the] Lotus Leaf be Obtained!"

19 The normative Sanskrit is süra; lit. "wise man, teacher."

20 A possible translation is, "Omniscient OM is Satisfying to [All] the Worthy Teachers HOH! The Vajras Abundantly Manifest in Space SVĀHĀ!" For a slight variation of this mantra, see Beyer 1973, p.203; see also Appendix IIa, notes 1359-1360.

21 Tib. nam mkha' mdzod; a samādhi meditation practice that signifies untainted and inexhaustible offerings.

22 Tib. sngags drug dang phyag rgya drug; this may refer to the Tantra of the Six Mantras and Six Mudras (Sngags drug phyag drug gi rgyud).

23 Tib. rol gnas; this illustrates the double, even triple, entendre that are often encountered in Tibetan verse, the nuances of which can be difficult to capture fully in English. While I chose "sky" for its metaphysical and poetic value, rol gnas can equally be translated as a "pleasure garden" (Tib. spro skyid gtong sa'i skyed tshal), which adds a vivid visual element, as well as a "stage for dance or play," which brings to mind the reenactments of such epic scenery in Tibetan ritual dance (Tib. 'chams). Likely, all three images are being referred to simultaneously in this instance.

${ }_{24}$ Tib. Sgyu 'phrul dra ba; Skt. Māyājālakramāryāvalokiteśvara; a five-headed form of Avalokiteśvara. Alice Getty translates this name in part as "he that passes through the net of illusion;" see Getty 1962, p.69.

25 Tib. rdo rje 'dzin pa; Skt. vajradhara. This refers to an accomplished tantric master possessing the samaya vow; see Khenpo Karthar Rinpoche 2004, p.342.

26 Tib. man dha ra; Skt. mandāra; the Indian coral tree, Erythrina variegata. 
I request that you abide forever, smiling31 with delight, in the sky in front [of me], in the middle of an immaculate rainbow [pavilion] 32 of five[-colored] light beams, on a lion throne [ornamented with] the sun and the moon, in the center of a thousand-petaled lotus.33

Having emanated bodies equal in number to the sands of the Ganges [River], [you] possess the garb of a skin-crawling 34 hindering spirit, 35 a born deceiver. [With] my palms joined in devotion and with flower blossoms, I receive the dust of [your] feet on the top of my head and respectfully pay homage.

An ocean-like libation of the nectar of immortality is held within an expansive vessel abounding [with] a thousand golden [lotus] petals. Flowers for the beautiful gods and humans completely cover the all-pervading path of the gods. 36

In jeweled vessels endowed with blooming rays of light, I burned snake's heart sandalwood, 37 divine substances, and aloe wood, 38 and a wheel of cloud-like smoke filled [the air]. The sky was congested by a garland of blazing lamps.

Delightful perfumed saffron water, saturated with camphor and sandalwood, swirls like an ocean of enjoyment and bestows immaculate bliss. Endowed with the excellence of a hundred tastes, ${ }^{39}$ [these are the] complete 40 food offerings 41 for gods and humans.

I have made a collection of mundane and supramundane offerings - such as a variety of horn instruments, [like] lutes and flutes, endowed with a hundred thousand reverberations of harmonious music. [171] They pervade all realms without exception, and I offer [them to you].

27 Tib. lag pad; read as lag pa.

28 Tib. 'Chi med bu mo; lit. "Deathless Girl." This seems to be a goddess figure, though little information on her is available.

29 Tib. mkha' lam; lit. "sky path."

${ }^{30}$ Though neither form is explicit in the text, the third person has shifted to second person here since the language has changed from describing Padmasambhava and his divine environs to beseeching him.

31 Tib. 'dzum chags; the chags is being read as a future continuative.

32 Tib. gur khyim; here again is a word with multiple meanings, as it can refer to a "tent," "dome," "pavilion," or a "rainbow." The common denominator is the dome shape of a tent that acts as a home, which is indicated by the etymological meaning of the word.

33 Tib. chu skyes; lit. "water-born."

34 Tib. spu long; lit. "hair standing on end."

35 Tib. yid srubs. This is a variant of bdud.

36 Tib. tshig mda'i lam.

37 Tib. tsan dan sbrul snying; short for tsan dan sbrul gyi snying po, a rare variety of sandalwood.

38 Tib. a ka ru; Skt. agaru.

39 Tib ro brgya; this refers to an incredibly delicious taste.

40 Tib. ma tshang med; lit. "not incomplete."

${ }^{41}$ Tib. zhal zas; this usually refers to gtor ma offerings. 
To you I offer jeweled Mount Meru, the four continents and eight sub-continents, the sun and the moon, the kingdom, the seven precious jewels, the great treasures of my body, my possessions, and all desirable things, as well as the merit that I have accumulated [throughout] the three times.

A cloud of offerings [emanated by] Samantabhadra42 - who arose from an untarnished ocean of devotion - completely fills the sky without exception. Nonetheless, the supreme bodhisattvas accordingly [and] properly make offerings [to] the Buddha of the three ages.43

Inside an immense skull cup as extensive as the billion-world system, [and] within an ocean of nectar, the five meats44 and, similarly, the five iron hooks are kept, the inherent nature of which are the five immaculate wisdoms that produce purification, realization, and illumination. An offering [of this is made].

Emaho!45 The joining together of the venerable lord Padma Tötreng Tsel 46 [and] his enchanting consort, who is a self-arising illusion, [produces] great bliss! This [most] superior of offeringswhich is beyond words, thoughts, and descriptions - [is] marvelous.

I bow to you, lord of the inconceivable Dharma body47 - the primordial ground beyond all signs of fabrication, innately free from the bonds of the two obscurations, 48 the supreme nature that completely pervades all of existence.

I bow to you, [body of] the perfect enjoyment49 of the nectar [of immortality] — which quickly dissolves the wheel of existence into space, possesses a network of the major and minor marks [of a Buddha] consisting of the five essences, and is the eye of the hero abiding on the bodhisattva's level.

I praise the emanation body, 50 which manifests as anything within the tamable realms or the particulars of thought-like the moon, which appears in the perfectly clear sky, reflecting in indescribably clean water.

[172] I bow to you, sole refuge of all beings - ascetic dressed as a monk, born from a lotus in the middle of a wish-fulfilling ocean in Oḍ̣iyāna, untarnished by even the smallest transgression.s1

\footnotetext{
42 Tib. Kun bzang (=Kun tu bzang po); lit. "Ever-Excellent One." This is the primordial Buddha.

43 Tib. dus gsum rgyal ba; given the context, this likely refers to Padmasambhava, who is known by the variant $d u s$ gsum sangs rgyas.

44 Tib. sgron ma lnga; lit. "five lamps" (figurative); see note 16.

45 This is an exclamation of amazement and wonderment.

46 Tib. Padma thod phreng rtsal; lit. "Powerful Skull-garland Lotus;" the secret epithet of Padmasambhava.

47 Tib. chos sku; Skt. dharmakāya.

48 Tib. sgrib gnyis; [1] emotional obscurations (Tib. nyon mongs pa'i sgrib) and [2] intellectual obscurations (Tib. shes bya'i sgrib pa).

${ }_{49}$ Tib. longs spyod rdzogs pa ['i sku]; Skt. sambhogakāya.

50 Tib. sprul pa'i sku; Skt. nirmānakāya.

51 This quatrain is in praise of Padmasambhava.
} 
Even in this country completely surrounded by a garland of snow[-covered] mountains, the beneficence created [by just] the slightest dust of [your] feet pacifies all the demon armies of the dark side [and] propagates the teachings of the victorious ones for the happiness and benefit of [all] beings; I bow to you.

[To] the five great Dharma-protectors 52 and [your] retinues - may you not transgress your orders and vows, may you preserve and protect the teachings of the victorious ones, and may you accomplish all the activities that I entrust [to you].

The emanated guardians of the [Buddha's] Word, the Five Sovereign Spirits - mind, speech, body, good qualities, and activities - [arise] from the primordial, pure, ultimate, and heavenly expanse. [They are] endowed with a variety of miraculous emanations in order to protect the teachings [of the Buddha].

A gathering of supreme secret consorts and ministers, [as well as their] functionaries and servants, completely fill the whole [of the] earth and sky. [Such] inconceivable power and miraculous emanations arise from the [elemental] expanse, like rainclouds gathering in the summertime.

[The below quatrains are derived from most of chapter 2 of the Ten-Chapter Sädhana, sans framing mantras] The Dharma protectors who I invite from the supreme realm-which is changeless and spontaneously perfected - and request to come to this mandala-which is generated through meditative concentration - are the Five Capricious-Sovereign Spirits together with their retinue. You, supreme beings that protect according to your fundamental samaya commitment, I request [that you] come to this place [where] I have invoked [your] samaya vow.

\section{[1 quatrain is skipped]}

King Gyajin, sovereign spirit of the mind, [your] great consort, the powerful Shatim Rozan, and [your council] minister, the lord of life Kayi Jarawa, together with [your] retinue-I request [you all] to come to this place.

[The following 4 quatrains are given in reverse order from the Ten-Chapter Sädhana]

[173] Great three-faced man, sovereign spirit of activities, [your] great consort, Düza Minkarma, and [your] council minister, Putra Nakpo, together with [your] retinue-I request [you all] to come to this place.

Enemy-defeating god Kyechikpo, sovereign spirit of speech, [your] great consort, Dzejé Padmakyé, and [your] council minister, Dorjé Drakden, together with [your] retinue-I request [you all] to come to this place.

Capricious spirit Shingjachen, sovereign spirit of good qualities, [your] great consort, Sergyi Putrima, and [your] council minister, Jagö Tangnak, together with [your] retinue-I request [you all] to come to this place.

52 Tib. chos skyong chen po sku lnga; lit. "five bodies [of] the great Dharma-protector." This refers to the Five Sovereign Spirits. 
Mönbuputra, sovereign spirit of the body, [your] great consort, the female hindering spirit Rolangma, and [your] council minister, Jatri Mikchikpo, together with [your] retinue-I request [you all] to come to this place.

[The below quatrains expand upon content found in chapter 3 of the Ten-Chapter Sädhana]

[You,] the sapphire-colored 53 sovereign spirit of the mind, grasp the lasso of the hindering spirits in your right hand and a razor in your left; wear a bear-skin coat [and] flowing black silk [on your body, and] an elegant thumb[-shaped] hat with black silk [fringe] on your head; [and] ride a long-nosed elephant that is like a drifting cloud. ${ }^{54}$ I request that you firmly reside, on top of a [throne made up of] a lotus, sun, and conjoined enemies and obstructing spirits, in the blazing dark-blue divine [mansion] in the center, along with your retinue.

[You,] the black-colored sovereign spirit of the body, [Mönbu]putra, ride a lion;55 [and] hold 56 a vajra in your right hand and a mendicant's staff [made from] a red tree in your left. I request that you firmly reside in the glittering white conch-shell mansion in the east,57 along with your retinue.

[174] [You,] the majestically dark-blue-colored sovereign spirit of good qualities, bear a battle axe in your right hand and the lasso of the hindering spirits in your left; [and] are endowed with many frightening magical emanations. I request that you firmly reside in the great golden divine mansion in the south, 58 along with [your] retinue.

[You,] sovereign spirit of speech, the enemy-defeating god Kyechik, wear a red cloak as radiant as rubies; ${ }^{59}$ grasp a sandalwood club; [and] are [surrounded by] a multitude of your entourage. I request that you firmly reside in the glittering red coral divine [mansion] in the west, 60 along with [your] retinue.

[You,] the white, black, and red-faced sovereign spirit of activities, [have] six arms-you hold an iron hook in your first right hand, an arrow in the second, and a sword in the third; in your left [hands] you brandish a blazing razor, an iron bow, and a club-you possess a crown [with] black silk [fringe]; [are endowed with] the eight charnel ground ornaments;61 [wear] fluttering silks; [and] ride a lion. I request that you firmly reside in the precious turquoise mansion in the north.62

\footnotetext{
${ }^{3}$ Tib. indra ni la' $i$ mdog; the first word is translating the Sanskrit indranila, meaning "sapphire."

54 Tib. chu 'dzin; lit. "water-holder." This is yet another example of the figurative and poetic language found throughout this text.

55 Tib. gdong lnga; lit. "five-tufted."

${ }^{56} \mathrm{Tib}$. gsil; this is likely a misspelling of $g s o l$, which means to wear, more specifically.

57 Tib. shar phyogs rab dkar dung gi khang bzang du; this phrasing differs slightly from the root text.

58 Tib. lho phyogs gser gyi gzhal med khang chen $d u$; this phrasing differs slightly from the root text.

59 Tib. padma rä ga; lit. "lotus-hued."

${ }^{60}$ Tib. nub phyogs rab dmar byi ru'i gzhal yas su; this phrasing differs slightly from the root text.

61 Tib. dur khrod chas brgyad; see Dung dkar Blo bzang 'phrin las 2002, p.1082.

62 Tib. byang phyogs rin cen g.yu yi khang bzang $d u$; this phrasing differs slightly from the root text.
} 
The Five Kings of the Dharma, ${ }^{63}$ guardians of the [Buddha's] Word, [are] the primordially pure five aggregates 64 and purify the tainted afflictions of the five poisons. Thus, I pay devoted homage to the essence of the five wisdoms.

The Dharma body [is] the great blissful one, Amitābha; the [body of] perfect enjoyment [is] the great glorious blood-drinker, Hayagrivva; [and] the emanation body [is] Tsokyé Dorjé.65 Having offered up your life essence in the presence of these three indivisible bodies, you protect the teachings, the monastery, and the monastic community; similarly, you promise to accomplish the activities entrusted [to you] by the yogins who keep their samaya vow. Do not forget the promise you previously made, and may you spontaneously perform the four activities!

[175] Since even I, the yogin, observe my samaya vow, I always rely on, and make offerings to, [these] Dharma protectors and their retinue. I have blessed the choicest medicine - made from a thousand different medicinal [herbs] — as the essence of the five wisdoms, and have contained it in an ocean of nectar that possesses the five sensual pleasures.66 I then offer it to the Five Sovereign Spirits and their retinue.

From the heavenly expanse of unconditioned great bliss, clouds of offerings that permeate all realms rain down nectar of immaculate wisdom. I offer [these] to the guardians of the [Buddha's] Word and their retinues. I [further] offer fluttering fringe as multicolored as rainbows [and] divine silken canopies [that] cover the sky.67 [These are] beautifully adorned by sapphire tips and [Dharma wheels] possessing a thousand golden spokes. [They are also] endowed with beautiful tassels and garlands of precious pearls. [I offer] cool shade [provided by] a multitude of various elegant parasols; a thousand banners of divine silk that flap [in the wind]; and a collection of victory banners [ornamented with the heads] of graceful peacocks, as well as [other] victory banners [made from] the skins of various carnivorous animals, like lions, tigers, bears, and leopards. May the five Dharma protectors and their retinues be appeased by these excellent [and] pleasing ritual offerings!

I offer a libation of bright red blood, swirling like an ocean; wreaths of lovely flowers; fragrant clouds of smoke that are burned in various censers [made of] radiant jewels [and that] adorn the sky; as well as various sweet-smelling butters 68 and grain oils 69 [that are kept] in supreme golden vessels endowed with blossoming rays of light [and] from which a series of blazing golden wicks [protrude]. May [the five Dharma protectors and their retinues] be appeased by this collection of exquisite lamps [and other offerings]!

\footnotetext{
63 Tib. chos kyi rgyal po sku lnga; I have chosen to translate rgyal po as the more standard 'king' here, since it seems these deities' status as pious kings (Tib. chos kyi rgyal po; Skt. dharmarāja) overrides their status as spirits.

64 Tib. phung po rnam lnga gdod nas rnam dag; this appears to be a reference to the Five Buddhas, who make up the fundamental nature of the primordially pure five aggregates (Tib. phung po lnga ye nas dag pa'i rang bzhin rgyal ba rigs $\operatorname{lng} a$ ).

65 Tib. Mtsho las skyes pa'i rdo rje; Skt. Padmavajra; lit. "Lotus Vajra." This is an epithet of Padmasambhava.

66 Tib. 'dod yon lnga.

67 Tib. lha lam; lit. "divine path."

68 Tib. rtsi mar; this is specifically butter produced from livestock fed on grass.

69 Tib. 'bru mar; this is usually oil produced from sesame, mustard, or rape seeds.
} 
[176] I offer waves of different kinds of scented waters that fill the entire word 70 - such as sandalwood and saffron properly sprinkled with drops of camphor-[and that are] endowed with a fragrance that fills all directions simultaneously. The foods of gods and humans - such as [the above-mentioned] gently waving ocean of perfume, the food of a hundred tastes, and the nectar of immortality-bestow complete and untainted bliss. May the great Dharma protectors and their retinues be appeased by all these food offerings!

This collection of countless instruments - such as lutes, flutes, drums 71 and larger drums, 72 as well as copper trumpets-[is] magnificent, and [their music] overflows [like] an elixir for the ears. May [the great Dharma protectors and their retinues] be appeased by this collection of divine instruments!

May the five Dharma protectors and their retinues be appeased by this pure golden libation 73 of ruby-colored grape wine, as well as wines [made from] rice, molasses, and honey, that are contained within an ocean!

I offer a herd of miraculous, thoroughbred horses endowed with fur of beautiful colors-like crystal, cymophane, emerald, and deep ruby-[and] adorned with various precious saddles and bridles. I [further] bestow handsome stud yaks possessing tails and long fur 74 that waver like rainclouds. They are of various [colors], such as black-and-white, spotted, and sorrel, and they have fluttering silk crowns. May [the five Dharma protectors and their retinues] be appeased by these [animals]!

Furthermore, I offer a real display of stuffed animal skins - like goats and sheep — various grains and medicines, and the seven kinds of gems. I [also] bestow a cloud of visualized offerings. May [the five Dharma protectors and their retinues] be appeased by these [offerings] that fill the earth and sky!

Within an extensive vessel as vast as the Ganges River, 75 [177] [these] torma offerings are adorned with ornaments elegantly arranged like the four continents, [eight] sub-continents, and Mount Meru. ${ }^{76}$ I bless and bestow these offerings as immaculate nectar.

The tongues of the Dharma protectors and their retinues transform into single-pointed vajras that arose from HŪM [and are each] endowed with a tube of light. With this they suck out and drink all the essence of the torma offerings.

Having visualized [the above], recite mantras [over] the tormas three or seven times and bestow them.

\footnotetext{
70 Tib. kun khyab 'khor lo.

71 Tib. rdza rnga; this is specifically a type of clay drum.

72 Tib. rnga bo che.

73 Tib. gser skyems.

74 Tib. rnga zhol.

75 Tib. gser ldan dga' ma.

76 Tib. lhun po'i dbang po; this appears to be a variant of ri dbang lhun po, meaning "Meru, lord of mountains."
} 
I praise you, great Dharma protector who, from the palace of the completely pure Source, 77 bring to completion all the pious activities of all the yogins that practice in accordance with the Dharma.

I praise you, great guardian of the [Buddha's] teachings who, in a previous life, promised to protect the teachings and the holders of the teachings after you were ordered [to act] as the guardian of [Samyé] monastery by the venerable Padma Tötreng.

I praise that the miraculous manifestions of the five bodies - body, speech, mind, qualities, and activities - appear everywhere from the Source itself, without even [the slightest] hesitation, like crystal that is nearly clear of a hundred hues.

I praise you [for] possessing body colors embellished with wrathful, boastful, and peaceful expressions, [and for] brandishing various hand implements, in order to perform the [four] activities - pacifying, enriching, conquering, and destructive.

I praise you heroes, who simultaneously fill the three planes 78 with physical emanations, shake the three planes with the thundering sound of laughter, and instantly encircle the billion-world system with the power of miraculous manifestations.

I praise the great secret consorts who display various wrathful and boastful appearances - in the manner of hindering, capricious, serpent, and savage spirits $79-$ [and] who fully embrace the bodies of the Five Sovereign Spirits. [178]

I praise the five ministers, who always carry out the orders of the great Dharma protectors, protect the [Buddha's] teachings [with] strong, powerful, and miraculous manifestations [that are] difficult to measure, and annihilate the enemies of the teachings.

Chief among all the attendants of these great Dharma protectors is the great and glorious capricious spirit Yangleber.80 [His body color] shines like a Mount Meru of rubies and has the brilliance of a hundred thousand fierce sunbeams. He wears armor that blazes intense firelight and a leather helmet that radiates dazzling lightbeams. [He holds in his] right hand a red lance from which a pennant gently waves. [He brandishes with his] left hand a lasso that binds the enemies and obstructing spirits-quick as lightening. He rides an excellent blue horse as beautiful as a raincloud, [and is surrounded by] a gathering of a thousand red imperial spirits, as well as hindering and savage spirits. I praise him and his circle of attendants, who instantly destroy all the enemies and obstructing spirits!

I praise the multitude [of deities] that completely fills the realms of the earth, the intermediate space, and the sky: the retinue of brigadiers and the eight classes of gods and spirits; 81 the

\footnotetext{
77 Tib. chos dbyings.

78 Tib.sa gsum; above the earth (Tib. sa bla), on the earth (Tib. sa steng), and below the earth (Tib. sa 'og).

79 Tib. srin mo; this word has the feminine nominalizing particle mo, which is not illustrated in the translation.

80 Tib. Yang le ber; this is another name for Tsiu Marpo.

81 Tib. lha srin sde brgyad.
} 
gathering of peaceful and tempered Disciples 82 [that have the] likeness of arhats; 83 the gathering of tantric practitioners 84 who perform religious dances 85 [while] weilding ritual daggers; 86 the gathering of heroes [clad] in tiger-skin garments 87 [and] brandishing weapons; and the gathering of black women tossing their matted locks of hair.

The embodiment of all the Buddhas, Padmasambhava, said, "After appointing you, great emanational Dharma protector, 88 to the mandala of the blood-drinking Mighty Lotus [Hayagrīva], I conferred initiation [upon you and] placed the samaya vajra on your head. Having poured into your mouth the sacred nectar [of immortality], may you protect the [Buddhist] teachings and monasteries, guard the awesome teachings of the Buddha, and bring to completion all the activities of the yogins!" [179]

May you reflect on your samaya entrustment, propagate the Buddha's teachings, and instantly smash into dust all the enemies and obstructing spirits that harm the teachings!

May you forever remain in this world like Mount Meru-[residing] atop the mansion of complete victory 89 [that is] the two systems; 90 bearing the lofty, golden victory banner of merit; and waving the glorious pennant of good activities!

Having covered the entire earth 91 with the sunlight of all the excellent laws, may you widely extend the lotus grove of the teachings and increase the harvest of the welfare and happiness of all beings!

This is the method for performing the torma offering to the great emanated Dharma protector, who was ordered [to act] as the guardian of [Samyé] Monastery by the supreme siddha, Padmasambhava. ${ }^{2}$ Lord 93 Sönam Gyeltsen

82 Tib. nyan thos; Skt. śrāvaka. This refers to the Buddha's disciples, specifically those of the 'lesser vehicle' (Tib. theg pa chung ba; Skt. hinayāna).

83 Tib. dgra bcom.

84 Tib. sngags pa.

85 Tib. gar 'chams.

86 Tib. phur ba.

87 Tib. stag shar; I am reading this as a misspelling of stag sham, based on previous descriptions of this retinue; see GRSD:72-73.

88 Tib. sprul pa'i chos skyong chen po. In past instances, this phrase and its variants have often failed to specify if it is singular or plural. Context is necessary in these cases, and for the most part it's clear that the Five Sovereign Spirits as a group is the focus. However, in the traditional mythology, Padmsambhava encounters and subjugates the deity Pehar alone, since it is from him that the other among the Five Sovereign Spirits emanate. Because of this, I have chosen to translate the term as singular here.

${ }^{89}$ Tib. rnam par rgyal ba'i khang bzang; mythologically, this refers to Indra's palace.

90 Tib. lugs gnyis; this refers to the religious (Tib. chos lugs) and secular (Tib. srid lugs) systems that were established in a coordinant manner during the Fifth Dalai Lama's administration. Given that this is a text composed by the Second Dalai Lama — though, collected by the Fifth Dalai Lama — it is difficult to ascertain whether this term held a different significance during the time of the Second Dalai Lama or if this was an uncredited emendation by the Fifth Dalai Lama.

91 Tib. 'dzam gling nor 'dzin.

92 Tib. Padma 'byung gnas.

93 Tib. mi'i dbang po; lit. "leader of men." 
Pelzangpo ${ }^{94}$ - whose lotus feet are worthy of being prostrated to by the crown jewel of all rulers - gave [the following] request, "May you write [a text] such as this!" He then accepted this text with great reverence. 95 The Venerable [Second Dalai Lama] Gendün Gyatsö Pel96 composed this text, while Chökyi Penjor Lekpa97 acted [as] scribe.

\section{[Text 2]}

\section{OM SVASTI!}

The one called Tsokyé Dorjé, who rose from the center of a lotus, 98 placed saffron that is famous in this land of snows on the cheeks of the local girls. Wherever he resides, rays of compassion cover the entire earth. May he fully perform a playful dance at the center of the lotus in my heart!

[180] Shouting out with a loud cry, [you,] the emanated Dharma King- [who is] part of the retinue in [Padmasambhava's] perfectly complete mandala-come to this place from your tall, multi-storied palace! The sky is obstructed by waves swirling in an ocean of tea and beer. [May you] consume these torma offerings [that are] piled [high] like a mountain [and] adorned with an ocean of muscle, flesh, blood, and fat.

Those who harm the teachings of the Thus-Gone One99 [are] the enemies and obstructing spirits [that have] evil thoughts and actions, [and that] possess a mind as wrathful as the rage found among the class of gods in the desire realm.100 Quickly liberate101 them at this very moment and drink a warm mouthful of their heart's blood.102 May you cut off such [evils] as sickness, [and] wrathfully annihilate them in accordance with their concurrent causes.

Like the meaning of the Perfection of Wisdom Sütras, 103 the state of the beautiful and allilluminating Source is unlimited. [You] earnestly undertake [to prepare] the playful banquet that accompanies the brilliance of this knowledge. Clouds of fangs as white as frost [and] rows of lightening bolt tongues flash forth. [You who] destroy those that [would] completely consume all three worlds 104 are similar to the gateways 105 visible [on the mandala palace]. 106

94 Bsod nams rgyal mtshan dpal bzang po. Per Sørensen gives as the dates for this figure [?]1532-66; see Sørensen, Hazod, and Tsering Gyalbo 2007, vol.2, p.516, n.200.

95 Tib. spyi bos mnos; lit. "accepted [it] with the crown of one's head." This refers to a common Tibetan gesture of respect where one places a text on the crown of one's head to honor it.

${ }_{96}$ Dge 'dun rgya mtsho'i dpal.

${ }_{97}$ Chos kyi dpal 'byor legs pa.

98 Tib. ka ma la; Skt. kamala.

99 Tib. ta thā ga ta; Skt. tathāgata.

100 Tib. me tog $m d a$ ' can; lit. "those who possess flower arrows." This is specifically an epithet of the Indian god of love, Kāmadeva; however, in this context, this phrase is synonymous with the more general 'dod lha, which is how I translate it here.

101 Tib. sgrol; this implies killing these beings in order to free them from further accruing bad merit.

102 These lines are likely addressing the aforementioned emanated Dharma King.

103 Tib. Pa ra mi ta; Skt. [Prajña]pāramita.

104 Tib. srid gsum; sometimes this word appears to be synonymous with sa gsum (see note 78 above), while other times it is synonymous with khams gsum (see note 114 below). 
Supported by a home of grass and leaves, [I] paint with the brush [of] meditiative concentration 107 [focused on] you. Despite hot or cold suffering, [I] strive to recite the [mantric] recitations like other sages. When [I do] purely recite JA six times, 108 do night idle! Do not idle! Come here now! Eliminate the enemies and obstructing spirits that are as [cunning] as foxes right now!

All the eight classes [of gods and spirits] receive the row of [your] toenails on their heads like the tip of a hat. [You reside] in the middle of a conflagration that completely displays the eon of destruction's powerful fires, mingled with violent winds making a great thrumming noise reverberating like a lute.109 I praise you [who are] completely surrounded by a retinue of ghosts, [as well as] the eight classes [of gods and spirits], such as Yama!

[181] [Your] two hands are adorned with a blazing vajra - its great spokes outspread-[and] a skull cup. [You] possess all kinds of fierce mudrās in order to subdue the various pernicious forces [that afflict] some people. Completely surrounded by a retinue of ten million flesh-eating spirits, [you] rule over the wish-fulfilling [tree] that bestows the fruits of all desires. May [you], the lord who protects the great land, forever remain [and] act virtuously until the end of samsära!

When [you] burst forth with a fierce booming laughter- "Ha ha!"-[beings in] the three worlds [become] very terrified and flee into the unproduced expanse of emptiness. Thinking of this, I become filled with doubt and hesitation.110 [May you] destroy all the enemies and obstructing spirits by quickly covering them with wolfsbane poison! [Exclaiming] "Alala!" 111 [and] performing a joyful dance, [may you] bestow [upon me] all desired yogic accomplishments!

Have placed the Word of the Glorious Monarch 112 on the crown of [my] head, I sang [these] verses of vowels and consonants as a song without hindrance.

This [rite] was also requested by the Great Hierarch, 113 who commanded, "You must write [a text] such as this!" Thus, the Venerable Omniscient One composed it.

105 Tib. rta babs.

106 Tib. ma lus srid gsum rab tu gsol byed mthar byed rta babs mngon sum bzhin; the meaning of this line is difficult to understand.

107 Tib. ting 'dzin; Skt. samādhi.

108 Tib. dus drug; three times during the day, and three at night.

109 Tib. rgyud mar; read as rgyud mang.

110 Tib. ...snyam bdag yid the tshom dpyang thag 'dzin; the meaning of this line is difficult to understand.

111 Tib. a la la; this is an interjection of delight.

112 Tib. 'khor los bsgyur ba; Skt. cakravartin; lit. "He who turns the wheel [of the Dharma]." This is an epithet of the Buddha.

113 Tib. dpon sa gong ma chen po. This likely also refers to Lord Sönam Gyeltsen Pelzangpo; see note 94 above. 


\section{[Text 3]}

The wisdom and compassion of all the Buddhas of the three times manifests as the Lord of Siddhas. [He,] Padmasambhava, the lama of the three worlds, bestows all yogic accomplishments [and] destroys all obstructions!

Great emanated Dharma King — who manifests everywhere [as] various miraculous emanations in order to protect the [Buddha's] teachings, without wavering from the innate disposition of the primordial spontaneous presence-along with [your] retinue, come to this place now!

In a manor painted with the brush [of] meditative concentration - a divine mansion made of various jewels, a precious palace blazing [with] a great many pearls - I request that [you] sit on a throne [made] of a lotus, sun, and moon. [182]

After Padma Tötreng - the lord of the Buddhas of the three times - placed the samaya vajra on [your] head, he ordered you to protect the [Buddha's] teachings, maintain [your] samaya vow, and accomplish all activities [entrusted to you]. Be mindful of your vow!

Tormas of sacred ornaments are piled [high] like a mountain. A draught of untainted nectar is dammed up like a lake. [Such] outer and inner offerings extensively fill the whole earth and sky. I offer [these offerings] to [you] and your retinue.

I praise the forms of the Five Sovereign Spirits, who accomplish pacifying, enriching, conquering, and destructive activities, and who are endowed with expressions adorned with the emanations of a hundred appearances - [such as] wrathful, peaceful, and boastful —in order to protect the [Buddha's] teachings.

I praise you who subjugate the three realms, 114 endowed with roaring laughs of "Ha ha!" [and] thundering voices [proclaiming] HŪM HŪṂ! Your mouths are like clouds of fangs gathering densely in the sky [and] rows of lightning bolt tongues consuming the three worlds.

I praise you who perceive the ultimate state [of things, and] who manifest everywhere [from] the primordially unfabricated, spontaneously present nature, the uncontrived, self-produced, coemergent reality, the all-pervading inherent existence of everything.

I praise you who spread all the mundane and supramundane qualities throughout the ten directions after you mastered the collection of the many good qualities, as well as approached and received the offerings and praise [presented] to you.

I praise you, the great Dharma protectors, who - endowed with the samaya vow-accomplish unhindered all the infinite activities of pacifying, enriching, conquering, and destroying, just as the Victorious One of the Three Times 115 commanded.

\footnotetext{
114 Tib. khams gsum; the desire realm (Tib. 'dod khams; Skt. kāmadhātu), the form realm (Tib. gzugs khams; Skt. rüpadhātu), and the formless realm (Tib. gzugs med khams; Skt. arūpadhātu).

115 Tib. dus gsum rgyal ba; while this phrase generally refers to the Buddhas of the three times, in this context it is clearly an epithet of Padmasambhava.
} 
HŪM

[183] Accept these offering tormas that arose from manifestations of immaculate wisdom and great bliss, and that fill the extent of the billion-world system! Perform the activities entrusted [to you] today!

Pacify all undesirable suffering that arises from past karma and present circumstances! Abundantly increase life, merit, and dominion!

Instantly conquer all the food, wealth, and possessions and all the arrogant beings that abide in the three worlds! 116

Instantly annihilate all the enemies and obstructing spirits that have incorrect thoughts, [and] that abide in the cardinal and ordinal directions, so that not even the smallest particle remains!

Increase the teachings of the Buddhas of the three times, the lifespans of the great leaders, as well as the kingdom, dominions, and politics, throughout the ten directions! May all be auspicious!

These are the offerings and praises for the great Dharma King, accompanied by activities. I honor [this text,] a prophetic order of the eminent great Dharma King, 117 by [placing it on] the crown of my head. The Dharma teacher Gendün Gyatsö Pel composed [this rite] in the Rasa Trülnang, 118 the emanated monastic complex.

\section{[Text 4]}

The treasury for the wisdom and compassion of all the Victorious Ones of the three times, the source of the [Buddha's] teachings [in] the Snowy Land, [is] Śantarakșita. The lord of the Victorious Ones, Padma Tötreng Tsel, rains down a nectar shower of the two [kinds of] yogic accomplishments. 119

This savior's Dharma Body of great bliss possesses a variety of manifestations in order to benefit [all] beings. [I] also honor the circle of the Eight Sädhana Deities with the choicest draught of white tea nectar.

In particular, great emanated Dharma King along with your retinue - the supreme guardian of the teachings of the Victorious Ones of the three times who possesses miraculous powers that are difficult to fathom-[may you] accept this offering of white tea that bears the splendor of a hundred flavors. [184]

\footnotetext{
116 Tib. 'jig rten gsum; this appears to be a synonym for sa gsum (see note 78 above).

117 Tib. gong ma chos rgyal chen po; this refers to the oracle of these deities, who appears to have requested that this text be composed while in a trance.

118 Tib. Ra sa 'phrul snang; this is an earlier name from the Jokhang Temple in Lhasa.

119 Tib. dngos grub gnyis; extraordinary accomplishments (Tib. mchog gi dngos grub) and ordinary accomplishments (Tib. thun mong gi dngos grub).
} 
May you always protect the Buddha's teachings, rain down a nectar shower of the four kinds of yogic accomplishments, and-having annihilated all the malignant enemies and obstructing spirits - fulfill all the yogins' desires!

This [rite] is based on the words of Lord [Gendün Gyatso] himself, in response to a request by the great abbot of Pekar. 120

\section{[Text 5]}

[204] 121 Great [and] powerful Dharma protector and your retinue-who were issued orders and bound to oath by Padmasambhava, the lord of the Victorious Ones-receive these torma offerings that fill the sky!

Recall the samaya promise you made accordingly in the presence of the great master in a past life! Remove all the inner and outer adverse conditions and obstacles that [affect] us, the yogins, as well as our retinue!

Quickly destroy with [your] great power all the enemies and obstructing spirits with wrong views! Always perform the activity of increasing and extending dominion, politics, wealth, and resources!

This [rite] entrusting the activities to the great Dharma king was bestowed at the Dzingchi [Monastery] in Ölkha. 122

\section{[Text 6]}

Having embodied the wisdom and compassion of the all the victorious ones, the victorious lord Padmasambhava - who was born well from the center of a lotus in Oḍ̣iyāna - acted to increase the race who [holds] dominion over this place.

I praise you, great Dharma protector, who was invested by that savior with the authority to guard all the monasteries, such as Samyé Monastery, 123 the [very] ground from which happiness and well-being arose [in] Tibet.

I praise you, great guardian of the teachings, who- even though you do not waver from the limitless Source-displays the various manifestations of the five [main] forms in order to protect the [Buddha's] teachings with the four activities.

120 Tib. Spel dkar mkhan chen po; it is unclear where Spel dkar is, let alone who its abbot was at this time.

121 The following two brief panegyrics to the Five Sovereign Spirits are separated from the previous rites by several pages of smaller ones dedicated to other deities.

122 Tib. 'Ol kha rdzing phyi; for a brief history of this monastery and its famous Maitreya statue, see Venturi 2002.

123 Tib. Zan yang mi 'gyur lhun gyis grub; lit. "the immutable, spontaneously present [monastery with] three styles of architecture." The three architectural styles (Tib. zan yang) refer to the Chinese, Nepali, and Tibetan levels that make the three-story central temple (Tib. Dbu rtse) of Samyé Monastery. 
I praise the king of the wish-fullfilling gems, who-like the wish-fulfilling tree or the excellent jeweled vase [of wishes]124 causes all desirable yogic accomplishments to rain down [on me] when [I] devote myself to the offerings, praises, and approach and accomplishments [performed] for whomever. [205]

Great emanated Dharma King along with your retinue, receive these offerings that fill the earth and sky, as well as this ocean of sacred torma offerings! Also perform the activity of increasing my parent's sublime lineage! 125

Fully support the ruler, his relatives, wives, and chidren in this world [for] a lifetime! Fill the whole world by increasing the essence of [his] family lineage, like the waxing moon!

Support the kingdom's might — which has a thousand sons with marvelous qualities - like a golden wheel-turning monarch 126 who governs all desires throughout the splendor of the four continents.

The venerable Dharma teacher Gendün Gyatsö Pel composed [this rite] at Tagtse Mansion 127 in eastern Ölkha in response to a request by Gongru Drakpa Pelzang, the mantric adept of Nyö. 128

124 Tib. ['dod 'jo'i] bum bzang nor bu.

125 Tib. phun tshogs cho rigs.

126 Tib. gser gyi 'khor los sgyur rgyal; this is two phrases combined into one. The 'golden wheel' (Tib. gser gyi 'khor lo) refers to the Buddhist wheel of Dharma, which emphasizes the religious status of this figure as a Dharma King. The 'wheel-turning monarch' (Tib. 'khor los sgyur rgyal; Skt. cakravartin) emphasizes the secular status of this figure as a world ruler.

127 Tib. Stag rtse'i pho brang.

128 Tib. Gnyos kyi sngags 'chang Gong ru Grags pa dpal bzang. Though the details on this figure are unknown, it seems clear that he comes from the Gnyos lineage of Yar klungs, and that Gong ru is a variant spelling of the central Tibetan region Gung ru; see Sørensen, Hazod, and Tsering Gyalbo 2007, vol.2, pp.677-678. 


\section{Appendix IIc}

\section{The Adamantine Melody}

The Unceasing Adamantine Melody: A Sädhana for Presenting Prayers and Offerings to the Five Great Sovereign Spirits (Tib. Rgyal po chen po sde lnga la gsol mchod 'bul tshul 'phrin las 'gags med rdo rje'i sgra dbyangs) was composed by the Fifth Dalai Lama and is the culmination of the two previous ritual texts. It is the other central rite at Nechung Monastery and is the basis for the monastery's extended name, which was granted at its renovation: Palace of Adamantine Melody (Tib. Rdo rje sgra dbyangs gling). There are four extant editions of the Adamantine Melody, and the abbreviations and bibliographic details for each are as follows:

GRSD Tā la'i bla ma 05 Ngag dbang blo bzang rgya mtsho (1617-1682). 1983. Rgyal po chen po sde lnga la gsol mchod 'bul tshul 'phrin las 'gags med rdo rje'i sgra dbyangs. In The Collected Works of Liturgy of the Gnas-chun Rdo-rje-sgra-dbyans-glin Monastery, vol.1. Delhi: Lobzang Tondan, pp.12-53. TBRC: W00EGS1016248.

DL511 Tā la'i bla ma 05 Ngag dbang blo bzang rgya mtsho (1617-1682). 1992. Rgyal po chen po sde lnga la gsol mchod 'bul tshul 'phrin las 'gags med rdo rje'i sgra dbyangs. In The Collected Works (Gsung-'bum) of the Vth Dalai Lama, Ngag-dbang blo-bzang rgya$m t s h o$, vol.11. Gangtok: Sikkim Research Institute of Tibetology, pp.207-252. TBRC: W294.

Tā la'i bla ma 05 Ngag dbang blo bzang rgya mtsho (1617-1682). 2007. Thogs med drag rtsal nus stobs ldan pa'i dam can chos srung rgya mtsho'i mngon rtogs mchod 'bul bskang bshags bstod tshogs sogs 'phrin las rnam bzhi lhun grub. In Thams cad mkhyen pa lnga pa chen po’i gsung 'bum, vol.11. Dharamsala: Nam gsal sgron ma, pp.121-616. TBRC: W2CZ5990.

Tā la'i bla ma 05 Ngag dbang blo bzang rgya mtsho (1617-1682). 2009. Thogs med drag rtsal nus stobs ldan pa'i dam can chos srung rgya mtsho'i mngon rtogs mchod 'bul bskang bshags bstod tshogs sogs 'phrin las rnam bzhi lhun grub. In Rgyal dbang lnga pa ngag dbang blo bzang rgya mtsho’i gsung 'bum (五世达赖阿旺洛桑嘉措文集), vol.14. Beijing: Krung go'i bod rig pa dpe skrun khang. TBRC: W1PD107937. 
I have continued to use the GRSD abbreviation in this context to refer to the first edition of the Adamantine Melody cited above, which is found in the Nechung Liturgy. Aside from different page numbers, this ritual manual belongs to the same collection as the Nechung Monastery edition of the Ten-Chapter Sädhana discussed in Appendix IIa; therefore, I am using the same abbreviation. The DL511 edition is found within a larger compendium of rituals composed by the Fifth Dalai Lama entitled the Spontaneous Achievement of the Four Activities: A Collection of Iconographies, Offerings, Amendments, Confessions, and Panegyrics for the Ocean of Oath-bound Dharma-protectors, who are Unhindered, Wrathful, and Powerful. 1 The last two unabbreviated editions are typed copies of the edition found in the latter work, located within other publications of the Fifth Dalai Lama's collected works. For this reason, as well as due to time constraints, I have not consulted them for this study. I was also unable to access a copy of the 2009 Beijing edition at the time of this writing, so I do not know the exact pagination of the text in that edition.

Like the Ten-Chapter Sädhana, I have created a diplomatic edition of the Adamantine Melody based on the above GRSD and DL511 editions, with the GRSD edition as its base. However, this diplomatic edition is only cursory in comparison to the one found in Appendix IIa. I have not included spelling, grammatical, or syntactical discrepancies, since my goal was not to trace scribal or institutional distinctions for the Adamantine Melody. My goal was simply to note occasional word differences in order to aid translation. For this reason, my English translation is based predominantly on the GRSD edition, with periodic assistance from the DL511 edition.

1 Tib. Thogs med drag rtsal nus stobs ldan pa'i dam can chos srung rgya mtsho'i mngon rtogs mchod 'bul bskang bshags bstod tshogs sogs 'phrin las rnam bzhi'i lhun grub; see Tā la'i bla ma $051992 \mathrm{~b}$. 


\section{Adamantine Melody Transcription}

[GRSD:12][DL511:207]

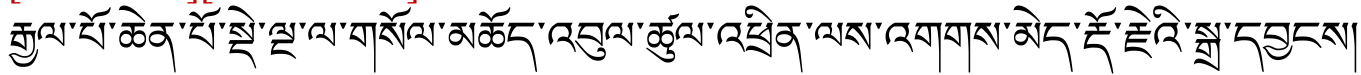

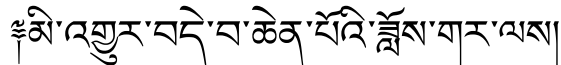

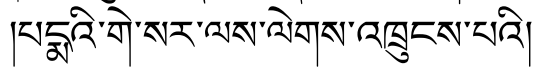

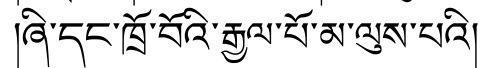

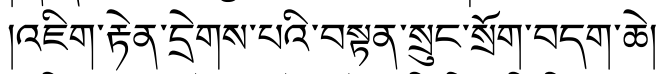

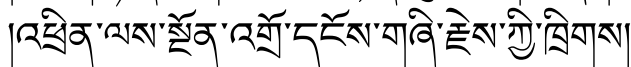

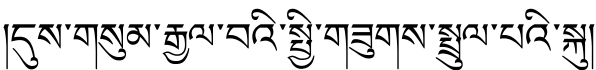

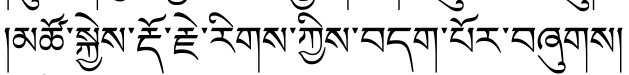

|

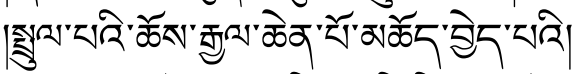

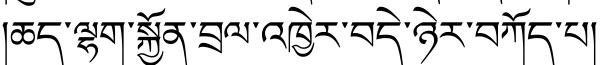

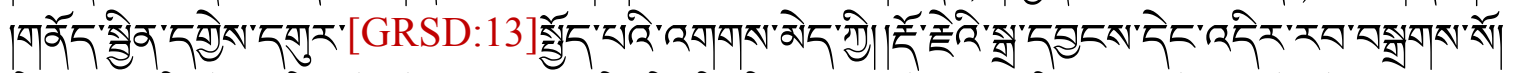

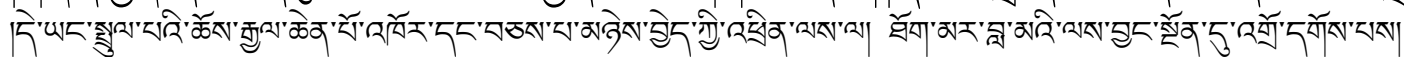

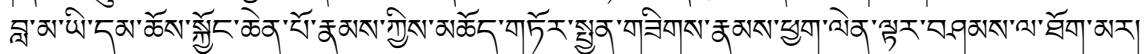

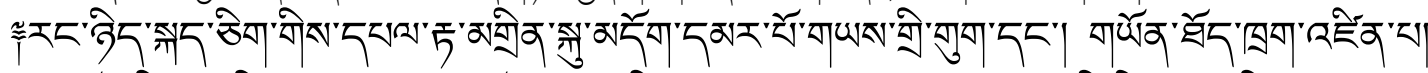

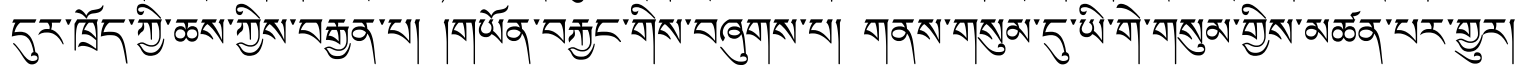

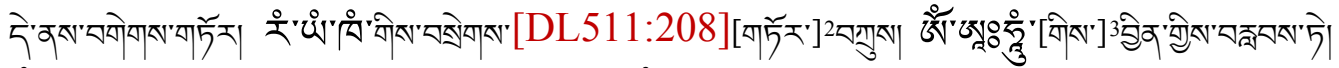

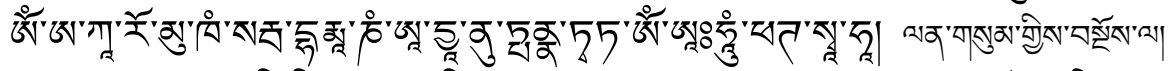

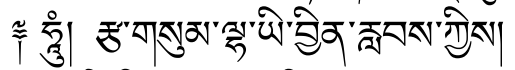

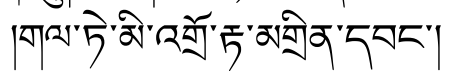

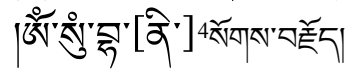

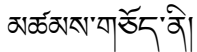

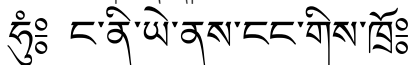

पयोग

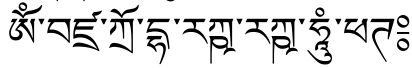

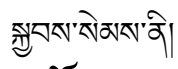

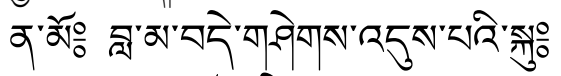

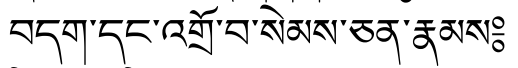

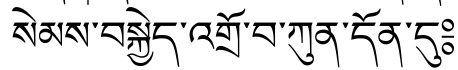

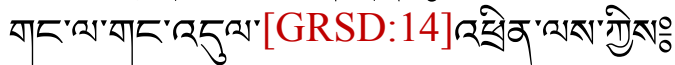

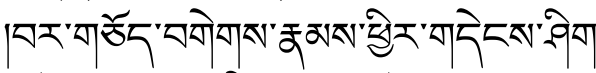

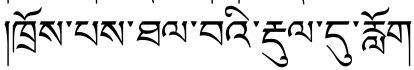

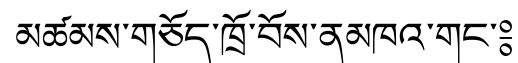

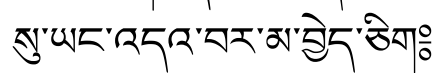

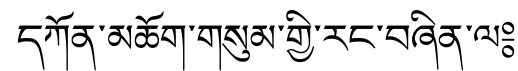

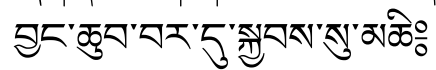

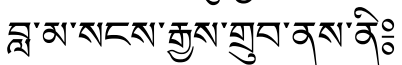

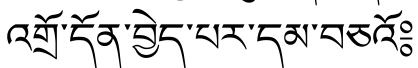

2DL511: ్ㅐㅈㅔ

3 DL511: बेत

4 DL511: omitted. 


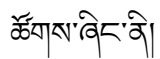

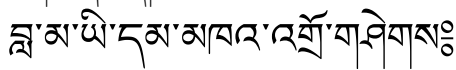

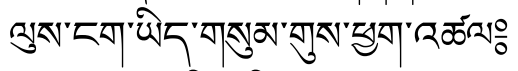

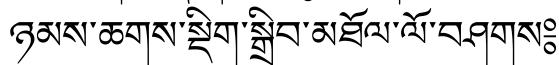

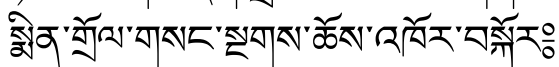

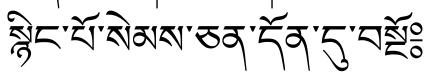

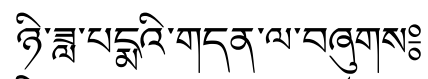

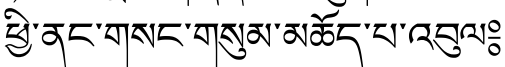

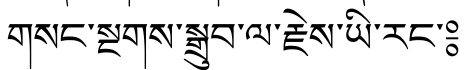

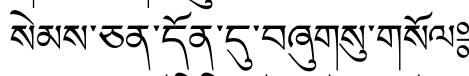

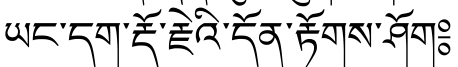

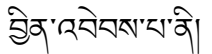

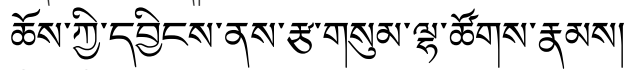

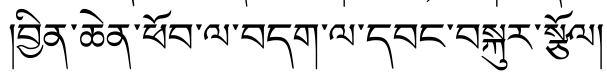

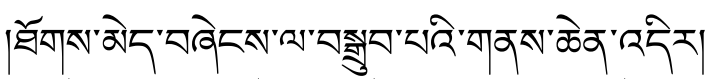

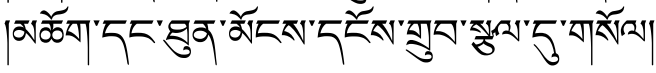

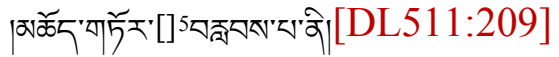

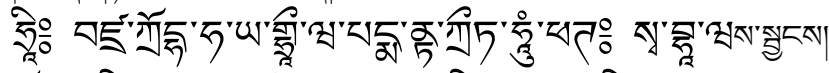

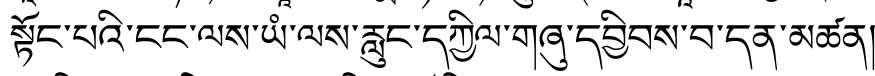

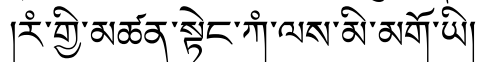

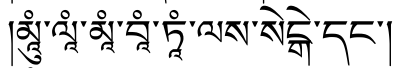

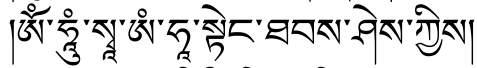

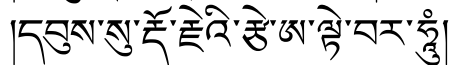

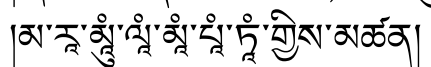

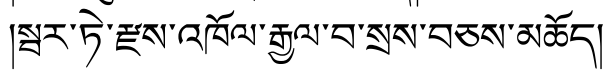

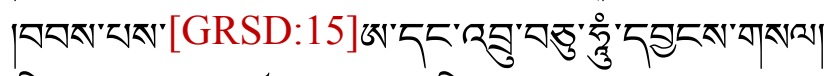

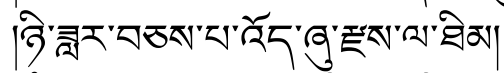

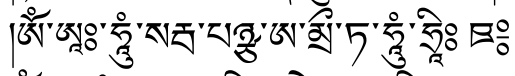

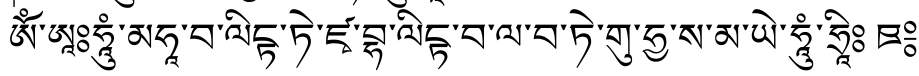

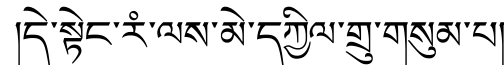

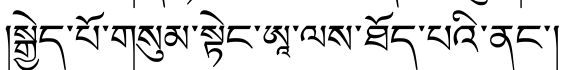

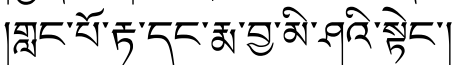

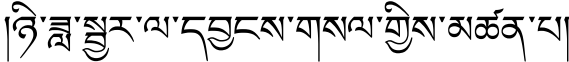

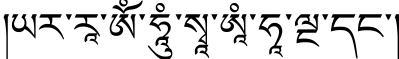

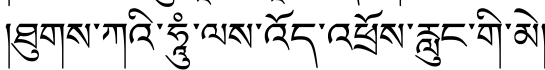

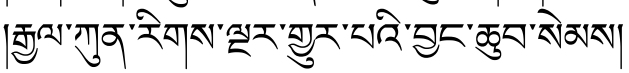

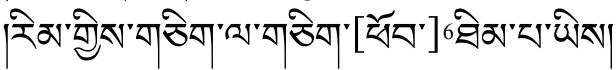

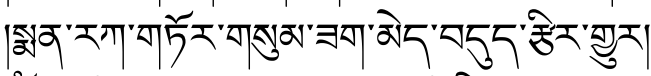

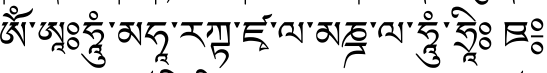

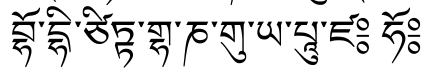

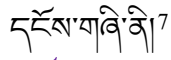

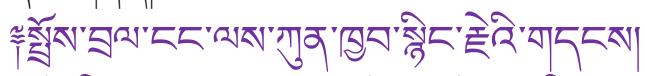

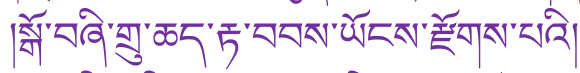

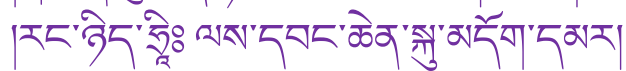

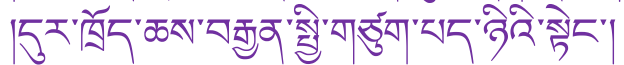

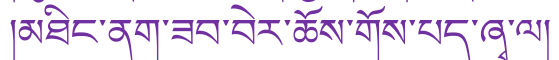

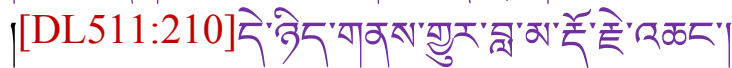

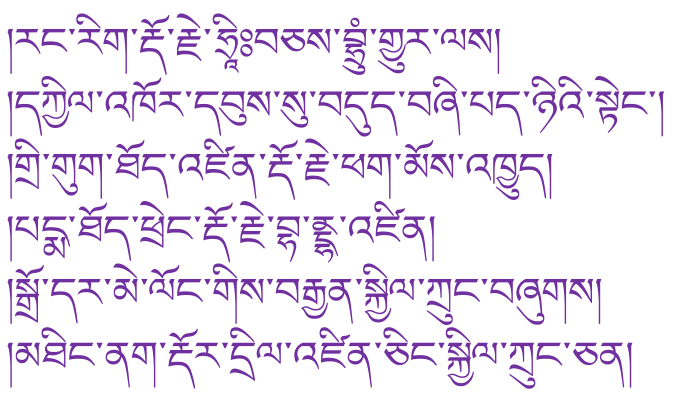

5 DL511: ड् ेबे

6DL511: 萧

7 While not copied verbatim, this section is based on the cosmology and general order found in Ratna gling pa 1976, pp.129-133. 


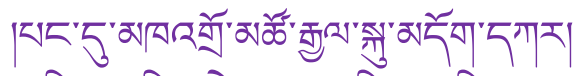

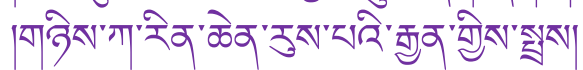

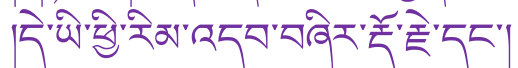

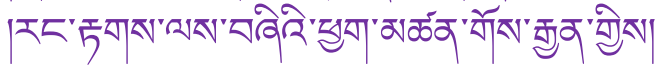

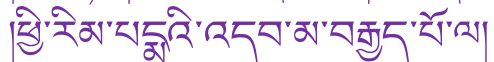

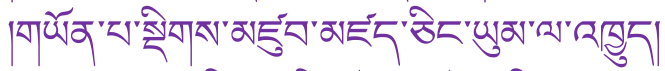

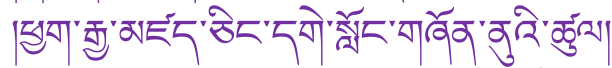

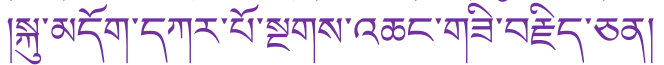

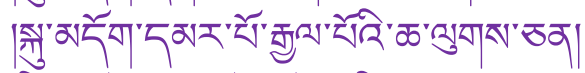

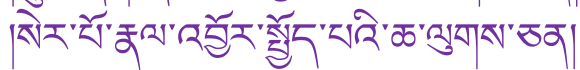

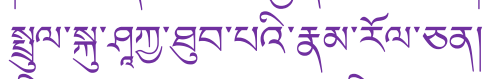

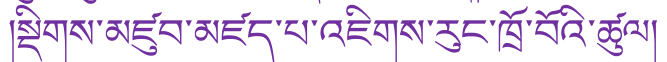

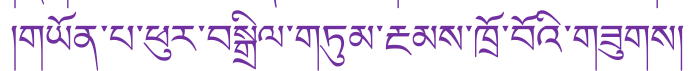

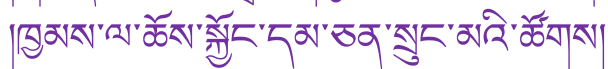

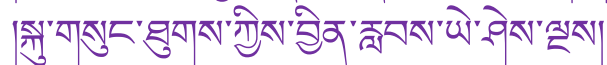

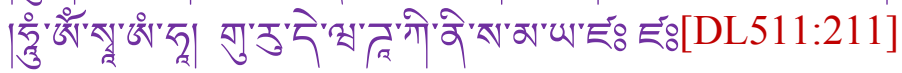

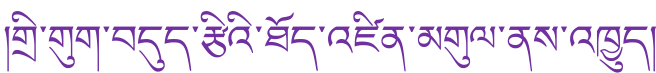

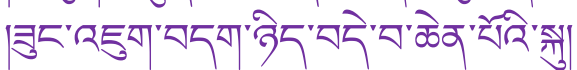

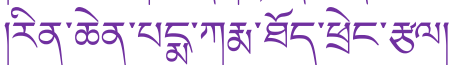

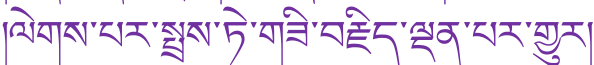

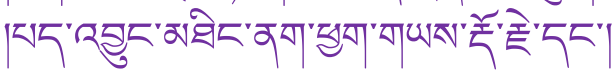

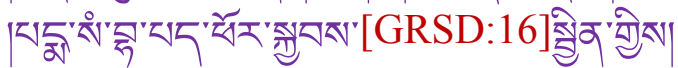

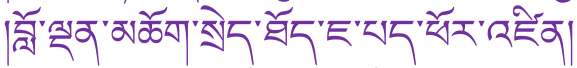

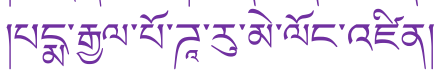

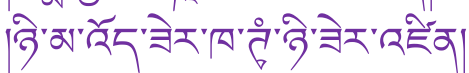

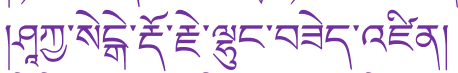

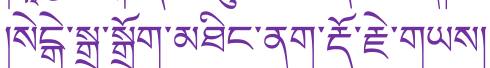

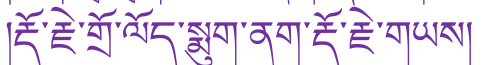

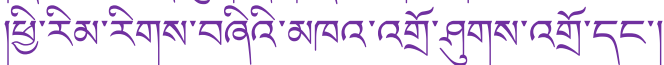

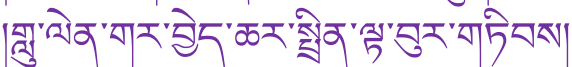

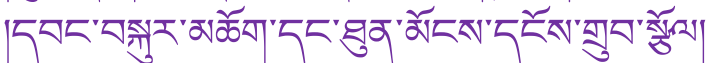

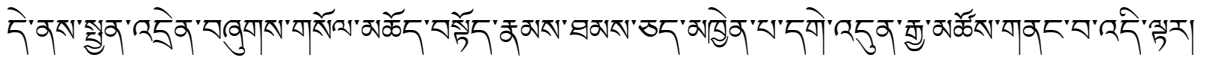

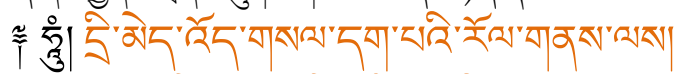

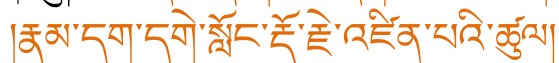

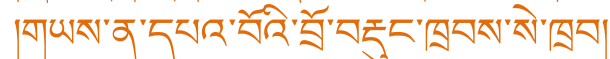

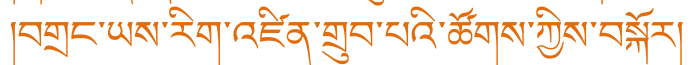

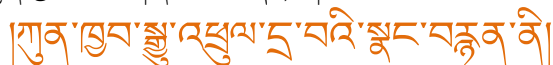

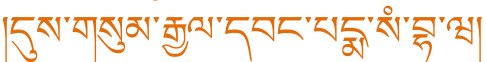

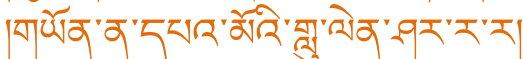

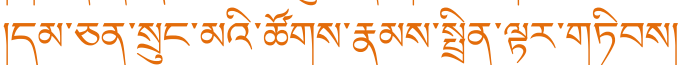

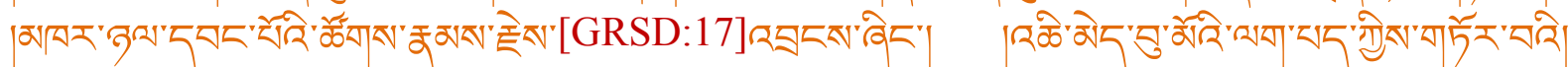

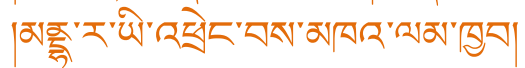

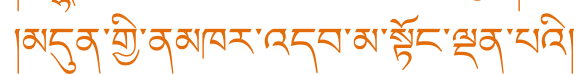

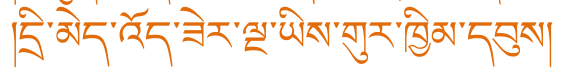

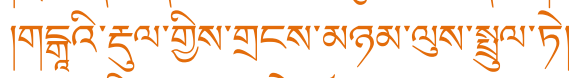

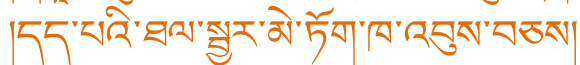

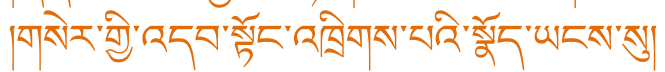

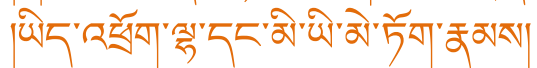
К्र

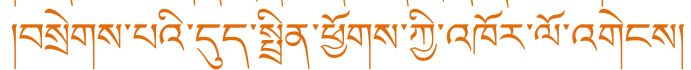

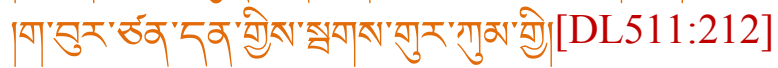

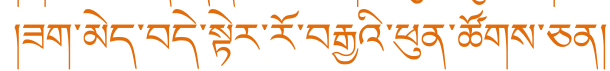

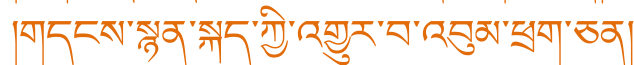

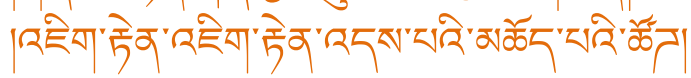

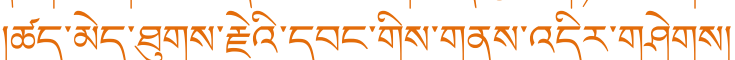

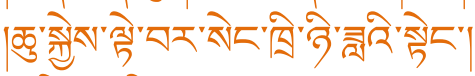

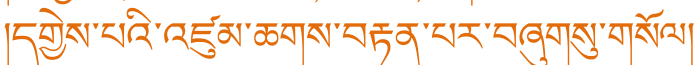

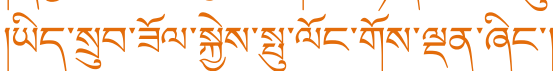

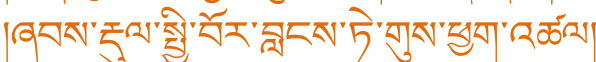

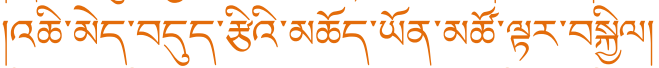

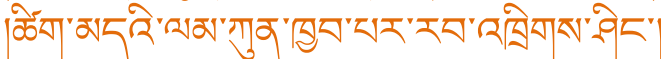

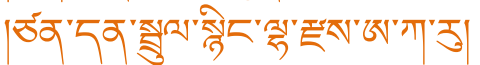

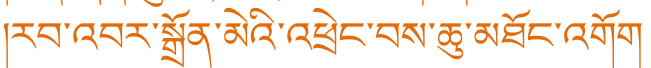

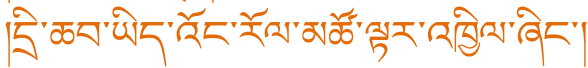

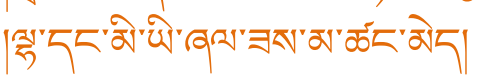

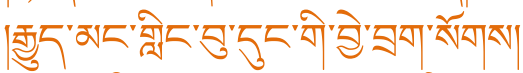

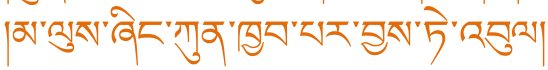




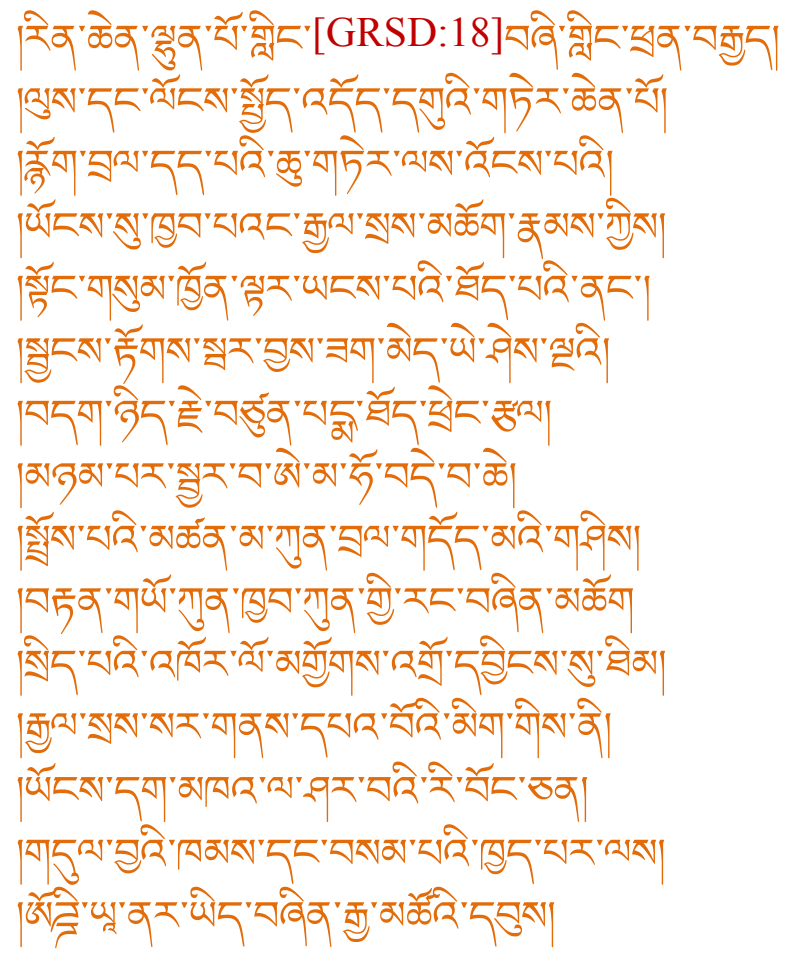

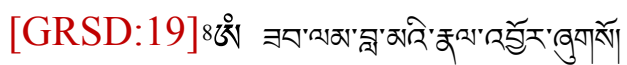

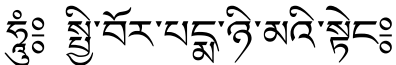

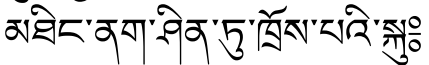

$$
\begin{aligned}
& \text { ×ख্য }
\end{aligned}
$$

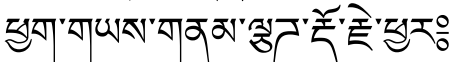

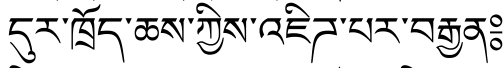

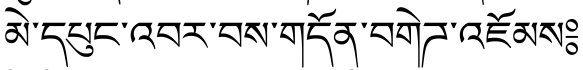

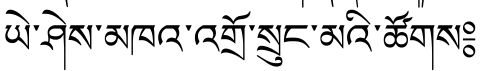

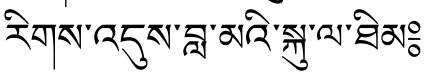

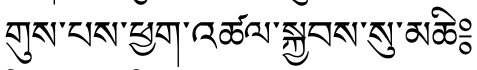

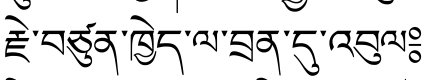

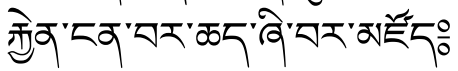

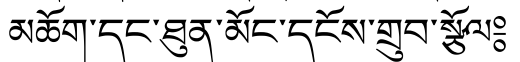

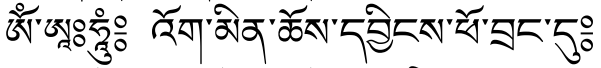

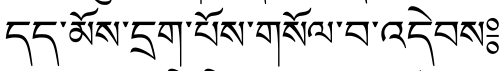

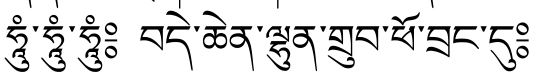

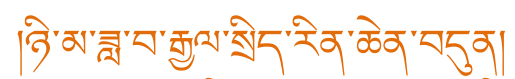
|

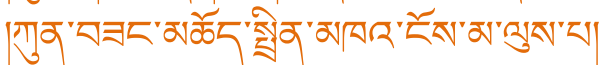

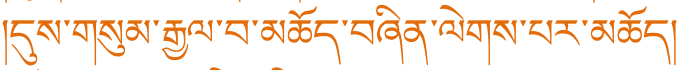

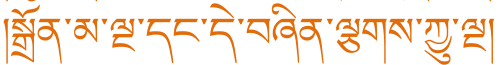

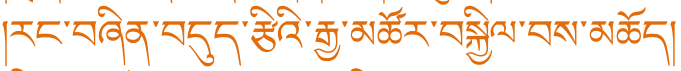

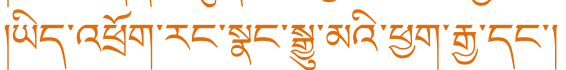

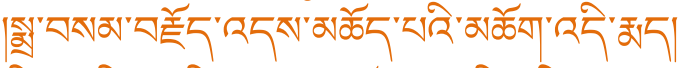

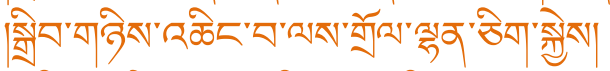

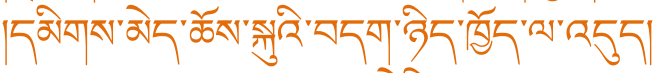

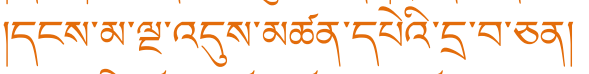

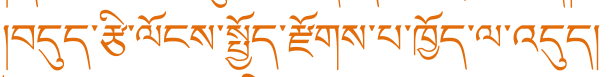

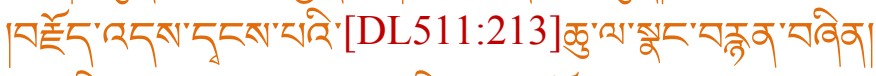

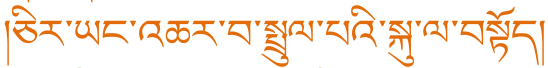

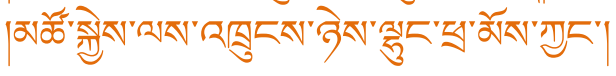

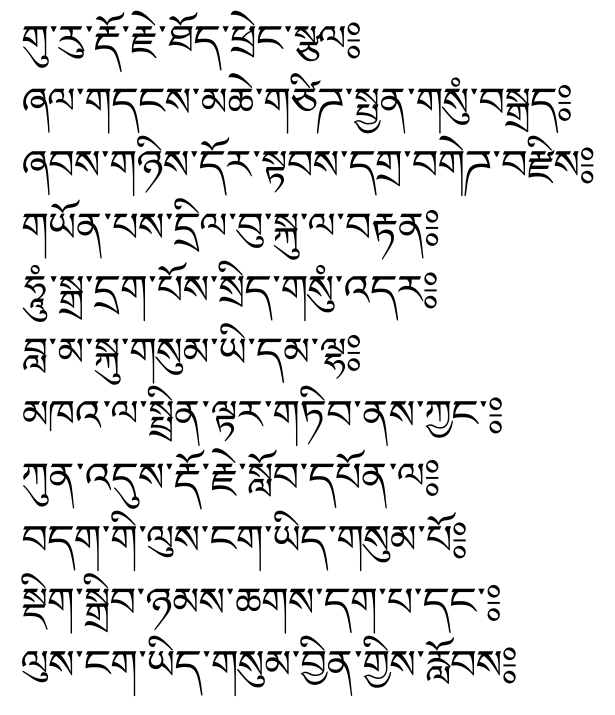

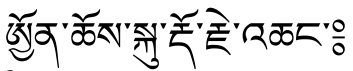

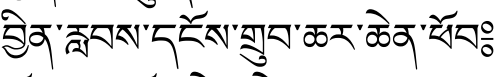

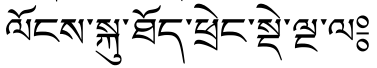

8 GRSD pages 19-20 consist of an extraneous folio that was clearly added. The folio is numbered 1 ( $g$ cig) and is placed between folios $9(\mathrm{dgu})$ verso and $10(\mathrm{bcu})$ recto. The script style is also noticeably different. Finally, since this section of the text is copied verbatum from the Second Dalai Lama's rite, this folio's content is a break in the preestablished verses. The contents of this folio are not found in the DL511 edition of this text. 


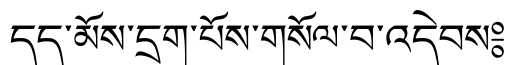

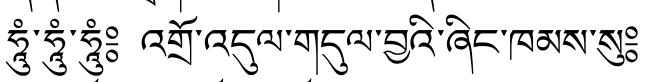

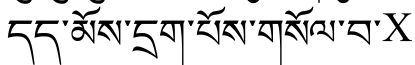

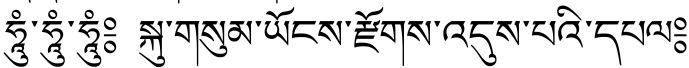

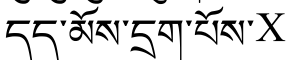

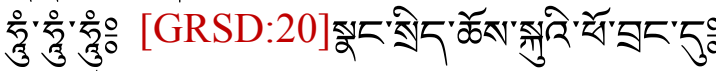

$55^{2}$ ขैसे $\mathrm{X}$

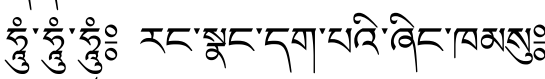

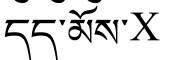

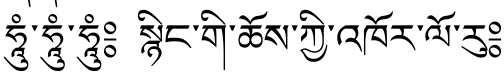

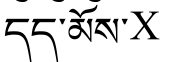

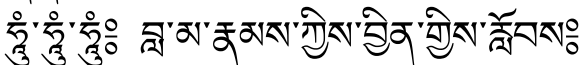

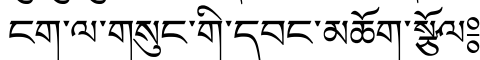

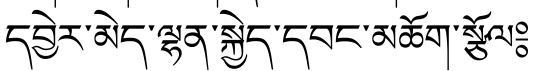

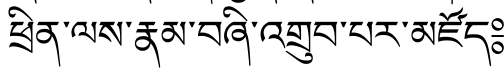

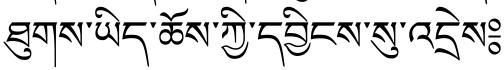

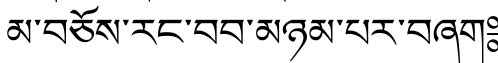

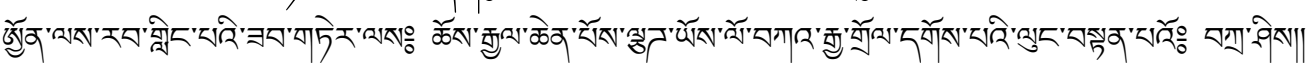

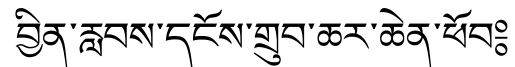

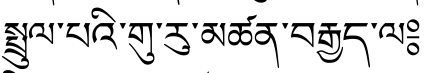

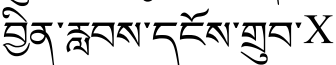

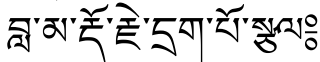

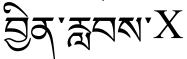

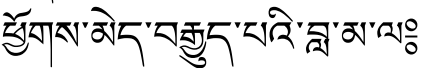

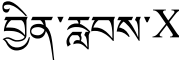

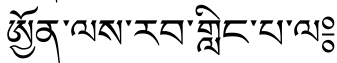

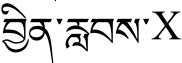

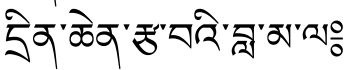

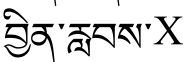

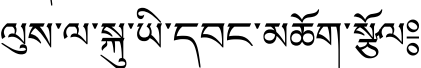

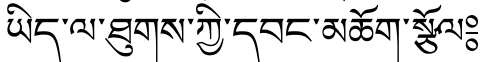

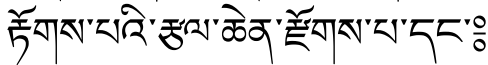

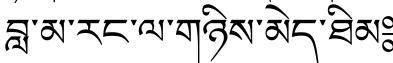

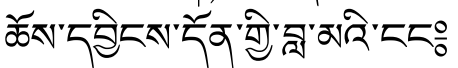

उत'

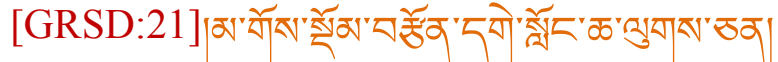

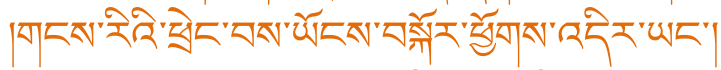

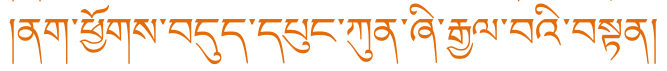

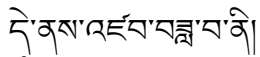

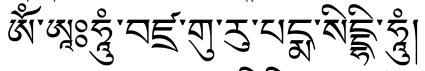

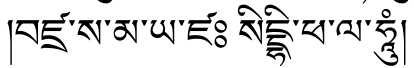

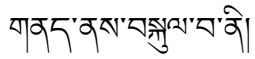

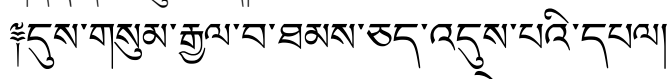

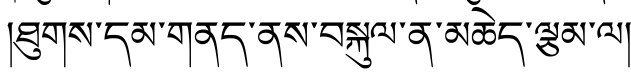

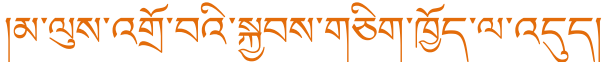

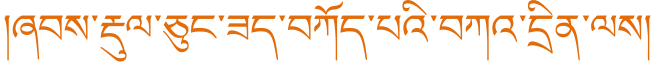

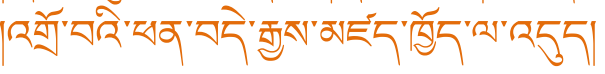

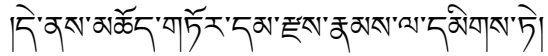

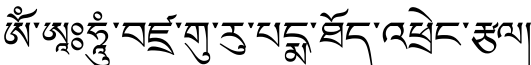

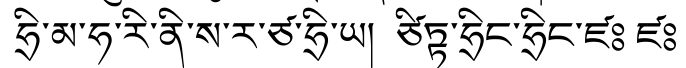

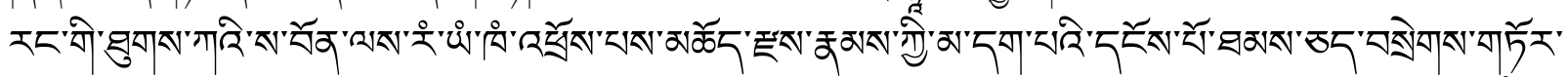

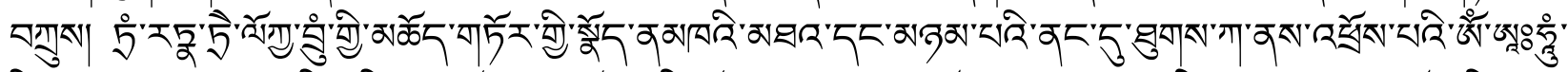

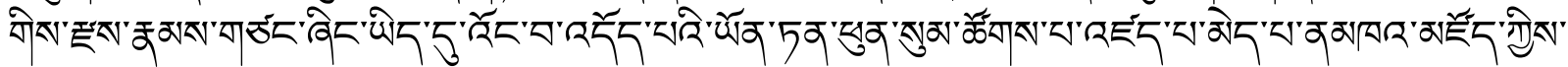

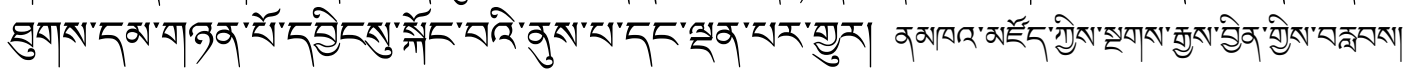




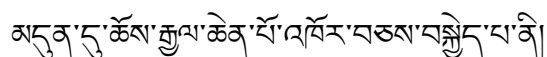

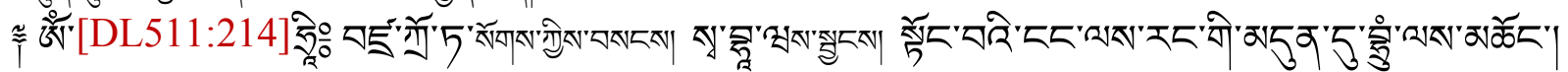

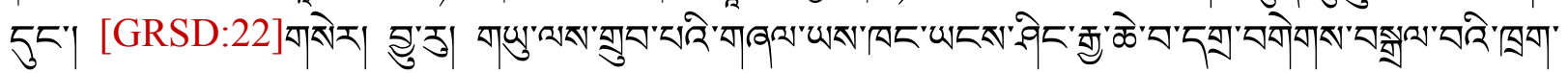

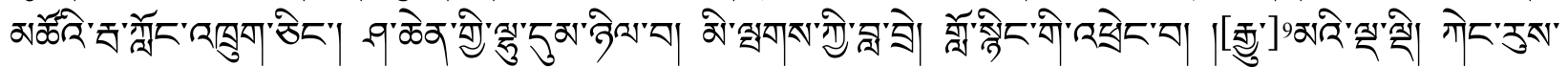

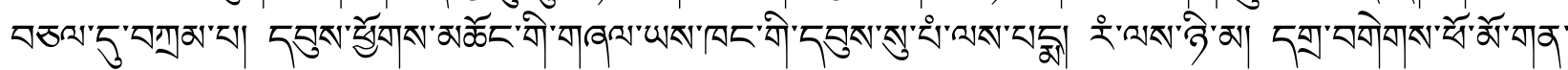

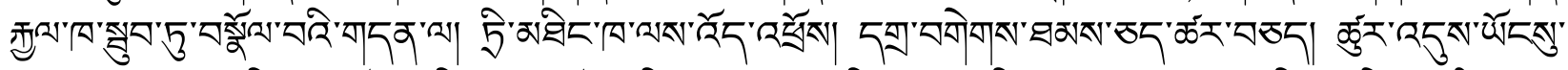

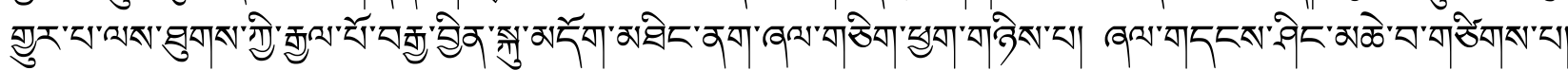

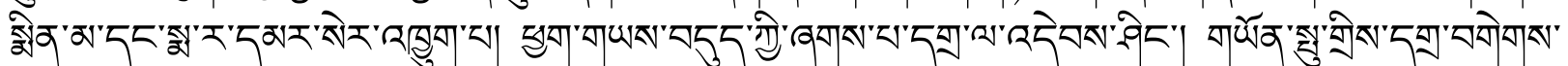

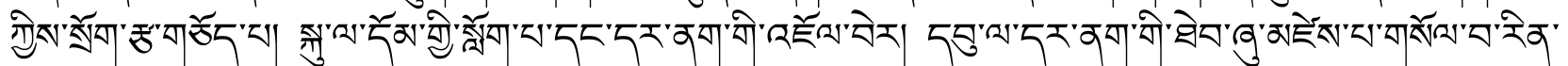

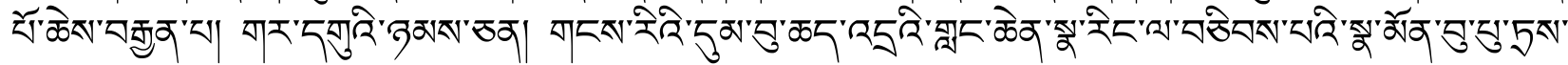

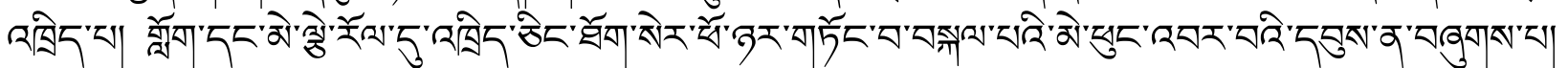

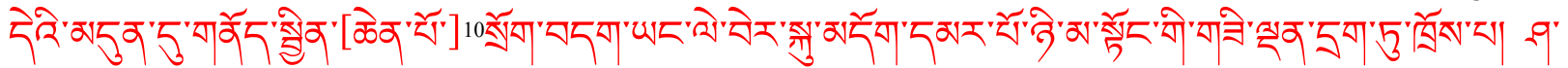

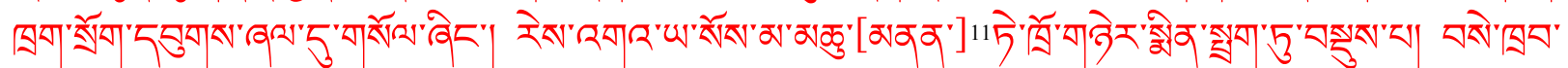

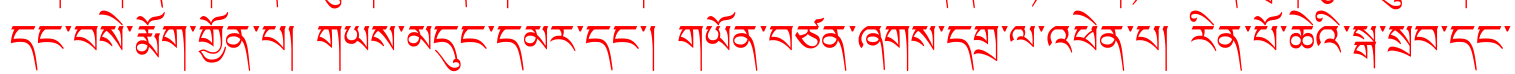

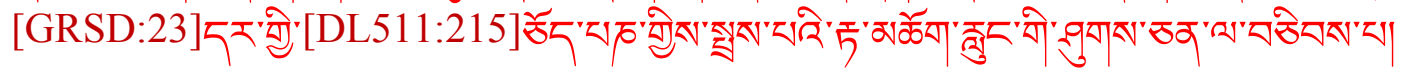

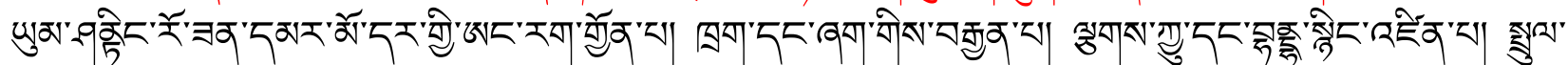

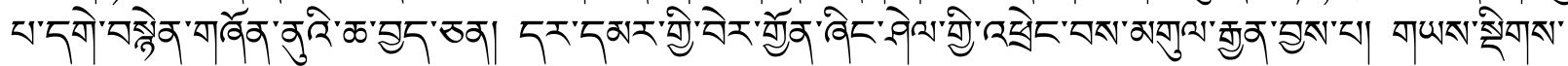

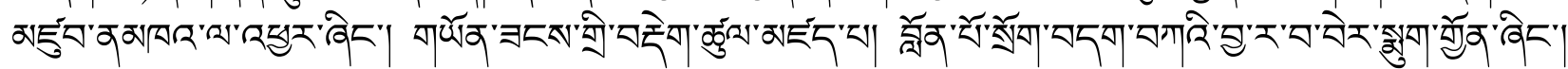

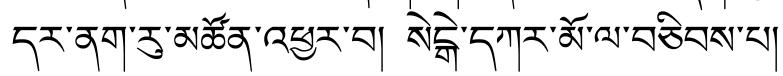

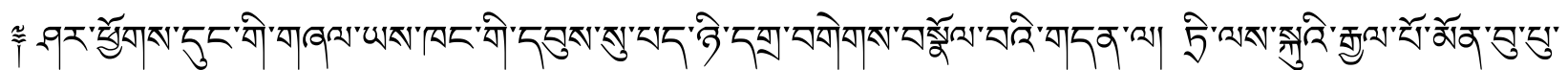

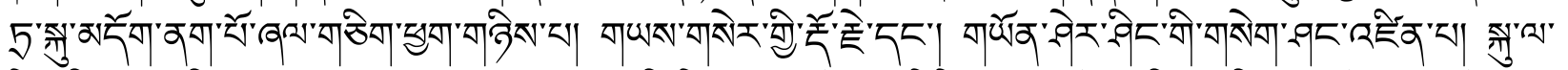

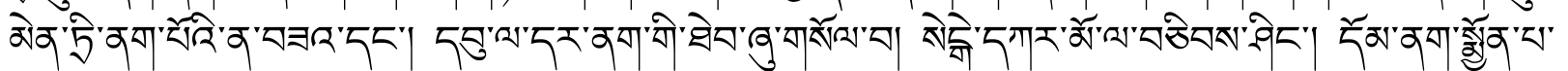

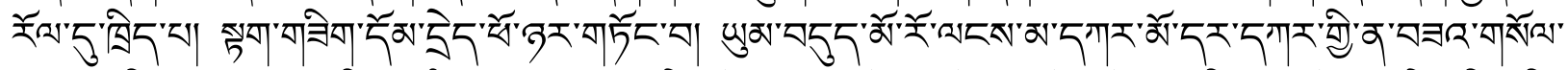

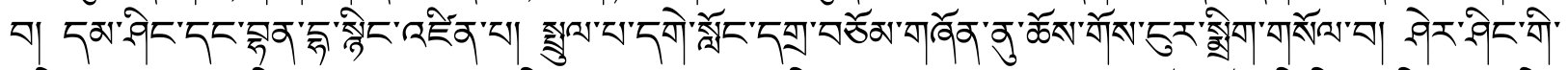

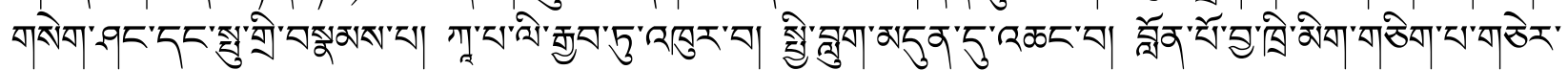

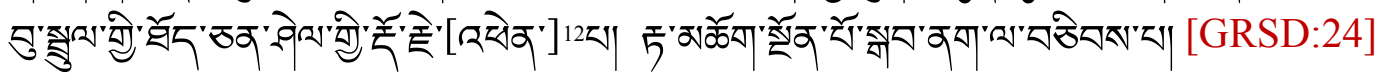

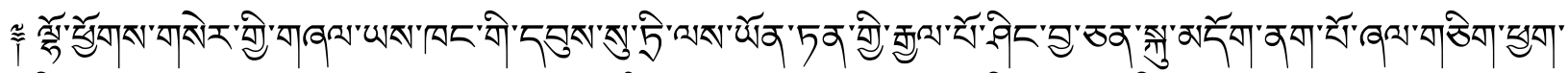

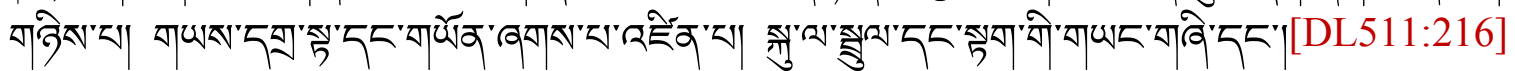

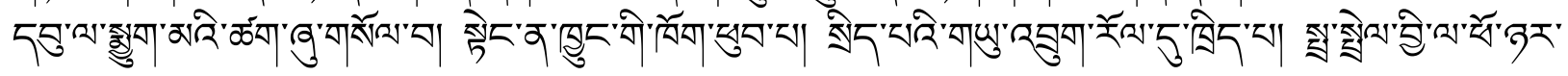

9 DL511: कु'

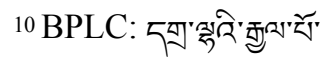

11 BPLC: অন্ডब

12 DL511: रहेत्र 


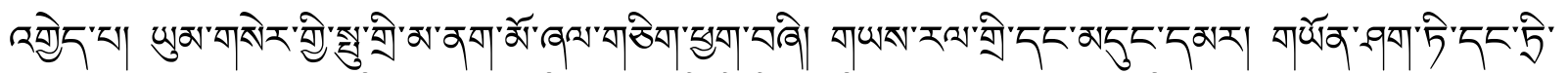

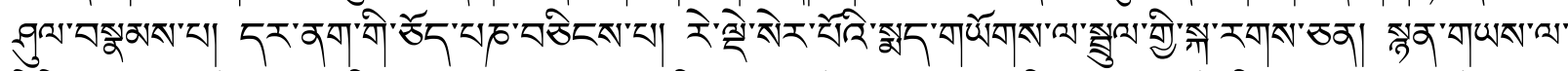

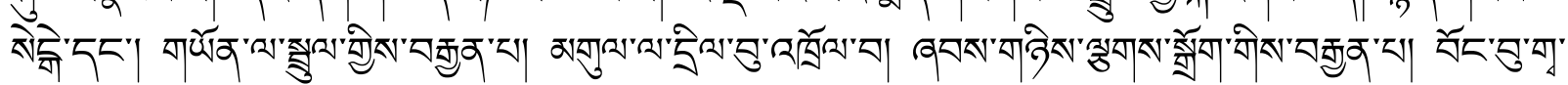

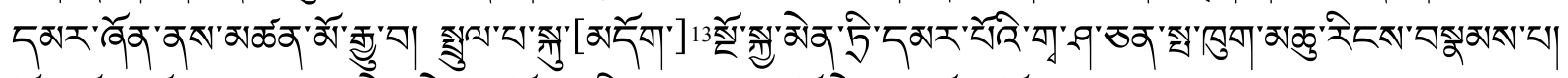

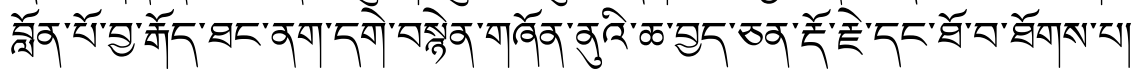

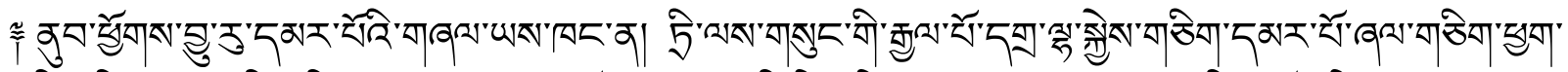

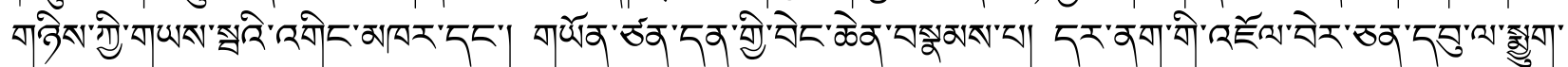

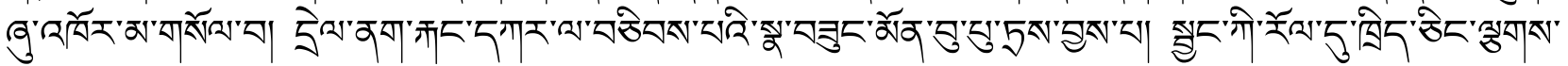

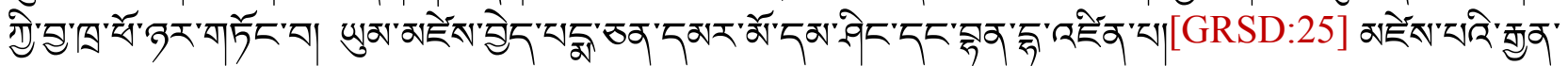

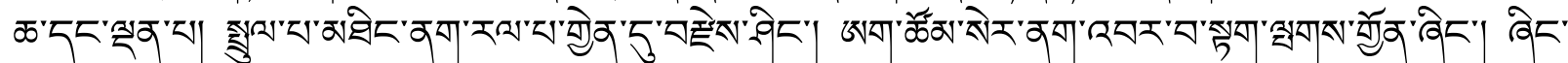

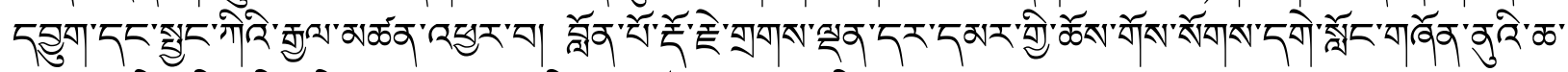

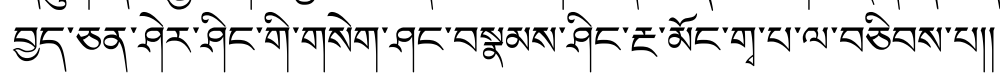

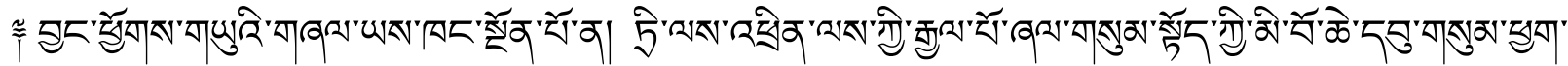

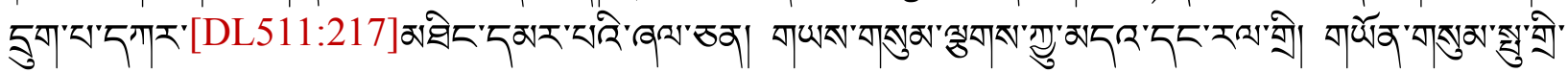

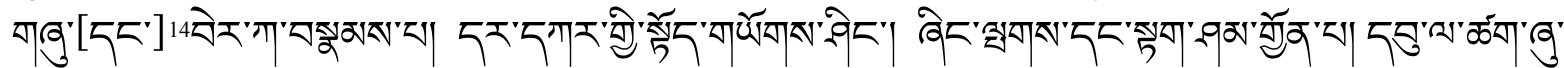

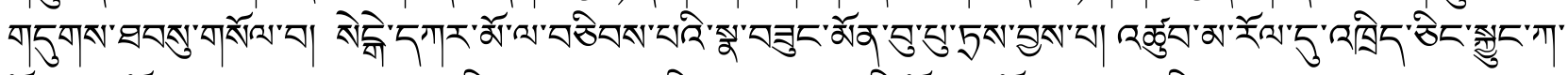

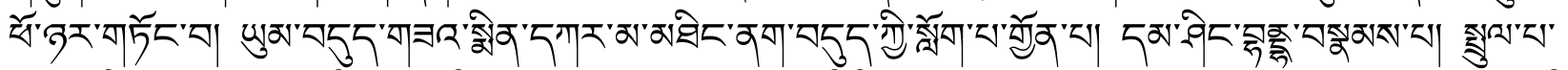

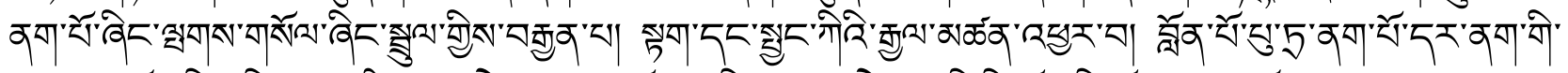

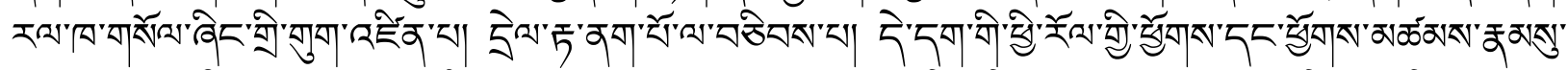

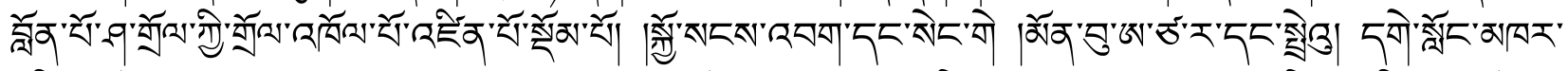

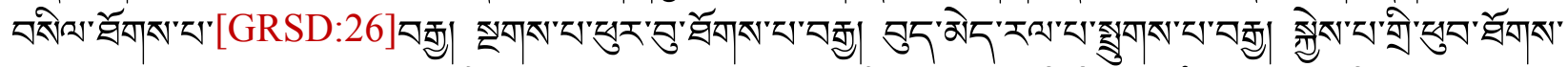

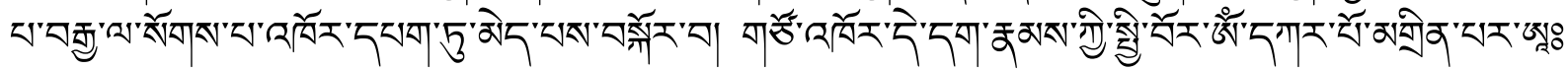

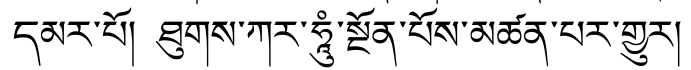

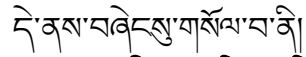

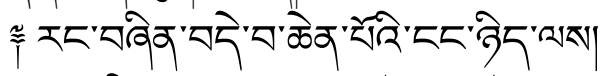

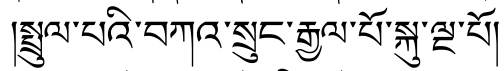

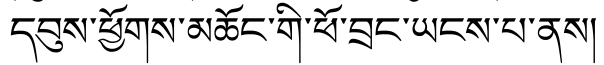

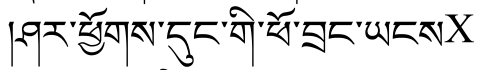

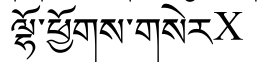

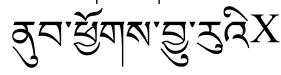

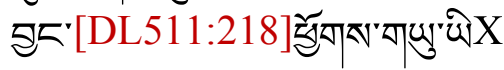

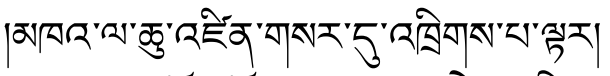

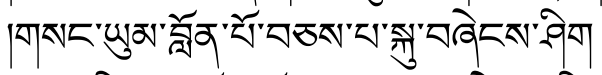

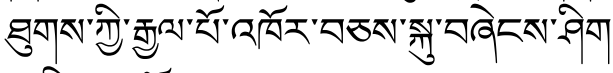

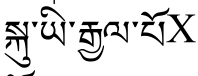
येन्व $5 \bar{X}$ बातुर बे रझ्षेक्वार

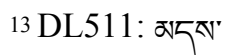

14 DL511: omitted. 


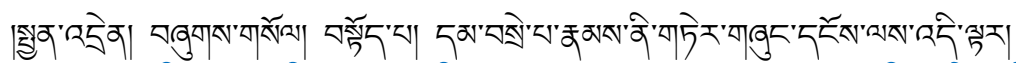

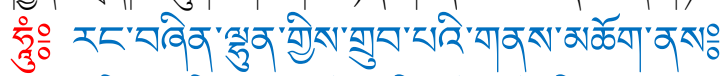

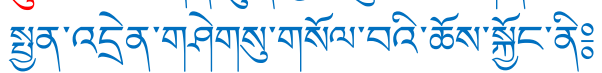

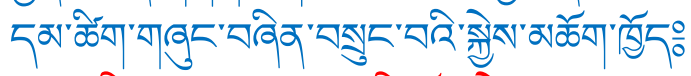

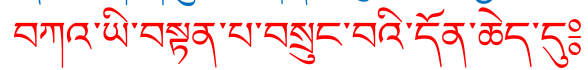

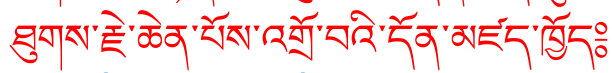

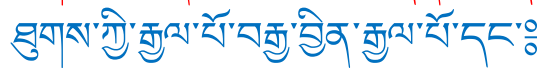

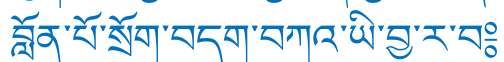

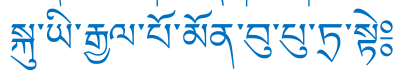

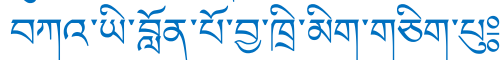

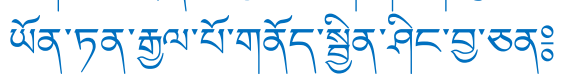

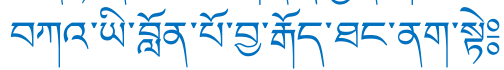

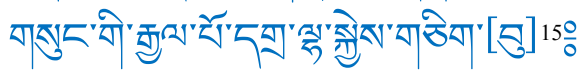

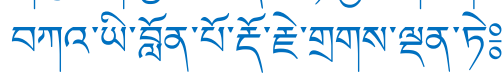

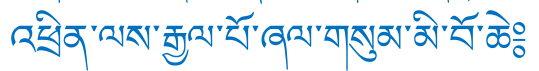

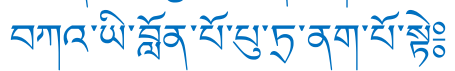

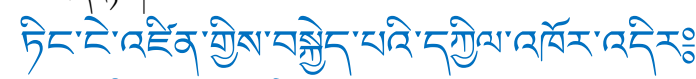

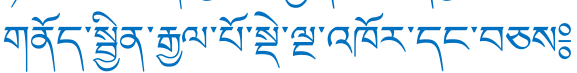

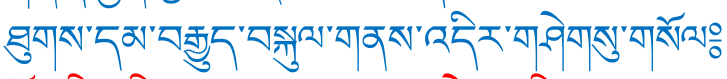

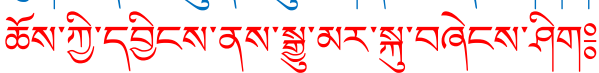

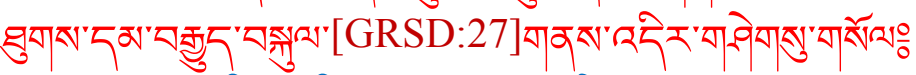

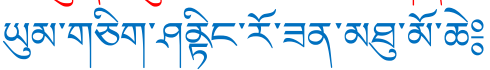

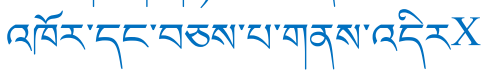

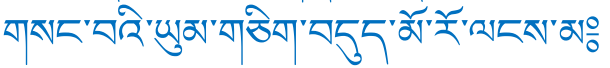

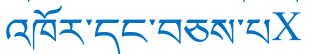

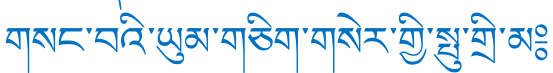

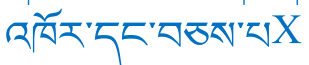

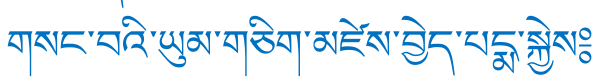

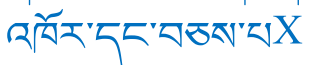

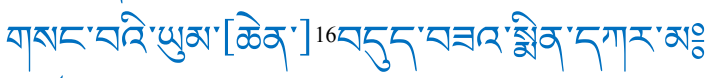

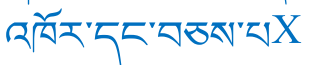

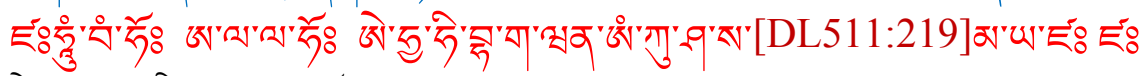

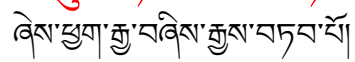

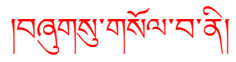

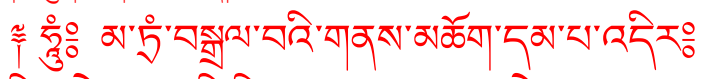

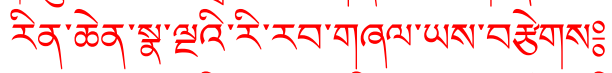

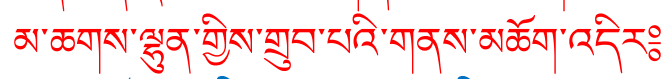

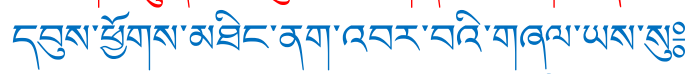

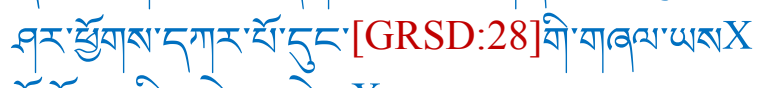

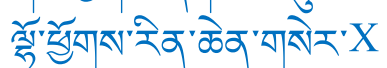

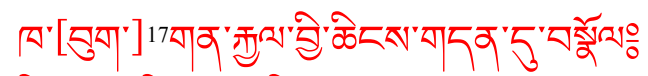

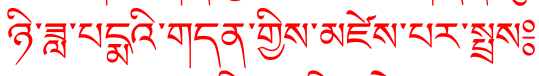

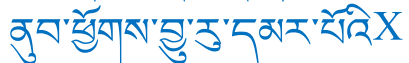

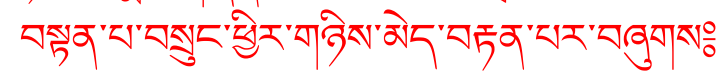

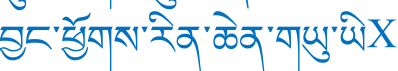

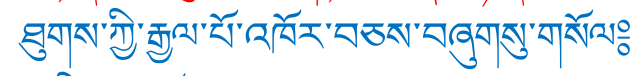

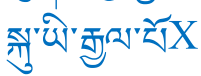

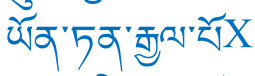

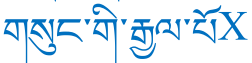

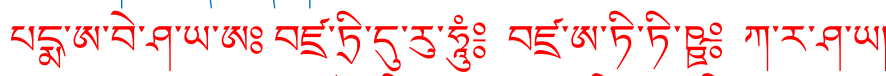

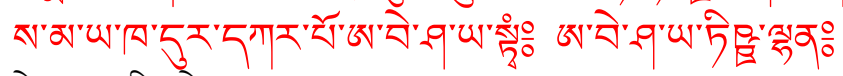

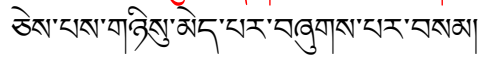

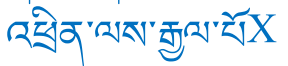

\footnotetext{
15 GRSD:59: 䒕

16 GRSD:60: उेषा"

${ }^{17}$ BCPC:416: same; GRSD:60: 점'
} 


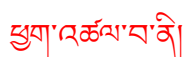

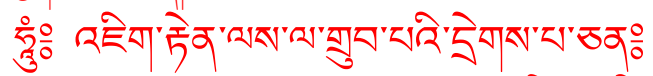

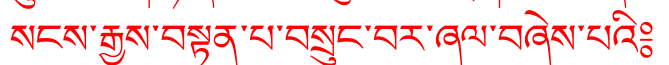

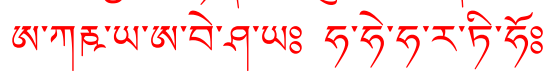

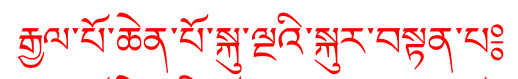

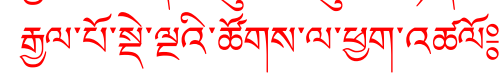

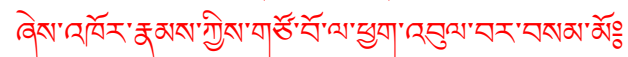

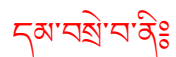

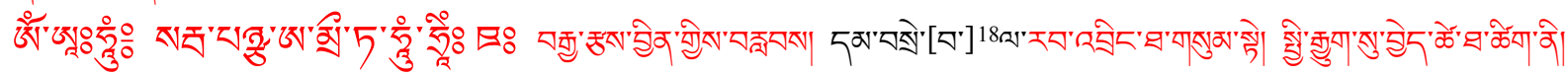

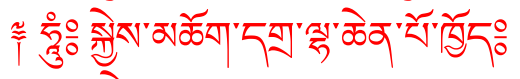

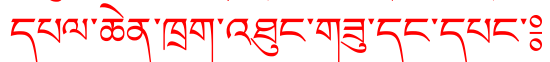

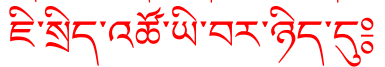

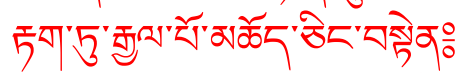

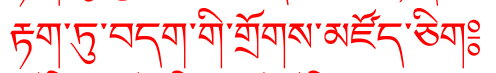

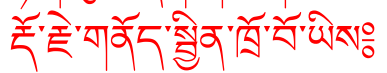

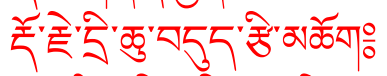

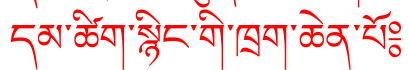

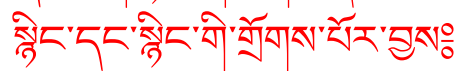

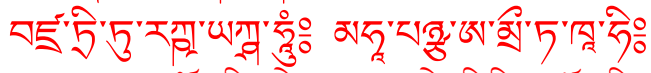

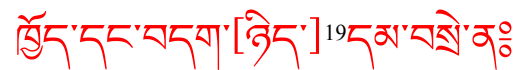

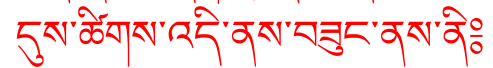

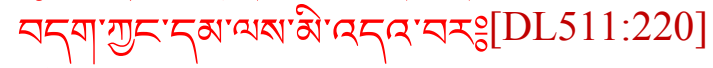

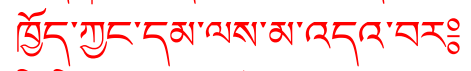

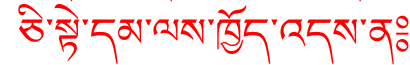

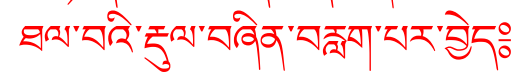

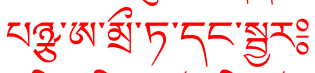

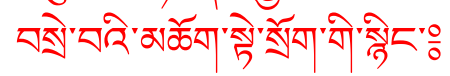

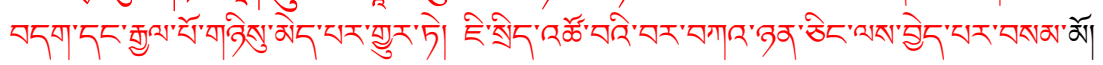

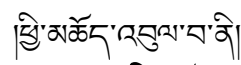

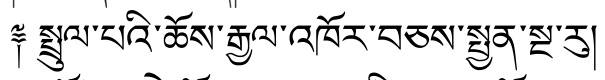

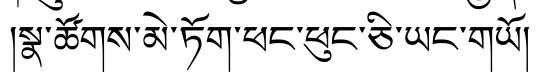

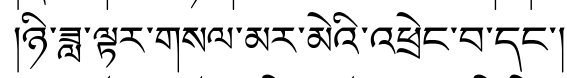

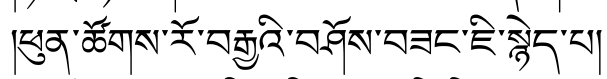

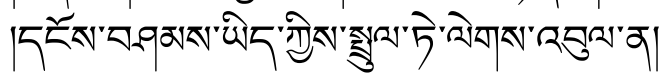

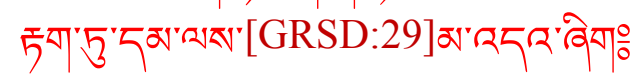

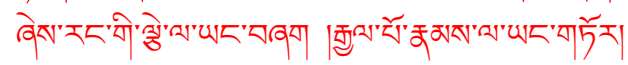

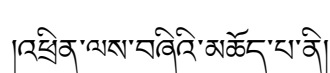

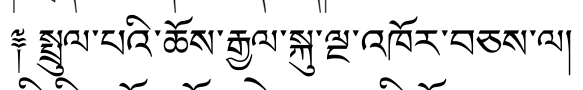

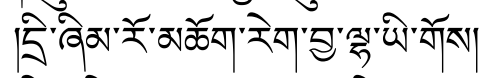

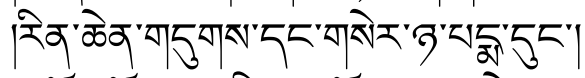

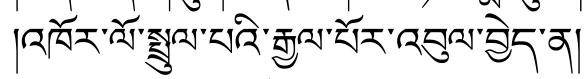

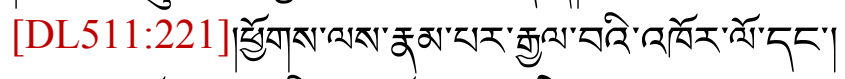

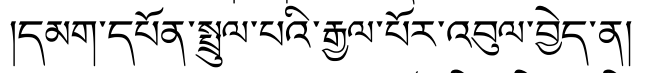

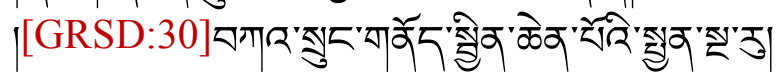

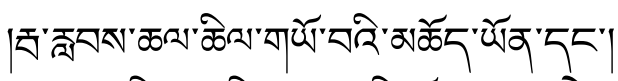

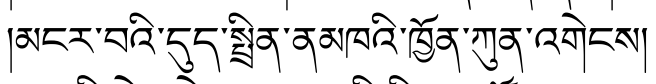

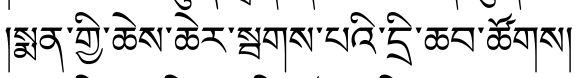

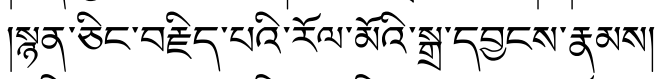

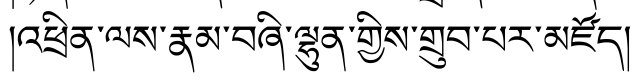

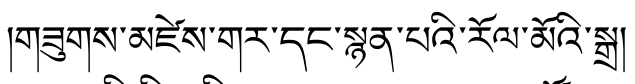

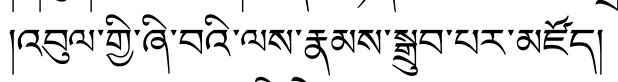

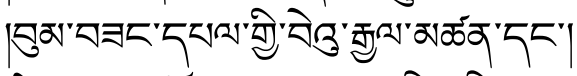

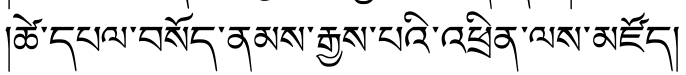

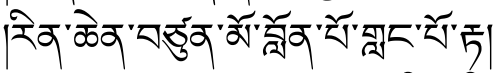

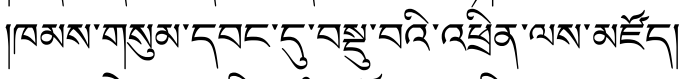

|

18 DL511: omitted.

19 DL511: बानेत" 


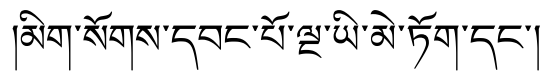

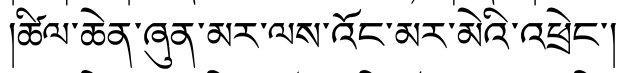

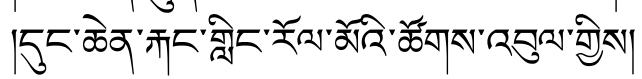

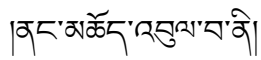

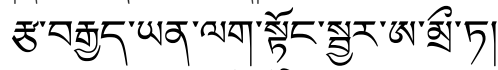

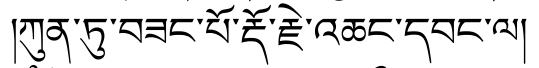

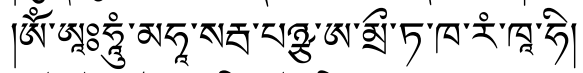

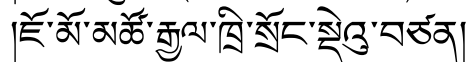

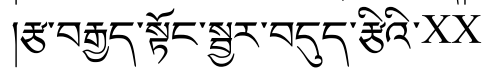

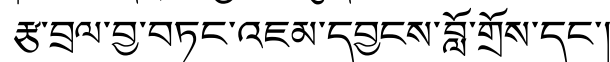

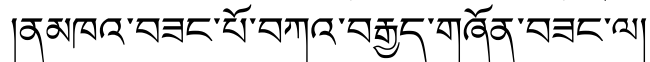

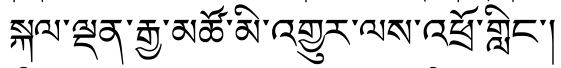

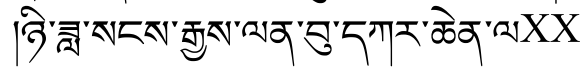

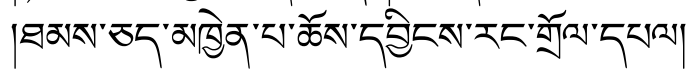

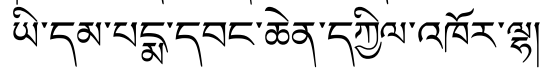

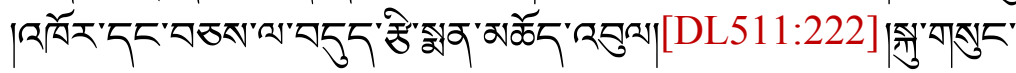

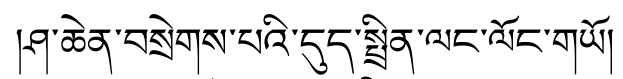

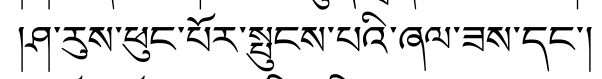

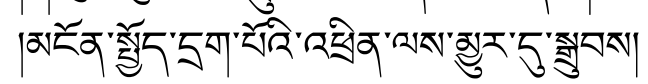

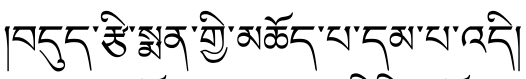

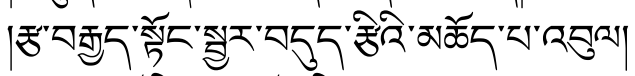

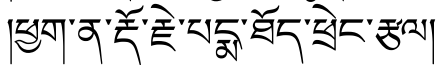

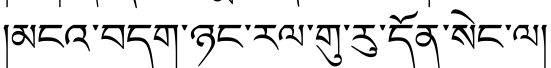

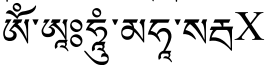

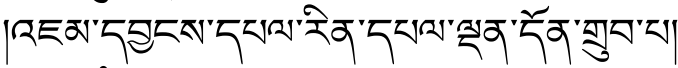
छX ڤँำ

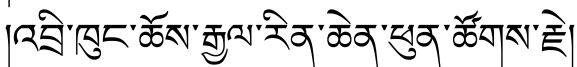

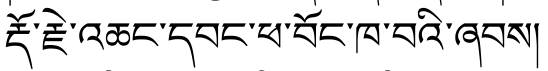

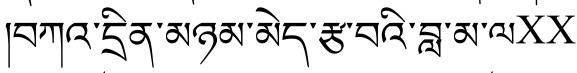

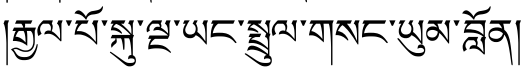

[GRSD:31]20

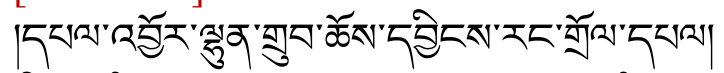

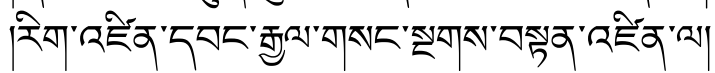

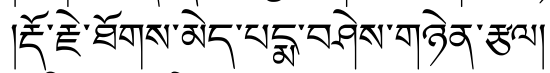

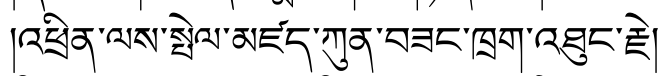

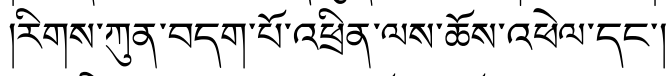

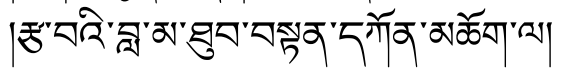

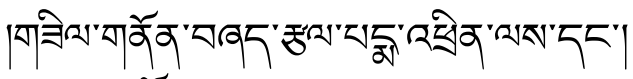

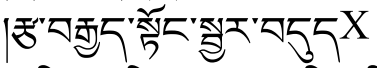

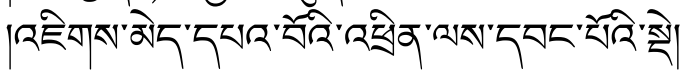

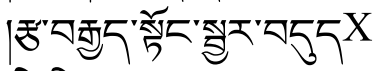

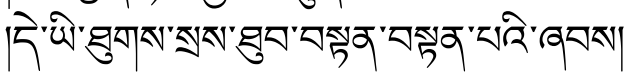

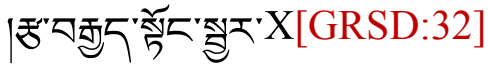

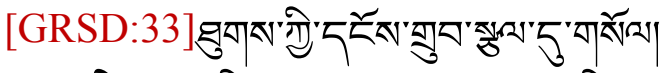

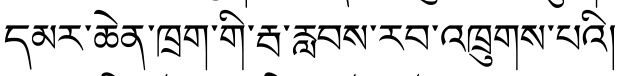

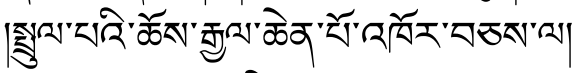

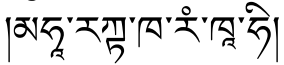

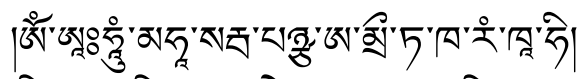

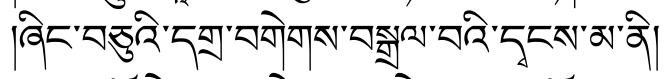

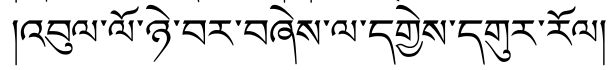

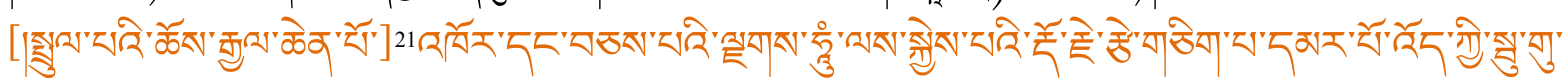

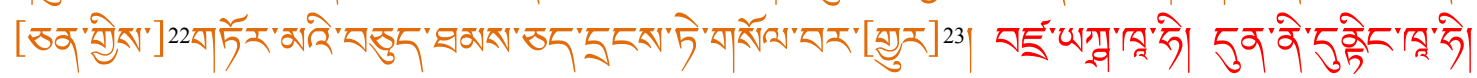

20 GRSD pages 31-32 also consist of an extraneous folio that was clearly added. As before (see note 8), the folio is numbered 1 ( $g c i g)$ and is placed here between folios 14 (bcu bzhi) verso and 15 (bco lnga) recto. The script style is likewise noticeably different. This folio contains less than three full lines of text, so the verso (page 32) is blank. The contents of this folio are not found in the DL511 edition of this text.

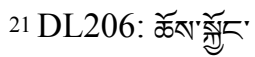




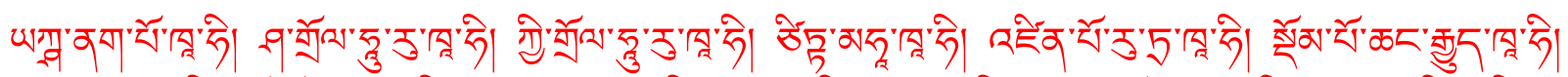

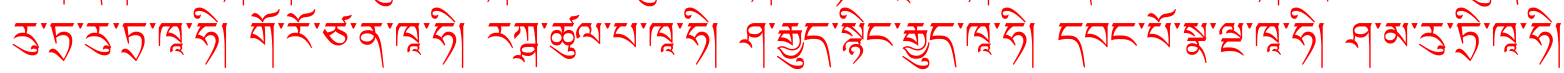

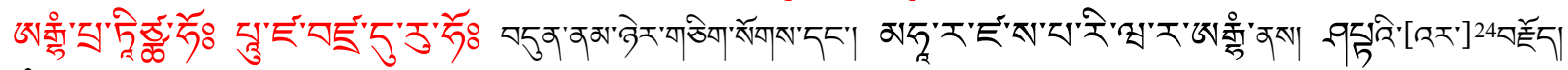

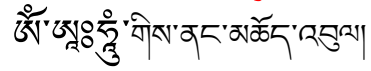

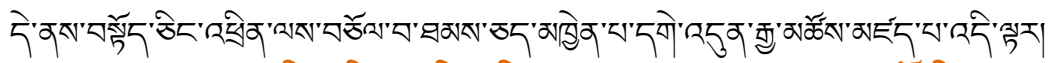

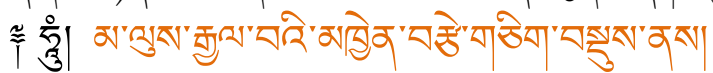

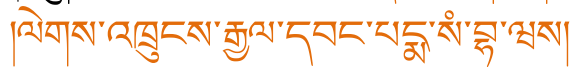

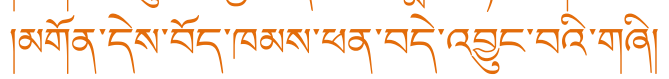

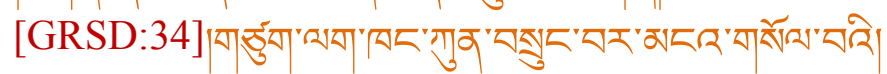

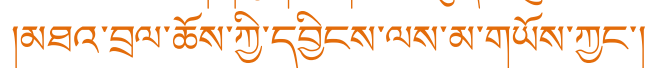

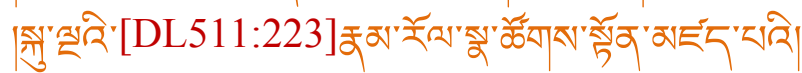

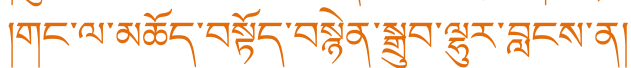

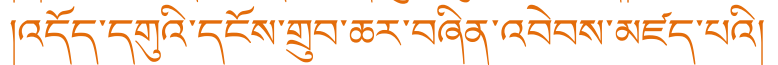

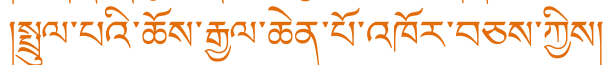

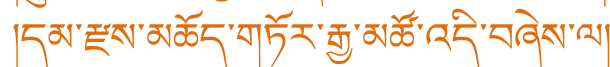

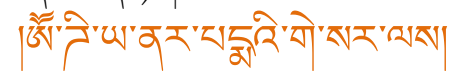

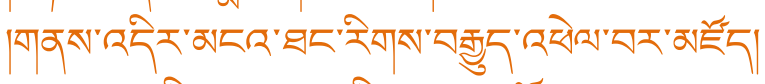

|ㅁ'ய

[1 quatrain is skipped]

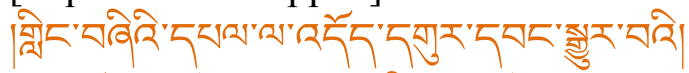

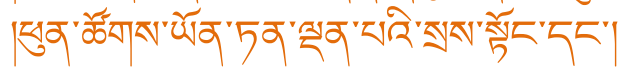

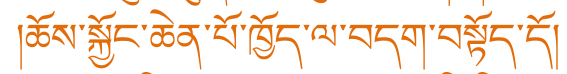

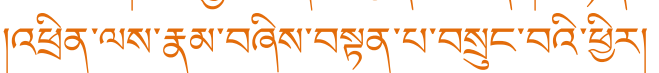

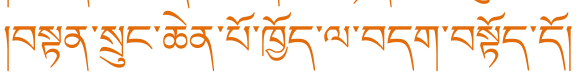

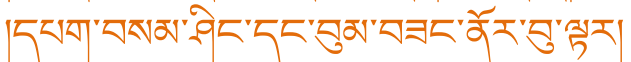

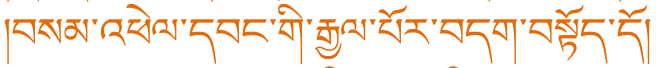

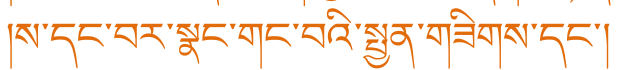

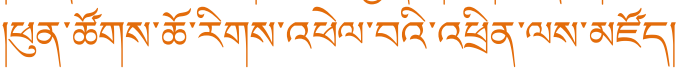

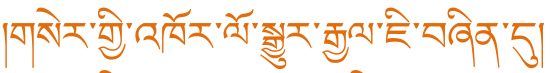

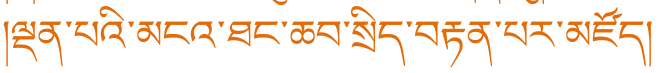

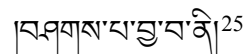

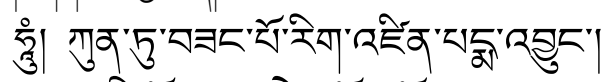

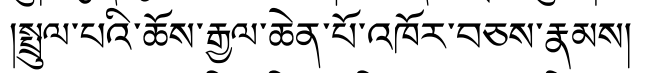

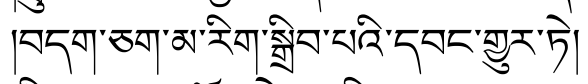

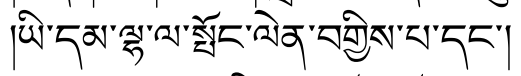

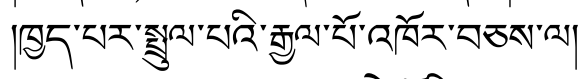

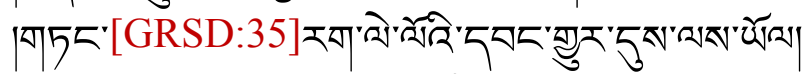

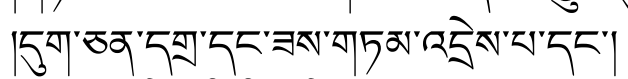

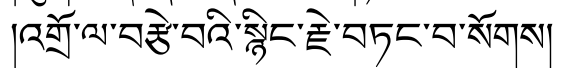

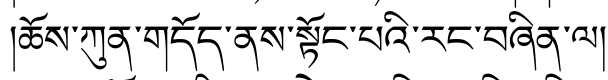

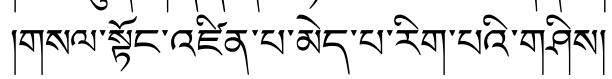

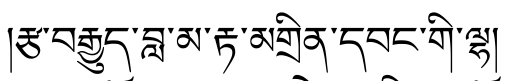

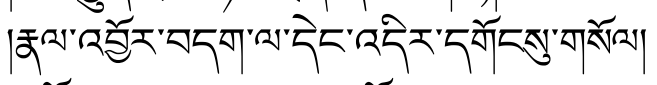

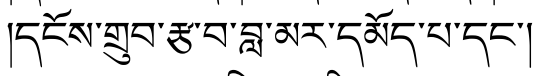

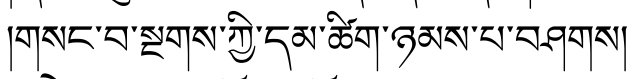

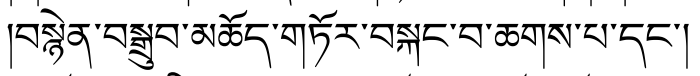

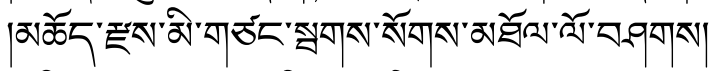

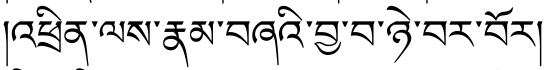

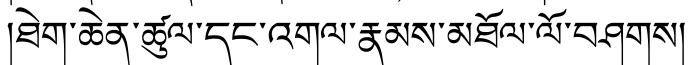

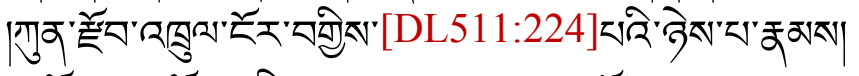

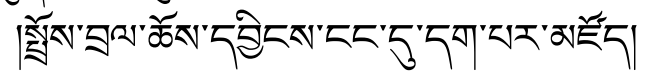

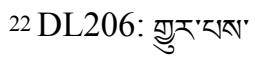

23 DL206: omitted.

24 DL511: $\square$ X'

25 This confessional prayer has been reproduced in a ritual dedicated to the Dharma King Ta-ok (Tib. Tha 'og chos rgyal), the central protector deity of Sera Monastery's Mé College; see Lama Gurudeva 1982, pp.513-514. 


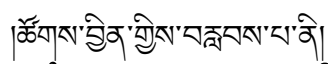

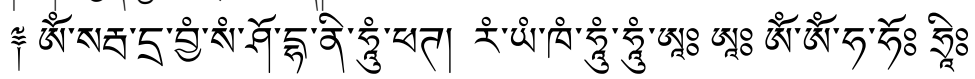

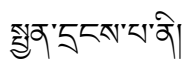

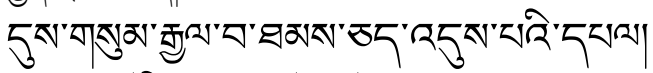

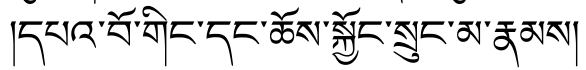

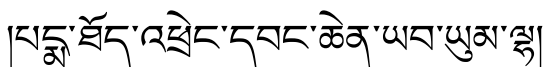

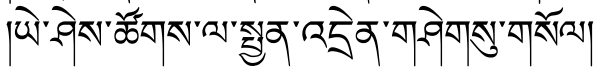

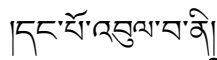

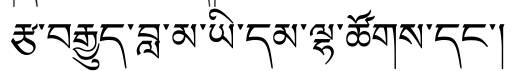

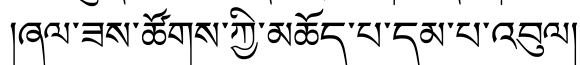

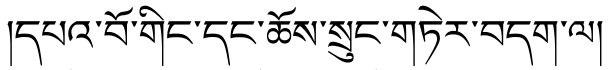

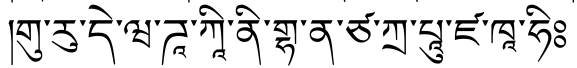

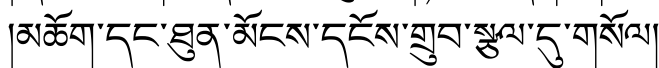

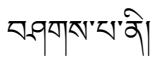

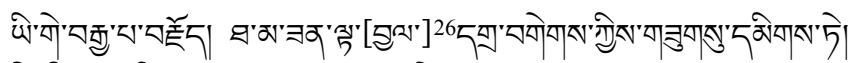

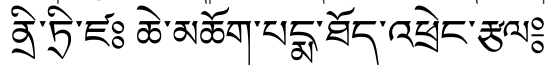

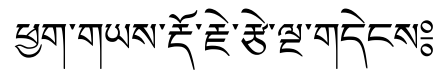

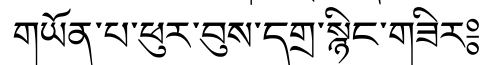

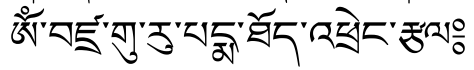

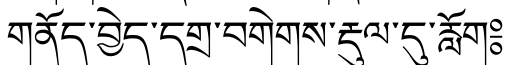

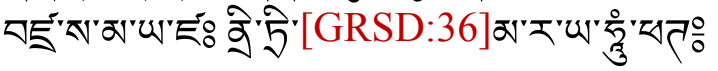

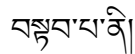

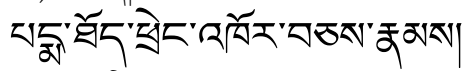

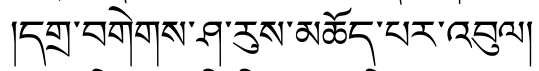

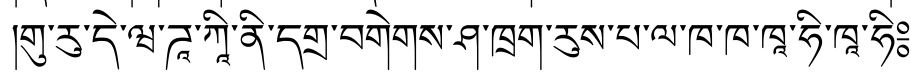

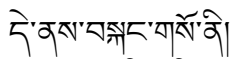

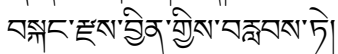

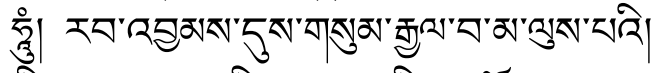

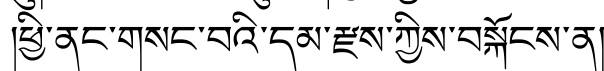

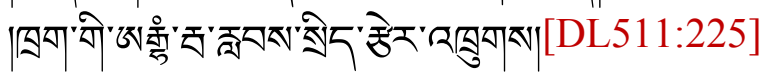

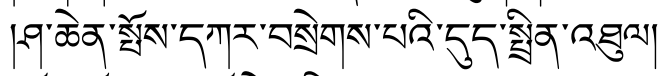

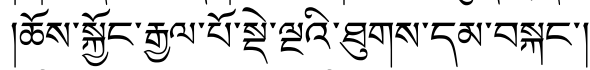

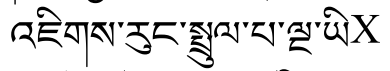

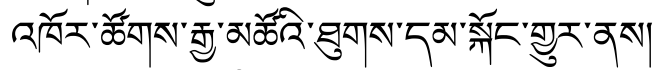

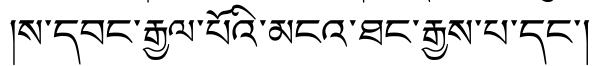

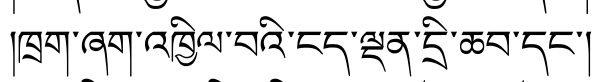

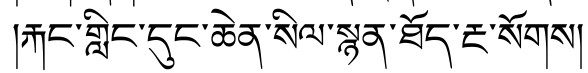

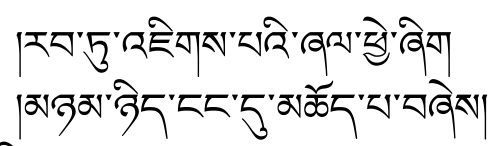

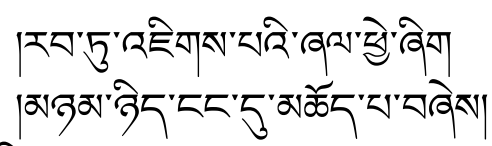

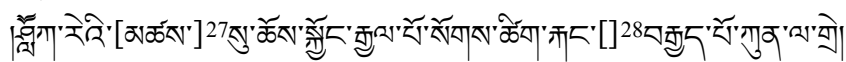

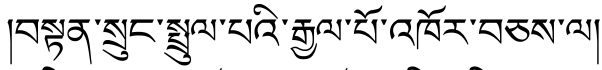

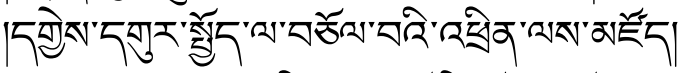

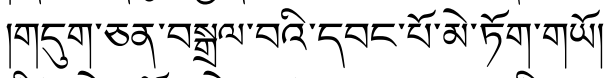

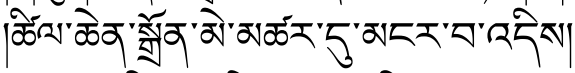

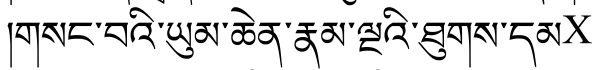

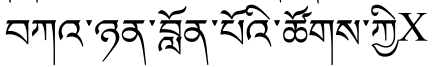

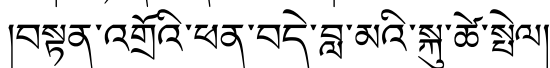

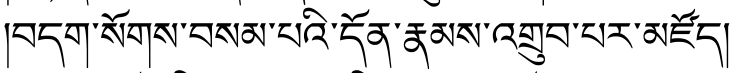

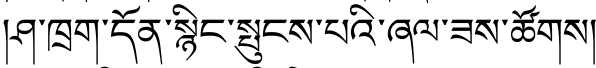

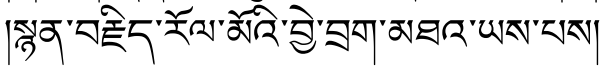

26 DL511: जুख্য 


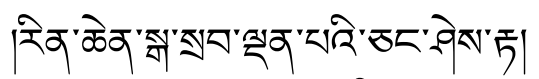

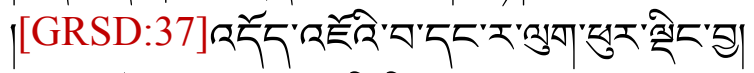

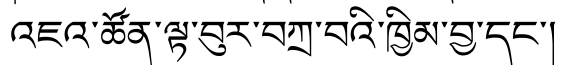

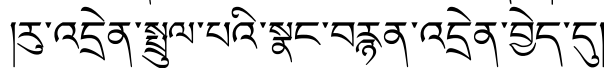

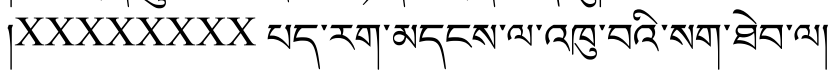

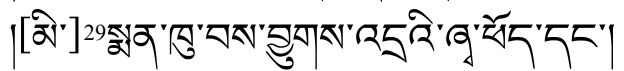

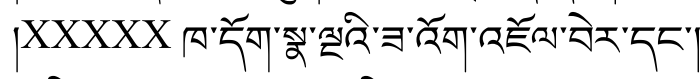

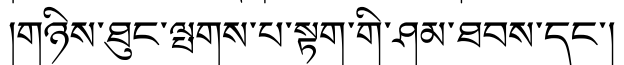

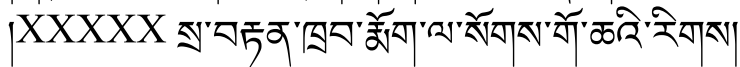

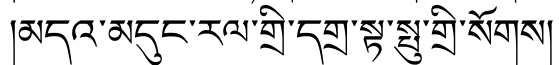

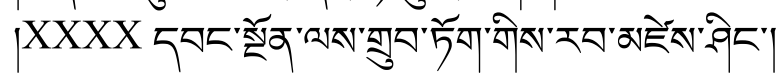

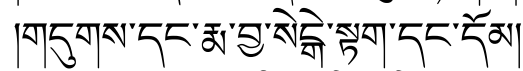

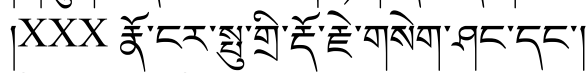

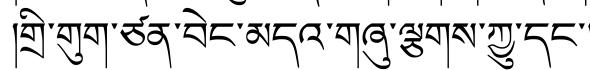

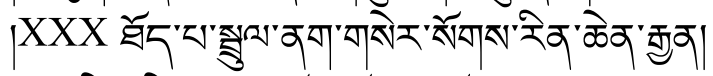

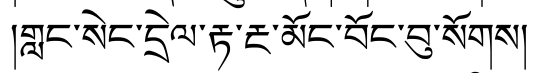

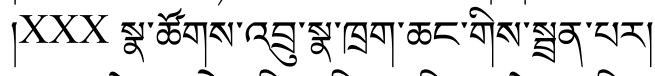

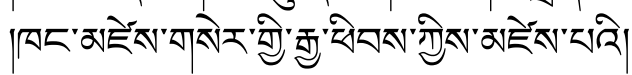

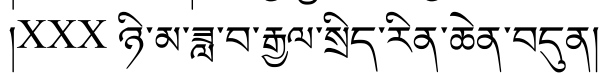

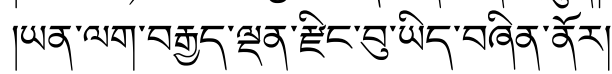

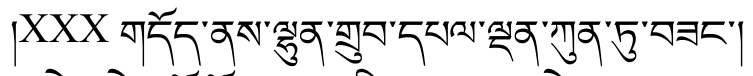

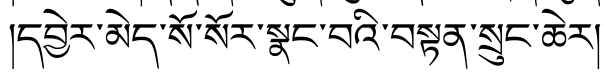

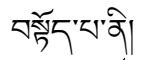

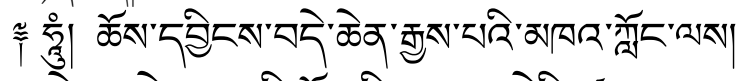

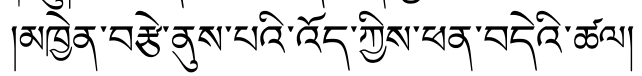

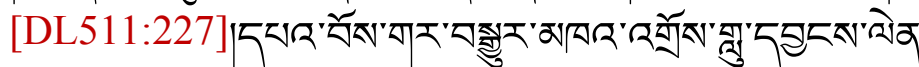

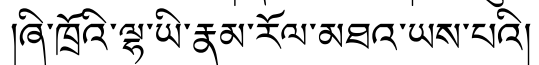

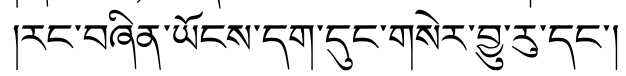

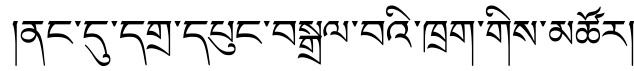

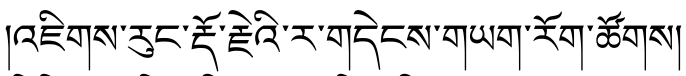

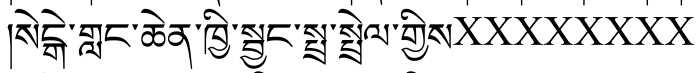

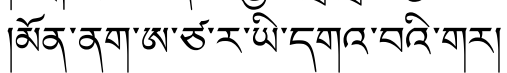

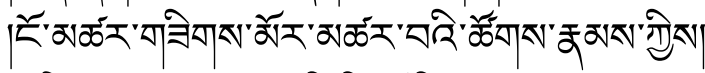

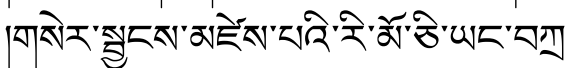

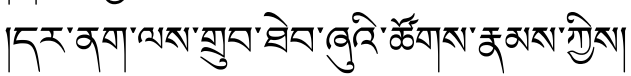

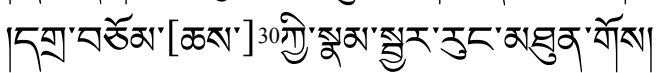

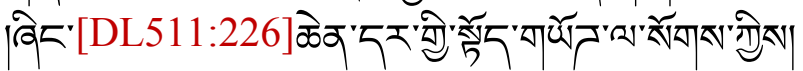

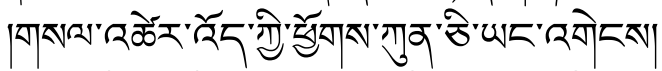

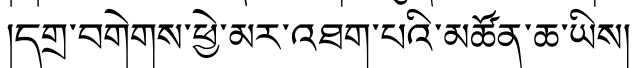

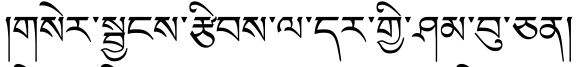

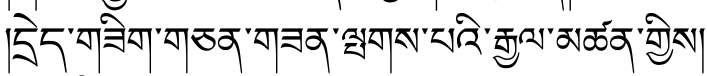

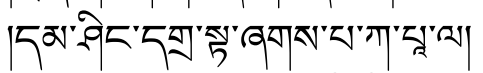

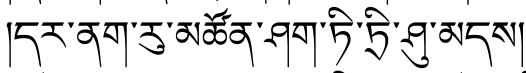

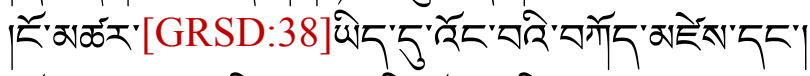

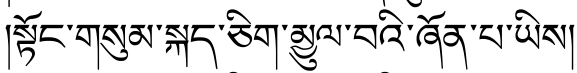

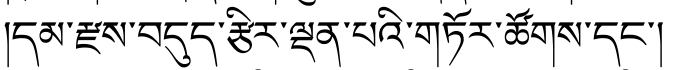

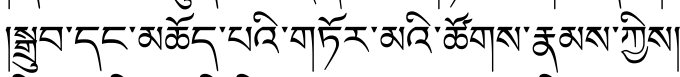

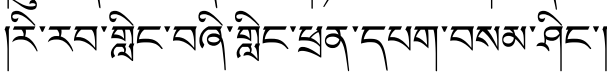

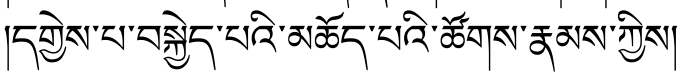

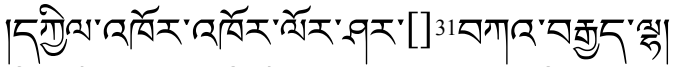

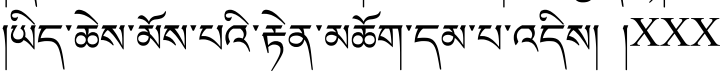

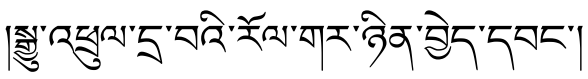

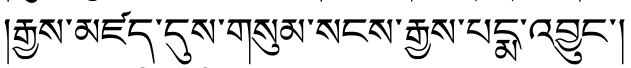

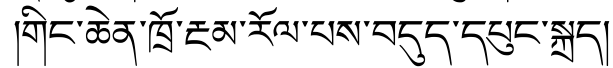

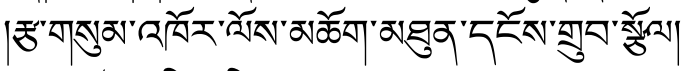

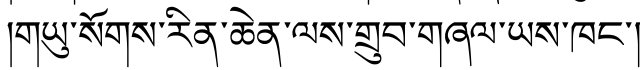

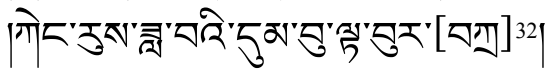

27 DL511: অळனন

28 DL511: ๘"

${ }^{29}$ DL511: ओेषा

30 DL511: केत्र

31 DL511: $\square^{\prime}$ 


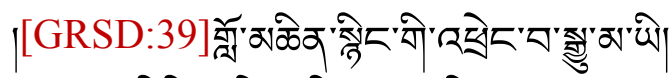

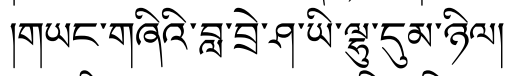

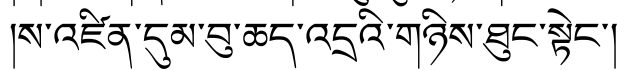

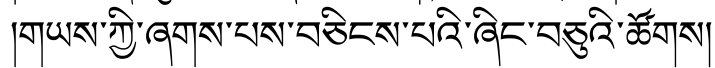

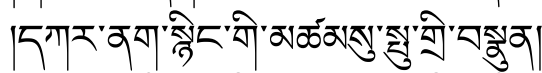

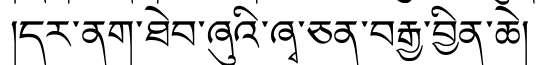

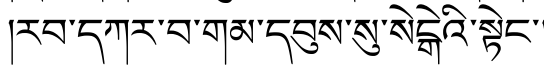

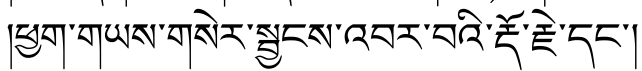

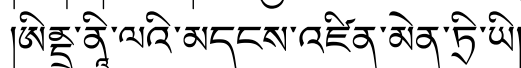

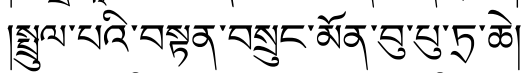

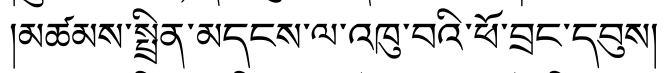

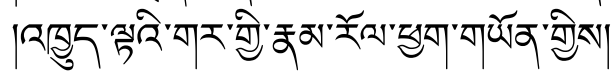

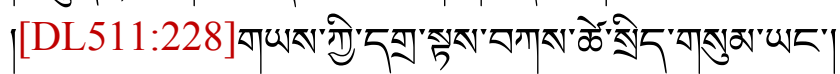

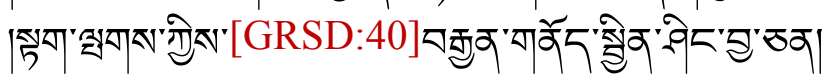

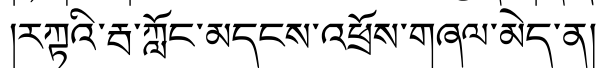

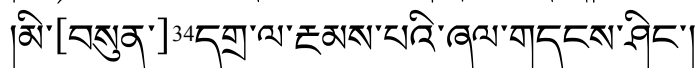

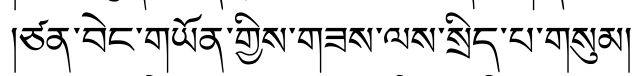

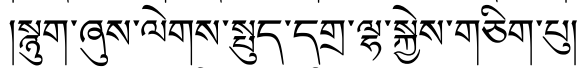

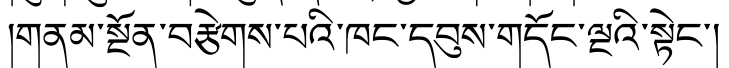

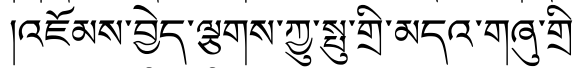

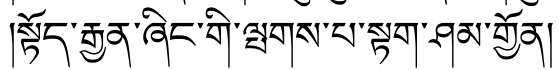

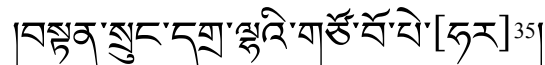

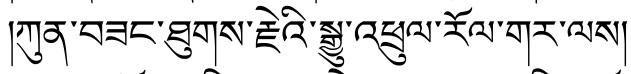

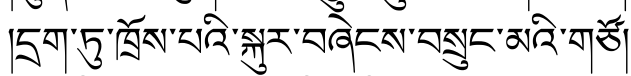

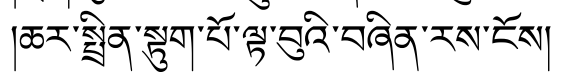

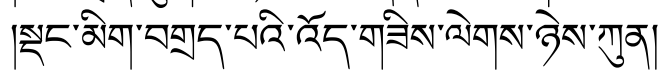

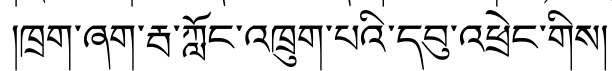

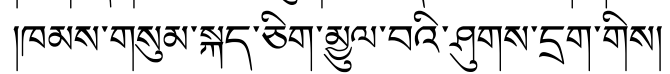

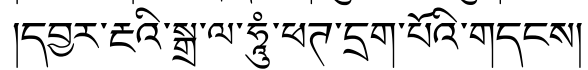

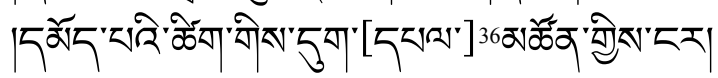

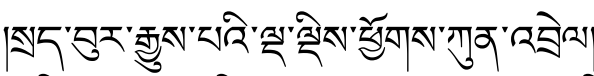

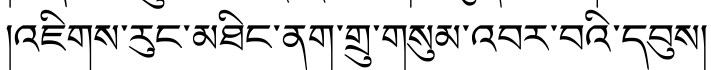

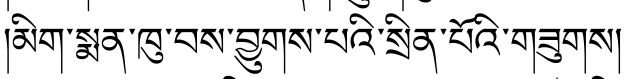

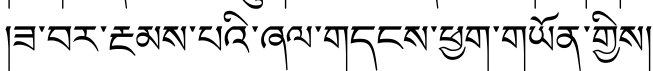

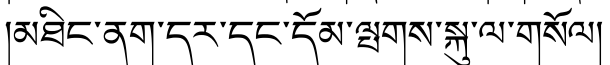

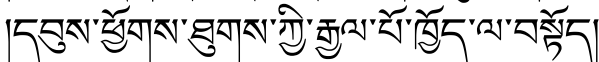

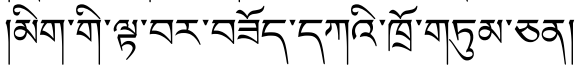

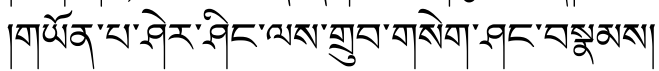

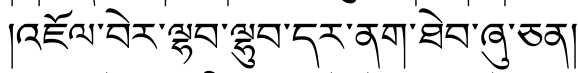

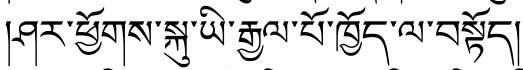

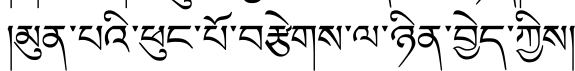

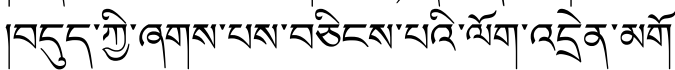

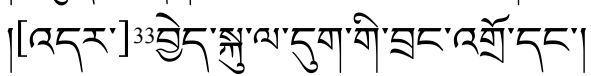

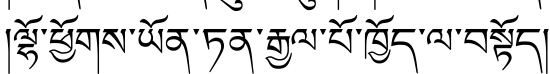

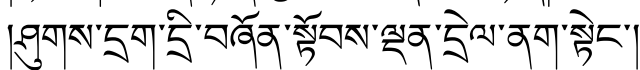

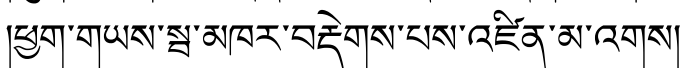

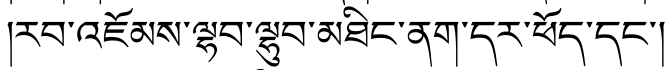

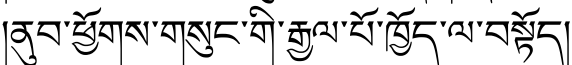

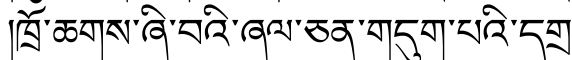

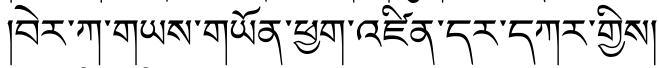

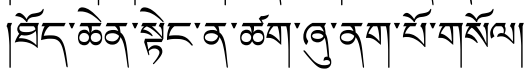

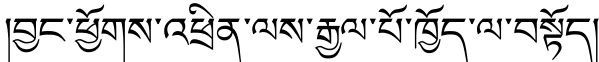

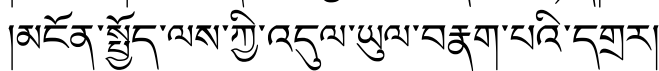

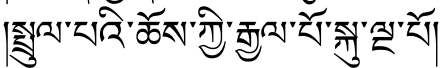

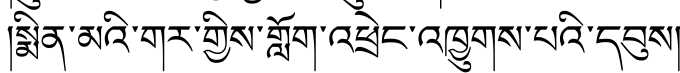

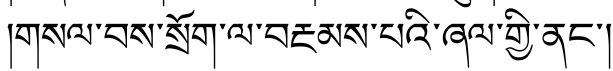

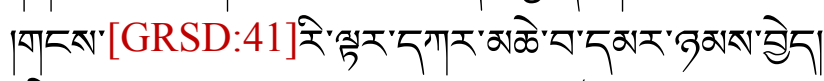

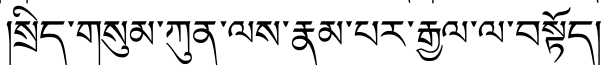

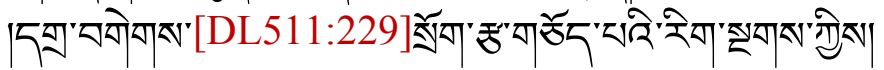

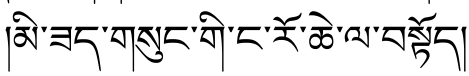

\footnotetext{
32 DL511: 멤

33 DL511: रदेशे

34 DL511: 점

35 DL511: 5x
} 


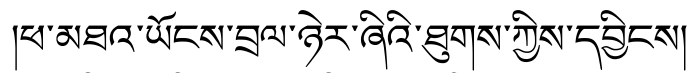

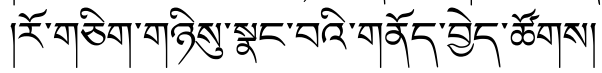

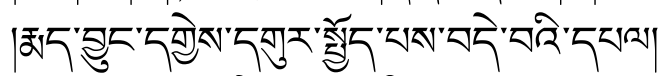

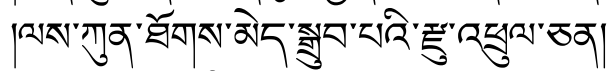

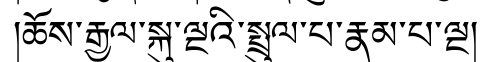

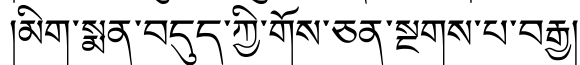

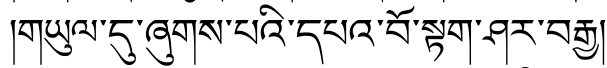

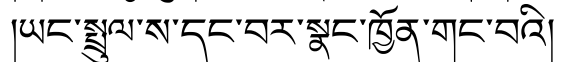

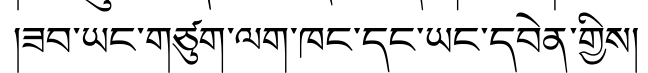

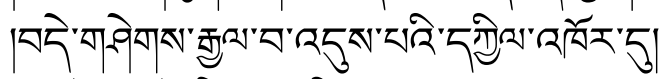

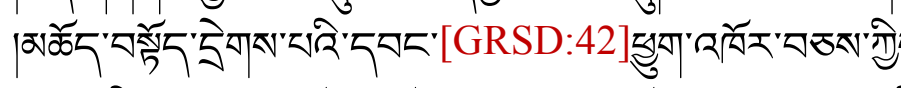

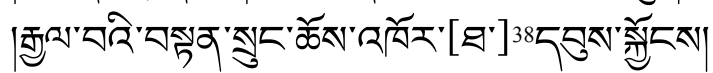

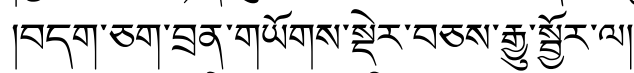

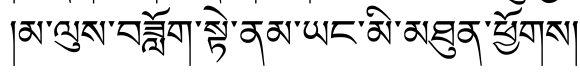

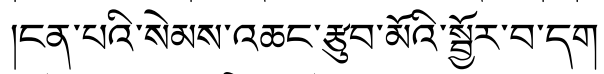

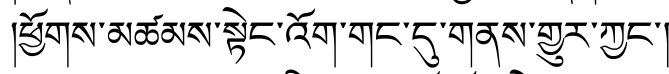

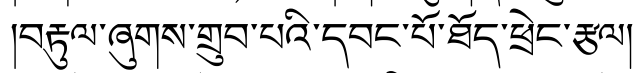

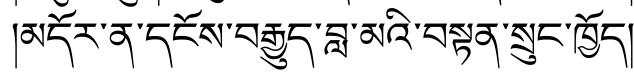

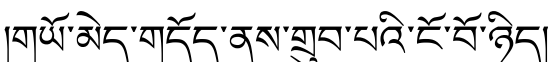

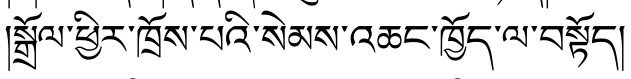

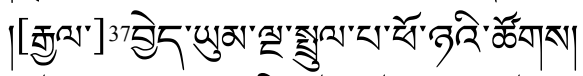

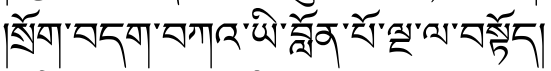

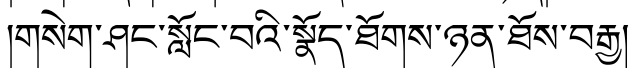

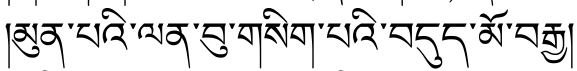

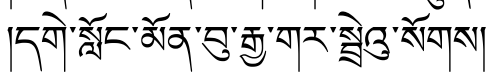

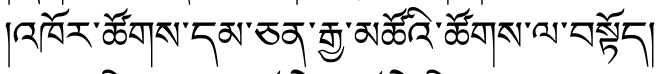

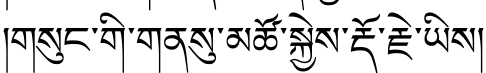

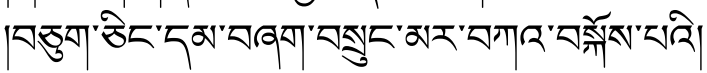

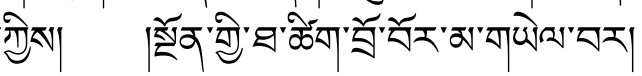

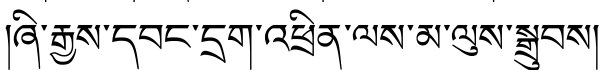

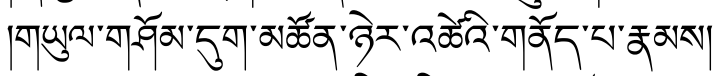

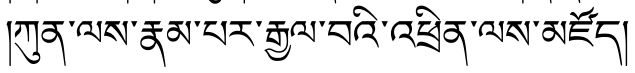

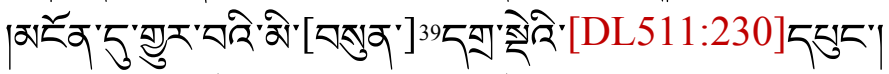

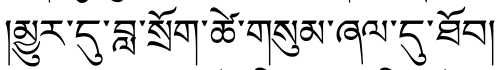

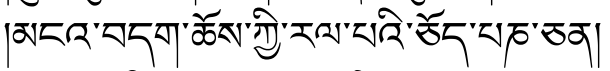

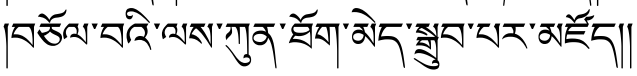

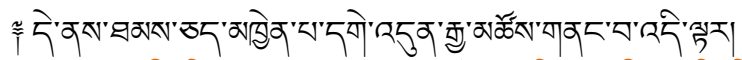

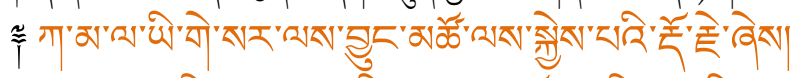

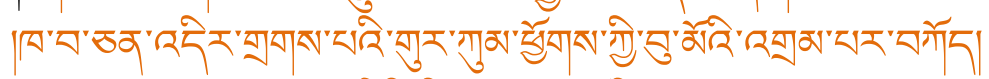

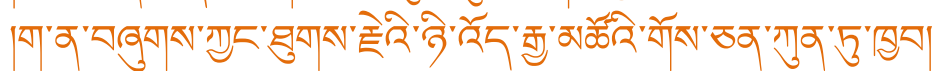

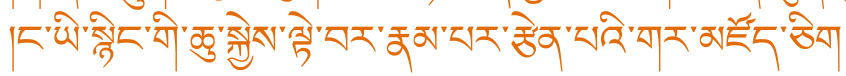

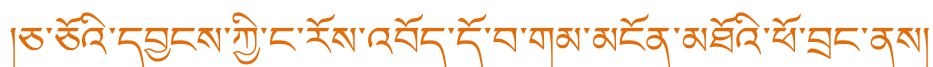

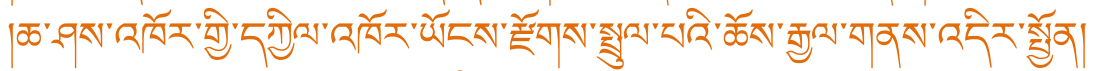

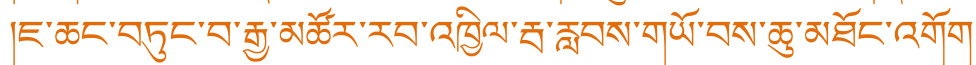

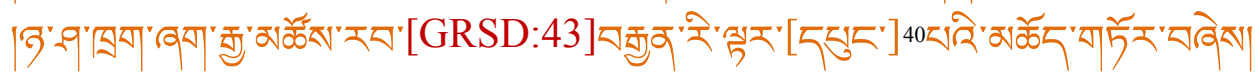

\footnotetext{
36 DL511: โロव2

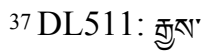

38 DL511: वहR०

39 DL511: অత্যুव

40 DL511: 재저
} 


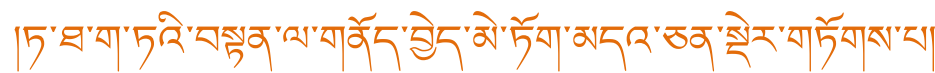

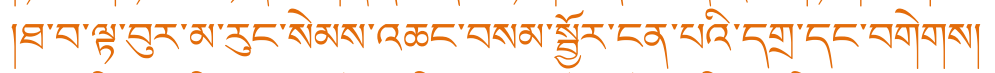

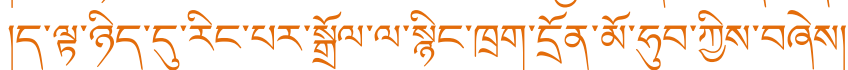

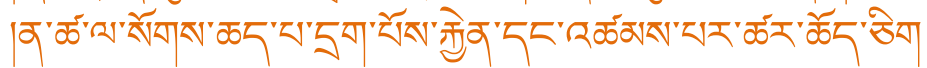

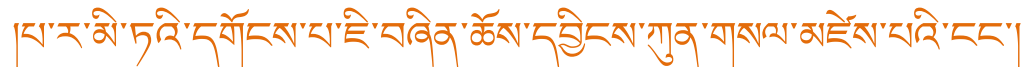

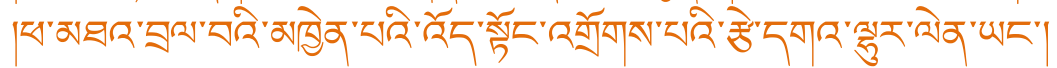

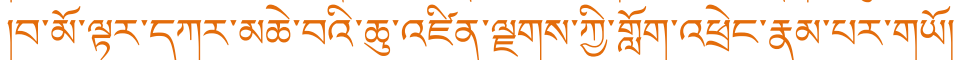

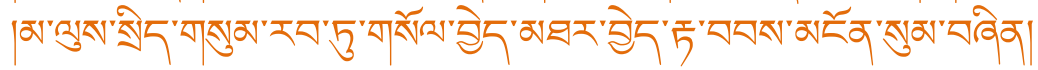

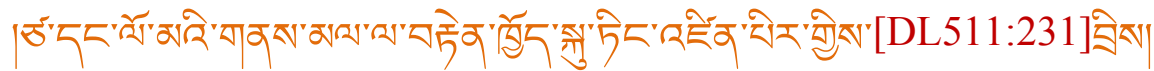

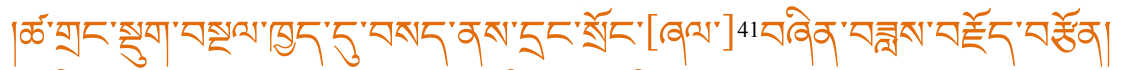

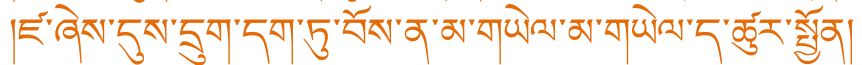

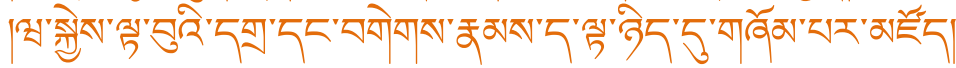

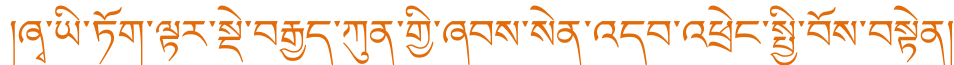

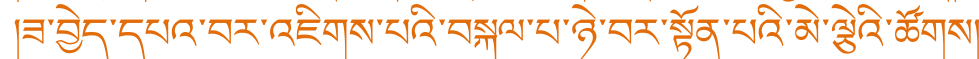

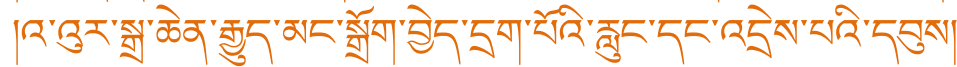

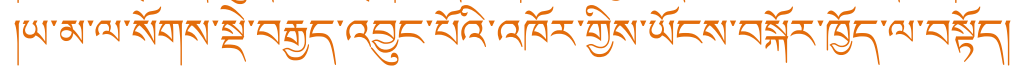

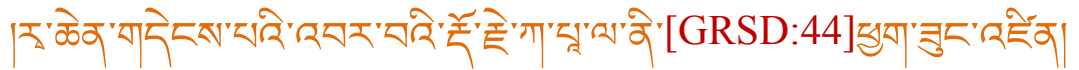

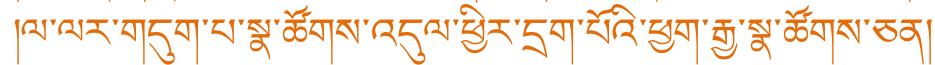

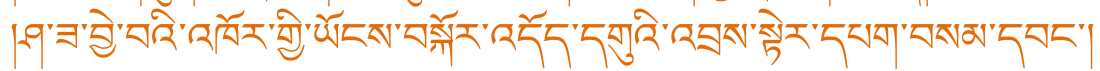

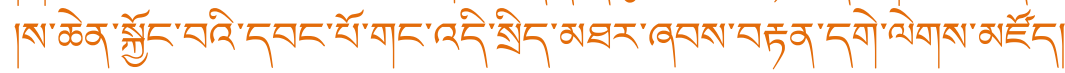

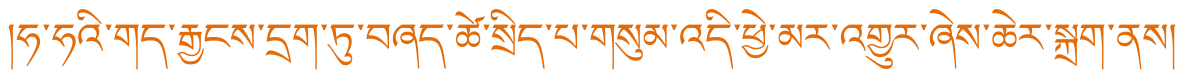

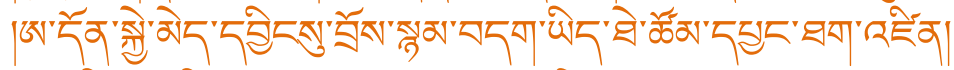

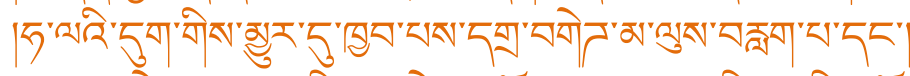

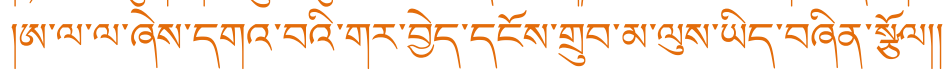

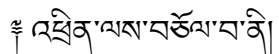

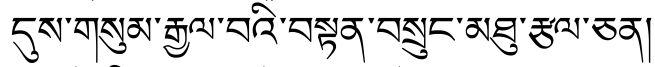

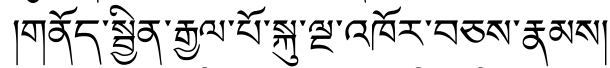

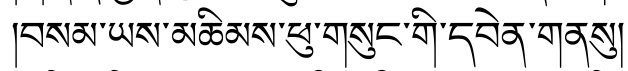

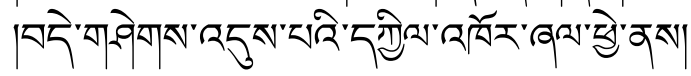

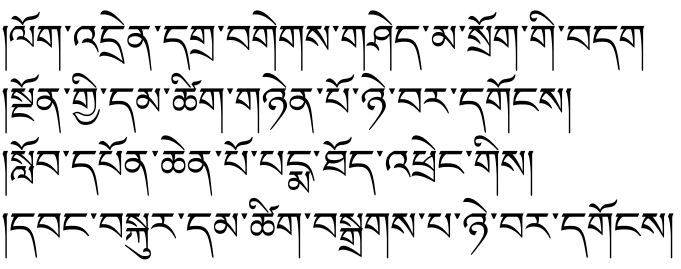

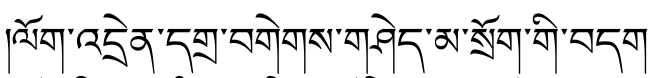

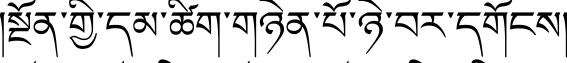

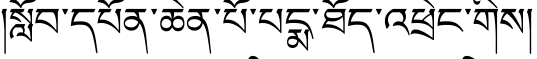

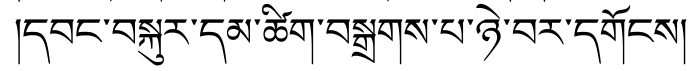

41 DL511: बाबव 


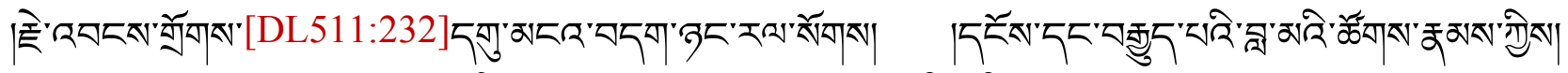

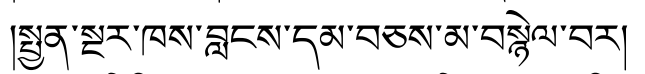

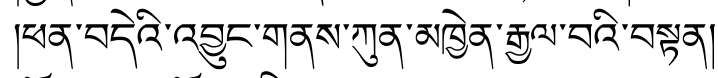

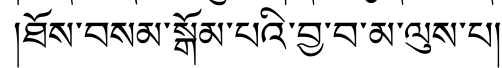
|व5ख़'

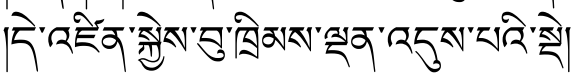

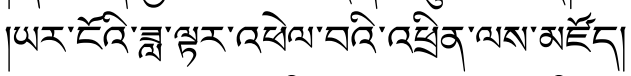

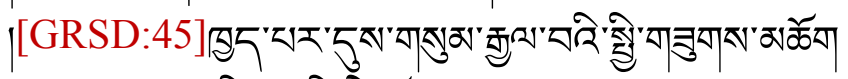

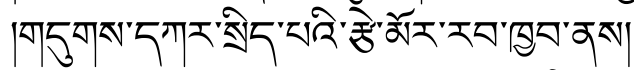

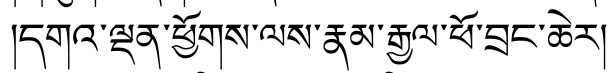

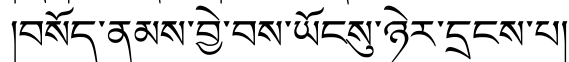

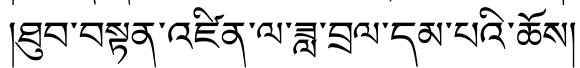

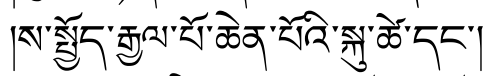

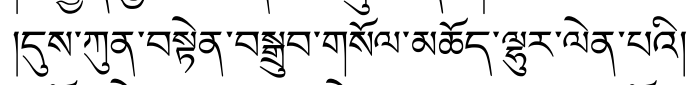

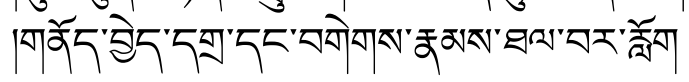

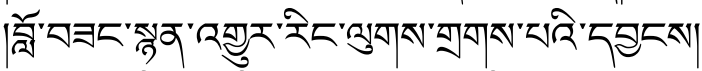

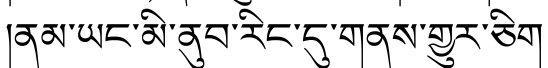

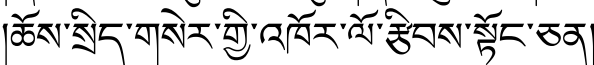

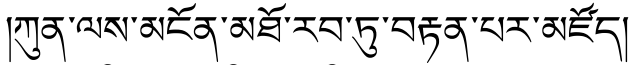

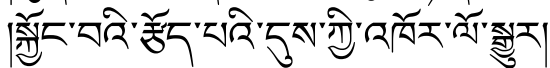

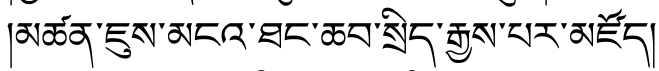

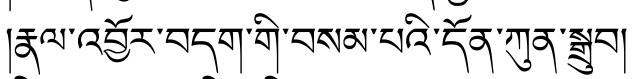

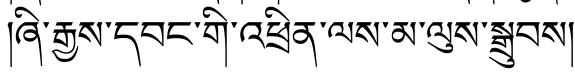

\section{|वस्तुथ के|}

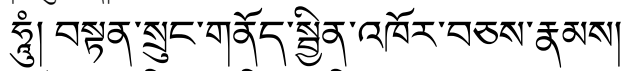

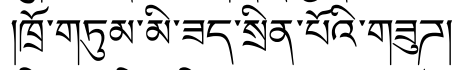

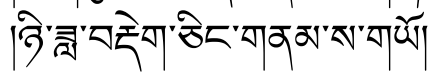

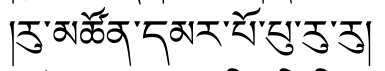

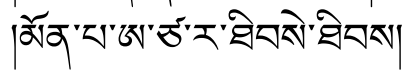

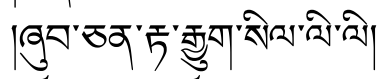

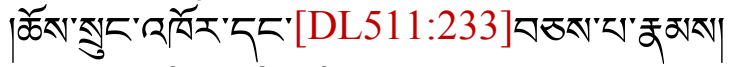

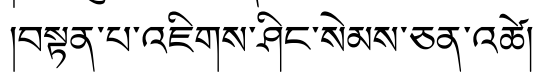
सार्वेद यर

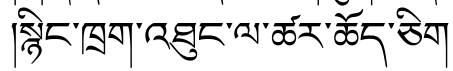

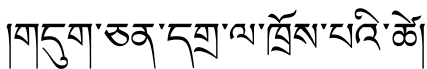

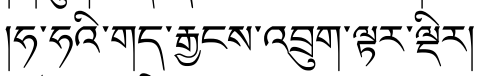

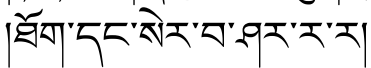

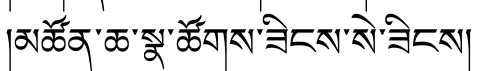

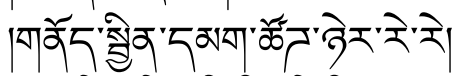

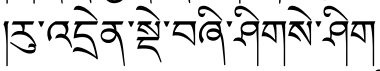

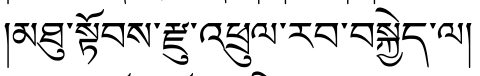

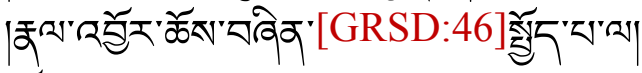

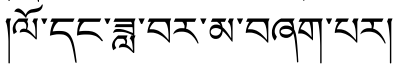

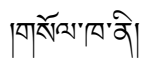

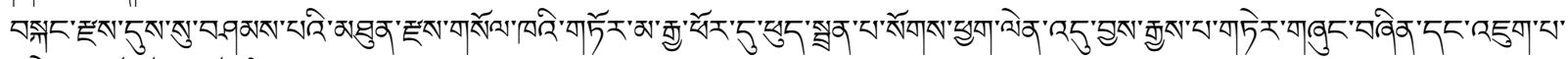

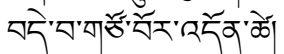

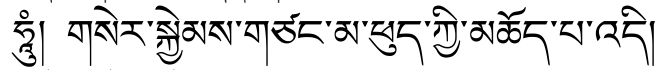

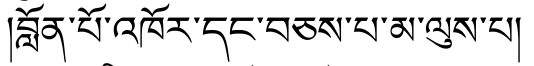

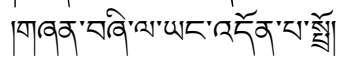

|

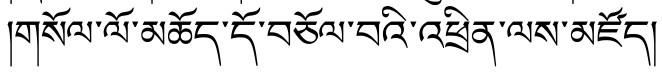

ज्ञैग'वंबे।

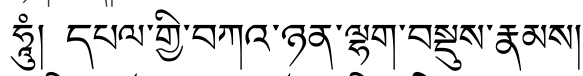

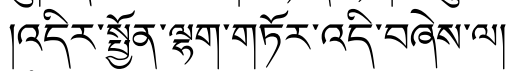

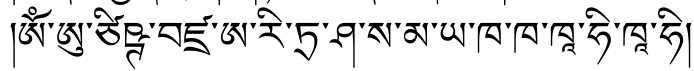

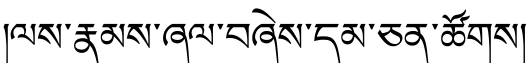

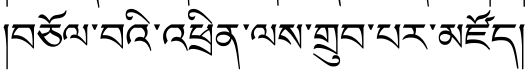

42 DL511: बेवे 
क5'वर्ष"वे।

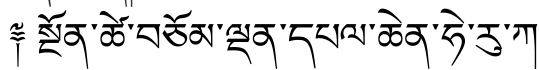

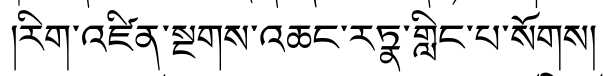

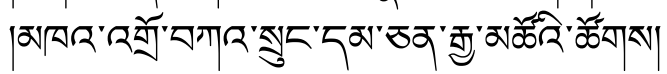

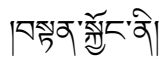

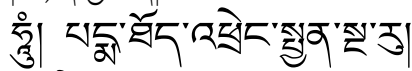

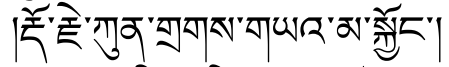

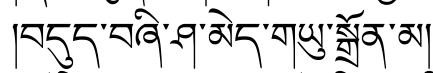

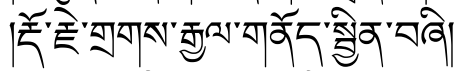

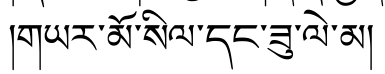

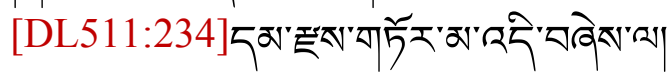

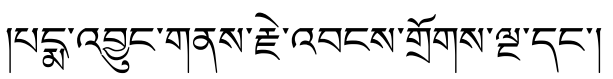

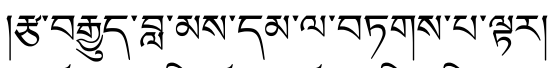

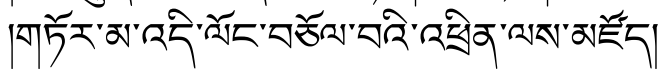

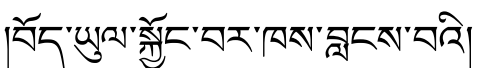

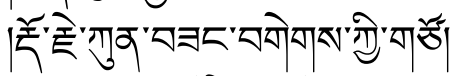

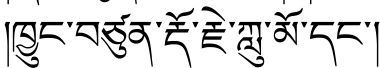

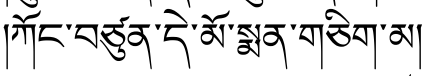

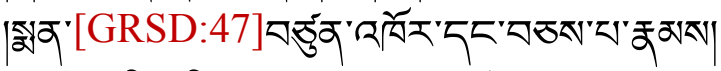

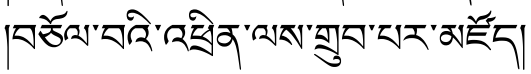

15 ‘्रेवे|

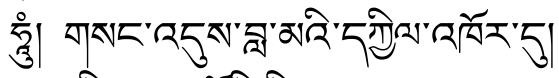

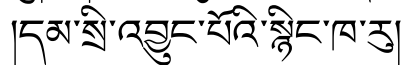

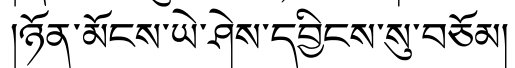

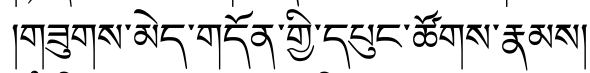

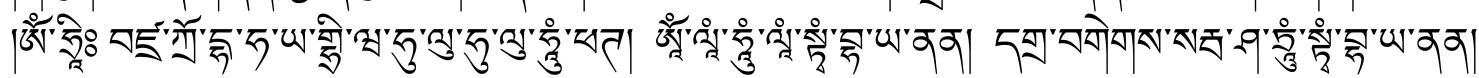

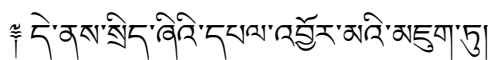

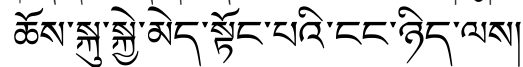

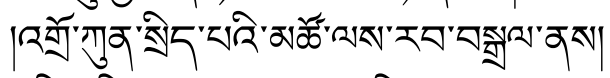

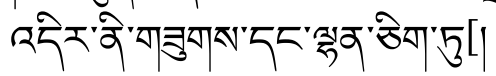

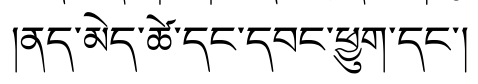

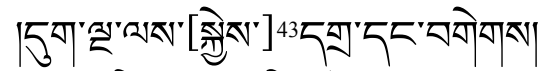

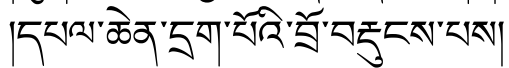

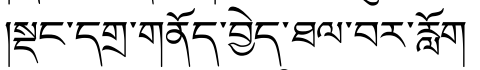

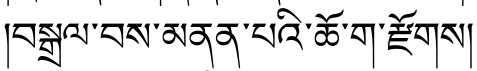

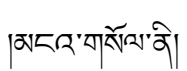

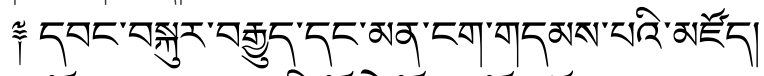

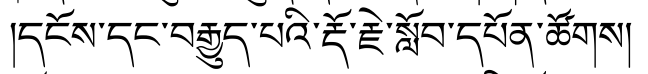

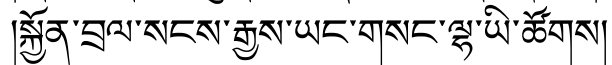

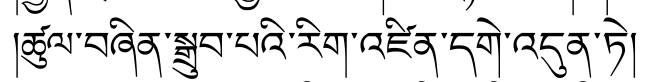

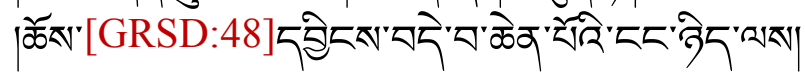

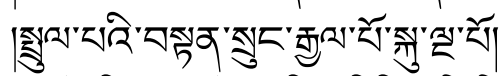

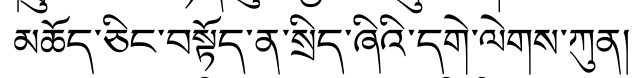

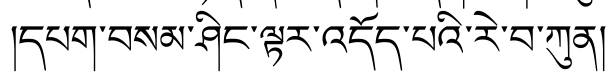

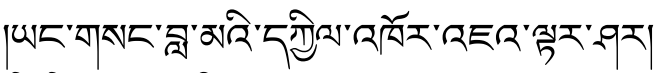

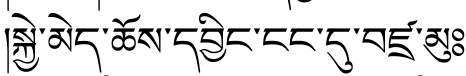

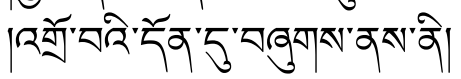

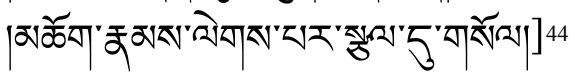

हि'মवेव

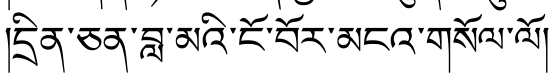

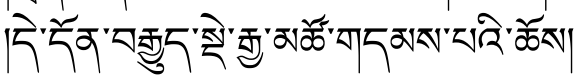

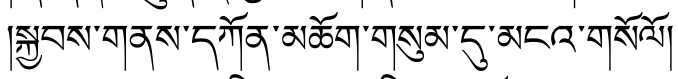

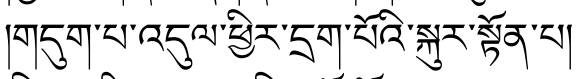

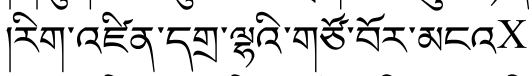

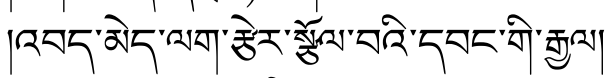

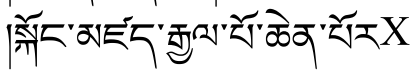




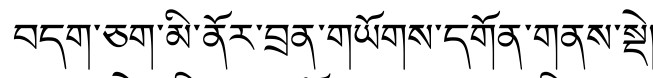

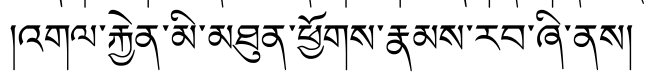

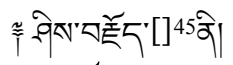

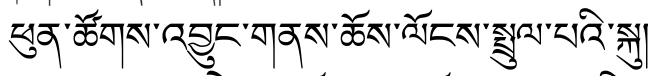

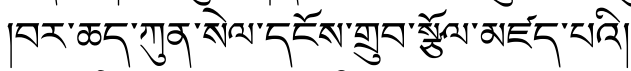

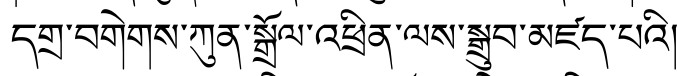

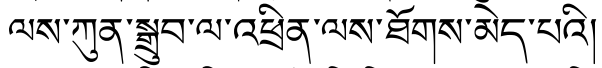

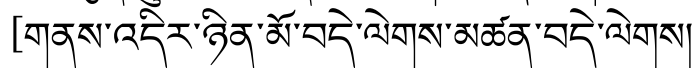

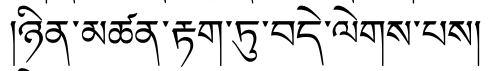

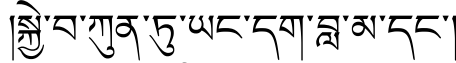

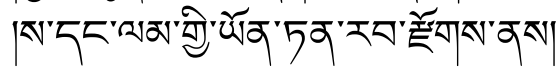

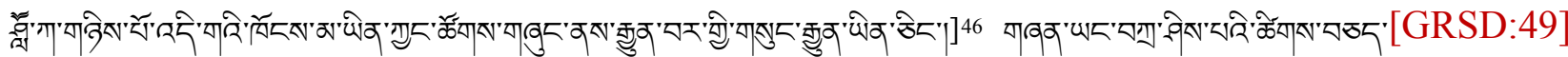

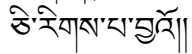

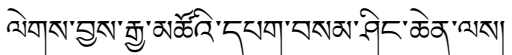

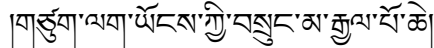

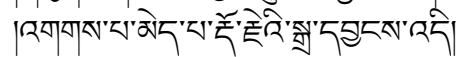

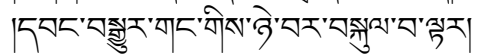

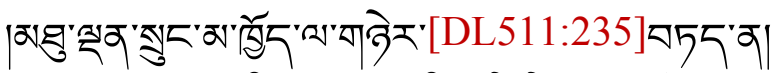

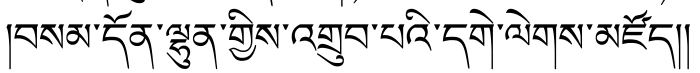

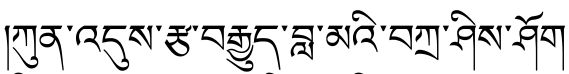

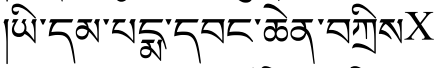

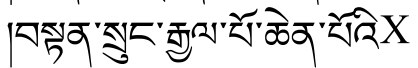

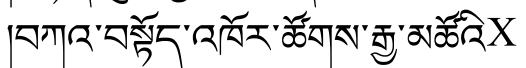

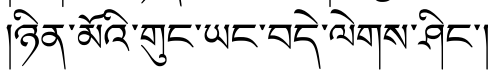

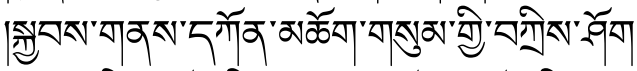

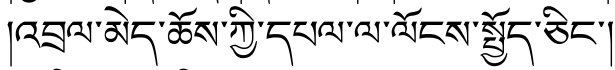

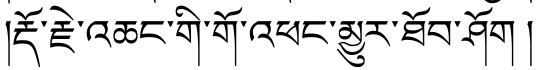

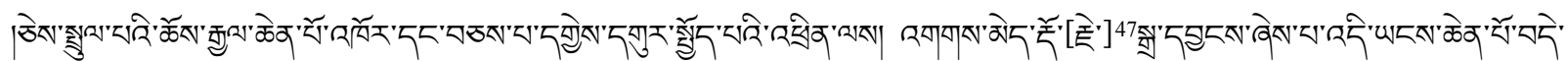

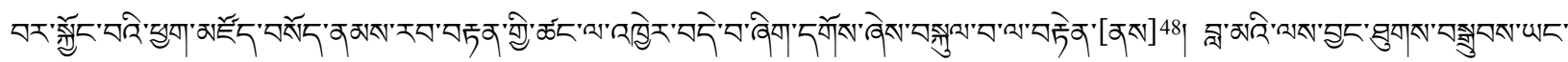

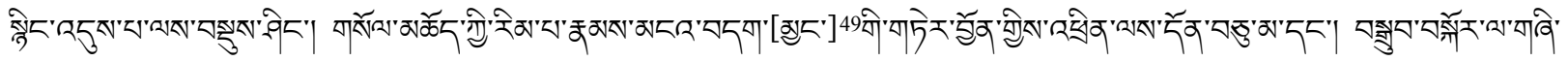

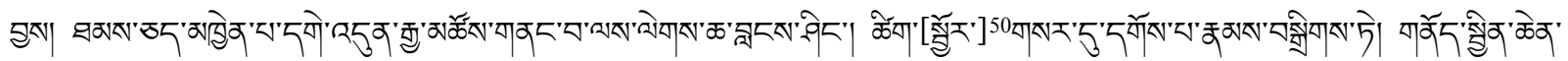

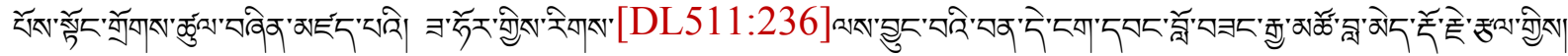

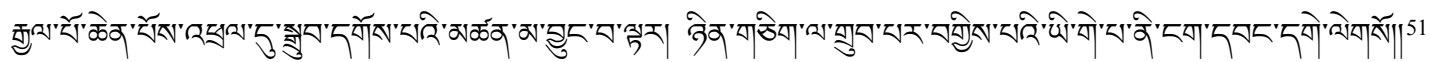

\footnotetext{
45 DL511: [5

46 DL511: omitted.

47 DL511: 골.

48 DL511: omitted.

49 DL511: omitted.

50 DL511: 脎.
}

51 The DL511 edition ends here with the conclusion of the ritual proper. 


\section{[GRSD:12][DL511:207]The Unceasing Adamantine Melody: Sädhana for Presenting Prayers and Offerings to the Five Great Sovereign Spirits}

From the emanating play 52 of great immutable happiness, the emanation body-the embodiment of the Buddhas of the Three Times - abides as the Lord of the Lineage, Tsokyé Dorjé, who was born well from the center of a lotus.

The great lord of life, the guardian of the [Buddha's] teachings among the worldly haughty spirits of the Eight Sädhana Deities-[under which] all the mandalas of the peaceful and wrathful kings are united without exception — is the great emanated Dharma King.

The order of the preliminary, main, and concluding actions for making offerings [to this deity is] easy to implement [and] fully established without omissions, additions, or faults.

[This] Unceasing Adamantine Melody that delights the capricious spirits [GRSD:13] will be proclaimed here and now!

Furthermore, regarding the actions that please the great emanated Dharma King and his retinue: first, you must [organize] the preliminary preparations for the lama's ritual practice. Then arrange the torma offerings and gifts for the lama, tutelary deity, and great Dharma protectors in accordance with ritual custom.

First: You will immediately transform into glorious Hayagrīva — red in body color, grasping a crooked knife in your right hand and a blood-filled skull in your left, adorned with the charnel ground ornaments, sitting with your left leg extended, and marked with the three letters over the three places. 53

Then, [regarding] the torma offerings for the obstructing spirits:

Burn, scatter, and wash [the offerings] with RAM, YAM, [and] KHAM. [DL511:208]

Bless [them] with OM ĀH HŪM.

Dedicate by [reciting the following] three times:

OM A KĀRO MUKHAM SARVA DHARMĀṆAM ĀTYĀNUTPANNATVAT!

OṂ ĀH HŪṂ PHAṬ SVĀHĀ!

HŪṂ!

Scatter the obstacles and obstructing spirits with the blessings of the three divine roots! 54

52 Tib. zlos gar; this word has multiple interconnected meanings. It can mean a play or drance drama, such as the religious dances (Tib. 'chams) performed at various sacred sites througout the year; it can also mean emanation. These meanings are intertwined, as the religious dances ritually recreate powerful acts of emanation conducted by the various transcendental and worldly deities, who are represented in such theatrical displays. The meaning here is both metaphysical and performative.

53 Tib. gnas gsum; the three places are [1] the head (representing the body), [2] the throat (representing speech), and [3] the heart (representing the mind). This likely refers to OM placed over the forehead, $\bar{A} H$ placed over the throat, and HŪM placed over the heart.

54 Tib. rtsa gsum lha; the three roots are [1] the lama (Tib. bla ma), [2] the tutelary deity (Tib. yi dam), and [3] the d̦ākinī(Tib. mkha' 'gro ma), along with the Dharma protectors (Tib. chos skyong) in some instances. 
If they do not go, crush them into particles of dust with Lord Hayagrīva's wrath!

Recite the OM SUMBHANI55 [mantra].

Demarcating the Boundary [from malevolent spirits]:

HŪṂ!

I am primordially, inherently fierce! I demarcate the boundary [and] fill the sky with ferocity! I subdue the obstructing spirits [with] wrathful emanations! Nobody [may] trangress the boundary! OM VAJRA KRODHA RAKȘA RAKȘA HŪM PHAṬ! 56

Taking Refuge and Arousing Bodhicitta:

I Pay Homage!57 I and all sentient beings take refuge in the essence of the Three Jewels - the holy corpus of the Assembly of the Sugatas 58 - until [we reach] enlightenment.

[After] arousing bodhicitta, the lama attained enlightenment for the sake of all beings. Then he vowed to work for the benefit of beings with activities [that] tame beings according to their needs. 59 [GRSD:14]

Regarding the Field of Merit: 60

Lama, tutelary deity, and $d \bar{a} k i n \bar{l}$ - come [and] sit on this throne [made up of] a sun, moon, and lotus. I respectfully pay homage [to you with my] body, speech, and mind,61 [and] make outer, inner, and secret offerings [to you].

I openly confess my transgressions, faults, and failings, [and] rejoice in accomplishing the Secret Mantra! 62 I request that [you] turn the Dharma wheel of the ripening and liberating Secret Mantra [and] abide for the benefit of [all] sentient beings!

I dedicate [my] heart for the benefit of [all] sentient beings! May [I] understand the meaning of the authentic Vajra!

55 This refers to the following mantra: OM SUMBHANI SUMBHANI HŪM HŪM PHAṬ! OM GRHN GRA GRNA HŪM HŪM PHAṬ! OṂ GṚHṆAPAYA GRTHṆAPAYA HŪṂ HŪṂ PHAṬ! OṂ ĀNAYA HOH! BHAGAVAN VAJRA HŪM HŪṂ PHAṬ! The meaning of this mantra is provided in Beyer 1973, p.263.

56 This mantra can be translated as: "OṂ Fierce Vajra [Hayagrīva], Protect! Protect HŪṂ PHAṬ!"

57 Tib. na mo; Skt. namo.

58 Tib. Bde gshegs 'dus pa; a collection of tantras that belong to the Practice Section (Tib. sgrub sde) of the Mahāyoga textual tradition.

59 Tib. gang la gang 'dul; this is an abbreviation of 'dul bya gang la thabs gang gis 'dul ba.

60 Tib. tshogs zhing.

61 Tib. lus ngag yid gsum; since these terms are non-honoric, this strongly suggests that the composer is referring to his own body, speech, and mind in a non-reverential manner, rather than referring to those of the divine beings cited in the first half of the quatrain.

62 This is synonymous with Vajrayāna and Mantrayāna, and thus refers to the tantric tradition as a whole. 
Regarding the Blessings:

I request that the host of the three divine roots arise unobstructed from the Source, bestow great blessings at this great place of accomplishment, confer empowerments on me, and give me the ordinary and extraordinary accomplishments!

Regarding the Blessing [of] the Torma Offerings: [DL511:209]

HRI !

VAJRA KRODHA HAYAGHRĪWA PADMANTA63 KṚTA HŪṂ PHAṬ! 64 Purify with the SVABHĀVA [mantra].

From within emptiness, YAM [arises]. From YAM, a bow-shaped wind mandala decorated [with] banners [arises]. Above that, from RAM, a triangular fire mandala [arises]. Above the sign of RAM, KAM [arises]. From KAM, a tripod fireplace 65 [made] of human heads [arises]. Above that, from $\bar{A}$, a skullcup [arises]. Inside that, from MŪM, LĀM, MĀM, BĀM, and TĀM, [respectively], the meat of a lion, an elephant, a horse, a peacock, and a human [arise]. Above that, OM, HŪM, SVĀ, AM, and HĀ [arise]. Above that, an expediently conjoined sun and moon [arise] decorated with vowels and consonants. [On] the tip of a vajra in the center of this, A [arises]. At the core of A, HŪM [arises]. Above this, the five-OM, HŪM, SVĀ, AM, and HĀ-[arise] and are decorated with MŪM, LĀM, MĀM, PĀM, and TĀM below. Light emanates from HŪM at the center [and] ignites [everything with] the fire of vital energy. [I] employ the [ritual] items and offer them to the Buddhas and Bodhisattvas. I have transmitted the bodhicitta that constitutes the five families of all the Buddhas. Then, [GRSD:15] A, the [above] ten seed syllables, HŪM, and the vowels and consonants, in succession, descend and dissolve one into the other. Because of this, together with the sun and the moon, they melt into light [and] dissolve into the [ritual] items. [Thus, the ritual items] transform into the immaculate nectar [of immortality that consists of] medicine, blood, and tormas.

OM ĀḤ HŪM SARVAPAÑCĀMRTA HŪM HRĪH ȚHĀ!

OM ĀH HŪM MAHĀRAKTA JVALAMAṆDALA HŪM HRĪH ṬHĀ! 66

OṂ ĀH HŪM MAHĀBALINGTA TE JVABHALINGTA BALABA TE GUHYASAMAYE HŪM HRĪH ṬHĀ! 67

BHODHICITTA GHAN়A GUYA PŪJA HO! 68

\footnotetext{
63 The normative Sanskrit is padmānta.

64 A possible translation of this mantra is, "Fierce Vajra Hayagrīva Bears the Lotus Leaves! HŪM PHAṬ!"

65 Tib. sgyed po gsum; this is a makeshift fireplace made with either three stones or three pieces of iron. In this case, human heads substitute the three stones.

66 A possible translation of this mantra is, "OM ĀH HŪM Great [Quantities of] Blood [and] a Blazing Mandala! HŪṂ HRĪH ȚHĀ !"

${ }^{67}$ A possible translation of this mantra is, "OM ĀH HŪM [I Present] a Great Many Torma Offerings to You, [I Present] Powerful Blazing Torma Offerings to You, within this Secret Covenant! HŪM HRĪH ȚHĀ!”

68 The normative Sanskrit for this mantra is, BODHICITTA GANA GUHYA PŪJA HO! A possible translation is, "[This Concludes] the Bodhicitta [and] the Multitude of Secret Veneration [Offerings] HO!"
} 
Regarding the Main Practice: 69

From within the unfabricated state, the all-pervading light of compassion and adamantine self-awareness create HRĪH. This transform into BHRUM, and from that, a mandala [arises] with four fully perfected gates, corners, and porticos. In the center of that, [a throne arises made of] the Four Hindering Spirits, 70 a lotus, and a sun. On top of that, from the HRĪH itself, the Mighty One [Hayagrīva] embraces Vajravārāhī.71 He has a red-colored body, grasps a crooked knife and skull cup, [and] is adorned with the charnel ground ornaments. Padma Tötreng, bearing a vajra and skull cup, sits cross-legged on top of a lotus and sun [disk] on the crown of [Hayagrīva's] head. [He wears] religious robes of dark blue brocade and a lotus crown, and is adorned with feathers, silken banners, and a mirror.

[DL511:210]The essential transmuted state [of this deity is] Guru Vajradhara, 72 who is dark blue [in color], holds a vajra and bell,73 and sits in a cross-legged position. The dākinī [Yeshé] Tsögyel,74 [sits] in his lap. She has a white-colored body, holds a crooked knife and a skull cup full of the nectar [of immortality], and clasps [Vajradhara's] neck. The two - adorned with jewels and bone ornaments - are united [and] personify the Great Bliss Body. 75

Beyond them, Dorjé Tötreng Tsel, Rinchen Tötreng Tsel, Padma Tötreng Tsel, and Karma Tötreng Tsel 76 magnificently appear within four [lotus] petals. 77 They are properly adorned with hand implements, garments, and ornaments that signify the four activities.

${ }^{69}$ While not copied verbatim, this section is based on the cosmology and general order found in Ratna gling pa 1976, pp.129-133.

70 Tib. bdud bzhi; these four demonic spirits are [1] the hindering spirit of the Lord of Death (Tib. 'chi bdag gi bdud), [2] the hindering spirit of emotional afflictions (Tib. nyon mongs pa'i bdud); [3] the hindering spirit of the psychophysical aggregates (Tib. phung po'i bdud); and [4] the hindering spirit of the divine child (Tib. lha'i bu'i bdud).

71 Tib. Rdo rje phag mo; Lit. "Adamantine Sow."

72 Tib. Rdo rje 'chang; lit. "Vajra-bearer." Lama Vajradhara here refers to one of Padmasambhava's manifestations, who is simultaneously being placed in the position of the ultimate Buddha.

73 Tib. dril bu; Skt. ghanțā.

${ }^{74}$ Tib. mkha' 'gro Mtsho rgyal; this is the famous spiritual consort of Padmasambhava. It is worth noting that Tsögyel's iconography here matches that of the ultimate Buddha Vajradhara's consort, Prājpäramitā ; see Getty 1962, pp.2-5.

75 Tib. bde ba chen po'i sku; Skt. mahāsukhakāya.

76 Tib. Rdo rje dang / /rin chen padma karma thod phreng rtsal; these refer to the four forms of Padmasambhava that, together with the central tathägata figure, represent the five Buddha families (Tib. rgyal ba rigs lnga).

77 This imagery illustrates the classic mandala structure, with the central deity and his consort in the center-in this instance, Vajradhara and Yeshé Tsögyel—while four subsidiary deities appear around them, each within a lotus petal pointing in a cardinal direction. 
[Further] beyond, in [each of] eight lotus petals, [reside the following]:

[1] Pema Jungné, 78 [who has] a dark-blue[-colored body], [holds] a vajra in his right hand, makes the tarjanī mudra [with] his left, and embraces his consort.

[2] Padmasambha[va], [who holds] a lotus bowl, [GRSD:16] makes the abhaya mudrā,79 and has the appearance of a young monk.

[3] Loden Choksé, 80 [who] holds a tea[-filled] skull-cup [and] a lotus bowl, has a whitecolored body, and possesses the dignified presence of a tantric adept. 81

[4] Pema Gyelpo,82 [who] holds a hand drum 83 [and] a mirror, has a red-colored body, and is endowed with royal attire.

[5] Nyima Özer, 84 [who] bears a trident 85 and sunbeams, has a yellow[-colored body], and possesses the appearance of a yogic practitioner.

[6] Sákya Sengé, 86 [who] holds a vajra and begging bowl, and manifests as the emanation body Śākyamuni.87

[7] Sengé Dradrok, 88 [who possesses] a dark-blue[-colored body], [holds] a vajra in his right hand, makes the tarjan̄ mudrā [with his left], and has a frightening, wrathful appearance.

[8] Dorjé Drolö,89 [who] has a dark maroon[-colored body], [holds] a vajra in his right hand, binds [spirits with] the ritual dagger in his left, and [possesses] a terrifying, wrathful form. 90

Outside [this], the dākinīs of the four classes, the [eight] secondary diakinīs, 91 as well as the assembly of oath-bound Dharma protectors and guardians in the [mandala's] courtyard, 92 are densely gathered like rainclouds, [and are] singing songs and performing dances.

\footnotetext{
78 Tib. Pad 'byung [=Pad ma 'byung gnas]; Skt. Padmakara.

${ }^{79}$ Tib. skyabs sbyin gyis [sic: gyi] phyag rgya; lit. "mudrā that grants refuge."

80 Tib. Blo ldan mchog sred; lit. "Learned Brahmin."

81 Tib. sngags 'chang.

82 Tib. Padma rgyal po.

${ }^{83}$ Tib. $d \bar{a} r u$ [= $=\bar{a}$ ma ru]; Skt. dẹmaru.

84 Tib. Nyi ma 'od zer; lit. "Sunlight."

85 Tib. kha țvam; Skt. khațvāña.

86 Tib. Śākya sengge; Skt. Śākya Siṃha; lit. "Lion of the Śākya [Clan]."

87 Tib. sprul sku Sākya thub pa.

88 Tib. Sengge sgra sgrog; lit. "Lion's Roar."

89 Tib. Rdo rje gro lod.

90 These figures make up the eight major manifestations of Guru Rinpoche (Tib. Gu ru mtshan brgyad).

91 Tib. shugs 'gro.

92 Tib. khyams la. This parallels the numerous murals of wrathful protectors and deities found in Nechung Monastery's courtyard galleries; due to their great quantity and detail, these murals are a particularly unique feature of the monastery; see Ricca 1999.
} 
Bestow blessings with [your] body, speech, and mind! Bestow the supreme empowerment with the five wisdoms! Bestow the ordinary accomplishments!

HŪM OM SVĀ AM HĀ!93 GURU DEVA ḌĀKINI SAMAYA JAH JAḤ! 94 [DL511:211]

Then, the invitation, request to reside, and offerings and praises composed by the omniscient [Second Dalai Lama] Gendün Gyatsö is as follows: ${ }^{95}$

\section{HŪṂ!}

Within a lucid and pure sky of immaculate light, a representation of the omnipresent Gyutrül Drawa [resides]. [This is] Padmasambhava - king of the victorious ones of the three eras - [possessing] the manner of a completely pure vajra-bearing monk.

On his right, heroes stomp about in a dance, [and] on his left, heroines sing an endless stream of songs. He is surrounded by an assembly of countless accomplished tantric scholars, [and] all the oath-bound guardians billow around him like clouds.

All the chiefs of the gods follow after [him], [GRSD:17] and garlands of mandāra [flowers] — which were strewn about by the hands of Chimé Bumo-fill the skies. By your immeasurable compassion, come to this place!

I request that you abide forever, smiling with delight, in the sky in front [of me], in the middle of an immaculate rainbow [pavilion] of five[-colored] light beams, on a lion throne [ornamented with] the sun and the moon, in the center of a thousand-petaled lotus.

Having emanated bodies equal in number to the sands of the Ganges [River], [you] possess the garb of a skin-crawling hindering spirit, a born deceiver. [With] my palms joined in devotion and with flower blossoms, I receive the dust of [your] feet on the top of my head and respectfully pay homage.

An ocean-like libation of the nectar of immortality is held within an expansive vessel abounding [with] a thousand golden [lotus] petals. Flowers for the beautiful gods and humans completely cover the all-pervading path of the gods.

In jeweled vessels endowed with blooming rays of light, I burned snake's heart sandalwood, divine substances, and aloe wood, and a wheel of cloud-like smoke filled [the air]. The sky was congested by a garland of blazing lamps.

Delightful perfumed saffron water, [DL511:212] saturated with camphor and sandalwood, swirls like an ocean of enjoyment and bestows immaculate bliss. Endowed with the excellence of a hundred tastes, [these are the] complete food offerings for gods and humans.

93 These five mantric syllables, though presented in a slightly different order, are central to the section above on the Blessing [of] the Torma Offerings.

94 This can be translated as, "The Samaya Vow [of] the Lama, Tutelary Deity, and Dākini-_Summon it! Summon it!" The DEVA in the mantra is short for istadevatā, meaning tutelary deity (Tib. yi dam). See note 54 above for more information on the "three divine roots" (Tib. rtsa gsum) to whom this mantra is dedicated.

95 The following section is directly copied from DL206, pp.169-172; see Appendix IIb, pp.451-454. 
I have made a collection of mundane and supramundane offerings - such as a variety of horn instruments, [like] lutes and flutes, endowed with a hundred thousand reverberations of harmonious music. They pervade all realms without exception, and I offer [them to you].

To you I offer jeweled Mount Meru, [GRSD:18] the four continents and eight subcontinents, the sun and the moon, the kingdom, the seven precious jewels, the great treasures of my body, my possessions, and all desirable things, as well as the merit that I have accumulated [throughout] the three times.

A cloud of offerings [emanated by] Samantabhadra - who arose from an untarnished ocean of devotion - completely fills the sky without exception. Nonetheless, the supreme bodhisattvas accordingly [and] properly make offerings [to] the Buddha of the three ages.

Inside an immense skull cup as extensive as the billion-world system, [and] within an ocean of nectar, the five meats and, similarly, the five iron hooks are kept, the inherent nature of which are the five immaculate wisdoms that produce purification, realization, and illumination. An offering [of this is made].

Emaho! The joining together of the venerable lord Padma Tötreng Tsel [and] his enchanting consort, who is a self-arising illusion, [produces] great bliss! This [most] superior of offerings - which is beyond words, thoughts, and descriptions - [is] marvelous.

I bow to you, lord of the inconceivable Dharma body - the primordial ground beyond all signs of fabrication, innately free from the bonds of the two obscurations, the supreme nature that completely pervades all of existence.

I bow to you, [body of] the perfect enjoyment of the nectar [of immortality] — which quickly dissolves the wheel of existence into space, possesses a network of the major and minor marks [of a Buddha] consisting of the five essences, and is the eye of the hero abiding on the bodhisattva's level.

[DL511:213] I praise the emanation body, which manifests as anything within the tamable realms or the particulars of thought-like the moon, which appears in the perfectly clear sky, reflecting in indescribably clean water.

I bow to you, sole refuge of all beings - ascetic dressed as a monk, born from a lotus in the middle of a wish-fulfilling ocean in Oḍdiyāna, untarnished by even the smallest transgression. 96

Even in this country completely surrounded by a garland of snow[-covered] mountains, the beneficence created [by just] the slightest dust of [your] feet pacifies all the demon armies of the dark side [and] propagates the teachings of the victorious ones for the happiness and benefit of [all] beings; I bow to you.

96 This and the last quatrain are actually found on page [GRSD:21]; see note 124 below. 
[GRSD:19] ${ }^{97} \mathrm{AM} !$ [Regarding the manner of] entering the profound path of guru yoga:

HŪM!

Guru Dorjé Tötreng Tsel [resides] on top of a lotus and sun [disk] on [the lama's] 98 head. He has an extremely wrathful dark blue[-colored] body and a gaping mouth [from which he] bares his fangs. His three eyes are open wide, his dark red hair is coiled into matted locks, and his two legs [are in] a dancing posture, trampling the enemies and obstructing spirits. He raises a vajra of meteoric iron [with] his right hand and pl aces a bell against his body with his left. He is frightfully decorated with charnel ground ornaments and shakes the three worlds with the fierce sound [of] HŪM. He subdues malevolent and obstructing spirits with a blazing mass of fires. The three-bodied lama, 99 the tutelary deity, the wisdom dākinīs, and the assembly of guardian deities densely gather like clouds in the sky. Then, [this] diverse collection becomes absorbed into the lama's body. I respectfully prostrate to and take refuge in the vajra master who is the embodiment of all. 100

I offer my body, speech, and mind in service to you, Venerable One! May you purify [my] misdeeds, obscurations, and corruptions, and pacify [my] adverse circumstances and obstacles! Bless my body, speech, and mind, and bestow [on me] the ordinary and extraordinary accomplishments!

\section{OM ĀH HŪM!}

With intense devotion, I supplicate the Dharma Body, Vajradhara from Oḍ̣iyāna,101 [who resides] in the Dharmadhātu102 Palace of Akanișțha.103 Send down [on me] a great rain of blessings and accomplishments!

\footnotetext{
97 GRSD pages 19-20 consist of an extraneous folio that was clearly added. The folio is numbered 1 (gcig) and is placed between folios $9(d g u)$ verso and $10(b c u)$ recto of the GRSD manuscript. The script style is also noticeably different, which I am illustrating here by using a font style distinct from the rest of the ritual text. However, page numbers will remain in Times Extended New Roman font for the sake of uniformity. Although this folio cuts into the second-to-last quatrain copied from DL206, I am placing it at the end of this copied section in order to aid clarity. 98 This signifies the lama who specifically leads the ritual performances as well as presides over empowerment ceremonies; in both instances, this is generally one's root lama (Tib. rtsa ba'i bla ma).

99 Tib. bla ma sku gsum, variation of sku gsum bla ma; Skt. trikāyaguru. This refers to the Mahāyāna Trikāya doctrine whereby the Buddha manifests in three major forms: the Dharma Body (Tib. chos sku; Skt. dharmakāya), the Enjoyment Body (Tib. longs sku [=longs spyod rdzogs pa'i sku]; Skt. sambhogakāya), and the Emanation Body (Tib. sprul sku; Skt. nirmāṇakāya). The standard representations of the three bodies are Amitābha (Dharma Body), Avalokiteśvara (Enjoyment Body), and the Padmakara form of Padmasambhava (Emanation Body), all of whom are ultimately one. However, in this context, it appears that Vajradhara represents the Dharma Body and Hayagriva (as a wrathful emanation of Avalokiteśvara) represents the Enjoyment Body; Padmasambhava still represents the Emanation Body.

100 Tib. kun 'dus rdo rje slob dpon.

101 See note 72 above.

102 Tib. chos dbyings; lit. "the ultimate sphere of phenomenal existence."

103 Tib. 'og min; lit. "below none." This realm is the highest Buddha field.
} 
HŪṂ HŪṂ HŪṂ!

With intense devotion, I supplicate the Enjoyment Bodies, the five Tötreng [emanations, 104 who reside] in the Palace of Great Spontaneous Bliss. Send down [on me] a great rain of blessings and accomplishments!

HŪṂ HŪṂ HŪṂ!

With intense devotion, I supplicate the Emanation Bodies, the eight manifestations of Guru [Rinpoche, 105 who] guide [all] beings in the tamable realms. Send down [on me] a great rain of blessings and accomplishments!

HŪṂ HŪṂ HŪṂ!

With intense devotion, I supplicate the glorious lama Dorjé Drakpo Tsel, 106 in whom the three bodies are completely united. Send down [on me] a great rain of blessings and accomplishments!

HŪṂ HŪṂ HŪṂ!

[GRSD:20] With intense devotion, I supplicate the lamas of the limitless lineages, [who reside] in the Palace of the Phenomenal Dharma Body.107 Send down [on me] a great rain of blessings and accomplishments!

HŪṂ HŪṂ HŪṂ!

With intense devotion, I supplicate Orgyan Lerap Lingpa, 108 [who resides] in the pure realm of self-manifestation. Send down [on me] a great rain of blessings and accomplishments!

HŪṂ HŪṂ HŪṂ!

With intense devotion, I supplicate [my] gracious root lama, [who resides] in Dharma wheel of [my] heart. S end down [on me] a g reat rain of blessings and accomplishments!

104 These were listed above, see note 76.

105 See note 90 above.

106 Tib. Rdo rje drag po stsal [sic: rtsal]; lit. "Fierce Adamantine Power." This is one of Padmasambhava's wrathful manifestations.

107 Tib. snang srid chos sku; this refers to dharma as the atomic element of all apparent and existential phenomena in Indian Buddhist metaphysics.

108 Tib. Ogyan Las rab gling pa. This refers to the turn-of-the-twentieth-century treasure revealer Lerap Lingpa (1856-1926; TBRC: P5970). As this folio's colophon explains, this short extraneous supplication was prophecied by the Nechung Oracle, likely during the time of the Thirteenth Dalai Lama. The 1969 edition of the Nechung Liturgy, from which the GRSD edition derives, explains on its title page that its contents were reproduced photographically from an 1845 xylographic edition; see Bskal bzang rin chen 1969, title page, as well as Lobzang Tondan 1983, vol.1, p.175.6. Thus, this folio was added much later. 
HŪṂ HŪṂ HŪṂ!

The lamas grant blessings, bestow the supreme empowerment of [their] bodies on [my] body, 109 bestow the supreme empowerment of [their] speech on [my] speech, bestow the supreme empowerment of [their] minds on [my] mind, and bestow the supreme empowerment of [their] innate indivisibility [on me]. May they perfect the great power of realization and ac complish the four activities! The I amas dissolve inseparably into me; their mind and mine merge within the Dharmadhātu. The state of the lamas within the ultimate Dharmadhātu remains in the equipoise of unfabricated naturalness. A A A !

In the Iron-Rabbit year [1891],110 the great Dharma King111 prophesied that [these] pith instructions based on Orgyan Lerap Lingpa's profound treasure [cycle] must be released. May all be] Auspicious!

[GRSD:21] Then recite the following whispered mantras:112

OṂ ĀH HŪṂ! VAJRA GURU PADMA SIDDHI HŪṂ! 113

OṂ ĀH HŪṂ! VAJRA GURU PADMA TÖTRENG TSEL!

VAJRA SAMAYA JAḤ! 114 SIDDHI PHALA HŪṂ! 115

HRIMA HARINISA RAJAHRIYA CITTA HRING HRING JAH JAH!! 116

Regarding the Essential Invocation:

The glorious Guru Vidhyādhara117—within whom all the Buddhas of the three times are united-sends down his accomplishments at the right time. When I essentially invoke

109 lus la sku yi dbang mchog stsol; the use of non-honorific for 'body' in the first instance (Tib. lus) and honorific in the second (Tib. sku) clarify their proper referents in this passage and the three parallel instances below.

110 Given Lerap Lingpa's dates, this year was either 1891 or 1951. I speculate that the former date is the correct one, given the turmoil of the latter year, as well as the fact that Lerap Lingpa had just visited Lhasa in 1888 and developed a close relationship with the Thirteenth Dalai Lama while there; see Samten Chhosphel 2011.

111 Tib. Chos rgyal chen po; this title refers to the Nechung Oracle in this context.

112 Tib. 'dzab; Skt. jāpa.

113 This is Padmasambhava's essence mantra. While it is full of multivalent meanings, a basic translation is, "The Adamantine Guru [Born from] a Lotus [who Bestows] Accomplishments HŪṂ!"

114 A possible translation is, "Summon the Adamantine Samaya Vow!"

115 The Sanskrit phala means "fruit, result, reward." A possible translation of this mantra is, "The Fruit of Accomplishments HŪM!!" Given that this follows after the previous mantra on the samaya vow, that is likely the subject of this mantra.

116 This is the Harinisa mantra (Tib. ha ri ni sa'i sngags). According to the Fourteenth Dalai Lama (Dalai Lama 14 2013), the four seed syllables, HA, RI, NI, and SA, represent the four dākiniss (of the cardinal directions). Moreover, the next four syllables, RA, JA, HRI, and YA, represent the four guardians of the doors. It is unclear what the first two mantric syllables-HRI and MA - mean; however, given this mandalic pattern, they likely represent the central tantric figure and his consort. In this mantric context, the central deity is likely Padmasambhava and his consort the dăkini Yeshé Tsögyel. The final portion of the mantra provides the action and verb. However, the meaning of HRING, or its variant HRIM, is difficult to decipher beyond it being a seed syllable. With this in mind, a possible translation is, "Padmasambhava and His Consort, the Four Dākinis and Four Door Guardians-HRING HRING Summon Them to Mind!" 
the samaya vow, bestow all accomplishments of body, speech, and mind on my Dharma siblings! 118

Then, while focusing on the offering tormas and sacred items, purify [them] with the SVABHĀVA [mantra].

After RAM, YAM, and KHAM emanate from the seed syllable in my heart, [I] burn, scatter, and wash all the impurities in the items to be offered. [I recite] the TRAM RATNATRAILOKYA BHRUM [mantra] and, with the OM ĀH HŪM that emanates from my heart, I purify the [sacred] items inside the vessel of offering tormas, which is as extensive as the sky; the beautiful, desirable qualities [and] abundance [of the offerings] are inexhaustible. [Thus, I] possess the ability to spontaneously amend the awesome samaya vow with this Sky Treasury [meditation]. 119

Bless [the offerings] with the Sky Treasury mantra and mudrā.

Regarding [the manner of] generating the Great Dharma King and his retinue in front [of you]: 120

OM [DL511:214] HRĪ!

Cleanse [the offerings] with the VAJRA KRODHA [mantra]; purify [them] with the SVABHĀVA [mantra].

Within emptiness, from the [syllable of] BHRUM in front of me, [GRSD:22] [there arise] vast and spacious divine mansions made of agate, conch-shell, gold, coral, and turquoise, [respectively]; churning waves of an ocean of blood that liberates the enemies and obstructing spirits; decaying chunks of human flesh; canopies of human skin; garlands of hearts and lungs; fringes of entrails; and skeletons that are scattered everywhere.

In the middle of the central divine mansion of agate, on a divan [made] of a lotus [that arose] from PAM, a sun [disk that arose] from RAM, and a male enemy and female obstructing spirit bound together-one laid face-down, the other in a supine position[there is] a dark blue TRI from which light emanates, annihilating all enemies and obstructing spirits. The light is reabsorbed [into the TRI], and from this transformation Gyajin, the sovereign spirit of the mind, [appears]. He has a dark blue-colored body, one face, and two arms. His mouth is gaping and he bares his fangs. His eyebrows and beard flash orange. He casts at enemies the lasso of the hindering spirits in his right hand, and with the razor in his left he cuts off the lifelines of the enemies and obstructing spirits. He wears a bear-skin coat and black silk robe on his body, as well as an elegant thumb[-

117 Tib. Rig 'dzin bla ma, a variant of Bla ma rig 'dzin; lit. "Tantric Scholar Lama." This deity is at the center of a mandala made up of the Eight Sādhana Deities; see chapter 1, note 310.

118 Tib. rdo rje'i mched lcam; lit. "vajra brothers and sisters."

119 While the wording is different, these instructions parallel those given in the GRSD edition of the Don bcu ma (see GRSD:57), right before chapter 1 of the ritual proper.

120 This section on generating the Five Sovereign Spirits does not draw verbatum from an earlier ritual, but its contents closely match the same descriptions found in the introduction of the Ten-Chapter Sädhana (see GRSD:5457). Some of the lines are even the same. Nonetheless, there are some important differences. For instance, the descriptions in this text generally provide more detail than those in the Ten-Chapter Sädhana. Also, the order of each deity's secondary emanations differs between the texts. In the Ten-Chapter Sädhana, the description of the principal deity is followed by those of his emanation, then consort, and then minister. While in this text, the order is consort, emanation, minister. 
shaped] hat with black silk [fringe] on his head. He is adorned with jewels and is endowed with the nine modes of expression. 121 He rides a long-trunked elephant similar to a broken off piece of a snowy mountain; 122 it is led by Mönbuputra. Lightening and flames accompany his reveling, and he sends forth hail and thunderbolts as heralds. He resides in the middle of a blazing mass of apocalyptic fire.

In front of [Gyajin, there is] the great 123 capricious spirit, the lord of life Yangleber. His body color is red [and has] the brilliance of a thousand suns. He is fiercely wrathful. He eats and drinks flesh, blood, and life-breath. Sometimes he bites his lower lip with his upper teeth, and his eyebrows and forehead are contorted into a wrathful grimace. $\mathrm{He}$ wears a coat of armor and a leather helmet. He throws at the enemy the red lance in his right hand and the lasso of the imperial spirits in his left hand. [GRSD:23] [DL511:215] He rides an excellent horse that is as fast as the wind, [and is] decorated with a jeweled saddle and bridle, and silken head ornaments. 124

[Gyajin's] consort is Shanting Rozan Marpo. She wears silk shorts, is adorned with blood and fat, and brandishes an iron hook and a heart[-filled] skull cup. His emanation [takes] the guise of a young layman. He wears a cloak of red silk [on his body] and a crystal garland for a necklace. He raises the tarjani mudrā to the sky with his right [hand] and makes a striking motion with the copper knife in his left. His minister is the lord of life Ké Jarawa. He wears a maroon cloak, holds aloft a military standard of black silk, and rides a white lioness.

In the middle of the eastern divine mansion of conch-shell, on a divan [made] of a lotus, a sun [disk], and an enemy and obstructing spirit bound together, TRI [appears]. From TRI, Mönbuputra, the sovereign spirit of the body, [appears]. He has a black-colored body, one face, and two arms. He holds a golden vajra in his right hand and a mendicant's staff [made from] a red tree in his left. He wears a black mentri coat on his body and a thumb[-shaped] hat with black silk [fringe] on his head. He rides a white lioness, and crazed black bears accompany his reveling. He sends forth tigers, leopards, [black] bears, and grizzly bears as heralds. His consort is the female hindering spirit Rolangma Karmo, who wears a white silk dress, and holds a holy branch and a heart[-filled] skull cup. His emanation is a young arhat wearing saffron-colored religious robes. He wields a mendicant's staff [made from] a red tree, and a razor. He carries a skull cup on his back and an anointing vase down his front. His minister is Jatri Mikchikpa, who is naked [but for] a turban [on his head] made of snakes. He flings a crystal vajra and rides an excellent black-bottomed blue horse. [GRSD:24]

121 Tib. gar dgu'i nyams. These attributes usually apply to wrathful deities, such as this figure, and include: [1] boastful (Tib. sgeg pa), [2] courageous (Tib. dpa' ba), [3] repulsive (Tib. mi sdug pa), [4] wild (Tib. rgod), [5] furious (Tib. drag shul), [6] frightening (Tib. 'jigs rung), [7] compassionate (Tib. snying rje), [8] splendorous (Tib. rngam), and [9] peaceful (Tib. zhi ba).

122 This poetic and concise description tells us about the elephant's shape and white color.

${ }^{123}$ Tib. chen po; the BPLC edition has dgra lha'i rgyal po, meaning "the king of the enemy-defeating gods."

${ }_{124}$ Except for a few minor variations, this section on Yangleber (Tsiu Marpo) is drawn from the BPLC edition (BPLC:213) of the Ten-Chapter Sädhana; see Appendix IIa, pp.405-406. As with that edition, this brief description of a secondary deity is awkwardly plugged into the middle of the description for Gyajin. 
In the middle of the southern divine mansion of gold, TRI [appears]. From TRI, Shingjachen, the sovereign spirit of good qualities, [appears]. He has a black-colored body, one face, and two arms. He grasps a battle axe in his right hand and a lasso in his left. He wears snake- and tiger-skins on his body and [DL511:216] a bamboo hat on his head. There is a garuda bust [in] the vault above him. Cosmic turquoise dragons accompany his reveling, and he sends forth apes, monkeys, and cats as heralds. His consort is Sergyi Putrima Nakmo, who has one face and four arms. She wields a sword and a red lance in her right hands, and a scimitar and trident in her left. She wears a black silk diadem, and a belt of snakes over a petticoat of yellow yak-hair felt. Her right ear is adorned with a lion [earring] and her left with [an earring of] snakes. There is a ringing bell around her neck, and her two feet are decorated with iron shackles. She roams the night mounted on a donkey with a red spot on its forehead. His emanation has a light blue-colored body, wears a bandoleer of red mentri [fur], and brandishes a long hooked cane. His minister is Jagö Tangnak, who has the appearance of a young layman, and brandishes a vajra and war hammer.

In [the middle of] the western divine mansion of red coral, TRI [appears]. From TRI, the enemy-defeating god Kyechik Marpo, the sovereign spirit of speech, [appears]. He has one face and two arms. He brandishes a cane staff in his right hand and a sandalwood club in his left. He wears a black silk 125 cloak [on his body] and a round bamboo hat on his head. He rides a white-heeled black mule, which is led by Mönbuputra. Wolves accompany his reveling, and he sends forth iron hawks as heralds. His consort is Dzejé Padmachen Marmo,126 who brandishes a holy branch and a skull cup, [GRSD:25] and who possesses beautiful ornaments. His emanation is dark blue, has locks of hair that flow upward and a blazing dark-yellow beard, and wears a tiger-skin garment. He holds aloft a corpse club and a victory banner [adorned with] a wolf's [head]. His minister is Dorjé Drakden, who wears such things as red silk monastic robes and has the appearance of a young monk. He brandishes a mendicant's staff [made from] a red tree and rides a camel with a white spot on its forehead.

In [the middle of] the northern divine mansion of blue turquoise, TRI [appears]. From TRI, [Pehar,] the sovereign spirit of activities, [appears]. This great three-faced celestial man has three heads and six hands [DL511:217] — the three faces are white, dark blue, and red, [respectively]. His three right hands brandish an iron hook, an arrow, and a sword. His three left hands brandish a razor, a bow, and a club. He wears white silk upper garments and human- and tiger-skin skirts. He wears a parasol-shaped bamboo hat on his head. He rides a white lioness, which is led by Mönbuputra. Storms accompany his reveling and he sends forth jackdaws as heralds. His consort is Düza Minkarma, who is dark blue and wears the fur-lined coat of the hindering spirits. She brandishes a holy branch and skull cup. His emanation is black, wears a human-skin [garment], and is adorned with snakes. He holds aloft victory banners [adorned with] tiger and wolf

125 Tib. dar nag; this differs from the description in the Ten-Chapter Sädhana (GRSD:56), which describes this deity's cloak being made of red silk (dar dmar).

126 Tib. Mdzes byed padma can dmar mo; lit. "Beautiful Red Lotus-endowed Woman." This is an uncommon variant of this deity's name. 
[heads]. His minister is Putra Nakpo, who wears a black silk robe, brandishes a curved knife, and rides a black mule.

In the cardinal and ordinal directions beyond [the Five Sovereign Spirits], they are surrounded by their limitless retinue - such as ministers, shadröl, kyidröl, servants, zinpo, dompo, masked entertainers and lion[-masked dancers], Mön barbarians, $127 \bar{a} c \bar{a} r y a s$, and monkeys, as well as a hundred monks wielding mendicant's staffs, [GRSD:26] a hundred mantric sorcerers wielding ritual daggers, a hundred women shaking their hair, and a hundred men wielding swords and shields. A white OM manifests on the heads of the [five] central deities and their retinue, a red $\bar{A} H$ manifests on their throats, and a blue HŪM on their hearts.

Then, Regarding [the Manner of] Requesting [the Deities] to Manifest:

May the Five Sovereign Spirits - emanated guardians of the [Buddha's] teachingsalong with their secret consorts and ministers, arise from the intrinsic state of great bliss, like freshly gathered clouds in the sky! May the sovereign spirit of the mind and his retinue arise from the vast central palace of agate! May the sovereign spirit of the body and his retinue arise from the vast eastern palace of conch-shell! May the sovereign spirit of good qualities and his retinue arise from the vast southern palace of gold! May the sovereign spirit of speech and his retinue arise from the vast western palace of coral! [DL511:218] May the sovereign spirit of activities and his retinue arise from the vast northern palace of turquoise! Their emanations and secondary emanations fill the entire earth and sky without exception; may they [all] arise in this place!

Regarding the Invitation, Request to Reside, Exaltation, and Integration of the Oaths, [they are drawn] directly from the root treasure text accordingly: 128

[Invitation:] ${ }^{129}$

HŪM!

The Dharma protectors that I invite from the supreme realm-which is changeless and spontaneously perfected-and request to come to this mandala-which is generated through meditative concentration-are the Five Capricious-Sovereign Spirits together with their retinue. You, supreme beings that protect according to your fundamental samaya commitment, I request [that you] come to this place [where] I have invoked [your] samaya vow. For the benefit of protecting the teachings of the [Buddha's] Word, arise from the Source of the Dharma as an illusion! You, who act with great compassion for the sake of [all] beings, [GRSD:27]I request [that you] come to this place [where] I have invoked [your] samaya vow.

The great Gyajin, sovereign spirit of the mind, [your secret] consort, the powerful Shantin Rozan, and [your council] minister, the lord of life Kayi Jarawa, together with [your] retinue-I request [you all] to come to this place.

\footnotetext{
127 See Appendix IIa, note 1391.

128 This large excerpt from the Ten-Chapter Sädhana spans chapters 2-5 and (GRSD) pp. 59-61.

129 This is a complete copy of chapter 2 of the Ten-Chapter Sädhana; see Appendix IIa, p.419.
} 
Mönbuputra, sovereign spirit of the body, [your] secret consort, the female hindering spirit Rolangma, and [your] council minister, Jatri Mikchikpu the butcher, together with [your] retinue-I request [you all] to come to this place.

The capricious spirit Shingjachen, sovereign spirit of good qualities, [your] secret consort, Sergyi Putrima, and [your] council minister, Jagö Tangnak, together with [your] retinue-I request [you all] to come to this place.

The enemy-defeating god Kyechikpo, sovereign spirit of speech, [your] secret consort, Dzejé Padmakyé, and [your] council minister, Dorjé Drakden, together with [your] retinue-I request [you all] to come to this place.

The great three-faced man, sovereign spirit of activities, [your] secret consort, Düza Minkarma, and [your] council minister, Putra Nakpo, together with [your] retinue-I request [you all] to come to this place.

JAH HŪM BAM HOH!! ALALA HOH!

EHYEHI BHAGAVAN AÑKUŚA [DL511:219] SAMAYA JAḦ JAH!!

Seal [this recitation] with the four mudrās. 130

Requesting to Reside: 131

HŪM!

In this supreme holy place where Matram [Rudra] was liberated [through destruction], on a divan [made of] a [male and female] adulterer bound together-one laid face-down, the other in a supine position-I have erected a measureless Mount Meru [made] of the five precious objects, and beautifully adorned it with the sun, the moon, and a lotus divan. In this supreme place where non-attachment is spontaneously perfected, reside firmly without duality in order to protect the teachings!

I request that [you,] sovereign spirit of the mind, along with [your] retinue, reside in the blazing dark-blue divine [mansion] in the center.

[GRSD:28]I request that [you,] sovereign spirit of the body, along with [your] retinue, reside in the white conch-shell divine [mansion] in the east.

I request that [you,] sovereign spirit of good qualities, along with [your] retinue, reside in the precious golden divine [mansion] in the south.

I request that [you,] sovereign spirit of speech, along with [your] retinue, reside in the red coral divine [mansion] in the west.

I request that [you,] sovereign spirit of activities, along with [your] retinue, reside in the precious turquoise divine [mansion] in the north.

PADMA ĀVEŚAYA ĀH!! VAJRATRIDURUȘA HŪM!

VAJRA ATITIȘṬA KARAŚAYĀ! White Bridle SAMAYA JAḤ JAḤ!

130 Tib. phyag rgya bzhi. These are the four mudrās of yogatantra: [1] the mudrā of karma (Tib. las kyi phyag rgya; Skt. karmamudrā); [2] the mudrā of the samaya vow (Tib. dam tshig gi phyag rgya; Skt. samayamudrā); [3] the mudrā of dharma (Tib. chos kyi phyag rgya; Skt. dharmamudrā); and [4] the great mudrā (Tib. phyag rgya chen po; Skt. mahāmudrā).

131 This is a complete copy of chapter 3 of the Ten-Chapter Sädhana; see Appendix IIa, p.420. 
ĀVEŚAYA STVAṂ! AVEŚAYA TIȘṬA LHAN!

Once you have recited this, imagine [the Five Sovereign Spirits] residing without duality.

Prostration: 132

HŪM!

The haughty spirits that accomplish mundane activities appear in the forms of the Five Great Sovereign Spirits. Prostrate and praise the assembly of the Five Sovereign Spirits, who promise to protect the Buddha's teachings!

$\bar{A} K A R S ̦ A Y \bar{A} \bar{A}$ VEŚAYA EHYEHI ĀRALLI HO!

Having recited this, imagine [the] retinues prostrating to the principal [deities].

Integrating the Oath:

Perform the consecration by [reciting the following] 10[8 times]:

OṂ ĀH HŪṂ! SARVAPAÑCĀMRTA HŪṂ HRĪH ȚHĀ!

The integration of the oath is three-fold-superior, moderate, and inferior. At the time of performing the usual [ritual] quickly, the oath is as follows:

HŪṂ!

You, supreme beings, great enemy-defeating gods-when [we] integrate the oath [between] you and myself, the Great Glorious One, the blood-drinking [Heruka], will be our mediator and witness. From this time onward, for as long as I live, may I not transgress my oath, [DL511:220] and may I always give offerings to and rely upon [you,] the sovereign spirits. May you also not transgress your oath, and may you always act as my friends. However, if you do transgress your oath, Dorjé Nöjin Trowo will crush you into particles of dust. The best integration is of the finest nectar [of immortality], adamantine urine - combined with the pañcamrta - with the great heart's blood of the samaya vow; [this is] the essence of life. May [you] act as the quintessential friends of my heart, [GRSD:29] and may [you] never transgress your vow.

VAJRA TRIDURAKṢA YAKṢA HŪM PHAṬ! MAHĀPAÑCĀMRTTA KHĀHIḤ!

Place this [nectar] on one's tongue [and] also distribute it to the sovereign spirits.

Contemplate [the following]: I and the sovereign spirits have become inseparable. For as long as I live, [you] will obey me and be my servants. 133

Bestowing the Outer Offerings:

In the presence of the emanated Dharma king and his retinue, once I properly offer them actual arranged offerings [and] those that were mentally created-libations that flow like giant waves, all kinds of flowers that sway [back and forth], clouds of sweet smoke that fill the whole sky, garlands of butter lamps as bright as the sun and the moon, a collection of perfumed waters that are widely filled with medicine, a variety of excellent foods that have a hundred sublime flavors, and a melodious and majestic symphony of music - may they spontaneously perform the four activities!

132 This section and the next are a near complete copy of chapters 4 and 5 of the Ten-Chapter Sädhana; see Appendix IIa, pp.421-422.

133 This verse is in recitation font size in the Ten-Chapter Sädhana (GRSD:61), but in instructional font size here. 
The Offerings of the Four Activities:

Since I offered, to the five emanated Dharma Kings and their retinues, beautiful dances and pleasant music, fragrant scents, excellent flavors, and garments that are divine to the touch, may they perform the activity of pacification!

Since I offered, to the emanated sovereign spirits, a precious parasol, [a pair of] golden fish, a lotus, a conch shell, an excellent vase, an endless knot, a victory banner, and a [golden] wheel,134 may they perform the activity of increasing longevity, wealth, and merit! [DL511:221]

Since I offered, to the emanated sovereign spirits, the wheel, jewels, queen, minister, elephant, horse, and general 135 [of the king] who is victorious in all directions, may they perform the activity of conquering the three realms!

[GRSD:30] Since I offered, in the presence of the great capricious spirits-guardians of the [Buddha's] teachings — an argham 136 of human blood contained like a lake, flowers of the five sense organs - such as eyes, etc.- a cloud of slowly wafting smoke [produced from] burnt human flesh, a garland of butter lamps made from clarified human fat, food offerings of piled-up flesh and bone, and a collection of large trumpets, thigh-bone trumpets, and cymbals, may they quickly perform the activity of fierce destruction!

Bestowing the Inner Offerings: 137

Amrta, composed of eight major and a thousand minor ingredients, is the supreme offering of medicinal nectar.

I make an offering of [this] nectar, made from eight major and a thousand minor ingredients, to the lords Samantabhadra and Vajradhara.

OṂ ĀH HŪṂ! MAHĀSARVAPAÑCĀMṚTA KHARAṂ KHĀHI!

I make an offering of [this] nectar, made from eight major and a thousand minor ingredients, to Vajrapāṇi, Padma Tötreng Tsel, Lady [Yeshé] Tsogyel, [King] Trisong Deutsen, Lord Nyangrel [Nyima Özer], and Guru Dönseng. 138

134 These are the Eight Auspicious Symbols (Tib. bkra shis rtags brgyad), which are ancient Indian items that signify royalty. For a detailed discussion of these symbols and their iconographic representations, see Beer 2004, pp.171187.

135 These are the Seven Royal Possessions (Tib. rgyal srid sna bdun), which are the emblems of a universal monarch. 136 This is the Sanskrit term for water offered to guests, usually for washing their faces.

137 All of the figures in this section make up the transmission lineage of the Ten-Chapter Sädhana as it came down to the Fifth Dalai Lama. With the exception of one individual, all of the lineage masters are presented here, and in the same order as in the Fifth Dalai Lama's Record of Received Teachings (gsan yig); see Tā la'i bla ma 05 1991-1995, vol.2, p.615. The variant names of each individual, if drastically different from what is provided in this ritual, will be given for each figure in their accompanying footnote. Similar variants can also be found for the figures in notes 115-119 on DL502:553.

$138 \mathrm{Gu}$ ru Don seng; a variant of this name is Gu ru Don seng rgyal mtshan. There is little information on this figure, but he is likely a thirteenth-century treasure-revealer, specifically one of Guru Chöwang's (Gu ru Chos dbang, 12121270; TBRC: P326) assistants; see 'Jam mgon kong sprul 1976-1980, vol.1, pp.514-515. Without other detailed historical references, it is diffficult to know with any certainty who this is and who a number of the below figures 


\section{OṂ ĀHH HŪṂ! MAHĀSARVAPAÑCĀMRTA KHARAṂ KHĀHI!}

I make an offering of [this] nectar, made from eight major and a thousand minor ingredients, to the rootless ascetic Jamyang Logrö, 139 Jamyang Pelrin, 140 Penden Döndrupa, 141 Namkha Zangpo, 142 Kagyé Zhönzang. 143 OṂ ĀḤ HŪṂ! MAHĀSARVAPAÑCĀMRTA KHARAM KHĀHI!

I make an offering of [this] nectar, made from eight major and a thousand minor ingredients, to Kelden Gyatso, 144 Mingyur Letroling, 145 the Dharma King of DrikungLord Rinchen Puntsok, 146 Nyida Sangyé, 147 and Lenbu Karchen. 148 OṂ ĀḤ HŪṂ! MAHĀSARVAPAÑCĀMRTTA KHARAṂ KHĀHI!

I make an offering of [this] nectar, made from eight major and a thousand minor ingredients, to the Vajra-bearer 149 -Venerable Lord Pabongkhawa, 150 and the Omniscient Chöying Rangdröl Pel;151 [my] beneficent and unequalled root lamas! OṂ ĀḤ HŪṂ! MAHĀSARVAPAÑCĀMRTTA KHARAṂ KHĀHI!

\section{[GRSD:31] 152 I make an offering of [this] nectar, made from eight major and a thousand minor ingredients, to Penjor Lhündrup, Chöying Rangdröl}

are. Nonetheless, as noted above (note 165), many of these individuals are important lineage masters in the Fifth Dalai Lama's Record of Received Teachings. Furthermore, it is clear from the order of those individuals that are dateable that these figures are generally given in chronological order.

139 'Jam dbyangs blo gros.

140 'Jam dbyangs dpal rin.

141 Dpal ldan don grub pa; variant: Gu shrī dpal ldan don grub.

142 Nam mkha' bzang po.

${ }^{143}$ Bka brgyad gzhon bzang; variant: Bka’ brgyad pa Gzhon nu dpal bzang.

${ }^{144}$ Skal ldan rgya mtsho, 1607-1677; TBRC: P711.

$145 \mathrm{Mi}$ 'gyur las 'phro gling; $16^{\text {th }}$ century; TBRC: P10460. Variant: Mi 'gyur Kun dga' dpal bzang. This figure is elsewhere listed as Mi 'gyur Las 'phro gling ba Kun dga' dpal bzang (DL503:205), where he is followed by the next figure, Rin chen phun tshogs (note 123).

146 Rin chen phun tshogs, 1509-1557; TBRC: P399. Variant: 'Bri gung Zur pa rin po che; secondary variant: 'Bri gung Gnam lcags me ’bar (DL504:610).

147 Nyi zla sangs rgyas.

148 Lan bu dkar chen; variant: E dkar chen Lan bu a mi.

149 Tib. rdo rje 'chang; this is the same wording as Vajradhara, but in this context it is a title for one's root lama.

150 Pha bong kha ba, 1561-1637; TBRC: P647. Variant: Pha bong kha pa Dpal 'byor lhun grub.

151 Chos dbyings rang grol dpal, 1604-1669; TBRC: P650. Variant: Zur kun mkhyen Chos dbyings rang grol.

152 GRSD pages 31-32 consist of an extraneous folio that was clearly added. As with the first extraneous folio (see note 97), the folio is numbered 1 ( $\mathrm{gcig}$ ) and is placed here between folios 14 ( $\mathrm{dcu}$ bzhi) verso and 15 (bco lnga) recto of the GRSD manuscript. The script style is also noticeably different, which I am illustrating here by using a font style different from the rest of the ritual text. Although this folio cuts into the second-to-last verse of this section, I am placing it before the verse in full, since its contents continue the nature of the preceding verses by offering the nectar to various lineage masters. The contents of this folio are particularly brief, only taking up less than half of the recto side, leaving the verso side blank. It is clearly imitating the style of the previous verses, and continues the pattern by adding more names, including the Fifth Dalai Lama himself and his contemporaries. A particular focus 
Pel, 153 Zilnön Zhetsel, 154 Padma Trinlé, 155 the tantric scholar Wangyel, 156 and Sangak Tenzin. 157

I make an offering of [this] nectar, made from eight major and a thousand minor ingredients, to Dorjé Tokmé, 158 Padma Shenyen Tsel, 159 Jikmé

Pawo, 160 Trinlé Wangpöde, 161 Trinlé Peldzé, 162 and Künzang Traktung Je. 163

\section{I make an offering of [this] nectar, made from eight major and a thousand minor ingredients, to the lord of all families 164 Trinlé Chöpel, 165 and his principal disciple 166 the venerable Tupten Tenpa,167 as well as [my] root lama Tupten Könchok.168 [GRSD:32]}

I make an offering of [this] medicinal nectar to the tutelary deity Mighty Lotus 169 and the deities of his mandala, as well as to the Five Sovereign Spirits, their secondary emanations, secret consorts, ministers, and retinues. [DL511:222] I request that you bestow [on me] the accomplishments of body, speech, and mind! [GRSD:33]

OM ĀH HŪM! MAHĀSARVAPAÑCĀMRTTA KHARAM KHĀHI!

seems to be on treasure-revealers from the Northern Treasure (Byang gter) tradition. The author and date of this brief addition is unknown, though it was no doubt added sometime during the $19^{\text {th }}-20^{\text {th }}$ century.

153 These first two names of this offering verse repeat the two names of the last verse, strongly suggesting that these extraneous verses are picking up where the Fifth Dalai Lama left off, and are even beginning with him.

154 Gzil gnon bzhad rtsal; this is the secret initiation name of the Fifth Dalai Lama.

155 Padma 'phrin las, 1641-1717; TBRC: P657.

156 rig 'dzin Dbang rgyal, b. $17^{\text {th }}$ century; TBRC: P10285[?].

157 Gsang sngags bstan 'dzin.

158 Rdo rje thogs med, 1746-1796; TBRC: P694.

159 Padma bshes gnyen rtsal, c. $18^{\text {th }}$ century; TBRC: P10267.

160 'Jigs med dpa bo, b.1682; TBRC: P672[?].

161 'Phrin las dbang po'i sde, b.1757; TBRC: P834.

162 'Phrin las spel mdzad.

163 Kun bzang khrag 'thung rje.

164 Tib. rigs kun bdag po; this is likely a variant of rigs kun khyab bdag, which means "lord who pervades all families" and is an epithet for Vajradhara.

165 'Phrin las chos 'phel.

166 Tib. thugs sras; lit. "heart son."

167 Thub bstan bstan pa.

168 Thub bstan dkon mchog.

169 Tib. Padma dbang chen; this is an epithet for Hayagriva. 
Regarding the essence that liberates the enemies and obstructing spirits of the ten defects, 170 swirling among waves of human blood: I offer [this nectar] to the great emanated Dharma King and his retinue; may they receive and enjoy it in full! MAHĀRAKTA KHARAṂ KHĀHI!

The tongues of the great emanated Dharma King171 and his retinue transform into singlepointed vajras that arose from HŪM [and are each] endowed with a tube of red 172 light. With this they suck out and drink all the essence of the torma offerings. 173

[Recite the following mantra] seven or twenty-one [times]:

VAJRAYAKȘA KHĀHI! DUNTIM DUNTIM KHĀHI! YAKȘA Black KHĀHI! Shadröl HŪRU KHĀHI! Kyidröl HŪRU KHĀHI! CITTAMAHĀ KHĀHI! Zinpo RUDRA KHĀHI! Lineage of Dompos and Upholders KHĀHI! RUDRA RUDRA KHĀHI! GOROCANA KHĀHI! RAKTA Lips and Nose KHĀHI! Streams of Flesh and Streams of Hearts KHĀHI! The Five Senses KHĀHI! ŚSAMARUTRI KHĀHI! ARGHAM PRATĪCCHA HO! PŪJA VAJRA DURU HO! 174

Then recite: MAHĀRAJA SAPARIVARA ARGHAṂ...ŚSBTA! 175

Bestow the inner offerings with OṂ ĀḤ HŪṂ!

Then the exaltation and entrusting of the activities composed by the omniscient Gendün Gyatso is as follows: 176 Having embodied the wisdom and compassion of the all the victorious ones, the victorious lord Padmasambhava - who was born well from the center of a lotus in Oḍdịāna — acted to increase the race who [holds] dominion over this place.

[GRSD:34]I praise you, great Dharma protector, who was invested by that savior with the authority to guard all the monasteries, such as Samyé Monastery, the [very] ground from which happiness and well-being arose [in] Tibet.

I praise you, great guardian of the teachings, who - even though you do not waver from the limitless Source - displays the various manifestations of the five [main] forms in order to protect the [Buddha's] teachings with the four activities.[DL511:223]

170 Tib. zhing bcu; the ten defects are [1] destroying a monastery (Tib. dgon pa bshig pa), [2] destroying the Buddhist teachings (Tib. bstan pa bshig pa), [3] stealing the property of the Buddhist community (Tib. dge 'dun gyi spyi rdzas phrogs pa), [4] destroying the body, speech, and mind supports (Tib. sku gsung thugs rten bshigs pa), [5] stealing the wealth of the kingdom (Tib. rgyal khab kyi rgyu nor brkus pa), [6] harming the [kingdom's] subjects (Tib. mi dmangs la gnod 'tshe byas pa), [7] disrespecting the gods and lamas (Tib. Iha dang bla ma la brnyas smod byas pa), [8] killing one's parents (Tib. pha ma gsod pa), [9] damaging politics (Tib. chab srid la gnod 'tshe byas $p a$ ), and [10] [holding] wrong views (Tib. log par lta ba); see Dung dkar Blo bzang 'phrin las 2002, p.1773.

171 Tib. sprul pa'i chos rgyal chen po; DL206 has chos skyong.

172 Tib. dmar po; this extra description is not in DL206.

173 This line is drawn from DL206:177; see Appendix IIb, p.457.

174 This string of mantras is drawn from the end of chapter 7 in the Ten-Chapter Sädhana; see Appendix IIa, p.427.

175 The last two words are the first and last of the main offerings, acting as an abbreviation of the full list; for these offerings, see the BPLC edition (pp.217-218) of the Ten-Chapter Sädhana's introduction.

176 These verses of exaltation are drawn from DL206:204-205; see Appendix IIb, pp.464-465. 
I praise the king of the wish-fulfilling gems, who-like the wish-fulfilling tree or the excellent jeweled vase [of wishes] — causes all desirable yogic accomplishments to rain down [on me] when [I] devote myself to the offerings, praises, and approach and accomplishments [performed] for whomever.

Great emanated Dharma King along with your retinue, receive these offerings that fill the earth and sky, as well as this ocean of sacred torma offerings! Also perform the activity of increasing my parent's sublime lineage! 177

Support the kingdom's might—which has a thousand sons with marvelous qualities—like a golden wheel-turning monarch who governs all desires throughout the splendor of the four continents.

Confessions: 178

HŪM!

Samantabhadra, the tantric scholar Padmasambhava, the root and lineage lamas, the empowerment deity Hayagrīva, and the great emanated Dharma King and his retinue-I request that [you all] have me, the yogin, in your thoughts at this very moment!

We confess that, being overpowered by ignorance and obstructions, we have disparaged our root lamas [who possess] yogic accomplishments, acted capriciously 179 toward our tutelary deity, and have broken our secret tantric samaya vow.

Specifically, I openly confess to doing such thing as disrupting 180 the approach and accomplish [practice], the torma offering, and the amending ritual for the emanated sovereign spirit and his retinue; [GRSD:35] not performing their thanksgiving rites in a timely manner, [due to] being overpowered by laziness; and defiling their offering items.

I openly confess to acting contrary to proper Mahāyāna conduct by doing such things as sharing food and conversation with poisonous enemies, completely giving up on performing the four activities, and abandoning merciful compassion towards [all] beings.

[DL511:224]May [you all] 181 purify, within the state of the unfabricated Dharmadhātuthe true state of insight, detached from luminosity and emptiness - [our] faults of mistakenly perceiving conventional reality as the inherent nature of all primordially empty phenomena.

\footnotetext{
177 The next quatrain in the Rites and Praises is omitted here.

178 This prayer has been reproduced in a ritual dedicated to the Dharma King Ta-ok (Tib. Tha 'og chos rgyal), the central protector deity of Sera Monastery's Mé College; see Lama Gurudeva 1982, pp.513-514.

179 Tib. spong len; lit. "abandon and accept."

180 Tib. chags pa.

181 This concluding request is likely directed at the figures listed in the first verse of this section.
} 
Blessing the Feast Offering: 182

OM SARVA DRAVYAṂ SAṂŚODHANI HŪM PHAṬ! 183

RAM YAM KHAM HŪṂ HŪṂ ĀḤ ĀH OM OṂ HA HOH HRĪH!

The Invitation:

I invite glorious Padma Tötreng - in whom all the Buddhas of three times are unitedand the great lord [Hayagrivva] with his consort, as well as the deities, heroes, servants, 184 Dharma protectors, and guardian deities [of his mandala], and request that they come to this accumulation of wisdom!

The First Offering:

I present this excellent feast offering of divine foods 185 to the root and lineage lamas, the host of tutelary deities, as well as the heroes, servants, Dharma protectors, and treasure guardians, 186 and request that they bestow [on me] ordinary and extraordinary accomplishments! GURU DEVA ḌĀKINĪ GAṆACAKRA PŪJĀ KHĀHI! 187

\section{Confessions:}

Recite the hundred-syllable mantra, 188 and at the end, visualize the food [offerings] as equal to the bodies of the enemies and obstructing spirits. NR TRI189 JAḤ!

The most supreme190 Padma Tötreng Tsel raises a five-pronged vajra in his right hand [and] stabs an enemy's heart with the ritual dagger in his left. He reduces the harmful enemies and obstructing spirits to dust!

OM VAJRA GURU PADMA TÖTRENG TSEL! VAJRA SAMAYA JAH!!

[GRSD:36] NR TRI MARAYA191 HŪM PHAṬ! 192

Serving [the Offerings]:

I offer the flesh and bones of the enemies and obstructing spirits to the absolutely terrifying open mouths of Padma Tötreng and his retinue. [May they] accept these offerings within a state of equanimity!

182 Tib. tshogs.

183 A possible translation of this mantra is, "OM Completely Purify All [of these] Substances HŪM PHAT!!"

184 Tib. ging.

185 Tib zhal zas.

186 Tib. gter bdag; lit. "lord of treasures." This refers specifically to guardian deities of treasure teachings.

187 A possible translation of this is, "I Honor the Lamas, Gods, and Ḍākinīs [with this] Feast Offering-Consume it!" 188 This is also known as the Vajrasattva mantra.

189 According to Beyer (1973, p.311, Fig.36), these two mantric seed syllables cast the enemies and obstructing spirits down into a physical object, such as the offering tormas, so that they may then be "liberated" through destruction by the invoked tantric deity.

190 Tib. che mchog.

191 The normative Sanskrit is marāya; this is the dative singular of mara, which here indicates the symbolic enemy or obstructing spirit.

192 A possible translation of these mantras is, "OM Adamantine Lama Padma Tötreng Tsel! Summon the Adamantine Samaya Vow! Cast the Demon into Form HŪM PHAṬ!" 
GURU DEVA ḌATKINĪ the Flesh, Blood, and Bones of the Enemies and Obstructing Spirits KHA KHA KHĀHI KHĀHI! 193

Then [Perform] the Amending and Restoring [Rite]:

Bless the amending offerings.

HŪM!

Since I have appeased the emanated sovereign spirit and his retinue-[who] guard the teachings of all the countless Buddhas of the three times - with [these] outer, inner, and secret sacred items, may they enjoy them and then perform the entrusted activities!

Waves of bloody argham crash against the peak of the world. [DL511:225] Flowers of the sense organs that liberate the wicked sway [to and fro]. Clouds of smoke- the white incense 194 of burnt human flesh-permeate [the air]. Wonderfully sweet butter lamps of human fat [flicker].

II: With these [items], I amend the samaya vow of the Dharma-protecting Five Sovereign Spirits.

With these [items], I amend the samaya vow of their five great secret consorts.

With these [items], I amend the samaya vow of their five frightening emanations.

With these [items], I amend the samaya vow of the multitude of their obedient ministers.

With these [items], I amend the samaya vow of the ocean of their retinues.

Having done this, for the benefit of the [Buddhist] teachings and sentient beings, may [these deities] augment the lifespan of the lamas, extend the royal dominion of the ruler, and bring about the completion of my desires as well as the desires of others. :\|

[There is] a collection of fragrant perfumed waters swirling [with] blood and fat, and food offerings piled high [with] flesh, blood, and hearts; as well as an infinite variety of melodious and majestic musical instruments, such as thigh-bone trumpets, large trumpets, cymbals, and skull drums.

$\|: . . .:\|$

Inbetween each quatrain, 195 repeat 196 all eight of the verses [concerning] the Dharma-protecting [Five]

Sovereign Spirits, etc. 197

[There is] a collection of thoroughbred horses endowed with jewelled saddles and bridles, and long-haired yaks raising fearsome, adamantine horns; [GRSD:37] as well as cows with bountiful [milk], goats and sheep, soaring birds, lions, elephants, jackals, monkeys, and apes.

$\|: \ldots:\|$

193 A possible translation is, "Lamas, Gods, and Ḍakinīs - Consume! Consume the Flesh, Blood, and Bones of the Enemies and Obstructing Spirits!"

194 Tib. spos dkar; this is a literal translation. However, the Tibetan term connotes a specific kind of incense produced from the Sala tree.

195 Tib. shlauka; Skt. śloka.

196 Tib. gre, variant of 'gre; lit. "move back [to]."

197 I have framed the eight verses to be repeated with the repeat signs used in musical notation. To save space, I reiterate these repeat signs after this and the rest of quatrains of this section in accordance with these instructions. 
[There are] domestic fowl as multicolored as rainbows, and the joyful dances of black mön [spirits] and ācäryas; as well as many wondrous spectacles that are astonishing to the eye, [such as] the manifestations of brigadiers and emanations.

$\|: \ldots:\|$

[There is] a collection of ministry hats 198 as radiant as ruby red lotuses arrayed [with] all sorts of beautiful patterns of refined gold; magical hats 199 that are akin to anointing [one's eyes] with a medicinal eye potion;200 and thumb-shaped hats made of black silk. $\|: \ldots:\|$

[There is] such clothing as five-colored cloaks of silk brocade; monk's robes [similar to] the attire of arhats; as well as lower garments of elephant- and tiger-skins, [DL511:226] and upper garments of human-skins and silks.

$\|: \ldots:$ :

[There are different] types of armor that fill all the directions with a gleaming light—such as strong coats of mail and helmets - and weapons that grind the enemies and obstructing spirits into powder - such as arrows, spears, swords, battle axes, and razors. $\|: \ldots:$ :\|

[There are] parasols possessing exquisite wooden shafts [topped] with sapphire finials, ribs of pure gold, and silk fringes; and victory banners [made from] the skins of carnivorous animals, [such as] peacocks, lions, tigers, black bears, grizzly bears, and leopards.

$\|: \ldots:\|$

[There are] sharp razors, vajras mendicant's staffs, holy branches, battle axes, lassos, skull cups, curved knives, sandalwood clubs, bows and arrows, iron hooks, black silk military standards, scimitars, tridents, and arrows.

$\|: \ldots:\|$

[GRSD:38] [There are] amazing and beautiful arrays [of] precious ornaments-such as skulls, black snakes, and gold - and mounts that [can] instantly roam the billion-world system — such as elephants, lions, mules, horses, camels, and donkeys.

$\|: \ldots .:\|$

198 Tib. sag theb, variant of bse theb; these are specifically lacquered hats worn by monk officials.

199 Tib. zhwa phod; this term is difficult to translate in full. While zhwa clearly means hat, the significance of phod in relation to it is uncertain; phod could refer to a kind of silken ornament or fringe that this particular hat possesses, or to certain mental powers it is capable of bestowing. Given the description appended to this hat here, I have chosen to read it as the latter.

200 Tib. mig sman; this is one of the eight ordinary accomplishments (Tib. thun mong dngos grub brgyad) that grant one control over the phenomenal world. This particular ointment allows one to see great distances as well as unseen beings. The other seven accomplishments include [1] the ability to make holy pills (Tib. ril bu), [2] the ability to see underground (Tib. $s a$ 'og) in search of treasures, [3] gaining possession of a magical sword (Tib. ral gri) that defeats all enemies, [4] the ability to fly (Tib. nam mkhar 'phur ba), [5] invisibility (Tib. mi snang), [6] immortality (Tib. 'chi med), and [7] the ability to overcome illness (Tib. nad 'joms). There appear to be other variants of this list. 
[There is] a multitude of tormas possessing sacred nectar sprinkled 201 with various grains, blood, and barley beer; and a multitude of [visually] produced tormas of beautiful abodes adorned with gilded roofs, as well as offering tormas.

$\|: \ldots:\|$

[There is] a collection of delightful offerings, [such as] the sun and moon, the seven precious [possessions] of a king, 202 Mount Meru, the four continents and [eight] subcontinents, the wish-fulfilling tree, a pond endowed with the eight qualities [of water],203 and the wish-fulfilling jewel.

$\|: \ldots:\|$

[There are] the most excellent foundations of trust and devotion in the Eight Sädhana Deities [who] appear in the mandalic circle [of] the primordial, spontaneous, and glorious Samantabhadra, [as well as] in the great guardians of the [Buddha's] teachings, who appear individually [yet are] indivisible.

$\|: \ldots:\|$

Exaltations:

HŪṂ!

From within the Dharmadhatu - the expanse of space that spreads great bliss-the Sun

Lord, an emanation of the magical net,204 arose from a lotus [as] the Buddha of the three times, [who] enriches the garden of happiness and well-being with the powerful light of wisdom and compassion. [DL511:227] He dances with heroes, sings with diakkinis, expels hosts of demons with the menacing manifestations [of] great servants, and bestows ordinardy and extraordinary accomplishments with the three channels and [four] wheels 205 of the infinite manifestations of peaceful and wrathful deities.

Within divine mansions, completely pure in nature [and] made of jewels - such as conchshell, gold, coral, and turquoise - skeletons, like fragments of the moon, float in bloody lakes that liberate enemy armies. [GRSD:39] Along with this, everywhere [in each mansion there are] garlands of lungs, livers, and hearts, and tassles of sinew [hanging] along cords of entrails. [There are also] canopies of skin and decaying chunks of flesh. [These surround] a terrifying, blazing dark-blue triangle, in the middle of [which are the following deities]:

\footnotetext{
201 Tib. sbran pa; read as bran pa.

202 These are the same as the Seven Royal Possessions (see note 135).

203 Tib. yan lag brgyad ldan; these qualities are [1] cool (Tib. bsil), [2] sweet (Tib. zhim pa), [3] light (Tib. yang ba), [4] soft (Tib. 'jam pa), [5] clear (Tib. dwangs pa), [6] pure (Tib. dri med), [7] it does not upset one's stomach (Tib. lto la mi gnod pa), and [8] it does not hurt one's throat (Tib. mgrin pa la mi gnod pa).

204 Tib. sgyu 'phrul dra ba.

${ }^{205}$ Tib. rtsa gsum 'khor lo; this refers to the three 'channels' (Tib. rtsa; Skt. $n \bar{a} d \bar{\imath}$ ) within the subtle body through which life energy flows, according to traditional Indian medicine. The accompanying 'wheels' (Tib. 'khor lo; Skt. cakra) are found along the center of the body and represent where the channels intersect.
} 
The great Gyajin [sits] atop an elephant that is like a broken off piece of a mountain. He has the form of a barbaric spirit [whose eyes] are anointed with medicinal eye potion. He opens his ferocious mouth wide to eat the mass of [enemies and obstructing spirits who possess] the ten defects; they are bound with the lasso in his right hand. With the razor in his left hand, he pierces the heart at the center of their chests.206 He wears dark-blue silk and bear-skin garments on his body, and possesses a thumb[-shaped] hat with black silk [fringe]. I praise you, central sovereign spirit of the mind!

The great Mönbuputra, emanated guardian of the [Buddha's] teachings, [sits] atop a lion in the middle of a magnificent white mansion. He is [so] wrathful that he is unbearable to look at. He grasps a radiant vajra of pure gold in his right hand, and a mendicant's staff made from a red tree in his left. He wears a flowing mentri coat gleaming with sapphires [and] a thumb[-shaped] hat with black silk [fringe]. I praise you, eastern sovereign spirit of the body!

The capricious spirit Shingjachen [sits] in the middle of a mansion that is as radiant as honey-colored clouds.207 The displays of his emanations are like sun[rays] bathing a dark mound. He binds misleading spirits with the lasso of the hindering spirits in his left hand, [DL511:228] and cleaves their heads with the battle axe in his right. When he does this, it makes even the three worlds tremble. His body is adorned with poisonous snakes and tiger-skin [garments]. [GRSD:40] I praise you, southern sovereign spirit of good qualities!

The enemy-defeating god Kyechikpu [sits] on a black mule endowed with the strength of a mighty wind, in a divine mansion flowing [with] radiant waves of blood. He has a gaping mouth that ravenously [devours] savage enemies. He splits the earth with the cane staff that he raises in his right hand; he completely conquers the three worlds with the sandalwood club that he brandishes in his left. He is beautifully adorned with a flowing robe [of] dark-blue silk and a bamboo hat. I praise you, western sovereign spirit of speech!

Pehar - protector of the [Buddha's] teachings and chief of the enemy-defeating gods[sits] on a lion in the middle of mansion piled up to the blue sky. He is endowed with [three] faces - wrathful, semi-wrathful, and peaceful — conquers the pernicious enemies, and grasps with his left and right hands an iron hook, a razor, a bow and arrow, a sword, and a club. His upper body is adorned with white silks [and his lower body] with humanand tiger-skin skirts. He wears a black bamboo hat atop his large head. I praise you, northern sovereign spirit of activities!

I praise [you] five emanated Dharma kings, chief among the protectors, who manifest in wrathful forms from Samantabhadra's compassionate display of miraculous emanations in order to subjugate with fierce activities the enemies who would strive after the tamable realms. The surfaces of their faces are [bulbous] like dense storm clouds. Amid their

206 Tib. dkar nag snying gi mtshams su; this appears to be a more detailed variant of dkar nag mtshams, which refers to the space in the middle of one's chest.

207 Tib. mtshams sprin; lit. "intermediate clouds." This refers to the beautiful color clouds have in the morning light and at dusk. 
thick eyebrows, flashing [like] garlands of lightning, the onyx light of their wide angry eyes illuminates all good and evil. Inside their mouths that ravenously [devour the enemies'] life force, there are garlands of heads churning in waves of blood and fat, [GRSD:41] and their fangs - as white as snow-covered mountains - are stained red [with blood]. With the power to roam the three realms in an instant, they are completely victorious everywhere within the three worlds.

I praise the great roar of [your] inexhaustible speech, the poisonous power of the gnostic mantra curse that cuts the lifeline of enemies and obstructing spirits, [DL511:229] the fierce chant HŪM PHAT that sounds [like] thunder [and possesses] the potency of a weapon.

I praise you [five] who appear in a dualistic [manner, yet are ultimately of] one nature 208 - a nature produced from the unwavering primordial expanse of the totally limitless and completely pacified mind - and who possess wrathful minds in order to liberate [through destruction] the horde of malevolent beings.

I praise the assembly of five consorts, emanations, and heralds, who increase the abundance of happiness with marvelous enjoyments. I praise the five council ministers, lords of life who possess miraculous powers that accomplish all activities without obstruction.

I praise the massive ocean of [your] oath-bound retinues, which fill the whole of the earth and sky - secondary emanations such as the five emanations of the five Dharma kings, a hundred śrāvakas raising mendicant's staff and bearing [alms] bowls, a hundred tantric practitioners endowed with eye potion and wearing the garments of hindering spirits, a hundred female hindering spirits shaking their dark tresses, and a hundred heroic men going into battle, as well as monks, men from Mön, and Indian monkeys.

At vast [Samyé] Monastery and the [Chimpu] retreat site,209 Tsokyé Dorjé placed [you] within the mandala of the Assembly of the Sugatas [of the Eight Proclamations],210 bound you under oath, and appointed you as a protector. [GRSD:42] This lord of the haughty spirits of the [mundane] offerings and praises, 211 along with his retinue did not hesitate in taking the aforementioned oath, protecting the teachings of the Victorious Ones, maintaining the central and peripheral Dharma centers, and accomplishing all pacifying, augmenting, subjugating, and destructive activities. He prepares to battle for

208 Tib. ro gcig; lit. "one taste."

209 Tib. dben gyi gsung gi gnas; lit. "retreat place of speech." A more common variant of this is gsung gi dben gnas, which refers to Chimpu (Tib. Mchims phu) Valley, the power place of Padmasambhava's speech. His other four major power places are [1] Sgrags yongs rdzong, the place of his body; [2] Mkhar chu in Lho brag, the place of his mind; [3] Mon kha ne ring, the place of his activities; and [4] Shel brag in Yar klung the place of his qualities.

210 Tib. Bde gshegs rgyal ba 'dus pa; lit. "Assembly of the Victorious Sugatas". While this title is an obscure variation, given the context it would have to refer to the corpus of treasure texts discovered by Nyangrel Nyima Özer and mentioned in chapter 1 , note 310 .

211 Tib. mchod bstod; abbr. 'jig rten mchod bstod; this refers to one of the eight categories among the Eight Sädhana Deities. 
his sponsors - us and our attendants - wards off all injuries [that could be] inflicted by poisonous weapons, and performs activities that completely conquer all opposition everywhere.

Wherever212 an army of uncivilized enemies who possess evil minds and illustrate unruly conduct appear, [DL511:230] he quickly devours their life forces, vital essences, and life spans.

In short, may you who guard the direct and indirect teachings of the lamas accomplish, without obstruction, all actions that have been entrusted to you [by] Tötreng Tsel, the lord of yogic achievements, the sovereign who possesses a crown that is a manifestation of the Dharma.

Next is the following [text] composed by the omniscient Gendün Gyatso: ${ }^{213}$

The one called Tsokyé Dorjé, who rose from the center of a lotus, placed saffron that is famous in this land of snows on the cheeks of the local girls. Wherever he resides, rays of compassion cover the entire earth. May he fully perform a playful dance at the center of the lotus in my heart!

Shouting out with a loud cry, [you,] the emanated Dharma King- - [who is] part of the retinue in [Padmasambhava's] perfectly complete mandala-come to this place from your tall, multi-storied palace! The sky is obstructed by waves swirling in an ocean of tea and beer. [May you] consume these torma offerings [that are] piled [high] like a mountain [and] adorned with an ocean of muscle, flesh, blood, and fat. [GRSD:43]

Those who harm the teachings of the Thus-Gone One [are] the enemies and obstructing spirits [that have] evil thoughts and actions, [and that] possess a mind as wrathful as the rage found among the class of gods in the desire realm. Quickly liberate them at this very moment and drink a warm mouthful of their heart's blood. May you cut off such [evils] as sickness, [and] wrathfully annihilate them in accordance with their concurrent causes.

Like the meaning of the Perfection of Wisdom Sütras, the state of the beautiful and allilluminating Source is unlimited. [You] earnestly undertake [to prepare] the playful banquet that accompanies the brilliance of this knowledge. Clouds of fangs as white as frost [and] rows of lightning bolt tongues flash forth. [You who] destroy those that [would] completely consume all three worlds are similar to the gateways visible [on the maṇdala palace].

Supported by a home of grass and leaves, [I] paint with the brush [of] meditative concentration [focused on] you. [DL511:231] Despite hot or cold suffering, [I] strive to recite the [mantric] recitations like other sages. When [I do] purely recite JA six times,

212 Tib. phyogs mtshams steng 'og gang $d u$; lit. "the cardinal and ordinal directions, up and down-where." In the original Tibetan, this phrase is much more complex since it refers to the ten major directions (four cardinal, four ordinal, up, and down), while the ending gang du emphasizes whereever. For the sake of brevity, I have contracted this significance in translation.

213 These verses of exaltation are drawn from DL206:179-181; see Appendix IIb, pp.460-461. 
do night idle! Do not idle! Come here now! Eliminate the enemies and obstructing spirits that are as [cunning] as foxes right now!

All the eight classes [of gods and spirits] receive the row of [your] toenails on their heads like the tip of a hat. [You reside] in the middle of a conflagration that completely displays the eon of destruction's powerful fires, mingled with violent winds making a great thrumming noise reverberating like a lute. I praise you [who are] completely surrounded by a retinue of ghosts, [as well as] the eight classes [of gods and spirits], such as Yama!

[Your] two hands grasp a blazing vajra —its great spokes outspread-[and] a skull cup. [GRSD:44] [You] possess all kinds of fierce mudrās in order to subdue the various pernicious forces [that afflict] some people. Completely surrounded by a retinue of ten million flesh-eating spirits, [you] rule over the wish-fulfilling [tree] that bestows the fruits of all desires. May [you], the lord who protects the great land, forever remain [and] act virtuously until the end of samsāra!

When [you] burst forth with a fierce booming laughter — "Ha ha!"-[ [beings in] the three worlds [become] very terrified, saying "we are doomed!"214 and flee into the unproduced expanse of emptiness. Thinking of this, I become filled with doubt and hesitation. [May you] destroy all the enemies and obstructing spirits by quickly covering them with wolfsbane poison! [Exclaiming] "Alala!" [and] performing a joyful dance, [may you] bestow [upon me] all desired yogic accomplishments!

Entrusting the Activities:

[May] the Five Capricious Sovereign Spirits and their retinues-powerful protectors of the teachings of the Buddhas of the three ages, executioners [of] misleading enemies and obstructing spirits, lords of life-thoroughly reflect on the awesome oath that they formerly [took].

[May they] thoroughly reflect on [how], at Samyé Chimpu, the retreat abode of [Padmasambhava's] speech, the great master Padma Tötreng opened the mandala of the Assembly of the Sugatas [of the Eight Proclamations],215 initiated them [into it], and proclaimed them samaya-bound.

[DL511:232] [May] they not forget the pledge they made in the presence of King [Trisong Deutsen], and all his subjects and allies, as well as all direct and indirect lamas, such as Lord Nyangrel [Nyima Özer]. When I entrust them with activities, [may] they not hold back their power.

May they perform activities that augment, like the waxing moon, the teachings of the omniscient Victorious Ones - the source of [all] benefits and happiness - the disciplined community of men that bears the [teachings], and all studious, contemplative, and meditative conduct.

214 Tib. phye mar 'gyur; lit. "pulverized." This short saying is an addition not found in DL206.

215 Tib. Bde gshegs 'dus pa. 
[GRSD:45] In particular, the supreme embodiment of the Buddhas of the three times, Lozang Nyengyur Ringluk Drakpé Yang, 216 having thoroughly spread a white parasol [of happiness and well-being] over the peak of existence, [may they] abide [here] for a long time without fail.

[Having been] completely and thoroughly invited with ten-million[-fold] merit into the great Joyous Land Palace, Victorious in All Directions217-the thousand-spoked golden wheel of religion and politics - may they make it remain absolutely, exalted everywhere.

As for the bearers of the Buddha's teachings, may the [deities] extend the lifespans of the universal monarchs, great kings, and rulers who protect the unmatched holy Dharma [during] troubled times, as well as their kingdoms, domains, and politics.

[May they] bring about all of my desires - the yogin who always practices relying on [them and] sincerely performs their prayers and offerings - crush harmful enemies and obstructing spirits, and accomplish all pacifying, augmenting, and subjugating activities.

Invocations:

HŪṂ!

When these capricious spirits and their retinues-guardians of the [Buddha's] teachings - rage against malicious enemies, [they take on] the form of vicious spirits [with] inexhaustible wrath [and] thunderously roar a far-reaching laugh of "Ha ha!"

Thoroughly visualize the miraculous powers [of] the Dharma protectors and their retinues. They strike the sun and the moon, and shake the earth and sky. Lightning and hail stream down, and red military standards flutter about; all their various weapons are upraised.218 [They are surrounded by] throngs of Mön natives and ācārya [spirits], impatient219 troops of capricious spirits, fast horses with clanking armor, and the four brigadiers marching forward. [DL511:233]

[GRSD:46] Without resting for a year or [even] a month, may they drink the heart's blood of malicious enemies who endanger the [Buddha's] teachings, hurt sentient beings, and inflict harm on yogins that act in accordance with the Dharma, and annihilate them!

Oblations:

At the time that the amendment items [are to be offered], once the extended compound [ritual] procedures are implemented according to the root terma text - such as the arrayed suitable materials, the oblation tormas, and the choicest parts [of the offerings] sprinkled into a broad bowl — and the primary, easily performed [recitations] are recited, [chant the following]:

216 Tib. Blo bzang snyan 'gyur ring lugs grags pa'i dbyangs. Given the context, this most likely refers to Tsongkhapa Lozang Drakpa (Tsong kha pa Blo bzang grags pa, 1357-1419; TBRC: P64), the famous founder of the Gelukpa sect; however, this is an unusual lengthening of his monastic name.

217 Tib. Dga' ldan phyogs las rnam rgyal pho brang; this is an extended name for the Ganden Podrang (Tib. Dga' ldan pho brang), the former Tibetan government.

218 Tib. zings se zings; this term is difficult to translate, though clearly it is an onomatopoeic phrase related to weaponry here. Since the root word is likely zing $b a$, I suspect it represents the sound of weapons being brandished.

219 Tib. nyer re re; read as nye re re. 
HŪṂ!

I entreat and present this offering of the best pure golden libations to the central sovereign spirit of the mind, along with [his] emanation, consort, minister, and retinue in its entirety. Perform the activities that I entrust to you!

Chant this recitation again for the four other [deities].

Remaining [Offerings]:

HŪM!!

To the remaining gathering of [the deities'] glorious servants - the host of oath-bound protectors that undertake all activities - come here, accept these remaining tormas, and accomplish the activities entrusted to you!

OṂ UCHIȘṬA220 VAJRA ARITRAȘA221 SAMAYA KHA KHA KHĀHI KHĀHI!

Covenant:

In accordance with being bound under oath long ago by the five-the Great Glorious Conqueror Heruka, Padmasambhava, King [Trisong Deutsen], his subjects, and his allies - as well as the root and lineage lamas, like the tantric scholar and adept Ratna Lingpa,222 may the gathering of $d \bar{a} k i n \bar{s}$ s and the ocean of oath-bound guardians of the teachings receive these tormas and perform the activities entrusted to them!

Guardians of the [Buddha's] Teachings:

HŪM!

May the four hindering spirits-Dorjé Kündrak, 223 [Dorjé] Yamakyong, 224 Dorjé Künzang,225 [and Dorjé] Gekyitso226 - the four capricious spirits-Shamé Yudrönma,227 [Karek] Kyungtsün, 228 Dorjé Lumo, 229 and Dorjé Drakgyel 230—and the [four] noble medicine goddesses231—Kongtsün Demo, 232 [Dorjé] Menjikma, 233 [Dorjé] Yarmosil,234 and [Dorjé] Zulema 235 - along with their retinue, 236 who, in the presence of Padma

220 The normative Sanskrit is ucchișta, which means "remainder."

221 Tib. A ri tra sha; DL511:233 has A ra ta sha. The meaning of this word or words is unclear.

222 Rat na gling pa, 1403-1479; TBRC: P470.

223 Tib. Rdo rje kun grags.

224 Tib. G.ya' ma skyong.

225 Tib. Rdo rje kun bzang.

226 Tib. Bgegs kyi gtso.

227 Tib. Sha med g.yu sgron ma. This is likely a misspelling of Sha med [rdo rje] g.yu bun ma; see NebeskyWojkowitz 1998, p.187. Otherwise this would refer to two names, [Gangs dkar] sha med and Rdo rje g.yu sgron ma, which would not work numerically or make sense given the usual ordering of these deities; see ibid, pp. 182-190.

228 Tib. [Mkha' reg] khyung btsun.

229 Tib. Rdo rje klu mo.

230 Tib. Rdo rje grags rgyal.

231 Tib. sman btsun.

232 Tib. Kong btsun de mo.

233 Tib. [Rdo rje] sman gcig ma.

234 Tib. [Rdo rje] g.yar mo sil.

235 Tib. [Rdo rje] zu le ma. 
Tötreng, promised to protect Tibet, [GRSD:47][DL511:234] accept these tormas [made of] sacred substances and accomplish the activities that have been entrusted to them!

\section{Horse Dance:}

HŪṂ!

In the mandala of the Secret Assembly Gurus,237 the great glorious [Hayagriva] performs a wrathful dance over the hearts of the enemies, obstructing spirits, transgressor spirits, and ghosts born from the five poisons. With this he subdues the afflictive emotions within the primordial expanse of wisdom, grinds into dust the harmful and hateful enemies, and liberates [through destruction] the entire horde of formless evil spirits.238 The ritual of subjugation is completed. OM HRĪH VAJRA KRODHA HAYAGHRIWA HULUHULU 239 HŪM PHAṬ! ŌM LĀM HŪM LĀM STVAM BHAYANAN! 240 Enemies and Obstructing Spirits SARVA ŚATRŪM 241 STVAM BHAYANAN! 242

Next, at the magnificent end of Samsāra and Nirvāna:

From within the continuum of Emptiness, the unproduced Dharma body, [the tutelary deity] 243 appears in accordance with the rainbow mandala of the most secret lamas,244 completely liberates all beings from the ocean of existence, and [departs] into the unproduced Source of the Dharma. VAJRA MUH! 245

Having resided in this place, together with the images, for the sake of [all] beings, I request that you thoroughly bestow [upon me] a life free of disease, as well as empowerments and supreme [qualities].246

236 These twelve deities make up the Twelve Guardian Goddesses (Tib. Bstan ma bcu gnyis), important protector deities with strong ties to Penden Lhamo and the Nyingma sect.

237 Tib. Gsang 'dus bla ma; Skt. Guhyasamajaguru. This refers to a cycle of treasure texts rediscovered by Guru Chöwang (Gu ru Chos kyi dbang phyug, 1212-1270; TBRC: P326).

238 Tib. gdon.

239 This Sanskrit term represents joyous exclamation.

240 This word likely stems from the Sanskrit bhayana, meaning "to fear, be afraid."

241 This word is based on the Sanskrit śatru, meaning "enemy, foe, hostile force."

242 A possible translation of this mantric line is, "All Hostile Enemies and Obstructing Spirits-Praise and Fear [Hayagrīva]!”

243 It is unclear in this section whether the deity being entreated is a tutelary deity, like Hayagrīva, or the Five Sovereign Spirits; I suspect it is the former.

244 Tib. yang gsang bla ma'i dkyil 'khor.

245 This is a departing mantra commonly used to send away the empowering deity (See Beyer 1973, pp.274, 358; and Bentor 1996, p.202.

246 Tib. 'dir ni gzugs dang lhan cig tu/ /'gro ba'i don du bzhugs nas ni/ /nad med tshe dang dbang phyug dang / /mchog rnams legs par stsal du gsol/ In DL511:234, only the first line of this quatrain is provided, with the rest being assumed. This is likely because this quatrain, with one minor variation, is quite popular in Geluk consecration literature. Though it may be older, its first instance in a Geluk context is with the sect's very founder, Tsongkhapa, who includes it in a consecration manual that he composed (See Tsong kha pa 1978, p.348). Other important Geluk masters besides the Fifth Dalai Lama have further copied it into their own manuals (See Dge 'dun grub pa 199x, p.426; and Lcang skya 02 n.d., p.120). 
Enthronement:

[I] enthrone [you] as the essence of the benevolent lamas - the assembly of direct and indirect vajra masters [who are] the embodiment of all the Victorious Ones that accordingly bestows the treasury of empowerment transmissions and oral instructions.

[I] enthrone [you] under the three supreme jewels of refuge - the divine assembly of the innermost faultless Buddhas, the Dharma that imparts the ocean of their ultimate lineages, and the scholarly community that properly practices it.

[GRSD:48] [I] enthrone [you] as knowledge-bearing lords of the enemy-defeating godsthe Five Sovereign Spirits, emanated guardians of the [Buddha's] teachings, who appear in wrathful forms from the condition of great bliss, the Source of the Dharma, in order to tame the malevolent forces.

[I] enthrone [you] as a great king who fulfills all that I desire like the wish-fulfilling tree- - a powerful king who effortlessly bestows by hand 247 all the virtue and goodness of Samsāra and Nirvāna once [I perform] the offerings and praises.

Once we, your unerring servants, and the holy places are entrusted to you powerful protectors, [DL511:235] after thoroughly pacifying all adverse and unfavorable conditions, perform the auspicious virtue of effortlessly accomplishing all our desires!

Benediction:

May the auspiciousness of the root and lineage lamas - the source of perfection who embody all Dharma, Enjoyment, and Emanation Bodies248_-be present!

May the auspiciousness of the tutelary deity Mighty Lotus249-who dispels all obstacles [and] bestows accomplishments 250 - be present!

May the auspiciousness of the great kings - guardians of the [Buddha's] teachings who accomplish the activities that liberate all enemies and obstructing spirits - be present!

May the auspiciousness of the ocean of your attendants and retinues-whose activities are unhindered in accomplishing all actions-be present!

In this place, the day is auspicious, the night is auspicious, even mid-day is auspicious; day and night are always auspicious. Because of this, may the auspiciousness of the three supreme jewels of refuge be present!

In all our lifetimes, may [we] be inseparable from the true lama, enjoy the glory of the Dharma, and thoroughly perfect the qualities of the ground and path. Thus, may [we] quickly attain the state of Vajradhara!

247 Tib. lag rtser; lit. "atop the hands."

248 Tib. chos longs sprul pa'i sku.

249 Tib. Padma dbang chen; this is an epithet for Hayagrīva.

250 Tib. dngos grub; Skt. siddhi. 
These two ślokas 251 are authentic;252 however, they are [in] the oral tradition within the continuum of the scriptural collection.253 Furthermore, one should perform various auspicious songs. [GRSD:49]

[May this] series of arranged activities please the great king, guardian of all the monasteries [of] Tibet, where the fruits of happiness and well-being hang from the great wish-fulfilling tree within an ocean of virtuous actions.

This unceasing adamantine melody is thoroughly requested by whoever rules over this great vast land with a host of virtuous actions. Accordingly, through this composition, may the four activities be accomplished!

This sädhana that pleases the great emanated Dharma King and his retinue, called the Unceasing Adamantine Melody, was requested by the treasurer who happily protects this great vast [land], Sönam Rapten, 254 who said, "We need a [ritual] that is complete and easy to implement." Because of this, [I] summarized [parts] from the Lama's Practice Manual [in] the Assembly of the Quintessential Mind Attainment, 255 based the series of prayers and offerings on the Ten-Chapter Sädhana and [other] sädhana cycles rediscovered by Lord Nyang[rel], and auspiciously took from the writings the Omniscient Gendün Gyatso, and compiled these necessary parts into a new composition. The monk born of the Zahor line, Ngawang Lozang Gyatso Lamé Dorjé Tsel,256 who was properly assisted by the great capricious spirits, wrote [this ritual] all in one day, in accordance with the Great Sovereign Spirit, 257 who said that an omen arose [suggesting the ritual] needed to be completed immediately. The scribe was Ngawang Gelek. 258

251 This Sanskrit word refers to the popular quatrain style found throughout this and other Tibetan rituals.

252 Tib. khongs ma; read as khungs ma.

253 The two aforementioned ślokas, as well as this explanation of their origin, are not found in the DL511 edition.

${ }^{254}$ Bsod nams rab brtan, 1595-1658 (served as regent, 1642-1658); TBRC: P4436.

255 Tib. Bla ma'i las byang thugs bsgrubs yang snying 'dus pa. The Assembly of the Quintessential Mind Attainment (Tib. Thugs sgrub yang snying 'dus pa) is an important cycle of treasure texts rediscovered by the treasure-revealer Ratna Lingpa (Ratna gling pa, 1403-1479; TBRC: P470). The text within this cycle referred to here is the Precious Garland Practice Manual (Tib. Las byang rin chen phreng ba).

$256 \mathrm{Ngag}$ dbang blo bzang rgya mtsho bla med rdo rje rtsal.

257 This refers to the Nechung Oracle.

258 Ngag dbang dge legs. 


\section{Appendix III}

\section{The Nechung Register}

The Nechung Register (Tib. Gnas chung dkar chag) is a detailed list of the sacred items, texts, and relics that were stored at Nechung Monastery after its 1682 expansion. As with most monastic registers, this work also includes praises to the monastery's central deities and descriptions of their mythologies, details behind the monastery's founding, and a list of those who worked on its renovation. The Nechung Register is coauthored by the Fifth Dalai Lama and his last regent, Sangyé Gyatso, and was inscribed on the southern wall of Nechung Monastery's courtyard (see Figure 98). The register is 75 lines long. The first 37 lines of the inscription consist of the Fifth Dalai Lama's contribution, while the remaining 38 lines were composed by Sangyé Gyatso. This appendix is a full transcription and translation of the Nechung Register.

The wall inscription of the Nechung Register was badly damaged during the Cultural Revolution; however, most of it is still legible today. There have been two attempts to transcribe and publish the register's contents. The first is the transcription produced by Lingön Padma Kelsang in the mid-1980s. The second transcription of the Nechung Register is a partial copy; it consists of a 13-folio block-print manuscript edition of Sangyé Gyatso's portion of the register. Although its publication date and location are unknown, this edition is presented as a distinct text entitled, Roar that Shakes the Three Realms: the Register of the Pehar Chapel Nechung, which is Exalted by Eight Unprecedented Kinds of Craftworks-Rāvana's Palace Transferred to Earth, where Offerings and Praises are Joyfully Performed [for] the Churning Whirlpool of the Host of Haughty Spirits and the Ocean of Oath-Bound [Guardians]. ${ }^{1}$ While Lingön Padma Kelsang copied the Fifth Dalai Lama's portion of the Nechung Register from the wall inscription itself, it is clear that he transcribed Sangyé Gyatso's portion from this manuscript. The Tibetan scholar Dobis Tsering Gyal has likewise published a typed transcription of this manuscript. ${ }^{2}$

\footnotetext{
${ }^{1}$ Tib. Mchod bstod dregs pa'i lha tshogs rba klong 'khrug cing dam can rgya mtsho dgyes par spyod pa'i mgrin bcu'i pho brang sa la 'phos pa sngon med bzo sna brgyad kyis 'phags pa'i gnas chung pe har lcog gi dkar chag sa gsum g.yo ba'i nga ro; see Sangs rgyas rgya mtsho n.dc.

${ }^{2}$ See Dobis Tsering Gyal 2009, pp.350-359.
} 
Lingön Padma Kelsang's transcription has until now been the only full copy of the Nechung Register. ${ }^{3}$ However, there are notable differences between the wall inscription of the register and Lingön Padma Kelsang's edition. Unfortunately, whether during transcribing or typing the register, a number of errors crept into Lingön Padma Kelsang's text. These errors include minor typographical mistakes as well as major issues like misplacing or omitting entire lines of verse. Understandably, Lingön Padma Kelsang also corrected the original Tibetan text in a number of places, since the wall inscription is rife with idiosyncratic or erroneous spellings. While this is admirable and even helpful, these corrections ultimately do damage to the original text, the errors and unique spelling of which contain valuable historical data. Nevertheless, Lingön Padma Kelsang's transcription has proven indispensible, since it was recorded nearly thirty years ago when the register was less decayed and more legible than it is today.

For this reason, in transcribing the Nechung Register anew, I have relied on Lingön Padma Kelsang's text as a base. I then used high definition photographs of the wall inscription taken in situ to make any necessary changes. ${ }^{4}$ I also referred to the Roar that Shakes the Three Realms manuscript, as well as Dobis Tsering Gyal's transcription, in order to aid understanding; differences between the wall inscription and the other editions are provided in footnotes. The primary distinction in the edition below is that abbreviated Tibetan words (Tib. bskungs yig) found in the wall inscription are spelled in full in my transcription. This difference makes the below transcription a semi-diplomatic edition. Otherwise, this edition is as accurate a copy of the original wall inscription as is possible given its state of deterioration. For my translation of the wall inscription, I used my transcription while taking advantage of the occasional differences in orthography visible in the other editions. Finally, the wall inscription of the Nechung Register does not have a distinct title, nor does it distinguish between the Fifth Dalai Lama's section and Sangyé Gyatso's section beyond starting the latter on a new line. Lingön Padma Kelsang's transcription provides a title for each of the two portions, so I have translated his titles as such for ease of reference.

\footnotetext{
${ }^{3}$ See Tibetan Academy of Social Sciences 2009, pp.470-488. There are three other shorter registers found on various walls within Nechung Monastery, which Lingön Padma Kelsang also transcribed (see ibid, pp.489-498); however, it is clear that the register discussed in this appendix is the oldest and most important one.

${ }^{4}$ I am grateful to Cecilia Haynes for diligently photographing the numerous quadrants of the Nechung Register wall inscription using her Nikon D7000 DSLR camera and 18-55 mm lens. These photographs provided me with detailed images of the entire register, line-by-line, from which I could accurately transcribe its legible contents. I am also grateful to Mikmar Tsering, who likewise provided me with detailed photographs of the register.
} 
The content of the Nechung Register is well structured. The first half of the register, composed by the Fifth Dalai Lama, begins with a series of poetic quatrains. The meter length of these verses diminishes gradually in odd numbers; the first quatrain has 19 vowels per line, while the final quatrains have 7 vowels. The contents of these quatrains match the contraction in meter, since the first verses concern the grand Buddhist cosmos while the final verses condense into the specific historical context of the Five Sovereign Spirits and Nechung Monastery's lineage. After this panegyric introduction, the prose of the register begins with a doctrinal and philosophical argument for why it is appropriate to venerate the Five Sovereign Spirits, and why they are the best protector deities to revere. This is followed by a brief outline of the deity Pehar's past lives, as well as his arrival at Samyé Monastery and eventual ties to Drepung Monastery. The register then discusses Nechung Monastery's expansion, along with its religious contents and the main tantras and ritual texts of its deity cult. The Fifth Dalai Lama's section concludes with more poetic verses praising Nechung and the Five Sovereign Spirits, tying them back to the Tibetan dynasty, before ending with a colophon.

The second half of the Nechung Register, composed by the regent Sangyé Gyatso, likewise begins with poetic quatrains. These stanzas also descend in meter length, though more simply-from 15- to 9-meter verses. Despite this simplicity, there is a noticeable contraction of focus in these verses. This is followed by prose, which begins with a much more detailed treatise on the metaphysical importance of the Five Sovereign Spirits. The register then continues Pehar's history where the Fifth Dalai Lama left off, explaining the deity's migration to Tsel Yangön Monastery and eventual arrival at Nechung. A stronger connection is made in this portion of the text between Pehar and the lineage of the Dalai Lamas, since their special relationship is consistently emphasized. The next section is the lengthiest as it details the workers and craftsmen involved in Nechung Monastery's 1682 expansion and renovation. After the temporary consecration ceremony is described, the last section concerns the eight different craftworks that make the monastery unique. As with the first half, this half of the register concludes with poetic stanzas and a colophon.

The following transcription and translation are color-coded and organized in various ways. The page numbers for Lingön Padma Kelsang's transcription are dark red, while the line numbers for the wall inscription are blue. Moreover, I have reintroduced the red coloring of key words found in the text of the wall inscription in order to highlight significant names and terms. Finally, I have divided the verses of poetry into stanzas to act as an immediate visual cue, 
separating the framing panegyrics from the enclosed exposition. It is with these changes and emendations that I hope to provide an improved and more reliable transcription of the Nechung Register, as well as a complete translation.

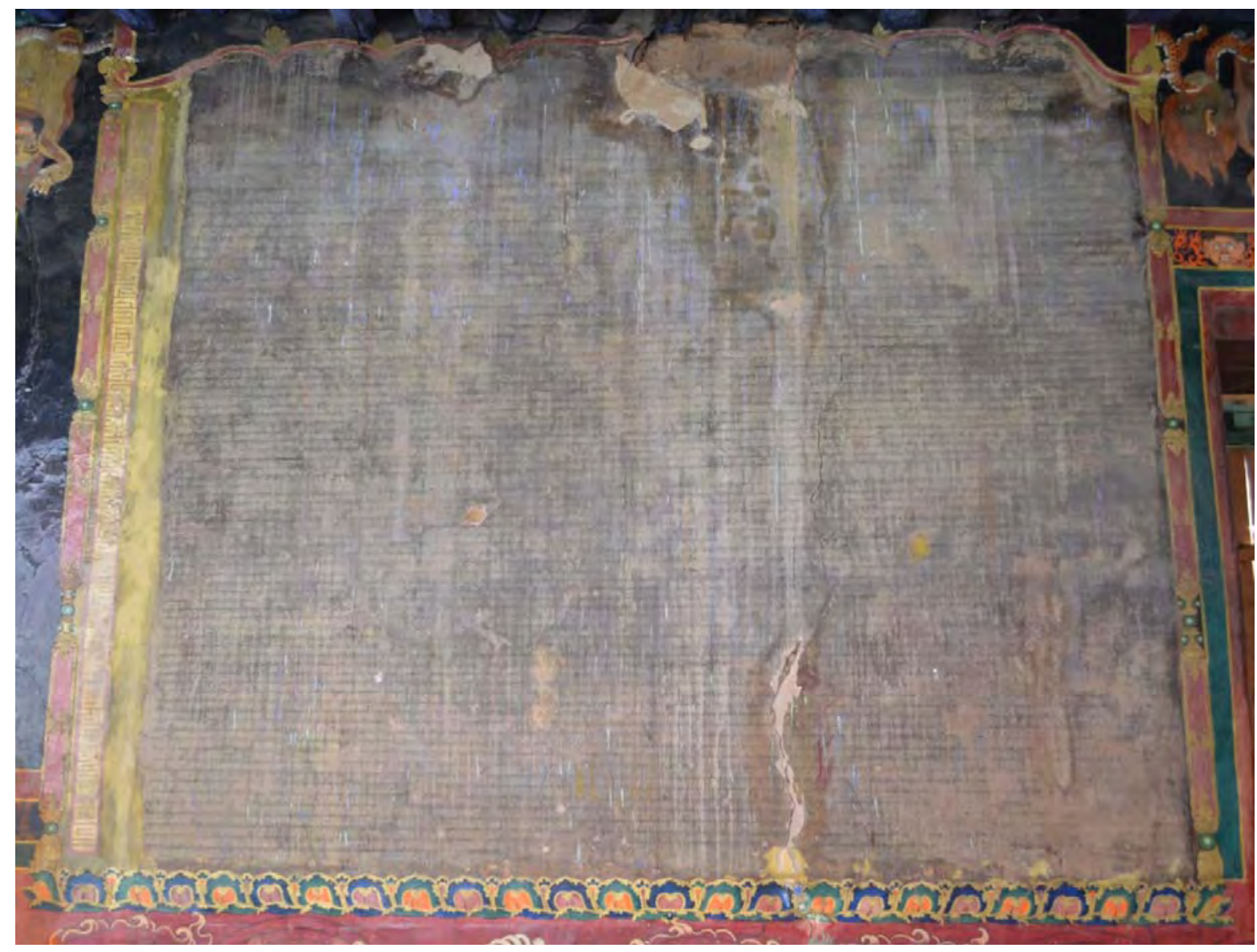

Figure 98: Wall inscription of the Nechung Register; Nechung Monastery Courtyard. (Photo: Cecilia Haynes, 2012) 


\title{
Nechung Register Transcription
}

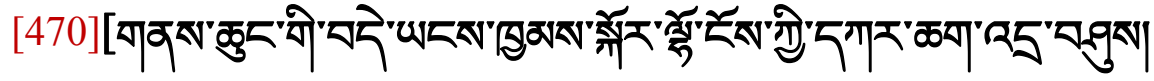

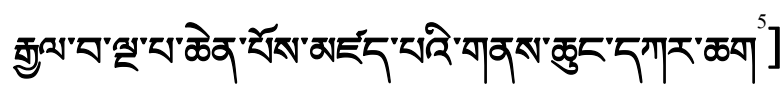

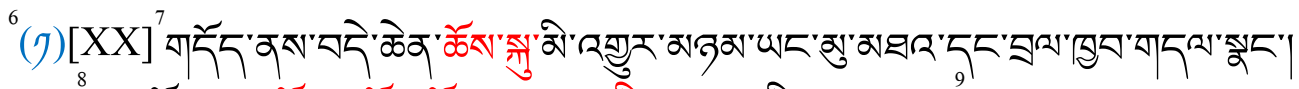

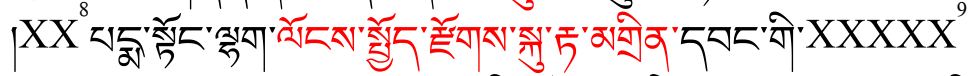

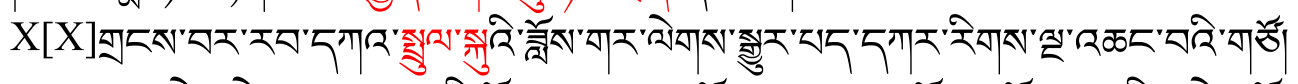

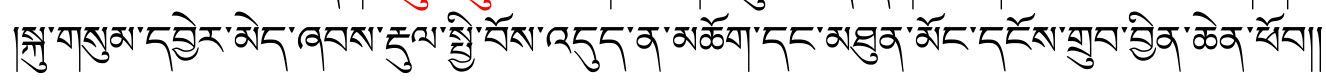

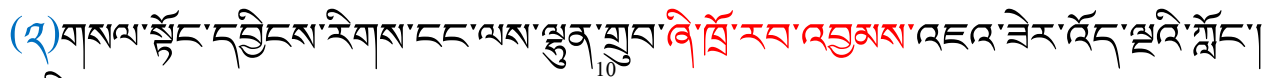 \\ बखेबा'万ु'XXXXXXX[XXXXXXX] चा।

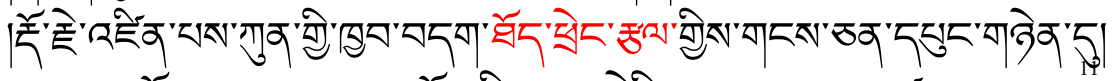

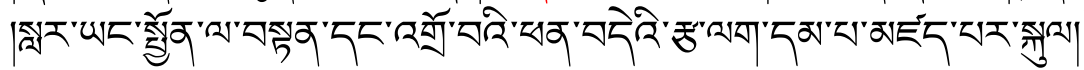

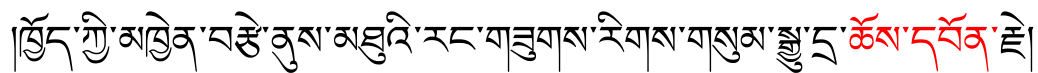

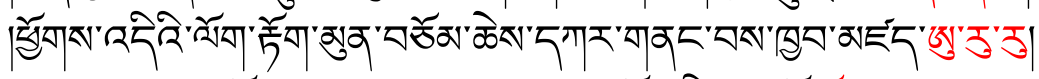

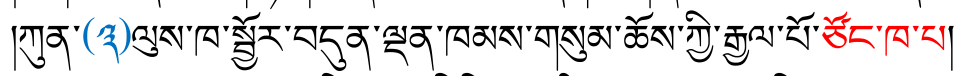

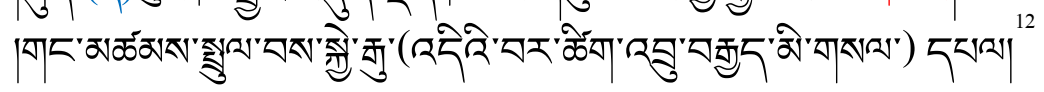

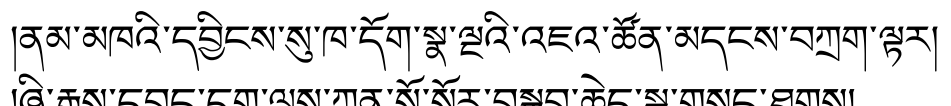

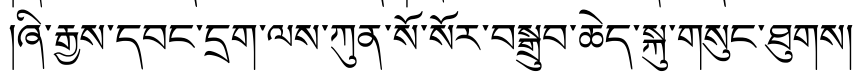

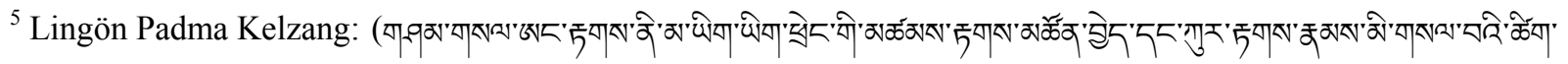

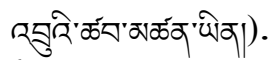

${ }^{6}$ Along the top of the register before the text proper, there is a Sanskrit prayer given first in Rañjanā (Tib. lanydza) script, and then transliterated with Tibetan letters. Both lines are so obscured by damage to the wall that they are almost completely unreadable, which may explain why Lingön Padma Kelzang did not transcribe them. Presumably, the first stanza of the text given here is the Tibetan translation of this prayer.

${ }^{7} \mathrm{X}$ marks represent syllables obscured by damage, as Lingön Padma Kelzang explains in the above note. X marks within brackets (e.g., [X]) are my own interpolation based on my observations of the original inscription.

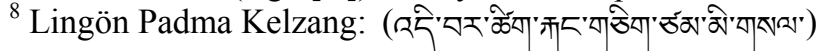

${ }^{9}$ It is unclear how many syllables are actually missing in these two middle verses. After viewing the original inscription on the southern wall of Nechung Monastery's courtyard, it appears that this prefacory poem is a four-line stanza, with each line consisting of either 17 or 19 syllables. Only the last line is of definitive length, at 19 syllables long. The two middle lines are the most difficult to ascertain, because damage to the inscription has obscured the line breaks as well as an unknown number of syllables. Lingön Padma Kelzang gives the first line 17 syllables, thought it appears that two syllables at the beginning were missed, also due to damage. If this is the case, all four lines may actually be 19 syllables long. I speculate that the latter is the case, since each subsequent stanze consists of four lines, each of the same length and with two syllables less than the previous stanza.

${ }^{10}$ Given the surrounding stanza of 17 -syllable lines, this line is most likely missing 14 syllables.

${ }^{11}$ The lines in this stanza are all 17 syllables long.

${ }^{12}$ The lines in this stanza are all 15 syllables long.
} 


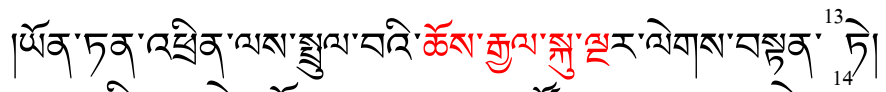

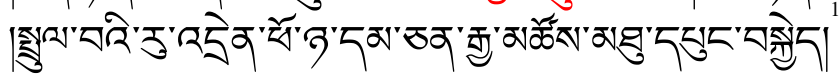

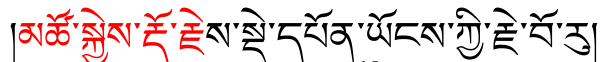

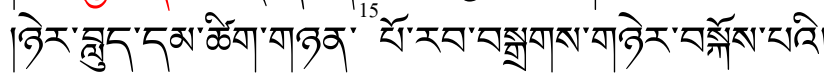

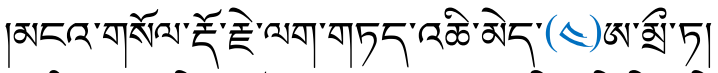

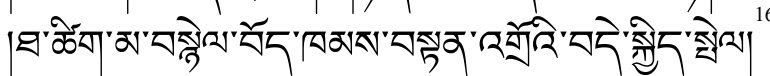

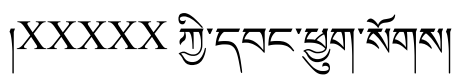

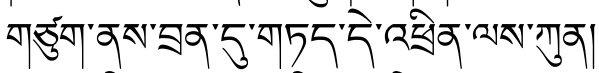

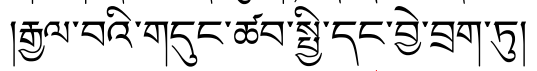

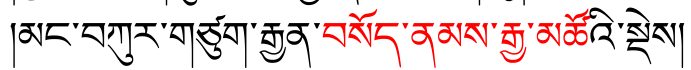

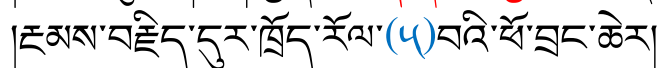

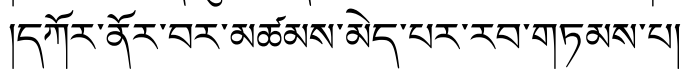

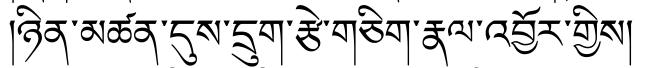

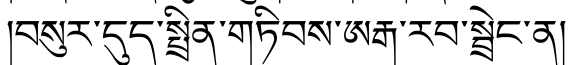

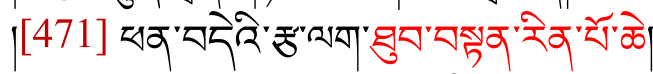

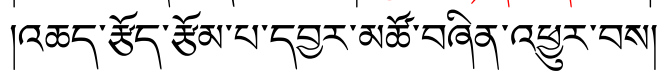

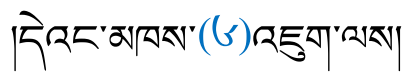

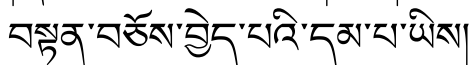

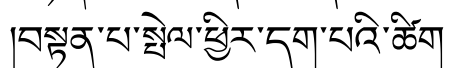

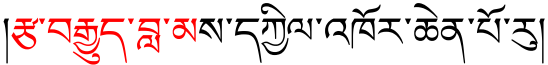

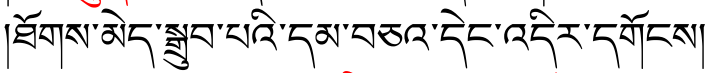

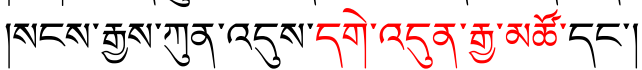

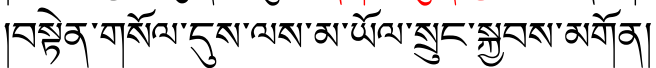

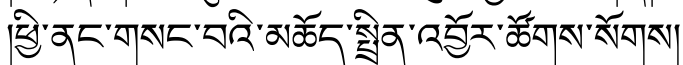

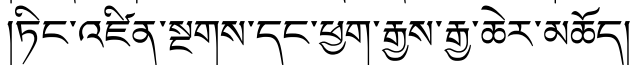

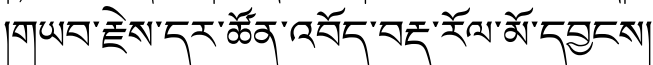

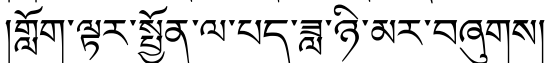

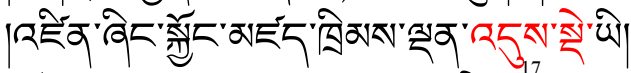

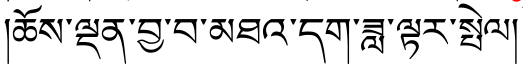

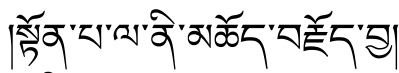

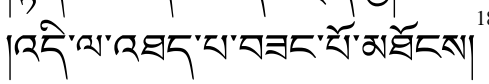

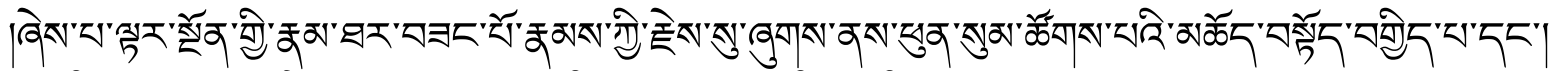

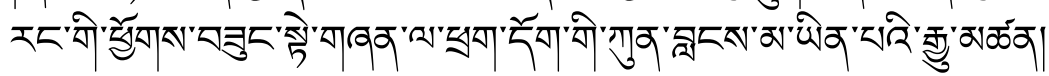

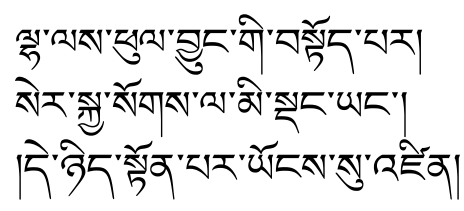

\footnotetext{
${ }^{13}$ Lingön Padma Kelzang: অন্ডু

${ }^{14}$ The lines in this stanza are all 13 syllables long.

${ }^{15}$ Lingön Padma Kelzang: गाఫेव; corrected to चाগুव:

${ }^{16}$ The lines in this stanza are all 11 syllables long.

${ }^{17}$ The lines in these 5 stanzas are all 9 syllables long.

${ }^{18}$ The lines in this stanza are all 7 syllables long.
}

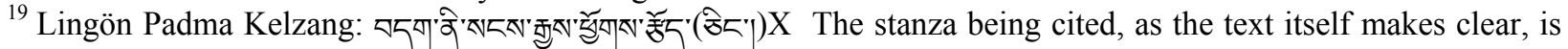
from the Lha las phul du byung bar bstod pa (Skt. Devātiśayastotra), composed by Śạ̣karapati and found in the commentarial collection (Tib. Bstan 'gyur) of the Tibetan Buddhist canon. After referring to the text directly (Śamkarapati 1982, p.88), and conferring with later texts that cite this stanza separately (see Gung thang 032000 , p.352, and Khri byang 03 199?, p.462), I have concluded that the last two syllables of this verse are actually के रदेंक् 


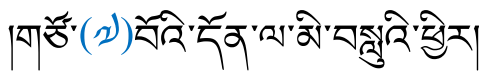

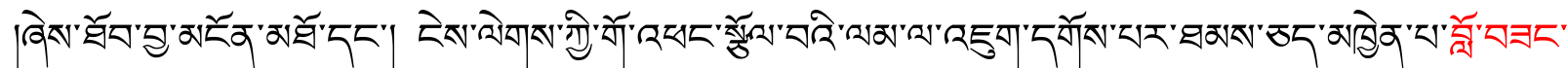

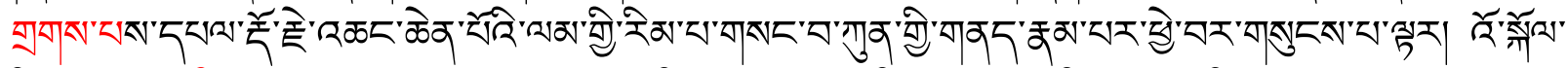

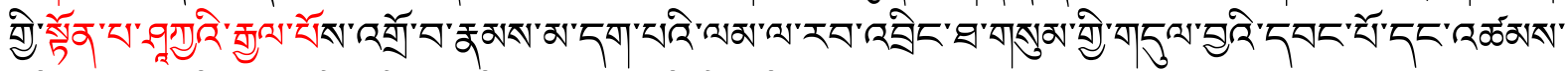

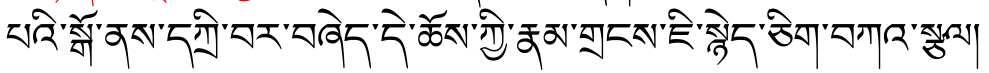

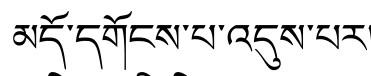

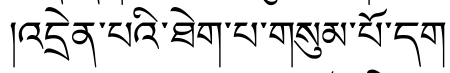

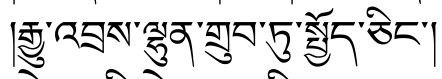

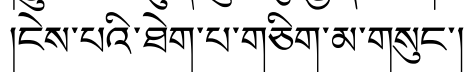

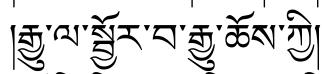

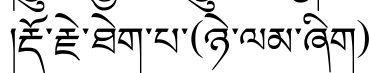

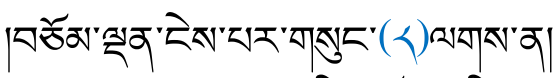

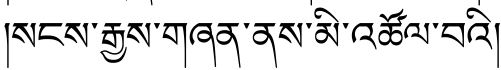

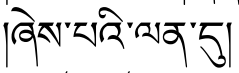

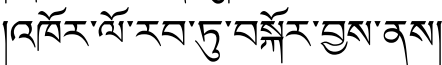

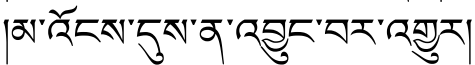

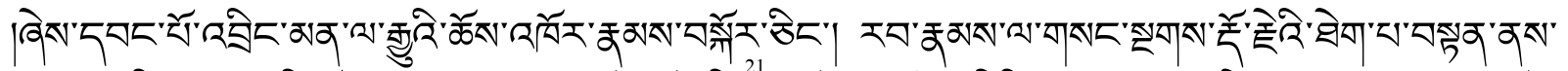

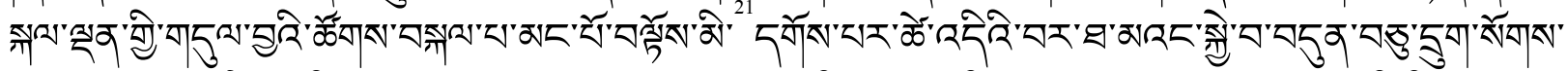

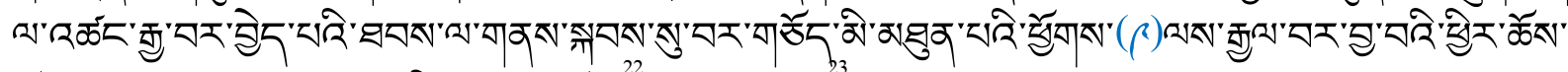

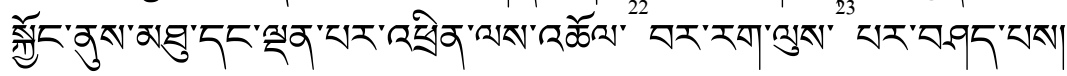

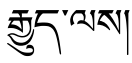

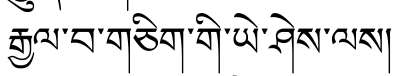

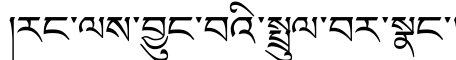

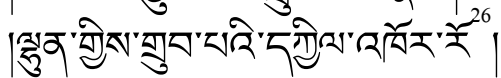

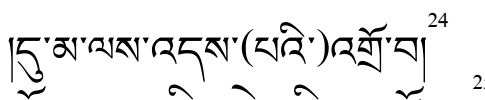

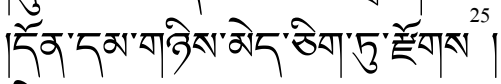

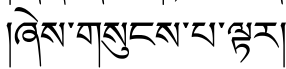

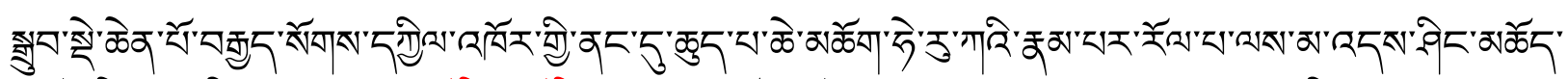

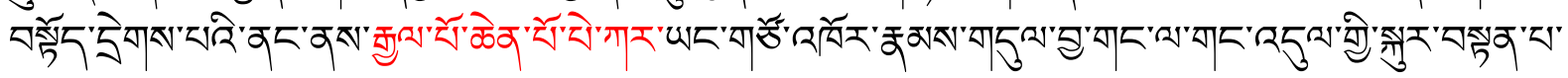

${ }^{20}$ The lines in these two stanzas are all 7 syllables long.

${ }^{21}$ Lingön Padma Kelzang: §"; corrected to के'.

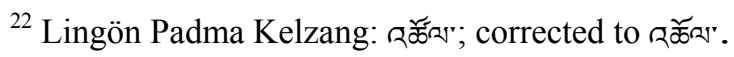

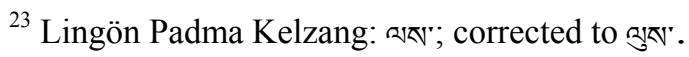

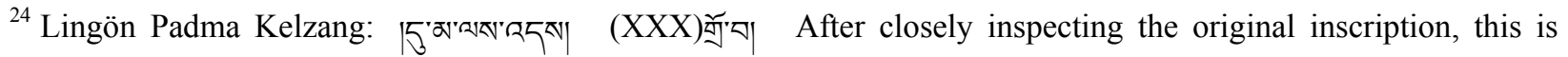
clearly a single 7-syllable verse. The $25^{\mathbb{N}^{*}}$ has since been lost; but with this information recorded by Lingön Padma

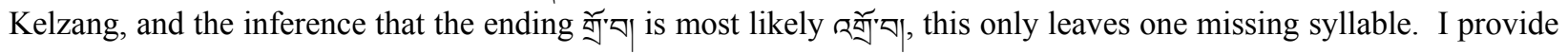
an interpolation for the missing syllable in my corrected transcription.

${ }^{25}$ Lingön Padma Kelzang: 䒓可

${ }^{26}$ Lingön Padma Kelzang: ’̀;'; corrected to 


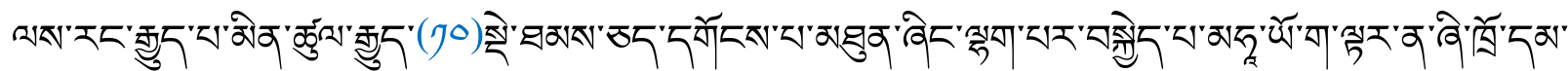

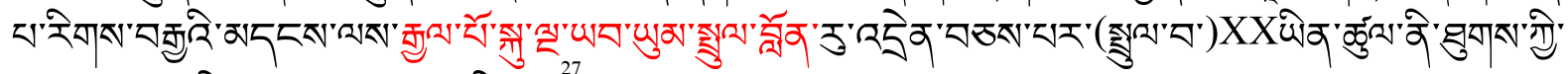

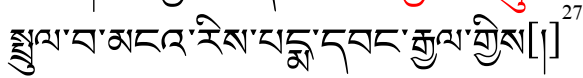

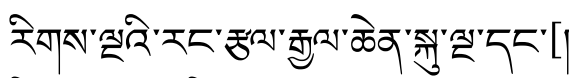

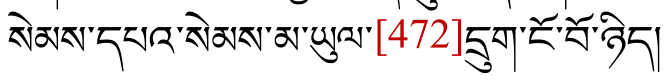

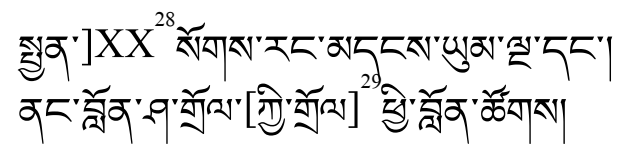

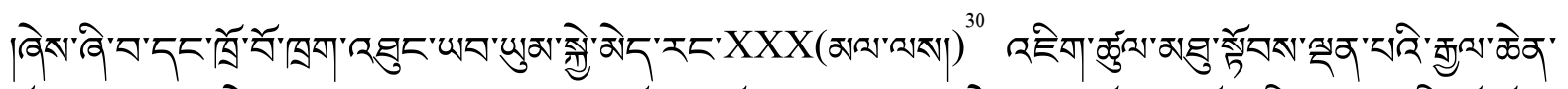

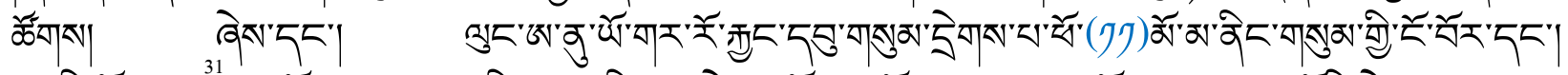

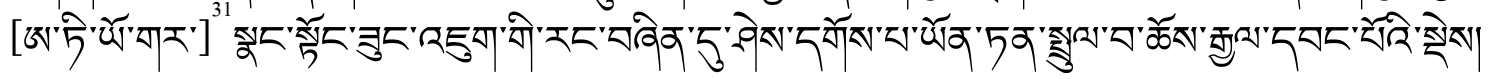

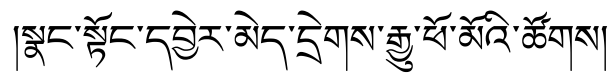

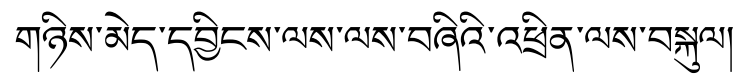

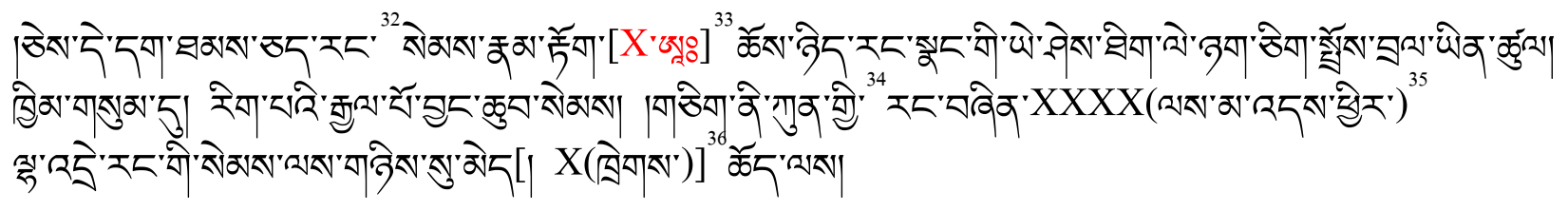

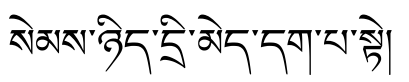

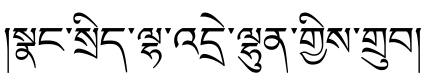

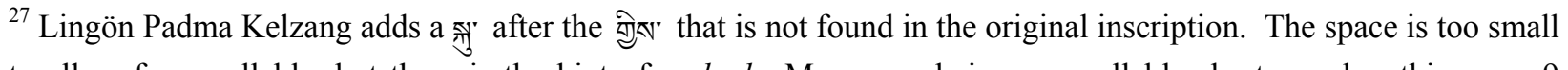
to allow for a syllable, but there is the hint of a shad. Moreover, being one syllable shorter makes this verse 9 syllables long, the same length as the next three verses, creating one uniform quatrain.

${ }^{28}$ Lingön Padma Kelzang: X. After consulting the original inscription, there is a clear shad line here and the

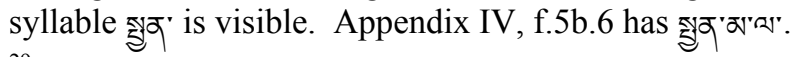

${ }^{29}$ Lingön Padma Kelzang: omitted. After consulting the original inscription, there is enough visible space to

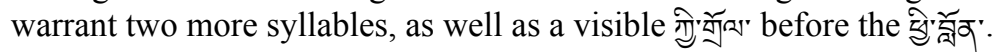

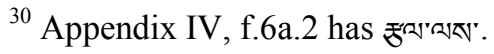

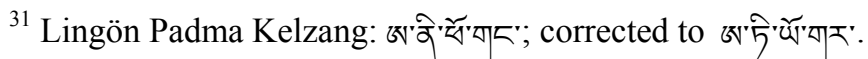

${ }^{32}$ Lingön Padma Kelzang adds a के ${ }^{\prime}$ after the $₹ 5^{*}$ that is not found in the original inscription.

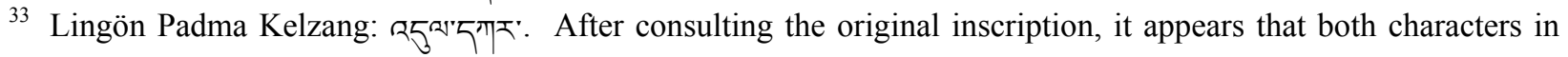
these spaces are colored red to distinguish them from the surrounding words. Moreover, the second character clearly ends in a visarga (h), which is preceeded by a partially visible $\mathbf{w}$. Since this second character is most likely उ్ㅀ, the first, more obscure character is also likely a mantric seed syllable, though the damage is to severe to make a confident reading. The content of this sentence will also bear this interpretation out. In any event, the suggestion provided by Lingön Padma Kelzang appears to be false. Compare with Appendix IV, f.6a.6.

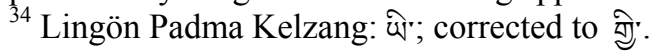

${ }^{35}$ Compare with Appendix IV, f.4a.3.

${ }^{36}$ Lingön Padma Kelzang: XX. After consulting the original inscription, there appears to be a full space here preceded by the hint of a shad clause ending. This would then suggest that only one syllable is missing, given this space. Moreover, I speculate that the missing syllable is ब्रेषास', giving us ब्रेषासे के ;, which is one of the major contemplative systems in Great Perfection (Tib. Rdzogs chen) meditation, the core of Atiyoga; see Germano 1992, pp.841-844. Compare with Appendix IV, f.4a.4. 


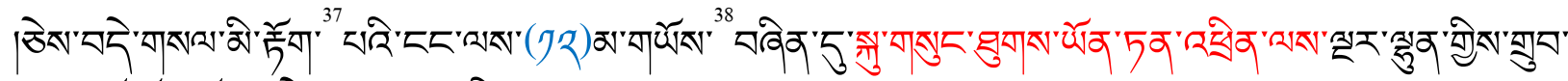

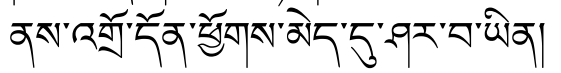

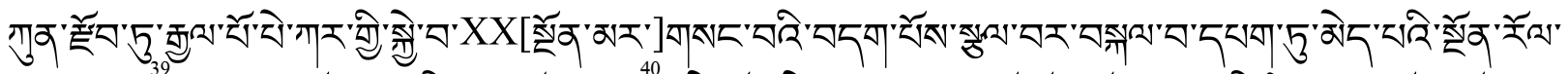

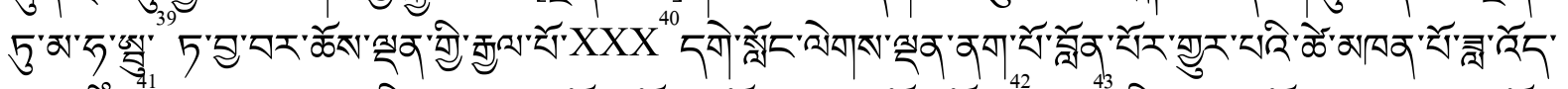

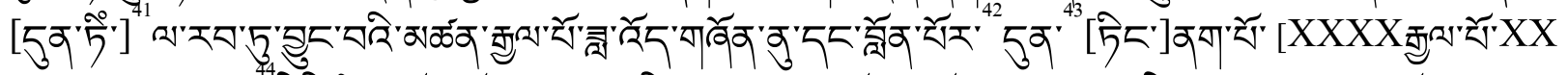

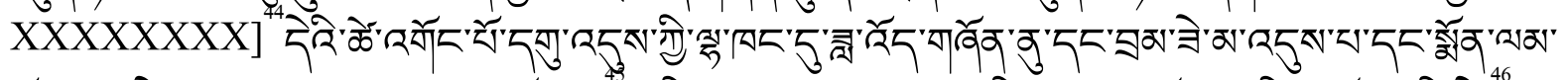

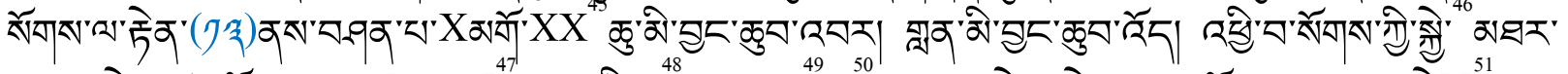

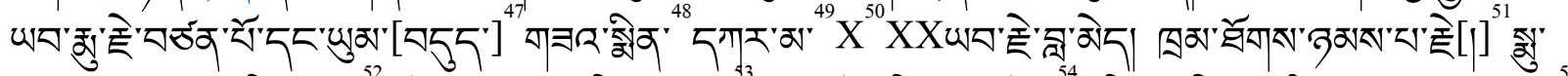

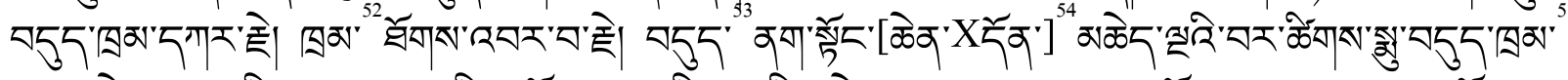

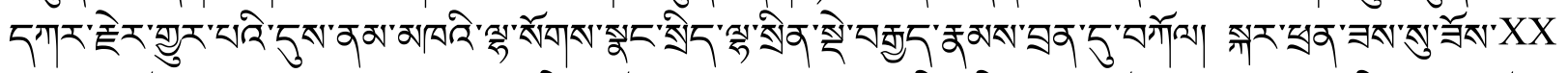

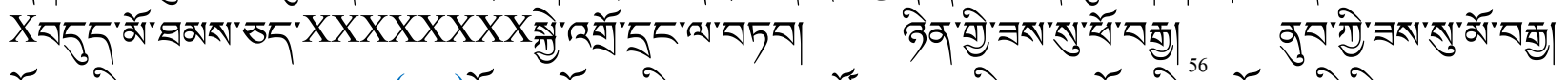

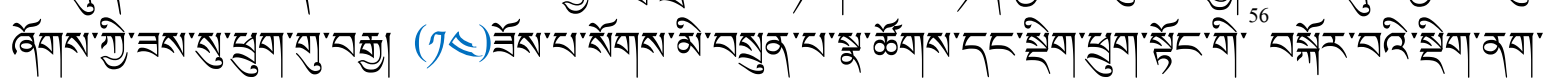

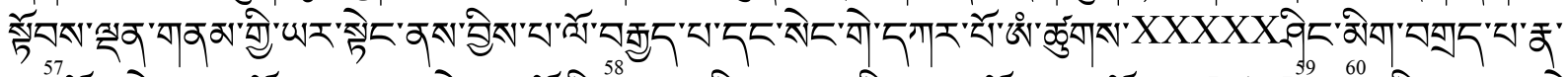

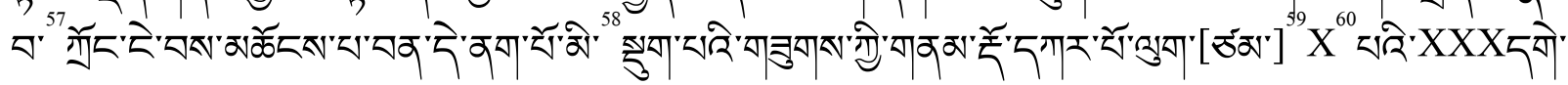

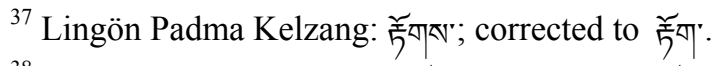

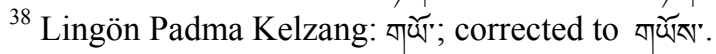

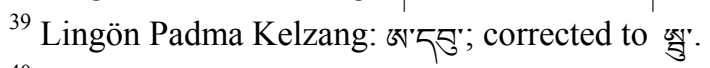

${ }^{40}$ Compare with Appendix IV, f.7b.1.

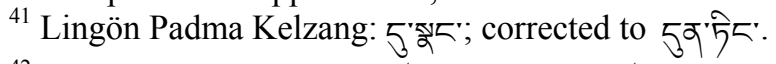

${ }^{42}$ Lingön Padma Kelzang: 㫕; corrected to 玄r.

${ }^{43}$ Lingön Padma Kelzang: Ђु; corrected to 5 वं.

${ }^{44}$ In the Lingön Padma Kelzang transcription, this large section of obscure words has been reduced to XXXX ब्रुब行 and misplaced 18 syllables back, following इुढे इ'. I present here the placement according to the inscription. Compare with Appendix IV, f.7b.3-4.

${ }^{45}$ The inscription is damaged here, but drawing on Sle lung rje drung 1979, p.38, as well as Appendix IV, f.7b.6, this name is clearly

${ }^{46}$ Lingön Padma Kelzang: 欹; corrected to 젱'

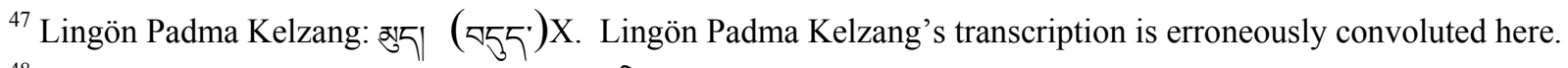

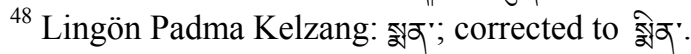

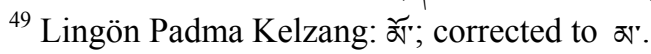

${ }^{50}$ The syllable looks like $\square$ 触; ; however, the following two syllables are too obscure to make a confident reading.

${ }^{51}$ Lingön Padma Kelzang: "; corrected to.

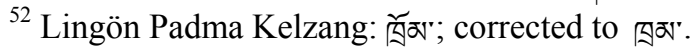

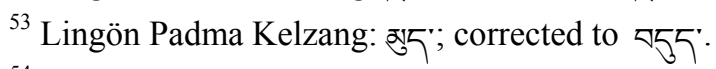

${ }^{54}$ This is Lingön Padma Kelzang's transcription. I suspect it is: 골 $\mathrm{X}_{\mid}$; but the inscription is too damaged to confirm.

${ }_{56}^{55}$ See note 52 above.

${ }^{56}$ Lingön Padma Kelzang: बोरे; corrected to बों.

${ }^{57}$ Lingön Padma Kelzang: خ̌'; corrected to $\square$.

${ }^{58}$ Lingön Padma Kelzang: 미 ; corrected to कें.
} 


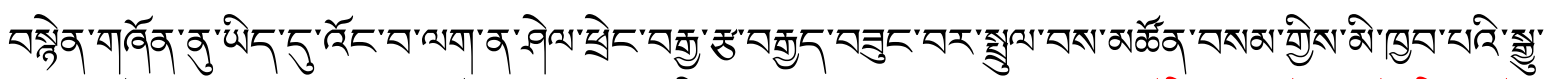

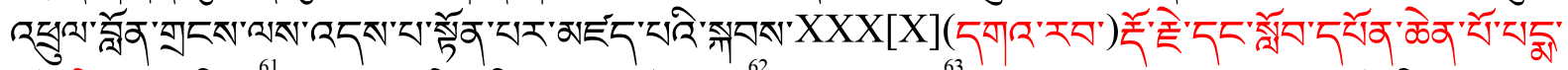

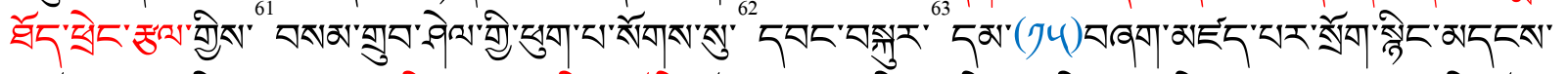

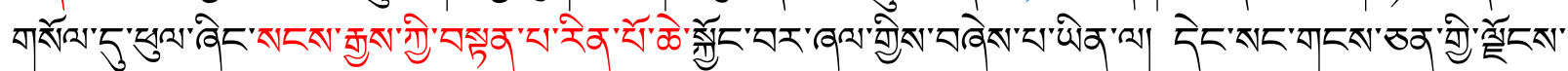

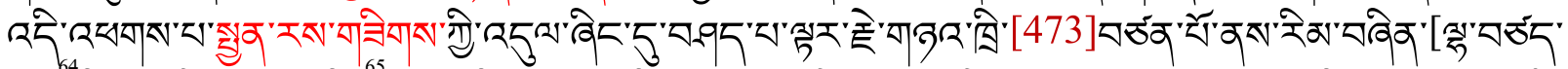

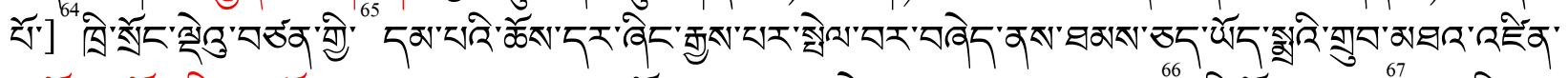

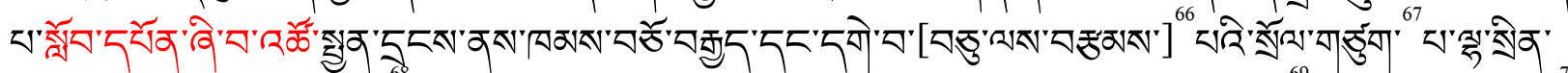

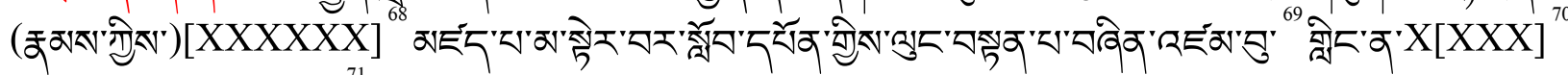

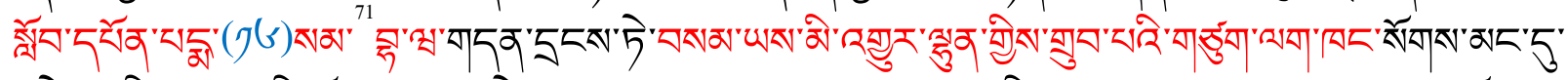

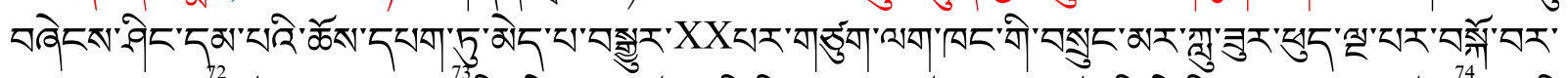

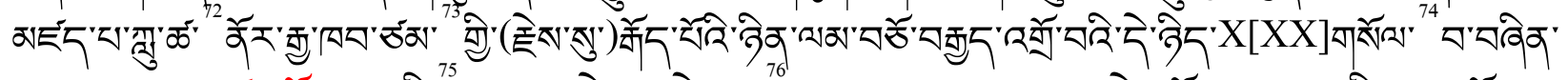

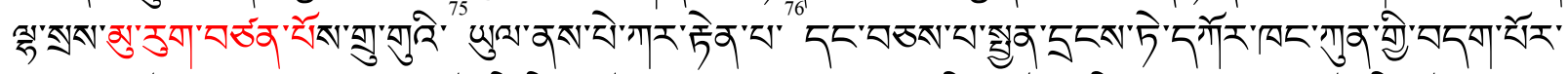

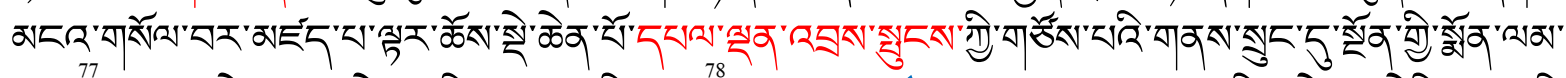

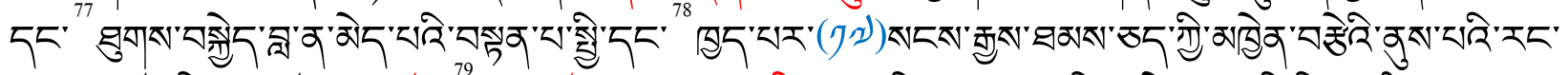

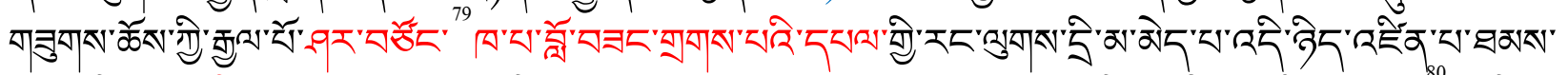

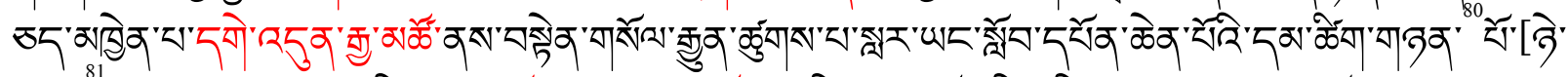

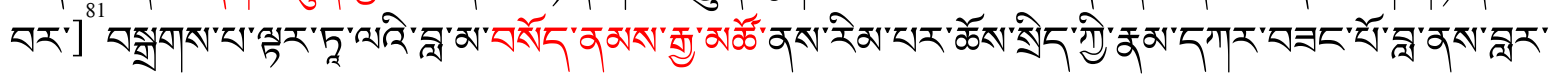

\footnotetext{
${ }^{59}$ Lingön Padma Kelzang: 爻; here I interpolate what I think is the most likely word, бீా.

${ }^{60}$ Lingön Padma Kelzang: XXX; corrected to X.

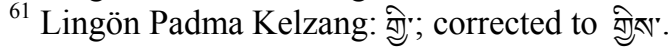

${ }^{62}$ Lingön Padma Kelzang: omitted.

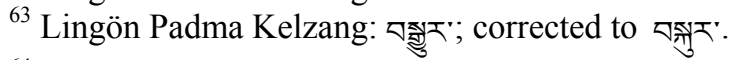

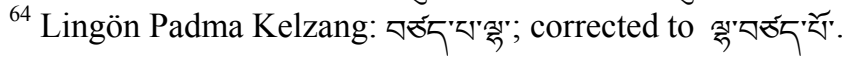

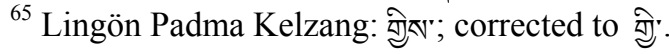

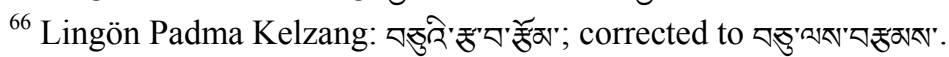

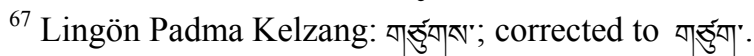

${ }^{68}$ There are obscured syllables here not recorded in the Lingön Padma Kelzang transcription.

${ }^{69}$ Lingön Padma Kelzang: omitted.

${ }^{70}$ There are obscured syllables here not recorded in the Lingön Padma Kelzang transcription.

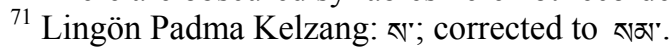

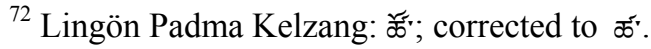

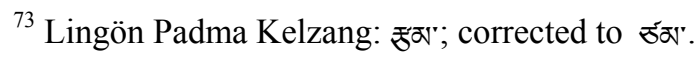

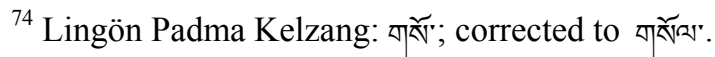

${ }^{75}$ Lingön Padma Kelzang: शిें; corrected to गुरें. Compare Tā la'i bla ma 05 1992, p.28.

${ }^{76}$ Lingön Padma Kelzang: omitted.

${ }^{77}$ Lingön Padma Kelzang: omitted.

${ }^{78}$ Lingön Padma Kelzang adds a shad and a space here that is not found in the inscription.

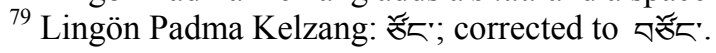

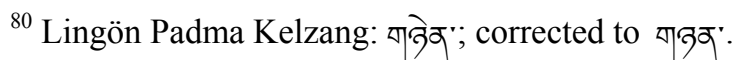

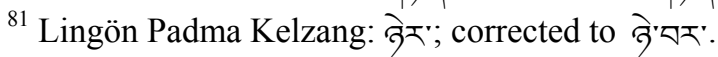




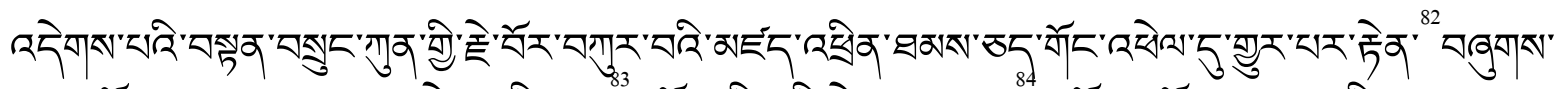

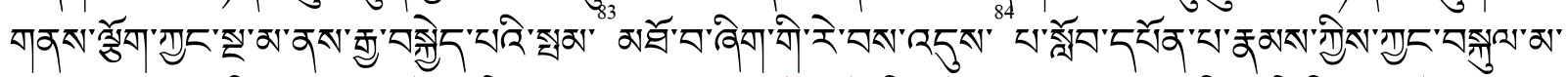

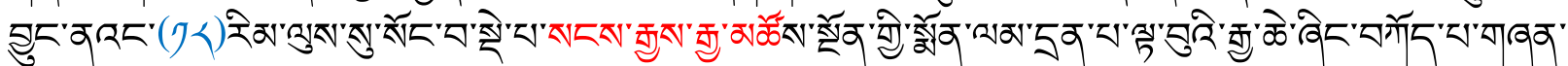

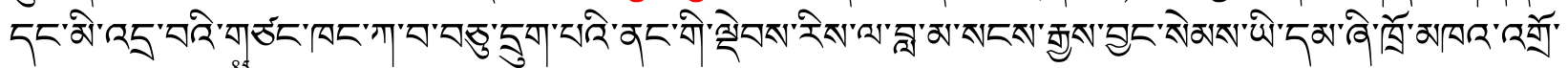

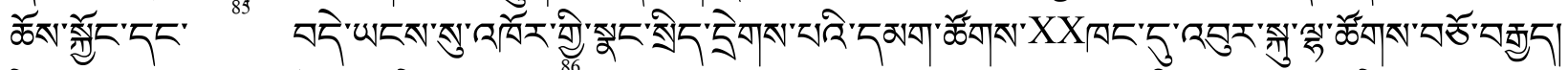

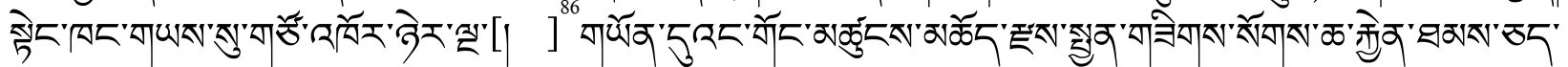

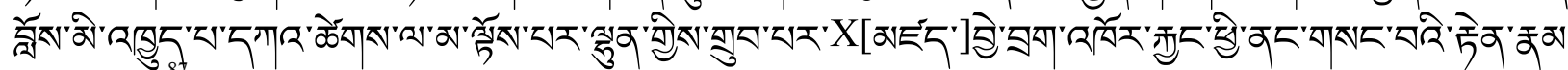

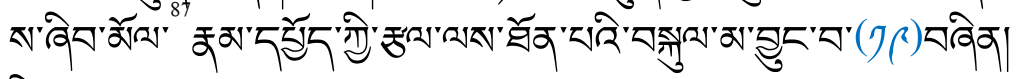

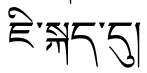

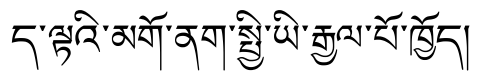

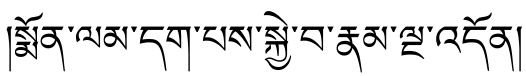

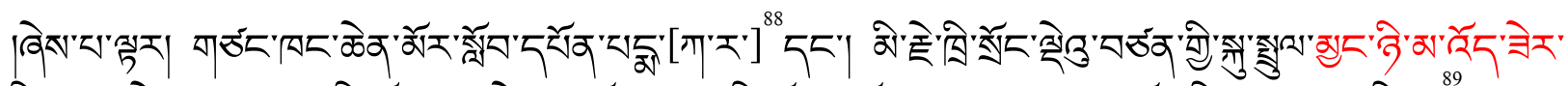

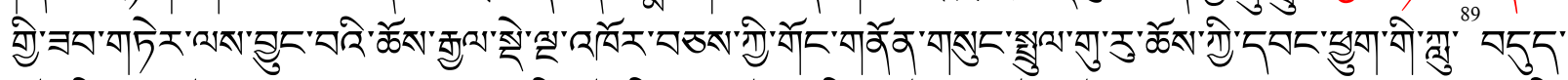

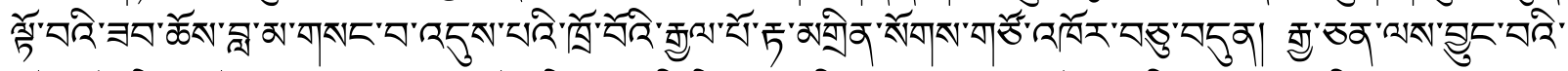

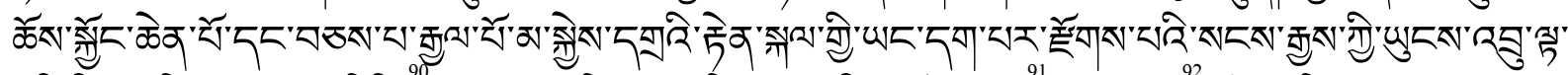

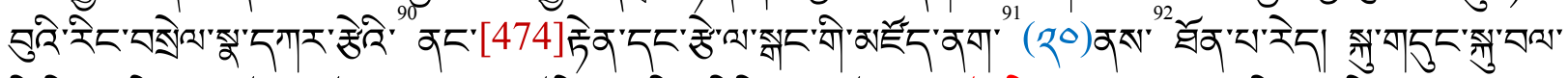

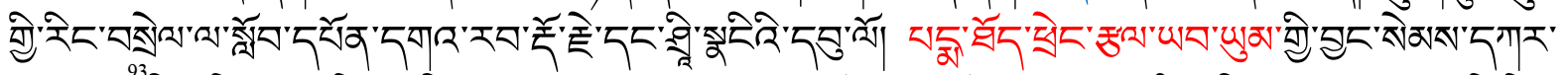

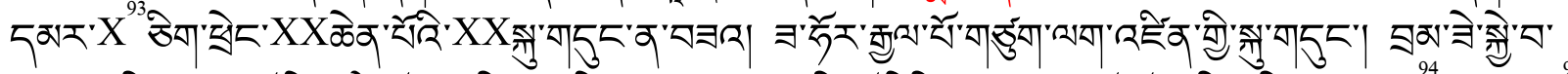

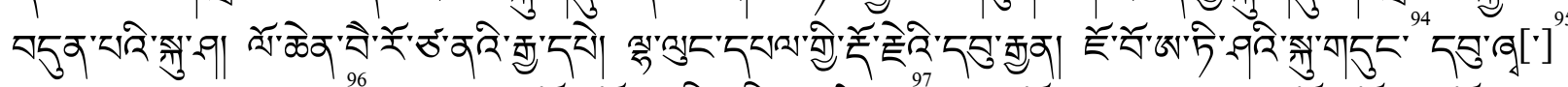

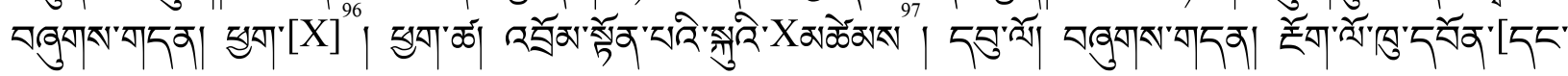

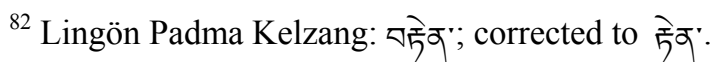

${ }^{83}$ Lingön Padma Kelzang: w्w"; corrected to 춿'.

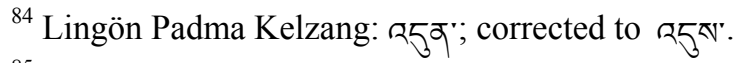

${ }^{85}$ Lingön Padma Kelzang adds a shad and a space here that is not found in the inscription.

${ }^{86}$ There is a space here following the hint of a shad.

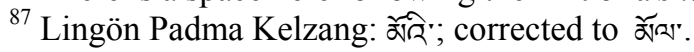

${ }^{88}$ Lingön Padma Kelzang: ఇ鸟

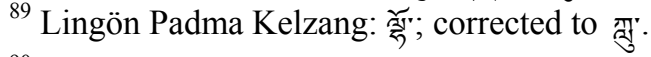

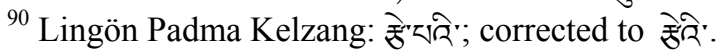

${ }^{91}$ Lingön Padma Kelzang: omitted.

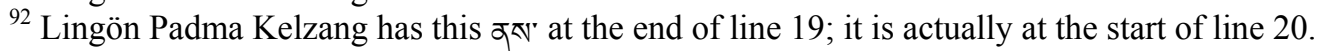

${ }^{93}$ Lingön Padma Kelzang has an extra X here than spacing would allow.

${ }^{94}$ Lingön Padma Kelzang adds a shad and a space here that is not found in the inscription.

${ }^{95}$ Lingön Padma Kelzang adds a shad and a space here that is not found in the inscription.

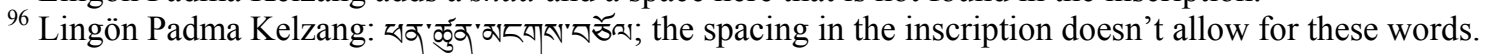

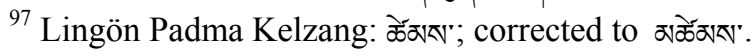




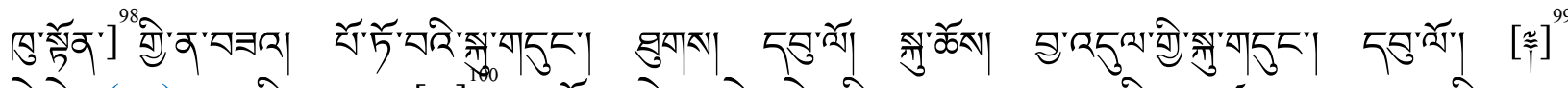

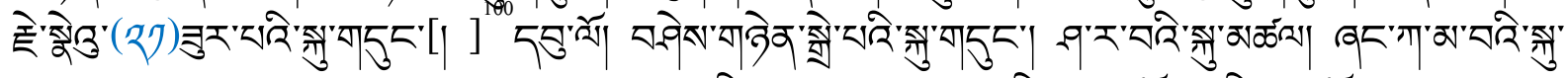

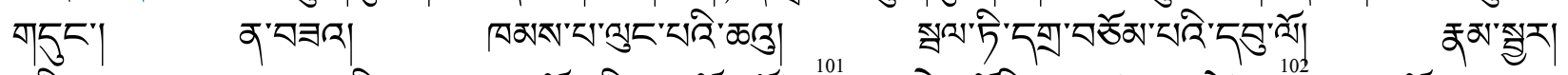

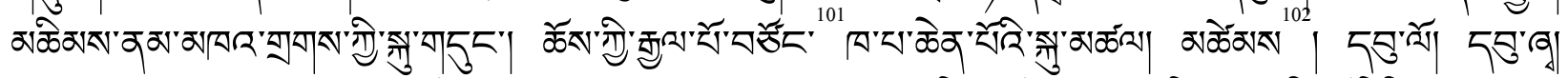

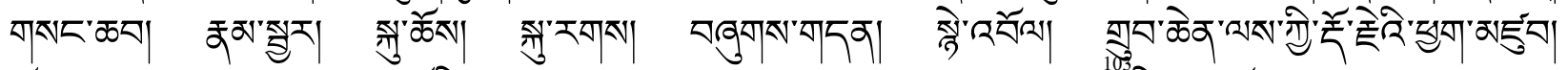

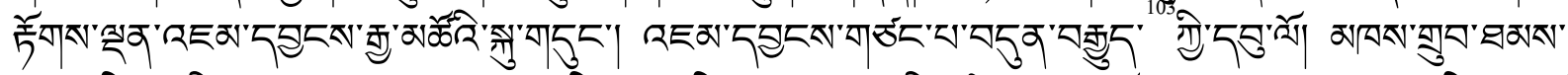

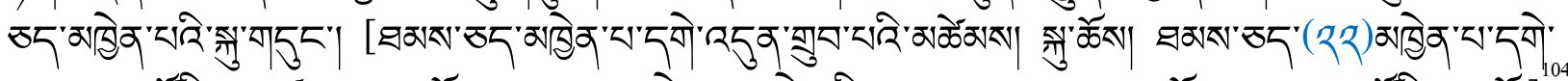

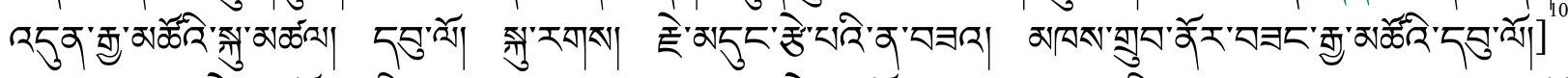

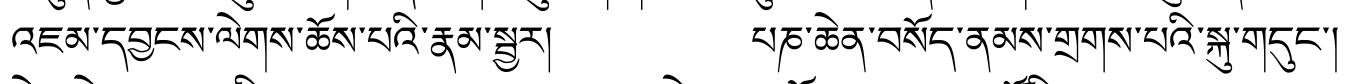

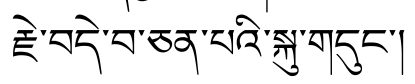

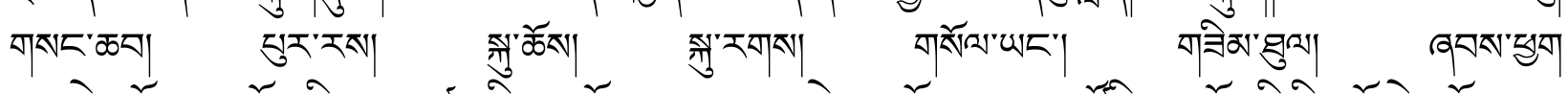
कవ'सेट 'रेख"तु|

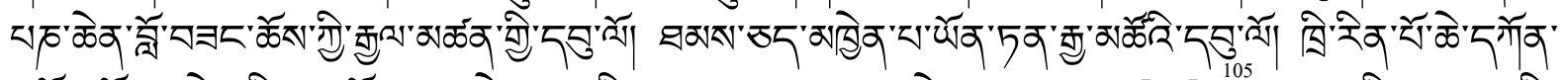

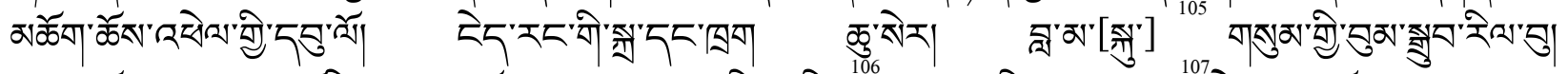

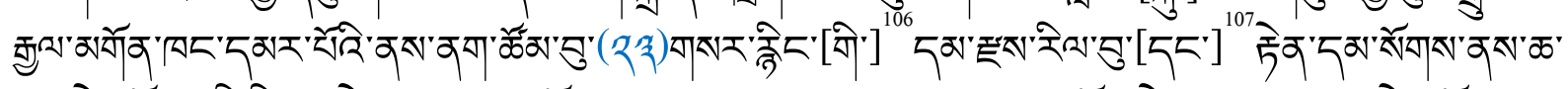

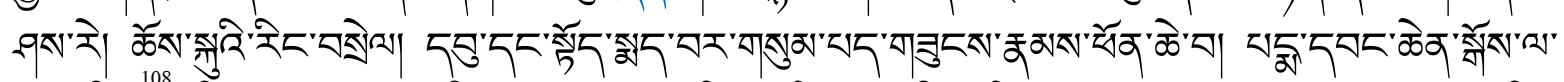

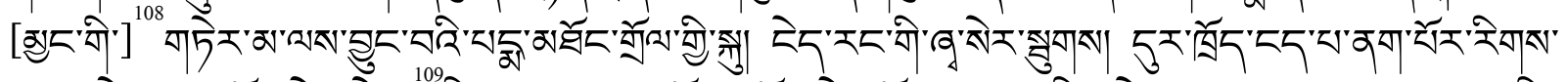

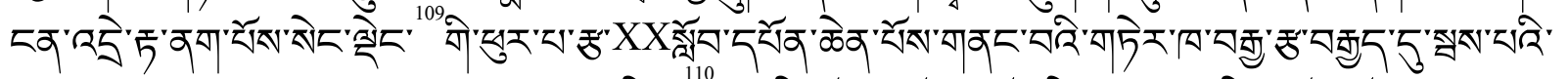

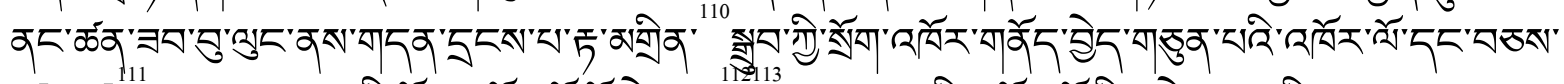

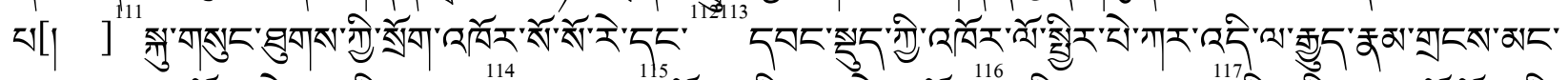

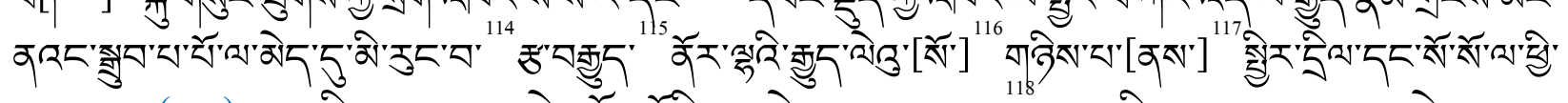

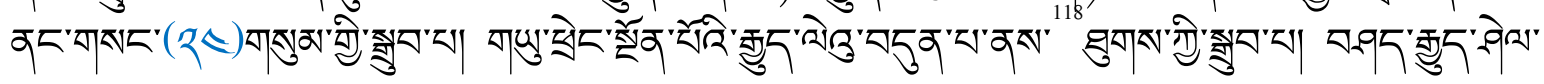

\footnotetext{
${ }^{98}$ Lingön Padma Kelzang: omitted.

${ }^{99}$ Lingön Padma Kelzang: omitted.

${ }^{100}$ Lingön Padma Kelzang: omitted.

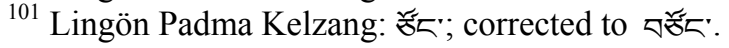

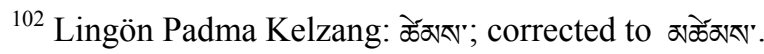

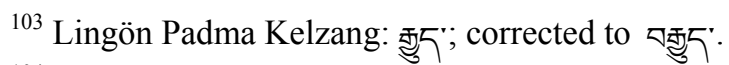

${ }^{104}$ In Lingön Padma Kelzang's transcription, these lines were displaced to line 23; see note 113 below.

${ }^{105}$ Lingön Padma Kelzang: omitted.

${ }^{106}$ Lingön Padma Kelzang: omitted.

${ }^{107}$ Lingön Padma Kelzang: omitted.

${ }^{108}$ Lingön Padma Kelzang: omitted.

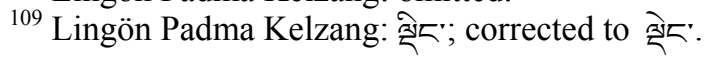

${ }^{110}$ Lingön Padma Kelzang adds đ্রে here.

${ }^{111}$ Lingön Padma Kelzang: *; corrected to $\mid$.

${ }^{112}$ Lingön Padma Kelzang: ख; corrected to $55^{\prime}$.

113 See note 104 above.

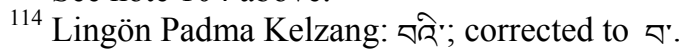

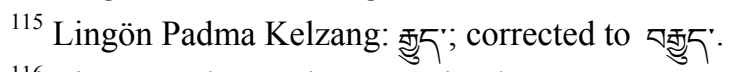

${ }^{116}$ Lingön Padma Kelzang: omitted.
} 


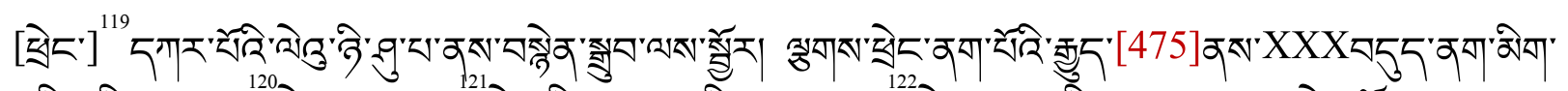

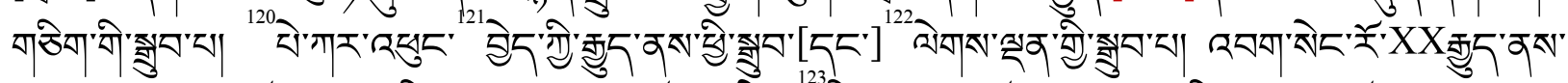

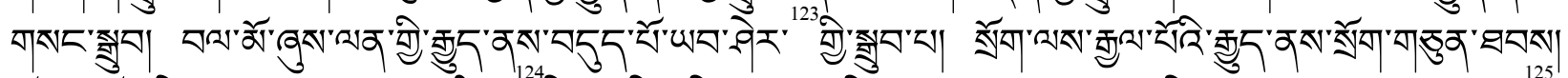

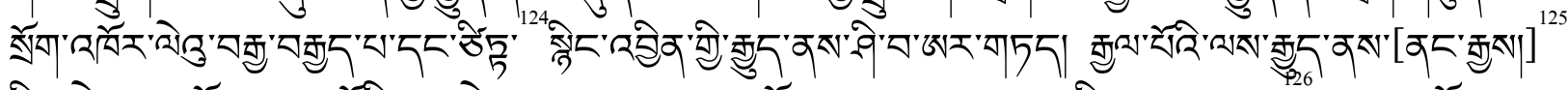

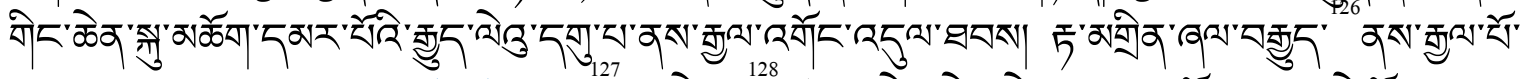

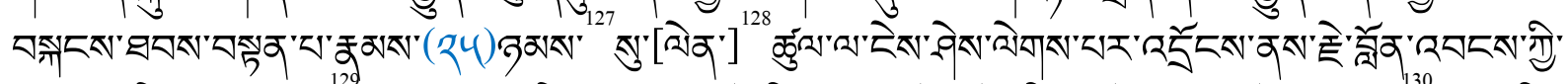

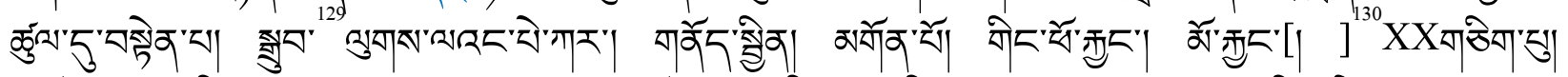

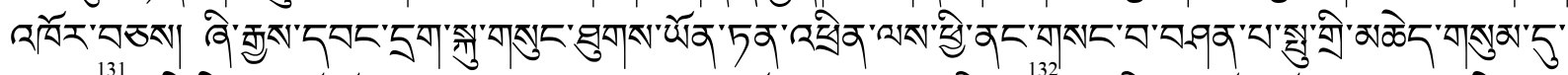

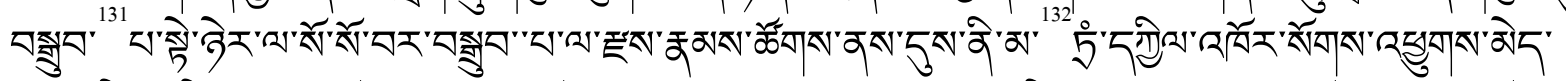

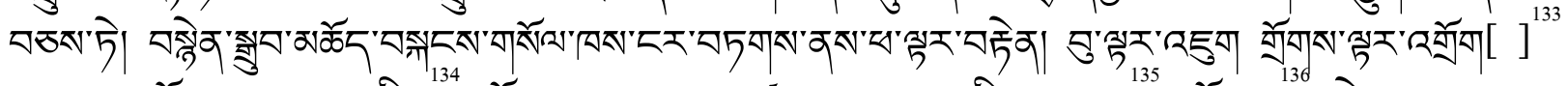

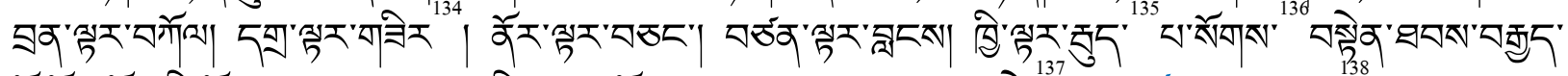

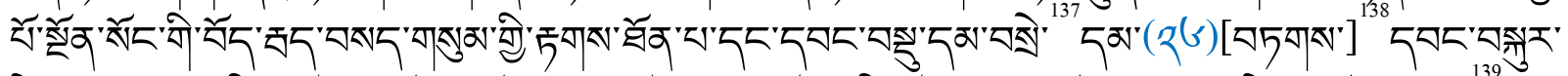

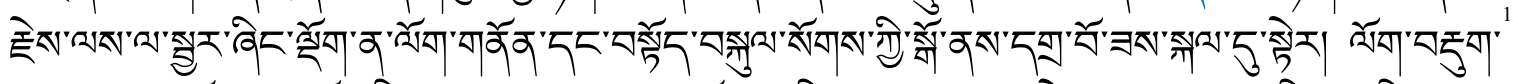

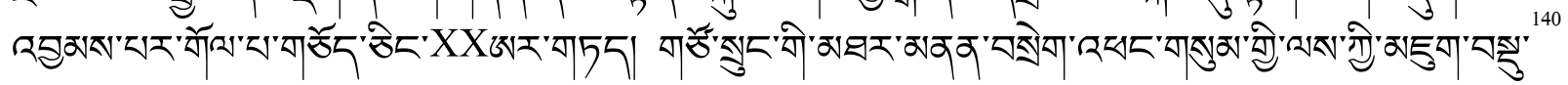

${ }^{117}$ Lingön Padma Kelzang: omitted.

${ }^{118}$ Lingön Padma Kelzang adds ar here.

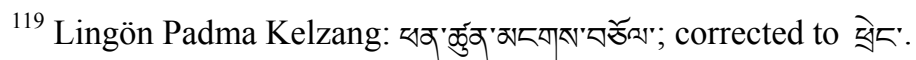

${ }^{120}$ Lingön Padma Kelzang adds $२ \square$ वा'तेट' here.

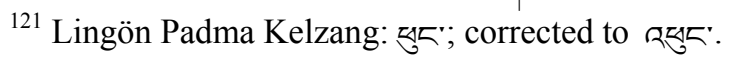

${ }^{122}$ Lingön Padma Kelzang: omitted.

${ }^{123}$ Lingön Padma Kelzang: शף; corrected to शेर'.

${ }^{124}$ Lingön Padma Kelzang: ठे; corrected to ठेॅू'.

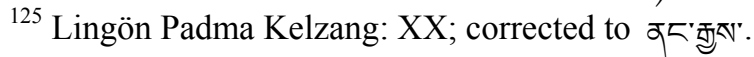

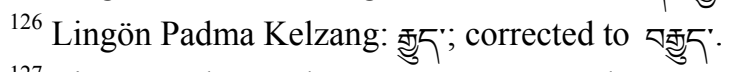

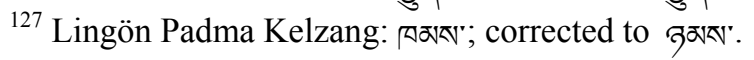

${ }^{128}$ Lingön Padma Kelzang: omitted.

${ }^{129}$ Lingön Padma Kelzang: 젬'; corrected to 정ㅁ'

${ }^{130}$ Lingön Padma Kelzang: omitted.

${ }^{131}$ Lingön Padma Kelzang: 적ㅁ; corrected to অ정ㅁ'

${ }^{132}$ Lingön Padma Kelzang: ఫे; corrected to ær'.

${ }^{133}$ Lingön Padma Kelzang adds a tsheg here, where the inscription has a space.

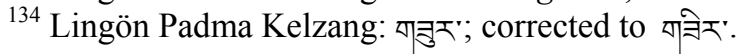

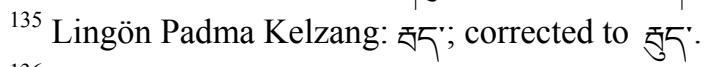

${ }^{136}$ Lingön Padma Kelzang:| ; corrected to :

${ }^{137}$ Lingön Padma Kelzang: | ; corrected to :

${ }^{138}$ Lingön Padma Kelzang has 쮜죄. The inscription is too damaged here to read the word correctly. There is a

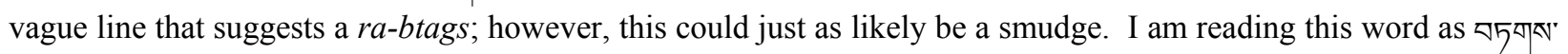
because it makes greater sense given the context.

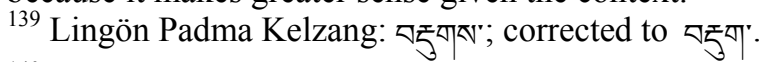

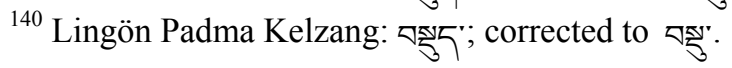




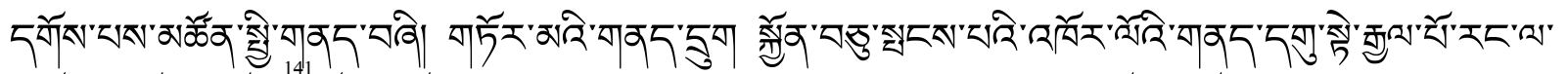

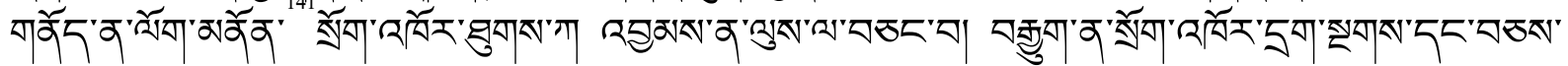

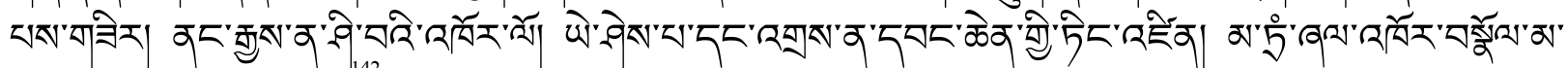

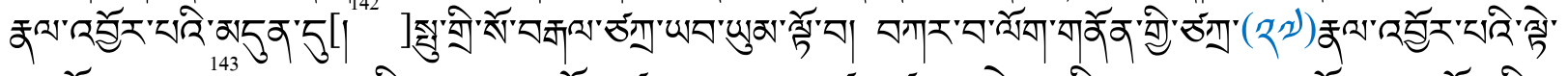

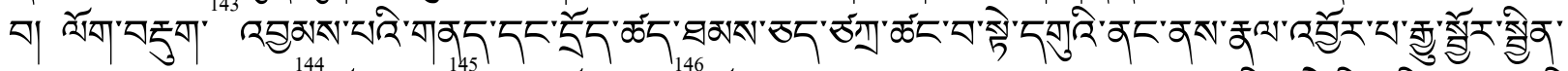

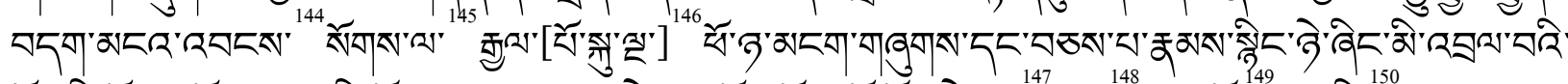

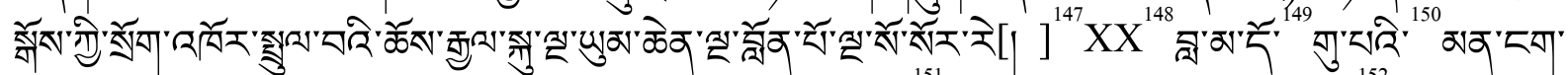

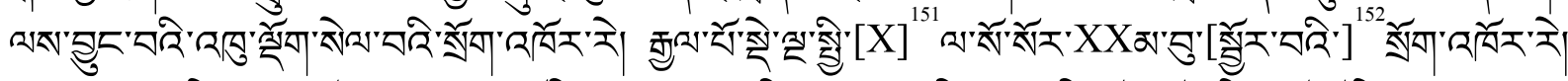

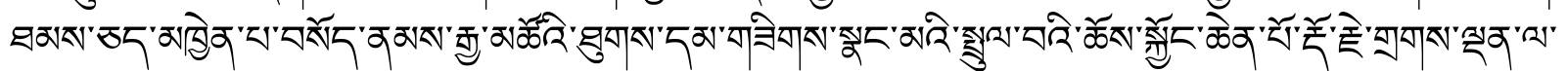

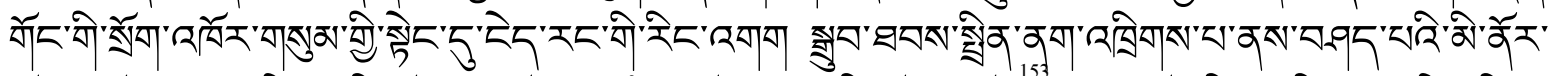

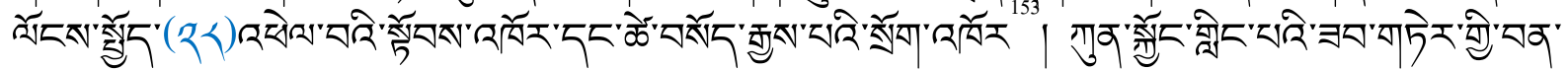

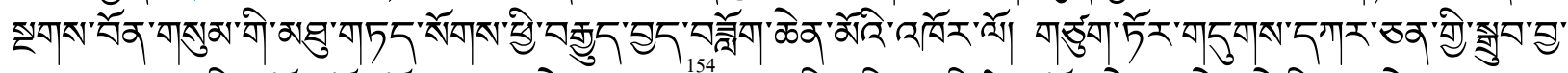

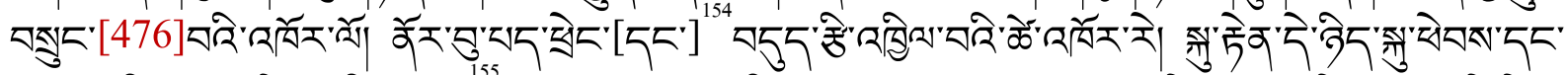

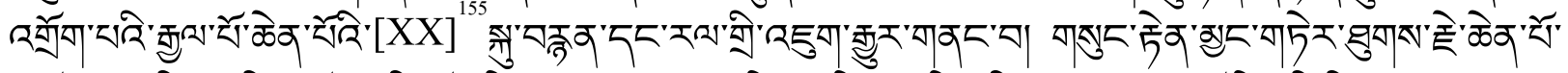

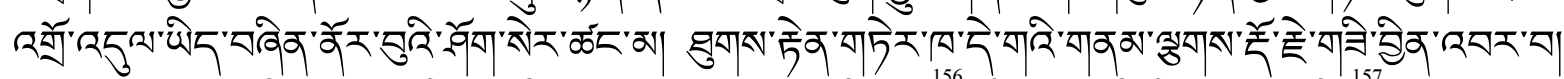

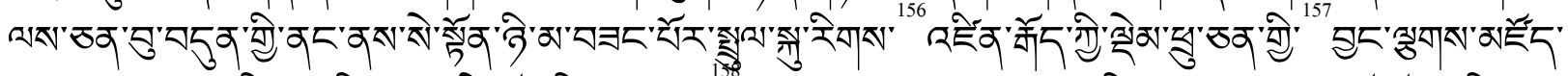

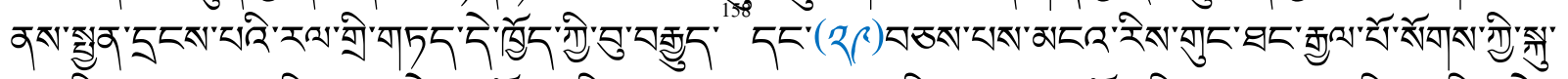

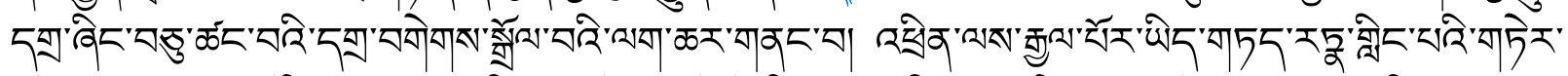

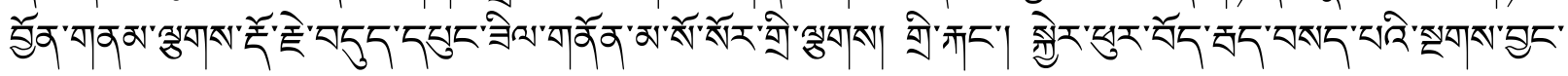

\footnotetext{
${ }^{141}$ Lingön Padma Kelzang: गार्वेव;; corrected to ॠवेन्व:

${ }^{142}$ Lingön Padma Kelzang: "; corrected to $\mid$.

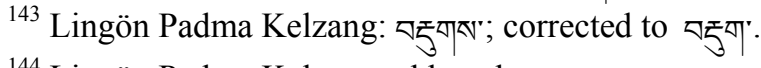

${ }^{144}$ Lingön Padma Kelzang adds 2 ' here.

${ }^{145}$ Lingön Padma Kelzang: zr; corrected to 2 .

${ }^{146}$ Lingön Padma Kelzang: 苚; Lingön Padma Kelzang misses two other nearly illegible words.

${ }^{147}$ Lingön Padma Kelzang: '; corrected to । .

${ }^{148}$ Lingön Padma Kelzang adds one more X than the space would allot.

${ }^{149}$ Lingön Padma Kelzang: 5 ; corrected to $\check{\zeta}^{\circ}$.

${ }^{150}$ Lingön Padma Kelzang: इरे; corrected to चरिे.

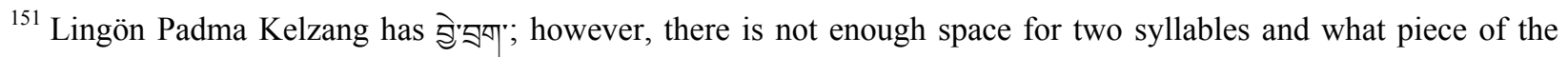
syllable remains legible clearly shows a gi-gu not a zhabs-kyu.

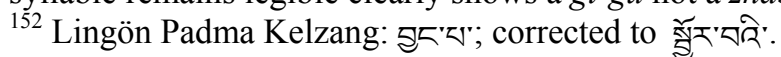

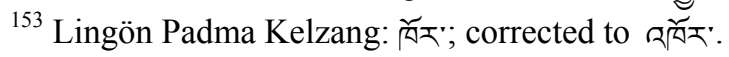

${ }^{154}$ Lingön Padma Kelzang: omitted.

${ }^{155}$ Lingön Padma Kelzang: omitted.

${ }^{156}$ Lingön Padma Kelzang: रेखा"; corrected to रेगास".

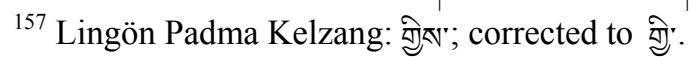

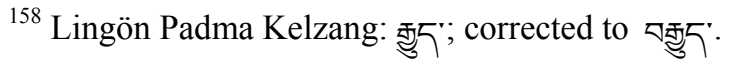




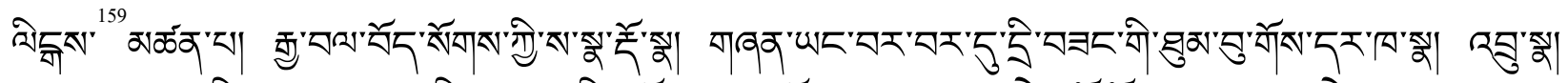

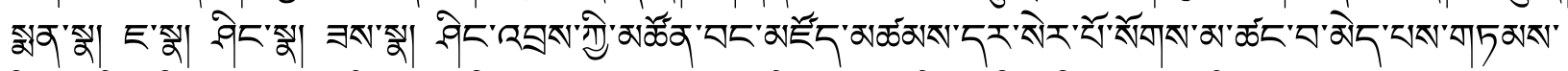

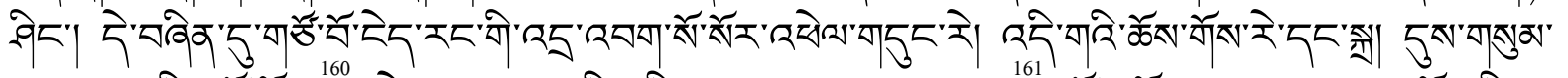

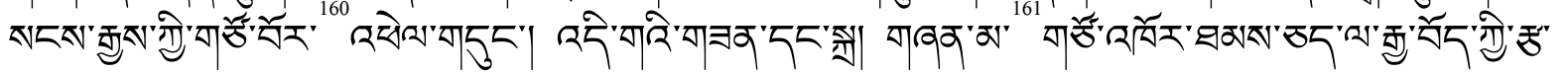

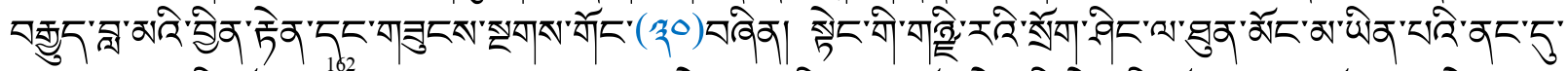

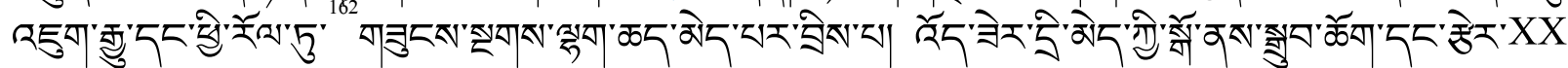

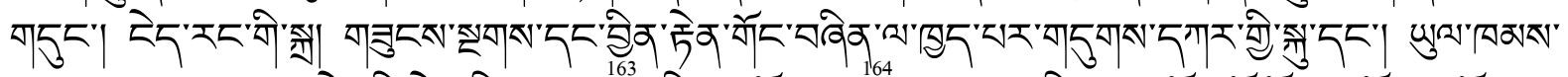

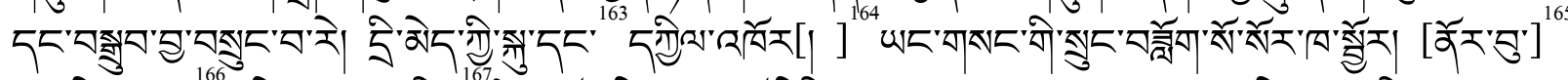

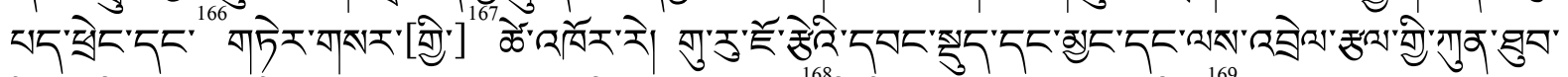

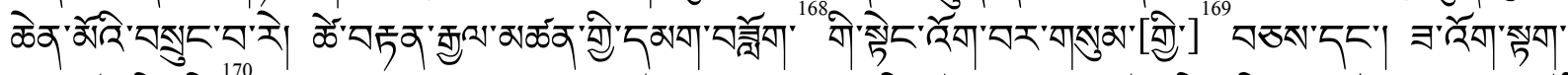

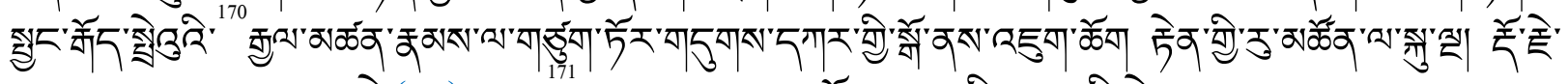

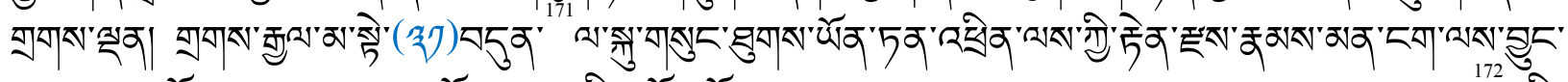

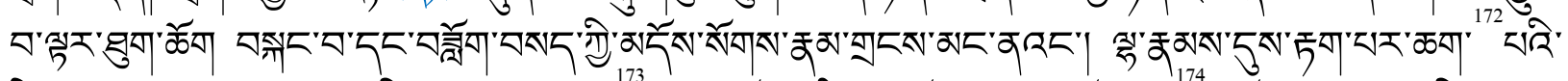

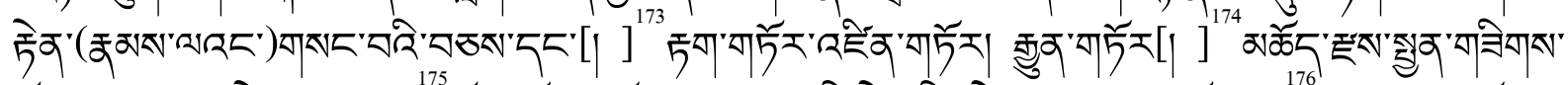

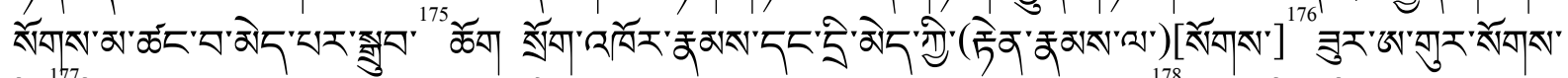

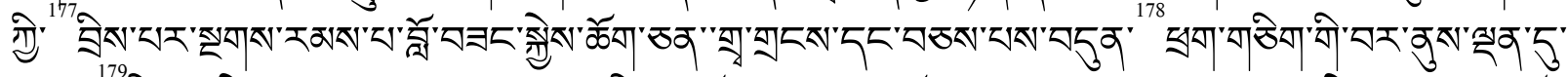

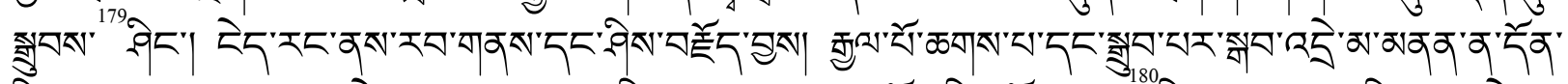

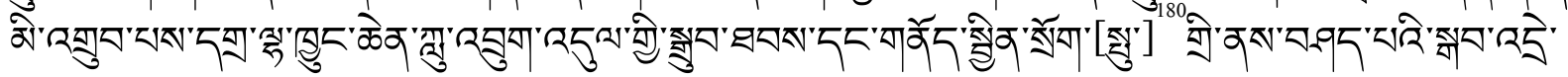

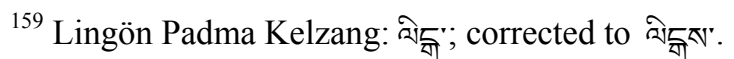

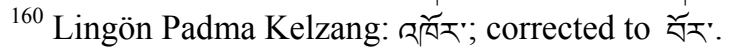

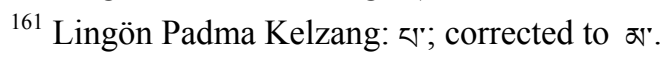

${ }^{162}$ Lingön Padma Kelzang: 5 ; corrected to చु' $^{\circ}$

${ }^{163}$ Lingön Padma Kelzang adds a shad and a space here that is not found in the inscription.

${ }^{164}$ Lingön Padma Kelzang: "; corrected to | .

${ }^{165}$ Lingön Padma Kelzang: 'XX; I have added my own interpolation here based on what is legible in the inscription.

${ }^{166}$ Lingön Padma Kelzang adds a shad and a space here that is not found in the inscription.

${ }^{167}$ Lingön Padma Kelzang: omitted.

${ }^{168}$ Lingön Padma Kelzang: 言》"; corrected to 口商》".

${ }^{169}$ Lingön Padma Kelzang: omitted.

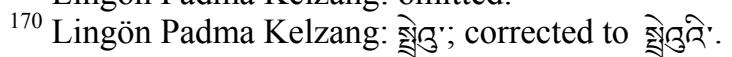

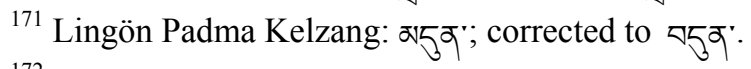

${ }^{172}$ Lingön Padma Kelzang: ळबासे; corrected to कबा".

${ }^{173}$ Lingön Padma Kelzang: omitted.

${ }^{174}$ Lingön Padma Kelzang: '; corrected to 1 .

${ }^{175}$ Lingön Padma Kelzang: 줯ㅈㅁ;

${ }^{176}$ Lingön Padma Kelzang: omitted.

${ }^{177}$ Lingön Padma Kelzang: ग्रेस"; corrected to गें.

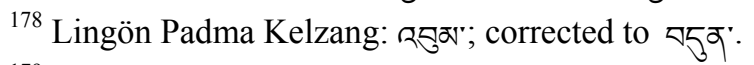

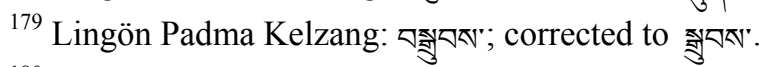

${ }^{180}$ Lingön Padma Kelzang: omitted.
} 


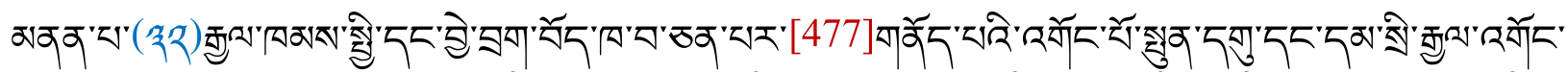

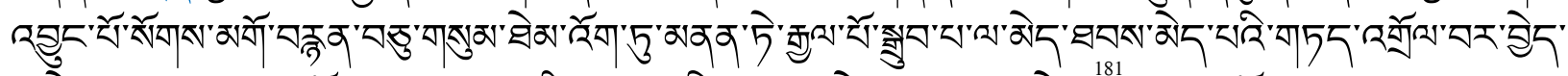

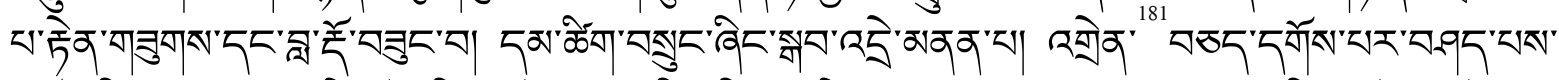

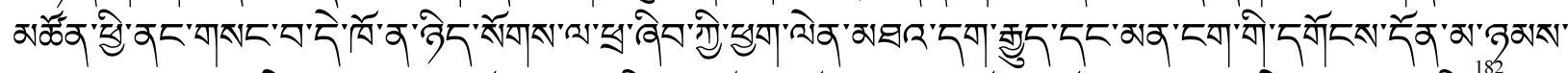

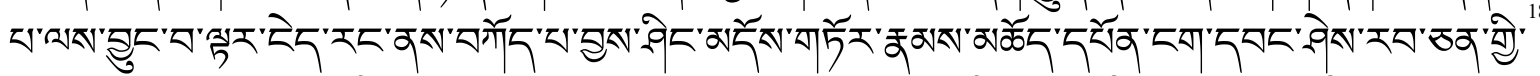

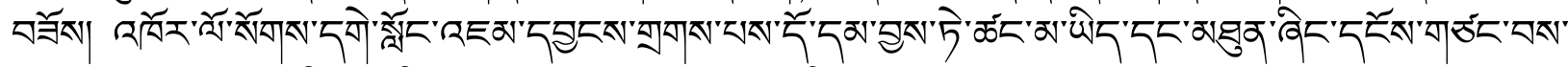

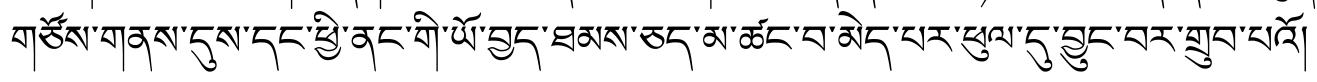

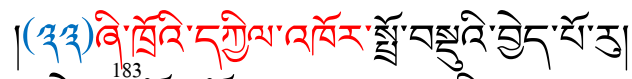

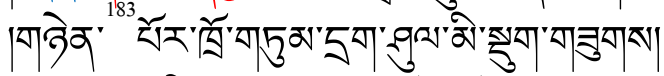

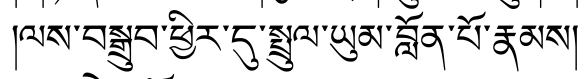

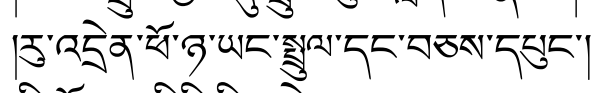

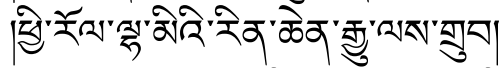

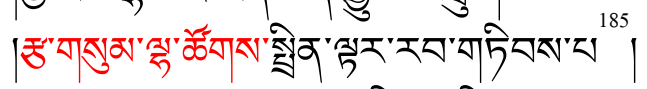

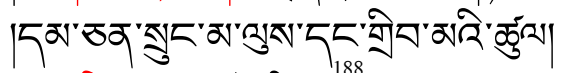

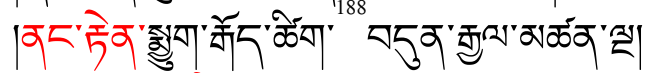

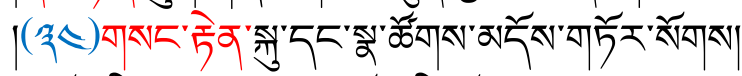

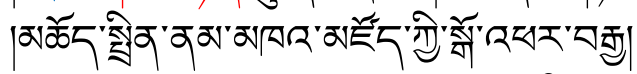

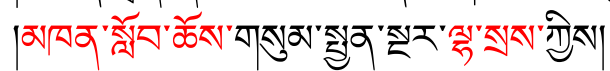

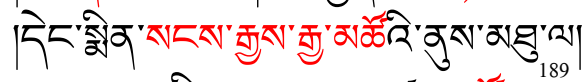

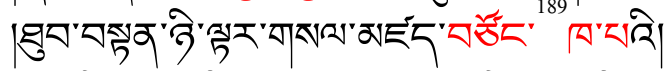

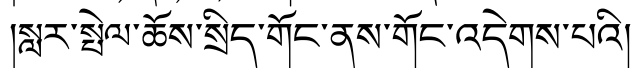

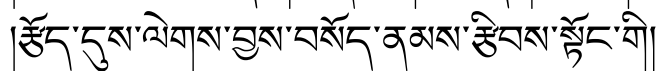

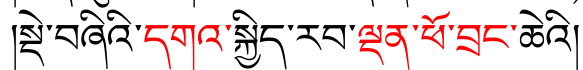

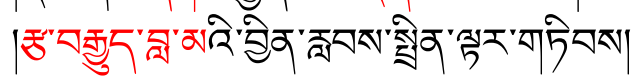

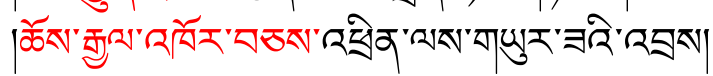

गुু

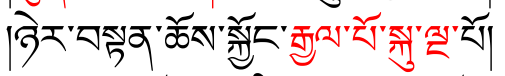

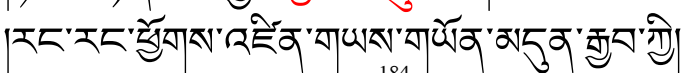

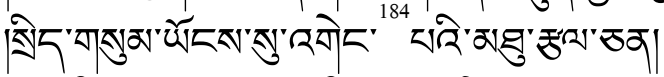

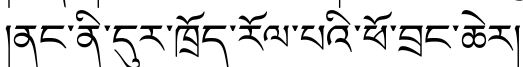

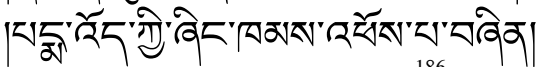

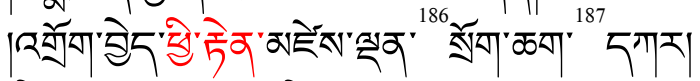
冈িষा

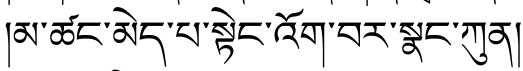

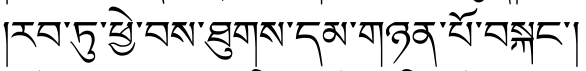

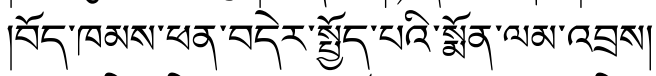

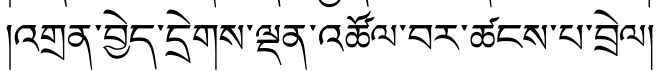

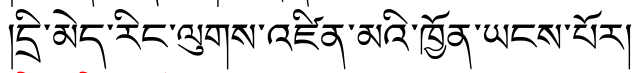

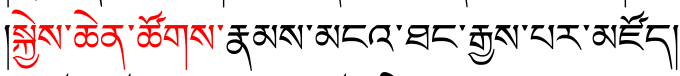

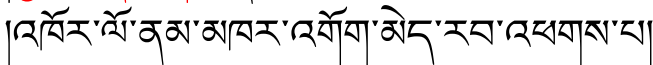

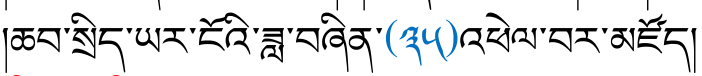

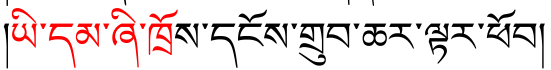

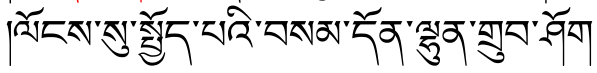

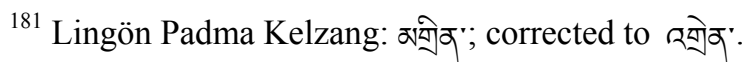

${ }^{182}$ Lingön Padma Kelzang: ब्रेश;; corrected to ब्रें.

${ }^{183}$ Lingön Padma Kelzang: गार्वेव;; corrected to गानेव;.

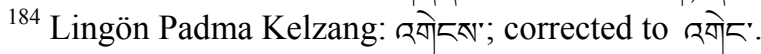

${ }^{185}$ Lingön Padma Kelzang:

${ }^{186}$ Lingön Padma Kelzang: 췱];

${ }^{187}$ Lingön Padma Kelzang: ळबासे; corrected to कबा".

${ }^{188}$ Lingön Padma Kelzang: ळेंगास;; corrected to ळेंगा".

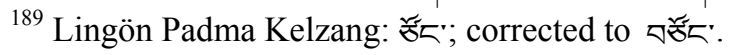




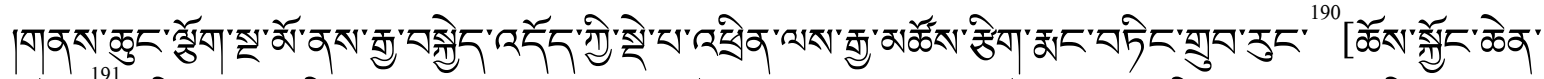

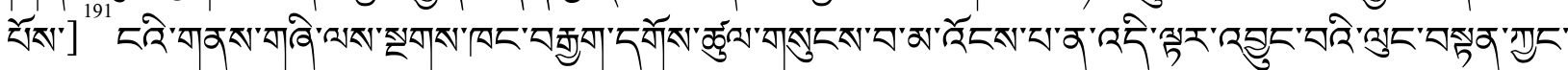

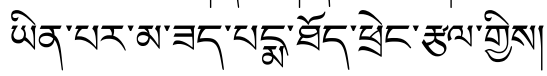

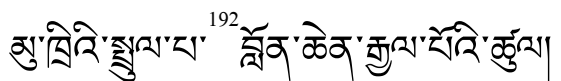
|खेसे दू'।

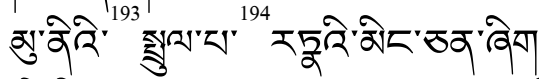

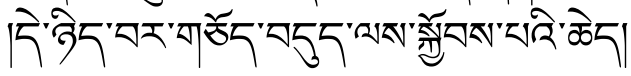

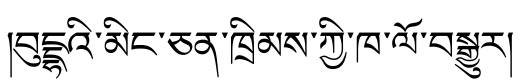

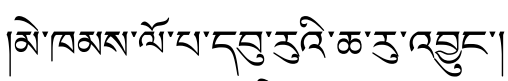

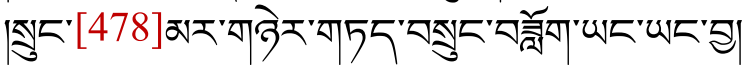

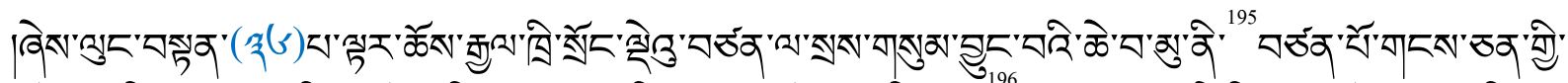

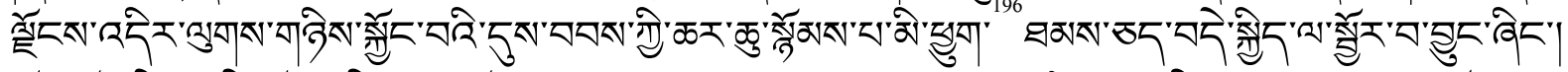

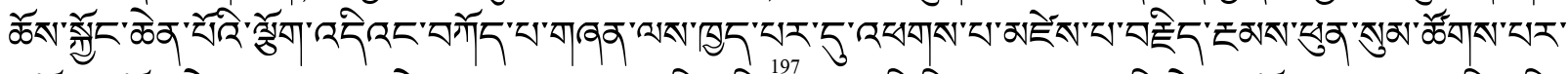

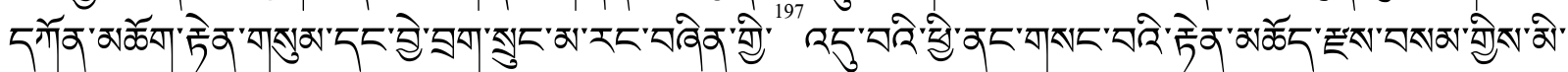

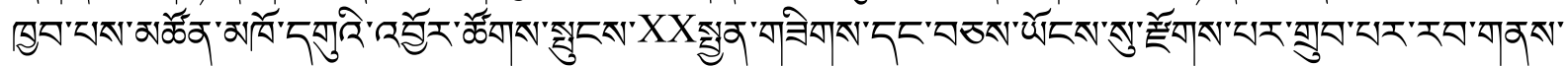

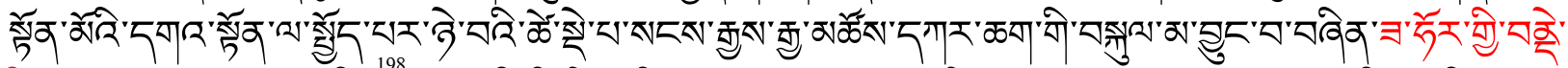

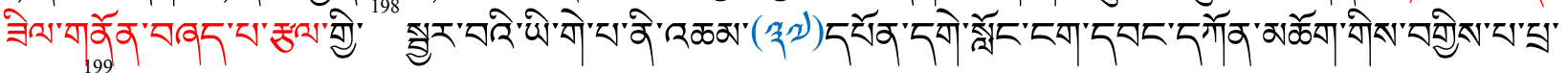

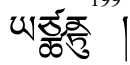

\footnotetext{
${ }^{190}$ Lingön Padma Kelzang adds a shad and a space here that is not found in the inscription.

${ }^{191}$ Lingön Padma Kelzang: omitted.

${ }^{192}$ Lingön Padma Kelzang: $\nleftarrow$; corrected to $\longleftarrow$ '.

${ }^{193}$ Lingön Padma Kelzang: वेरे; c corrected to वेरें.

${ }^{194}$ Lingön Padma Kelzang: ฐ"; corrected to $\longleftarrow$ '.

${ }^{195}$ Lingön Padma Kelzang: वे;; corrected to वे.

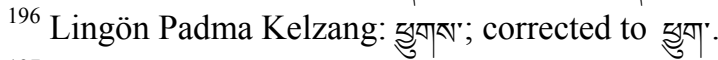

${ }^{197}$ Lingön Padma Kelzang: ब্ৰेस"; corrected to ब्रें.

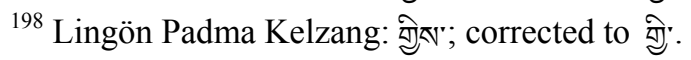

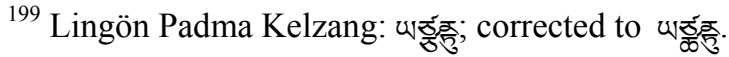




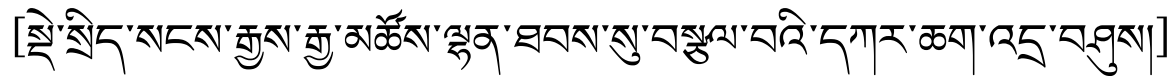

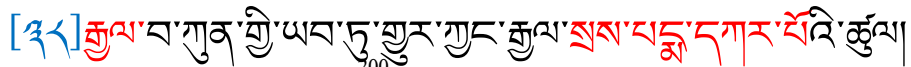

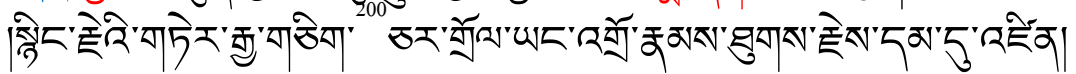

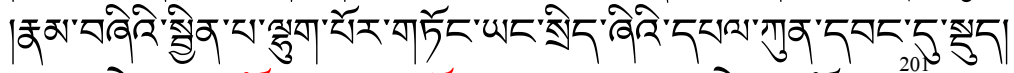

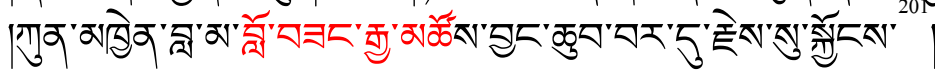

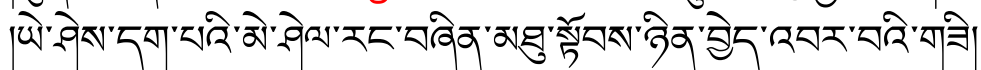

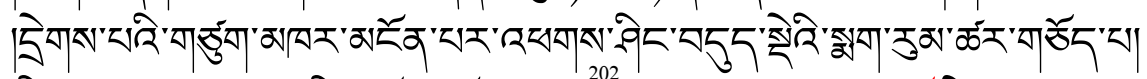

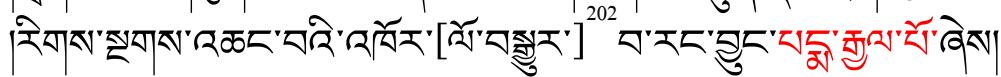

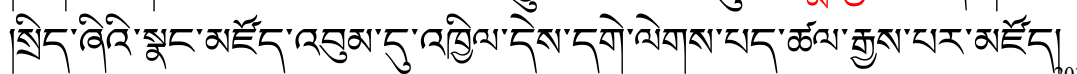

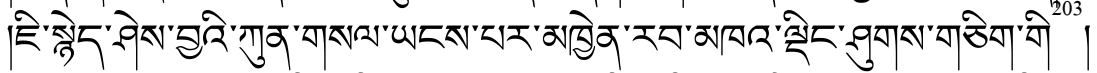

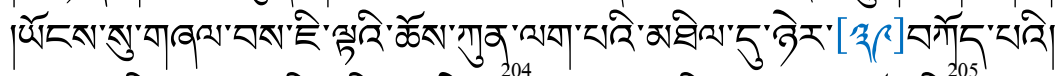

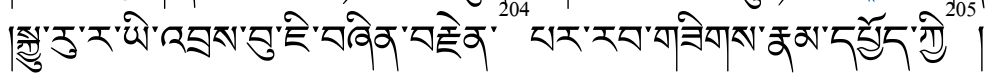

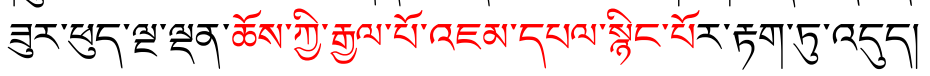

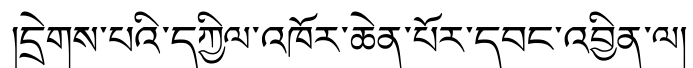

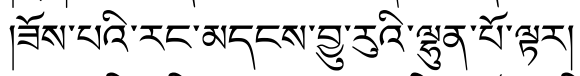

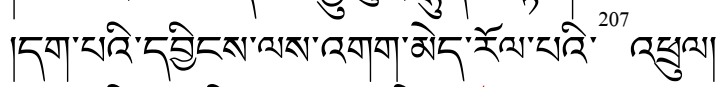

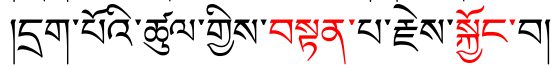

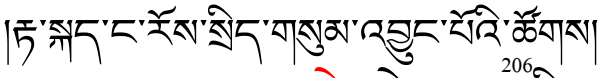

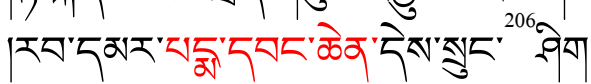

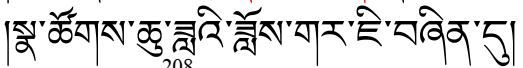

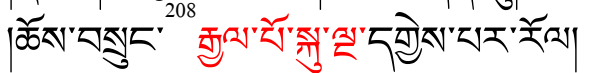

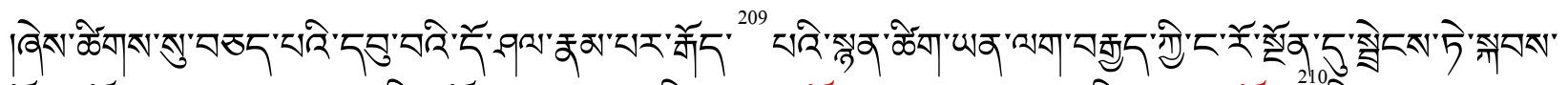

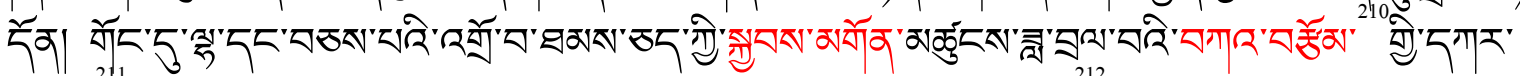

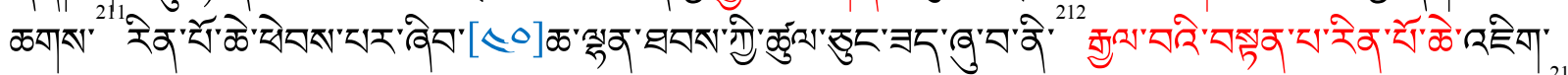

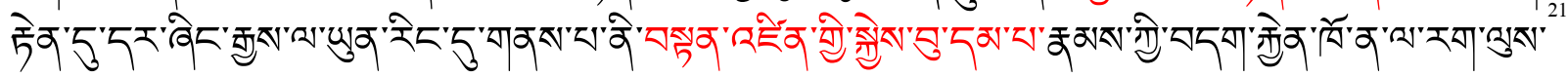

\footnotetext{
${ }^{200}$ Lingön Padma Kelzang: ठेगा"; corrected to बारेषा".

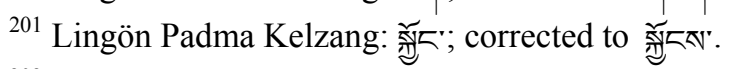

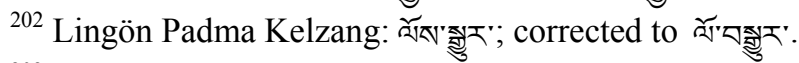

${ }^{203}$ Lingön Padma Kelzang: गोरे; corrected to गों.

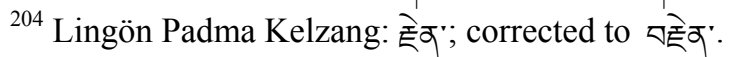

${ }^{205}$ Lingön Padma Kelzang: 정;; corrected to ग्रे.

${ }^{206}$ Lingön Padma Kelzang: 젇ㅊ; corrected to 젇'.

${ }^{207}$ Lingön Padma Kelzang: \रें; corrected to चरें.

${ }^{208}$ Lingön Padma Kelzang: 젇; corrected to অत्ञुद.

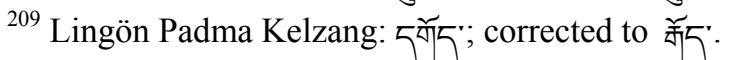

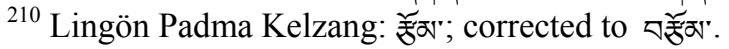

${ }^{211}$ Lingön Padma Kelzang: कबा"; corrected to कవासे".

${ }^{212}$ Lingön Padma Kelzang: | ; corrected to :
} 


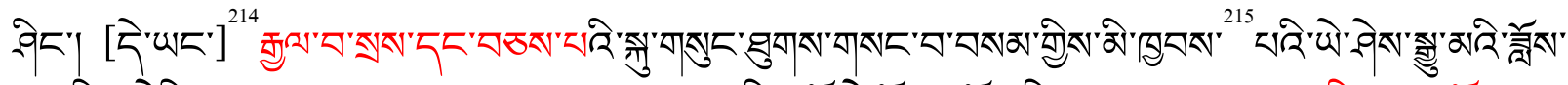

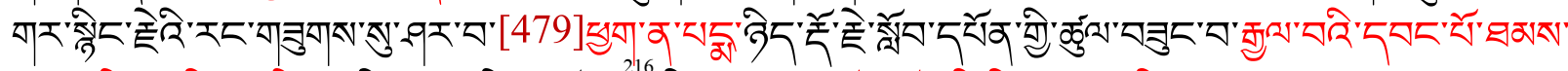

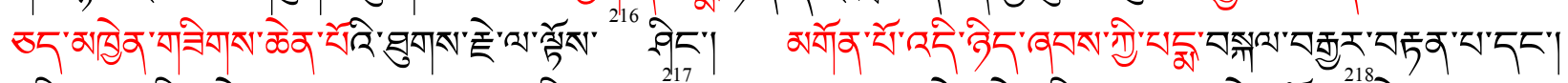

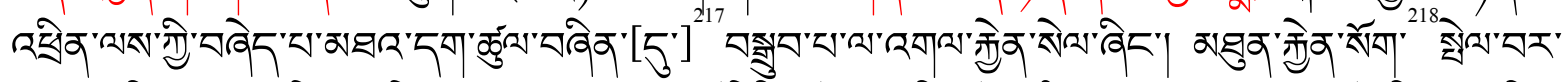

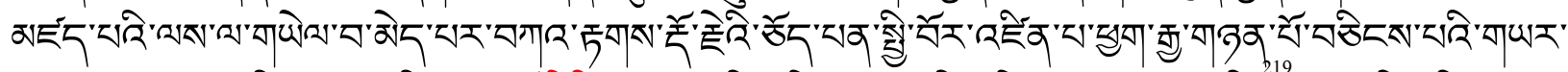

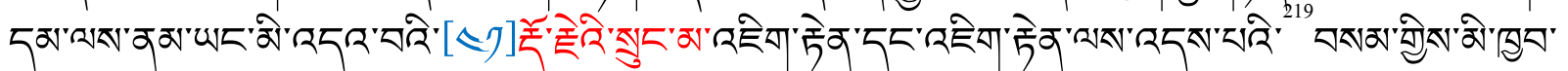

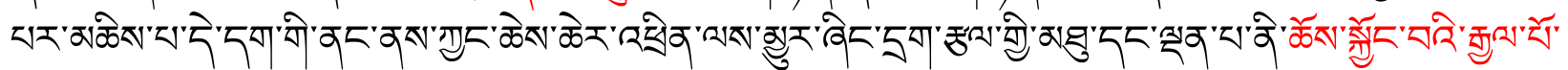

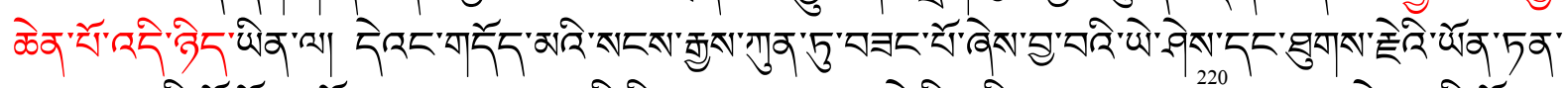

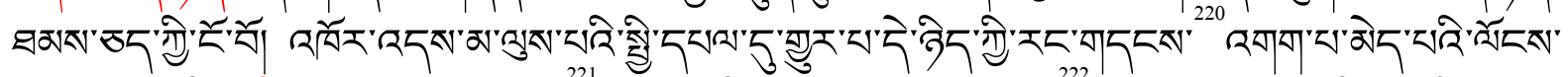

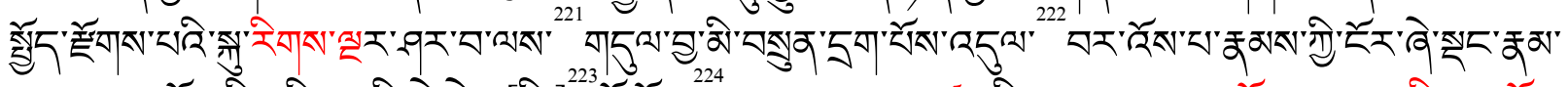

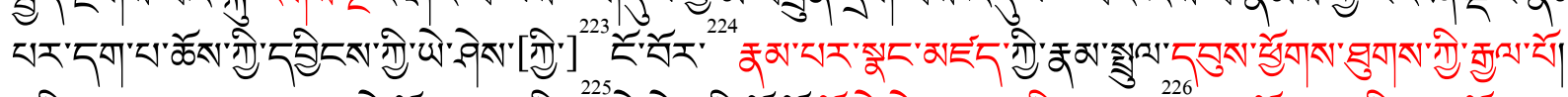

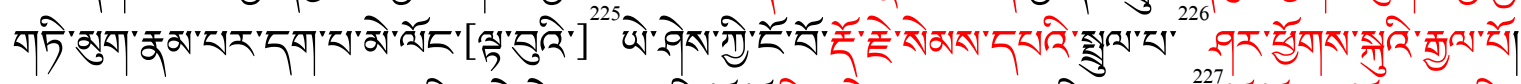

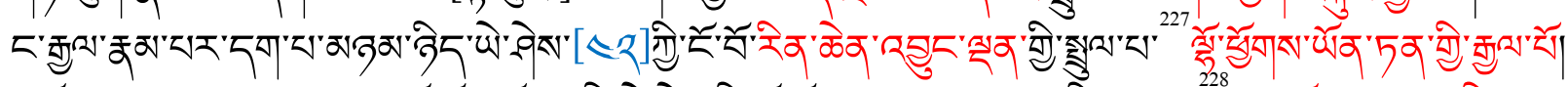

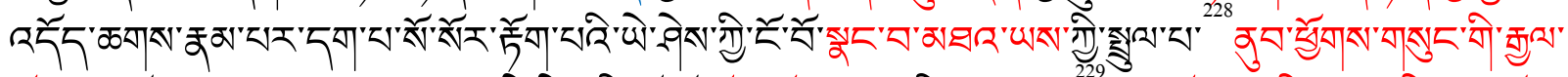

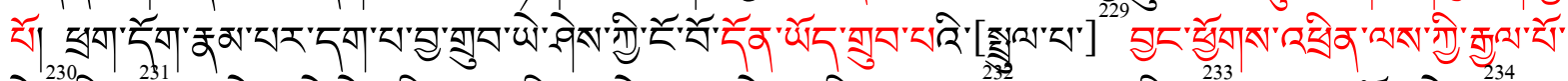

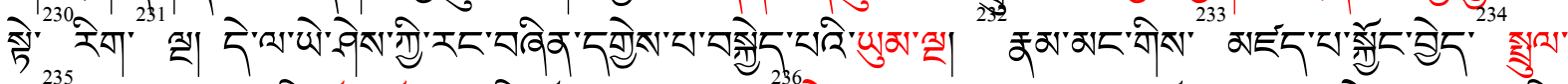

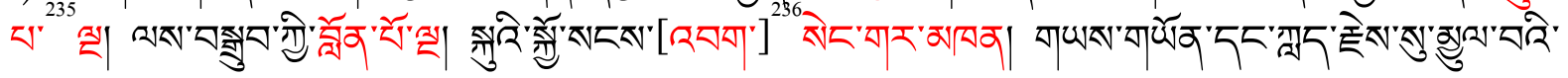

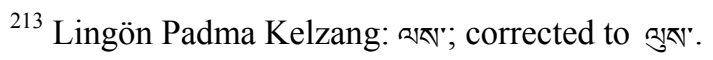

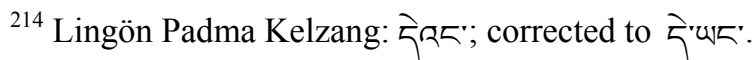

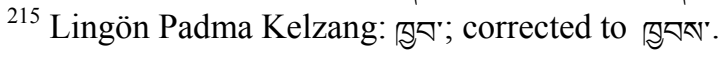

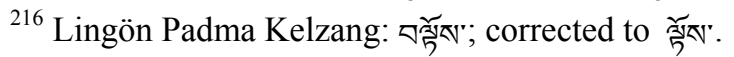

${ }^{217}$ Lingön Padma Kelzang: omitted.

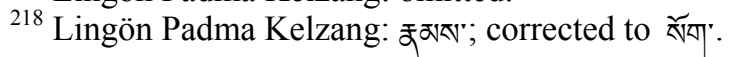

${ }^{219}$ Lingön Padma Kelzang: ㅈ; corrected to इरें.

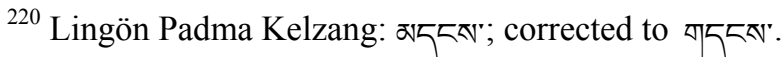

${ }^{221}$ Lingön Padma Kelzang: | ; corrected to :

${ }^{222}$ Lingön Padma Kelzang: गाइु'; corrected to 25ुख'.

${ }^{223}$ Lingön Padma Kelzang: omitted.

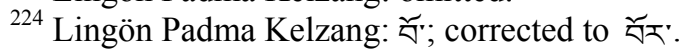

${ }^{225}$ Lingön Padma Kelzang: omitted.

${ }^{226}$ Lingön Padma Kelzang: $₫$; corrected to $\longleftarrow$ ".

${ }^{227}$ Lingön Padma Kelzang: $\nleftarrow$; corrected to $\longleftarrow$ '.

${ }^{228}$ Lingön Padma Kelzang: $₫$; corrected to $\longleftarrow$ '.

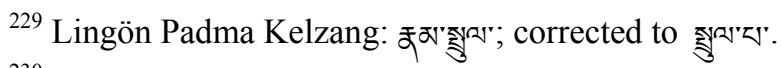

${ }^{230}$ Lingön Padma Kelzang: | ; corrected to ?

${ }^{231}$ Lingön Padma Kelzang: रेगास"; corrected to रेगा".

${ }^{232}$ Lingön Padma Kelzang adds a «a' here that is not found in the inscription.

${ }^{233}$ Lingön Padma Kelzang: गे'; corrected to बोसे'.

${ }^{234}$ Lingön Padma Kelzang: के५; corrected to ड్ 


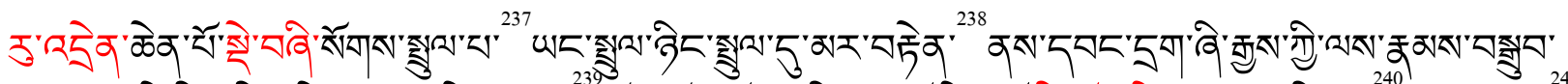

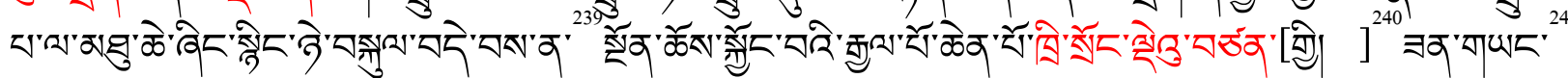

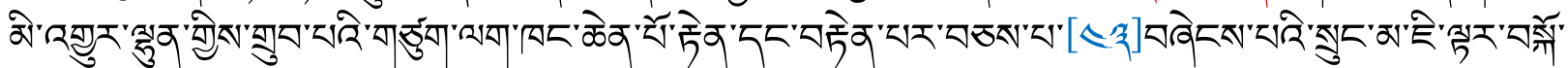

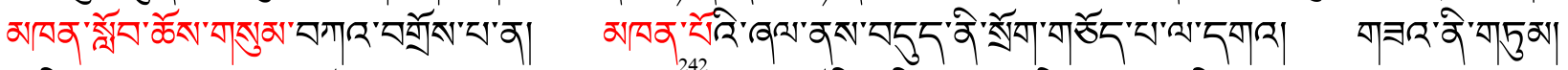

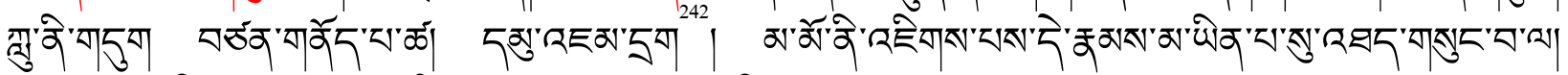

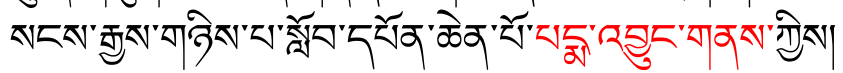

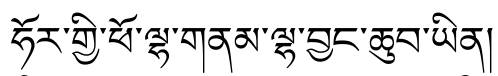

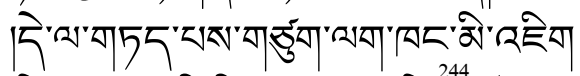

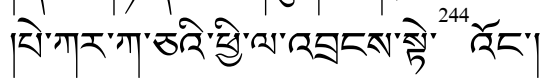

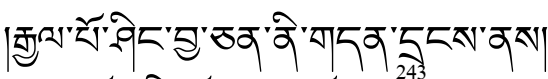

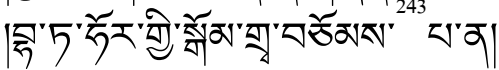

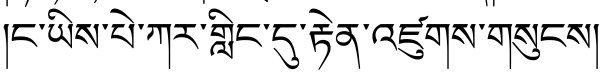

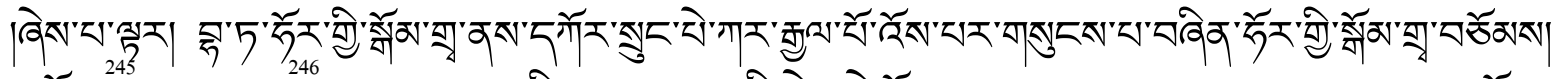

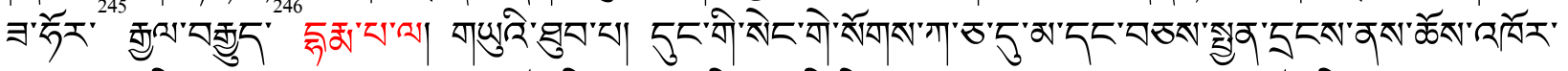

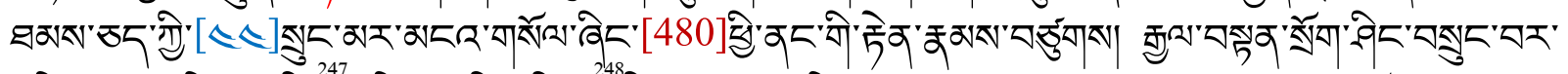

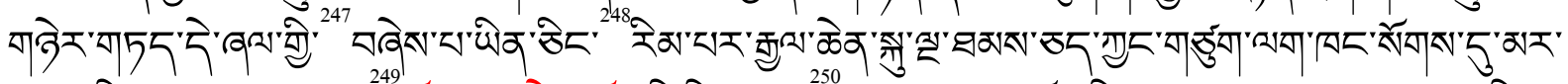

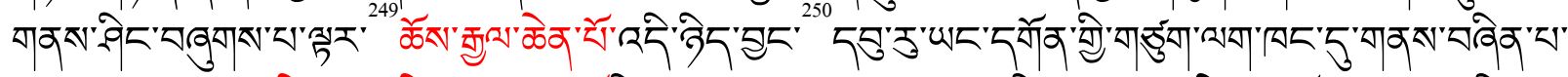

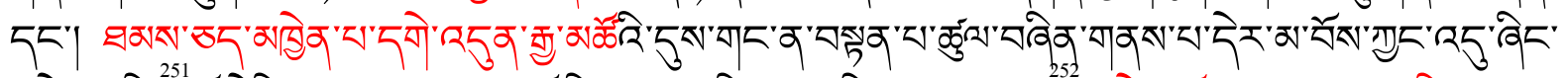

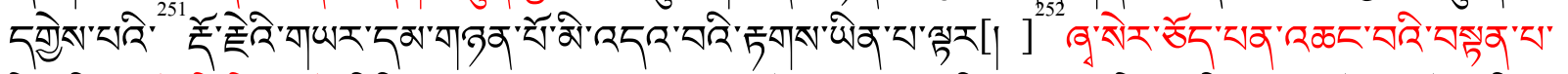

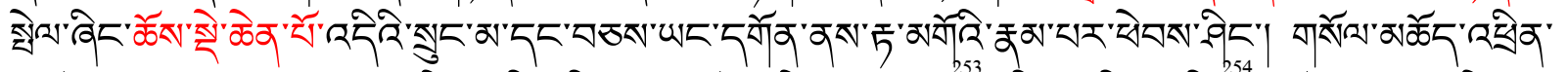

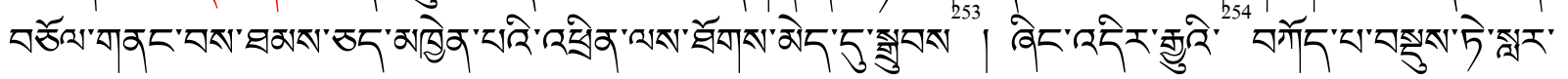

${ }^{235}$ Lingön Padma Kelzang: ๙;; corrected to

${ }^{236}$ Lingön Padma Kelzang: omitted.

${ }^{237}$ Lingön Padma Kelzang: $₫$; corrected to $\longleftarrow$.

${ }^{238}$ Lingön Padma Kelzang: ॠत्रुव; corrected to

${ }^{239}$ Lingön Padma Kelzang: | ; corrected to :

${ }^{240}$ Lingön Padma Kelzang: ब्रेते; corrected to ब्रे| ·

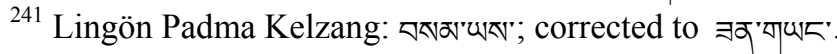

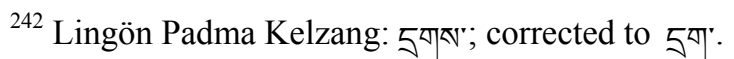

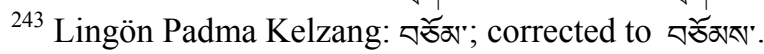

${ }^{244}$ Lingön Padma Kelzang: 亏े;; corrected to 太્Ңे'.

${ }^{245}$ Lingön Padma Kelzang adds a ब्रें' here that is not found in the inscription.

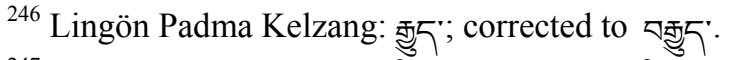

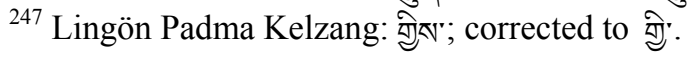

${ }^{248}$ Lingön Padma Kelzang adds a shad and a space here that is not found in the inscription.

${ }^{249}$ Lingön Padma Kelzang: | ; corrected to :

${ }^{250}$ Lingön Padma Kelzang: गুरॅ; corrected to వ్రా'.

${ }^{251}$ Lingön Padma Kelzang: 지; ; corrected to दरिे.

${ }^{252}$ Lingön Padma Kelzang: '; corrected to $\mid$. 


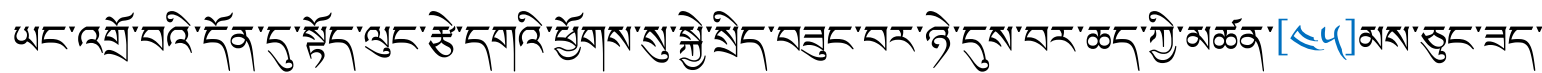

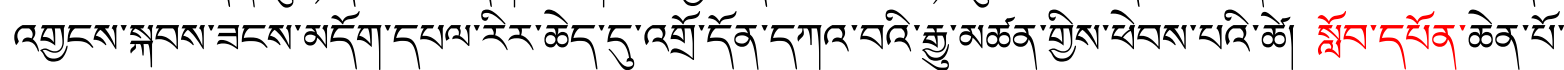

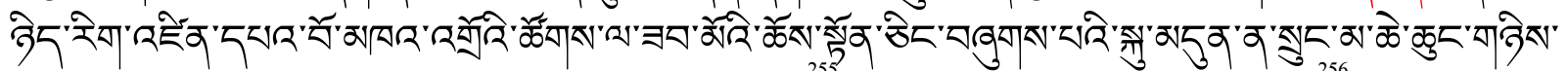

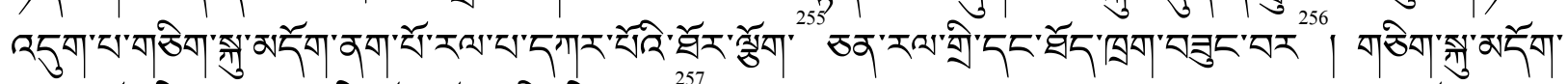

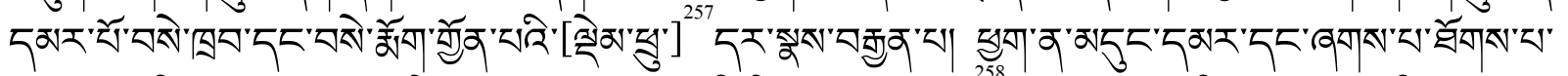

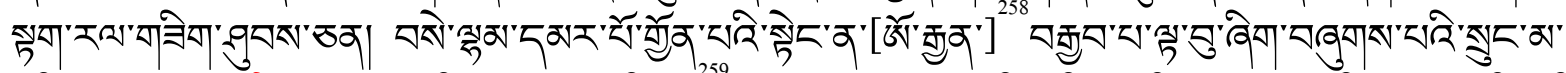

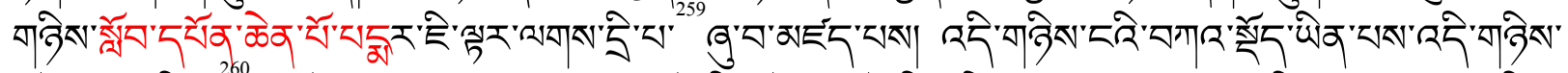

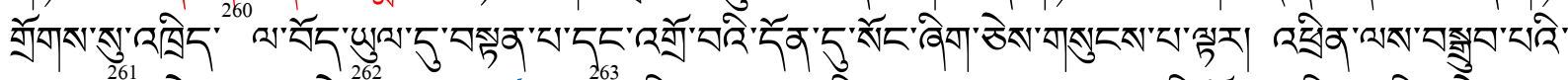

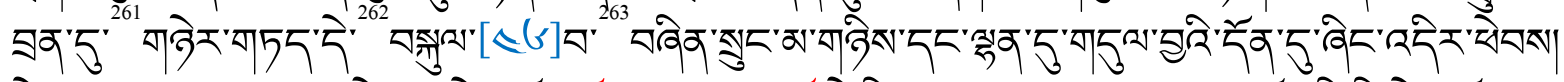

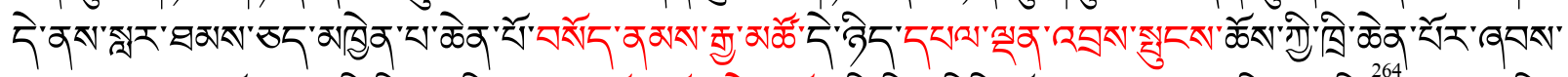

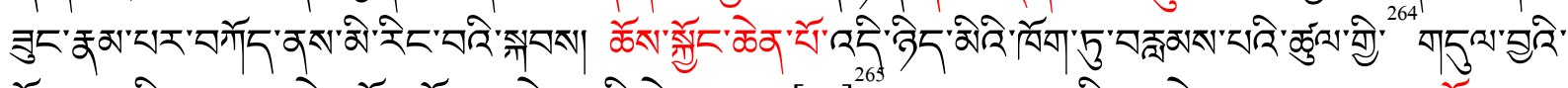

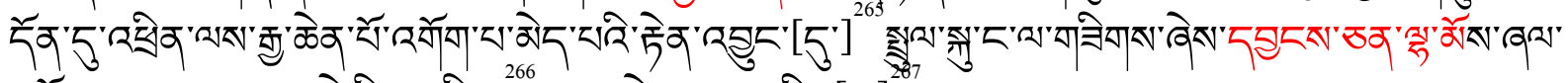

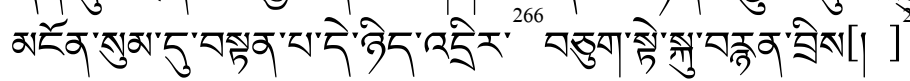

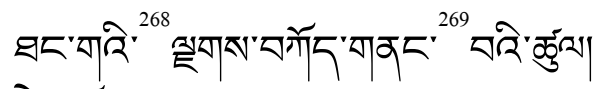

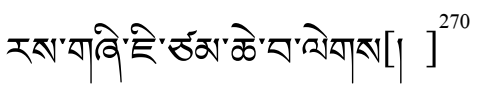

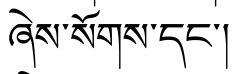

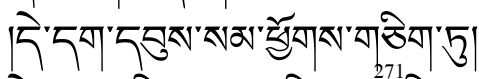

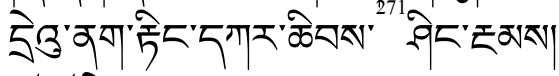

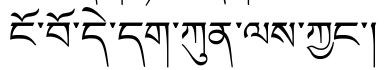

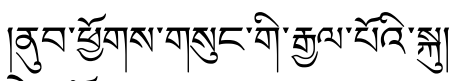

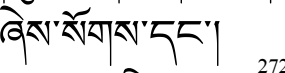

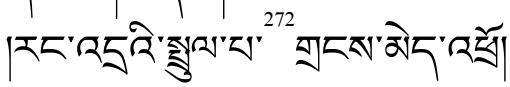

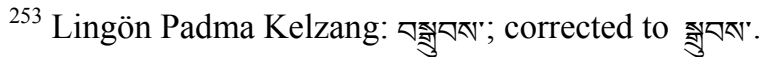

${ }^{254}$ Lingön Padma Kelzang: 쥐रें; corrected to क्षुरें.

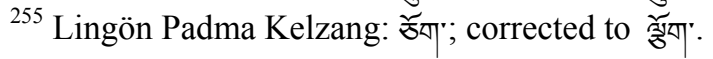

${ }^{256}$ Lingön Padma Kelzang: $₫$; corrected to $\square \times$.

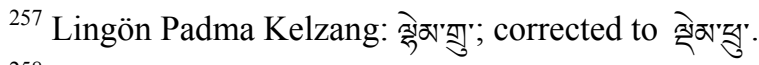

${ }^{258}$ Lingön Padma Kelzang suggests that this word should be ๘াव'.

${ }^{259}$ Lingön Padma Kelzang: $\nleftarrow$; corrected to $\longleftarrow$ ".

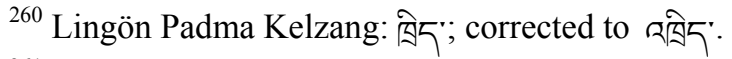

${ }^{261}$ Lingön Padma Kelzang: Ђु;; corrected to 5 ;.

${ }^{262}$ Lingön Padma Kelzang: 5 ; corrected to $\bar{\zeta}$.

${ }^{263}$ Lingön Padma Kelzang: ㅈ'; corrected to $\nwarrow$ '.

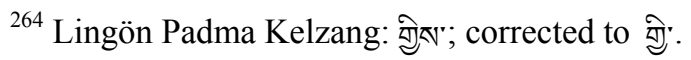

${ }^{265}$ Lingön Padma Kelzang: omitted.

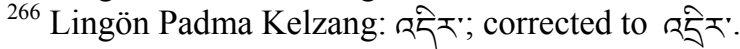

${ }^{267}$ Lingön Padma Kelzang: "; corrected to $\mid$.

${ }^{268}$ Lingön Padma Kelzang: गे'; corrected to बारें.

${ }^{269}$ Lingön Padma Kelzang: 죋"; corrected to गावृ

${ }^{270}$ Lingön Padma Kelzang: '; corrected to । .

${ }^{271}$ Lingön Padma Kelzang: వరివন"; corrected to ळेవন".
} 


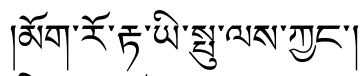

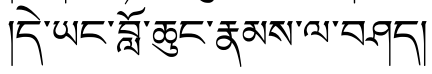

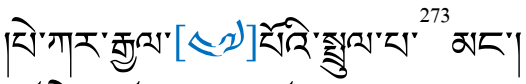

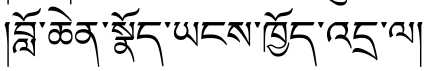

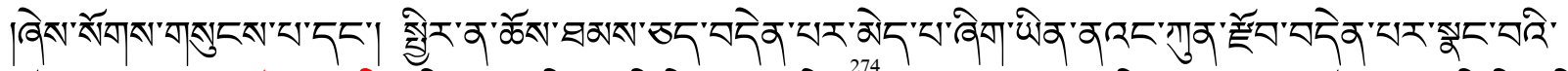

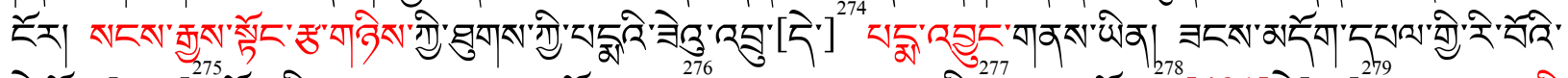

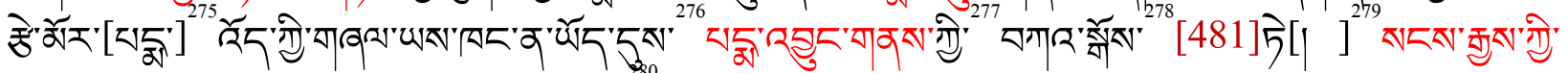

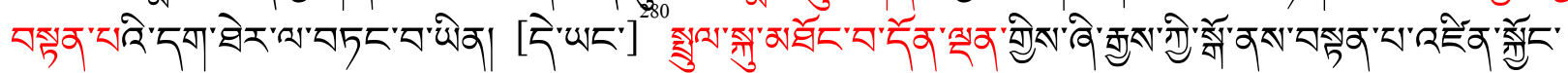

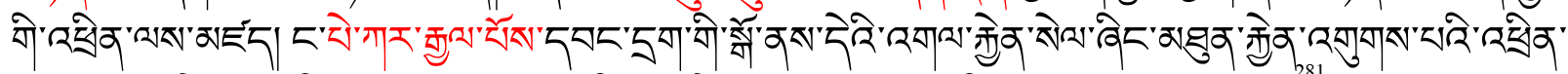

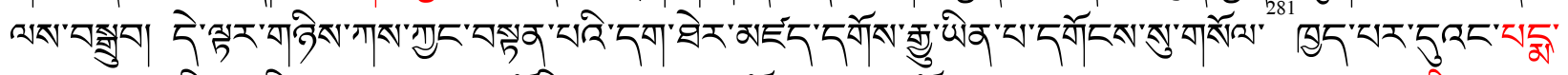

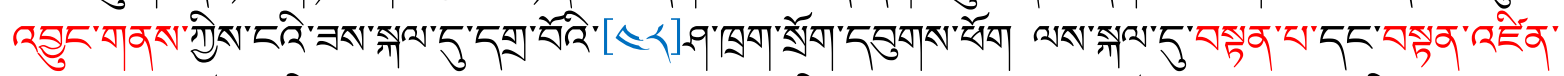

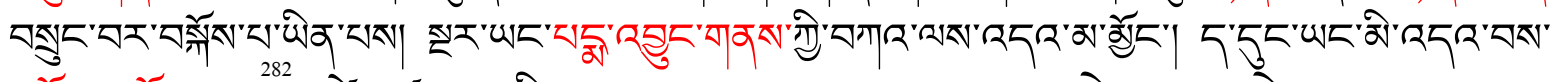

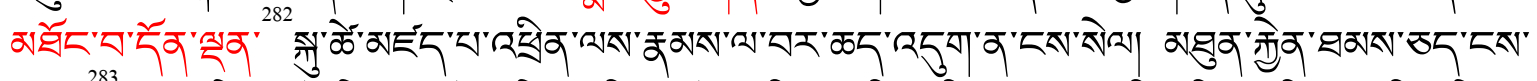

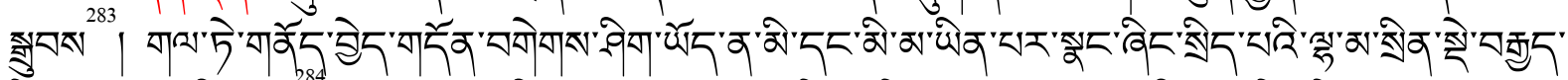

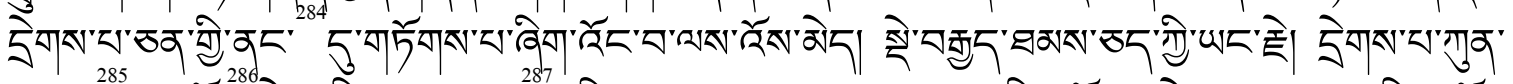

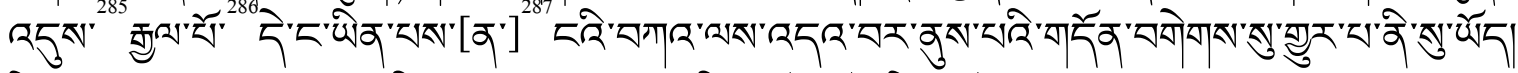

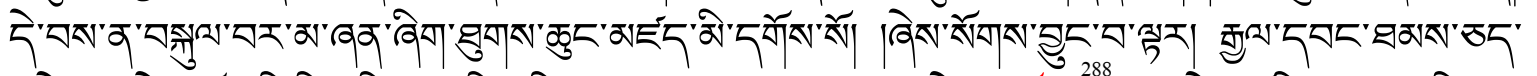

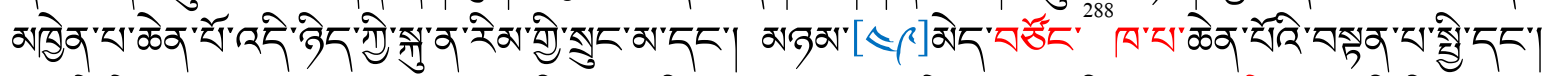

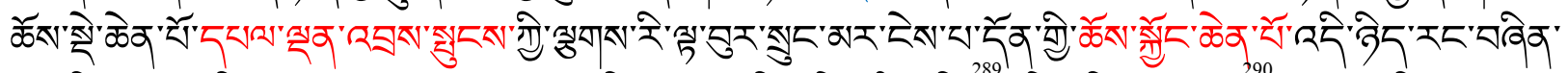

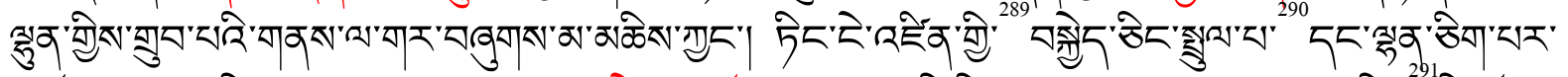

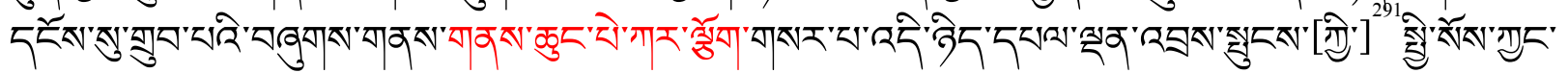

\footnotetext{
${ }^{272}$ Lingön Padma Kelzang: $₫$; corrected to

${ }^{273}$ Lingön Padma Kelzang: §; corrected to $\longleftarrow$ r.

${ }^{274}$ Lingön Padma Kelzang: omitted.

${ }^{275}$ Lingön Padma Kelzang: omitted.

${ }^{276}$ Lingön Padma Kelzang: | ; corrected to :

${ }^{277}$ Lingön Padma Kelzang: ग्रेस"; corrected to ग्रें.

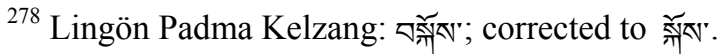

${ }^{279}$ Lingön Padma Kelzang: "; corrected to | .

${ }^{280}$ Lingön Padma Kelzang: خे२६'; corrected to خेख्य'.

${ }^{281}$ Lingön Padma Kelzang: | ; corrected to :

${ }^{282}$ Lingön Padma Kelzang adds a ब্ৰু' here that is not found in the inscription.

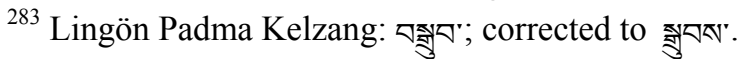

${ }^{284}$ Lingön Padma Kelzang adds a ळॅ here that is not found in the inscription.

${ }^{285}$ Lingön Padma Kelzang adds a ग्रें' here that is not found in the inscription.

${ }^{286}$ Lingön Padma Kelzang: | ; corrected to ?

${ }^{287}$ Lingön Padma Kelzang: omitted.

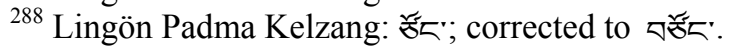

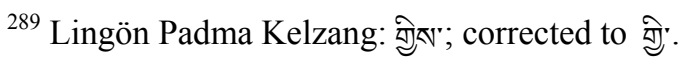

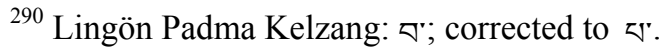




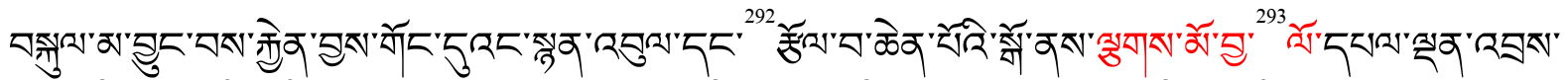

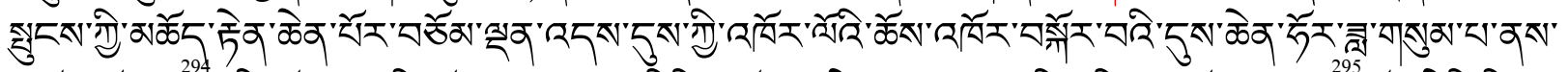

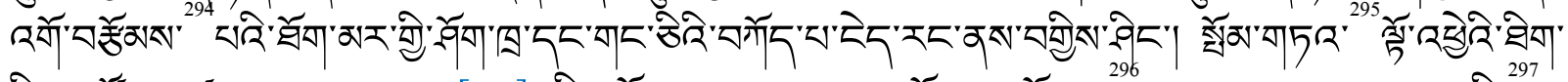

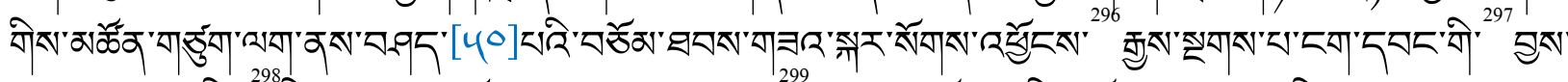

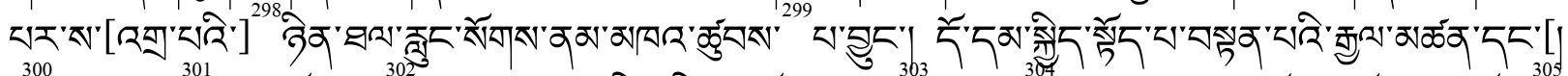

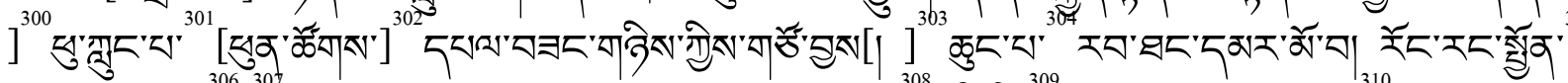

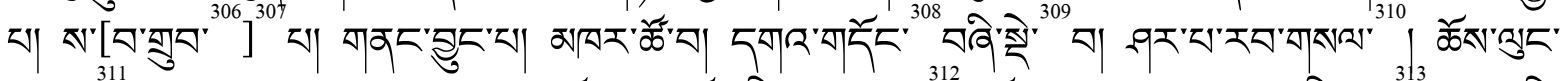

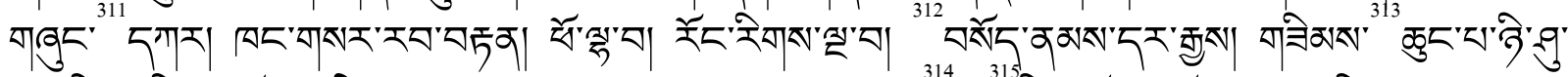

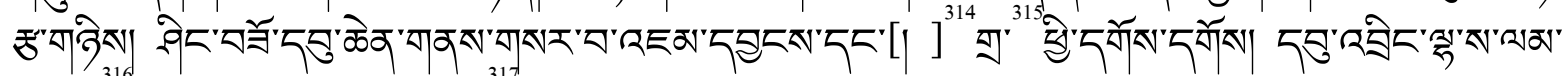

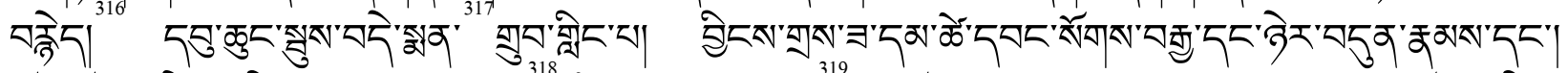

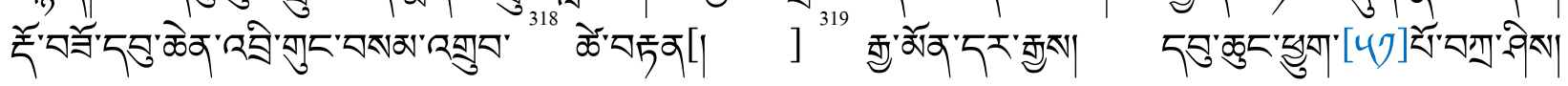

${ }^{291}$ Lingön Padma Kelzang: omitted.

${ }^{292}$ Lingön Padma Kelzang adds a shad and a space here that is not found in the inscription.

${ }^{293}$ Lingön Padma Kelzang: इुरे"; corrected to इㄹ.

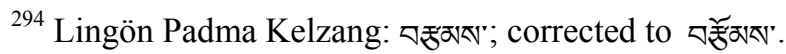

${ }^{295}$ Lingön Padma Kelzang: ड్ ذेरें; Dobis Tsering Gyal (2009, p.353.3): 55*. The inscription is heavily damaged at this juncture and nearly illegible; however, the syllable count strongly suggests that there is no word at this point.

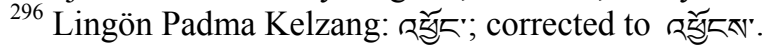

${ }^{297}$ Lingön Padma Kelzang: बोरे'; corrected to बें.

${ }^{298}$ Lingön Padma Kelzang: २క

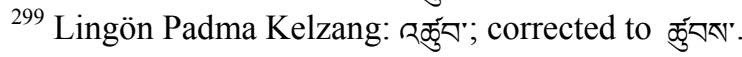

${ }^{300}$ Lingön Padma Kelzang: omitted.

${ }^{301}$ Dobis Tsering Gyal: $₫$ '.

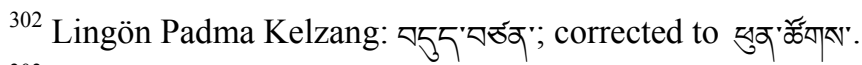

${ }^{303}$ Lingön Padma Kelzang: '; corrected to $\mid$.

${ }^{304}$ Lingön Padma Kelzang: $ه$; corrected to $\longleftarrow$ '.

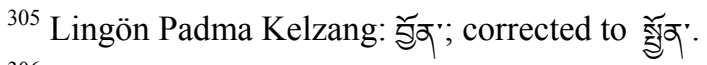

${ }^{306}$ Lingön Padma Kelzang: 점; corrected to 젖'.

${ }^{307}$ Dobis Tsering Gyal: $\square$ गु'.

${ }^{308}$ Dobis Tsering Gyal: | .

${ }^{309}$ Lingön Padma Kelzang: Ђरे;; corrected to ్ㅗㄱ.

${ }^{310}$ Lingön Padma Kelzang adds $\varpi^{*}$ here.

${ }^{311}$ Lingön Padma Kelzang: गाबु; corrected to गाबुर:

${ }^{312}$ Lingön Padma Kelzang adds छुكु' ब्बेट here.

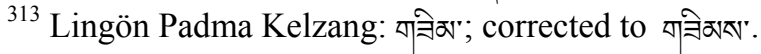

${ }^{314}$ Lingön Padma Kelzang: omitted.

${ }^{315}$ Lingön Padma Kelzang: 줙; corrected to 지'

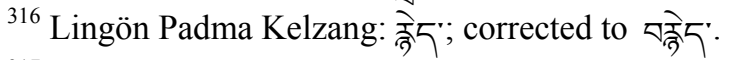

${ }^{317}$ Lingön Padma Kelzang: 쥔;

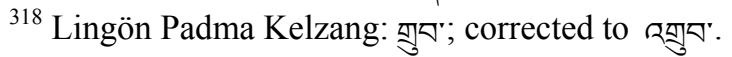

${ }^{319}$ Lingön Padma Kelzang: $5\ulcorner$; corrected to 1 . 


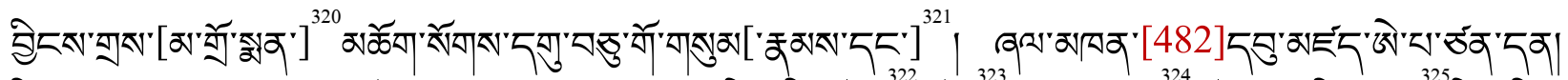

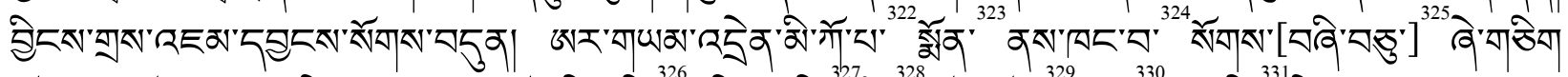

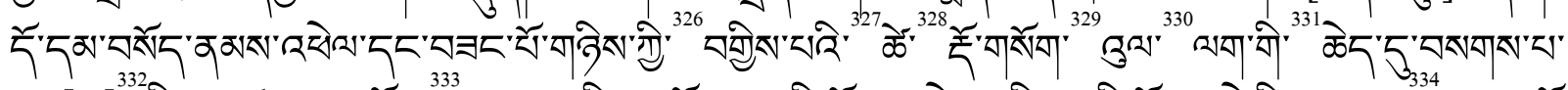

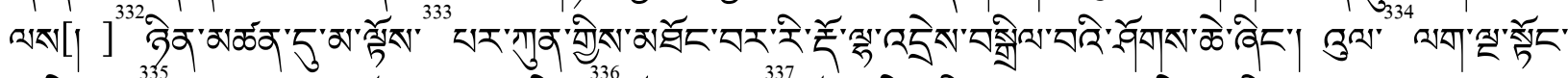

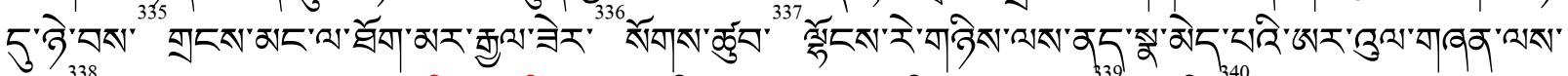
155 "

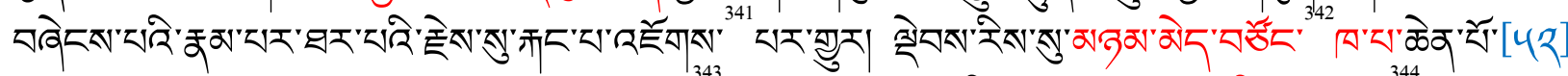

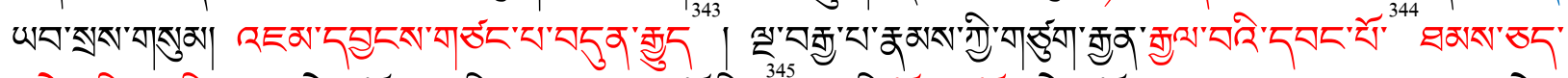

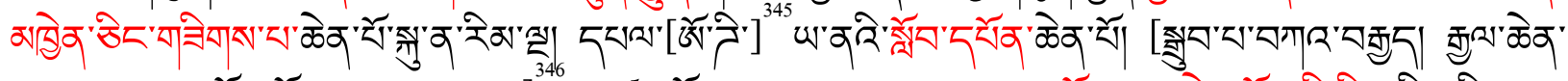

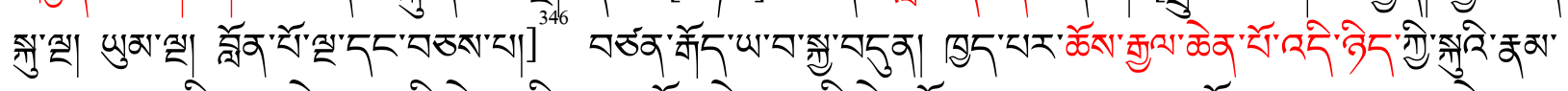

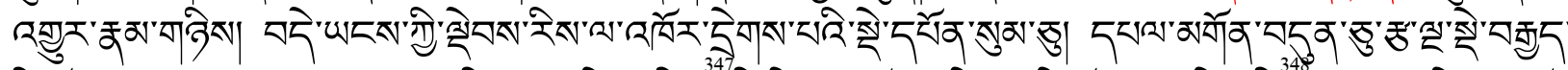

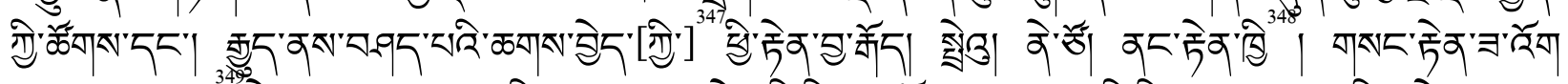

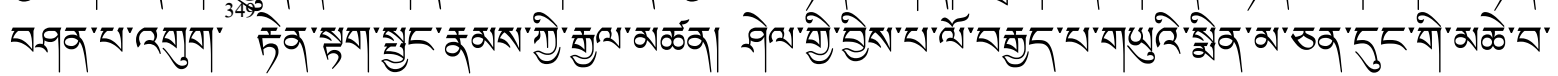

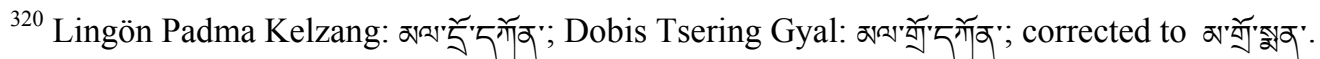

${ }^{321}$ Lingön Padma Kelzang: omitted.

${ }^{322}$ Dobis Tsering Gyal: $₫$.

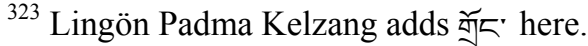

${ }^{324}$ Lingön Padma Kelzang: $\asymp$; corrected to $\square$.

${ }^{325}$ Lingön Padma Kelzang: omitted.

${ }^{326}$ Lingön Padma Kelzang: ग्रेस"; corrected to ग्रें.

${ }^{327}$ Lingön Padma Kelzang:| ; Dobis Tsering Gyal: omitted; corrected to चरिे.

${ }^{328}$ Lingön Padma Kelzang: ळे"; corrected to ळे'.

${ }^{329}$ Lingön Padma Kelzang adds (অ//ब大) here.

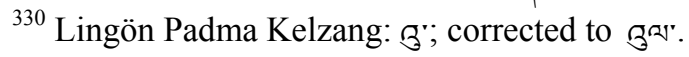

${ }^{331}$ Lingön Padma Kelzang: गोरू'; corrected to बों'.

${ }^{332}$ Lingön Padma Kelzang: '; corrected to $\mid$.

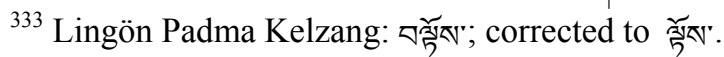

${ }^{334}$ Lingön Padma Kelzang: 乃ु; ; corrected to శुख'.

${ }^{335}$ Lingön Padma Kelzang: इरे"; corrected to వর'"

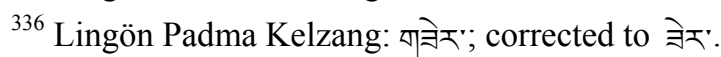

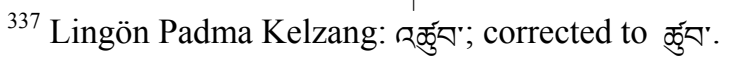

${ }^{338}$ Lingön Padma Kelzang adds 다' here.

${ }^{339}$ Lingön Padma Kelzang adds פ্्रेत' here.

${ }^{340}$ Lingön Padma Kelzang: उरि"; corrected to गें.

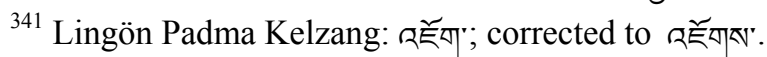

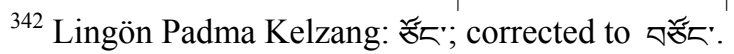

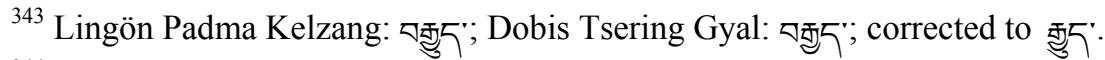

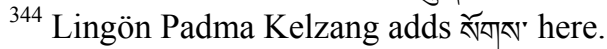

${ }^{345}$ Dobis Tsering Gyal:

${ }^{346}$ Lingön Padma Kelzang: omitted.
} 


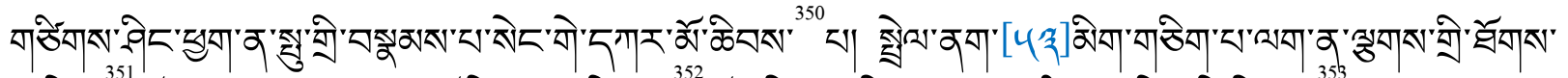

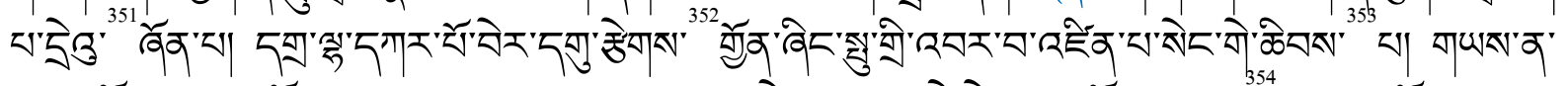

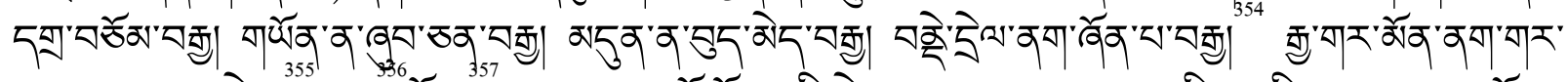

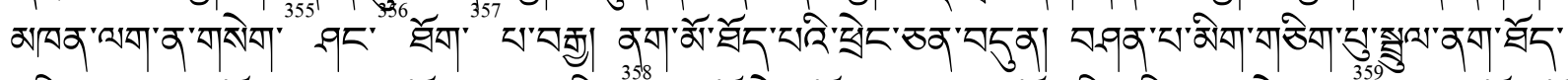

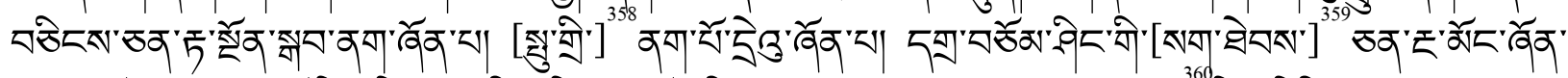

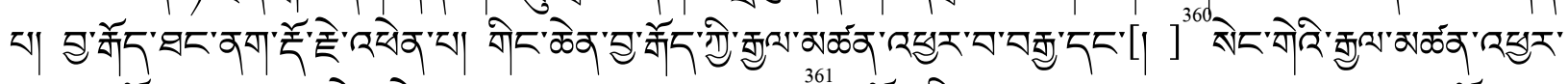

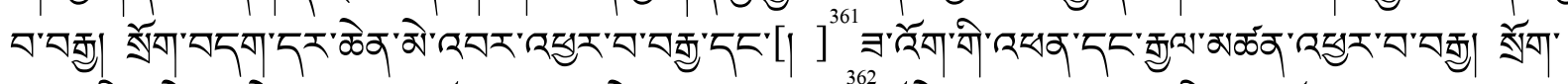

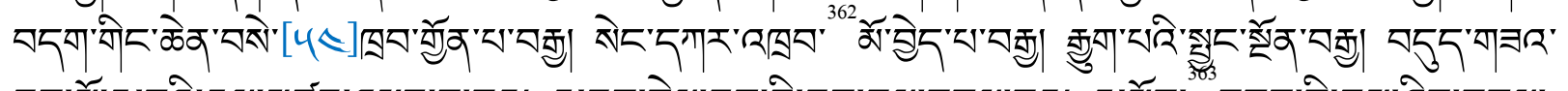

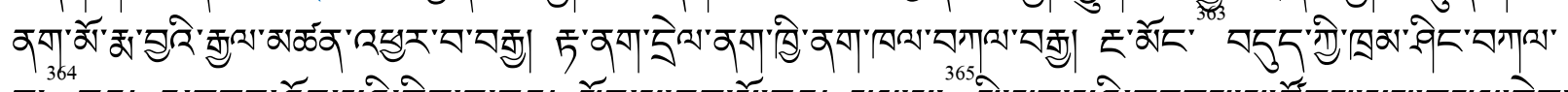

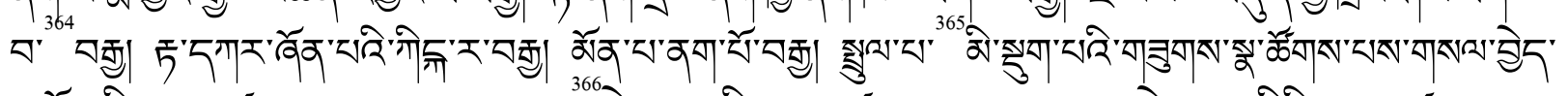

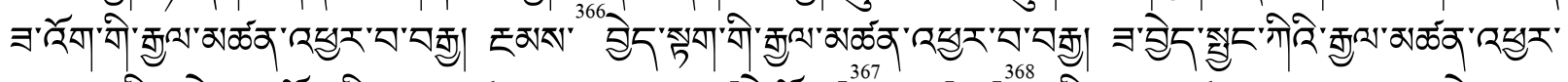

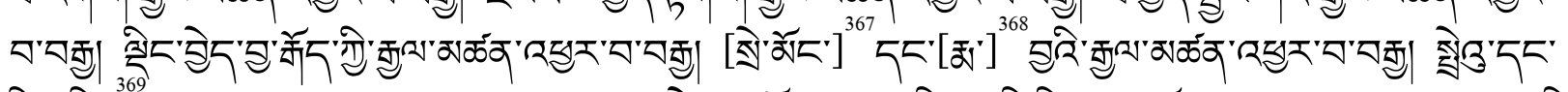

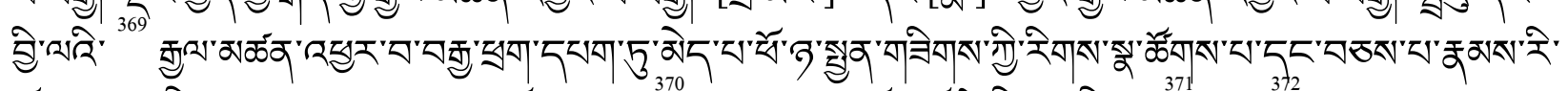

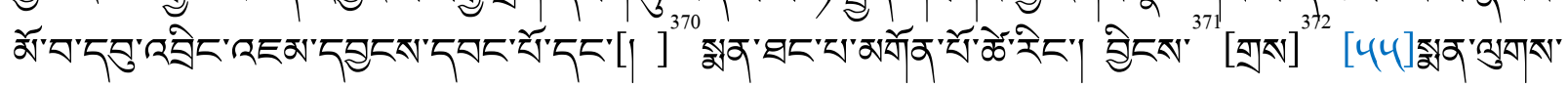

\footnotetext{
${ }^{347}$ Lingön Padma Kelzang: omitted.

${ }^{348}$ Dobis Tsering Gyal: ל్

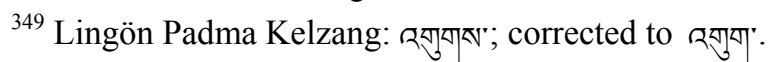

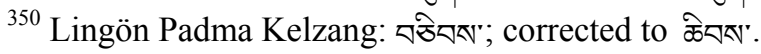

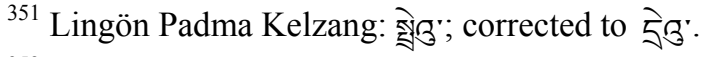

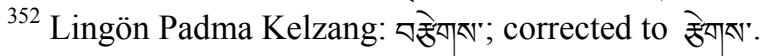

${ }^{353}$ Lingön Padma Kelzang: వరेমন"; corrected to ळివর'.

${ }^{354}$ Lingön Padma Kelzang places this line two lines prior to here.

${ }^{355}$ Lingön Padma Kelzang: तोषा"; corrected to गाशेषण".

${ }^{356}$ Dobis Tsering Gyal: शेट

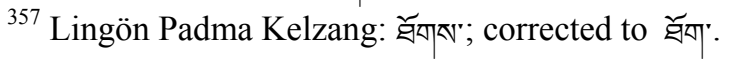

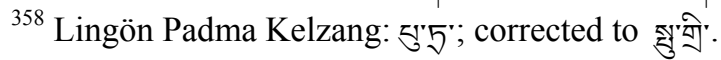

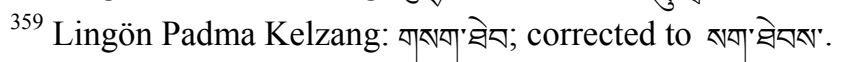

${ }^{360}$ Lingön Padma Kelzang: omitted.

${ }^{361}$ Lingön Padma Kelzang: omitted.

362 Dobis Tsering Gyal: ब্রৈ'.

${ }^{363}$ Dobis Tsering Gyal: केّ".

${ }^{364}$ Lingön Padma Kelzang: 『্; corrected to $\varangle$ '

${ }^{365}$ Lingön Padma Kelzang: $₫$; corrected to $\longleftarrow$ "

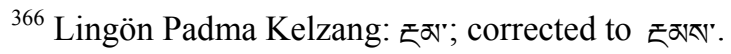

${ }^{367}$ Dobis Tsering Gyal: خे̀े".

${ }^{368}$ Lingön Padma Kelzang: omitted.

${ }^{369}$ Dobis Tsering Gyal: रैरें.

${ }^{370}$ Lingön Padma Kelzang: omitted.

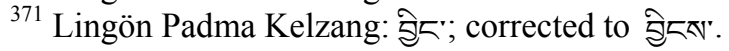

${ }^{372}$ Lingön Padma Kelzang: omitted.
} 


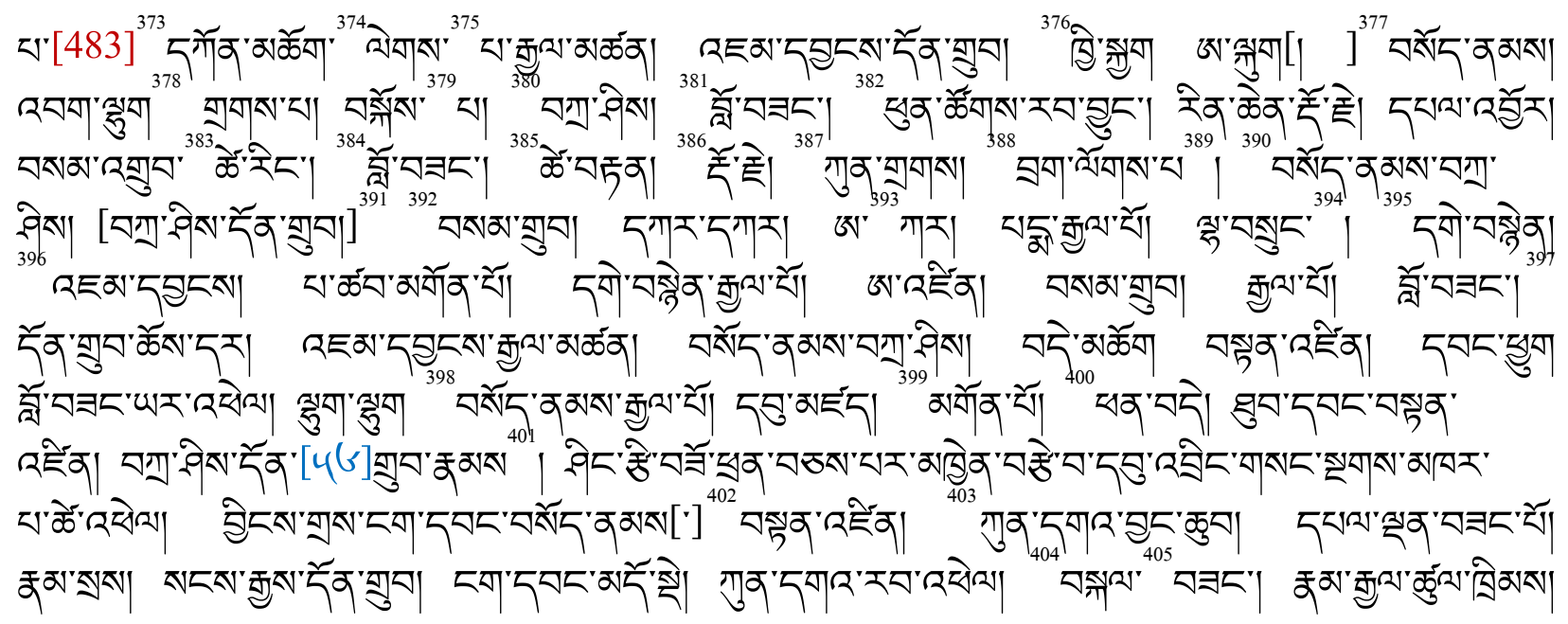

\footnotetext{
${ }^{373}$ Lingön Padma Kelzang adds fश् ' ब्रेट' here.

${ }^{374}$ Dobis Tsering Gyal adds | here.

${ }^{375}$ Dobis Tsering Gyal: 저|র

${ }^{376}$ Lingön Padma Kelzang adds 잼:97' here.

${ }^{377}$ Lingön Padma Kelzang: '; corrected to | .

${ }^{378}$ Lingön Padma Kelzang: 저미; corrected to 죽미.

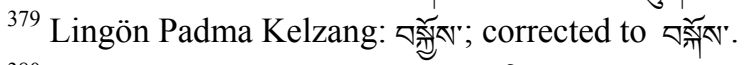

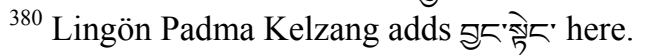

${ }^{381}$ Lingön Padma Kelzang adds б̆ॅ here.

${ }^{382}$ Lingön Padma Kelzang adds $\square र े '$ 'के ' here.

${ }^{383}$ Lingön Padma Kelzang: 제ऽ"; corrected to २్ㅐऽ".

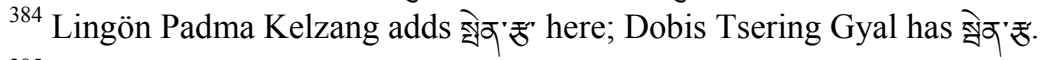

${ }^{385}$ Lingön Padma Kelzang adds 称 'क์ட here.

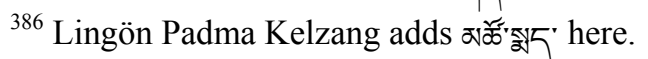

${ }^{387}$ Lingön Padma Kelzang adds बाबव ‘रेव here.

${ }^{388}$ Lingön Padma Kelzang adds エख"び here.

${ }^{389}$ Dobis Tsering Gyal: $₫$.

${ }^{390}$ Lingön Padma Kelzang adds $\Xi^{\prime} \nwarrow^{\mathbf{\gamma}}$ here.

${ }^{391}$ Lingön Padma Kelzang places this name later in the text.

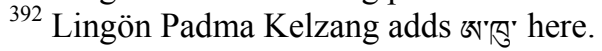

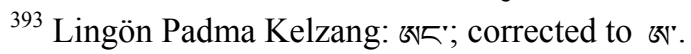

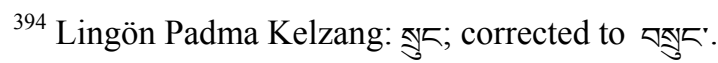

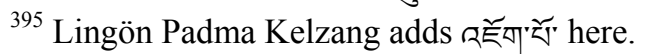

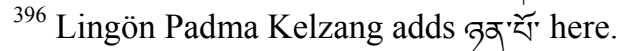

${ }^{397}$ See note 391.

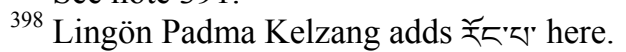

${ }^{399}$ Lingön Padma Kelzang adds অுवঅ" here.

${ }^{400}$ Lingön Padma Kelzang adds ऩे ज्ञेटत' here.

${ }^{401}$ Lingön Padma Kelzang adds ' $5\ulcorner$ ' here.

${ }^{402}$ Lingön Padma Kelzang:| ; corrected to :
} 


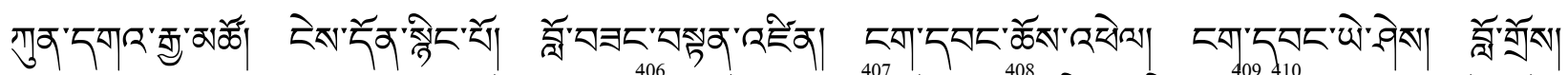

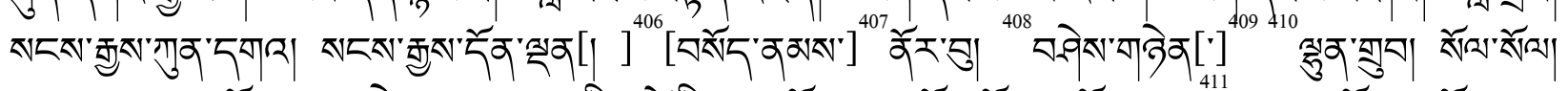

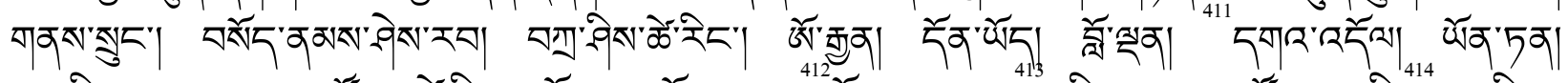

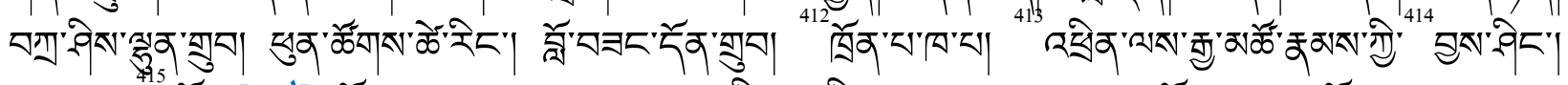

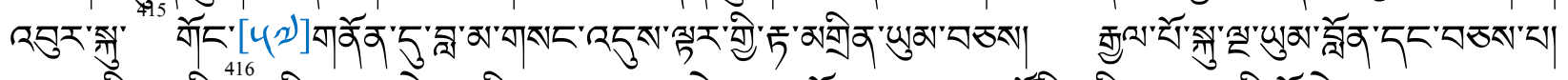

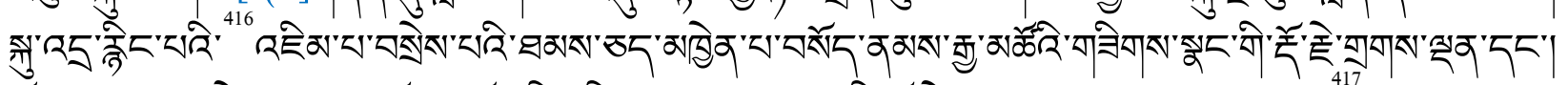

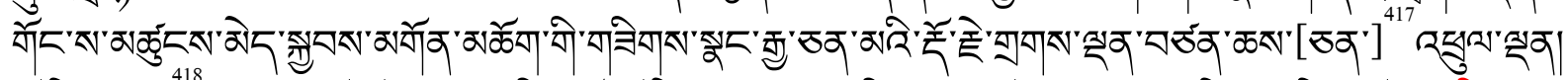

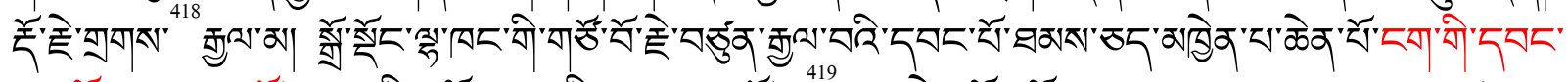

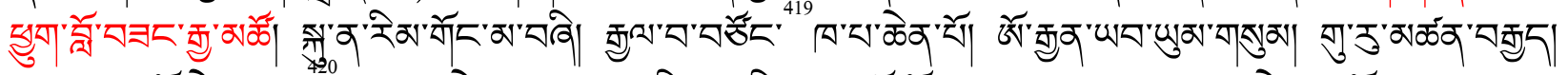

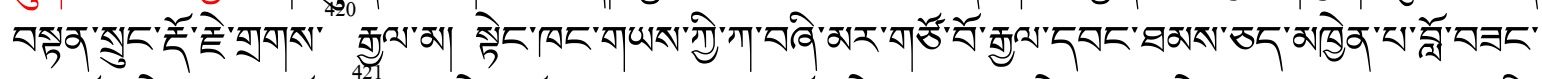

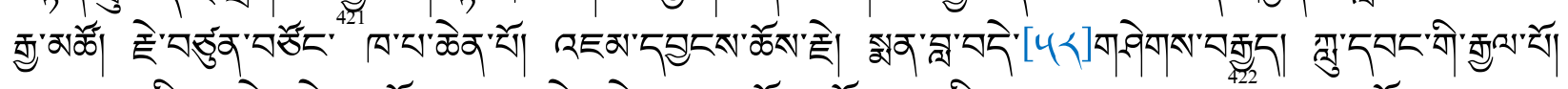

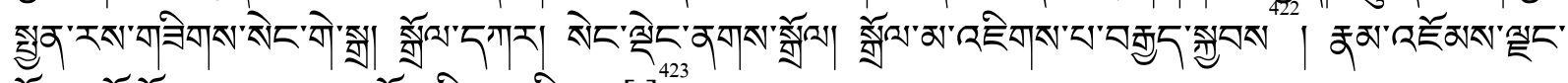

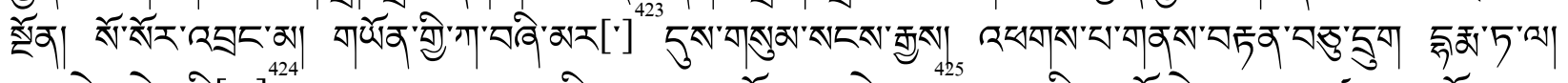

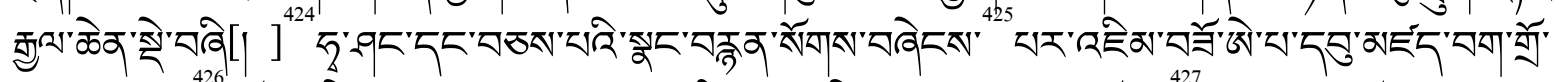

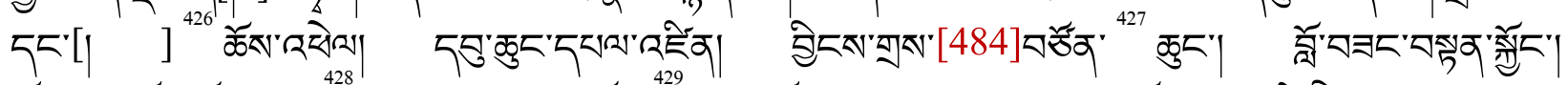

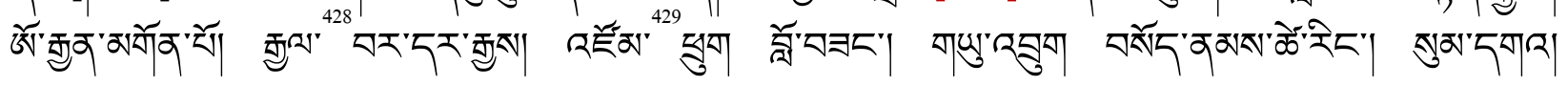

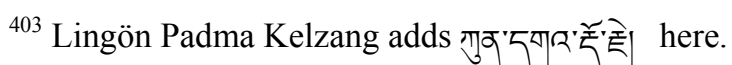

${ }^{404}$ Lingön Padma Kelzang adds केर' 'बे' here.

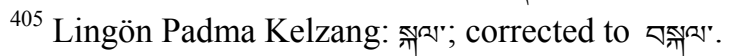

${ }^{406}$ Lingön Padma Kelzang: "; corrected to | .

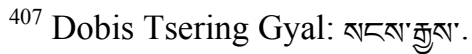

${ }^{408}$ Lingön Padma Kelzang adds 쥒멈 here.

${ }^{409}$ Lingön Padma Kelzang: | ; corrected to :

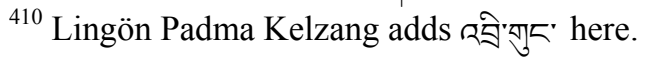

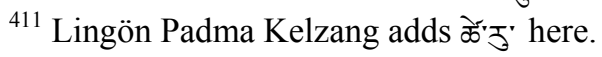

${ }^{412}$ Lingön Padma Kelzang adds 싵제 here.

${ }^{413}$ Lingön Padma Kelzang adds ్̆ำ घ5' here.

${ }^{414}$ Lingön Padma Kelzang: ग्रेस'; corrected to ग्रें.

${ }^{415}$ Lingön Padma Kelzang: 젲'; corrected to 잼.

${ }^{416}$ Dobis Tsering Gyal: Ђरे:

${ }^{417}$ Lingön Padma Kelzang: omitted.

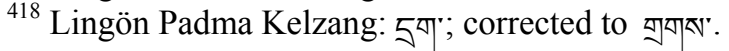

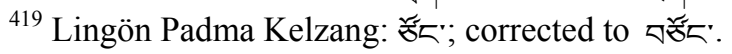

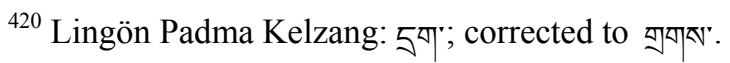

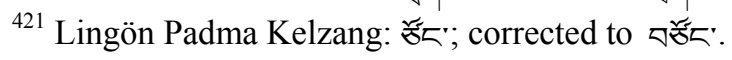

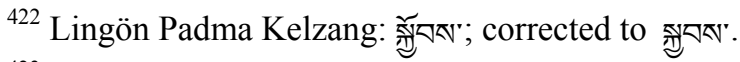

${ }^{423}$ Lingön Padma Kelzang: | ; corrected to :

${ }^{424}$ Lingön Padma Kelzang: '; corrected to | .

${ }^{425}$ Dobis Tsering Gyal: ఐबेर'.
} 


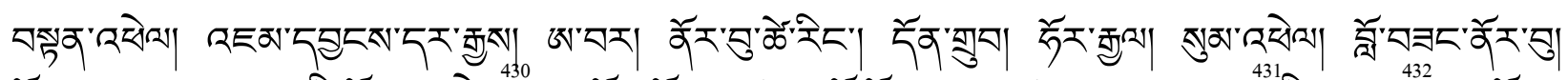

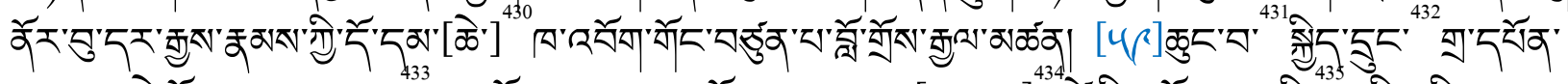

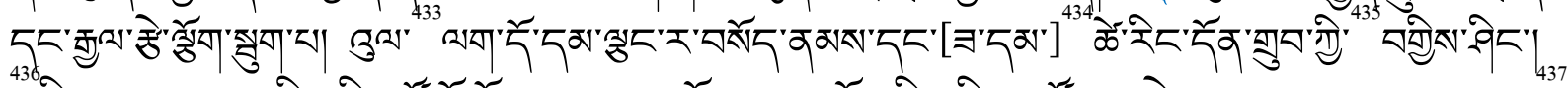

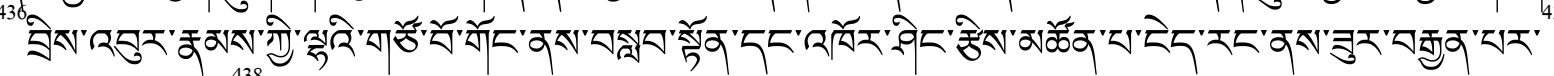

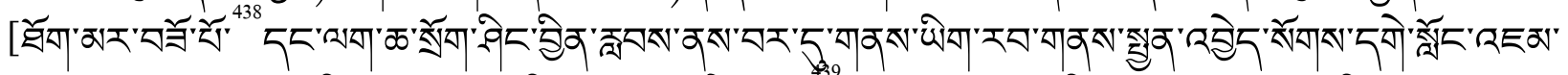

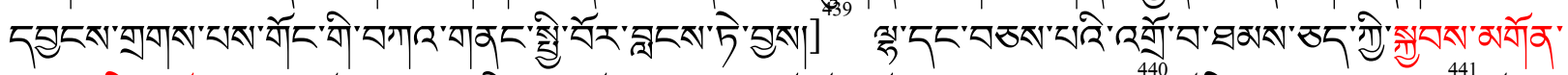

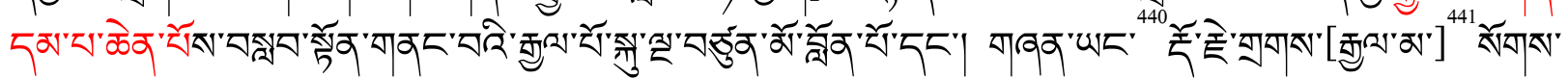

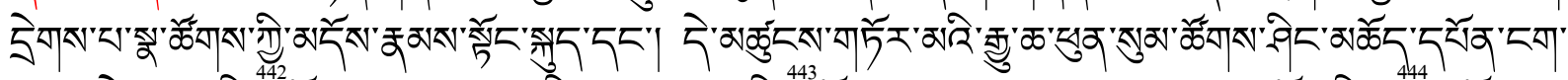

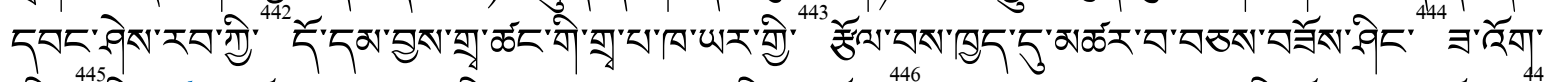

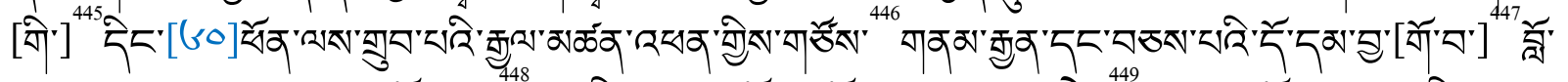

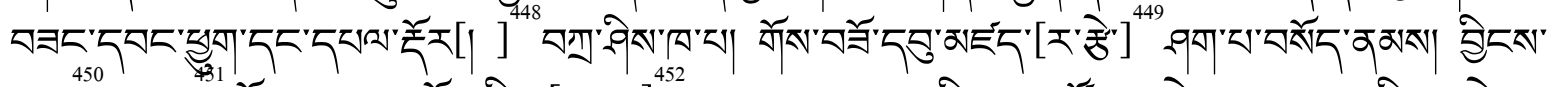

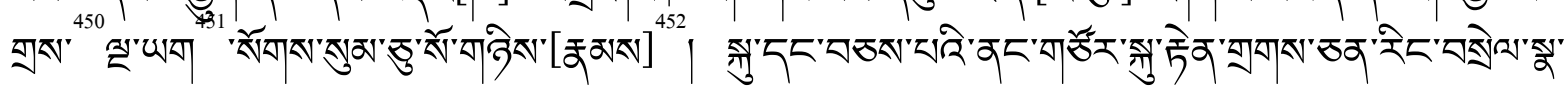

${ }^{426}$ Lingön Padma Kelzang: omitted.

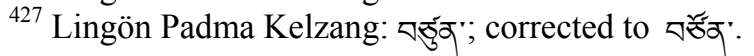

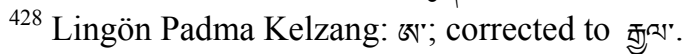

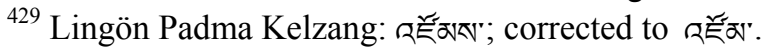

${ }^{430}$ Lingön Padma Kelzang: omitted.

${ }^{431}$ Lingön Padma Kelzang: $ه$; ; corrected to $\square$ '.

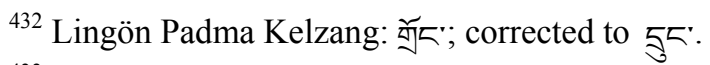

${ }^{433}$ Lingön Padma Kelzang: ণु; ; corrected to

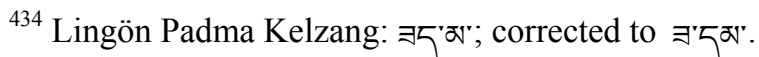

${ }^{435}$ Lingön Padma Kelzang: ग्रेस"; corrected to गें.

${ }^{436}$ Lingön Padma Kelzang places the following fragment later in the text, after the portion bracketed for note 439.

${ }^{437}$ Dobis Tsering Gyal: $\square \times ’$

${ }^{438}$ Lingön Padma Kelzang: خ̌ॅ; corrected to خัॅ".

${ }^{439}$ See note 436.

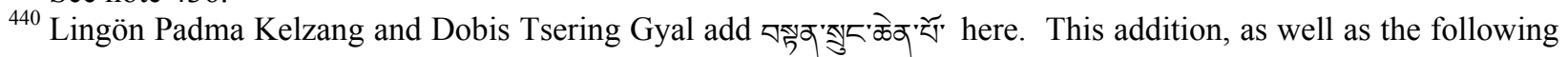

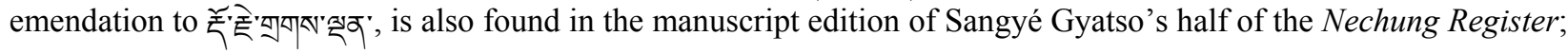
see Sangs rgyas rgya mtsho n.d., f.8a.1.

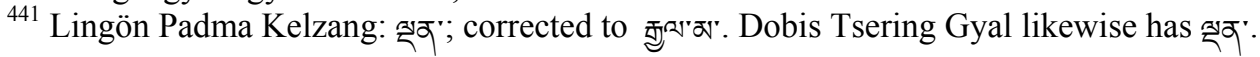

${ }^{442}$ Lingön Padma Kelzang: ग्रेस्र; corrected to गें.

${ }^{443}$ Lingön Padma Kelzang: ब্ৰेస'; corrected to ब्रें.

${ }^{444}$ Lingön Padma Kelzang adds | here.

${ }^{445}$ Lingön Padma Kelzang: omitted.

${ }^{446}$ Lingön Padma Kelzang adds चरें' here.

${ }^{447}$ Lingön Padma Kelzang: 伒

${ }^{448}$ Lingön Padma Kelzang: '; corrected to $\mid$.

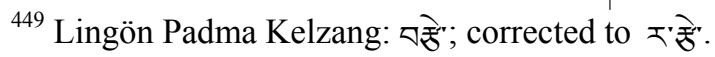

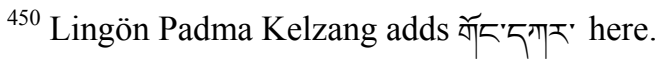

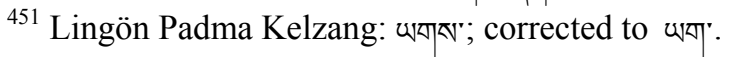

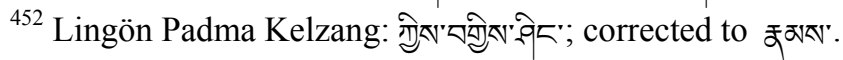




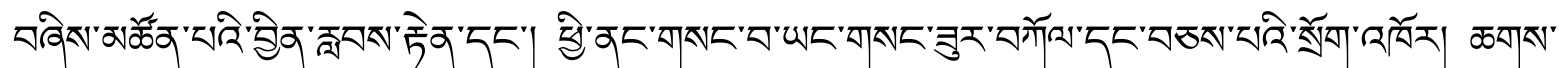

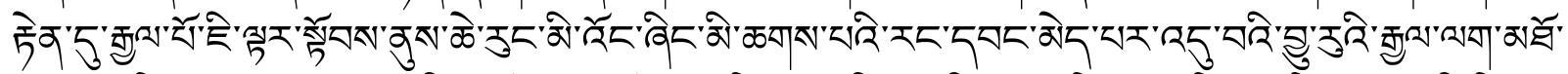

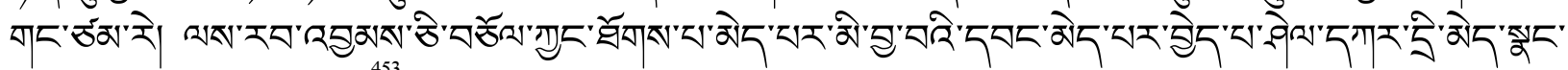

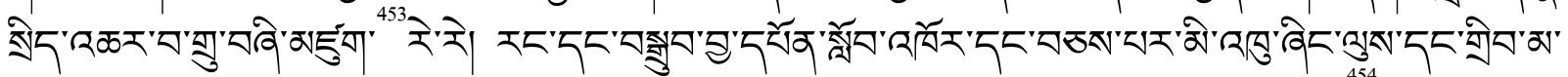

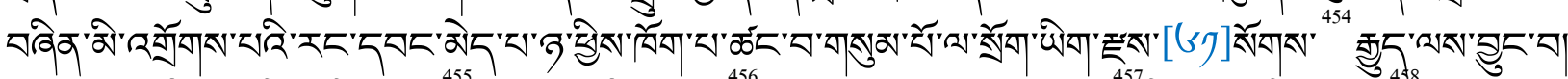

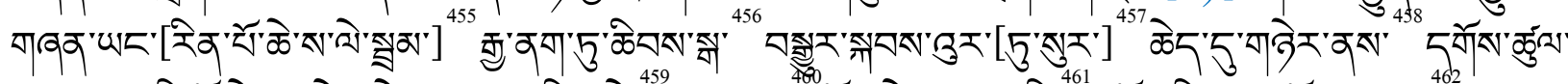

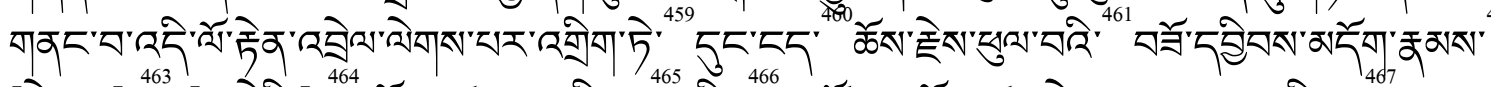

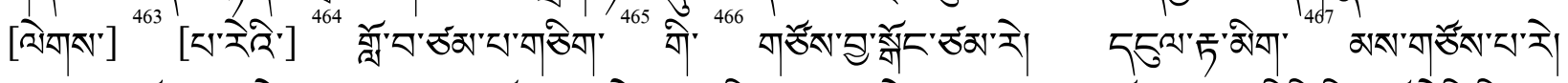

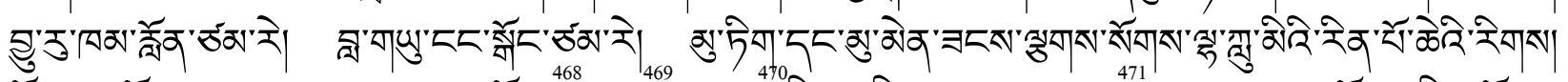

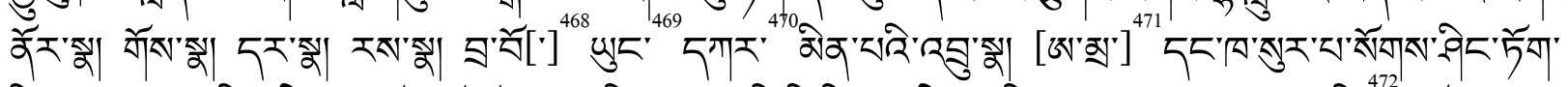

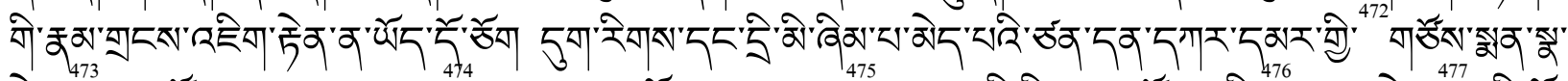

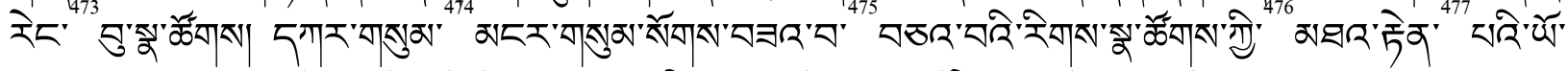

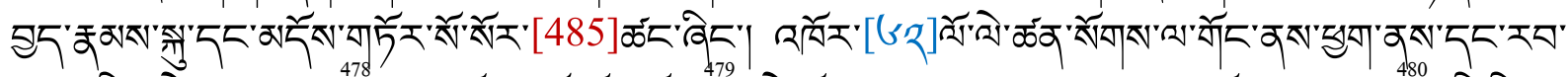

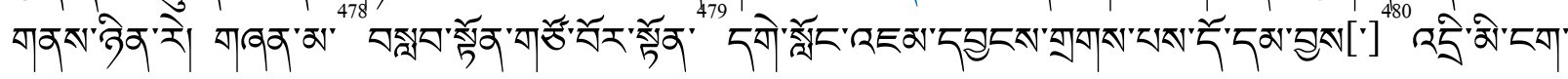

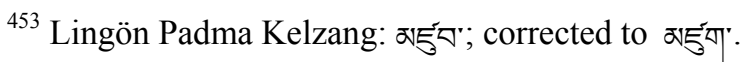

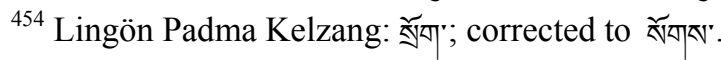

${ }^{455}$ Lingön Padma Kelzang places this phrase later in this line.

${ }^{456}$ Lingön Padma Kelzang: $ه$ "; corrected to 죽"

${ }^{457}$ Lingön Padma Kelzang: 5 स'

${ }^{458}$ Dobis Tsering Gyal: Ђন".

${ }^{459}$ Lingön Padma Kelzang: 号; corrected to

${ }^{460}$ Lingön Padma Kelzang: $55^{\prime}$; corrected to 55 ;

${ }^{461}$ See note 455.

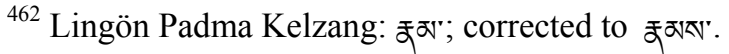

${ }^{463}$ Lingön Padma Kelzang: omitted.

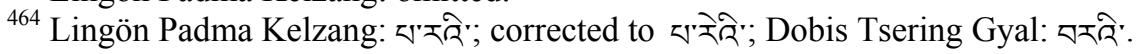

${ }^{465}$ Lingön Padma Kelzang: वेग"; corrected to गाखेग".

${ }^{466}$ Lingön Padma Kelzang: गोरे"; corrected to बों"

${ }^{467}$ Lingön Padma Kelzang: ईेग"; corrected to बेगा".

${ }^{468}$ Lingön Padma Kelzang: | ; corrected to :

${ }^{469}$ Lingön Padma Kelzang: ్ㅓㅈㅟ; corrected to ్ㅐㄷ.

${ }^{470}$ Dobis Tsering Gyal: गार.

${ }^{471}$ Dobis Tsering Gyal: 낌.

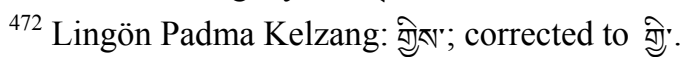

${ }^{473}$ Lingön Padma Kelzang: रेख'; corrected to रेद'.

${ }^{474}$ Dobis Tsering Gyal adds a $55^{*}$ here.

${ }^{475}$ Lingön Padma Kelzang adds a $\left\ulcorner^{\circ}\right.$ here.

${ }^{476}$ Lingön Padma Kelzang: ग़्रेN; corrected to ग्रें.

${ }^{477}$ Dobis Tsering Gyal: অईेवे.

${ }^{478}$ Lingön Padma Kelzang: 나; corrected to ${ }^{2}$ '.
} 


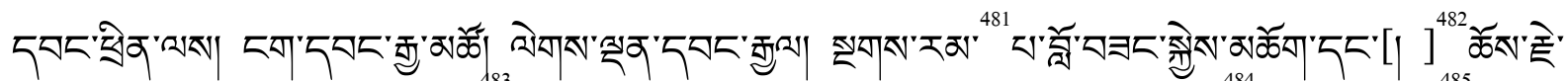

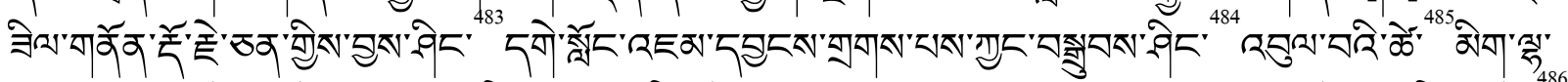

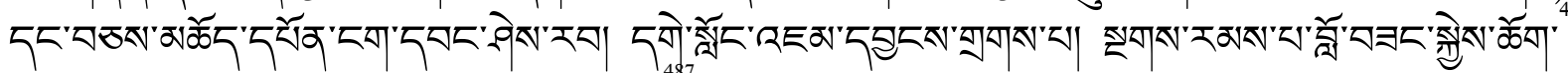

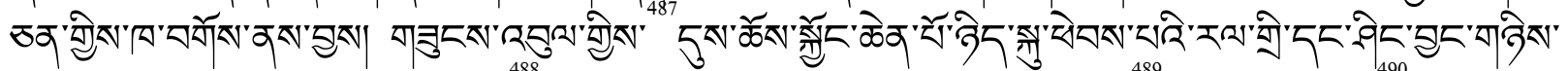

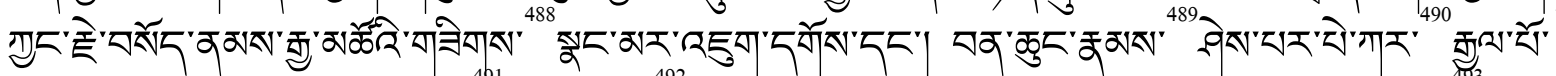

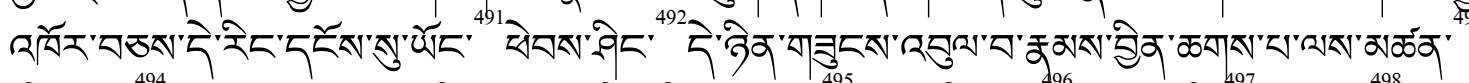

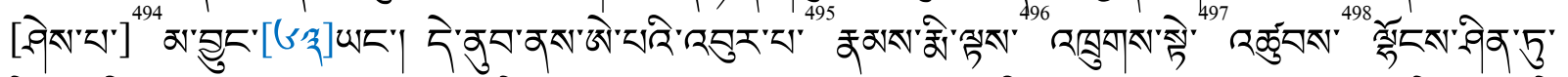

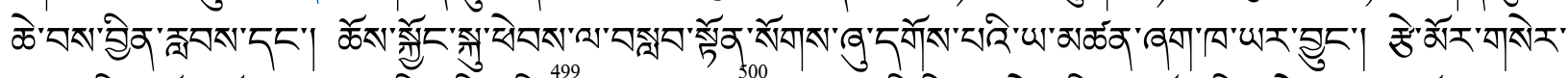

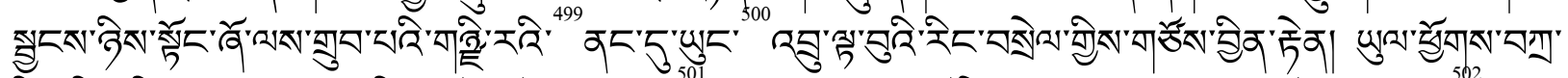

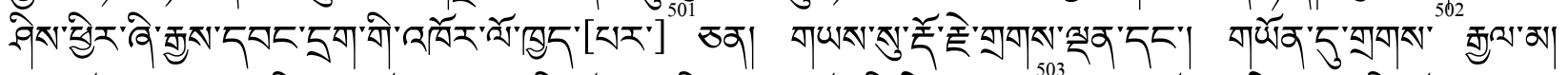

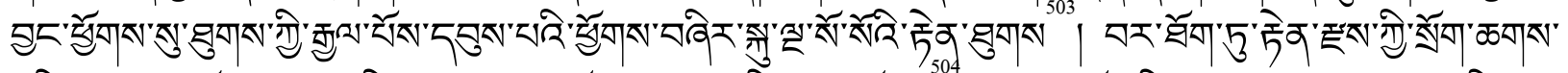

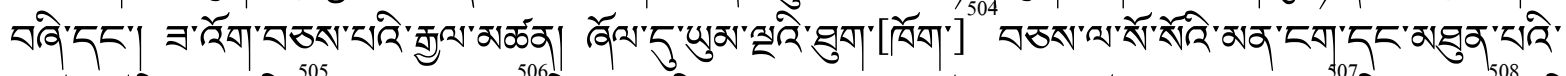

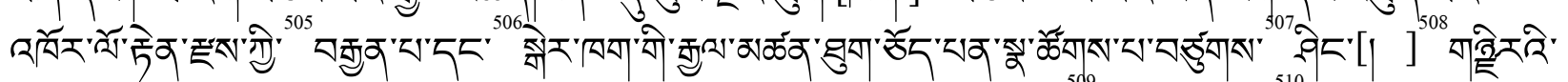

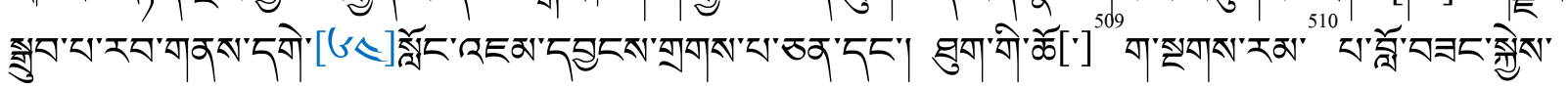

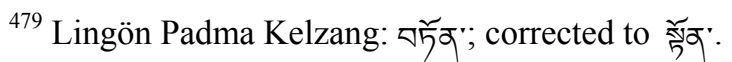

${ }^{480}$ Lingön Padma Kelzang:| ; corrected to :

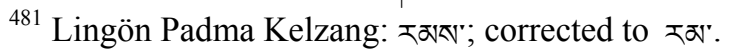

${ }^{482}$ Lingön Padma Kelzang: omitted.

${ }^{483}$ Lingön Padma Kelzang adds | here.

${ }^{484}$ Lingön Padma Kelzang: | ; corrected to शेद:

${ }^{485}$ Dobis Tsering Gyal: ळ5.

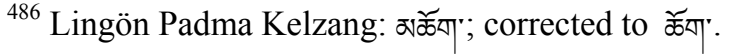

${ }^{487}$ Lingön Padma Kelzang: D্ৰे; corrected to ग्रेसे.

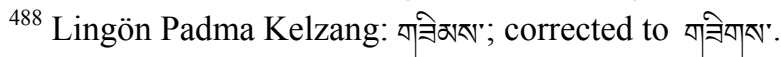

${ }^{489}$ Lingön Padma Kelzang adds ग्रेत्र here.

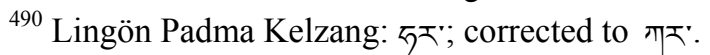

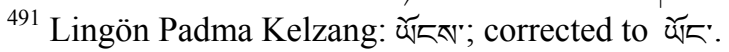

${ }^{492}$ Lingön Padma Kelzang adds here.

${ }^{493}$ Lingön Padma Kelzang adds ж' here.

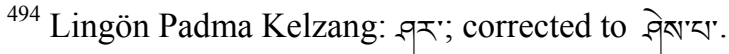

${ }^{495}$ Lingön Padma Kelzang: $₫$; corrected to

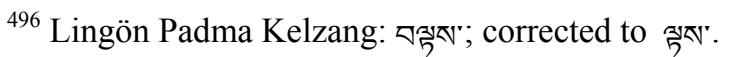

${ }^{497}$ Lingön Padma Kelzang: দे;; corrected to 今్ Эें.

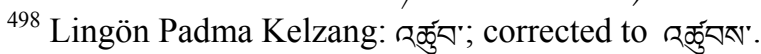

${ }^{499}$ Lingön Padma Kelzang: ×“; corrected to ररें.

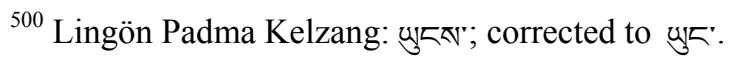

${ }^{501}$ Lingön Padma Kelzang: omitted.

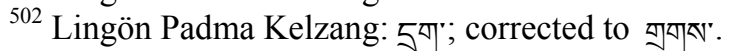

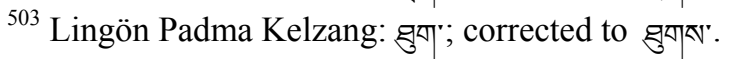

${ }^{504}$ Lingön Padma Kelzang: omitted.
} 


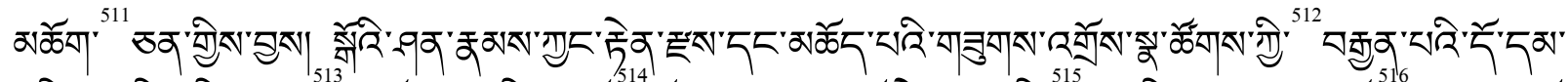

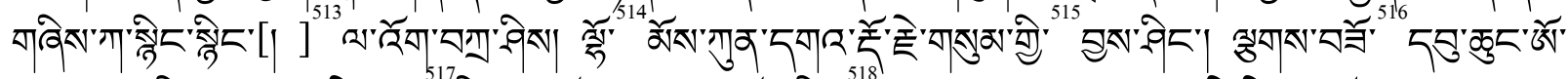

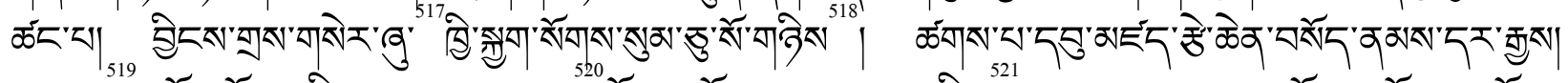

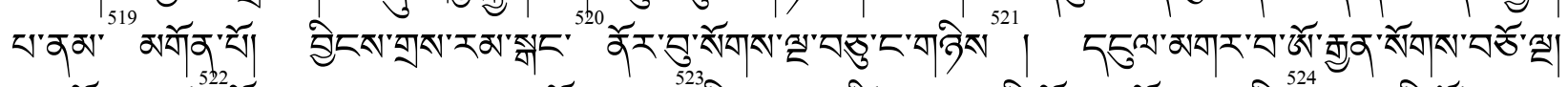

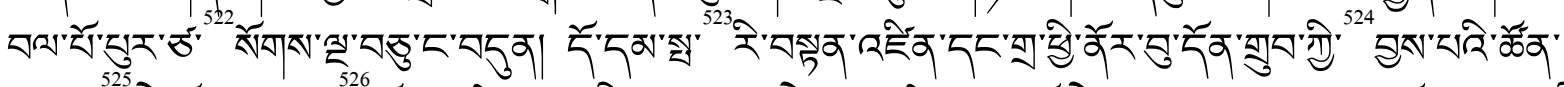

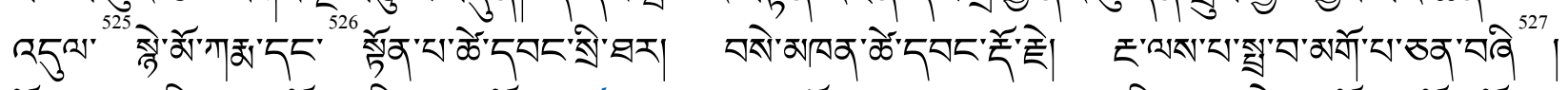

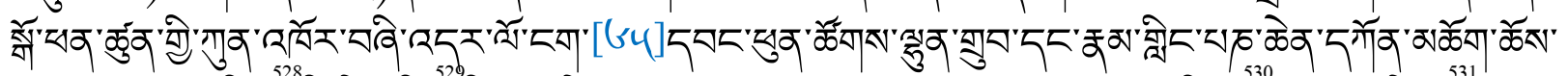

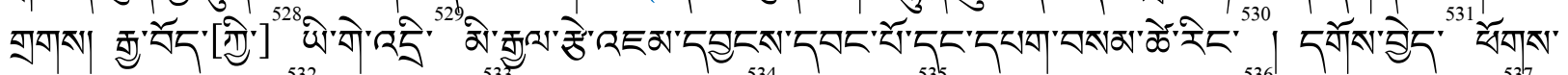

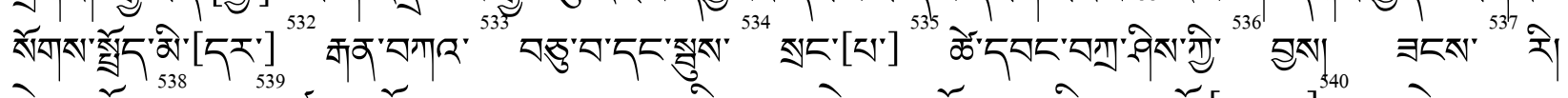

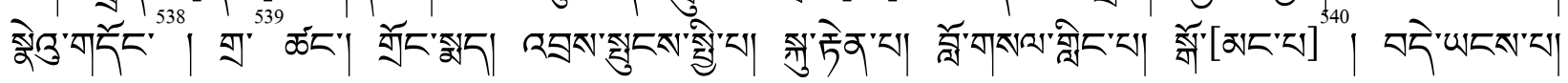

\footnotetext{
${ }^{505}$ Lingön Padma Kelzang: ग़्रे'; corrected to गें.

${ }^{506}$ Lingön Padma Kelzang adds | here.

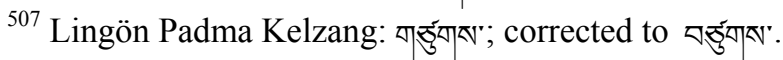

${ }^{508}$ Lingön Padma Kelzang: omitted.

${ }^{509}$ Lingön Padma Kelzang: omitted.

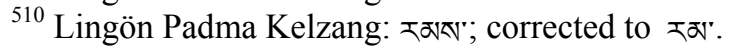

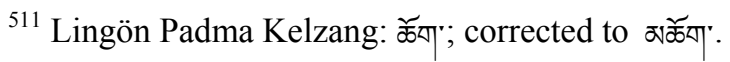

${ }^{512}$ Lingön Padma Kelzang: ग्रोस"; corrected to गें.

${ }^{513}$ Lingön Padma Kelzang: 5 ₹; corrected to 1 .

${ }^{514}$ Lingön Padma Kelzang: 羿; corrected to 套.

${ }^{515}$ Lingön Padma Kelzang: D্তুর্'; corrected to ब्रें.

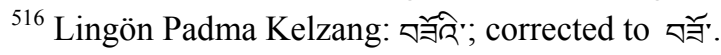

${ }^{517}$ Lingön Padma Kelzang: \बु;; corrected to gु.

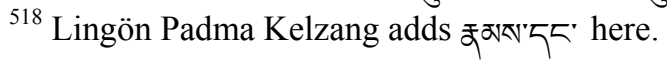

${ }^{519}$ Lingön Padma Kelzang: ₹邓"; corrected to व邓".

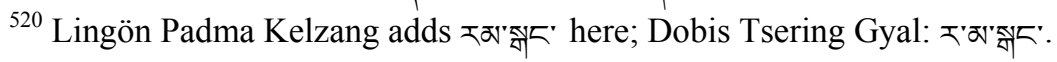

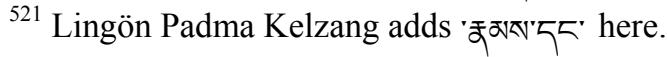

${ }^{522}$ Lingön Padma Kelzang: ळ゙; corrected to §ॅ.

${ }^{523}$ Lingön Padma Kelzang: 직; corrected to 줙'

${ }^{524}$ Lingön Padma Kelzang: ग्रेत;; corrected to ग्रें.

${ }^{525}$ Lingön Padma Kelzang adds $\square$ here.

${ }^{526}$ Lingön Padma Kelzang adds | here.

${ }^{527}$ Lingön Padma Kelzang adds ' 55 ' here.

${ }^{528}$ Lingön Padma Kelzang: omitted.

${ }^{529}$ Lingön Padma Kelzang: Rबें; corrected to २६े.

${ }^{530}$ Lingön Padma Kelzang adds गोस'ডुस here.

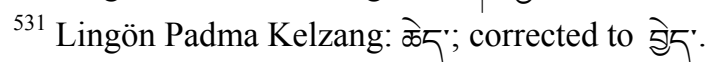

${ }_{532}^{532}$ Lingön Padma Kelzang: omitted.

${ }^{533}$ Lingön Padma Kelzang: 5 गाR'; corrected to $\square \pi / R$.

${ }^{534}$ Lingön Padma Kelzang: 젖ㅊ; corrected to 젖ㅊ.

${ }^{535}$ Lingön Padma Kelzang: omitted.
} 


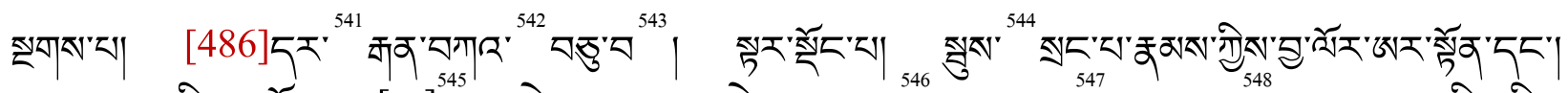

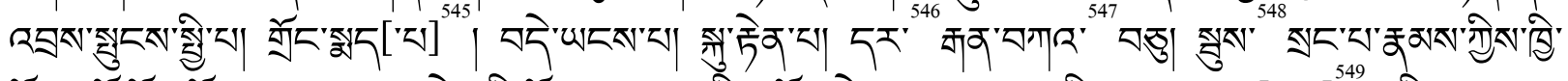

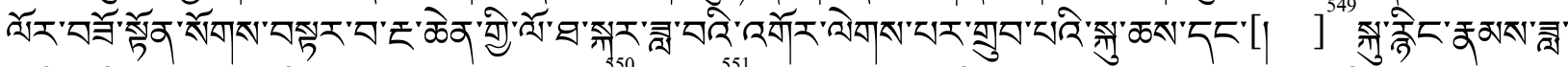

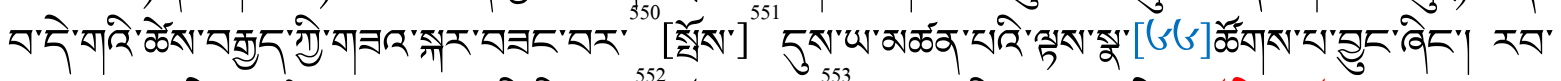

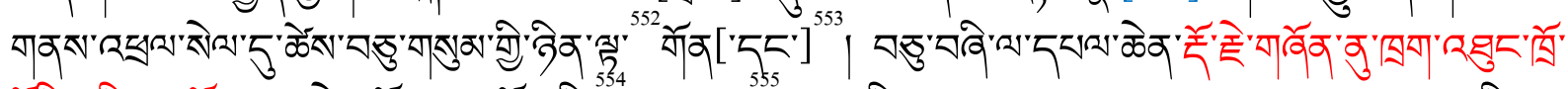

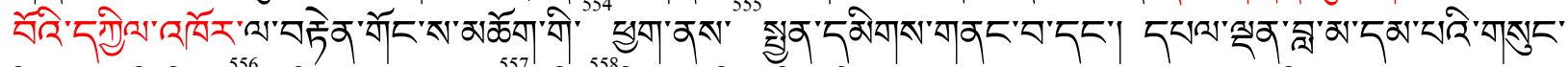

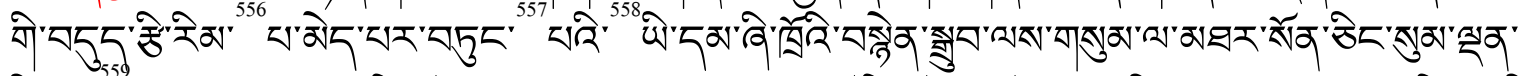

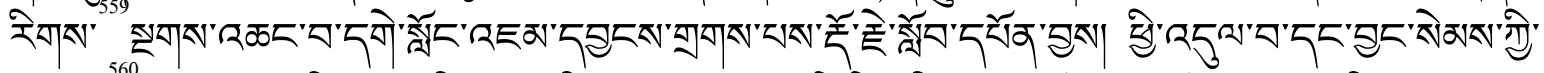

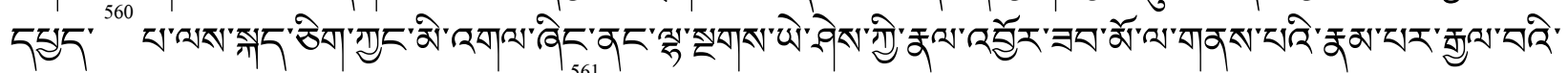

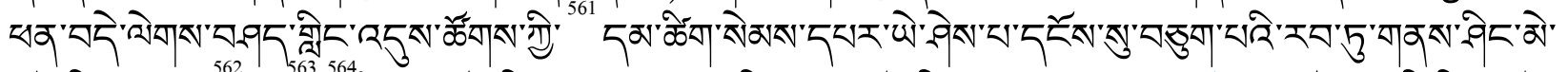

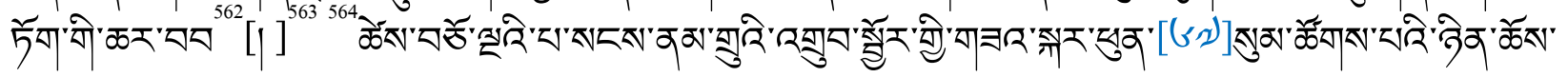

${ }^{536}$ Lingön Padma Kelzang: ग्रेस"; corrected to ग्रें.

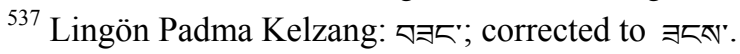

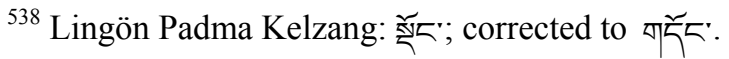

${ }^{539}$ Lingön Padma Kelzang: ㅈyㄱ; corrected to 귀'·

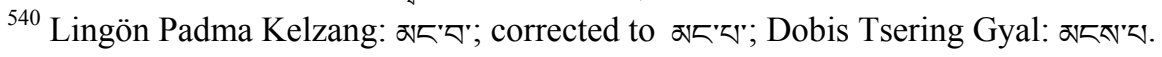

${ }^{541}$ Lingön Padma Kelzang: 5 ; corrected to $5{ }^{\mathbf{2}}$.

${ }^{542}$ Lingön Padma Kelzang: $5^{\pi} \mid \Omega^{\prime}$; corrected to $\square \pi / 2$.

${ }^{543}$ Lingön Padma Kelzang: $\downarrow$ '; corrected to $\varangle$ '.

${ }^{544}$ Lingön Padma Kelzang: 젖주; corrected to 정자.

${ }^{545}$ Lingön Padma Kelzang: omitted.

${ }^{546}$ Lingön Padma Kelzang: 5 ; corrected to $5{ }^{\mp}$.

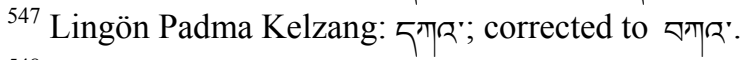

${ }^{548}$ Lingön Padma Kelzang: 젖주; corrected to 정ㅊ‥

${ }^{549}$ Lingön Padma Kelzang: omitted.

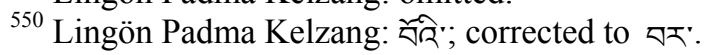

${ }^{551}$ Lingön Padma Kelzang: omitted.

${ }^{552}$ Lingön Padma Kelzang: $\frac{\mathrm{y}}{5}$; corrected to

${ }_{553}^{55}$ Lingön Padma Kelzang: omitted.

${ }^{554}$ Lingön Padma Kelzang: गोरे'; corrected to बों'.

${ }^{555}$ Lingön Padma Kelzang adds $55^{\circ}$ here.

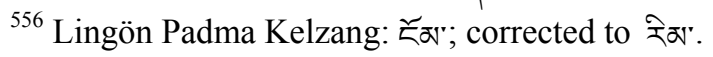

${ }^{557}$ Dobis Tsering Gyal: Ђদुॅస'.

${ }^{558}$ Lingön Padma Kelzang: इरें; corrected to इरेें.

${ }^{559}$ Lingön Padma Kelzang: रेग|; corrected to रेग|स".

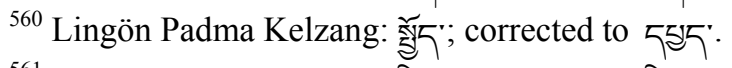

${ }^{561}$ Lingön Padma Kelzang: ग्रोस्र"; corrected to ग्रें.

${ }^{562}$ Lingön Padma Kelzang: \\ন;; corrected to $\square$.

${ }^{563}$ Lingön Padma Kelzang: omitted.

${ }^{564}$ Based on the manuscript edition of Sangyé Gyatso's portion of the Nechung Register, Lingön Padma Kelzang and Dobis Tsering Gyal both include at this point the following lengthy addition in their transcriptions: 


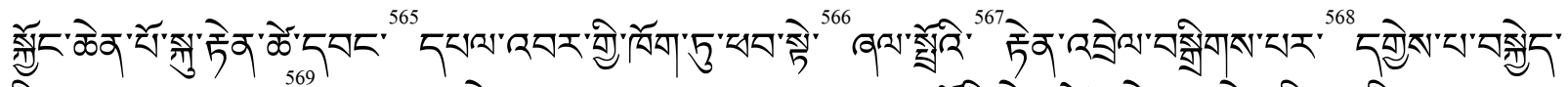

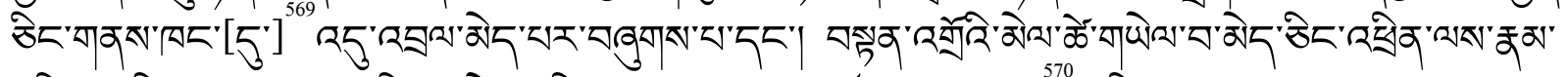

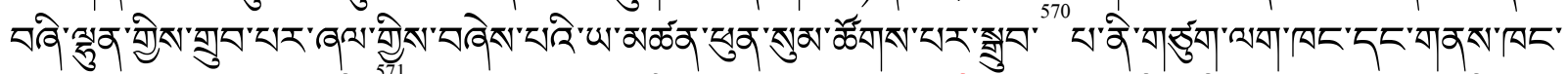

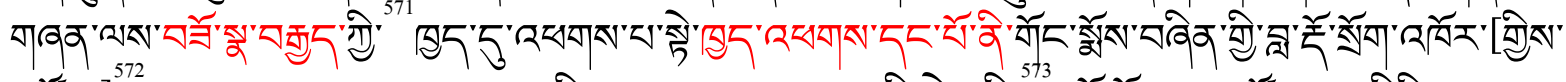

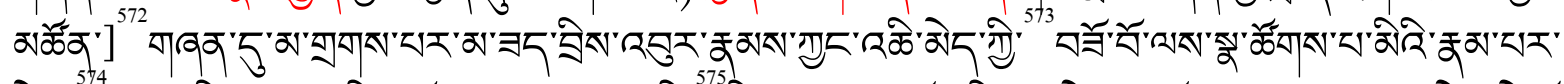

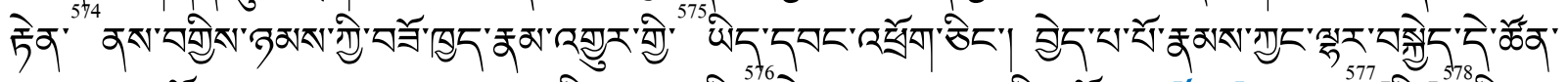

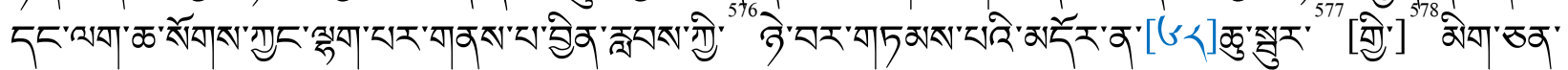

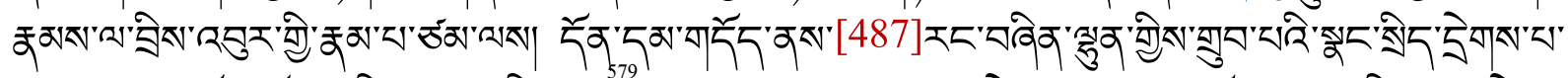

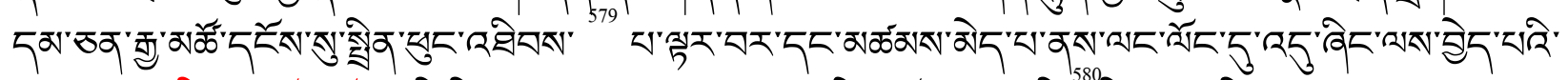
क्र5

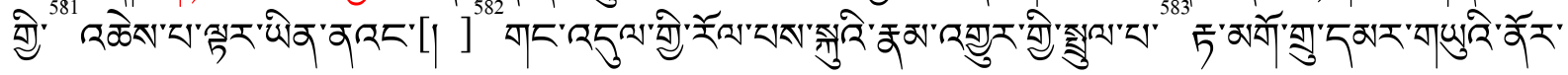

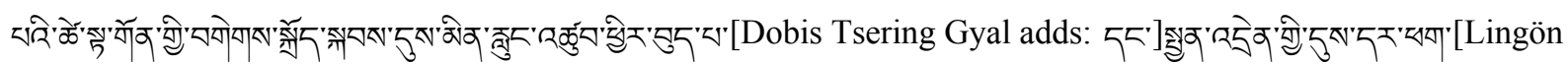

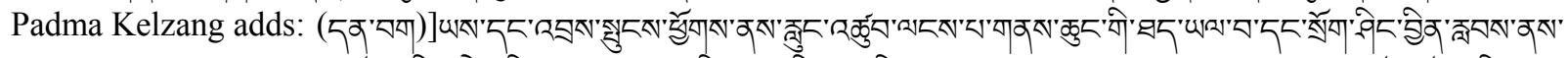

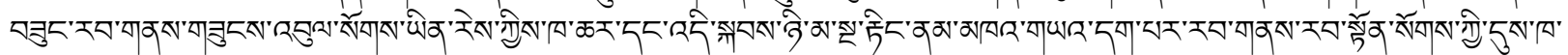

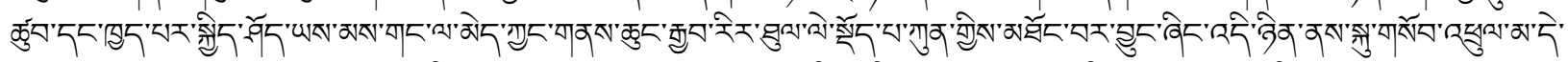

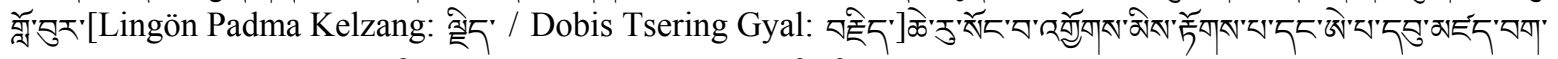

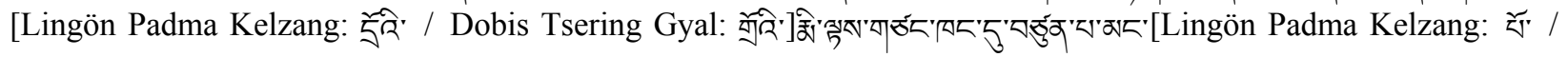

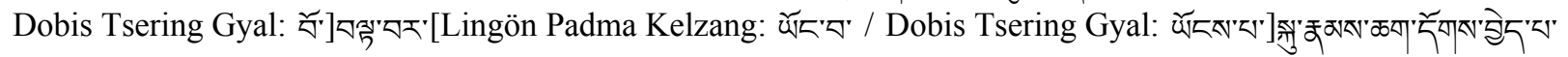

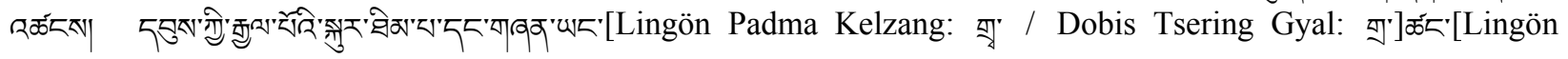

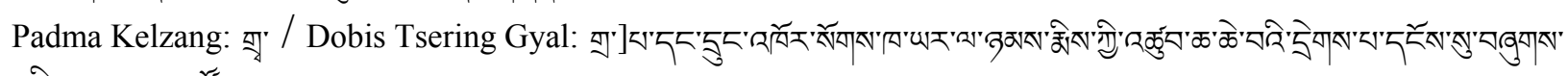

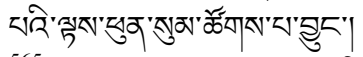

${ }^{565}$ Dobis Tsering Gyal: शे 5 .

${ }^{566}$ Dobis Tsering Gyal: 亏े.

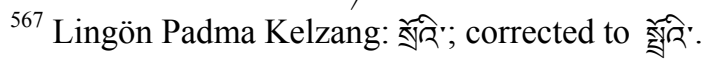

${ }^{568}$ Lingön Padma Kelzang: 자; corrected to 다․

${ }^{569}$ Lingön Padma Kelzang: omitted.

${ }^{570}$ Lingön Padma Kelzang: 젖'; corrected to 적'.

${ }^{571}$ Lingön Padma Kelzang: ग़ेर'; corrected to गें:

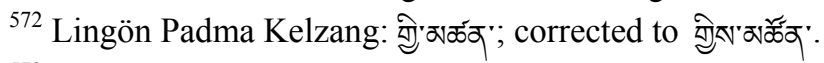

${ }^{573}$ Lingön Padma Kelzang: ब्रें; corrected to ग्रें.

${ }^{574}$ Lingön Padma Kelzang: অर्गुव'; corrected to 亏ेवे.

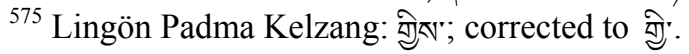

${ }^{576}$ Lingön Padma Kelzang: ग्रेस; ; corrected to ग्रें.

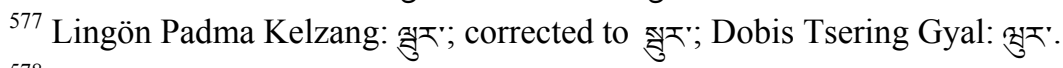

${ }^{578}$ Dobis Tsering Gyal: omitted.

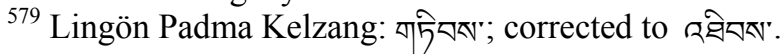

${ }^{580}$ Lingön Padma Kelzang: ग्रेस'; corrected to गें'.

${ }^{581}$ Lingön Padma Kelzang: ग्रेसे; corrected to ब్రें.

${ }^{582}$ Lingön Padma Kelzang: omitted.

${ }^{583}$ Lingön Padma Kelzang: $₫$;" corrected to $\longleftarrow$ ‘'. 


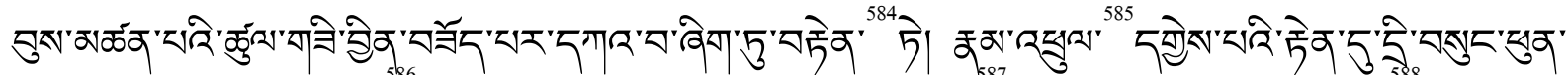

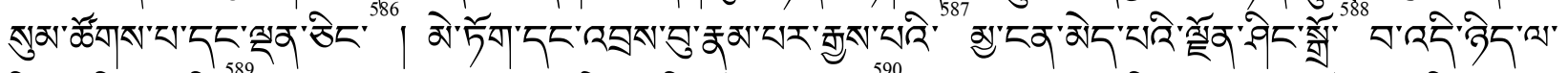

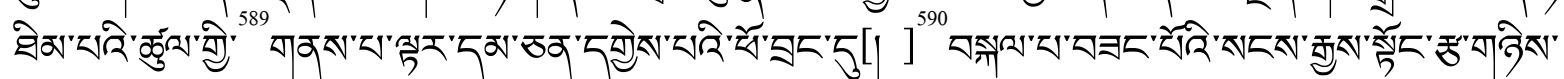

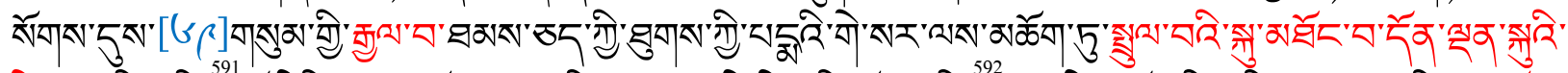

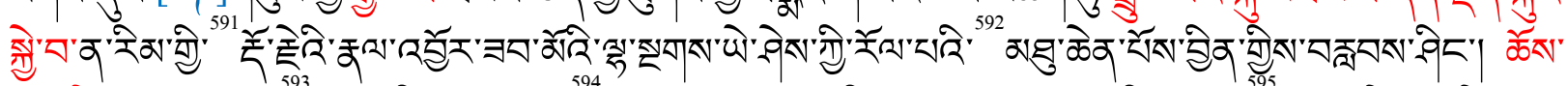

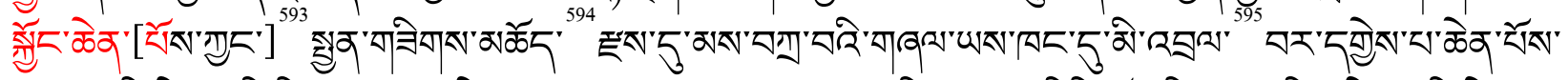

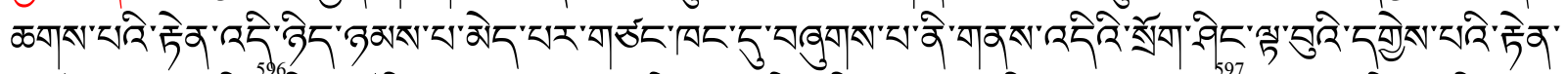

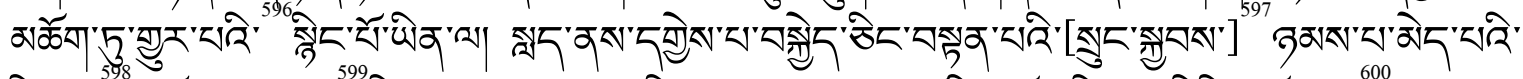

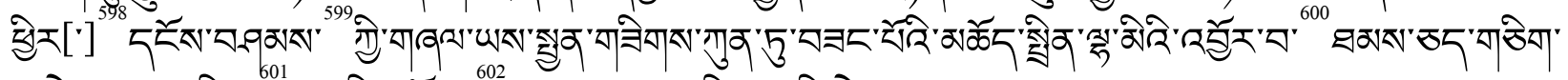

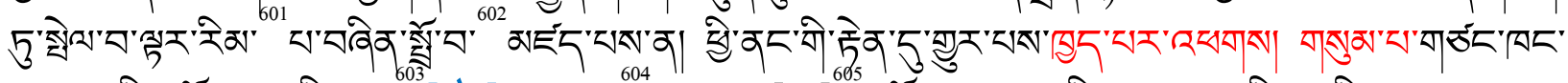

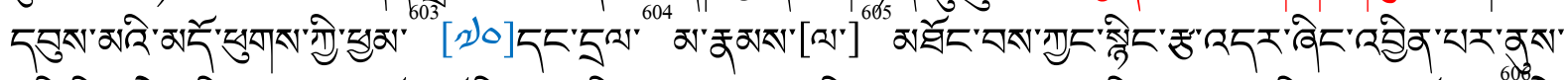

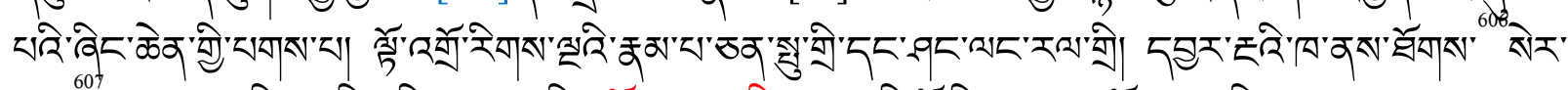

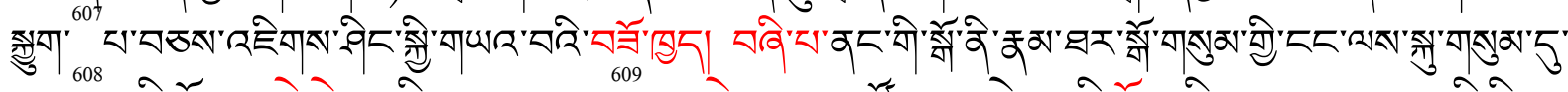

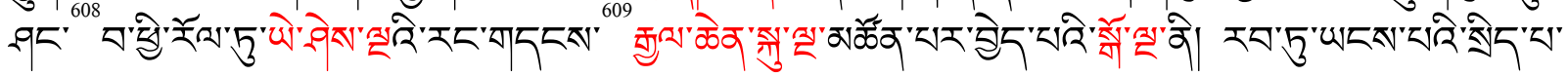

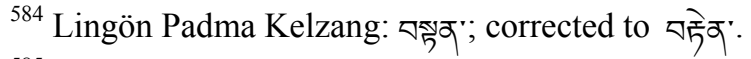

${ }^{585}$ Dobis Tsering Gyal: 적ㄹ.

${ }^{586}$ Lingön Padma Kelzang: बेद; corrected to ठे६'.

${ }^{587}$ Lingön Padma Kelzang: ㄱ; corrected to चरें.

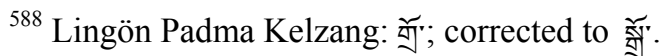

${ }^{589}$ Lingön Padma Kelzang: D্তুর্'; corrected to ब्रें.

${ }^{590}$ Lingön Padma Kelzang: '; corrected to 1 .

${ }^{591}$ Lingön Padma Kelzang: ब্ৰুస'; corrected to ब्रें.

${ }^{592}$ Dobis Tsering Gyal: অरें.

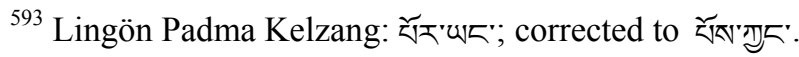

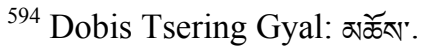

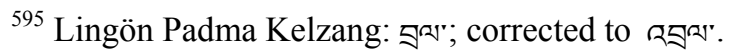

${ }^{596}$ Lingön Padma Kelzang: \रे"; corrected to चरें.

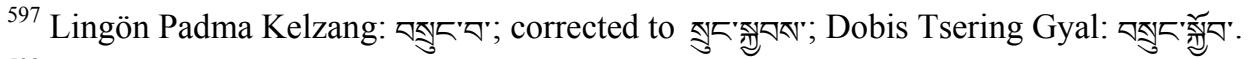

${ }^{598}$ Lingön Padma Kelzang: | ; corrected to :

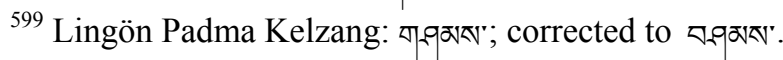

${ }^{600}$ Lingön Padma Kelzang: $\downarrow$;; corrected to $\square$.

${ }^{601}$ Lingön Padma Kelzang: 5a'; corrected to रेखా.

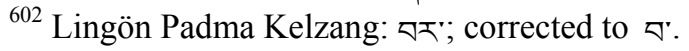

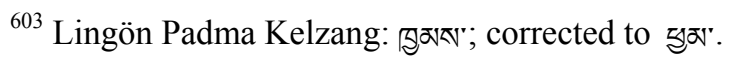

${ }^{604}$ Lingön Padma Kelzang: 5 ; corrected to $5{ }^{2}$.

${ }^{605}$ Lingön Padma Kelzang: omitted.

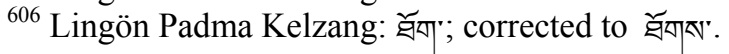

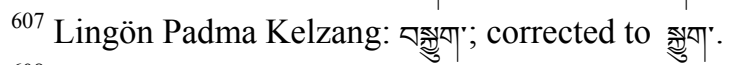

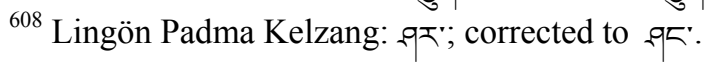




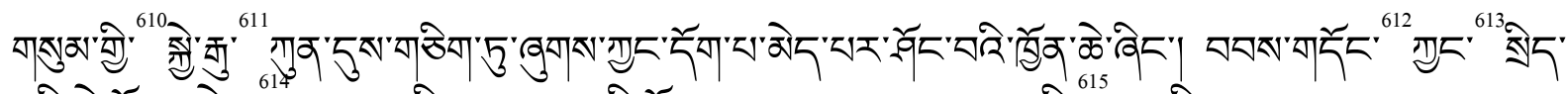

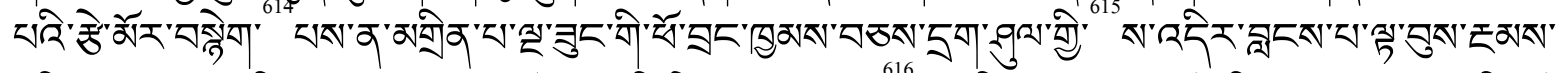

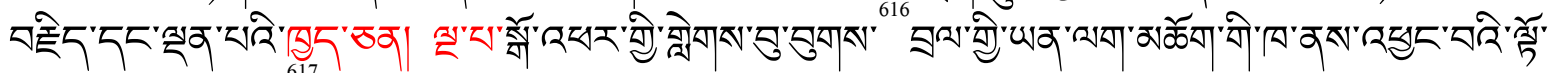

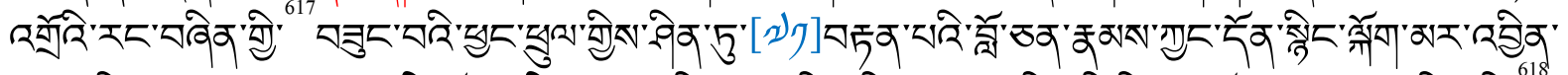

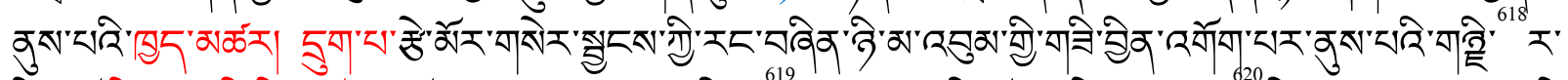

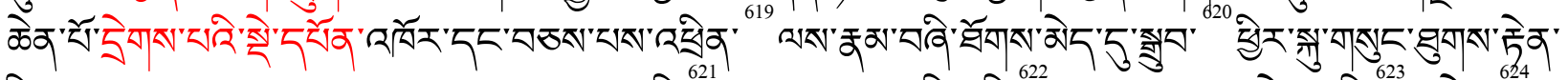

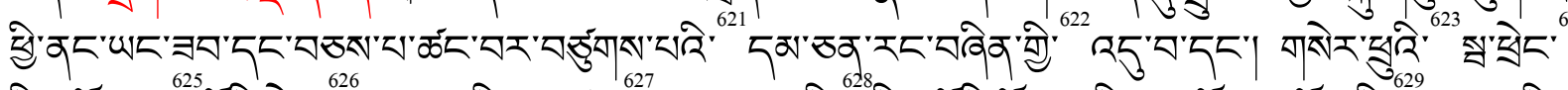

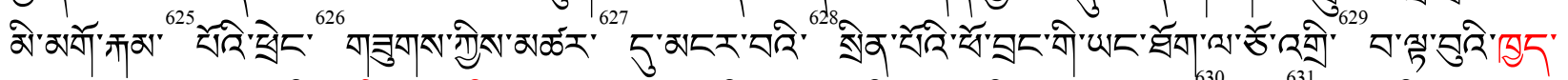

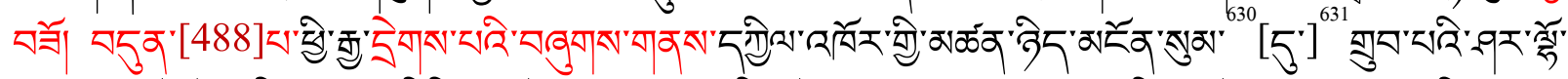

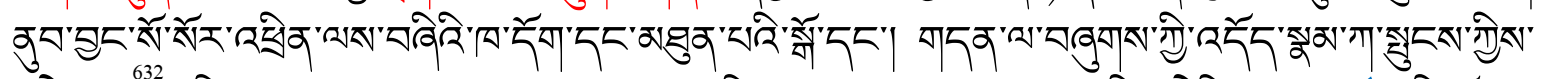

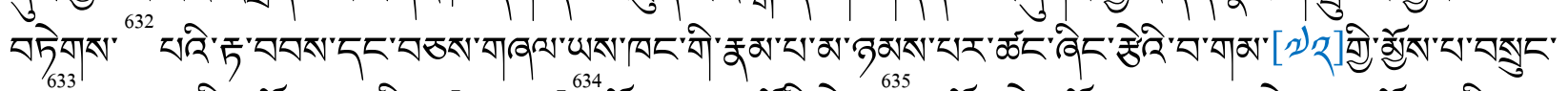

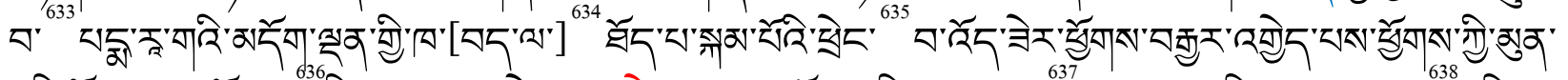

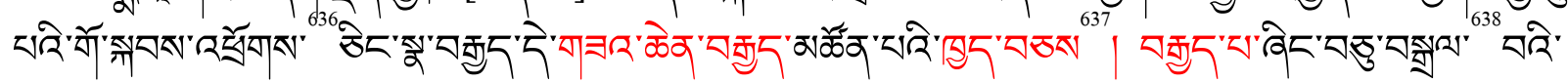

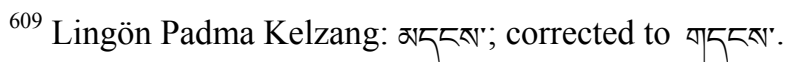

${ }^{610}$ Lingön Padma Kelzang: ब्रेस्र"; corrected to ब्रें.

${ }^{611}$ Lingön Padma Kelzang: \खु;; corrected to 牙.

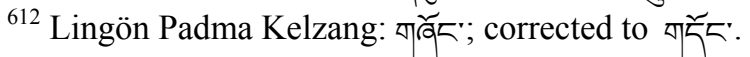

${ }^{613}$ Dobis Tsering Gyal: ur

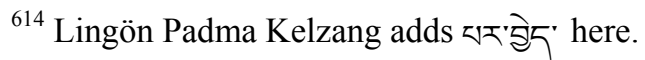

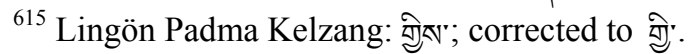

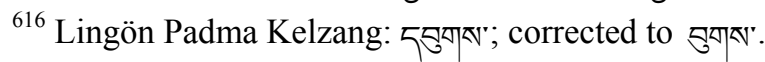

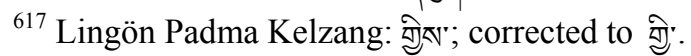

${ }^{618}$ Lingön Padma Kelzang: यात्के; corrected to गात्तें.

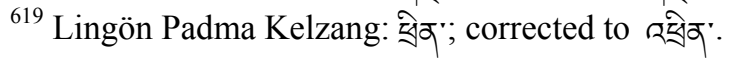

${ }^{620}$ Lingön Padma Kelzang: \정ㅁ; corrected to 적

${ }^{621}$ Lingön Padma Kelzang: 저'; corrected to चरें.

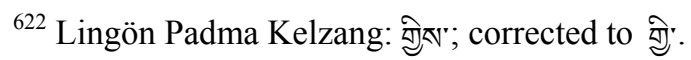

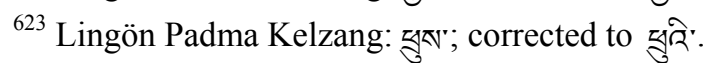

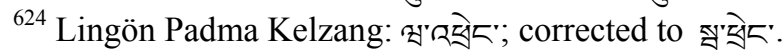

${ }^{625}$ Lingön Padma Kelzang: 쥬

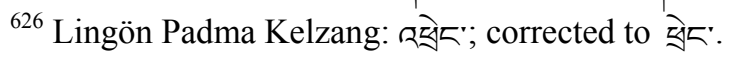

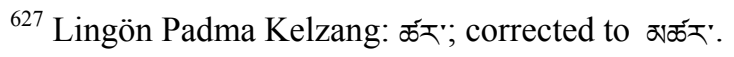

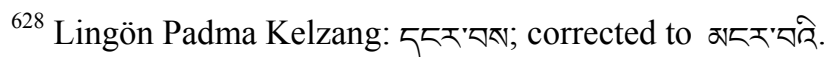

${ }^{629}$ Lingön Padma Kelzang: २亏े; corrected to २ब्रें.

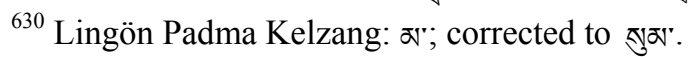

${ }^{631}$ Lingön Padma Kelzang: omitted.

${ }^{632}$ Dobis Tsering Gyal: অদিশা"

${ }^{633}$ Lingön Padma Kelzang: $\llbracket ;$; corrected to $\square$ '.

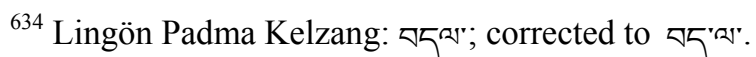

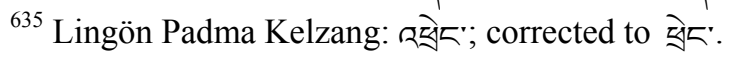




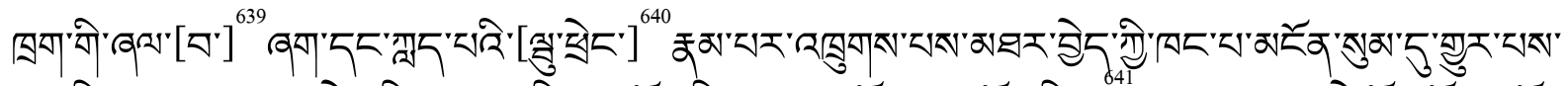

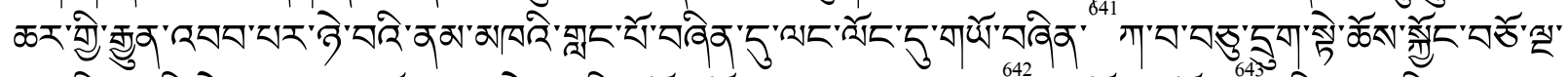

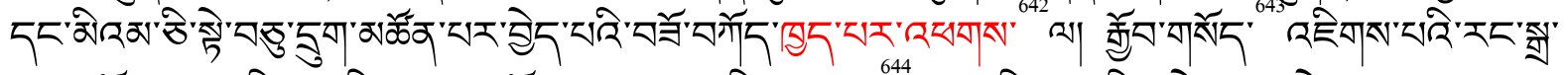

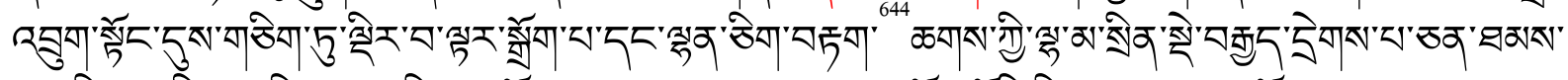

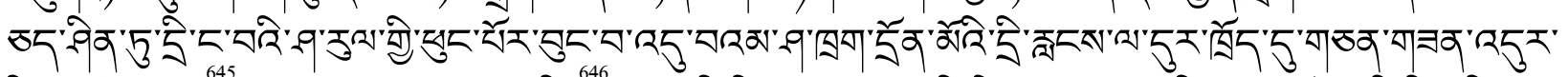

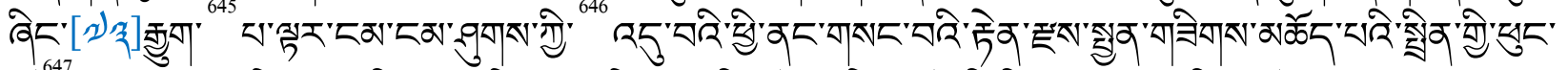

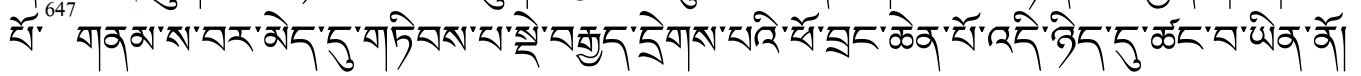

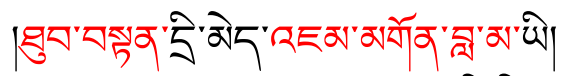

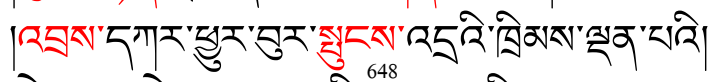

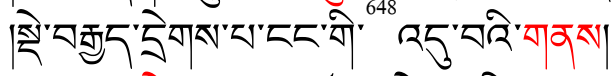

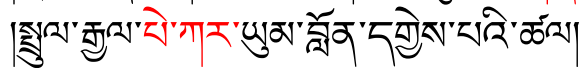

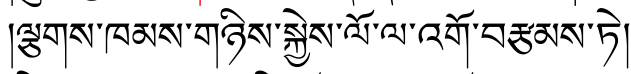

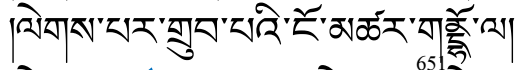

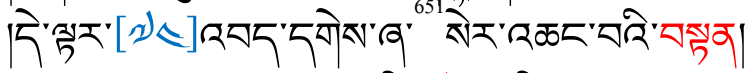

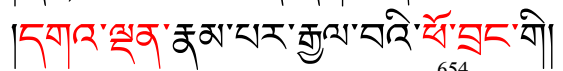

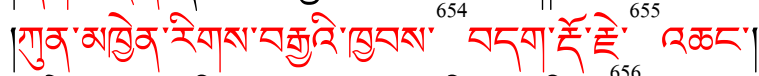

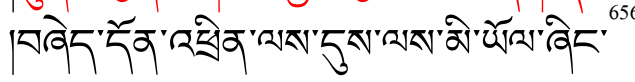

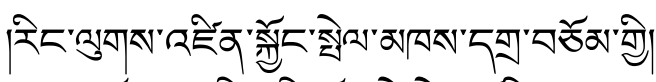

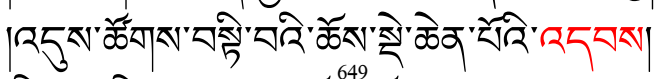

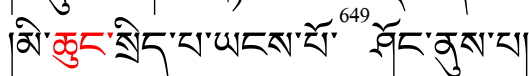

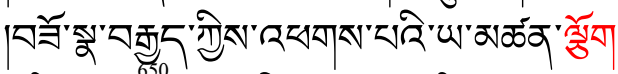

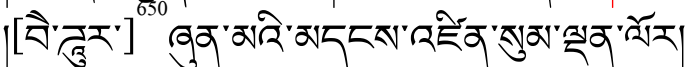

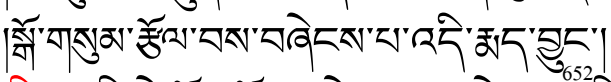

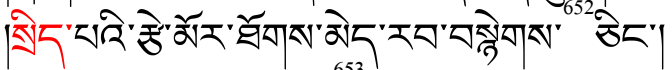

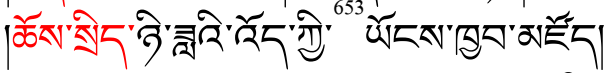

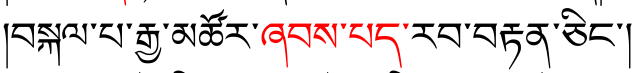

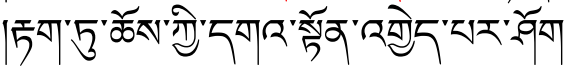

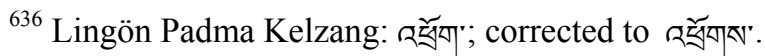

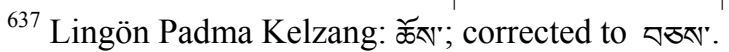

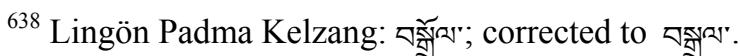

${ }^{639}$ Lingön Padma Kelzang: omitted.

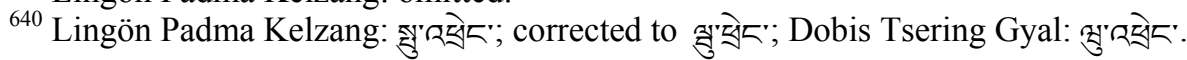

${ }^{641}$ Lingön Padma Kelzang: बेट; corrected to వबेव:

${ }^{642}$ Lingön Padma Kelzang adds $\longleftarrow$ here.

${ }^{643}$ Dobis Tsering Gyal: শার্থু'.

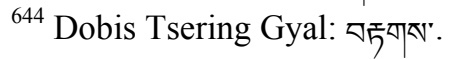

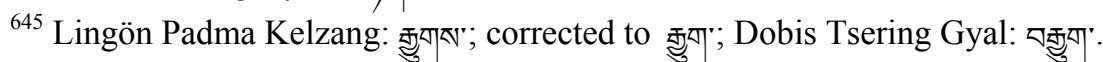

${ }^{646}$ Lingön Padma Kelzang: ग्रेस"; corrected to ग्रें.

${ }^{647}$ Dobis Tsering Gyal: خ̌ॅ'.

${ }^{648}$ Lingön Padma Kelzang: बोसे; corrected to बों.

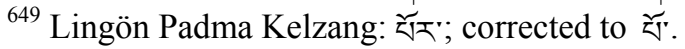

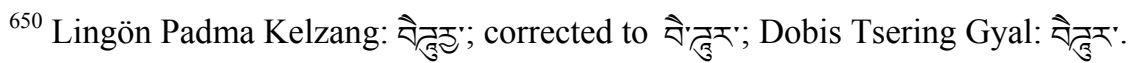

${ }^{651}$ Lingön Padma Kelzang: ğ; corrected to $\propto$ '.

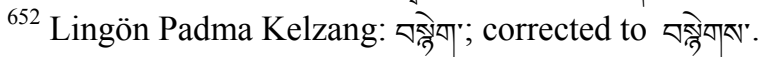

${ }^{653}$ Lingön Padma Kelzang: ग्रेस;; corrected to गेे.

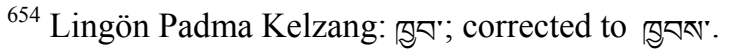

${ }^{655}$ Dobis Tsering Gyal: 솟.े.

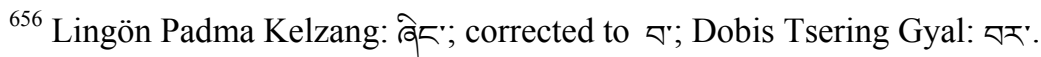



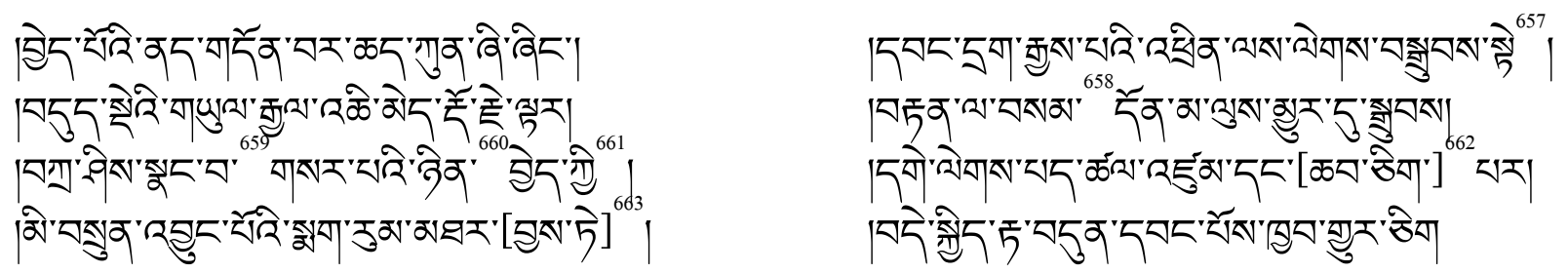

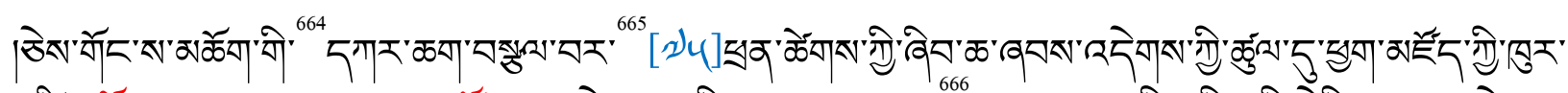

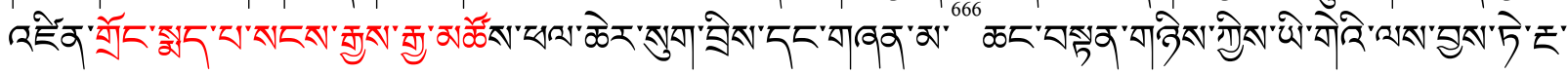

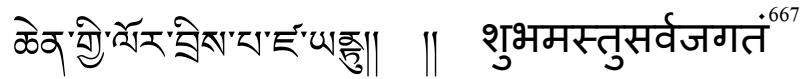

${ }^{657}$ Lingön Padma Kelzang: দ̆; corrected to 令.

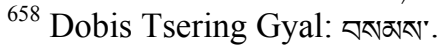

${ }^{659}$ Dobis Tsering Gyal: ${ }^{2}$.

${ }^{660}$ Lingön Padma Kelzang: శ్;; corrected to శ్వావ

${ }^{661}$ Lingön Padma Kelzang: ग्रेN"; corrected to ग्रें:

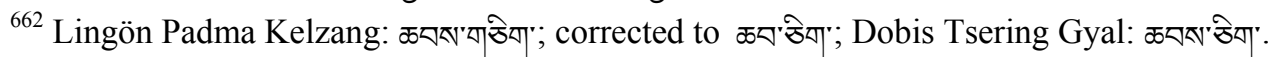

${ }^{663}$ Dobis Tsering Gyal: ذ్

${ }^{664}$ Lingön Padma Kelzang: गोर्श; corrected to पों.

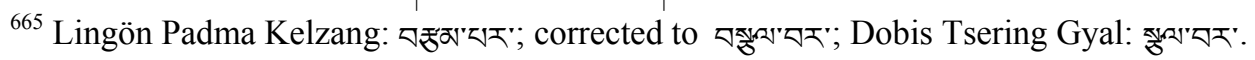

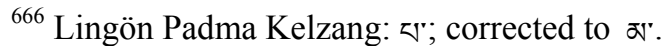

${ }^{667}$ This final Sanskrit prayer is presented in Rañjanā script, or perhaps the Vartu script. Transliterated, it is as

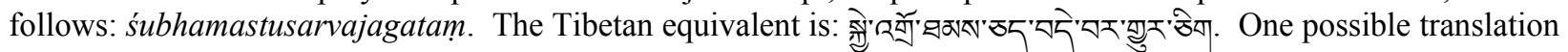
is, "May all living beings prosper!" I am grateful to Daisy Cheung for her assistance in deciphering the faded and difficult letters of this concluding phrase; personal communication, December 27, 2012. 


\section{[470] [A Copy of the Register on the Southern Side of Nechung Monastery's Courtyard}

\section{The Nechung Register composed by the Great Fifth Dalai Lama ${ }^{668}$ ]}

${ }^{669}$ (1) To the indivisible three bodies - the immutable Dharma body [of] primordial great bliss, which appears undifferentiated, limitless, and all-pervading; $\mathrm{XX}^{670}$ the perfect enjoyment body, Mighty Hayagrivva, [who possesses] more than a thousand lotuses XXXXX; and the lord who, [from among] the five families, bears the white lotus, ${ }^{671}$ and who auspiciously multiplies the play of emanation bodies that are exceedingly difficult to calculate-when [I] pay homage by [placing] the crown of my head at the dust of [their] feet, [may they] bestow [on me] the great blessings [of] ordinary and extraordinary accomplishments! ${ }^{672}$

(2) The Vajra-holding all-pervading lord Tötreng Tsel emanates XXXXXXXXXXXXXX as one, amid five-colored rainbows and countless peaceful and wrathful deities, selfproduced from within the condition of luminous emptiness and [inseparable] space and awareness. I entreat [him] to come once again to aid Tibet and act [as] our most supreme kinsman for the benefit and well-being of the [Buddha's] teachings and [sentient] beings!

Lord Dharma master ${ }^{673}$ - the powerful essence of your knowledge and kindness, the magical net [of] the three families - conquered the darkness [of] wrong views in this realm and endowed it with virtuousness, pervading [everywhere like] a roaring [wind]. (3) Tsongkhapa-omnipresent ${ }^{674}$ Vajradhara, ${ }^{675}$ Dharma king of the three

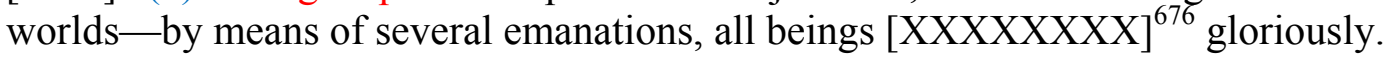

In order to accomplish each and every pacifying, augmenting, subjugating, and destructive activity, like a luminous five-colored rainbow in the expanse of the sky, the Five Dharma Kings ${ }^{677}$ — who emanate [as] body, speech, mind, good

\footnotetext{
${ }^{668}$ Lingön Padma Kelzang: The numbers given below indicate the lines of the original text, and the X marks represent unclear syllables.

${ }^{669}$ The wall inscription itself begins at this line, since it lacks a title, which has otherwise been given to it here.

${ }^{670}$ Lingön Padma Kelzang adds a parenthetical note here: (about one line of verse is unclear here); however, judging from the original inscription, it appears that only half a line or less is obscured.

${ }^{671}$ Tib. pad dkar rigs lnga 'chang ba'i gtso. The rigs lnga here seems misplaced; otherwise this is clearly referring to Padmapāni (Tib. Pad dkar 'chang), a form of Avalokiteśvara.

${ }^{672}$ While a number of the words that make up this poem are missing because of damage to the original inscription, enough has been salvaged that the overall meaning is clear. This is a prayer to the three bodies (Tib. sku gsum; Skt. trikāya), particularly of the Lotus Family (Tib. pad ma rigs; Skt. padmakula), that they might bestow accomplishments (Tib. dngos grub; Skt. siddhi) on the speaker.

${ }^{673}$ Tib. chos dbon rje. It is unclear who this refers to, especially in relation to the "your" mentioned below. I speculate that it is an abbreviated reference to chos rgyal mes dbon rnam gsum, the three Tibetan Dharma Kings, used to fit the meter. If this is the case, it likely refers to King Trisong Deutsen specifically, making the "your" below reference Padmasambhava, who was the subject of the previous stanza.

${ }^{674}$ Tib. kun lus; read as kun las.

${ }^{675}$ Tib. kha sbyor bdun ldan; lit. "endowed with the seven attributes of union." This is an epithet for Vajradhara.

${ }^{676}$ Instead of X's, Lingön Padma Kelzang adds the following parenthetical note here: (eight syllables are unclear here).

${ }^{677}$ Tib. Chos rgyal sku lnga.
} 
qualities, and activities - auspiciously appear, and produce through emanation a powerful army of brigadiers, servants, and an ocean of oath-bound protectors.

Tsokyé Dorjé invested the lord of all leaders ${ }^{678}$ with power, placed a vajra [on his head], (4) thoroughly gave him immortal amrta to drink, and completely proclaimed his awesome samaya vow. [May he] not forget the oath that was entrusted to him, and [may he] increase the wellbeing of the [Buddha's] teachings and [all] beings in Tibet!

Here and now, remember how you were placed into the great mandala of the root and lineage lamas-such as XXXXX-kyi Wangchuk ${ }^{679}$ - as a servant by [the vajra placed on] your head; ${ }^{60}$ reflect on your promise to accomplish all activities without obstruction.

[When] the communities under Gendün Gyatso, the embodiment of all the Buddhas, and Sönam Gyatso, ${ }^{681}$ the crown ornament respected by all ${ }^{682}$ - [both of whom] generally and specifically represented the lineage of the Victorious Ones-relied on and prayed to [you, you acted as their] savior, guarding them in a timely fashion.

(5) By means of meditation, mantras, and mudrās, I offer in full a great palace that displays fearsome charnel grounds, completely filled with a constant [stream] of valuables, such as clouds of outer, inner, and secret offerings, as well as riches.

After beckoning [you] with the yoga of one-pointedness for a full day and night, ${ }^{683}$ we [stream] colored silks, sing songs and play instruments, build up dense clouds of smoke from burnt offerings, and thoroughly sprinkle the argham oblation. Once we have done this, come [fast] like lightening and sit on your [throne made of] a lotus, moon, and sun [disc]!

[471] The teachings, debates, and compositions of the disciplined community that bears and protects the precious teachings of the Buddha- the roots and branches of which [bring] happiness and

\footnotetext{
${ }^{678}$ Tib. sde dpon yongs kyi rje bo; given the context, this clearly refers to Pehar.

${ }^{679}$ Tib. XXXXX kyi dbang phyug. I speculate that the figure mentioned here is the treasure-revealer Guru Chökyi Wangchuk (Gu ru Chos kyi dbang phyug, 1212-1270; TBRC: P326). The rest of his name would fill in three of the five missing syllables, while the first two are likely gter ston (treasure-revealer) or another honorific title.

${ }^{680} \mathrm{Tib}$. gtsug nas bran du gtad. While the second part of this phrase is clear, the gtsug nas is not. I suspect that it concerns the gesture by which Pehar was pressed into servitude, which involved Padmasambhava placing his vajra on his head as a seal. I have interpolated the phrase as such.

${ }^{681}$ Bsod nams rgya mtsho, 1543-1588; TBRC: P999. This is the Third Dalai Lama.

${ }^{62}$ Tib. mang bkur gtsug rgyan.

${ }^{683}$ Tib. nyin mtshan dus drug; lit. "the six times of the day and night." This refers to how a 24-hour day was divided into six 4-hour parts in the ancient Indian system.
} 
benefit-overflow like a lake [in the] summer. Because of this, all the activities of those who are devout wax like the moon.

Regarding these [panegyrics], (6) from the [Door that] Leads to Scholarship: ${ }^{684}$

The holy masters who composed the commentaries ${ }^{685}$ wrote praises ${ }^{686}$ to the Buddha. ${ }^{687}$ Since they increased the teachings, they had correct and excellent insights into these pure words.

Accordingly, following after the excellent hagiographies of past [masters], I performed plentiful offerings and praises and understood their position. ${ }^{688}$ The reasons - which were not motivated by jealousy toward others-[are as follows]:

In the Praise Exceeding that of Gods ${ }^{689}$ it is stated, "I do not favor the Buddha, nor am I angry at [the followers of] Kapila $^{690}$ and the like. I will only accept he whose words are logical as a teacher." ${ }^{691}$ Also, the Lord of Knowledge [Dharmakīrti] ${ }^{692}$ said, (7) "Since [the Buddhist scripture] is infallible with regards to the primary subjects, we can subsequently infer that [the same is the case] for other [secondary] subjects.",693

As for the need to enter onto the path that ensures the [most] exalted status to be attained and the most transcendent state, the omniscient [Tsongkhapa] Lobzang Drakpa said, "the stages of the path of the great glorious Vajradhara distinguish the essential point of all secrets." In accordance with this, our Teacher Śākyamune intended to guide sentient beings onto the sublime path ${ }^{694}$ on the basis of their being compatible with the capabilities of superior, intermediate, and inferior students. Therefore, he taught whatever sections of the Dharma were suitable.

\footnotetext{
${ }^{684}$ Tib. Mkhas 'jug; this is an abbreviation of Mkhas pa 'jug pa'i sgo, a famous treatise on Buddhist Scholasticism composed by Sakya Paṇịita Künga Gyentsen (Sa skya paNDi ta Kun dga' rgyal mtshan, 1182-1251; TBRC: P1056), one of the five great forefathers of the Sakya sect.

${ }^{685}$ Tib. bstan bcos; Skt. śāstra.

${ }^{686}$ Tib. mchod brjod; lit. "offering verses." This term specifically refers to the prefatory stanzas written in honor of the Buddha at the beginning of commentaries.

${ }^{687}$ Tib. ston pa; lit. "teacher." This is a common epithet for the Buddha.

${ }^{688}$ Tib. rang gi phyogs bzung ste; the meaning of this phrase in unclear in this context.

${ }^{689}$ Tib. Lha las phul byung gi bstod pa; see note 693 below.

${ }^{690}$ An important Vedic sage, the followers of whom generally represent the Hindu opponents of Buddhism.

${ }^{691}$ My translation of this stanza is indebted to Geshe Wangyal (1986, pp.64-65).

${ }^{692} \mathrm{Tib}$. rig pa'i dbang phyug. While this epithet is too generic to give any indication as to whom it refers, it is clear from the quoted verse that the great Buddhist sage Dharmakirti is intended.

${ }^{693}$ see Dharmakīrti 1986, pp.204-205 for the original verse. I am indebted to Engle (2009, pp.85-86) for providing the origin and understanding of this verse.

${ }^{694}$ Tib. ma dag pa'i lam; given the obscurity of the original text here, I am reading this as yang dag pa' $i$ lam.
} 
In the Sütra which Gathers All Intentions, ${ }^{695}$ [it is stated]:

"[You,] the Conqueror, ${ }^{696}$ definitively taught the three pure guiding vehicles. ${ }^{697}$ (8) This being so, [why did you] not teach the one definitive vehicle that accomplishes spontaneously-present cause and effect without [needing to] seek out enlightenment from the other [vehicles]?" In reply, [the Conqueror] said [to] those who practice the [vehicles of] Cause, ${ }^{698}$ "Once the Wheel of the Dharma is completely turned, (the short path) [of] the Diamond Vehicle will appear in the future."

For those with intermediate capabilities and below, [the Buddha] turned the wheels of the causal doctrine; ${ }^{700}$ for those with superior [capabilities], he taught the Diamond Way of the Secret Mantras. The multitude of fortunate students does not need to depend on many eons; they can achieve enlightenment in the middle or at the end of this lifetime, in seven lifetimes, sixteen lifetimes, etc. In this method, it is said that in order to overcome temporary hindrances and discordant factors, (9) [one must] entrust activities to, and depend on, powerful Dharma protectors.

From the Tantras: ${ }^{701}$

Many transcendent beings appear to spontaneously emanate from the wisdom of the Victorious One. [They] are utterly completed [in] ultimate non-duality, [within] the spontaneously present mandiala. ${ }^{702}$

\footnotetext{
${ }^{695}$ Tib. Mdo dgongs pa 'dus pa. This is the principal text of the Anuyoga Tantras. It can be found in volume 97 (ff.110a-314a) of the Dergé (Tib. Sde dge) edition of the Translated Words [of the Buddha] (Tib. Bka' 'gyur) under its longer title, De bzhin gshegs pa thams cad kyi thugs gsang ba'i ye shes don gyi snying po rdo rje bkod pa'i rgyud rnal 'byor grub pa'i lung kun 'dus rig pa'i mdo theg pa chen po mngon par rtogs pa chos kyi rnam grangs rnam par bkod pa zhes bya ba'i mdo. The colorful history of this important text is discussed in Dudjom Rinpoche 1991, Book 2, Part 5. See also ibid, Book 2, Part 7, Chapter 3.

${ }^{696}$ Tib. bcom ldan; Skt. bhagavat; this is a common epithet for the Buddha.

${ }^{697}$ Tib. 'dren pa'i theg pa gsum po. According to Rangjung Yeshe, this term is synonymous with mtshan nyid kyi theg pa gsum, the 'three vehicles of characteristics.' These are (1) the Vehicle of those who Heard [the Buddha] (Tib. nyan thos kyi theg pa; Skt. śrāvakayāna), who achieve enlightenment as arhats; (2) the Vehicle of Solitary Buddhas (Tib. rang sangs rgyas kyi theg pa; Skt. pratyekabuddhayāna), who achieve enlightenment on their own but don't teach others; and (3) the Vehicle of Bodhisattvas (Tib. byang chub sems dpa'i thegs pa; Skt. bodhisattvayāna), who take the bodhisattva vow. The last vehicle is synonymous with the Great Vehicle (Tib. theg pa chen po; Skt. mahāyāna).

${ }^{698}$ Tib. rgyu la sbyor ba rgyu; the rgyu is short for rgyu yi theg pa, or alternatively, rgyu mtshan nyid kyi theg pa. This refers to those who belong to the three vehicles discussed in the previous note.

699 This dialogue is fully quoted in the Blue Annals (see Roerich 1996, p.158).

${ }^{700}$ see notes 697 and 698 above.

${ }^{701}$ Tib. rgyud las; the text does not specify which tantra the following quote is derived.

${ }^{702}$ Tib. Ihun gyis grub pa'i dkyil 'khor. This likely refers to one of the three main Anuyoga mandalas called rang bzhin lhun grub kyi dkyil 'khor, which is a Samantabhadra mandala.
} 
Accordingly, the great sovereign spirit Pekar and his retinue [are] contained within such mandalas as that of the great Eight Sädhana Deities. They do not surpass the emanations of the Supreme Heruka ${ }^{703}$ and are among the haughty spirits of [mundane] offerings and praise. They manifest in whatever forms are necessary [to aid] each student. Thus, their extraordinary methods $^{704}$ (10) are compatible with the essential intention of all the tantras.

Specifically, in accordance with the generation stage[-oriented] Mahāyoga, the Five Sovereign Spirits, their consorts, emanations, and ministers, along with their brigadiers, (emanate) from the radiance of the 100 supreme families of peaceful and wrathful deities. Regarding this, the emanation of [Padmasambhava's] mind, Ngari Padma Wangyel ${ }^{705}$ said:

[These] manifestations ${ }^{706}$ of the Five [Buddha] Families [are] the Five Great Kings, as well as their five self-appearing consortssuch as Jenma ${ }^{707}$ - male and female bodhisattvas [472] that are the very essence of the six sense objects, and the assembly of their cabinet ministers, shadröl, kyidröl, and external ministers.

[Also,] "The Great Kings endowed with destructive power gather from the unborn selfmanifestation [of] the peaceful and wrathful blood-drinkers ${ }^{708}$ and their consorts."

In the scripture[-oriented] Anuyoga, [these deities] are the essence of the right, left, and middle [channels], ${ }^{709}(11)$ as well as the male, female, and hermaphroditic haughty spirits.

In the Atiyoga, one must know that they are the fundamental nature of the unity of appearance and emptiness. The emanation of [Padmasambhava's] good qualities, the Dharma King Wangpo Dé $^{710}$ said:

Incite the assembly of male and female haughty spirits-who [represent] inseparable appearance and emptiness-[ [to come] from the non-dualistic expanse [and perform] the four activities!

All those [deities are] the discursive thoughts [of] one's own mind; they are the single wisdom drop $^{711}$ of self-arising phenomena-X $\bar{A} H-$ free from elaboration. Within three households, one mind [focused] on enlightenment - the king of awareness - (does not transcend) the nature of all.

\footnotetext{
${ }^{703}$ Tib. Che mchog He ru ka; Skt. Mahottara Heruka. This is the central deity of the Eight Sādhana Deities, sometimes considered synonymous with Vajrāmrta, the deity of good qualities.

${ }^{704}$ Tib. rang rgyud pa min tshul; lit. "methods that are not ordinary." The meaning of this phrase is unclear in this context.

${ }^{705}$ Tib. Mnga’ ris Padma dbang rgyal, 1487-1542; TBRC: P1699. See Ahmad 1999, pp.164-170.

706 Tib. rang rtsal; lit. "self-expressed play."

707 Tib. Spyan ma. It is unclear to which deity this refers.

708 Tib. khrag 'thung; this is a common epithet for the Herukas.

${ }^{709}$ Tib. ro rkyang dbu gsum. This refers to the three channels (Tib. rtsa; Skt. nädi) of the subtle body in yogic philosophy.

${ }^{710}$ Tib. Chos rgyal Dbang po'i sde, 1551-1603; TBRC: P646. See Ahmad 1999, pp.170-178.

711 Tib. thig le; Skt. bindu.
} 
(Because of this,) gods and spirits are indivisible from one's own mind. ${ }^{712}$ From the Breakthrough $[$ System $]:^{.713}$

The mind-essence ${ }^{714}$ is immaculate and pure; thus, the gods and spirits of phenomenal existence spontaneously appear.

While unmoved from the [meditative] states of bliss, clarity, and non-thought, (12) [the Five Sovereign Spirits] are spontaneously present as body, speech, mind, good qualities, and activities; they impartially appear for the benefit [of all] beings.

In a conventional sense, throughout King Pekar's [past] lives, the Lord of Secrets ${ }^{715}$ commanded $^{716}$ [him to relinquish his life essence]. ${ }^{717}$ Countless eons ago, there was a devout king named Mahābuta ${ }^{718}$ XXX [and] a monk [named] Lekden Nakpo, ${ }^{719}$ who became his minister. ${ }^{720}$ At this time, they were ordained under the abbot Daö Dünting. ${ }^{721}$ The king's ordination name was Daö Zhonnu ${ }^{722}$ and the minister's was Dünting Nakpo. ${ }^{723}$ XXXX the king XXXXXXXXXX. $^{724}$ Then, at the Temple where Nine Evil Spirits Gathered, ${ }^{725}$ Daö Zhonnu and a Brahmin woman made love, ${ }^{726}$ [then] he gave a [perverse] prayer of aspiration, and so forth. Because of this, (13) [he became] the butcher Ragochen, ${ }^{727}$ [then] Chumi Jangchupbar, ${ }^{728}$ Lenmi

712 khyim gsum du/ rig pa'i rgyal po byang chub sems/ /gcig ni kun gyi rang bzhin XXXX(las ma 'das phyir) lha 'dre rang gi sems las gnyis su med/ This passage is particularly difficult to translate, in part because many of the key words are missing. Despite Lingön Padma Kelzang's interpolations, the meaning is still not clear. Moreover, the original inscription has been further damaged since his transcription efforts, leaving even less material to consult. Because of this, I can only rely on his transcription and interpolations for the majority of this passage. Nevertheless, the ultimate meaning is clear even if the argument is not.

713 Tib. (khregs) chod; see note 36.

${ }^{714}$ Tib. sems nyid; this refers to the nature of the mind, which is believed to be identical to the enlightened mind.

715 Tib. Gsang ba'i bdag po; this is an epithet for Vajrapāni (Tib. Phyag na rdo rje).

716 Tib. [bka'] stsal.

717 see A myes zhabs 2000, p.405.

718 Tib. Ma ha abu ta. The ma ha here is too damaged in the original inscription to verify. A later source (Sle lung rje drung 1979, p.36) gives the name of this king who would become Pehar as Dharmajvala. This is clearly not the name here, so for now Lingön Padma Kelzang's suggestion stands. In the quote of this line found within the Hagiography of Jokpa Jangchup Penden, the king's name is Dharmarāja; see Appendix IV, f.7b.1.

719 Tib. Legs ldan nag po; lit. "Excellent Black One."

${ }^{720}$ This differs from Sle lung rje drung (1979, p.36), who says that this figure is the minister's son, not the minister himself.

${ }^{721}$ Tib. Zla 'od dun ting; lit. "Moonlight Dünting." The meaning of dun ting is unclear.

722 Tib. Zla 'od gzhon nu; lit. "Young Moonlight."

${ }^{723}$ Tib. Du nag po; lit. "Black Du." Sle lung rje drung (1979, p.36) gives his name as Dünting Nakpo (Tib. Dun ting nag po); the original inscription is too damaged to confirm that this was the minister's ordination name here.

${ }^{724}$ A significant portion of the story is missing here. However, we can fill in the gaps by drawing on Sle lung rje drung 1979, pp.36-37. The king preferred exposition (Tib. bshad pa), while the minister enjoyed meditation (Tib. sgom $\mathrm{pa}$ ), and the two friends grew apart and started practicing separately. The king's loneliness no doubt paved the way for what follows.

${ }^{725}$ Tib. 'Gong po dgu 'dus kyi lha khang. There is little information on 'gong po spirits as a distinct spirit type; see Nebesky-Wojkowitz 1998, pp.283-284.

${ }^{726}$ Tib. 'dus pa; lit. "united."

727 Tib. Ra mgo can; lit. "Goat-headed One."

${ }^{728} \mathrm{Tib}$. Chu mi byang chub 'bar; this is an alternative form of Chu mig byang chub 'bar (see Sle lung rje drung 1979, p.38), a literal translation of which is, "Blazing Enlightenment Spring." 
Jangchupö, ${ }^{729}$ and a marmot. ${ }^{730}$ After such lives as these, there was the father Muje Tsenpo ${ }^{731}$ and the mother Düza Minkarma, ${ }^{732}$ XXX [who had the following children:] Yapjé Lamé, ${ }^{733}$ Tramtok Nyampajé, ${ }^{734}$ Mudü Dramkarjé, ${ }^{735}$ Tramtok Barwajé, ${ }^{736}$ and Dünak Tongjé. ${ }^{737}$ Of these five siblings, [Pehar] became the middle-named one, Mudü Dramkarjé. At this time, he enslaved all of the eight classes of gods and spirits of phenomenal appearance, such as the gods of the sky, and so forth. ${ }^{738} \mathrm{He}$ ate small stars for food, XXX all female hindering spirits XXXXXXXX [and] striking the chests [of] sentient beings. ${ }^{739}$ [He performed] a variety of malicious acts, such as eating a hundred men for food every day, a hundred women every evening, and a hundred children every morning. (14) [He transformed into] a powerful black scorpion surrounded by a thousand scorpion offspring, an eight-year-old child [that appeared] from the sky above, ${ }^{740}$ and a white lion, established AM XXXXX. ${ }^{741}$ [As a lion], he glared [at the master], ears upraised and [about] to pounce. [In the] form of an ugly black monk, [he threw down on Padmasambhava's head] a white meteorite (about the size of) a sheep XXXX. ${ }^{742}$ He transformed into a handsome young layman holding a 108[-bead] crystal rosary in his hand. He then displayed magical emanations with an inconceivable number of weapons, and innumerable ministers. At that time, XXXX Dorjé ${ }^{743}$ and the great master Padma Tötreng Tsel, at places such as the Wish-Fulfilling

${ }^{729}$ Tib. Glan mi byang chub 'od; lit. "Dumb Man, Enlightened Light.” Sle lung rje drung (1979, p.38) explains that this version of the name is given in a non-extant text entitled the Gathering of Black Clouds (Tib. Sprin nag 'khrigs pa). However, the White Crystal Rosary (Tib. Shel phreng dkar po) has the alternative, Glan mi dbang phyug 'bar.

${ }^{730}$ Tib. 'phyi ba. Drawing on Sle lung rje drung 1979, p.38, this refers to a story where Pehar, in one of his former lives, transformed into a marmot in order to harass his old friend, Dünting Nakpo, while he was meditating. He was summarily subdued by Vajrapāṇi.

${ }^{731}$ Tib. Rmu rje btsan po; lit. "Emperor Lord of the Savage Spirits."

732 Tib. Bdud gza' smin dkar ma; lit. "Female Hindering-Planetary Spirit, White-Eyebrowed Woman."

733 Tib. Yab rje bla med; lit. "Unsurpassed Lord Father."

${ }^{734}$ Tib. Khram thogs nyams pa rje; lit. "Obstructing Charlatan, Lord of Degeneration."

${ }^{735}$ Tib. Smu bdud khram dkar rje; an alternative form of this name is Dmu bdud brang dkar (see Sle lung rje drung 1979, p.39), a literal translation of which is, "Savage-Hindering Spirit, White Chest."

736 Tib. Khram thogs 'bar ba rje; lit. "Lord Blazing Obstructing Charlatan."

${ }^{737}$ Tib. Bdud nag stong chen; drawing on Sle lung rje drung 1979, p.39, I strongly suspect that this deity’s name is actually Bdud nag stong rje, a literal translation of which is, "Lord of a Thousand Black Hindering Spirits." This would also coincide well with the rje found in the names of the four preceding deities, as well as their father.

${ }^{738}$ For a descriptive list of this category of beings, see Nebesky-Wojkowitz 1998, pp.264-266, as well as the surrounding chapter.

${ }^{739}$ A lot of words are missing from this section; however, according to Sle lung rje drung 1979, p.40, after enslaving the minor gods, Mudü Tramkarjé ate small stars, bound the sun and the moon to his crown, and tormented all living beings. There is no mention of female Hindering Spirits, so their purpose here remains a mystery.

${ }^{740}$ At this point we are aided by A myes zhabs 2000, p.412, where the story picks up here.

${ }^{741}$ Due to the missing words, the action here is unclear. However, by relying on Sle lung rje drung 1979, p.43, as well as A myes zhabs 2000, p.412 - both of which are drawing on the White Crystal Rosary-we can infer what is happening at this moment. Pehar mischievously attempts to distract Padmasambhava from meditating. He transforms into a white lion and disturbs the master's mandala configuration, making the threatening gestures that follow. The meaning of aM tshugs here is difficult to ascertain; Sle lung rje drung, ibid, does not mention it, while A myes zhabs, ibid, has khyi tshugs ma byas, which is itself difficult to understand in context.

${ }^{742}$ See Sle lung rje drung, ibid, and A myes zhabs, ibid.

${ }^{743}$ Lingön Padma Kelzang interpolates this as Garap Dorjé (Tib. Dga' rab rdo rje; Skt. Vajraprahe), who first transmitted the Dzogchen system after divinely receiving it; see Germano 1992, p.43. However, I have no confidence in this reading, since no other known account corroborates it. Every account has Padmasambhava meditating alone; the one exception is an account cited by Sle lung rje drung (1979, p.49), where Padmasambhava is accompanied by his consort, presumably Yeshé Tsogyal (Tib. Ye shes mtsho rgyal). My own suspicion is that this name refers to Vajrapāni (Tib. Phyag na rdo rje), who has also subjugated and bound Pehar to oath in the course of 
Crystal Cave ${ }^{744}$ conferred empowerments on him and (15) bound him under oath. [Pehar then] offered his radiant life essence in supplication, and he promised to protect the precious teachings of the Buddha.

Nowadays, this snowy land ${ }^{745}$ is described as Noble Avalokiteśvara's realm of conversion. Accordingly, [473] it is said that [the Tibetan kings,] from Lord Nyatri Tsenpo ${ }^{746}$ down to the divine ruler Trisong Deutsen, propagated and expanded the Holy Dharma. [During King Trisong Deutsen's time,] Master Śāntaraksita, ${ }^{747}$ who adhered to the Sarvāstivāda ${ }^{748}$ tradition, was invited [to Tibet], where he established ${ }^{799}$ a system that was in accordance with the 18 elements ${ }^{750}$ and the 10 virtuous actions. ${ }^{751}$ He did not allow the gods and spirits to do XXXXXX. ${ }^{752}$ According to what Master [Padmasambhava] prophesied, in Jambudvīpa ${ }^{753}$ XXXX. ${ }^{754}$ Master (16) Padmasambhava was invited [to Tibet], where he erected many [sacred sites], such as Changeless and Spontaneously Present Samyé Monastery, and XX translated countless [texts of] the Holy Dharma. He nominated the serpent spirit Zurpü Ngapa ${ }^{755}$ [to act] as protector of [Samyé] Monastery. [However, Zurpü Ngapa] explained that XXX there was a nephew of the serpent spirits who [could] (track) riches the size of a small needle, traveling [in one day] the distance a vulture covers in eighteen. ${ }^{756}$ In accordance with this, Prince Muruk Tsenpo ${ }^{757}$ invited Pekar and his supporting elements from the land of Drugu, and appointed him master of the entire treasury. Likewise, as the principal local guardian ${ }^{78}$ of the great Dharma center Glorious Drepung, (17) [Pekar] was asked by the omniscient Gendün Gyatso-who upheld the

his lives (see Sle lung rje drung 1979, p.41). However, in lieu of stronger evidence, I have chosen to ignore the interpolation provided and leave the name a mystery.

${ }_{744}$ Tib. bsam grub shel gyi phug pa.

${ }^{745}$ Tib. gangs can gyi ljongs; a common epithet for Tibet.

${ }^{746}$ Gnya' khri btsan po; this is the first semi-mythical ruler of Tibet.

${ }^{747}$ Tib. Zhi ba 'tsho; lit. "Peaceful Guardian." This famous eighth-century Indian Buddhist is responsible for inaugurating the Sarvāstivādin lineage of monastic ordination in Tibet.

${ }_{748}$ Tib. thams cad yod smra.

${ }^{749}$ Tib. gtsug pa; read as gtsugs pa.

${ }^{750}$ Tib. khams bco brgyad; These are the six sense powers (Tib. rten gyi khams drug; sight, smell, touch, taste, hearing, and thinking), their objects (Tib. dmigs pa'i khams drug; image, scent, texture, flavor, sound, and idea), and the conscious awareness of each one (Tib. brten pa'i khams drug).

${ }^{751}$ Tib. dge bcu las; alternatively, dge bcu'i las. These are (1) abandoning the destruction of life (Tib. srog gcod pa spong $b a$ ); (2) abandoning the taking of what was not given (Tib. ma byin par len pa spong ba); (3) abandoning improper sexual practices (Tib. 'dod pas log par g.yem pa spong ba); (4) abandoning the telling of lies (Tib. brdzun du smra ba spong ba); (5) abandoning abusive language (Tib. tshig rtsub po smra ba spong ba); (6) abandoning slander (Tib. phra mar smra ba spong ba); (7) abandoning gossip (Tib. tshig bkyal ba smra ba spong ba); (8) abandoning covetousness (Tib. brnab sems spong ba); (9) abandoning malice (Tib. gnod sems spong ba); and (10) abandoning wrong views (Tib. log par lta ba spong $b a$ ).

${ }^{752}$ There are too many obscure words to determine the meaning of this segment.

${ }^{753}$ Tib. 'Dzam bu gling; lit. "Rose Apple Continent." In ancient Indian cosmology, this was the name of the southern continent of the world and refers to the Indian subcontinent. It is also a synonym for the world.

${ }^{754}$ Once again, the details of this passage are unfortunately obscured.

${ }^{755}$ Tib. Zur phud lnga pa; lit. "[The One with] Five Locks of Hair."

${ }^{756} \mathrm{Tib}$. klu tsha nor rgya khab tsam gyi (rjes su) rgod po'i nyin lam bco brgyad 'gro ba'i de nyid. To clarify this sentence, I relied on an extended version of it provided by the Fifth Dalai Lama himself, and in his own autobiography; see Tā la'i bla ma 05 1992, p.27. Moreover, this section has been translated by Tucci; see Tucci 1999, vol.2, p.735.

${ }^{757}$ Tib. Mu rug btsan po.

${ }^{758}$ Tib. gnas srung; this refers to the deity's particular capacity to guard and protect the local vicinity of a monastery or sacred site. 
immaculate tradition of the Dharma King Shar Tsongkhapa Lozang Drakpé Pel, ${ }^{759}$ the embodiment of the power of the wisdom and compassion of all Buddhas - to eternally adhere to past aspirations, to a mind [focused] on enlightenment, and to the unsurpassed general and specific teachings [of the Buddha]. Moreover, in accordance with the awesome samaya vow that was fully proclaimed by the Great Master [Padmasambhava], the Dalai Lamas from Sönam Gyatso and on have worshipped the lord of all the guardians of the [Buddha's] teachings, who more and more supports the excellent virtuous deeds of the religious and secular [government]. ${ }^{760}$

Since $^{761}$ all the activities of [such worship] had been increasing, there was also a desire to make his temple abode ${ }^{762}$ much larger by expanding it beyond its former [size]. Because of this, the gathering [of] masters also called for it. (18) Likewise, Regent Sangyé Gyatso, who has passed through successive [human] bodies, ${ }^{763}$ remembered his past aspirations and accordingly built an extensive divine mansion. ${ }^{764}$ He had murals [of] lamas, buddhas, bodhisattvas, peaceful and wrathful tutelary deities, dēkiniss, and Dharma protectors [painted] inside a sixteen-pillared assembly hall $^{765}$ that is like no other. In the courtyard [there are murals of] the retinue, the army of the haughty spirits of phenomenal existence. In the XX chapel, ${ }^{766}$ there are bas-relief statues of the 18 deities. $^{767}$ In the top-floor chamber, there are [images of] Master [Padmasambhava] and his 25 disciples $^{768}$ on the right as well as on the left, and all the implements, such as offering materials and wrathful gifts, are inconceivable ${ }^{769}$ [in number]. [This] was spontaneously accomplished regardless of difficulties. In particular, during an exhortation that arose from the force of a detailed ${ }^{770}$ analysis [of] the outer, inner, and secret sacred objects [of] just the retinue, (19) it was said:

You, [who are] presently the king of all Tibetans, ${ }^{771}$ emanate five beings with your pure aspiration prayer.

In the great assembly hall, [there are as follows: the text of] the subjugation of the Five Dharma Kings $^{772}$ and their retinue, which comes from the profound treasure text of Nyang Nyima Özerthe body emanation of Master Padmakara ${ }^{773}$ and the lord of men Trisong Deutsen; [the corpus of]

\footnotetext{
${ }^{759}$ Tib. Shar Btsong kha pa Blo bzang grags pa'i dpal; this is an alternative form of Tsongkhapa's name.

${ }^{760}$ Tib. chos srid; here this is an abbreviation for chos srid lugs gnyis, the Tibetan government that combined religious and secular systems.

761 Tib. rten; read as brten.

762 Tib. bzhugs gnas lcog.

${ }^{763}$ Tib. rim lus su song ba; this is an obscure epithet, but it appears to be a complimentary one. Given Sangyé Gyatso's series of human lives preceding him (see Lobzang Tondan 1983, vol. 1, pp.5-11), I am reading this epithet as one honoring a consistently human succession of lives, which is highly prized in Buddhism and a mark of one's wealth of merit.

${ }^{764}$ Tib. zhing bkod pa; lit. "established a divine realm."

${ }^{765}$ Tib. gtsang khang; while this term usually refers to shrines, it is clear that the Nechung assembly hall is meant, which still has sixteen pillars today.

${ }^{766}$ Unfortunately, the original inscription is too damaged here to know which chapel in Nechung this is.

${ }^{767}$ Tib. lha tshogs bco brgyad; I am uncertain to which deities this refers.

768 Tib. gtso 'khor nyer lnga.

769 Tib. blos mi 'khud pa; lit. "unable to grasp with the mind."

${ }^{770}$ Tib. zhib mol; read as zhib mo'i, as per Lingön Padma Kelzang's understanding.

771 Tib. mgo nag; lit. "Black-headed [Ones]." This is an epithet for Tibetans.

772 Tib. Chos rgyal sde lnga; in this context, this is an epithet for the Five Sovereign Spirits.

773 Tib.Padma ka ra; this is an epithet for Padmasambhava.
} 
the principal deity and his retinue [equaling] seventeen, ${ }^{774}$ such as the wrathful king Hayagrīva, from the Assembly of Secrets Guru, ${ }^{775}$ the profound teaching of Guru Chökyi Wangchuk-the speech emanation [of Padmasambhava and King Trisong Deutsen]—which [was drawn from] the belly of a serpent-hindering spirit; the Great Dharma protector and his retinue, which came from a hidden [source]; and a mustard seed-sized relic of the completely and perfectly [enlightened] Buddha, which was an heirloom of King Ajātaśatru. ${ }^{776}$ [474] These were taken from among the sacred objects of Nakartse ${ }^{777}$ and from the dark treasury ${ }^{778}$ of Tselagang. ${ }^{779}$ (20)

Regarding body and clothing relics, [Nechung Monastery houses the following:] the hair of Masters Garap Dorjé and Śrī Siṃha; ${ }^{780}$ a great XX rosary [made] of some ${ }^{781}$ of the white and red bodhicitta $^{782}$ [produced] by Padma Tötreng Tsel and his consort, [along with their] body and clothing relics; relics of Arsadhara, the King of Zahor; ${ }^{783}$ flesh of a seventh-born Brahmin; ${ }^{784}$ Indian manuscripts of the Great Translator Vairocana; the crown of Lhalung Pelgyi Dorjé; ${ }^{785}$ relics, hat, divan, hand $\mathrm{X}$, and clay miniature ${ }^{786}$ of Lord Atiśa; ${ }^{787}$ bodily $\mathrm{X}$, a tooth, hair, and divan of Dromtönpa; ${ }^{788}$ clothing of the translators of Ngok, uncle and nephew, ${ }^{789}$ and of Khutön; ${ }^{790}$ relics, heart, hair, and monastic robes of Potowa; ${ }^{791}$ relics and hair of Jadül; ${ }^{792}$ (21) relics and hair of Lord Neuzurpa; ${ }^{793}$ relics of the Spiritual Guide Drepa; ${ }^{794}$ blood of Sharawa; ${ }^{795}$

\footnotetext{
774 Tib. gtso 'khor bcu bdun; it is unclear which group of deities these are.

${ }^{775}$ Tib. Bla ma gsang ba 'dus pa.

776 Tib. Rgyal po Ma skyes dgra; Ajātaśatru (ruled 491-461 BCE) was king of the ancient Indian Magadha empire and contemporary of the Buddha.

${ }^{777}$ Tib. Sna dkar rtse; this is a county south west of Lhasa. For details and relevant historical sites, see Dorje 2004, pp.224-227.

${ }^{778}$ Tib. mdzod nag; according to Peter Alan Roberts (2007, p.31), dark treasury refers to texts that are kept hidden from the public.

779 Tib. Rtse la sgang; this is an area in Kongpo (Tib. Kong po), south east of Lhasa.

${ }^{780}$ Tib. Shrī Senge; like Garap Dorjé, Śrī Siṃha is another important semi-mythical Dzogchen master.

${ }^{781}$ The inscription is difficult to read here, with the transcription being $X$ cig; however, I am reading it as $k h a c i g$.

${ }^{782} \mathrm{Tib}$. byang sems dkar dmar; this refers to the drops of male semen and female blood produced and united during tantric sexual yoga.

${ }^{783}$ Tib. Za hor rgyal po Gtsug lag 'dzin.

${ }^{784}$ Tib. bram ze skye ba bdun pa; this is an individual who has been reborn as a Brahmin seven times in a row, signifying their holiness.

${ }_{785}$ Tib. Lha lung Dpal gyi rdo rje; this is the famous monk who assassinated the last Tibetan King, Lang Darma.

786 Tib. phyag tsha; this is the honorific form of tsha tsha.

${ }^{787}$ Atiśa Dīpaṃkaraśrījñāna (980-1054); this is the great 11th-century reformer of Buddhism in Tibet.

${ }^{788}$ This refers to Dromtönpa Gyewé Jungné ['Brom ston pa Rgyal ba'i 'byung gnas (1005-1064)], Atiśa's heart disciple.

${ }^{789}$ Tib. Rngok lo khu dbon; this refers to the lesser translator of Ngok, Lekpé Sherap [Rngog lo chung Legs pa'i shes rab, b.10th century; TBRC: P3389] and his nephew, the great translator of Ngok, Loden Sherap [Rngog lo chen Blo ldan shes rab, 1059-1109; TBRC: P2551].

${ }^{790}$ This refers to Khutön Tsöndrü Yungdrung [Khu ston Brtson 'grus g.yung drung, 1011-1075; TBRC: P3464], one of Atiśa's students.

${ }^{791}$ This refers to Potowa Rinchensel [Po to ba Rin chen gsal, 1027-1105; TBRC: P3442], an important Kadampa [Tib. Bka' gdams pa] master.

${ }^{792}$ This refers to Jadülzin Tsöndrübar [Bya 'dul 'dzin Btson 'grus 'bar, 1091-1166; TBRC: P2273], and important transmitter of the Vinaya in Tibet.

${ }^{793}$ This refers to Neuzurpa Yeshebar [Sne'u zur pa Ye shes 'bar, 1042-1118; TBRC: P1316], an important Kadampa master.

${ }^{794}$ Tib. Bshes gnyen sgre pa.

795 This refers to Sharawa Yöntandrak [Sha ra ba Yon tan grags, 1070-1141; TBRC: P1405], an important Kadampa master.
} 
relics and clothing of Zhangkamawa; ${ }^{796}$ a small piece of Khampa Lungpa; ${ }^{797}$ hair and mantle of the Arhat of Pelti; ${ }^{798}$ relics of Chim Namkhadrak; ${ }^{799}$ blood, a tooth, hair, hat, urine, mantle, monastic robes, belt, divan, and cushion of the Dharma King, Great Tsongkhapa; ${ }^{800}$ a finger of the Great Saint Lekyi Dorjé; ${ }^{801}$ relics of the Realized Yogi Jamyang Gyatso; ${ }^{802}$ hair of the seven abbots of Ganden Monastery after Tsongkhapa; ${ }^{803}$ relics of the Omniscient Scholar; ${ }^{804}$ a tooth and monastic robes of the Omniscient Gendün Drupa; ${ }^{805}$ (22) blood, hair, and belt of the Omniscient Gendün Gyatso; ${ }^{806}$ clothing of Lord Dungtsepa; ${ }^{807}$ hair of the Scholar Norzang Gyatso; ${ }^{808}$ mantle of Jamyang Lekchöpa; ${ }^{809}$ relics and hair of Paṇchen Sönam Drakpa ${ }^{810}$ relics of Lord Dewachenpa; ${ }^{811}$ brains, flesh, relic pills of pus, urine, death shroud, monastic robes, belt, gsol-yang, ${ }^{812}$ assembly garment, and shoes of the Omniscient Sönam Gyatso, ${ }^{813}$ hair of Panchen Lozang Chökyi Gyentsen; ${ }^{814}$ hair of the Omniscient Yöntan Gyatso; ${ }^{815}$ hair of the Precious Abbot Könchok Chöpel; ${ }^{816}$ as well as my own hair, blood, puss, and medicinal pills [that I produced with] the vase consecration of the lama's three bodies.

Within the sovereign spirit's red protector chapel, [there are:] (23) a heap of black barley, and portions of new and old sacred substances, medicinal pills, sacred supporting items, and such; relics of the Dharma body; many lotus dhäranīs [from] all over Tibet; ${ }^{817}$ a Hayagrīva

\footnotetext{
${ }^{796}$ Tib. Zhang ka ma ba; this refers to Zhangkamapa Sherapö [Zhang ka ma pa Shes rab 'od, 1057-1131; TBRC: P1321], who founded Kam Monastery [Kam dgon pa].

${ }^{797}$ This refers to Khampa Lungpa Śākya Yöntan [Khams pa lung pa Shākya yon tan, 1023-1115; TBRC: P3466], an important Kadampa master.

${ }_{798}^{79}$ Tib. Sbal ti dgra bcom pa.

${ }^{799}$ Mchims Nam mkha' grags, 1210-1285; TBRC: P1060. This is an important Kadampa scholar.

${ }^{800}$ This refers to Tsongkhapa Lozang Drakpa [Tsong kha pa Blo bzang grags pa, 1357-1419; TBRC: P64], the famous founder of the Geluk sect.

${ }^{801}$ Grub chen Las kyi rdo rje, 1326-1401; TBRC: P1317. This is the first Lelung Jedrung [Sle lung rje drung] incarnation.

${ }^{802}$ Rtogs ldan 'jam dbyangs rgya mtsho; this likely refers to Rtogs ldan Khri rin po che 'Jam dbyangs mkhyen rab rgya mtsho; see Khri ba 'Jam dbyangs rgya mtsho 2009.

${ }^{803}$ Tib. 'Jam dbyangs gtsang pa bdun brgyud; lit. "Lineage of the Seven Men of Tsang who are [like] Mañjughoṣa [Tsongkhapa]."

${ }^{804}$ Mkhas grub Thams cad mkhyen pa; this likely refers to the first Panchen Lama, the Scholarly Lord Gelek Pelzang [Mkhas grub rje Dge legs dpal bzang, 1385-1438; TBRC: P55], who was Tsongkhapa's other heart disciple alongside the first Dalai Lama.

${ }^{805}$ Dge 'dun grub pa, 1391-1474; TBRC: P80. This is the first Dalai Lama.

${ }^{806}$ Dge 'dun rgya mtsho, 1476-1542; TBRC: P84. This is the second Dalai Lama.

${ }^{807}$ Mdung rtse pa.

${ }^{808}$ Nor bzang rgya mtsho, 1423-1513; TBRC: P75. This was a student of the first Dalai Lama and teacher of the second Dalai Lama.

809 'Jam dbyangs legs chos pa, b.15th century; TBRC: P449.

${ }^{810}$ Pan chen Bsod nams grags pa, 1478-1554; TBRC: P101. This is a famous Geluk master who was Ganden Monastery's fifteenth abbot, and also served as abbot at Drepung and Sera monasteries.

811 This like refers to Dewachenpa Gelek Pelzang [Bde ba can pa Dge legs dpal bzang, 1505-1567; TBRC: P998], the 21st abbot of Ganden Monastery.

${ }^{812}$ The meaning of this word is uncertain. Judging from the inscription, the second syllable may also be spang.

${ }^{813}$ Bsod nams rgya mtsho, 1543-1588; TBRC: P999. This is the third Dalai Lama.

${ }^{814}$ Pan chen Blo bzang chos kyi rgyal mtshan, 1570-1662; TBRC: P719. This is the fourth Panchen Lama.

${ }^{815}$ Yon tan rgya mtsho, 1589-1616; TBRC: P177. This is the fourth Dalai Lama.

${ }^{816}$ Khri rin po che Dkon mchog chos 'phel, 1573-1644; TBRC: P2565. This is the 35th abbot of Ganden Monastery.

${ }^{817}$ Tib. $d b u$ [sic: dbus] dang stod smad bar gsum; lit. "the central as well as the three-upper, lower, and middle [parts]."
} 
[image] ${ }^{818}$ — in particular, the form of Padma Tongdröl, ${ }^{819}$ which arose from Myang[ral Nyima Özer]'s treasure texts; my own yellow hat and official seal; ${ }^{820}$ a XX ritual dagger made from a cutch tree [struck?] by a barbaric black mule ${ }^{821}$ in a dark pungent charnel ground; the life-force cakra for the Hayagrīva accomplishment and the cakra for subduing harmful [forces], which were revealed at Zambulung ${ }^{822}$ [and are] a section concealed within the 108 treasures that were bestowed by the Great Master [Padmasambhava]; as well as each and every life-force cakra of body, speech, and mind, and the subjugation cakras.

In general, although there are numerous tantras for Pekar, the root tantras that are indispensible to the practitioner are: the 32-chaptered Wealth God's Tantra, ${ }^{823}$ within which there is a general summary as well as individual outer, inner, and secret (24) accomplishment practices; the sevenchaptered Blue Turquoise Rosary Tantra, ${ }^{824}$ within which there is the heart practice; the 20 chaptered White Crystal Rosary ${ }^{825}$ explanatory tantra, within which are the approach, accomplishment, and application of activities; the Black Iron Rosary Tantra, ${ }^{826}$ [475] within which there is the practice of the one-eyed black hindering spirit XXX; the Tantra that Harms Pekar, ${ }^{827}$ within which are the outer practice and the excellent practice; the Tantra [of] the XX Lion-masked Corpse, ${ }^{828}$ within which there is the secret practice; the Tantra of the Nepalese Woman's Dialogue, ${ }^{829}$ within which there is the practice of the hindering spirit Yapsher; ${ }^{830}$ the Tantra of the Sovereign Spirit of Life Force and Karma, ${ }^{831}$ within which there is the method for subduing the [sovereign spirit's] life force; the 108-chaptered Life Force Cakra ${ }^{832}$ and the Tantra of Bestowing the Heart Citta, ${ }^{833}$ within which there is the [method for] pressing ${ }^{834}$ to death; the Tantra of the Sovereign Spirit's Karma, ${ }^{835}$ within which there is the inner strife ${ }^{836}$ [practice]; the ninth chapter of the Tantra of the Great Servant Kuchok Marpo, ${ }^{837}$ within which there is the method for subduing the ghost king; ${ }^{838}$ as well as the Oral Tantra of Hayagriva, ${ }^{839}$ within which there is the method for mending [the samaya vow of] the sovereign spirits.

${ }^{818}$ Tib. Padma dbang chen.

819 Tib. Padma mthong grol; lit. "Lotus [Crown] that Liberates upon Seeing it." This is an epithet for Padmasambhava.

${ }^{820}$ Tib. sbugs; read as an abbreviation of sbug dam.

${ }^{821}$ Tib. 'dre [sic: drel] rta nag po.

${ }^{822}$ Tib. Zab [sic: zam] bu lung; a holy place in Gtsang.

${ }^{823}$ Tib. Nor lha'i rgyud.

${ }^{824}$ Tib. G.yu phreng sngon po'i rgyud.

825 Tib. Shel phreng dkar po.

${ }^{826}$ Tib. Lcags phreng nag po'i rgyud.

${ }^{827}$ Tib. Pe kar 'phung byed kyi rgyud.

${ }^{828}$ Tib. 'Bag seng ro XX rgyud.

${ }^{829}$ Tib. Bal mo zhus lan gyi rgyud.

${ }^{830}$ Tib. Yab sher; lit. "Father Confronter."

${ }^{831}$ Tib. Srog las rgyal po'i rgyud.

${ }^{832}$ Tib. Srog 'khor. Given the context, this seems to refer to a specific text, but the title is ambiguous.

${ }^{833}$ Tib. Tsitta snying 'byin gyi rgyud.

${ }^{834}$ Tib. ar gtad.

${ }^{835}$ Tib. Rgyal po'i las rgyud.

${ }^{836}$ Tib. nang rgyas.

${ }^{837}$ Tib. Ging chen sku mchog dmar po'i rgyud.

838 Tib. rgyal 'gong.

${ }^{839}$ Tib. Rta mgrin zhal brgyud. 
(25) Regarding the manner in which to implement these teachings: having received them with proper conviction, adhere to them just as the Lord, his ministers, and his subjects do. Regarding also the system of practice: Pekar, the capricious spirits, the savior spirits, ${ }^{840}$ the single male skeleton dancers, the single female skeleton dancers, the lone $\mathrm{XX}$, and their retinue are established as the outer, inner, and secret body, speech, mind, qualities, and activities - [as well as] the butchers, the Three Razor Brothers ${ }^{841}$ - [which perform] the pacifying, augmenting, subjugating, and destructive [actions]. Once you have thoroughly assembled all the items for the individual practices, you must unerringly construct such things as the Matram mandala. Having forcefully bound [Pekar] with the approach and accomplishment practices, the offerings, amendment rites, and oblations, rely on him like you would a father, control him like you would a son, associate with him like you would a friend, employ him like you would a servant, overpower him like you would an enemy, treasure him like you would riches, receive him like you would a king, $\operatorname{sic}^{842}$ him [on enemies] like you would a dog, and so forth. [After] omens that the three [acts] - summoning, dispatching, and slaying ${ }^{843}$ — of the preceding eight methods for cultivating [a relationship with the deity were successful] appear, subjugate him, integrate your oaths, (26) bind him to his samaya vow, and invest him with authority. Then apply the activities; if they are counteracted, suppress the countermeasures and praise and invoke [the deity]. Through such [methods], offer your enemies [to the deity] as food, cut off [all] errors in increasing the conquering of misfortune, and press intently XX. To conclude the principal protector's [rites], you must end with the three actions of crushing, burning, and blowing away [your enemies]. Thus, [there are] the four essences of the general weapons, the six essences of the tormas, and the nine essences of the cakras that eliminate the ten defects [of recitation]. If the sovereign spirit would harm you, [keep] the life-force cakra that suppresses misfortune ${ }^{844}$ [at] your heart; if he proliferates, keep [the text] on your body. If he runs away, overpower him with the life-force cakra and fierce mantras. If there is internal strife, [use] the wheel of death. If he is hostile toward the Wisdom Being, ${ }^{845}$ [perform] the meditative stabilization of Hayagrīva. [Within] the crossed mandala of Matram [Rudra], ${ }^{846}$ in front of the yogin, there is the cakra of Overcoming the Serated Razor ${ }^{847}$ at the center of the united Father and Mother [deities]. ${ }^{848}$ Separately, there is the cakra of suppressing misfortune (27) at the yogin's navel. This completes the crucial practice that increases the conquering of misfortune, as well as the cakra of all faith.

In all [of this], the yogins, sponsors, patrons, subjects, and so forth, keep the Five Sovereign Spirits - together with their messengers and servants - close to their hearts and are inseparable from them. In particular, there is the life-force cakra of the five emanated dharma kings, their five great consorts, and their five ministers, individually; the life-force cakra that dispels malice,

\footnotetext{
${ }^{840}$ Tib. mgon po.

${ }^{841}$ Tib. Spu gri mched gsum.

${ }^{842}$ Tib. rbud; read as rbod.

${ }^{843}$ Tib. bod [sic: 'bod] rbad bsad gsum.

${ }^{844}$ Tib. log mnon [sic: gnon].

${ }^{845}$ Tib. ye shes pa.

846 Tib. ma tram zhal 'khor bsnol ma; this meaning of this line is uncertain.

${ }^{847}$ Tib. Spu gri so brgal; this refers to the tantra entitled Dpal lha mo spu gri so rgal gyi rgyud, found in vol. 42 of the Rnying ma rgyud 'bum.

${ }^{848}$ Tib. yab yum.
} 
which came from the oral instructions of XX Lama Dogupa; ${ }^{849}$ and the life-force cakra that unites the mother and $\operatorname{son}^{850} \mathrm{XX}$ for each X [of] the Five Sovereign Spirits generally.

Regarding the great emanated Dharma protector Dorjé Drakden, which the omniscient [Third Dalai Lama] Sönam Gyatso beheld in a vision [during] meditation: in addition to the three above life-force cakras, there is my own waistcoat; the cycle of methods for increasing family, wealth, and possessions, which is explained within the Gathering of Black Clouds Sädhana ${ }^{851}$ (28) as well as the life-force cakra for augmenting life and merit; the cakra of the Great Outer Tantras that Avert Malevolent Influences, ${ }^{852}$ [possessing] such [content] as Buddhist, Tantrika, and Bönpo spells, [found within] the profound treasures of Künkyong Lingpa; ${ }^{853}$ the protective cakra that is the object of practice for the one endowed with a white parasol topknot; ${ }^{854}$ [476] and the life cakra of Norbu Petreng ${ }^{855}$ and [Vajrā]mṛtakuṇdalī. ${ }^{856}$

The body support itself is the [Nechung] medium, ${ }^{857}$ as well as the XX images and sword of the great sovereign spirit with whom he is associated, which were bestowed as items for him to infuse. The speech support is the entire yellow scroll of Myang[ral]'s treasure text, the Great Compassionate Wish-Fulfilling Jewel that Tames [All] Beings. ${ }^{858}$ The mind support is the Blazing Brilliance of the Adamantine Meteor, ${ }^{859}$ which is from that very [same] treasure cycle.

The reincarnate scholar Gökyi Demtruchen ${ }^{860}$ gave a sword that he revealed from the Northern Iron Treasury ${ }^{861}$ to the Teacher of the Se clan, Nyima Zangpo, ${ }^{862}$ [who is] among the seven meritorious sons. Then [you, Gökyi Demtruchen,] and your disciple (29) bestowed [it] as a weapon that liberate [through destruction] the personal enemies of the kings of Ngari, Gungtang, and so forth - the enemies and obstructing spirits in which the ten defects are complete.

Regarding a reliance on the sovereign spirit of activities [Pehar]: There is the Adamantine Meteor that Overpowers the Army of Hindering Spirits, ${ }^{863}$ a treasure text rediscovered by Ratna

${ }^{849}$ Tib. Do gu pa; it is unclear to whom this refers.

${ }^{850}$ Tib. ma bu sbyor ba; this is a Dzogchen phrase referring to when the primordial state (the mother) and knowledge (the son) are united in non-duality; see Reynolds 1996, p.166.

${ }^{851}$ Tib. Sgrub thabs sprin nag 'khrigs pa.

${ }^{852}$ Tib. Phyi brgyud byad bzlog chen mo.

${ }^{853}$ Kun skyong gling pa, 1396-1477; TBRC: P10646.

854 Tib. Gtsug tor gdugs dkar; Skt. Ușṇīṣasitātapatra; this refers to a Buddhist goddess.

${ }^{855}$ Tib. Nor bu pad phreng; lit. "Jewels and Lotus Garland." Given that this phrase is paired with a deity, it is likely the name of a deity itself; however, it is unclear which deity is being reference. The jewel and lotus motif suggest a form of Avalokiteśvara.

${ }^{856}$ Tib. [Rdo rje] bdud rtsi 'khyil ba; lit. "[Adamantine] Nectar Swirler."

${ }^{857}$ Tib. sku phebs.

${ }^{858}$ Tib. Thugs rje chen po 'gro 'dul yid bzhin nor bu; this cycle of treasure texts is available in the 'Jam mgon kong sprul 1976-1980, vol.33, pp.1-275.

${ }^{859}$ Tib. Gnam lcags rdo rje gzi byin 'bar ba; this line suggests that this is a text drawn from the above-mentioned treasure cycle by Nyangral Nyima Özer; however, a cursory perusal of this cycle reveals no text by this name. Given that this is the mind support, which is usually a reliquary, this may be the name of said reliquary, the design of which was taken from this treasure cycle. Another possibility is that the reliquary contains the text to which this refers.

${ }^{860}$ Tib. Sprul sku rigs ’dzin Rgod kyi ldem phru can, 1337-1409; TBRC: P5254.

861 Tib. Byang lcags mdzod.

${ }^{862}$ Tib. Se ston Nyi ma bzang po, b.14th century; TBRC: P8839.

${ }^{863}$ Tib. Gnam lcags rdo rje bdud dpung zil gnon ma. 
Lingpa; ${ }^{864}$ iron swords, thigh swords,${ }^{865}$ and barberry daggers,${ }^{866}$ respectively; mantra manuals for summoning, dispatching, and slaying; ling a emblems; and various soils and stones from India, Nepal, Tibet, and so forth. Moreover, occasionally there are bundles of fragrant saffron, as well as measures of various clothes, silks, grains, medicines, teas, lumber, foods, and fruits. These completely fill a secluded storehouse, with nothing left out, such as yellow silks. Similarly, the principal [items are] my own images and individual relics - these being [my] monastic robes and [my] hair; [and] the relics of the lord of the Buddhas of the three times [Padmasambhava] - these being his shawl and hair. Other [items] for the principal deity and the entire retinue [include] the holy relics ${ }^{867}$ of the Indian and Tibetan root and lineage lamas and dhäranis and mantras, which were mentioned above. (30)

Regarding the life tree of the gañjira [spire] on top [of the monastery, there are:] extraordinary dhäranis and mantras placed within it and along the outside of it, written without adding or omitting anything; as well as the accomplishment ritual from the Spotless Rays of Light. ${ }^{868}$ At its peak there are X relics: ${ }^{869}$ my own hair, dhäranis and mantras, as well as the relics mentioned above. In particular, these were arranged above, below, and in-between an image of White Parasoli ${ }^{870}$ protective [amulets] for the country and for one's object of practice; flawless images and mardalas; the most secret protection and aversion rites, and rituals for [sexual] union, respectively; life cakras from the Norbu Petreng [cycle] and the new treasure texts; Guru Jotsé's ${ }^{871}$ rite for overpowering [spirits]; a protective [amulet] by Nyang[rel] and one from the Great Almighty ${ }^{872}$ [treasure text rediscovered] by [Padma] Lendretsel; ${ }^{873}$ and a rite for averting armies by Tseten Gyentsen. ${ }^{874}$ For the victory banners that have, [respectively,] tiger-, wolf-, vulture-, and monkey[-headed tips, as well as] silk brocade, the insertion ritual ${ }^{875}$ was based on the White Parasol Topknot cycle. For the supporting banners, [there are:] (31) support items of the body, speech, mind, good qualities, and activities for the seven - the Five [Sovereign Spirits], Dorjé Drakden, and [Dorjé] Drakgyelma - as well as a rooftop ornament ritual ${ }^{876}$ that accordingly came from oral instructions.

There are also many kinds of [items], such as thread-cross [structures] for mending, averting, and slaying, as well as supports that [compel] the deities to always remain, ${ }^{877}$ which were constructed in secret. Over the course of one week, the mantric scholar Lozang Kyechokchen ${ }^{878}$ along with a number of monks, powerfully completed [these as well as] rituals for thoroughly establishing

\footnotetext{
${ }^{864}$ Tib. Ratna gling pa, 1403-1479; TBRC: P470.

${ }^{865}$ Tib. gri rkang.

${ }^{866}$ Tib. skyer phur.

${ }^{867}$ Tib. byin rten; lit. "blessing support."

${ }^{868}$ Tib. 'Od zer dri med; this is a tantra from the Kriyayoga system.

${ }^{869}$ Tib. X gdung; the first syllable is illegible; however, given the context, this word is most likely sku gdung or 'phel gdung.

${ }^{870}$ See note 854 above.

${ }^{871}$ Tib. Gu ru Jo rtse; this figure appears to be a prominent Bönpo treasure-revealer; see Bellezza 2005, p.97.

872 Tib. Kun thub chen mo.

${ }^{873}$ Las 'brel rtsal, b.1248; TBRC: P7628. See Harding 2003, p.32.

${ }^{874}$ Tib. Tshe brtan rgyal mtshan.

${ }^{875}$ Tib. 'jug chog.

${ }^{876}$ Tib. thug chog.

${ }^{877}$ Tib. chag pa; read as chags pa.

${ }^{878}$ Tib. Sngags rams pa Blo bzang skyes chog [sic: mchog] can.
} 
such [offerings] as continuous tormas, ${ }^{879}$ immediately-offered tormas, ${ }^{880}$ daily tormas,${ }^{881}$ offering materials, and deity gifts; along with life-force cakras, flawless support objects, and so forth, which were composed by such figures as Zur Agur. ${ }^{82}$ I consecrated [these objects] and recited the benedictions myself.

Regarding the appearance and establishment of the sovereign spirits, if concealed spirits ${ }^{883}$ were not overpowered then they were not successful. Therefore, overpower concealed spirits with the sädhana of the enemy[-defeating god] Khyungchen Ludrukdül ${ }^{884}$ and the exposition within the Razor [that Cuts] the Life of the Capricious Spirits. ${ }^{885}$ (32)[477] Press down beneath the threshold thirteen masks of such [spirits] as the Nine Spirit Brothers, ${ }^{886}$ transgressor spirits, ghost kings, and ghosts, which harm countries in general and Tibet in particular. For the realization of the sovereign spirits, it is explained that you must apprehend [these] indispensible spells that liberate [through destruction], as well as the form supports ${ }^{887}$ and soul stones; protect the samaya vow; and overpower the concealed spirits and cut off their heads. ${ }^{888}$

Regarding such things as the essential nature of the outer, inner, and secret symbols, they arose from all the detailed ritual practices [and] the undefiled intended meaning of the tantras and oral instructions. Accordingly, these were arranged by myself, the thread-cross [structures] and tormas were created by the shrine-keeper Ngawang Sherapchen, ${ }^{889}$ and the cakras and so forth were commissioned by the monk Jamyang Drakpa. ${ }^{890}$ Everything was agreeable and of excellent quality. Most importantly, the place, time, and all the outer and inner [ritual] necessities were thoroughly established to the highest degree.

(33) Even though they arise from the Five [Buddha] Families [that emanate from] Samantabhadra-from whom the mandala of the peaceful and wrathful [deities] emanates and is absorbed - the Five Sovereign Spirits, who thoroughly protect the teachings of the Dharma, [take on] wrathful, ferocious, and repulsive forms in order to cure communities of their wrong views.

In order to accomplish their activities, [the Five Sovereign Spirits'] emanations, consorts, and ministers each take a side, and their army of right, left, front, and back brigadiers, as well as emissaries

\footnotetext{
${ }^{879}$ Tib. rtag gtor.

${ }^{880}$ Tib. 'dzin gtor.

881 Tib. rgyun gtor.

${ }^{882}$ Tib. Zur a gur.

${ }^{883}$ Tib. sgab 'dre.

${ }^{884}$ Tib. Dgra lha Khyung chen Klu 'brug 'dul; lit. "Great Garuḍa, Subduer of Serpent Spirits and Dragons;” a variant of this is Rdo rje Khyung chen Klu 'brug 'dul. This is Pehar's secret initiation name, bestowed upon him when he was subdued by Padmasambhava; see A myes zhabs 2000, p.413.

${ }^{885}$ Tib. Gnod sbyin srog spu gri.

886 Tib. 'Gong po spun dgu.

887 Tib. rten gzugs.

${ }^{888}$ Tib. 'gren bcad; Lingön Padma Kelzang has mgrin bcad, which literally means, "to cut off from the neck." I am translating this phrase as such since 'gren is not a known Tibetan word. It is possible that 'gren is an abbreviation (Tib. bskungs yig); however, if so, I am uncertain of what words it is meant to condense.

${ }^{889}$ Tib. Ngag dbang shes rab can.

${ }^{890}$ Tib. 'Jam dbyangs grags pa.
} 
and secondary emanations, have the power to completely fill the three worlds.

Within [this] great palace - the outside of which is made from materials precious to gods and humans [and] the inside of which displays charnel grounds - the assembly of the three divine roots densely gathers like clouds; it is like passing into the pure land of the Lotus Light [Palace]. ${ }^{891}$

The oath-bound guardians accompany them like a shadow follows a body. The outer supports are beautiful white animals; the inner supports are seven-line [supplications written with] wild bamboo, five victory banners, eight auspicious [pillar ornaments], ${ }^{892}$ large arrows, and black silks hanging on vulture feathers.

(34) The secret supports are images, various thread-cross [structures] and tormas, and such. These plentiful clouds of offerings [that fill] the whole sky, high and low, completely open the one hundred doors of the Sky Treasury, and fulfill the awesome samaya vow.

In the presence of the Abbot [Śāntaraksita], the Master [Padmasambhava], and the Dharma King [Trisong Deutsen], Prince [Muné Tsenpo made] prayers of aspiration to act for the happiness and welfare of Tibet. ${ }^{893}$ The fruit of [these prayers] has ripened today [in the form of the Regent] Sangyé Gyatso. The haughty spirits that challenged his ability and power were appointed $^{894}$ [as guardians] and bound to Brahma. ${ }^{895}$

The stainless tradition of Tsongkhapa, who illuminated the Buddha's teachings like the sun, consequently spread throughout the expanse of the world, [and] the multitudes of great men who more and more support the religious and secular [government] expand its dominion.

[In this] degenerate age, may the government of the great palace possessing the superior joy and happiness of the four [abundances] $^{896}$ - the thousand-spoked wheel of virtuous actions

\footnotetext{
${ }^{891}$ Tib. Padma 'od; this refers to the palace in Padmasambhava's pure land.

${ }^{892}$ Tib. legs brgyad; read as an abbreviation of $k a$ 'phan che legs brgyad.

${ }^{893}$ Tib. bod khams; more specifically this refers to Central and East Tibet.

${ }^{894} \mathrm{Tib}$. 'tshol ba; read as 'chol ba. I would like to thank Cameron Bailey for suggesting this reading.

${ }^{895}$ Tib. deng smin sangs rgyas rgya mtsho'i nus mthu la/ 'gran byed dregs ldan 'tshol bar tshangs pa brel/ The meaning of the second half of this stanza is difficult to ascertain.

896 Tib. sde bzhi; read as an abbreviation of phun tshogs sde bzhi. The four abundances are (1) spreading the Buddhadharma (Tib. sangs rgyas kyi chos dar ba); (2) possessing wealth (Tib. nor longs spyod dang ldan pa); (3) enjoying the five sense pleasures (Tib. 'dod yon lnga la spyod pa); and (4) achieving the level of liberation (Tib.
} 
and merit, which is completely exalted throughout the heavens without obstruction - grow like the waxing moon. (35)

The blessings of the root and lineage lamas gather like clouds [and] the peaceful and wrathful tutelary deities shower down accomplishments [upon us] like rain. May the Dharma Kings and their retinue spontaneously accomplish the desired activities, which would be [like] enjoying fully ripe fruit.

Although Regent Trinlé Gyatso ${ }^{897}$ — who wanted to expand Nechung Chapel long before [now] - finished laying its foundation, the Great Dharma Protector ${ }^{898}$ said, "A tantric house 899 must be built within my estate." He also prophesied that it would arise accordingly in the future. Moreover, Padma Tötreng Tsel prophesied:

A great minister who is an emanation of Mutri [Tsenpo], ${ }^{900}$ possessing a regal manner [and] the name of 'Buddha,' will become the magistrate. ${ }^{901}$

He also [prophesied]:

An emanation of Muné Tsenpo, ${ }^{902}$ possessing the name of 'Jewel, ${ }^{, 903}$ will be born in a fire year in a part of the Ü region. ${ }^{904}$ In order to protect against interfering hindering spirits, [478] this very [person] will entrust [the deities] as guardians and have them protect and avert [misfortune] again and again. (36)

Accordingly, three sons were born to the Dharma King Trisong Deutsen. The eldest, Muné Tsenpo, ${ }^{905}$ protected the two traditions, [spiritual and temporal,] here in this Land of Snows. Being as impartial as timely rainfall, he acted for the happiness and well-being of all people and cattle. He even established this chapel for the Great Dharma Protector. In [this] beautiful, majestic, and sublime [chapel] that is superior to others, the three precious supports, and in particular, a wealth of necessities exemplified by countless outer, inner, and secret supports and

thar pa myang 'das kyi go 'phang 'thob pa). As the coloring in the original Tibetan text reveals, this line actually gives the name of the Tibetan government, the Ganden Podrang (Tib. Dga' ldan pho brang).

${ }_{897}$ Tib. 'Phrin las rgya mtsho, d.1667; TBRC: P3649.

898 Tib. Chos skyong chen po; in this context this epithet refers to the Nechung Oracle.

899 Tib. sngags khang.

$900 \mathrm{Tib}$. Mu khri. This refers to the second Tibetan King Mutri Tsenpo (Mu khri btsan po), who was the son of the first Tibetan King Nyatri Tsenpo (Gnya' khri btsan po); see Haarh 1969 pp.34-35.

${ }^{901}$ The belief is that this prophecy refers to Sangyé Gyatso, whose name 'Sangyé' means Buddha, and who was believed to be an emanation of Mutri Tsenpo; see Lobzang Tondan 1983, vol.1, p.7.5.

902 Tib. Mu ni [sic: ne]. This refers to the 39th Tibetan King Muné Tsenpo (Mu ne btsan po), who was the son of Trisong Deutsen, the 38th Tibetan King; see Haarh 1969, pp.56-57.

903 The Tibetan text transliterates the Sanskrit ratna.

${ }^{904}$ This prophesy also appears to refer to Sangyé Gyatso, who was believed to have also been an emanation of Muné Tsenpo; see Lobzang Tondan 1983, vol.1, p.8. Moreover, his personal name was Könchok Dondrup (Dkon mchog don grub) - Könchok means 'jewel.' However, the fire-year birth is an inconsistency, since Sangyé Gyatso was born in 1653, a Water-Snake year; the next fire year would be 1656 .

${ }_{905}$ Tib. Mu ni [sic: ne] btsan po. 
offering substances for the protector deities that naturally assemble [here], were [all] piled up. When [Nechung Monastery] XX, along with the gifts for the deities, were completely established and [we] were about to enjoy the celebration of the consecration banquet, Regent Sangyé Gyatso urged [me to write] a register. Accordingly, [I], the Monk of Zahor, Zilnön Zhepatsel ${ }^{906}$ composed [this register]. The scribe was (37) the dance master, ${ }^{907}$ monk Ngawang Könchok. ${ }^{908}$

May [all accomplishments] be bestowed! $!^{909}$

\footnotetext{
${ }^{906}$ Tib. Zil gnon bzhad pa rtsal; this is the Fifth Dalai Lama's secret initiation name.

${ }^{907}$ Tib. 'cham dpon.

${ }^{908}$ Tib. Ngag dbang dkon mchog.

909 Tib. pra yatstshantu; Skt. prayacchantu. This is the imperative third person plural for the Sanskrit prayam/prayacchati, meaning "to bestow, send forth, produce." I would like to thank Kathleen Erndl for providing me with the root and grammatical details of this word (personal correspondence, August 21, 2012).
} 


\section{[A Facsimile of the Addendum to the Nechung Register Composed by Regent Sangyé Gyatso]}

[38]Although he is the father of all Victorious Ones, he [takes on] the appearance of the Bodhisattva Padma Karpo. ${ }^{910}$ Although he - the vast treasure of compassionwas instantaneously liberated, he firmly upholds all beings with compassion. Although he makes offerings of the four [actions] in abundance, he conquers samsāra and nirvāna in all their glory. May the Omniscience Lama Lozang Gyatso $^{911}$ look after [us] until we reach enlightenment!

[Like] the brilliance of a powerful sun blazing with the natural sunlight of pure wisdom, he directly manifests within the castle of the haughty spirits and annihilates the darkness of the demon horde. This self-produced universal monarch who bears the gnostic mantras [is] named Padma Gyelpo. ${ }^{912} \mathrm{He}$ is wreathed in [the light of] the a hundred thousand suns of samsāra and nirvāna. May he expand the lotus garden of virtue and auspiciousness!

He fully comprehends the vast wisdom that illuminates all that can be known with the strength [of] the garuda. [39] Therefore, just like gooseberries thoroughly spread across the palm of one's hand, he completely perceives and analyzes all phenomena unadorned as they are. We permanently pay homage to this Dharma King with five topknots, ${ }^{913}$ Jampel Nyingpo! ${ }^{914}$

He conquered the great mandala of the haughty spirits and, with a neighing roar, ate the host of spirits [throughout] the three worlds. May he, Hayagrīva - who is incredibly red, like a Mount Meru[sized heap] of naturally radiant coral—protect us!

They [produce] various miraculous emanations unimpeded from the pure expanse- just like the [multiple] reflections of the moon in water-and with a fierce manner they watch after the [Buddha's] teachings. May these Dharma protectors, the Five Sovereign Spirits, delightfully play!

I fully composed ${ }^{915}$ a wreath of stanzas [to decorate] the head [of this work] and placed this melodious chant possessing the eight qualities of poetry in the lines above. As for the present

\footnotetext{
${ }^{910}$ Tib. Padma dkar po; Skt. Puṇdarikka; lit. "White Lotus." This is an epithet for the Bodhisattva Avalokiteśvara, but refers here to the Dalai Lama.

911 This is the Fifth Dalai Lama.

912 Tib. Padma rgyal po. This is a form of Padmasambhava.

${ }^{913}$ Tib. Zur phud lnga ldan. This is an epithet for the Bodhisattva Mañjuśrī, of whom Tsongkhapa is believed to be an emanation.

${ }^{914}$ Tib. 'Jam dpal snying po. This is an epithet for Tsongkhapa, specifically in reference to his name in Tuṣita heaven.

${ }^{915}$ Tib. rgod; read as 'god.
} 
matter, the precious register composed by the unrivaled savior ${ }^{916}$ of all sentient beings, including gods, is given above. [40] I offer this minor [work] as a detailed addendum.

The precious teachings of the Buddha spread, flourished, and have dwelled in the world for a long time. They rely solely on the empowering conditions of the holy ones who uphold the teachings. Moreover, they rely on the compassion of the Highly-Exalted Omniscient Lord of the Victorious Ones - who is the secret body, speech, and mind of the Buddhas and Bodhisattvas, ${ }^{917}$ the magical emanation of inconceivable wisdom, the one who manifests as the very embodiment of compassion, [479] and the one who is Padmapanni ${ }^{918}$ himself in the form of a tantric master. I will ever remain at the lotus feet of this savior for one-hundred eons; I will properly complete all activities that he desires and clear away discordant conditions.

Ordered [to perform] activities that accumulate ${ }^{919}$ and augment concordant conditions without hesitation, bearing on their heads a vajra crown, never transgressing the oath to which they were bound [by] the awesome seal[41] — the worldly and transcendental adamantine protectors are inconceivable [in number]. However, among these, the ones that quickly [accomplish] the most activities, and who are the most fiercely powerful, are the Great Sovereign Spirits that Protect the Dharma. Furthermore, they are the essence of all the qualities of the wisdom and compassion of the primordial Buddha Samantabhadra. Complete enjoyment bodies ${ }^{920}$ that are the unhindered inherent radiance of he who is the universal splendor of all samsāra and nirvāna arose as the five [Buddha] families. From these, in response to wicked tamable beings that must be subdued wrathfully, the five [appeared]: the central sovereign spirit of the mind, who is an emanation of Vairocana ${ }^{921}$ - the essence of the wisdom of the Dharmadhātu, the purification of hatred; the eastern sovereign spirit of the body, who is an emanation of Vajrasattva ${ }^{922}$ - the essence of mirror-like wisdom, the purification of ignorance; [42] the southern sovereign spirit of good qualities, who is an emanation of Ratnasambhava ${ }^{923}$ - the essence of impartial wisdom, the purification of pride; the western sovereign spirit of speech, who is an emanation of Amitābha ${ }^{924}$ - the essence of the wisdom of discriminating awareness, the purification of desire; and the northern sovereign spirit of activities, who is an emanation of Amoghasiddhi ${ }^{925}$ - the essence of all-accomplishing wisdom, the purification of envy. They [are accompanied by] many primary, secondary, and tertiary emanations, such as five consorts that instill delight and are the inherent nature of wisdom, five emanations that are protective and perform many kinds of activities, five ministers that accomplish [their assigned] activities, lion-masked dancers that entertain, and the four great brigadiers of the right, left, front and back sides. By relying on them, they accomplish all pacifying, enriching, conquering, and destructive activities. They have great power, are loyal, and are easy to invoke.

\footnotetext{
916 This refers to the Fifth Dalai Lama.

917 Tib. rgyal ba sras dang bcas pa; lit. "Victorious Ones and their sons."

918 Tib. Phyag na padma; lit. "Lotus-holder." This is a form of the Bodhisattva of compassion, Avalokiteśvara.

919 Tib. sog, read as gsog.

${ }_{920}$ Tib. longs spyod rdzogs pa'i sku; Skt. sambhogakāya.

${ }^{921} \mathrm{Tib}$. Rnam par snang mdzad. Vairocana is the head of the Buddha family and takes the central position.

922 Tib. Rdo rje sems dpa'. Vajrasattva is a form of Akșobhya (Tib. Mi bskyod pa), who is more generally considered the head of the Vajra family in the east.

${ }^{923}$ Tib. Rin chen 'byung gnas. Ratnasambhava is the head of the Ratna family in the south.

${ }^{924}$ Tib. Snang ba mtha' yas. Amitābha is the head of the Padma family in the west.

${ }^{925}$ Tib. Don yod grub pa. Amoghasiddhi is the head of the Karma family in the north.
} 
Consequently, long ago, the great Dharma-protecting King Trisong Deutsen constructed the great Changeless and Spontaneously Present Three-styled ${ }^{926}$ [Samyé] Monastery, together with its temples and sacred images. [43] When the Abbot [Śāntarakșita], the Master [Padmasambhava], and the Dharma King [Trisong Deutsen] were discussing how they would appoint a protector [for the monastery], the Abbot said, "the hindering spirits enjoy killing, the planetary spirits are vicious, the serpent spirits are noxious, the imperial spirits are harmful [and cause] pain, the savage spirits are too gentle, and the maternal spirits are terrifying. None of them [will do], so who is suitable?" The Second Buddha, Great Master Padmasambhava said:

The tutelary deity ${ }^{927}$ of Mongolia is Namlha Jangchub. ${ }^{928}$ Once we
invite this sovereign spirit Shingjachen [here], we will entrust the
monastery to him and it will be indestructible. If we conquer the
meditation center of Bhatahor, Pekar will follow after his
possessions and come [here]. I will establish his supports at
Pekarling.

Likewise, [the others said,] "the sovereign spirit Pekar, the treasure guardian from the Bhatahor meditation center, is suitable." And so, they conquered the Mongolian meditation center. Along with Dharmapāla of the Zahor royal line, as well as many [of the deity's] possessions - such as a turquoise Buddha [statue] and a conch-shell lion [statue] - [Pekar] was invited [to Tibet] and [44] installed as the guardian of the entire Dharma center [of Samyé]. [480] His outer and inner supports were also established. [Pekar] was entrusted to protect the life pillar of the Buddha's teachings and promised to do so. However, all Five Great Sovereign Spirits successively came to reside and remain at many such monasteries. Thus, this Great Dharma King [Pekar went] to reside at Yangön Monastery, ${ }^{930}$ in the central region to the north. One day during the lifetime of the Omniscient Gendün Gyatso, ${ }^{931}$ though he was uninvited, [Pekar and the Second Dalai Lama] met at that place [Yangön] in accordance with the [Buddha's] teachings. This was a sign that [the deity] would not transgress his awesome and delightful adamantine oath. Accordingly, [the Second Dalai Lama] spread the Gelukpa ${ }^{932}$ teachings and, together with the protector of this great Dharma center, he left Yangön by way of a coracle ${ }^{933}$ Because [he] offered [Pekar] prayers,

\footnotetext{
${ }^{926}$ Tib. zan g.yang; read as zan yang. This refers to the three styles that make up Samyé Monastery's central temple (Tib. dbu rtse), the three stories of which were each designed in a different cultural style: Indian, Chinese, and Khotanese, traditionally.

${ }^{927}$ Tib. pho lha. This usually refers to one of the five personal protector deities (Tib. 'go ba'i lha lnga) that are attached to an individual from birth; see Jovic 2010.

${ }_{928}$ Tib. Gnam lha byang chub; lit. "Enlightened Sky God."

929 Tib. Pe kar gling. This is a condensed form of Pe kar dkor mdzod gling, the monastic treasury. This entire exchange is summarized and quoted from the $63^{\text {rd }}$ chapter of the Padma bka' thang; see O rgyan gling pa 1996 , pp.384-385. For translations see Douglas and Bays 1978, pp.391-392, and Lin 2010, p.9, n.15; the latter translation is far more accurate.

${ }^{930}$ Tib. Yang dgon gyi gtsug lag khang.

931 This is the Second Dalai Lama, whose dates are 1476-1542.

932 Tib. zhwa ser cod pan 'chang ba; lit. "bearers of the yellow hat."

933 Tib. rta mgo; read as rta mgo can. I would like to thank Bryan Cuevas for suggesting this reading (personal correspondence, October 8, 2012. This segment of the Nechung Register concerning Yangön is summarized in the Gung thang dkar chag; see Sørensen, Hazod, and Tsering Gyalbo 2007, p.216. However, since this segment in the latter text is a summary, it is missing some important details that have affected how Sørensen and Hazod translate this event. Their interpretation is that Pehar left Yangön alone in the form of Hayagrīva, translating rta mgo as such.
} 
offerings, and entrusted actions, [the deity] accomplished without obstruction these actions that the Omniscient one [requested].

A summary record of [Pekar's] coming here: Moreover, when he was close to being born in the direction of Tölung Tsega ${ }^{934}$ for the benefit of all beings, he was slightly delayed by a hindrance. [45] At this time, he deliberately went to the glorious Copper-colored Mountain ${ }^{935}$ because he was exhausted from benefiting beings. When [he arrived], the great master was teaching the profound Dharma to an assembly of knowledge-bearing $d \bar{a} k a s$ and $d \bar{a} k i n \bar{s}$. There were two protector deities - one large and one small - in front of where he was sitting. The [large] one had a black body and white plaited locks ${ }^{936}$ of hair, and held a sword and a blood-filled skull-cup. The [small] one had a red body and wore leather armor and a leather helmet, the top ${ }^{937}$ of which was adorned with silk ribbons. He brandished in his hands a red spear and a lasso. He possessed a tiger-skin quiver and a leopard-skin bow case, and wore red leather boots. The [two deities] stood as such with Padmasambhava above and behind them. [The Dalai Lama] asked the great master Padma[sambhava], "Who are these two protectors?" [He replied,] "These two are my attendants and they will accompany [you] as companions. Go to Tibet in order to benefit the [Buddha's] teachings and sentient beings!" Accordingly, they were entrusted as [the Dalai Lama's] servants to accomplish all [desired] activities. [46] As requested, [the Dalai Lama, together with the two protectors, came to this land in order to benefit [all] tamable beings. ${ }^{938}$ Later, [after he was born,] the great omniscient one Sönam Gyatso was placed ${ }^{939}$ on the great Dharma throne at Glorious Drepung Monastery. Not long after, this great Dharma protector [the red guardian] possessed the human body ${ }^{940}$ [of the Nechung Oracle]. In this manner, and expressing [himself] here ${ }^{941}$ [like] Sarasvatī [did when she] vividly revealed herself, he said, "Through the interdependent connection of [our] extensive and unhindered activities that benefit [all] tamable beings, [may] the incarnate one [the Third Dalai Lama] behold me!"942

Yet the full text of the Nechung Register suggests rather that the Second Dalai Lama himself came to Yangön, befriended Pehar, and left with him.

${ }^{934}$ Tib. Stod lung rtse dga'. The full name of the Third Dalai Lama's birth place is Stod lung rtse dga' khang gsar, located in the Töling valley just west of Lhasa.

${ }^{935}$ Tib. Zangs mdog dpal ri; this is Padmasambhava's pure land.

${ }_{936}$ Tib. thor lcog; read as thor cog.

${ }^{937}$ Tib. ldem phru; read as ldem 'phru.

${ }^{938}$ This encounter with Padmasambhava and the two protectors, which is said to have taken place in the intermediate state between the death of the Second Dalai Lama and the rebirth of the Third, was drawn almost verbatim from the biography of the Third Dalai Lama composed by the Great Fifth; see Tà la'i bla ma 05 1982, pp.16-17. For a second edition, see Sku sger yig tshang 1977, vol.2, p.7. Amy Heller (1992b, pp.223-225) discusses this event in detail. She explains that the identification of the smaller red deity is ambiguous in this account; however, given its placement at this point in the Nechung Register, it seems that Sangyé Gyatso is making the argument that it is Pehar or one of his emanations. For a larger discussion of the identity conflict between the deity Begtse and Pehar's emanation Dorjé Drakden, see Heller 1992a.

${ }^{939}$ Tib. zhabs zung rnam par bkod; lit. "his two feet were fully established."

${ }^{940}$ Tib. khog; lit. "trunk of the body."

${ }^{941}$ Tib. 'drir; read as 'dir.

${ }^{942}$ This and the following verses greatly summarize an encounter between the Third Dalai Lama and Pehar-in possession of the Nechung Oracle - recorded in the Third Dalai Lama's biography. This event, recorded here in a piecemeal and disjointed way, occurred around the turn of 1589, shortly after the Third Dalai Lama was appointed abbot of Sera Monastery. For the full account, see Tā la'i bla ma 05 1982, pp.116.3-126.4; see also Department of Religion and Culture 2004, pp.29-37. Here, the two deliberate on the commissioning of a biographical tangka for the Dalai Lama before the oracle gives iconographic instructions to the painter, Trengkhawa Penden Lodrö Zangpo ('Phreng kha ba Dpal ldan blo gros bzang po, b.16th cent.; TBRC: P7529). This specific quote does not appear to be 
The image was drawn [as such]:

Regarding the way to make the tangka display, ${ }^{943}$ however large [you want] the cotton canvas is fine. ${ }^{944}$...In the middle of those [images] or on one side, ${ }^{945}$ [paint] the form of the western sovereign spirit of speech. He rides a black mule with white heels and is majestic. ${ }^{946}$...Countless emanations that look like [the sovereign spirit] radiate [from him], even more than all of these beings. ${ }^{947}$ The emanations of the sovereign spirit Pekar are many-even more than the hairs on a tawny horse's [body]. [47] Moreover, a description is for small-minded people [while] this image is [for] you-a great mind, worthy and expansive... ${ }^{948}$

[The Nechung Oracle further] said: ${ }^{949}$

In general, even though all phenomena do not truly exist, they appear true in a conventional [sense]. With respect to this, in the center of the lotus at the heart of the 1002 Buddhas there is Padmasambhava. When [we] were in the Lotus Light Palace at the peak of the glorious copper-colored mountain, Padmasambhava instructed [us] [481] to act for the improvement of the Buddha's teachings. That is to say, the Incarnate One Meaningful to Behold, ${ }^{950}$ through pacifying and augmenting means, performs activities that protect those who bear the [Buddha's] teachings; [while] I, the sovereign spirit Pekar, through subjugating and destructive means, accomplish activities that clear away discordant conditions for

verbatim, since it paraphrases two disparate elements. The first element is earlier in the exchange and concerns the activities of the Dalai Lama and Pehar working in tandem. This exchange is quoted verbatim below; see Tā la'i bla ma 05 1982, p.121.3-4. The second element is at the end of the account and makes mention of the goddess Sarasvatī (Tib. Dbyangs can lha mo; var. Dbyangs can ma). The Nechung Oracle explains that when Trengkhawa was beginning to paint a tangka of Sarasvatī, he had doubts about the iconography. In response, the goddess appeared to the Third Dalai Lama in a vision and said, "Behold me, incarnate one!" In similar fashion, when painting the tangka of the Third Dalai Lama's biography, which includes a detailed image of the Sovereign Spirit, the Nechung Oracle says that he proclaimed same thing; see Tà la'i bla ma 05 1982, p.126.3-4. The next few lines of verse are quoted verbatim and describe iconographic elements given to Trengkhawa by the Nechung Oracle. Macdonald (1978a, pp.1140-1141) also briefly discusses this event.

${ }_{943}$ Tib. thang ga'i ljags bkod gnang ba'i tshul; unlike the following verses, this line does not appear to be drawn verbatim from the Third Dalai Lama's biography. It does not precede the next line.

${ }_{944}$ For this line, see Tā la'i bla ma 05 1982, p.124.3.

${ }^{945}$ This positioning is explained in greater detail in the Third Dalai Lama's biography. The Nechung Oracle expounds on the proper iconography for the tangka, and immediately before this line he states that there should be a monastery in the corner under the Dalai Lama's right knee and a Savior Spirit under his left knee. The oracle then explains that the image of one of the Five Sovereign Spirits should go in-between these two images.

${ }_{946}^{94}$ See Tà la'i bla ma 05 1982, p.124.5.

${ }^{947}$ This line is preceded by a detailed description of the entities that make up the Five Sovereign Spirits' retinue.

${ }_{948}^{948}$ See Tā la'i bla ma 05 1982, p.125.3-4.

${ }^{949}$ The below lengthy quote is also found in the Third Dalai Lama's biography; see Tã la'i bla ma 05 1982, pp.121.2-122.1. This prose was spoken by the Nechung Oracle to the Third Dalai Lama while the former was possessed by Pehar.

${ }_{950}$ Tib. Sprul sku Mthong ba don ldan. This is an epithet for the Dalai Lamas often used by the Nechung Oracle; see Nair 2010, p.123. 
him and that bring about concordant conditions. Accordingly, both [of us] must also act for the improvement of the [Buddha's] teachings. Please consider this! In particular, Padmasambhava gave the enemies' flesh, blood, life essence, and life breath to me as food rations. [48] For [my] allotted work, he entrusted me with protecting the [Buddha's] teachings and the bearers of those teachings. Because of this, I have also never transgressed Padmasambhava's commands in the past. Again and again I have not transgressed [his commands]. So if there are obstacles to the activities that the One Meaningful to Behold performs in his lifetime, I will clear them away. I will accomplish all the concordant conditions! If there are harmful demons and obstructing spirits, human beings and inhuman spirits are not suitable [for dealing with them] unless they are included among the haughty spirits, the eight classes of gods and spirits of the phenomenal world. I am the overlord of all eight classes, the king who is the embodiment of the haughty spirits. What demons and obstructing spirits are able to transgress my command? Therefore, [my] entreaty is not insignificant. There is no need to act humble!

Accordingly, [49] this great Dharma protector ultimately [acts] as the guardian of the life stages ${ }^{951}$ of the great Omniscient King of the Victorious Ones, ${ }^{952}$ as well as the guardian of all the teachings of the great [and] incomparable Tsongkhapa, and he is like a rampart for the great Dharma center Glorious Drepung [Monastery]. [Yet] this [deity] did not have a natural and spontaneously present abode where he could live. Nevertheless, he generated one through meditation and [then], together with his emanations, created a real one. The manager of Glorious Drepung [Monastery] also requested that this new dwelling place, Nechung Pekar Chapel, ${ }^{953}$ [be built]. Consequently, by means of the earlier request and through great effort, [construction] began in the Iron-Female-Bird year [1681], in the third month, which celebrates when the Buddha turned the Dharma wheel of the Kālacakra at the great reliquary of Glorious Dhānyakațaka. ${ }^{954}$ First, I myself made an arrangement of multicolored papers and various [other things]. The area [of the site] was cleared ${ }^{955}$ and marked out by the cords of the serpent. ${ }^{956}[50]$ The Mantrika of Chongyé, Ngawang, performed the methods for subjugating [the Lord of the Soil, interpreted] the planets and stars, and so forth; these are explained in the [geomantic and astrological] literature. On the day when the ground was dug up, there was a dust storm and the sky was turbulent.

There were 22 supervisors. The two chiefs were Kyitöpa Tenpé Gyentsen and Pulungpa Püntsok Pelzang. [Other supervisors included] Chungpa Raptang Marmowa, Rongrang Chönpa, Sawa Druppa, Nang Jungpa, Kartsowa, Gadong Zhidewa, Sharpa Rapsel, Chölung Zhungkar, Kangsar Rapten, Polhawa, the Five folks from Rong, Sönam Dargyé, and Zimchungpa. There were 127

\footnotetext{
${ }^{951}$ Tib. sku na rim; lit. "series of [one's] ages."

${ }^{952}$ Tib. Rgyal dbang Thams cad mkhyen pa; in this context this appellation is an epithet for the Dalai Lamas.

953 Tib. Gnas chung pe kar lcog.

${ }^{954}$ Tib. Dpal ldan 'bras spungs; this site is located in Amaravati, Andhra Pradesh, India and is the place after which Drepung Monastery in Tibet was named.

${ }^{955}$ Tib. spom gta'.

${ }^{956} \mathrm{Tib}$. lto 'phye'i thig. This refers to the practice of using cords to divide the site space into a chessboard-like configuration. This iconometry then determines the location of the serpent-like Lord of the Soil (Tib. sa bdag) underneath the ground, to whom offerings must be made before he will grant permission to dig the foundation. For a discussion of this construction ritual in the closely-related Bhutanese context, see Wongmo 1985.
} 
carpenters. Their chief craftsmen were Nesarwa Jamyang and Drachi Gögö, their medium craftsman was Lhasa Lamnyé, and their lesser craftsman was Büdé Mendrup Lingpa; their remaining [craftsmen included] Zadam Tsewang. There were 93 masons. Their chief craftsmen were Drigung Samdrup Tseten and Gyamön Dargyé, [51] and their lesser craftsman was Chukpo Tashi; their remaining [craftsmen included] Madro Menchok. [482] There were 7 bricklayers. Their chief craftsman was Epa Tsenden and the remaining [craftsmen included] Jamyang. There were 44 [other workers] such as roofers, transporters, leathersmiths, and builders from Mön. When both Sönam Pel and Zangpo acted as supervisors, they gathered stone collectors for corvée labor. In this they followed in the footsteps of the story of Samyé Monastery ${ }^{957}$ being built by the Dharma King Trisong Deutsen: [at that time] the gods and spirits gathered a mountain of stones for all to see, regardless of whether it was day or night. There was a great output [of work] and a great number of corvée laborers - nearly 5000. Prior to that, other than one or two bad omens-like sovereign spirit diseases ${ }^{958}$ - there had been no illnesses and the builders were exceptionally wonderful.

For the murals, there is the great incomparable Tsongkhapa [52], the First Panchen Lama, and the First Dalai Lama; the Lineage of the Seven Men of Tsang who are [like] Mañjughoșa; ${ }^{959}$ the five successive bodies of the great All-Knowing, All-Seeing Lord of the Victorious Ones, the crown jewel of the five hundred [bodhisattvas?]; ${ }^{960}$ the great master of Glorious Uḍdiyāna [Padmasambhava]; the Eight Sädhana Deities; the great Five Sovereign Spirits, their five consorts, and five ministers; the Seven Wild Imperial Spirit Riders; and, in particular, the two physical expressions ${ }^{961}$ of this great Dharma King. For the murals in the courtyard, there is the retinue: the 30 chiefs of the haughty spirits, the 75 glorious protectors, and the horde of the eight classes [of gods and spirits].

Arranged according to the explanations within the tantras, ${ }^{962}$ the interstices [of the walls] have innumerable servants and various kinds of wild animals: the outer supports consist of vultures, monkeys, and parrots; the inner supports consist of dogs; and the secret supports consist of silk brocade. The supports that summon the butchers are the victory banners [topped with the heads of] tigers, wolves, [etc.] There is an eight-year-old crystal child with turquoise eyebrows who bares his conch-shell fangs, brandishes a razor in his hand, and rides a white lion. [53] [He is flanked by] a one-eyed black monkey holding an iron knife in his hand and riding a small mule, and a white enemy[-defeating] god wearing a nine-layered robe, holding a flaming razor, and riding a lion. There are 100 arhats on their right, 100 armored [soldiers] on their left, 100 women in front of them, and 100 monks riding black mules [behind them]. [There are also] 100 black Indian Mön dancers holding mendicant's staffs in their hands, and 7 black women wearing skull-garlands. There is the butcher [Jatri] Mikchikpu ${ }^{963}$ wearing a turban of black serpents and

\footnotetext{
957 Tib. lugs gsum mi 'gyur lhun grub kyi gtsug lag khang; lit. "changeless and spontaneously present monastery of three styles."

${ }^{958}$ Tib. rgyal zer [sic: gzer].

959 Tib. 'jam dbyangs gtsang pa bdun rgyud; this refers to the first seven abbots of Ganden Monastery who followed after Tsongkhapa.

960 This refers to the first five Dalai Lamas.

${ }^{961}$ Tib. sku'i rnam 'gyur rnam gnyis; this refers to the two forms, peaceful and wrathful, of the central deity.

${ }^{962}$ This likely refers to the many tantras that concern Pehar, which were listed above in the Fifth Dalai Lama's section, lines 23-24.

963 This is Mönbuputra's minister.
} 
riding a blue horse with a black bottom; Putra Nakpo ${ }^{964}$ riding a small mule; an arhat wearing a wooden summer hat and riding a camel; ${ }^{965}$ and Jagö Tangnak ${ }^{966}$ throwing a vajra. ${ }^{967}$ There are great skeleton servants, ${ }^{968} 100$ of which are holding aloft victory banners [topped with the heads] of vultures, and 100 of which are holding aloft victory banners [topped with the heads] of lions. There are Lords of Life, 100 of which are holding aloft flaming [military] standards, and 100 of which are holding aloft silk ribbons and victory banners. There are 100 armored Lords of Life and great skeleton servants. [54] There are 100 quarreling ${ }^{969}$ white lions and 100 racing blue wolves. There are 100 black female hindering-planetary spirits holding aloft victory banners [topped with the heads] of peacocks. There are 100 packs of black horses, black mules, and black dogs. There are 100 camels loaded with notched wooden plates ${ }^{970}$ that [summon] hindering spirits. There are 100 emissaries, ${ }^{971}$ mounted on white horses, and100 black Mön. Of those emanations that have a variety of repulsive forms, 100 of those who shine ${ }^{972}$ hold aloft silk victory banners; 100 of those who are covetous ${ }^{973}$ hold aloft victory banners [topped with the heads] of tigers; 100 of those who devour ${ }^{974}$ hold aloft victory banners [topped with the heads] of wolves; and 100 of those who fly ${ }^{975}$ hold aloft victory banners [topped with the heads] of vultures. There are 100 [deities] holding aloft victory banners [topped with the heads] of mongooses and peacocks. [Lastly,] there are 100 [deities] holding aloft victory banners [topped with the heads] of monkeys and cats.

The painters [were as follows]: ${ }^{976}$ the medium craftsmen were Jamyang Wangpo and Mentangpa Gönpo Tsering. [55] The remaining [craftsmen were] [483] Menlugpa (Sharling) Könchok, Lekpa Gyentsen, Jamyang Döndrup, (Shünshak) Kyikyak, Akuk, Sönam, Baklhuk, Drakpa, Köpa, (Jangteng) Tashi, (Zhöl) Lobzang, (Dechen) Püntsok Rabjang, Rinchen Dorjé, Penjor, Samdrup Tsering, (Pentsa) Lobzang, (Gentsang) Tseten, (Tsomé) Dorjé, (Zhendön) Kündrak, (Rampa) Draklokpa, (Zadam) Sönam Tashi, Tashi Döndrup, (Aku) Samdrup, Karkar, Akar, Padma Gyelpo, Lhasung, (Jokpo) Genyen, (Nyenpo) Jamyang, Patsap Gönpo, Genyen Gyelpo, Azin, Samdrup, Gyelpo, Lobzang, Döndrup Chödar, Jamyang Gyeltsen, Sönam Tashi, Dechok, Tenzin, Wangchuk, Lobzang Yarpel, Lhuklhuk, (Rongpa) Sönam Gyelpo, Umzé, (Panam) Gönpo, (Nyiding) Pendé, Tupwang Tenzin, and Tashi Döndrup. [56] Along with [the painting] there was some varnishing. The wise and compassionate medium craftsman [of the varnishers] was the Tantrika Karpa Tsepel. The remaining [craftsmen included] Ngawang Sönam, Tenzin,

\footnotetext{
${ }^{964}$ Tib. Spu gri [sic: tra] nag po; I have incorporated Lingön Padma Kelzang's correction here, since the context indicates that this refers to Pehar's minister, who also rides a mule.

965 This refers to Kyechik Marpo's minister, Dorjé Drakden, in his original form.

966 This is Shingjachen's minister.

${ }^{967}$ Gyajin's minister, the lord of life Jarawa, is oddly absent from this list.

968 Tib. ging chen.

969 Tib. 'khrab mo byed pa. Lingön Padma Kelzang considers the first word of this phrase to be a misspelling of $k h r a b$, making its meaning somehow relate to armor; however, I propose that it is a phonetic misspelling of 'thab mo byed pa, meaning to quarrel or fight. The trend of the next clause appears to agree with this interpretation.

${ }^{970}$ Tib. khram shing; this refers to wooden boards with crosses notched into them that are used in Tibetan sorcery to summon malicious spirits.

${ }^{971}$ Tib. kingka ra; Skt. kimkara; the common Tibetan abbreviation for this word, encountered above, is ging.

972 Tib. gsal byed; this likely refers to Indian devas.

973 Tib. rngams byed; this likely refers to Indian asuras.

974 Tib. za byed; this refers to rākșasas, a type of Indian demon.

975 Tib. lding byed; this likely refers to gandharvas, a type of Indian deity.

${ }^{976}$ Many of these names are given a toponym or clan affiliation in the manuscript edition of this text, which was transcribed by Lingön Padma Kelzang and Dobis Tsering Gyal; I include these added names in parentheses.
} 
(Künga Dorjé), Künga Jangchup, Penden Zangpo, Namsé, Sangyé Döndrup, Ngawang Dodé, Künga Rappel, (Tserna) Kelzang, Namgyel Tsultrim, Künga Gyatso, Ngedön Nyingpo, Lobzang Tenzin, Ngawang Chöpel, Ngawang Yeshé, Lodrö, Sangyé Künga, Sangyé Dönden, Sönam Norbu, (Lhakpu) Shenyen, (Drigung) Lhundrup, Sölsöl, Nesung, Sönam Sherap, Tashi Tsering, Orgyan, Dönyö, Loden, (Tseru) Gadöl, Yönten, Tashi Lhündrup, Püntsok Tsering, Lobzang Döndrup, (Jang) Trönpa Kapa, and (Nyetang) Trinlé Gyatso.

For the bas relief statues, [57] as stated above, there is Hayagrīva and his consort in accordance with the Lama's Secret Assembly [cycle]; ${ }^{977}$ the Five Sovereign Spirits, along with their consorts and ministers; Dorjé Drakden as envisioned by the Omniscient Sönam Gyatso [Third Dalai Lama], which was mixed with the clay of an ancient statue; a miraculous Dorjé Drakden, wearing the garments of the imperial spirits, as secretly envisioned by the Incomparable Sovereign, the Supreme Savior [Fifth Dalai Lama], ${ }^{978}$ as well as Dorjé Drakgyelma. In the Birch Tree Chapel, there is the venerable Lord of the Victorious Ones, the great Ominiscient One, [the Fifth Dalai Lama] Ngagi Wangchuk Lobzang Gyatso - the chief [statue]; the four successive bodies of Eminent One; ${ }^{979}$ the great Victorious One Tsongkhapa; Padmasambhava and his two consorts; ${ }^{980}$ the Eight Manifestations of Guru [Padmasambhava]; as well as the guardian of the [Buddha's] teachings, Dorjé Drakgyelma. In the four-pillared right upper chapel, there is the Lord of the Victorious Ones, the Omniscient [Fifth Dalai Lama] Lobzang Gyatso - the chief [statue]; the great venerable Tsongkhapa; Jamyang Chöjé; ${ }^{981}$ the Eight Medicine Buddhas; [58] Nāgeśvararāja; ${ }^{982}$ Roaring Lion Avalokiteśvara; ${ }^{983}$ White Tārā; Tārā of the Acacia Forest; ${ }^{984}$ Tārā who Protects against the Eight Fears; ${ }^{985}$ Turquoise [Vajra]vidārana; ${ }^{986}$ as well as Pratisarā. ${ }^{987}$ In the four-pillared left [upper chapel], there are the Buddhas of Three Times; the 16 Noble Sthaviras; Dharmatala; the Four Great Kings; as well as Hwashang [Mahāyāna].

The sculptors who built such images [are as follows]: [The chief craftsmen] were Epa Umzé Bakdro and Chöpel, and the lesser craftman was Pelzin. The remaining [craftsmen included] [484] Tsönchung, Lobzang Tenkyong, Orgyan Gönpo, Gyelwar Dargyé, Dzomtruk, Lobzang, Yutruk, Sönam Tsering, Sumga, Tenpel, Jamyang Dargyé, Awar, Norbu Tsering, Döndrup, Horgyel, Sumpel, Lobzang Norbu, and Norbu Dargyé. Their main supervisors were Lodrö Gyentsen, the high monk of Kabok, [59] as well as Chungwa Kyidrung Drapön and Gyeltse Chokbukpa. The supervisors for the corvée laborers were Changra Sönam and Zadam Tsering Döndrup.

\footnotetext{
${ }^{977}$ Tib. Bla ma gsang 'dus; this refers to a cycle of treasure texts rediscovered by Guru Chökyi Wangchuk (Gu ru Chos kyi dbang phyug, 1212-1270; TBRC: P326).

${ }_{978}$ This may refer to the vision the Fifth Dalai Lama had of Dorjé Drakden in 1653; see Karmay 1988, p.35.

979 This refers to the four previous Dalai Lamas.

980 Tib. O rgyan yab yum gsum; Padmasambhava's two consorts are Yeshé Tsogyel and Mandarava.

${ }^{981}$ Tib. 'Jam dbyangs chos rje Bkra shis dpal ldan, 1379-1449; TBRC: P35. This is the founder of Drepung Monastery.

982 Tib. Klu dbang gi rgyal po; lit. "Mighty King of the Serpent Spirits." This figure is the head of the system of 35 Confessional Buddhas (Tib. Ltung bshags sangs rgyas so lnga) developed by Tsongkhapa.

${ }^{983}$ Tib. Spyan ras gzigs seng ge sgra; Skt. Siṃhanāda Avalokiteśvara. This form of Avalokiteśvara rides a lion, as the name suggests.

984 Tib. Seng ldeng nags sgrol; Skt. Khadiravaniitāāa.

${ }^{985}$ Tib. Sgrol ma 'jigs pa brgyad skyabs [sic: skyob]; Skt. Așțamahābhaya Tārā.

986 Tib. [Rdo rje] rnam ’joms ljang sngon; Skt. Śyāmanīla Vajravidāraṇa.

${ }^{987}$ Tib. So sor 'brang ma.
} 
The central deities of these paintings and statues were designed according to the instructions and supplemental [texts] explained above, as well as in the astrological works; [however,] I did amend them. Prior to doing this, from blessing the craftsmen, tools, and life tree, ${ }^{988}$ to [writing] the guide book, consecrating [the site], and opening the eyes [of the images], the monk Jamyang Drakpa ordered such activities, which were [discussed] above, and I placed my head at his feet.

The Great Holy Savior of all beings, including gods, [the Fifth Dalai Lama] gave instructions for the silk thread-cross mansions of various haughty spirits - such as the Five Sovereign Spirits, their consorts and ministers, as well as Dorjé Drakden ${ }^{989}$ - and, similarly, for the abundant torma materials. The shrine master Ngawang Sherap acted as the supervisor [for this].

Each monk in the college made an effort and they made wonderful things, [such as] [60] victory banners made of embroidered silk, which were topped with banners and included canopies. Their supervisors were Jagowa Lobzang Wangchuk, Peldor, Tashi Kapa, and the head tailor Ratse Shakpa Sönam. The remaining 32 [craftsmen] included (Gongkar) Ngayak.

Along with the images, inside [the monastery] there is, chiefly, the renowned body support [the Nechung Oracle]; consecration supports, represented by the four kinds of relics, ${ }^{990}$ as well as the outer, inner, secret, innermost secret, and supplemental Life Force Cakras. For the attachment supports, there are three things [that hold the deity's] soul syllables: [1] a [piece of] coral about the length of the sovereign spirit's hand, which gathers against his will whatever great power of his is not suitable or desired; [2] an immaculate square of white crystal [the size of] a single finger, which appeared within phenomenal existence [and] which makes it so that, even if the sovereign spirit is entrusted with infinite activities, there is no way he will no do them without obstruction; and [3] a complete shell of mother of pearl, [which makes it so] that the sovereign spirit will not turn against oneself, the object of accomplishment, or the master with his disciples and attendants, and that there is no way [the deity] will not accompany us like a shadow follows a body. [61] Such [items] originated from the tantras.

Furthermore, [regarding] the precious and high-quality [possessions]: There was a horse in China that would startle whenever it was turned; for this reason, when this would happen, it would need to be [carefully] supervised. This year, the proper karmic connections were right and the horse was presented [to the monastery] by the Dharma Lord Dungé. ${ }^{991}$ The horse's features and color were excellent and it had an agreeble disposition. ${ }^{992}$ Headed by this, there was the best in the world of the jewels of the gods, serpent spirits, and humans, such as, chiefly, silver ingots the size of bird's eggs, as well as [chunks of] coral the size of fresh peaches, [pieces of] soul-

\footnotetext{
988 Tib. srog shing; this does not refer to Pehar's soul tree, but rather to the central beam or axis that is placed at the sacred center of all monasteries, statues, and reliquaries - the axis mundi of such a site or object.

989 The original wall inscription has Rdo rje grags rgyal ma, while the manuscript amends this to Rdo rje grags ldan; see Sangs rgyas rgya mtsho n.dc., f.8a.1. The manuscript also adds bstan srung ("Protector of the [Buddha's] Teachngs") before the name. Given the context, I am interpreting the amendation to be correct. Nonetheless, that one deity is confused for another carries interesting implications.

${ }^{990}$ Tib. ring bsrel sna bzhi; this is a variant of ring bsrel rnam bzhi. These four are: [1] relics of the Dharma body (Tib. chos sku'i ring bsrel); [2] relics of the corpse (Tib. sku gdung ring bsrel); [3] relics of clothing (Tib. sku bal ring bsrel); and [4] miniature relics (Tib. nyung du lta bu'i ring bsrel).

${ }^{991}$ Tib. Dung ngad chos rje; Lingön Padma Kelzang has Dung dad chos rje. Regardless of spelling, the identity of this figure is unknown.

${ }^{992}$ Tib. glo ba tsam pa; this is read as a variant of blo dang 'tsham pa.
} 
turquoise the size of goose eggs, pearls, lapis lazuli, copper, and iron; riches, garments, silks, and fabrics; ripened ${ }^{993}$ grains like buckwheat and mustard seeds; as well as fruits like mangoes and jujubes. There was [also] a variety of medicinal pills [made from] different medicines - chiefly, white and red sandalwood that was neither poisonous nor fetid - and various kinds of food and drink, like the three whites and three sweets. ${ }^{994}$ Each and every one of the items of these final supports, as well as the images, thread-cross mansions, and tormas were complete. [485]

[62] Each day, barley was [ceremoniously] scattered and there were consecrations, as explained earlier, such as with the cakra sections. Moreover, during the main instructions, the monk Jamyang Drakpa acted as the supervisor for the recitations. Ngawang Trinlé, Ngawang Gyatso, Lekden Wangyel, the Tantric scholar Lobzang Kyechok, and the Dharma Lord Zilnön Dorjechen transcribed [the recitations]; the monk Jamyang Drakpa also completed [them]. At the time of the offerings, along with Miklha, the shrine master Ngawang Sherap, the monk Jamyang Drakpa, and the Tantric scholar Lobzang Kyechokchen acted according to the oral instructions.

When the dhäranīs were being inserted [into the statues], the Nechung Oracle's sword and wooden placard needed to be placed within the statue of [the Third Dalai Lama] Lord Sönam Gyatso's vision [of the deity]. The young monks know this, and now King Pekar and his retinue truly do come [here]. [However], on that day, those who inserted the dhäraniss were deceitful, so the known omens did not appear. [63] Then, from that night on, the sculptors from Epa were disturbed by ominous dreams and there were very bad signs. Because of this, they needed to receive blessings, ask the Nechung Oracle for advice, and so forth. These strange [events] took place over several days.

On the roof [of the monastery], inside a gañjira spire made from 2,000 zho ${ }^{995}$ of refined gold, blessed supports - chiefly, relics as small as mustard seeds - [were placed]. In order to bring good fortune to the region, an extraordinary circle of protection for pacifying, enriching, conquering, and destroying [was also placed]. [This consists of] $t u k^{996}$ supports for Dorjé Drakden on the right [of the gañjira] and [Dorjé] Drakgyelma on the left; in the northern area there are each of the Five [Sovereign Spirits] in the four cardinal directions, with the sovereign spirit of the mind [Gyajin] in the center. On [the roof of] the middle floor, for the support materials, there are victory banners of the four animals as well as silk. ${ }^{997}$ On the bottom [roof], the tuks of the five consorts [of the sovereign spirits] were placed. A circle of protection was also made in accordance with the oral instructions for each of them, decorated with their support materials. Various aristocratic victory banners, $t u k$, and silken ribbons were also established. ${ }^{998}$ When the gañjira was finished, the consecration [64] was performed by the monk Jamyang Drakpachen and the tuk rituals were performed by the Tantric scholar Lobzang Kyechokchen.

\footnotetext{
${ }^{993}$ Tib. min $p a$; this is read as a misspelling of smin $p a$.

${ }^{994}$ Tib. dkar gsum mngar gsum. The three whites are curds, milk, and butter, and the three sweets are sugar, molasses, and honey.

${ }_{995}$ Tib. zho; this is a traditional Tibetan measurement. One zho equals approximately one-tenth an ounce of gold or silver; ten zho equals one srang, or approximately one ounce of gold or silver; see French 2002, p.127.

${ }_{996} \mathrm{Tib}$. thug. This refers to a type of cylindrical banner found on the roves of Tibetan monasteries, generally covered with black yak or horse hair; see Alexander 2005, p.115.

${ }^{997}$ Four of these victory banners are topped with the heads of a tiger, wolf, vulture, and monkey, respectively, while the fifth is silk; see line 30 above.

${ }_{998}$ To see the orientation of the gañjira and these victory banners on the various levels of Nechung Monastery, see Ricca 1999, pp.48-50.
} 
The [iron] door bands are also decorated with various kinds of images of support materials and offerings. The supervisors for this were Zhika Nyingnying, Laok Tashi, and Lhomö Künga Dorjé. There were 32 blacksmiths. Their lesser craftsman was Otsangpa; the remaining [craftsmen included] Serzhu Kyikyak. There were 52 goldsmiths. Their head craftsmen were Tsechen Sönam Dargyé and Panam Gönpo; the remaining [craftsmen included] Ramgang Norbu. There were 15 silversmiths, such as Orgyan. There were 57 wool-spinners, such as Purtsa. They were supervised by Pari Tenzin and Drachi Norbu Döndrup. There were four dyers [for the wool]: Nyemo Karma, Tönpa Tsewang Sitar, the leathersmith ${ }^{999}$ Tsewang Dorjé, and the drummaker Trawa Gopachen. The four acrostic poems ${ }^{1000}$ on both sides of the [monastery's] entrances [were composed by] [65] Darlo Ngawang Püntsok Lhündrup and Namling Paṇchen Könchok Chödrak. The Indian and Tibetan letters [surrounding the poems] were painted [on the walls] by Gyantsé Jamyang Wangpo and Paksam Tsering. Those who gave the necessary salaries and such were Geshé Dargen and Busangpa Tsewang Tashi.

In the bird year [1681], the heads of Zangri, Neudong, Dratsang, Drongmé, and Drepung, the [Nechung] medium, the monks of Loseling, Gomang, Deyang, and the Tantric College, [486] Geshé Dargen, Tardongpa, and Busangpa conducted the construction feast. In the dog year [1682], the heads of Drepung, monks from Drongmé and Deyang College, the [Nechung] medium, Geshé Dargen, and Busangpa conducted the craftswork feast. [After] such things, the [monastery's] possessions and ancient images were properly established at the beginning of the $9^{\text {th }}$ month of the Water-Dog year [1682]. When these were transferred [to the monastery] on the $8^{\text {th }}$ day of the month - an auspicious [configuration of] planets and stars-various wondrous omens appeared. [66] Preparations were made for the temporary consecration on the $13^{\text {th }}$ day [of the month]. On the 14th [day], the Dalai Lama ${ }^{1001}$ [ceremoniously] scattered barley and meditated based on the mandala of the fierce blood-drinker Vajrakumāra, ${ }^{1002}$ the great Glorious One. He completed the approach, accomplishment, and activities of the peaceful and wrathful tutelary deities that insatiably drink the nectar of the glorious and holy lama's speech. The tantric master endowed with the three [wisdoms], the monk Jamyang Drakpa, acted as the vajra master [for the temporary consecration].

Subjugating external [forces] does not contradict enlightened conduct even for an instant. And so, the monastic assembly of Namgyel Monastery ${ }^{1003}$ - which abides in the profound yoga of the inner deity, mantra, and wisdom - directly inserted the wisdom being into the samaya being ${ }^{1004}$ and consecrated [the monastery]; [as a result,] a rain of flowers fell. ${ }^{1005}$

\footnotetext{
${ }^{999}$ Tib. bse mkhan; this refers specifically to rhinoceros leather.

${ }^{1000}$ Tib. kun 'khor; these Nechung acrostics have been transcribed in Tibetan Academy of Social Sciences 2009, pp.660-669.

${ }^{1001}$ Tib. gong sa mchog; lit. "Supreme Sovereign." This is a common epithet for the Dalai Lama. Given that this register was composed after the Great Fifth's death, it would seem Sangyé Gyatso is keeping up the appearance of the Dalai Lama's continued existence in official documentation for all to see.

${ }^{1002}$ Tib. Rdo rje gzhon nu; lit. "Young Vajra." This is an epithet for Vajrakîlāya.

${ }^{1003}$ Tib. Rnam par rgyal ba'i phan bde legs bshad gling; lit. "Palace that Elegantly Teaches the Happiness and WellBeing that Conquers All."

${ }^{1004}$ See Bentor 1996, pp.xix-xx.

${ }^{1005}$ The following paragraph is a significant portion of text that is found in the manuscript edition of Sangye Gyatso's section of the Nechung Register, as well as in the transcriptions by Lingön Padma Kelzang and Dobis Tsering Gyal; see Sangs rgyas rgya mtsho n.dc., ff.10a.3-10b.1. Although this additional information is not present in the wall inscription of the Nechung Register and was clearer added later, it provides greater detail on events
} 


\begin{abstract}
When that happened, the forces that obstructed the preparations were driven out; then the untimely storms were expelled and [the Nechung deity] was invited. At that time, a storm came from the direction of upper Dambak ${ }^{1006}$ and Drepung, and the whole of Nechung disappeared. From the life tree blessing to the consecration, dhärañi-insertion, and so forth, there was snow and rain by turns. Now, there are cloudless skies one day after another. During the consecration, concluding feast, and such, there was a snowstorm. In particular, although there was no [storm] whatsoever around Kyishö, ${ }^{1007}$ it stayed swirling over the hill behind Nechung and everybody saw it. From that day on, the magical effigies ${ }^{1008}$ would suddenly become heavier and heavier, and the carriers realized this. [Also,] Epa Umzé Bakdro had a portentous dream [that concerned him] going to see many monks in the Central Chapel; they squeezed [together] the forces obstructing ${ }^{1009}$ the statues and they were absorbed into the statue of the central sovereign spirit [Gyajin]. Furthermore, the monks of the college, the lay government officials, and others each had visions or [portentious] dreams. These abundant omens appeared, [showing] that haughty spirits of great trouble did actually live [around Nechung].
\end{abstract}

On the 15th day, an auspicious day for planets and stars - the favorable conjunction of Venus and Zeta Piscium - [67] the great Dharma Protector descended into the body of the [Nechung] medium, Tsewang Pelwar, and arranged the inauguration ceremony; this produced [much] delight. [The deity] is inseparably united with and resides within his abode; he is the attentive sentinel of the [Buddha's] teachings and sentient beings, and has promised to effortlessly accomplish the four activities.

Regarding the sublime completion of these wondrous things: this monastery and abode is distinquished by eight kinds of craftworks. The first distinquished [craftwork] is endowed with [the following] special qualities: The characteristics of the soul stones and life-force cakras mentioned above are not found anywhere else. In addition to this, even the paintings and sculptures look as if they were produced by the immortal craftsmen of the gods in human form; the appearance of these exceptional works is enchanting. The manufacturers are also visualized as deities, and the paint pigments, tools, and such are likewise consecrated and completely filled with blessings. In short, [68] If those with eye disease do nothing more than [see the basic] form of these paintings and sculptures, [487] they will spontaneously achieve the primordial nature of ultimate reality. Then the ocean of the oath-bound haughty spirits of phenomenal existence will assemble in reality, rolling without interruption like rainclouds gathering [in the sky], and perform the actions [entrusted to them].

The second [distinquished craftwork is as follows]: This Dharma Protector consumes an arrangement of whatever life breath [of] mortal beings he catches through countless manifestations. Even though he is like this, because it is the emanation [most] suitable for

surrounding Nechung Monastery's 1682 consecration. I include this material in the body of the text as a block quote, in a smaller font, and bolded to distinquish it from the content of the wall inscription proper.

1006 This word is spelled Dar phag here.

1007 Tib. Skyid shod; lit. "Lower Kyi[chu Valley]." This term generally refers to the area around the Kyichu River, including Lhasa; see Sørensen, Hazod, and Tsering Gyalbo 2007, pp.17-27. In this context, it refers especially to the area just below Nechung, at the base of the mountain and thereabouts.

1008 Tib. sku gsob 'phrul ma. It is unclear to what this refers, though it is likely the various statues that were carried to and installed at the monastery.

1009 Tib. chag dogs byed pa; this is read as a misspelling of chags thogs byed pa. 
subjugating anyone, he appeared as the physical manifestation [of] overwhelming splendor, [who came] by way of a coracle decorated with red turquoise jewels. He then dissolved into this birch Aśoka tree ${ }^{1010}$ endowed with a marvelous fragrance and abundant flowers and fruits - as the support that delights [this] manifestation-and abides in such a manner. Accordingly, this palace that delights the oath-bound [guardian deities] [69] was blessed with the great power that is the manifestation of the deity, mantra, and wisdom of the profound Vajra Yoga by the successive incarnations of the form that is meaningful to behold, who emanated supremely from the center of the lotus that is the heart of all the Victorious Ones of the Three Times-like the 2000 Buddhas of the good eon. ${ }^{1011}$ The great Dharma Protector, with great delight, also became inseparable from this divine mansion that is adorned with many gifts and material offerings; the supports [that cause this attachment] remain unimpaired in the assembly hall. These [supports] are like the life tree of this place - they are the essence of the supreme supports that delight [the deity]. Subsequently, in order to instill delight and [have the deity] protect the [Buddha's] teachings unimpaired, gifts, clouds of ever-excellent offerings, and all the wealth of the gods and humans are together spread out [over] the measureless shrine ${ }^{1012}$ where the real [offerings] are arranged; [the offerings] are dispersed in this way one after the other. These become the outer and inner supports and thus are distinquished.

The third [distinquished craftwork is as follows]: [70] Even if one [just] looks at the beam and rafter junctures at the edges of the Central Chapel, it can make the heart tremble and cause [people] to flee. There are human skins, snakes endowed with the qualities of the five [Buddha] families, razors, knives, and swords, as well as lightning and hail being vomited from the mouths of thunder [dragons]. These superior works of art are terrifying and [cause people] to shudder in fear.

The fourth [distinquished craftwork is as follows]: The internal doors appear as the three bodies [of the Buddha] within the state of the three doors of liberation. ${ }^{1013}$ Beyond this, there are the five doors that represent the Five Great Sovereign Spirits [who are] the self-manifestations of the Five Wisdoms. ${ }^{1014}$ These [five doors] are incredibly vast; they are so wide that even if all the living beings in the three worlds were to enter them at the same time, they would [still] fit through them without a doubt. Even the façades ${ }^{1015}$ [of the doors] reach the pinnacle of existence. [The doors] are regarded as [a sign that] the palace and courtyard of the pair of five necks ${ }^{1016}$ have been accepted into this savage land. Thus, these are special [doors] endowed with magnificence.

\footnotetext{
${ }^{1010}$ Tib. mya ngan med pa'i ljon shing; lit. "sorrowless tree." This tree's taxonomic name is Saraca asoca.

1011 This lengthy epithet refers to the Dalai Lama.

${ }^{1012}$ Tib. gzhal yas; in this context, this term refers to a large shrine dedicated to the deities where their offerings are displayed.

${ }^{1013}$ Tib. rnam thar sgo gsum. Symbolically, this refers to the three approaches to liberation: [1] emptiness (Tib. stong pa nyid), [2] aspirationlessness (Tib. smon pa med pa), and [3] attributelessness (Tib. mtshan nyid med pa). Here this term refers to the three doors that lead into the Central Chapel.

${ }^{1014}$ These are the five doors that lead into the assembly hall from the courtyard; see Figure 42 for the placement of the three doors leading to the Central Chapel as well as these five doors.

${ }^{1015}$ Tib. babs gdong; lit. "surface condition." The meaning of this term is difficult to fully ascertain; however, the context suggests it pertains to the nature and size of the doors.

1016 Tib. mgrin pa lnga zung; this refers to the Five Sovereign Spirits and their consorts.
} 
The fifth [distinquished craftwork is as follows]: The threshold door frames are fully established with dangling ornaments fastened by the self-existing [forms] of snakes hanging from the mouths of corpse heads. ${ }^{1017}$ [71] These marvelous [door frames] can cause even an intelligent person's heart to jump up into their throat.

The sixth [distinquished craftwork is as follows]: On the peak [of the monastery, the spire with] the nature of refined gold can block out the splendor of a hundred thousand suns. This great gañjira was established to complete the body, speech, and mind supports, together with the outer, inner, and most profound [supports], in order for the leader of the haughty spirits and his retinue to accomplish the four activities without obstruction. This [spire] is a special work of art, such that it rivals the top story of a barbaric spirit's palace, where the oath-bound [guardians] are naturally gathered and the garlands of golden roof ornaments ${ }^{1018}$ and garlands of dried human heads are arranged in order by appearance.

[488] The seventh [distinquished craftwork is as follows]: On the outside, this abode for the haughty spirits was actually established [with] the attributes of a mandala. In the east, south, west, and north [of the monastery], respectively, there is a gate that accords with a color of the four activities, ${ }^{1019}$ a stylobate sitting on the ground, and an archway supported by pillars; these complete the faultless appearance of the divine mansion. [72] The parapet balustrades on the rooves and the garlands of dried skulls on the ruby-colored friezes radiate light in a hundred directions; therefore, the opportunities for darkness [to take over the ten] directions are diminished. These eight parts represent the eight great planets; ${ }^{1020}$ such is the special quality [of this monastery].

The eighth [distinquished craftwork is as follows]: The wall plaster of blood ${ }^{1021}$ that liberates [those suffering from] the ten defects is completely stirred [with] bubble garlands of fat and brains, thus actualizing the house of [Yama,] the Lord of Death. [This blood] is seething and churning like clouds ${ }^{1022}$ close to pouring down a deluge of rain. Furthermore, [the monastery's] sixteen pillars represent the sixteen [deities] - the fifteen Dharma protectors ${ }^{1023}$ and the kimnaras. ${ }^{1024}$ This design is [truly] distinquished!

The roars of the terrifying ones [the Five Sovereign Spirits] who strike and kill resound like a thousand thunder claps rumbling simultaneously. Accompanying [them], all the haughty spirits

\footnotetext{
1017 See Figure 41 for a glimpse of these macabre door frame decorations.

1018 Tib. gser phru'i sba phreng; the specific meaning of this term is difficult to ascertain.

1019 These collors are white for pacifying activities, yellow for augmenting activities, red for subjugating activities, and black for destructive activities.

${ }^{1020}$ Tib. gza' brgya chen; The eight planets in traditional Indo-Tibetan astrology are [1] the Sun (Tib. Nyi ma; Skt. Sūrya), [2] the Moon (Tib. Zla ba; Skt. Candra), [3] Mars (Tib. Mig dmar; Skt. Mañgala), [4] Mercury (Tib. Lhag pa; Skt. Budha), [5] Jupiter (Tib. Phur bu; Skt. Bṛhaspati), [6] Venus (Tib. Pa sangs; Skt. Śukra), [7] Saturn (Tib. Spen pa; Skt. Śani), and [8] Rāhula (Tib. Sgra gcan). The eight parts likely refer to [1-4] the four gates of the cardinal directions, [5] the stylobate, [6] the archways, [7] the balustrades, and [8] the skull garlands.

${ }^{1021}$ Tib. khrag gi zhal ba; this refers to the ocean of blood painted on the lower register of all the murals along the entrance, courtyard, and assembly hall.

1022 Tib. nam mkha'i glang po; lit. "bull of the sky."

${ }^{1023}$ It is unclear to which fifteen Dharma protectors this refers. Given that this concerns the assembly hall, it could be 15 of its 18 murals, sans the two images of the Nechung Oracle and a painting of Padmasambhava. This could also refer to the Five Sovereign Spirits along with each of their consorts and ministers.

${ }^{1024}$ Tib. mi' am ci; this refers to the animal-headed attendants of the Dharma protectors.
} 
[of] the eight classes of gods and spirits attached to the field of imputations ${ }^{1025}$ gather automatically, like bees swarming over piles of utterly fetid rotten meat or carnivorous beasts in charnel grounds trotting and running toward the steaming odor of warm flesh and blood. [73] The heaps of their outer, inner, and secret support objects, gifts, and clouds of offerings are piled up throughout heaven and earth without interruption; they are [fully] contained within this great palace for the eight classes of haughty spirits.

The great Dharma center where the ethical monastic community lives upholds, preserves, and spreads the tradition of the Gentle Savior lama [Tsongkhapa], the immaculate teachings of the Buddha, and is like an overflowing pile of the wise arhat's white rice. [Located among] its foothills-

This abode where the eight classes of haughty spirits automatically gather is not small; ${ }^{1026}$ it can hold the vast expanse [of] existence. This grove that pleases the emanated sovereign spirit Pekar, his consort, and minister is a marvelous chapel that is distinquished by eight kinds of craftworks.

[Nechung] was begun in the Iron-Bird year [1681] and thoroughly established in the third-eon year 'Splendor of Melted Cymophane' [1682?]. ${ }^{1027}$ This amazing monastery, erected with the efforts [of] body, speech, and mind, ${ }^{1028}$ is marvelous!

[74] Such efforts were necessary; ${ }^{1029}$ [now] the teachings of those who wear the yellow hats [the Gelukpa] have utterly reached, without obstruction, the pinnacle of existence. The religious and secular [government] of the joyous all-victorious palace pervades everything like the light of the sun and the moon.

May the lotus feet ${ }^{1030}$ of the Omniscient Vajra-Holder, the Universal Lord of the One Hundred [Buddha] Families [the Dalai Lama], remain steadfast for innumerable eons; ${ }^{1031}$ may the actions that he desires [be performed] without delay; and may a Dharma banquet always be held [here].

\footnotetext{
${ }^{1025}$ Tib. brtag chags kyi lha ma srin sde brgyad; this is read as a variant of btags shing chags pa'i lha srin sde brgyad.

${ }^{1026}$ Referring to the fourth distinquished craftwork, this line interprets the monastery's name ironically. Despite being called "Small Abode," it is considered a sacred realm vast enough to hold all of existence.

${ }^{1027}$ Tib. bai d̦üra [sic: d̦ürya] zhun ma'i mdangs 'dzin sum ldan lor; it is clear that this line refers to a Tibetan year, though it is uncertain to which specific year it refers. This phrase appears to extend from an esoteric system of poetic labels for specific Tibetan years.

1028 Tib. sgo gsum; lit. "three doors."

1029 Tib. dges; this is read as a misspelling of dgos.

${ }_{1030}$ Tib. zhabs pad; this term is an honorific epithet for high officials.

1031 Tib. bskal pa rgya mtsho; lit. "oceans of eons."
} 
[The Five Sovereign Spirits] successfully accomplish the [four] activities that pacify, subjugate, destroy, and augment [against] all the diseases, negative influences, and obstacles for those who perform [the above rites]. [These deities] conquer the demon armies, remain [in] vajra-like immortality, and quickly accomplish [whatever is] desired without exception.

May the auspicious sun of new light simultaneously smile [down on this] lotus grove of virtue and goodness, and destroy the intense darkness of savage beings and malevolent ghosts! May the sun ${ }^{1032}$ of joy and happiness pervade [all]!

This register was bestowed by the Supreme Sovereign [the Fifth Dalai Lama]; [75] Drongmepa Sangyé Gyatso hand-wrote most of it, [having] accepted the responsibility of secretary by way of this finely detailed service. Other writing duties were done by the two Changtens. ${ }^{1033}$ [This register] was written in the Water-Dog year [1682]. ${ }^{1034}$ May it be Victorious! ${ }^{1035}$

May all living beings prosper! ${ }^{1036}$

1032 Tib. rta bdun dbang po; lit. "Lord of Seven Horses; an epithet for the Indian sun god Sūrya." This line illustrates the depth of Sangyé Gyatso's poetic knowledge; he was quite skilled at filling the meter with an impressive array of idioms and epithets, as the third quatrain above also illustrates.

${ }^{1033}$ Tib. chang bstan; it is unclear whether this is a name or a job title.

${ }^{1034}$ Tib. rnga chen gyi lo; lit. "year of the large drum." This term is a poetic synonym for the Water-Dog year (Tib. chu khyi).

${ }^{1035}$ Tib. dza yantu; Skt. jayantu.

${ }^{1036}$ Skt. śubhamastusarvajagatam. 


\section{Appendix IV}

\section{The Hagiography of Jokpa Jangchup Penden}

The Hagiography of Jokpa Jangchup Penden is a short 18-folio biography of Jokpa Jangchup Penden, ${ }^{1}$ the founder and first abbot of Deyang College at Drepung Monastery as well as the founder of Nechung Chapel. The full title of the text is A Summary of the Hagiography of Jokpa Jangchup Pendenpa along with the Origins of the Great Dharma Protector. ${ }^{2}$ According to Per Sørensen and Guntram Hazod, this text was composed by the regent Sangyé Gyatso. ${ }^{3}$ However, this is in question since the text contradicts a claim made in the portion of the Nechung Register also composed by Sangyé Gyatso, which states that the deity Pehar left Tsel Yangön Monastery with the Second Dalai Lama. The text itself does not explain its authorship; however, we know it was composed within a century after Nechung Monastery's seventeenth-century expansion. The hagiography quotes heavily from the Nechung Register, placing it after 1682, and it was in turn quoted in the Gung thang dkar chag, placing it before $1782 .{ }^{4}$

This text is particularly difficult to read. It has numerous misspellings, the grammar is often unruly, and sentences sometimes appear to interrupt one another. The quotations from the Nechung Register are also haphazard and even redundant at one point. Nevertheless, it is the most detailed account so far available on the mythic events surrounding Pehar's arrival at Nechung. Moreover, one unexpected value of this text is that it occasionally cites portions of the Nechung Register that have since been too damaged to transcribe reliably. Although the hagiography paraphrases from the register just as much as it quotes-making a confident rendering of the damaged text unlikely - it still offers significant insights into the Nechung Register's contents that are otherwise unavailable.

This final appendix consists of two parts. The first part is a transcription of the original manuscript of the Hagiography of Jokpa Jangchup Penden, typed using the common 'headed' (Tib. $d b u$ can) Tibetan script. The original manuscript was written with the 'headless' Tibetan script (Tib. dbu med) and uses many abbreviations (Tib. bskungs yig), some of which are very

\footnotetext{
${ }^{1}$ Lcog pa Byang chub dpal ldan, 1404/1464-1471/1531.

2 Tib. Lcog pa byang chub dpal ldan pa'i rnam thar rags bsdus chos skyong chen po'i 'byung khungs dang bcas pa. The bibliographic reference for this text is Sangs rgyas rgya mtsho n.da.

${ }^{3}$ See Sørensen, Hazod, and Tsering Gyalbo 2007, p.217n.572.

${ }^{4}$ See ibid, p. 13.
} 
obscure. I would like to thank Mikmar Tsering for taking the time to personally parse out these abbreviations with me. Along with the color-coding seen in Appendix II, I have highlighted in blue all passages quoted or paraphrased from the Nechung Register. The second part of this appendix is a facsimile of the manuscript itself, based on a photocopy generously provided to me by Tsering Gyelbo. This rich text is given here so that it may gain more exposure, since it is otherwise only available at the Tibetan Academy of Social Sciences in Lhasa.

I do not include a full translation of this text for two reasons. First, a translation of those portions that quote or summarize the Nechung Register would be redundant. Second, two key sections, Pehar's arrival and Deyang College's founding, have already been translated and presented in chapters 2 and 4, respectively. Nevertheless, along with the Tibetan transcription and manuscript of the text, I offer below an index of its contents enumerated by folio page:

1. 1a: Title page.

2. 1b: The Buddha's prophecy regarding Jokpa Jangchup Penden.

3. 2a.5-3a.4: Jangchup Penden's birth circumstances; born in the morning of the $10^{\text {th }}$ day of the $1^{\text {st }}$ month of the Wood-Male-Monkey year (2b.4-5).

4. 3a.4-5: Jangchup Penden becomes a lay devotee (Tib. dge bsnyen) at the age of 11.

5. 3b.6: Jangchup Penden becomes a novice monk (Tib. dge tshul) at the age of 14 .

6. 4a.2: Jangchup Penden becomes a fully-ordained monk (Tib. bsnyen par rdzogs pa) at the age of 25 .

7. 4a.3-6: Text quotes Nechung Register, lines 11-12 (Fifth Dalai Lama section).

8. 4a.6: Text quotes Nechung Register, short sentence in lines 9-10 (Fifth Dalai Lama section).

9. 4a.6-4b.2: Text quotes Nechung Register, tantra verse on line 9 (Fifth Dalai Lama section).

10. 4b.2-5: Text quotes Nechung Register, lines 41-42, (Sangyé Gyatso section).

11. 5a.5-5b.1: Text states that Pehar is a supramundane protector deity.

12. 5b.1-6b.1: Text quotes Nechung Register, lines 9-11 (Fifth Dalai Lama section).

13. 6b.1-7a.4: Continues the previous quote by requoting passages from the Nechung Register already given on ff.4a.3-4b.5.

14. 7a.6-7b.6: Text interrupts and intersects the previous quote; elaborates on and quotes Nechung Register, lines 12-13 (Fifth Dalai Lama section). 
15. 7b.6-8a.1: Text skips some of the Nechung Register then continues quoting line 13 (Fifth Dalai Lama section).

16. 8a.1-4: Text summarizes the story of Pehar and Padmasambhava from the Nechung Register, line 13 (Fifth Dalai Lama section).

17. 8a.4-8b.5: Text abbreviates and quotes Nechung Register, lines 42-44 (Sangyé Gyatso section).

18. 8b.5-10a.5: Jangchup Penden founds Deyang College at the age of 37.

19. 10a.5-11a.3: When Jangchup Penden is 66 years old, there is a conflict between Pehar and Donyö Dorjé that results in the former leaving Tsel Yangön; this occurs on the $3^{\text {rd }}$ day of the $1^{\text {st }}$ month of the Earth-Ox year.

a. 10a.6-10b.2: Pehar takes possession of a medium [1]

b. 10b.6-11a.3: Pehar takes possession of a medium [2].

20. 11a.3-6: Jangchup Penden has a clairvoyant dream about Pehar's arrival.

21. 11b.1-14b.1: Pehar arrives on the banks of the Kyichu River below Dambak Marserchen on the $5^{\text {th }}$ day of the $1^{\text {st }}$ month.

a. 11b.5-12a.3: Pehar takes possession of a medium [3].

b. 12b.1-13a.5: Pehar takes possession of a medium [4].

22. 14b.1-15a.2: Pehar takes possession of a medium [5].

23. 16a.1-16b.2: Jangchup Penden dies in the Iron-Male-Rabbit year at the age of 68 .

24. 16b.2-17a.1: Pehar takes possession of a medium [6].

25. 17b.1-18a.3: Colophon. 


\section{Hagiography of Jokpa Jangchup Penden Transcription}

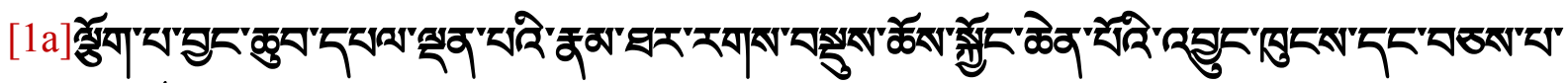

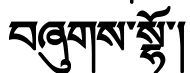

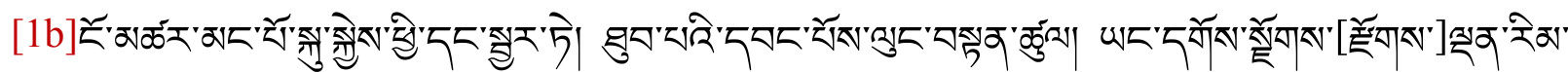

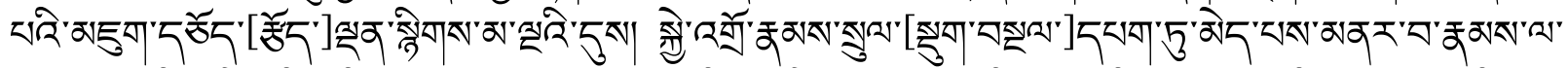

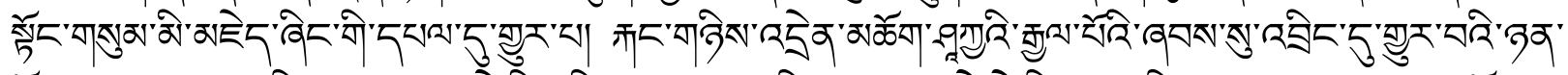

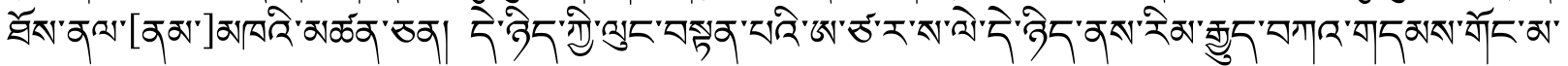

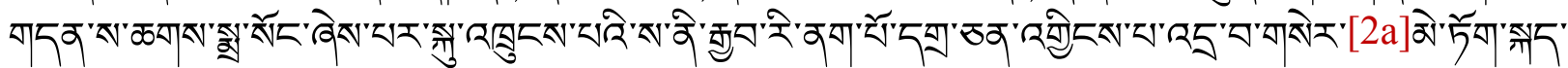

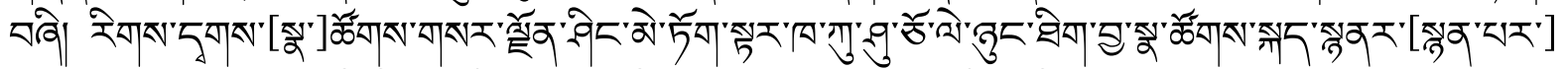

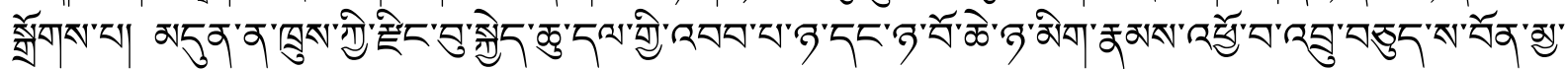

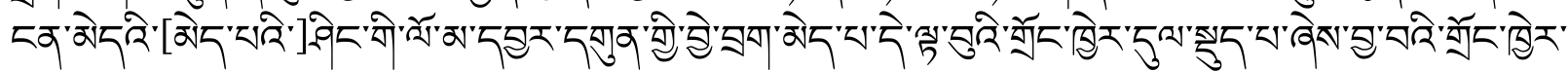

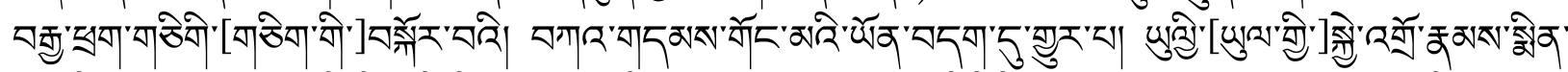

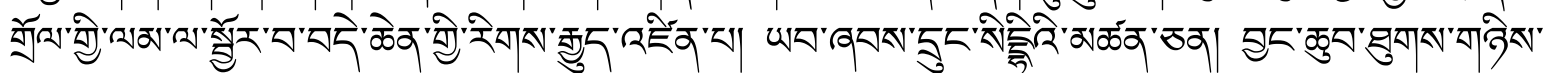

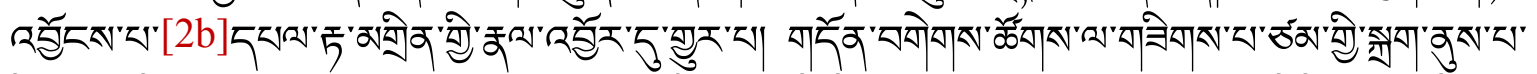

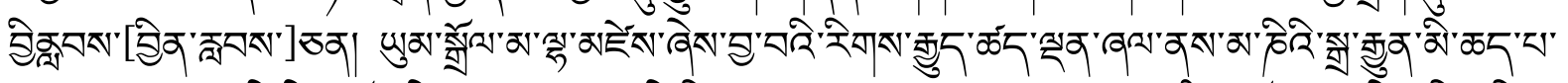

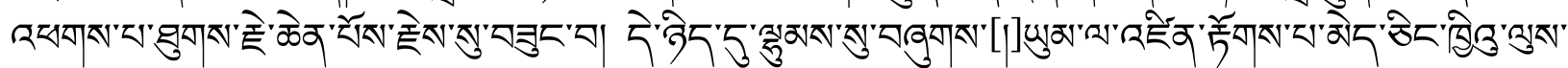

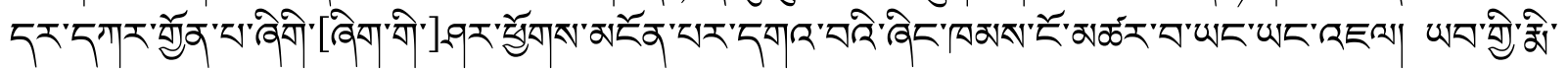

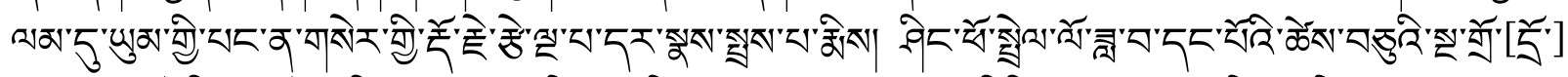

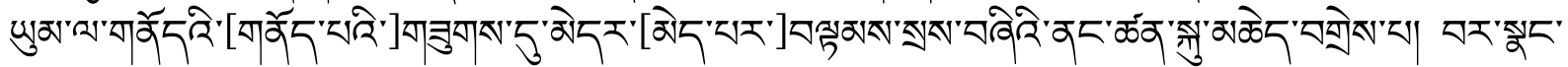

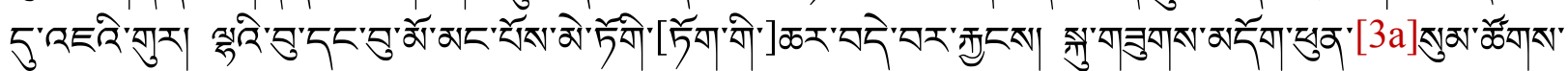

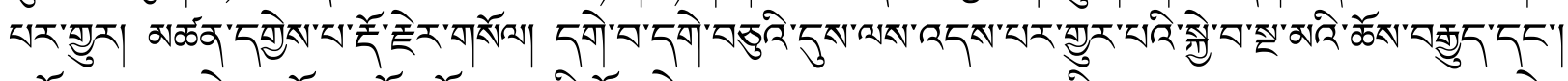

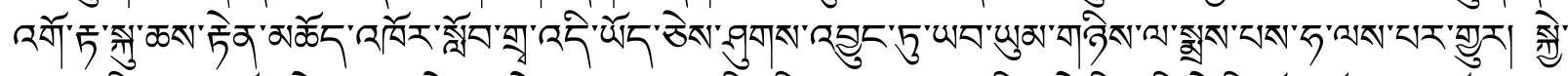

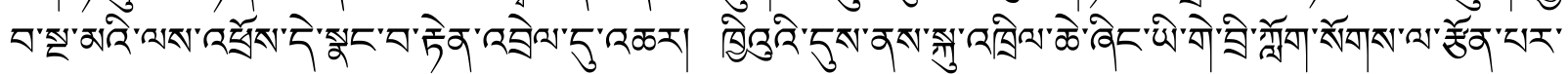

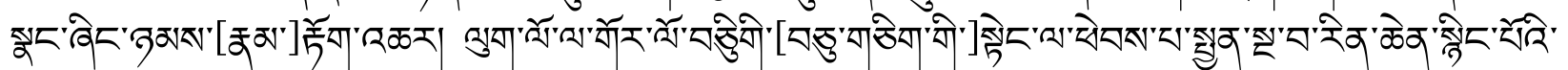

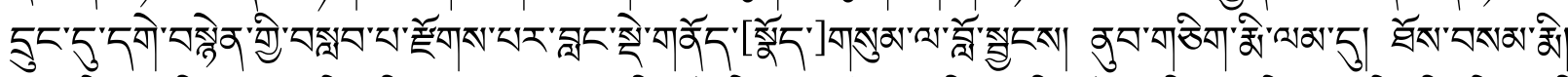

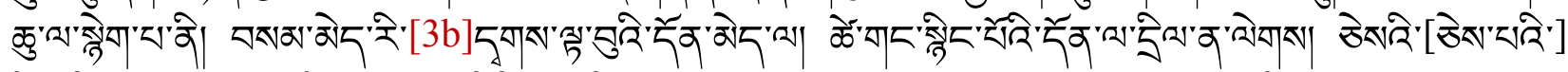

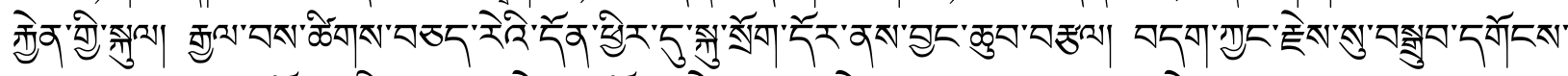

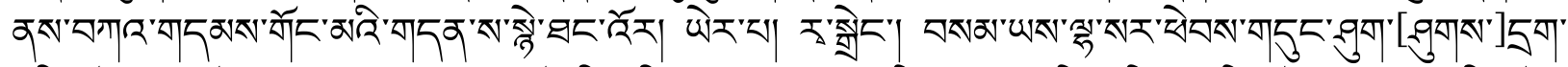

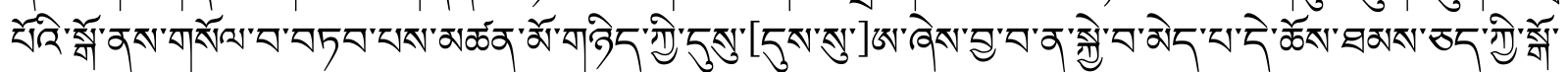

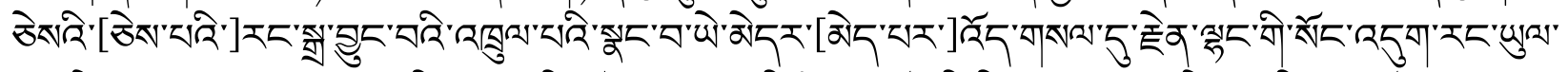

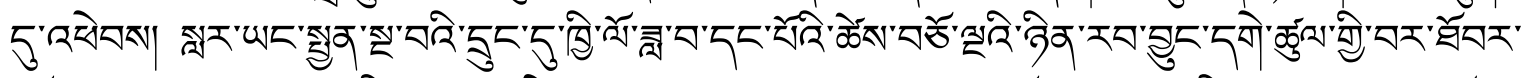

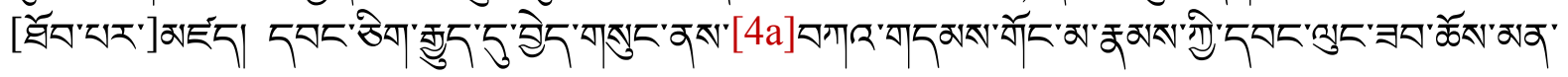




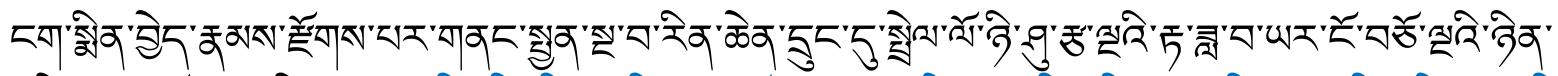

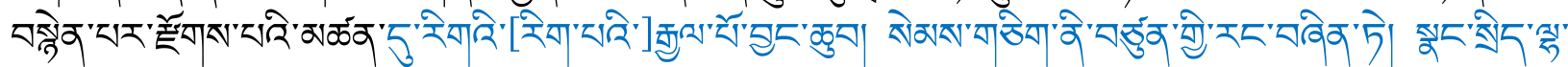

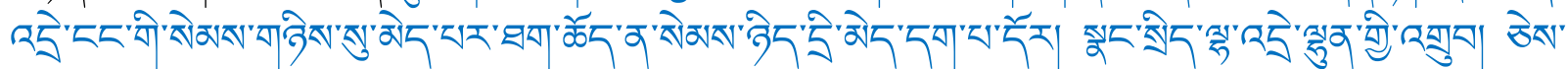

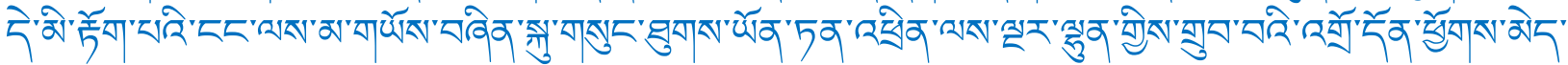

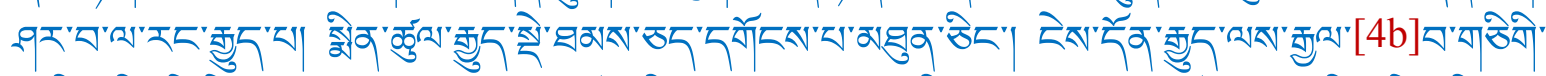

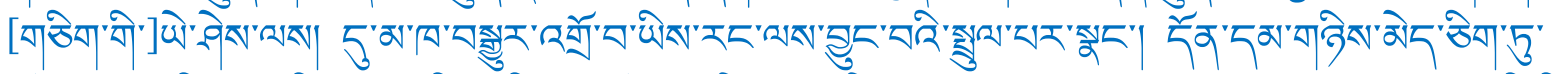

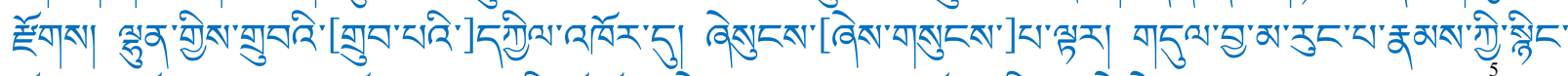

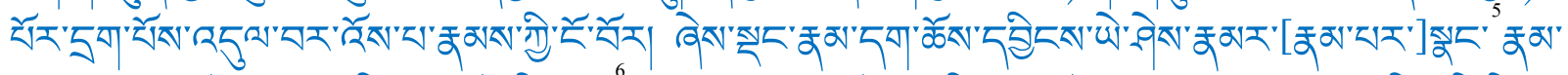

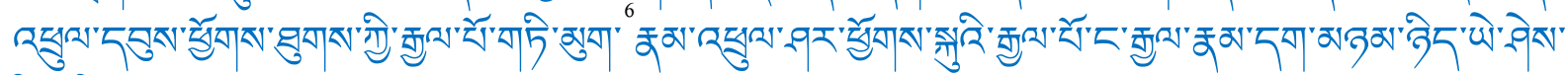

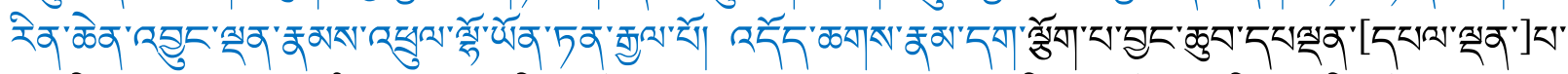

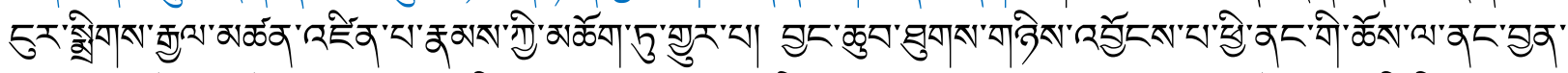

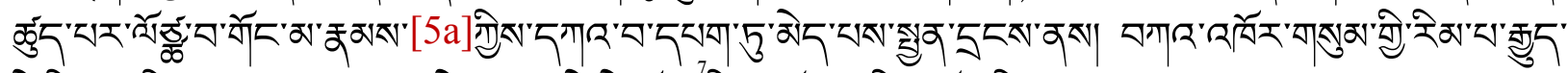

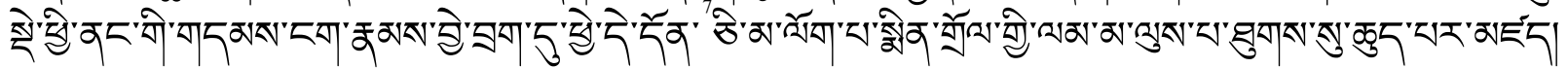

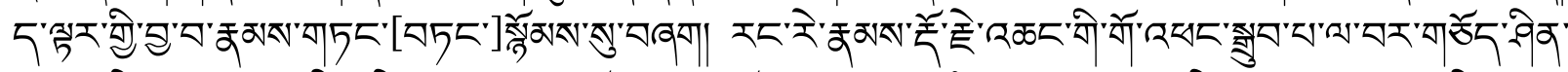

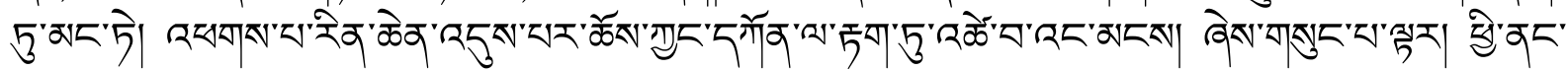

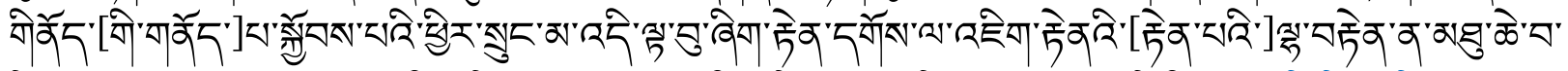

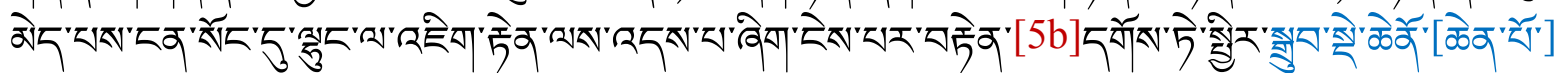

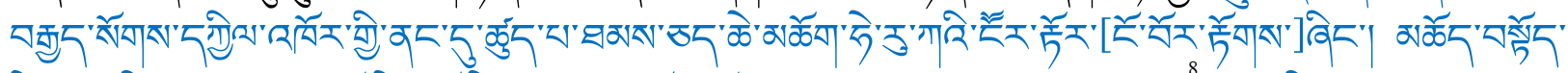

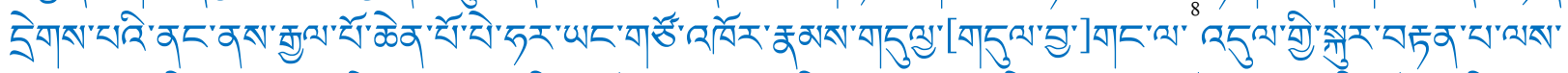

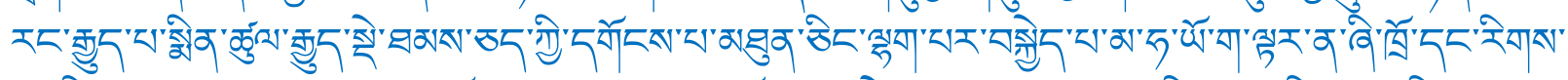

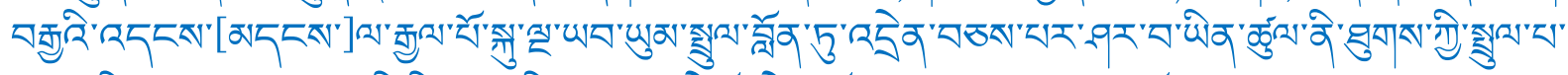

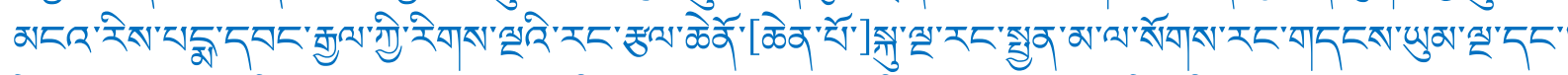

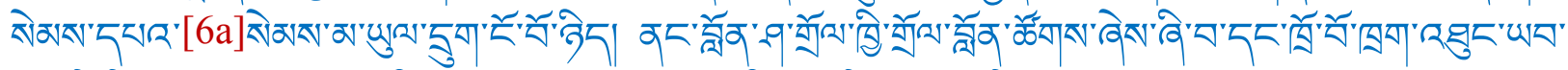

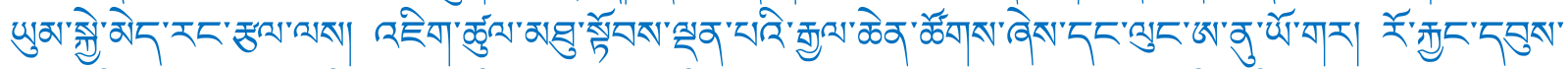

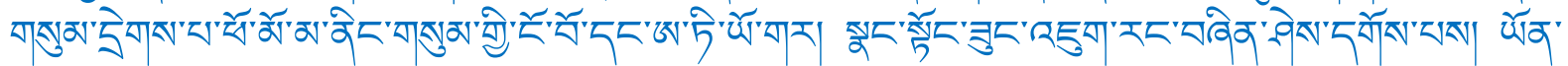

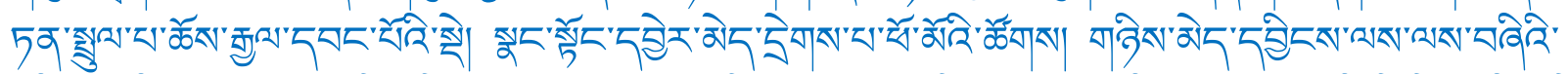

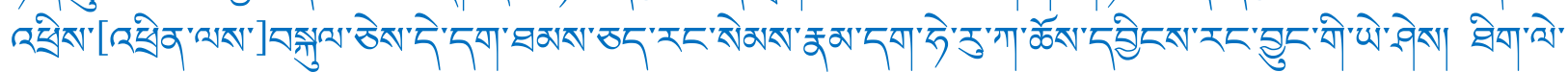

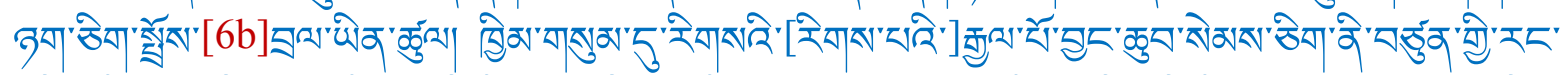

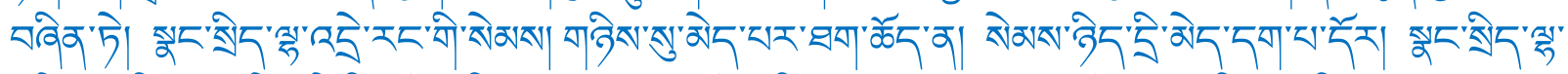

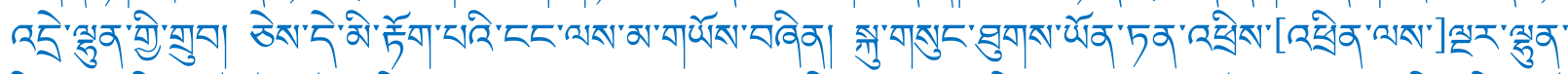

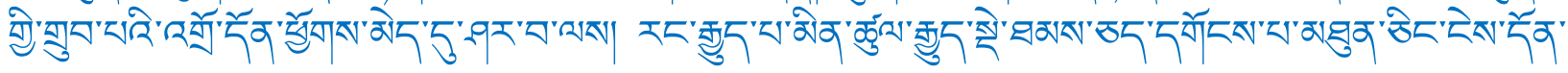

\footnotetext{
5 वहूॅ'

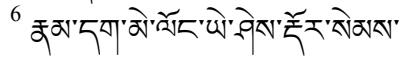

7 ड्रेव

${ }^{8}$ पार
} 


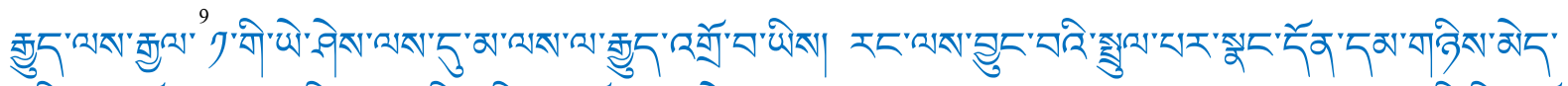

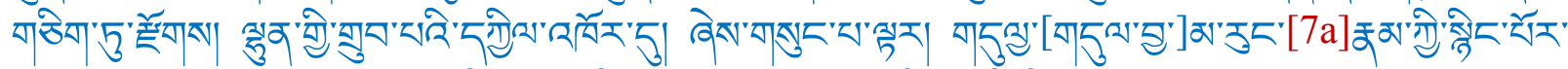

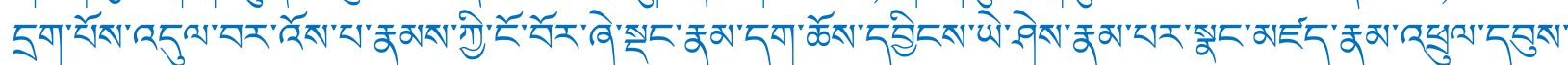

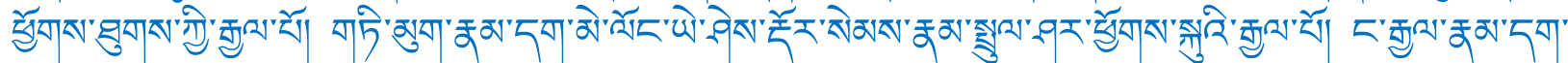

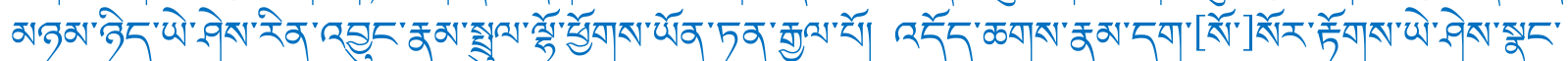

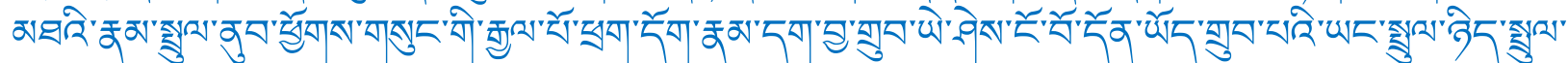

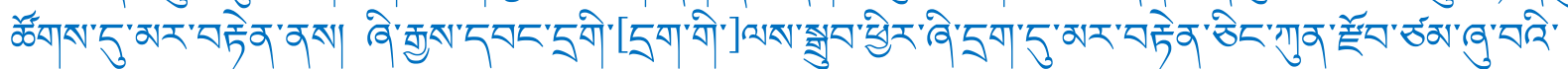

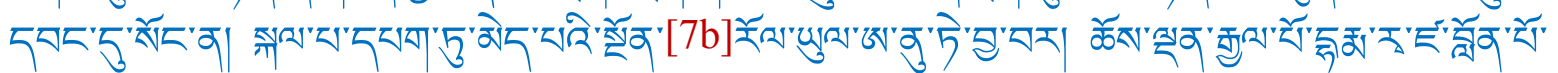

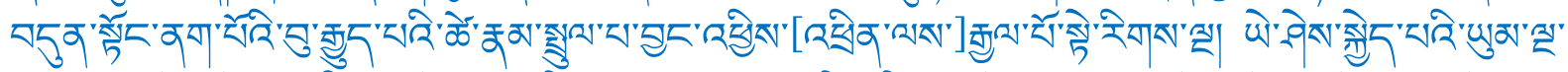

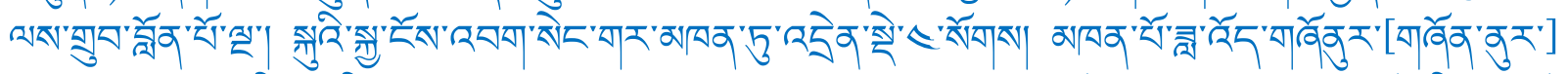

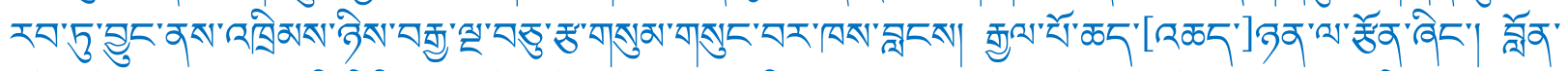

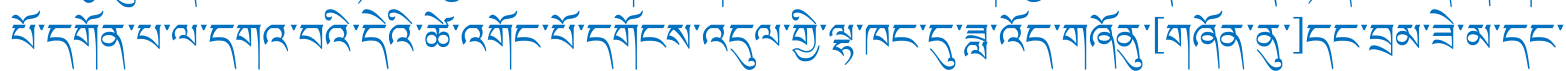

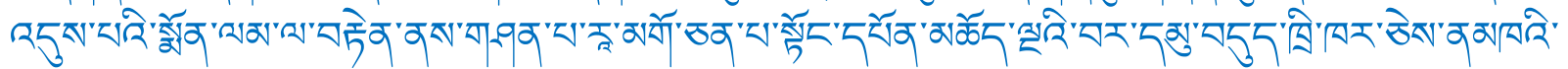

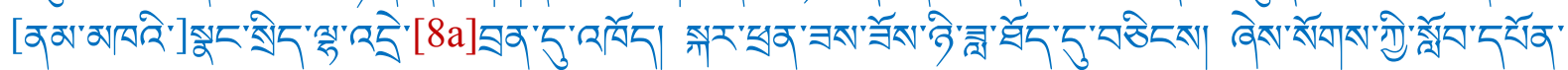

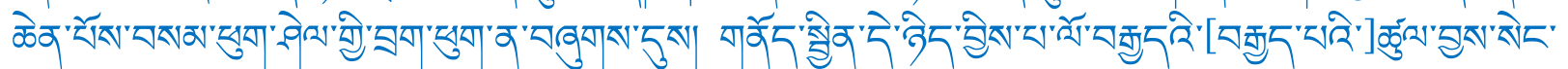

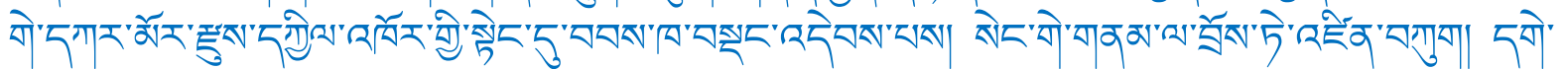

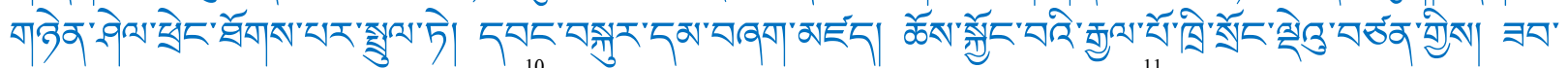

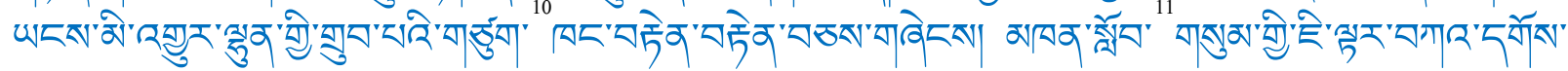

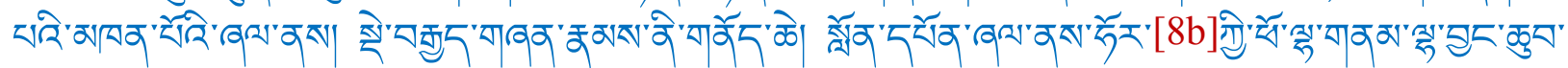

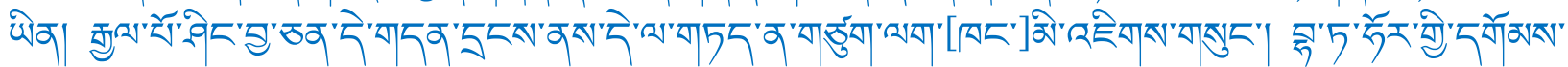

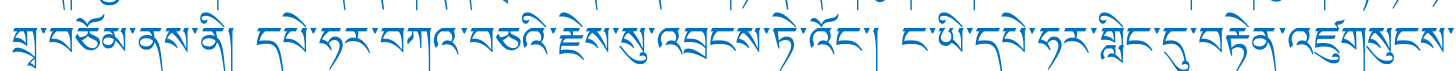

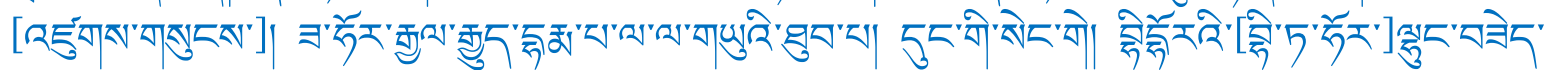

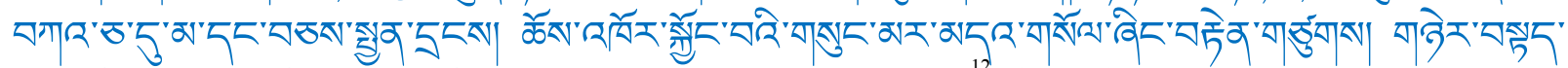

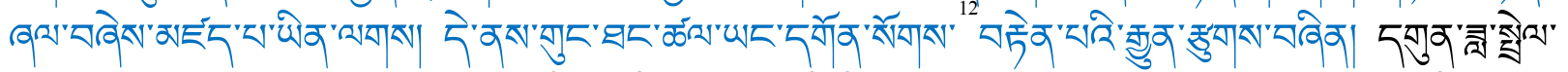

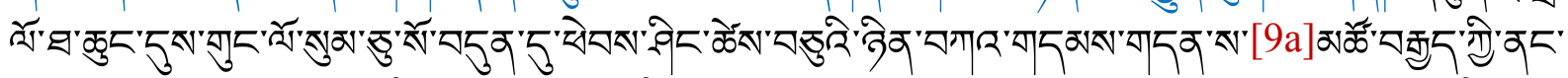

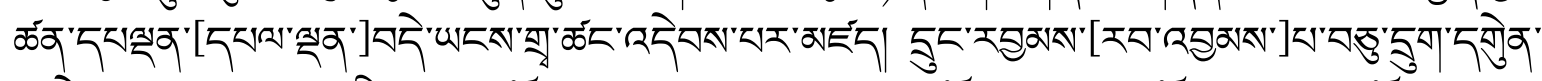

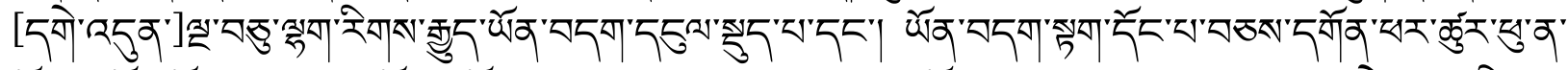

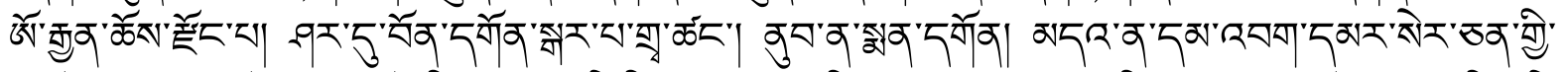

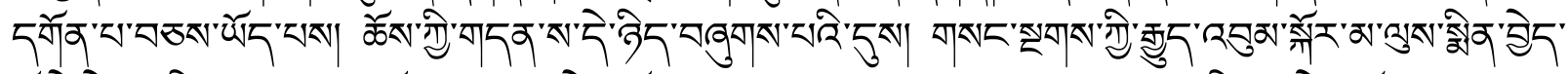

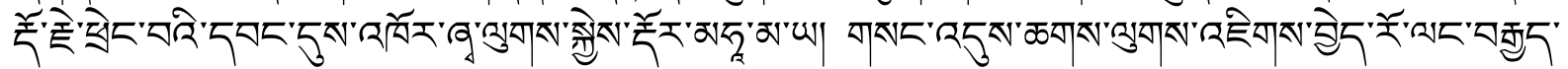

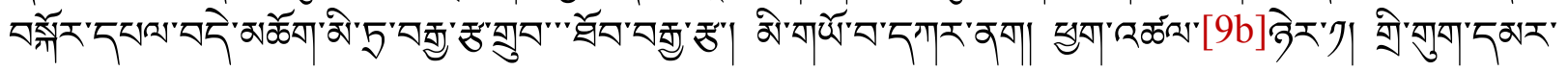

\footnotetext{
${ }^{9} \square$

10 जबा

11 केसे"

12 太ู
} 


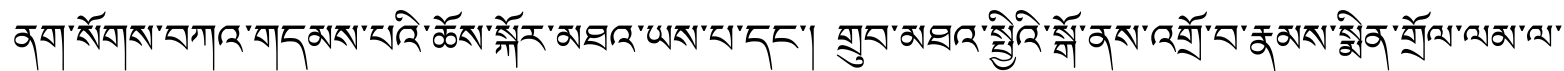

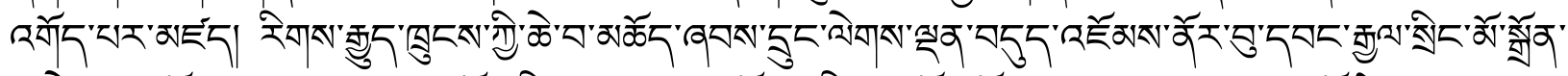

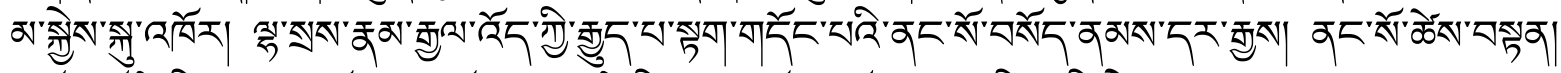

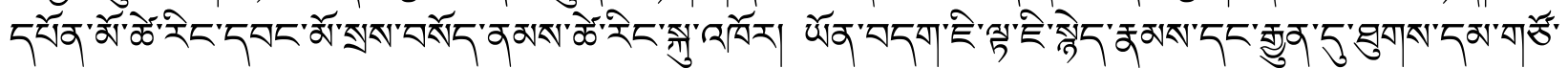

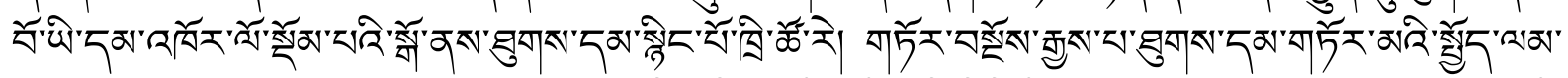

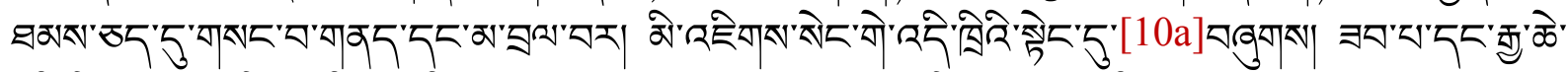

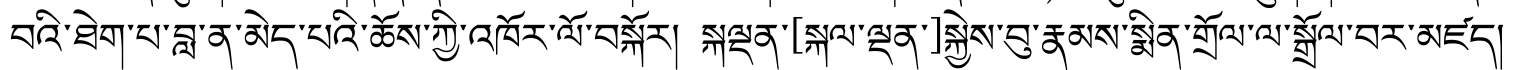
"ा万ु

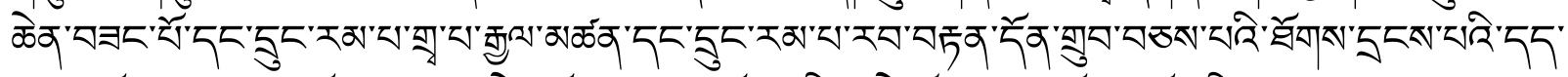

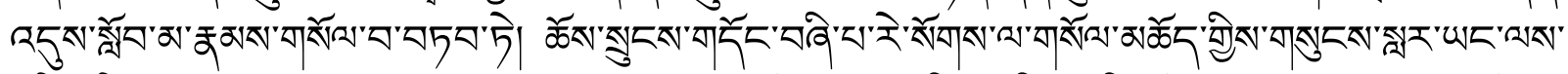

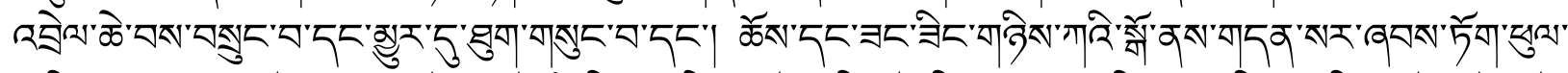

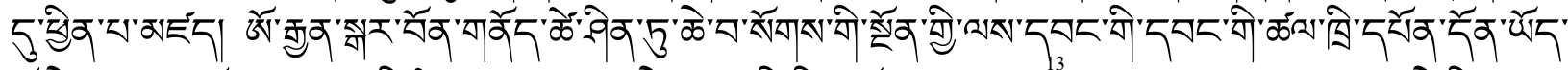

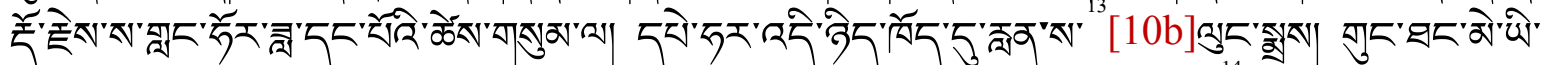

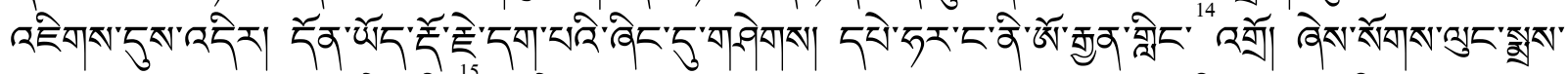

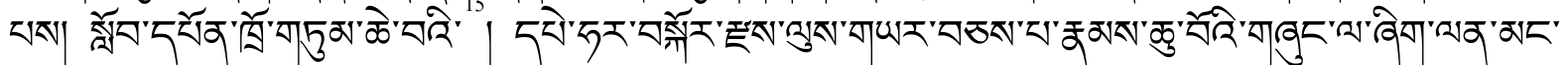

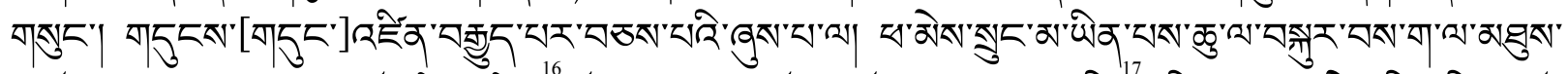

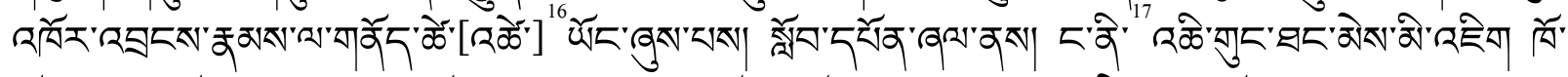

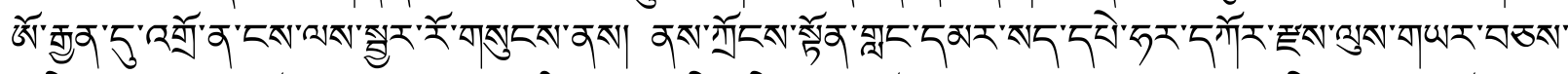

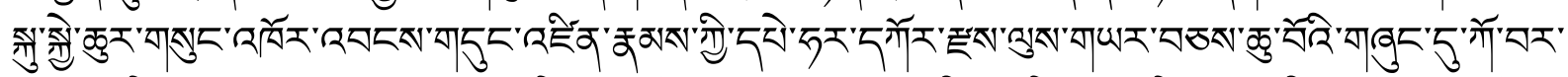

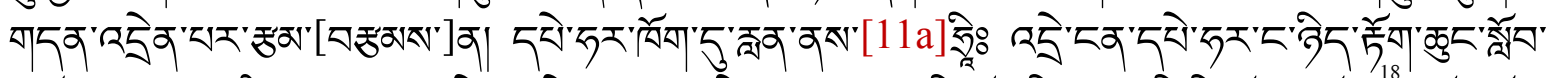

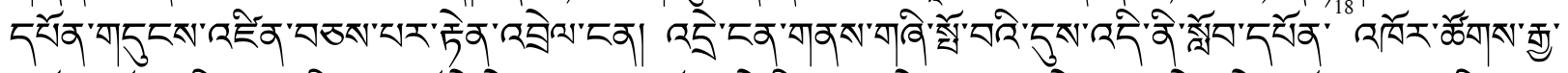

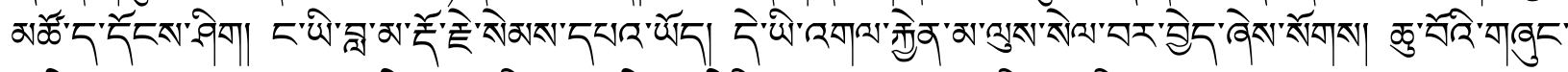

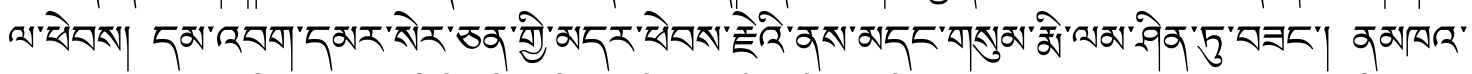

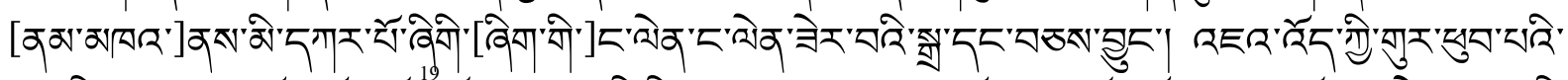

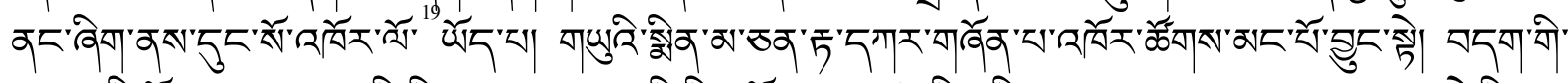

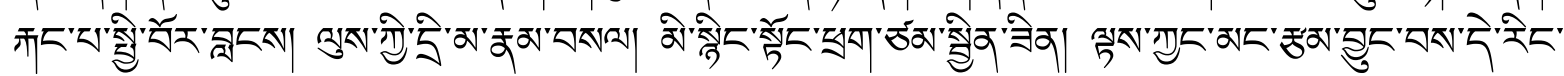

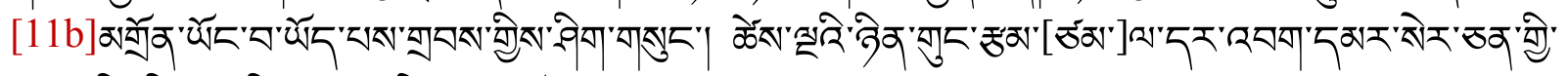

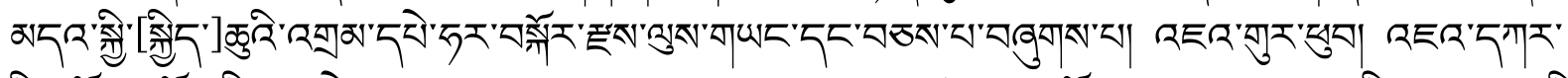

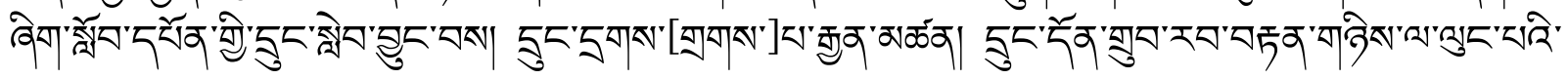

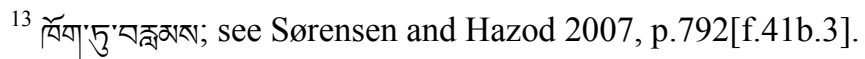

${ }^{14} 5^{\circ}$

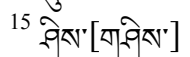

16 केवे दूर

17 ओे

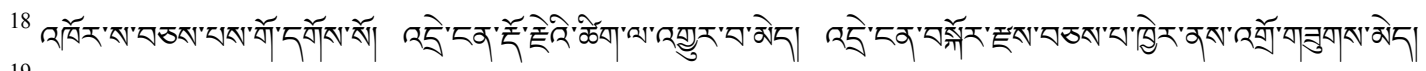
${ }^{19}$ [खХ]
} 
अ5 R'

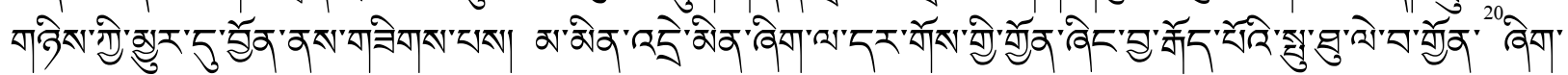

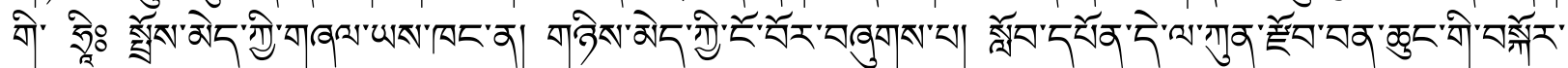

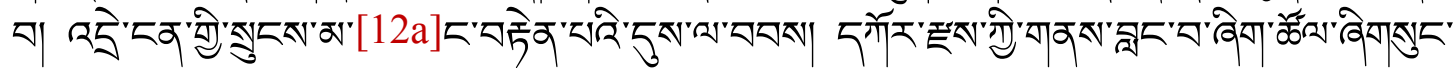

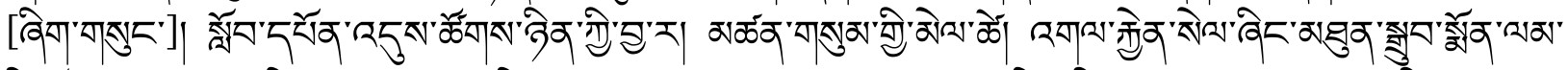

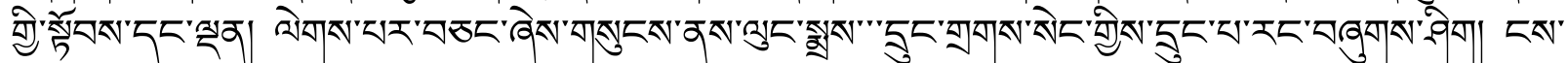

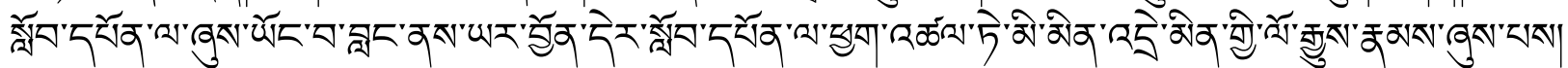

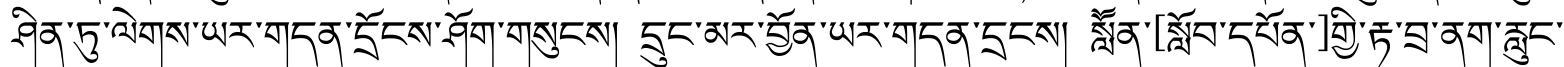

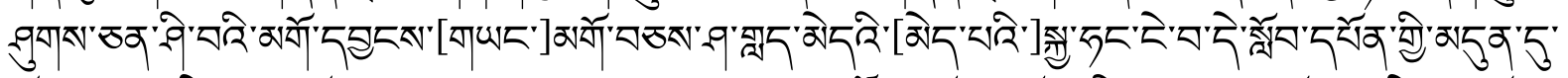

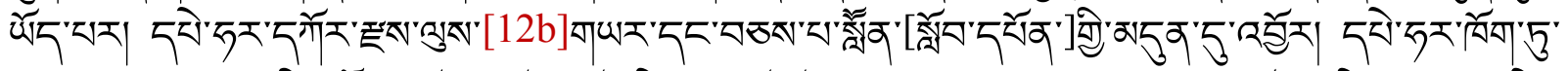

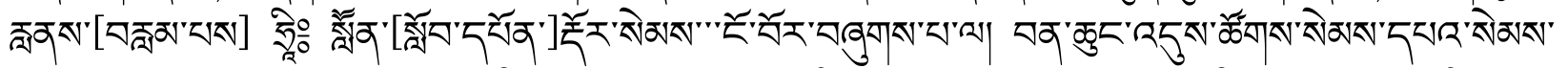

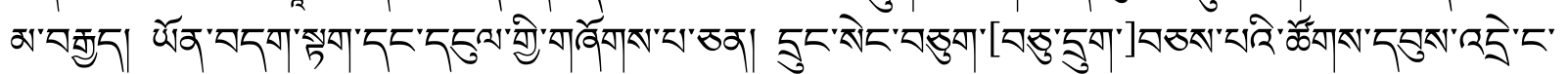

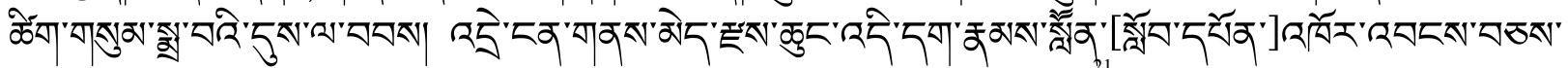

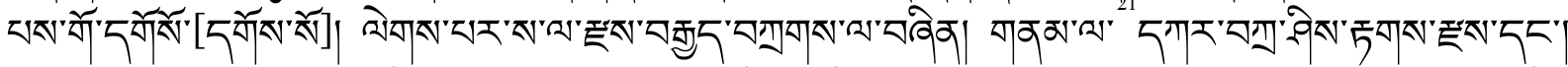

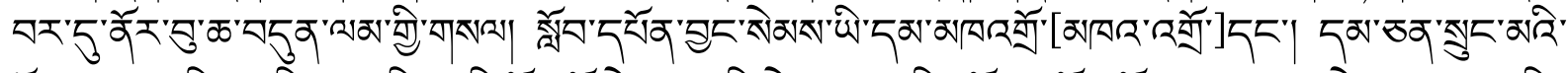

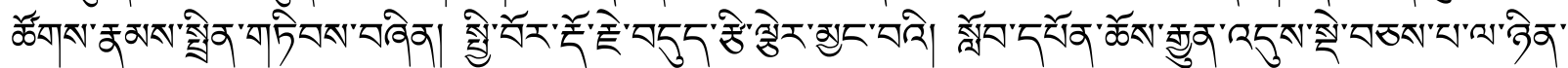

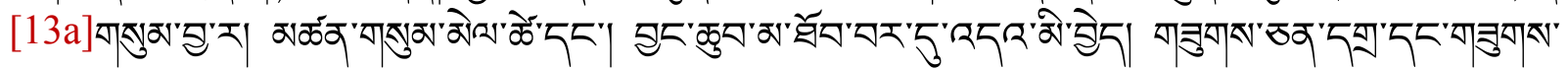

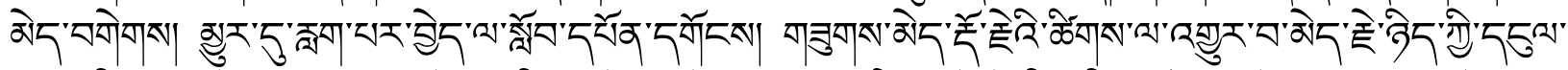

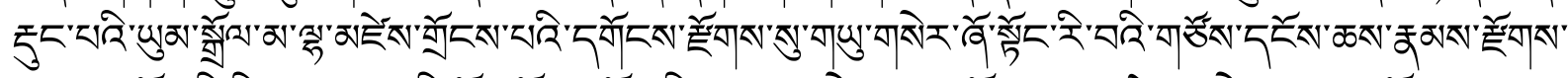

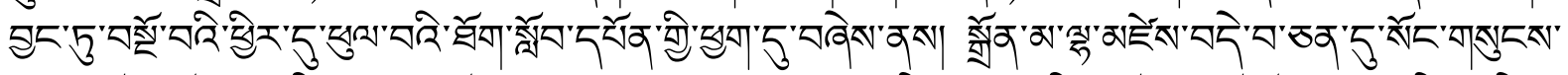

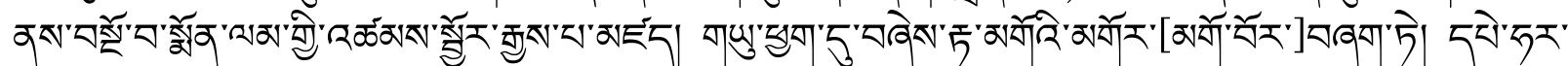

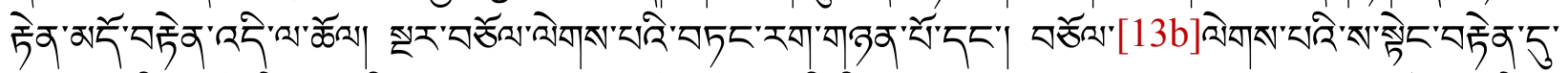

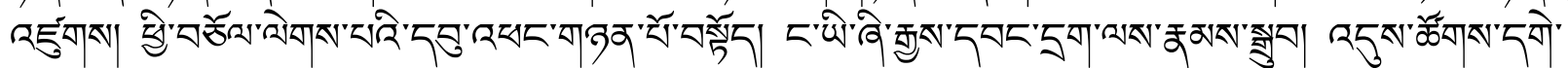

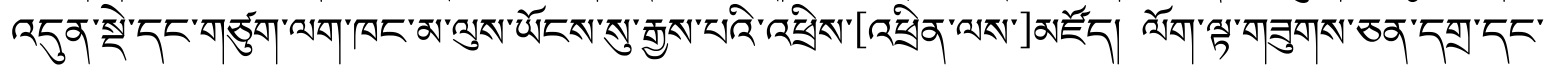

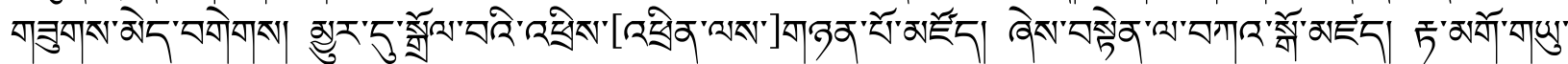

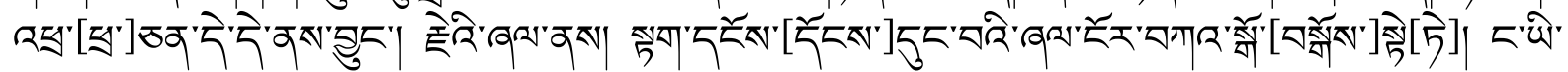

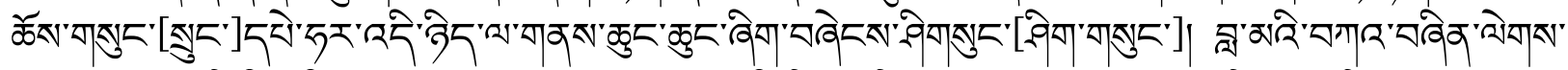

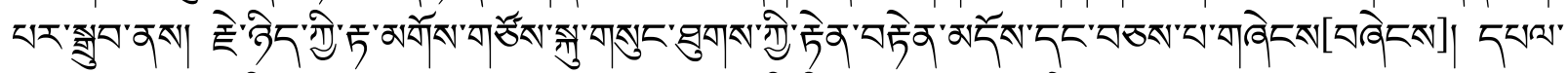

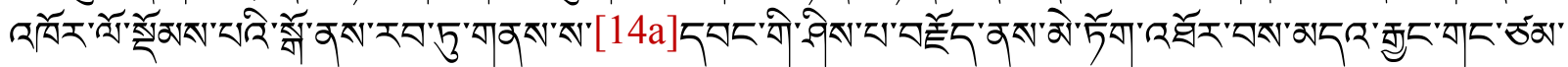

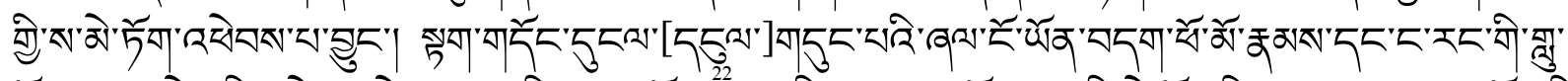

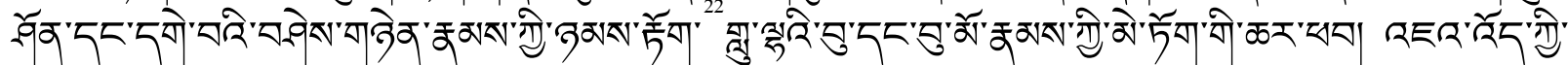

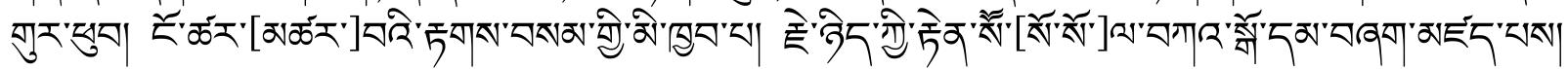

\footnotetext{
${ }^{20} \mathrm{LV}^{\circ}$

21 वारुण

22 स्रेंरे.
} 


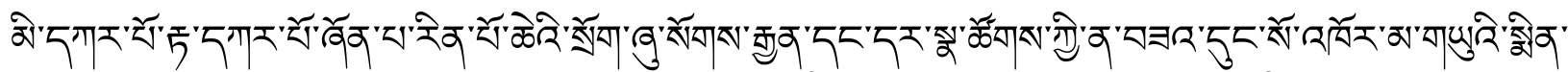

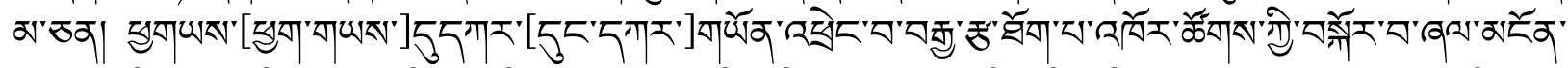

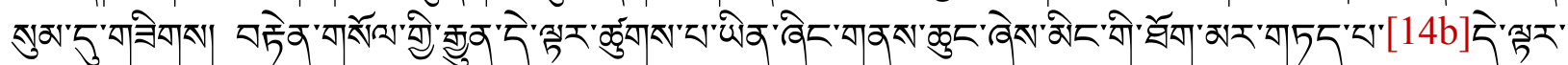

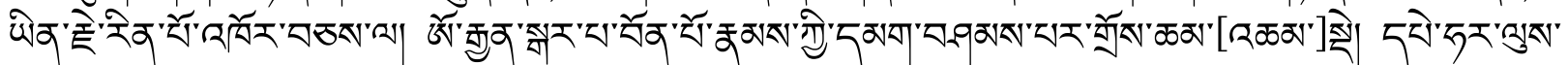

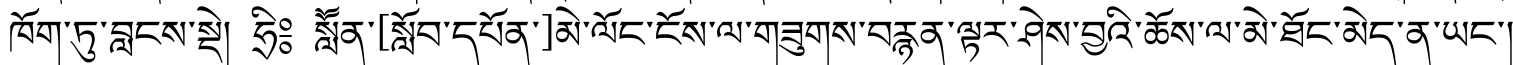

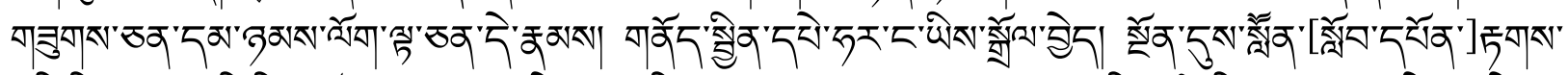

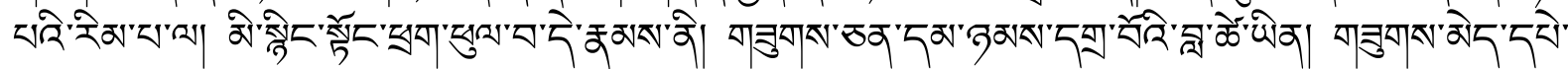

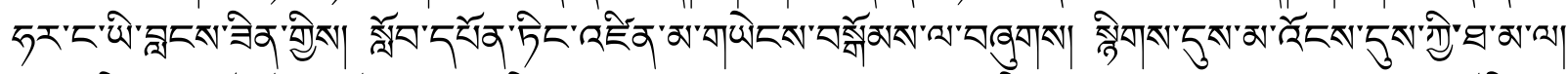

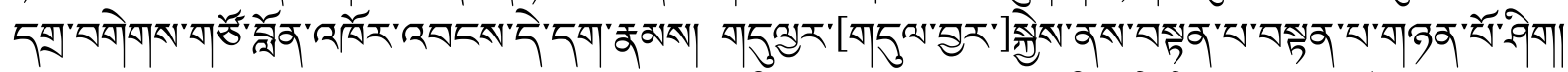

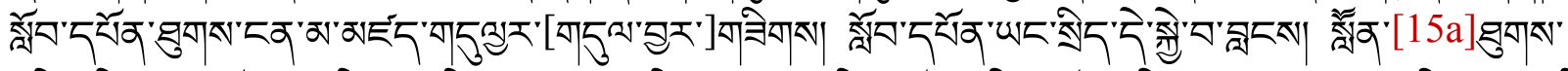

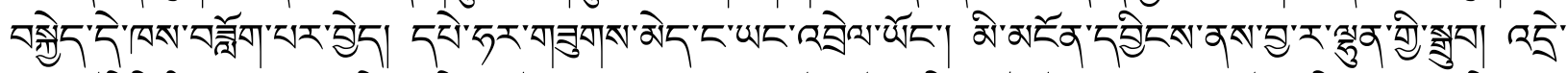

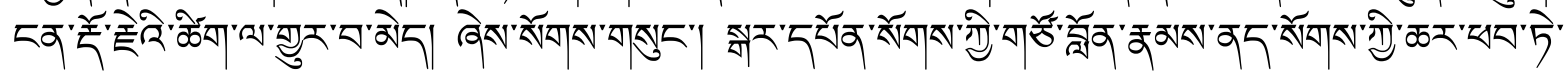

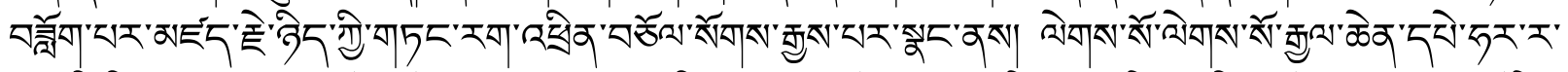

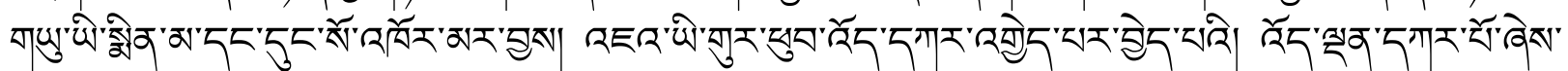

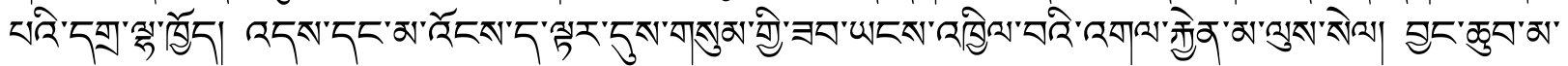

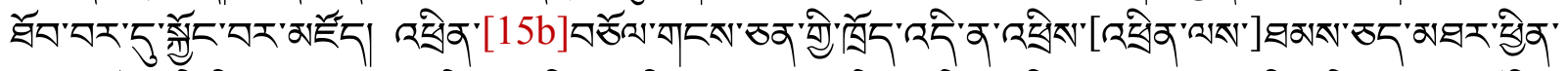

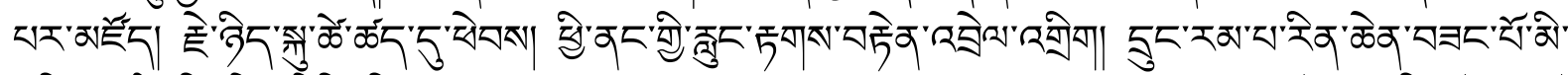

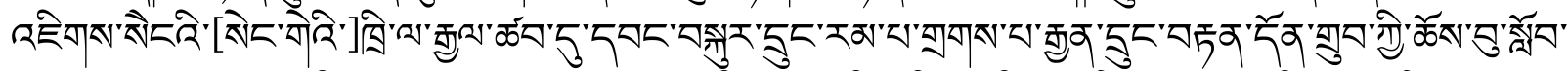

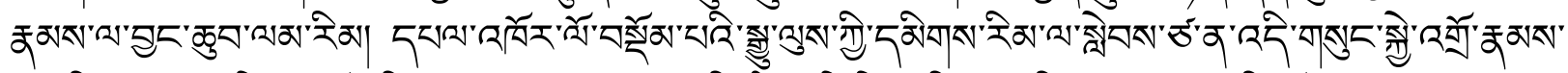

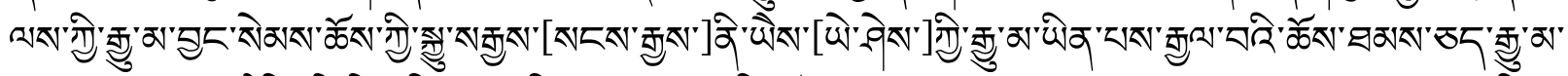

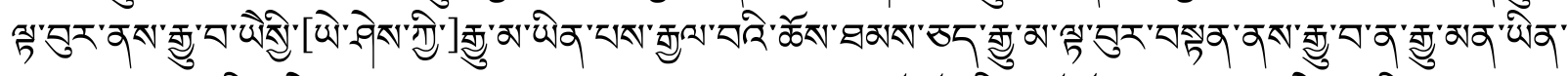

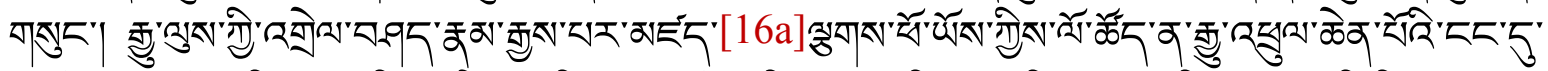

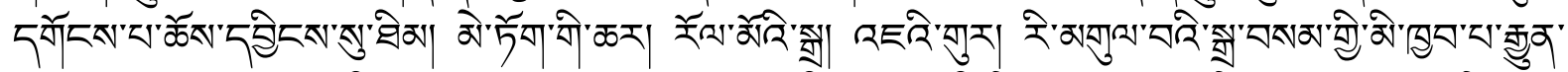

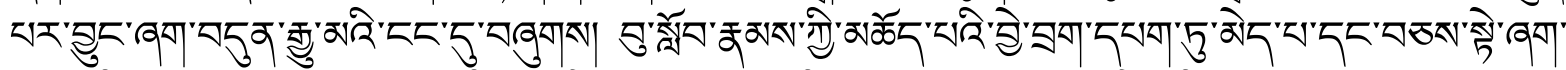

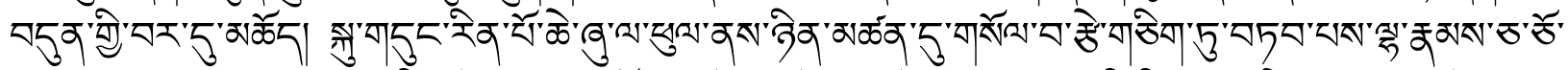

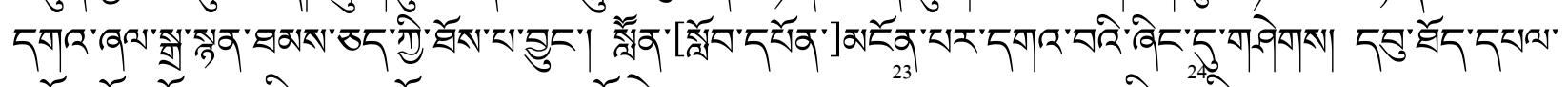

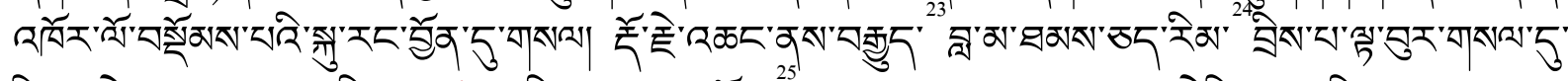

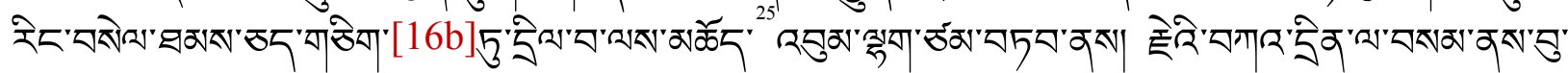

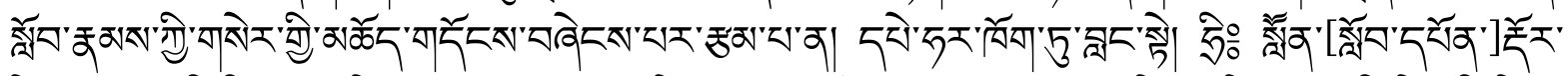

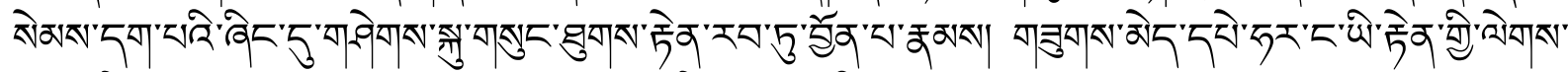

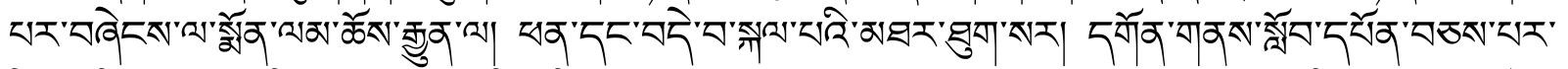

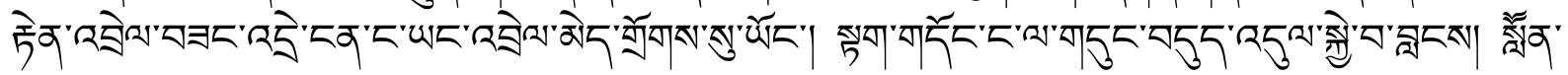

\footnotetext{
${ }^{23}$ [वस']

24 रक्वानेन्]

25 मेव
} 


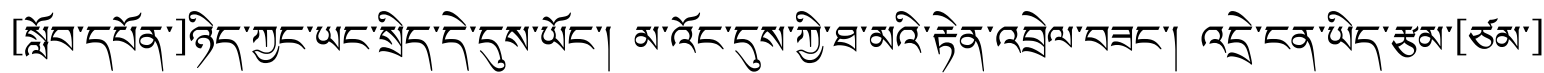

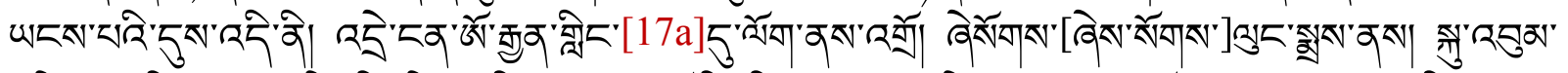

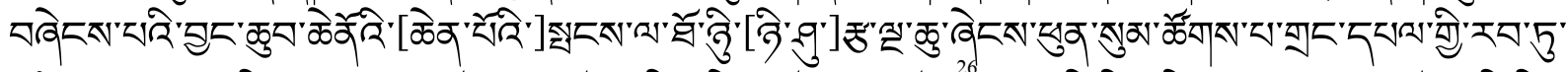

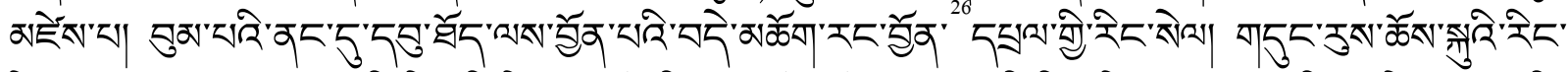

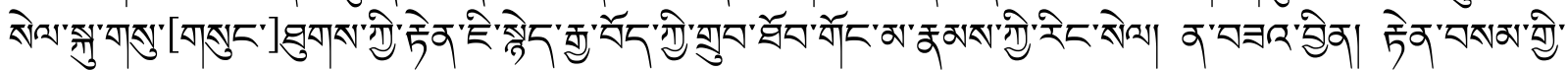

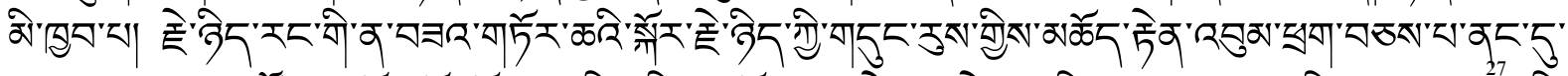

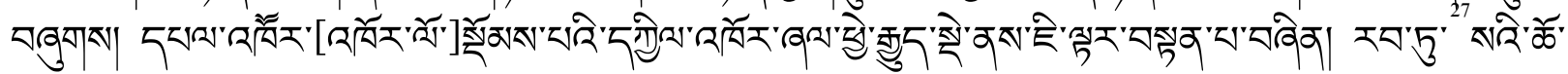

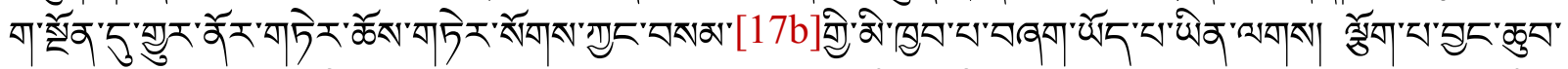

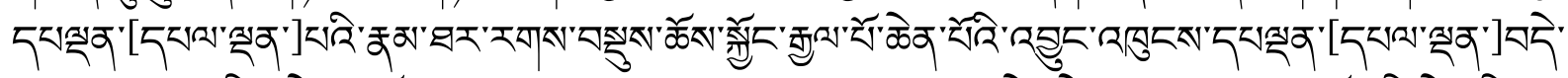

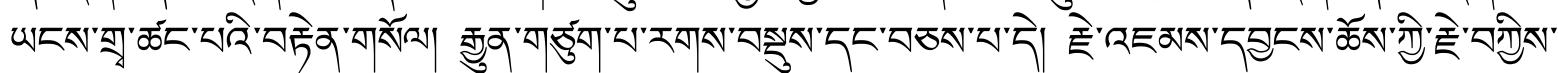

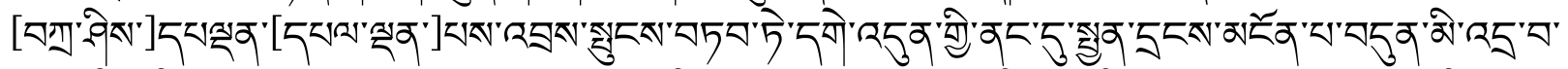

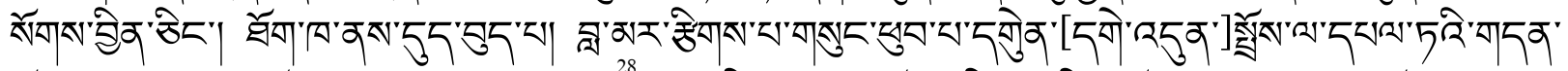

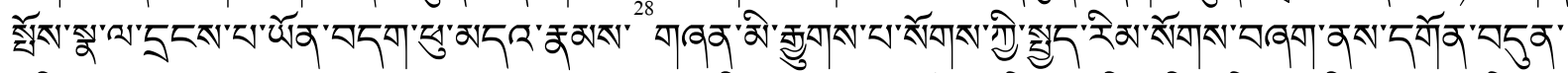

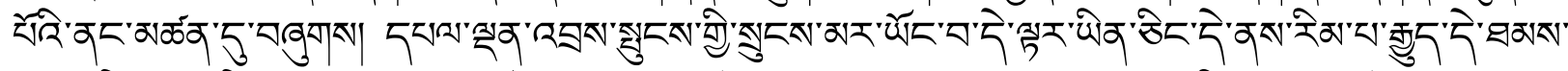

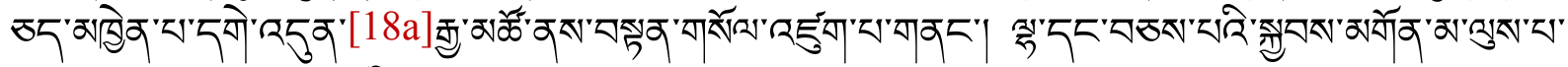

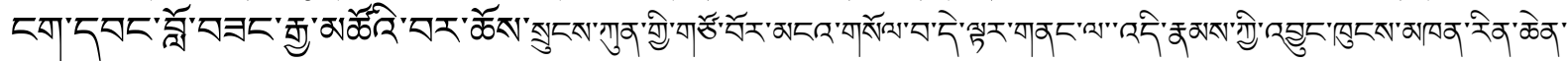

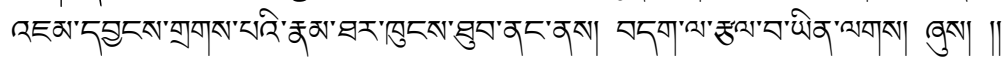

\footnotetext{
26 雪

27 पावस्ता

28 (a)
} 


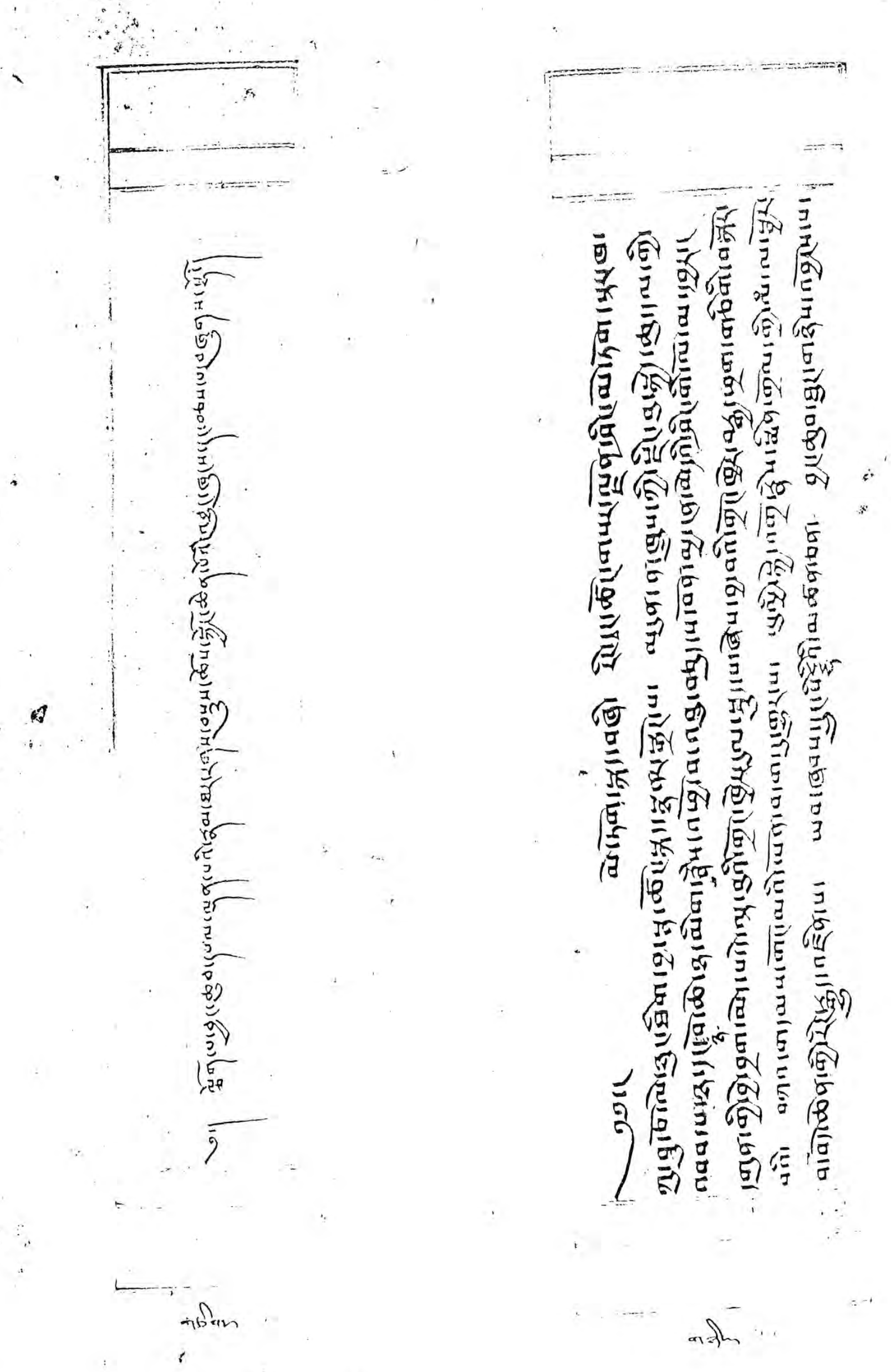




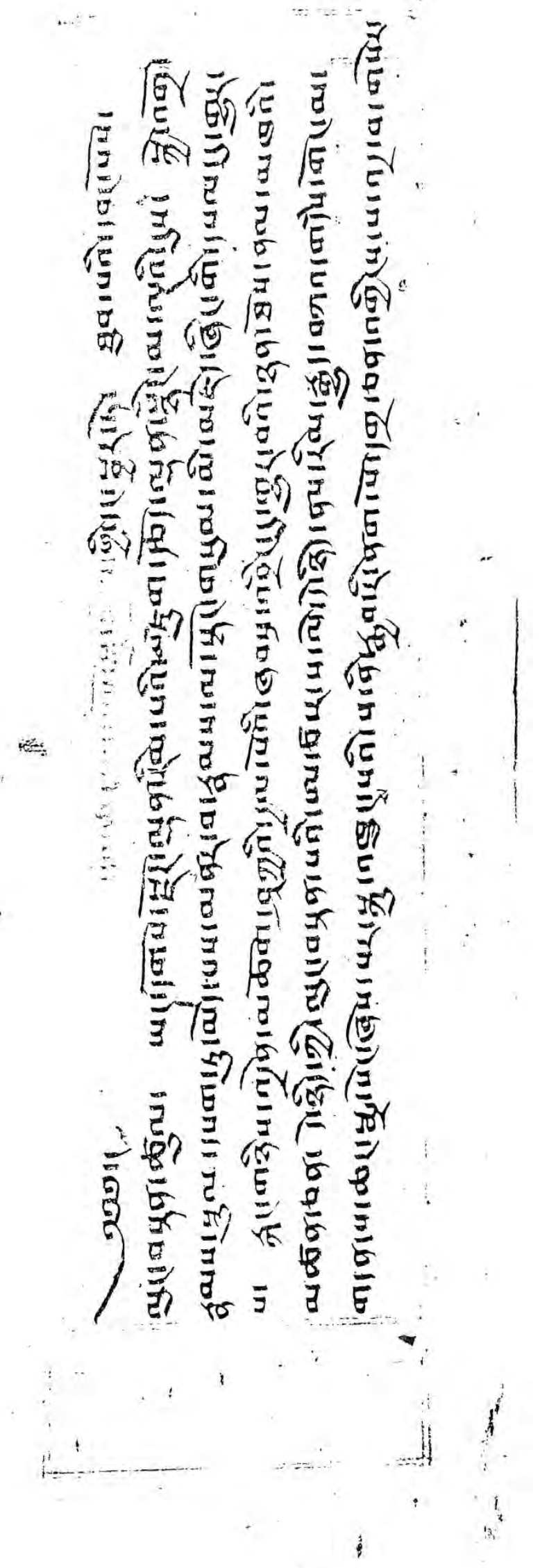

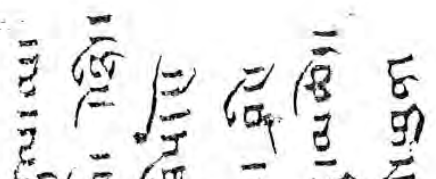

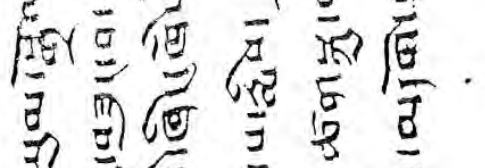

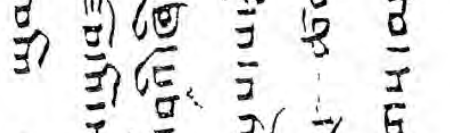

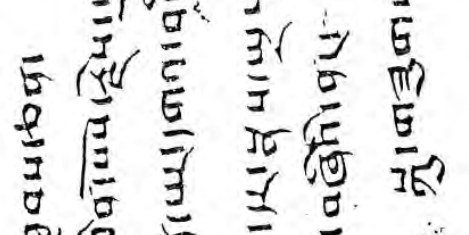

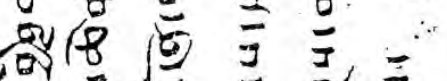

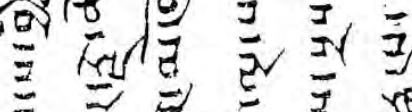

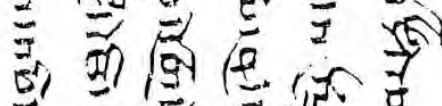

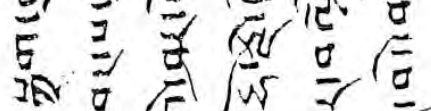

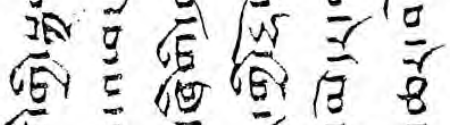

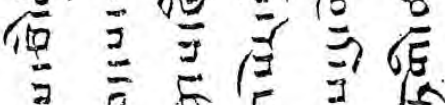

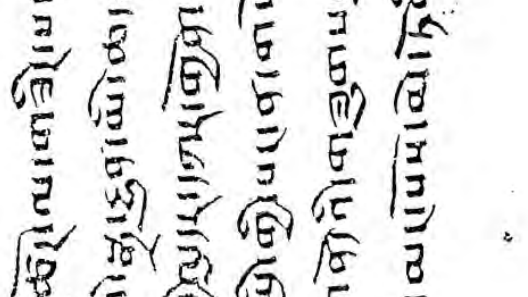

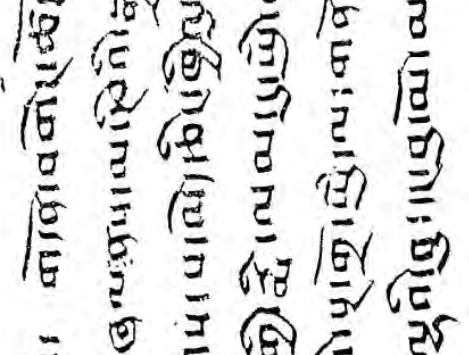

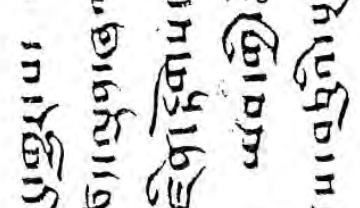

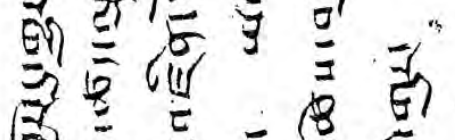

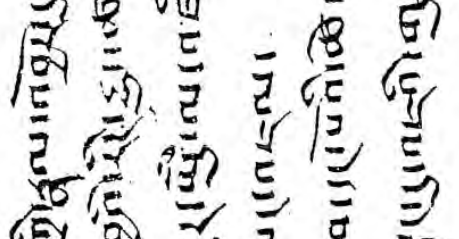

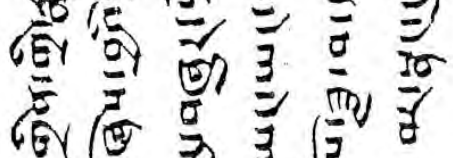

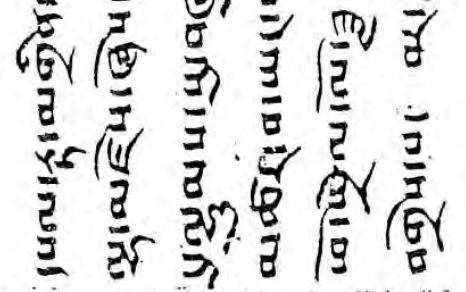




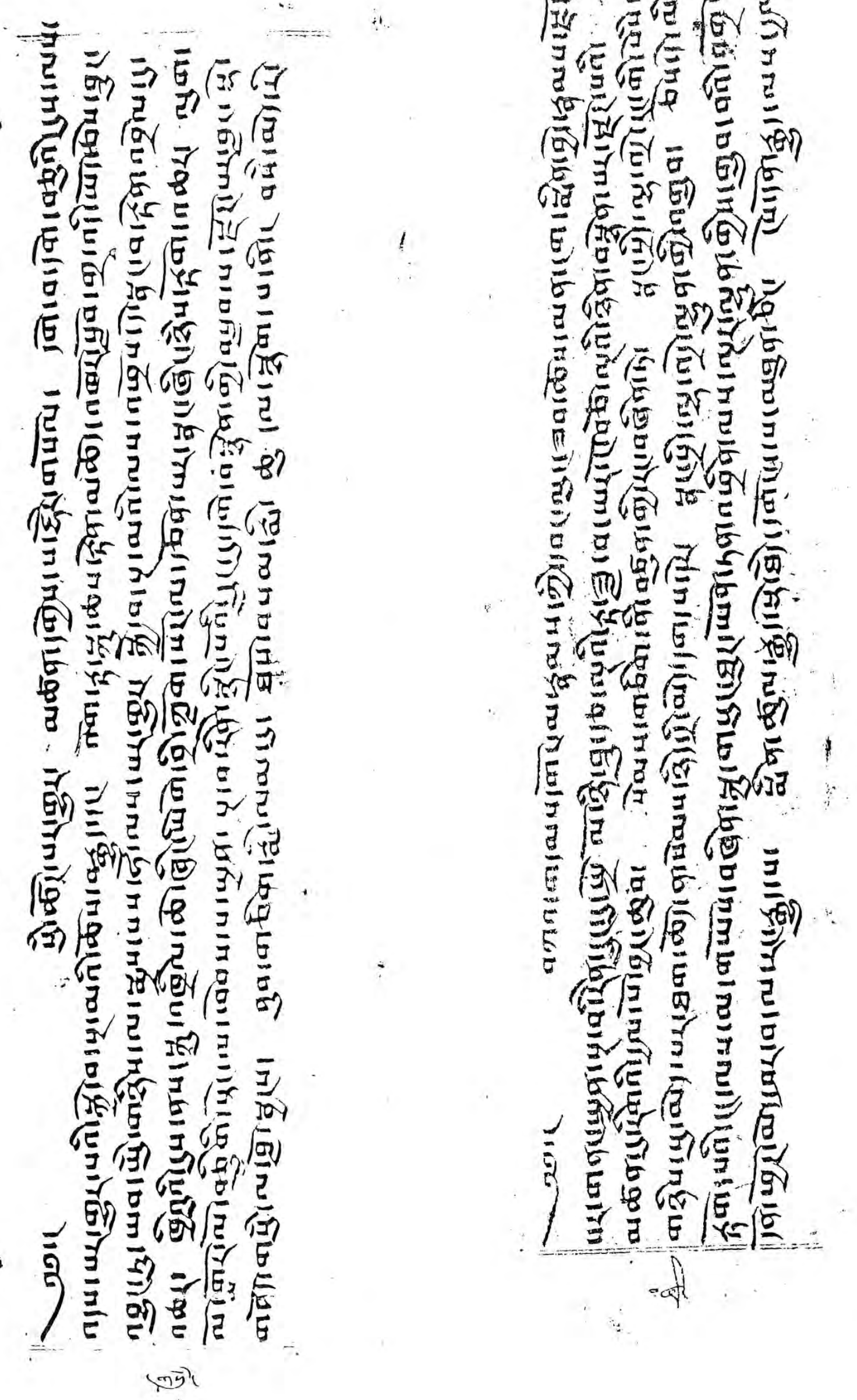




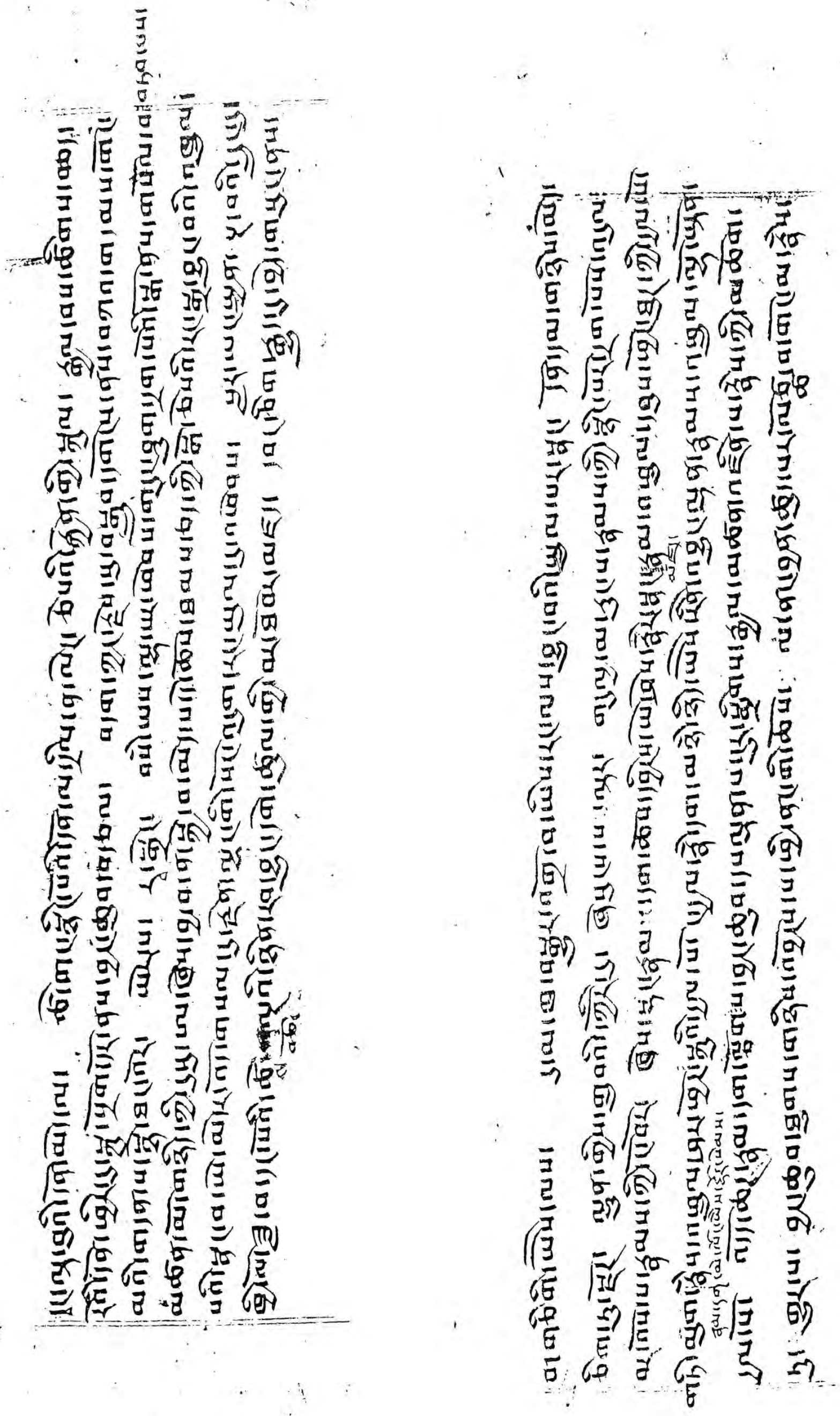



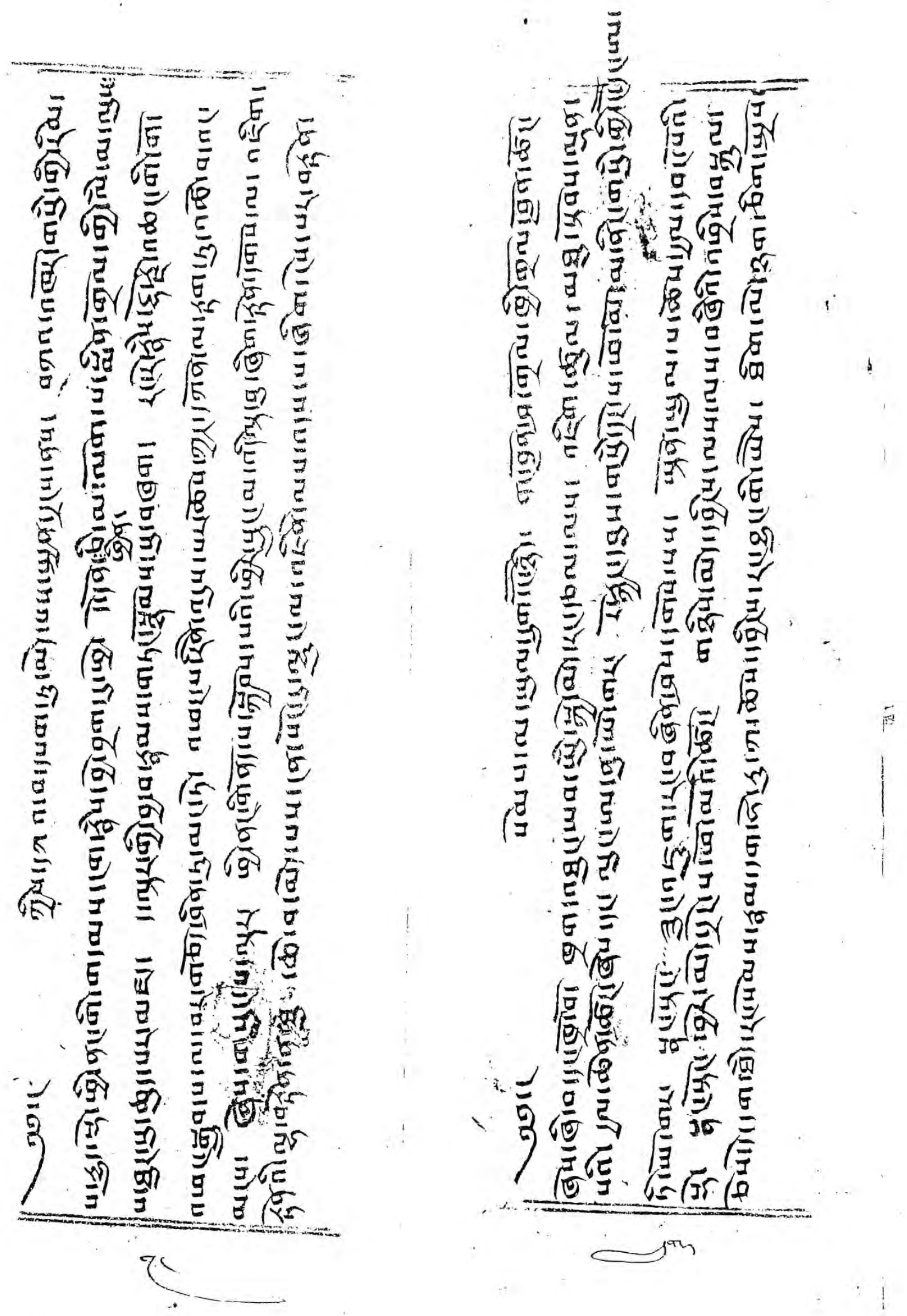


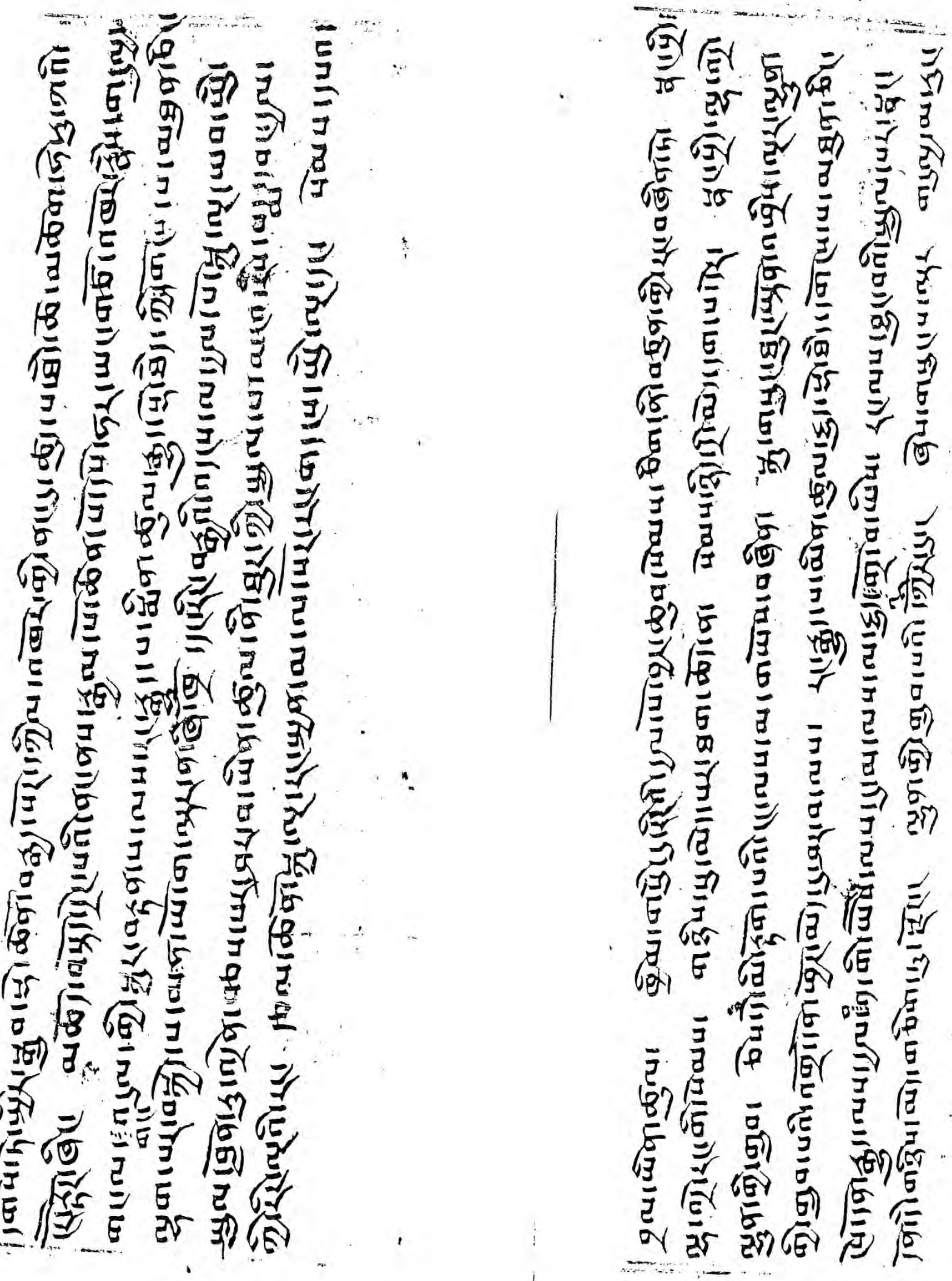




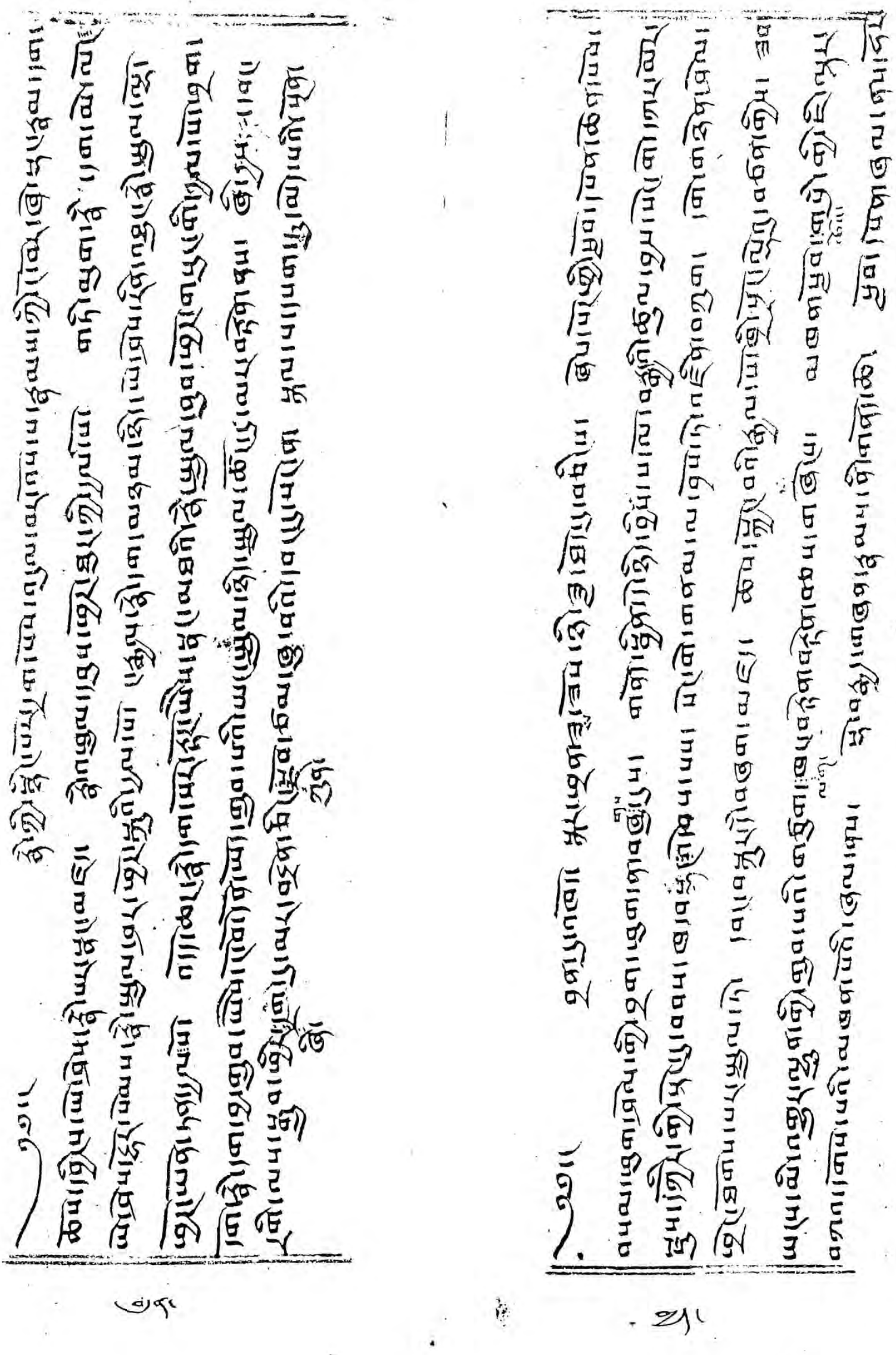



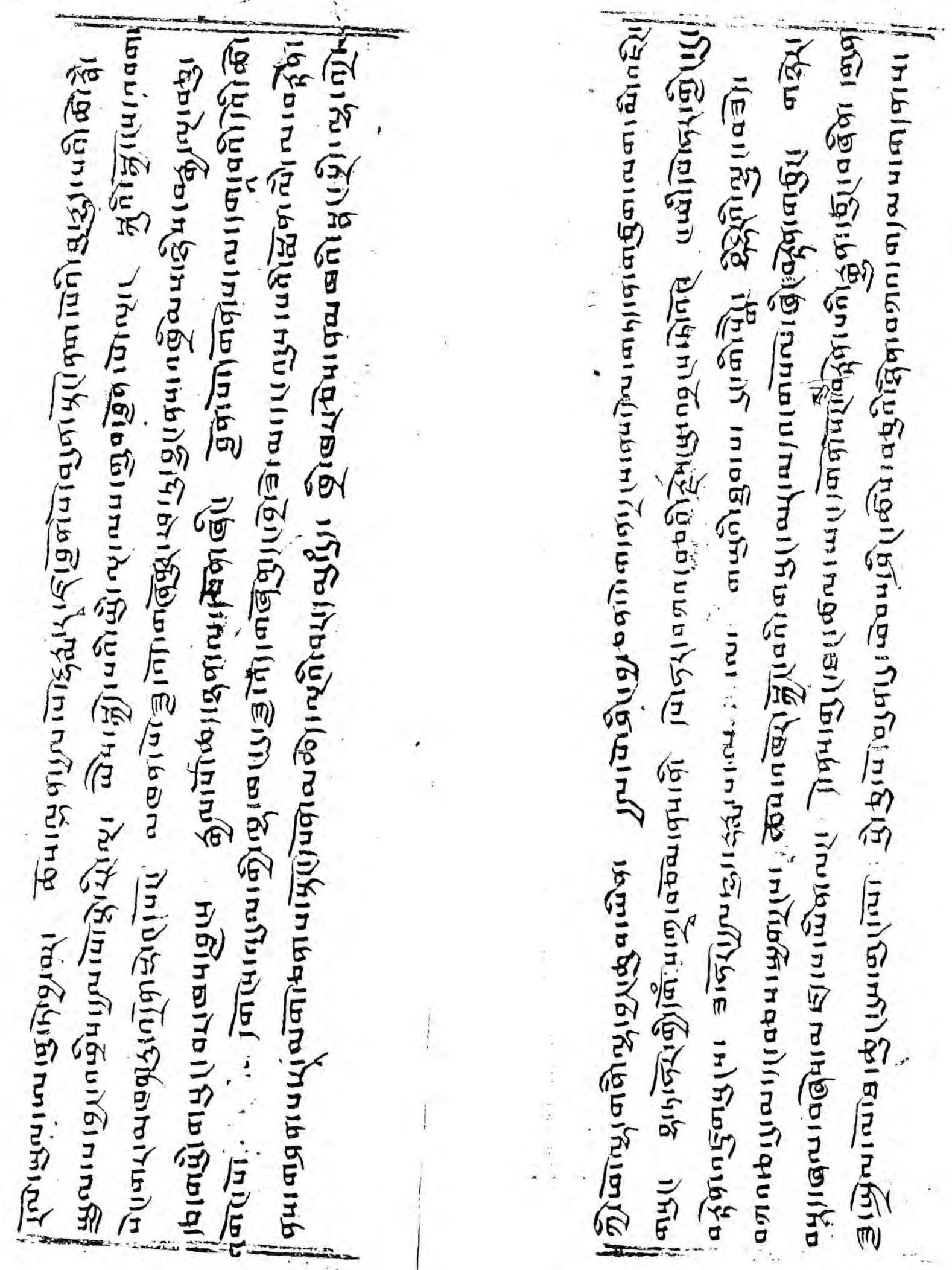


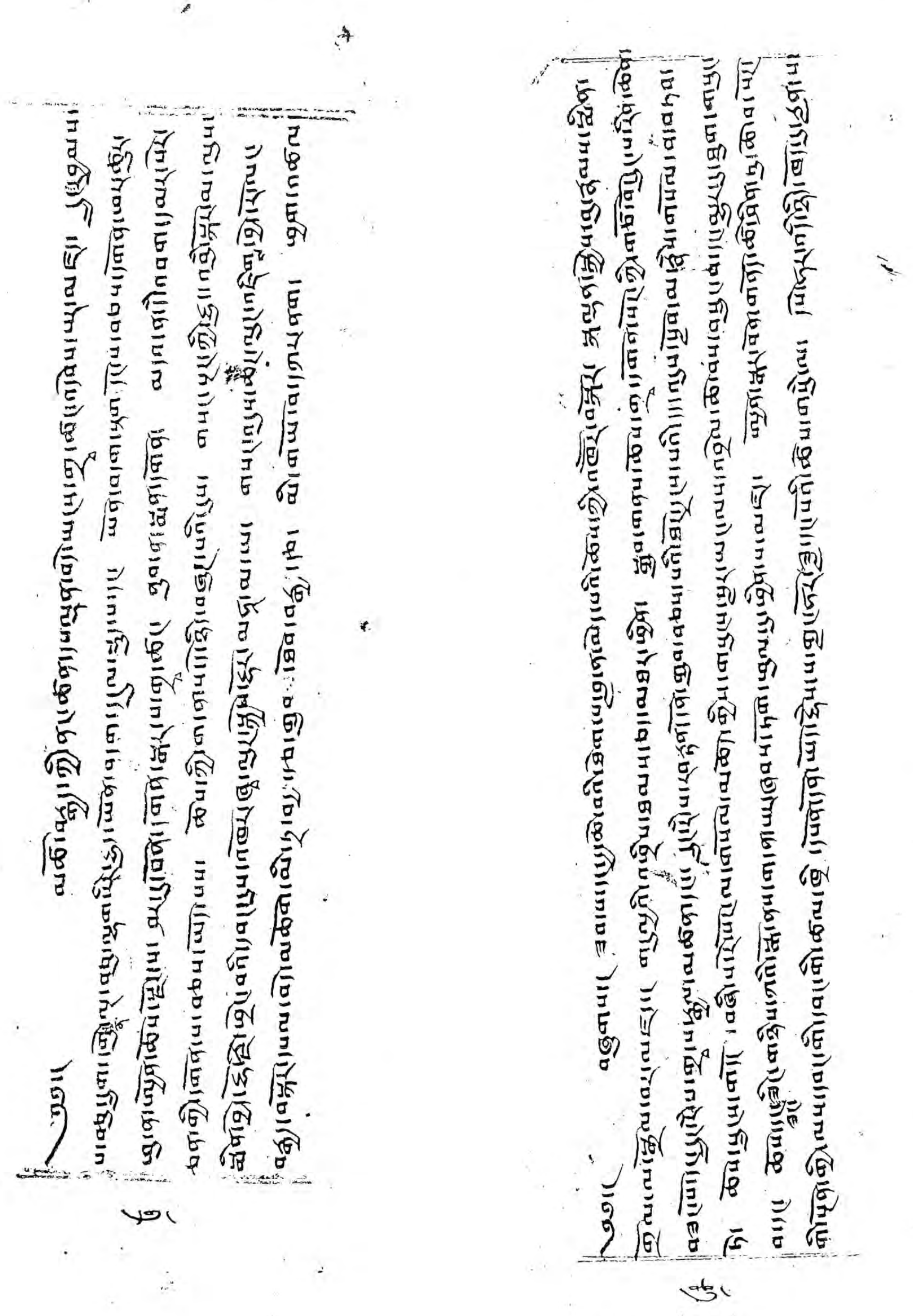



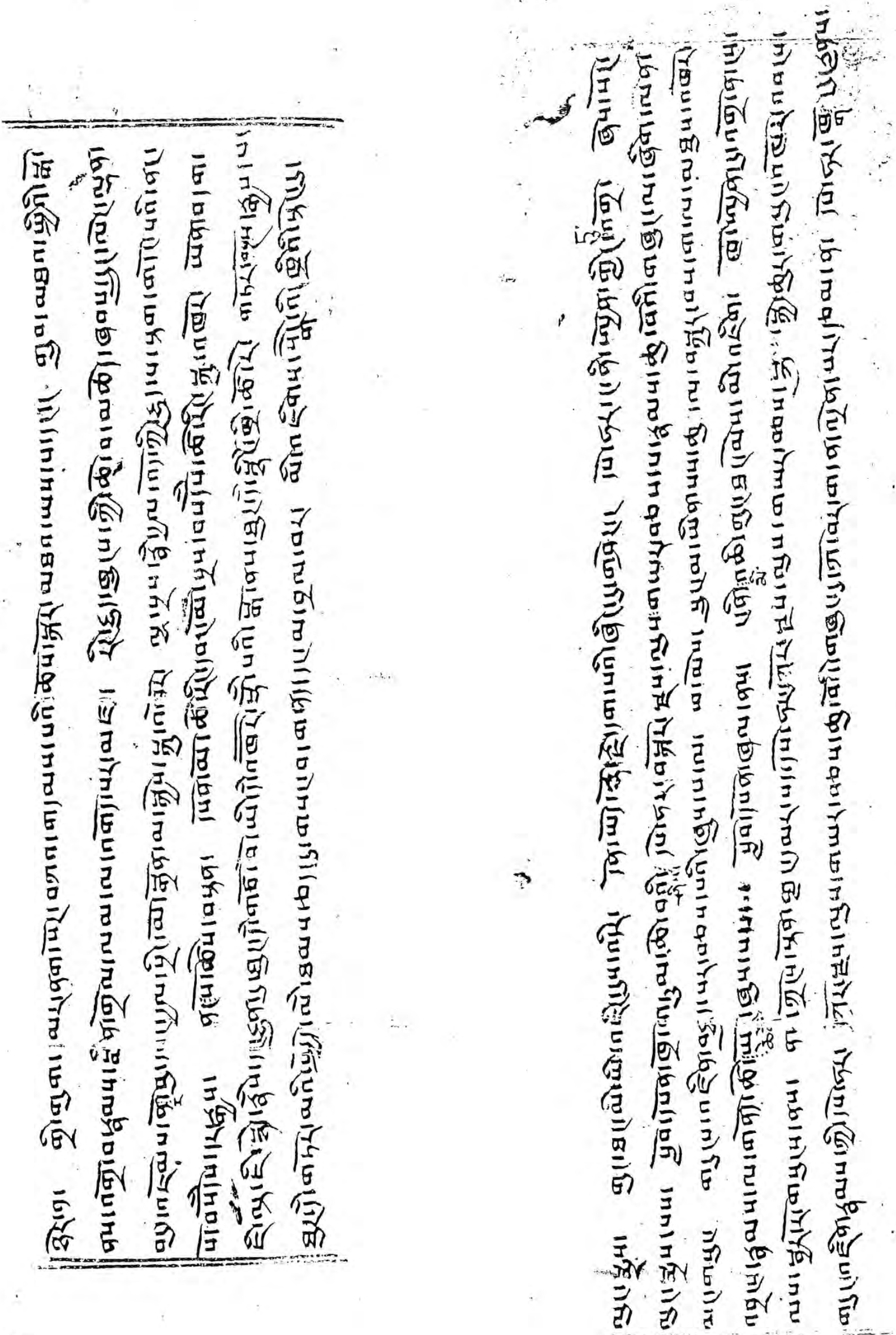


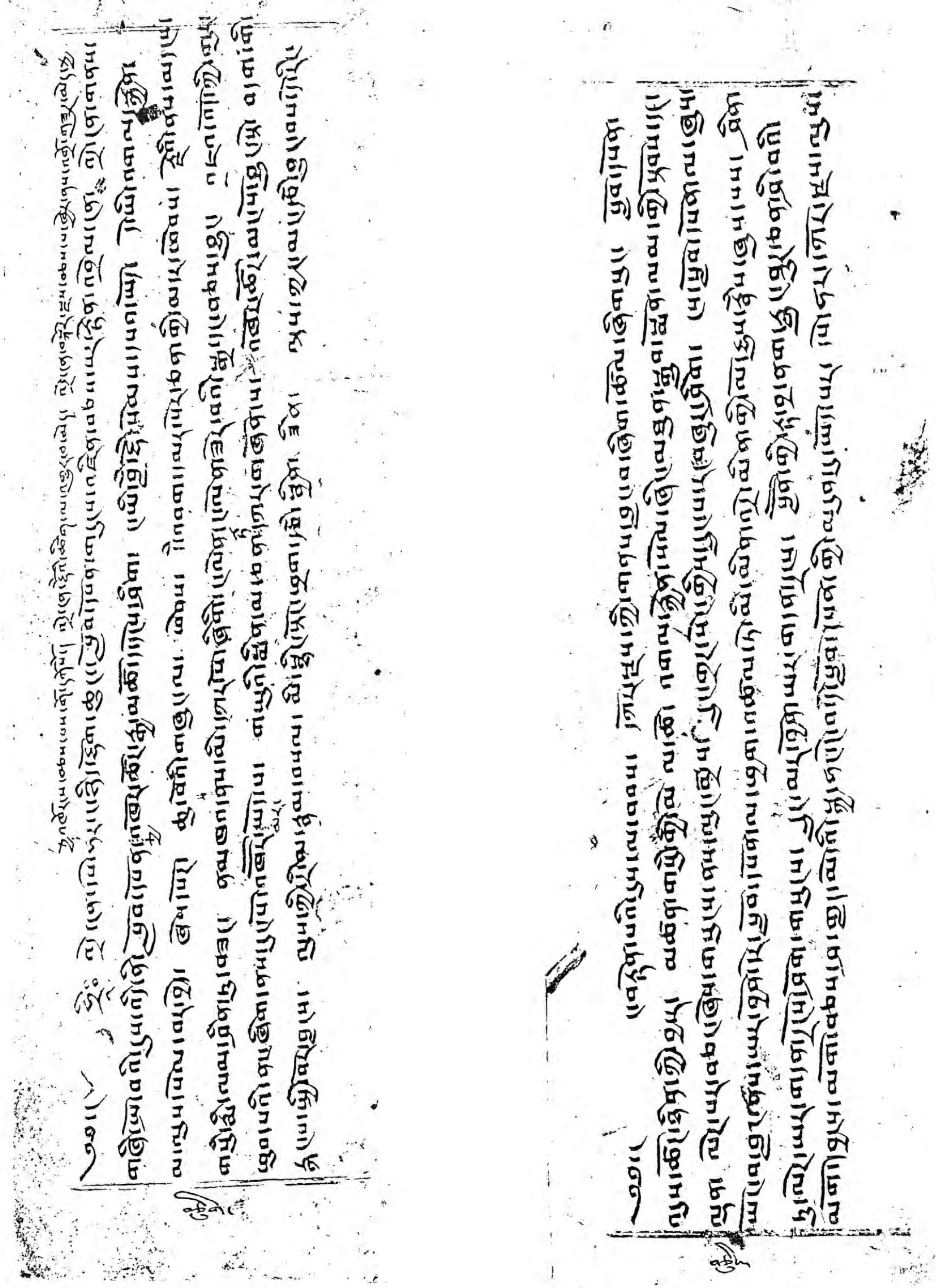




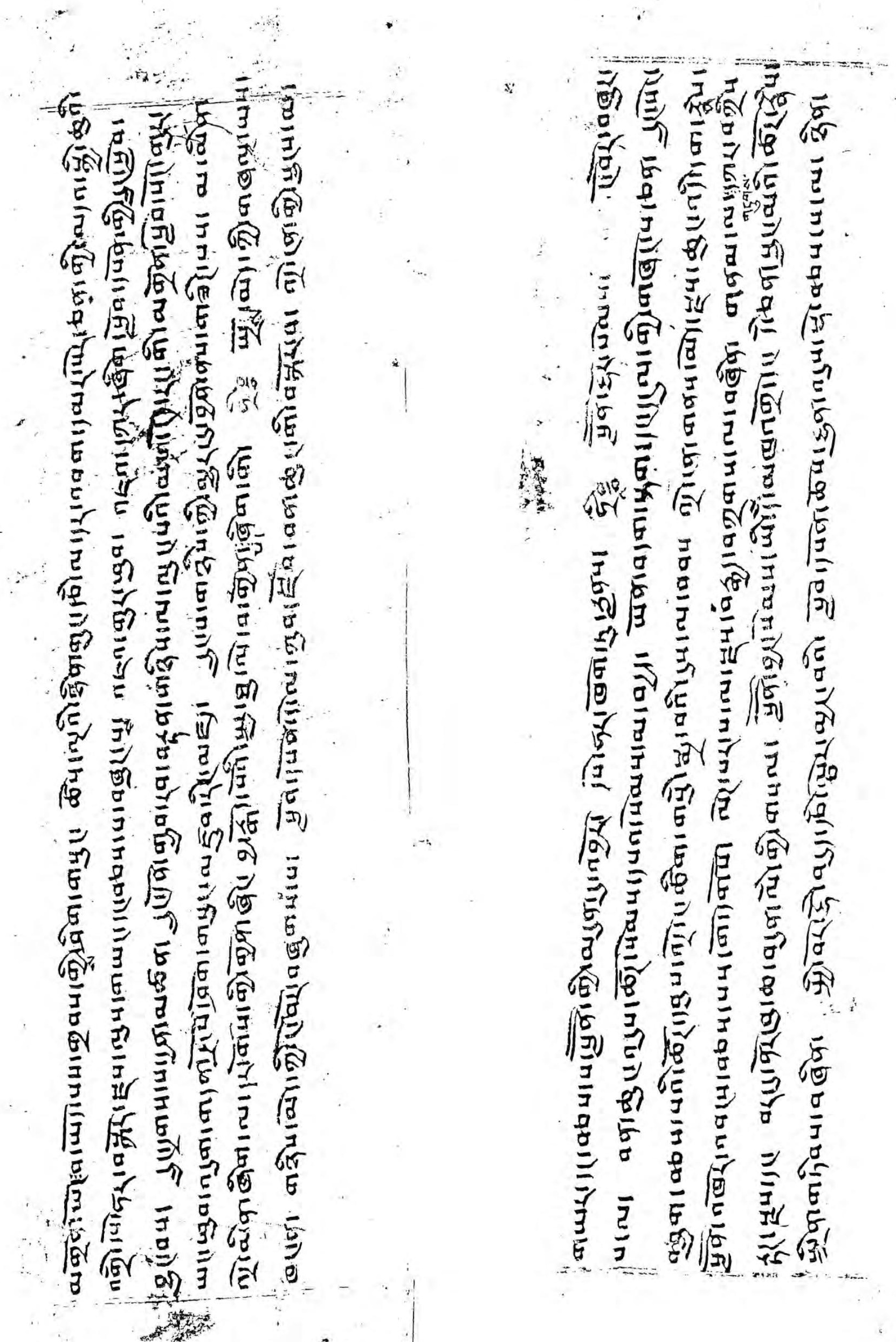



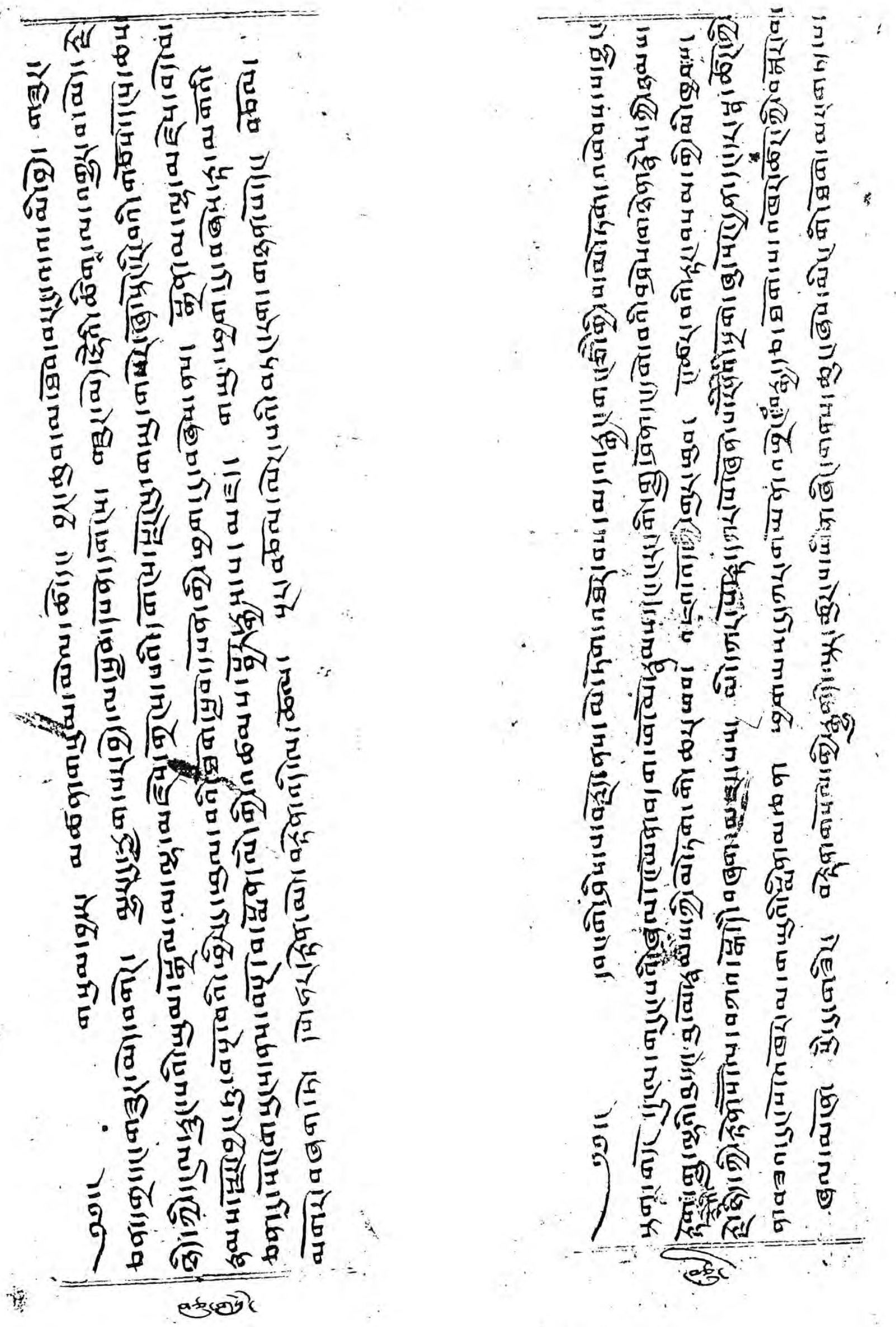

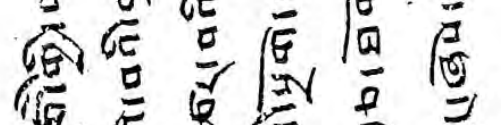

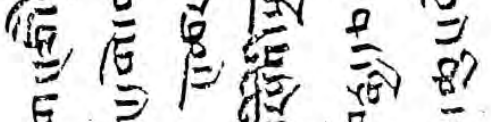

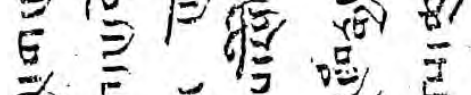

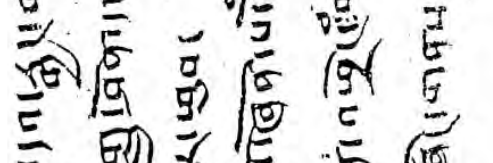

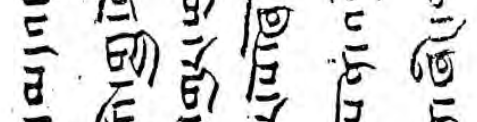

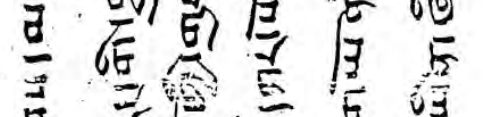

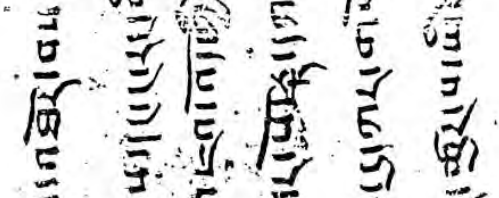

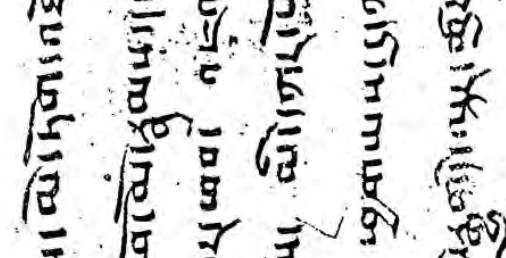

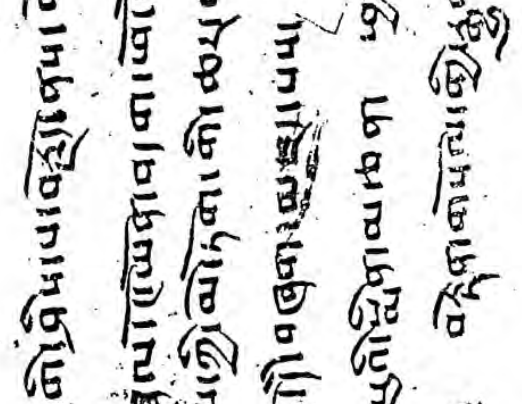

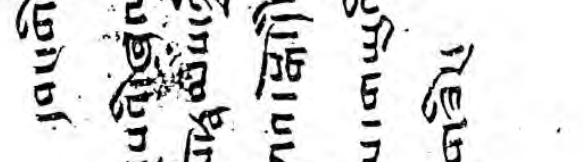




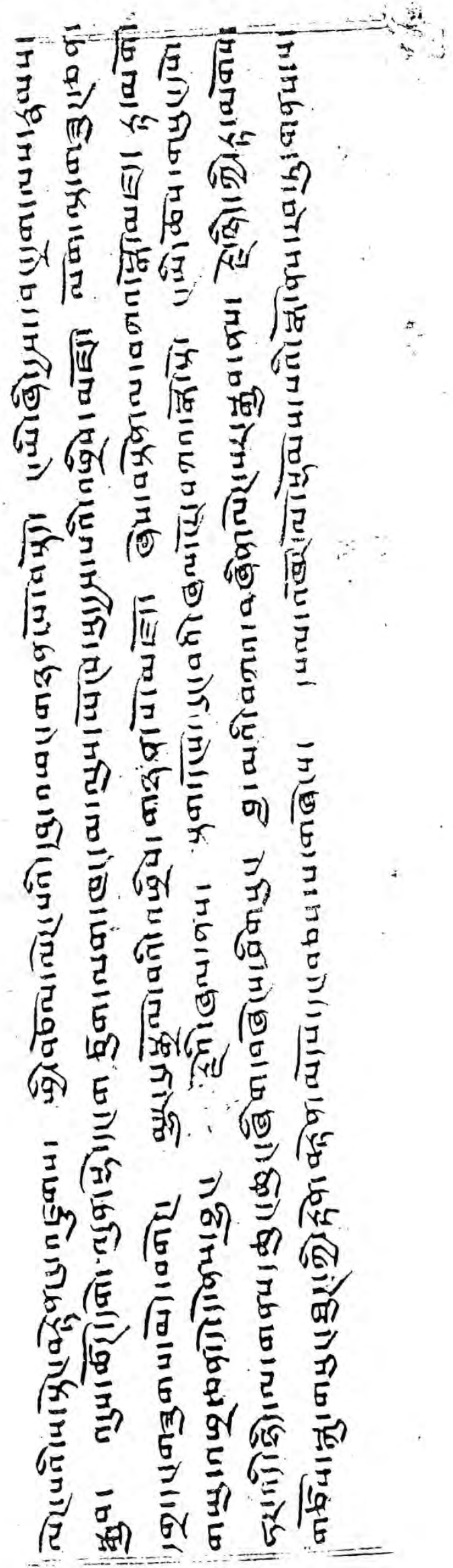

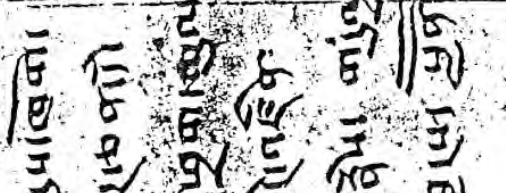

हो (i) है

IF E J E E

(ज. 要

ए

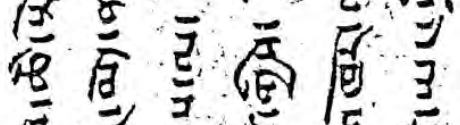

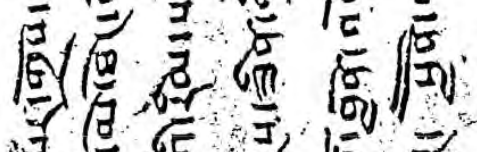

过

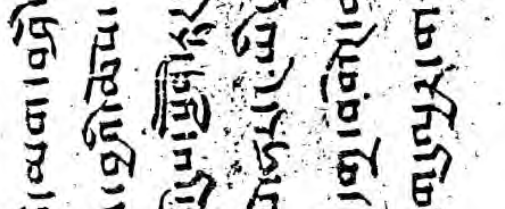

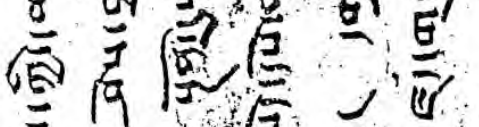

उ.

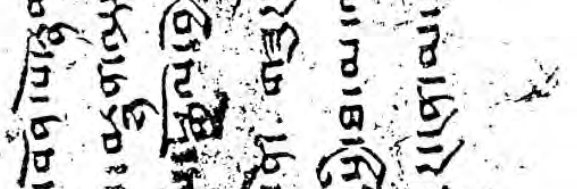

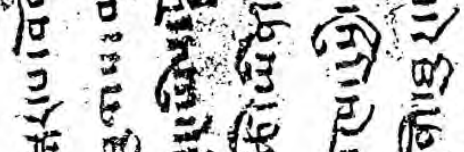

E है

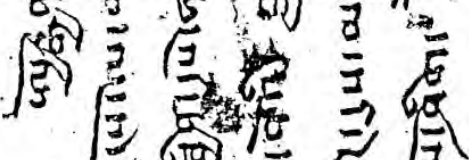

三

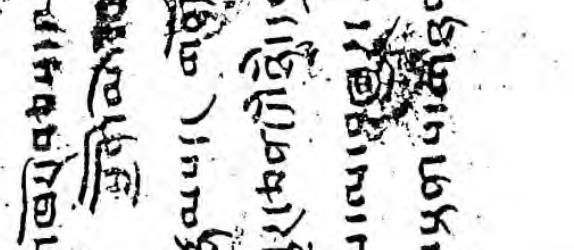

证 (ii) इ

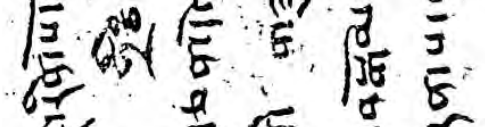

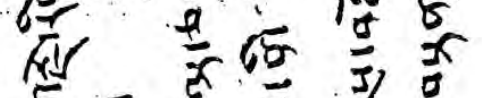

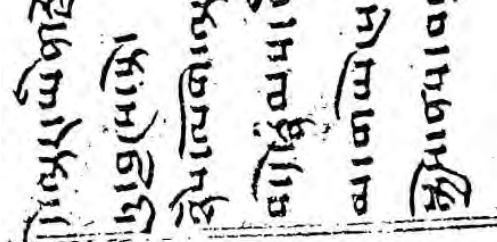




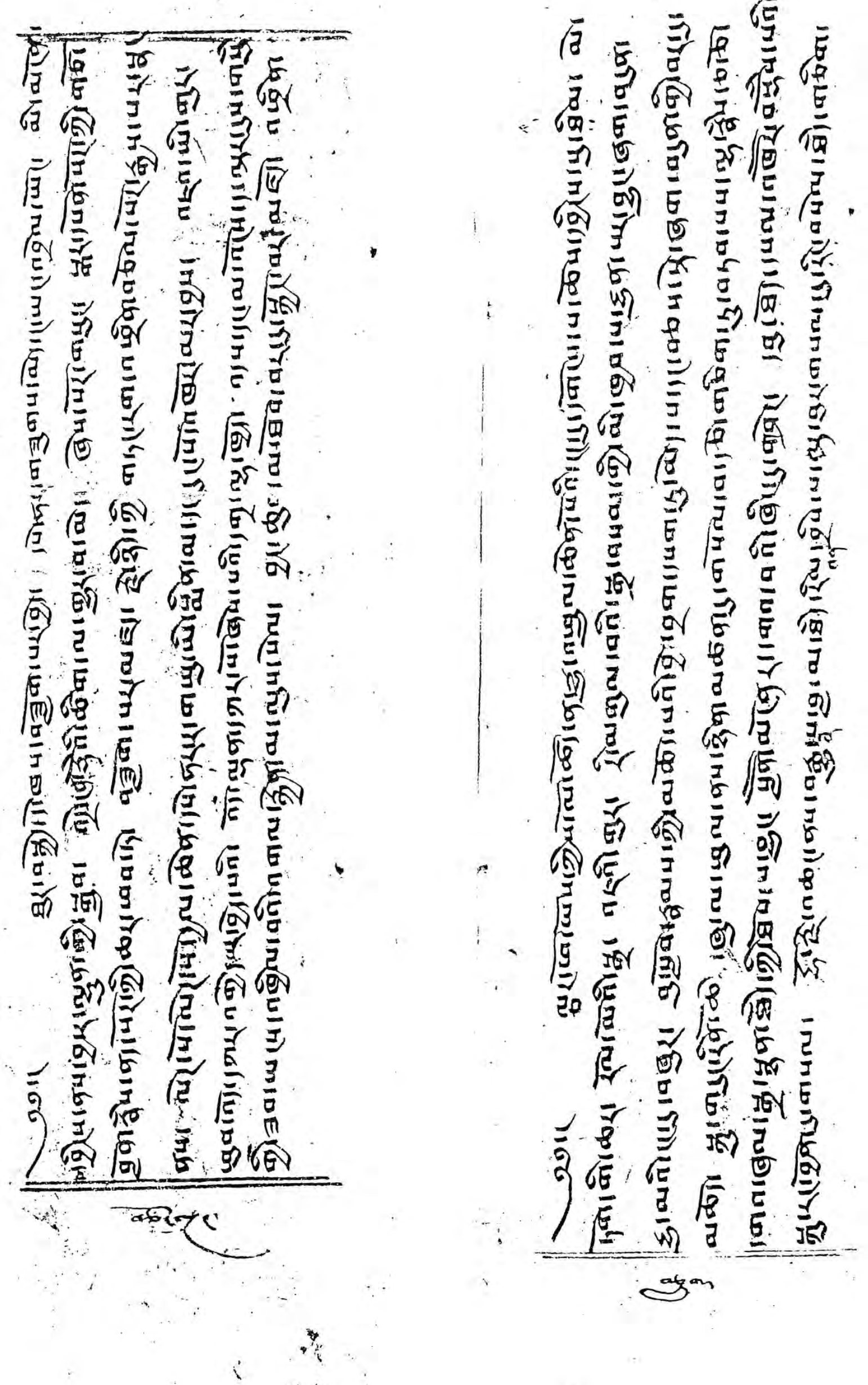




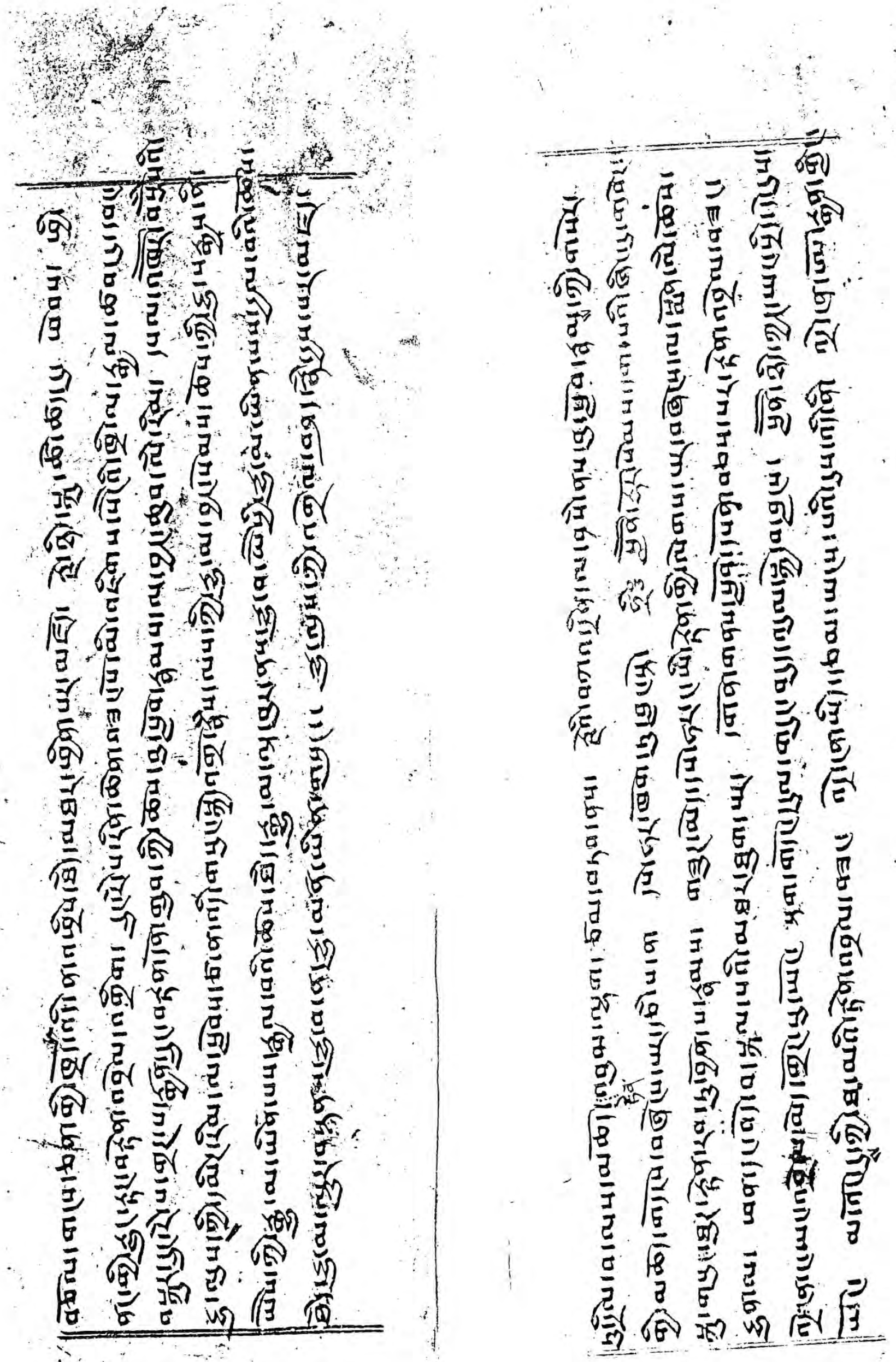




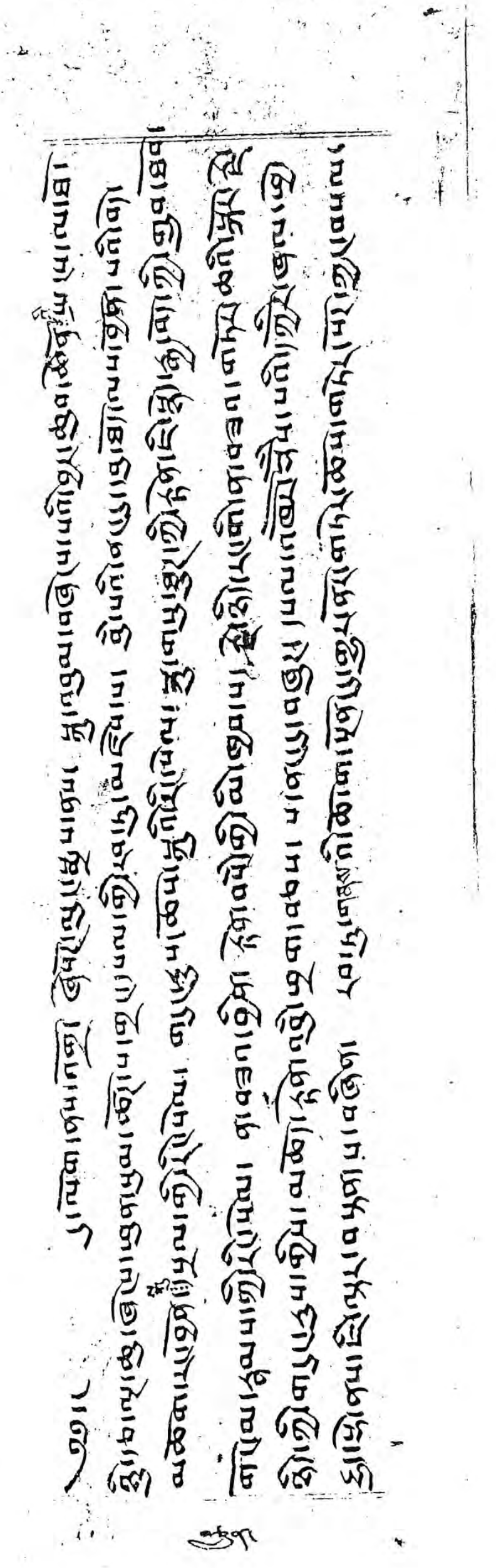




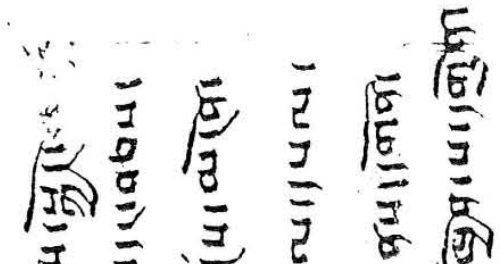

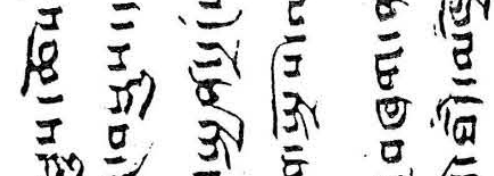

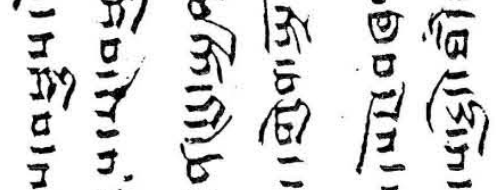

豆宫鸽䂞

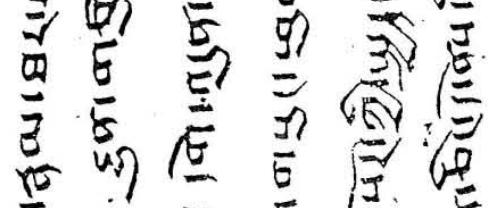

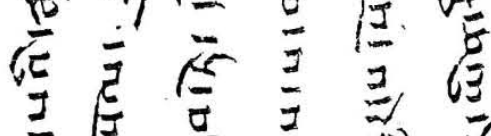

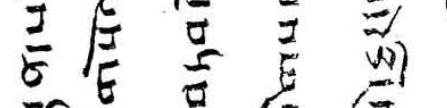

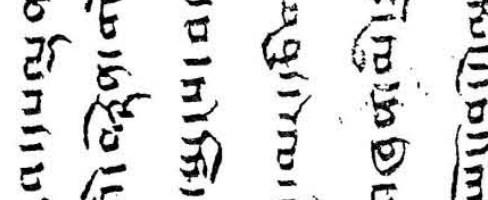

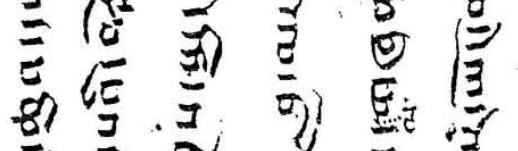

$=$ or

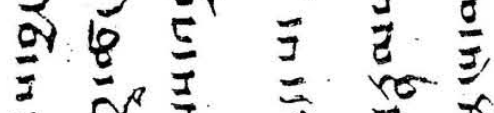

है

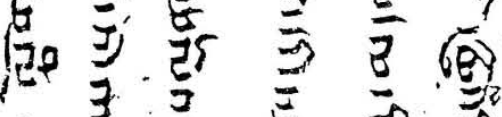

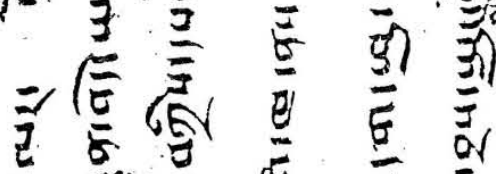

局 है है

得罂

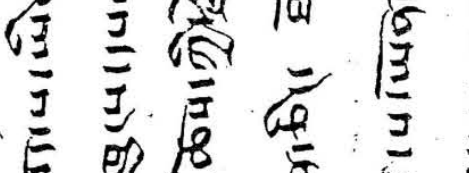

层影量高要

前 可居

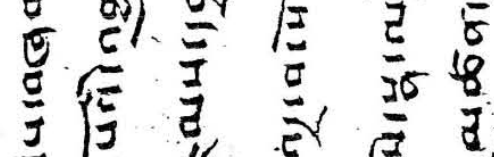

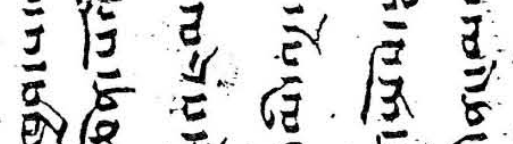

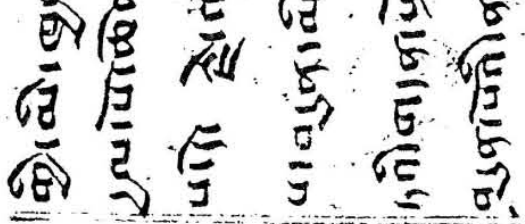




\section{Bibliography}

\section{Primary Sources}

A myes zhabs Ngag dbang kun dga' bsod nams (1597-1659). [1633] 2000. Dpal bsam yas lhun gyi grub pa'i gtsug lhag khang chen po bka' srung dang bcas pa'i byon tshul legs par bshad pa chos skyong yid bzhin nor bu dges par byed pa'i yid 'phrog lha'i rol mo dgos 'dod kun 'byung. In Dpal sa ska pa chen po sngags 'chang thams cad mkhyen pa ngag dbang kun dga' bsod nams kyi gsung 'bum, vol.4. Kathmandu: Sa skya rgyal yongs gsung rab slob gnyer khang, pp.338-431.

Blo gros rgyal mtshan, Sog bzlog pa (1552-1624). 1975. Gsang snangs snga 'gyur la bod du rtsod pa snga phyir byung ba rnams kyi lan du brjod pa nges pa don gyi 'brug sgra. In the Collected Writings of Sog-bzlog-pa Blo-gros-rgyal-mtshan: Reproduced from a unique but incomplete dbu-can manuscript from the library of the Ven. Bdud-joms Rinpo-che, vol.1. New Delhi: Sanje Dorji, pp.262-435.

Bskal bzang rin chen (19th cent.). 1969. Sa Gsum Na Mngon Par Mtho Ba Rdo Rje Sgra Dbyangs Gling Gi Zhal 'Don Bskang Gso’i Rim Pa Phyogs Gcig Tu Bsgrigs Pa'i Ngo Mtshar Nor Bu'i 'Phreng Ba Skal Bzang Gzhon Nu'i Mgul Rgyan: The collected liturgical texts of Gnas-chung Rdo-rje-sgra-dbyangs-gling, the residence of the State Oracle of Tibet. Gangtok: Sonam Topgay Kazi.

Dge 'dun grub pa (1391-1474). 199x. Dpal gsang ba 'dus pa'i sgo nas rab tu gnas par byed pa'i chog mdor bsdus pa. In Phyag na pad dkar 'chang ba thams cad mkhyen pa dge 'dun grub pa dpal bzang po'i gsung 'bum, vol. 6. Bkra shis lhun po[?]: Bkra shis lhun po gzhung, pp.411-432.

Dharmakīrti (Chos kyi grags pa). 1986. Tshad ma rnam 'grel gyi tshig le'ur byas pa [=Skt. Pramānavārttika]. In Sde-dge Bstan-'gyur, vol. 174. Delhi: Delhi Karmapae Choedhey, Gyalwae Sungrab Partun Khang, pp.187-301.

Dpal sprul rin po che (1808-1887). 1970. Ston pa bde bar gshegs pa'i gsungs gsang ba bsam gyis mi khyab pa la bsngags pa padma dkar po'i chun 'phyang. In The Collected Works of Dpal-sprul O-rgyan-'jigs-med-chos-kyi-dbang-po, vol.1. Gangtok: Sonam Topgay 
Kazi, pp.103-136. TBRC: W21857.

Gung thang 03 Dkon mchog bstan pa'i sgron me (1762-1823). 2000. Phul byung legs bshad ma'i 'grel pa mkhas pa'i dga'ston. In the Collected Works (Gsung 'bum) of Gung thang Bkon mchog bstan pa'i sgron me, vol.5. Lhasa: Zhol par khang gsar pa, pp.337-361.

Gu ru bkra shis Ngag dbang blo gros (18th cent.). 1990. Gu bkra'i chos 'byung. Beijing: Krung go'i bod kyi shes rig dpe skrun khang.

'Jam mgon kong sprul Blo gros mtha' yas (1813-1899), ed. 1976-1980. Rin Chen Gter Mdzod Chen Mo: A reproduction of the Stod-lun Mtshur-phu redaction of 'Jam-mgon Konsprul's great work on the unity of the gter-ma traditions of Tibet: With supplemental texts from the Dpal-spuns redaction and other manuscripts, 111 vols. Paro: Ngodrup and Sherab Drimay. TBRC: W20578.

Khri ba 'Jam dbyangs rgya mtsho. 2009. Rtogs ldan khri rin po che 'jam dbyangs mkhyen rab rgya mtsho'i gsung 'bum, 4 vols. Chengdu: Si khron mi rigs dpe skrun khang.

Khri byang 03 Blo bzang ye shes bstan 'dzin rgya mtsho (1901-1981). 199?. Smyung gnas kyi phan yon dang bka' slob khag sogs. In Blo bzang ye shes bstan 'dzin rgya mtsho' $i$ gsung 'bum, vol. 7. Chengdu[?]: s.n., pp.435-505.

Lama Gurudeva, ed. 1982. Ser smad thos bsam nor gling grwa tshang gi thun mong ma yin pa'i nye mkho chos spyod. In Chos sde chen po rnams su gsung pa'i chos spyod kyi rim pa dang ser smad thos bsam nor gling grwa tshang gi thun mong ma yin pa'i nye mkho chos spyod bcas. Delhi: Lama Gurudeva.

Lcang skya 02 Ngag dbang blo bzang chos ldan (1642-1714). n.d. Rab gnas mdor bsdus lag tu blang bde. In Ngag dbang blo bzang chos ldan gyi gsung 'bum, vol. 6. Beijing: s.n., pp.111-128.

Lhodrak Kharchu Monastery. 1999. Rgyags brngan lha bsangs. In the Lho brag mkhar chu bdud 'joms gling gi 'don cha'i skor, vol.3. Jakar Dzong: 'Brug Bum-thang Lho-bragmkhar-chu Grwa-tshang, pp.675-778.

Lobzang Tondan, ed. 1983. The Collected Works of Liturgy of the Gnas-chun Rdo-rje-sgradbyans-glin Monastery, 3 vols. Delhi: Lobzang Tondan. TBRC: W00EGS1016248.

Nyi ma 'od zer, Mnga' bdag Nyang ral (1124-1192). 1976. Rgyal po sku lnga 'khor bcas kyi gsol kha phrin las don bcu ma. In Rin Chen Gter Mdzod Chen Mo: A reproduction of the Stod-lun Mtshur-phu redaction of 'Jam-mgon Kon-sprul's great work on the unity of the 
gter-ma traditions of Tibet: With supplemental texts from the Dpal-spuns redaction and other manuscripts, vol.62. Paro: Ngodrup and Sherab Drimay, pp. 275-298. TBRC: W20578.

—. 1976-1980. Rgyal mdos dkar po drug mdos kyi gzhung gshegs gsol dang bcas pa bzhugs pa' $i$ dbu phyogs legs so. In Rin chen gter mdzod chen mo: a reproduction of the Stod-lun Mtshur-phu redaction of 'Jam-mgon Konsprul's great work on the unity of the gter-ma traditions of Tibet, with supplemental texts from the Dpal-spuns redaction and other manuscripts, vol. 69. Paro: Ngodrup and Sherab Drimay, pp.307-345.

- 1983. Rgyal po chen po sku lnga'i gsol mchod 'phrin las don bcu ma. In The Collected Works of Liturgy of the Gnas-chun Rdo-rje-sgra-dbyans-glin Monastery: Reproduced from blockprints from Gnas-chun and other Tibetan establishments, vol. 1. Delhi: Lobzang Tondan, pp. 53-75. TBRC: W00EGS1016248.

-. 1988. Chos 'byung me tog snying po sbrang rtsi'i bcud. Gangs can rig mdzod 5. Lhasa: Bod ljongs mi dmangs dpe skrun khang.

—. 1994. Rgyal po sku lnga 'khor bcas kyi gsol kha phrin las don bcu ma. In Byang gter phur pa lha nag gi chos tshan. Yol mo sprul sku 03 Bstan 'dzin nor bu (1589-1644), ed. Gangtok: Tingkey Gonjang Rinpoche, pp.209-247. TBRC: W1KG3566.

-. n.d. Rgyal po sku lnga 'khor bcas kyi gsol kha phrin las don bcu ma. In Bla ma mchod pa'i cho ga nor bu'i phreng ba sogs chos tshan khag cig. Pad ma 'phrin las, Rdo rje brag rig 'dzin 2 (1641-1717), ed. Ladakh: La dwags brag thog dgon, pp. 405-442. TBRC: W1KG3707.

O rgyan gling pa (1323-1360). 1996. Padma bka' thang. Chengdu: Si khron mi rigs dpe skrun khang, pp.648-661.

Pạ̣ chen Bsod nams grags pa (1478-1554). 2007. Bka' gdams gsar rnying gi chos 'byung yid kyi mdzes rgyan. Rnga ba: Rnga yul kirti dgon dge ldan legs bshad gling.

Ra shag Gter ston (c. late 11th-early 12th cent.). 1976. Sher phreng dkar po'i rgyud las/ Rgyal po pe har gyis dkar po drug mdos. In Mdos chog: A Collection of Mdos and Related Rituals by Karma-chags-med, Legs-ldan-bdud-'joms-rdo-rje, and Others. Bir: Pema Lodoe, pp.223-245.

Ra shag Gter ston and Gra sgom Chos kyi rdo rje (c. late 11th-early 12th cent.). 1976-1980. Srog bdag rgyal po dkar po drug mdos ra shag gter byon gyi ngag 'don khrigs su bsdebs pa. 
In Rin chen gter mdzod chen mo: a reproduction of the Stod-lun Mtshur-phu redaction of 'Jam-mgon Konsprul's great work on the unity of the gter-ma traditions of Tibet, with supplemental texts from the Dpal-spuns redaction and other manuscripts, vol. 69. Paro: Ngodrup and Sherab Drimay, pp.381-393.

Ratna gling pa Rin chen dpal bzang po (1403-1479). 1976. Thugs sgrub yang snying 'dus pa las: Las byang rin chen phreng ba. In Rin chen gter mdzod chen mo: a reproduction of the Stod-lun Mtshur-phu redaction of 'Jam-mgon Kon-sprul's great work on the unity of the gter-ma traditions of Tibet, with supplemental texts from the Dpal-spuns redaction and other manuscripts, vol. 10. Paro: Ngodrup and Sherab Drimay, pp.121-169.

Rgyal sras Legs ldan pa (1290-1365), ed. 1976-1980. Rgyal mdos dkar po drug mdos kyi bca' thabs mdun bskyed/spyan 'dren rnams. In Rin chen gter mdzod chen mo: a reproduction of the Stod-lun Mtshur-phu redaction of 'Jam-mgon Konsprul's great work on the unity of the gter-ma traditions of Tibet, with supplemental texts from the Dpal-spuns redaction and other manuscripts, vol. 69. Paro: Ngodrup and Sherab Drimay, pp.347-380.

Sangs rgyas rgya mtsho, Sde srid (1653-1705). [1698] 1980. Baidūr-ser-po: A history of Dga'ldan (=Dge-lugs-pa) sect, 2 vols. New Delhi: Ngawang Gelek Demo.

—. 1989. Thams cad mkhyen pa drug pa blo bzang rin chen tshangs dbyangs rgya mtsho'i thun mong phyi'i rnam par thar pa du kū la'i 'phro 'thud rab gsal gser gyi snye ma. Lhasa: Bod ljongs mi dmangs dpe skrun khang.

—. 2007. Lnga pa drug par 'phos pa'i gtam rna ba'i bcud len [=Pad dkar 'dzin pa ngur smrig gar rol lnga pa sdom brtson rgyal po'i tshul 'chang ba drug par 'phos pa'i gtam rna ba'i bcud len yid kyi kun dga']. Sarnath: Siddhartha Publications.

—. 2009. "Sde srid sangs rgyas rgya mtshos lhan thabs su bstsal ba'i dkar chag 'dra bshus." In Dpal ldan 'bras spungs dgon gyi dkar chag dri med dwangs gsal shel gyi me long. Tibetan Academy of Social Sciences, ed. Beijing: Krung go'i bod rig pa dpe skrun khang, pp.478-488.

-. n.da. Lcog pa byang chub dpal ldan pa'i rnam thar rags bsdus chos skyong chen po'i 'byung khungs dang bcas pa. Lhasa: s.n.

-. n.db. Drin can rtsa ba'i bla ma ngag dbang blo bzang rgya mtsho'i thun mong phyi'i rnam thar du kū la'i gos bzang, 3 vols. Lhasa: Dga' lda pho brang. 
-. n.dc. Mchod bstod dregs pa'i lha tshogs rba klong 'khrug cing dam can rgya mtsho dgyes par spyod pa'i mgrin bcu'i pho brang sa la 'phos pa sngon med bzo sna brgyad kyis 'phags pa'i gnas chung pe har lcog gi dkar chag sa gsum g.yo ba'i nga ro. s.1.: s.n. TBRC: W2DB20789.

Śamkkarapati (Bde byed bdag po). 1982. Lha las phul du byung bar bstod pa [=Skt. Devātiśaya -stotra]. In Sde-dge Bstan-'gyur, vol. 1. Delhi: Delhi Karmapae Choedhey, Gyalwae Sungrab Partun Khang, pp.86-89.

Sku sger yig tshang, ed. 1977. 'Phags pa 'jig rten dbang phyug gi rnam sprul rim byon gyi 'khrungs rabs deb ther nor bu'i phreng ba, 5 vols. Dharamsala: Sku sger yig tshang. Sle lung rje drung Bzhad pa'i rdo rje (1697-1740). 1976. Dam can bstan srung rgya mtsho'i rnam par thar pa cha shas tsam brjod pa sngon med legs bshad. Thimphu: Kunzang Topgey.

—. 1978. Dam can bstan srung rgya mtsho'i rnam par thar pa cha shas tsam brjod pa sngon med legs bshad, vol. 2. Paro: Ngodrup and Sherab Drimay.

—. 1979. Dam can bstan srung rgya mtsho'i rnam par thar pa cha shas tsam brjod pa sngon med legs bshad, vol. 2. Smanrtsis Shesrig Spedzod, vol.105. Leh: T. S. Tashigang.

-. 2003. Dam can bstan srung gi rnam thar [=Dam can bstan srung rgya mtsho'i rnam par thar pa cha shas tsam brjod pa sngon med legs bshad]. Beijing: Mi rigs dpe skrun khang.

Tā la'i bla ma 02 Dge 'dun rgya mtsho (1476-1542). 2006. Rje btsun thams cad mkhyen pa'i gsung 'bum thor bu las chos rgyal chen po tshe ring mched lnga rdo rje grags mo rgyal rdo rje g.yu sgron ma 'phyos lha kong btsun de mo 'o de gung rgyal sogs kyi gsol kha bstod pa dang bcas pa rnams. In The Collected Works of the Second Dalai Lama Dge 'dun rgya mtsho, vol.6. Dharamsala: Library of Tibetan Works and Archives, pp.167-179.

Tà la'i bla ma 05 Ngag dbang blo bzang rgya mtsho (1617-1682). 1982. Rje btsun thams cad mkhyen pa bsod nams rgya mtsho'i rnam thar dngos grub rgya mtsho'i shing rta. Dolanji: Tashi Dorje.

-. 1983. Rgyal po chen po sde lnga la gsol mchod 'bul tshul 'phrin las 'gags med rdo rje'i sgra dbyangs. In The Collected Works of Liturgy of the Gnas-chun Rdo-rje-sgra-dbyans-glin Monastery, vol.1. Delhi: Lobzang Tondan, pp.12-53.

—. 1991-1995. Thams cad mkhyen pa rgyal ba lnga pa chen po ngag dbang blo bzang rgya mtsho'i gsung 'bum: The Collected Works (Gsung-'bum) of Vth Dalai Lama, Ngag- 
dbang-blo-bzang-rgya-mtsho, 25 vols. Gangtok: Sikkim Research Institute of Tibetology.

- 1991-1992. Zab pa dang rgya che ba'i dam pa'i chos kyi thob yig gang gA'i chu rgyun. In

Tā la'i bla ma 05 1991-1995, vols.1-4. Gangtok: Sikkim Research Institute of Tibetology.

-. 1992a. Za hor gyi ban de ngag dbang blo bzang rgya mtsho'i 'di snang 'khrul pa'i rol rtsed rtogs brjod kyi tshul du bkod pa du ku la'i gos bzang las glegs bam dang po. In Tā la'i

bla ma 05 1991-1995, vol.5. Gangtok: Sikkim Research Institute of Tibetology, pp.26-30.

-. 1992b. Thogs med drag rtsal nus stobs ldan pa'i dam can chos srung rgya mtsho'i mngon rtogs mchod 'bul bskang bshags bstod tshogs sogs 'phrin las rnam bzhi'i lhun grub. In Tā la'i bla ma 05 1991-1995, vol.11. Gangtok: Sikkim Research Institute of Technology, pp.129-591. TBRC: W212.

—. 1992c. Rgyal po chen po sde lnga la gsol mchod 'bul tshul 'phrin las 'gags med rdo rje'i sgra dbyangs. In Tā la'i bla ma 05 1992b, pp.207-252.

—. 2007. Thogs med drag rtsal nus stobs ldan pa'i dam can chos srung rgya mtsho'i mngon rtogs mchod 'bul bskang bshags bstod tshogs sogs 'phrin las rnam bzhi lhun grub. In Thams cad mkhyen pa lnga pa chen po'i gsung 'bum, vol.11. Dharamsala: Nam gsal sgron ma, pp.121-616.

—. 2009a. "Gnas chung gi bde yangs khyams skor lho ngos kyi dkar chag 'dra bshus." In Dpal ldan 'bras spungs dgon gyi dkar chag dri med dwangs gsal shel gyi me long. Tibetan Academy of Social Sciences, ed. Beijing: Krung go'i bod rig pa dpe skrun khang, pp.470478.

—. 2009b. Rgyal dbang lnga pa ngag dbang blo bzang rgya mtsho'i gsung 'bum (五世达赖阿旺 洛桑嘉措文集), vol.14. Beijing: Krung go’i bod rig pa dpe skrun khang.

Tā la'i bla ma 05 Ngag dbang blo bzang rgya mtsho (1617-1682), et al. n.d. Sa gsum na mngon par mtho ba rdo rje sgra dbyangs gling gi zhal 'don 'phrin las don bcu ma'i gton bsgrigs rag rig. s.n. 53 folios.

Tsong kha pa Blo bzang grags pa (1357-1419). 1978. Rab gnas rgyas pa'i zin bris. In The Collected Works (Gsun 'Bum) of the Incomparable Lord Tson-kha-pa Blo-bzang-gragspa, vol. 8. New Delhi: Lama Gurudeva, pp.317-378.

Ye shes seng ge (b. 12th century). 1974. Mthu stobs dbang phyug rje btsun rwa lo tsä ba'i rnam par thar pa kun khyab snyan pa'i rnga sgra. In The Lives of Two Esoteric Adepts: Being the rnam-thar of Rwa Lo-chen Rdo-rje-grags written by Rwa Ye-śes-senge and the rnam- 
thar of Grub-chen Thar-pa'i-rgyal-mtshan composed by one Dge-slon Nag-gi-dban-po. New Delhi: Ngawang Gelek Demo, pp.1-301.

\section{Secondary Sources}

Achard, Jean-Luc, ed. 2002. Revue d'Etudes Tibétaines: Numéro Spécial Lha srin sde brgyad. Paris: Langues et Cultures de l'Aire Tibétaine.

Ahmad, Zahiruddin. 1970. Sino-Tibetan Relations in the Seventeenth Century. Rome: Istituto Italiano per il Medio ed Estremo Oriente.

Alexander, André. 2005. The Temples of Lhasa: Tibetan Buddhist Architecture from the 7th to the 21st Centuries. Chicago: Serindia Publications.

Aris, Michael. 1989. Hidden Treasures and Secet Lives: A Study of Pemalingpa (1450-1521) and the Sixth Dalai Lama (1683-1706). London: Kegan Paul International.

Attisani, Antonio, and Ludbrook, Geraldine. 1999. "Tibetan Secular Theatre: The Sacred and the Profane." In PAJ: A Journal of Performance and Art 21(3), pp. 1-12.

Avedon, John F. 1984. In Exile from the Land of Snows. New York: Alfred A. Knopf.

Bailey, Cameron. 2012. The Raven and the Serpent: "The Great All-Pervading Rāhula" and Dǽmonic Buddhism in India and Tibet. Master's thesis, Florida State University.

Barnett, Robert. 2006. Lhasa: Streets with Memories. New York: Columbia University Press.

Beer, Robert. 2004. The Encyclopedia of Tibetan Symbols and Motifs. Chicago: Serindia Publications.

Bell, Catherine. 1992. Ritual Theory, Ritual Practice. New York: Oxford University Press.

Bell, Charles. 1946. Portrait of the Dalai Lama. London: Collins.

Bell, Christopher. 2006. Tsiu Marpo: The Career of a Tibetan Protector Deity. Master's thesis, Florida State University.

Bellezza, John Vincent. 1997. Divine Dyads: Ancient Civilization in Tibet. Dharamsala:

Library of Tibetan Works and Archives.

- 2005. Spirit-Mediums, Sacred Mountains and Related Bon Textual Traditions in Upper Tibet: Calling Down the Gods. Leiden: Brill.

-. 2008. Zhang Zhung: Foundations of a Civilization in Tibet: A Historical and

Ethnoarchaeological Study of the Monuments, Rock Art, Texts, and Oral Tradition of the Ancient Tibetan Upland. Vienna: Verlag der Österreichischen Akademie der 
Wissenschaften.

Bentor, Yael. 1996. Consecration of Images and Stūpas in Indo-Tibetan Tantric Buddhism. Leiden: Brill.

Berglie, Per-Arne. 1976. "Preliminary Remarks on Some Tibetan 'Spirit Mediums' in Nepal.” In Kailash 4(1), pp. 85-108.

Berzin, Alexander. [1991] 2003. “A Brief History of Mindrol-ling Monastery.” In The Berzin Archives: The Buddhist Archives of Dr. Alexander Berzin. http://www.berzinarchives. com/web/en/archives/study/history_buddhism/buddhism_tibet/nyngma/brief_history_ mindrol-ling_monastery.html (accessed April 17, 2013).

Beyer, Stephan. 1973. The Cult of Tara: Magic and Ritual in Tibet. Berkeley: University of California Press.

Bla brang skal bzang. 1996. Bod skyong srung ma khag gi lo rgyud: Detialed [sic] History of the Wrathful Miracles of Vajra Dharma Protectors. Dharamsala: Konchog Tashi.

Blondeau, A. M. 1971. “Le Lha'dre bka'-than.” In Études Tibétaines Dédiées à la Mémoire de Marcelle Lalou. Paris: Librairie d'Amérique et d'Orient, pp. 29-126.

Blondeau, A. M., ed. 1998. Tibetan Mountain Deities, Their Cults and Representations. Wien: Verlag Der Österreichischen Akademie Der Wissenschaften.

Brooks, E. Bruce, and Brooks, A. Taeko. 1998. The Original Analects: Sayings of Confucius and His Successors. New York: Columbia University Press.

Bshes gnyen tshul khrims. 2008. Lha sa'i dgon tho rin chen spungs rgyan. Lhasa: Bod ljongs mi dmangs dpe skrun khang.

Bstan 'dzin rgya mtsho, ed. n.d. Snga 'gyur rgyud 'bum las btus pa'i gtam rgyud phyogs bsgrigs. Gser rta dgon po'i par khang.

Bstan pa mkhyen rab. 1993. "Tshal yang dgon gyi byung ba rags rim zhig." In Bod ljongs nang bstan 1993.1, pp.12-26.

Cabezón, José, ed. 2010. Tibetan Ritual. Oxford: Oxford Unity Press.

Central Tibetan Administration. 2013. "The Tibetan National Flag." http://tibet.net/ about-tibet/the-tibetan-national-flag/ (accessed April 27, 2013).

Chos 'phel. [2004] 2009. Gangs can bod kyi gnas gshad lam yig gsar ma - Lha sa sa khul gyi gnas yig. Beijing: Mi rigs dpe skrun khang.

Clarke, Elizabeth A. 2004. History, Theory, Text: Historians and the Linguistic Turn. Cambridge: 
Harvard University Press.

Conze, Edward, trans. 1975. The Large Sutra on Perfect Wisdom: with the divisions of the Abhisamayālanikāra. Berkeley: University of California Press.

Cornu, Philippe. 1990. L'astrologie Tibétaine. Paris: Collection Présences.

Cuevas, Bryan. 2001. "Gu-ru Bkra-shis Chos-'byung: A Selective Outline of the Beijing Edition." Unpublished Paper.

- 2003. The Hidden History of the Tibetan Book of the Dead. Oxford: Oxford University Press. Dalai Lama 14, Tenzin Gyatso. [1984] 2013. "Commentary on Gyalwa Gyatso.” In Lama Yeshe Wisdom Archive: The Archive of the FPMT. http://www.lamayeshe.com/index.php? sect $=$ article\&id=412 (accessed June 11, 2013).

Dalton, Jacob. 2004. "The Early Development of the Padmasambhava Legend in Tibet: A Study of IOL Tib J 644 and Pelliot tibétain 307.” In Journal of the American Oriental Society 124(4), pp.759-772.

- 2011. The Taming of the Demons: Violence and Liberation in Tibetan Buddhism. New Haven: Yale University Press.

Dargyay, Eva. 1985. “The White and Red Rong-Btsan of Matho Monastery.” In Journal of the Tibet Society 5, pp. 55-65.

Davidson, Ronald. 2005. Tibetan Renaissance: Tantric Buddhism in the Rebirth of Tibetan Culture. New York: Columbia University Press.

Day, Sophie. 1989. "Embodying Spirits: Village Oracles and Possession Ritual in Ladakh, North India." Ph.D. dissertation, London School of Economics and Political Science.

- 1990. "Ordering Spirits: The Initiation of Village Oracles in Ladakh." In Wissenschaftsgeschichte und gegenwärtige Forschungen in Nordwest-Indien 9(3), pp. 206-222.

Decleer, Hubert. 1992. "The Melodious Drumsound All-Pervading: Sacred Biography of Rwa

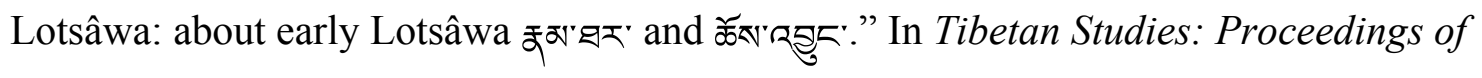
the 5th Seminar of the International Association for Tibetan Studies, Narita 1989, vol. 1. Ihara Shōren and Yamaguchi Zuihō, eds. Narita: Naritasan Shinshoji, pp.13-28.

Delicateear. (2012, June 11). NECHUNG ORACLE.mp4 [Video file]. http://www.youtube.com/ watch?v=12oQM92om14 (accessed April 17, 2013).

Department of Religion and Culture. 2004. Rgyal ba'i bstan srung gnas chung sprul pa'i chos 
rgyal chen po'i rtogs brjod lha yi rol mo dam can dgyes pa'i sgra dbyangs. Dharamsala: CTA, Gangchen Kyishong.

Diemberger, Hildegard. 2005. "Female Oracles in Modern Tibet." In Women in Tibet. Janet Gyatso and Hanna Havnevik, eds. New York: Columbia University Press.

Dobis Tsering Gyal. 2009. "Remarks on the State Oracles and Religious Protectors of the dGa' ldan pho brang Government." In Contemporary Visions in Tibetan Studies: Proceedings of the First International Seminar of Young Tibetologists. Brandon Dotson, et al., eds. Chicago: Serindia Publications, pp.343-361.

Doniger, Wendy. 2009. The Hindus: An Alternative History. New York: Penguin Press.

Dorje, Gyurme. 2004. Footprint Tibet. 3rd ed. Bath: Footprint Travel Guides.

Douglas, Kenneth, and Gwendolyn Bays, trans. 1978. The Life and Liberation of Padmasambhava, 2 vol. Berkeley: Dharma Publishing.

Dowman, Keith. 1988. The Power-Places of Central Tibet: The Pilgrim's Guide. London: Routledge \& Kegan Paul.

Dreyfus, Georges. 1998. “The Shuk-den Affair: History and Nature of a Quarrel.” In Journal of the International Association of Buddhist Studies 21(2), pp. 227-270.

—. 2006a. "The Deyang Monastic College (Deyang Dratsang)." Drepung Monastery Project. Tibetan and Himalayan Library. http://www.thlib.org/places/monasteries/drepung/ colleges.php\#!essay=/dreyfus/drepung/colleges/s/b3 (accessed April 17, 2013).

-. 2006b. "Interactive Map of Drepung Monastery." Drepung Monastery Project. Tibetan and Himalayan Library. http://www.thlib.org/places/monasteries/drepung/map/ (accessed April 17, 2013).

Duara, Prasenjit. 1988. "Superscribing Symbols: The Myth of Guandi, Chinese God of War." In The Journal of Asian Studies 47(4), pp.778-795.

Dudjom Rinpoche, Jikdrel Yeshe Dorje. 1991. The Nyingma School of Tibetan Buddhism: Its Fundamentals \& History, 2 vols. Gyurme Dorje and Matthew Kapstein, trans. and eds. Boston: Wisdom Publications.

Dung dkar Blo bzang 'phrin las. 2002. Dung dkar tshig mdzod chen mo. Beijing: Krung go'i bod rig pa dpe skrun khang.

Ekvall, Robert B. 1963. "Some Aspects of Divination in Tibetan Society." In Ethnology 2(1), pp.31-39. 
Elverskog, Johan. 2003. The Jewel Translucent Sütra: Altan Khan and the Mongols in the Sixteenth Century. Leiden: Brill.

Engle, Artemus B. 2009. The Inner Science of Buddhist Practice: Vasubandhu's Summary of the Five Heaps with Commentary by Sthiramati. Ithaca: Snow Lion Publications.

Frankenberg, Ruth. 2001. "The Mirage of an Unmarked Whiteness." In The Making and Unmasking of Whiteness. Birgit Brander Rasmussen, Eric Klinenberg, Irene J. Nexica, and Matt Wray, eds. Durham: Duke University Press, pp.72-96.

French, Rebecca Redwood. 2002 [1995]. The Golden Yoke: The Legal Cosmology of Buddhist Tibet. Ithaca: Snow Lion Publications.

Garrett, Frances. 2010. "Tapping the Body's Nectar: Gastronomy and Incorporation in Tibetan Literature.” In History of Religions 49(3), pp.300-326.

Germano, David. 1992. Poetic Thought, the Intelligent Universe, and the Mystery of Self: The Tantric Synthesis of rDzogs Chen in Fourteenth Century Tibet. PhD dissertation, University of Wisconsin - Madison. Ann Arbor: ProQuest/UMI. (Publication No. 9231691.)

Germano, David and Gyatso, Janet. 2000. "Longchenpa and the Possession of the Ḍākinīs." In Tantra in Practice. David White, ed. Princeton: Princeton University Press, pp. 239-265.

Germano, David, Tournadre, Nicolas, and THL. 2003. THL Simplified Phonetic Transcription of Standard Tibetan. http://www.thlib.org/reference/transliteration/\#!essay=/thl/phonetics/ (accessed April 28, 2013).

Geshe Wangyal. 1986. The Jewelled Staircase. Ithaca: Snow Lion Publications.

Getty, Alice. 1962. The Gods of Northern Buddhism: Their History, Iconography and Progressive Evolution through the Northern Buddhist Countries. Rutland: Charles E. Tuttle Company.

Gibson, Todd Allen. 1985. "Dgra-lha: A Re-Examination." In Journal of the Tibet Society 5, pp. 67-72.

-. 1991. "From btsanpo to btsan: The demonization of the Tibetan sacral kingship." $\mathrm{Ph} . \mathrm{D}$. dissertation, Indiana University.

Goldstein, Melvyn, ed. 2001. The New Tibetan-English Dictionary of Modern Tibetan. Berkeley: University of California Press.

郭净 [Guo Jing]. 1997. 西藏山南扎囊县桑耶寺多德大典 [The Great Dödé Ceremony of 
Samyé Monastery, in Dranang County, Lhoka Prefecture, Tibet]. Taipei: Shihe Zheng Foundation.

Gyatso, Janet. 1986. "Signs, Memory and History: A Tantric Buddhist Theory of Scriptural Transmission.” In The Journal of the International Association of Buddhist Studies 9(2), pp. 7-35.

-. 1993. "The Logic of Legitimation in the Tibetan Treasure Tradition." In History of Religions 33(2), pp.97-134.

Haarh, Erik. 1969. The Yar-lun Dynasty. Copenhagen: G.E.C. Gad's Forlag.

Hansen, Valerie. 1990. Changing Gods in Medieval China, 1127-1276. Princeton:

Princeton University Press.

Hao, Wangdui and Xiao Hao. 1992. "Between God and Human Beings: A Visit to Sorceress Losang Zizen." In China's Tibet 3(1), pp. 32-40.

Harding, Sarah, trans. 2003. The Life and Revelations of Pema Lingpa. Ithaca: Snow Lion Publications.

Havnevik, Hanna. 2002. “A Tibetan Female State Oracle.” In Religion and Secular Culture in Tibet; Tibetan Studies: Proceedings of the Ninth Seminar of the International Association for Tibetan Studies, Leiden 2000. Henk Blezer, ed. Leiden: Brill, pp. 259-287.

Heller, Amy. 1988. "Early Textual Sources for the Cult of Beg-ce.” In Tibetan Studies: Proceedings of the $4^{\text {th }}$ Seminar of the International Association for Tibetan Studies. Schloss Hohenkammer - Munich 1985. Helga Uebach and Jampa L. Panglung, eds. Munich: Kommission für Zentralasiatische Studien Bayerische Akademie der Wissenschaften, pp.185-195.

—. 1992a. "Historic and Iconographic Aspects of the Protective Deities Srung-ma dmar-nag." In Tibetan Studies: Proceedings of the 5th Seminar of the International Association for Tibetan Studies, Narita 1989, vol 2. Ihara Shōren and Yamaguchi Zuihō, eds. Tokyo: Naritasan Shinshoji, pp. 479-492.

—. 1992b. "Etude sur le développement de l'iconographie et du culte de Beg-tse, divinité protectrice tibétaine." Diplôme de l'École Pratique des Hautes Études, Paris.

- 1997. "Notes on the Symbol of the Scorpion in Tibet." In Les Habitants du Toit du Monde, Études Recueillies en Hommage à Alexander W. Macdonald. Samten Karmay and Philippe Sagant, eds. Nanterre: Société d'Ethnologie, pp. 283-297. 
—. 2003. "The Great Protector Deities of the Dalai Lamas." In Lhasa in the Seventeenth Century: The Capital of the Dalai Lamas. Françoise Pommaret, ed. Leiden: Brill, pp.81-98.

—. 2005a. "The Second Dalai Lama Gendün Gyatso." In The Dalai Lamas: A Visual History. Martin Brauen, ed. Chicago: Serindia, pp.42-51.

—. 2005b. "The Protective Deities of the Dalai Lamas." In The Dalai Lamas: A Visual History. Martin Brauen, ed. Chicago: Serindia, pp.212-229.

—. 2006. "Armor and Weapons in the Iconography of Tibetan Buddhist Deities." In Warriors of the Himalayas: Rediscovering the Arms and Armor of Tibet. Donald J. LaRocca, ed. New Haven: Yale University Press, pp.34-41.

Himalayan Art Resources. 2013a. "Buddhist Deity: Avalokiteshvara, Chaturbhuja (Four Hands)." http://www.himalayanart.org/search/set.cfm?setID=1285 (accessed April 17, 2013).

—. 2013b. "Dalai Lama Incarnation Lineage Painting Set." http://www.himalayanart.org/ pages/dalaiset7/index.html (accessed April 17, 2013).

Hodge, Stephen, trans. 2003. The Mahā-Vairocana-Abhisambodhi Tantra: With Buddhaguhya's Commentary. Abingdon: RoutledgeCurzon.

Hummel, Siegbert. 1962. "Pe-har." In East and West 13(4), pp. 313-316.

Hymes, Robert. 2002. Way and Byway: Taoism, Local Religion, and Models of Divinity in Sung and Modern China. Berkeley: University of California Press.

Jovic, Nika. 2010. The Cult of the 'Go ba'i lha lnga: A Study with Pictorial and Written Material of the Five Personal Protective Deities. Master's thesis, University of Vienna.

Kapstein, Matthew. 1992. "Remarks on the Mani bKa'-'bum and the Cult of Avalokiteśvara in Tibet." In Tibetan Buddhism: Reason and Revelation. Steven D. Goodman and Ronald M. Davidson, eds. Albany: SUNY Press, pp.79-93.

-. 2000. The Tibetan Assimilation of Buddhism: Conversation, Contestation, and Memory. Oxford: Oxford University Press.

—, ed. 2009. Buddhism between Tibet \& China. Somerville: Wisdom Publications. Karmay, Samten. 1988. Secret Visions of the Fifth Dalai Lama. London: Serindia.

-. 1998a. "King Tsa/Dza and Vajrayana." In The Arrow and the Spindle: Studies in History, Myths, Rituals and Beliefs in Tibet. Kathmandu: Mandala Book Point, pp.76-93.

-.1998b. "The Soul and the Turquoise: a Ritual for Recalling the bla." In The Arrow and the 
Spindle: Studies in History, Myths, Rituals and Beliefs in Tibet. Kathmandu: Mandala Book Point, pp.310-338.

-. 1998c. "The Man and the Ox: A Ritual for Offering the glud." In The Arrow and the Spindle: Studies in History, Myths, Rituals and Beliefs in Tibet. Kathmandu: Mandala Book Point, pp.339-379.

—. 1998d. "The Local Deities and the Juniper Tree: a Ritual for Purification (bsang)." In The Arrow and the Spindle: Studies in History, Myths, Rituals and Beliefs in Tibet. Kathmandu: Mandala Book Point, pp.380-412.

—. 1998e. "Mountain Cult and National Identity." In The Arrow and the Spindle: Studies in History, Myths, Rituals and Beliefs in Tibet. Kathmandu: Mandala Book Point, pp.423-431.

-. 1998f. "The Cult of Mountain Deities and its Political Significance." In The Arrow and the Spindle: Studies in History, Myths, Rituals and Beliefs in Tibet. Kathmandu: Mandala Book Point, pp.432-450.

—. 1998g. "The Cult of Mount dMu-rdo in rGyal-rong." In The Arrow and the Spindle: Studies in History, Myths, Rituals and Beliefs in Tibet. Kathmandu: Mandala Book Point, pp.451-462.

—. 1998h. "The Gold Seal: The Fifth Dalai Lama and Emperor Shun-chih." In The Arrow and the Spindle: Studies in History, Myths, Rituals and Beliefs in Tibet. Kathmandu: Mandala Book Point, pp.518-522.

-. 2005a. "The Rituals and their Origins in the Visionary Accounts of the Fifth Dalai Lama." In The Arrow and the Spindle: Studies in History, Myths, Rituals and Beliefs in Tibet, vol.2. Kathmandu: Mandala, pp.73-94.

—. 2005b. "A Most Pleasing Symphony: An Unknown Biography of the Fifth Dalai Lama." In The Arrow and the Spindle: Studies in History, Myths, Rituals and Beliefs in Tibet, vol.2. Kathmandu: Mandala, pp.95-108.

- 2005c. "The Mural Paintings in the Red Palace of the Potala." In The Arrow and the Spindle: Studies in History, Myths, Rituals and Beliefs in Tibet, vol.2. Kathmandu: Mandala, pp.109-118.

-. 2005d. "rDo-rje Gling-pa and his Rediscovery of the 'Gold Needle' in Bhutan." In The Arrow and the Spindle: Studies in History, Myths, Rituals and Beliefs in Tibet, vol.2. 
Kathmandu: Mandala, pp.119-145.

Katz, Paul R. 1995. Demon Hordes and Burning Boats: The Cult of Marshal Wen in Late Imperial Chekiang. Albany: State University of New York Press.

Kelényi, Béla, ed. 2003. Demons and Protectors: Folk Religion in Tibetan and Mongolian Buddhism. Budapest: Ferenc Hopp Museum of Eastern Asiatic Art, pp.28-44.

Kelley, Glen. 1993. Nechung, Tsang pa, Ghadong, Youdronma: Some Research on Four Tibetan Oracles and Their Deities. Independent Study Project. School for International Training, Brattleboro, VT.

Khandro.net. 2013. Tale of Two. http://www.khandro.net/deity_tale_of_two.htm (accessed April 17, 2013).

Khenpo Karthar Rinpoche. 2004. Karma Chakme’s Mountain Dharma, vol. 1. Woodstock: KTD Publications.

Kleisath, C. Michelle. 2013. “Start Saying 'White,' Stop Saying 'Western': Transforming the Dominant Vocabulary of Tibet Studies.” In Transforming Anthropology 21(1), pp.15-26. Kohn, Richard. 2001. Lord of the Dance: The Mani Rimdu Festival in Tibet and Nepal. Albany: SUNY.

Ladrang Kalsang [=Bla brang skal bzang]. 1996. The Guardian Deities of Tibet. Pema Thinley, trans. Dharamsala: Little Lhasa Publications.

Lama Chime Radha Rinpoche. 1981. "Tibet.” In Oracles and Divination. Michael Loewe and Carmen Blacker, eds. Boulder: Shambhala, pp.3-37.

林純瑜 [Lin Shen-Yu]. 2009. “貝哈護法神與西藏政治 [Guardian Deity Pehar and Tibetan Politics].” In 臺灣宗教研究 [Taiwan Journal of Religious Studies] 8(1), pp.83-101.

—. 2010. "Pehar: A Historical Survey.” In Revue d'Etudes Tibétaines 19, pp.5-26.

Linrothe, Rob. 2000a. "Delivering Threats, Threatening Deliverance: Forms and Functions in Indo-Tibetan Esoteric Buddhist Wrathful Deities, Part One.” In Oriental Art 46(2), pp.24-35.

—. 2000b. "Delivering Threats, Threatening Deliverance: Forms and Functions in Indo-Tibetan Esoteric Buddhist Wrathful Deities, Part Two.” In Oriental Art 46(3), pp.92-105.

Lobsang Dorje. 1984. "Lhamo: The Folk Opera of Tibet.” In Tibet Journal 9(2), pp.13-22.

Lohia, Sushama. 1994. Lalitavajra's Manual of Buddhist Iconography. New Delhi: International Academy of Indian Culture and Aditya Prakashan. 
Macdonald, Ariane. 1978a. "Le culte de Pehar et de Ci’u dmar-po dans la tradition écrite et orale. Histoire du monastère de Gnas-chung et de ses médiums (suite)," "Histoire et philologie tibétaines" (conférences 1976-1977). In Annuaire de l'Ecole Pratique des Hautes Etudes, Paris, pp.1139-1145.

—. 1978b. "Les rivalités politiques et religieuses centrées sur Samye au XVIe siècle. La lignée spirituelle du Ve Dalai-Lama dans la littérature, dans l'histoire, et dans l'art." "Histoire et philologie tibétaines" (conférences 1977-1978). In Annuaire de l'Ecole Pratique des Hautes Etudes, Paris, pp.1023-1030.

Martin, Dan. 1996a. "The Star King and the Four Children of Pehar: Popular Religious Movements of 11 th-to 12th-century Tibet.” In Acta Orientalia Academiae Scientiarum Hungaricae 49(1-2), pp. 171-195.

—. 1996b. "Lay Religious Movements in 11th- and 12th-Century Tibet: A Survey of Sources." In Kailash 18(3-4), pp. 23-55.

—. 1997. Tibetan Histories: A Bibliography of Tibetan-Language Historical Works. London: Serindia Publications.

- 2001. Unearthing Bon Treasures: Life and Contested Legacy of a Tibetan Scripture Revealer, with a General Bibliography of Bon. Leiden: Brill.

McCune, Lindsay. 2007. Tales of Intrigue from Tibet's Holy City: The Historical Underpinnings of a Modern Buddhist Crisis. Master's thesis, Florida State University.

Mig dmar tshe ring, Gra bzhi. 2010. Gnas chung dgon (乃琼寺): Dbang drag rol pa'i dga' tshal gnas chung rdo rje sgra dbyangs gling gi dkar chag mthong ba don ldan. Lhasa: Bod ljongs mi dmangs dpe skrun khang.

—. 2011. Tshal gung thang gtsug lag khang gi dkar chag skyid chu'i rang mdangs. Lhasa: Tibetan Academy of Social Sciences.

Mills, Martin. 2003. Identity, Ritual and State in Tibetan Buddhism: The Foundations of Authority in Gelukpa Monasticism. London: RoutledgeCurzon.

Monier-Williams, Monier. [1899] 1993. A Sanskrit-English Dictionary. Delhi: Motilal Banarsidass Publishers.

Muldowney, Kristen. 2011. Outward Beauty, Hidden Wrath: An Exploration of the Drikung Kagyü Dharma Protectress Achi Chökyi Drölma. Master's thesis, Florida State University. 
Mumford, Stan. 1989. Himalayan Dialogue: Tibetan Lamas and Gurung Shamans in Nepal. Madison: University of Wisconsin Press.

Nair, Urmila. 2004. The Sociological Inflection of Ontology: A Study of the Multiple Ontological Statuses of a Tibetan Buddhist Protective Deity. Master's thesis, University of Chicago. —. 2010. When the Sun's Rays are as Shadows: The Nechung Rituals and the Politics of Spectacle in Tibetan Exile. Unpublished doctoral dissertation, University of Chicago, Chicago, IL.

Nebesky-Wojkowitz, René de. [1948] 1972. "Das tibetische Staatsorakel.” In Archive für Völkerkunde, vol.3. Etta Becker-Donner and Annemarie Schweeger-Hefel, eds. Vienna: Wilhelm Braumüller Universitäts-Verlag, pp.136-155.

- 1976. Tibetan Religious Dances. The Hague: Mouton \& Co.

- [1956] 1998. Oracles and Demons of Tibet: The Cult and Iconography of the Tibetan Protective Deities. New Delhi: Paljor Publications.

Nechung Monastery. 2004. Dus gsum rgyal ba thams cad kyi gno bo ma hā gu ru padma sam bha ba'i sku'i 'khrungs skar sprel lo sprel zla tshes bcu'i dus chen ngo sprod dang /o rgyan las rab gling pa'i gter byon gu ru'i sku tshab mthong grol yid bzhin nor bu lha ldan du ji ltar gdan drangs tshul/ gnas chung chos rgyal chen po'i rtogs brjod bsdus pa bcas phyogs gcig gces bsdebs. Dharamsala: Nechung Monastery.

Ṅag-dBan் Blo-bZan் rGya-mTSHo. 1995. A History of Tibet by Nag-dBaí Blo-bZaí rGyamTSHo, Fifth Dalai Lama of Tibet. Zahiruddin Ahmad, trans. Boomington: Indiana University Research Institute for Inner Asian Studies.

Ortner, Sherry. [1978] 1999. Sherpas through their Rituals. Cambridge: Cambridge University Press.

Padma skal bzang, Gling dbon. 1988. Dbang drag rol pa'i dga' tshal gnas chung rdo rje sgra dbyangs gling gi dkar chag bskyar sgrig. In Bod ljongs nang bstan 1988.1, pp.32-68.

Pasang Yonten Arya. 1994. Bod kyi sman rdzas rig pa'i tshig mdzod g.yu thog sngo 'bum dgongs rgyan: Dictionary of Tibetan Materia Medica. Milan: Lama Gangchen World Peace Foundation.

Peter, Prince of Greece and Denmark. 1978a. "Tibetan Oracles in Dharamsala." In Proceedings of the Csoma de Körös Memorial Symposium. Louis Ligeti, ed. Budapest: Akadémiai Kiadó, pp. 327-334. 
—. 1978b. "Tibetan Oracles." In Himalayan Anthropology: The Indo-Tibetan Interface. Hague: Moulon, pp. 287-298.

Pommaret, Françoise, ed. 2003. Lhasa in the Seventeenth Century: The Capital of the Dalai Lamas. Howard Solverson, trans. Leiden: Brill.

Reynolds, John Myrdhin. 1996. The Golden Letters. Ithaca: Snow Lion Publications.

Ricca, Franco. 1999. Il Tempio Oracolare di gNas-chun: Gli Dei del Tibet più Magico e Segreto. Alessandria: Edizioni dell'Orso.

Richardson, Hugh. 1985. A Corpus of Early Tibetan Inscriptions. London: Royal Asiatic Society. —. 1993. Ceremonies of the Lhasa Year. London: Serindia Publications.

Rigpa Shedra. 2012. "Yang Nying Pudri.” In Rigpa Shedra Wiki. http://www.rigpawiki.org/ index.php?title=Yang_Nying_Pudri (accessed April 17, 2013).

Roberts, Peter Alan. 2007. The Biographies of Rechungpa: The Evolution of a Tibetan Hagiography. New York: Routledge.

Rock, Joseph F. 1935. "Sungmas, the Living Oracles of the Tibetan Church.” In National Geographic Magazine 68, pp. 475-486.

Roerich, George N. [1949] 1996. The Blue Annals: Parts I \& II (Bound in one). Delhi: Motilal Banarsidass Publishers.

Ruegg, David. 2008. The Symbiosis of Buddhism with Brahmanism/Hinduism in South Asia and of Buddhism with 'Local Cults' in Tibet and the Himalayan Region. Vienna: Verlag der Österreichischen Akademie der Wissenschaften.

Samuel, Geoffrey. 1993. Civilized Shamans. Washington: Smithsonian Institution Press, pp.162-163.

Samten Chhosphel. 2011. "Lerab Lingpa." In The Treasury of Lives: A Biographical Encyclopedia of Himalayan Religion. http://www.treasuryoflives.org/biographies/ view/Lerab-Lingpa/8538 (accessed June 11, 2013).

Sañs-rGyas rGya-mTSHo. 1999. Life of the Fifth Dalai Lama: Volume IV, Part I. Zahiruddin Ahmad, trans. New Delhi: International Academy of Indian Culture and Aditya Prakashan.

Schaeffer, Kurtis. 2004a. "Indian Intellectuals at the Court of the Fifth Dalai Lama, 1654-1682." Talk presented at the Tibet and her Neighbors Symposium, Harvard University, Cambridge, Massachusetts. April 23-24, 2004. 
—. 2004b. "Avalokiteśvara's Diary." Talk presented at the Annual Meeting of the American Academy of Religion, San Antonio, Texas. November 21, 2004.

—. 2005a. "The Fifth Dalai Lama." In The Dalai Lamas: A Visual History. Martin Brauen, ed. Chicago: Serindia, pp.64-91.

-. 2005b. "Canon and Contemporary Innovation in the Era of the Fifth Dalai Lama." Talk delivered at the South Asia Seminar, University of Chicago, Illinois. April 28, 2005.

—. 2006. "Ritual, Festival, and Authority under the Fifth Dalai Lama." In Power, Politics and the Reinvention of Tradition in Seventeenth and Eighteenth Century Tibet: Proceedings of the International Association for Tibetan Studies, Xth Seminar, Oxford University, 2003. Kurtis R. Schaeffer and Bryan J. Cuevas, eds. Leiden: Brill, pp.187-202.

—. Forthcoming. "New Tibetan Scholarship, 1650-1700." In Forms of Knowledge in Early Modern South Asia. Sheldon Pollock, ed. Raleigh: Duke University Press.

—. Forthcoming. "Salt and the Sovereignty of the Dalai Lama, circa 1697." Talk presented at a seminar in Honor of Koichi Shinohara, UBC, October 14-16, 2004. Forthcoming in a festschrift for Koichi Shinohara. James Benn, ed.

Schenk, Amelia. 1993. "Inducing Trance: On the Training of Ladakhi Oracle Healers." In Proceedings of the International Seminar on the Anthropology of Tibet and the Himalaya; September 21-28, 1990, Zurich. Charles Ramble and Martin Brauen, eds. Druck: BuchsDruck, pp. 331-342.

Shakabpa, Tsepon Wangchuk Deden. 2010. One Hundred Thousand Moons: An Advanced Political History of Tibet, 2 vols. Derek F. Maher, trans. Leiden: Brill.

Sidky, Homayun. 2011. "The State Oracle of Tibet, Spirit Possession, and Shamanism." In Numen 58, pp.71-99.

Simmer-Brown, Judith. 2001. Dakini's Warm Breath: The Feminine Principle in Tibetan Buddhism. Boston: Shambhala Publications.

Smith, Frederick M. 2006. The Self Possessed: Deity and Spirit Possession in South Asian Literature and Civilization. New York: Columbia University Press.

Smith, Jonathan Z. 1987. To Take Place: Toward Theory in Ritual. Chicago: University of Chicago Press.

Snellgrove, David. 2002. Indo-Tibetan Buddhism: Indian Buddhists and Their Tibetan Successors. Boston: Shambhala Publications. 
Sørensen, Per K. 1994. Tibetan Buddhist Historiography: The Mirror Illuminating the Royal Genealogies, An Annotated Translation of the XIVth Century Tibetan Chronicle: rGyalrabs gsal-ba 'i me-long. Wiesbaden: Harrassowitz Verlag.

Sørensen, Per K., Hazod, Guntram, and Tsering Gyalbo. 2005. Thundering Falcon: An Inquiry into the History and Cult of Khra-'brug Tibet's First Buddhist Temple. Vienna: Verlag der Österreichischen Akademie der Wissenschaften.

-. 2007. Rulers on the Celestial Plain: Ecclesiastic and Secular Hegemony in Medieval Tibet: A Study of Tshal Gung-thang, 2 vols. Vienna: Verlag der Österreichischen Akademie der Wissenschaften.

Stablein, William. 1973. "A Medical-Cultural System Among the Tibetan and Newar Buddhists: Ceremonial Medicine.” In Kailash 1(3), pp.193-203.

Stein, R.A. 1959. "Recherches sur l'Epopée et le Barde du Tibet." In Bibliothèque de l'Institut des hautes Études Chinoises 13. Paris: Presses Universitaires.

—. 1961. Une Chronique Ancienne de bSam-yas: sBa-bžed. Paris: Publications de l'Institut des Hautes Études Chinoises.

Stoddard, Heather. 1997. "The Nine Brothers of the White High. On the 'Re-membering' of History and the Creation of Gods." In Les Habitants du Toit du Monde: Études Recueillies en Hommage à Alexander W. MacDonald. Samten Karmay and Philippe Sagant, eds. Nanterre: Société d'Ethnologie, pp.75-109.

Stuart, Kevin. 1995. "Mountain Gods and Trance Mediums: A Qinghai Tibetan Summer Festival." In Asian Folklore Studies 54(2), pp. 219-237.

Sutherland, Gail Hinich. 1991. The Disguises of the Demon: The Development of the Yakșa in Hinduism and Buddhism. Albany: SUNY Press.

Tenzin Samphel. 2008. "Les bKa' brgyad - Sources Canoniques et Tradition de Nyang ral Nyi ma 'od zer." In Revue d'Etudes Tibétaines 15, pp.251-274.

Tewari, Ramesh Chandra. 1987. "Pre-Buddhist Elements in Himalayan Buddhism: The Institution of the Oracles." In The Journal of the International Association of Buddhist Studies 10(1), pp. 135-155.

Thub bstan phun tshogs. 2007. Gnas chung rdo rje sgra dbyangs gling gi chos 'byung kun gsal chu shel dbang po. Dharamsala: Nechung Monastery.

Thub bstan yar 'phel, Rnam grwa. 2009. "Lha sa'i btsan khang bzhi." In Gangs ljongs lha ldan 
grong khyer gyi sa khams chags dbyibs dang / grags can gyi gna' shul ngo sprod sogs lha sa'i dngos byung bden dpang gzur gnas dgyes pa'i glu dbyangs. Dharamsala: Rgyal sa lha sa'i mthun grogs nas dpar bskrun dang 'grems spel zhus.

Tibetan Academy of Social Sciences, ed. 2009. Dpal ldan 'bras spungs dgon gyi dkar chag dri med dwangs gsal shel gyi me long. Beijing: Krung go'i bod rig pa dpe skrun khang.

Tibetan and Himalayan Library. 2007. The Chapel of the Protector Deity Taok at the Mé College of Sera Monastery [Video file]. http://www.thlib.org/places/monasteries/sera/ essays/images/01044_sera_mgon.mp4 (accessed April 17, 2013).

—. 2013. Meru Nyingpa. http://www.thlib.org/places/monasteries/meru-nyingpa/ (accessed April 17, 2013).

Toyo Bunko. 2002. “Call No.294, Ref. No. 2470, Folios 1a1-9b4.” In Online Search of Kawaguchi Collection of Tibetan Texts. http://61.197.194.9/Database/Kawaguchi_ QueryResult.php?sw_vol1 $=47 \&$ sw_vol2 $=\&$ sw_vol3 $=\&$ sw_vol1 $=47 \&$ sw_vol $2=\&$ sw vol3 $=\&$ sw4all $=\& i$ Start $=121 \& i$ Stop $=150 \& i P a g e=1 \&$ andor $=($ accessed April 17, 2013 $)$.

Tsepak Rigzin [=Tsepak Rinzin]. 1993. Festivals of Tibet. Dharamsala: Library of Tibetan Works \& Archives.

Tsepak Rinzin, et al. 1992. "Nechung - The State Oracle of Tibet” In Tibetan Bulletin, JulyAugust, pp.17-32.

Tshe ring don grub, ed. 2009. Bsam yas dkar chag. Lanzhou: Kan su'u mi rigs dpe skrun khang. Tshe ring rgyal po, Gu ge. 2005. "Lha ldan rme ru rnying pa dang de'i chos skyong skor phran tsam brjod pa." In Gu ge tshe ring rgyal po'i ched rtsom phyogs bsgrigs. Beijing: Krung go'i bod rig pa dpe skrun khang, pp.395-401.

Tucci, Giuseppe. [1949] 1999. Tibetan Painted Scrolls, 3 vols. Bangkok: SDI Publications. van der Kuijp, Leonard W.J. 1998. Review of the book Les Habitants du Toit du Monde: Études Recueillies en Hommage à Alexander W. MacDonald, by Samten Karmay and Philippe Sagant. In The Journal of Asian Studies 57(4), pp.1147-1151.

- 2013. "On the Edge of Myth and History: Za hor, its Place in the History of Early Indian Buddhist Tantra, and Dalai Lama V and the Genealogy of its Royal Family." In Studies on Buddhist Myths: Texts, Pictures, Traditions and History (佛教神话研究: 文本、图像、 传说与历史). Wang Bangwei, Chen Jinhua, and Chen Ming, eds. Shanghai: Zhongxi Book Company, pp.114-176. 
van Schaik, Sam. 2000. "Sun and Moon Earrings: Teachings Received by Jigmé Lingpa.” In Tibet Journal 25(4), pp. 3-32. http://earlytibet.com/about/earrings/ (accessed April 17, 2013).

van Schaik, Sam, and Doney, Lewis. 2007. "The Prayer, the Priest and the Tsenpo: An Early Buddhist Narrative from Dunhuang." In Journal of the International Association of Buddhist Studies 30(1-2), pp.175-217.

Venturi, Federica, trans. 2002. Guide to the Rdzing phyi monastery. Rome: Istituto Italiano per L'Africa e L'Oriente.

Vitali, Roberto. 1996. The Kingdoms of Gu.ge Pu.hrang: According to mNga'.ris rgyal.rabs by Gu.ge mkhan.chen Ngag.dbang grags.pa. Dharamasala: Tho.ling gtsug.lag.khang lo.gcig.stong 'khor.ba'i rjes.dran.mdzad sgo'i go.sgrig tshogs.chung.

-.2011. "Historical and Ethnic Traits in the Mes rabs of Rig 'dzin rGod ldem can." In Buddhist Himalaya: Studies in Religion, History, and Culture, vol.2. Alex McKay and Anna Balikci-Denjongpa, eds. Gangtok: Namgyal Institute of Tibetology, pp.191-208.

von Glahn, Richard. 2004. The Sinister Way: The Divine and the Demonic in Chinese Religious Culture. Berkeley: University of California Press.

Waddell, L. Austine. 1895. The Buddhism of Tibet or Lamaism: With its Mystic Cults, Symbolism and Mythology, and in its Relation to Indian Buddhism. London: W.H. Allen \& Co., Limited.

Wangdu, Pasang, and Hildegard Diemberger. 2000. $d B a$ ' bzhed: The Royal Narrative concerning the bringing of the Buddha's Doctrine to Tibet. Vienna: Verlag der Österreichischen Akademie der Wissenschaften.

Wayman, Alex. 1967. "Significance of Dreams in India and Tibet." In History of Religions 7(1), pp.1-12.

Weber, Max. 1968. On Charisma and Institution Building: Selected Papers. S.N. Eisenstadt, ed. Chicago: University of Chicago Press.

White, Hayden. 1985. Tropics of Discourse: Essays in Cultural Criticism. Baltimore: Johns Hopkins University Press.

Willson, Martin and Martin Brauen, eds. 2000. Deities of Tibetan Buddhism: The Zürich Paintings of the Icons Worthwhile to See (Bris sku mthon ba don ldan). Boston: Wisdom Publications. 
Wongmo, Chime. 1985. "Rituals of Bhutanese House Construction.” In Soundings in Tibetan Civilization. Barbara Nimri Aziz and Matthew Kapstein, eds. New Delhi: Manohar Publications, pp.107-114.

Wylie, Turrell. 1959. "A Standard System of Tibetan Transcription.” In Harvard Journal of Asiatic Studies 22, pp.261-267.

- 1962. The Geography of Tibet According to the 'Dzam-gling-rgyas-bshad. Rome: Istituto Italiano per il Medio ed Estremo Oriente.

Yamaguchi Zuihō. 1995. "The Sovereign Power of the Fifth Dalai Lama: sPrul sku gZimskhang-gong-ma and the Removal of Governor Nor-bu." In Memoirs of the Research Department of The Toyo Bunko (The Oriental Library) 53, pp.1-27.

—. 1999. "The Emergence of the Regent Sangs-rgyas-rgya-mtsho and the Denouement of the Dalai Lamas' First Administration.” In Memoirs of the Research Department of The Toyo Bunko (The Oriental Library) 57, pp.113-136.

Yamamoto, Carl. 2009. Vision and Violence: Lama Zhang and the Dialectics of Political Authority and Religious Charisma in Twelfth-Century Central Tibet. Ph.D. dissertation, University of Virginia.

张怡荪 [Zhang Yisun], ed. 1985. Bod rgya tshig mdzod chen mo. Beijing: Mi rigs dpe skrun khang. 